\title{
Marriage as a Covenant: \\ A study of biblical law and ethics governing marriage developed from the perspective of Malachi
}

by

Gordon Paul Hugenberger

A thesis submitted in partial fulfilment of the requirements of the Council for National Academic Awards

for the degree of Doctor of Philosophy

Sponsoring establishment:

Cheltenham \& Gloucester College of Higher Education

(The College of St. Paul \& St. Mary)

Collaborating establishment:

Oxford Centre for Postgraduate Hebrew Studies

May 1991 


\title{
Abstract \\ Marriage as a Covenant: A study of biblical law and ethics governing marriage developed from the perspective of Malachi
}

\author{
by Gordon P. Hugenberger
}

The purpose of the present study is to investigate Malachi's teaching concerning marriage as a בִּרִ in Malachi 2:10-16, especially in the light of recent interpretations which deny this identification.

In particular, after an examination of the context and literary structure of the book of Malachi (Chapter 1), it is argued that Malachi refers to literal marriage in 2:10-16, rather than intending a metaphor for Israel's relation to Yahweh, and that the mentioned in 2:14 refers specifically to the marriage relationship, not to the Sinaitic covenant (Chapter 2). Reflecting this identification of marriage as a בְר רית , Malachi condemns literal divorce when based on aversion (Chapter 3), which viewpoint does not contradict Deuteronomy 24:1-4, as often alleged. Moreover, the relationship between divorce and mixed marriage in Malachi 2:10-16, while problematic, may be deemed neither artificial, nor an evidence for a figurative interpretation of marriage in Malachi, as some scholars have supposed based on an assumed toleration of polygyny in Malachi's day (Chapter 4).

After thus exploring the coherence of Malachi's theory of marriage, the study investigates the corroboration which Malachi sought for his understanding in the allusion which he makes in 2:15 to Genesis 2 (Chapter 5).

Finally, an attempt is made to answer several more fundamental objections which have been advanced against the identification of marriage as a iִ iִ in in the Old Testament period. In particular, it is argued that for marriage to constitute a בִּר it must be accompanied by a ratifying oath and/or oath-sign -- though these need not be explicitly self-maledictory (Chapter 6). As against those who deny that marriage was accompanied by such an oath, it is suggested that in the biblical period marriage was probably ratified by verba solemnia as well as by the complementary oath-sign of sexual union (Chapter 7). After examining texts other than Malachi 2:14 which similarly identify marriage as a בִּרִ (i.e., Proverbs 2, Ezekiel 16, 1 Samuel 18-20, etc.), consideration is given to the supposed contradiction between Malachi's view of marriage as a ברית and the apparent indifference of the Old Testament to a husband's sexual fidelity (Chapter 8). 


\section{Table of Contents}

Acknowledgements........................................................ ii

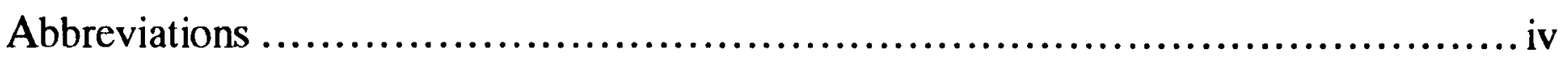

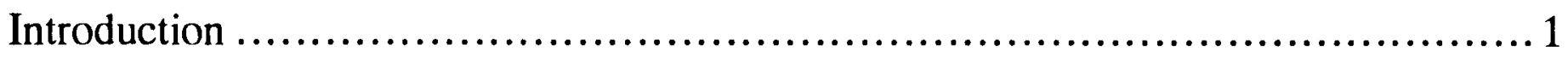

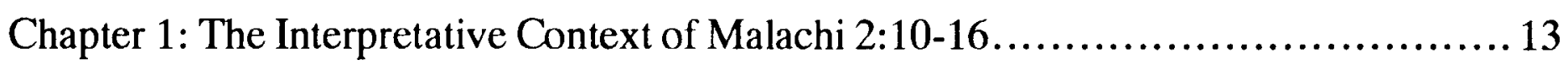

Chapter 2: "Covenant [ברית]" in Malachi 2:14: Does it refer to marriage?...............27

Chapter 3: Malachi 2:16 and Divorce.......................................... 48

Chapter 4: Malachi 2:10-16 and the Toleration of Polygyny Elsewhere in the Old

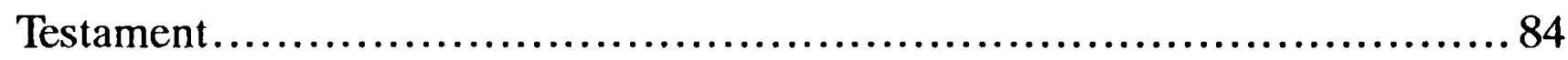

Chapter 5: Malachi 2:15a: Malachi's appeal to Adam and Eve for his understanding

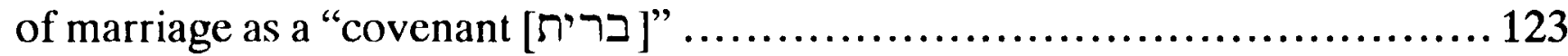

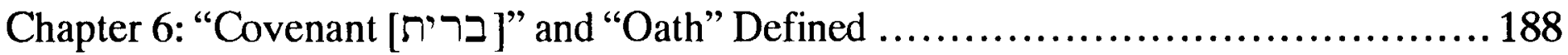

Chapter 7: Verba Solemnia and Sexual Union: The requisite covenant-ratifying oath and oath-sign for marriage................................................ 234

Chapter 8: Marriage as a "Covenant [ברית]" Elsewhere Within the Old Testament.......296

Summary and Conclusions................................................. 354

Bibliography of Cited Works ................................................ 359

Index of Biblical Citations..................................................... 416

Index of Other Ancient Sources................................................ 424

Index of Words .......................................................... 427

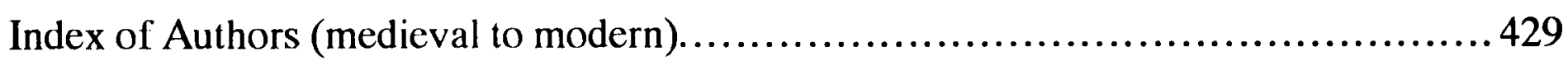

Index of Topics ........................................................ 431 


\section{Acknowledgements}

It is a very pleasant duty to express here my sincere thanks to my supervisor, Dr. G. J. Wenham, for his patience, careful guidance, and many helpful suggestions over the course of the production of this thesis. Beyond this specific help, he has provided a model of meticulous, productive, and relevant scholarship, which I can only hope to emulate.

I am grateful also to the Rev. Canon A. C. J. Phillips for his help as my outside supervisor, offering many valuable comments and encouragement when needed.

While my indebtedness to the community of scholarship is cheerfully acknowledged throughout this thesis, at almost every turn I am aware of a more personal debt to the scholarly example, academic interests, and encouragement of my colleagues in the Biblical Studies Division at Gordon-Conwell Theological Seminary and especially of two former teachers, Prof. M. G. Kline also of Gordon-Conwell Theological Seminary and Prof. W. G. Lambert of Birmingham University.

It would be impossible to register adequately my sense of gratitude to each of my brothers and sisters at the Orthodox Congregational Church of Lanesville. Without the original prompting of Edwin B. Cobb I would never have dared to undertake this work. Without the subsequent willingness of the whole church to grant me the necessary time to do this research, as well as their on-going prayer, constant encouragements (especially from Richard N. Gray, who also preached in my stead one year), and financial support, the work would never have been completed.

As for my family, and especially Janie, חברתי ואשת ברית, I know I can never repay them for their love and support.

Naturally, in spite of the substantial help I have received, I bear full responsibility for the views expressed and the remaining defects of this work. 


\section{$\underline{\text { Abbreviations }}$}

AASOR

$\mathrm{AB}$

$A B L$

AfO

$A H w$

AJSL

AnBib

ANEP

ANET

AnOr

AOAT

ARM

ARN

ASV

AT

$A T$

ATD

AUSS

AV

$B A$

$B A R$

BASOR

Bauer-Leander
The Annual of the American Schools of Oriental Research (1920-)

The Anchor Bible, ed. W. F. Albright and D. N. Freedman (for more recent volumes add F. M. Cross, Jr. and J. C. Greenfield)

R. F. Harper, Assyrian and Babylonian Letters, 14 vols. (1892-1914) Archiv für Orientforschung

W. von Soden, Akkadisches Handwörterbuch (1959-1985)

American Journal of Semitic Languages and Literature

Analecta biblica

Ancient Near Eastern Pictures, Second Edition with Supplement, ed. J.

B. Pritchard (1969)

Ancient Near Eastern Texts Relating to the Old Testament, Third Edition with Supplement, ed. J. B. Pritchard (1969)

Analecta orientalia, Rome (1931-)

Alter Orient und Altes Testament, ed. K. Bergerhof, M. Dietrich, and O. Loretz

Archives royales de Mari (1-10 = Textes cunéiformes du Louvre, 22-31;

14, 18, 19, 21 = Textes cunéiformes de Mari, 1-3, 5) (1946-)

Altbabylonische Rechtsurkunden aus Nippur, M. Çiğ, H. Kizilyay, F.

R. Kraus (1952)

The Holy Bible containing the Old and New Testaments. Newly Edited by the American Revision Committee, A.D. 1901, Standard Edition (1901)

Alte Testament

D. J. Wiseman, The Alalakh Tablets (1953)

Das Alte Testament Deutsch, ed. V. Herntrich and A. Weiser; for more recent volumes, O. Kaiser and L. Perlitt (1949-)

Andrews University Seminary Studies

Authorized Version (Bible)

Biblical Archaeologist

Biblical Archaeology Review

Bulletin of the American Schools of Oriental Research

H. Bauer and P. Leander, Historische Grammatik der hebräischen

Sprache des Alten Testamentes (1922) 
BDB

$B E$

BHS

BibOr

BKAT

F. Brown, S. R. Driver, C. A. Briggs, A Hebrew and English Lexicon of the Old Testament (1907)

The Babylonian Expedition of the University of Pennsylvania, Series A: Cuneiform Texts, Philadelphia (1893-1911), München (1913-14)

Biblia Hebraica Stuttgartensia, ed. K. Elliger and W. Rudolph (1983)

Biblica et orientalia

Biblischer Kommentar: Altes Testament, ed. M. Noth, S. Herrmann, and H. W. Wolff (1955-)

Blass and Debrunner

F. Blass and A. Debrunner, A Greek Grammar of the New Testament and Other Early Christian Literature, trans. and revised by R. W. Funk (1961)

$B M S$

$B O$

BOT

Brockelmann

BWANT

BZAW

$C A D$

$C A H$

$\mathrm{CBC}$

$C B Q$

$\mathrm{CD}$

$\mathrm{CH}$

COT

Cowley

$C T$

D

DJD

E
L. W. King, Babylonian Magic and Sorcery

Bibliotheca orientalis

De Boeken van het Oude Testament, ed. A. van den Born, J. van Dodewaard, W. Grossouw, and J. van der Ploeg

C. Brockelmann, Hebräische Syntax (1956)

Beiträge zur Wissenschaft vom Alten und Neuen Testament

Beihefte zur Zeitschrift für die alttestamentliche Wissenschaft

The Assyrian Dictionary of the Oriental Institute of the University of Chicago, ed. J. A. Brinkman, M. Civil, I. J. Gelb, B. Landsberger, A. L. Oppenheim, and E. Reiner (1956-)

Cambridge Ancient History

The Cambridge Bible Commentary on the New English Bible, ed. P. R.

Ackroyd, A. R. C. Leaney, and J. W. Packer

Catholic Biblical Quarterly

Damascus Document or Zadokite Fragment

Laws of Hammurabi

Commentaar op het Oude Testament, ed. G. C. Aalders, W. H. Gispen, and N. Ridderbos

A. E. Cowley, Aramaic Papyri of the Fifth Century B.C. Edited with Translation and Notes (1923)

Cuneiform Texts from Babylonian Tablets, etc., in the British Museum, 52 vols. (1896-)

Deuteronomic Source

Discoveries in the Judaean Desert of Jordan, ed. P. Benoit, J. T. Milik, and R. de Vaux

Elohist Source 
$E A$

ET

Even-Shoshan

$E v T$

ExpTim

FRLANT

Fs

$G A G$

Gesenius

GKC

H

HAT

Hermeneia

HL

Holladay

Huehnergard

HSM

HSS

HSSt

HTR

HUCA

HKAT

ICC

$I D B$

IDBSup

IEJ
J. A. Knudtzon, O. Weber, and E. Ebeling, Die El-Amarna-Tafeln, 2 vols. (1915)

English translation

A New Concordance of the Old Testament Using the Hebrew and Aramaic Text, ed. A. Even-Shoshan (1983)

Evangelische Theologie

Expository Times

Forschungen zur Religion und Literatur des Alten und Neuen

Testaments

Festschrift

W. von Soden, Grundriss der Akkadischen Grammatik (1969)

Gesenius' Hebrew and Chaldee Lexicon, trans. S. P. Tregelles (1949)

Gesenius' Hebrew Grammar, second edition, ed. E. Kautzsch, trans.

A. E. Cowley (1910)

The Holiness Code, i.e., Leviticus 17-26. Alternatively, in the context of a marriage document, $\mathrm{H}$ represents the husband's name

Handbuch zum Alten Testament, ed. O. Eissfeldt (1937-)

Hermeneia - A Critical and Historical Commentary on the Bible, ed.,

F. M. Cross, Jr., K. Baltzer, P. D. Hanson, S. D. McBride Jr., and R. E. Murphy

Hittite Laws

W. L. Holladay, A Concise Hebrew and Aramaic Lexicon of the Old Testament (1971)

J. Huehnergard, "Five Tablets From the Vicinity of Emar" (1983)

Harvard Semitic Monograph

Harvard Semitic Series, 24 vols.

Harvard Semitic Studies

Harvard Theological Review

Hebrew Union College Annual

Handkommentar zum Alten Testament, ed. W. Nowack

The International Critical Commentary, ed. S. R. Driver, A. Plummer,

C. A. Briggs (1895-1951); ed. J. A. Emerton and C. E. B.

Cranfield (1975-)

Interpreter's Dictionary of the Bible, ed. G. A. Buttrick, T. S. Kepler,

J. Knox, H. G. May, S. Terrien, and E. S. Bucke

Supplement volume to Interpreter's Dictionary of the Bible, ed. K.

Crim, L. R. Bailey Sr., V. P. Furnish, and E. S. Bucke (1976)

Israel Exploration Journal 
$I S B E$

J

JANESCU Journal of the Ancient Near Eastern Society of Columbia University

JAOS

Jastrow

JB

$J B L$

JCS

JETS

JJS

JNES

JNSL

Joüon

JSJ

JSOT

JSOTSup

$J S S$

JTS

$K A J$

KAT

KB

Keel

Kraeling

Lambdin

LB

LE

LI

LU

The International Standard Bible Encyclopedia, Revised, ed. G. W.

Bromiley, E. F. Harrison, R. K. Harrison, W. S. LaSor, and E. W.

Smith Jr. (1979-1988)

Yahwist Source

Journal of the American Oriental Society

M. Jastrow, A Dictionary of the Targumim, the Talmud Babli and

Yerushalmi, and the Midrashic Literature (1903)

The Jerusalem Bible (1966)

The Journal of Biblical Literature

Journal of Cuneiform Studies

Journal of the Evangelical Theological Society

Journal of Jewish Studies

Journal of Near Eastern Studies

Journal of Northwest Semitic Languages

P. Joüon, Grammaire de l'hébreu biblique, 2nd ed. (1923)

Journal for the Study of Judaism in the Persian, Hellenistic and Roman

Period

Journal for the Study of the Old Testament

Journal for the Study of the Old Testament - Supplement Series

Journal of Semitic Studies

Journal of Theological Studies

Keilschrifttexte aus Assur juristischen Inhalts, ed. E. Ebeling (1927)

Kommentar zum Alten Testament, ed. E. Sellin, and later, J. Herrmann (1913-); ed. W. Rudolph, K. Elliger, and F. Hesse (1962-)

L. Koehler and W. Baumgartner, Hebräisches und aramäisches Lexicon zum Alten Testament, 3e Aufl. (1967, 1974, 1983, 1990)

O. Keel, The Symbolism of the Biblical World. Ancient Near Eastern Iconography and the Book of Psalms (1978)

E. Kraeling, The Brooklyn Museum Aramaic Papyri. New Documents of the Fifth Century B.C. from the Jewish Colony of Elephantine (1953)

T. O. Lambdin, Introduction to Biblical Hebrew (1971)

Late Babylonian (cir. 625 B.C.-75 A.D.)

Laws of Eshnunna

Laws of Lipit-Ishtar

Laws of Ur-Nammu 
Septuagint (when particular MSS are cited this is based on J. Ziegler, ed., Duodecim Prophetae. Septuaginta, Vetus Testamentum Graecum, Auctoritate Academiae Scientiarum Gottingensis editum [1984]. Otherwise, the LXX is taken from The SuperGreek Old Testament ( 1986 P. B. Payne, based on Septuaginta id est Vetus Testamentum graece iuxta LXX interpretes, ed. Alfred Rahlfs [1935])

$\mathrm{LXX}^{\mathrm{N}}$

$\mathrm{LXX}^{*}$

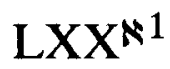

$\operatorname{LXX}^{N^{2}}$

$\operatorname{LXX}^{\mathrm{A}}$

$\mathrm{LXX}^{\mathrm{B}}$

$\mathrm{LXX}^{\mathrm{B}-* *-68}$

LXXChr. III221

LXXConst

$\mathrm{LXX}^{\Gamma}$

$\mathrm{LXX}^{\mathrm{L}}$

LXXQ

$\mathrm{LXX}^{\mathrm{V}}$

LXXW

$\operatorname{LXX}^{68}$

$\mathrm{LXX}^{86}$

MA

MAL

MB

MSL

MSS

MT

Mur

NA

$\mathrm{NAB}$
Codex Sinaiticus (fourth century A.D.)

Codex Sinaiticus, the original hand (fourth century A.D.)

Codex Sinaiticus, the first corrector (fourth -sixth century A.D.)

Codex Sinaiticus, the second corrector (seventh century A.D.)

Codex Alexandrinus (fifth century A.D.)

Codex Vaticanus (fourth century A.D.)

The use of a dash in listing LXX MSS, as in LXX ${ }^{\mathrm{B}-*^{*}-68}$, implies that the listed MSS form a family group

Sermons of Chrysostom (344-407 A.D.)

Apostolic Constitutions (380 A.D.)

Codex Cryptoferratensis (eighth century A.D.)

Lucianic Recension of LXX MSS

Codex Marchalianus (sixth century A.D.)

Codex Venetus (eighth century A.D.)

The Freer Greek MS (third century A.D.), reproduced in H. A. Sanders and C. Schmidt, The Minor Prophets in the Freer Collection and The Berlin Fragment of Genesis (1927)

a fifteenth century A.D. cursive MS in Venice, Biblioteca San Marco a ninth century A.D. cursive MS in Rome, Vatican Library, Barberini Middle Assyrian (cir. 1500-1000 B.C.)

Middle Assyrian Laws

Middle Babylonian (cir. 1600-1000 B.C.)

Materialien zum sumerischen Lexikon, B. Landsberger, et al.(1937-)

Manuscripts

Masoretic Text, as found in $B H S$ (generally as reproduced in

MacHebrew Scriptures (C) 1987-1988 P. B. Payne or

ThePerfectWORD ${ }^{\mathrm{TM}}$ 2.0)

P. Benoit, J. T. Milik, and R. de Vaux, Les Grottes de Murabba'at, DJD, II (1961)

Neo-Assyrian (cir. 1000-600 B.C.)

The New American Bible (1970) 
NASB

NB

NBL

NCB

NEB

NF

NICOT

NIV

NovT

NJPS

NS

OA

OB

OT

OTA

OTL

OTS

$\mathrm{P}$

PN

POT

PRU

Porten-Yardeni

$R A$

$R B$

$R G G^{3}$

$R L A$
The New American Standard Bible (1960)

Neo-Babylonian (cir. 1000-625 B.C.)

Neo-Babylonian Laws

New Century Bible, ed. R. E. Clements and M. Black

New English Bible

Neue Folge

The New International Commentary on the Old Testament, ed. E. J. Young (1965) and R. K. Harrison (1962-)

New International Version (generally as reproduced in

ThePerfectWORD ${ }^{\mathrm{TM}}$ 2.0, or The Holy Bible, New International

Version [London: Hodder and Stoughton, 1979])

Novum Testamentum

Tanakh, a new translation of the Holy Scriptures according to the traditional Hebrew text $(1985)=$ the new Jewish Publication Society translation

New Series

Old Assyrian (cir. 1950-1750 B.C.)

Old Babylonian (cir. 1950-1600 B.C.)

Old Testament

Old Testament Abstracts

Old Testament Library, ed., P. Ackroyd, J. Barr, J. Bright, and G. E. Wright (1962-); for more recent volumes, ed. P. Ackroyd, J. Barr, B. W. Anderson, and J. L. Mays

Oudtestamentische Studiën

Priestly Source

some proper noun (typically used in the translation of Akkadian texts)

De Prediking van het Oude Testament, ed. A. van Selms, A. S. van der

Woude, and C. van Leeuwen

Le palais royal d'Ugarit, ed. C. Schaeffer

B. Porten and A. Yardeni, Textbook of Aramaic Documents From Ancient Egypt, Volume 2: Contracts (1989)

Revue d'assyriologie et d'archéologie orientale

Revue biblique

Die Religion in Geschichte und Gegenwart, 3e Aufl. (1957-65), ed. K. Galling

Reallexikon der Assyriologie und Vorderasiatischen Archäologie, Bände 1-2, ed. E. Ebeling and B. Meisser (1932-38), for Bände 3-, ed. E. Ebeling and E. Weidner (1957-) 
Roth

RS

RSP

RSV

RV

SBLDS

SBLMS

SL

Strassmaier, Liverpool

J. N. Strassmaier, Die babylonischen Inschriften im Museum zu

Liverpool, Actes du 6e Congrès International des Orientalistes, II, Section Sémitique (1) (1885)

StrB

$T B$

$T D N T$

TDOT

THAT

TIM

TOTC

TRE

TWOT

UET

$U T$

UT

$V A T$

$V S$

M. T. Roth, Babylonian Marriage Agreements: 7th - 3rd Centuries B.C (1989)

Ras Shamra (field numbers of tablets)

Ras Shamra Parallels. The Texts from Ugarit and the Hebrew Bible, ed.

L. R. Fisher, et al., I, AnOr 49 (1972); II, AnOr 50 (1975)

Revised Standard Version (generally as reproduced in

ThePerfectWORD ${ }^{\text {TM }}$ 2.0)

The Holy Bible. The Revised Version (1885)

The Society of Biblical Literature Dissertation Series

The Society of Biblical Literature Monograph Series, R. A. Kraft, ed. (1967-1972); L. Keck, ed. (1973-)

Sumerian Laws

L. Strack and P. Billerbeck, Kommentar zum Neuen Testament aus

Talmud und Midrasch (1922-61)

Tyndale Bulletin

Theological Dictionary of the New Testament, English ed. (1964-74), ed. G. Kittel and G. Friedrich

Theological Dictionary of the Old Testament, English revised ed. (1977), ed. G. J. Botterweck and H. Ringgren

Theologisches Handwörterbuch zum Alten Testament, ed. E. Jenni and

C. Westermann (1984)

A. Al-Zeebari, Texts in the Iraq Museum (1964)

Tyndale Old Testament Commentaries, ed. D. J. Wiseman (1964-)

Theologische Realenzyklopädie, ed. G. Krause and G. Müller

Theological Wordbook of the Old Testament, 2 vols., ed. R. L. Harris,

G. L. Archer Jr., and B. K. Waltke (1980)

Ur Excavations, Texts, 10 vols. (1934-66)

C. H. Gordon, Ugaritic Textbook (1965)

Ugaritic texts as listed in C. H. Gordon, Ugaritic Textbook (1965)

tablets in the collections of the Staatliche Museen, Berlin

(Tafelsignaturen der Vorderasiatischen Abteilung der Berliner

Museen)

Vorderasiatische Schriftdenkmäler der königlichen Museen zu Berlin, 7 vols. (1907-1916) 


$\begin{array}{ll}\text { vs. } & \text { verse } \\ \text { vss. } & \text { verses } \\ V T & \text { Vetus Testamentum } \\ \text { VTSup } & \text { Supplements to Vetus Testamentum } \\ \text { Vulgate } & \text { Biblia Sacra Iuxta Vulgatam Versionem, ed. R. Weber, et al. (1983) } \\ \text { W } & \text { In the context of a marriage document, W represents the wife's nam } \\ \text { Waltke and O'Connor } & \text { Bruce K. Waltke, and M. O'Connor, An Introduction to Biblical } \\ & \quad \text { Hebrew Syntax (1990) } \\ \text { WBC } & \text { Word Biblical Commentary, ed. D. A. Hubbard, G. W. Barker, and Watts } \\ & \text { R. J. Williams, Hebrew Syntax: An Outline, 2nd ed. (1976) } \\ \text { Williams, Syntax } & \text { Wissenschaftliche Monographien zum Alten und Neuen Testament } \\ \text { WMANT } & \text { Westminster Theological Journal } \\ \text { WTJ } & \text { Yale Oriental Series, Babylonian Texts, 12 vols. (1915-1978) } \\ \text { YOS } & \text { Zeitschrift für die alttestamentliche Wissenschaft } \\ Z A W & \text { Zeitschrift der Deutschen Morgenländsichen Gesellschaft } \\ Z D M G & \end{array}$

\section{Abbreviations of cited Orders and Tractates in Mishnaic and Related Literature}

$\begin{array}{ll}\text { Ber. } & \text { Berakot } \\ \text { B. Mes. } & \text { Baba. Mesi'a } \\ \text { B. Qam. } & \text { Baba Qamma } \\ \text { Gen. Rab. } & \text { Genesis Rabbah } \\ \text { Git. } & \text { Gittin } \\ \text { Ketub. } & \text { Ketubot } \\ \text { Nid. } & \text { Niddah } \\ \text { Pe'a } & \text { Pe'a } \\ \text { Soța } & \text { Sota } \\ \text { Seb. } & \text { Sebi'it } \\ \text { Qidd. } & \text { Qiddušin } \\ \text { Yebam. } & \text { Yebamot }\end{array}$


To distinguish tractates by the same name in the Mishnah, Tosefta, and Talmuds, the following prefixes are employed:
$b$.
Babylonian Talmud
$m$.
Mishnah
$t$.
Tosefta
$y$.
Jerusalem Talmud

\section{Conventions}

Unless otherwise marked, English translations of biblical texts are either taken from the RSV or are the author's. Unless otherwise marked, translations of Akkadian texts are either taken from $A N E T$ or are the author's. Normalization of Akkadian texts differs from the conventions of $A H w$ mainly in one respect: Here, a macron is used to indicate tone long vowels ( $\bar{v})$; a circumflex marks vowels assumed to have experienced compensatory lengthening $(\mathrm{vC}>\hat{\mathrm{v}})$; and a tilde marks vowels assumed to have been lengthened due to contraction $(\mathrm{vCv}>\tilde{\mathrm{v}})$.

When reference is made to Dutch individuals whose surnames include van, de, den, and der, standard Dutch practice regarding capitalization will be followed. As a result, these particles, or the first in a series of these particles, will be capitalized when an individual's forename, initials, or title are not included (hence, A. S. van der Woude, but Van der Woude).

Statistics of word uses throughout the dissertation which are unattributed derive, in general, from either Even-Shoshan or from computer searches conducted by the writer utilizing The PerfectWORD ${ }^{\mathrm{TM}}$, version 2.0, with complete RSV, NIV, and $B H S$ text modules produced and marketed by Star Software, Inc., Casselberry, Florida (1988) for use on an Apple ${ }^{\mathrm{TM}}$ brand Macintosh ${ }^{\mathrm{TM}}$ computer. 


\section{Outline of the Introduction}

0.1 Survey of recent scholarship on marriage in the Old Testament.................... 1

0.2 The desirability at the present time for a study of the covenantal nature of marriage in the Old Testament................................................

0.2 .1 The importance of the topic.......................................... 2

0.2.2 The contradictory results of those who support the identification of marriage as a "covenant".............................................. 2

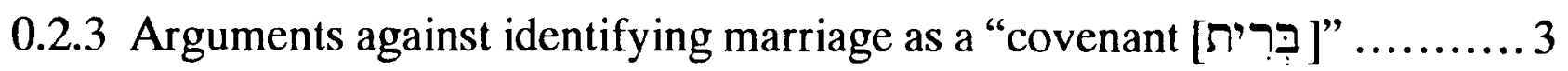

0.2.3.1 Arguments based on a more precise definition of "covenant [ [ברִ

0.2.3.2 Arguments based on the prophetic blending of images where God is alternatively depicted as being both in covenant with His people and married to them............................5

0.2.3.3 Arguments based on the notable absence of any text (biblical or extra-biblical) which explicitly identifies marriage

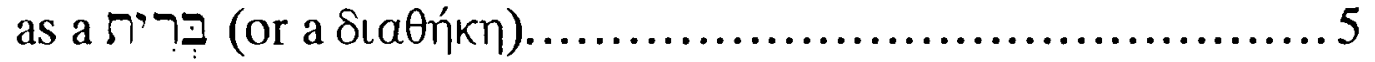

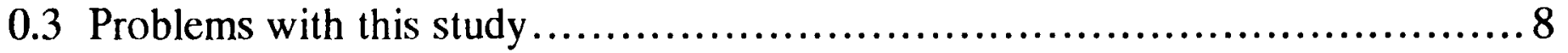

0.3.1 Controversies surrounding "covenant" ................................ 8

0.3 .2 Method of approach ............................................... 11

0.3.2.1 The deeper consensus on which we wish to build ...............11

0.3.2.2 A normative versus a descriptive study....................... 12 


\section{Introduction}

\subsection{Survey of recent scholarship on marriage in the Old Testament}

The twentieth century has witnessed a proliferation of studies which deal comprehensively with the subject of marriage in the Old Testament: M. Burrows (1938), ${ }^{1}$ L. M. Epstein (1942), ${ }^{2}$ E. Neufeld (1944), ${ }^{3}$ D. R. Mace (1953), ${ }^{4}$ R. Patai (1959), ${ }^{5}$ W. Plautz (1959), ${ }^{6}$ B. Maarsingh (1963), ${ }^{7}$ S. F. Bigger (1974), ${ }^{8}$ and A. Tosato (1982). ${ }^{9}$ Besides these full-scale works, the following briefer studies deserve mention as having exerted a profound influence: R. de Vaux (1961) ${ }^{10}$ and Z. W. Falk (1964). ${ }^{11}$

After such a list, it may seem that there is little left to be said on this topic. But on closer inspection, what emerges from this survey is the fact that while much attention has been focused on legal, historical, comparative (both diachronic and synchronic), and sociological concerns, the relationship between biblical marriage law and covenantal concepts has been left largely unresolved and, much of the time, virtually ignored.

Of course, in one sense this reticence concerning the covenantal nature of marriage is not at all surprising. While this century has witnessed a profusion of research into the nature and administration of covenants within both the Old Testament and the ancient Near East, the result of this massive scholarly enterprise, seemingly, has been to render the biblical concept of "covenant [דּרּר] ]" forbiddingly problematic. ${ }^{12}$ Given this state of affairs there would appear to be little to commend the burdensome task of seeking to apply such controversial results.

1 The Basis of Israelite Marriage.

2 Marriage Laws in Bible and Talmud.

3 Ancient Hebrew Marriage Laws -- With special references to General Semitic Laws and Customs.

${ }^{4}$ Hebrew Marriage: A Sociological Study.

5 Sex and Family in the Bible and in the Middle East (Garden City, NY: Doubleday 1959), published the following year in London under the title Family, Love and the Bible.

6 "Die Frau in Familie und Ehe. Ein Beitrag zum Problem ihrer Stellung im Alten Testament," Ph.D. diss., Kiel Univ.

${ }^{7}$ Het Huwelijk in Het Oude Testament.

8 "Hebrew Marriage and Family in the Old Testament Period. A Perspective from the Standpoint of Social History and Social Anthropology," Ph.D. diss., University of Manchester.

9 Il matrimonio israelitico. Una theoria generale.

10 Ancient Israel, Vol. 1, Social Institutions (1961), 24-38, originally published as Les Institutions de L'Ancien Testament, 1 (Paris: Les Editions du Cerf, 1958).

11 Hebrew Law in Biblical Times. An Introduction.

12 For a useful summary of this research cf. D. R. Hillers, Covenant: The History of a Biblical Idea (1969); D. J. McCarthy, Old Testament Covenant (1972); idem, Treaty and Covenant. A Study in Form in the Ancient Oriental Documents and in the Old Testament (1981); and E. W. Nicholson, God and His People. Covenant and Theology in the Old Testament (1986). 


\subsection{The desirability at the present time for a study of the covenantal nature of marriage in the Old Testament}

Nevertheless, at least three considerations make an attempt at a more rigorous examination of the possible covenantal aspects of marriage in the Old Testament desirable.

\subsubsection{The importance of the topic}

First of all, regardless of whether firm conclusions are within our present reach, the topic has a potential importance which is simply too great to ignore. ${ }^{13}$ It is possible that such a study may suggest new solutions to some of the remaining difficulties in understanding the biblical ethics and practice of marriage (e.g. the precise role of the "brideprice," the dissolubility of marriage, the legal status of premarital sexual union, etc.). But whether or not this proves to be the case, there is a reciprocal benefit from a study of the possible covenantal aspects of marriage which may allow the modern reader to appreciate more fully the breadth of the biblical concept of political (treaty-document) or cultic orientation.

\subsubsection{The contradictory results of those who support the identification of marriage as a "covenant"}

Second, while a number of scholars have sought to apply covenantal concepts to marriage in the Old Testament, ${ }^{14}$ leaving an initial impression of a mounting consensus, a closer comparison reveals that this has been done with strikingly dissimilar and even contradictory results. So, for example, there is confusion over who are the precise "covenant partners" within marriage. O. J. Baab, for example, explicitly identifies the partners as the families of the bride and groom. ${ }^{15} \mathrm{~S}$. L. McKenzie and H. N. Wallace slightly modify this by claiming that the covenant was generally between the husband (not his family) and his father-in-law or brother-in-law. ${ }^{16}$ Yet a third view is suggested by D. J. Atkinson, who appears to view the husband and wife as the covenant partners within marriage. ${ }^{17}$

Similarly there is confusion over what it is that "ratifies" the covenant of marriage.

13 Cf. D. J. McCarthy, Treaty and Covenant, ix.

14 While often this is done somewhat incidentally, the following have offered extended attempts along this line: P. F. Palmer, "Christian Marriage: Contract or Covenant?" (1972); G. R. Dunstan, "The Marriage Covenant" (1975); D. J. Atkinson, To Have and to Hold. The Marriage Covenant and the Discipline of Divorce (1979); J. B. Job, The Covenant of Marriage (1981); and R. S. Westcott, "The Concept of $b{ }^{e}$ rit with Regard to Marriage in the Old Testament" (1985).

15 "Marriage" (1962) 284.

16 "Covenant Themes in Malachi" (1983) 553. So also W. E. Barnes, Haggai, Zechariah and Malachi (1934) 124.

13 Op. cit., Chapter 3. 
M. Burrows considers that the delivery of a bridal gift sealed the marriage covenant. ${ }^{18} \mathrm{P}$. F. Palmer, on the other hand, considers sexual union to have been the ratifying act, ${ }^{19}$ while D. J. Atkinson appears to agree with G. R. Dunstan in speaking of a "vow of consent" between the bride and the groom. ${ }^{20}$ Finally, J. B. Job suggests that the marriage covenant was ratified with blood, either from circumcision, as in Exodus 4:24-26, or from the stained garment of Deuteronomy 22:15.21

Further disagreement exists as to what constitutes covenant breaking. D. J. Atkinson writes, "If marriage is understood in covenant terms, then the possibility of divorce must be discussed as the possibility of breaking covenant."22 Others would argue that it is not divorce which "breaks" the covenant, but only sexual infidelity. P. F. Palmer, on the other hand, claims that precisely unlike contracts, covenants are inherently "inviolable" 23 and "unbreakable."24

It is possible that some of these apparent disagreements in applying a covenantal model to marriage are no more than terminological. ${ }^{25}$ But if this is so, one could wish for greater precision in the use of terms which have acquired rather precise technical meanings elsewhere in the scholarly discussion of covenant. Not all the disagreement, however, seems so amenable to semantic clarification. The simple fact is that such discordant results do not commend the initial assumption that marriage in the Old Testament was in fact covenantal, and hence, in their own way, these results demand a more meticulous study of the underlying evidence for this assumption.

\subsubsection{Arguments against identifying marriage as a "covenant [פרּרִ}

Finally, and most importantly, a number of scholars have recently challenged not only particular applications of covenantal concepts to marriage, but also the long-standing underlying assumption that marriage was itself covenantal within the Old Testament. The

18 The Basis of Israelite Marriage, 21.

19 Op. cit., 655. Palmer is speaking here not so much of marriage in the OT as of Christian marriage.

20 G. R. Dunstan, op. cit., 247f., and D. J. Atkinson, op. cit., 75.

Strictly speaking, here as elsewhere Dunstan is considering either the New Testament view of marriage or a theology of marriage and not its Old Testament practice.

21 Op. cit., 9 f.

22 To Have and to Hold, 91.

23 Op. cit., 618. But cf. p. 619.

24 Ibid., 639.

25 Cf., e.g., P. F. Palmer who develops his concept of "covenant" as much from the evidence of foedus (ecclesiastical Latin) as from בִּרית (Biblical Hebrew). So, for example, Palmer writes "covenants are not broken; they are violated when there is a breach of faith on the part of either or both of the covenanters" (op. cit., 619). Whatever may be the evidence for this assertion from ecclesiastical Latin, in terms of Hebrew usage covenants may be both violated and dissolved -- with both of these concepts expressed by the same underlying Hebrew expression which is customarily rendered "broken" in most English versions (Hiphil of

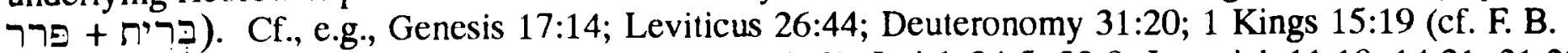
Knutson, "Political and Foreign Affairs," RSP, II, 111f.); Isaiah 24:5; 33:8; Jeremiah 11:10; 14:21; 31:32; 33:20ff.; Ezekiel 16:59; 17:15ff.; 44:7; and Zechariah 11:10f. Cf. also D. J. McCarthy, Old Testament Covenant, $4 \mathrm{f}$. 
following is a summary of the principal arguments which have been advanced against marriage being viewed as a covenant.

\subsubsection{Arguments based on a more precise definition of "covenant

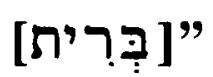

In the past, all too often the defence of marriage as "covenantal" in the Old

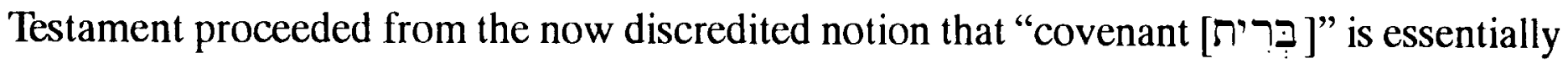
a synonym for "relationship."26 It is now recognized that the sine qua non of "covenant [בְּרִ [?רית]" in its normal sense appears to be its ratifying oath, whether this was verbal or symbolic (a so-called "oath sign"). ${ }^{27}$ However, in the case of marriage, according to J. Milgrom and others, there is no evidence for the existence of any such oath. Milgrom observes, "though countless marriage contracts and laws from [the] ancient Near East are known, not a single one to my knowledge stipulates an oath."28 Milgrom proceeds to counter specific arguments which might imply that an oath did accompany marriage either elsewhere in the ancient Near East or in Israel. For example, the fact that ancient Near Eastern laws so frequently allow an injured husband to mitigate or waive the death penalty against an adulterer itself implies, according to Milgrom, that adultery did not entail the breach of an oath. ${ }^{29}$ Milgrom further notes that the oath mentioned in Genesis 31:50ff. prohibits Jacob from contracting any future marriage, but does not regulate his longexisting marriages to Rachel and Leah. ${ }^{30}$

P. F. Palmer offers another argument against the identification of marriage in the Old Testament as a "covenant [בּּרִית]," which likewise begins with a more precise definition of "covenant." Although we cited Palmer in our earlier discussion as generally supportive of the notion that marriage was covenantal in the Old Testament, in fact Palmer holds that this was the case only in terms of the prophetic vision held out most explicitly by Malachi. Because Palmer construes "covenant" as necessarily entailing an exclusive and indissoluble bond (over against a "contract"), he concludes: "In a society where polygamy and divorce were sanctioned by Mosaic law, where the wife was regarded as the property

26 So, for example, D. J. Atkinson begins his defence of the covenantal nature of marriage with the claim that "all human relations can be expressed in covenantal terms..." (op. cit., 71). If the meaning of the

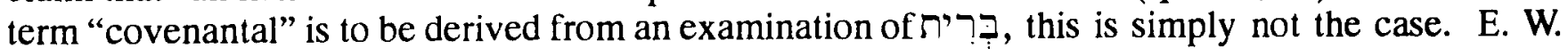
Nicholson points out an analogous error among those who exaggerate the early evidence for identifying Yahweh's relation to Israel in terms of "covenant" by an overly facile identification of "covenant" with "relationship" (God and His People, p. 20 and passim).

27 This point is widely acknowledged and is made, for example, by J. Barr, "Some Semantic Notes on the Covenant," 23-38, esp. p. 32. See our further discussion in Chapter 6 below.

28 Cult and Conscience. The Asham and the Priestly Doctrine of Repentance (1976) 134.

29 Op. cit., 134, where he cites CH \$129, MAL A \$\$14-16, and HL §\$192f. Milgrom is not explicit that he would draw this implication from the evidence he cites.

30 Although Milgrom discusses this example at some length, with the implication that it is erroneously used to buttress the theory of covenantal marriage, he does not cite any scholar who has made the mistake he alleges. 
of the husband and adultery a violation of the rights of the Hebrew male, where fecundity was still the overriding concern, it would be unreal to speak of Jewish marriage as a covenant either of love or of fidelity." 31 It is crucial to note that Palmer does not base his conclusion on the all-too-familiar discrepancy between theory and practice, but rather on the quite striking discrepancy which he alleges existed between the Mosaic legal corpus and the later prophetic reform.

\subsubsection{Arguments based on the prophetic blending of images where God is alternatively depicted as being both in covenant with His people and married to them}

While most scholars who defend marriage as a covenant consider the force of the prophetic allusions to Yahweh's marriage covenant with Israel to be almost self-evident, ${ }^{32}$ J. Milgrom's counter argument appears as a tour de force -- he simply notes that in such cases "the term bryt ... is a literary usage and carries no legal force." 33

Specifically, with reference to Ezekiel 16:8, ${ }^{34}$ Milgrom objects that the oath mentioned in this text "is taken by God whereas it should have been expected of the bride, Israel, for it is the bride, not the husband, who is subject to the laws of adultery." Milgrom adds that there is a similar anomaly with respect to the charge of infidelity in Malachi 2:14.

M. Greenberg agrees with Milgrom and explains the origin of the oath mentioned in Ezekiel 16:8 not as a reflection of marital practice, but as a fusion of the literal divine oath to the patriarchs promising the land of Canaan to their descendants and "the solemn declaration of mutual obligation connected with the Exodus and covenant with the people."35 In other words, although Ezekiel 16:8 mentions "swearing" and "covenant" in connection with the marriage metaphor, in this case the underlying referent has intruded into the metaphor and so implies nothing with respect to literal marriage. ${ }^{36}$

\subsubsection{Arguments based on the notable absence of any text (biblical or extra-biblical) which explicitly identifies marriage as a בְּרִ (or a

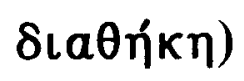

Of course, the mere absence of a term, such as

31 "Christian Marriage: Contract or Covenant?" 621. Cf. also pp. 619, 639.

32 Cf., e.g., D. J. Atkinson, op. cit., 71-73, and P. F. Palmer, op. cit., 619-621. The following passages are typically included in this discussion: Hosea 1-3, Isaiah 54:5-8, Jeremiah 3:1ff., and Ezekiel 16.

33 Cult and Conscience, 134.

34 "When I passed by you again and looked upon you, behold, you were at the age for love; and I

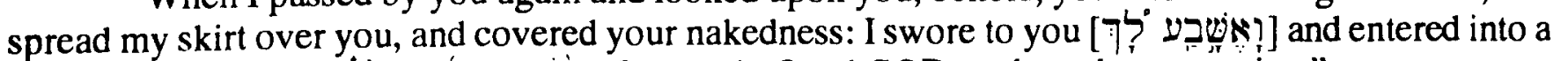

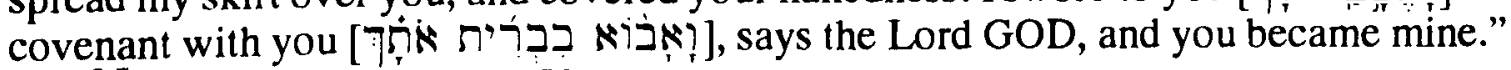

35 Ezekiel 1-20(1983) 278.

36 So also J. Herrmann, Ezechiel (1924); B. M. Vellas, Israelite Marriage (1956) 24; P. Kalluveettil, Declaration and Covenant (1982) 79; and M. Malul, "Adoption of Foundlings in the Bible and Mesopotamian Documents. A Study of Some Legal Metaphors in Ezekiel 16:1-7" (1990) 126, n. 112. 
signified. ${ }^{37}$ For example, although the term בִּרִ prophets, nevertheless a number of scholars have argued that the prophetic books may presuppose covenant "as an invisible framework." 38 Similarly, it has been remarked that nowhere appears in the "covenant with David" as recorded in 2 Samuel 7, and yet this arrangement is so identified in 2 Samuel 23:5 and particularly Psalm 89 (where בִּרִ found no less than four times). ${ }^{39}$ Not surprisingly G. E. Mendenhall observes there are "numerous references to covenants and covenant relationships where this term does not occur."40

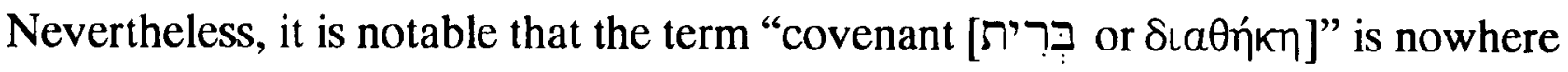
applied to marriage at 5 th century B.C. Elephantine, nor during the intertestamental period (e.g., Tobit 7), nor is it to be found in the New Testament. Finally, although W. A. Heth aִּרִ is likewise conspicuously absent in this paradigmatic marriage. 41

Traditionally, three passages have been cited as exceptions to this rule, as they seem explicitly to identify marriage with a בִּרִית. We have already noted that the first of these, Ezekiel 16:8, on closer examination may not prove what is being alleged because of its use of marriage as a metaphor.

The second text, Proverbs 2:17, is likewise problematic, as M. Greenberg notes. ${ }^{42}$ The RSV renders this verse about the adulteress: "who forsakes the companion of her youth and forgets the covenant of her God." While it is possible that the "covenant" mentioned is an individual covenant of marriage between the woman and her husband, many scholars consider it to be equally possible and perhaps more probable that the covenant is the one she shares with all Israelites and their God. ${ }^{43}$ In the same vein, some scholars have suggested that "the companion of her youth" is to be understood as referring not to her husband but to her Lord.

The third text, Malachi 2:14, is perhaps the chief pillar of the traditional identification of marriage in the Old Testament as a covenant. ${ }^{44}$ The following is a

${ }^{37} \mathrm{M}$. Silva makes a similar point, offering as one example the lack of the term "hypocrisy" in Isaiah 1:10-15 (Biblical Words and their Meaning [1983] 26ff.).

38 So writes D. R. Hillers, Covenant: The History of a Biblical Idea (1969) 123f. Cf. J. Limburg, "The Root ryb and the Prophetic Lawsuit Speeches" (1969) 291ff. For a different assessment of the prophets, cf., inter alios, E. W. Nicholson, op. cit., 114ff., following L. Perlitt.

In the same regard, cf. F. C. Fensham's discussion directed against Wellhausen concerning "covenant" in the Former Prophets ("Covenant, Alliance," [1980] 330).

39 Cf. Psalm 132 (I am grateful to N. Kiuchi for pointing out this example). M. Weinfeld uses this

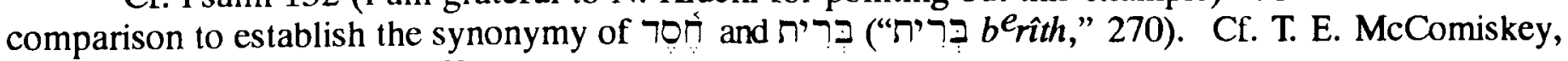
The Covenants of Promise, 59.

40 “Covenant" (1962) 715. Cf. P. Kalluveettil, Declaration and Covenant, 3, n. 12.

41 Jesus and Divorce, 100-103.

42 Ezekiel 1-20, 278.

43 So, H. W. Wolff, Anthropology of the Old Testament (1974) 168, citing E. Kutsch, Verheissung und Gesetz (1973) 134ff. Wolff nevertheless accepts the evidence of Malachi 2:14 and Ezekiel 16:8 as referring to the covenant of marriage.

44 P. F. Palmer appears to consider it to be the only explicit such identification (op. cit., 619-21). 
summary of the reasons currently being advanced for rejecting the traditional exegesis of this passage, which is apparently assumed by the RSV: “... Because the LORD was witness to the covenant between you and the wife of your youth

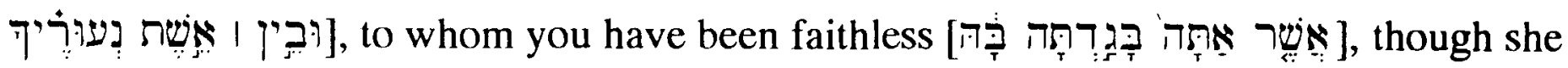

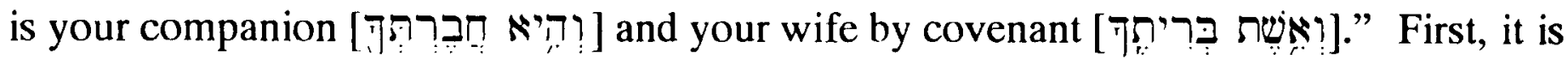
argued by some that the covenant mentioned in Malachi 2:14 cannot refer to a literal marriage because in a literal marriage the partners to the marriage agreement are the groom (or his parents) and the bride's father (or her brother), not the bride and groom as is implied here. 45 Second, because the Old Testament considers that "it is the bride, not the husband, who is subject to the laws of adultery," J. Milgrom, for example, insists that Malachi 2:14 cannot be referring to a literal marriage since it suggests that "the husband rather than the bride violates the covenant." 46 Third, most commentators relate Malachi to the period either just before or contemporaneous with Ezra. ${ }^{47}$ But if Malachi 2:10-16 is taken to refer to literal marriage and divorce, then a contradiction is introduced between the "I hate divorce" of Malachi 2:16 and the program of enforced divorce mentioned in Ezra 10.48 Fourth, if Malachi is as indebted to Deuteronomic ideas as is widely believed, ${ }^{49}$ then on a literal marriage interpretation Malachi unaccountably departs from that dependency by seeming to contradict the provision of divorce presupposed in Deuteronomy 24:1-4.

For these reasons and especially because of its claimed suitability to the larger context of Malachi, B. Vawter, for example, has reiterated a view originally set forth by C. C. Torrey. Vawter argues that the divorce which Yahweh hates is not the dissolution of literal marriages, but the repudiation of "the covenant of our fathers" (vs. 10), which is expressed figuratively as "the wife of your youth" (vs. 14). 50

It has long been recognized that the primary interpretative problem of Malachi 2:1016 is whether to understand this text as referring to a literal marriage or to a symbolic marriage (whether to God, or to the covenant, or to the priesthood). ${ }^{51}$ Unhappily, any

45 A. Isaksson broadens this criticism by asserting that the Old Testament concept of covenant was incompatible with the meaning of marriage at this time (Marriage and Ministry in the New Temple [1965] 27-34).

46 Op. cit., 134.

47 See the discussion in Chapter 1.

48 Thus the passage is interpreted by L. Kruse-Blinkenberg, "The Pesitta [sic] of the Book of Malachi" (1966) 103-104.

49 Cf., e.g., J. Swetnam, "Malachi 1:11 An Interpretation" (1969) 203, and W. J. Dumbrell, "Malachi and the Ezra-Nehemiah Reforms," 42.

50 "The Biblical Theology of Divorce" (1967) 232; C. C. Torrey, "The Prophecy of Malachi" (1898).

51 A symbolic view has been supported by C. C. Torrey, "The Prophecy of Malachi" (1898); H. Winckler, "Maleachi" (1901) 531-9; A. C. Welch, Post-Exilic Judaism (1935); I. G. Matthews, "Haggai, Malachi" (1935); F. F. Hvidberg, Weeping and Laughter in the Old Testament (1962); A. Isaksson, Marriage and Ministry in the New Temple (1965) 27-34; B. Vawter, "The Biblical Theology of Divorce" (1967); G. W. Ahlström, Joel and the Temple Cult of Jerusalem (1971); J. Milgrom, Cult and Conscience (1976); M. Greenberg, Ezekiel 1-20 (1983); G. S. Ogden, "The Use of Figurative Language in Malachi 2:10-16" (1988); and J. M. O'Brien, Priest and Levite in Malachi (1990).

Favouring the literal view are, among others, G. A. Smith, The Books of the Twelve Prophets (1899); A. von Bulmerincq, "Die Mischehen im B. Maleachi" (1926); idem, Der Prophet Maleachi, Vol. 2: 
resolution of this problem depends to a great extent on the interpretation of a number of exceedingly obscure phrases or passages including: "the daughter of a foreign god" $(2: 11) ; 52$ "You cover the Lord's altar with tears" ( $2: 13) ; 53$ and the even more problematic $2: 15$, which has been called "one of the most difficult verses in the OT."54 But unless and until these complex interpretative problems are resolved, appeal cannot be made to Malachi as supportive of covenantal marriage.

It is the purpose of the present study to take these crucial verses in Malachi as our point of departure for a much needed reassessment of the possible covenantal nature of marriage within the Old Testament. Before doing so, however, we must first consider two major impediments which may seem to prohibit such an investigation.

\subsection{Problems with this study}

\subsubsection{Controversies surrounding "covenant"}

Already allusion has been made to the problematic nature of "covenant" within current Old Testament scholarship. ${ }^{55}$ Certainly, if there is no agreement as to the meaning and nature of a בִּרִ , there is not mucis point in going beyond such a foundational problem to contemplate the possible interrelation of Old Testament marriage law and covenantal concepts.

It should be noted, however, that the areas most plagued with uncertainty are unlikely to affect the proposed investigation into the possible identification of marriage as a "covenant [בּּרִית]." This is the case, for example, with the centuries old controversy surrounding a posited "covenant of works" and "covenant of grace" associated with

Kommentar zum Buche des Propheten Maleachi (1932) 289; J. M. Myers, The World of the Restoration (1968); T. Chary, Aggée - Zacharie - Malachie (1969) 259; E. Kutsch, Verheissung und Gesetz (1973) 93f.; S. Schreiner, "Mischehen-Ehebruch-Ehescheidung: Betrachtungen zu Mal 2 10-16" (1979) 207-28; R. L. Smith, Micah-Malachi (1984); P. A. Verhoef, The Books of Haggai and Malachi (1987).

As will be discussed in Chapter 2 , an alternative approach accepts a reference to literal marriage in Malachi 2:10-16, but nevertheless denies that Malachi 2:14 identifies marriage as a covenant. On this approach, the mentioned covenant refers to Israel's covenant with Yahweh, identifying this wife as a fellowIsraelite. Cf., e.g., ad loc., K. Marti, Das Dodekapropheton (1904); W. Nowack, Das kleinen Propheten (1922); E. Sellin, Das Zwölfprophetenbuch (1929-30); and B. M. Vellas, Israelite Marriage (1956) 24. B. Glazier-McDonald similarly identifies the covenant in 2:14 with that mentioned in 2:10, but nevertheless supports an identification of marriage as a covenant in Ezekiel 16:8 and Proverbs 2:17 (Malachi [1987] 101f.).

52 Considered by A. C. Welch to be unparalleled as a description of a non-Jewish woman (op. cit., 120, as cited by R. L. Smith, op. cit., 322f.).

53 F. F. Hvidberg (op. cit., 120.) and A. Isaksson (op. cit., 31-32) relate this to ritual mourning which they feel points to a distinctly cultic interpretation for the בִּרית.

54 A. S. van der Woude, Haggai Maleachi (1982) 121.

55 Here, and throughout our discussion, we shall follow the convention of rendering every occurrence of בִר with the English term "covenant." This is done merely for convenience and without prejudice to the meaning of בִּר כe For a recent defence of the relative suitability of "covenant" as a translation for תכּרִ cf. E. W. Nicholson, op. cit., $105 f$. 
"federal theology." 56 It is also so with the biblical-theological discussion regarding "covenant" as a possible "centre" for Old Testament theology, if indeed there is a "centre." 57 It is also the case with the biblical-theological question concerning the interrelation of the various covenants within the Old Testament and between the testaments. 58

Beyond these more theological questions, there are also several historical / sociological questions regarding "covenant" that remain problematic: Is the concept of a covenant between God and Israel a unique feature of the religion of Israel over against her neighbours?59 What was the precise role of covenant in the formation of Israel? ${ }^{60}$ And what was the precise interrelation between covenant and cult?61

Perhaps the foundational historical question which plagues much of the discussion of "covenant" concerns the antiquity of the concept of "covenant" within Israel62 and whether there is evidence for any significant development of this concept within the Old Testament. 63

Related to these historical questions, and in many respects overshadowing all of the preceding debates, is the attempt over the past four decades to assess and relate to the Old

56 Cf. P. A. Lillback, "Covenant" (1988); W. W. Benton Jr., "Federal Theology: Review for Revision" (1985) 180-204; and J. H. Hughes and F. Prussner, Old Testament Theology (1985) 19.

57 Of course, the most notable example of such a theology is that of W. Eichrodt, Theologie des Alten Testaments, I Leipzig (1933), II (1935), III (1939); ET: Theology of the Old Testament, I (1961), II (1967).

For the present debate concerning the problem of a "centre" in Old Testament theology, cf. G. F. Hasel, "The Problem of the Center in the Old Testament" (1974); idem, Old Testament Theology. Basic Issues in the Current Debate (1975) 77-103; J. H. Hughes and F. Prussner, Old Testament Theology (1985) 257ff.; and H. G. Reventlow, Problems of Old Testament Theology in the Twentieth Century (1985) 125-133.

58 Cf., e.g., R. E. Clements, Abraham and David (1967); F. C. Prussner, "The Covenant of David and the Problem of Unity in Old Testament Theology" (1968) 17-41; F. C. Fensham, "The Covenant as Giving Expression to the Relationship between Old Testament and New Testament" (1971); M. G. Kline, The Structure of Biblical Authority (1975) 145 and passim; R. T. Beckwith, "The Unity and Diversity of God's Covenants" (1987); and I. H. Marshall, "Some Observations on the Covenant in the New Testament" (1990).

$59 \mathrm{~K}$. Baltzer claims that Israel's covenantal relation to her God is unparalleled in antiquity (The

Covenant Formulary, 90, n. 4), while F. C. Fensham says it is well-attested ("Covenant, Alliance," 328).

60 Here attention is particularly focused on M. Noth's hypothesis of an ancient Israelite amphictyony.

Cf. M. Noth, Das System der zwölf Stämme Israels (1930); idem, The History of Israel (1960) 53-109; and the discussion in J. Bright, A History of Israel (1981) $162 \mathrm{ff}$.

61 Cf. S. Mowinckel, who considers the renewal of the covenant in a New Year festival (Tabernacles) to have been a central feature of Israel's cultus (The Psalms in Israel's Worship [1962]). Cf. the discussion in D. J. McCarthy, Old Testament Covenant, $6 \mathrm{f}$.

62 Considered not to be particularly old by G. Fohrer, "Altes Testament - 'Amphiktyonie' und 'Bund'?" (1966) 801-16, 893-904; L. Perlitt, Bundestheologie im Alten Testament (1969); and more recently E. W. Nicholson, op. cit.

Supporting the antiquity of the covenantal concept within the Old Testament are W. Eichrodt, "Prophet and Covenant" (1970); T. C. Vriezen, "The Exegesis of Exodus 24:9-11" (1972); J. Halbe, Das Privilegrecht Jahwes. Ex 34, 10-26 (1975); D. J. McCarthy, Treaty and Covenant; and J. Day, "PreDeuteronomic Allusions to the Covenant in Hosea and Psalm LXXVIII" (1986) 1-12. Cf. also H. G. Reventlow, Problems of OT Theology in the Twentieth Century, 127.

For a summary of this controversy, cf. D. L. Magnetti S.J., "The Oath in the Old Testament in the Light of Related Terms and in the Legal and Covenantal Context of the Ancient Near East," 110f.

63 Cf., e.g., J. Begrich, who argues against the radical development posited by J. Wellhausen ("Berit. Ein Beitrag zur Erfassung einer alttestamentlichen Denkform" [1944]). 
Testament the treaty form(s) and terminology exhibited in numerous Hittite Treaties, the Treaties of Esarhaddon, and the Aramaean Sefire Treaty inscriptions, along with a number of more fragmentary treaties as well as some indirect evidence from Mari and Amarna. 64

Since the early studies of G. E. Mendenhall 65 and K. Baltzer, 66 the debate has raged over the possible presence either of individual elements or of the whole of the "treaty document" literary genre within various texts of the Old Testament including: the Decalogue; ${ }^{67}$ Deuteronomy, either in whole ${ }^{68}$ or in part; ${ }^{69}$ Joshua $23 ; ;^{70}$ Joshua $24 ; 71$ and 1 Samuel 11:14-12:25.72

An important aspect of this debate in applying the treaty form to biblical texts is the need stressed by some scholars to give greater attention to the treaty versus covenant distinction. Perhaps of even greater importance, there appears to be an increasing awareness of the variety of treaty forms and by-forms with which comparisons should be sought. ${ }^{73}$ The more important varieties include: suzerainty (or vassal) treaties, parity treaties, patron treaties, promissory (or grant) treaties, and perhaps still other types; ${ }^{74}$ as well as related by-forms including the law collections, the covenant "lawsuit", and the treaty-like kudurru stones. 75

${ }^{64}$ For a recent survey of the fifty-seven currently extant treaties with their publication data, cf. J. H. Walton, Ancient Israelite Literature in its Cultural Context (1989) 95-107.

65 Law and Covenant in Israel and the Ancient Near East (1955) [= BA 17 (1954) 26-46, 50-76].

66 The Covenant Formulary in Old Testament, Jewish, and Early Christian Writings [from Das Bundesformular, 2nd. rev. ed., 1964] (1971). The first edition of Baltzer's work was published in 1960.

67 Cf., e.g., G. E. Mendenhall, op. cit.; M. G. Kline, "The Two Tables of the Covenant" (1963); K. A. Kitchen, Ancient Orient and Old Testament (1966) 90-102; and A. Phillips, Ancient Israel's Criminal Law. A New Approach to the Decalogue (1970).

More recently Phillips has reversed his earlier position ("The Decalogue - Ancient Israel's Criminal Law" [1983]). Cf. also D. J. McCarthy, Treaty and Covenant, 158-60, 249ff., and F. B. Knutson, "Literary Genres in $P R U$ IV," RSP, II, 175-77.

68 So, e.g., M. G. Kline, Treaty of the Great King (1963); K. A. Kitchen, op. cit., 96-102; M. Weinfeld, Deuteronomy and the Deuteronomic School (1972); and P. C. Craigie, The Book of Deuteronomv (1976).

69 Typically chapters 5-26, 28 (cf. K. Baltzer, The Covenant Formulary, 45f.; D. J. McCarthy, Treaty and Covenant [1981] 158f.; F. B. Knutson, "Literary Genres in PRU IV," RSP, II, 165f.). But elements of the treaty form are commonly seen combined in various subsections of Deuteronomy including, Deuteronomy 1:1-4:40 (K. Baltzer, op. cit., 41-43 vs. D. J. McCarthy, op. cit., 188-194; cf. F. B. Knutson, "Literary Genres in PRU IV," RSP, II, 167ff.); Deuteronomy 4 (cf. M. G. Kline, Treaty of the Great King, 136f.); Deuteronomy 5 (D. J. McCarthy, op. cit., 159f.; F. B. Knutson, RSP, II, 163f.) and Deuteronomy 28:69-30:20 (K. Baltzer, op. cit., 44-5; F. B. Knutson, RSP, II, 168-71).

70 Cf. F. B. Knutson, "Literary Genres in PRU IV," RSP, II, $174 \mathrm{f}$.

71 G. E. Mendenhall acknowledges that while Joshua 24 follows the treaty schema, as a narrative is it not itself the text of a treaty. Cf. also K. A. Kitchen, op. cit., 96ff.; H. B. Huffmon, "The Exodus, Sinai and the Credo" (1965) 104, n. 16.

72 Cf. D. J. McCarthy, op. cit., 141f., F. B. Knutson, "Literary Genres in PRU IV," RSP, II, 171-3, and, especially, J. R. Vannoy, Covenant Renewal at Gilgal (1978).

73 So D. J. McCarthy, op. cit. Cf. also F. B. Knutson, "Literary Genres in PRU IV," RSP, II, 160; and R. P. Gordon, 1 and 2 Samuel, 76.

74 Cf. G. E. Mendenhall, "Covenant Forms in Israelite Tradition" (1954). Cf. also M. Weinfeld, "The Covenant of Grant in the OT and in the Ancient Near East" (1970).

75 H. B. Huffmon, "The Covenant Lawsuit in the Prophets" (1959); G. E. Wright, "The Lawsuit of God" (1962); B. Gemser, The rîb-or Controversy-Pattern in Hebrew Mentality (1955). Cf. E. W. Nicholson, op. cit., $63 \mathrm{f}$. 


\subsubsection{Method of approach}

\subsubsection{The deeper consensus on which we wish to build}

Happily for our purpose, much of the present day confusion concerning "covenant" (particularly regarding issues of theology and literary genre) has little bearing on the question whether marriage in the Old Testament was viewed in covenantal terms. What is necessary, however, for us to begin our investigation is an awareness of the major elements

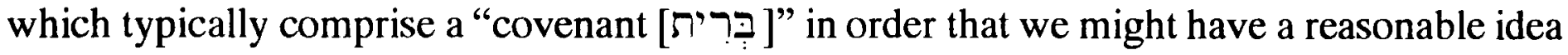
of what to look for. Fortunately, there is a substantial scholarly consensus as to what these elements are.

Anticipating here some of the conclusions of Chapter 6, we may offer the following

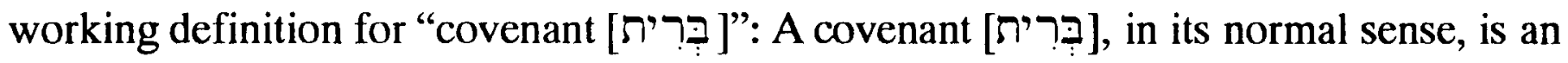
elected, as opposed to natural, relationship of obligation under oath. ${ }^{76}$ Supportive of this emphasis on an elected, as opposed to natural, relationship, D. J. McCarthy remarks that covenant was "the means the ancient world took to extend relationships beyond the natural unity by blood."77

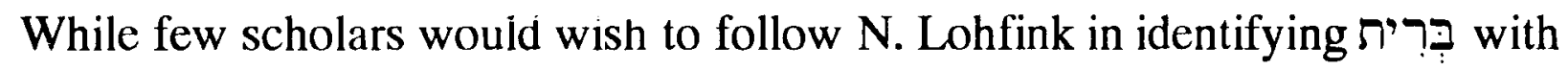
oath, ${ }^{78}$ the indispensability of an oath for ratifying a covenant commands a widespread scholarly consensus. We may note the statement of G. M. Tucker: "the covenant formula was based on the oath pattern and the contract was not."79 Likewise M. Weinfeld states "berith as a commitment has to be confirmed by an oath.... The oath gives the obligation its binding validity...." 80 Hence D. J. McCarthy concludes that the basic idea of a covenant is "a union based on an oath." 81

Accordingly, the lack of an oath in marriage, if it proves to be the case as Milgrom argues, indeed would appear to prohibit marriage from being identified as a "covenant."

76 Cf. also M. G. Kline, who defines relationship or follow a stipulated course of action. In general, then a covenant may be defined as a relationship under sanctions" (By Oath Consigned, 16).

Similar also is the definition offered by G. E. Mendenhall, "A solemn promise made binding by an oath, which may be either a verbal formula or a symbolic oath" ("Covenant," 714). Cf. also M. Newman, "Review of E. Kutsch, Verheissung und Gesetz" (1975) 120; and W. Dyrness, Themes in Old Testament Theology (1979) 113.

${ }_{77}$ Treaty and Covenant, 1st ed., 175. P. Kalluveettil notes "Covenant is relational, in one way or other it creates unity, community" (Declaration and Covenant, 51). But not all would agree. M. G. Kline offers a more general definition, for which see above, which includes either a relationship or a stipulated course of action.

78 Die Landverheissung als Eid, 101-13.

79 "Covenant Forms and Contract Forms" (1965). So also D. J. McCarthy, Old Testament Covenant, 34.

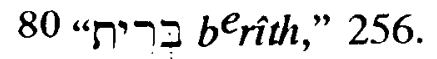

81 Treaty and Covenant, 141. Supportive of this same observation are K. A. Kitchen (who stresses the invariable presence of sanctions and a ratifying oath even when not explicitly mentioned in the covenant document), E. Gerstenberger (cf. F. B. Knutson, "Literary Genres in PRU IV," RSP, II, 158), J. Barr ("Some Semantic Notes on the Covenant," esp. p. 32), and E. W. Nicholson (op. cit., 103). 


\subsubsection{A normative versus a descriptive study}

Finally, it is important to clarify that we are not seeking to elucidate the actual practice of marriage in ancient Israel (the concern of historical anthropology) -- which, no doubt, often fell short of the prophetic ideal. ${ }^{82}$ Ours is rather a study of that ideal: a study of Old Testament canonical ethics. In particular, we shall attempt to establish that Malachi, along with several other biblical authors, identified marriage as a "covenant [פרּרִ ]" and that the implications of such a theory of marriage are not contradicted by other biblical texts, even where the term בִּרִ does not happen to appear.

82 A similar disparity between marital ideal and practice is true for all societies according to Malinowski (as cited by S. F. Bigger, op. cit., vi).

As an analogy, one may compare the Old Testament's teaching regarding monotheism and the apparent rampant polytheism suggested in much of the Old Testament's apologetic and independently attested in archaeology. The admitted presence of the later in no way diminishes either the validity or importance of a study of the former. 


\section{Outline of Chapter 1: The Interpretative Context of Malachi 2:10-16}

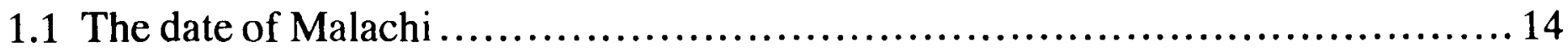

1.1.1 Malachi in relation to Ezra and Nehemiah .............................. 16

1.1.2 Malachi in relation to Dtr and especially P........................... 18

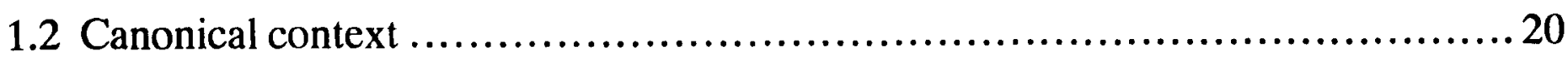

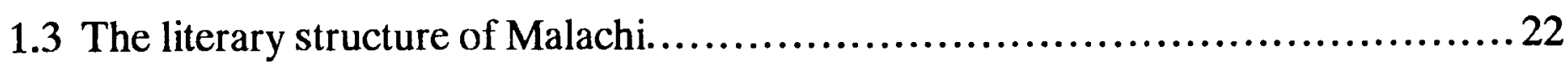




\section{Chapter 1: \\ The Interpretative Context of Malachi 2:10-16}

As indicated in the Introduction, Malachi 2:14 is perhaps the chief pillar of the traditional identification of marriage in the Old Testament as a covenant: "You ask, 'Why does he not?' Because the LORD was witness between you and the wife of your youth, to whom you have been faithless, though she is your companion and your wife by covenant

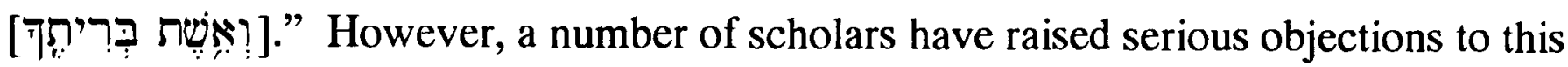
identification, preferring a reference to a figurative marriage, whether between Israel and Yahweh (I. G. Matthews; F. F. Hvidberg; A. Isaksson; and others), or between Israel and the covenant (C. C. Torrey; B. Vawter), or between the priests of Malachi's day and the original priestly community (G. S. Ogden). ${ }^{1}$

Even among scholars who accept a reference to a literal marriage in Malachi 2:10-

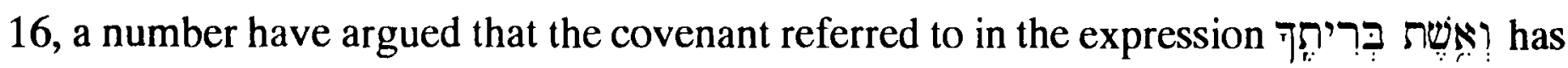
nothing to do with the marital relationship as such, but merely designates the wife as a member of the same covenant community as her husband. In other words, כִּרִ in this context refers to Israel's covenant with God, not to a particular marital covenant between the husband and his wife. ${ }^{2}$

It turns out that the arguments used to support these two distinct interpretative options overlap at significant points, and so for convenience it will be useful to consider them together. In the next chapter we shall focus on arguments which rest mainly on evidence adduced from within the book of Malachi itself. Before doing so, however, it will

1 In addition to J. Milgrom (Cult and Conscience, 133ff.) who holds that ברית in Malachi 2:14 is used only as a "literary metaphor," a symbolic view has been supported by C. C. Torrey, "The Prophecy of 'Malachi'" (1898); H. Winckler, "Maleachi" (1901), who argues that the passage builds on an attack on the Antiochus altar in the temple; A. C. Welch, Post-Exilic Judaism (1935); I. G. Matthews, "Haggai, Malachi" (1935); F. F. Hvidberg, Weeping and Laughter in the Old Testament (1962) 120-123; A. Isaksson, Marriage and Ministry in the New Temple (1965) 27-34; B. Vawter, "The Biblical Theology of Divorce" (1967); G. W. Ahlström, Joel and the Temple Cult of Jerusalem (1971); M. Greenberg, Ezekiel 120 (1983); G. S. Ogden, "The Use of Figurative Language in Malachi 2:10-16" (1988); and J. M. O'Brien, Priest and Levite in Malachi (1990).

2 Cf., e.g., R. Kraetzschmar, W. Nowack, O. Isopescul, and B. Duhm, according to S. R. Driver, The Minor Prophets, 316, and J. M. P. Smith, Malachi, 53. See also footnote 51 on pp. 7f. above.

More recent interpreters who hold this view include A. S. van der Woude, "Malachi's Struggle for a Pure Community" (1986) 68f., W. Rudolph, Haggai, Sacharja 1-8, Sacharja 9-14, Maleachi (1976); idem, "Zu Mal 210-16" (1981); A. Tosato "Il ripudio: delitto e pena (Mal 2,10-16)" (1978) 552, n 19 and p. 553 (where, with Rudolph, the covenant in question is the one between Yahweh and Israel which obligates Israelite men not to marry non-Israelites -- cf. Leviticus 19:17-18); and B. Glazier-McDonald, Malachi (1987).

Some interpreters seem to view $2: 14$ as a reference primarily to Yahweh's covenant with Israel, but also the marriage covenant. Cf., e.g., T. V. Moore, A Commentary on Haggai and Malachi (1856) 134, and A. R. Fausset in A Commentary, Critical and Explanatory on the Old and New Testaments (1887) 738. 
be useful to consider certain matters of introduction to the book of Malachi as a whole in an effort to set our discussion of Malachi 2:14 within a proper interpretative context. In this first chapter, therefore, we propose to consider briefly the date of Malachi; the book's relationship to Ezra, Nehemiah and the pentateuchal sources; and finally the overall arrangement of the book itself.

\subsection{The date of Malachi}

Unlike most of the other prophetic books, the book of Malachi offers no explicit indication of the date of its composition. It mentions no datable event nor any

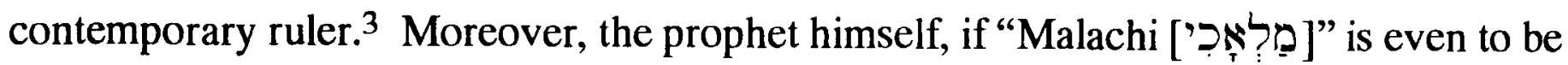
regarded as a proper noun, ${ }^{4}$ is nowhere else mentioned -- not in Ezra, who mentions Haggai and Zechariah $(5: 1 ; 6: 14)$; nor even in Josephus, who mentions most of the major characters of the period. ${ }^{5}$

Nevertheless, there appears to be a scholarly consensus that the book of Malachi was composed at some point within the Persian period (515 - 330 B.C.) and, more particularly, at a time roughly contemporaneous with the ministries of Ezra and Nehemiah in the mid-fifth century B.C. ${ }^{6}$

\footnotetext{
3 It is uncertain whether the mentioned demise of Edom in 1:2-5 should be related to the the campaigns of Nabonidus or, as is more generally thought, to the gradual displacement of the Edomites by the Nabataeans, causing them to relocate in southern Judah. Other historical references appear less likely, as, for example, to the supposed depredations by Arab tribes following the Babylonian downfall. Cf., e.g, J. G. Baldwin, Haggai, Zechariah, Malachi (1972) 223; P. A. Verhoef, The Books of Haggai and Malachi (1987) 203-204; and especially, B. Glazier-McDonald, Malachi: The Divine Messenger (1987) 34-41, who suggests that the Nabataeans may have wreaked their devastation less by military means than by the effects of their grazing herds, destroying previously arable land. Cf. also P. C. Hammond, The Nabataeans (1973) 13; and J. I. Lawlor, The Nabataeans in Historical Perspective (1974).

If the reference is to the displacement by the Nabataeans, unfortunately, this cannot be dated with any certainty.

Alternatively, it is possible that no particular historical event is intended in Malachi 1:3-5, but that Edom is cited merely as a representative enemy. Cf., e.g., C. C. Torrey, "The Edomites in Southern Judah" (1898) 20; R. A. Mason, The Books of Haggai, Zechariah, and Malachi (1977) 141; P. R. Ackroyd, "The History of Israel in the Exilic and Post-Exilic Periods" (1979) 332; and R. J. Coggins, Haggai, Zechariah, Malachi (1987) 75.

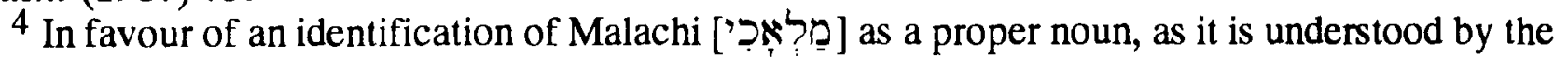
Peshitta, Theodotion, Symmachus, and the Vulgate, with 3:1 offering a word-play on the prophet's name, cf., e.g., J. G. Baldwin (Haggai, Zechariah, Malachi [1972] 211-213), W. Rudolph (Haggai, Sacharja 1-8, Sacharja 9-14, Maleachi [1976] 247f.), B. S. Childs (Introduction to the Old Testament as Scripture [1979] 493f.), and P. A. Verhoef (The Books of Haggai and Malachi [1987] 154-156).

If the meaning of מִ מלאי is felt to be unacceptable, with A. von Bulmerincq, W. Rudolph, and others,

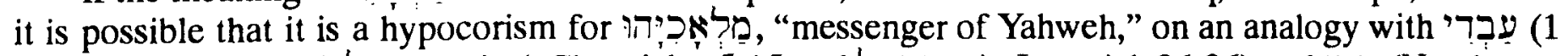

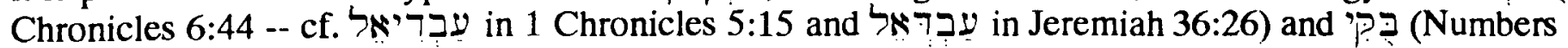
34:22; Ezra 7:14 -- cf. כיק 1 in 1 Chronicles 25:4,13).

5 Antiquities XI, iv, i-v, 8. Malachi is mentioned, however, in the second century A.D. book 2 Esdras.

6 Cf., e.g., S. R. Driver, The Minor Prophets (1906) 287-93; W. H. Schmidt, Introduction to the Old Testament (1984) 281; and R. L. Smith, Micah - Malachi (1984) 298-299.
} 
The following arguments have been adduced in support of this approximate dating of Malachi:

1) The canonical placement of Malachi at the end of the Minor Prophets, which in part reflects a chronological arrangement, offers some confirmation for a post-exilic date. ${ }^{7}$

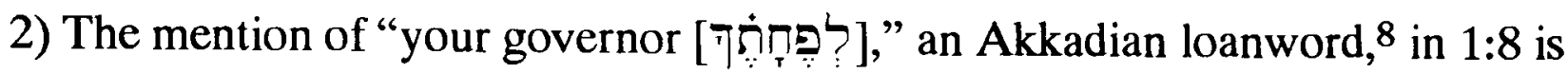
thought to point to the Persian period -- especially since Judah was not administered by "governors" in the pre-exilic period. Cf., e.g., the use of פָָ as a designation for Zerubbabel in Haggai 1:1, 14; 2:2, 21 and for Nehemiah in Nehemiah 5:14, 15, 18; $12: 26.9$

3) Malachi presupposes the existence of the temple $(1: 10 ; 3: 1,8)$ and so is to be dated after its erection in 516 B.C.

4) The problem of hypocritical formalism and apathy which Malachi addresses (1:6$14 ; 2: 1-9 ; 3: 6-12)$ suggests a considerable period of decline from the standard of temple worship which may be supposed to have attended the ministries of Haggai and Zechariah. ${ }^{10}$

5) Many of the sins reproved by Malachi are those addressed by Ezra and Nehemiah, suggesting that these were roughly contemporaneous. Cf., e.g., the issue of corruption of the priesthood (Malachi 1:6-2:9; Nehemiah 13:4-9, 30); mixed marriage (Malachi 2:10f.; Ezra 9-10; Nehemiah 10:31 [ET 30]; 13:1-3, 23-27); abuse of the disadvantaged (Malachi 3:5; Nehemiah 5:1-5); and the failure to pay tithes, etc. (Malachi 3:8; Nehemiah 10:33-40 [ET 32-39]; 13:10-13). ${ }^{11}$

6) The allusion to Malachi 3:24 [ET 4:6] in Sirach 48:10 and the mention of "the twelve prophets" in 49:10 imply that the book could not be later than 180 B.C. This refutes the view of $\mathrm{H}$. Winckler, for example, who dates Malachi to the period of Antiochus. ${ }^{12}$

In addition to the more general parallels between Malachi and Ezra and Nehemiah enumerated above, we may suggest several further parallels specifically between Nehemiah and Malachi 2:10-16. In particular, the mention of godly children in Malachi 2:15 may explain or be compared to Nehemiah's emphasis on the unholy children born of interfaith marriages (Nehemiah 13:24). Second, in addition to the parallel between Nehemiah 13:29

7 On the approximate chronological order of the minor prophets, cf. R. Rendtorff, The Old Testament (1985) 215f. -- an order supported by the opening formulae (so G. M. Tucker, "Prophetic Superscriptions and the Growth of a Canon" [1977]).

8 Cf. KB, 872; $A H w$ 120a Nr. 18 [bēl pīhăti / pähăati]. Cf. also G. Widengren, "The Persian Period" (1970) 510 , as cited by B. Glazier-McDonald, op. cit., 15.

9 Although a reference to Persian appointees is the predominant use of פע, the term is capable of being used more generally. Cf., e.g., 1 Kings 10:15; 20:24; 2 Kings 18:24; Isaiah 36:9; Jeremiah 51:23, 28, 57; Ezekiel 23:6, 23; and 2 Chronicles 9:14.

10 So, e.g., P. A. Verhoef, op. cit., 157.

11 These points of contact are so impressive that J. Blenkinsopp wonders if the "messenger of the covenant" in Malachi 3:1 may be Nehemiah (Ezra - Nehemiah, A Commentary [1988] 365f.)!

12 So R. L. Smith, op. cit., 299. 
and the corrupted covenant of Levi in Malachi 2:4, 8 (which is unrelated to marital offences), there is a further parallel between Nehemiah 13:29 and the profaning of "the covenant of our fathers" in Malachi 2:10 which is the result of a marital offence. Finally, Nehemiah's imprecation in 13:25, 29 and his remedy of excommunication in 13:28 may both be compared to Malachi 2:12, where Malachi's curse implies excommunication. ${ }^{13}$

Given the meagre state of the available evidence, however, attempts at greater precision in dating Malachi are bound to be speculative. ${ }^{14}$ Nevertheless, scholars have sought to date Malachi more exactly based mainly on one of two lines of argumentation. The first approach attempts to correlate Malachi's ministry with that of Ezra and Nehemiah. The second approach, which can be complementary to the first, seeks evidence in Malachi for dependence on Deuteronomic and/or Priestly material.

\subsubsection{Malachi in relation to Ezra and Nehemiah}

The attempt to correlate Malachi's ministry with that of Ezra and Nehemiah is complicated by the uncertainty regarding the relative chronology of Ezra and Nehemiah. ${ }^{15}$ The traditional view, still held by a majority of scholars, considers that Ezra preceded Nehemiah and arrived in Jerusalem about 458 B.C. Nehemiah came for his first term about 445 B.C., worked together with Ezra for a period of 12 years, and returned to Susa about 433 B.C. After an unknown period away, Nehemiah returned for a second visit to Jerusalem, also of unknown duration. An alternative chronology argues that Nehemiah's ministry preceded that of Ezra.

With respect to the more precise attempts to date Malachi, there are five possible views: 1) Malachi precedes Nehemiah and probably also Ezra;16 2) Malachi precedes Nehemiah, but perhaps not Ezra;17 3) Malachi coincides with Nehemiah's ministry;18 4)

13 Cf. F. C. Fensham, op. cit., $267 \mathrm{f}$.

14 So, e.g., R. A. Mason, The Books of Haggai, Zechariah and Malachi (1977) 137-139; P. R. Ackroyd, "The History of Israel in the Exilic and Post-Exilic Periods" (1979) 332; R. J. Coggins, op. cit., 74-75; and R. R. Deutsch, "Calling God's People to Obedience" (1987) 67f.

15 Cf., e.g., H. H. Rowley, "The Chronological Order of Ezra and Nehemiah" (1948).

For a defence of the traditional order, cf. E. M. Yamauchi, "The reverse order of Ezra/Nehemiah reconsidered" (1980) 7-13, and H. G. M. Williamson, "The Chronological Order of Ezra and Nehemiah," in Ezra, Nehemiah (1985) xxxix-xliv.

16 B. S. Childs considers this view to be held by a majority of critical scholars (Introduction, 489).

Cf., e.g., D. K. Marti (1904); B. Stade (1905); A. van Hoonacker (1908); W. Nowack (1922); A. von Bulmerincq (1926 -- who suggests that Malachi was Ezra's assistant and that Ezra was none other than the

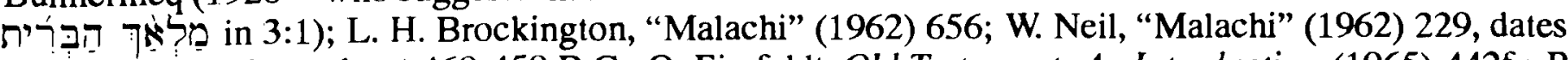
Malachi somewhere about 460-450 B.C.; O. Eissfeldt, Old Testament: An Introduction (1965) 442f.; R. K. Harrison, Introduction to the Old Testament (1969) 960f.; J. G. Baldwin, Haggai, Zechariah, Malachi (1972) 213; and W. J. Dumbrell, "Malachi and the Ezra-Nehemiah Reforms" (1976).

17 Among others, this view is held by J. T. Marshall, "The Theology of Malachi" (1896) 16f.; G. A. Smith, The Book of the Twelve Prophets II (1899) 337f. (who does not discount the possibility that 
Malachi ministered between Nehemiah's two visits to Jerusalem; ${ }^{19}$ and 5) Malachi follows both Ezra and Nehemiah. ${ }^{20}$ However, the arguments which have been advanced for each of these alternatives appear inconclusive.

With respect to the evidence of Malachi 2:10-16 in relation to Ezra and Nehemiah, we need to consider only one argument which has been advanced: namely that Malachi should be dated after Ezra on the assumption that Malachi's repudiation of divorce in 2:16' is the result of the bitter experience of Ezra's enforced program of divorce. ${ }^{21}$ However, on closer examination it appears that Malachi shares Ezra's abhorrence of mixed marriage (Malachi 2:10-12) and condemns it in the strongest possible terms as infidelity [בגד], as a

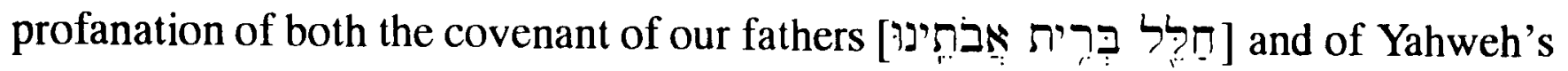

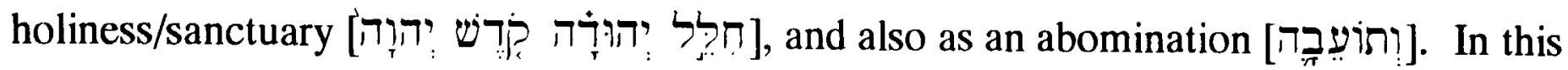
light, regardless of how the curse in Malachi 2:12 is to be interpreted, it is doubtful that Malachi would have countenanced any lesser remedy than the dissolution of these marriages for so grave an offence. On the other hand, whatever the relation between 2:1012 and 2:13-16, most scholars assume that 2:14-15 implies that the divorces which Malachi condemns in 2:16 are divorces of Jewish rather than pagan wives, and so Malachi's condemnation of divorce appears unrelated to the enforced divorces of Ezra's day. ${ }^{22}$

Although the evidence does not allow us to be sure whether Malachi preceded, followed, or was a contemporary of Ezra and Nehemiah, that he preached in the same general period is assured, and this is significant for the interpretation of the text.

Malachi may have preceded both Ezra and Nehemiah); and most recently, W. C. Kaiser Jr., Malachi. God's Unchanging Love (1984) 15-17.

18 This view is held by, among others, H. Cowles, The Minor Prophets (1867) 383f., 392 [Cowles considers that the "second time" in Malachi 2:13 "means ye have a second time relapsed into this great sin; the first time being that great apostasy from which they were reclaimed under Ezra. (See Ezra 9)"]; J.

Packard, The Book of Malachi (1876) 3; C. F. Keil, The Twelve Minor Prophets, II (1868); W. H. Lowe, "Malachi" (n.d.) 597f.; and C. von Orelli, The Twelve Minor Prophets (1893).

19 Cf. especially P. A. Verhoef, The Books of Haggai and Malachi, 158. Cf. also A. F. Kirkpatrick, The Doctrine of the Prophets (1907) 500-502; and R. L. Alden, "Malachi" (1985) 701f. (though, cf. p. 703).

20 T. T. Perowne, Malachi (1908) 10; G. V. Smith, "Malachi" (1986) 227.

Arguing for dates in the fourth century B. C. are F. Hitzig, Die zwölf kleinen Propheten (1881); and I. G. Matthews, "Haggai, Malachi," viii-x.

Arguing for a third century B.C. is O. Holtzmann ("Der Prophet Maleachi und der Ursprung des Pharisäerbundes" [1931]), and for a second century B.C. date is H. H. Spoer ("Some New Considerations towards the Dating of the Book of Malachi" [1908] 179f.) -- the latter, based on the contradiction between Malachi and Ezra on the subject of divorce.

21 Cf., e.g., L. Kruse-Blinkenberg, "The Pesitta [sic] of the Book of Malachi" (1966) 103f. H. H. Spoer, likewise, considers the contradiction between Malachi and Ezra on the subject of divorce to be supportive for dating Malachi well after Ezra -- he dates Malachi about 150 B.C. ("Some New Considerations towards the Dating of the Book of Malachi" [1908] 179f.). Alternatively, G. V. Smith argues that Malachi's stance against the divorce of Israelite wives was a necessary corrective to an assumed illegitimate extension of Ezra and Nehemiah's prior permission for the divorce of foreign wives ("Malachi" [1986] 227).

$22 \mathrm{Cf}$. also the fuller discussion of Malachi 2:16 in Chapter 3 below. 


\subsubsection{Malachi in relation to Dtr and especially $P$}

We turn now to the second line of argumentation which attempts a more precise dating of Malachi based on its dependence on Deuteronomic and/or Priestly material.

In 445 B.C. the "law" accepted by the people of Israel in Nehemiah 8:13-18 and 10:33-40 [ET 32-39] (cf. also Ezra 7:12, 25-26) clearly included the Priestly legislation of the Pentateuch and, according to most scholars, was identical with our present Pentateuch, or nearly so. ${ }^{23}$ This has been used to prove a late dating for the $\mathrm{P}$ source and a corresponding earlier date for Malachi, prior to 445 B.C. Accordingly, scholars have often stressed the evidence for "Deuteronomic" influence in Malachi over against a supposed lack of evidence for any influence from the "Priestly Code."24

Perhaps the clearest example of Deuteronomic influence may be seen in Malachi's understanding of the right of Levites to serve at the altar, rather than reserving this prerogative for the priests (the exclusive right of priests in this regard has been considered by most scholars since J. Wellhausen, including J. Milgrom, to be a distinguishing characteristic of P). ${ }^{25}$ More exactly, Malachi does not distinguish clearly between "priests

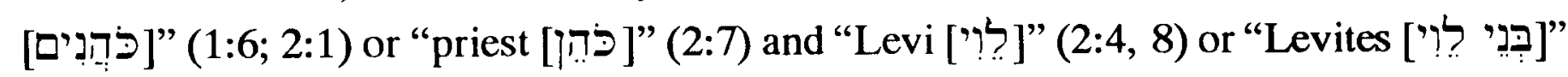
$(3: 3) .^{26}$

Other possible examples of Deuteronomic influence include Malachi's mention of a male animal for sacrifice in Malachi 1:14, where the Priestly Code permits either male or

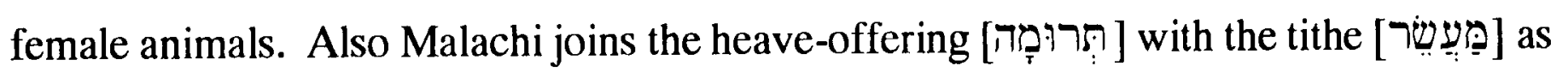
does Deuteronomy, while the Priestly Code separates them, assigning the heave-offering to the priests rather than the Levites. ${ }^{27}$

On the other hand, with respect to other aspects of tithing Malachi seems to anticipate the insistence of the Priestly Code that all tithes are to be paid in Jerusalem, where they are to be stored, while Deuteronomy has the triennial tithe paid to the Levites and poor in their city gates, where they are to be eaten. ${ }^{28}$ Aware of this slight departure from the

23 Cf. "The Identification of the Book of the Law," in H. G. M. Williamson, Ezra, Nehemiah, xxxviixxxix. Cf. also S. Japhet, "Law and 'the Law' in Ezra-Nehemiah" (1988).

24 E.g., cf. O. Eissfeldt, The Old Testament: An Introduction, 443; C. Stuhlmueller, "Malachi" (1970) 398f. Stuhlmueller lists the following allusions to Deuteronomy: Malachi 1:9 with Deuteronomy 10:17; Malachi 1:12 with Deuteronomy 7:8; Malachi 2:1, 4; 3:3 with Deuteronomy 18:1; Malachi 2:6 with Deuteronomy 33:10; Malachi 3:22 with Deuteronomy 4:10. Cf. also B. Glazier-McDonald, op. cit., p. 73, n. 126.

25 Cf., e.g., E. Rivkin, "Aaron, Aaronides," 1-3.

26 While this assumed synonymy of "priests" and "levites" in Malachi has been challenged by $\mathrm{K}$. Elliger (Maleachi, 189), it has been carefully argued by J. M. O'Brien (Priest and Levite in Malachi [1990] 143f., and passim). Cf. also G. S. Ogden and R. R. Deutsch, A Commentary on the Books of Joel and Malachi, 93.

27 For a more complete listing of Deuteronomic words and phrases within Malachi, cf. A. von Bulmerincq, Der Prophet Maleachi, 1., $436 \mathrm{f}$.

28 So, e.g., J. M. P. Smith, op. cit. 
provisions of Deuteronomy, J. Wellhausen and J. M. P. Smith considered Malachi to be a kind of "missing link" between D and P.29

However, more recent scholars have challenged Wellhausen's views concerning the literary nature and supposed lateness of $P, 30$ and many would now question the earlier conviction that Malachi was unaware of Pentateuchal material assigned to P. ${ }^{31}$ For example, it has often been noted that Malachi does not use the distinctive Deuteronomic

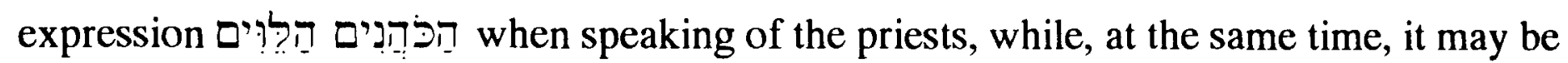
questioned whether Malachi's designation for the priests as "sons of Levi" necessarily proves his ignorance of the Priestly Code. Refuting Wellhausen's oversimplification of the evolution of Israel's religious development, B. Glazier-McDonald has argued that a division in clerical orders long preceded Malachi and that Malachi's stress on the Levitical descent of the priests merely accords with post-exilic practice. ${ }^{32}$ In addition, the "covenant with Levi" is more likely intended as a reference to Numbers 25:12f. than to Deuteronomy 33:10 or Jeremiah 33:20. 33 Furthermore, Glazier-McDonald notes that Malachi's treatment of the תמרוּמָה (which she renders "levy, contribution") actually accords quite well with the provisions of Numbers 18:26f.34 Moreover, with respect to his treatment of tithes, "Malachi's presuppositions are best met by the provisions found in the Priestly Code, cf. Lev 27:30f and Num 18:21-31."35 Additional evidence of dependence on the Priestly Code has been argued by M. Fishbane, who demonstrates how Malachi 1:6-2:9 offers an artfully crafted aggadic exegesis of Numbers 6:23-27.36

29 Op. cit., 7-9.

30 Among those who consider the $P$ material to be the result of editorial activity, rather than a literary source, are F. M. Cross Jr., Canaanite Myth and Hebrew Epic (1973), and R. Rendtorff, The Old Testament. An Introduction (1985).

Among those who have argued for the antiquity of $\mathrm{P}$, including the suggestion that the $\mathrm{P}$ source may well antedate J, are S. R. Külling, Zur Datierung der "Genesis-P-Stücke," namentlich des Kapitels Genesis 17 (1964); G. A. Rendsburg, "Late Biblical Hebrew and the Date of P" (1980); idem, "A New Look at the Pentateuchal HW" (1982); idem, The Redaction of Genesis (1986); A. Hurvitz, "The Evidence of Language in Dating the Priestly Code; A Linguistic Study in Technical Idioms and Terminology" (1974); idem, A Linguistic Study of the Relationship between the Priestly Source and the Book of Ezekiel: A New Approach to an Old Problem (1982); idem, "The Language of the Priestly Source and its Historical Setting - the Case for an Early Date" (1983); Z. Zevit, "Converging Lines of Evidence Bearing on the Date of P" (1982); J. G. McConville, "Priests and Levites in Ezekiel: A crux in the interpretation of Israel's History" (1983) 3-31; M. Weinfeld, "Social and Cultic Institutions in the Priestly Source against their Ancient Near Eastern Background" (1983) 95-129; and G. J. Wenham, Genesis 1-15 (1987) xxxi-xlv.

31 Cf. especially E. M. Meyers, "Priestly Language in the Book of Malachi" (1986); B. GlazierMcDonald, Malachi. The Divine Messenger (1987) 73-80 and passim; J. M. O'Brien, “Torah and Prophets: Malachi and the Date of the Priestly Code" (1988) and idem, Priest and Levite in Malachi (1990).

32 Op. cit., 76ff. Cf. also W. Rudolph, op. cit., 267.

33 So, according to B. Glazier-McDonald, op. cit., 77-80.

34 Ibid., 190. Glazier-McDonald erroneously cites "Num 26:26f."

35 Ibid.

36 Biblical Interpretation in Ancient Israel (1985) 332-334. This particular argument has been challenged by J. M O'Brien on the grounds that the priestly blessing may predate P ("Torah and Prophets: Malachi and the Date of the Priestly Code"). Fishbane's conclusions, however, are supported by E. M. Meyers, "Priestly Language," 225, among others. 
Summarizing her study of Malachi's relation to the Priestly Code, J. M. O'Brien notes simply that Malachi appears to be aware of $P$, though it does not follow $P$ exactly, and similarly Malachi appears to be aware of $D$, although once again it does not follow $D$ precisely. ${ }^{37}$ Putting this observation somewhat differently, rather than hypothesizing an on-going "Deuteronomic School" or "Priestly School" with their divergent traditions possibly influencing Malachi, it appears more plausible with D. L. Petersen to suppose that Malachi merely adduced motifs which are paralleled in earlier Deuteronomic or Priestly literature or, even better, that Malachi made textual allusions to the then written and received Torah, as it existed in his day. ${ }^{38}$

Although there is uncertainty among scholars concerning the originality of Malachi

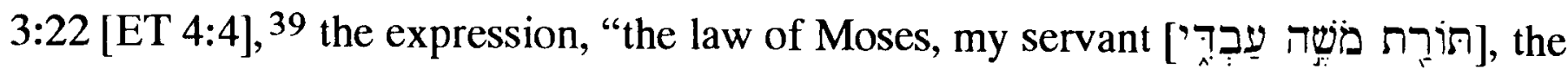
decrees and laws I gave him at Horeb for all Israel," appears as a plausible instance of synecdoche intended to encompass the Pentateuch as a whole, even though large portions of the Pentateuch do not present themselves as having been received at Horeb. 40

\subsection{Canonical context ${ }^{41}$}

Accordingly, although the evidence is insufficient to support a precise dating of Malachi, it is apparent that its post-exilic origin permits it to be heir to a substantial body of received scripture and that this "canonical context" may be of even greater import for exegesis than the elusive historical context of Malachi. This is so because at almost every

37 J. M. O'Brien, “Torah and Prophets: Malachi and the Date of the Priestly Code” (1988), and idem, Priest and Levite in Malachi (1990).

38 In comments made during the Israelite Prophetic Literature Section, Annual Meeting of the Society of Biblical Literature, Chicago, IL, November 20, 1988.

39 Denying the originality of Malachi 3:22 [ET 4:4] are, among others, K. Elliger (1956), W. Rudolph (1976), R. A. Mason (1977), A. Deissler (1981), A. S. van der Woude (1982), R. L. Smith (1984), and R. J. Coggins (1987).

The originality of Malachi 3:22 [ET 4:4] is favoured, however, by W. Nowack (1922), E. Sellin (1929), G. Smit (1934), A. von Bulmerincq (1926), H. Junker (1938), D. Deden (1953), J. Ridderbos (1968), H. Frey (1963), J. G. Baldwin (1972), S. Schreiner (1979), P. A. Verhoef (1972; 1987), B. GlazierMcDonald (1987), and J. M. O'Brien (1990).

However, W. Nowack, E. Sellin, G. Smit, and D. Deden consider 3:23-24 [ET 4:5-6] to be secondary.

Perhaps the most objective evidence for the secondary nature of 3:22-24 [ET 4:4-6] is found in the LXX which reverses the order of the appendices, placing the Moses appendix after the Elijah appendix. S. L. McKenzie and H. N. Wallace see in this an evidence that the appendices "were not completely fixed in form at the time of the separation of the traditions to which the MT and the LXX belong" ("Covenant Themes in Malachi," 560 n. 34). However, it is possible that the LXX was motivated by the same concern which led to the later rabbinic practice of repeating 3:22 [ET 4:4] after 3:24 [ET 4:6], namely, the desire to end Malachi on a more positive note (a practice followed also in the case of Isaiah, Lamentations, and Ecclesiastes). Cf. P. A. Verhoef, The Books of Haggai and Malachi, 344.

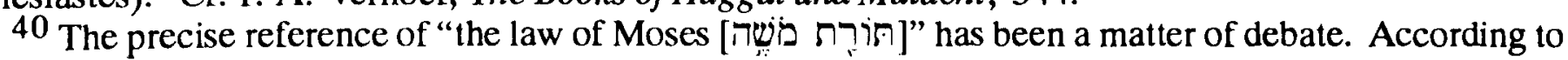
A. von Bulmerincq, for example, it refers to the "lawbook" of Ezra, while J. Wellhausen and R. Rendtorff (The Old Testament. An Introduction, 242) equate it with Deuteronomy. On the other hand K. Marti, J. G. Baldwin (op. cit., 251), and J. M. O'Brien suggest that it refers to the entire Pentateuch.

${ }^{41}$ For an discussion of the significance of Malachi in its canonical placement at the close of "The Twelve," cf. P. R. House, The Unity of the Twelve (1990). 
point Malachi betrays an intense interest in applying and (re)interpreting antecedent scripture -- very much in the spirit of Malachi 3:22 [ET 4:4]. 42 Such appears to be the case with Malachi's major emphases, especially his exceptional interest in "covenant [בר? $(2: 4,5,8,10,14 ; 3: 1) .{ }^{43}$ As stressed by R. L. Smith, Malachi's dependence on the work of the Deuteronomists is not simply a matter of shared isolated vocabulary, it is also a matter of motifs and perspective (cf., e.g., the theme of election, though the term does not appear in Malachi 1:2-3). 44 Accordingly R. J. Coggins observes: "Malachi appears to have been attempting to apply the particular emphases of the Deuteronomists in the circumstances of his own day."45

In a similar manner, $\mathrm{H}$. Marks notes that, typical of the post-exilic prophets, "the author of Malachi uses intertextual echoes to sharpen his protest against current abuses [of the temple cult]."46 Marks has in mind the probable "echo" in Malachi 1:6-2:9 mentioned above, which finds here an extended allusion to and ironic reversal of the Priestly Blessing in Numbers 6:23-27.47 However, this is hardly an isolated example. Similar "echoes" are evident in texts such as Malachi 1:2f. (Esau and Jacob) and 3:12 ("Then all nations will call you blessed," cf. Genesis 12:3). Compare also A. Tosato's suggestion that Malachi 3:5 may refer to Leviticus 19.48

Although B. S. Childs considers 3:23f. [ET 4:5f.] to be secondary, his claim that the appeal to Elijah is informed by typological analogy, if true, suggests a nearly identical hermeneutic with that found elsewhere in Malachi: "Like Malachi, Elijah addressed 'all Israel' (1 Kings 18:20). The people of Israel were severely fragmented by indecision of faith (18:21). A curse had fallen on the land (18:1// Mal. 3:24, EVV 4:6). Elijah challenged all Israel to respond to God by forcing a decision between the right and the

42 Cf. H. Marks, "The Twelve Prophets" (1987) 231f. Cf. also Malachi 3:6.

43 C. T. Begg sets Malachi alongside Hosea, Jeremiah, Ezekiel, and Deutero/Trito-Isaiah as comprising one of the three great tradition-complexes, namely, the prophetic, within which the term fị figures prominently (" $B e_{\text {rit }}$ in Ezekiel" [1986] 79). The other two tradition-complexes are the Deuteronomic/Deuteronomistic (with which Malachi has strong affinities), and the Priestly.

Stressing the centrality and sophistication of "covenant" within Malachi, cf. J. G. Baldwin, op. cit., 216f.; L. C. H. Fourie, "Die betekenis van die verbond as sleutel vir Maleagi" (1982), as cited by P. A. Verhoef, op. cit., 180, n. 2; S. L. McKenzie and H. N. Wallace, "Covenant Themes in Malachi" (1983); R. L. Smith, "The Shape of Theology in the Book of Malachi" (1987) 24; and P. A. Verhoef, The Books of Haggai and Malachi, 179-184.

44 Op. cit., 300. So also R. J. Coggins, Haggai, Zechariah, Malachi, 76.

45 Op. cit., 76.

46 "The Twelve Prophets," 229.

47 M. Fishbane, Biblical Interpretation in Ancient Israel (1985) 332-334; E. M. Meyers, "Priestly Language," 225; and H. Marks, "The Twelve Prophets" $229 \mathrm{f}$.

Malachi 2:1-9 may also include echoes of Deuteronomy 33:8-11, as noted by R. R. Deutsch, "Calling God's People to Obedience" (1987) 71.

48 A. Tosato, "Il ripudio: delitto e pena (Mal 2,10-16)" (1978) 553. Tosato similarly compares Lev. 19:17-18 (and also 19:34) to Malachi 2:10 and 16.

C. Stuhlmueller argues for a literary dependence of Malachi on Ezekiel, based on a number of plausible allusions: cf. Malachi 1:7, 12 with Ezekiel 44:16; Malachi 1:11 with Ezekiel 36:23; Malachi 2:3 with Ezekiel 5:10; 6:5; 12:15; 30:36; and Malachi 3:2 with Ezekiel 44:27 (“Malachi” [1970] 398f.).

Malachi 1:11 may echo Isaiah 45:6; 59:19; and 66:20-1 (cf. also Psalm 50:1; 113:3; Zephaniah 3:9-10; Zechariah 2:15). 
wrong (// Mal. 3:18). He did it by means of the right offering (// Mal. 3:3) and a fire which fell from heaven (// Mal. 3:3, 19).... The appendix served to equate the hearers of Malachi's prophecy - along with future generations who heard his words in scripture with the disobedient, vacillating people whose national allegiance to the God of their fathers was in danger of being dissolved." 49

Summing up, we conclude that the book of Malachi derives from a period roughly contemporaneous with the ministries of Ezra and Nehemiah in the mid-fifth century B.C. This dating shifts the burden of proof onto those scholars who deny that Malachi shared Ezra's and Nehemiah's concern with the problem of literal mixed marriage. Furthermore, having drawn attention to Malachi's corresponding "canonical context," which allows it to be heir to a substantial body of received scripture, including the Pentateuch in particular, the interpreter is prepared for the possibility that Malachi 2:10-16 may presuppose or allude to that antecedent scripture. For example, we shall argue in Chapter 5 below that Malachi 2:15 alludes to Genesis 2, which is central to the argument of Malachi 2:10-16. This allusion may be suggested already in $2: 10$ by its use of the imagery of creation, ${ }^{50}$ and it may be further anticipated in 2:14, if its ideal of marriage parallels Genesis 2.51 Beyond this indebtedness to Pentateuchal traditions, Malachi 2:10-16 appear also to echo Proverbs $2: 16 f .52$

On the other hand, this awareness of Malachi's canonical context only heightens the apparent contradiction between the prohibition of divorce in 2:16 and a text such as Deuteronomy 24:1-4 with its seemingly quite lenient attitude toward divorce. This difficulty will be considered in more detail in Chapter 3 below.

\subsection{The literary structure of Malachi}

Having explored the wider historical and literary context of Malachi, we turn now to examine the literary structure of Malachi as a whole, and of Malachi 2:10-16 in particular,

49 Introduction, 495f. Cf. also B. Glazier-McDonald, who shares a similar view to that of Childs regarding 3:22-24 [ET 4:4-6], but accepts this passage as original to Malachi (Malachi, 243-270, esp. 257).

Malachi 3:22-24 [ET 4:4-6] may also include echoes of Deuteronomy 34:10-12 and Joel 3:4 [ET 2:31]. Cf. B. S. Childs, Introduction, 495; B. Glazier-McDonald, Malachi, 253.

50 This allusion is indirect, however, since the creation immediately in view in $2: 10$ is not the primeval creation, but the recapitulation of creation in the formation of Israel in the Exodus.

51 So, e.g., W. C. Kaiser Jr., Malachi, 70. Although S. Schreiner does not accept an allusion to Genesis 2 in 2:15a, he too recognizes a possible allusion to Genesis 2:23f. in the wider context of Malachi 2:15, citing Tob 8:6ff. as a parallel (op. cit., 226). According to Schreiner, this possibility was also favoured by J. Saurin, Kurtzer Entwurff [sic] der Christlichen Theologie und Sitten-Lehre (= abregé de theologie et morale chretienne, dt.) (1723) 473.

52 This point is argued by A. Robert, "Les attaches litteraires bibliques de Prov. I-IX" (1934/35) especially 44:505-25; and C. V. Camp Wisdom and the Feminine in the Book of Proverbs, 235-237 and 269-271. Cf. also $\$ 8.2 .2$ below. 
in the hope that by understanding this immediate context of 2:10-16 we may appreciate its concerns more adequately.

There is a widespread scholarly consensus that the book of Malachi is carefully structured in terms of a heading (1:1), followed by six quite distinct pericopes or "disputations" (1:2-5; 1:6-2:9; 2:10-16; 2:17-3:5 [or 3:6]; 3:6 [or 3:7]-12; 3:13-21 [ET 4:3]), followed by a closing "appendix" (3:22-24 [ET 4:4-6]). 53 Each of these disputational units is relatively coherent in its content and is introduced with an assertion made either by Yahweh or by the prophet: "I have loved you..." (1:2); "A son honours his father, and a servant his master. If then I am a father, where is my honour..?" (1:6f.); "Have we not all one father? Has not one God created us? Why then are we faithless to one another..." (2:10); "You have wearied the Lord with your words" (2:17); "For I the Lord do not change..." (3:6f.); "Your words have been stout against me, says the Lord" (3:13). ${ }^{54}$ In each unit also the opening assertion is followed by an anticipated challenge

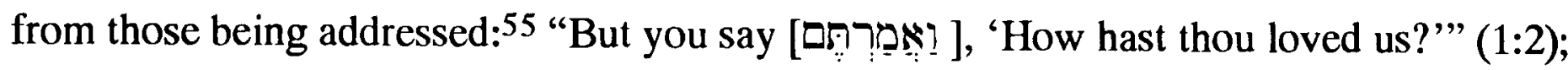

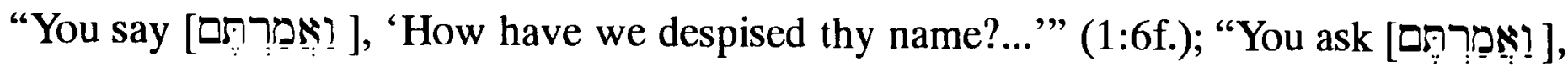
'Why does he not?"” (2:14); "Yet you say [ו]

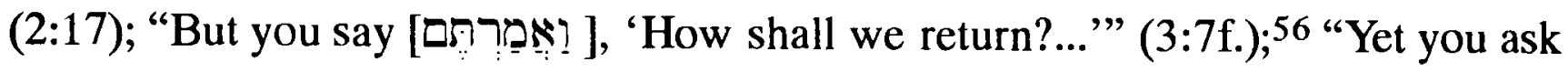

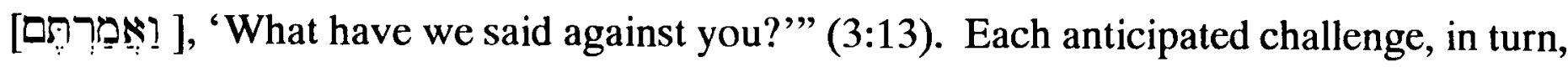
is answered with fuller substantiation by Yahweh or the prophet speaking in Yahweh's behalf. This structure is further reinforced and unified by the repetition of important themes, such as the imagined ignorance or indifference of Yahweh to apathetic worship and to evil-doers, especially as this indifference appears to be revealed in the prosperity of the

53 Favouring the above analysis are, among others, E. Pfeiffer, "Die Disputationsworte im Buche Maleachi" (1959); W. Neil, "Malachi" (1962) 230f.; O. Eissfeldt, The Old Testament, An Introduction (1965); J. Ridderbos, De Kleine Profeten, 3de druk (1968); R. K. Harrison, Introduction to the Old Testament (1969) 958f.; J. A. Fischer, "Notes on the Literary Form and Message of Malachi" (1972); W. J. Dumbrell, "Malachi and the Ezra-Nehemiah Reforms" (1976); A. S. Van der Woude, Haggai, Maleachi (1982); R. L. Smith, Micah-Malachi (1984) 299f.; R. Rendtorff, The Old Testament. An Introduction (1985) 242; and G. V. Smith, "Malachi" (1986) 226f.

P. A. Verhoef agrees with the above analysis except Verhoef divides the second unit into two: 1:6-14 and 2:1-9 (Maleachi verklaart (1972) 35-37 and The Books of Haggai and Malachi [1987] 171-179). Similar is R. R. Deutsch, "Calling God's People to Obedience" (1987) 68. J. G. Baldwin likewise notes a subdivision within 1:6-2:9 between 1:14 and 2:1, although unlike Verhoef, Baldwin maintains with the above analysis that there are six principal units (Haggai, Zechariah, Malachi [1972]).

Less compelling is the five-fold structure suggested by W. C. Kaiser Jr.: 1:1-5; 1:6-14; 2:1-16; 2:173:12; 3:13-24 [ET 4:6] (Malachi [1984]).

54 This selection of verses seems preferable to that offered by W. J. Dumbrell in support of the same outline (op. cit., 43). Dumbrell lists the following six statements by Yahweh (usually in the first person) as providing the theological core for the book: $1: 2 ; 2: 14 ; 2: 16 ; 3: 1 ; 3: 6$; and 3:17.

55 At times these are priests $(1: 6 ; 2: 1,8 ; \mathrm{cf} .3: 3)$, but the book does not appear to divide so clearly into a speech to priests followed by one to laymen, as G. Wallis has argued ("Wesen und Strukture der Botschaft Maleachis"[1967]). (1979)

For a further discussion of the literary problems of Malachi, cf. A. Renker, Die Tora bei Maleachi

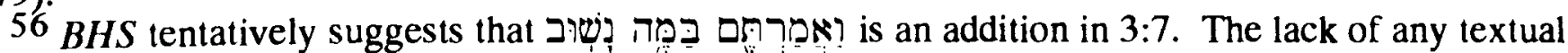
support, as well as the literary structure presently being considered, does not favour this suggestion. 
wicked; the problem of deficient offerings and the contemptuous attitude this reveals; the theme of covenant; the "fatherhood" of God; etc.

In addition to this careful linear structuring of Malachi, there may also be an unobtrusive concentric structure to the book as a whole which has not been recognized hitherto, although E. Wendland and others have noted Malachi's fondness for concentric patterning within the individual disputations. 57 The most visible literary indicator of this overall concentric pattern is found in the double introductory assertion ("but you say

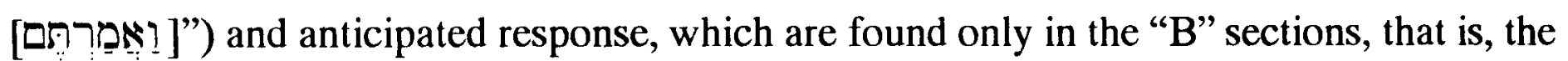
2nd (1:6-2:9) and 5th (3:6-12) disputations. 58 As may be noted, at certain points the concentricity concerns ancillary matters and vocabulary, rather than the main topic of the disputation.

Accordingly, without excluding other possible (even overlapping) outlines, we suggest the following concentric outline:

57 "Linear and Concentric Patterns in Malachi" (1985) Cf. also S. D. Snyman, "Chiasmes in Mal. 1:2-5" (1984); idem, "Antiteses in die boek Maleagi" (1985); and P. A. Verhoef, The Books of Haggai and Malachi, 164-168.

58 אמרת in 3:14 differs not only because it lacks the expected introductory conjunction ? found everywhere else, but also because it does not introduce a second objection. Rather, it merely introduces the answer to the previous question, "How have we spoken against you?" -- "You have said [אמר:? vain to serve God." 
Heading (1:1) - identifying the source (Yahweh), prophetic intermediary (Malachi) and audience (Israel ${ }^{59}$ ) for this book

A. 1st disputation (1:2-5) - Does God make a distinction between the good and the arrogant wicked? Yahweh's elective love for Jacob vindicated in his judgement against Esau (to be laid waste)

B. 2nd disputation (1:6-2:9) - Israel's begrudging offerings condemned. The profanation of Yahweh through contemptuous priestly service and sacrifice and the corruption of the covenant with Levi judged by Yahweh, who will reverse the priestly blessing into a curse; Yahweh's name to be great among the nations

C. 3rd disputation (2:10-16) - Yahweh a witness between a man and his wife by covenant. Yahweh is invited to cut off those who intermarry and yet bring an offering; those who divorce based on aversion are puzzled over their rejected offerings. Judah is unfaithful to Yahweh through the parallel offences of intermarriage with pagan women and divorce based on aversion

C'. 4th disputation (2:17-3:5 [or 3:6]) - Yahweh a witness against adultery and other moral offences. The promise that the offerings of Judah and Jerusalem will be made pleasing. Yahweh's justice to be vindicated when the "messenger of the covenant" comes to judge the wicked and purify his people

B'. 5th disputation (3:6 [or 3:7]-12) - Israel's begrudging offerings condemned. Repentance demanded in the tithe with a subsequent promise of blessing to be recognized by all nations

A'. 6th disputation (3:13-21 [ET 4:3]) - Does God make a distinction between the good and the arrogant wicked? Yahweh's justice and elective love vindicated in the contrasting fates of the righteous and the evil-doer (the latter to be burned up)

Closing exhortations which summarize the main points of Malachi (3:22-24 [ET 4:4-6]) Remember the law of Moses (the focus of disputations 1-3) and the promise of Elijah and the coming day of the Lord (the focus of the disputations $4-6)^{60}$

In addition to this possible concentric outline for the whole of Malachi, as mentioned above E. Wendland and others have argued for the presence of concentricity as a

59 On the significance of applying the name "Israel" to the post-exilic rump state of Judah, identifying Judah as obligated to the covenant and heir to the promises of Yahweh, cf. W. J. Dumbrell, op. cit., 44f., and R. L. Smith, op. cit., 302f. Cf. also the preponderance of "Israel" over "Judah" in Ezekiel and Ezra.

$60 \mathrm{Cf}$. also E. Wendland, who interprets 3:23f. [ET 4:5f.] as an appropriate summary of the main points of Malachi's message (op. cit., 114). 
prominent literary feature within each of the individual disputations. With respect to the third disputation, 2:10-16, which is of special interest to the present thesis, Wendland offers the following outline (slightly modified here):

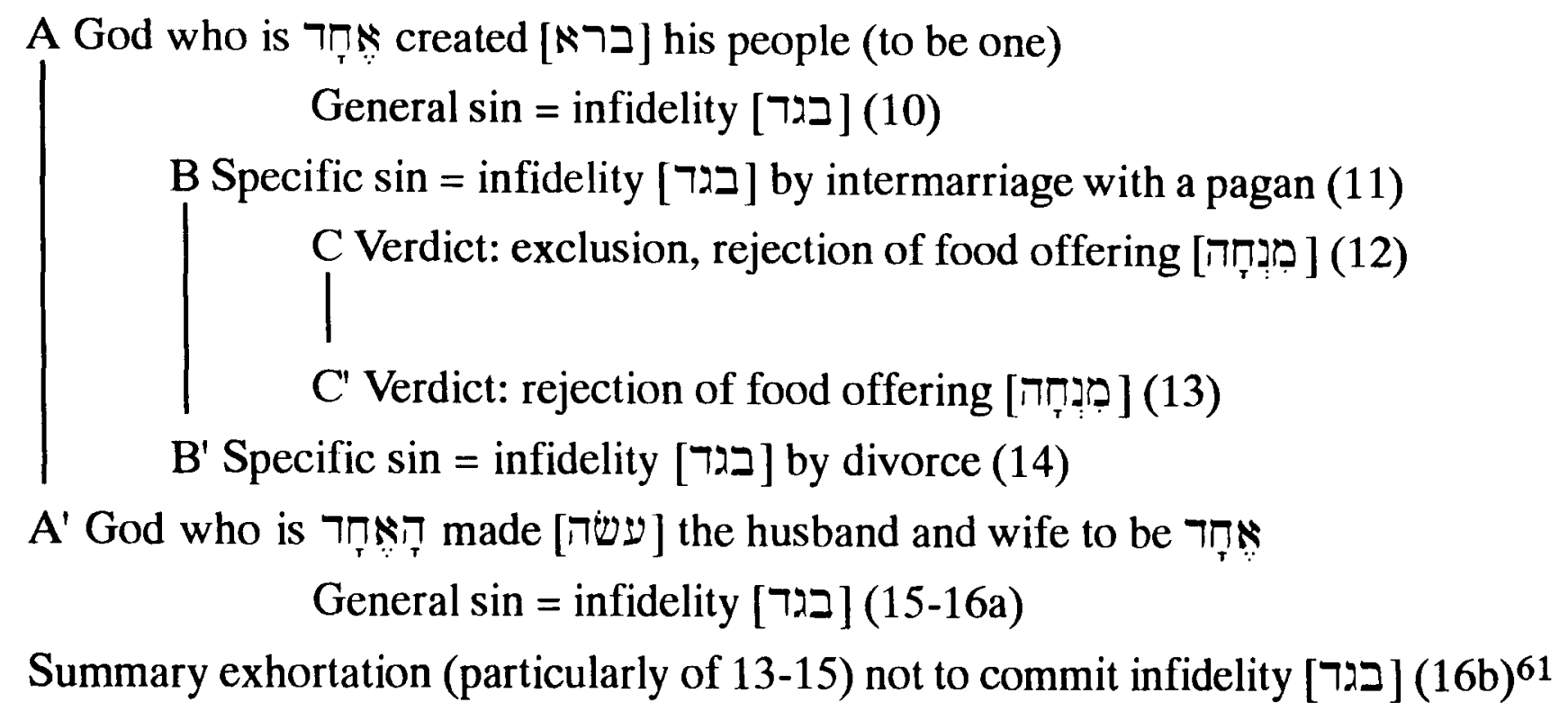

To summarize briefly, with respect to the suggested outline for 2:10-16, the artful composition and impressive degree of parallelism appear to favour the integrity of the whole, as against those scholars who would excise 2:11f. as secondary, and to suggest a parallelism between the offences of mixed marriage and divorce as instances of בגד. These matters will be treated in more detail in Chapter 4 below. With respect to the concentric literary structure of Malachi as a whole, while many interpretative problems remain, this structure appears to favour a reference to literal marital offences in the 3rd disputation $(2: 10-16)$, the first $\mathrm{C}$-section, since this finds a corroborating parallel in the sexual and other ethical offences treated in the second $C$-section, the 4th disputation (2:17-3:5 [or $3: 6]$ ). In the next chapter we shall attempt to build on this suggestive evidence as we examine more closely the interpretation of Malachi 2:14.

61 Note how the mention of "covering [הס $] \mathrm{X}$ with $\mathrm{Y}$ " in this verse forms an inclusio with verse 13. 


\section{Outline of Chapter 2: "Covenant [ברית]" in Malachi 2:14: Does it refer to marriage?}

2.1 The "traditional" view, according to which Malachi 2:14 identifies marriage as a

2.2 Arguments against the "traditional" view of Malachi 2:14 answered ............... 30

2.2.1 The uncertain בִּרִ in Malachi 2:14 should be interpreted in the light of the ברּר in Malachi 2:10, which refers to Israel's covenant with God........................................................... 30

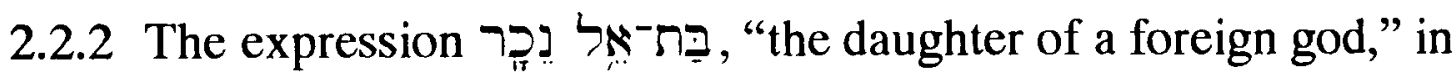
Malachi 2:11 must refer to a goddess and not to a literal bride, thus requiring a figurative "marriage" throughout Malachi 2:10-16

2.2.3 Hostility to literal "mixed" marriages in $2: 11,12$ would be antithetical to the "universalist" tenor of the rest of Malachi, thus implying a figurative "marriage" throughout Malachi 2:10-16 .................... 36

2.2.4 The treatment of literal marriage in Malachi 2:10-16 is deemed unsuitable to the larger context of Malachi.

2.2.5 Alleged ritual weeping in Malachi 2:13 favours the interpretation of

2:11 and 2:14 as referring to idolatry rather than to literal marriage 43

2.3 Summary and Conclusions 


\section{Chapter 2: \\ "Covenant ברית]" in Malachi 2:14: Does it refer to marriage?}

Having considered the interpretative framework within which Malachi 2:14 must be read, we may now sketch the traditional arguments for supposing that the

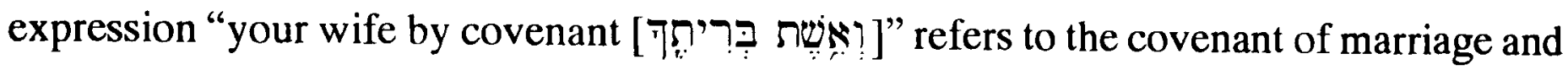
so differs in its reference from the בִּרִ mentioned in 2:10. As noted earlier, it is this traditional view which many modern scholars have rejected. In the second half of the chapter we shall examine their objections in detail.

\subsection{The "traditional" view, according to which Malachi 2:14 identifies marriage as a בִּרִ}

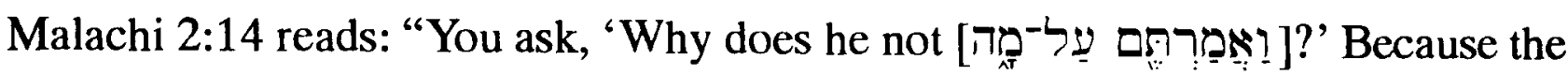

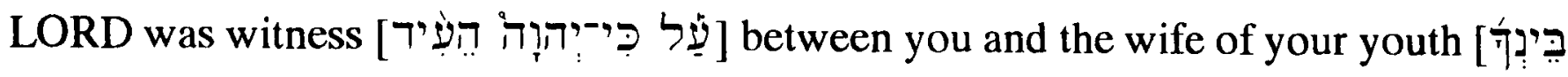

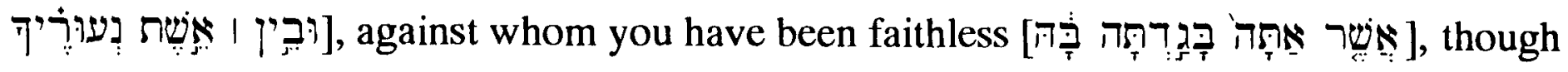

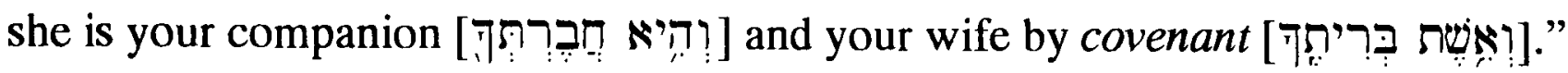

Although the "traditional" interpretation is more often assumed than argued, the following arguments may be advanced in its support: 1

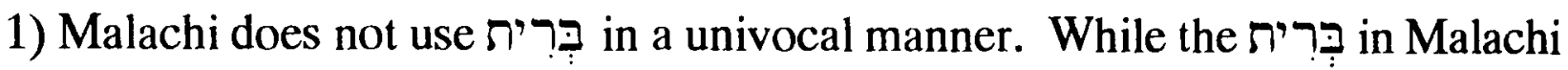
2:10 (and possibly 3:1 as well) may refer to Yahweh's covenant with Israel, the בִּר $2: 4,5$, and 8 ("the covenant of Levi") does not. Consequently, there can be no inherent objection to the view that Malachi intends yet another reference by his use of בִּרִ 2:14.

2) Furthermore, Yahweh is described in 2:14a as a "witness [העיר] ] between you and the wife of your youth." The endearing designation "the wife of your youth [ִ

\footnotetext{
1 The most common argument in favour of the "traditional" interpretation is the citation of Proverbs 2:17 and Ezekiel 16:8, where כִּר is also used with reference to marriage. However, since the traditional interpretation of these texts is also frequently defended by a citation of the remaining texts, a degree of circularity results. To avoid this difficulty, these texts will be treated separately in Chapter 8 , after the interpretation of Malachi 2 is established independently.

Favouring the "traditional" view of Malachi 2:14 are, among others, Martin Luther, "Lectures on Malachi," ad. loc.; E. B. Pusey, The Minor Prophets (1860) 483; H. Cowles, The Minor Prophets (1867) 392f.; G. A. Smith, The Books of the Twelve Prophets (1899); A. von Bulmerincq, "Die Mischehen im B. Maleachi" (1926); idem, Der Prophet Maleachi, Band 2: Kommentar zum Buche des Propheten Maleachi (1932) 289; J. M. Myers, The World of the Restoration (1968); T. Chary, Aggée - Zacharie - Malachie (1969) 259; J. G. Baldwin, Haggai, Zechariah, Malachi (1972) 239f.; H. W. Wolff, Anthropology of the Old Testament (1974) 167; S. Schreiner, "Mischehen-Ehebruch-Ehescheidung: Betrachtungen zu Mal 210 16" (1979); W. C. Kaiser Jr., Malachi (1984) 69f.; R. L. Smith, Micah-Malachi (1984); R. S. Westcott,

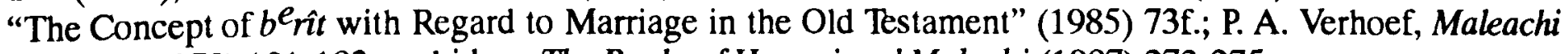
verklaart (1972) 181-183; and idem, The Books of Haggai and Malachi (1987) 273-275.
} 


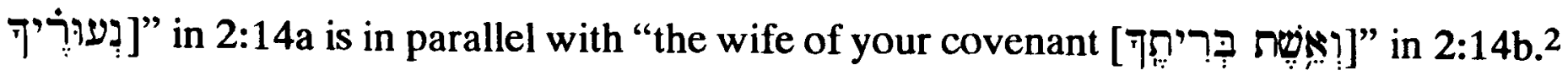
This implies that the covenant in 2:14b was between the husband and the wife.

Although the precise idiom of בין ... ובין + העיר is found only here, a close parallel, בין ... ובין + עיר is attested in Genesis 31:50, "God is witness between you and

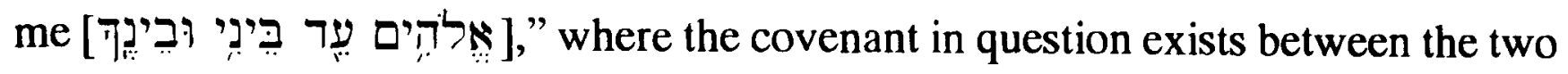
persons so described, i.e., Jacob and Laban. See also Genesis 31:44 and especially 48f., where the Lord is invited to watch between the covenant parties. Accordingly, this idiomatic usage likewise supports the inference that the covenant in $2: 14 \mathrm{~b}$ was between the husband and the wife.

3) A third reason for holding that the בִּרִ 2:14 refers to a marriage covenant is

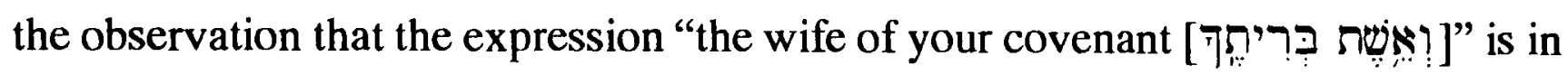

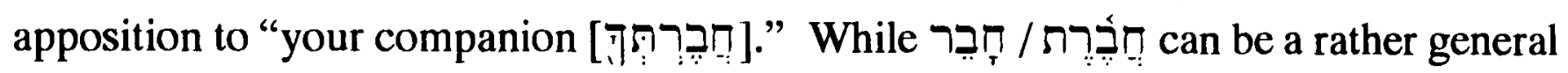
designation for "companion," deriving from its root meaning "to unite, to join together," חבר (verbal or nominal forms) frequently designates persons who have come into association by an agreement or contract. ${ }^{3}$ In particular, in some cases חבר is used with reference to covenant partners. According to P. Kalluveettil, for example, covenant associations may be present in Daniel 11:6, 23; 2 Chronicles 20:35ff.; and Hosea 4:17.4 While the evidence is not sufficient to require such a covenantal reference in Malachi 2:14, it does suggest it. Moreover, it is notable that there are no cases where fellow Israelites are designated with the term (verbal or nominal forms) merely on the basis of their mutual involvement in Yahweh's covenant with Israel. ${ }^{5}$

4) Fourthly, the expression בגר, "to act faithlessly against," which appears in Malachi 2:14, is supportive of the recognition of marriage as a covenant between husband and wife: "You ask, 'Why does he not?' Because the LORD was witness between you and

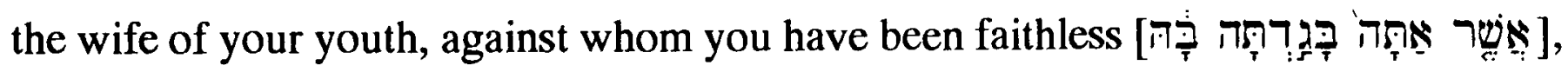
though she is your companion and your wife by covenant."

2 Cf. also Proverbs 5:18 and Isaiah 54:6. Cf. also S. Schreiner, "Mischehen-Ehebruch-Ehescheidung. Betrachtungen zu Mal 2,10-16" (1979) 216, n. 66.

3 Cf., e.g., H. Cazelles, “חָר, chäbhar," TDOT 4 (1980) 196, and M. O’Connor, "Northwest Semitic Designations for Elective Social Áffinities" (1986) 73-80. Cazelles notes that חבר in Sirach 7:25 may mean "to marry" (op. cit., 197).

4 P. Kalluveettil, Declaration and Covenant (1982) 51-53.

חבר may also appear with reference to Jonathan and David in 1 Samuel 20:30, if the text is emended with the LXX -- so P. K. McCarter Jr., 1 Samuel, 339.

5 So, e.g., while 2 Chronicles 20:35 uses חבר to describe the Judahite king Jehoshaphat's relation to Ahaziah, the king of Israel, it does so because of a special alliance, not because of their mutual relation to Yahweh. 
As noted by S. Erlandsson, בגד is often used of acts of infidelity committed against a covenant partner (cf., e.g., 1 Samuel 14:33, Jeremiah 3:21, Psalm 78:57, etc.). ${ }^{6}$ However, since ב ב ב can also be used to describe the infidelity of fellow-Israelites bound together under the terms of Yahweh's covenant with his people, as it is in Malachi $2: 10$, the appearance of this idiom in $2: 14$ is obviously not decisive.

5) Finally, while the semantic parallel between "the wife of your covenant [ن]

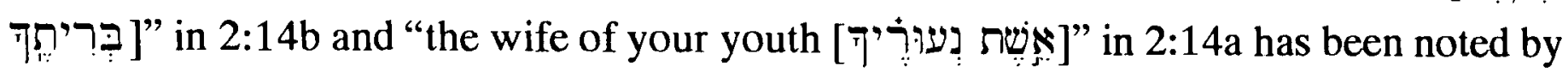
other scholars, what has gone unnoticed elsewhere are the various parallel nominal syntagms of בִּרִ

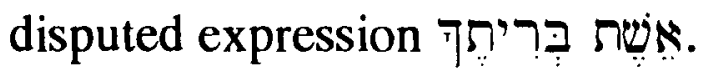

There are only four such nominal syntagms attested in Biblical Hebrew where the nomen regens refers to a person and בִּר ית is suffixed or is in construct. ${ }^{7}$ What is noteworthy is the fact that in each case the referenced בִּרִ exists between the person(s) indicated by the nomen regens and the person referred to by the pronominal suffix or

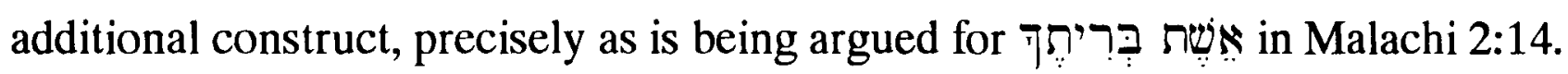

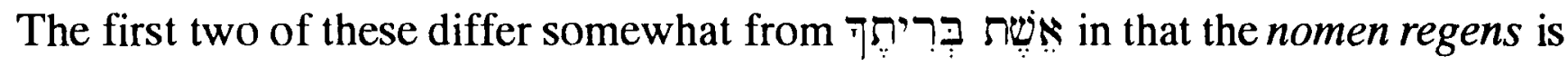

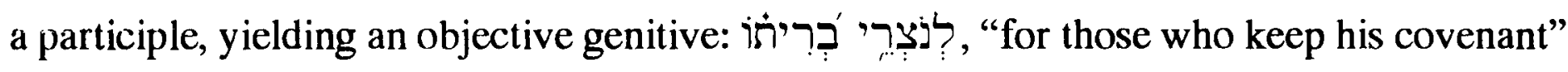

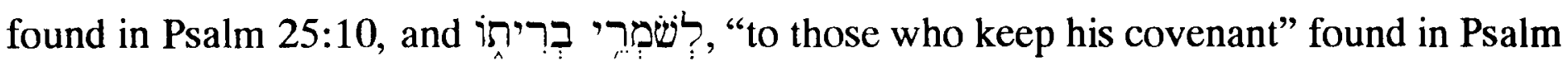
103:18. Nevertheless, the referenced בִּרִ רִית exists between the person(s) indicated by the nomen regens ("those who keep") and the person referred to by the pronominal suffix (i.e., God).

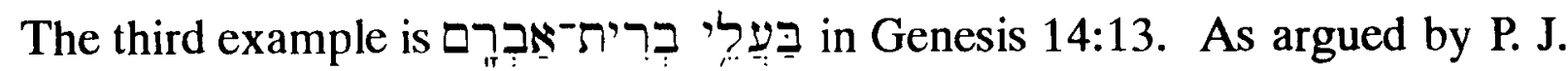
Naylor, this expression signifies those who were "participants in" a covenant with Abraham. The text does not refer to members in covenant with some other, perhaps unnamed, political entity. Rather, a covenant existed between Mamre, Eshcol, and Aner,

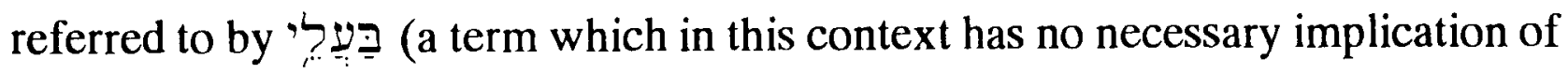
superiority) and Abraham -- on an analogy with the covenant which exists between you and your wife in the expression,

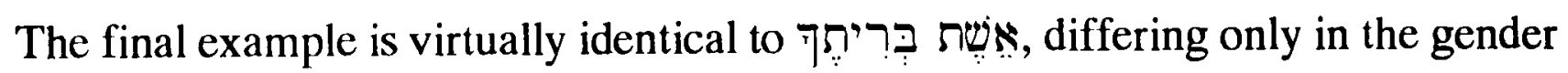

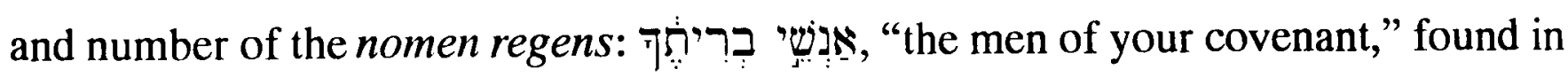
Obadiah 7! Although there are some obscurities at both the beginning and the ending of this verse, there is little doubt about its general sense. Edom was betrayed (or will be betrayed) by her allies in a punishment which reflects her own earlier betrayal of Israel: "All

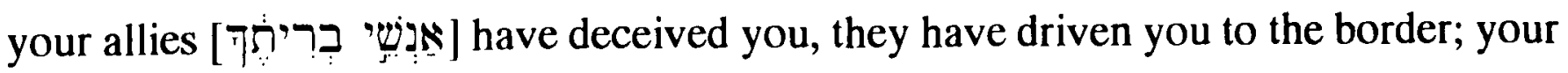

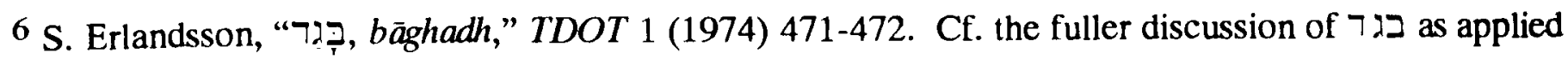
to marriage in Chapter 8 below.

7 P. J. Naylor, "The Language of Covenant" (1980) 199.

8 Ibid., 130, 219. 


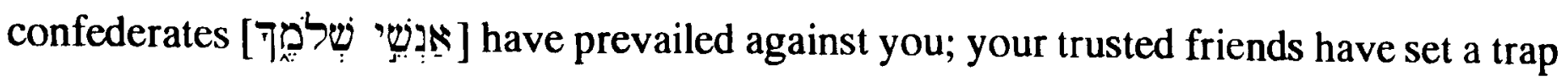
under you -- there is no understanding of it." As indicated in the rendering of the RSV,

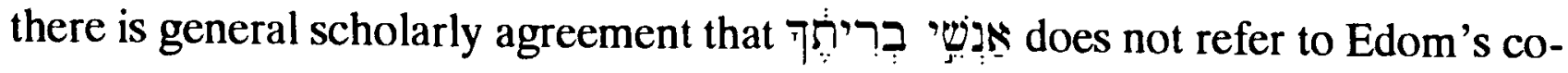

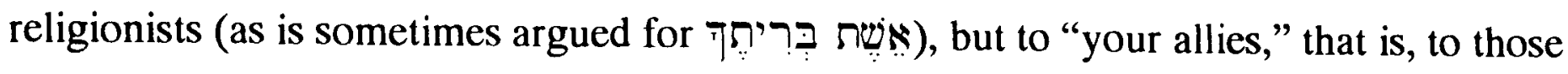
with whom Edom had a covenant. 9 This interpretation is corroborated by the synonymous

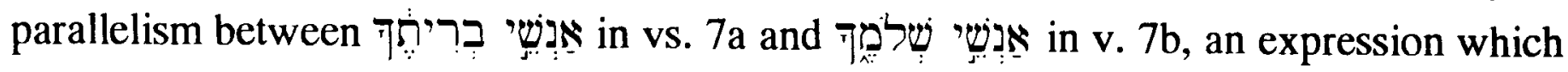
identifies persons with whom Edom shared peace, i.e., "your friends."

With this weight of evidence in mind, especially this last argument concerning the

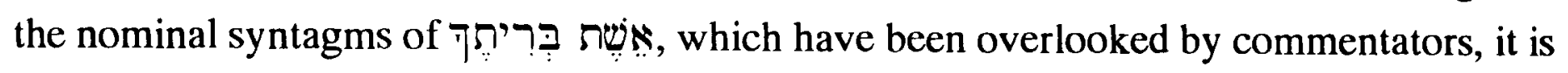
apparent that Malachi employs the expression exists between a husband and his wife. Accordingly, the burden of proof must rest with any interpreters who deny an identification of marriage as a בִּרִ in Malachi 2:14. However, objections to this understanding of have often been raised, and so we must turn now to a consideration of these.

\subsection{Arguments against the "traditional" view of Malachi 2:14 answered}

\subsubsection{The uncertain בִִּּרִ in Malachi 2:14 should be interpreted in the light of the בִּרִ in in Malachi 2:10, which refers to Israel's covenant with God}

In view of the literary structure of the book of Malachi considered earlier, it is not particularly surprising to find that, on any interpretation, the בִּרִ 2:14, occurring in Malachi's third disputation, bears an altogether different reference from the covenant with Levi") mentioned in the second disputation, in $2: 4,5,8$. On the other hand, it seems reasonable to expect that the $2: 14$ may well have the same reference as the 2:10, since these do occur within the same disputation. ${ }^{10}$

Various literary parallels between vss. 10 and 11 on the one hand and vss. 14 and 15 on the other may appear to offer further support for this identification. It may be noted, for example, that within both vs. 10 and vs. 14 Israel is charged with the sin of בבר, a charge which is repeated and elaborated in both vs. 11 and the notoriously problematic vs. 15. Further, there is a striking parallel between the double use of double appearance in vs. 15 . And finally, depending on one's interpretation of vs. 15 ,

9 So, e.g., J. A. Bewer, Obadiah (1911) 24f.; G. C. Aalders, Obadja en Jona (1958) 27f.; L. C. Allen, The Books of Joel, Obadiah, Jonah and Micah (1976) 150f.; H. W. Wolff, Obadiah and Jonah (1986) 50f.; D. K. Stuart, Hosea - Jonah (1987) 411, 417f.; and D. W. Baker, Obadiah (1988) 34f.

10 A. Isaksson, after urging that marriage could not have been considered a כִּר in the period of Malachi, states simply "The covenant mentioned in v. 14 must be the same covenant as in v. 10, viz. the covenant between Yahweh and his chosen people" (op. cit., 31). Cf. also C. C. Torrey, "The Prophecy of 'Malachi'”(1898) 9. 
there is the possibility of a parallel allusion to creation in these verses, even though the immediate reference in vs. 10 probably is to the formation of Israel, rather than of humanity. 11

Of course, these observations merely permit the proposed identification of the covenant in vs. 14 , they do not require it -- especially since, as has already been noted, Malachi uses wִירִ with a very different reference only a couple of verses earlier (vs. 8, cf. vss. 4,5$)$ in a clause that also closely resembles vs. 10.12 Indeed, the traditional interpretation of the covenant in vs. 14 takes account of the close relationship between vss. 14 and 10 precisely by suggesting a parallelism and close interrelation between these two distinct covenants, rather than synonymy between them. ${ }^{13}$

A closer examination of this approach, however, reveals a number of difficulties. Unfortunately for this view we do not find in vs. 14 an exact repetition of בִּרִ אִברת expression which appears in vs. 10, or simply בִּרִ what we find is the strikingly dissimilar expression "the wife of your covenant."

Some interpreters, proceeding on the assumption that the covenant in vs. 14 is the same as that in vs. 10, namely one between Israel and God, then suggest that the "wife" mentioned is merely a vivid figure for God. ${ }^{14}$ Two considerations militate against this interpretation, however. First, everywhere else in Scripture where the marriage figure is applied to Israel's relation to God, it is uniformly Israel or Judah who is depicted as the wife, and never God. ${ }^{15}$ This fact would appear not to be merely coincidental but may be a reflection of the profound similarity between God's self-imposed obligation to provide for Israel and her requisite submission to him as Lord and the corresponding responsibilities of

11 The precise parallelism is most explicit in the use of בר in vs. 10 which corresponds to its synonym, עשטה in vs. 15. Both these verbs are notably prominent in Genesis 1-2. Possible, though less clear, allusions to Genesis may be detected in the mention of the "sanctuary of Yahweh" in vs. 11 and the "spirit" in vs. 15. Cf. G. J. Wenham, "Sanctuary Symbolism," and M. G. Kline, Images of the Spirit.

The following exegetes, among others, support a reference to creation in vs. 15 (although in some cases based on uncertain textual emendations): J. Wellhausen (1892), A. van Hoonacker (1908), E. Sellin (1922), D. Deden (1953), F. Nötscher (1957), A. Deissler (1964), and W. Rudolph (1976), acc. to A. S. van der Woude, "Malachi's Struggle for a Pure Community," 69. Cf. also P. Grelot, Man and Wife in Scripture, 69.

12 In both vs. 8 and vs. 10 the בִּרִ is in construct with Israel's forebears ("Levi" finds a close parallel in "our fathers") and the charge in both cases is synonymous ("corrupting [שיחסקט]" the covenant in vs. 8 parallels "profaning [ח

13 Cf., e.g., P. Grelot, who offers the following comment on Malachi 2:14-16, "There is, however, no

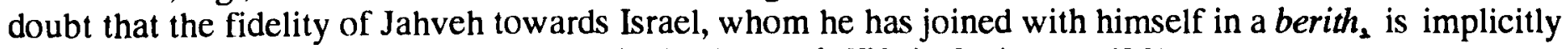
put forward as a model for husband and wife" (Man and Wife in Scripture, 69f.).

14 F. F. Hvidberg writes, “'the wife of thy youth', who was a 'companion' and 'the wife of thy covenant'... are similes which denote the cult of Yahweh, the faith in Yahweh. Yahweh is himself very nearly 'the wife of youth', with whom Judah had a covenant" (op. cit., 123).

15 This difficulty is acknowledged by A. Isaksson, who defends the identification of Yahweh as a wife here in Malachi as suggested by the image employed in vs. 11, i.e., marriage to "the daughter of a foreign god" (op. cit., 33). But this explanation proceeds only by assuming what needs to be proven, namely that "the daughter of a foreign god" is in fact a reference to a goddess. 
husbands and wives within Israelite society. Second, vs. 14a asserts that Yahweh himself is witness "between you and the wife of your youth." An interpretation that would make Yahweh both the witness and the wife within the same figurative marriage appears contrived. 16

Taking account of these two objections, an alternative interpretation has been offered by B. Vawter, following C. C. Torrey. ${ }^{17}$ These scholars identify the "wife" in vs. 14 as a vivid personification of the "covenant" itself. 18 Although this interpretation succeeds in eliminating the two difficulties mentioned above, it creates difficulties of its own. The metaphor of marriage applied to the relationship between Israel and the covenant is unprecedented elsewhere in the Old Testament. Likewise, it is nowhere to be found in the New Testament or, to the present writer's knowledge, in post-biblical Judaism. Furthermore, the imagery of God's people being "married" to the covenant appears strained precisely because there are so few points of resemblance between a literal marriage and one's relationship to a covenant. Indeed, it is difficult to get beyond the profound dissimilarities which immediately suggest themselves to extract any plausible comparison whatsoever. Not only is a "covenant" impersonal and to that degree dramatically unlike a wife, but also the most prominent obligation of Israelites toward the covenant is obedience, and this would hardly typify an Israelite husband's obligation toward his wife.

In addition, leaving aside for the moment the need to relate the exegesis of vs. 14b to the admittedly problematic vss. 15 and 16,19 it should be noted that the view of Torrey and Vawter runs into difficulties with both vs. 13 and vs. 14a. In terms of vs. 13, the

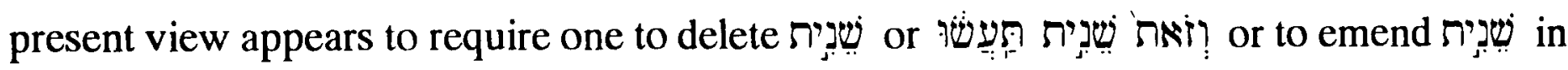
order to avoid its conventional meaning of "second(ly)" or "second time." This is so because if the covenant in vs. $14 \mathrm{~b}$ is the same as that in vs. 10 , and the "marriage" is taken in a figurative sense, then the wrong condemned in vs. 14 is not a "second" failing, but the very same failing as that mentioned in vs. 10. However, the proposed deletions of שִׁנית or

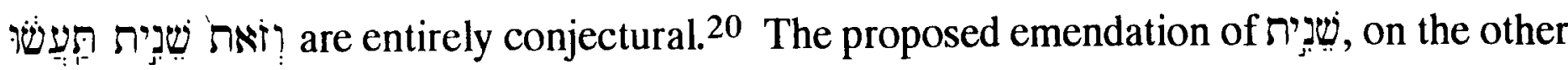

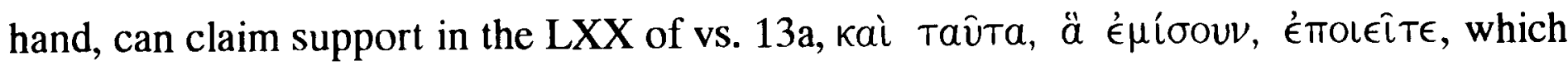

16 F. F. Hvidberg seems to sense the awkwardness of this (op. cit., 123). After noting how Yahweh is both wife and witness and judge, he suggests without support, "It is, however, possible here, too, that the text has been elaborated by later hands, who wanted to reinterpret it in the direction of an attack on faithlessness in marriage."

17 "The Biblical Theology of Divorce," 621.

18 C. C. Torrey defines ברּר in in this expression as "covenant religion" in contrast to vs. 11 as "the daughter of a strange god, i.e., a foreign cult" ("The Prophecy of "Malachi"” [1898] 9f.).

19 E.g., C. C. Torrey declares them to be "hopelessly corrupt" (op. cit., 10, note 20). It is possible, as R. A. Mason notes, that "the very bad state of the text bears its own witness to the probability that it did originally condemn divorce outright. If so, ... it would be small wonder if it suffered from scribal efforts to soften it" (The Books of Haggai, Zechariah, and Malachi [1977] 150).

$20 \mathrm{Cf}$. BHS. A. S. van der Woude claims the proposed deletion is "unwarranted (despite LXX) and only based on the false thesis that the prophecy of Malachi originally spoke of divorce only" ("Malachi's Struggle for a Pure Community," 68, n. 19). 
interprets שנית as "which I hate" [שָנטנאתית]. 21 Nevertheless, it is likely that the LXX reflects a corruption in its Vorlage which took place under the influence of שנ in vs. 16.22 In addition, the prevalence of the relative particle elsewhere in the MT of Malachi (11x) would lead one to expect its presence here if the reading of the LXX were correct. ${ }^{23}$

Furthermore, in order to relate vs. $14 \mathrm{~b}$ to $14 \mathrm{a}$, on the view of Torrey and Vawter, it

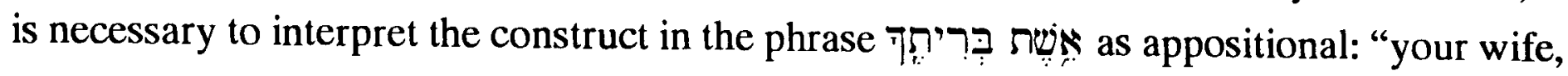
that is, the covenant." While such an appositional use of the construct is widely attested, in the present case it requires the reader to ignore the evident parallelism between in vs. $14 \mathrm{~b}$ and

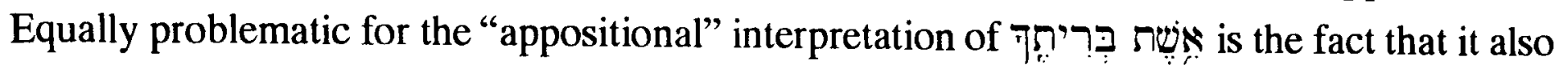

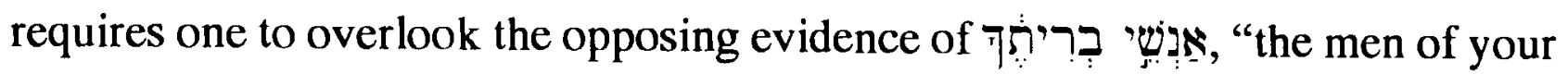
covenant," that is, "your allies," found in Obadiah 7, as discussed above.

A. S. van der Woude avoids some of the objections discussed above by accepting a reference to literal marriage in Malachi 2:14. However, Van der Woude's position needs to be discussed here because of his insistence, shared by a number of other scholars, that the mentioned in vs. 14 refers to Israel's relationship with Yahweh, not to the relationship between a husband and his wife. In effect, then, describes the man's wife as a fellow Jew, a partner with her husband in the same national covenant which constituted Israel as the people of God. ${ }^{24}$

In trying to account for the precise force of the expression ℶִִּ goes on to suggest that בִּר here bears the special meaning "covenant community." He defends this suggestion by asserting that it is a meaning which is also "intimated [italics added] by Mal. 2:10; 3:1c and Ps. 74:20a," as well as Daniel 11:28, 30, 32 and the Dead

21 One should not minimize this emendation with the term "revocalizing" since in Malachi's time Hebrew was written consistently with final matres lectiones (at the least the MT must be assumed to involve a metathesis of the $y \hat{o d}$ ) and in not one of the 112 biblical occurrences of the verb wiש does the 'aleph fail to appear. The reading שנית in 4QXIIa also supports the MT. Cf. R. Fuller's forthcoming discussion of 4 QXII ${ }^{\mathrm{a}}$ in $J B L$ and DJD.

22 So, e.g., P. A. Verhoef, op. cit., 262.

23 R. Althann's suggestion that ite should be interpreted as meaning "gnashing of teeth" lacks adequate support ("Malachy 2,13-14 and UT 125, 12-13" [1977] 418-21).

Althann's other suggestion, based on a proposal of M. Dahood (Psalms I, 42), to interpret תin as "indignity" has been accepted by A. S. van der Woude, "Malachi's Struggle for a Pure Community," 68, n. 19. While it is suggested that $\mathrm{n}$ i, with the meaning "indignity," appears also in Psalm 7:4; 44:18; 74:18; and Job 17:8, none of these texts require this newly posited sense. Cf., e.g., A. A. Anderson, Psalms, 94, 545.

24 The following scholars likewise equate the בִּר 2:14 with that in 2:10, with the implication that אשטת בּריחק, "the wife of your covenant," is understood as meaning simply "a wife who is a fellow Jew": K. Marti, Das Dodekapropheton (1904); W. Nowack, Das kleinen Propheten (1922); E. Sellin, Das Zwölfprophetenbuch (1929-30); B. M. Vellas, Israelite Marriage (1956) 24; W. Rudolph, Haggai Sacharja 1-8, Sacharja 9-14, Maleachi (1976) 274; C. Locher, "Altes und Neues zu Maleachi 2,10-16" (1981) 254f.; and B. Glazier-McDonald, Malachi, 101, who cites C. C. Torrey and A. Isaksson in support. 
Sea Scrolls. 25 But "intimated" is not the same thing as "required," and in the work of lexical semantics it is unwise to ignore the principle of parsimony. Accordingly, the evidence is insufficient to posit this new sense for בִּרית .

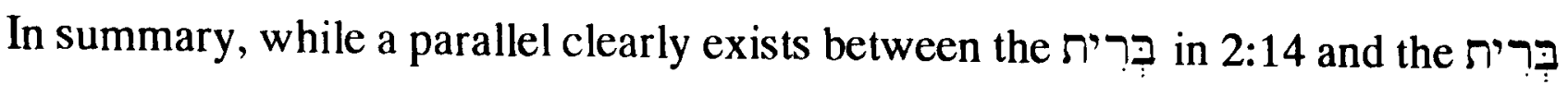
in $2: 10$, it is not one involving an identity of reference. The precise nature of this parallel will be explored more carefully in the next chapter. For the present it appears that none of the arguments considered thus far are sufficient to overturn the implication of the five arguments considered in $\$ 1.2$ above that the refers to a covenant between "you," i.e., the husband, and "your wife."

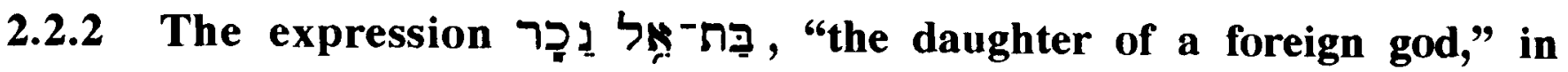

\section{Malachi 2:11 must refer to a goddess and not to a literal bride, thus} requiring a figurative "marriage" throughout Malachi 2:10-16

Another argument which has been advanced in support of a figurative reference for

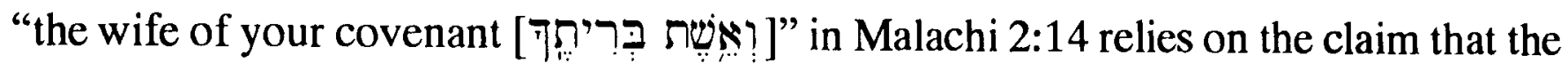

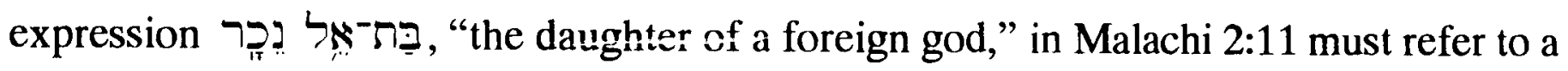
goddess and not to a literal bride, thus requiring a figurative "marriage" throughout Malachi 2:10-16.

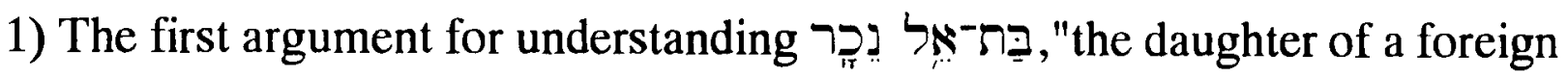
god," as a reference to a goddess rather than a woman is the simple observation that to be the daughter of a god, if understood literally, is to be a goddess. ${ }^{26}$

However, at least two considerations weigh against this interpretation. First, had it been Malachi's intention to speak of a goddess, it is unclear why he chose to use the circumlocution "the daughter of a foreign god," rather than simply saying "a goddess" or,

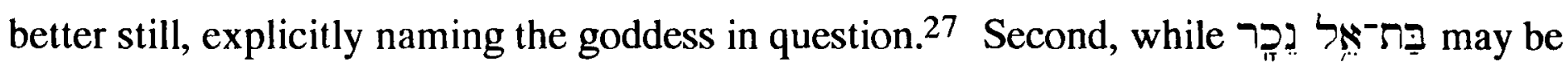

25 A. S. van der Woude, "Malachi's Struggle for a Pure Community," 69. For other scholars who support a similar interpretation of בִּרִ in Malachi 3:1, cf. P. A. Verhoef, Malachi, 289, n. 13.

26 So F. F. Hvidberg, who writes, "The expression bat 'él nēkār in verse 11 undoubtedly cannot - as generally maintained - mean 'eine Ausländer,' 'Heiden.' A 'daughter of a god' is a goddess..." (Weeping and Laughter in the Old Testament, 121). So also, A. Isaksson, op. cit., 31, and J. M. O'Brien, Priest and Levite in Malachi, 68. Cf. also R. Kraetzschmar, Die Bundesvorstellung in Alten Testament in ihrer geschichtlichen Entwicklung (1896) 168, and C. C. Torrey, op. cit., 9.

Alternatively, J. Morgenstern has argued that Malachi 2:10-16 refers to a marriage between Menahem (= "Judah") and a Tyrian princess (בח-אל נכר (בת ("Jerusalem - 485 B.C." [1957] 15-47). Lacking sufficient evidence for such a precise reference, this view appears fanciful.

27 E.g., "Ashtoreth," "the Queen of Heaven," etc., mentioned elsewhere in the OT.

Although unattested elsewhere in Biblical Hebrew, it is plausible that Hebrew did possess such a term, presumably אלה, אלת (cf. also Akkadian iltu). However, if Biblical

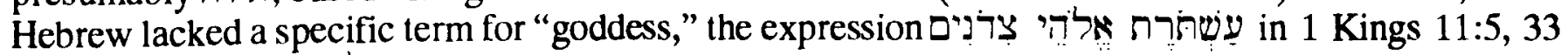
demonstrates that אל included "goddess" within its semantic range.

G. W. Ahlström notes that בתז-אל נכר "daughter of a foreign god" finds a reasonably close parallel in the phrase בני אלים, "sons of gods," appearing in Psalm 29:1 and 89:7 (Joel and the Temple Cult of Jenusalem, 49). However, occurring in such mythopoeic contexts, apparently with reference to angelic 
understood in a literal manner, such literalism can hardly be insisted upon since, on the present interpretation, this expression is located in the midst of a very striking simile --

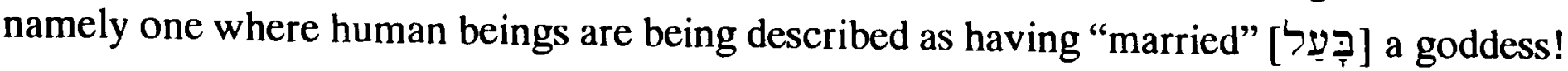

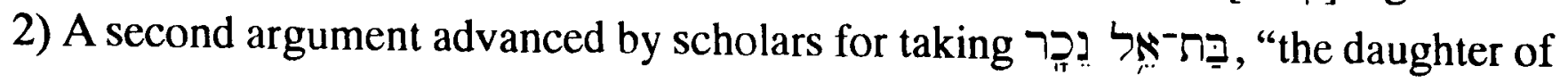
a foreign god," as a reference to a goddess is the observation that this expression would be unparalleled in the Old Testament as a description of a non-Jewish woman. 28

However, as P. A. Verhoef has argued, even if this expression were unprecedented elsewhere as a description of a non-Jewish woman, within Malachi it is entirely fitting. ${ }^{29}$ This is so because Malachi intends for it to be understood antithetically to his description of Yahweh as a father: "Have we not all one Father?" (Malachi 2:10). If Israelites are all the children of Yahweh, their Father, by virtue of their covenant relation to him, then by definition a pagan woman would be the daughter not of Yahweh, but of a "foreign god." Furthermore, the expression "the daughter of a foreign god" is not entirely without parallel in the Old Testament. As pointed out by R. L. Smith, just as Israelites are called "sons and daughters of Yahweh" in Deuteronomy 32:19, Moabites are called "sons and daughters of Chemosh" in Numbers 21:29.30

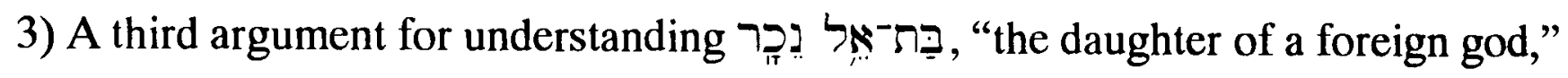
as referring to a goddess is its singular form. ${ }^{31}$

This is unpersuasive since in the context Malachi refers to the offending Israelites corporately as דוּרה: This corporate reference leads one to expect a similarly corporate (and so singular) reference for Judah's bride. Clearly it would have been inappropriate for Malachi to have written: "Judah has profaned the sanctuary of the Lord, which he loves, and has married the daughters of a foreign god" -- perhaps yielding an unintended implication of polygyny. 32

4) Finally, as noted by C. C. Torrey and A. Isaksson, the LXX and dependent versions interpret Malachi 2:11 as an attack on apostasy to an alien cult. ${ }^{33}$ The LXX, in

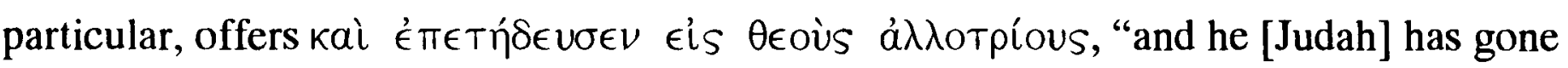

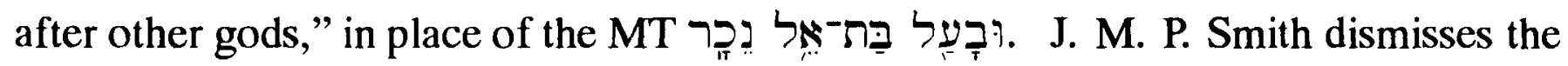

beings rather than to pagan deities, the value of this evidence for an interpretation of Malachi 2:11 is greatly diminished.

28 So A. C. Welch, Post-Exilic Judaism, 120, as cited by R. L. Smith, Micah-Malachi, 322f. Cf. also G. W. Ahlström, who argues that had it been Malachi's intention to speak of foreign women he would have employed נשים נכריות (1 Kings 11:1, 8; Ezra 10:2; Nehemiah 13:26) (op. cit., 49).

29 The Books of Haggai and Malachi, 265.

30 Op. cit., 319, n. 11b. So also S. R. Driver, The Minor Prophets (1906) 312.

31 So C. C. Torrey, op. cit., 9, especially n. 18.; F. F. Hvidberg, op. cit., 122; implied also by A. Isaksson, op. cit., 31, who cites W. Nowack, Die kleinen Propheten, ad v. 14, and R. Kraetzschmar, Die Bundesvorstellung im Alten Testament (1896) 168, 240.

32 J. M. P. Smith concedes the awkwardness of the singular, but argues that "it is more natural to interpret the statement as meaning that an alliance has practically been made between Judah and some people that does not worship Yahweh through the common celebration of such [literal] marriages" (op. cit., 49).

33 C. C. Torrey, op. cit., 4, n. 10, and A. Isaksson, op. cit., 32. 
LXX reading as paraphrastic and tendentious, an assessment with which $\mathrm{P}$. A. Verhoef agrees. ${ }^{34}$ Verhoef explains that mixed marriages had become normal among Hellenistic Jews, and so Malachi's condemnation is avoided. Whether or not this explanation is accepted, the final clause of the MT is widely recognized as preferable on the principle of the lectio difficilior and appears to have the support of 4QXIIa. 35

To sum up, none of the arguments for supposing that the "daughter of a foreign god

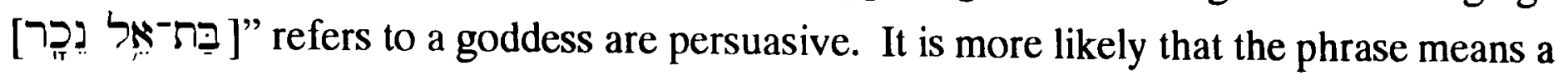
"pagan woman" and hence $2: 11$, like $2: 14$, is referring to literal marriage.

\subsubsection{Hostility to literal "mixed" marriages in $2: 11,12$ would be antithetical to the "universalist" tenor of the rest of Malachi, thus implying a figurative "marriage" throughout Malachi 2:10-16}

Yet a third argument in support of a figurative reference for "the wife of your

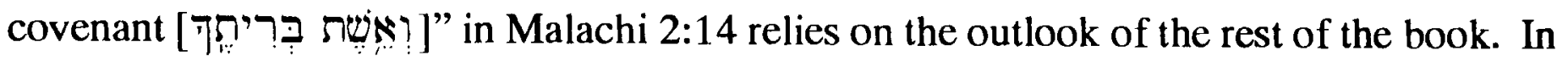
particular, it has been argued that if $2: 11,12$ is interpreted as a repudiation of literal intermarriage with foreign women, then its perspective would be antithetical to the universalism which is so prominent eisewhere in Malachi (e.g., Malachi 1:5, 11, 14; 2:10). A number of scholars have used this observation to support the identification of $2: 11,12$ as a later interpolation, with the conclusion that Malachi 2:10-16 originally opposed only divorce. ${ }^{36}$ However, since these scholars do not deny a reference to literal marriage in $2: 10-16$, the point at issue here, we may defer a more detailed consideration of this approach until Chapter 4.

Alternatively, the alleged tension between the perspective of Malachi 2:11, 12 and the sympathetic view of foreigners elsewhere, for example in Malachi 1:11, has been used to argue that $2: 11,12$ must not in fact be referring to literal intermarriage -- that here is one

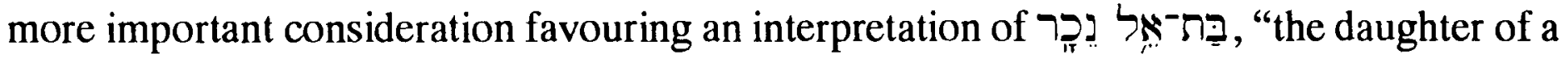
foreign god," as referring to a goddess and the marriage in these verses as a figure of speech.

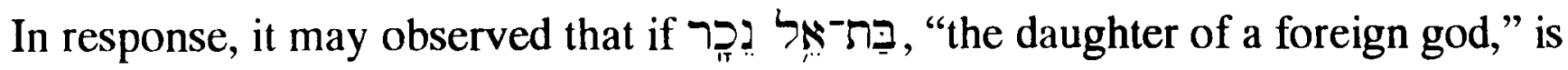
taken as a reference to non-Jewish women, such an expression may be deemed particularly felicitous precisely because it places the emphasis not on an ethnic or racial disqualification,

34 J. M. P. Smith, op. cit., 58; P. A. Verhoef, Malachi, 269. Verhoef cites in support G. J. Botterweck, "Schelt- und Mahnrede gegen Mischehe und Ehescheidung" (1960), among others.

35 So, according to R. Fuller in his forthcoming discussion of 4QXII ${ }^{\mathrm{a}}$ in $J B L$ and DJD.

36 So, e.g., K. Marti (1904), E. Sievers (1905), E. Sellin (1922), C. Kuhl (1963), and R. A. Mason (1977). 
which would be in tension with Israel's calling to lead the nations into the knowledge of Yahweh, but on a distinctively religious one. ${ }^{37}$

Furthermore, it may be questioned whether scholars have not misconstrued the evidence for Malachi's “universalism."

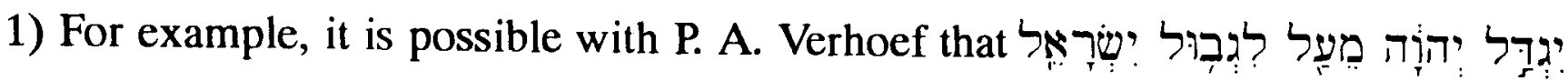
in Malachi 1:5 should be rendered "Great is the Lord over the territory of Israel," rather than following the traditional rendering of "beyond the territory of Israel."38 P. A. Verhoef notes that "over" is by far the more common rendering of מִעַ elsewhere in Biblical Hebrew, and his interpretation is supported by both the LXX $\dot{u} \epsilon \rho a ́ v \omega$ and Vulgate super. However, even if "beyond the territory of Israel" is retained in Malachi 1:5, this does not require a kind of "universalism" which would be congenial to interfaith marriage. In the context of 1:2-5, Malachi's point seems to be that Yahweh's coming judgment and wrath against Edom (whether or not "Edom" is understood literally) will elicit Israel's acknowledgment of the reality of Yahweh's election and universal sovereignty. As Israel will see, Yahweh is no mere local deity incapable of expressing his displeasure with offending foreign nations.

2) The verse which has been most featured in the modern scholarly discussion of Malachi's "universalism" is Malachi 1:11: "For from the rising of the sun to its setting my name is great among the nations, and in every place incense is offered to my name, and a pure offering; for my name is great among the nations, says the Lord of hosts." 39 Malachi 1:14b likewise offers a close parallel to vs. 11 and so may be considered together with it for convenience: "for I am a great King, says the Lord of hosts, and my name is feared among the nations."

G. A. Smith's commendation of Malachi 1:11 as “perhaps the most original contribution which the Book of Malachi makes to the development of prophecy" is characteristic of the view of many modern interpreters. ${ }^{40}$ However, it is precisely the "originality" or, perhaps better, "oddity" of Malachi's alleged acceptance of sincere heathen worship which renders this interpretation so suspect. On Smith's view, Malachi 1:11 does not merely teach that there are decent and righteous people in every nation, but that "the very sacrifices of the heathen are pure and acceptable to Him."41

37 Cf. J. G. Baldwin, op. cit., 238. Cf. also E. M. Yamauchi, "Cultural Aspects of Marriage in the Ancient World" (1978) 250, and idem, "Ezra, Nehemiah" (1988) 677.

38 The Books of Haggai and Malachi, 194 and 206.

39 See the extensive bibliography on this verse in P. A. Verhoef, The Books of Haggai and Malachi, 222 , n. 64.

40 Op. cit., II, 350. Cf., among others, C. C. Torrey, op. cit., 3; W. Nowack; K. Marti; E. Cashdan, The Twelve Prophets (1948) 336; R. C. Dentan, "The Book of Malachi" (1956) 1120; L. H. Brockington, "Malachi" [1962] 657; and H. Frey, Das Buch der Kirche in der Weltwende (1963) 148. Cf. also F. Horst, who refers to the heterodox Jewish worship of Samaria (Die zwölf kleinen Propheten [1964] 267).

41 Op. cit., 351. 
We note the following principal objections which have been raised against the present view:42

a) The claim that Malachi considered pagan sacrifices offered to idols to be acceptable to God ignores the important qualification within 1:11, that the offerings in question are made לִשְִִׁ "to my name."

b) This view contradicts other indications of uncompromising "particularlism" within Malachi, such as Yahweh's enmity against Edom in Malachi 1:2ff.

c) To suppose that Malachi 1:11 commends pagan sacrifices offered by nonLevitical priests would set this verse completely at odds with the pervasive concern of Malachi throughout his prophecy with the abuses and false teaching of Israel's own priesthood. 43

d) The claim that Malachi considered "sincere" pagan worship to be acceptable to God sets Malachi at radical variance with the teaching of the Old Testament at almost every other point. The only apparent exceptions are passages such as Isaiah 19:18-25 and Zephaniah 2:11, which are widely recognized as figurative and having an eschatological reference. Certainly such a view would be difficult to square with Malachi's own exhortation concerning the law of Moses (Malachi 3:22 [ET 4:4]).

e) What makes the proposed interpretation of Malachi 1:11 particularly untenable is the way Malachi presupposes general agreement among his hearers with his assertions about God's relation to the nations. ${ }^{44}$ Such a presupposition seems impossible given the unmitigated abhorrence of paganism reflected in the roughly contemporaneous works of Ezra and Nehemiah. ${ }^{45}$

f) Finally, the present interpretation fails to note that the expression "from the rising of the sun to its setting" in Malachi 1:11 appears to echo Isaiah 45:6; 59:19; and 66:20-1.46 If so, this would support an eschatological interpretation of this notorious crux, since these antecedent texts are clearly eschatological, referring to a future conversion of the Gentiles. 47

42 To these, one may add the claim upheld by some scholars that Malachi 1:11-14 is a later addition to Malachi's prophecy (so as does F. Horst [Die zwölf kleinen Propheten, 265-67], K. Elliger [Das Buch der zwölfkleinen Propheten, 194], R. Rendtorff ["Maleachibuch," 628], and A. S. van der Woude [op. cit., 66]).

43 So J. T. Marshall, "The Theology of Malachi" (1896) 12f., and G. L. Robinson, The Twelve Minor Prophets (1952) 157-69, acc. to P. A. Verhoef, The Books of Haggai and Malachi, 227.

44 So notes A. von Bulmerincq, Der Prophet Maleachi, II (1932) 122, cited with approval by P. A. Verhoef, op. cit., 227. This presupposed agreement assumes a present reference for $1: 11$. If this verse is to be rendered as a future, e.g., following the NIV, then Malachi's "universalism" is no different from the eschatological hope for the conversion of the nations reflected in Isaiah 19:18-25 and Zephaniah 2:11.

45 Cf. J. T. Marshall, "The Theology of Malachi."

46 Cf. also Psalm 50:1; 113:3; Zephaniah 3:9-10; and Zechariah 2:15.

47 Cf. A. van Hoonacker, Les douze petits prophètes (1908) 713; J. G. Baldwin, "Malachi 1:11 and the Worship of the Nations in the OT" (1972); E. Achtemeier, Nahum-Malachi (1986) 177f.; B. GlazierMcDonald, Malachi, 55-61 -- less certain is the claim of C. V. Camp that Malachi has "literalized" Isaiah's image of the priesthood of the Gentiles into a real expectation (op. cit., 323 n. 8). 
Malachi may have understood himself to be living in the age of the beginning of the fulfilment of these promises, as evidenced by the worship of contemporary proselytes. ${ }^{48}$ But the bold language of $1: 11$, in contrast to the modest numbers of proselytes likely to have existed in Malachi's day, would seem to favour the view of P. A. Verhoef that Malachi's reference may include the acceptable worship of contemporary proselytes and perhaps also diaspora Jews, but that it goes beyond this to encompass a still future, more comprehensive fulfilment. ${ }^{49}$ The reminder of Yahweh's purpose for the conversion of the nations, a plan entailed in Israel's calling to be a blessing to the nations (cf. Malachi 3:12) and one which features the temple as its focus, would not be out of place in the light of Malachi's prominent interest in eschatology (cf., e.g., Malachi 3:1ff.) and would add force to his condemnation of the apathetic sacrificial cult of his contemporaries. 50

Possible, but less likely in the light of these antecedent texts, is the view that Malachi 1:11 refers solely to the worship of diaspora Jews ${ }^{51}$ or the view that Malachi was speaking in hyperbole, where even the ignorant worship of heathen is more acceptable to Yahweh than the blood sacrifices offered in Jerusalem in a spirit of indifference -- though Malachi's intention is to condemn Israel, not to approve pagans. 52

However, none of these interpretations for 1:11 (and 1:14), except the view of Smith which seems least likely, raises any difficulty with respect to $2: 11$; they all allow 2:11 to refer to literal marriage. 53

3) Malachi 2:10, "Have we not all one Father? Did not one God create us?...," is yet another verse which is alleged to support a "universalism" at variance with the implied bigotry of $2: 11$, if $2: 11$ is understood as referring to literal mixed marriage. After all, if we acknowledge the common Fatherhood of God, does not this imply the universal brotherhood of mankind?

48 Cf. C. von Orelli, The Twelve Minor Prophets (1893) 389, and T. C. Vriezen, "How to Understand Malachi 1:11" (1975).

49 "Some Notes on Malachi 1:11" (1967).

50 This "evangelistic" calling of Israel was made clear already in the Abrahamic covenant in Genesis 12:2f. and exemplified in the careers of the Patriarchs, especially Joseph. Cf. H. W. Wolff, "The Kerygma of the Yahwist" (1966). It appears to be reasserted in the career of David and is especially prominent in the following (mainly eschatological) texts: Psalm 47; 87; Isaiah 2:1-4; 19:23-25; 41:5; 42:4-6; 45:14; 49:6, 22-23; 60:3; 66; Jeremiah 4:1-2 (Israel's obedience is the condition of her blessing to the nations); Micah 4:1-5; Daniel; Jonah; Zechariah 2:15 [ET 11]; 8:23; and Esther 8:17.

51 Cf. e.g., J. M. P. Smith; J. Swetnam, "Malachi 1,11: An Interpretation" (1969), who argues that the "sacrifices" in question are metaphorical for prayer and study of the Torah; and R. R. Deutsch, "Calling God's People to Obedience" (1987) 84-87.

52 Cf. R. A. Mason, who notes the lack of any blood sacrifice in 1:11 and the fact that Psalm 50, to which the text may allude, rejects animal sacrifice in favour of more spiritual sacrifices of thanksgiving (op. cit., 144f.). So also R. J. Coggins, Haggai, Zechariah, Malachi, 78.

53 Accordingly, if Malachi 1:11 does not contradict the "particularism" elsewhere in Malachi, there is little ground left for viewing this text as secondary (as do, e.g., F. Horst, K. Elliger, R. Rendtorff, and A. S. van der Woude). 
Such an inference may seem reasonable to modern man, but it is not at all apparent that this train of thought was in the mind of the prophet. Indeed, Malachi's point of reference for the "we" of his rhetorical question appears to be his fellow-Israelites, not mankind indiscriminately. ${ }^{54}$ Moreover, the only brotherhood Malachi goes on to consider is that which derives from the profaned "covenant of our fathers" (2:10b). Whether this "covenant" is a reference to the Sinaitic covenant in particular, or some more general reference to the Abrahamic covenant and its subsequent developments which brought Israel into existence, it is clearly one unique to fellow Israelites.

This parochial perspective for 2:10 may find further support if "one Father" in 10a is allowed to be defined by the "covenant of our fathers" in $10 \mathrm{~b}$, that is, if we follow commentators like J. G. Baldwin in recognizing "Father" as a reference to Abraham or Jacob. 55 On the other hand, if "one Father" is defined by synonymous parallelism with "one God," and so refers to God's "fatherhood," as seems more likely, it has often been observed that the "fatherhood" of God within the Old Testament defines God's special relation not to mankind in general, but to Israel in particular: "fatherhood... not in a natural sense but in the spiritual sense of adoption and on the basis of his covenant."56 Passages such as Deuteronomy 32:6, Isaiah 63:16, and 64:7 [ET 8], which describe God as the "creator" and "father" of Israel, offer clear instances of this usage.

In summary, it appears that the alleged "universalism" in Malachi 1:5, 11, 14 and $2: 10$ is not such as would prohibit a repudiation of literal intermarriage with pagan women in $2: 11 \mathrm{f}$.

\subsubsection{The treatment of literal marriage in Malachi 2:10-16 is deemed unsuitable to the larger context of Malachi}

The fourth argument in support of a figurative reference for "the wife of your

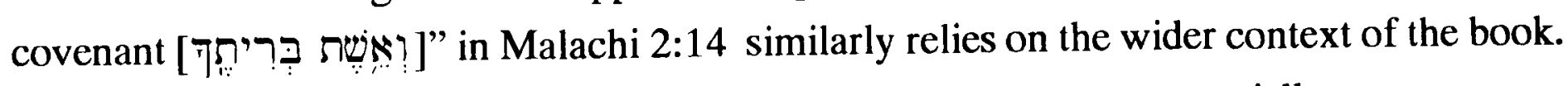
Here it is observed that elsewhere in the book the prophet does not especially concern himself with matters of personal or social ethics. Rather, Malachi seems absorbed with cultic and priestly matters: condemnation of the priests (for their complicity) and the people for offering inferior sacrifices (1:6-14); condemnation of the priests for their violation of the

54 So P. A. Verhoef, The Books of Haggai and Malachi, 266.

55 In support of this interpretation, held earlier by Jerome, Ibn Ezra, David Kimchi, J. Calvin and M. Luther, cf., e.g., A. von Bulmerincq, Der Prophet Maleachi, II, 243f.; D. R. Jones, Haggai, Zechariah and Malachi, 193f.; and J. G. Baldwin, op. cit., 237.

However, A. S. van der Woude notes that some LXX MSS transpose the first two clauses of vs. 10, probably due to a desire to give God preeminence (op. cit., 67). The present order may, consequently, favour an identification of the "one father" as God.

56 P. A. Verhoef, The Books of Haggai and Malachi, 265. Cf. Malachi 1:6. So also J. G. Baldwin, op. cit., 237; A. S. van der Woude, op. cit., 67; and most modern commentators. 
covenant with Levi and the need for priestly instruction from the law (2:1-9); the promise of the Lord's coming to his temple to purify the Levites and the securing of pure offerings from Judah and Jerusalem (2:17-3:5); the nation's failure with respect to tithes and offerings (3:6-18); etc. Accordingly, A. Isaksson writes: "This interpretation of Mal. 2.1016 as an attack on apostasy to an alien cult is in entire agreement with the rest of the contents of the Book of Malachi.... Malachi is a priestly reformer, not a prophetic renovator of the ethics of marriage."57

Three answers may be given in response to this claim of Isaksson:

1) Acknowledging the priority Malachi gives to cultic offences is not the same thing as saying cultic offences are Malachi's exclusive concern. It is simply unwarranted for the modern interpreter to reduce everything outside 2:10-16 to cultic matters.

Malachi 1:6, at least incidentally, reinforces the 5th Commandment, a concern to which Malachi returns in 3:24 [ET 4:6]. It is also possible that the priestly instruction being neglected or perverted in 2:6ff. may include ethical and legal matters. In any case, in Malachi 3:5 Yahweh quite explicitly threatens His impending judgment against "adulterers," that is, against those who violate marriage, as well as his judgment against "sorcerers, ... against those who swear falsely, against those who oppress the hireling in his wages, the widow and the orphan, against those who thrust aside the sojourner...." These cannot all be reduced to merely cultic transgressions. Indeed, highlighting this concern with Yahweh's judgment against "adulterers," etc., in Malachi 3:5 is the overall literary structure of Malachi considered in the previous chapter. There it was suggested that the second Csection, the 4th disputation (2:17-3:5 [or 3:6]), which treats sexual and other ethical offences, offers a corroborating parallel to the literal marital offences treated in the 3 rd disputation (2:10-16), the first C-section.

Finally, a general concern with the Lord's decrees and laws seems to be indicated in Malachi 3:7, 14, 18, 22 [ET 4:4] -- in this last verse the laws in question are specified as "the law of my servant Moses, the statutes and ordinances that I commanded him at Horeb for all Israel."

2) Although we may grant a predominant, though not exclusive, interest in cultic matters in the work of Malachi, this need not rule out a concern with mixed marriage and divorce in 2:10-16. As evidence for this, it is widely recognized that the book and ministry of Ezra, and to a lesser degree of Nehemiah, provide a striking and historically relevant parallel to the same blend of interests as we find in Malachi -- a predominant concern with cultic matters together with special attention to the problem of mixed marriage.

57 Marriage and Ministry in the New Temple, 32. G. W. Ahlström similarly comments, "Malachi is always interested primarily in what he himself considers to be a pure and right Yahweh cult, and the social and moral problems are not his main concern here" (Joel and the Temple Cult of Jerusalem, 50). 
3) Finally, in keeping with Malachi's cultic orientation elsewhere, it may be noted that the prophet frames much of his objection to Israel's aberrant marital practice precisely in cultic terms.

In 2:11 Malachi condemns the marrying of "the daughter of a foreign god" as חירליל

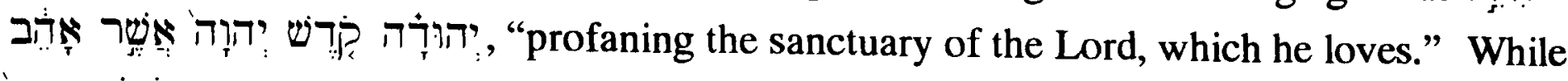

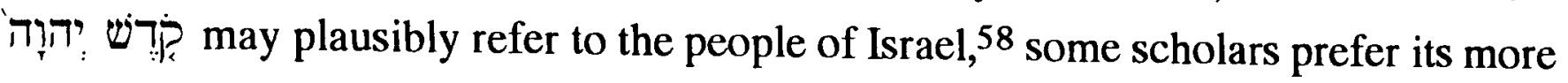
customary usage as a reference to the temple. ${ }^{59}$ In either case cultic concepts are being employed as a way of underscoring the reprehensible character of this $\sin .60$

Malachi's imprecation in 2:12 involves a number of difficult interpretative

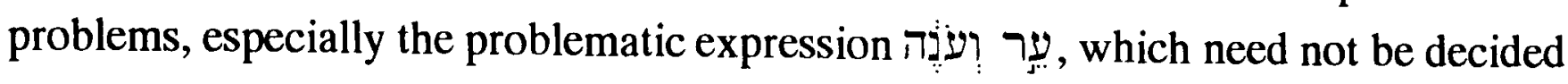
here. ${ }^{61}$ For our purposes it is enough to note that there are two major ways of relating the

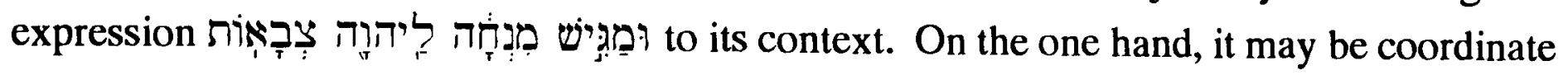

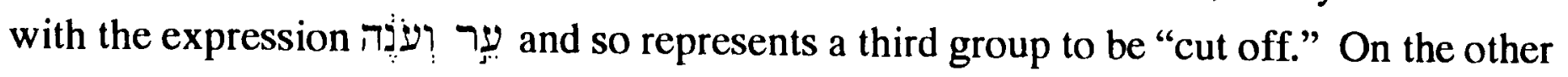

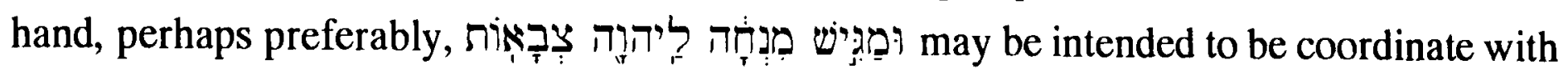

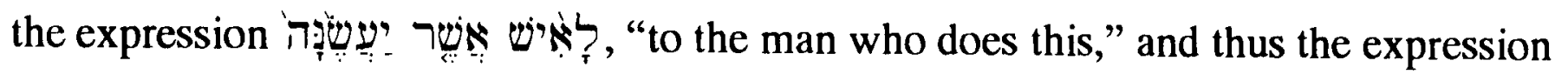
stresses the reprehensible hypocrisy of men who so intermarry and yet presume to bring

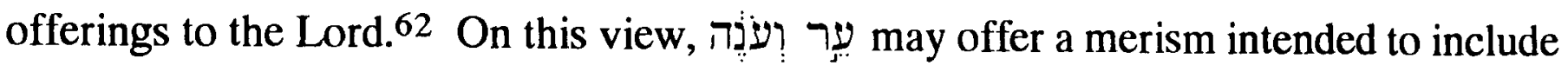

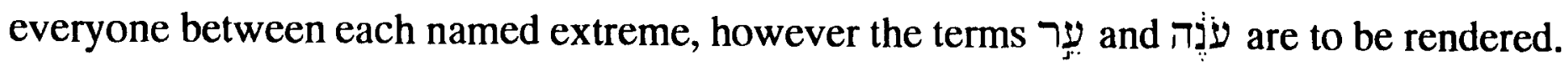
While it is impossible to be sure of this second option, because of the obscurity of such an intention for this passage comports with the frequently encountered prophetic indictment concerning the contradiction between Israel's flagrant $\sin$ and her external religiosity. ${ }^{63}$

58 Based largely on context, so C. von Orelli, E. Sellin, and P. A. Verhoef. See also the arguments of A. S. van der Woude, op. cit., $67 \mathrm{f}$.

59 So G. A. Smith, K. Marti, R. C. Dentan, acc. to P. A. Verhoef. So also G. W. Ahlström, op. cit., 49, who cites K. Elliger, Das Buch der zwölf kleinen Propheten, 189. This approach is also preferred by J. G. Baldwin, who notes, "Certainly it is they whom He loves" (op. cit., 238f.). A. S. van der Woude considers it more likely that cit. 67, n. 14).

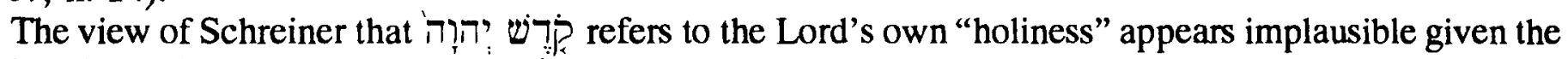
relative clause, "which he loves" (op. cit., 210).

$60 \mathrm{C}$. Stuhlmueller offers the rather improbable view that " 'the temple' that 'Judah has profaned' and 'which the Lord loves' is none other than the divorced wife" ("Malachi" [1970] 400).

61 Cf. the intriguing "sexual" interpretation offered by B. Glazier-McDonald, "Malachi 2:12: 'ēr we'oneh - Another Look" (1986). This seems more plausible the "cultic" understanding of G. W. Ahlström, who writes "The terms עִר וְעִגה, 'he who arouses himself and [he who] answers' (or 'sings a lament'), may have something to do with rituals which the prophet did not accept as Yahwistic" (op. cit., 49f., n. 8). Against Glazier-McDonald, however, cf. J. M. O'Brien, Priest and Levite in Malachi, 70f. Cf. also R. Fuller's forthcoming articles on the evidence of 4QXIIa in support of reading עִ ער , "a witness," in place of עy, as already suggested by J. Wellhausen, Skizzen und Vorarbeiten (1892) 207.

62 P. A. Verhoef renders the verse with this sense: "May the Lord cut off from the tents of Jacob that man, whoever he may be, even though he brings offerings to the Lord Almighty" (The Books of Haggai and Malachi, 262).

63 P. A. Verhoef offers further support for this interpretation by an attractive, if still uncertain, exegesis of "covering one's garment with violence" in vs. 16. 
Finally, in 2:13f. Malachi depicts frustrated Israelites grieving at the altar because Yahweh will no longer accept their offerings, and he explains this rejection as due to their marital infidelity. As with the suggested interpretation of $2: 12$, this verse exemplifies the same prophetic antipathy for a merely external religiosity.

Accordingly, in spite of Malachi's sustained interests in cultic and priestly matters, it appears that there is no reason to deem inappropriate a concern with literal marital offences in Malachi 2:10-16, particularly in the light of the example of Ezra, where these same concerns coexist, and given the detrimental effects of these offences on the cult, as stressed by Malachi.

\subsubsection{Alleged ritual weeping in Malachi 2:13 favours the interpretation of}

\section{2:11 and 2:14 as referring to idolatry rather than to literal marriage}

A final objection to a reference to a literal marriage covenant in Malachi 2:14 is based on a supposed allusion to an idolatrous practice in Malachi 2:13. In particular, F. F. Hvidberg has refurbished an older argument that the weeping mentioned in $2: 13$ is an allusion to syncretistic ritual weeping. 64 Hvidberg's primary argument for this

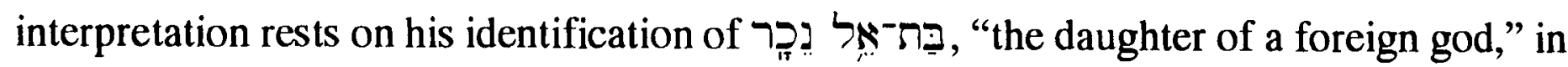
2:11 as a goddess. 65 Hvidberg explains: "It cannot be doubted that this is a deity of the Anat-Astarte type, and that her lover, for whom the weeping is done, is an 'Adonis' deity."

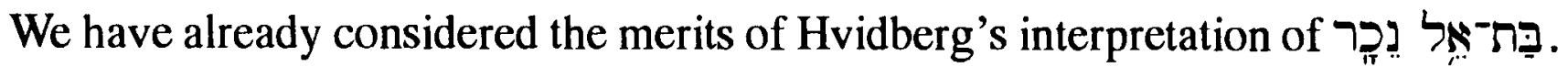
Here we merely need to take up any additional arguments which support a cultic interpretation of the weeping in Malachi 2:13.

At issue is not the question of whether cultic weeping is attested elsewhere in the ancient Near East or elsewhere in Israel's apostasy. For example, it is granted that a similar weeping is mentioned in Ezekiel 8:14, where Jewish women wept for Tammuz in the temple of the Lord. ${ }^{66}$ What is at issue is whether this is what Malachi intends, particularly since this weeping is mentioned in the absence of the explicit mention of Tammuz or any other alien deity in Malachi 2:13. Hvidberg renders the verse, "And this have ye done again: Covering the altar of Yahweh with tears, with weeping and groaning, insomuch that he regardeth not the offering any more or receiveth gifts with good will at your hand."67

64 Weeping and Laughter in the Old Testament, 120-123. Cf. also H. Winckler, "Maleachi" (1899) 531-9; H. Ringgren, Israelite Religion (1966) 197, and G. W. Ahlström, op. cit., 49.

J. M. P. Smith dismissed Winckler's view as "a curiosity of interpretation" (op. cit., 52; cf. also p. 57).

65 Based on this identification, F. F. Hvidberg explains the expression "Judah ... has married the daughter of a foreign god" (2:11) as reminiscent of Hosea's depiction of Yahweh as the husband of Israel. 66 Singled out as supportive of this thesis by A. Isaksson, op. cit., 33.

67 Op. cit., 121. 
Grammatically Hvidberg's argument rests on two points: 1) that in 2:13, rendered by Hvidberg as "again," implies that the weeping in 2:13 is a second abomination related to the marriage mentioned in 2:11 and 2) that מאי in vs. 13b bears the meaning "insomuch that ... not," with the implication that Yahweh will not accept Judah's offerings because of Judah's reprehensible weeping. ${ }^{68}$

In response to the first of these arguments, while it is appropriate to recall our earlier discussion regarding the uncertainty of שִנִית, both textual and semantic (cf. pp. 32f. above), we may grant with Hvidberg and others that some such meaning as "again" or "secondly" is a plausible rendering. ${ }^{69}$ However, this does not settle the matter at issue. What needs to be proven is that the second abomination is precisely Judah's weeping, rather than the infidelity mentioned in vs. 15 . Strongly favouring this latter interpretation is

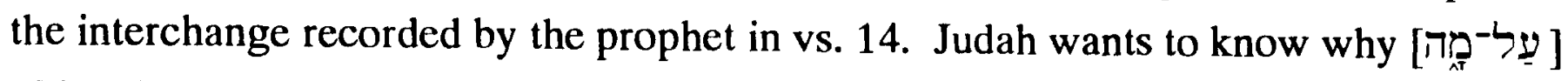
Yahweh no longer accepts their offerings. Malachi's explicit answer is that it is because of [ [ِ Hvidberg's view, because of their weeping. ${ }^{70}$

In response to the second of Hvidberg's arguments, it is not at all clear that the passage cited by Hvidberg in support of his definition of pephaniah 3:6, means what hc alleges: “... I have laid waste their streets so that none walks in them; their cities have

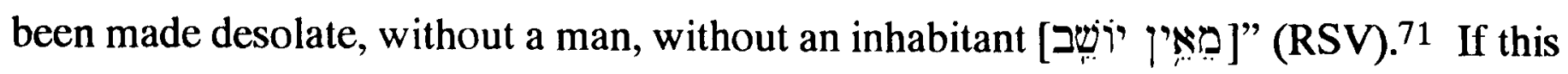
hypothetical resultative use is rejected, one is left with a causal use which yields the exact opposite sense to that which Hvidberg desires: "You cover the Lord's altar with tears, with weeping and groaning because he no longer regards the offering or accepts it with favour at your hand" (RSV). If for the moment the precise force of ממא ist in left ibeyance, 2:13f. clearly implies that Judah's weeping and her question "why?" are both due to the fact that Yahweh refuses to accept her offering, not the reverse, as Hvidberg supposes.

Entirely consistent with this reading of the evidence, and highly problematic for

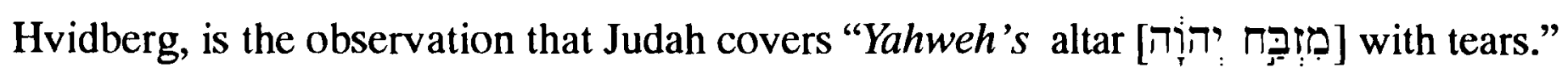
Indeed, this mention of Yahweh is so embarrassing for Hvidberg's thesis that he makes the gratuitous suggestion: “It is, however, possible that 'Yahweh's altar' is due to an elaboration by later hands, who reinterpreted the text and would not submit to the mention of the name of a strange god in this passage." 72 Such an ad hoc argument lacks conviction.

68 F. F. Hvidberg, op. cit., 121, 122, n. 1. Cf. also A. Isaksson, op. cit., 29.

69 So also S. R. Driver, The Minor Prophets (1906) 315.

$70 \mathrm{To}$ assert, as Hvidberg does, that this infidelity in vs. 14 "must refer to the same treachery as that mentioned in $11 \mathrm{~b}$ and 13a" is merely to assume what needs to be proven (op. cit., 122).

Cf. also W. Rudolph, who argues that the "tears" are not likely to be cultic, against the view of S. Schreiner, since vs. 13b makes clear the people's lament is due to Yahweh's refusal to accept their offerings. Besides the idea of cultic weeping is rather remote from the context ("Zu Mal 2 10-16," 89).

71 In support of this rendering, cf., e.g., J. M. P. Smith, A Critical and Exegetical Commentary on the Book of Zephaniah, 242, and R. L. Smith, op. cit., 139.

72 Op. cit., 122; so also A. Isaksson, op. cit., 32. 


\section{In his exegesis of Malachi 2:10-16, A. Isaksson reiterates F. F. Hvidberg's}

conclusions concerning the alleged ritual mourning in 2:13, while adding one further argument of his own (which is repeated by G. W. Ahlström). ${ }^{73}$ Isaksson takes issue with interpreters who consider that it is "the divorced wives who, in their sorrow and despair, cover Yahweh's altar with tears."74 Isaksson offers Hvidberg's interpretation as a more satisfying exegesis, remarking: "it seems very unlikely that they [the priests] would have admitted divorced women to the altar itself, so that they might weep there in despair."75 Whether this is unlikely or not, ${ }^{76}$ the vast majority of commentators, convinced that it is the offending men who are weeping at the altar, would agree with Isaksson in rejecting this view concerning divorced wives without feeling the least compelled to embrace the approach of Hvidberg. The argument for cultic weeping is not advanced by the posing of a false dilemma.

A final argument which needs to be considered briefly is one put forth by G. W. Ahlström, building on the views of Hvidberg and Isaksson. Ahlström notes that "the usual mode of designating a rite or phenomenon as non-Yahwistic, i.e. as belonging to another deity, is, in the prophetical books, to call it as is done here in Malachi [2:11]."77 However, for Ahlström to restrict his attention solely to occurrences in the prophetical books is artificial and lacking in justification -- particularly given the similarities, if not literary dependence in some cases, between Malachi and Ezra, Nehemiah, Proverbs, and especially Deuteronomy, but also the Pentateuch more generally, as noted earlier.

In any case, while תוֹ not limited to this use. ${ }^{78}$ is frequently used of unspecified wrongs, as well as of

G. W. Ahlström, willing to accept "Yahweh" as original to the text, can only maintain a reference to "cultic weeping" by recourse to special pleading (op. cit., 28). He writes, "Mal. 2:13 does not quite prove that the rite was Yahwistic from the point of view of the prophet, but it could have been so from the point of view of the priests."

While Israel's syncretism allowed worship of alien gods to take place in the Lord's temple or sanctuary, it appears it generally involved distinct altars set up to honour the foreign deity -- hence repeatedly we read about "the altar of Baal," "the altars for Baalim," "altars for all the host of heaven," etc., in such passages as Judges 6; 1 Kings 16:32; 2 Kings 11:18; and 2 Chronicles 14:3; 33:3ff.

73 A. Isaksson, op. cit., 31-32. Cf. also G. W. Ahlström, op. cit., 49.

74 This view is based on the Targum and accepted by Jerome (so J. G. Baldwin, op. cit., 239). Such also is the view of, inter alios, E. Henderson, The Twelve Minor Prophets (1858) 454; H. Cowles, The Minor Prophets (1867) 392; and G. H. A. von Ewald, Commentary on the Prophets of the Old Testament, 2 (1875) 81.

75 Op. cit., 29.

76 G. W. Ahlström, citing J. M. P. Smith, op. cit., 51 in support, asserts: "women are not allowed to approach Yahweh's altar" (op. cit., 49). But with Smith, clearly the language of "covering the altar with tears" is figurative and "the legitimacy of the figure does not depend upon the proximity of the women to the altar (cf. Hb. 2:17)." Perhaps more convincing is J. G. Baldwin, who notes that this view is untenable since the deserted wives have not yet been mentioned (op. cit., 239).

77 Op. cit., 27f. Cf. also p. 50. G. W. Ahlström cites numerous authorities in support, including D. E. Gowan, who asserts חועבה "always seems to refer to cultic irregularities" ("Prophets, Deuteronomy and Syncretistic Cult in Israel” [1968] 107).

78 Cf. E. Gerstenberger, "“עת t'b pi. verabscheuen," THAT 2, 1051-1055, and R. F. Youngblood, "תִ העב abhor, etc.," TWOT 2, 976-977. 
sexual offences in particular, in a manner which would support its presence in Malachi $2: 11$, if Malachi has in mind an offence involving literal intermarriage. Compare, for example, Leviticus 18:22-30; 20:13; Deuteronomy 23:19 [ET 18]; 24:4; and perhaps Ezekiel 16:22.

Of special interest in the present case, however, are the occurrences of Ezra 9:1, 11, and 14. ${ }^{79}$ Here Ezra recalls the reason for the prohibition of intermarriage with pagans -- namely their "abominations": "Shall we break thy commandments again and

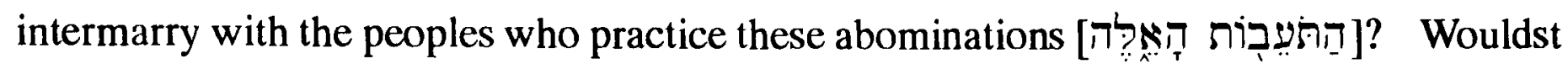
thou not be angry with us till thou wouldst consume us, so that there should be no remnant, nor any to escape?" (Ezra 9:14) Although Ezra does not use תוֹ עִכָה to refer to the prohibited intermarriage itself, its use in the justification of that prohibition makes reasonable its presence in Malachi 2:11, where literal intermarriage is also in view. As argued by B. Glazier-McDonald, intermarriage is banned precisely because of the idolatrous practices of the pagan wife which cause intermarriage to profane the sanctuary of Yahweh. 80

In summary, as against F. F. Hvidberg, G. W. Ahlström, and others, it appears that Malachi 2:13 does not allude to syncretistic ritual weeping and that in the same verse does not require a reference to idolatry. Accordingly, Malachi 2:13 does not support a reference to idolatry rather than literal marriage in Malachi 2:11 and 14.

\subsection{Summary and Conclusions}

This chapter began by reviewing the arguments for holding that 2:14 refers to marriage. In particular it was argued that:

1) Although the בִּרִ in vs. 14 may bear some relation to the 10 , claim that it is one of synonymy raises intractable problems. Certainly in the attempt to

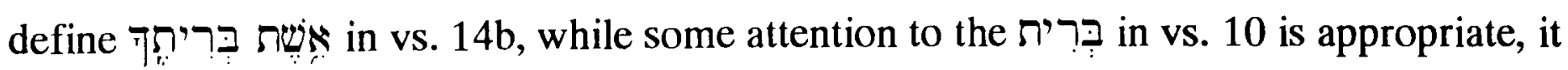

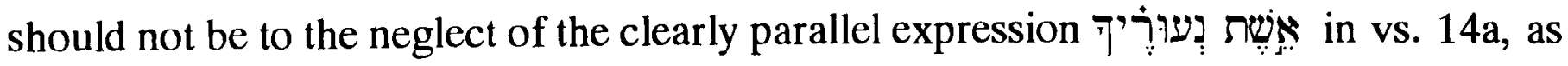

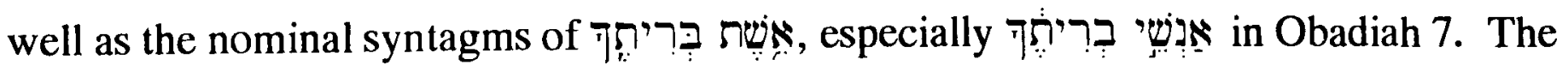
implication of these parallels is that the covenant in Malachi 2:14 is one which exists between a husband and his wife.

Cf. also M. Weinfeld, Deuteronomy and the Deuteronomic School (1972) 267-9, and R. Westbrook, "The Prohibition on Restoration of Marriage in Deuteronomy 24:1-4" (1986) 405.

79 Cf. A. S. van der Woude, op. cit., 67

80 Malachi, 89-91. B. Glazier-McDonald cites Leviticus 20:2-5, as well as Ezekiel 8:10, 14, and 16, as proving that idolatrous practices, even when not conducted within the temple, defile Yahweh's sanctuary. 
Subsequently, we reviewed the objections which have been raised against interpreting בדּרִ in Malachi 2:14 as a reference to literal marriage. It was concluded that:

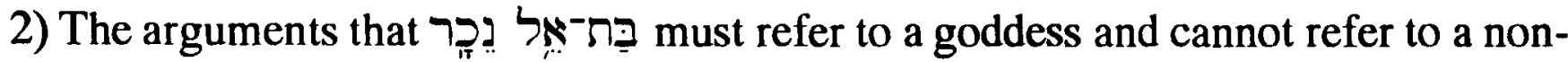
Jewish woman lack conviction.

3) The so-called "universalism" of Malachi is not such as forbids a reference to literal "interfaith marriage" in 2:11f. and hence a reference to literal marriage throughout 2:10-16.

4) While Malachi shows a special interest in cultic matters throughout his work, including 2:10-16, as with the work of Ezra, this need not exclude a concern with Judah's literal marital practice.

5) The claim that Malachi 2:13 refers to an idolatrous "cultic weeping" is unconvincing.

In short, no objection based on considerations internal to the book of Malachi is sufficient to overturn the weight of evidence of the five arguments considered in $\$ 2.1$ above

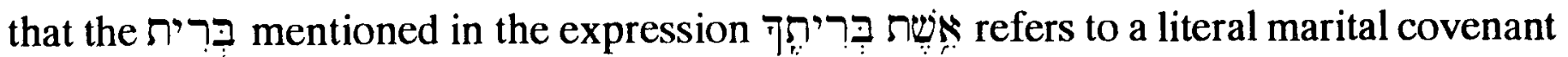
between "you," i.e., the husband, and "your wife." 


\section{Outline of Chapter 3: \\ Malachi 2:16 and Divorce}

3.1 Approaches which deny any reference to divorce in Malachi $2: 16 \ldots \ldots \ldots \ldots \ldots \ldots . . .51$

3.1.1 The text and meaning of Malachi 2:16 is too uncertain to claim that it addresses the subject of divorce .................................. 51

3.1.2 Malachi 2:16 condemns an idolatrous ritual (I. G. Matthews) ............. 52

3.1.3 Malachi 2:16 deals with the secondary status of a former Jewish wife, not with divorce (A. S. van der Woude).......................54

3.2 Approaches which interpret Malachi 2:16 as requiring (or permitting) divorce...... 57

3.2.1 Malachi urges divorce (4QXII ${ }^{\mathrm{a}}$, LXX ${ }^{\mathrm{LW}}$, and Targum) .................57

3.2.2 Malachi urges divorce of heathen wives (A. von Bulmerincq).............59

3.2.3 Malachi recommends divorce in Malachi 2:16 as the lesser of two evils, i.e., as preferable to polygyny (S. Schreiner) .................60

3.3 Approaches which interpret Malachi 2:16 as an absolute prohibition of divorce .... 62

3.4 Approaches which limit the kind of divorce prohibited in Malachi 2:16............66

3.4.1 Malachi prohibits only divorce when initiated by the woman (one

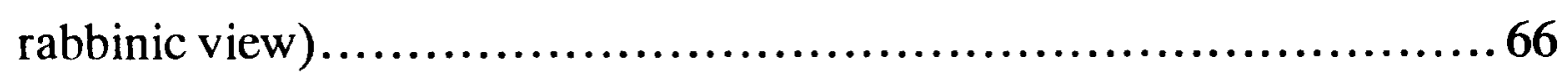

3.4.2 Malachi condemns only unjustified divorce, that is, divorce based on aversion.....................................................66 66

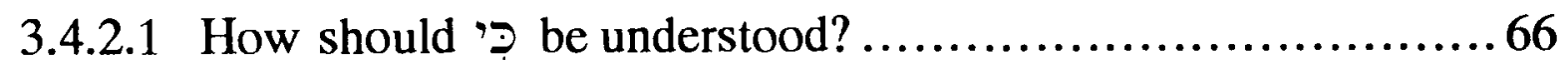

3.4.2.1.1 is non-conditional (R. Westbrook) ........667 67

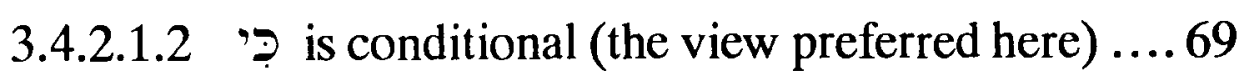

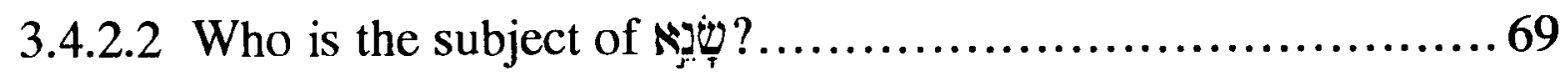

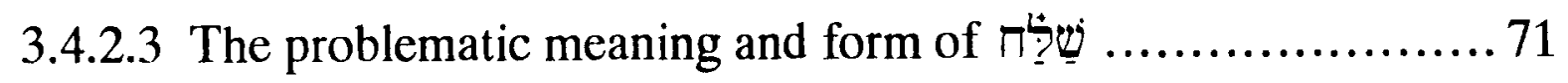

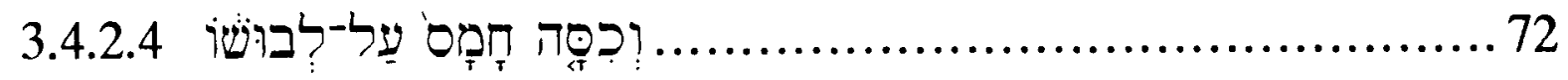

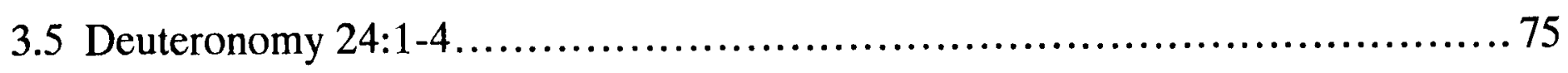

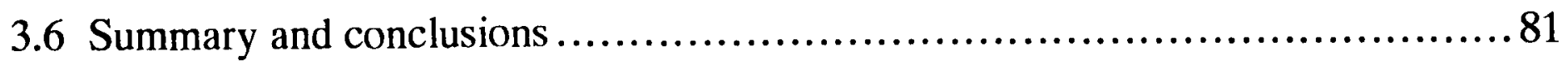




\section{Chapter 3: \\ Malachi 2:16 and Divorce}

Traditionally Malachi 2:16 has been understood to be a condemnation of divorce per se. This interpretation coheres with taking the reference in 2:14 to a covenant as a reference to marriage. But many scholars hold that 2:16 does not refer to literal divorce and therefore 2:14 need not refer to literal marriage. This viewpoint will now be evaluated.

“... It must be sincerely doubted whether in Old Testament times even a prophet would have denounced divorce as a crime. Deuteronomy 24 tells against this interpretation." So writes A. S. van der Woude, as he rejects an interpretation of Malachi 2:16 which would construe this verse as a repudiation of literal divorce when based on aversion, an interpretation which on other grounds Van der Woude would be prepared to accept. ${ }^{1}$ A. Isaksson echoes this same sentiment when he concludes: "Interpreting the text as a condemnation of divorce means that we are reading into it a view of divorce which was first expounded about 500 years after Malachi...."2 Accordingly, Isaksson argues that the impossibility of such a reference to literal divorce in Malachi 2:16 offers significant support to the view that Malachi 2:10-16 as a whole is concerned with an attack against apostasy to an alien cult and has nothing to do with literal marriage and divorce.

In support of Van der Woude and Isaksson, there is a wide scholarly consensus that Malachi is heavily indebted to the Deuteronomic perspective. ${ }^{3}$ The following points of comparison have been noted:

1) Of all the Old Testament books, only Malachi and Deuteronomy commence with an address to all "Israel."

1 "Malachi's Struggle For a Pure Community" (1986) 71.

2 Marriage and Ministry in the New Temple (1965) 34. At another point Isaksson asserts: "He [Malachi] goes far beyond Dt. 24:1-4, and indeed seems to set himself in downright opposition to what is written there about divorce" (p. 30).

3 So, e.g., J. Swetnam, "Malachi 1:11 An Interpretation" (1969) 203; W. J. Dumbrell, "Malachi and the Ezra-Nehemiah Reforms," 42; and R. J. Coggins, Haggai, Zechariah, Malachi, 75-76.

L. H. Brockington lists five conceptual parallels between Malachi and Deuteronomy: Malachi 1:2// Deuteronomy 7:8 -- God's love for Jacob; Malachi 1:9// Deuteronomy 10:17 -- God does not show favour; Malachi 2:1, 4; 3:3 // Deuteronomy 18.1 -- priest and Levite synonymous; Levites may offer sacrifice; Malachi 2:6 // Deuteronomy 33:10 -- the law of truth in Levi's mouth; Malachi 4:4 // Deuteronomy 4:10 -revelation to Moses on Horeb ("Malachi," 656).

C. Stuhlmueller adds two further examples: Cf. Malachi 1:12 with Deuteronomy 7:8 and Malachi 3:22 with Deuteronomy 4:10 ("Malachi," 399).

4 So notes W. J. Dumbrell, "Malachi and the Ezra-Nehemiah Reforms," 44. Dumbrell goes on to stress how the post-exilic application of the covenant injunctions in Deuteronomy, such as the call to remember Yahweh's elective love, represents a "bold transference to the rump-state by the post-exilic prophets of the projected ideal."

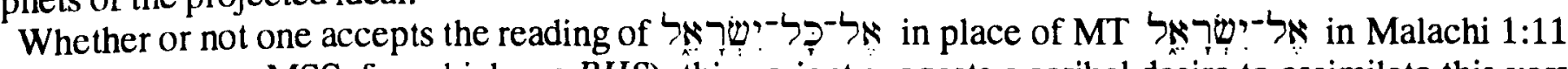
(supported by some MSS, for which see $B H S$ ), this variant suggests a scribal desire to assimilate this verse to Deuteronomy 1:1. Cf. also Malachi 3:22 [ET 4:4]. 
2) Malachi concludes his work with an emphatically Deuteronomic injunction: "Remember the law of my servant Moses, the statues and ordinances that I commanded him at Horeb for all Israel" (3:22 [ET 4:4]). ${ }^{5}$ Horeb is mentioned as the site where Moses and Israel received God's revelation in Deuteronomy 4:10ff. ${ }^{6}$

3) Malachi's special interest in affirming Yahweh's elective love for Israel against her doubt of that love finds a parallel in Deuteronomy's similar affirmation of Yahweh's love over against the anticipated doubts of a "potentially refractory Israel" (Deuteronomy $4: 37 ; 7: 6$ ff. $).^{7}$

4) Malachi's concern for Yahweh's despised "name" (1:6ff.) may presuppose the "Name Theology" of Deuteronomy. ${ }^{8}$

5) Given the relatively infrequent mention of the "fatherhood" of God outside of Deuteronomy (but within Deuteronomy, cf. Deuteronomy 8:5; 14:1; 32:6), Malachi's appeal to this concept may likewise suggest Deuteronomic influence.

6) Malachi's appeal to the "covenant with Levi" finds a possible source in Deuteronomy 33:8-11.9 Similarly, it has been argued that Malachi reflects Deuteronomy's usage where, it is claimed, "priest" and "Levite" are employed synonymously (or at least without a rigorous distinction) and "Levites" are permitted to offer sacrifice, as in Deuteronomy 18:1ff. ${ }^{10}$

7) Malachi's concern for the tithe may be related to the provision made in Deuteronomy 26:12ff. ${ }^{11}$ As Dumbrell notes, Malachi's dependence on Deuteronomy regarding the tithe includes not only the stipulation, but also the blessing sanction of a bounty which will command the respect of the nations (Deuteronomy 26:19).

8) A further possible evidence of Deuteronomic influence is found in Malachi 3:17

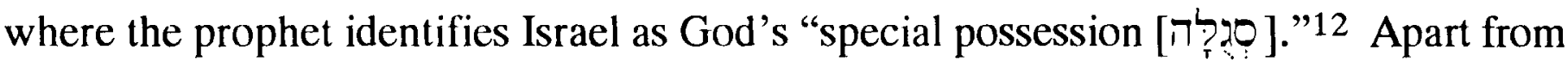
Psalm 135:4, which is regarded as post-exilic and dependent on earlier Deuteronomic texts,

5 Accordingly, Dumbrell considers Malachi to be a book "bound together by Deuteronomic inclusions, a fact which tends to underscore the derivative prophetic nature of the work" (op. cit., 44). Cf. A. Renker, Die Tora bei Maleachi (1979) 98-101.

6 So notes L. H. Brockington, op. cit.

7 So W. J. Dumbrell, op. cit., 44, and L. H. Brockington, op. cit., 656.

8 So U. Kellermann, "Erwägungen zum Esragesetz" (1968) 383, n. 81, as cited by W. J. Dumbrell, op. cit., 45.

9 So W. J. Dumbrell, op. cit. But against this, see S. L. McKenzie and H. N. Wallace, “Covenant Themes in Malachi," 550.

10 So, e.g., L. H. Brockington, "Malachi," 656.

But see J. G. McConville for a careful reappraisal of Wellhausen's reconstruction of the history of the priesthood and, related to this, the supposed synonymy of the terms "priest" and "Levite" in Deuteronomy (Law and Theology in Deuteronomy [1984] 124-153). Cf. also J. M. O'Brien, Priest and Levite in Malachi (1990).

11 So W. J. Dumbrell, op. cit., 49. However, a contrary view is expressed by a number of other scholars who argue that Malachi presupposes the legislation of P rather than D. Cf., e.g., G. A. Smith (The Book of the Twelve Prophets, II, 2nd ed. [1929] 328-330), A. Bentzen, W. Neil ("Malachi," 229), and P. A. Verhoef (The Books of Haggai and Malachi, 159).

12 Or, "covenant possession," according to S. L. McKenzie and H. N. Wallace, who cite M. Weinfeld, "The Covenant of Grant in the Old Testament and the Ancient Near East" (1970) 195 (op. cit., 561). 
this designation for Israel is found elsewhere only in texts which are thought to be Deuteronomic, namely Exodus 19:5, Deuteronomy 7:6, 14:1-2, and 26:18. Moreover, in

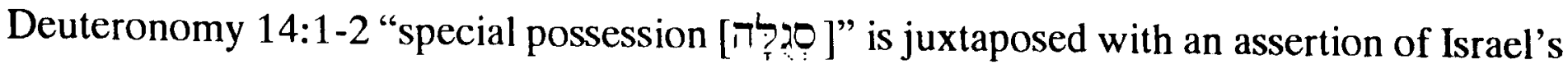
sonship, much as it is in Malachi 3:17.

9) Finally, perhaps the most notable evidence of Deuteronomic influence within Malachi is the prominence of covenant concepts throughout this brief work. ${ }^{13}$ As has been demonstrated by S. L. McKenzie and H. N. Wallace, this importance goes far beyond the six explicit references to בְּר (Malachi 2:4, 5,8,10,14;3:1) to include the Deuteronomic vocabulary of covenant (e.g., "love," "hate," "father," "son," "cursed," "great king," etc.), as well as characteristic perspectives and themes. ${ }^{14}$ Deuteronomic perspective

In view of Malachi's profound debt to the Deuteronomic perspective, a number of scholars have argued that the apparent lenience in Deuteronomy 24:1-4 regarding the practice of divorce should control one's exegesis of Malachi 2:16, thereby disallowing any kind of denunciation of divorce on the part of the prophet. ${ }^{15}$ Certainly, if Malachi is so indebted to the Deuteronomic perspective, any interpretation which considers Malachi 2:16 to prohibit divorce will have to give an account for this apparent radical departure from that dependency. Nevertheless, before one seeks to harmonize, compare, or contrast these two texts, it is surely preferable to study each of them in its own right. ${ }^{16}$

At the close of this chapter we shall turn our attention to Deuteronomy 24:1-4, unquestionably the locus classicus for any discussion of divorce in the Old Testament. Before doing so, however, we shall examine Malachi 2:16 in its own right. In particular, we shall seek to demonstrate the superiority of the MT of Malachi 2:16 over against the versions or $4 \mathrm{QXII}$ (or any conjectural emendations). Furthermore, we shall seek to establish that the text condemns not divorce in general, but specifically what may be called "unjustified divorce," that is, divorce based on aversion. If successful, an important implication of this conclusion for the present thesis will be to eliminate Malachi 2:16 as

13 Stressing the centrality and sophistication of "covenant" within Malachi, cf. J. G. Baldwin, Haggai, Zechariah, Malachi (1972) 216C.; A. Tosato, "Il ripudio: delitto e pena (Mal 2,10-16)" (1978); L. C. H. Fourie, "Die betekenis van die verbond as sleutel vir Maleagi" (1982), as cited by P. A. Verhoef, The Books of Haggai and Malachi, 180, n. 2; S. L. McKenzie and H. N. Wallace, "Covenant Themes in Malachi" (1983); C. T. Begg, "B' rit in Ezekicl" (1986) 79; R. L. Smith, "The Shape of Theology in the Book of Malachi" (1987) 24; and P. A. Verhoef, The Books of Haggai and Malachi, 179-184.

14 Op. cit. Cf. also R. L. Smith, Micah-Malachi, 300, and R. J. Coggins, Haggai, Zephaniah, Malachi, 75-76.

${ }^{15}$ See, e.g., A. S. van der Woude, "Malachi's Struggle For a Pure Community," and A. Isaksson, op. cit., as discussed above.

Cf. also S. L. McKenzie and H. N. Wallace, who leave undecided the question of whether Malachi 2:10-16 has to do with mixed marriage and divorce or apostasy and some other offence, noting: "If Mal 2:13-16 concerns divorce, it is in striking contrast to the law of divorce in Deut 24:1-4" (op. cit., 552f.).

16 For those who consider that Malachi not only prohibited divorce, but also urged polygyny as a preferable alternative, yet a further tension is introduced between Malachi and Deuteronomy, that is, if the prohibition of polygyny in Deuteronomy 17:17 is taken as implying a general prohibition. 
evidence against a reference to literal marriage in Malachi 2:10-16 and, at the same time, to elucidate a key implication of the identification of marriage as a "covenant [?ִּרִ ]."

Overlooking minor differences in detail, there are nine major interpretative approaches to Malachi 2:16 which, for convenience, may be divided into four categories: 1) Approaches which deny any reference to divorce in Malachi 2:16;2) Approaches which interpret Malachi 2:16 as requiring, or permitting divorce; 3) Approaches which interpret Malachi 2:16 as an absolute prohibition of divorce; and 4) Approaches which limit the kind of divorce prohibited in Malachi 2:16.

\subsection{Approaches which deny any reference to divorce in Malachi 2:16}

\subsubsection{The text and meaning of Malachi 2:16 is too uncertain to claim that it addresses the subject of divorce}

The MT of 2:16a reads,

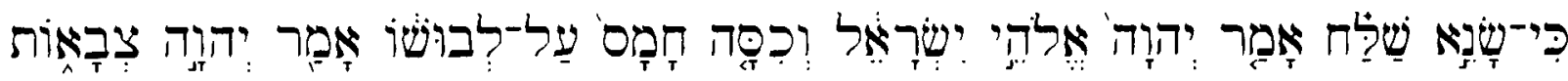

This may be rendered literally, "For he hates 'sending,' says Yahweh, the God of Israel, 'and he covers his garment with violence,' says Yahweh of hosts."

The following is a brief listing of the principle lexical, grammatical, and textual problems associated with this passage: How should the be understood? The LXX, Vulgate, and Targum take it as a conditional, "if a man hates...."17 Because they do so, the versions (excluding $\mathrm{LXX}^{\mathrm{NABQV}}$ ) construe Malachi 2:16 as providing an express permission for divorce. In other words, they consider the apodosis to begin with שֶׁ? :If you hate (her), divorce (her)...."18 Alternatively, with $\mathrm{LXX}^{\wedge \mathrm{ABQV}}$, it is possible that the apodosis

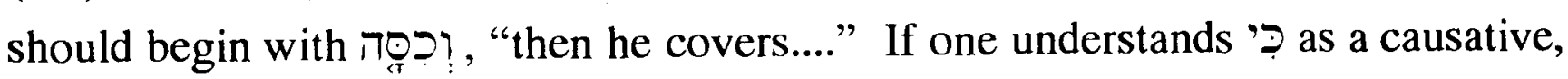
"because," or as a more mild conjunction, "for," one must still account for the problematic

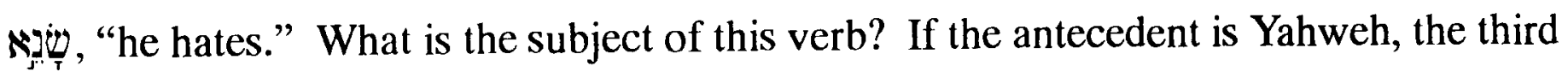
person is awkward in what purports to be direct discourse. Moreover, the shift in reference from the "he" [= Yahweh] of "he hates" to the "he" [= the divorcing man] of "he covers

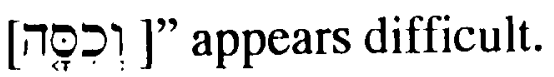

A further difficulty concerns the precise meaning of explicit object and which may be parsed as a Piel infinitive construct, or as an alternative form of the Piel infinitive absolute, or as a masculine singular imperative. In spite of the concurrence of both tradition and the vast majority of modern scholars in understanding

17 See below for a discussion of these witnesses.

18 So notes, e.g., A. Isaksson, op. cit., 32; R. L. Smith, Micah-Malachi, 323; and P. A. Verhoef, The Books of Haggai and Malachi, 278. Cf. also J. G. Baldwin, op. cit., 241. 
שלח as referring to divorce, it is often noted that the use of this verb with this sense is by no means customary for the Old Testament.

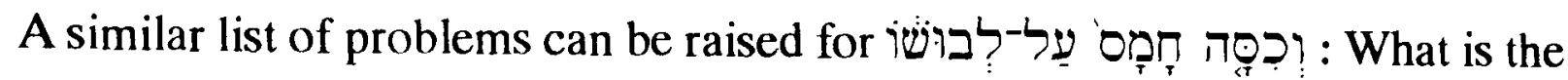
relation of this expression to what precedes? If it is a second thing which is hated, why is

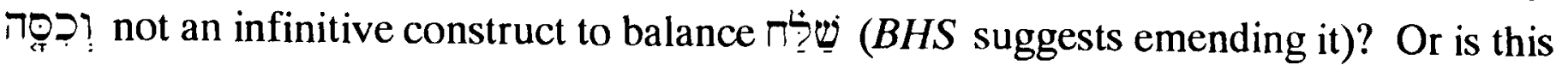

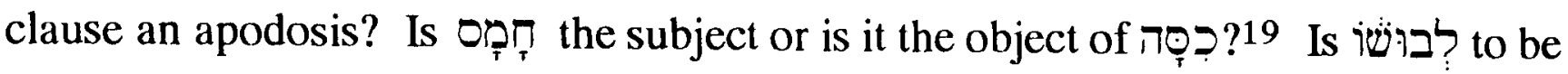
interpreted as a metaphor referring to the wife, or is there a cultic reference here, etc.?

Despairing in the face of all these problems, C. C. Torrey simply declares Malachi 2:16 (and 2:15) to be "hopelessly corrupt."20 Similarly, F. F. Hvidberg writes: "nothing definite can be said about Verses 15 and 16, the text being completely unintelligible in these." 21 Repeating the same thought with only a slight elaboration, A. Isaksson writes, "nothing definite can be said as to the content of vv. 15-16 on account of the poor state of the text. When scholars construe from them that Yahweh hates divorces or that the purpose of marriage is to procreate children, they can only do so, as I have already pointed out, by resorting to quite arbitrary emendation of the text." 22

All interpreters acknowledge the difficulty of the MT of 2:16, as well as the striking disparity in the witness of the versions for this verse. Nevertheless, most scholars are willing to attempt an exegesis of 2:16. The few who demure, because the verse is so "hopelessly corrupt," are most often those who also deny any reference to literal marriage in Malachi 2:10-16. May this textual agnosticism be a rather too convenient means of eliminating contrary evidence? Indeed, it is possible, as R. Mason notes, that "the very bad state of the text bears its own witness to the probability that it did originally condemn divorce outright. If so, ... it would be small wonder if it suffered from scribal efforts to soften it." 23 At any rate, it is necessary to see if sense can be made of the verse before giving up and claiming that it is beyond interpretation.

\subsubsection{Malachi 2:16 condemns an idolatrous ritual (I. G. Matthews)}

I. G. Matthews offers another approach which denies any reference to literal divorce in Malachi 2:16. Building on the views of C. C. Torrey and $\mathbf{H}$. Winckler, Matthews understands Malachi 2:10-16 as a sustained attack against some variety of Tammuz worship rather than having do to with literal marriage. ${ }^{24}$ In terms of this context,

19 Favouring the identification of cit. Favouring the identification of cit.

20 "The Prophecy of 'Malachi'," 10, note 20.

21 Weeping and Laughter in the Old Testament, 123. So also A. C. Welch, Post-Exilic Judaism, 120.

22 Op. cit., 34. J. M. O'Brien appears to share this view and, accordingly, offers no interpretation of 2:16a (Priest and Levite in Malachi, 72f.).

23 The Books of Haggai, Zechariah and Malachi (1977) 150. Cf. also S. Schreiner, "MischehenEhebruch-Ehescheidung" (1979) 208.

24 I. G. Matthews, "Malachi" (1935) 27. 
Matthews renders 2:16, "For I hate stripping off ... and putting a pagan device on one's garment, says Yahweh of hosts. So preserve your good sense and do not apostatise."

In support of this rendering, Matthews proposes to emend the MT שָּנָּ, "he hates,"

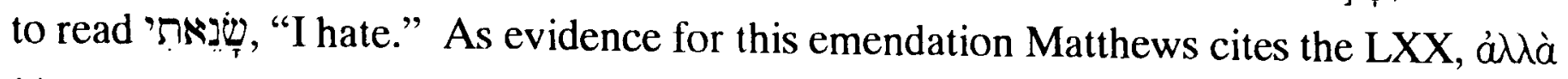

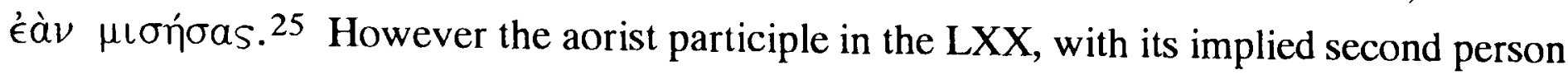
subject, makes the proposal unlikely. 26

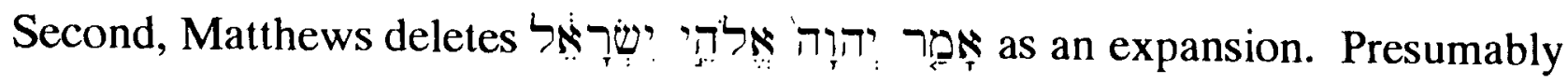

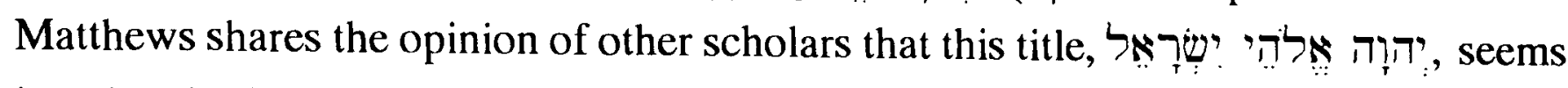
inauthentic since it occurs only here in Malachi, and that it is also repetitive (a vertical

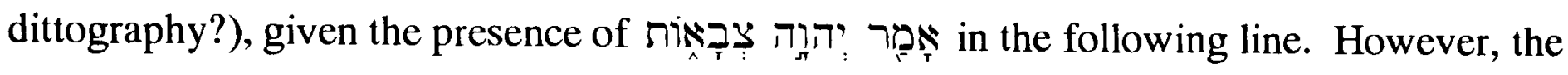
MT has the support of all the versions, including 4QXII ${ }^{\mathrm{a}}$, and the proposed deletion appears unwarranted.

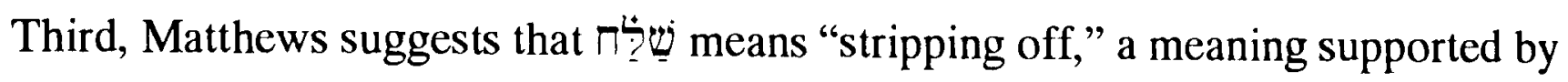
the Targum. Matthews explains that "stripping off ... may have been one of the features in Tammuz worship." 27 However, there is no evidence for such a cultic practice.

Furthermore, the Targum does not require the meaning posited by Matthews. ${ }^{28}$ Given the fact that there is no other example where the meaning "strip off" is required for שלח among its 847 biblical occurrences, including 267 instances of the Piel, Matthews' suggestion must be deemed highly improbable. 29

Finally, Matthews asserts that "no meaning of oמח can be made to fit context."30

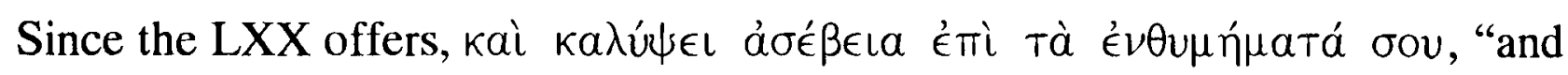
ungodliness will cover your thoughts," Matthews wonders whether its Vorlage may have read חשב חשב means "girdle," an item of dress associated with the high priest's vestments in Exodus 28:27f., etc. Accordingly, Matthews supposes that Malachi's original reference may have been to some pagan equivalent of this garniture. However, any such use of חשבב is speculative and Matthews' handling of the LXX is

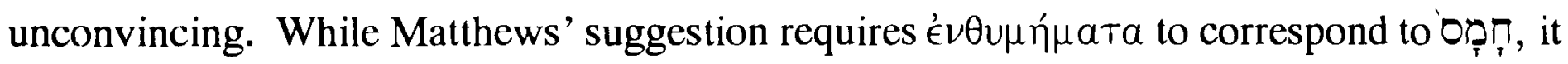
is more likely that it renders לבוּשוּ?

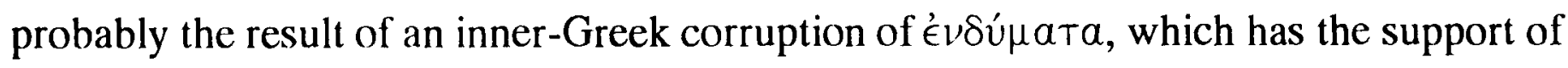

25 Ibid., 37.

26 The LXX aorist participle has an implicit second person subject, based on agreement with the

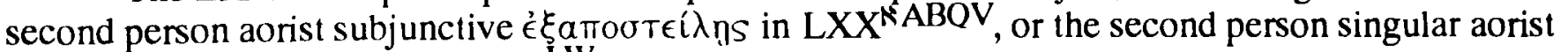

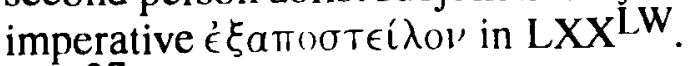

27 Ibid., 23.

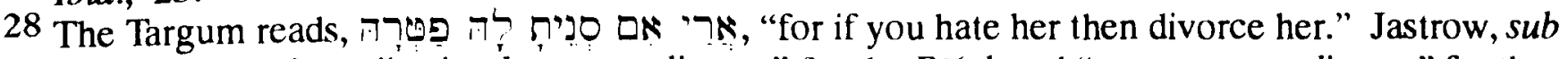
verbo רפ, offers "to free, dismiss, let go; to divorce" for the Pe 'al, and "same, esp. to divorce" for the $\mathrm{Pa}$ 'él.

29 For these statistics, see THAT 2, $910 \mathrm{f}$.

30 Ibid., 37. 
$\mathrm{LXX}^{\mathrm{W}}$ as well as the daughter versions (Peshitta, Arabic, Armenian, Ethiopic, and Georgian). ${ }^{31}$

As a result it is unnecessary to suppose that the Vorlage of the LXX differed from the MT in this clause. We therefore conclude that to find a reference to idolatry in 2:16 and to dismiss its reference to divorce is improbable.

\subsubsection{Malachi 2:16 deals with the secondary status of a former Jewish wife, not with divorce (A. S. van der Woude)}

Other scholars, while admitting that 2:16 deals with marriage-related problems, deny that it treats divorce. A. S. van der Woude, for example, argues that the exclusive concern of 2:10-15 is with mixed marriage and that at no point prior to vs. 16 is there any intimation of divorce. In particular, Van der Woude notes that, as with the בָגָר in vs. 10, the בָָָּ in vs.14 "does not necessarily imply divorce."32 After reviewing the difficulties mentioned above concerning an overly facile identification of שִֵַׁח in 2:16 with divorce, Van der Woude offers his own view, namely that שלח "is an abbreviation of the idiomatic expression šälah yād (the same abbreviation can be found in 2 Samuel 6:6 and Obadiah 13) that designates a morally detestable hostilc act."33 Accordingly, Van der Woude renders the verse, "For he who neglects (his Jewish wife) puts forth his hand (in hostility), says Yahweh the God of Israel, and covers his garment with violence, says Yahweh Almighty...."34 Van der Woude explains Malachi's intent in this verse as one of condemning not divorce, but the "subordination and maltreatment of married Jewish women because of foreign heathen wives."

Van der Woude's thesis is appealing for its avoidance of any conjectural emendation

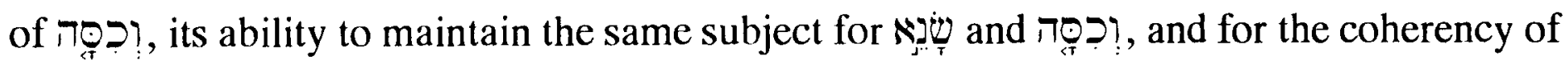
theme which it supposes for 2:10-16 (mixed marriages). Nevertheless, there are several difficulties which make it doubtful:

1) Van der Woude rejects several alternative views of 2:16, in part because they require conjectural emendation (including revocalization) of the text. But it is to be noted

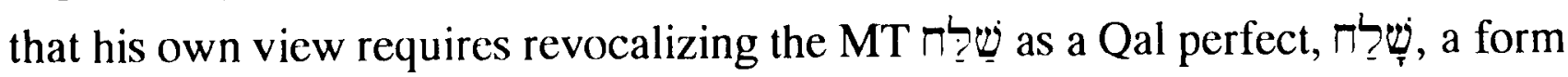
unsupported by any of the versions. ${ }^{35}$

31 Op. cit., 60. Accordingly, the eclectic text of the Göttingen Septuagint, prepared by J. Ziegler,

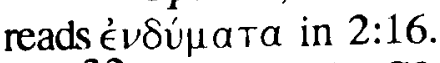

32 Op. cit., 69. Cf. also p. 67, where he examines vs. 10, adding the observation that Deuteronomy 24:1 demonstrates that "divorce as such could hardly violate the covenant community."

33 Ibid., 71. In support, A. S. van der Woude cites P. Humbert, "Etendre la main" (1962) 383-395.

34 Haggai, Maleachi, POT, 116. Van der Woude cites Genesis 29:31, 33; and Deuteronomy 21:15-17 in support of the rendering "achterstelt," that is "discriminates against" or "neglects" for wiv (op. cit., 124).

35 Op. cit., 71, n. 36. 


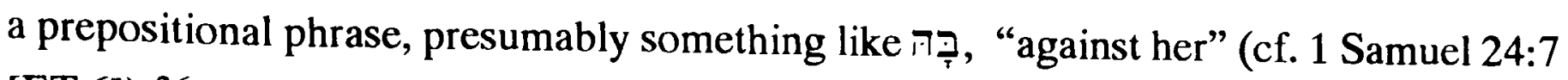
[ET 6]). ${ }^{36}$

3) More seriously, Van der Woude's entire proposal depends on the identification of שלח as "an abbreviation of the idiomatic expression šălah yād." Van der Woude defends this proposal by citing two texts, 2 Samuel 6:6 and Obadiah 13, but it turns out that neither proves the point at issue.

In the case of 2 Samuel 6:6, it appears that את ידו should be restored in this verse (the MT of Samuel is notoriously haplographic), following the multiple witness of 4QSama, LXX, Peshitta, Targum, and Vulgate. ${ }^{37}$ However, if the MT is retained, an ellipsis of the sort suggested by Van der Woude might be feasible in 2 Samuel 6:6, where the context makes clear what is intended. But this is precisely not the case with Malachi. Making this example still less apt for the purpose to which Van der Woude puts it, the meaning of the expression (אלח (את ידו in 2 Samuel 6:6 is not the same as that proposed by Van der Woude for Malachi! In Samuel it refers to a literal extension of Uzzah's hand, intended to steady the ark, not to an act of hostility.

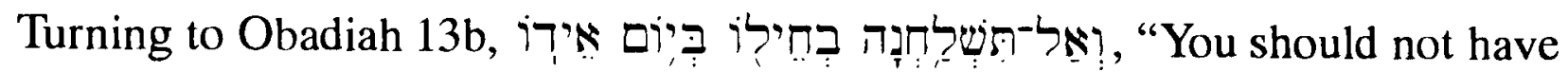
looted his goods in the day of his calamity," once again the contention of Van der Woude scems dubious. There appears to be a consensus among modern commentators that the key

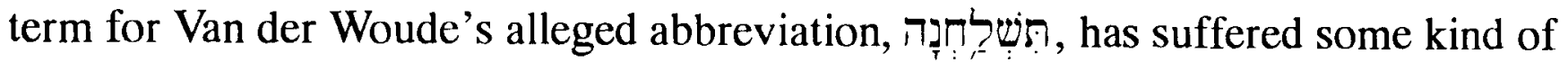
corruption. This conviction is based on the observation that the form of each of the seven other parallel jussives in vss. 12-14 is a third person feminine singular, rather than the third person or second person feminine plural as here. The LXX offers further support for an emendation with its expected third person singular, $\sigma v \nu \in \pi \iota \theta \hat{n}$. Not surprisingly, many

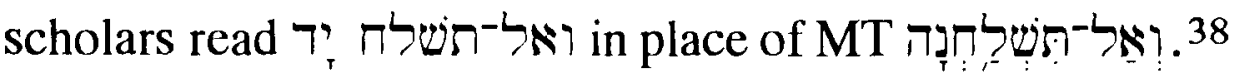

36 In every one of the fifty-seven examples of שלח יד in the OT (so Even-Shoshan), this expression either 1) refers to a very literal stretching forth of the hand (or an anthropomorphic "stretching forth" in the case of passages having God or an angel as their subject), which in every case is indicated by a complementary infinitive or a coordinate finite verb descriptive of a subsequent action accomplished by the outstretched hand, such as, grasping, seizing, taking, touching, or smiting, or 2) is accompanied by a prepositional phrase ( $ב$ is most common, but על על and are frequent as well). Some, though not all, of the examples in this second category are metaphoric.

Based on this evidence, on Van der Woude's interpretation of 2:16, we would expect an appropriate prepositional phrase (perhaps elided, though there are no biblical examples for this), since the metaphoric usages are confined to the second category.

37 So BHS; E. C. Ulrich Jr., The Qumran Text of Samuel and Josephus, 56; P. K. McCarter Jr., II Samuel, 164 (with some uncertainty); R. P. Gordon, 1 \& 2 Samuel, 356, n. 32; and A. A. Anderson, 2 Samuel (1989) 98.

38 So, e.g, C. F. Keil, The Twelve Minor Prophets, vol. 1, 364; A. B. Ehrlich, Randglossen zur hebräischen Bibel, vol. 5, 261; BHS; and J. D. W. Watts, Obadiah (1969) 35.

Alternatively, L. C. Allen assumes an ellipse of 7 , "hand," and repoints the MT as a second masculine singular form of the energic imperfect, (The Books of Joel, Obadiah, Jonah and Micah [1976] 157, n. 11).

Yet a third option is favoured by $\mathrm{H}$. W. Wolff, who argues that the MT arose through a corruption of תשלח-ניח (Obadiah and Jonah [1986] 37). This suggestion was first made by J. A. Bewer, but Bewer considered it equally possible that the original text read Exegetical Commentary on Obadiah and Joel [1911] 42). 
4) A further difficulty with Van der Woude's proposal is that it requires acceptance of his possible, but nevertheless speculative, reconstruction of the social circumstances of Judah's mixed marriages. Van der Woude writes, “By marrying foreign women Judaeans tried to share the privileges of their alien overlords. The common cause they made with them gave rise to severe tensions between a well-to-do class and the poor in one and the same religious community." 39 The problem with this posited class struggle is that there is no hint of it in the text. Nevertheless, since Van der Woude is unwilling to allow an allusion to divorce in vs. 10 , he must insist on this reconstruction because only in this way can he explain the faithlessness of Jews toward their brothers mentioned in that verse, as well as the violation of the "covenant community."40 To be sure, the expression (vs. 10) may refer to mixed marriage, as Van der Woude suggests. However it is not enough for Van der Woude to discuss whether divorce may or may not "violate the covenant community [italics added]," since, as was argued in the previous chapter, Van der Woude has not succeeded in establishing this rather idiosyncratic definition of 41

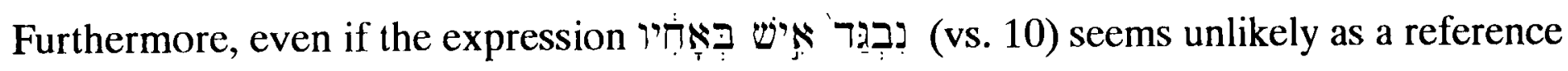
to the relationship between a husband and his wife, ${ }^{42}$ in the light of a passage such as Genesis 31:50 it is possible that it describes the breach between husbands and father-inlaws which may well have resulted from unjustified divorce. ${ }^{43}$

5) Finally, Van der Woude states but nowhere explains why, on his view, these polygynous mixed marriages necessarily resulted in the disdainful treatment of the Jewish wives. If the motive for these second marriages was merely political or economic, as Van der Woude claims, they would appear to be similar to a category of equally utilitarian marriage about which a fair amount is known, namely bigynous marriages contracted for

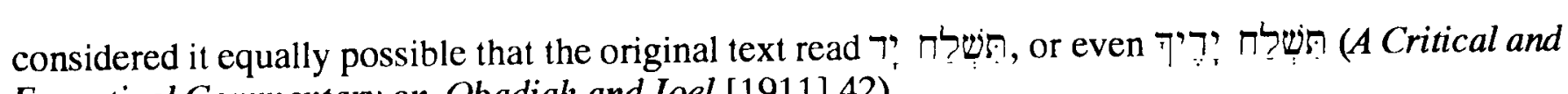
Exegetical Commentary on Obadiah and Joel [1911] 42).

39 Op. cit., 66 . Van der Woude also states, "Our text envisages the internal controversies in the Judaean community engendered by those who preferred social privileges and economic gains to religious and nationally loyalty and unity by marrying foreign women" (ibid., 67).

40 So, op. cit., 67.

Of course, if one admits a reference to divorce in Malachi 2:16, it is possible to find ample evidence for the intimation of this problem prior to vs. 16. E.g., cf. P. A. Verhoef, The Books of Haggai and Malachi, 262-281, especially 278.

41 Van der Woude appears to be more tentative in his identification of the בִּרִ in vs. 10, stating it "may [italics added] have here already, as in vs. 14, the meaning of covenant community" (op. cit., 67).

Van der Woude's understanding of the expression "profaning the covenant of our fathers" as a reference to mixed marriage appears plausible. Against Van der Woude, however, it is possible that just as adultery was recognized as a violation of Israel's covenant with Yahweh, in terms of the stipulation of the seventh commandment, frivolous divorce may have been viewed similarly.

42 So A. S. van der Woude, op. cit., 67.

43 Laban's concern over the future treatment of Leah and Rachel in Genesis 31:50 is instructive as an example of a father-in-law's on-going concern for his married daughters. Viewed from the husband's side, cf. also the corresponding breach of fellowship which resulted from the unjust action of Saul, David's father-in-law, and the Timnahite father-in-law of Samson, when these men attempted to dissolve the inchoate marriages of their daughters. 
the purpose of procuring offspring. If biblical and ancient Near Eastern parallels are to be trusted, under this kind of circumstance the "wife of one's youth" need not have suffered the disdain of her husband, indeed, the second wife was more commonly the one who was relegated to a secondary status. 44

Thus we conclude that Van der Woude has not proved his case that 2:16 is referring to the abuse of secondary wives. We should therefore leave open the possibility that $2: 16$ refers to divorce and investigate the thrust of Malachi's remarks.

\subsection{Approaches which interpret Malachi 2:16 as requiring (or permitting) divorce}

The great majority of commentators, from the ancient versions to the modern era, agree that Malachi 2:16 refers to divorce, but there is a wide diversity of view as to Malachi's precise attitude toward divorce. At one extreme, some hold that divorce is encouraged, at the other, that divorce is condemned unreservedly. We shall review the main options.

\subsubsection{Malachi urges divorce ( $4 Q X I^{\mathrm{a}}, \mathrm{LXX} \mathrm{LW}$, and Targum)}

As noted above, the MT of 2:16 may permit an alternative reading, "If he hates, send (her) away...."45 This interpretation of as a conditional particle, and the related understanding of LXX ${ }^{\mathrm{LW}},{ }^{47}$ Vulgate, ${ }^{48}$ Targum, ${ }^{49}$ and Talmud. ${ }^{50}$ Accordingly, this interpretation is accepted by Rashi, 51 David Kimchi, 52 and Maimonides, 53 among others.

44 Cf., e.g., CH §§145f. and the classic biblical examples of Abraham, Sarah, and Hagar and also Elkanah, Hannah, and Peninnah. However, cf. LI §28, which recognizes the possibility that the second wife may be preferred over the first. Cf. also the case of Jacob's marriage to Leah and Rachel. Cf. further T. E. McComiskey, "The Status of the Secondary Wife: Its Development in Ancient Near Eastern Law" $(1965)$.

45 See J. G. Baldwin, op. cit., 241.

46 According to R. Fuller, "Does Yahweh Hate Divorce? Malachi 2:16 and Text of Malachi at

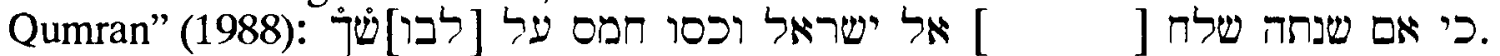

R. Fuller (unpublished paper on Malachi 2:10-16 [n.d.]) notes that שנתח [epresents a second person perfect form (quiescent 'aleph, as in the expected form שנאתה, is often not represented in the orthography at Qumran -- cf. E. Qimron, The Hebrew of the Dead Sea Scrolls [1986] \$100.61).

Accordingly, we may render this text, "For if you hate, divorce!... God of Israel, and they cover your garment with violence." Fuller considers that the text of $4 \mathrm{QXII}{ }^{\mathrm{a}}$ in $2: 15 \mathrm{f}$. is "so corrupt we must still resort to conjectural emendation" (so, according to R. Fuller, unpublished paper on Malachi 2:10-16 [n.d.]).

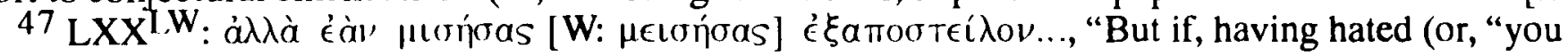
hate"), divorce!...."

48 cum odio habueris, dimitte.

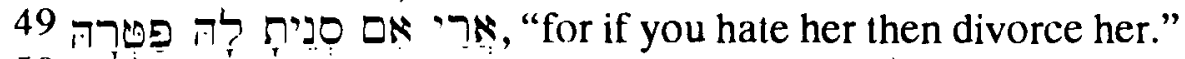

50 See Rabbi Jehuda in b. Git. 90b: "R. Jehuda said, 'If you hate her, you should put her away [אם שנאת[ה] שלח..."." For this restoration of the text, cf. C. Locher, "Altes und Neues zu Maleachi 2,10-16," 245.

51 Rashi (Rabbi Solomon ben Isaac), 1040-1105 A.D., whose commentary on the Twelve is included in מקראות גדולות (n.d.). Rashi begins by acknowledging a division of opinion in the Talmud tractate $b$. Gittin regarding Malachi 2:16. "Some say "if you hate her send her away with a bill of divorce and marry 
In spite of the ancient pedigree of this view, at times called "the traditional Jewish interpretation," the following objections may be noted:

1) LXXLW ("But if, having hated [or "you hate"], divorce her!") and the other versions, to which appeal is made, support this view only by eliminating the awkward shift

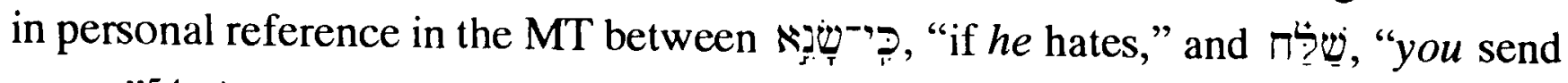
away."54 Accordingly, the MT may be preferable as the lectio difficilior.

2) In spite of the apparent support for divorce in $L X X^{L W}$, the uniform rendering of

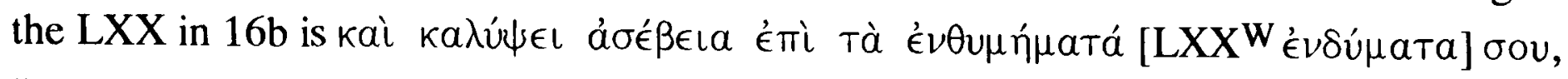
"and ungodliness will cover your thoughts [garment]." This rendering is basically

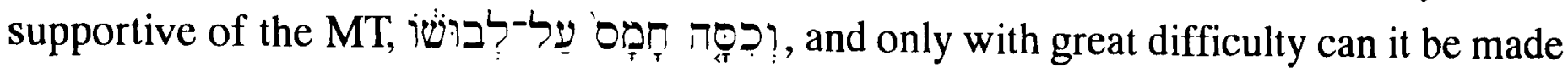
to support the present interpretation, since it appears implicitly to condemn divorce. 55 Furthermore, it should be noted that LXX ${ }^{\star A B Q V}$, understood by J. Ziegler to preserve the Old Greek, differs significantly from $\mathrm{LXX} \mathrm{LW}^{\mathrm{W}}$ in that it explicitly condemns divorce.

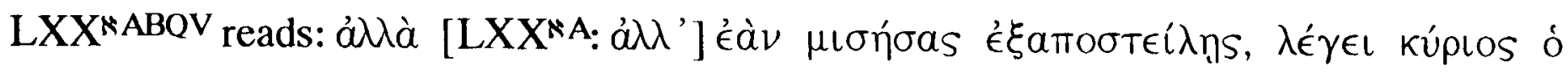

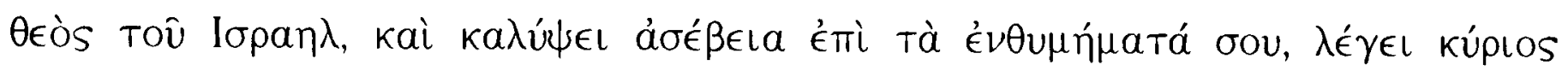

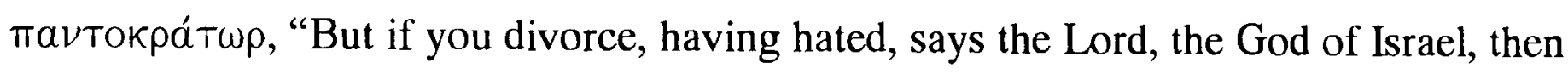
ungodliness will cover your thoughts [or "garment" if $\mathrm{LXX}^{\mathrm{ABBV}}$ are corrected with LXX' ${ }^{\mathrm{w}}$ ], says the Lord Almighty." 50

3) The reading of the versions, with their approval of divorce, is considered by many scholars to be tendentious. ${ }^{57}$ For example, L. Kruse-Blinkenberg argues that Malachi originally opposed the provision of divorce in Deuteronomy 24:1-4 and that LXX ${ }^{\mathrm{LW}}$, Targum, and the Peshitta of vs. 16 were all corrected precisely to bring them into agreement with Deuteronomy. A similar view has been expressed by R. Fuller with respect to the reading of 4QXII ${ }^{5}{ }^{5}$ It should be noted that in spite of the great antiquity of 4QXIIa, dated to $150-125$ B.C. based on its semicursive script, Fuller notes that more than half of

another[אם שנאת שלח אותה בגט ותנשא לאחר]." But Rashi prefers the alternative, imperatival view, urging that it is kinder to divorce a hated wife than to keep her in a marriage "causing her anger and pain."

52 So C. Locher, "Altes und Neues zu Maleachi 2,10-16," 245.

53 Hil. Geruschin X, 21, as cited by S. Schreiner, "Mischehen-Ehebruch-Ehescheidung," 228.

54 Understanding שe

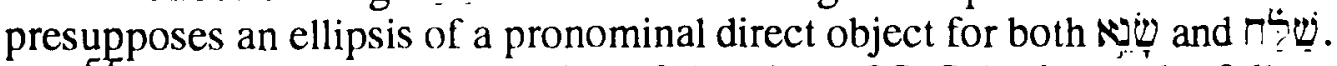

55 See below for a discussion of the view of S. Schreiner, who follows the LXX in this curious shift from the seeming endorsement of divorce in 16a $\alpha$ to an emphatic disapproval of divorce in $16 a \beta$ ("Mischehen-Ehebruch-Ehescheidung" [1979]).

56 For the use of kai to introduce an apodosis, see Blass and Debrunner, \$442(7).

57 So L. Kruse-Blinkenberg, "The Pesitta [sic] of the Book of Malachi" (1966) 102-104; 111; J. G. Baldwin, op. cit., 241; W. Rudolph, Haggai, Sacharja 1-8, Sacharja 9-14, Maleachi (1976) 270; C. Locher, "Altes und Neues zu Maleachi 2,10-16," 245, and R. L. Smith, Micah-Malachi (1984) 323. R. A. Mason makes a similar point with regard to the seemingly disturbed MT (The Books of Haggai, Zechariah, and Malachi [1977] 150).

58 R. Fuller, unpublished paper on Malachi 2:10-16 (n.d.) 7f.: “The readings preserved in $G^{W^{W}}$ and $4 \mathrm{QXII}$ and the Targum seem more likely to this writer to preserve an intentional change of the text of $\mathrm{v}$. 16 which is in disagreement with the content of vv. 13-15 and in obvious agreement with Dt 24:1-4." 
the times where 4 QXII a agrees with the LXX over against the MT, it offers a reading which is inferior to the MT. 59

4) Most seriously, as noted by J. Baldwin, "such a reading undermines all that the prophet is seeking to convey." 60 To be more specific, we may observe with R. Westbrook that this interpretation, which considers that $2: 16$ a commends divorce, is difficult to reconcile with the strenuous disapproval implied at the conclusion of the verse: "So take heed to yourselves and do not be faithless." 61

\subsubsection{Malachi urges divorce of heathen wives (A. von Bulmerincq)}

A significant modification of the previous view has been proposed by A. von Bulmerincq. ${ }^{62}$ According to Von Bulmerincq, Malachi 2:16 requires the divorce only of heathen wives, a view which comports with Von Bulmerincq's identification of Malachi as

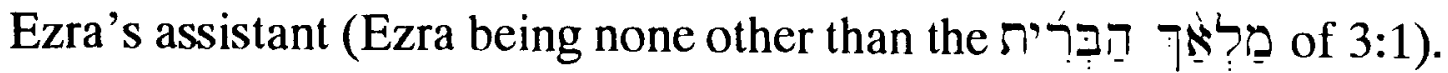

However, to support this interpretation, Von Bulmerincq proposes the following

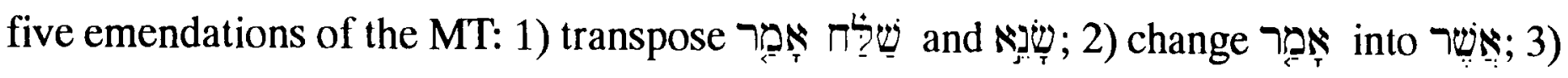

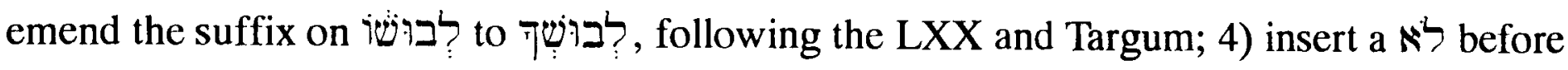

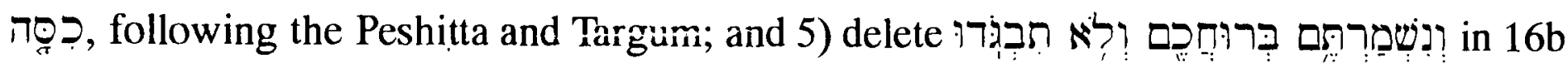

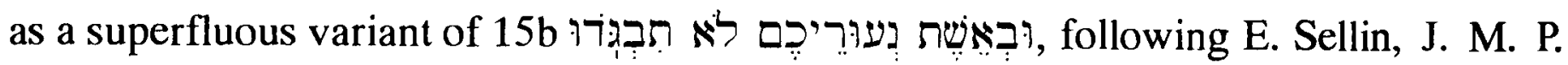

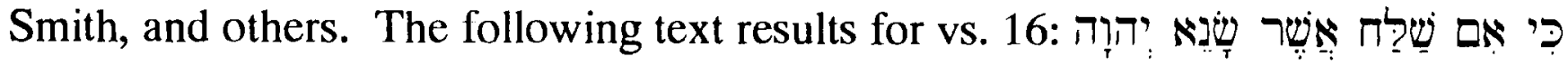

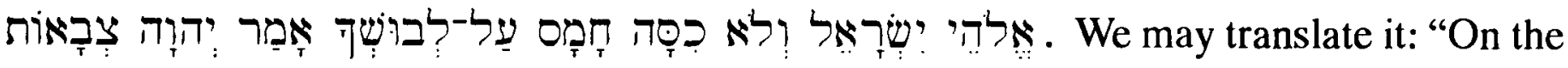
contrary, divorce the one whom Yahweh, the God of Israel, hates, then wrong will not cover your garment (any more), says Yahweh of hosts." 63 Consequently, Von Bulmerincq views this verse as an encouragement to divorce a non-Jewish wife, the sort of woman whom Yahweh "hates" because such a marriage constitutes the most heinous sort of sin and a hindrance to the advent of Yahweh.

Whatever the merits of Von Bulmerincq's third and fourth proposals, the first two proposals and the last proposal are entirely speculative and appear to be merely a reflex of Von Bulmerincq's attempt to relate Malachi 2:10-16 to Ezra 10. Such a cavalier treatment of the text renders Von Bulmerincq's approach unconvincing.

${ }^{59}$ More precisely, according to Fuller there are seven readings where 4 QXII ${ }^{\mathrm{a}}$ agrees with the LXX against the MT, four of which are inferior. On the other hand, there are four readings where $4 \mathrm{QXII}{ }^{\mathrm{a}}$ agrees with the LXX against the MT, only one of which appears to be an inferior reading. In addition, 4QXII ${ }^{\mathrm{a}}$ offers one unique reading, the omission of

60 Op. cit., 241.

61 R. Westbrook, "The Prohibition on Restoration of Marriage in Deuteronomy 24:1-4," 403, citing Abarbanel in support.

62 A. von Bulmerincq, "Die Mischehen im B. Maleachi" (1926) 41-42; and idem, Der Prophet Maleachi, Band 2 (1932).

63 A. von Bulmerincq, Der Prophet Maleachi, Band 2, 306. 


\subsubsection{Malachi recommends divorce in Malachi 2:16 as the lesser of two evils, i.e., as preferable to polygyny (S. Schreiner)}

S. Schreiner offers a significant modification of the traditional Jewish view which understands Malachi 2:16 as urging divorce. ${ }^{64}$ Following $\mathrm{LXX}{ }^{\mathrm{LW}}$, Vulgate, and Targum, Schreiner interprets as a conditional particle, with the apodosis beginning with the

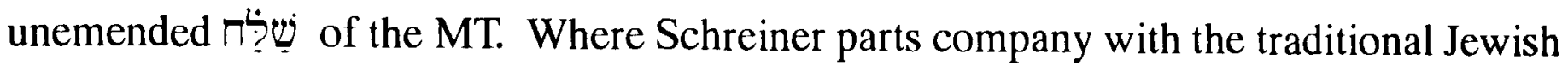
interpretation is in his contrastive rendering of the ? which introduces the clause, a עַל-לבוּשו verse, "If one no longer loves, divorce, says YHWH the God of Israel; but such a one covers his garment with shame, says YHWH Sebaoth."65

Schreiner explains that the husbands in Malachi 2:16 were wanting children (based on $2: 15$ ) and so were taking second wives, without regard to their heathen identity. As a consequence, their conduct entailed a three-fold violation of the law (perhaps intended by the "covenant" in 2:10). ${ }^{66}$ First, they were committing adultery because they had failed to divorce their first wife before taking a second (Exodus 20:14; Deuteronomy 5:18; 22:22-29; Leviticus 20:10; and 19:20). Second, they were marrying pagan women in violation of such texts as Exodus 7:3 and Deuteronomy 7:3. Finally, they were sinning with respect to their children (cf. Malachi 3:18-21), since the offspring of these mixed marriages would be prohibited from the assembly according to Deuteronomy 23:4 [ET 3] (cf. Nehemiah 13:1ff.). In response, according to Schreiner, Malachi upheld the ideal of monogamy and urged that men who wanted to marry a second wife must divorce their first wife. However, this action is merely the lesser of two evils [ "die Wahl des kleineren Übels"] because any such divorce constitutes the defiling of one's garments, that is, a personal defilement. ${ }^{67}$

The chief advantage of Schreiner's treatment of Malachi 2:16 is its fidelity to the unemended MT and the support it can claim from the versions. Attractive also is

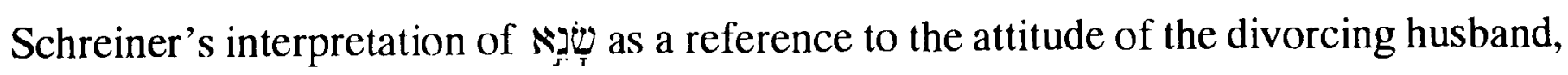
which is consistent with the use of this term when it appears elsewhere in connection with divorce. On Schreiner's view Malachi appeals to Deuteronomy 24:1ff. Following Rashi,

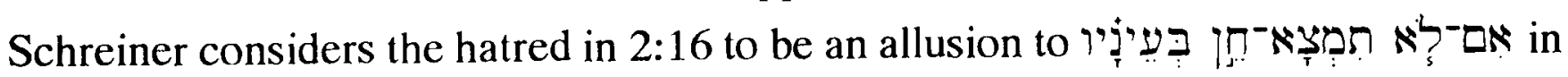

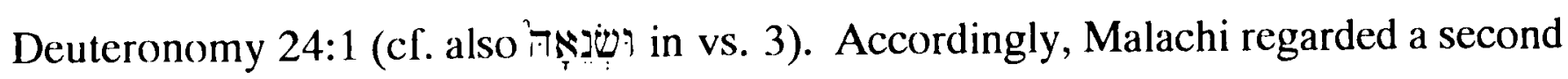

64 "Mischehen-Ehcbruch-Ehescheidung" (1979) 217f.

In certain respects, Schreiner's view resembles that of Martin Luther, Lectures on Malachi, 406f., to whom he appeals to support (op. cit., 207), however Luther says nothing about polygyny and interprets Malachi mainly in the light of Matthew 19:3-10.

Cf. also J. Gerhard, Loci theologici, tomus VII: De coniugio, coelibatu et cognatis materiis (1620) $1000 \$ 596,2$, to whom Schreiner appeals for support (op. cit., 227).

65 "Wenn einer nicht mehr liebt, Ehe scheiden, spricht YHWH, der Gott Israels; aber derjenige besudelt mit Schande sein Gewand, spricht YHWH Zebaoth" (op. cit., 217f.).

66 Ibid., 220.

67 Ibid., $226 f$. 
marriage as permissible, but only after a legal divorce, which Malachi tolerates as a lesser evil to the alternative of polygyny.

However, there are some serious problems with this otherwise appealing view:

1) As was noted above with respect to the traditional Jewish view, the versions support this view only by eliminating the awkward shift in personal reference in the MT

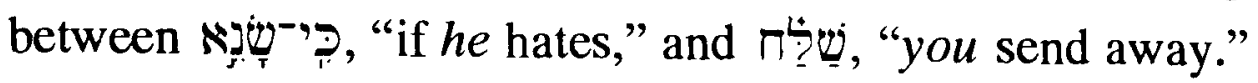

2) Although the apodosis of conditionals introduced by are often unmarked (as in Exodus 21:14, 36, 37 [ET 22:1]; 22:9f. [ET10f.], etc.), hence supporting Schreiner's

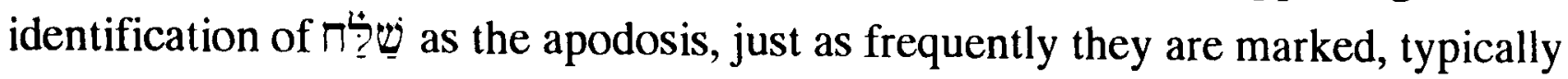
employing a converted perfect (as in Genesis 4:24; Exodus 1:10, 12:15, 19; 22:26 [ET 27], etc.). Accordingly, some justification is needed for preferring to begin the apodosis with

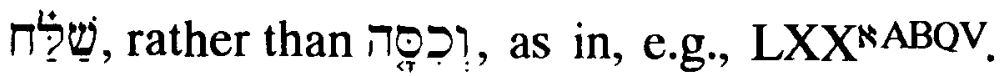

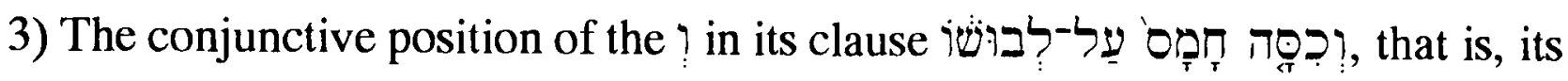
position attached directly to the main verb, may permit, but does not favour Schreiner's interpretation of this clause as contrastive: "but, such a one covers his garment with shame" (italics added). 68

4) Related to this grammatical observation, the contradictory change from the seeming commendation of divorce in vs. 16aa ("If one no longer loves, divorce") to the disapproval of divorce in $16 \mathrm{a} \beta$ and $16 \mathrm{~b}$ ("but such a one covers his garment with shame, says YHWH Sebaoth. Therefore guard your spirit and do not act faithlessly") fails to commend itself as too abrupt and unexpected. 69 Moreover, the language of that disapproval is far too strenuous to allow Schreiner's claim that Malachi considered divorce "the lesser of two evils" -- an ethical calculus which seems rather too modern for the fifth century B.C. in any case. Furthermore, Schreiner's assumption that Malachi 2:15-16 alludes to Deuteronomy 24 , as opposed to Genesis $1-2$, is uncertain and has been challenged by W. Rudolph. 70

5) Schreiner's conclusion is unconvincing that Malachi 2:16 was an attempt to address the problem of polygyny, which Malachi deemed to constitute adultery. Neither

68 Cf., e.g., T. O. Lambdin, Introduction to Biblical Hebrew, $\$ 132$ and Waltke and O’Connor \$39.2.3, who consider one of the main uses of the disjunctive clause, where 1 does not attach directly to the verb, to be to express the contrastive idea ("but," "however," etc.).

The apparent clarity of Lambdin's and Waltke and O'Connor's interpretation of inter-clausal syntax contrasts with the practice of modern English translations which commonly render examples of conjunctive ? (especially converted imperfects) with "but," etc. Cf., e.g., Genesis 3:9, 6:18, 8:1, etc.

Lacking a full-scale study of the biblical evidence for the contrastive use of 7 , a study which would be alert not only to word order, but also to key particles, such as the presumed effect of a prior negative (cf., e.g., F. I. Andersen, The Sentence in Biblical Hebrew [1974] 183), etc., the most that can be safely asserted here is that there appears to be a tendency for the contrastive use of 7 to manifest itself in disjunctive, rather than conjunctive clauses.

69 So also C. Locher, "Altes und Neues zu Maleachi 2,10-16," 243.

70 “Zu Mal 2 10-16" (1981) 85-90. Cf. also Chapter 5. 
Ezra nor Nehemiah, nor any other ancient source, suggests that polygyny was a problem in the post-exilic community, and the text of Malachi nowhere else mentions this matter. ${ }^{71}$

With such an "astonishing result [erstaunliche Ergebnis ]," as his conclusions have been termed by W. Rudolph, Schreiner's interpretation has failed to commend itself among more recent interpreters. ${ }^{72}$

\subsection{Approaches which interpret Malachi 2:16 as an absolute prohibition of} divorce

Having rejected those interpretations which view Malachi 2:16 as encouraging divorce, we now turn to approaches which interpret Malachi 2:16 as an absolute prohibition of divorce.

"I hate divorce, says the Lord God of Israel, and covering one's garment with violence, says the Lord of hosts." This rendering of the RSV is typical of those who favour a view which has been called "the traditional Christian approach."73 In reality, however, the interpretation of Malachi 2:16 as a condemnation of divorce is just as well represented among early Jewish commentators as is the "traditional Jewish approach." Cf., e.g., Rabbi Johanan, mentioned in b. Git. 90b, and the medieval commentators, AlQumisi, Jephet Ben Eli, and Ibn Ezra (who mentions this as one option), among others. ${ }^{74}$

P. A. Verhoef's treatment is typical of those who favour this interpretation. ${ }^{75} \mathrm{He}$ begins by considering the primary interpretative question to be the determination of the

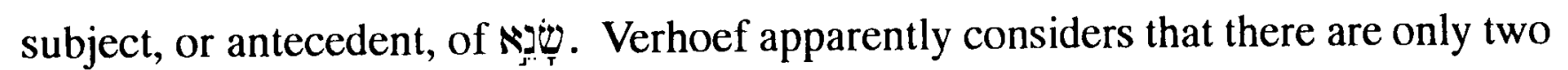
alternatives: either the subject is an impersonal "one," referring to the divorcing man (with this option sceming to necessitate the view of $\mathrm{LXX}^{\mathrm{LW}}$, etc., that the text commends divorce), or the subject is Yahweh. Since the former conclusion is deemed impossible on contextual grounds, a way is found to make Yahweh the subject.

The following suggestions have been offered for accomplishing this objective:

a) It has often been noted that Biblical Hebrew tolerates a high degree of variation in personal reference, from an English reader's stand-point, particularly in prophetic

71 See W. Plautz, "Monogamie und Polygynie im Alten Testament" (1963) and the discussion of polygyny in $\$ 4.6$ below.

72 Cf., e.g., C. Locher, "Altes und Neues zu Maleachi 2,10-16" (1981) 242-246; W. Rudolph, "Zu Mal 2 10-16" (1981) 85-90; R. L. Smith, Micah-Malachi (1984) 324; and R. Westbrook, "The Prohibition on Restoration of Marriage in Deuteronomy 24:1-4" (1986) 403.

73 See R Westbrook for this designation (op. cit., 402).

74 So, C. Locher, "Altes und Neues zu Maleachi 2,10-16," 245.

See b. Git. 90b: "R. Jehuda said, 'If you hate her, you should put her away' R. Johanan said: 'He that sends his wife away is hated שנוי המשלח]]." The Talmud attempts to reconcile these views by claiming, rather implausibly, that Johanan was speaking only of the second marriage: "They are not differing in opinion, since the one speaks of the first marriage and the other of the second."

Accordingly, the objection of A. Isaksson must be dismissed as uninformed: "No instance can be quoted of these verses being understood in earlier times as an attack on divorce" (op. cit., 32).

75 Op. cit., 278. 
speech. ${ }^{76}$ In essence, this appears to be the view, for example, of T. Laetsch, who explains that "the prophet states a fact, and then claims divine authority for this fact."77 While this approach has the merit of avoiding textual emendation, it results in what must be deemed an unexpected and awkward change in the subject with

b) Perhaps the majority of scholars holding this view have suggested an emendation

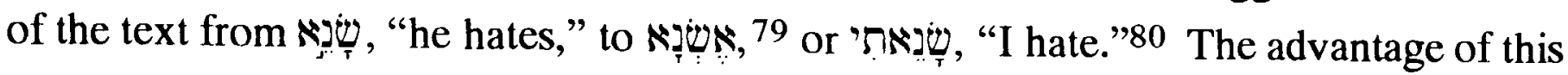
approach is that it relieves the grammatical incongruity between the third person verb and the context of direct discourse. The disadvantage is, of course, that these emendations are purely conjectural.

c) With W. Rudolph and others, שָׁנָא may be identified as a verbal adjective, which is being employed as a participle. ${ }^{81}$ In addition, Rudolph suggests that שָנטא first person singular pronominal subject, an occasional feature of participles (cf. GKC $\$ 116$ s, which, however expresses its reservation concerning this and other alleged examples). Accordingly, שָׁנִ may be rendered, "I am hating." This approach has the

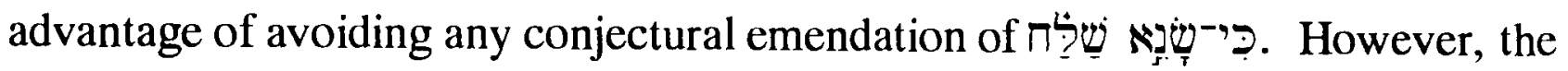
supposition of an elided first person singular pronominal subject when there are no other first person pronouns in the context, and the fact that a verbal adjective of שis is otherwise unattested, fail to commend this approach. 82

76 Cf., e.g., E. W. Bullinger, Figures of Speech Used in the Bible (1898) 524f., and GKC \$144p.

Prophetic speech is especially susceptible to this phenomenon because of its self-presentation as both the words of the prophet and, simultaneously, the word of the Lord.

77 T. Laetsch, The Minor Prophets (1956) 527.

Cf. the AV, which relieves the awkward change in personal reference by assuming the use of indirect discourse, "For the Lord, the God of Israel, saith, that he hateth putting away: for one covereth violence with his garment, saith the Lord of hosts: therefore take heed to your spirit, that ye deal not treacherously."

${ }^{78}$ Laetsch discusses 70 ? I, but he does not answer this objection (op. cit., 527). He offers two possible explanations of this clause: Either this is an example of the suppression of the demonstrative pronoun (cites GK $\$ 155 n$ and the examples of Isaiah 41:24 and Exodus 4:13), "or it may simply add the personal consequence of the sin." On this second approach Laetsch suggests rendering, "and (by doing that) he covers his garment with violence."

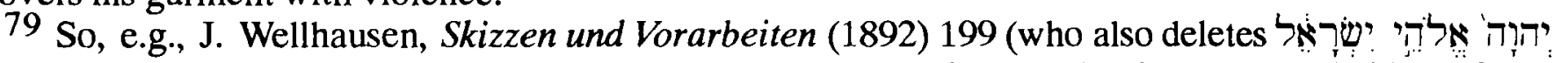
אמר as secondary and revocalizes an infinitive construct, interpreting it as a second object of Yahweh's hatred), perhaps the RSV, and R. Fuller, untitled paper on Malachi 2:10-16 (n.d.).

80 So, e.g., R. L. Smith, who renders 16a: "Because I hate divorce, says Yahweh God of Israel, and he (who) covers his garment with violence, says Yahweh of hosts" (op. cit., 319f.). Smith offers no support

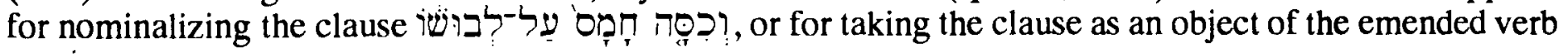
שנאים

$8 \mathrm{i}$ W. Rudolph, Haggai - Sacharja 1-8 - Sacharja 9-14 - Maleachi (1976) 270. Cf. also idem, "Zu Malachi 2:10-16" (1981) 90, and C. Locher, "Altes und Neues zu Maleachi 2,10-16" (1981) 245-247.

A simpler way of stating this is that for intransitive stative verbs of the form $>0$, or bop, the participle generally coincides with the third masculine singular perfect. See GKC $\$ 50 \mathrm{~b}$ and Waltke and O'Connor \$37.1b.

82 Probably because שֶׁ is transitive, in spite of its stative vowel pattern, it has a well-attested active participle of the form $N$ ש. Even-Shoshan lists eight occurrences. Cf. also GKC $\$ 50 \mathrm{~b}$.

A. Tosato appears to accept and to build on Rudolph's approach to 2:16 ("Il ripudio: delitto e pena [Mal 2,10-16]" [1978] 552 -- the writer is indebted to Mr. Paul J. Collacott, of Cheltenham, for his help in translating Tosato). Tosato renders Malachi 2:16, "Since Yahweh the God of Israel has said 'I hate divorce' and Yahweh of hosts has said '(I hate) a man covering his garment with violence,' therefore be careful for your lives and don't act faithlessly." 
C. F. Keil, P. A. Verhoef, and others prefer a slight revocalization of the text from

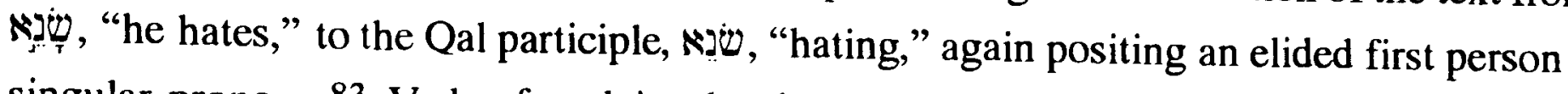
singular pronoun. 83 Verhoef explains the significance this form: "The participle suggests continuity. The Lord continually and habitually hates." While this view has the merit of restoring an attested form, the Qal participle, rather than Rudolph's hypothesized verbal adjective, it does so at the expense of introducing a conjectural emendation of the MT, albeit slight. The appeal to an elided pronoun, which is nowhere explicit in the context, remains problematic.

Finally, there are three further problems which need to be considered with respect to this approach to Malachi 2:16:

1) As Van der Woude has noted, since there is an awkward shift in the subject from שנא (whether emended or not) to this approach inevitably needs to explain away or

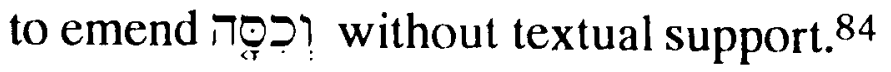

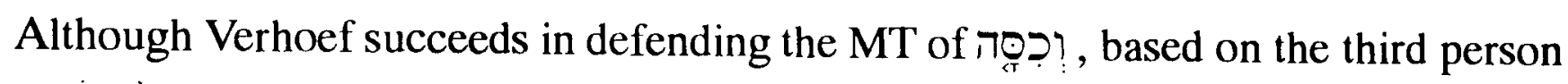
suffix on לבוּשו, he fails to support his rendering of this perfect (as if it were a substantive use of the participle): "I hate divorce, says the Lord God of Israel, even the one who covers [italics added] his garment with (the marks of) violence, says the Lord Almighty."

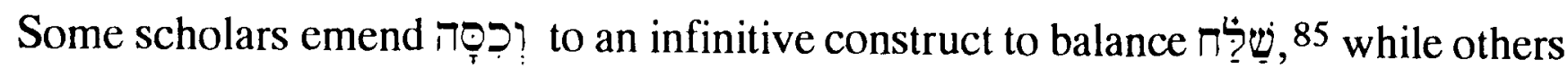
prefer an infinitive absolute with a preposition, 20 . suggestions is impossible, they lack textual support.

2) By failing to interpret שָׁנָ as a reference to the divorcing husband's attitude, this approach overlooks a considerable body of evidence, both biblical and extrabiblical, where

\footnotetext{
Although A. Tosato does not discuss this verse at length, he does say that Malachi is persuaded that divorce is sinful because it violates the covenant between Yahweh and Israel (op. cit., 552, esp. note 19). Tosato supports this assessment by noting the fairly extensive terminological parallels between Malachi 2:14-16 and Jeremiah 3:1-13, where Judea is called בּגָר $2(8,11)$ and toward Yahweh, the friend of its youth (עלון נעצר: vs. 4), infidelity which is the cause of its divorce (8). Consequently, Malachi 2:13-16, in effect, makes the behaviour of the man who would divorce the wife of his youth equivalent to that of the unfaithful "wife" in Jeremiah with respect to her husband, Yahweh -- an equivalence (men are no less obligated than their wives to marital fidelity) found also in the Gospels.

However, Tosato's view shares the difficulties of the "traditional Christian interpretation" mentioned above. In addition, Tosato's rendering of the third masculine singular perfect

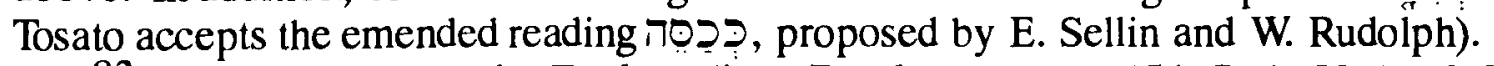

83 E.g., C. F. Keil, The Twelve Minor Prophets, vol. 2, 454; P. A. Verhoef, Maleachi verklaart (1972) 190; and idem, The Books of Haggai and Malachi (1987) 278.

Verhoef cites GK $\$ 116$ s (as does W. Rudolph) in support of the suppressed pronominal subject (Maleachi verklaart [1972] 190).

84 Op. cit., 70.

85 So, e.g., BHS.

86 So E. Sellin, Das Zwölfprophetenbuch (1922) 554, and W. Rudolph, Haggai, Sacharja 1-8, Sacharja 9-14, Maleachi (1976) 270, n. 16.

Cf. discussion in A. S. van der Woude, "Malachi's Struggle For a Pure Community," 71, n. 35
} 
in the context of divorce, "hate" is a frequently specified attribute of one of the marriage partners. This evidence will be discussed in detail below.

3) Of the approaches to Malachi 2:16 considered thus far, this is the first which necessarily involves a conflict with the seemingly lenient attitude toward divorce in Deuteronomy 24:1-4. Although we must defer judgment until a more detailed evaluation of that text, it may be useful to note here two alternative responses which have been made to this objection by those wishing to support the "traditional Christian" interpretation of 2:16:

a) W. J. Dumbrell has argued that Malachi's attitude toward divorce need not be considered incongruous with Deuteronomy 24, if, as J. Murray and others have argued, the purpose of Deuteronomy 24 was not "to facilitate divorce (the possibility of which is admittedly presupposed), but rather [to affirm] the indissolubility of the (original) marriage relationship."87

b) Alternatively, Malachi's view of divorce may have gone beyond the more lenient provision of Deuteronomy, but in so doing may simply reflect a well-represented hermeneutical approach during the post-exilic period to antecedent scripture. ${ }^{88}$ For example, P. Grelot observes how Malachi's view of marriage and divorce goes "far beyond the tolerances of the Torah." 89 To account for this Grelot notes that during this same time the requirements of the Torah were also being made more strict by the reforms of Nehemiah and Ezra. Only Ruth "makes a tactful protest against this severity...."90 Also of significance is the fact that Malachi appears to base his argument quite explicitly on Genesis $1-2$, precisely rather than Deuteronomy $24 .{ }^{91}$

The problem here in reconciling Malachi 2:16 with Deuteronomy is similar to the difficulty of relating Ezra 9-10 to Deuteronomy (in view of Ezra's widely recognized affinity with Deuteronomy). H. G. M. Williamson believes that Ezra did, in fact, go far beyond the stipulations of Deuteronomy, both in his identification of the nations of his day with the Canaanites of pre-exilic days and, perhaps also, in his insistence on the dissolution of mixed marriages. ${ }^{92}$

87 "Malachi and the Ezra-Nehemiah Reforms," 47f. See also J. Murray, Divorce (1961).

C. F. Keil offers an alternative explanation, "The thought is not at variance with Deuteronomy xxiv. 1 sqq., where the putting away of a wife is allowed; for this was allowed because of the hardness of their hearts, whereas God desires that a marriage should be kept sacred" (The Twelve Minor Prophets, II, 454).

88 P. A. Verhoef observes, "In the postexilic period stricter demands were made on the marriage bond, apparently in connection with the prohibition of marriages with Canaanites and heathen people in general (Exod. 34:16; Deut. 7:4). The prophecy of Malachi endorses these stricter stipulations..." (op. cit., 280f.).

89 Man and Wife in Scripture, 69.

90 Ibid. Against this alleged "tactful protest," cf. A. Phillips, "The Book of Ruth - Deception and Shame" (1986) 2.

91 Cf. W. Rudolph, Haggai, Sacharja 1-8, Sacharja 9-14, Maleachi, 274f., and R. L. Smith, op. cit., 325 .

92 Ezra, Nehemiah, 161. For further discussion, cf. M. Fishbane, Biblical Interpretation in Ancient Israel, 114-129. 
In summary, while the view that Malachi 2:16 prohibits all divorce is easier than the view that it encourages divorce, this absolutist interpretation has enough problems to encourage the search for a better approach.

\subsection{Approaches which limit the kind of divorce prohibited in Malachi 2:16}

\subsubsection{Malachi prohibits divorce only when initiated by the woman (one rabbinic view)}

The view of $y$. Qidd. I 58c, 16 and Gen. Rab. 18,12c, ascribed to rabbis living in the 4th century A.D., is that the divorce which God "hates" in Malachi 2:16 is "mutual divorce." What is intended by "mutual divorce" is divorce which may be initiated by either the husband or the wife, such as is practiced among pagan couples, not Jewish divorce which, according to the rabbinic view, could only be initiated by the husband. ${ }^{93}$ An apparent assumption of this interpretation is that it was the offended women who initiated the dissolution of their marriages in Malachi. Perhaps the rabbis based this assumption on the curious order in Malachi's treatment of mixed marriage and divorce. Malachi mentions the problem of mixed marriage before divorce, as if to suggest that the divorces were a response of the offended Jewish wives (forcing their bigamous husbands to divorce them), rather than the preparatory action of husbands anticipating a second marriage (this time to a pagan). ${ }^{94}$ However, apart from its interest for the history of interpretation, this view has little to commend it.

\subsubsection{Malachi condemns only unjustified divorce, that is, divorce based on aversion}

We turn, finally, to consider the interpretative approach which views Malachi 2:16 as condemning divorce when it is based on aversion: "If one hates and divorces, says Yahweh, God of Israel, he covers his garment with violence, says Yahweh of hosts...." We shall seek to establish this approach as that which is most faithful to the text, requiring minimal or no emendation of the MT, and as most congruent with the larger context of Malachi 2:10-16.

\subsubsection{How should כִִּ be understood?}

As has been indicated, there are essentially two options from which to choose for the interpretation of $:$ : It may be understood in a non-conditional manner, perhaps to be

93 See M. Barth, who notes that $y$. Qidd. I 58c, 16 and Gen. Rab. 18, 12c are quoted in StrB., I, 213; II, 24 (Ephesians, 659, n. 311).

94 This curious order of treatment is also noted by W. F. Luck, who concludes that the divorce condemned by Malachi is divorce based merely on the desire to be monogamously married to another (Divorce and Remarriage [1987] 82). 
rendered "because" or "for," or possibly to be left untranslated as an emphasizing particle; 95 or 2) it may be intended as a conditional particle, "if one hates...."96 It is important here to clarify these options further. When functions as a causal subordinating conjunction, the main clause most commonly precedes the כִ כִ clause. 97 When as a conditional particle introducing a protasis, the apodosis, or independent clause, most often follows the clause. 98 It should be noted that conditional may be rendered "if," or it may bear one of its other senses, such as "when," "whenever," etc., especially if the context suggests a higher probability that the condition will actually occur. 99 Given the order of clauses in Malachi 2:16, it is easier to take ’ִ is "if."

\subsubsection{1 כִכי is non-conditional (R. Westbrook)}

R. Westbrook has recently defended an interpretation of Malachi 2:16 which understands this text as condemning unjustified divorce and, in so doing, favours the nonconditional causal(?) sense of (against the view preferred above). He renders the verse, "For he has hated, divorced ... and covered his garment in injustice."100 Perhaps the chief advantage of this non-conditional causal(?) interpretation is the way it explicitly relates Malachi 2:16a to 2:15b, "Take heed to yourselves, and let none be faithless to the wife of your youth...," making clear that 2:16a provides the expected underlying reason for this dire injunction. 101 It appears that there must be some such logical connection between $2: 16 a$ and this warning in $2: 15 b$ since the injunction is essentially repeated in $2: 16 \mathrm{~b}$, "So take heed to yourselves and do not be faithless," thereby forming an inclusio which frames $2: 16 a .^{102}$ If this posited logical connection permits the causal 9 clause in 2:16a to follow the main clause in $2: 15 \mathrm{~b}$, then this medial position for the 9 clause conforms to the usual pattern discussed above.

Nevertheless, there are some difficulties connected with Westbrook's view:

a) Although it is only a modest emendation, Westbrook follows J. M. P. Smith, et

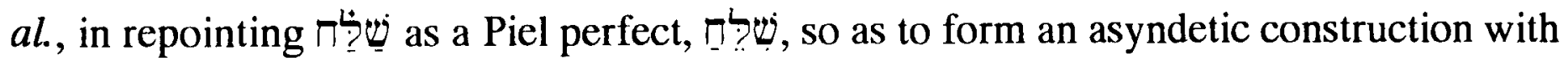
103

95 So NIV. Cf., e.g., T. Muraoka, Emphatic Words and Structures in Biblical Hebrew (1985) 158164, and Waltke and O'Connor \$39.3.4.e. A. Aejmelaeus considers that the emphatic use of ' frequent than is often alleged ("Function and Interpretation of ' $\supset$ in Biblical Hebrew" [1986] 208).

96 The context of Malachi 2:16 appears to exclude the other principal uses of listed, for example, in Williams, Syntax, $\S \S 444-452$.

97 In support of this analysis of 'כ clauses, cf. A. Aejmelaeus, "Function and Interpretation of in Biblical Hebrew” (1986) 193-209, esp. 197-199. Cf. also Waltke and O’Connor \$39.3.4.e.

98 Deuteronomy $4: 29 ; 28: 2,9$, offer rare counter-examples.

99 A. Aejmelaeus, op. cit., 197.

100 "The Prohibition on Restoration of Marriage in Deuteronomy 24:1-4," 403.

101 Cf. P. A. Verhoef, who, following a different interpretation, argues that 2:16a provides an explanation not merely for $2: 15$ b, but for each of the preceding problems back to 2:13 (op. cit., 278).

102 Although the MT here is supported by the versions, $B H S$ and others suggest deleting this.

103 So also A. van Hoonacker, H. Junker, F. Nötscher, and T. Chary, acc. to A. S. van der Woude, op. cit., 70. 
b) The ellipsis in Westbrook's translation offers mute testimony to the problematic

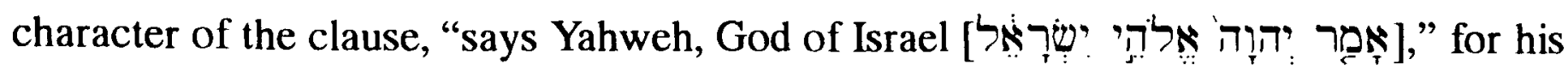
interpretation. While some scholars have argued that this clause should be deleted as a gloss, this is conjectural and is now opposed by the additional evidence of 4QXIIa 104 Situated where it is, it appears as an intrusion on Westbrook's interpretation. As such it may favour a view that places a more significant break between what comes before the clause and what comes after, as does the conditional view of

c) Finally, on Westbrook's view there seems to be an awkward change in pronominal reference from vs. $15 \mathrm{~b}$ to vs. $16 \mathrm{a}$. To be fair, Westbrook does not discuss this point and so, apart from any implication which may be drawn from his rendering of the mild causative "for," it is unclear precisely what relation he sees between these verses. However, in addition to the shift from the second person plural of vs. $15 \mathrm{~b}$ to the third person singular in 16a (and then back to the second person plural in 16b), one is left to puzzle over the precise antecedent of the "he" in vs. 16a. ${ }^{106}$ Furthermore, it is not clear how the assertion, "for he has hated, divorced...," actually explains the command, "Take heed to yourselves...."107

A translation of the whole makes these difficulties readily apparent: " Take heed to yourselves, and let none be faithless to the wife of your youth. For he has hated, divorced,' says Yahweh, God of Israel, 'and covered his garment in injustice." Who is the intended referent of this " $h e$ "? Moreover, as is evident from the capitalization of "For," Westbrook fails to render the clause in 2:16a in a manner which makes clear its grammatical subordination to $2: 15 \mathrm{~b}$ (although he insists on its logical subordination). If $2: 16 \mathrm{a}$ is not grammatically subordinate to $2: 15 \mathrm{~b}$, then the frontal position of the clause no longer favours the causal interpretation. ${ }^{108}$

104 J. M. P. Smith favours this proposed deletion, citing in support J. Wellhausen, W. Nowack, K. Budde, and E. Sievers (op. cit., 55).

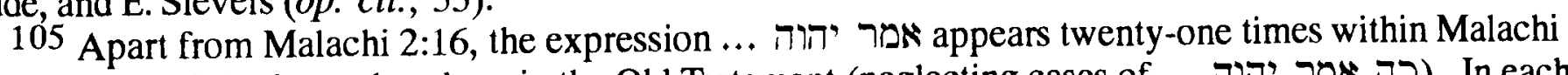
and only sixty-eight times elsewhere in the Old Testament (neglecting cases of ... כמה אמר יהוה). In each $11,13,14 ; 2: 2,4,8 ; 3: 1,5,7,10,11,12,13,17,19,21$.

106 The grammar of third person form 7 ? in vs. $15 \mathrm{~b}$ is discussed below. Here we merely note that even if it is left unemended (against the versional evidence), it appears inadequate to account for the wholesale shift to the third person in vs. 16a.

107 E.g., with such an explanatory clause, it would seem more logical for the command to be: "Expel such a man, for he has hated...." Alternatively, if the command is to be maintained, it would seem more logical for a rather different explanatory clause: "Take heed to yourselves.... for I will judge all such faithless husbands."

108 It is possible that special emphasis is intended when a causal 2 clause precedes the main clause (Joüon $\$ 170$ n). If so, the fact that no particular emphasis is required in 16a does not favour the present causal interpretation of its ' $?$ clause. However, other grammarians fail to confirm this point. Cf., e.g., A. Aejmelaeus, op. cit., $196 \mathrm{f}$. 


\subsubsection{2 כִ כִ is conditional (the view preferred here)}

Given the difficulties of taking $\supseteq$ as a causal subordinating conjunction ("because," "for"), an alternative interpretation of conditional sense in 2:16: "If one hates and divorces, says Yahweh, God of Israel, he covers his garment with violence, says Yahweh of hosts...."109

This conditional option has often been rejected seemingly out of a desire to avoid the implication of the versions that Malachi 2:16 endorses divorce. But this implication is

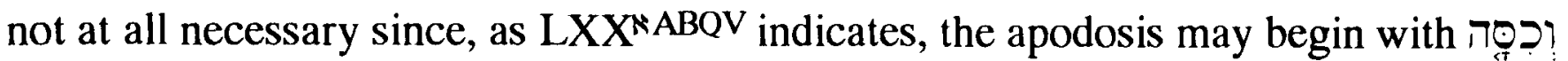
rather than 110 If this interpretation is accepted, the objections listed earlier $(\$ 3.2 .1$ above) against the traditional Jewish view are fully met.

T. V. Moore has raised an additional objection to the conditional interpretation. He notes that while may at times be rendered "if," this is not its customary sense. 111 But to have any force, this objection needs to be strengthened by a more nuanced comparison of the syntax of the present verse and the use of ' elsewhere in conditional clauses. While it is true that other uses of predominate, כִ כי fifty verses, as rendered by the RSV.112 Moreover, in a significant number of cases, the apodosis is marked by a ? + perfect, as is being suggested for Malachi 2:16 (cf., e.g., Exodus 23:5; Leviticus 13:16; 25:25; Numbers 27:8, etc.). ${ }^{113}$

\subsubsection{Who is the subject of}

We have already noted the following difficulties which result from the assumption

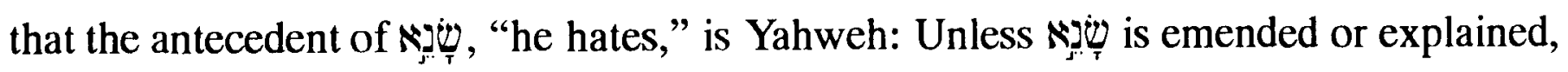
there is a resulting grammatical awkwardness in the presence of a third person verb in what purports to be the direct discourse of Yahweh. Furthermore, there is a puzzling change in subject from Yahweh to the divorcing husband in וְְְ , or there is a need to emend this

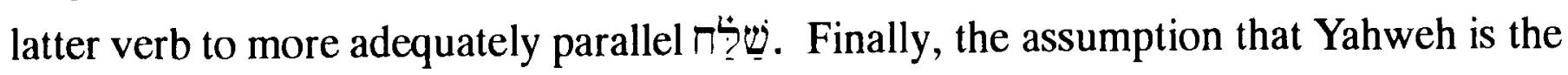
subject of שנא ignores a substantial body of evidence that when שנא appears in the context of divorce, it typically refers to the disposition of one of the marriage partners.

The alternative approach being suggested here is that the subject or antecedent of שָּני , "he hates," is not Yahweh, but the divorcing man, or, more precisely, an impersonal subject: "if one hates...."

109 Alternatively, if שָׁ is identified as a verbal adjective, or participle (cf. GKC $\$ 50 \mathrm{~b}$ and Waltke and O'Connor \$37.1b), the MT may be rendered, "if one who hates divorces..., then he covers...."

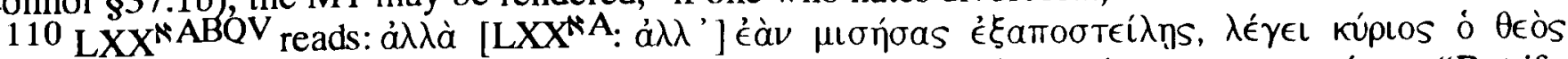

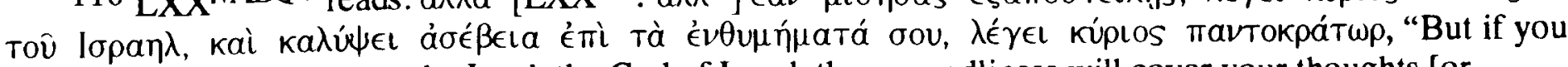
divorce, having hated, says the Lord, the God of Israel, then ungodliness will cover your thoughts [or "garment" if $\mathrm{LXX}^{\aleph \mathrm{ABOV}}$ are corrected with $\mathrm{LXX}^{\mathrm{W}}$, says the Lord Almighty."

111 A Commentary on Haggai and Malachi, 138.

112 Cf., e.g., Genesis 4:24; Exodus 21:14, 37; 22:9f. [ET 10f.], 13 [ET 14], 15 [ET 16]; Leviticus $11: 38 ; 13: 40$; etc.

113 Cf. also Deuteronomy 18:21f., where a non-converted perfect appears in an unmarked apodosis. 
There are several advantages to this interpretation: First, it has the the support of the versions, though as we have noted, apart from $\mathrm{LXX}^{\star \mathrm{ABOV}}$, they interpret the passage as an authorization rather than a condemnation of divorce. ${ }^{114}$ Second, this interpretation requires no emendation of שָׁנִנא because it is not in conflict with its context as Yahweh's direct

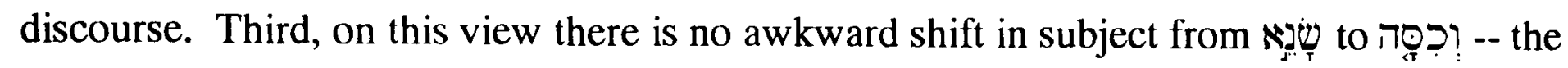
subject of both of these third masculine singular perfects is the divorcing man (i.e., the impersonal subject "one"). Finally, it has often been noted how שנא is found elsewhere in the Old Testament in the context of marriage, where it refers to the attitude of husbands toward their wives. So, for example, J. M. P. Smith cites Genesis 29:31 and

Deuteronomy 21:15-17.115 To these we may add Deuteronomy 22:13, 16; 24:3; Judges 15:2; Proverbs 30:23; and Isaiah 60:15.

More recently, this association of שנא and marriage has received fresh support. On the basis of several Aramaic marriage contracts from Elephantine, where the formula "I hate so and so my husband/wife" is to be pronounced by the divorcing partner, some scholars have argued that "hate" may be a technical synonym for "divorce."116

Bringing to bear numerous Akkadian parallels, however, R. Westbrook has recently reviewed this evidence and has concluded that the term "hate" in the context of marriage cannot simply be equated with "divorce." 117 When "hate" occurs alone, it appears to be an encapsulation 118 for the fuller expression, "hate and divorce," and this combination refers to divorce motivated by hatred or, in other words, divorce that is without justification. In support of his contention that "hate" is at most an encapsulation of "hate and divorce," and that "hate" implies something beyond mere divorce, Westbrook notes that while two of the Elephantine contracts employ the term "hate" by itself to express the concept of divorce, ${ }^{119}$ a third reads, "if H... says "I hate my wife W, she shall not be my wife'...."120 Since "she shall not be my wife" is widely recognized as a divorce formula, there would be an awkward redundancy here if "hate" were simply a synonym for divorce. Similarly, a marriage contract from Alalakh reads, "if W hates $\mathrm{H}$ and divorces

114 It is also the view of a considerable number of modern scholars, including A. van Hoonacker, H. Junker, F. Nötscher, T. Chary, S. Schreiner, and M. Smith, who render the passage either "if one sends away out of hate," or "if one hates, (let him) send away."

115 Op. cit., 56.

116 The foundational study to make this point was that of J. J. Rabinowitz, "Marriage Contracts in Ancient Egypt in the Light of Jewish Sources" (1953), although the biblical example cited by Rabinowitz, Deuteronomy 21:15, has been rejected by R. Yaron, “On Divorce in Old Testament Times" (1957) 119. Cf. also R. Yaron, Introduction to the Law of the Aramaic Papyri (1961).

A. S. van der Woude notes simply that while "hate" bears the sense of "divorce" in Aramaic, it is unattested with this meaning in Biblical Hebrew ("Malachi's Struggle for a Pure Community," 70, n. 32).

117 "The Prohibition on Restoration of Marriage in Deuteronomy 24:1-4," 398ff.

118 Westbrook does not use the term "encapsulation." For an examination of the phenomenon of "encapsulation" in lexical semantics, cf. J. Lyons, Semantics, I, 262.

119 Cowley 15 (= PY B2.6) and Kraeling 2 (= PY B3.3).

120 Kraeling 7 lines $21-22$ (= PY B3.8) is obviously intended, correcting the typographical mistake in R. Westbrook, op. cit., 401, n. 51. 
him...,"121 implying that these are not identical terms, and another Neo-Assyrian contract has "if W hates (and) divorces, he must pay...,"122 this time lacking the conjunction.

Based on references to "hate" in non-marital contexts within various Akkadian legal texts, Westbrook argues that this term stresses the culpable motive of a purely subjective aversion which typically turns an innocent act (like leaving a city, in $\mathrm{CH} \S 136$ ) into a criminal one. ${ }^{123}$

Turning to Malachi 2:16, Westbrook argues that the MT can be rendered without emendation, "For he has hated, divorced ... and covered his garment in injustice." Since the asyndetic expression, "he has hated, divorced," is paralleled by the Neo-Assyrian contract mentioned earlier, Westbrook suggests that it was "taken from a standard legal idiom" and means "divorced without justification." Nevertheless, it seems better still to take a "if" and to translate 2:16, "If one hates and divorces, says Yahweh, God of Israel, he covers his garment with violence, says Yahweh of hosts...." However this proposal requires us to examine the meaning and form of שַׁi, which is not without its own problems.

\subsubsection{The problematic meaning and form of}

In spite of the presence of other terms for divorce in Biblical Hebrew, including גרש (Leviticus 21:7; 22:13; Numbers 30:10; Ezekiel 44:22) and יכּר ית (Deuteronomy 24:1, 3; Isaiah 50:1; and Jeremiah 3:8), ${ }^{124}$ there is adequate evidence to establish the meaning "divorce" within the semantic range of the Piel of שלח, based on Deuteronomy 22:19, 29; 24:1, 3, 4; and possibly 21:14; Genesis 21:14; Ezra 10:44; Isaiah 50:1; and Jeremiah 3:1,

121 D. J. Wiseman, “Supplementary Copies of Alalakh Tablets," JCS 8 (1954) 7, No. 94, lines 1719, as cited by R. Westbrook, op. cit., 400.

122 B. Parker, "The Numrud Tablets, 1952 - Business Documents," No. ND 2307, lines $49-50$ read sum-ma (m)Mil-ki-ra-mu [itti-ši] e-zi-ra e-zip-pi iddan(an). Similarly, R. Westbrook: sum-ma He-zi-raezip-pi SUM-an (op. cit., 400). Westbrook rejects the various alternative interpretations/emendations of this text proposed by CAD E (1958) 422; V. Jakobson, "Studies in Neo-Assyrian Law" (1974) 116; and N. Postgate, Fifty Neo-Assyrian Legal Documents (1976) $105 \mathrm{f}$.

To this evidence, Westbrook adds a legal formula attested in the ana ittišu series (VII iv 1-5 = ana ittisu A §5): "if a wife hates her husband and says 'You are not my husband'..." (B. Landsberger, Die Serie ana ittišu, MSL I, 103).

123 Op. cit., 401. Cf. also LE $\S 30$ and CH $\$ \S 142,193$.

124 On the use of גר with reference to divorce, see R. Yaron, "On Divorce in Old Testament Times" (1957) 117-121.

W. L. Callison posits a radical contrast between כִּרִ (requiring a written document and permitting remarriage), and שִ שִ in Malachi 2:16, which, according to Callison, was little more than desertion and did not permit remarriage ("Divorce, the Law, and Jesus" [1986]).

However, Callison commits two linguistic errors. First, he regularly confuses parts of speech, in this

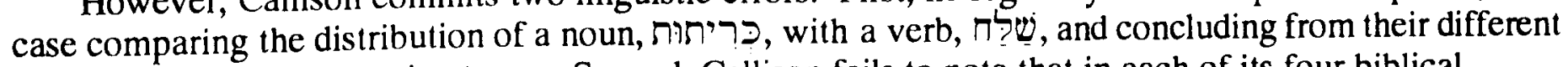
uses that they are contrastive terms. Second, Callison fails to note that in each of its four biblical

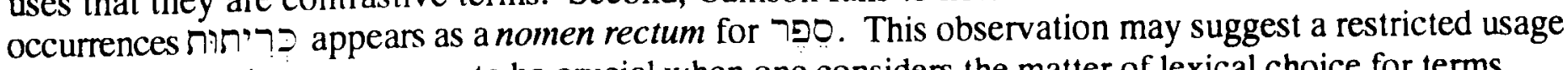
for this term and so may prove to be crucial when one considers the matter of lexical choice for terms having to do with divorce.

In addition to those terms listed above, H. J. Hendriks mentions עזב (Isaiah 54:6, 7; 60:15), a term which "denotes the position of the divorced, forsaken wife" ("Juridical Aspects," 57). 


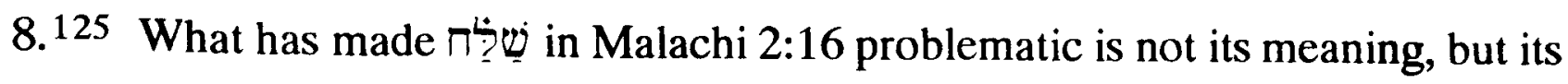
grammatical form.

Westbrook's claim that the MT of Malachi 2:16 need not be emended on the basis of a Neo-Assyrian marriage contract may go beyond the evidence. While it is true that this Akkadian parallel, along with the rest of Westbrook's evidence, offers impressive support for interpreting שנא as referring to the husband's attitude (rather than Yahweh's, etc.) and also for permitting an asyndetic construction, it should be noted that the Akkadian formula which Westbrook cites has both verbs in the I/1 Present/Future, while the MT of Malachi 2:16 involves one perfect and one infinitive construct.

It is possible that one should follow the suggestion of J. M. P. Smith and others and repoint 126 In 126 as a perfect Assyrian marriage contract mentioned above, this modest emendation allows an asyndetic construction which is typical for Biblical Hebrew, with the two perfects to be rendered, "if one hates and repudiates/divorces" (i.e., "if one divorces because of hatred").

A preferable alternative, however, may be to leave this form as an Piel infinitive absolute functioning as a substitute for a finite form, in this case a perfect. 127 Other interpreters may have overlooked this possibility because the Piel

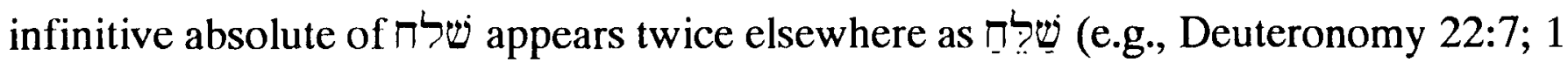
Kings 11:22). This does not preclude our proposal, however, since in the Piel conjugation the infinitive construct often provides an alternative form for the infinitive absolute. ${ }^{128}$

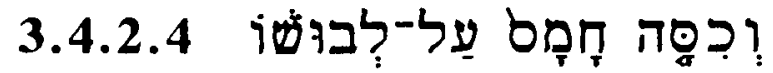

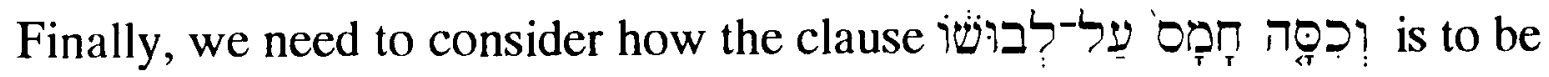
understood on the present interpretation. We have already argued that this clause ought to be construed as an apodosis, against the view of $\mathrm{LXX}{ }^{\mathrm{LW}}$, etc. (see $\$ 3.4 .2 .1 .2$ above). In

125 I.e., שלח is used to refer to the "sending away" of one's spouse that coincides with and expresses the termination of marriage. S. L. McKenzie and H. N. Wallace state, "Divorce is apparently involved, though the use of sallah to mean 'divorce' is unusual..." (op. cit., 552f., n. 14). Cf. also KB, s.v. שלח.

For a fuller discussion of the use of שלח with reference to divorce, cf. D. W. Amram, The Jewish Law of Divorce According to Bible and Talmud (1896) 55ff. (who includes Genesis 21:14); R. Yaron, op. cit.; Z. W. Falk, Hebrew Law in Biblical Times, 155; H. J. Hendriks, "Juridical Aspects," 56, 76, n. 288 ; and J. Scharbert, "Ehe und Eheschliessung in der Rechtssprache des Pentateuchs und beim Chronisten" (1977) 216, $219 f$.

126 Op. cit., ad loc. Smith renders the verse, "For one who hates and sends away covers his clothing with violence, says Yahweh of hosts." Cf. also A. van Hoonacker, H. Junker, F. Nötscher, T. Chary, and R. Westbrook.

127 Waltke and O'Connor \$35.5.2. Waltke and O'Connor note that all of the narrative examples which they cite occur in direct discourse, a fact which may lend additional support to the recognition of in 2:16 as an infinitive absolute. Cf. also W. L. Moran, "The Use of the Canaanite Infinitive Absolute as a Finite Verb in the Amarna Letters from Byblos" (1950) 169-172.

Within the immediate context of Malachi, it is possible that תְְִ in 2:13 offers another, generally undetected, example of an infinitive absolute used as a finite form.

$128 \mathrm{Cf}$. GKC $\$ 520$, which notes that in the Piel, the infinitive construct form is "much more frequently" employed for the infinitive absolute than the special infinitive absolute form. 
addition to offering greater congruence with its context, one special advantage of this proposal is that it obviates any need to emend 129

However, even though we may have clarified its grammatical function within its context, because this figure occurs nowhere else in the Old Testament there remains considerable uncertainty as to its interpretation. In addition, there is further uncertainty regarding the grammar within the clause itself. T. V. Moore rules out the rendering "who covers violence with his garment" on the ground that עִ עסה , כhen whed with designates the thing covered. ${ }^{130}$ Nevertheless, it may be asked whether of כְִָה (so LXX, Vulgate), ${ }^{131}$ or whether it is the object describing that with which "his garment" is covered (so Peshitta, Targum). ${ }^{132}$

Although the sense of the passage is not greatly affected by the choice, favouring this later option is the grammatical parallel with שֶָ, to which reference has been made -namely, the desirability of having the same subject, the divorcing man, for both of these perfects.

There are three main alternative interpretations for an identification of "his garments [לבוּ? ?

1) The first view understands "garment" in a literal manner, supposing the reference to be to the worshipper's attire within a cultic setting. There are two variations on this approach. The first assumes a context of idolatrous worship, while the second assumes a context of hypocritical worship. We have already rejected the idolatrous context posited by H. Winckler and I. G. Matthews which leaves their interpretation of לבוּ without foundation ( $\$ 2.2 .2 ; \S 2.2 .5$; and $\$ 3.1 .2$ above). The second variation on this literal view of "garment" is represented by P. A. Verhoef. Comparing the use of כסה in vs. 13, where the semantic domain is predominantly cultic, Verhoef suggests that "despite the fact that the people were accused of divorcing their wives [unjustly, we might add], they indulged in sacrificial activities."133 Verhoef suggests that the "violence" may refer to the splashed blood of hypocritically sacrificed animals (cf. Micah 6:7). In any case, the mention of garments besmirched with violence or injustice would appear to stress their heinous desecration and hypocrisy. However, while an allusion to $2: 13$ is plausible, the posited

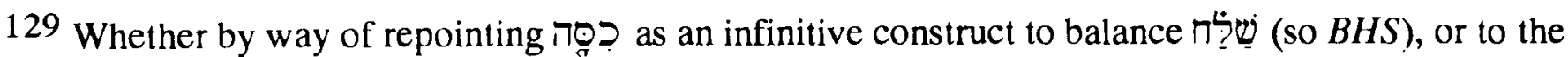
infinitive absolute with prefix, הO\૫. Cf. discussion of this in A. S. van der Woude, "Malachi's Struggle for a Pure Community," 70 and 71, n. 35.

130 Malachi (1856) 139. So also W. C. Kaiser Jr., Malachi, 73, who cites Moore.

Cf. Deuteronomy 13:8, Habakkuk 2:14, etc. These parallels, likewise, appear to offer little support for the interpretation of the NIV (assuming that it is not intended to be paraphrastic): "I hate a man's covering himself with violence as well as with his garment."

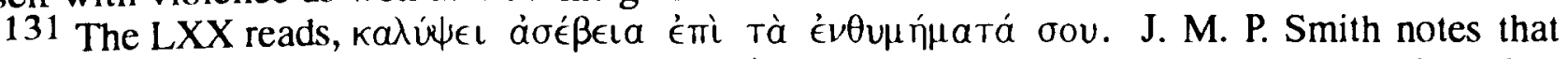

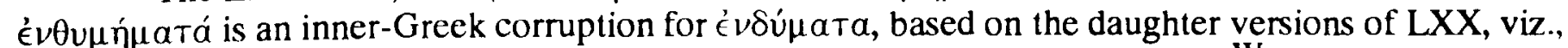
Peshitta, Arabic Armenian, Ethiopic, and Georgian (op. cit., 60). So also LXXW.

132 So, e.g., P. A. Verhoef, The Books of Haggai and Malachi, 279.

133 Op. cit., 280. 


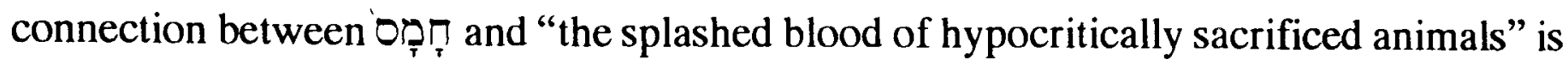
unconvincing.

2) Since the suggestion was first made by E. Pococke, the majority of modern

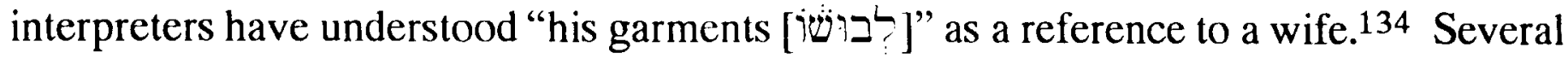
arguments have been offered in support. Perhaps least convincing is the frequent appeal to the Qur'ān 2:187, which is offered as an extrabiblical example where "garment" appears as a poetic reference to one's wife: “... They (your wives) are a covering to you, and you are a covering to them [lb's lh hg lb's lkm w'ntm]." The use of "garment," however, whether as a metaphor (as in the Qur'ān) or as a designation, is hardly customary as a reference to a wife, being attested nowhere else in Arabic literature or Biblical Hebrew. ${ }^{135}$ A second argument in favour of recognizing "his garments [לבוּשט:]" as a reference to a wife is the intimate proximity of clothes to the wearer, which suggests to some its aptness as a metaphor for a wife in relation to her husband. ${ }^{136}$ The final, and perhaps strongest argument for interpreting "his garments [לברוּש ] ? obtaining a wife by means of covering her with a garment (Deuteronomy 22:30 [ET 23:1], Ruth 3:9, Ezekiel 16:8). ${ }^{137}$ Based on this association with a marriage rite, "his garments [?רבוּ]

3) The older view of לברוּש , which is perhaps still to be preferred, is that "his garments" is simply another instance of the pervasive biblical image of clothes as the outward expression of the inner state of a man. ${ }^{139}$ See, for example, Jeremiah 2:34, "Also on your skirts is found the lifeblood of guiltless poor"; Psalm 73:6, "Therefore pride is

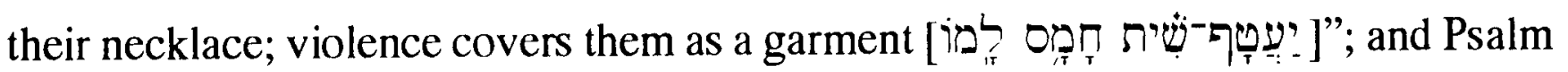

134 E. Pococke, A Commentary on the Prophecy of Malachi (1740) -- so, according to A. von Bulmerincq, Der Prophet Maleachi, Band 2, 315.

This view is supported by, among others, E. Henderson, The Twelve Minor Prophets (1858) 455; J. Wellhausen, Skizzen und Vorarbeiten (1892) 199; G. A. Smith, The Book of the Twelve Prophets (1899) 365; K. Marti, Das Dodekapropheton (1904); 472; R. C. Dentan, "The Book of Malachi" (1956) 1136; and C. M. Carmichael, Law and Narrative in the Bible (1985) 198.

135 Cf. E. B. Pusey, The Minor Prophets (1883) 484, n. 5, and J. M. P Smith, op. cit., 60, against G. H. A. von Ewald, who terms לברוש ? "a genuinely popular phrase... for his wife" (Mal'aki [1881] 82).

136 So, e.g., W. E. Barnes, Malachi (1917) 125.

137 So, e.g., J. M. P. Smith, op. cit., 55f., and W. C. Kaiser Jr., Malachi, 73f., who writes, "The word 'garment,' no doubt, refers to the ancient custom of spreading a garment over a woman, as Boaz did over Ruth, to claim her as a wife...." Cf. also E. Achtemeier, Nahum-Malachi (1986) 183.

138 Cf., e.g., A. Phillips, “Uncovering the Father's Skirt” (1980) 38.

139 Cf. Martin Luther, Lectures on Malachi, 406; C. F. Keil, The Twelve Minor Prophets, vol. 2 (1868) 454; J. Packard, "The Book of Malachi" (1876) 17; E. B. Pusey, The Minor Prophets (1883) 609, n. 13; T. T. Perowne, Malachi (1890) 27; C. von Orelli, The Twelve Minor Prophets (1893) 397f.; S. R. Driver, The Minor Prophets (1906) 317; E. Sellin, Das Zwölfprophetenbuch (1922) 554; P. M. Schumpp, Das Buch der zwölf Propheten (1950) 396; D. R. Jones, Haggai, Zechariah, Malachi. (1962) 197; C. Stuhlmueller, "Malachi” (1970) 400; W. Rudolph, Haggai, Sacharja 1-8, Sacharja 9-14, Maleachi (1976) 275; and S. Schreiner, “Mischehen-Ehebruch-Ehescheidung. Betrachtungen zu Mal 2,10-16” (1979) 227. 


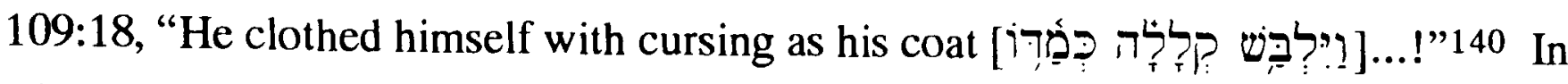
addition, the customary use of garments in claiming a woman as a wife, as discussed above, with its implicit pledge of protection and support, may make this metaphor especially apt in the present context. ${ }^{141}$

In any case, against the apparent assumption of Van der Woude, nothing about Malachi's use of this image and its mention of "violence [\$ָָ viewed divorce on the ground of aversion to be an illegal act. ${ }^{142}$ The concern of the prophet is rather to condemn such divorces as unethical and, as an instance of infidelity [בגד], or covenant breaking (cf. 2:14), liable to divine judgment: "Therefore, take heed to yourselves!"

In summary, we may paraphrase Malachi 2:16, "If one hates and divorces [that is, if one divorces merely on the ground of aversion], says Yahweh, God of Israel, he covers his garment with violence [i.e., such a man visibly defiles himself with violence], says Yahweh of hosts. Therefore, take heed to yourselves and do not be faithless [against your wife]."

\subsection{Deuteronomy $24: 1-4$}

We began this chapter noting how A. S. van der Woude rejects an interpretation of Malachi 2:16 which is similar to the one just defended -- that Malachi repudiated not divorce in general, but divorce based on aversion. ${ }^{143}$ Van der Woude acknowledges that he might be prepared to accept this interpretation on other grounds were it not for the lenient attitude toward divorce attested in Deuteronomy 24:1-4. We turn now to this decisive passage.

140 Cf. also Zechariah 3:3-5, Psalm 109:29, Proverbs 31:25, Isaiah 59:17; 61:10, 64:5 [ET 6], etc.

141 Cf. J. M. P. Smith, op. cit., 55f. Smith also cites W. R. Smith, Kinship and Marriage in Early Arabia, 1st ed., p. 87, as offering Arabic parallels for the use of garments in claiming a wife. N.B., Smith is careful to distinguish his view from the view which uses these texts to argue an identification of "his garments" with the man's wife (op. cit., 60).

Possibly there is some connection also between the garment mentioned in 2:16 and the Akkadian practice of "cutting the hem/veil," as expressive of divorce (perhaps also reflected in the expression, רפ "כִ כִרית , bill of divorce [cutting]"). In any case, the expression "the wife of your youth," with its allusion to the time of one's wedding, may offer some indirect support to an association between the garments mentioned in 2:16 and the use of garments in the act of betrothal.

Moreover, it is also possible that an allusion is intended to 2:13, where 30 also appears, in this case in what is a distinctly cultic context. Cf. P. A. Verhoef, The Books of Haggai and Malachi, 279f. Thus understood, Malachi employs an image which is reminiscent of that found in Zechariah 3 in order to indicate that the offerer has been spiritually disqualified from cultic participation by his divorce.

142 "It must be sincercly doubted whether in Old Testament times even a prophet would have denounced divorce as a crime [italics added]" ("Malachi's Struggle For a Pure Community," 71).

143 Ibid. 
It is not possible within the limits of the present study to establish which, if any, of the ten major competing views is to be preferred for the rationale behind the prohibition of palingamy to a former spouse in Deuteronomy $24: 4.144$

Nevertheless, in spite of this unresolved debate, a scholarly consensus has emerged that the intent of this casuistic law is not to authorize divorce, nor to stipulate its proper grounds, nor to establish its requisite procedure. Rather, its sole concern is merely to prohibit the restoration of a marriage after an intervening marriage. ${ }^{145}$ If so, there is no necessary contradiction between Malachi's prophetic indictment of divorce on the ground of aversion and Deuteronomy 24.146 In grammatical terms this consensus reflects the

144 The ten views in question are:

a) To renew such a marriage would be to condone adultery (the adultery is implicit in the second marriage, whether or not a remarriage to the first husband takes place). Cf. Philo, Special Laws, 3:30f. Philo's approach is discussed and rejected by R. Yaron, "The Restoration of Marriage" (1966) 6f., and R. Westbrook, op. cit., 388f.

b) The remarriage of a divorced woman is tantamount to adultery. Cf. C. F. Keil and F. Delitzsch, The Pentateuch (1878) 418, and S. R. Driver, Deuteronomy (1902) 272. Against this, cf. R. Yaron, "The Restoration of Marriage," 7.

c) Protect the first marriage (a deterrent against rash divorce). Cf. S. R. Driver, Deuteronomy, 272. Against this, however, cf. R. Yaron, “The Restoration of Marriage," 5f.; J. A. Thompson, Deuteronomy (1974) 244; G. J. Wenham, “The Restoration of Marriage Reconsidered” (1979) 36; and R. Westbrook, op. cit., 389.

d) A consequence of marriage as an unobliterable relationship. Cf. J. Murray, Divorce (1961) 14.

e) Codify natural revulsion. Cf. H. Junker, Das Buch Deuteronomium (1933) 100, as cited by R. Westbrook, op. cit., 391; C. M. Carmichael, The Laws of Deuteronomy (1974) 203-207; and idem, Women, Law, and the Genesis Traditions (1979) 8-21. Against this view, cf. G. J. Wenham, "The Restoration of Marriage Reconsidered," 37 and R. Westbrook, op. cit., 391.

f) Protect the second marriage. Cf. S. R. Driver, Deuteronomy, 272; and R. Yaron, "The Restoration of Marriage," 8-11. Against this view, cf. C. M. Carmichael, The Laws of Deuteronomy, $204 ; \mathrm{R}$. Westbrook, op. cit., 389f.; and G. J. Wenham, “The Restoration of Marriage Reconsidered," 37.

g) Avoid incest. Cf. G. J. Wenham, "The Restoration of Marriage Reconsidered," 37ff., and W. A. Heth and G. J. Wenham, Jesus and Divorce. Towards an Evangelical Understanding of New Testament Teaching (1984) 106-110. Against this view, cf. R. Westbrook, op. cit., 390f.; and H. W. Hoehner, "A Response to Divorce and Remarriage [a paper read by W. A. Heth]" (1987) 240-246, at 243.

h) Protect the woman. Cf. W. F. Luck, Divorce and Remarriage (1987) 57. Against this, cf. H. W. Hoehner, "A Response to Divorce and Remarriage [a paper read by W. A. Heth]," 242.

i) Prohibit unjust enrichment (due to estoppel). Cf. R. Westbrook, op. cit., 387-405.

j) Avoid legalized adultery (closing a possible loophole in the prohibition against adultery). Cf. J. Calvin, Commentaries on the Four Last Books of Moses arranged in the form of a Harmony, III, 94: "The reason of the law is, that, by prostituting his wife, he would be, as far as in him lay, acting like a procurer." For more recent scholars in support of this view, cf. S. F. Bigger, "Hebrew Marriage and Family in the Old Testament Period" (1974) 237, and P. C. Craigie, Deuteronomy (1976) 306f.

It will be noted that these ten main approaches are not necessarily mutually exclusive and that not all scholars confine themselves to just one of these opinions. For example, at various points in his discussion, S. R. Driver supports positions c), which he most favours, but also b) and f). Similarly, C. F. Keil and F. Delitzsch, The Pentateuch, 416ff., appear to hold a combination of b), c) and h), while J. A. Thompson, Deuteronomy, 245, speaks in favour of b), c), and f).

For a further discussion of this issue, see the writer's unpublished paper, "Alternative approaches to Deuteronomy 24:1-4 and a defence of the 'adultery loophole' view" (submitted to G. J. Wenham on 18/8/87).

145 So, already, J. Calvin, Commentaries on the Four Last Books of Moses, III, 94.

Cf. also, e.g., C. F. Keil and F. Delitzsch, The Pentateuch, III, 416f.; S. R. Driver, Deuteronomy (1895) 269; M. G. Kline, Treaty of the Great King (1963) 114f.; A. Phillips, Deuteronomy (1973) 159f.; J. A. Thompson, Deuteronomy (1974) 243.; P. C. Craigie, Deuteronomy (1976) 304; and A. D. H. Mayes, Deuteronomy (1979) 322. Cf. also the RSV, the NIV, and most modern translations.

146 The regulation of a practice does not thereby imply moral approval for that practice. Cf., e.g., $\$ 4.6 .2 .1 .3$ below. 
conviction that that the only apodosis in Deuteronomy 24:1-4 is the clause which begins לאיריוּרל

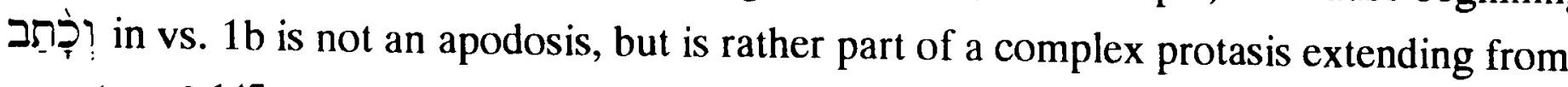
vss. 1 to 3.147 Reflecting this consensus, it may help to set out the various elements of Deuteronomy 24:1-4 in the following manner:

\section{Complex protasis:}

\section{Condition 1: An initial legal marriage}

"When a man takes a wife and marries her,..."

\section{4:1}

Condition 2: Because the wife commits some offence her,..."

"... if then she finds no favour in his eyes because he has found some indecency in

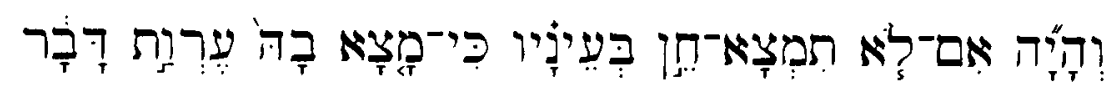

Condition 3abcd: He legally divorces her

a) "... and he writes her a bill of divorce..."

b) "... and puts it in her hand...."

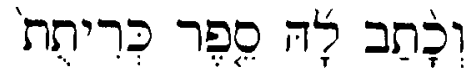

c) “... and sends her out of his house,..."

d) "... and she departs out of his house,..."

\section{Condition 4: And then she remarries}

"... and if she goes and becomes another man's wife,..."

147 AV: "When a man taketh a wife, and marrieth her, then it shall be, if she find no favour in his eyes, because he hath found some unseemly thing in her, that he shall write her a bill of divorcement, and give it in her hand, and send her out of his house. 2 And when she is departed out of his house, she may go and be another man's wife. 3 And if the latter husband hate her, and write her a bill of divorcement, and give it in her hand, and send her out of his house; or if the latter husband die, which took her to be his wife; 4 her former husband, which sent her away, may not take her again to be his wife, after that she is defiled; for that is abomination before the LORD: and thou shalt not cause the land to sin, which the LORD thy God giveth thee for an inheritance." (Deuteronomy 24:1-4)

Cf. also the English Revised Version, the American Revised Version, and the ASV of 1901. These translations give the impression that divorce is not merely permitted, it is mandatory under the circumstances described in vs. 1 (so notes J. Murray, Divorce, 4).

Typical of the present scholarly consensus is the view of R. C. Campbell who writes, "There is scarcely any question that these verses constitute one conditional sentence, the protasis of which is to be found in the first three verses and the apodosis of which beings [sic for "begins"] only with v. 4" ("Teachings of the Old Testament Concerning Divorce" [1963] 174f.).

148 The MT of Deuteronomy 24:1-4 is considered by most commentators to be reliable. In the present

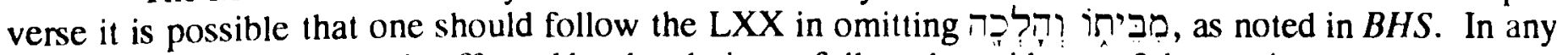
case, the sense is not greatly affected by the choice to follow the evidence of the versions. 
Condition 5: And either the second husband hates her

"... and the latter husband dislikes her..."

Condition 6abc: And legally divorces her

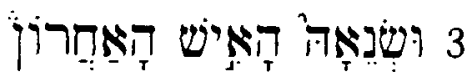

a) "... and writes her a bill of divorce..."

b) "... and puts it in her hand..."

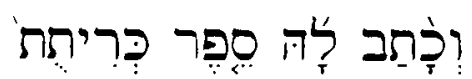

c) "... and sends her out of his house,..."

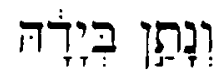

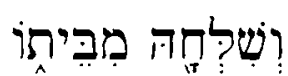

Alternative to Conditions 5 and 6abc: Or the second husband dies

"... or if the latter husband dies, who took her to be his wife,..."

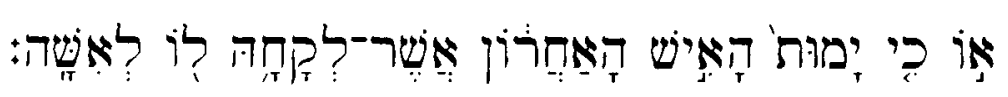

Apodosis: Under such conditions remarriage to the first husband is prohibited

“... then her former husband, who sent her away, may not take her again to be his wife..."

$$
4
$$

Reason part 1: because the woman is defiled

"... after she has been defiled;..."

Reason part 2: because it would be an abomination

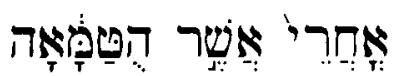

"... for that is an abomination before the LORD,..."

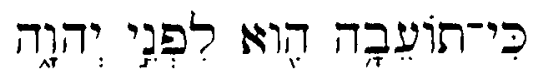

Reason part 3: and would bring guilt on the land

"... and you shall not bring guilt upon the land which the LORD your God gives you for an inheritance."

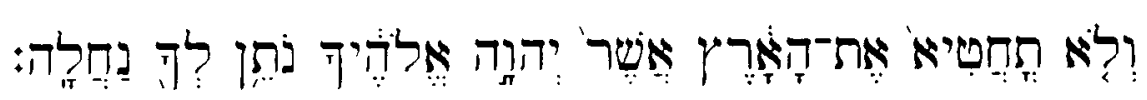

Accordingly, since Deuteronomy 24:1-4 is concerned only with the prohibition of palingamy to a former spouse, there is no necessary contradiction with the interpretation being advanced for Malachi 2:16. Moreover, it now appears probable that Deuteronomy 24:1-4 may, in fact, presuppose a similar outlook as Malachi 2:16. This is the case because, as R Westbrook has argued, this law appears to assume a widely attested legal 
practice according to which a husband incurs a substantial financial penalty if he divorces his wife merely on the ground of aversion. 149

Westbrook emphasizes the distinction between the sort of divorce which terminates

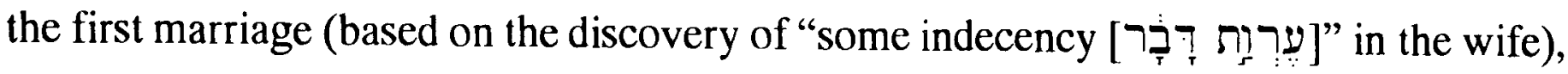

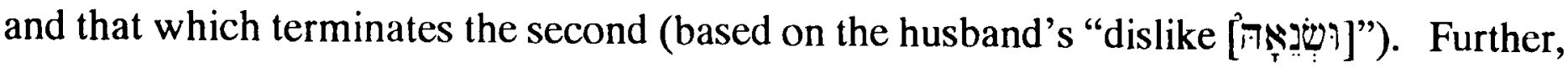
Westbrook notes that there must be some factor, heretofore overlooked, which would account for the remarkable pairing of the second divorce with death. That factor, Westbrook hypothesizes, is the favourable financial consequence for the woman which would result either from the death of her husband, or from that particular kind of divorce.

Based on an extensive survey of both ancient Near Eastern and post-biblical Jewish practice, Westbrook concludes that typically when a marriage was dissolved by death or divorce, a woman was entitled to a financial settlement at least consisting of the return of her dowry, but often also including a further payment from her husband's own resources. ${ }^{150}$ However, in cases where the divorce was justified because of some serious misconduct on the part of the woman less than adultery (for which the penalty would be death according to Westbrook), the financial consequences were radically different. Under such a circumstance the husband was entitled to keep the dowry and incurred no financial penalty. 151

149 R. Westbrook, op. cit., 387-405.

150 Westbrook suggests that if the wife had borne children, LE $\$ 59$ and $\mathrm{CH} \$ 137$ [Westbrook mistakenly cites $\mathrm{CH}$ \&147] may indicate that the financial consequences for divorce were still more severe, requiring the husband to forfeit the whole of his property (op. cit., 395, n. 26). This suggestion is not without difficulties. In support, Westbrook cites his Old Babylonian Marriage Law, Chapter 4.

Cf. CH §§171b-172; NBL $\S 12$; and less explicitly, $m$. Ketub. 7:1; 10:1-2. Note that in addition to the returned dowry, the widow in each case is entitled to additional payments (either martial property given to her by her husband or some equitable share of the estate).

For the financial settlement in the case of death, Westbrook notes Rashi's suggestion that the wife contributes to the husband's death, but considers this too farfetched and so remarks that Yaron does not consider it (op. cit., 390, n. 10). While Westbrook is probably correct in rejecting this interpretation for Deuteronomy 24 , a law such as $\mathrm{CH} \$ 153$ demonstrates that the possibility of this kind of murderous intrigue on the part of a wife is anything but farfetched.

For the financial settlement in the case of divorce, cf. LU §§6-7; CH §§138-140; MAL A §§20, 37, 38; $m$. Ketub. 1:2 (cf. b. B. Qam. 82b). CH $\$ 138$ specifies the general case where the divorced woman is entitled to her returned dowry [ ¿eriktam] and a divorce payment equal to her marriage present [kaspam mala terhatiša]. Westbrook argues that MAL A $\$ 37$ need not be understood as giving the husband total discretion with respect to the divorce settlement (op. cit., 395, n. 27). It may intend only to relieve him of a statutory minimum, such as mentioned in $\mathrm{CH} \$ \S 6-7,138$.

151 Westbrook cites $\mathrm{CH} \S 141$, where the wife's misconduct, according to Westbrook, was of a financial nature, and the punishment is expulsion "without giving her anything, not her journey-money, nor her divorce-money." Westbrook also notes $\mathrm{CH} \S \S 142-143$, where the wife in an inchoate marriage is to be cast into the water if she was unchaste and involved in some financial misconduct, but if she is innocent of the charge she may leave with her dowry. Finally, Westbrook cites MAL A $\$ 29$ (following the interpretation offered by G. Cardascia, Les lois assyriens [1969] 161-163) and m. Ketub. 7:6.

Westbrook's assumption of the death penalty for adultery presumably reflects the typical case of a guilty spouse caught in flagrante delicto. Cf., e.g., CH \$129; LE §28; HL \$\$195, 197, 198; MAL A $\$ \$ 13,15,16$, and 23 . It is important, however, to stress the condition of being caught in flagrante delicto and also to note that some laws suggest the possibility that the death penalty for an adulterous wife, even if caught in flagrante delicto, could be waived by her husband so long as equal leniency was shown to the guilty lover. Cf., e.g., $\mathrm{CH} \$ 129, \mathrm{HL} \$ 198$ and MAL A $\$ \$ 14,15,16$, and 23 . See the fuller treatment of this topic in Chapter 8 below. 
Westbrook then argues that the first divorce in Deuteronomy 24 was precisely such as would involve "the kind of misconduct referred to in $\mathrm{CH} \$ \$ 141-142$ and in $m$. Ketub. 7:6 and therefore justifies the husband in divorcing his wife without a financial settlement."152 The second divorce, on the other hand, because it specifies a motive of "hate," a term that in numerous other legal contexts expresses "the mens rea, the "guilty mind', which is a necessary constituent of the offence," would entitle the wife to receive the normal financial settlement. ${ }^{153}$

We have already considered Westbrook's argument concerning the meaning of "hate [שנא]" in the context of divorce. The point to be noted here is simply that under such a circumstance, the second divorce would leave the woman in much the same financial condition as would be the case were her husband to have died.

Westbrook concludes, "The effect would be that the first husband profits twice: firstly by rejecting his wife and then by accepting her. It is a flagrant case of unjust enrichment which the law intervenes to prevent." In modern law such a prohibition would be grounded in the concept of "estoppel," the principle that a man who has benefited from asserting a particular set of facts may not benefit a second time from conceding that the facts were otherwise.

Whether or not one agrees with Westbrook that estoppel is the underlying rationale for the prohibition in Deuteronomy 24:1-4, his analysis of the distinction between the two divorces and the resulting financial benefit to the first husband, which may have motivated the remarriage, appear plausible. Of course, in the absence of corroborating evidence, there

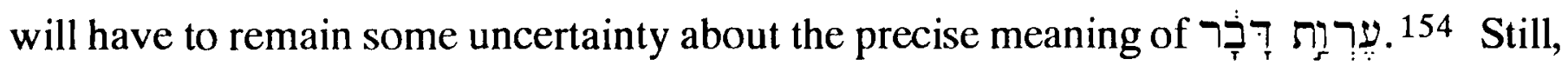

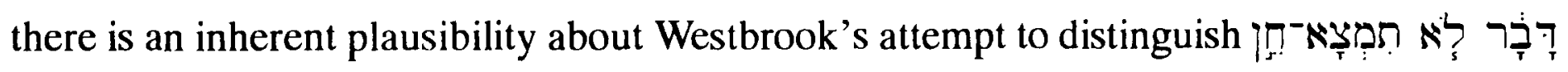

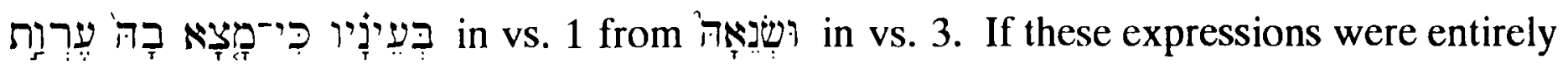
synonymous why would the author bother with the fuller expression when שנא כi כe sufficiently clear and well attested elsewhere in divorce contexts? ${ }^{155}$ Likewise, the

152 Op. cit., 399.

153 Op. cit., 401. Westbrook cites LE $\S 30, \mathrm{CH} \S \S 136,142,193$, as offering examples for this usage of "hate."

154 Whatever the precise origin and meaning of this crux interpretum, Westbrook's conclusion seems warranted that it refers to some serious cause such as would permit the husband to divorce his wife while avoiding any financial penalty. Cf. also, e.g., M. G. Kline, Treaty of the Great King, 115.

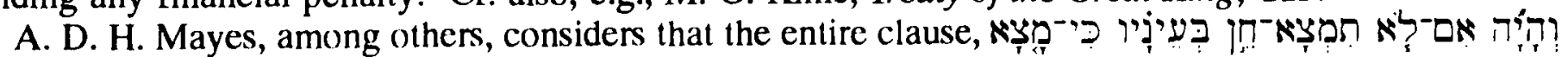

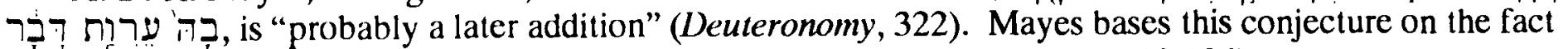
that the verse "has a new beginning with the word wehayajh; see comment on 18:19."

But Mayes' comment at 18:19 proves to be unilluminating and the argument must be judged unconvincing since ות is so widely attested with this same grammatical function in texts of unquestioned integrity (e.g., Mayes himself does not consider 18:19 to be a later interpolation). Indeed, given the repetition in phraseology between the description of the first divorce where we read

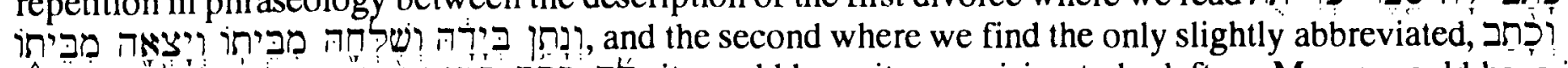

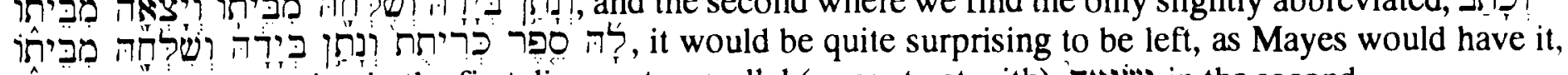

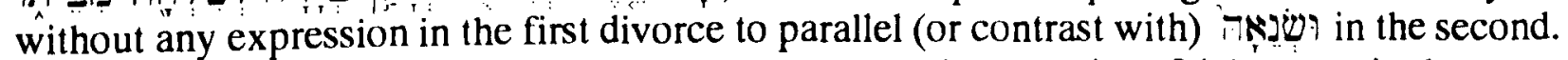

155 Here we assume the widely conceded observation that since $24: 1$ occurs in the protasis of this case law, the legislator was not intending to introduce a novel requirement in the procedure for divorce which would necessitate the unusually full description. 
evidence from the ancient Near East and post-biblical Judaism presented by Westbrook should predispose the interpreter to discover in the biblical legislation a similar practice of distinguishing various grounds for divorce -- in particular, mere aversion (שנא) from some

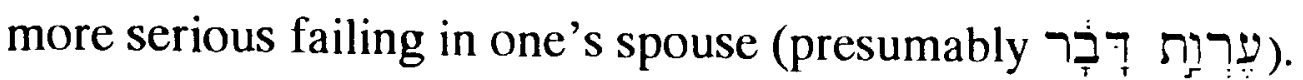

Accordingly, as against those scholars who consider Malachi 2:16 to be in tension with Deuteronomy 24:1-4, the implied financial penalty on the second husband who divorces in Deuteronomy 24:3, in reality reflects a similar disapprobation of divorce when grounded in mere aversion as is attested in Malachi 2:16. 156

\subsection{Summary and conclusions}

We began the present chapter by acknowledging the importance of Malachi 2:16, if it refers to literal divorce, for the support it offers for a reference to literal marriage in Malachi 2:14. Not surprisingly those scholars who reject a reference to literal marriage in $2: 14$ either refrain from offering any interpretation of $2: 16$, claiming that the text is "hopelessly corrupt" (so C. C. Torrey, cf. also F. F. Hvidberg and A. Isaksson), or they resort to unwarranted emendation of the MT of 2:16 and the attribution of otherwise unattested meanings to its vocabulary in order to restore a reference to idolatry (I. G. Matthews).

Following a discussion of these approaches we considered one other interpretation which also denies a reference to literal divorce in $2: 16$, namely that of A. S. van der Woude. Van der Woude holds that 2:16 condemns the mistreatment of Jewish wives within polygynous mixed marriages. The principal advantage of this view is that it removes an apparent contradiction between the absolute prohibition of divorce in Malachi $2: 16$, as it has been traditionally interpreted, and the acceptance of divorce in Deuteronomy 24:1-4. While Van der Woude's interpretation does not exclude a reference to literal

156 Less convincing is Westbrook's interpretation of reference to the first husband's allegation of defilement: “... the first husband's earlier assertion that she was unclean makes her unclean now for the purposes of marrying her. Having profited from the claim that she was unfit to be his wife, he can not now act as if she were fit to marry him because circumstances have made her a more profitable match" (op. cit., 404f.).

Also problematic is the characterization in 24:4 of any such remarriage as an "abomination [תוֹערה]"

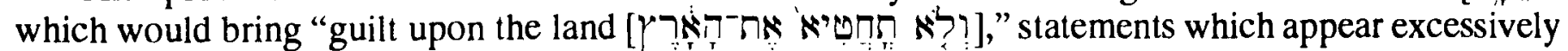
harsh for the pecuniary wrong he alleges. Although Westbrook cites M. Weinfeld, Deuteronomy and the Deuteronomic School (1972) 272-269, in defence of uncertain and, even if possible elsewhere, unconvincing for Deuteronomy 24:4 (cf. also S. A. Kaufman, "The Structure of the Deuteronomic Law" [1978-79] 127 and 156, n. 107).

Finally, Jeremiah 3:1-10 tells against the assumed rationale of estoppel since, on Westbrook's view, the restoration of a marriage after an intervening marriage is entirely permissible if this can be accomplished without estoppel. In other words, the precise terms under which each marriage is ended is of critical importance for determining the propriety of the remarriage. However Jeremiah 3:1 repudiates any remarriage without specifying the grounds for the termination of either marriage. Westbrook is aware of the difficulty posed by Jeremiah 3 for his interpretation and so argues against the vast majority of scholars that Jeremiah 3 has no relation to the law in Deuteronomy 24 (op. cit., 405, n. 66.). 
marriage in Malachi 2:14,157 it is unconvincing especially because of its supposition that

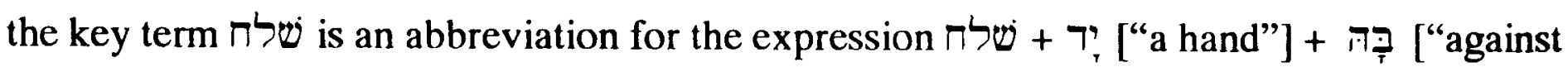
her"], a usage that lacks any convincing parallel.

Each of the remaining three main alternative interpretations of 2:16 accepts a reference to literal divorce and so coheres with the view of this thesis that the covenant mentioned in Malachi 2:14 refers to literal marriage. The first of these is that Malachi urges divorce, whether of a hated wife (so 4QXIIa, LXX ${ }^{\mathrm{LW}}$, Targum, and S. Schreiner), or perhaps of a heathen wife (so A. von Bulmerincq): "If ..., then divorce [שِ However, the versional evidence in support of interpreting שِ be tendentious, having arisen from a desire to harmonize Malachi with the liberal tolerance of divorce in Deuteronomy 24:1-4. Moreover, this interpretation is opposed by the resulting awkward shift in pronominal reference in 2:16a, a shift which can only be eliminated by emending the MT (which should be maintained as the lectio difficilior): "if he hates [her], then you divorce [her] [שِ reconcile with the strenuous disapproval implied in 2:16b: "and he covers his garment with violence," and especially the warning, "So take heed to yourselves and do not be faithless."

Alternatively, perhaps the majority of interpreters have held that Malachi 2:16 condemns divorce unconditionally: "I hate divorce, says the Lord God of Israel...." On this view, however, Malachi 2:16 contradicts the lenient attitude toward divorce implied in Deuteronomy 24:1-4. Such a contradiction is troubling given Malachi's indebtedness to the Deuteronomic perspective. In addition this traditional interpretation of the text finds the form of שָׁנינָ difficult (generally requiring an emendation or the assumption of an ellipsis) and neglects a considerable body of evidence that "hate [שנא]," when occurring in the context of divorce, is a frequently specified attribute of one of the marriage partners. Finally, the traditional view struggles with וֹ ובְָ , generally emending the form without textual support.

Accordingly, we prefer to maintain the MT and to interpret Malachi 2:16 as condemning only unjustified divorce, that is, divorce based on aversion: "If one hates and divorces, [i.e., if one divorces merely on the ground of aversion] says Yahweh, God of Israel, he covers his garment with violence [i.e., such a man visibly defiles himself with violence], says Yahweh of hosts. Therefore, take heed to yourselves and do not be faithless [against your wife]." This interpretation accepts the evidence of 4 QXIIa and the versions that 2 is a conditional particle, favoured also by the fronted position of the

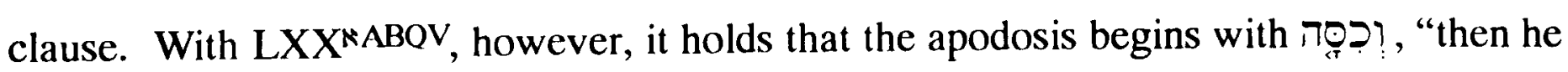

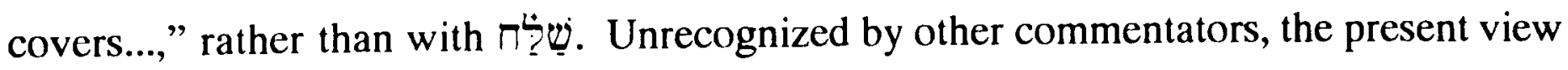

157 However, cf. \$2.2.1 above for a discussion of Van der Woude's understanding of בריח in the expression האיחת ase a reference to the "covenant community." 
understands offers an example of asyndeton: "If he hates and divorces...."158

Finally, far from contradicting Deuteronomy $24: 1-4$, on the present view Malachi 2:16 shares the same assessment of divorce when based on aversion as seems to be presupposed for the second divorce in Deuteronomy 24:3 with its adverse financial consequences for the offending husband ( $\$ 3.5$ above). While the prophet says nothing to imply that such divorces were illegal, Malachi condemns divorce based on aversion as ethically reprehensible and, as an instance of infidelity [בגד], or covenant breaking (cf. 2:14), susceptible to divine judgment: "Therefore, take heed to yourselves!" Such a perspective offers significant support for the identification of literal marriage as a covenant in $2: 14$.

158 For this asyndetic construction, cf. pp. 71f. above. Alternatively, if otherwise unattested verbal adjective, and hence the equivalent of a participle, the MT may be rendered without significant difference in meaning, "if one who hates divorces..., then he covers...." Cf. GKC §50b and Waltke and O'Connor $\$ 37.1 \mathrm{~b}$. 


\section{Outline of Chapter 4: \\ Malachi 2:10-16 and the Toleration of Polygyny Elsewhere in the Old Testament}

4.1 Malachi 2:10-16 originally condemned only divorce and therefore carries no implication regarding the practice of polygyny (the majority critical view)

4.2 Malachi 2:10-16 originally condemned only mixed marriage, and therefore is not only consistent with the practice of polygyny, but presupposes it (A. S. van der Woude). 94

4.3 Malachi 2:10-16 condemns Ezra's enforced dissolution of mixed marriages in Ezra 9-10 and so carries no implication regarding the practice of polygyny (G. H. A. von Ewald, H. H. Spoer, L. Kruse-Blinkenberg, J. J. Collins, and M. Smith).

4.4 There is no necessary interrelation between mixed marriage and divorce in Malachi 2:10-16, apart from a similarity of theme. Accordingly, the text carries no implication regarding polygyny (the view preferred here)............98 98

4.5 Malachi 2:10-16 condemns both mixed marriage and divorce in a manner which suggests that these were typically interrelated, with the implication that polygyny was exceptional, discountenanced, or possibly even illegal in

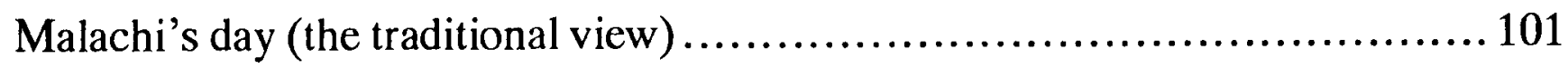

4.6 Excursus on the practice of polygyny in ancient Israel ........................ 106

4.6.1 The prevalence of polygyny in the Old Testament....................... 108

4.6.2 The ethical stance of the Old Testament with respect to polygyny......... 110

4.6.2.1 Texts which are alleged to approve polygyny ................ 111

4.6.2.1.1 Jeremiah 3:6-13 and Ezekiel 23............. 111

4.6.2.1.2 2 Samuel 12:7-8 ......................... 112

4.6.2.1.3 Exodus 21:10-11 and Deuteronomy

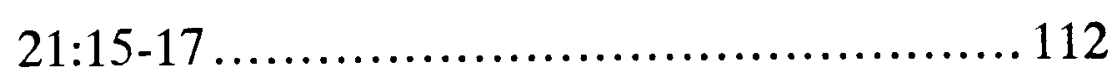

4.6.2.1.4 Deuteronomy 25:5-10.................... 113

4.6.2.1.5 Leviticus $18: 17,18 \ldots \ldots \ldots \ldots \ldots \ldots \ldots \ldots \ldots . \ldots . \ldots 114$

4.6.2.2 Texts which presuppose or may encourage monogamy as

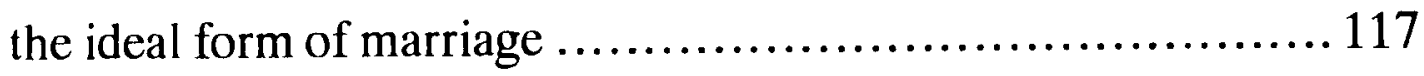

4.6.2.3 Texts which undermine or prohibit the motive for polygyny ... 118

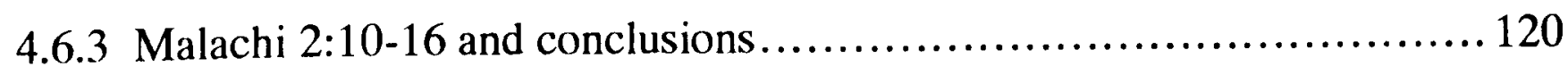

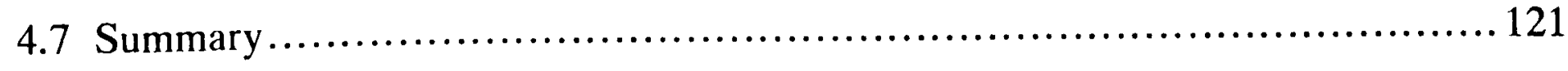




\title{
Chapter 4: \\ Malachi 2:10-16 and the Toleration of Polygyny Elsewhere in the Old Testament
}

\begin{abstract}
We turn now to consider the primary argument of C. C. Torrey against the traditional interpretation of Malachi 2:10-16, which finds in this text a condemnation of literal interfaith marriage and divorce. Writes Torrey, "To assume, in the first place, that divorce of Israelitish wives stood in any necessary or even probable connection with the wedding of women from other nations is ridiculous. Jews occasionally married gentiles, not because they were dissatisfied with their own countrywomen, or with their religion, but because they found some of the gentile women attractive."1 More recently, A. Isaksson has argued in similar terms, "it could not have been necessary for a Jew at this period to divorce his Jewish wife in order to marry a woman belonging to another people and another religion...."2
\end{abstract}

What is at issue in these observations is the apparent implication of Malachi 2:10-16 that polygyny, in spite of its assumed toleration elsewhere in the Old Testament, was no longer an option for Malachi's contemporaries. It is important to realize that this rejection of polygyny, if it is so, was not merely on the part of the prophet, who may have held an idiosyncratic view, but it was apparently also the conviction of the very men Malachi was condemning. The divorce of their Jewish wives was seemingly a necessary prelude to (or a consequence of) the mixed marriages into which these men had entered.

We have already rejected the alternative interpretation which Torrey and Isaksson propose for Malachi 2:10-16, an interpretation which avoids the alleged difficulty by arguing for a figurative reference in the text. It remains for the present chapter to support a reference to literal marriage and divorce by attempting to resolve this apparent contradiction between Malachi 2:10-16 and the assumed toleration of polygyny elsewhere in the Old Testament. Among scholars who support a reference to literal marriage in Malachi, there are five main alternative approaches to resolve this apparent contradiction, each of which we shall consider in turn:

1) Malachi 2:10-16 originally condemned only divorce and therefore carries no implication regarding the practice of polygyny (the majority view among modern critical scholars).

2) Malachi 2:10-16 originally condemned only mixed marriage, and therefore is not only consistent with the practice of polygyny, but presupposes it (A. S. van der Woude).

1 "The Prophecy of 'Malachi'," 9.

2 Marriage and Ministry in the New Temple, 30. 
3) Malachi 2:10-16 condemns both mixed marriage and divorce in a manner which suggests that these were typically interrelated acts. However, the divorces in question refer to Ezra's enforced dissolution of mixed marriages in Ezra 9-10, and so the text carries no implication regarding the practice of polygyny (G. H. A. von Ewald, H. H. Spoer, L. Kruse-Blinkenberg, J. J. Collins, and M. Smith).

4) Malachi 2:10-16 condemns both mixed marriage and divorce, but these offences bear no necessary causal relationship to each other. Accordingly, once again, the text carries no particular implication regarding the practice of polygyny (J. Wellhausen and others -- perhaps the most convincing view).

5) Malachi 2:10-16 condemns both mixed marriage and divorce in a manner which suggests that these were typically interrelated, with the implication that resort to polygyny under such a circumstance was exceptional, discountenanced, or possibly even illegal in Malachi's day (the traditional view).

Since this traditional view remains possible, it will be necessary to digress in order to examine the widely assumed toleration of polygyny elsewhere in the Old Testament and particularly in the post-exilic period. From this examination it will be concluded that although polygyny was never illegal, monogamy was seen as the marital ideal, particularly in the post-exilic period, and that actual marital practice was monogamous with few exceptions. As a consequence, there is no compelling reason for denying a reference to literal marriage and divorce in Malachi 2 or, more particularly, for denying the identification of literal marriage as a "covenant" in 2:14.

\subsection{Malachi 2:10-16 originally condemned only divorce and therefore carries no implication regarding the practice of polygyny (the majority critical view)}

Supposing a rejection of polygyny to have been unlikely in post-exilic times, perhaps the majority of modern critical scholars have resolved the seeming rejection of polygyny in Malachi's day by their conclusion that Malachi 2:11f. is unoriginal to the text. ${ }^{3}$

3 So G. A. Smith, The Book of the Twelve Prophets (1899) 340, 363-65; K. Marti, Das Dodekapropheton (1904) 469; E. Sievers, Alttestamentliche Miscellen, 4, Zu Maleachi (1905) [so, according to J. M. P. Smith, Malachi, 57]; W. Nowack, Die kleinen Propheten (1922) 404, 418f.; M. Haller, Das Judentum (1925) [so, according to R. Vuilleumier, Malachie, 237, n. 4]; E. Sellin, Das Zwölfprophetenbuch (1922); K. Elliger, Das Buch der zwölf kleinen Propheten (1950) 189, 193; C. Kuhl, The Prophets of Israel, 2nd ed. (1963) [so, according to P. A. Verhoef, The Books of Haggai and Malachi, 263]; R. Rendtorff, "Maleachi," $R G G^{3}$, IV, col. 629; R. A. Mason, The Books of Haggai, Zechariah, and Malachi (1977) 149; A. Renker, Die Tora bei Maleachi (1979) 90; and R. Vuilleumier, Malachie (1981) $237,240 \mathrm{f}$.

There are minor differences among scholars as to whether to include vss. 10,11a, or 13a in the proposed interpolation. So, e.g., R. Vuilleumier considers only $11 \mathrm{~b}-12$ to be secondary, while K. Elliger prefers 11b-13a. A. van Hoonacker, on the other hand, considers all of vss. 10-12 to be secondary. 
In other words, according to this approach, Malachi originally attacked only the practice of divorce, not mixed marriage.

Although G. A. Smith maintained the traditional view that foreign marriages in fact had led to the frequent divorces which Malachi condemns, Smith's interpretation prepared for the modern critical consensus by arguing that vss. 11-12 may have been dislocated, or more probably were a later addition. ${ }^{4}$ He offers four arguments for considering vss. 11 and 12 to be secondary:

1) Vss. 11 and 12 do not cohere with vs. 10. In vs. 10 the prophet chides his brethren for being faithless to each other, but vss. 11 and 12 "do not give an instance of this: they describe the marriages with the heathen women of the land, which is not a proof of faithlessness between Israelites."5

2) If vss. 13-16 are allowed to follow immediately upon vs. 10, they make perfect sense as they offer the expected example of faithlessness between Israelites which is condemned in vs. 10.6

3) Vss. 11 and 12 "lack the characteristic mark of all the other oracles of the book: they do not state a general charge against the people, and then introduce the people's question as to the particulars of the charge."7 In other words, the expected retort of the people, "but you say," occurs not in vs. 11, where it might have been expected, but in vs. $14 .^{8}$

4) One can readily account for how vss. 11 and 12 may have been intruded in the text "when the question of heathen marriages came to the front with Ezra and Nehemiah."9

To these arguments of Smith, the following additional arguments have been advanced by others:

5) The criticism of mixed marriage in vs. 11 contradicts the universalism which is characteristic of other portions of Malachi's prophecy (e.g., Malachi 1:11, and perhaps $2: 10) .10$

6) The change from the first person in vs. 10 to the third person in these verses is abrupt and so supports the recognition of these verses as secondary. ${ }^{11}$

4 The Book of the Twelve Prophets (1899) 340, 363-65.

5 So G. A. Smith, The Book of the Twelve Prophets (1899) 340. Cf. also p. 363, where Smith writes, "Certain verses, 11-13a, ... disturb the argument by bringing in the marriages with heathen women...."

This objection is summarized by J. M. P. Smith, "their interest is not in ethics as in v. 10, but in cultus" (Malachi, 57).

6 So also, inter alios, R. A. Mason, The Books of Haggai, Zechariah, and Malachi, 149.

7 G. A. Smith, The Book of the Twelve Prophets (1899) 340.

8 So notes R. L. Smith without necessarily agreeing that vss. 11-13b are secondary (Micah-Malachi, 320)

9 G. A. Smith, The Book of the Twelve Prophets (1899) 340. Cf. also E. Sellin, Das Zwölfprophetenbuch, 551; J. Morgenstern, "Jerusalem -485 B.C." (1957) 21; and E. Lipiński, "Malachi," EJ, 11 , col. 814.

10 So, e.g., E. Sellin, op. cit., 551.

11 R. A. Mason, The Books of Haggai, Zechariah, and Malachi, 149. 
7) The descriptive and prosaic character of these verses does not fit Malachi's style elsewhere. ${ }^{12}$

8) Although A. S. van der Woude considers vs. 11 to be original, with respect to vs. 12 he writes, "The metre, the wording and the contents of the verse strongly suggest that it is a gloss."13 More specifically regarding the contents of the verse, Van der Woude explains, "the curse clashes with the call on the audience of the prophet to heed to their spirit and not to be unfaithful." 14

9) O. Eissfeldt notes "the removal of these words which condemn the marriage of foreign women, would give a more general character to the reproach made to the people in ii, 10-16, since divorce then would be absolutely condemned here, and not just divorce occasioned by a desire for a foreign wife." 15

10) Finally, perhaps the most important argument for the secondary character of vss. 11-12 is that the proposed deletion would resolve the problem of an apparent rejection of the option of polygyny. ${ }^{16}$

The following answers may be offered in response to this approach:

1) Contrary to G. A. Smith, vss. 11 and 12 are organically related to vs. 10.17 This unity is evident first of all in terms of the general audience to which they are directed. While 2:1-9 is quite explicitly and narrowly directed against the priests, vs. 10 broadens this perspective to include all Israel: "Have we not all one father? Has not one God created us? Why then are we faithless to one another, profaning the covenant of our fathers?" 18 Vss. 11 and 12 share this same broad perspective, naming Judah as the one who has been faithless, Israel and Jerusalem as the locale of her abomination, and "the tents of Jacob" as the dwelling from which offenders are to be cut off. ${ }^{19}$ Second, vss. 11 and 12 are further

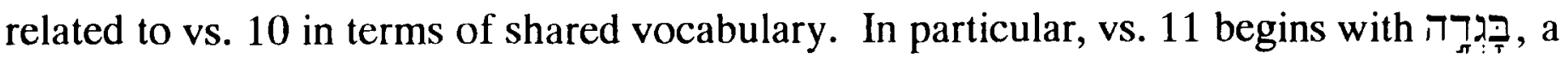

12 E. Sellin, op. cit., 551; K. Elliger, op. cit., 189; G. J. Botterweck, "Schelt- und Mahnrede gegen Mischehe und Ehescheidung. Auslegung von Malachias 2, 10-16" (1960) 181; and A. Renker, op. cit., 73.

13 "Malachi's Struggle for a Pure Community," 68.

14 Ibid., 68, n. 17. In a similar manner, R. A. Mason notes that "the separateness of verses $11-12$ is further shown by the finality of the concluding curse in verse 12" (The Books of Haggai, Zechariah, and Malachi, 149).

15 The Old Testament: An Introduction, 442.

16 Cf., e.g., K. Marti, Das Dodekapropheton, 469, and A. S. van der Woude, "Malachi's Struggle for a Pure Community," 66. A. S. van der Woude unaccountably cites G. A. Smith and E. Sellin in support of this argument (op. cit., 66, n. 6).

17 Recognizing this difficulty, A. van Hoonacker has argued that vs. 10 is also secondary, along with vss. 11 and 12 (Les douze petits prophètes [1908] 721ff.). Other scholars, however, have not followed Van Hoonacker in this suggestion.

18 The MT pointing here of a Niphal, נברגר, a conjugation otherwise unattested for this verb, may have been motivated by the misguided concern to protect Malachi from including himself among the offenders.

$19 \mathrm{G}$. S. Ogden argues that the priests continue to be the assumed audience of 2:10-16 ("The Use of Figurative Language in Malachi 2:10-16" [1988] 223-230). However, Ogden fails to take account of the overall literary structure of Malachi which distinguishes the disputation in 2:10-16 from what precedes. Furthermore, Ogden's assumption that "Judah" in 2:11 is intended as a figurative reference to the priesthood appears unconvincing. 
verb and concept which is not only found in vs. 10, but also turns out to be a unifying element for the whole of 2:10-16 (forms of בגר are found in Malachi 2:10, 11, 14, 15, 16, but nowhere else in this book). In addition, the verb חלל בל is employed in both vs. 10 and again in vs. 11; otherwise within Malachi it is found only in 1:12. Finally, contrary to Smith, vss. 11 and 12 do "cohere with verse 10" since it is plausible that the prophet would have considered these interfaith marriages to constitute a breach of faith between fellow-

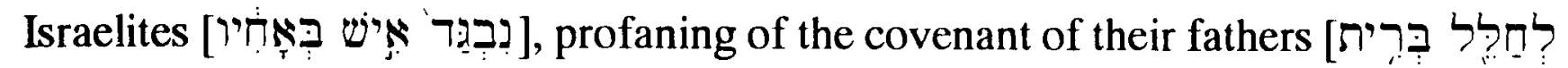

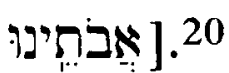

Of course, if these interfaith marriages precipitated the divorce of Jewish wives, it would be especially clear that they entailed a breach of faith [בגר] against fellow-Israelites. Even apart from the issue of divorce, Ezra and Nehemiah offer ample testimony to the postexilic conviction that interfaith marriage put the entire covenant community at risk before the wrath of God; as such this sin necessarily constituted a breach of faith against fellowIsraelites. This notion of a profound corporate responsibility for these prohibited marriages is clear in Ezra's response in 9:3-15, particularly in his use of the first person plural pronoun. Compare also, for example, Ezra 10:10 and Nehemiah 13:29.

As to whether Malachi would have viewed interfaith marriage as an example of

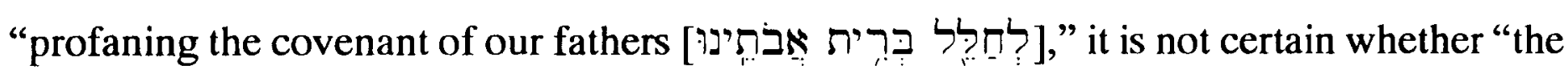
covenant of our fathers" refers to the covenant with the patriarchs (as this expression seems to in Deuteronomy $4: 31 ; 7: 12-14 ; 8: 18$ ), or to the covenant at Sinai (as in 2 Kings $17: 15$ and Jeremiah 4:13), or comprehensively to both. ${ }^{21}$ It is not necessary to decide the matter for the present argument since on either interpretation it appears likely that interfaith marriage could be characterized as an instance of covenant profaning or breaking. If a reference to the patriarchs is preferred in $2: 10$, then intermarriage was implicitly prohibited by the covenant promise of the dispossession of the Canaanites (cf. especially Genesis 24:7) and explicitly opposed in a number of texts associated with the patriarchs (cf. Genesis $24: 2-4 ; 26: 34-35 ; 27: 46 ; 34$; and especially $31: 50) .{ }^{22}$ Alternatively, as is perhaps more

20 It should be noted that vs. 10 does not teach that the infidelity and profaning are separate (coordinate) failings. To "profane the covenant" is to break faith with fellow members of the covenant community. ? used with the infinitive construct here is either explanatory, "Why then are we faithless... by profaning the covenant...," or it expresses a result, "Why then are we faithless ... with the result of profaning the covenant...." Cf. Waltke and O'Connor \$36.2.3.d and e.

21 S. L. McKenzie and H. N. Wallace prefer a reference to the patriarchal covenant, based on the references to Jacob (1:2-5), Levi (2:1-9), and perhaps Abraham (2:15) "Covenant Themes in Malachi," 552). Alternatively, they suggest the reference is intentionally ambiguous because Malachi regarded the Sinaitic covenant and the patriarchal covenants "as standing in continuity with the original covenant of election."

$22 \mathrm{~J}$. Van Seters considers the emphasis on racial purity inherent in the Abrahamic covenant and texts like Genesis 24:7 (which prohibits intermarriage with Canaanites) to reflect exilic and post-exilic concerns (Abraham in History and Tradition [1975] 272ff.).

B. Glazier-McDonald, however, challenges Van Seters' emphasis on racial purity to the neglect of the issues of apostasy and syncretism (Malachi, 86-88). Glazier-McDonald cites G. W. Ahlström in support of the notion that the threat of apostasy and syncretism remained issues in the exilic and post-exilic periods (G. W. Ahlström, Joel and the Temple Cult of Jerusalem, 27). 
probable in view of Malachi's use of "fathers" in 3:7, if the reference in 2:10 is to the Exodus generation, then interfaith marriage was explicitly prohibited by the stipulations of the Sinaitic covenant (cf. Exodus 34:12-16; Numbers 25:1ff.; Deuteronomy 7:3f.). ${ }^{23}$

Further supporting the coherence of 2:11f. with 2:10, it is notable that Ezra specifically relates interfaith marriage to the transgression of God's commandments (e.g., 9:10f., 14) and to breaking faith [מעל] with $\operatorname{God}(9: 2,4 ; 10: 2,10)$. Likewise, Nehemiah 13:1ff., 26ff. explicitly recalls the critical failure of Israel's idolatrous sexual alliance with Moab, when Israel yoked herself with the Baal of Peor (Numbers 25), as well as Solomon's sinful interfaith marriages. ${ }^{24}$ Finally, Nehemiah decries interfaith marriage in a manner which closely parallels Malachi 2:10ff., thus supporting its unity: “... they have

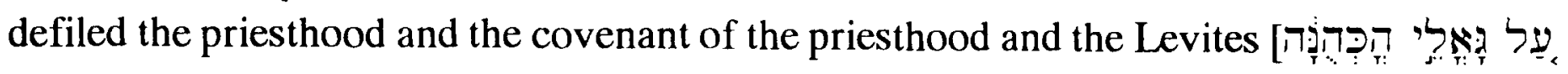

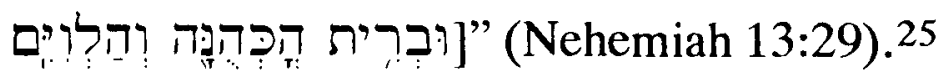

2) If a section of text, such as vss. 11-12, can be removed without disrupting the flow of a narrative or argument, this fact may indicate that the portion is secondary, but it hardly requires this conclusion. As has often been observed, the criterion of excisability is notoriously precarious as a means for determining the originality of a work. This is so particularly with respect to biblical and ancient Near Eastern texts which are fond of such literary techniques as repetition, digression, layering, etc. As a matter of fact, vss. 11 and 12 cannot be removed and still leave a coherent result, at least not without radical

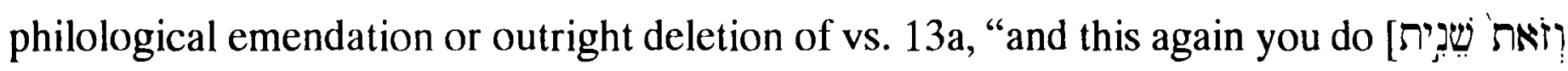

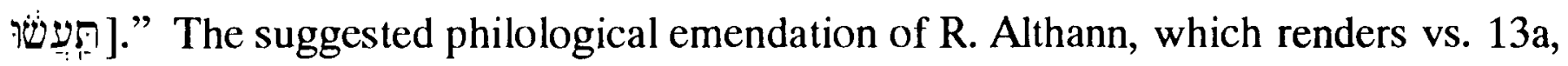
"Even indignity, gnashing of teeth you perform," does not commend itself. 26 The alternative expedient of deletion, although widely accepted, offends the principle of parsimony and is not favoured by 4 QXII ${ }^{\mathrm{a}}$ or the versional evidence. ${ }^{27}$

23 Further supporting a reference to the Exodus generation, it has been argued that the reference in $2: 10$ to God as our "father" (cf. Malachi 1:6) and as the one who "created us" probably refers to the formation of Israel as a people at Sinai (cf. Deuteronomy 32:6; Isaiah 43:1, 15; 44:7; 63:16; 64:8; etc.). So, e.g., E. Sellin, Das Zwölfprophetenbuch, 551; A. S. van der Woude, "Malachi's Struggle for a Pure Community," 67; and P. A. Verhoef, The Books of Haggai and Malachi, 265f.; as against, inter alios, J. Wellhausen, Skizzen und Vorarbeiten (1892) 198, and W. Nowack, Die kleinen Propheten (1922) $417 \mathrm{f}$.

24 Cf. discussion of Ezra 9:10f. in H. G. M. Williamson, Ezra, Nehemiah, 137.

25 H. G. M. Williamson would prefer to relate Nehemiah's statement to Malachi $2: 4-8$, where the covenant of Levi is explicitly mentioned (op. cit., 401). To be sure, the perspective of this passage does offer some parallel to that found in Nehemiah. Nevertheless, it is only in Malachi 2:10ff. that the problem of interfaith marriage is treated.

26 "Malachy 2, 13-14 and UT 125, 12-13" (1977) 418-19.

27 In support of deleting 13a, cf., inter alios, G. A. Smith, The Book of the Twelve Prophets (1899) 340; K. Marti, Das Dodekapropheton (1904) 470; and W. Nowack, Die kleinen Propheten (1922) 419.

Against the proposal to delete שי

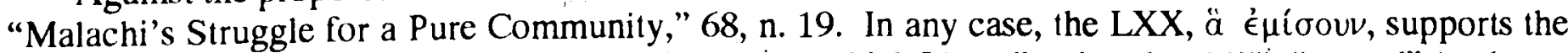

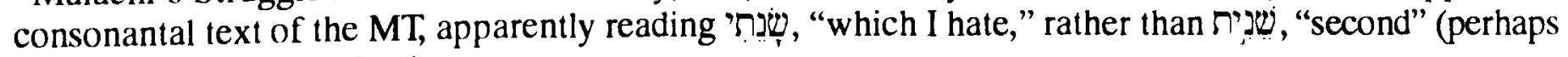
under the influence of $2: 16$ ). 
3) G. A. Smith's observation that vss. 11 and 12 do not include the expected prophetic charge and the anticipated retort of the people at first seems plausible. In each of the other disputations of Malachi $(1: 2-5 ; 1: 6-2: 9 ; 2: 17-3: 5 ; 3: 6-12 ; 3: 13-21$ [ET 4:3]), an assertion, which is generally found in the first verse, made by Yahweh or by the prophet introduces the disputation, and in each case this assertion is closely followed by the

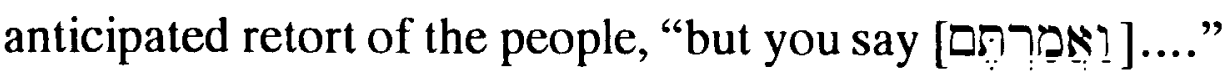

However, this observation fails for two reasons. First, if G. A. Smith is correct about the uniform structure of each of Malachi's disputations, then the logic of his objection ought to require him to delete not just vss. 11 and 12 , but also vs. 10. This is so because the assertion, "... he no longer regards the offering or accepts it with favour at your hand," and the retort, "But you say, 'Why does he not?'," found in vss. 13 and 14 have no direct relation to the opening rhetorical questions in vs. 10. Nevertheless, neither Smith, nor the majority of modern scholars have favoured this proposal because of the evident authenticity of that verse (supported in terms of vocabulary, style, and viewpoint). ${ }^{28}$

Second, the literary structure of Malachi is not so rigid as would prohibit an elaboration of the charge before the retort, as is found in the canonical text of 2:10-16. This variety in the structure of the various pericopes of Malachi is most evident simply in terms of length. While the length of each of the other disputations ranges between four verses and nine verses, the second disputation, 1:6-2:9, includes eighteen verses, twice the length of any other pericope, yet the originality of the whole of this disputation has never been seriously challenged. ${ }^{29}$ Another evidence for variety in the literary structure of the disputations is the observation that in three of these, 1:6-2:9, 3:6-12, and 3:13-21 [ET 4:3], there are actually two distinct retorts, each introduced by the key word you say." Critical scholarship, in general, has accepted each of these as original. ${ }^{30}$ Finally, it should be noted that two of the disputations, 1:6-2:9 and 3:6-12, closely resemble the structure of 2:10-16 without the proposed deletion of vss. 11 and 12 . This is so because in each of these sections the retort of the people is not made in response to the initial assertion of Yahweh or his prophet. Rather, there is a significant development in the opening assertion (in the case of 2:10-16, extending over four verses), and in each case the retort is directed only against the last point in the discourse.

4) While the concern of Ezra and Nehemiah with respect to mixed marriage might account for some later editor inserting a reference to this problem in the present text of

28 However, cf., e.g., A. van Hoonacker, who argues against the originality of vs. 10 (Les douze petits prophètes [1908] 721ff.). G. A. Smith, W. Nowack, E. Sellin, F. Horst, and K. Elliger do not appear to doubt the authenticity of vs. 10, contrary to P. A. Verhoef's assertion to this effect (The Books of Haggai and Malachi, 267, n. 15).

$291: 2-5$ has but four verses; $1: 6-2: 9$ has eighteen verses; $2: 10-16$ has seven verses; $2: 17-3: 5$ has six verses; 3:6-12 has seven verses; $3: 13-21$ has nine verses.

30 However, cf. BHS on 3:7. 
Malachi, it hardly requires this conclusion. This supposition of a later interpolation would be greatly helped, of course, if it could be shown that Malachi was written significantly before Ezra and Nehemiah (as was argued, e.g., by A. C. Welch, who considered Malachi to be a contemporary of Haggai and Zechariah, cir. 520 B.C. ${ }^{31}$ ). Such an early date for Malachi appears unlikely and has been all but abandoned among modern scholars.

Curiously, G. A. Smith himself argues for a period contemporaneous with Ezra and Nehemiah, offering as evidence the mention of mixed marriages in Malachi! ${ }^{32}$ If Malachi can be dated on other grounds to a period nearly contemporaneous with Ezra and Nehemiah, as it appears it can, it would be quite surprising if there were no reference to this problem, given the overlap of Malachi's concerns with those of Ezra and Nehemiah (e.g., tithes, sacrifice, priesthood, the law of Moses) and especially given his intention to treat the subject of marriage. 33

5) The alleged contradiction between the universalism of 1:11-14 and the parochialism of $2: 12,13$ need not require the conclusion that $2: 12,13$ is secondary. Indeed, A. S. van der Woude, for example, draws the very opposite conclusion; he argues that it is Malachi 1:11-14 which is the later addition. ${ }^{34}$ However, neither is Van der Woude's position necessary. As was argued in Chapter 2 above, Malachi's "universalism" has been grossly distorted if it is imagined by modern scholars to have been in any way congenial to idolatry. ${ }^{35}$ Further, as was discussed earlier, the "parochialism" of 2:12, 13 has nothing to do with racism or nationalism. Rather, the concern here is emphatically religious as is suggested by the unusual reference to "daughter of a foreign god."36 R. A. Mason explains, "They are foreigners who, unlike Ruth the Moabitess, refused to become worshippers of Yahwch."37

6) The observation concerning the change in person from vs. 10 (first person plural) to vss. 11 and 12 (third masculine singular) may make too much of what appears as a natural transition. The first person plural is entirely appropriate in the rhetorical questions of vs. 10, but would seem less fitting in the specific charge levelled in vss. 11 and 12 ,

31 Post-Exilic Judaism (1935) 113-25. Cf. the discussion of Welch's views in R. L. Smith, Micah Malachi, 298f.

32 Op. cit., 334f.

33 On the dating of Malachi, cf. our discussion in Chapter 1.

34 Op. cit., 66, citing in support K. Elliger, F. Horst, and R. Rendtorff, "Maleachibuch," as well as his own commentary, Haggai, Maleachi.

35 Cf. also P. A. Verhoef, "Some Notes on Malachi 1:11" (1967); J. G. Baldwin, "Malachi 1:11 and the worship of the nations in the Old Testament" (1972) 117-24; and T. C. Vriezen, "How to Understand Malachi 1:11" (1975) 128-136.

36 Cf., e.g., C. F. Keil, The Twelve Minor Prophets, 449, and R. A. Mason, The Books of Haggai, Zechariah, and Malachi, 150.

37 Cf. the similar assessment of 2:11, 12 offered by, e.g., J. G. Baldwin, Haggai, Zechariah, Malachi, 238; and W. C. Kaiser Jr., Malachi, 68. 
unless Malachi himself had been guilty of an interfaith marriage. It should be noted that while the grammatical reference of the verbs does change from vs. 10 to vss. 11 and 12 , there is a consistency of reference between these verses in the way they represent the prophet's direct discourse: God or Yahweh is maintained in the third person. In any case, Hebrew is well-known to tolerate fluctuations in personal reference to a degree which would be unacceptable for English, and Malachi elsewhere offers numerous examples of this phenomenon. ${ }^{38}$ Compare, for example, Malachi 1:7, 9; 2:3, 10, 15;39 3:1, 5, 18, and 23 [ET 4:5]. It is doubtful that all of these examples are secondary or stand in need of emendation and the prevalence of this practice should caution one against a too hasty rejection of vss. 11 and 12 . Furthermore, the proposed deletion of vss. 11 and 12 would not, in fact, eliminate the "problem" of altered personal reference from the first person plural forms of vs. 10 , since vs. 13 switches to the second person masculine plural.

7) The suggestion that the descriptive and prosaic character of vss. 11 and 12 does not fit Malachi's style elsewhere is amply refuted by a passage such as Malachi 3:16 (of undoubted authenticity), as A. S. van der Woude has argued. ${ }^{40}$

8) Van der Woude's objection that the curse in vs. 12 does not fit the "metre" of Malachi can be dismissed partly based on the fact that too little is known regarding metre, particularly in late Biblical Hebrew, and also based on the likelihood that, while Malachi is characterized by elevated prose exhibiting a number of poetic features, it is not poetry. ${ }^{41}$

As for the supposed discrepant "wording" of this curse, there should be no

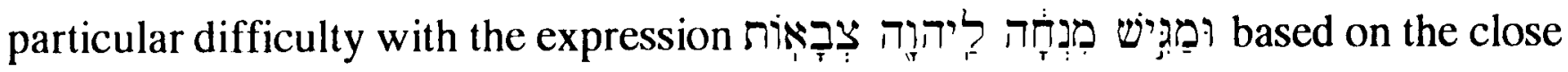
parallel found in Malachi 1:11. Nor should there be any objection to Malachi's use of the

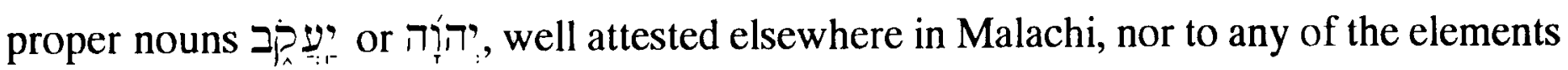

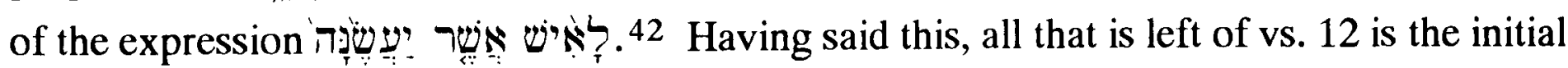

38 Cf., e.g., GKC $\$ 144$ p and the examples of heterosis of person and number offered by E. W. Bullinger, Figures of Speech Used in the Bible, 524f.

R. Yaron makes a similar observation with respect to Akkadian noting that abrupt changes of person in the LE may offend our Sprachgefiuhl, but, apparently, it did not so affect the ancient speaker (The Laws of Eshnunna, 2nd ed. [1988] 284).

39 The clause, "Let none be faithless to the wife of your youth," is a parade example of the fluidity of personal reference permissible in Hebrew even within a sentence. A. S. van der Woude finds similar examples in Isaiah 1:29 and Psalm 49:20 and cites, for further support, C. F. Keil, The Twelve Minor Prophets; P. A. Verhoef, Maleachi; and S. Schreiner, "Mischehen-Ehebruch-Ehescheidung," 213 ("Malachi's Struggle for a Pure Community," 70, n. 30).

40 "Malachi's Struggle for a Pure Community," 66. On the lack of scholarly agreement concerning the prosody of Malachi, see below.

41 Cf. J. M. P. Smith, Malachi, 4f., and P. A. Verhoef, The Books of Haggai and Malachi, 166. So also the RSV, NEB, and most English commentators and translations.

A contrary opinion is expressed by a number of German scholars, including K. Marti, E. Sievers, W. Nowack, and W. Rudolph, who have been joined in their opinion most recently by R. L. Smith, MicahMalachi, 301.

42 The other examples of יע: יע: are found in Malachi 1:2 and 3:6. There are thirty-nine other examples of the tetragrammaton, $\pi i i^{n}$ ', apart from the two in this verse: E.g., Malachi 1:1, 2 [bis], 4 [bis], 5, 6, 7, 


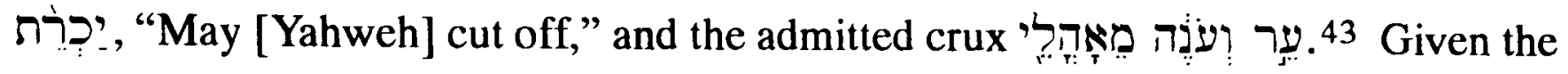
observation that every other word within this verse is entirely at home within Malachi, it would appear unwarranted to judge the wording of this curse unlikely for Malachi. This is

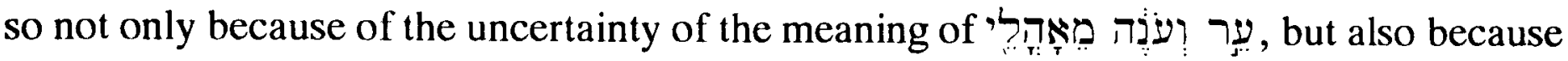
of the extremely limited corpus of Malachi's undisputed writings by which one is to judge his customary manner of expressing curses. 44

Finally, Van der Woude's explanation that "the curse clashes with the call on the audience of the prophet to heed to their spirit and not to be unfaithful" lacks cogency. Not only is the Bible replete with examples of curses used as dire warnings, but also the prophets provide a number of apt parallels where imprecation based on past sin is followed by an urgent appeal to repentance (cf., e.g. Jeremiah 17:5-21; 11:3ff.). ${ }^{45}$ Indeed, a particularly striking parallel for this exact phenomenon can be found elsewhere in Malachi itself, namely in 1:14ff. In this text Malachi prays a curse against those who offer blemished sacrifices, but then Yahweh proceeds to warn the priests that they will indeed be cursed, if they will not "take it to heart" to give glory to his name.

9) In response to O. Eissfeldt, who wants to remove vss. 11 and 12 so that "divorce then would be absolutely condemned here [in 2:16], and not just divorce occasioned by a desire for a foreign wife," it is precisely some such limitation which makes sense of 2:16, as we have argued above in $\$ 3.4$. The unconditional prohibition of divorce, which Eissfeldt would wish for 2:16, would place that verse in intolerable and unnecessary tension with the testimony of the rest of the Old Testament concerning the practice of divorce (including Deuteronomy 24:1-4). 46

10) Finally, it is notable that the interests and perspective, if not vocabulary, of Malachi 2:10-16 find significant parallels in Nehemiah 13:23-29, a fact which tells against the proposed deletion of vss. 11-12. Nehemiah's emphasis on the unholy children born of

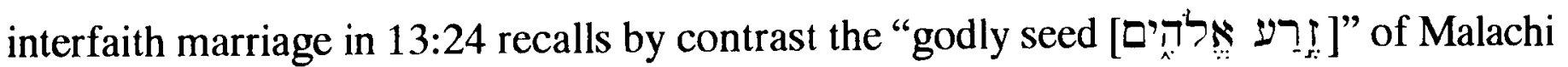

etc. Excluding the present text, the verb עשה appears seven times in Malachi $(2: 13,15,17 ; 3: 15,17,19$ [ET 4:1], 21 [ET 4:3]); the noun wree times (Malachi 2:10;3:16,17); and the relative particle, ten times (e.g., Malachi 1:4; 2:9, 11, 14; 3:1 [bis], 17, 18, 19 [ET 4:1], 21 [ET 4:3]).

43 For yet another, not entirely convincing, attempt to interpret this expression, cf. B. GlazierMcDonald, "Malachi 2:12: 'êr we'ōneh - Another Look" (1986) 295-298. R. Fuller notes that 4QXIIa reads עי ער וענה ,"witness and respondent [perhaps one who speaks in defence of the accused]," which would support J. Wellhausen's proposed emendation of the MT (untitled paper on Malachi 2:10-16 [n.d.] 2-3).

44 Without implying agreement with their methodology, it may be noted that Y. T. Radday and M. A. Pollatschek consider Malachi 1 and 2 to exhibit a coherency of vocabulary throughout ("Vocabulary Richness in Post-Exilic Prophetic Books" [1980] 333-46).

45 For curses used as dire warnings, cf. Genesis 17:14; Exodus 12:15; etc.

46 J. M. P. Smith makes the further suggestion that had divorce alone been in view in $2: 10-16$, rather than the additional offence of mixed marriage, one might expect some term designating the wronged women in vs. 10 in place of the mentioned "brothers" (Malachi, 48). 
$2: 15$, however the rest of this problematic verse is to be rendered. Nehemiah's use of cursing in 13:25, 29 and his remedy of excommunication in 13:28 invite a comparison with Malachi 2:12, where Malachi's curse implies excommunication. Lastly, as mentioned above, Nehemiah's description of the dire consequences of "the Jews who had married women of Ashdod, Ammon, and Moab" seems to echo the indictment of Malachi 2:10-11. Nehemiah asserts: “... they have defiled the priesthood and the covenant of the priesthood

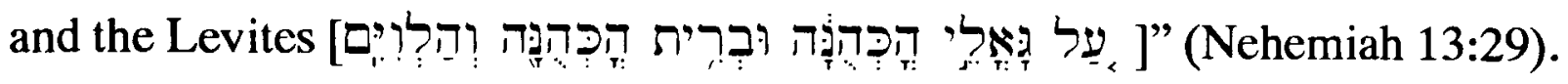

We conclude, then, that there are no compelling literary-critical arguments for regarding Malachi 2:11 and 12 as secondary; indeed, the evidence supports their originality. The only remaining reason for considering these verses to be secondary is their supposed conflict with the alleged tolerance of polygyny elsewhere in the Old Testament. This prompts us to examine other exegetical options to determine if Malachi 2:10-16 really does disparage or reject polygyny and, after this, to examine the remainder of the Old Testament to determine if it does, by contrast, approve polygyny.

\subsection{Malachi 2:10-16 originally condemned only mixed marriage, and therefore is not only consistent with the practice of polygyny, but presupposes it (A. S. van der Woude)}

Agreeing with scholars who claim "that in a community that permitted polygamy, contracting a new marriage with a foreign woman has in principle nothing to do with divorce," A. S. van der Woude has argued that Malachi 2:10-16 makes no reference to divorce. $^{47}$ Rather, according to Van der Woude, the concern of 2:16 is to attack "the subordination and maltreatment of married Jewish women because of [polygamous marriages with] foreign heathen wives."48

Although this approach succeeds in eliminating the supposed failure of Malachi to reckon with polygyny, and, accordingly, allows a reference to literal marriage throughout 2:10-16, Van der Woude's translation of 2:16 is unconvincing: "For he who neglects (his Jewish wife) puts forth his hand (in hostility), says Yahweh the God of Israel, and covers his garment with violence, says Yahweh Almighty...."49 See our detailed criticism of Van der Woude's view in the previous chapter (\$3.1.3). Here we merely add that our objections to Van der Woude's treatment of vs. 16 are made even more compelling by the evidence provided by R. Westbrook and others regarding the widespread use of "hate"

47 A. S. van der Woude, “Malachi's Struggle for a Pure Community” (1986) 66.

48 Ibid., 71.

49 Haggai, Maleachi, 116: "Immers, wie (zijn vrouw) achterstelt, strekt zijn hand uit (ten onheil), spreekt YHWH, de God van Israël, en bedekt zijn gewaad met onrecht, spreekt YHWH almachtig...." 
[whether Hebrew or Aramaic שנט or Akkadian zẽrum] in connection with divorce. 50 Furthermore, as will be discussed in $\$ 4.6$ below, it is far from evident that polygyny was as prevalent among post-exilic Jews as Van der Woude supposes.

\subsection{Malachi 2:10-16 condemns Ezra's enforced dissolution of mixed} marriages in Ezra 9-10 and so carries no implication regarding the practice of polygyny (G. H. A. von Ewald, H. H. Spoer, L. Kruse-Blinkenberg, d. I. Collins, and M. Smith)

In contrast to those who argue that Malachi 2:10-16 originally opposed only divorce, but also in contrast to Van der Woude who argues that Malachi 2:10-16 opposes only mixed marriage, each of the three views remaining for our consideration concedes that Malachi opposed both mixed marriage and divorce. The first of these is represented by L. Kruse-Blinkenberg, who in his influential study of the Peshitta of Malachi renewed a suggestion made earlier by G. H. A. von Ewald and H. H. Spoer that the "I hate divorce" of Malachi 2:16 may have been intended to oppose the dissolution of marriages which is recorded in Ezra 9-10.51

Offering more argumentation, J. J. Collins similarly observes, "Many scholars have assumed that Malachi supported Ezra's reform, but that view is difficult to reconcile with Malachi 2:13-16, which unequivocally rejects divorce as itself a breach of covenant."52 In support, Collins notes: “There is nothing to suggest that Malachi opposes only the divorce of Jewish wives, nor is there any reason to believe that the Jews who married foreign women had divorced the wives of their youth. Malachi's objection is to divorce as such." 53 In addition, Collins considers that the unqualified rejection of divorce in Malachi 2:16 amply refutes those scholars who suppose that Malachi may have helped prepare for Ezra's reform. The weeping at the altar suggests that an attempted reform had already taken place, presumably the one which was led by Ezra. In other words, it is possible that those who had complied with Ezra's mandate and had divorced their wives were now perplexed as to why Yahweh still did not accept their offerings. If this evidence is accepted, then not only did Malachi fail to pave the way for Ezra's work, it must be assumed that he

50 "The Prohibition on Restoration of Marriage in Deuteronomy 24:1-4," 399-402. Cf. also D. Daube, "Terms for Divorce," (1973) 366. This evidence was discussed in detail in Chapter 3 above.

51 "The Pesitta [sic] of the Book of Malachi" (1966) 95-119, cf. esp. 103-104. Although not cited by Kruse-Blinkenberg, the same suggestion was made earlier by G. H. A. von Ewald, Commentary on the Prophets of the Old Testament, Vol. 5 (1881) 79f., and by H. H. Spoer, "Some New Considerations towards the Dating of the Book of Malachi" (1908) 179f. -- the latter as part of his argument for a second century date for Malachi.

Cf. also M. Smith, who considers Malachi to be the work of a "segregationist" prophesying before Ezra, but 2:16 to be a later interpolation into the text by an "assimilationist" who repudiated Ezra's program of enforced divorce ("Jewish religious life in the Persian period" [1984] 273).

52 "The Message of Malachi" (1984) 212.

53 Ibid., 212. 
condemned it. Finally, as argued by Collins, if certain of these intermarriages led to idolatry, this would constitute an abomination, but it is not a necessary consequence of intermarriage as such. Malachi's starting point, that we all have one Father, demonstrates his fundamental openness to intermarriage with Gentiles. This openness, which is diametrically opposed to the view of Ezra, is similar to that expressed in Isaiah 56:1-8.

However, the following four considerations weigh against this proposal. First, it is plausible that the expression "the wife of your covenant" in vs. 14 may not require that this wife was Jewish. ${ }^{54}$ Nevertheless, Malachi 2:10-16 does not readily give the impression that the mixed marriages, which Malachi so vehemently condemns in vss. 11 and 12 , are the self-same marriages he is so concerned to defend in vss. 14-16.

Second, Collins correctly observes that Malachi does not explicitly relate the offence of divorce to that of mixed marriage. Contrary to Collins, however, we have already argued in the previous chapter that Malachi's condemnation is directed only against divorce based on aversion [שנא] ] and not against divorce as such.

Third, it is unclear that there is any necessary relation between the weeping at the altar mentioned in vs. 13 and the reforming work of Ezra. Nevertheless, even if this verse does reflect that reforming work, it hardly requires the view that Malachi intended to repudiate Ezra's program of the enforced dissolution of interfaith marriages. Vs. 11 explicitly condemns interfaith marriages as an "abomination [תוֹ

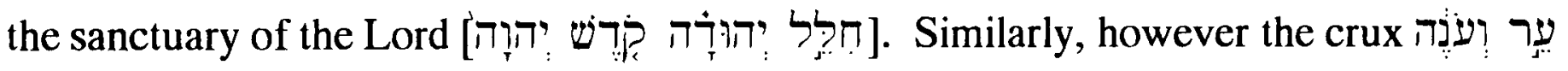

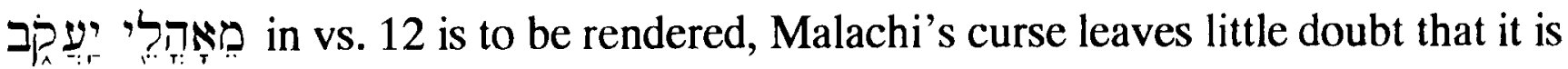
interfaith marriage, and not merely divorce, which renders Israel's offerings repulsive to Yahweh: "May the LORD cut off to the man who does this ... and brings an offering to the LORD of hosts!" (cf. 1:10). It is hard to imagine how Malachi could use stronger language to condemn these marriages; accordingly, there appears little difference between his attitude and that of Ezra.

As for Malachi's repudiation of divorce, the chief difficulty for Collins' suggestion is that it is not clear that what Ezra 10 describes can legitimately be termed "divorce." W. A. Heth and G. J. Wenham, for example, argue that what took place in Ezra 10 was not divorce, but the dissolution of invalid unions (perhaps similar to the presumed dissolution of Michal's marriage to Paltiel). ${ }^{55}$ Support for this contention may be found first in the unusual vocabulary employed by Ezra to describe both the original unions (Hiphil forms of

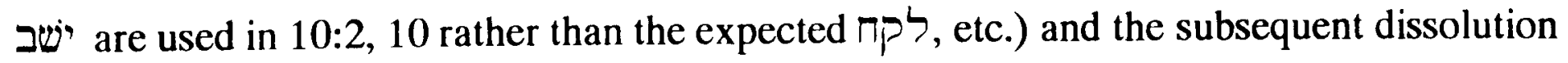

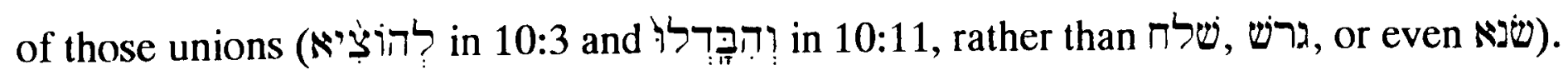

54 Contrary, e.g., to W. C. Kaiser Jr., Malachi, 70.

55 Jesus and Divorce, 162-164. This interpretation has also been argued by, inter alios, G. Rawlinson, Ezra and Nehemiah (1890); H. Wolf, Malachi, 95; and W. F. Luck, Divorce and Remarriage, 282, n. 27. 
In particular, it should be noted that Malachi's terms in 2:16 are not those employed by Ezra.

Perhaps no less striking are the remarkable circumstances which prompted these dissolutions. Specifically, unlike divorce, these dissolutions were initiated neither by the husband, nor by the wife, but by a corporate action imposed on the guilty husbands. As such, in this respect particularly, they resemble the dissolution of Michal's invalid "marriage" to Paltiel at the instigation of Ishbosheth (2 Samuel 3:15). ${ }^{56}$ In any case, by contrast to Ezra, the divorces which Malachi condemns in 2:16 are explicitly divorces which are the result of a husband's unjustified aversion (שנא) and not the result of a corporate action. This last point merits particular emphasis, since both Kruse-Blinkenberg and Collins, based on their rendering "I hate divorce," assume that Malachi condemns divorce in an unqualified manner. As argued above in Chapter 3, this rendering and interpretation are unsatisfactory.

Finally, Collins' appeal to Malachi 2:10 is unconvincing; as we have already argued, the reference to our "one Father" may not intend anything beyond God's paternal/covenantal relationship to Israel by which all members of the covenant community (but not those outside it) are constituted brothers. Nevertheless, it is possible, though uncertain, that Malachi might have accepted intermarriage with a converted Gentile (as in Boaz's marriage to Ruth). ${ }^{57}$ Certainly the phrase "daughter of a foreign god" appears to stress the threat of idolatry, rather than racial miscegenation as the basis for Malachi's rebuke. On the other hand, at least a superficial concern with biological descent does appear prominent in Ezra. In part, this emphasis may be a reflex of the need for priestly genealogical purity, which may also have been extended to all the people as a "kingdom of priests." 58 On closer inspection, Ezra implies that the primary motive for the prohibition against intermarriage was the danger of religious syncretism (cf., e.g., Ezra 9:2, 11, 14).59 Such a perspective is entirely congenial with Malachi and, accordingly, does not favour Collins' hypothesis.

56 Cf. G. P. Hugenberger, "Michal" (1986).

57 Cf. Ruth 1:16. For a similarly open attitude toward intermarriage with presumably converted Gentiles and the inclusion of converted Gentiles in Israel, cf. Genesis 41:45; Exodus 12:38; Numbers 12:1ff.; 32:12; Deuteronomy 20:14; 21:10-14; Joshua 6:25; 2 Samuel 23:39; Esther 8:17; Psalm 87; Isaiah 56:3, 5ff.; 60:7, 10; 61:5-6; 66:18ff.; Zechariah 2:11; etc.

Cf. further Judith 14:10; Tobit; and examples of intermarriage at the Jewish colony in Elephantine (Cowley 14, 25, 28). Cf. also S. J. D. Cohen, "Conversion to Judaism in Historical Perspective: From Biblical Israel to Post-Biblical Judaism."

58 Cf. Leviticus 21:14. Cf. also D. Bossman, "Ezra's Marriage Reform: Israel Redefined" (1979) 3238, and M. Fishbane, Biblical Interpretation in Ancient Israel, 121-123.

59 For a discussion of Ezra's prohibition of intermarriage understood as an exegetical extension of the law in Deuteronomy 7:1-3, 6 and Deuteronomy 23:4-9, and possibly also Leviticus 18, cf. S. J. D. Cohen, "From the Bible to the Talmud: The Prohibition of Intermarriage" (1984) and especially M. Fishbane, Biblical Interpretation in Ancient Israel (1985) 114-129.

The Pentateuchal texts to which Ezra alludes leave little doubt that the Canaanites, and hence by analogy Ezra's non-Israelite contemporaries, were disqualified for intermarriage because of their idolatry and abominable religious practices. Cf. Exodus 34:16. Cf. also J. Blenkinsopp, Ezra - Nehemiah, 176f. 
In conclusion, while the view that Malachi condemned Ezra's enforced divorces does succeed in eliminating the alleged contradiction between Malachi 2:10-16 and the assumed toleration of polygyny elsewhere and, as such, permits Malachi 2:14 to identify literal marriage as a "covenant," the difficulties listed above leave this interpretation in serious doubt.

\subsection{There is no necessary interrelation between mixed marriage and divorce in Malachi 2:10-16, apart from a similarity of theme. Accordingly, the text carries no implication regarding polygyny (the view preferred here) $^{60}$}

A number of scholars who acknowledge an original reference both to literal mixed marriage and to literal divorce in Malachi 2:10-16 consider these two offences to have been causally independent of each other. C. von Orelli, for example, notes that the text nowhere requires the view that each of these mixed marriages was preceded by the divorce of a Jewish wife, though some, or even many, may have been. ${ }^{61}$ In any case, the laws against mixed marriage in Exodus 34:16 and Deuteronomy 7:3f. are sufficiently general to apply whether or not there has been a previous divorce. ${ }^{62}$ Furthermore, given that the text does not explicitly relate the divorces in 2:14-16 to the mixed marriages in $2: 11-12$, there is little reason to deny that at least some mixed marriages may have been formed without a previous divorce, just as some divorces need not have been followed by remarriage to a Gentile. ${ }^{63}$

This is not to suggest that Malachi intended no relation whatsoever between the offence of mixed marriage in vss. 11-12 and that of divorce in vss. 13-16. T. Chary, for example, distinguishes three sermons in 2:10-16, namely 2:10, 2:11-12, and 2:13-16, which are linked by the shared theme and vocabulary of בגד ${ }^{64} \mathrm{~J}$. G. Baldwin shares this

60 J. Wellhausen, Skizzen und Vorarbeiten (1892) 198f. So also, inter alios, E. Henderson, The Twelve Minor Prophets (1858) 453-455; C. von Orelli, The Twelve Minor Prophets (1893) 397; T. Chary, Aggée - Zacharie - Malachie (1969) 255-263; and J. G. Baldwin, Haggai, Zechariah, Malachi (1972) 237.

61 The Twelve Minor Prophets (1893) 397. In support, von Orelli cites A. Köhler, Die Weissagungen Maleachis (1865), a work which was unavailable to the present writer.

62 As with Ezra and Nehemiah, Malachi extended the application of this law to include the non-Israelite women living in Palestine in his day. Von Orelli considers this extension to have been warranted based on the original reasons for the prohibitions as stated in Exodus 34:16 and Deuteronomy 7:4, namely the concern to avoid the idolatrous influence of a heathen wife (The Twelve Minor Prophets, 398).

For a more recent discussion of this matter, cf. D. Bossman, "Ezra's Marriage Reform: Israel Redefined" (1979) 32-38; S. J. D. Cohen, "From the Bible to the Talmud: The Prohibition of Redefined" (1979)" (1984); and especially M. Fishbane, Biblical Interpretation in Ancient Israel (1985) 114-129.

${ }^{63}$ Less convincing is J. Wellhausen's observation that since the text characterizes the divorced wife as "the wife of your youth" (vs. 14), it implies that these divorces may have been motivated not by any plans to enter into a mixed marriage, but simply by the fact that these Jewish wives were no longer youthful and attractive (Skizzen und Vorarbeiten [1892] 199).

64 T. Chary, Aggée - Zacharie - Malachie (1969) 255-263. 
view and suggests that these three sermons may be related in terms of their concern with "covenant loyalty" or, alternatively, in terms of a family concept: "... for the prophet begins (vs. 10) with a question that bears on the nation as one family. He continues (vss. 11, 12) to see the nation as a spiritual family, and in the last four verses turns to individual family life within the nation." 65

Perhaps clearest is the view of $\mathrm{J}$. Wellhausen, who observes that mixed marriage with Gentiles (vss. 11-12) and the divorce of Jewish wives (vss. 13-16) are simply two different examples of the more general offence prohibited in vs. 10.66

Arguing against Wellhausen's interpretation, C. C. Torrey insists that "it is not possible thus to separate vs. 13-16 from vs. 10-12."67 Torrey's objection, however, fails to do justice to Wellhausen's concern to stress the unifying role of vs. 10. Further neutralizing Torrey's objection, it is not difficult to detect literary and thematic parallels between vs. 10 , as the controlling rubric, and vss. 11-12 and vss. 13-16, which suggest that mixed marriage and divorce are merely parallel offences without any necessary causal connection between them. C. V. Camp notes, for example, the significant repetition of several catchwords: “'one' ('ehad, vv. 10 [bis], 15 [bis]); 'faithlessness' (bgd, vv. 10, 11, 14, 15, 16); 'covenant,' (berît, vv. 10, 14); 'offering' (minhâ, vv. 12, 13); 'do' ('śh, vv. 11, 12 [bis], 15)."'68

As has already been discussed, had it been the intention of the text to suggest that these divorces were the necessary prerequisite for the subsequent mixed marriages, one might have expected Malachi to treat these two offences in the reverse order of what is found. In any case, the present order appears to have been dictated largely by a literary purpose, rather than by any attempt to reproduce the chronology of offences. In particular, as was argued above in the first chapter, the present arrangement yields an artful envelope structure for Malachi 2:10-16:

A God who is $\prod_{i} \aleph$ created [ברא] his people (to be one)

$\mid$

$$
\text { General sin = infidelity [בגר] (10) }
$$

B Specific sin = infidelity [בגד] by intermarriage with a pagan (11)

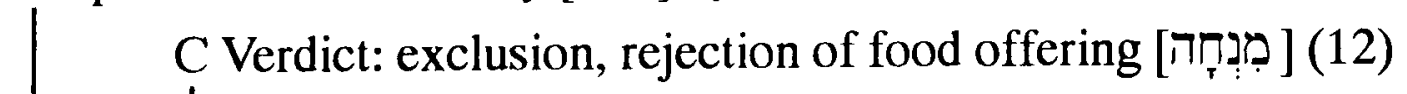

1

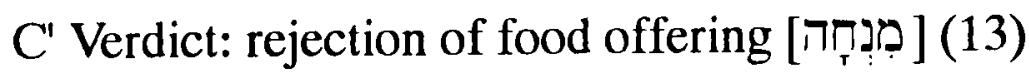

B' Specific sin = infidelity [בגד] by divorce (14)

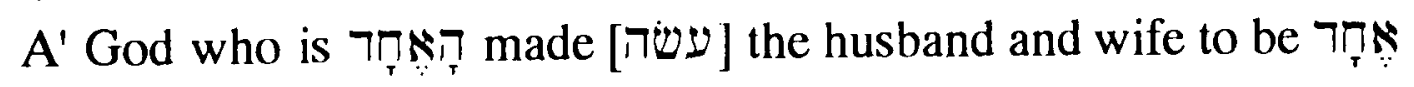

General sin = infidelity [ $[$ ב $]$ (15-16a)

65 Haggai, Zechariah, Malachi, 237. Cf. also W. C. Kaiser Jr., Malachi, 65.

66 Skizzen und Vorarbeiten (1892) 199.

67 "The Prophecy of 'Malachi'," 9.

68 Wisdom and the Feminine in the Book of Proverbs (1985) 323, n. 12.

To Camp's list one might add "profane" (חל, vss. 10,11) and "cover" (הOد, vss. 13, 16), among other terms. 
In addition to general subject matter (i.e., marital offences), shared vocabulary, and parallel literary structure, there may be yet other indications of an intended parallelism between vss. 11-12 and vss. 13-16, the two parade examples of the more general offence set forth in vs. 10. It is possible, for example, that both vss. 11-12 and vss. 13-16 intend to stress the unacceptability and particularly the hypocrisy of offerings made by worshippers who have so flagrantly sinned by committing בגד (cf. the rejected offering in vs. 12 and the reference to garments covered in violence in vs. 16, if "garment" is to be taken as a reference to literal cultic attire)..$^{70}$

Noteworthy is the manner in which appreciate fully the import of this stress on "oneness" and its possible indirect support for monogamy, it will be necessary to turn our attention in the next chapter to a closer study of vs. 15. Nevertheless, in the words of C. V. Camp, the unmistakeable effect of all this parallelism "is to equate the faithlessness to the Lord involved in marrying foreign women to the faithlessness to one's wife involved in divorce."71

Finally, if 2:15 asserts that Yahweh's purpose for marriage is that it should produce a "seed of God (or, godly seed) [ו]רע אליהים],"72 then in Malachi's view divorce may have frustrated this purpose in a manner analogous to mixed marriage. Compare Nehemiah 13:23ff. where Nehemiah stresses the adverse impact of mixed marriage on the children of these unions. Compare also Ezra 10:3, 44. Certainly it appears that the expression "seed

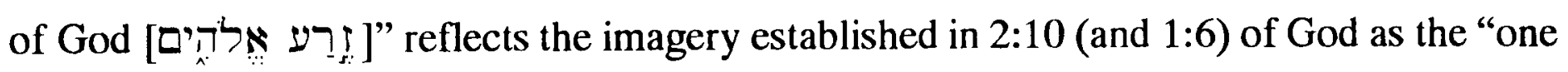

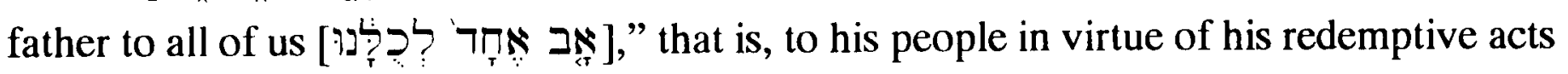
and covenant, and offers an intentional contrast to the phrase "the daughter of a foreign god

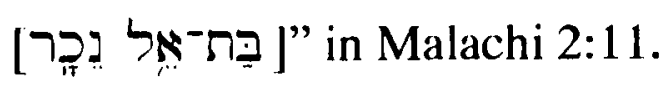

To sum up, if Malachi's intention in juxtaposing the offences of mixed marriage and divorce was to stress their similarity as instances of infidelity [בגר], rather than to imply that these were causally interrelated, then Malachi 2:10-16 carries no implication regarding polygyny and so is in no conflict with the alleged toleration of polygyny elsewhere in the

69 Note that the mention of "covering [הסב ] X with $Y$ " in this verse forms an inclusio with vs. 13. This suggested outline of 2:10-16 is based on the study of E. Wendland, "Linear and Concentric Patterns in Malachi" (1985) 108-21.

70 Cf. P. A. Verhoef, for this possible interpretation which reflects an important subtheme of Malachi (cf. 1:10) (The Books of Haggai and Malachi, 279f.). Cf. also our discussion of 2:16aß in \$3.4.2.4 above.

71 C. V. Camp, Wisdom and the Feminine in the Book of Proverbs (1985) 323, n. 12. Camp adds that "a similar sort of implicit equation is also made by the use of the zara-figure in Proverbs. The editors of both books seemed to have had such an equation in mind."

72 Cf. \$5.8.1.5 below. 
Old Testament. ${ }^{73}$ Accordingly, this view supports the identification of literal marriage as a "covenant" in 2:14.

While the present interpretation seems preferable, the traditional interpretation of Malachi 2:10-16 (that the offences of mixed marriage and the divorce of Jewish wives were typically interrelated) remains a possibility which cannot easily be excluded. We turn now to examine this approach and its implications.

\subsection{Malachi 2:10-16 condemns both mixed marriage and divorce in a} manner which suggests that these were typically interrelated, with the implication that polygyny was exceptional, discountenanced, or possibly even illegal in Malachi's day (the traditional view)

As C. C. Torrey noted, the traditional interpretation of Malachi 2:10-16, which has been popular since the time of Jerome, considers that the problems of mixed marriage and divorce were interrelated. ${ }^{74}$ In O. Eissfeldt's words, "Jewish men have divorced their Jewish wives in order to marry foreign women in their place."75 Although this causal connection is more often assumed than argued, the following considerations may be advanced in support:

1) The fact that Malachi 2:10-16 juxtaposes its condemnation of mixed marriage and its condemnation of divorce suggests a possible causal linkage between these two marital offences. It is important to realize that this approach does not require that every mixed marriage was preceded by a divorce, nor that every divorce was necessarily followed by a mixed marriage. It only requires that these two offences were typically related. This recognition of the presence of possible exceptions may help to explain why Malachi 2:1016 does not relate these two offences in a more explicit fashion. Furthermore, the traditional view does not exclude the various literary and conceptual parallels which may exist between these offences, as illumined by the previous approach.

2) Only by positing a typical connection between these divorces and subsequent mixed marriages, which presumably would have been materially advantageous, can a reasonable explanation be offered for the apparent prevalence of the problem of divorce based on aversion in Malachi's day. ${ }^{76}$

73 Cf. W. Rudolph, "Zu Malachi 2:10-16” (1981) 86.

74 "The Prophecy of 'Malachi'," 4.

75 Introduction, 442. Cf. also, e.g., C. F. Keil, The Twelve Minor Prophets (1878) 447f.; S. R. Driver, The Minor Prophets (1906) 312; J. M. P. Smith, Malachi (1912) 47, 52; G. L. Robinson, The Twelve Minor Prophets (1955) 164; J. Kodell, Lamentations, Haggai, Zechariah, Malachi, Obadiah, Joeh, Second Zechariah, Baruch (1982)102; P. C. Craigie, Twelve Prophets, II (1985) 236; E. Achtemeier, Nahum - Malachi (1986) 181; and J. A. Soggin, Introduction to the Old Testament (1989) 344.

76 P. A. Verhoef, The Books of Haggai and Malachi, 275. 
3) It is significant that the divorces condemned in Malachi 2:16 are specifically those which are based on mere "aversion [שנא]," Such a description is eminently suitable for divorce motivated by the desire to enter into another marriage. ${ }^{77}$

4) It appears likely that most divorces in Malachi's day would have been followed by a remarriage. In the context of life in post-exilic Palestine, where the population of available Jewish women would have been at a minimum, many of these remarriages would have been necessarily mixed. ${ }^{78}$

5) More specifically, it is often supposed that the appellation "the wife of your youth" in Malachi 2:14 suggests that the aging of one's wife, and by implication the presence of younger, more attractive (Gentile) women, was the primary motive for the divorces and subsequent mixed marriages. ${ }^{79}$

6) Attempting to account for the lack of opposition when the mixed marriages of Ezra 9-10 were forcibly dissolved, H. G. M. Williamson has suggested that "knowledge of this fact [that the guilty men had previously divorced their Jewish wives in order to enter into these mixed marriages] may have reduced the sympathy of the majority of the families concerned." 80

7) It is possible that Malachi's stress in 2:15 on "godly offspring" as Yahweh's intention for marriage is best explained as due to Malachi's assumption that such divorces would be followed inevitably by a mixed marriage and that mixed marriage poses a clear threat to this purpose (cf. Nehemiah 13:23ff.; Ezra 10:3, 44). ${ }^{81}$

While these considerations have merit, perhaps especially the last, the following objections may be mentioned:

1) The fact remains that Malachi 2:10-16 nowhere explicitly interrelates the offences of intermarriage and divorce. As noted earlier, it is possible, for example, that the two offences are juxtaposed not to suggest a causal connection, but simply to emphasize how each of them is a prime example of the more general infidelity [בגר] condemned in 2:10.

2) It is uncertain whether divorce based on aversion was especially prevalent in Malachi's day, particularly given the fact that neither Ezra nor Nehemiah mentions the problem. Nevertheless, if the divorce rate was particularly high among Malachi's contemporaries, alternative explanations are possible. For example, the upsurge of

77 As M. T. Roth has observed with respect to Neo-Babylonian marriage documents, it appears that the clauses anticipating such unjustified divorces are all predicated on the assumption that the offending man will divorce in order to marry another woman ("She will die by the iron dagger," 188, n. 8).

78 Cf. A. C. Welch, Post-Exilic Judaism, 251. If the first marriages (with Jewish wives) were formed while still in exile, with the divorces and subsequent mixed marriages taking place back in Judah, one might compare the concern and remedy of Laban with respect to Jacob's marriage to his daughters in Genesis 31:50.

79 Such was the view of Rabbi Johanan (cf. Yamauchi, "Ezra," 677). Cf. also W. Neil, “Malachi," 231, and R. L. Alden, "Malachi," 717.

80 Ezra, Nehemiah, 160.

81 In a private communication dated $17 / 4 / 91$, A. C. J. Phillips suggests this argument. 
religious relativism (e.g., Malachi 1:13; 2:17; 3:14f.), the disregard of vows (Malachi 1:14), and disintegration of family and moral values (Malachi 3:5 and 3:24 [ET 4:6]) may all have contributed to increased marital breakdown. In any case, Malachi offers no hint as to the particular motivation for divorce based on aversion in $2: 16$, perhaps because he intends to make his condemnation of unjustified divorce as general as possible.

3) While it is likely that divorce for the sake of marrying another would constitute a case of "aversion," it is uncertain that every, or even most subsequent remarriages were necessarily mixed or that every, or even most mixed marriages were necessarily preceded by a divorce. Nothing about Malachi's condemnation permits one to conclude that he would have approved mixed marriage in cases where it was not preceded by a divorce, or unjustified divorce, as long as it was not followed by a mixed marriage.

4) It is uncertain that there was such a disparity in the relative number of marriageable Jewish women versus men in the mid-fifth century B.C. province of Judah (Yehud). ${ }^{82}$ Moreover, had there been such a disparity, presumably this would have affected the majority of first marriages as well, since it is likely in this later period that most of these would have been contracted in Judah.

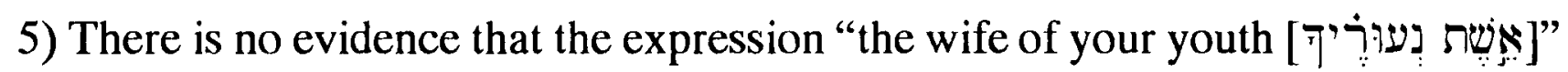
was in any way intended to allude to the fact that these Jewish wives had now become aged and unappealing! Of course, even if they had, this fact cannot explain why the problem of divorce had become acute in the post-exilic community, since wives, along with their husbands, inevitably aged in every period of Israel's history. 83 In any case, when one compares the use of "the wife of your youth" elsewhere in the Old Testament (e.g., Proverbs 2:17; 5:18; Isaiah 54:6; cf. Joel 1:8), it appears that, far from having any pejorative connotation, it was an expression of endearment and may have been employed by Malachi to offer the strongest possible incentive for revivified love. ${ }^{84}$

Furthermore, as opposed to the hypothesized motive of romance, it is more likely that most of the mixed marriages in Malachi's day were mariages de convenance. In a world where property frequently was inalienable and where wealth and status were primarily in non-Israelite hands, the temptation for the returned exiles to secure these

82 A. C. Welch bases his argument in favour of this disparity on the doubtful assumption that Malachi should be dated nearly a century earlier than is argued by most scholars, namely about 520 B.C. (Post-Exilic Judaism, 251).

83 Given the modern flavour of commentator's suggestions regarding how pretty young Canaanite women might have seemed (cf. W. Neil, "Malachi," 231), as an ad hominem argument it may be noted that in modern times, divorce is most common among younger couples, not those who have matured together, with the highest rate of divorce attested for the first year of marriage.

84 There may be a nostalgic allusion in this expression to the first blush of marital love. Cf. Deuteronomy 24:5; Song of Songs 8:5; and Revelation 2:4, 5. T. T. Perowne speaks about "the tender recollection of 'the kindness of youth and the love of espousals' (Jerem. ii. 2), and the binding force of years since spent together in intimate companionship..." (Malachi [1910] 26). 
through intermarriage must have been significant. 85 Consistent with this, Nehemiah 6:1719 and 13:4, 28 enumerate instances of intermarriage between members of the Jewish aristocracy and the powerful families of Sanballat the Horonite, later governor of Samaria, and of Tobiah the Ammonite, perhaps a governor of the sub-province of Ammon or deputy to Sanballat. 86 Similarly, J. M. Myers notes the disproportionate prominence of members of the upper classes in the list of offenders in Ezra 10.87

6) H. G. M. Williamson's explanation appears unconvincing for the lack of opposition to the forcible dissolution of the mixed marriages of Ezra 9-10. ${ }^{88}$ Neither Ezra nor Nehemiah makes any mention of the problem of divorce, perhaps suggesting that many individuals had entered their mixed marriages without a previous divorce. Furthermore, what is surprising is not the lack of opposition from some imagined third parties who may have been previously injured (i.e., the previously divorced wives and their families), but the lack of opposition from the offending husbands themselves or from their present Gentile wives and in-laws. Of course, there may have been plenty of opposition which was simply unrecorded. 89

7) Malachi's order of treatment of mixed marriage followed by divorce is unexpected on the traditional view. H. Cowles, among others, explains this order by suggesting that men who were already married to a Jewish wife practiced polygyny by taking a second wife who was a Gentile. Subsequently, the slighted Jewish wife would find the situation intolerable and be put away. 90 In other words, Malachi's order of treatment reflects the proper chronological order: the divorce of one's Jewish wife typically followed a second marriage to a Gentile wife.

This explanation, however, is unconvincing for several reasons. First, while there is evidence to support the practice of a wife-initiated divorce intended as a response to an unwanted polygynous marriage, Cowles' view reads too much into a text which nowhere hints that these divorces were instigated by, or were a response to, the Jewish wives'

85 G. A. Smith argues "such alliances were the surest way both to wealth and to political influence" (The Book of the Twelve Prophets, 344). Cf. also W. J. Dumbrell, "Malachi and the Ezra-Nehemiah Reforms," 47; and A. S. van der Woude, "Malachi's Struggle for a Pure Community," 66.

86 Cf. J. Blenkinsopp, who also cites an account of the marriage between Manasseh, the brother of the high priest Jaddua, to a daughter of Sanballat, recorded in Josephus, Antiquities 11.302-312 (Ezra Nehemiah, 365).

87 J. M. Myers, The World of the Restoration (1968) 88f., 98, 122.

88 Ezra, Nehemiah, 160. Ezra 10:15 is ambiguous in its implication.

89 It is possible, for example, that Joiada refused to divorce his wife and so was ostracised in Nehemiah 13:28 (as suggested by J. M. Myers, Ezra, Nehemiah, 218).

$90 \mathrm{H}$. Cowles, The Minor Prophets (1867) 391-393. Cf. also C. F. Keil, The Twelve Minor Prophets, 447; L. H. Brockington, "Malachi," 657; and W. J. Dumbrell, "Malachi and the Ezra-Nehemiah Reforms," 48.

Rashi's interpretation may be mentioned here, although his understanding of vs. 16 is unconvincing (see previous chapter). On his view, Malachi rebukes his contemporaries for two offences: first for interfaith marriage, which would be reprehensible under any circumstances, and secondly for the resulting injury to one's Jewish wife when the rival Gentile wife is brought into the home. Consequently, Malachi urges such men to divorce their Jewish wives, rather than to treat them with such cruelty. 
discontent. 91 Second, in most cases of polygyny in the ancient Near East, the pre-eminent status of the first wife was protected. ${ }^{92}$ Indeed, if Jewish men contracted their mixed marriages for economic or social reasons, as is widely argued, it is questionable whether the Gentile aristocracy would have permitted their daughters to enter such polygynous marriages, where they would be relegated to a secondary status. Finally, Cowles' view assumes that an unrestricted polygyny was practiced in Malachi's day and that Malachi would have preferred polygyny to divorce. Against these assumptions, there is little evidence for unrestricted polygyny anywhere in the ancient Near East and considerable doubt whether even a restricted polygyny would have been prevalent in post-exilic Israel. There is a wide scholarly consensus that not only was monogamy seen as the marital ideal in this period (post-exilic Israel), but actual marital practice was monogamous with few, if any, exceptions. 93

Alternatively, G. A. Smith, among others, considers that Malachi's order of treatment of mixed marriage and divorce is logical, rather than chronological. Smith suggests that "the relatives of their half-heathen brides made it a condition of the marriages that they should first put away their old wives...."94 While this view succeeds in recognizing the normal pre-eminence accorded a first wife and the likely concern of Gentile families to safeguard the status interests of their daughters, it must still be acknowledged that the text offers no hint that Gentile families in fact made such demands.

8) It is possible that Malachi viewed the purpose of marriage (to produce "godly offspring") to be directly threatened only by mixed marriage, but that he mentions this matter in the context of divorce in 2:15 precisely because he assumes that mixed marriage would inevitably follow divorce. It is also possible, however, that Malachi recognized that both mixed marriage (with the "daughter of a foreign god") and divorce equally endanger this purpose. As such, this implied consequence for divorce may offer an additional parallel between the offences of mixed marriage and divorce (see $\$ 4.4$ above).

In summary, the weight of evidence appears to favour the view that the offences of mixed marriage and divorce are juxtaposed not because they were causally interrelated, but because they are parallel instances of the more general infidelity [בגד] condemned in 2:10. Nevertheless, since the traditional view remains possible, in order to secure the identification of literal marriage as a covenant in 2:14 against the claim that a literal reference would be contradicted by the toleration of polygyny in Malachi's day, it is necessary to

91 For example, cf. Nuzi marriage tablets Nos. 1 and 2 discussed above. Cf. also E. Lipiński, "The Wife's Right to Divorce in the light of an Ancient Near Eastern Tradition" (1981).

92 Cf., e.g., T. E. McComiskey, "The Status of the Secondary Wife: Its Development in Ancient Near Eastern Law" (1965) 1 and passim.

93 For evidence, cf. the fuller discussion below in $\$ 4.6$.

94 The Book of the Twelve Prophets, 344. Cf. J. M. P. Smith, op. cit., 52; P. A. Verhoef, The Books of Haggai and Malachi, 275. 
digress in order to examine the practice of polygyny elsewhere in the Old Testament and particularly in the post-exilic period.

\subsection{Excursus on the practice of polygyny in ancient Israel}

No one denies that polygyny was practiced within Israel throughout much of the Old Testament period. Unfortunately, a similar scholarly consensus is lacking for virtually every other important question surrounding this practice. In particular, it would be helpful to know the prevalence and class distribution of polygyny during each period. 95

95 A useful summary of the evidence for polygyny in the Old Testament is provided by W. Plautz, "Monogamie und Polygynie im Alten Testament" (1963) 3-27.

It should be noted, however, that it is often difficult, or impossible, to ascertain whether a particular example is one of polygyny, rather than of successive monogamous marriages (cf., e.g., the doubtful example of polygyny in 1 Chronicles 8:8-11 based on multiple descent lines). Cf. also J. M. Brenenan, who acknowledges the same problem with respect to evidence from Nuzi, "It is clear that in some cases a man has two wives; however, sometimes when another wife and her sons are mentioned (as in texts 6 and 13) we can not be sure if it refers to a former wife, either deceased or divorced, or to another living wife. In text 4 the other sons are definitely from a divorced wife" (Nuzi Marriage Tablets, 291). Brenenan goes on to note the same problem in treating the evidence of wills.

In an attempt to gain more reliable evidence for the possible prevalence of polygyny in ancient Israel, a number of scholars have sought to extrapolate from the practice attested in comparative Semitic cultures. One of the most influential sources for this comparison has been the meticulous work of $\mathrm{H}$. Granqvist. Granqvist notes that of the 112 men residing in the modern village of Artas near Bethlehem, 11 had 2 wives, and 1 had three. Granqvist, however, was rightly sceptical about attempts to draw parallels between twentieth century Palestinian Arabs and ancient Israelites. Regrettably, biblical scholars have not always been so judicious (Marriage Conditions in a Palestinian Village [1935] II, 205).

While much of the biblical and epigraphic evidence for the relative prevalence of polygyny proves to be ambiguous on closer examination, or inconclusive, one apparent exception is provided by A. S. van Selms' analysis of UT 119 (Marriage and Family Life in Ugaritic Literature [1954] 20). Where the text can be read or reasonably restored, there appears to be a list of twenty households, among which four are listed as having two wives and one as having three wives. This would imply a $25 \%$ rate of polygyny.

This evidence is problematic, however, in that there is considerable uncertainty as to the nature of the list. While C. H. Gordon lists this as "census of households in the town of Alasiya," A. Alt has expressed an alternative view that this is a list of captives from Cyprus (C. H. Gordon, UT, 262; A. Alt, "Ein phönikisches Staatswesen des frühen Altertums," 207-209). Certainly the closing notice given for each family, that they are "in the house of" [b.bt ] some other individual, makes this list rather peculiar. Also striking is the unparalleled identification of some of the wives as "a mighty wife" [att adrt in 119:4, 7, 9, $16,18]$, interpreted by Gordon as an "upper-class wife" (op. cit., 352). Regardless of the outcome of this debate, given the damaged nature of the text and the limited data base it represents, it would seem precarious to draw conclusions for Ugaritic society as a whole, much less for ancient Israel -- Van Selms appends his own qualifying judgment: "A percentage of 25 for polygamic marriages may certainly be regarded as high" (op. cit., 20). Moreover, since the time of Van Selms' study a number of additional Ugaritic texts have come to light which C. Gordon classifies as "household statistics or census records" and which dramatically change this ratio: UT 1080, 1142, 2044, and 2068.

In UT 1080 we have a list, with relatively few lacunae, of 8 households, including the mention of wives, children, and animals. Based on Gordon's transliteration and occasional reconstruction of the text, in each case we read of only one wife. UT 1142 is too fragmentary to be of use. UT 2044 is also rather fragmentary, but yields clear information about three households, one of which may possibly mention "two wives." However the critical $\underline{t}$, "two," in line 11 is reconstructed by Gordon within a lacuna and Gordon indicates his own serious reservations about the reconstruction (UT, Supplement, 14). Text 2068 lists ten households and in each case mentions only one wife ( $w$. at th h, "and his wife").

Finally, to these texts, we may add one more particularly significant text, UT 1077, classified by Gordon under the heading "Lists of personal and/or geographical names" $(U T, 291)$. After a broken beginning, the text lists four men each of whom is simply identified as a $b^{\prime} l$ att , "the husband of a wife." Following this are listed six men each of whom is identified as a $b$ ' ssimt, "the husband of a concubine(?)." 
Furthermore, there is considerable uncertainty regarding the legal status of concubines and

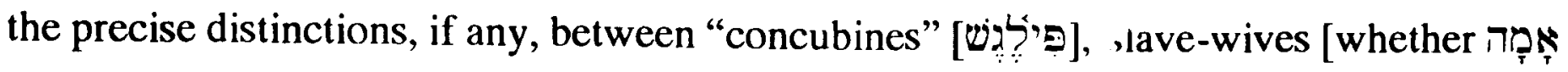

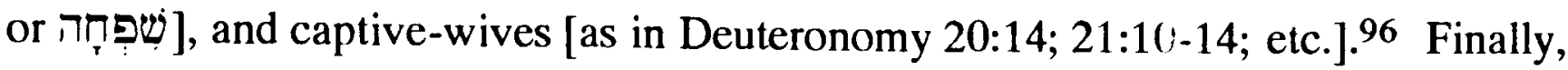
assuming that polygyny was a legally valid form of marriage in every period, what legal restrictions were placed on this practice, if any, and what was its ethical status -- was it required (for example, in the case of levirate marriage), recommended, approved, merely tolerated, or condemned? Obviously, it is impossible to treat these matters in detail within the scope of the present study. Nevertheless, it is hoped that the evidence to be presented will be adequate to challenge the overly facile assumption that in post-exilic Israel polygyny was a viable alternative to the divorces indicated in Malachi 2:16.

In no case is any individual mentioned as having more than one wife. (This text may offer corroboration for an interpretation of Abraham as monogamously married to his concubine Keturah, and the Levite of Judges 19 who may have been monogamously married to his concubine).

There is no point in summing up these totals to offer a new measure for the relative prevalence of polygyny in Ugaritic society. An undetected special purpose lying behind any or all of these lists would radically skew the results of any such computation. We need merely observe that even this modest amount of new data leaves one with a very different impression for what may have been the typical marital practice than Van Selms was able to offer on the basis of UT 119 alone.

96 Without denying that there are important distinctions in the usage of these terms, such as the fact that is only used of a married woman, it is notable that a number of Old Testament texts employ them in an overlapping manner. For example, Bilhah is variously identified as Rachel's 30:3), Rachel's שִ שִפִ (Genesis 29:29; 30:4, 7; 35:25), Jacob's (Genesis 32:23 [ET:22]; and possibly

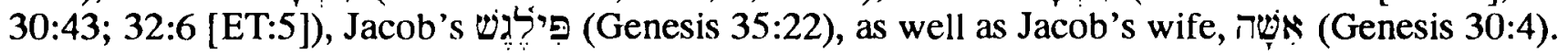

Reflecting their views of Mesopotamian practice, however, many scholars have sought to distinguish "concubines" from slave-wives, though with decidedly dissimilar results. For example, while E. Neufeld

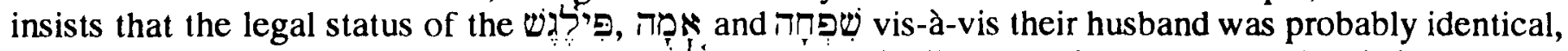
nevertheless he considers it likely that the was originally a prostitute and so had a distinctly lower

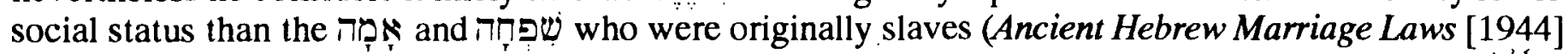
121-123). L. M. Epstein and S. F. Bigger, on the other hand, take the opposite view, placing the both legally (as a free woman) and socially over the שפחזה (L. M. Epstein, Marriage Laws in Bible and Talmud [1942] 35, 50, and S. F. Bigger, "Hebrew Marriage and Family in the Old Testament Period"

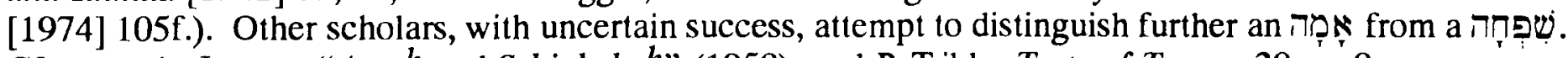
Cf., e.g., A. Jepsen, "Amah und Schiphchah" (1958), and P. Trible, Texts of Terror, 30, n. 9.

Perhaps most problematic, however, is the view of some scholars who simply disqualify all biblical examples of "concubines" by insisting that they do not offer instances of marriage. Cf., e.g., E. Neufeld, who writes, "The concubine was not married by her master, and her status differed very slightly from that of a slave" (Ancient Hebrew Marriage Laws [1944] 124). So also C. J. H. Wright, An Eye for an Eye (1983) 176, and P. Trible, Texts of Terror: Literary-Feminist Readings of Biblical Narratives (1984) 66.

Such an assessment of the meaning and status of the uncritical acceptance of S. I. Feigin's classic study of concubinage in Mesopotamia, and on assumed parallels with occidental practice, in part fostered by the misleading traditional rendering "concubine" (S. I. Feigin, "The Captives in Cuneiform Inscription" [1934]). Unfortunately, Feigin's results are in urgent need of re-examination in view of his consistent identification of šugitum as a "concubine." Given that CH $\$ 184$, for example, appears in the midst of legislation concerned with the dowries of priestesses, and given the frequent association elsewhere, as in $\mathrm{CH} \S \S 137,144,145$ and 183, between the sugittum and the naditum (a high priestess who was forbidden from bearing children), it appears that the older view of Landsberger and Eilers, that the sugîtum was some kind of "lay priestess," is still to be preferred. It is true that in occidental practice a concubine was, in general, a mere sexual consort and was not considered to be a member of her partner's household. Because her relationship was not one of marriage, it was protected neither by the laws of adultery, nor by the requirement for some sort of formal divorce for its dissolution. However, such an understanding fails to do justice to the complex phenomena of concubinage both in the Bible and elsewhere in the ancient Near East, including many texts which identify concubines as wives (cf., e.g., Genesis 16:3; 25:1, 6; 1 Chronicles 1:32; 2 Samuel 16:22; and Judges 19:1-5). 


\subsubsection{The prevalence of polygyny in the Old Testament}

With respect to the relative prevalence and class distribution of polygyny, it is wellknown that although the Old Testament offers numerous examples of tribal leaders and kings who practiced polygyny, the only clear instance of a non-monogamous marriage for any "commoner" is Elkanah in 1 Samuel 1.97 Based on this slender evidence, E. Neufeld, for example, claimed that "among the middle classes, of which Elkanah of the Book of Samuel may be taken as representative, it was probably the normal practice to have two wives."98 Of course, if this were so, then this would greatly help those scholars who reject the traditional interpretation of Malachi 2:10-16, including C. C. Torrey and A. Isaksson mentioned above.

Against Neufeld, however, it appears necessary to qualify drastically the example of Elkanah by giving more adequate attention to the likely special motive for this bigyny, namely Hannah's infertility. ${ }^{99}$ It is a remarkable fact that perhaps the majority of legal texts and marriage documents from Mesopotamia which bear on the question of polygyny authorize it precisely in the exceptional circumstance that one's wife proves to be infertile (cf., e.g., $\mathrm{CH} \$ 145$ and LE $\$ 59$; the only other specific case where polygyny was expressly permitted was when one's wife was gravely ill, cf. $\mathrm{CH} \S 148) .{ }^{100}$ This is not to

97 To this one example, we could possibly add 1 Chronicles 7:4f., if the commonly proposed emendation is accepted to restore a comparative $\triangle$ at the beginning of vs. 5, which would yield "...because they had more wives and sons, than their brothers" (cf. E. L. Curtis and A. A. Madsen, A Critical and Exegetical Commentary on the Books of Chronicles, and W. Rudolph, Chronikbücher).

Based on the armies they could muster, etc., it appears that J. Bright has correctly identified the patriarchs as "chieftains of semi-nomadic clans" and not "commoners" (A History of Israel, 3rd. ed. [1981] 92f.).

98 Ancient Hebrew Marriage Laws (1944) 118.

99 So the Talmud, b. Yebam. 64b, and most modern commentators. Cf. also L. M. Epstein, Marriage Laws in Bible and Talmud (1942) 20.

100 Cf. R. Westbrook, "Old Babylonian Marriage Law" (1982) I, 56 .

While $\mathrm{CH} \S 145$ pertains to the special case of marriage to a naditum-priestess (who was prohibited from bearing children), the presence of other laws, such as LE \$59, and similar stipulations within extant marriage tablets supports the inference that this law was applied more generally. For a discussion of LE \$59, cf. R. Yaron, The Laws of Eshnunna (1988) 79, 211-222.

Demonstrating that these laws reflect actual practice, the following Nuzi marriage contracts contain an explicit prohibition against bigyny unless the first wife proved to be infertile: Nuzi marriage contracts 1,2, 4, 5, 6, 8, and 101 (cf. also 104), as edited by J. M. Brenenan, "Nuzi Marriage Tablets" (1971). Cf. also C. H. Gordon, "Nuzi Tablets Relating to Women" (1935) 163-84.

For a similar provision at Alalah, cf. texts 91:24-31 and 92 (D. J. Wiseman, The Alalakh Tablets [1953]). Cf. I. Mendelsohn, "On Marriage in Alalakh," 355-357. Mendelsohn concludes that the prohibition of a second wife was "probably inserted in all marriage contracts of well-to-do brides where the girl's father was in a position to impose such a pledge on his future son-in-law" (ibid., 355).

Cf. also similar clauses in three Old Assyrian marriage contracts, I 490, ICK 3, and TC 67, discussed by J. Lewy, "On some Institutions of the Old Assyrian Empire," 6-10; A. J. Skaist, "Studies in Ancient Mesopotamian Family Law" (1963) 71; and T. L. Thompson, The Historicity of the Patriarchal Narratives, 262.

For the Neo-Babylonian period, cf. No. 3 in M. T. Roth, Babylonian Marriage Agreements: 7th - 3rd Centuries B.C. This contract is for a second concurrent marriage for a man whose first wife was infertile (lines 10f.). Otherwise fifteen of the forty-five agreements preserve a clause anticipating what will happen if the husband divorces his wife because he wants to marry another woman (Nos. 1, 2, 4, 5, 6, 8, 15, 16, 
claim that polygyny was never practiced apart from infertility or sickness. Indeed, the opposite is implied by the very presence of these laws and marriage contracts, some of which stipulate stiff financial penalties and authorize the offended wife to leave, should her husband acquire a second wife after she has borne children. Nevertheless, the legal texts leave little doubt that unjustified polygyny, that is, polygyny unmotivated by infertility or illness, was officially and widely discountenanced. Accordingly, the majority of cuneiform texts which allude to marriage, whether in the legal corpora or wisdom literature, etc., presuppose monogamy as the normal, if not also the ideal, form of marriage in Mesopotamia. 101

$17,19,20,25,26,30$, and 34$)$. No contract anticipates the possibility of an additional marriage without a preceding divorce.

Alternatively, other laws permit a wife to pre-empt the action of her husband by providing him with a concubine of her own choosing (so $\mathrm{CH} \S \S 144-47$ ) or, going one step further, require a barren wife to provide her husband a second wife or concubine -- so Nuzi HSS 5 (1929) No. 67, as treated by E. A. Speiser in "New Kirkuk Documents Relating to Family Laws" (1930) 31ff.; "Ethnic Movements in the Near East in the Second Millennium" (1933) 44; and more recently in Genesis (1964) 120f. Cf. also R. de Vaux, Ancient Israel, I, 24. Cautioning against certain aspects of Speiser's application of these texts to Genesis, cf., J. Van Seters, "The Problem of Childlessness in Near Eastern Law and the Patriarchs of Israel" (1968) and T. L. Thompson, The Historicity of the Patriarchal Narratives, 252-280.

LI $\$ 28$ may appear to offer an exception. It is more likely, however, that since this law mandates the support of the first wife, it merely parallels $\mathrm{CH} \S 148$. Unfortunately a lacuna occurs at the decisive point where the original text may have have mentioned the first wife's illness.

Laws which treat the inheritance rights of the children of different wives may not contradict the assumption that bigyny was typically limited to cases of infertility or illness (e.g., CH $\S \S 146,147,170$, 171; LI §§24, 25; SL $\S 12,13,14$; Deuteronomy 21:15-17). This is so because these laws may have been intended to address the case of the offspring of successive monogamous marriages or cases such as that of Abraham and Sarah and Elkanah and Hannah, where the barren wife had her children later after a second marriage had already been concluded (this seems probable in the case of $\mathrm{CH} \S \S 146,147$ ). In any case, even if these laws envision the consequences of a more general polygyny, they may not approve polygyny any more than the laws regarding premarital intercourse (Exodus 22:16f. and Deuteronomy 22:20-21) necessarily authorize or approve that practice. They merely provide a remedy to mitigate some adverse consequences of these perhaps disapproved practices.

It is unclear whether $\mathrm{CH} \$ 141$ authorizes bigyny as a penalty against a wayward wife or whether, as seems more likely, the first wife is stripped of her wifely status and reduced quite literally to the status of a slave as a lex talionis. Cf., perhaps, 2 Samuel 6:23 and Hosea 3.

For examples of bigyny motivated by infertility, other than Elkanah and Hannah, cf. Abraham's simultaneous marriage to Sarah and Hagar (Genesis 16), motivated by Sarah's infertility. Although Jacob already had three sons by his wife Leah, it seems likely that Jacob's marriage to Rachel's maid Bilhah (Genesis 30:4) should be considered as an example of this motive. As such, this example is particularly instructive in that the biblical text stresses the role of Rachel and her desire for children "Give me children, or I shall die!" Genesis 30:1) as the cause of polygyny, and not Jacob's desire. Cf. also Genesis 30:9, where Leah gives her maid Zilpah to Jacob, because she "saw that she had ceased bearing children."

On the other hand, it should be noted that the acute need posed by barrenness did not always lead to bigyny (cf. Isaac and Rebekah in Genesis 25:21, Manoah and his wife in Judges 13 and, presumably, Seled and his wife in 1 Chronicles 2:30). Further, the modern reader should not suppose that the ancients were unaware of male infertility as a contributing factor to childlessness. Cf. Abraham's incredulous response to the divine promise: "Shall a child be born to a man who is a hundred years old?" (Genesis 17:17).

Similarly other passages readily acknowledge in a striking manner that a moral deficiency in a man, just as in a woman, can be the precipitating cause of infertility as a divine judgment: E.g., Genesis 20:17f. and possibly Leviticus 20:20f. Cf. also K. van der Toorn, Sin and Sanction in Israel and Mesopotamia, 85-87.

101 Accordingly, I. Mendelsohn, J. Klíma and others summarize the evidence stating that Babylonian marriage was with few exceptions essentially monogamous. Cf. I. Mendelsohn, Slavery in the Ancient Near East (1949) 50; idem, "On Marriage in Alalakh" (1959) 351-57; J. Klíma, "Marriage and Family in 
Thus, the case of Elkanah, far from suggesting widespread polygyny, suggests that actual Israelite practice resembles very closely that of Mesopotamia and of ancient Egypt. In the latter case, excluding the royal family, polygyny is attested only twice throughout the whole of Egyptian antiquity -- a fact which is all the more remarkable because, as S. Allam has noted, "we are relatively well informed about Egyptian marriage, due to numerous documents beginning in the Late Period (11th - 4th centuries B.C.)."102

\subsubsection{The ethical stance of the Old Testament with respect to polygyny}

Concerning the ethical status of polygyny in the Old Testament, nowhere do we find an express biblical permission for polygyny comparable, for example, to what obtains in the Code of Hammurabi, much less the Qur'ān or Talmud. ${ }^{103}$ Nevertheless, it has often been argued that the Old Testament does not merely recognize polygyny as a legal form of marriage, but that it also approves it. This conclusion does not rest on any particular Old Testament examples of polygyny since most of these are reported without any indication of

Ancient Mesopotamia" (1966) 100, 102; R. Yaron, The Laws of Eshnunna (1988) 79, 211-222; and R. Westbrook, "Old Babylonian Marriage Law" (1982) 1, 56f.

Cf., e.g., MAL A $§ 55$, which is of special interest in that it explicitly presupposes monogamy. This law, which resembles Deuteronomy 22:23-27, specifies that if a married man ravishes an unbetrothed virgin his wife will be ravished in a talionic punishment and then taken from him, and he must then marry the ravished virgin at the discretion of her father. If the ravisher is unmarried, he must pay an inflated marriage present (perhaps to be understood as threefold the customary amount [కalsăte kaspa svîm batülte] as a penalty, rather than merely an additional third as in $A N E T$ ) and, once again, he must marry the ravished virgin at the discretion of her father.

102 So S. Allam, Everyday Life in Ancient Egypt (1985) 27. Cf. also p. 35; idem, "Ehe" (1975) 1162-81; and P. W. Pestman, Marriage and Matrimonial Property in Ancient Egypt (1961) passim.

W. A. Ward confirms that monogamy was the exclusive form of marriage for non-royalty throughout Egypt's history, and denies any evidence for the existence of harems or concubinage even among royalty during the Old and Middle Kingdoms. Only with the new internationalism of the Empire did royal polygyny (not concubinage) for the purpose of diplomatic marriages become a necessity ("Reflections on some Egyptian terms presumed to mean 'harem, harem-woman, concubine'" [1983] 67f., 74).

103 Cf. CH $\S \S 144-148$ and Qur'àn 4:3. Cf. W. M. Watt, who argues that Qur'än 4:3 does not merely limit polygyny to four wives, as it is generally understood, or it would condemn Muhammed himself who is said to have taken thirteen wives, but that it encourages men who had only one or two wives to marry as many as four ("Muhammad, Prophet and Statesman [1964] 151-159).

Although contradictory opinions are expressed, at other points Mishnaic and Talmudic interpretation saw polygyny not as a tolerated deviation, but as a legal right (cf., e.g., b. Yebam. 65a). Furthermore, according to the positive view, polygyny was obligatory in the case of infertility $(b$. Yebam. $61 \mathrm{~b} ; b$. Sota 24a) and the levirate (cf., e.g., b. Yebam. 44a). Cf. also m. Yebam. 4:11; m. Ketub. 10:1-6; m. Git. 2:7; 3:1; m. Qidd. 2:6-7; m. Sota 6:2; m. Ber. 8:4.

Nevertheless, the Talmud shows a general tendency to favour monogamy and specifically commends monogamy for priests (cf. E. Neufeld, Ancient Hebrew Marriage Laws [1944] 119, n. 4, and L. M. Epstein, Marriage Laws in Bible and Talmud [1942] 10). In fact, it seems likely that the discussion concerning the right of polygyny was largely theoretical. For this reason not a single rabbi among the more than two thousand sages mentioned in the entire Talmud, nor a single plaintiff is mentioned as actually having had more than one wife -- so, according to G. F. Moore, Judaism in the First Centuries of the Christian Era, II (1927) 122; D. M. Feldman, Marital Relations, Birth Control, and Abortion in Jewish Law (1968) 37; and R. Biale, Women and Jewish Law (1984) 49. However, L. M. Epstein challenges this observation (Marriage Laws in Bible and Talmud [1942] 17). 
moral approbation. ${ }^{104}$ Rather, it seeks its support in eight specific texts: Exodus 21:10-11; Leviticus 18:17, 18; Deuteronomy 21:15-17; Deuteronomy 25:5-10; 2 Samuel 12:7-8; Jeremiah 3:6-13; Ezekiel 23; and, of particular interest to our study, Malachi 2:10-16. On closer examination, however, it is not so clear that any of these texts require the conclusion that polygyny was ethically approved.

\subsubsection{Texts which are alleged to approve polygyny}

\subsection{Jeremiah 3:6-13 and Ezekiel 23}

Jeremiah 3:6-13 and Ezekiel 23 depict Yahweh as a bigynist in his relationship to Israel and Judah. Accordingly, R. Holst and B. Vawter, among others, consider these texts to reflect the prophets' ethical approval of polygyny. ${ }^{105}$ Precisely because these texts are allegorical, however, it is precarious to press their details in an attempt to derive from them legal or ethical norms. This is especially so given the historical exigencies which these texts seek to symbolize; the two kingdoms with their separate destinies could not easily be made to fit the pattern of monogamy except in the eschaton (cf. Ezekiel 16:5363). 106

As an evidence of the need for caution, both Jeremiah 3 and Ezekiel 23 depict Yahweh's "wives" as "sisters" (so Jeremiah 3:7f. and especially Ezekiel 23:2ff., which specifies further that they were uterine sisters). This detail admirably suits the religiohistorical relationship between Israel and Judah and their ostensibly common faith in Yahweh. But Leviticus 18:18, if it is not to be interpreted as a prohibition against polygyny in general, is emphatic in explicitly prohibiting this particular form of polygyny.

A similar problem obtains in the treatment of parables and allegories in the New Testament. For example, although most scholars concede that Paul would have rejected

104 Indeed, some of these examples, such as Lamech, Abraham, David, Solomon, and possibly Jacob and "the sons of the gods" in Genesis 6, if anything, suggest moral disapprobation. For one possible interpretation of this last, obviously problematic text, which finds in it a reference to royal polygyny, cf. M. G. Kline, "Divine Kingship and Genesis 6:1-4" (1961/62). Supporting Kline's interpretation over against the more common view may be the recognition that nowhere in Ugaritic literature do the gods have sexual relations with men (so A. S. van Selms, Marriage and Family Life in Ugaritic Literature [1954] 19).

105 R. Holst, "Polygamy and the Bible" (1967) 205-213, and B. Vawter, "The Biblical Theology of Divorce" (1967) $226 \mathrm{f}$.

106 Cf. also Isaiah 54; 61:1-6.

However, the warning against the over-interpretation of allegory cuts both ways. It cautions equally against the emphasis P. Grelot wishes to place on the fact that in the eschatological wedding feast of Ezekiel 16:53-63, and hence in the ideal state, Jerusalem is Yahweh's only bride, with the other cities identified only as her daughters ("The Institution of Marriage: Its Evolution in the Old Testament" [1970] 46).

Similarly, not too much should be made of the other prophetic texts which metaphorically depict Yahweh in a monogamous marriage with Israel (e.g., cf. Isaiah 1:1; Jeremiah 2:2; Ezekiel 16:8; and Hosea 2:18). Against such arguments, S. F. Bigger correctly insists that the pre-eminent concern in these texts is surely with fidelity to the marital bond, not with the number of one's wives ("Hebrew Marriage and Family in the Old Testament Period" [1974] 97). 
polygyny, nevertheless Paul was quite willing to use Abraham's bigynous marriage to Hagar and Sarah as an allegory for the old and new covenants in Galatians 4. 107

\subsection{Samuel 12:7-8}

Although Nathan's words to David in 2 Samuel 12:7-8 appear to endorse royal polygyny by implicating the deity in the acquisition of David's wives ("I gave you your master's house, and your master's wives into your bosom"), unfortunately moral approbation cannot be inferred so easily from Yahweh's acts. ${ }^{108} 2$ Samuel 12:11, for example, appears to offer a deliberate parallel to 12:8. Here Yahweh threatens David with a talionic punishment, that he will "take your wives before your eyes, and give them to your neighbour, and he shall lie with your wives in the sight of this sun." Nevertheless, even though this text asserts that Yahweh will "give" David's concubines to Absalom, 2 Samuel leaves little doubt that what Absalom did on the palace roof "in the sight of all Israel" ( 2 Samuel 16:22) constituted an act of flagrant adultery deserving of the death penalty. ${ }^{109}$

\subsection{Exodus 21:10-11 and Deuteronomy 21:15-17}

Exodus 21:10-11 and Deuteronomy 21:15-17 may regulate polygyny and, as such, support the view that polygyny was considered to be a legally valid form of marriage (unlike homosexual unions, for example, or marriage to a woman who was already another man's wife $\left.{ }^{110}\right)$. This is not enough, however, to support the inference that these texts tacitly approve polygyny. ${ }^{111}$ Such a phenomenon, where a law regulates an existing practice without thereby according it approval, is a recognized feature in both ancient and modern jurisprudence.

For example, one would be loath to conclude that Deuteronomy 21:15-17 endorses or approves the practice of a husband "hating" one of his wives, although this law seeks to mitigate some of the potential injury which may result from such hatred. Additional examples are easily multiplied. Does the prohibition against bringing the hire of a harlot or

$107 \mathrm{Cf}$. also the parable in Matthew 25 of the wise and foolish virgins awaiting the bridegroom.

108 Since they do not affect the point at issue, we leave aside for the moment a number of text critical problems in 2 Samuel 12:7-8. Cf., e.g., P. K. McCarter Jr., II Samuel, 292, 295.

109 For an alternative approach to 2 Samuel 12:7-8 which denies any reference to polygyny, cf. C. J. Goslinga, Het Tweede Boek Samuël (1962) 215, and, especially, W. C. Kaiser Jr., Toward Old Testament Ethics (1983) 187.

However, in support of a reference to polygyny in 2 Samuel 12:7-8, cf. M. Tsevat, "Marriage and Monarchical Legitimacy in Ugarit and Israel" (1958) 237-43, and J. D. Levenson and B. Halpern, “The Political Import of David's Marriage" (1980) 507-518.

110 Cf., e.g., the case of Paltiel's "marriage" to Michal, the wife of David (1 Samuel 25:44; 2 Samuel 3:14f.). Presumably the fact that David never divorced Michal (nor did he willingly flee his city -- cf. MAL A §36) rendered Paltiel's marriage invalid. Accordingly, it could be dissolved and their own marriage to be restored, apparently without violation of Deuteronomy 24:1-4. Cf. J. D. Martin, “The Forensic Background to Jeremiah III 1" (1969) 82-92; Z. Ben-Barak, "The legal background to the restoration of Michal to David" (1979) 15-29; and G. P. Hugenberger, "Michal" (1986) 348.

111 As against, e.g., W. Plautz, "Monogamie und Polygynie im Alten Testament" (1963) 8. 
"dog" into the temple in Deuteronomy 23:19 [ET 18] approve these practices as long as these earnings are not brought into the temple? Or is this law merely regulatory, intended to prohibit the compounding of these offences by the additional sacrilege of these forbidden offerings? In modern jurisprudence one may compare any number of regulatory statutes, such as the stipulation of the U.S. Revenue Code which requires all tax-payers to report any income derived from embezzlement, theft, etc. Such a provision, which regulates one's earnings from embezzlement, theft, etc., should not be misconstrued as if it accorded these acts official approval.

Furthermore, depending especially on the interpretation of עי 21:8f., it is possible that Exodus 21:10-11 does not treat polygyny at all, but considers only the case of a broken engagement (betrothal). ${ }^{112}$

\subsection{Deuteronomy 25:5-10}

The law of levirate marriage in Deuteronomy 25:5-10 provides a starting point for the Talmudic discussion of polygyny, and it remains a key evidence for modern scholars who consider that the Old Testament approved, rather than merely tolerated, polygyny. ${ }^{113}$ According to the school of Shammai, since Deuteronomy makes no provision for exempting a married brother from his levirate duty, it thereby implicitly requires, and hence approves, polygyny under such a circumstance. A closer examination, however, reveals that this law simply does not bear on the issue.

To begin with, it is important to recognize that Deuteronomy 25:5-10 makes no pretence at an exhaustive coverage of the possible situations to which it might apply. ${ }^{114}$ So, for example, there is no attempt to treat the situation when there is no living brother or when a living brother might be disqualified by his immaturity from entering a levirate marriage. 115 Given this incompleteness, it is entirely possible that if a brother happened to

$112 \mathrm{Cf}$. the detailed treatment of this text in $\$ 8.3 .4$ below.

Similarly, L. M. Epstein has questioned whether Deuteronomy 21:15-17 treats a case of polygyny. Noting the usage of שנא elsewhere in connection with divorce, including at Elephantine, Epstein argues that שִננויהָה, "hated," implies that the wife in question had been divorced (Marriage Laws in Bible and Talmud [1942] 4).

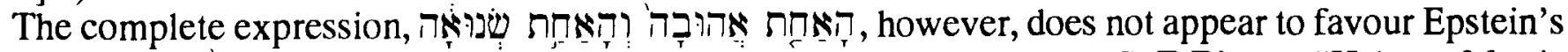
suggestion since "šr, "loved," is offered as a contrastive term. Cf. also S. F. Bigger, "Hebrew Marriage and Family in the Old Testament Period," 95, n. 1.

113 Cf. b. Yebam. 44a (and m. Yebam. 4:11). Cf. also B. Vawter, "The Theology of Divorce," 226, n. 8, and W. F. Luck, Divorce and Remarriage, $230 \mathrm{ff}$.

114 On the typical incompleteness of biblical and ancient Near Eastern law, cf. R. Westbrook, "Biblical and Cuneiform Law Codes" (1985) 247-264. Of course, it was precisely the incompleteness of Deuteronomy 25:5-10 which stimulated so much of the Talmudic speculation in Yebamot.

115 That such exceptional cases were not unknown is clear from their presence within the biblical record. Cf., e.g., the situation of the widowed Ruth, left without any living brother, in Ruth 1:11-12. The

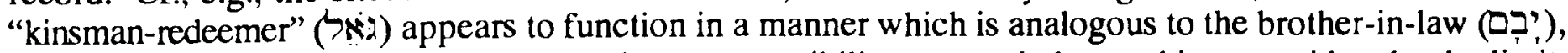
and yet Ruth 1:11-12 implies that the levirate responsibility was, strictly speaking, considered to be limited to the immediate family (in the wording of Deuteronomy 25:5, "If brothers dwell together..."). Such also was, evidently, the view of the Sadducees in Matthew 22:23-33. Cf. the fuller treatment of these complex issues in D. A. Leggett, The Levirate and Goel Institutions in the Old Testament (1974); E. Levine, "On 
be married already, this too may have disqualified him from assuming the levirate obligation. The situation in Genesis 38 certainly allows for this possibility since the direction of levirate responsibility seems to have been downward to increasingly younger, and hence normally unmarried, brothers.

Deuteronomy 22:23-27, the law requiring a ravisher to marry his victim, may offer an instructive analogy in that this law too does not consider the case when the ravisher happens to be married already. One might be tempted to argue from this omission that under such a circumstance this law also would require and thus approve polygyny. The comparative evidence of MAL A $\$ 55$, however, challenges such an inference. MAL A $\$ 55$ provides a close parallel to Deuteronomy 22:23-27, but it is more complete in several of its specifications, including its treatment of the exceptional case when the ravisher is already married (under which circumstance the law requires both a talionic ravishing of the ravisher's wife and the prior dissolution of that marriage before any marriage to the victim).

More explicit support for the view that levirate marriage may not have required polygyny may be found in the Targum for Ruth 4:6: "I cannot marry her, because I am already married; I have no right to take an additional wife, lest it lead to strife in my home." While offering an inferior text for the passage, the Targum nevertheless reveals what must have been the common understanding in its day, namely that an existing marriage would exempt one from performing the duty of the levirate. ${ }^{116}$

\subsection{Leviticus 18:17, 18}

According to the traditional interpretation, Leviticus 18:17, 18 prohibits a man from simultaneously marrying a woman and her daughter, or a woman and her sister. Such a prohibition, it is argued, implies a more general permission for (or approval of) polygynous marriage to women unrelated to each other. This implication is possible, but it is by no means necessary. For example, the fact that Leviticus 19:29 prohibits a man from turning his daughter into a harlot does not necessarily imply permission for him to turn other women into harlots, etc.

More problematic for these verses, however, is the likelihood that the traditional interpretation of Leviticus 18:18 is wrong and that this text, in fact, offers a general (ethical)

Intra-familial Institutions of the Bible" (1976); A. A. Anderson, "The Marriage of Ruth" (1978); and W. C. Kaiser Jr., Toward Old Testament Ethics (1983) 190ff.

On the other hand, immaturity was the ostensible reason for postponing Shelah's levirate marriage to Tamar in Genesis 38. Cf. MAL A $\$ 43$ and J. Morgenstern, "The Book of the Covenant, Part II," (1930) 164.

116 Cf. J. H. Hertz, "Foreword" to The Babylonian Talmud. Seder Nashim, I, xvii.

Cf. also the notice of the death of Judah's wife in Genesis 38:12, which appears to be recorded in order to establish the transference of the levirate responsibility now to Judah. Cf. HL $\$ 193$. On this view, the text implies that Judah was not responsible to perform the levirate duty during the earlier period when his wife was still alive. 
prohibition of polygyny. ${ }^{117}$ The following seven arguments may be advanced in support of this alternative interpretation.

1) The operative expression Testament in the distributive sense of "one to another" and nowhere else refers to literal

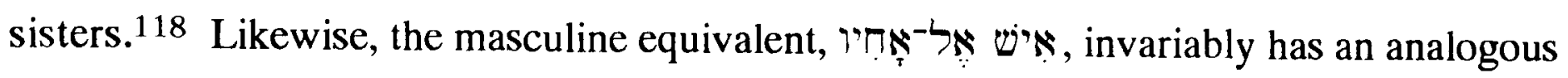
distributive sense, "one (man) to another," and does not refer, except by coincidence, to literal brothers. ${ }^{119}$ Indeed had it been the intention of Leviticus 18:18 to prohibit a man from marrying two women who were literal sisters, it could have done so with considerably less ambiguity by the use of the conjunction ?, rather than the preposition,

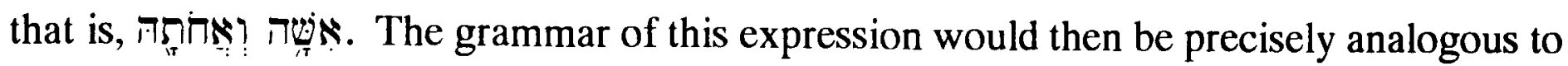

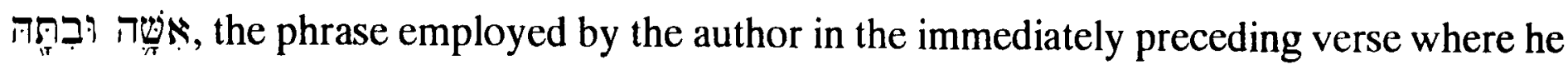
prohibits sexual relations with a woman and her daughter (cf. also Leviticus 20:14). It appears likely that it was the awareness of this usage which already led the Zadokites and the Qumran community in the first century B.C., as well as the much later Karaites, to interpret Leviticus 18:18 as an explicit prohibition against polygyny. 120

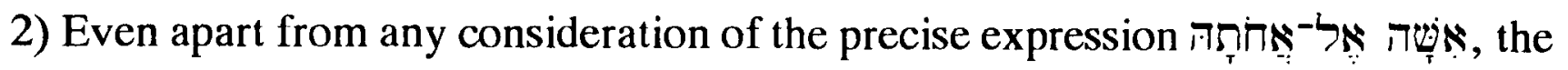
possibility of a non-literal sense for a meaning in Leviticus 18:18 has often been overlooked because of the assumption that vs. 18 must be interpreted in the light of the long series of incestuous unions which are prohibited in vss. $7-17$, where noted, however, "Elsewhere in Leviticus 18 we find 'ahôt, and not as in v. 18 'iššâ...

117 So, according to, inter alios, M. Poole, Annotations upon the Holy Bible (1803) ad loc.; S. E. Dwight, The Hebrew Wife (1836) 105-27; anon., "Art. IV - The General Assembly of 1842" (1842) 518520; J. Murray, Principles of Conduct (1957) 250-256, esp., p. 253; and A. Tosato, "The Law of Leviticus 18:18: A Reexamination" (1984) -- each of whom argues that Leviticus 18:18 offers a general prohibition against polygyny. Against this view, cf. G. Bush, Notes, Critical and Practical, on the Book of Leviticus (1842) 192-98, cited with approval by W. C. Kaiser Jr., Toward Old Testament Ethics, 114-16.

Confusingly, however, at other points Kaiser interprets Leviticus 18:18 as a prohibition of polygyny (op. cit., 93-94, 186, 189).

118 This is so whether or not persons are in view: Exodus 26:3(bis), 5, 6, 17; Ezekiel 1:9, possibly 11 (cf. BHS), 23; 3:13. Cf. J. Murray, Principles of Conduct (1957) 253. This summary of actual usage is not intended to imply, of course, that the expression was necessarily incapable of referring to literal sisters.

119 I.e., Genesis 42:21, 28; Exodus 16:15; 25:20 37:9; Numbers 14:4; Isaiah 9:18 [ET 19]; Jeremiah $13: 14 ; 23: 35 ; 25: 26$; Ezekiel 24:23.

120 For the Zadokite interpretation of Leviticus 18:18, cf. "Fragments of a Zadokite Sect," 7:1, in R. H. Charles, ed., The Apocrypha and Pseudepigrapha of the Old Testament in English, II (1913) 810. Cf. also R. Holst, who summarizes the whole of 7:1-4 in the Fragments, noting that the Zadokites prohibited polygyny based not only on Leviticus 18:18, but also on Genesis 1:27 and Deuteronomy 17:17 ("Polygamy and the Bible" [1967] 210). Cf. G. F. Moore, Judaism in the First Centuries of the Christian Era, I, 202; and L. M. Epstein, Marriage Laws in Bible and Talmud, 13.

For the Qumran interpretation of Leviticus 18:18, cf. CD 4:20-21, which reads "and you shall not take a woman as a rival wife to another...." This interpretation is further confirmed in 11QTemple 57:17-19, "And he (=the king) shall not take in addition to her another wife, for she alone shall be with him all days of her life; but if she dies, then he can take to himself another...." Cf. A. Tosato, "The Law of Leviticus 18:18: A Reexamination" (1984) 199-201.

For the Karaite interpretation, cf. L. M. Epstein, Marriage Laws in Bible and Talmud (1942) $22 \mathrm{f}$.

121 Cf., e.g., A. Tosato, op. cit., 201f., n. 8 and n. 9.

122 So, e.g., G. J. Wenham, Leviticus, 258, n. 27, arguing against J. Murray. 
'ahōtāh. A simple equation between these two philologically different expressions seems to be false."123

3) Moreover, according to Tosato, the overall literary structure of Leviticus 18 suggests that there is a major break between vss. 17 and 18. As Tosato outlines the chapter, there is a parenetic framework consisting of vss. 1-5 and 24-30. Vs. 6 is then introductory to two series of laws: the first series concerned to prohibit incestuous unions and the second series concerned to prohibit a variety of non-incestuous sexual unions. Up to this point virtually all scholars are in agreement; the problem comes in determining the precise dividing point between the two series. While some interpreters favour 7-18 and 1923, others, including Tosato, consider the proper division to be 7-17 and 18-23. In favour of this second analysis, whereby vs. 18 is placed with other non-incestuous sexual unions, Tosato notes that each of the eleven prohibitions in vss. 7-17 has precisely the same formal

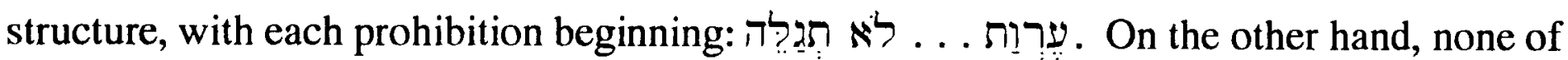

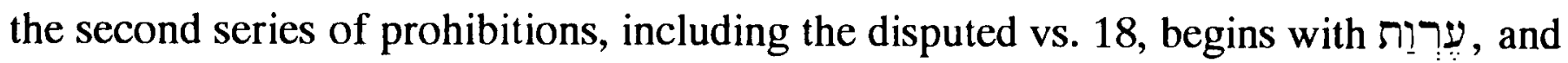

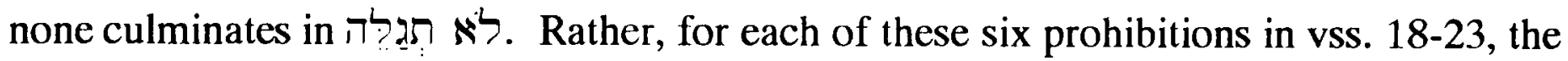
prohibition begins with the conjunction ?, and the main verb, which is some second person

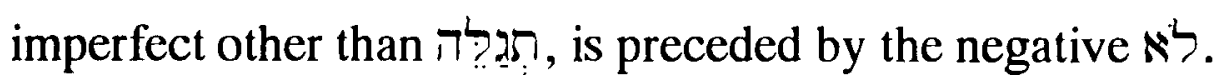

4) Further favouring Tosato's analysis is the observation that all but one of the antiincest laws concludes with a justification based on the identity of the forbidden individual. ${ }^{124}$ In form, each justification appears as a verbless clause with a pronominal

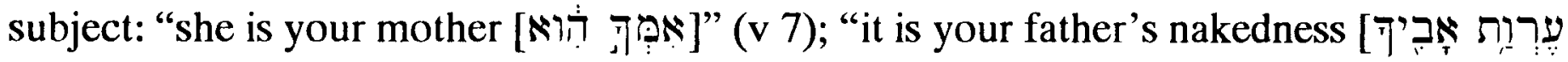

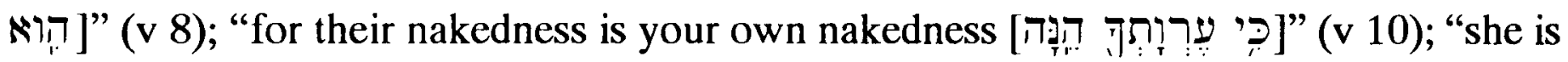

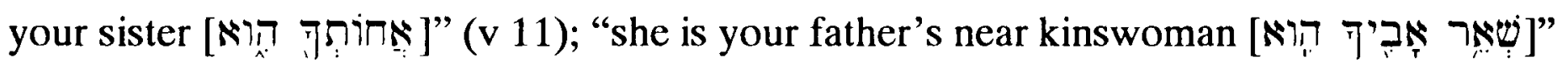

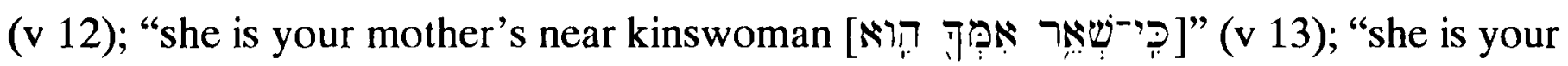

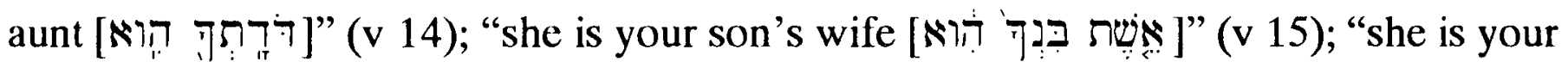

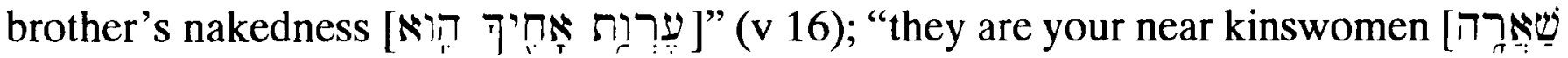
הִִ̣ ]" (v 17). As is readily apparent, however, the prohibition in vs. 18 lacks any similar explanatory clause; this would be expected if the writer had intended it to be classified with the first series of laws, rather than the second. ${ }^{125}$

5) What is perhaps even more striking, the justification which is offered in vs. 18 ,

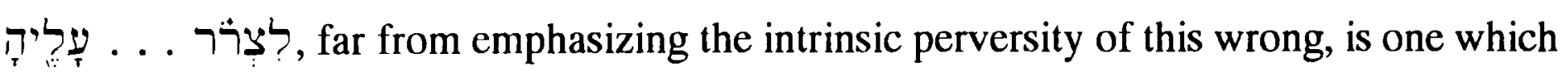
is quite general and applicable to any bigynous marriage. As Tosato remarks, "the harm which the law wants avoided is such (rivalry, enmity) that any woman (and not necessarily

123 “The Law of Leviticus 18:18: A Reexamination," 202, n. 8.

Tosato is not denying that other pronominally suffixed forms of

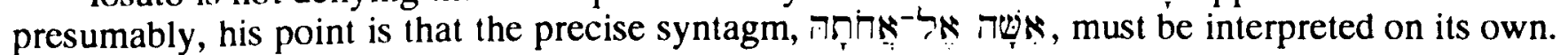

124 Vs. 9 is the only exception.

125 As A. Tosato notes, had the writer intended Leviticus 18:18 to prohibit the simultaneous marriage of sisters, and thus to have this law complete the first series of prohibitions, it should have read something

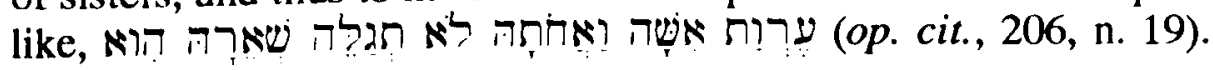


a sister of the first wife) is capable of causing...."126 Indeed, the same root, צרר, is used in 1 Samuel 1:6 to describe the discordant relationship between Peninnah and Hannah, who need not have been literal sisters. ${ }^{127}$ Accordingly, if the motive of this prohibition was to avoid vexation to one's wife, there is little justification for limiting its prohibition to a literal sister; both the Bible and anthropology provide ample testimony to the unpleasant reality of contention among co-wives who are not sisters. ${ }^{128}$

6) Further, if Leviticus $18: 18 \mathrm{r} \cdot \mathrm{d}$ been concerned to avoid the incestuous implication of marriage to a woman and her literal sister, it would be difficult to account for the explicit time limit on the application of the present law, among the anti-incest laws.

7) Finally, such a prohibition against polygyny ought not be dismissed as out of character for the Holiness Code because of its impossible idealism. Rather, it compares favourably with a number of other equally idealistic provisions, such as the prohibition against hatred in Leviticus 19:17, 18! The fact that Leviticus 18:18, as well as many of these other "idealistic" stipulations, lacks any criminal sanctions suggests that these may have been intentionally ethical, rather than legal norms. Putting this observation somewhat differently, this law can be categorized as a lex imperfecta, a law which prohibits something without thereby rendering it invalid (reflecting a society which would have lacked the requisite means of enforcement in any case). ${ }^{129}$

\subsubsection{Texts which presuppose or may encourage monogamy as the ideal form of marriage}

Having concluded that Leviticus 18:18 may plausibly be interpreted as it was at Qumran, namely as an ethical prohibition of polygyny, we need to consider if other texts within the Old Testament similarly discourage or disapprove polygyny, even if polygyny remained a legally valid form of marriage. Certainly a number of texts appear to presuppose monogamy and perhaps even to advocate monogamy as desirable, if not normative. As R. de Vaux, B. Vawter, W. Plautz, and other scholars have noted, this preference for monogamy seems to be the case particularly with respect to the wisdom literature and the $\mathbf{J}$ account of creation (i.e., the paradigmatic monogamous marriage of

126 Ibid., $206 \mathrm{f}$.

127 Some scholars consider צִּר, "adversary," in 1 Samuel 1:6 to be a technical term for a co-wife (cf. Akkadian serritum). This is possible, but unnecessary, given the actual hostility between Peninnah and Hannah described in the text.

128 Cf. also the example of contention between Sarah and Hagar in Genesis 16 and 21; Sirach 26:6; 37:11.

Indeed, in G. P. Murdock's classic survey of 250 cultures, the majority of those cultures which permit polygyny actually prefer polygyny involving natural sisters, apparently to help minimize conflict (Social Structure [1949] 284ff.)!

129 For other examples and a more general discussion of leges imperfectae, cf. S. E. Loewenstamm, "The Laws of Adultery and Murder in Biblical and Mesopotamian Law" (1980) 153, n. 9, and R. Yaron, The Laws of Eshnunna (1988) 212. 
Adam and Eve in Genesis 2, to be discussed more fully in Chapter 5 below, and the decidedly unflattering account of the origin of polygyny in the reprobate line of Cain in Genesis 4:19ff.). ${ }^{130}$ As argued by W. Plautz, however, many of the texts which initially appear to favour monogamy may do so merely because they reflect monogamy as the prevalent and typical practice at the time, but they need not require the conclusion that monogamy was the exclusive, nor even ideal form of marriage. 131

\subsubsection{Texts which undermine, or prohibit, the motive for polygyny}

Nevertheless, it is a striking fact that the Old Testament excludes both of the most clearly approved, if not the only approved motives for polygyny among Israel's neighbours (omitting the case of grave illness), namely infertility and, in the case of royalty, the need to secure diplomatic alliances. The promise of fertility for covenant fidelity, taught both by example, as in the case of Abraham (recourse to Hagar because of Sarah's infertility only demonstrated Abraham's lack of faith), and by precept, as in Exodus 23:26, Deuteronomy $7: 14$, and $28: 4$, should have obviated the most common need for polygyny. ${ }^{132}$ Similarly, foreign alliances were forbidden to Israel (cf., e.g., Deuteronomy 17:16; Isaiah 7; 30:1f.; $31: 1$, and royal polygyny, the means by which such alliances were secured, was condemned both by example (e.g., Solomon in 1 Kings 11:1-10) and by precept in Deuteronomy 17:17.133

Admittedly, the prohibition in this last text, "he [the king] shall not increase wives

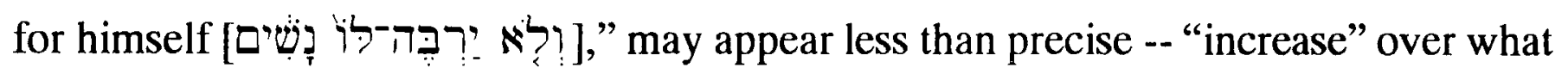

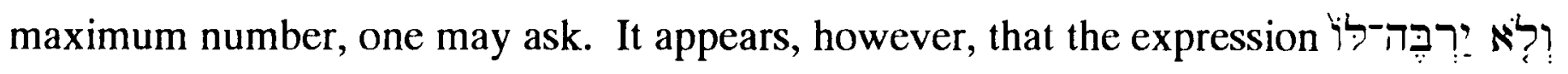

130 R. de Vaux, Ancient Israel, II, 25f.; B. Vawter, Genesis, 76; idem, "The Biblical Theology of Divorce," 223f.; and W. Plautz, "Monogamie und Polygynie im Alten Testament" (1963) 3-6.

Cf. Psalm 128:3 (discussed by W. Plautz, op. cit., 4); Proverbs 5:15-21; 12:4; 18:22; 19:14; 31:1031; Ecclesiastes 9:9; and Song of Songs (according to "the Shepherd Hypothesis"). Other "non-Wisdom" passages could also be added, such as Deuteronomy 28:54, 56, Jeremiah 5:8; 6:11, Malachi 2:14 -- cf. discussion of these verses in W. C. Kaiser Jr., Toward Old Testament Ethics, $189 \mathrm{f}$.

By contrast, texts which attest to the inexpedience of polygyny (factiousness and jealousy of wives, favouritism toward children, etc.) abound. Cf. Genesis 16;21;29-31; 1 Samuel 1 (including the use in vs. 6 of the term צִ צִר , "adversary," for a co-wife); 2 Chronicles 11:21; Deuteronomy 21:15; Sirach 26:6; and $37: 11$.

131 "Monogamie und Polygynie im Alten Testament," 5. Cf. also S. F. Bigger, "Hebrew Marriage and Family in the Old Testament Period" (1974) 86ff. However, as will be argued in Chapter 5 below, this objection appears to be unjustified in the case of Genesis 2.

132 Cf. also W. Berg, who argues that narrative analogy may offer a key to condemning the patriarch's practice of polygyny: Abraham is presented as a second Adam figure, who falls when he heeds the advice of Sarah, his Eve ("Der Sündenfall Abrahams und Saras nach Gen 16,1-6" [1982] 7-14).

Less clear, but nevertheless possible, is the example of Hannah's temporary infertility, which may have motivated Elkanah to take Peninnah as a second wife, but which the text explains was an evidence of Yahweh's judgment (cf., e.g., 1 Samuel 1:5f., 11, perhaps reflected also in Hannah's unwillingness, or inability, to partake of the peace offerings in Shiloh until after Eli's priestly benediction).

133 Cf., also 1 Kings 3:1 and Nehemiah 13:26.

I. Mendelsohn, notes that the anti-monarchical polemic of 1 Samuel 8 and Deuteronomy 17, including its prohibition of royal polygyny, was very likely an early direct repudiation of the excesses of Canaanite kingship, rather than a late reflection of Israel's own bitter experience from Solomon, et al. ("Samuel's Denunciation of Kingship in the Light of the Akkadian Documents from Ugarit" [1956] 17-22). 


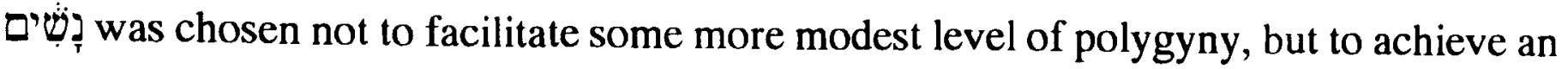
artful parallelism between the three characteristic sins of Canaanite (and Israelite) kingship:

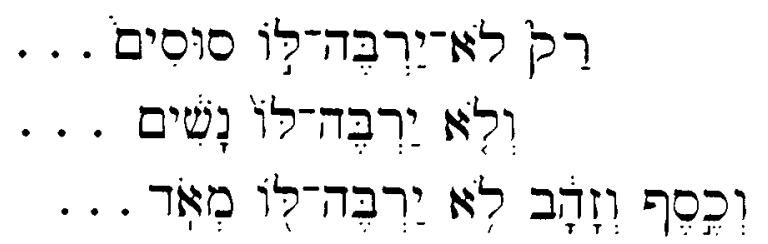

What makes each of these sins particularly dangerous for any would-be king of Israel, the evident reason for conjoining them here, is that each of them constitutes an acute temptation for the king to vaunt himself over his brethren and, especially, to apostatise. As A. D. H. Mayes notes, horses and wealth are the very things which would later lead the king "to pride, to a loss of awareness of the need to trust in Yahweh, and so to unfaithfulness and apostasy" (cf. Isaiah 2:7-9 and Micah 5:10ff.; and for the related problem of an alliance with Egypt, cf. Isaiah 30:1-7; 31:1-3). ${ }^{134}$ Similarly, the prohibition against "increasing" wives is not so much concerned with the legality of polygyny in the abstract, but with the inevitable result of royal polygyny in apostasy and accommodation to the gods of one's wives: as the text explicitly states, "lest his heart turn away" (cf. 1 Kings 11:1ff.; 16:31-33). ${ }^{135}$ Since this danger can attend diplomatic polygyny practiced to any degree and since the text insists that the king not allow his heart to be "lifted above his brethren" or to think himself above the law (vss. 18-20), it appears that the seemingly

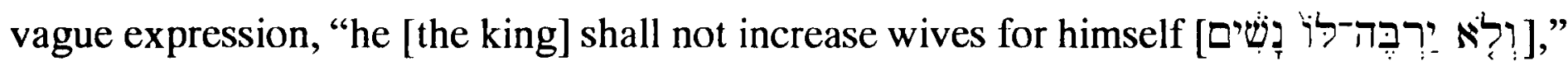
was intended to prohibit the king precisely from having any more wives than would have been permitted other men, just as the parallel lines prohibit him from having any more horses or wealth. ${ }^{136}$ In other words, the Zadokites and community at Qumran do not appear to have been misguided in their interpretation of Deuteronomy 17:17 as requiring monogamous marriage for the king. ${ }^{137}$

134 Deuteronomy (1979) $272 \mathrm{f}$.

135 By its very nature, royal polygyny typically involves foreign, and hence heathen, wives. Cf. especially 1 Kings 11:1-8, where all, or virtually all, of Solomon's wives appear to be of foreign extraction. Cf. also 2 Samuel 3:3; 1 Kings $3: 1 ; 14: 21,31$; and 16:31.

136 It is this implicit comparison with other men which rescues each of these prohibitions from meaningless imprecision.

In terms of this sustained concern to promote humility, if status display was ever a motive for Israelite polygyny, such a motive would also be prohibited to the king.

137 Cf. 11QTemple 57:17-19, "And he (=the king) shall not take in addition to her another wife, for she alone shall be with him all days of her life; but if she dies, then he can take to himself another...."

For the Zadokite interpretation of Deuteronomy 17:17, cf. "Fragments of a Zadokite Sect," 7:4, in R. H. Charles, ed., The Apocrypha and Pseudepigrapha of the Old Testament in English, II (1913) 810. Cf. also G. F. Moore, Judaism in the First Centuries of the Christian Era, I, 202 and R. Holst "Polygamy and the Bible" (1967) 210.

As an aside, it may objected that this prohibition would have been clearer had it simply stated "the king shall not take a second wife," or "shall not have more than one wife," etc. However, given the undeniable right to remarry following divorce or the death of a spouse, the expression as it exists in 17:17 may be deemed adequate. 


\subsubsection{Malachi 2:10-16 and conclusions}

Based on our brief survey above, we may offer the following tentative conclusions regarding the practice of polygyny in the Old Testament:

1) Although polygyny appears to have been practiced within Israel throughout most, if not all of the pre-exilic period, it was largely confined to Israel's chieftains and royalty and only rarely attested outside this circle.

2) Although polygyny was implicitly recognized as constituting a legally valid form of marriage throughout the Old Testament, and although one or two texts even regulate this practice (Deuteronomy 21:15-17 and, perhaps, Exodus 21:10-11), nevertheless no text requires it or commends it as ethically approved.

3) On the other hand, a number of texts appear to advocate monogamy as the assumed, if not also the normative and ideal form of marriage (e.g., Genesis 2; Proverbs; etc.).

4) Consistent with this ideal, other texts demonstrate the inexpedience of polygyny; a few suggest that it was ethically disapproved, and perhaps even prohibited (e.g., Genesis 4:19ff.; Leviticus 18:18; and Deuteronomy 17:17).

5) The two motives for polygyny which seem to have been most generally approved elsewhere in the ancient Near East, namely the securing of diplomatic alliances for leaders and especially a remedy for infertility, were obviated or excluded within the Old Testament. 138 Of course, even apart from this idealistic exclusion, if Malachi 2:15 implies that the Jewish wives of Malachi's day had borne children, then recourse to polygyny under such a circumstance would be unexpected and disapproved even in terms of nonIsraelite norms.

With respect to the post-exilic period in particular, although Malachi 2:10-16 has been supposed by some scholars to assume (A. S. van der Woude) or even to commend polygyny (e.g., H. Cowles and W. F. Luck), it is far more likely that monogamy was seen as the marital ideal in this period and that actual marital practice was monogamous with few, if any, exceptions. ${ }^{139}$ Such an assumption may find some support in the rejection of

138 This is not to deny the existence of many other possible motives for polygyny in the Old Testament, as well as clscwhere in the ancient Near East, including love (Genesis 29:26-30); guilt (2 Samuel 11:27); the desire to please parents (Genesis 27:46; 28:8f.); and perhaps display status (Esther 1,2), among others. However, no law or marriage document appears to accord any of these its approval, while many would penalize the husband who would take a second wife on these grounds (apart from the infertility or grave illness of the first wife).

139 Cf. W. Nowack, Die kleinen Propheten (1922) 417; E. Sellin, Das Zwölfprophetenbuch (1930) 550ff.; R. Yaron, Introduction to the Law of the Aramaic Papyri (1961) 61; B. Vawter, "The Biblical Theology of Divorce" (1967) 223-43; S. Schreiner, "Mischehen-Ehebruch-Ehescheidung" (1979) 226; A. Tosato, "The Law of Leviticus 18:18: A Reexamination" (1984) 199-214; E. Achtemeier, Nahum-Malachi (1986) 181; and B. Glazier-McDonald, Malachi (1987) 114.

As argued by these scholars, Genesis 2:18-25 appears to support monogamy as an ideal and many of the Pentateuchal laws, as well as statements in the wisdom literature, seem to presuppose it as the normal, or ideal, marriage form. Cf., e.g., Exodus 20:7; 21:5; Leviticus 18:8, 16, 18; 20:10; 21:13; Numbers 
polygyny among the Jews in 5th century B.C. Elephantine, as well as in later sectarian Judaism. ${ }^{140}$ In any case, at least in terms of the biblical record there is not a single example of polygyny among the Israelites during the post-exilic period (excluding Esther). Even apart from any considerations of the relevant biblical and epigraphic evidence, however, the rarity of polygyny in Malachi's day should be readily apparent from the sociological observation that polygyny is most commonly associated with men who enjoy considerable wealth and status, characteristics which hardly typified Malachi's beleaguered contemporaries living in the rump state of Judah. ${ }^{141}$

\subsection{Summary}

The present chapter has been concerned to answer an objection of C. C. Torrey, A. Isaksson, and others against a reference to literal marriage in Malachi 2:10-16, and hence against the identification of literal marriage as a "covenant" in 2:14. Their objection is based on a contradiction between the traditional interpretation of these verses and the scholarly assumption that polygyny would have been freely tolerated by Malachi and his contemporaries. More particularly, on the traditional view Malachi condemns both mixed marriage and divorce in 2:10-16 because Israelite men were committing both of these offences when they divorced their Jewish wives in order to marry Gentile women. If polygyny was freely tolerated, there would have been no reason for these divorces; hence, as argued by these scholars, Malachi must not be referring to literal marriage and divorce. ${ }^{142}$

In response we noted that the traditional interpretation of the relationship between the offences of mixed marriage and divorce in Malachi 2:10-16 represents only one of five alternative views, each of which supports a reference to literal marriage. In considering

5:12; Deuteronomy 5:21; 22:22; Proverbs 5:18-20; 12:4; 18:22; 19:13; 31:10-31; Ecclesiastes 9:9; Sirach 26:1-4; Tob 7:12; 8:6-8; and the Damascus Document.

140 Cf., e.g., R. Yaron, Introduction to the Law of the Aramaic Papyri, 60.

This growing tendency to reject polygyny in a more explicit manner may reflect a later tendency to apply earlier priestly standards to the covenant people as a whole. Cf., e.g., D. Bossman, "Ezra's Marriage Reform: Israel Redefined," 37f., and M. Fishbane, Biblical Interpretation in Ancient Israel, 114ff.

In support, it may be noted that there is no clear example of polygyny among the priesthood during the whole of Israel's history. (In favour of Moses as a monogamist, cf. W. Plautz, op. cit., 4, and F. M. Cross, Canaanite Myth and Hebrew Epic, 204). Cf. also the New Testament requirement for church leaders to be the "husband of but one wife" in 1 Timothy 3:2,12; and Titus 1:6, an uncertain expression which may have a more general application, perhaps intending to prohibit remarriage (cf. also 1 Timothy 5:9), but would nevertheless appear to exclude polygyny as well.

141 So also B. Glazier-McDonald, Malachi: The Divine Messenger, 114.

142 As we noted in the course of the chapter, this same argument regarding the apparent contradiction between Malachi 2:10-16, if it refers to mixed marriage and divorce, and the assumed toleration of polygyny elsewhere is advanced by critical scholars to eliminate any reference in Malachi 2:10-16 to the offence of mixed marriage and, alternatively, by A.S. van der Woude to eliminate any reference to the offence of divorce. Neither expedient is required, however, if there is no causal relationship between these offences, as is argued, for example, by J. Wellhausen, et al. See $\$ 4.4$ above. 
each of these alternative views, it appeared that the fourth was the most probable interpretation, namely the view of $\mathrm{J}$. Wellhausen and others that the offences of mixed marriage and divorce were merely parallel examples of the infidelity [בגר] which Malachi condemns in 2:10 and that there was no necessary causal connection between them. As a result, on this view Malachi 2:10-16 carries no implication for the practice of polygyny.

Nevertheless, since the traditional view remains possible, it was necessary to examine the practice of polygyny elsewhere in the Old Testament and particularly in the post-exilic period. In the course of this study it was concluded that, although polygyny was never illegal, monogamy is seen as the marital ideal in a number of texts and that actual marital practice would have been monogamous with few, if any, exceptions, particularly in the post-exilic period.

Consequently, there is no contradiction between Malachi 2:10-16, when understood as referring to literal marriage and divorce, and the probable attitudes toward and practice of polygyny in Malachi's day; hence there is no compelling reason for denying a reference to literal marriage as a "covenant" in 2:14. 


\section{Outline of Chapter 5: \\ Malachi 2:15a: Malachi's appeal to Adam and Eve for his understanding of marriage as a "covenant [בר ["]"}

5.1 Views which considers either $\prod_{\pi} \aleph$ in $15 \mathrm{a} \alpha$ or $\prod_{\pi}$ in $15 \mathrm{a} \gamma$, or both, to refer to Abraham (on these views, $\prod_{\pi}$ is necessarily the subject of its clause).

5.1.1 Objections to views which consider $\prod_{\pi}$ in $15 \mathrm{a} a$ or $\prod_{\tau}$ in $15 \mathrm{a} \gamma$, or both, to refer to Abraham.

5.2 Views which consider $7 \prod_{\pi} \aleph$ to be a reference to God and, consequently,

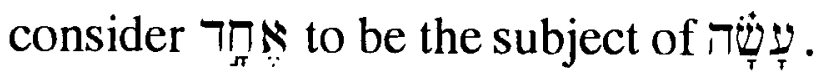

5.2.1 Objections to views which consider $7 \prod_{\pi} \$$ to be a reference to God

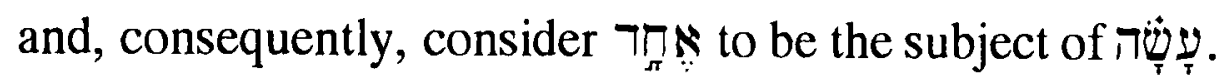

5.3 Views which consider 1 to be employed in a pronominal sense (i.e., איזָר understood as the subject of its clause

5.3.1 Objections to views which consider $\prod_{\pi} \aleph$ to be employed in a

pronominal sense (i.e., לאיאיזד is taken to mean "not one," "no one," or "nobody").

5.4 Views which, following the LXX, emend אָח אחר

5.4.1 Objections to views which emend

5.5 Views which, following the Peshitta, read consequently either delete ${ }_{\pi}$ or construe it as an attributive adjective

5.5.1 Objections to views which read איש

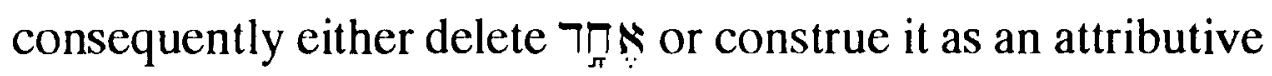
adjective.

5.6 Vicws which consider such,

5.7 Views which consider

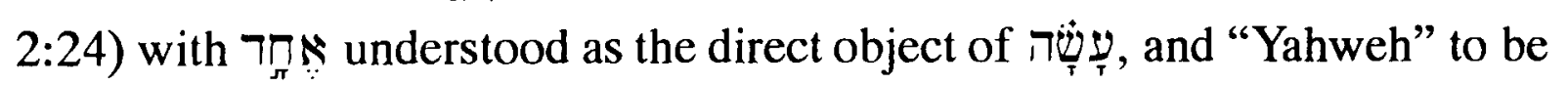
the assumed subject of ע்ָָׁ

5.8 Views which consider $\prod_{\pi} \aleph$ to offer an allusion to the "one flesh" marital unity of Adam and Eve in Genesis 2:24. On this approach $7 \pi \pi_{\pi}$ is the direct object

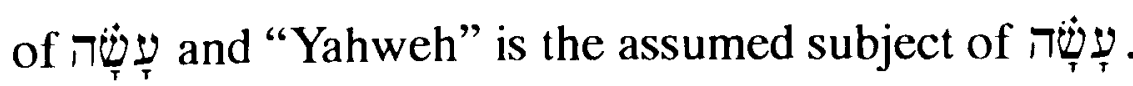

5.8.1 Special features of the present view

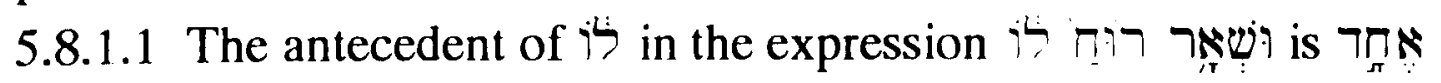
and not Yahweh. 


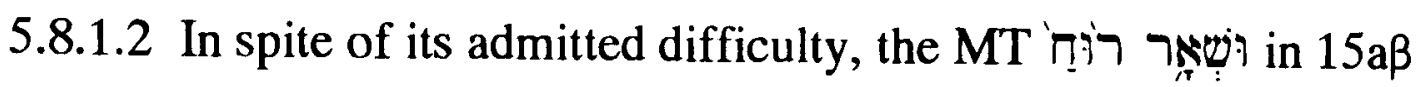
should be maintained

5.8.1.3 The MT of 15ay should be maintained in spite of the evidence of the LXX and 4QXII

5.8.1.4 160

5.8.1.5 זינרע אלדים refers to a "godly generation" which includes, but need not be confined to, literal children in their minority...... 161

5.8.2 Objections raised, and answered, to the present approach which considers Adam and Eve in Genesis 2:24

5.8.2.1 The problem of conjectural textual emendations.

5.8.2.2 The problem of the supposed need for an interrogative $\mathrm{B}$ in $15 \mathrm{a} \alpha$

5.8.2.3 The problem of the use of בר in vs. 10 to refer to God's

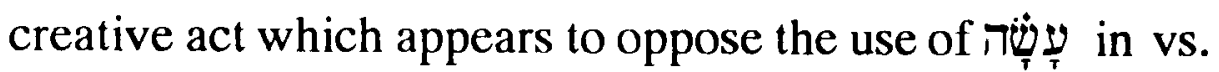
15 as a reference to creation

5.8.2.4 The problem with Yahweh as the assumed antecedent of

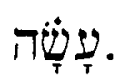

5.8.2.5 The problem with a lack of parsimony in requiring

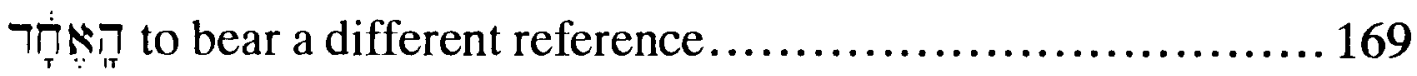

5.8.3 Further support for an allusion to Genesis 2:24 in Malachi 2:15

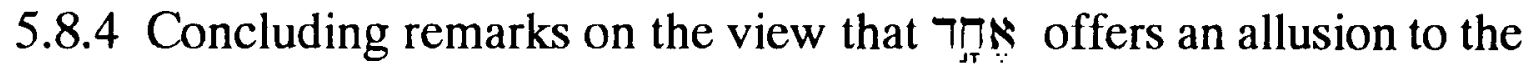
"one flesh" marital unity of Adam and Eve in Genesis 2:24.

5.9 The likelihood that Malachi justified or, perhaps, even derived his view of marriage as a covenant $(2: 14)$ from Genesis $2-3$

5.9.1 Adam and Eve as a paradigm for marriage

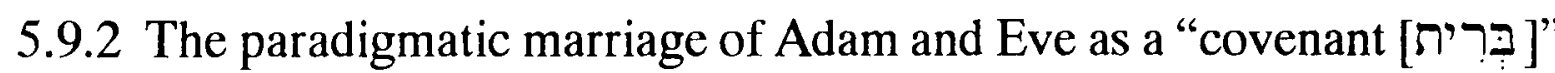

5.9.2.1 "Therefore a man shall leave his father and his mother and cleave to his wife..." (Genesis 2:24a)......................... 178

5.9.2.2 “... and they will become one flesh" (Genesis 2:24b).

5.9.2.3 The Bundesformel: "This at last is bone of my bones and flesh of my flesh..." (Genesis 2:23) 184

5.10 Summary 186 


\section{Chapter 5: \\ Malachi 2:15a: Malachi's appeal to Adam and Eve for his understanding of marriage as a "covenant [ברית"]"}

"Interpreting the text [of Malachi 2:10-16] as a condemnation of divorce means that we are reading into it a view of divorce which was first expounded about 500 years after Malachi and a view of the wife's status in marriage which did not begin to be put into practice in this part of the world until about 2500 years after the prophet Malachi worked there." 1 So writes A. Isaksson, who adds at another point in his discussion, "A really quite decisive argument against interpreting these verses as dealing with marriage and divorce is that the O.T. concept ברית is quite incompatible with what marriage meant at this period. Marriage was not a compact entered into by man and wife with Yahweh as witness but a matter of commercial negotiation between two men."2

While recognizing the intimate connection between the danger of intermarriage and the threat of idolatry which underlies Malachi's condemnation of intermarriage, we have already rejected the view held by Isaksson and others that Malachi was employing the image of marriage merely as a metaphor for idolatry. ${ }^{3}$ Moreover, although in 2:10 refers to Israel's covenant with God which was being desecrated by intermarriage, we have rejected the view that בִּר in vs. 14 refers to Israel's covenant in which the husband and the wife (or, according to some, the wife's family) are considered to be fellow partners, rather than a description of the marital relation itself. 4

However, we still need to consider this more fundamental and intriguing criticism of Isaksson's, namely his assertion that Malachi could not have considered literal marriage and divorce in terms of covenant concepts since such a view of marriage would be unprecedented and anachronistic within the post-exilic period. Of course, if Malachi did indeed consider marriage and divorce in terms of covenant concepts, as we have argued, one cannot rule out a priori the possibility that Malachi was a religio-ethical genius and that he articulated a theory of marriage which was in many profound respects unprecedented. Nevertheless, as Isaksson appears to have appreciated, such an hypothesis of originality is ruled out in the present case precisely because of the manner in which Malachi conducts his argument. Nowhere else is Malachi averse to anticipating objections and misunderstandings on the part of the people, but in 2:10-16 there is not the least hint that

1 A. Isaksson, Marriage and Ministry in the New Temple (1965) 34.

2 Ibid., 31. Isaksson cites in support R. Kraetzschmar, Die Bundesvorstellung im Alten Testament, 168, 240, and C. C. Torrey, "The Prophecy of 'Malachi'," 9.

3 For the danger of idolatry resulting from mixed marriage, cf., e.g., Exodus 34:11-16; Deuteronomy 7:1-4; 1 Kings 11:1-11; Ezra 9:1ff.; and Nehemiah 13:23-31.

4 See $\$ 2.2 .1$ above. 
his contemporaries might object to his identification of their wives as חָברִ In other words, in this section, as throughout his work, Malachi's argument appears to proceed not by way of bold new insights and novelties, but by way of reminder and appeal to the ancient standards and to common convictions (cf. Malachi 3:22 [ET 4:4]). ${ }^{5}$ No doubt some were prepared to justify their divorces and to insist that they had not committed בגד against their wives. Perhaps many even assumed that Yahweh would be indifferent to such acts (cf. $2: 17 ; 3: 15,18$ ) and that he would never act as a "witness" against them and so reject their offerings (2:14, cf. 3:5). ${ }^{6}$ But Malachi's condemnation of his contemporaries would lose all its force if the underlying understanding of marriage as a covenant could not command their assent or could not be substantiated from the ancient texts.

In Chapter 8 we shall attempt to place Malachi's conception of marriage in its proper context in terms of other biblical texts which appear to view marriage as a covenant (or, alternatively, which presuppose such a view). Our immediate concern, however, is to establish the plausibility of that interpretation of Malachi 2:15a according to which Malachi grounds his view of marriage in the "law of my servant Moses" and, specifically, in the paradigmatic "covenantal" marriage of Adam and Eve. ${ }^{7}$ We have already argued (Chapter 1) that Malachi's frequent appeal and allusion to pentateuchal law and traditions makes it likely that he knew the Pentateuch in its final form. Accordingly, the fact that he refers to Genesis 1-2 in 2:15 is widely recognized, although commentators disagree about whether Malachi is referring to the creation of mankind (Genesis 1:27), the creation of Eve (Genesis 2:18-22), or the marriage of Adam and Eve (Genesis 2:24). Since there is this difference of opinion and since there are yet other scholars who find no allusion to Genesis 1-2 here, it is necessary to give a comprehensive survey of the interpretations of this verse, acknowledged to be the most problematic in Malachi. Following this survey, and after supporting an allusion to Genesis 2:24 in Malachi 2:15, we shall then seek to establish that the character of Adam and Eve's marriage would have lent itself to being identified by Malachi as a "covenant [ברּר $]$ ]" (2:14) and, as such, would have provided a plausible justification for Malachi's understanding of marriage.

\footnotetext{
5 For example, Malachi 2:10 begins with the rhetorical question, "Have we not all one Father?" -- a question which presupposes a body of theological common knowledge. Of course, Judah may have been ignoring this fact of its "sonship" and mutual "brotherhood," and certainly many offenders were prepared to conveniently overlook the idolatrous paternity of their foreign wives (hence Malachi's pointed reminder that

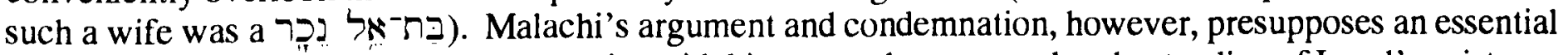
agreement on the part of his contemporaries with his own rather nuanced understanding of Israel's existence as a people in covenant with Yahweh.

6 According to certain interpretations, vs. 15a offers this kind of self-justification, either in terms of an appeal to the example of Abraham, or by reference to the mandate to have children which possibly may have motivated the taking of a new wife.

$7 \mathrm{Cf} . \S \$ 1.2$ and 1.3 above for a defence of the authenticity of 3:22 [ET 4:4] within Malachi and an

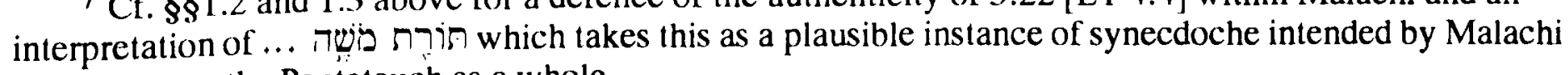
to encompass the Pentateuch as a whole.
} 
To facilitate our discussion of the text, it may help to have before us the following citation of the MT and LXX, with each segment labelled according to a scheme of reference commonly employed among commentators:

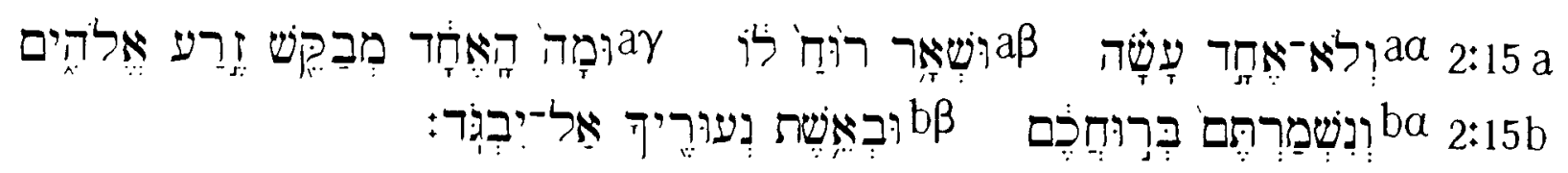

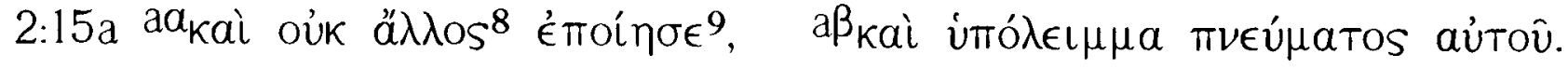

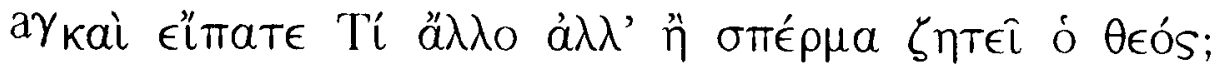

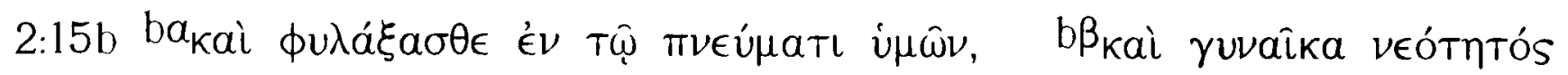

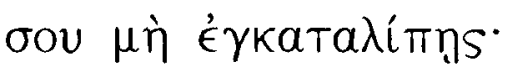

"This is unquestionably the most difficult v. in Mal."10 So noted J. M. P. Smith, who at another point commented, "The beginning of this verse as found in $\mathrm{m}$ is hopelessly obscure."11 After surveying a variety of interpretative approaches, including a conjecture of his own, Smith was forced to conclude, "No satisfactory solution of the problem of this verse has yet been found." 12 Taking account of the proliferation of contradictory attempts to elucidate this verse in the seventy years since Smith, A. S. van der Woude recently observed: "Mal. 2:15 is one of the most difficult passages of the whole Old Testament. It would be a hopeless task to record all the attempts that have been made to explain this verse." 13 It is hard to imagine a greater disincentive to new scholarship than such an assessment coming from a scholar of Van der Woude's stature. Nevertheless, the very proliferation of those failed attempts offers its own witness to the conviction of the majority of modern scholars that the text and sense of Malachi 2:15 may not be so irrecoverable after

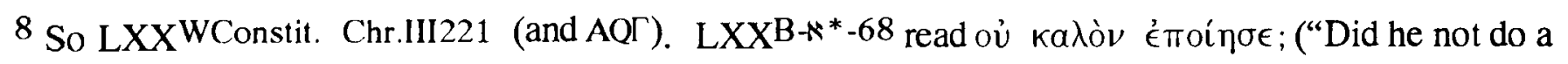
good thing?").

9 So Ziegler's edition (Duodecim Prophetae). A. Ralphs reads émoí $\eta \sigma \in \nu$.

10 A Critical and Exegetical Commentary on Haggai, Zechariah, Malachi and Jonah, 59. Cf. also, e.g., E. Sellin, Das Zwölfprophetenbuch (1922) 553, and W. Rudolph, Haggai, Sacharja 1-8, Sacharja 9-14, Maleachi, 270.

11 Op. cit., 54.

12 lbid., 55.

J. G. Baldwin suggests "Here the text becomes difficult, having suffered perhaps at the hand of scribes who took exception to its teaching" (Haggai, Zechariah, Malachi, 240). A. Tosato makes a similar comment concerning the ancient versions suggesting that perhaps their confusion with regard to 2:15 may be less the result of misunderstanding the meaning of the text than a studied attempt to avoid that meaning ("Il ripudio: delitto e pena [Mal 2,10-16]," 553).

13 "Malachi's Struggle for a Pure Community," 69.

Cf. also the comment of W. Rudolph, "V. 15a is die große crux des Maleachibuchs, und es wäre uferlos, alle vorgetragenen Deutungen Revue passieren zu lassen" (op. cit., 270, n. 15).

Other scholars who share W. Rudolph's and A. S. van der Woude's assessment regarding the difficulty of Malachi 2:15 include J. C. de Moor, De profeet Maleachi (1903) ad loc.; R. C. Dentan, "Malachi," IB, 6 (1956) 1136; and H. Frey, Das Buch der Kirche in der Weltwende (1957) 159; and P. A. Verhoef, Maleachi (1972) 183 . 
all. In any case, although the evidence is such as will require any conclusions to be tentative, the apparent centrality of Malachi 2:15 in Malachi's argument and its potential importance for insight into Malachi's theory of marriage, not to mention its possible bearing on the teaching of Jesus, make imperative the present attempt at understanding.

Although forewarned by Van der Woude specifically about the "hopeless task to record" previous interpretations, the reader's indulgence is asked for the present survey. The justification for such an anthology (with no claim to exhaustive coverage) is the absence elsewhere of a similarly comprehensive list of views, and the help to be gained from such a list in clarifying the interpretative and textual issues posed by Malachi 2:15a. ${ }^{14}$

What emerges from this anthology is a confirmation that the primary interpretative issue of the verse concerns the grammar and reference of distinguished based on whether they consider object of which may be variously "it," referring to the offence described in vs. 14, or, requiring some emendation, "her," or "them" or "זiר) and if so, whether (I.) they consider either $7 \prod_{\pi}$ in $15 \mathrm{aa}$ or $7 \prod_{\tau} \underset{\text { ז }}{\mathrm{N}}$ in $15 \mathrm{a} \gamma$, or both, to refer to Abraham, or whether (II.) they consider $\prod_{\pi}$ to refer to God, or whether (III.) they consider $\prod_{\pi}$ to be employed in a pronominal sense (i.e., לאיאח is taken to mean "no one" or "nobody") or whether, (IV.) they follow the LXX and read

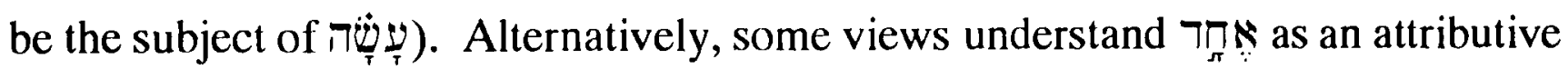
adjective, or delete it altogether, in that (V.) they follow the Peshitta and read $\boldsymbol{N}$ in place

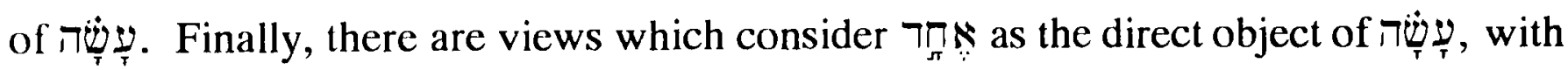
"Yahweh" as its assumed subject. These may be distinguished based on whether (VI.) they consider $7 \prod_{\pi} \times$ to have some reference other than Genesis 1, 2 or whether (VII.) refer to Adam or, alternatively, to Eve or whether (VIII.) marital unity of Adam and Eve in Genesis 2:24.

Within the anthology special cases of each of these eight general approaches are distinguished according to such factors as a) whether or not they consider

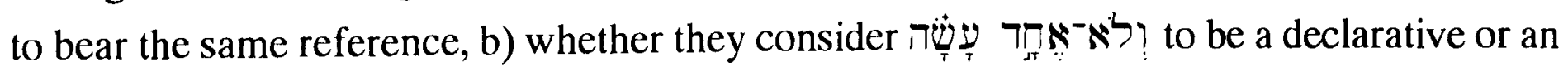
interrogative clause, and c) the manner in which they interpret the phrase,

In addition, within each of these general approaches, there are a number of textcritical issues needing to be decided, perhaps the most important of which focuses, once

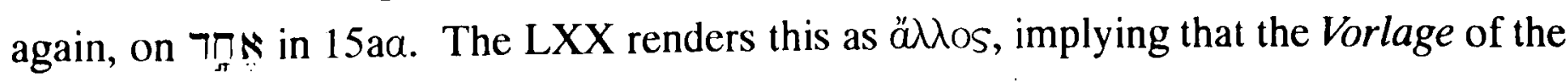

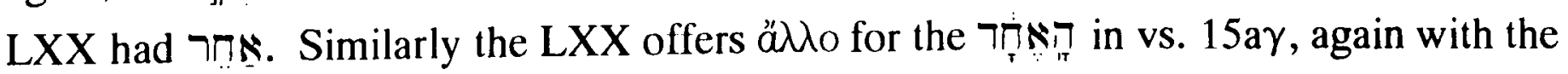
same implication of an original reading of

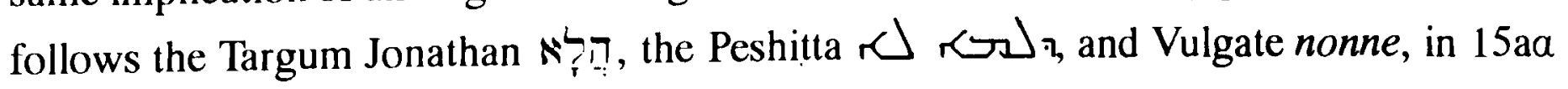

14 Partial lists of views, however, are offered by numcrous scholars. Particularly useful are are those offered by J. C. de Moor, De' Propheet Maleachi (1903), A. von Bulmerincq, Der Prophet Maleachi, 2 vols. (1926-1932), P. A. Verhoef, Maleachi (1972), and B. Glazier-McDonald, Malachi: The Divine Messenger (1987). 


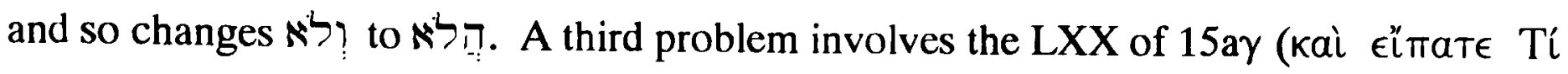

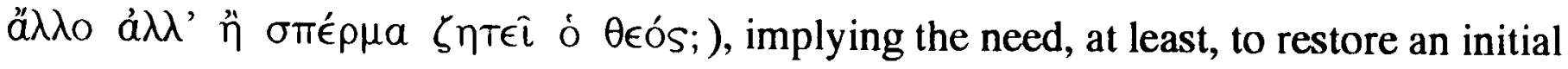

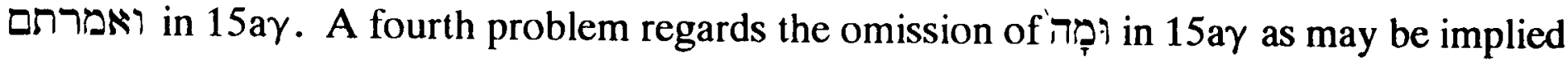
in the Peshitta.

Further, although it does not greatly affect the sense, there are several odd shifts of

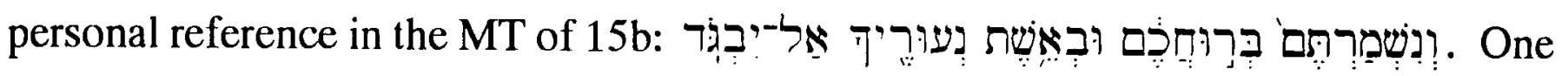
frequent suggestion is to follow the Peshitta and read a third masculine singular suffix,

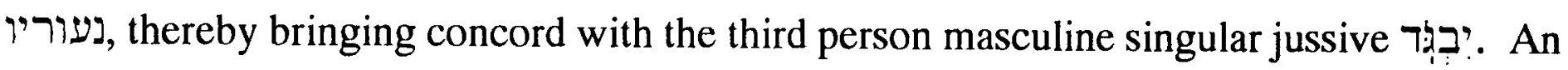
alternative proposal is to follow the LXX, Targum, Vulgate, some MSS of MT and read a second person masculine singular form (תבגד) in place of the jussive.

Finally, numerous emendations ad sensum have also been proposed. 15 Of these,

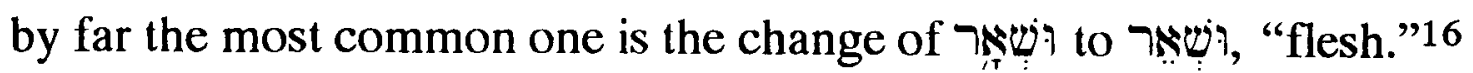

It is impossible within the limits of the present study to assess the individual strengths and weaknesses of each variation of the eight main approaches. Rather, we shall consider only in a general manner each of these approaches, concluding each section with arguments which are applicable to any of the advocates of that particular approach. Following this, we shall present a series of arguments in favour of the eighth approach, that רח a further confirmation of this approach we shall examine Genesis 2 to determine if Malachi was justified in appealing to this text in support of his identification of marriage as a

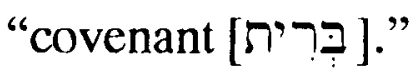

\subsection{Views which consider either $7 \pi$ in $15 \mathrm{a} a$ or $7+1$ in $15 \mathrm{a} \gamma$, or both, to refer to Abraham (on these views $7 \Pi$ is necessarily the subject of its clause)}

With E. Cashdan, we may paraphrase Malachi 2:15a according to its traditional Jewish interpretation as represented by the Midrash, Targum, and Kimchi: "The people defended their conduct of divorcing their wives by saying, 'Did not the one (viz. Abraham, cf. Ezek. xxxiii. 24) do so and marry Hagar? To which the prophet replies, 'Yes, but he had an excellence of spirit; he desired a godly seed." 17 While it may seem contrived, this was also, until modern times, the most common interpretation of vs. 15a among both

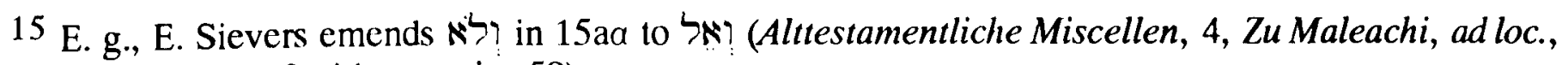
according to J. M. P. Smith, op. cit., 59).

16 This is accepted by, e.g., W. Rudolph, T. Chary, J. G. Baldwin, JB, and NEB.

17 E. Cashdan, "Malachi" (1948) 347.

Cashdan also lists Rashi as supporting this view. A more careful reading of Rashi, however, suggests that he supports this interpretation only for Targum Jonathan, not for the MT. His view concerning the latter is that it refers to Adam and Eve's marital union. 
Catholics and Protestants. Although differing over such matters as whether to take אח Targum Jonathan, W. Drake) and whether or not $\prod_{\pi}$ in 15aa and same antecedent, all those who follow this approach consider that an appeal has been made to some aspect of Abraham's example in support of the practice of mixed marriage.

While Isaiah 51:2 and Ezekiel 33:24 are often appealed to as evidence for an identification of Abraham as the "one" in Malachi 2:15, perhaps a more persuasive argument for the present interpretation is the possibility that refer to Abraham. ${ }^{18}$ In addition, as already pointed out by Martin Luther, the most common form of this view, which construes 2:15a $a$ as an interrogative, has the advantage of allowing vs. 15 to anticipate and answer an objection on the part of Malachi's opponents in a manner which parallels the disputational method used elsewhere in Malachi's book (cf. $1: 2,6,7 ; 2: 14,17 ; \mathrm{cf} .3: 7,8,13 \mathrm{ff}$.). Malachi anticipated that the accused offenders would object, "Did not one (namely father Abraham) do so?" -- that is, when Abraham married the Egyptian woman, Hagar, did he not set a precedent for the kind of exogamous marriage which Malachi was now condemning? Alternatively, when Abraham put away Hagar with God's approval, does his example not sanction the practice of divorce among Malachi's contemporaries?

There are two possible reasons for the relevance of this appellation for Abraham. First, provide a justification for the practice of Malachi's contemporaries: "Did not one do so...?" As J. Calvin notes, "We indeed know how prone men are to pretend the authority of fathers when they wish to cover their own vices." 19 Alternatively the point of this reference may be to underscore precisely the extenuating circumstance which distinguished Abraham's example from the practice of his would-be followers -- he was "one" alone (the point of his being called "one" in Isaiah 51:2 and Ezekiel 33:24) when he took Hagar to have children, while those in Malachi's day were presumably motivated by lust, or some other similarly unworthy purpose. ${ }^{20}$

The principal interpretative issues for those who adhere to this approach concern the following:

1) Whether both the traditional view, e.g., Targum Jonathan, Kimchi, and M. Luther), or whether only the

18 Cf., e.g., T. Laetsch who argues that the appellation “one" emphasizes Abraham's childlessness (Bible Commentary on the Minor Prophets [1956] 528f.). Cf. also W. F. Luck, who favours this view (Divorce and Remarriage [1987] 283, n. 35).

It should be noted that some scholars consider ${ }^{\mathrm{N}} \mathrm{N}$ to be a reference to Abraham in Malachi 2:15 but not in 2:10 (so, e.g., T. Laetsch), just as others favour this identification for 2:10 but not 2:15 (so, e.g., D. R. Jones, Haggai, Zechariah, Malachi, 193-6).

19 John Calvin, Zechariah and Malachi, 554.

20 Ibid., $554 f$. 
הָז sense (e.g., Ibn Ezra, C. F. Keil, F. Hitzig, and C. von Orelli). 21

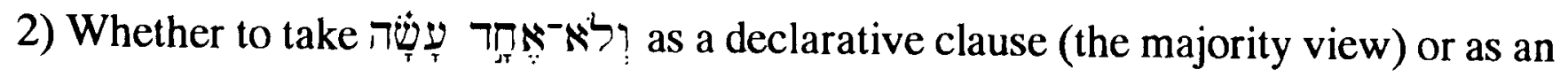
interrogative clause (e.g., Targum Jonathan and J. de Moor). 22

3) Whether vs. 15a consists entirely of Malachi's own words responding to an appeal by Malachi's opponents to Abraham's unsavoury example (e.g., M. Luther, E. F. K. Rosenmüller, J. Halévy, and NIVmargin), or whether Malachi was reporting a dialogue between himself and his opponents (e.g., D. Kimchi, J. C. de Moor, and P. Riessler). If

${ }^{21}$ Specifically, the following take both the האחד in $15 \mathrm{n}$ in 15 as as references to Abraham: Targum Jonathan; J. Kimchi; D. Kimchi; David Altschul (מרורת "מרור")," a seventeenth century commentary included in מקראות גדולות); M. Luther (Lectures on the Minor Prophets, Pt. I, 405); A. Calovius ("Annotata ad Malachiam" [1672-1676] -- according to A. von Bulmerincq); Hugo Grotius (Opera omnia theologica, I, Annotationes ad Vetus Testamentum [1732]); J. D.Michaelis (Die zwölf Kleinen Propheten [1782] -- according to A. von Bulmerincq); E. F. K. Rosenmüller (Scholia in Vetus Testamentum, Partis Septimae, Prophetas Minores Continentis, Volumen Quartum [1816] 396); W. M. L. de Wette (A Critical and Historical Introduction to the Canonical Scriptures of the Old Testament [1843]); M. Sänger (Maleachi [1867] 22-35); J. C. de Moor (De Propheet Maleachi [1903]); J. Halévy ("Le prophète Malachie" [1909] 30-31); T. Laetsch (Bible Commentary on the Minor Prophets [1956] 526-529); and NIVMargin (1978).

Alternatively, the following consider that

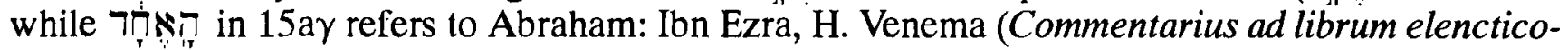
propheticum Malachiae [1763]); F. J. V. D. Maurer, Commentarius grammaticus criticus in Vetus Testamentum, 3 Bde., Malachias: II, 717-36 [1835-38]) and E. Reuss (Die Propheten [1892]) -- the last three according to A. von Bulmerincq, Der Prophet Maleachi, II, 293, 297. So also C. F. Keil (The Twelve Minor Prophets [1868] 452); F. Hitzig (in F. Hitzig and H. Steiner, Die zwölf kleinen Propheten [1881] 424); C. von Orelli (The Twelve Minor Prophets [1893] 395f., a view which von Orelli rejected in his third edition, Die zwölf kleinen Propheten, 3e Aufl. [1908]; W. Drake ("Malachi" [1897]); H. M. Wolf (Haggai and Malachi [1976] 93f.; and W. F. Luck (Divorce and Remarriage [1987] 283).

Finally, J. Bachmann (Dodekapropheton Aeithopum, Heft II: Der Prophet Maleachi [1893] -- according to A. von Bulmerincq) and P. Riessler (Die kleinen Propheten oder das Zwölfprophetenbuch [1911]) consider $7 \Pi \mathbb{N}$ in 15aa to be a reference to Abraham, but urge that

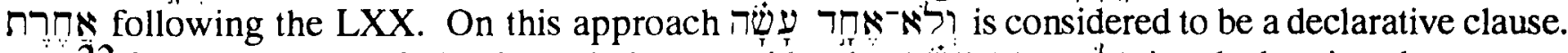

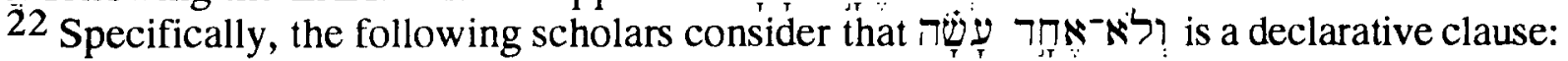

Ibn Ezra; M. Luther (Lectures on the Minor Prophets, Pt. I, 405); A. Calovius ("Annotata ad Malachiam" [1672-1676] -- according to A. von Bulmerincq); H. Venema (Commentarius ad librum elenctico-propheticum Malachiae [1763]); J. D.Michaelis (Die zwölf Kleinen Propheten [1782] -- according to A. von Bulmerincq); E. F. K. Rosenmüller (Scholia in Vetus Testamentum, Partis Septimae, Prophetas Minores Continentis, Volumen Quartum [1816] 396); F. J. V. D. Maurer, Commentarius grammaticus criticus in Vetus Testamentum, 3 Bde., Malachias: II, 717-36 [1835-38]); W. M. L. de Wette (A Critical and Historical Introduction to the Canonical Scriptures of the Old Testament [1843]); C. F. Keil (The Twelve Minor Prophets [1868] 452); F. Hitzig (in F. Hitzig and H. Steiner, Die zwölfkleinen Propheten [1881] 424); E. Reuss (Die Propheten [1892]); J. Bachmann (Dodekapropheton Aeithopum, Heft II: Der Prophet Maleachi [1893] -- according to A. von Bulmerincq); C. von Orelli (The Twelve Minor Prophets [1893] 395f., a view which von Orelli rejected in his third edition, Die zwölfkleinen Propheten, 3e Aufl. [1908]; J. Halévy ("Le prophc̀tc Malachie" [1909] 30-31); P. Riessler (Die kleinen Propheten oder das Zwölfprophetenbuch [1911]); T. Laetsch (Bible Commentary on the Minor Prophets [1956] 526-529); H. M. Wolf (Haggai and Malachi [1976] 93f.; NIVMargin (1978); and W. F. Luck (Divorce and Remarriage [1987] 283).

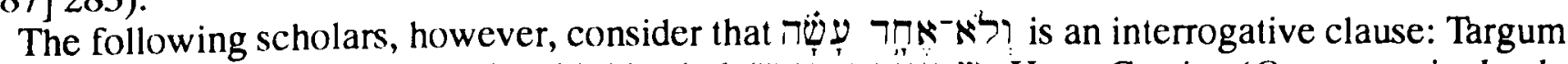
Jonathan; J. Kimchi; D. Kimchi; David Altschul ("מצורת דَרור"), Hugo Grotius (Opera omnia theologica, I, Annotationes ad Vetus Testamentum [1732]); M. Sänger (Maleachi [1867] 22-35); W. Drake ("Malachi" [1897]); and J. C. de Moor (De Propheet Maleachi [1903]) -- the last three so according to A. von Bulmerincq. 
15a constitutes a dialogue, then there is the further question of the precise point where Malachi begins his response, whether with 23

4) What particular aspect of Abraham's example is in view? His marriage to the Egyptian Hagar (e.g., J. Kimchi and E. F. K. Rosenmüller)? His expulsion of Hagar (e.g., M. Sänger)? The fact that he maintained his marriage to the barren Sarah (e.g., P. Riessler)? Or some combination of the above (e.g., J. C. de Moor)? The answer to this question will depend in large measure on the prior decision of whether ולאזיאחד עָשָׁה the words of Malachi or his opponents.

5) Finally there is a question concerning the precise meaning of 'חר in the phrase

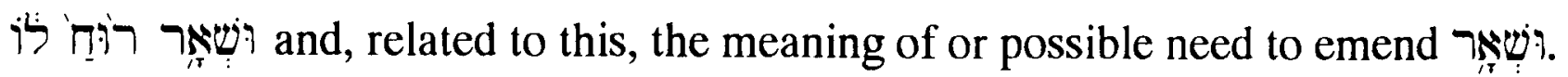

\subsubsection{Objections to views which consider either $15 \mathrm{a}$, or both, to refer to Abraham}

Leaving aside any individual weaknesses of the particular views subsumed under the present approach, here we wish merely to consider in a more general fashion several crucial objections to the underlying assumption of an intended reference to Abraham in Malachi 2:15a.

1) Although, as has been noted, 51:2 and Ezekiel 33:24 with reference to Abraham, neither case offers any real evidence that

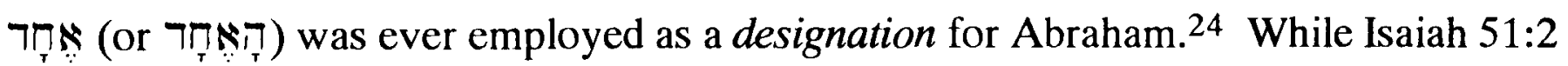

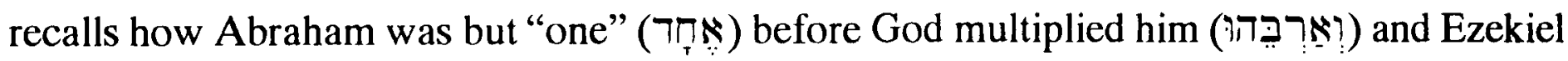
33:24 recalls how Abraham was only “one" (אָָ ) in contrast to Israel's present multitude

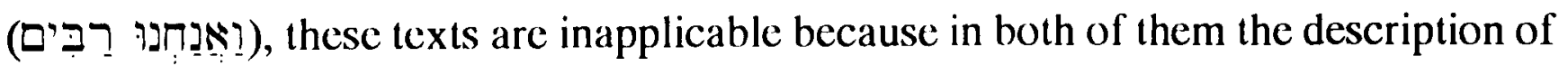
Abraham as "one" is prompted by a pointed contrast to the "many." There is no such contrast in Malachi 2. Morcover, in both Isaiah 51:2 and Ezekicl 33:24 there is an explicit mention of Abraham, which, again, is not the case in Malachi. ${ }^{25}$

2) As argued in $\$ 2.2 .3$ above, the crucial prior identification of $7 \prod_{\uparrow}$ in vs. 10 (bis) as a reference to Abraham is far from certain. While it is true that vs. 10b mentions "the covenant of our fathers," perhaps intending a reference to the patriarchs (although the exodus generation appears more probable), the very presence of a plural form [אברתינו] with reference to those human spiritual fathers would appear to weigh against singling out

23 This issue was discussed already among Abrabanel's contemporaries in the fifteenth century A.D. (so A. von Bulmerincq, Der Prophet Maleachi, II, 292, based on Pococke's treatment of Abrabanel).

24 A similar point is made by, among others, S. R. Driver, The Minor Prophets: Nahum, Habakkuk, Zephaniah, Haggai, Zechariah, Malachi (1906) 316, A. van Hoonacker, Les douze petits prophètes (1908) 727, and W. C. Kaiser Jr., Malachi (1984) 71.

25 So J. Packard, "The Book of Malachi" (1876) 17. 
Abraham as our "one father."26 Furthermore, the synonymous parallelism in vs. 10a between "one Father" and "one God" does not favour a reference to Abraham: "Have we not all one father? Has not one God created us? Why then are we faithless to one another, profaning the covenant of our fathers?" (RSV). ${ }^{27}$ This assumption of synonymous parallelism in vs. 10 between our "one Father" and the "one God" who created us is reinforced by the observation that elsewhere in the Old Testament God is called a "father" precisely because he is the "creator" of his people: Deuteronomy 32:6, Isaiah 63:16, and 64:7 [ET 8]. ${ }^{28}$ When Malachi 2:10-16 is considered as a whole, there is yet further corroboration for a reference to God as "father" in vs. 10, as opposed to Abraham, namely

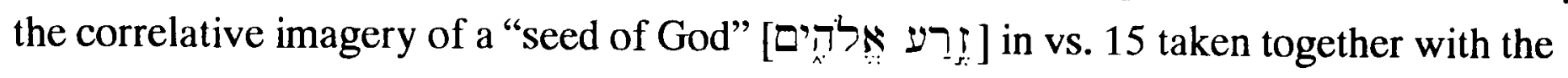

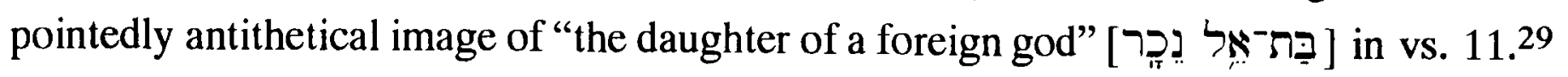

3) It has often been noted that the supposed anticipated objection from Malachi's opponents lacks conviction because Abraham took Hagar at Sarah's request, not as the Jews would later do, in disregard of the wishes of their first wives. In other words, Abraham did not send away Sarah, the wife of his youth, in order to take Hagar. ${ }^{30}$ If the present interpretative approach were correct, it would be difficult to explain why Malachi would fail to emphasize this crucial dissımilarity as a means to condemn more forcefully their practice of divorce, instead of choosing to focus on the seemingly peripheral issue of the way their motive for exogamy differs from that of Abraham, who sought a "godly seed."31

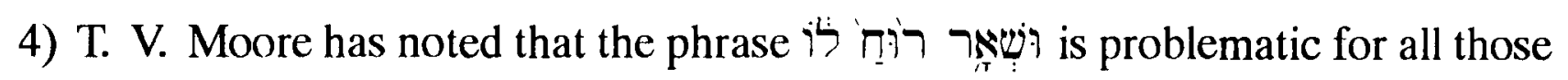
holding to the present line of interpretation. ${ }^{32}$ As we proceed, it will be noticed that this expression is equally problematic on almost every other interpretation as well. However, as discussed above, the rabbinic understanding of שִָׁ as "excellence," an interpretation which is frequently associated with the present view and is perhaps even required by it, is particularly unconvincing and as such, affords further evidence of the inadequacy of the

26 If Malachi intended his hearers to think in terms of merely human spiritual father, his rhetorical question "Have we not all one father" would be answered by verse 10b, "NO! We have many 'fathers,' the covenant of whom we ought not profane!"

27 So E. Henderson, The Twelve Minor Prophets (1858) 453.

28 Cf. R. L. Smith, Micah-Malachi (1984) 321.

29 Cf. P. A. Verhoef, The Books of Haggai and Malachi, 265.

30 This observation is made by G. A. Smith, The Book of the Twelve Prophets, 364, against the view of F. Hitzig and C. von Orelli, and is repeated by, among others, P. A. Verhoef, The Books of Haggai and Malachi, 277. While this argument carries considerable force against the majority of scholars who favour a reference to Abraham in $2: 15$, it does not affect those who consider $2: 15$ a a to be a declarative clause.

Cf. also T. T. Perowne, Malachi (1890) 26, and W. C. Kaiser Jr., Malachi (1984) 71.

$31 \mathrm{~J}$. G. Baldwin seems to be making this same point when she observes, "The disadvantage of these interpretations is that they do not provide the prophet with a very strong case for his main argument" (Haggai, Zechariah, Malachi, 240, n. 1).

32 Op. cit., $135 \mathrm{ff}$. 
view. Putting the matter rather sharply, Calvin writes: "The Rabbins take שאר, shar, as meaning excellence; but I know not what reason have induced them, except that they ventured to change the sense of the word, because they could not otherwise extricate themselves; for the mistake, that Abraham is spoken of here, had wholly possessed their minds." 33

5) The absence of "but you say" (ואמרתם) in vs. 15 is problematic for the present view, since in every other case Malachi employs this formal indicator to make explicit the objections of his opponents. ${ }^{34}$ Strictly speaking, this objection applies only to the

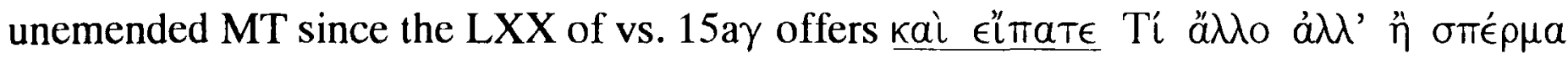

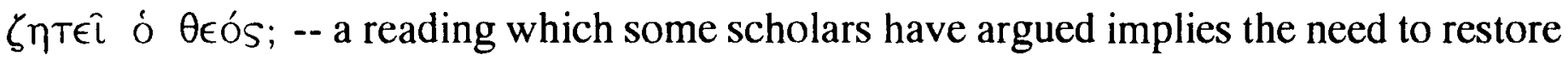

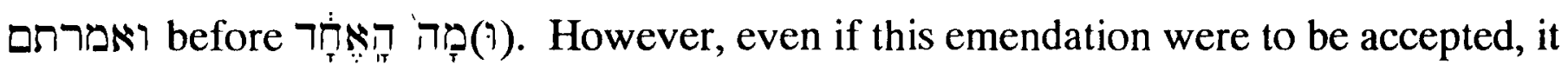
would only support that variety of the present interpretative approach which in other respects has the least to commend it, namely the view that the objection of Malachi's

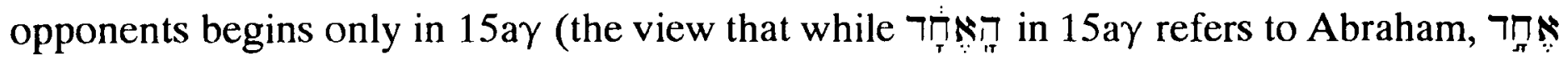
in $15 \mathrm{aa}$ is used as a pronoun,

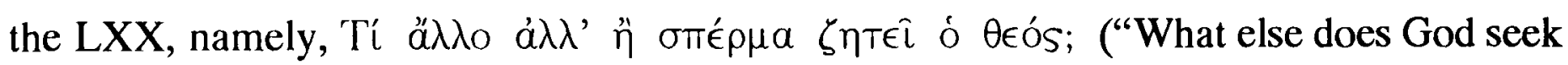
than a seed?"), offers no support for the view that הָז refers to Abraham.

After taking account of the above objections, T. V. Moore was forced to conclude, "This interpretation [which finds a reference to Abraham in 2:15] is so unnatural that it is amazing that it should have been so generally adopted." 36 However, this approach does bear witness to the conviction that Malachi is alluding to Genesis, which we believe is a correct insight.

33 Op. cit., 556.

34 So notes T. V. Moore who calls this omission "fatal" to the present view (A Commentary on Haggai and Malachi [1856] 136). Cf. also W. C. Kaiser Jr., Malachi (1984) 71.

35 Along with most commentators, J. M. P. Smith rejects the LXX here as "almost certainly due to interpretation, and not to the presence of a Heb. equivalent for it" (op. cit., 60). However, it now appears likely that $4 Q X I^{\mathrm{a}}$ supports the LXX based on space considerations for this line. Nevertheless, even if is was originally present in $4 \mathrm{QXII}{ }^{\mathrm{a}}$, it is still possible that this reading is interpretive. Cf. the fuller discussion of $4 \mathrm{QX} \mathrm{II}^{\mathrm{a}}$ below in \$5.8.1.3.

36 T. V. Moore, A Commentary on Haggai and Malachi (1856) $135 \mathrm{ff}$. 


\subsection{Views which consider 7 to be a reference to God and, consequently, consider 7 Th to be the subject of}

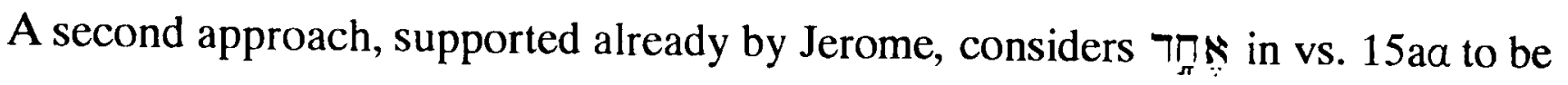

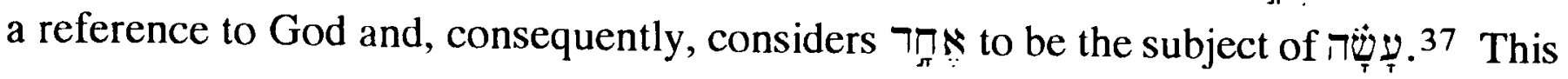
approach, too, finds Genesis to be the key to Malachi's thought.

Typical of those who follow this approach, the NEB renders the verse: "Did not the one God make her, both flesh and spirit? And what does the one God require but godly children? Keep watch on your spirit, and do not be unfaithful to the wife of your youth."38 L. H. Brockington notes that in the first clause the rendering of the NEB presupposes two

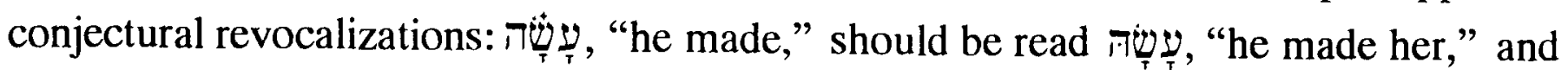

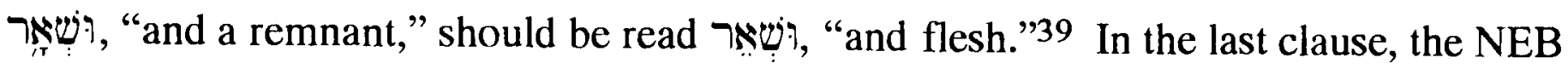
follows the witness of the LXX over the MT and reads a second person masculine singular form (תבגר), "do not be unfaithful," in place of the third person masculine singular jussive יברגלרד

Support for this approach comes mainly from a comparison with Malachi 2:10, where, as has been argued, one of the other patriarchs. Second, it is frequently observed that attribute of Yahweh in Deuteronomy 6:4 and Job 31:15 that it is plausible that it had already become an appellation for the deity in Malachi's day. 40

37 The Vulgate renders 2:15: "nonne unus fecit et residuum spiritus eius est? et quid unus quaerit, nisi semen Dei? custodite ergo spiritum vestrum et uxorem adulescentiae tuae noli despicere" [Didn't the One make [her] and she is a remnant of His spirit? and what does the One seek if not a godly seed? Therefore guard your spirit and do not despise the wife of your youth"]. Cf. also Jerome, Commentariorum in Malachiam Prophetam, ad loc. The writer wishes to express his gratitude to Mr. L. David Green, M.A., of Beverly, Massachusetts, for his help translating Jerome's commentary.

J. Calvin represents Jerome's view as “'Has not one,' that is, God, 'made them?' and then he added, 'And in him alone,' that is, Abraham, 'was an exuberant [?] spirit'" (J. Calvin, Zechariah and Malachi, 555). However, Calvin appears to have misunderstood Jerome (and misled subsequent scholars) when he implies that Jerome intended a reference to Abraham in vs. $15 \mathrm{a} \beta$. Neither the Vulgate nor Jerome's commentary on Malachi suggests such a reference. In fact, in commenting on vs. $15 \mathrm{a} \beta$, Jerome explicitly discusses a difference of opinion in his day concerning the antecedent of $i$, some holding that it referred to God, and others to the husband -- but there is not even the mention of a third view which would refer it to Abraham: "Et residuum spiritus eius, sive Dei, ut quidam putant, sive mariti, ut alii suspicantur ..." ["And the residue of his spirit, whether of God, as some think, or of the husband, as others suspect..."] (In Malachiam, PL 1561 [lines 450f. in the Corpus Christianorum edition]). It is not uncommon for Jerome to leave undecided an interpretative issue such as this.

$38 \mathrm{Cf}$. also the view of J. Wellhausen (Die kleinen Propheten, 3 Aufl. [1898] 53). Wellhausen

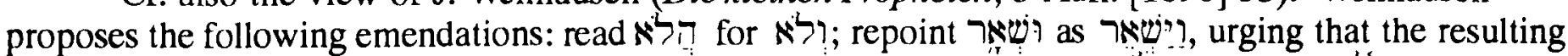
sense would be "and he maintained (or preserved) breath (or spirit);" correct is in 15a Wellhausen suggested reading the 2 m.s. has the support of the LXX, Targum, Vulgate, and some MSS of MT. As a result, Wellhausen renders the verse, "Hat nicht der selbe Gott euch den Athem geschaffen und erhalten? und was verlangt er? Samen Gottes! Also nehmt euch in Acht für euer Leben und brecht eurem Jugendweibe nicht die Treue" [= "Has not the same God made and preserved for us the breath (of life)? And what does he seek? A seed of God. Therefore, take heed for your lives and do not break faith with the wife of your youth"].

39 L. H. Brockington, The Hebrew Text of the Old Testament (1973).

40 Among those who follow the present general approach are Jerome (Commentariorum in Malachiam Prophetam]), C. à Lapide (Commentaria in duodecim prophetas minores [1625]), L. de Dieu (Critica sacra [1693]), A. Calmet (Les douze petits prophetes [1715]), L. Reinke (Der Prophet Maleachi [1856]), G. H. A. 
The most crucial difference among scholars who take this approach is,

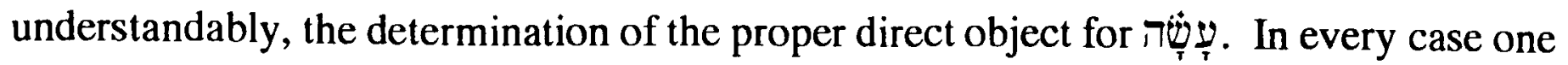
must hold that the direct object has been elided and can be assumed from the context, or it is necessary to emend the text in order to recover the otherwise missing direct object. A secondary issue among scholars taking this approach concerns their acceptance of the MT

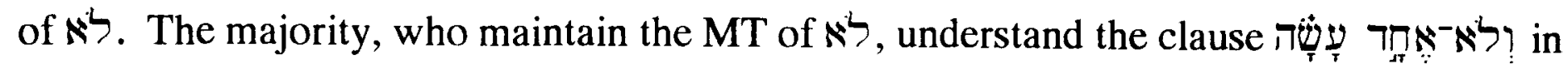
an interrogative sense. A few scholars, however, emend לא לא and, consequently, are able to interpret the clause as a declarative.

\subsubsection{Objections to views which consider

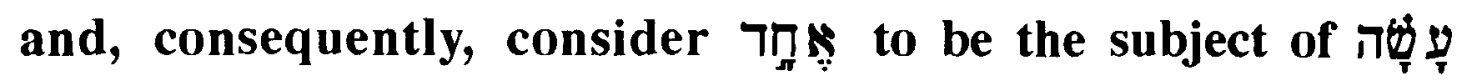

This interpretative approach entails the following difficulties:

1) In spite of the popularity and modesty of the proposed repointing of remnant," as וּשְֵּׁ, "and flesh," it is nevertheless opposed by the versions which uniformly

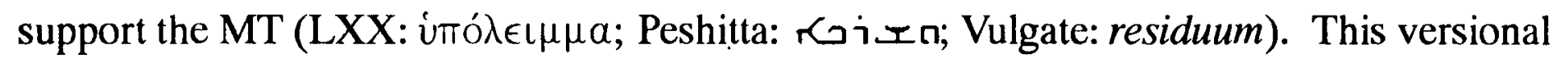
support is made all the more striking because of the numerous divergences among these same versions elsewhere in the versc. Mivieover, while this conjecture is undeniably attractive on other interpretations of the verse, on the present interpretation it appears less so, since the expression "both flesh and spirit" adds little to the rhetorical question, "Did not the one God make her...?"41

2) W. C. Kaiser Jr. has objected to the present view, "why this stress on the oneness of God in a text where the oneness of marriage is at stake?"42 This problem is perhaps most acute in a rendering of 2:15a such as is posited by L. Sabottka: "For the

von Ewald (Commentary on the Books of Haggái, Zakharya, Mal'aki, Yona, Barâkh, Daniel [1881]), W. Nowack (Die kleinen Propheten [1 Aufl. 1897 and 2 Aufl. 1903, but not 3. Aufl. 1922]), J. Wellhausen (Die kleinen Propheten, 3 Aufl. [1898]), S. R. Driver (The Minor Prophets: Nahum, Habakkuk, Zephaniah, Haggai, Zechariah, Malachi [1906]), C. von Orelli (Die zwölfkleinen Propheten (3 Aufl. [1908 -- this view is not supported in earlier editions]), O. Isopescul (Der Prophet Malachias [1908]), M. Haller (Das

Judentum. Geschichtsschreibung, Prophetie und Gesetzgebung nach dem Exil, 2 Aufl. [1925 -- this view is not supported in the 1st edition]), and J. Ridderbos (De Kleine Profeten [1968] 208f.).

The following scholars emend $\kappa^{2}$ as and, consequently, consider 15 aa to be a declarative clause: E. Sievers (Alttestamentliche Miscellen, 4: Zu Maleachi [1905]), O. Procksch (Die kleinen prophetischen Schriften nach dem Exil [1916]), and L. H. Brockington ("Malachi" [1962] 657). In most cases those who follow this approach consider the direct object in 15aa to be "her," which is recovered by repointing MT

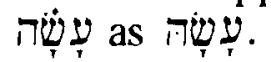

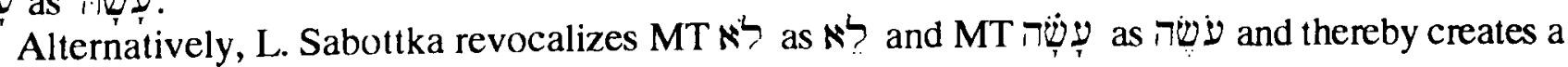
nominal clause (Zephanja [1972] 17f.).

41 Why would it be necessary to stress that God made the wife, both flesh and spirit? Would anyone have supposed that only her flesh was made by God, or alternatively, only her spirit?

Rather similar to the NEB is the rendering offered in The Holy Bible. An American Translation, William F. Beck, translator (1976): "Did not the one God make her? Her flesh and spirit belong to Him. And what does the one God want but godly offspring. Then watch your own spirit and don't be disloyal to the wife of your youth."

${ }^{42}$ Malachi. God's Unchanging Love (1984) 72. 
Almighty, the One, is the creator; so the body and the spirit is his." While these assertions concerning "the Almighty" appear profound, they have little to do with the context and do not materially advance Malachi's argument against his contemporaries for the mistreatment of their wives.

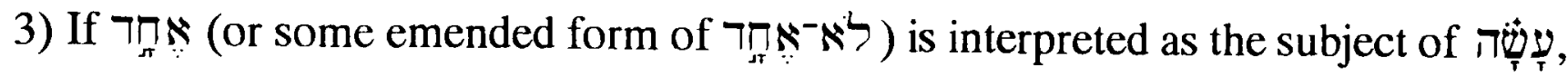
as is the case on the present approach, then $15 \mathrm{a} a$ lacks an obligatory direct object. Consequently, all interpreters who follow this approach are forced to posit, without versional support, an emendation of the text to recover the "missing" object or to argue that the object may be assumed from the context.

4) The present interpretative approach cannot easily account for why

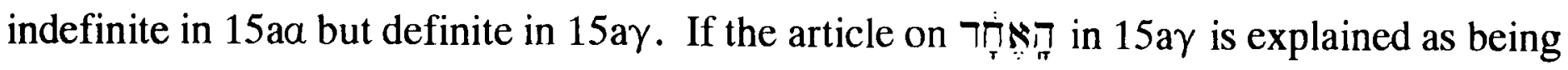
due to its backward reference to the inexplicable the absence of the article on $\prod_{\pi}$ in $15 \mathrm{a} a$, which, on the present view, similarly refers back to the on $7 \prod_{r}$ in $15 \mathrm{a} \gamma$ is employed to indicate that this substantive is well-known (GKC $\$ 126 \mathrm{~d}$; Williams, Syntax $\$ \S 85,88$ ), in other words, that this is not just any "one" but "the One," that is, God, then once again this renders inexplicable the absence of the article on $15 \mathrm{a} a$, if this too is not just any "one."

Scholars supporting the present approach appear to solve this crucial problem of the lack of an article on $15 \mathrm{aa}$ in one of two ways. Either they do so by proposing an emendation of לאי, so that of E. Sievers, et al.), or they seek to identify $7 \prod_{\tau} \aleph$ as an appellation for the deity. Since we have already considered the doubtful merit of the proposed emendation of ל ל , here we need consider only this second alternative. If would yield a ready solution to the problem at hand since appellations are notoriously whimsical in their use of (or lack of) the article, even within a single verse. For example, out of the forty-three verses in the Bible where these cases one of the references has the article (usually the first) while the other does not. $^{43}$

Is it likely, however, that $7 \prod_{\tau}$ by itself could serve as an appellation for God? While אחר is attested as a name for God in later Judaism, K. Marti has argued against J. Wellhausen expressing his doubt that $\prod_{\tau}$ would have been employed by Malachi in this

43 Examples of this sort of thing could be multiplied with other similar appellations (where common nouns have come to be used in a manner which approximates a proper noun) such as (T), with reference to Gibeah; (ד) (ד) (ד) "the rock" as a designation of God, appearing both with and without the article in Deuteronomy 32:4, 18, 37. Because this is such an early poetic text, however, the lack of the article may be explained more probably as an archaism or as due to the demands of prosody. 
manner. 44 To the same effect, T. Chary cites É. Dhorme as stating that in the Bible itself is nowhere used as a name for God. ${ }^{45}$ Certainly, the use of important for those who identify it is significant that $7 \prod_{\tau}$ does not stand alone in Malachi 2:10, as it does in 2:15, but appears there only as an attributive adjective modifying first אָ it is this difficulty which has motivated scholars like E. Sievers to emend the MT in 2:15aa to $2: 10.46$ In the absence of any versional support, however, this conjectured emendation is not convincing.

Deuteronomy 6:4 is also frequently cited in support of identifying $\prod_{\tau} \mathrm{s}$ as a divine appellation; this comparison, however, has force only on two of the most recent, and perhaps least plausible interpretations of that verse, namely the view of C. H. Gordon ("Yahweh is "One") and that of M. Dahood ("Yahweh our God is the Unique"). 47 On any of the four historic and most commonly held interpretations of Deuteronomy 6:4, not an appellative, but only a predicate or attributive adjective: "Yahweh our God, [even] Yahweh is one [or 'unique']," "Yahweh is our God, Yahweh is one [or 'unique']," "Yahweh is our God, Yahweh alone," or "Yahweh our God is one Yahweh").48

There are two other texts which are also cited in support of the interpretation of as a divine appellation: Job 31:15 and Zechariah 14:9. On closer examination, however, neither requires this conclusion. In pleading his innocence of perfidy even against his

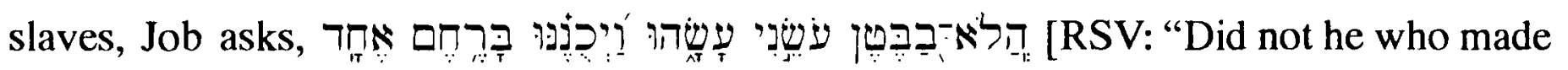
me in the womb make him? And did not one fashion us in the womb?"] (Job 31:15). Even if $ר$ for the deity (hence the use of the lower case "one" in the RSV, for example).

Alternatively, it is possible with the LXX that modifying רח: "And did he not fashion us in one [or, the same] womb?" Since it is

44 For אח 'ähä̀d einer," THAT, I, 107. Cf. K. Marti, Das Dodekapropheton (1904) 471.

45 Aggée - Zacharie - Malachie (1969) 261. Chary does not document this opinion of Dhorme. Dhorme acknowledges that appellative. He renders this verse, "Was it not He who made me who made him in the womb also, And was it not He alone [italics added] who formed us in the womb?"

46 This proposal may have been prompted by the complaint of $H$. Venema that had Malachi intended

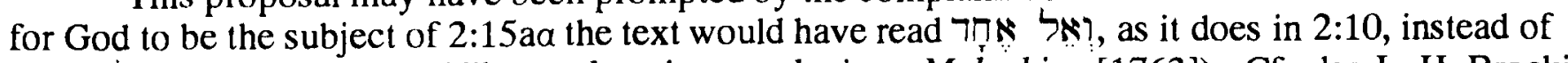
ולאז-אחר (Commentarius ad librum elenctico-propheticum Malachiae [1763]). Cf. also L. H. Brockington ("Malachi" [1962] 657).

47 Cf. C. H. Gordon, "His Name is 'One”" (1970) 198f., and M. Dahood, with T. Penar, "UgariticHebrew Parallel Pairs," RSP I (1972) 361.

48 Cf. S. R. Driver, Deuteronomy, 89f., and P. C. Craigie, Deuteronomy, 168f.

N. Lohfink suggests a further possibility, relating where the term is used in an endearing manner. Lohfink interpretatively renders the verse, "Yahweh is Israel's only one and unique one" ("א "echädh," TDOT, I, 196).

Without attempting to enter into the vast literature on the Shema', still useful is the frequently cited article of G. A. F. Knight, "The Lord is One" (1967/68) 8-10. 
doubtful that Job and his slave were uterine brothers, presumably "womb" here is to be understood in a poetic sense, much as in Job 1:21, "Naked I came from my mother's womb, and naked I shall return." 49

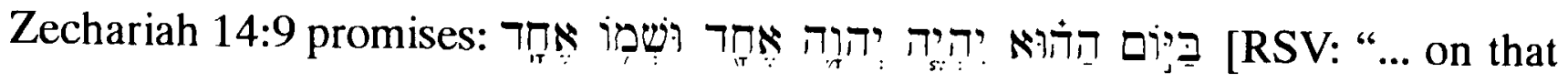
day the LORD will be one and his name one"]. While one could render name will be 'One'," this is opposed not only by the apparent underlying allusion to

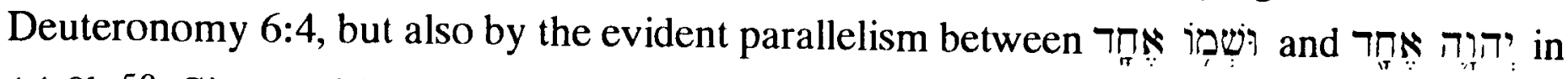

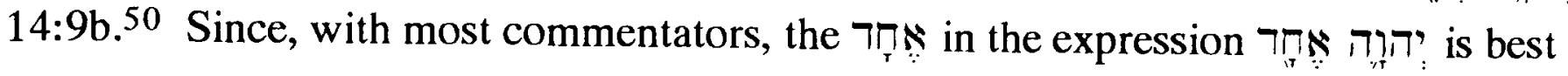
understood as an attributive adjective (whether "one" or "unique" or "alone," or perhaps "unrivalled"), it appears that this provides the most likely interpretation of the second as well: not that "his name will be 'One'," but that "his name will be one (or 'unrivalled,' etc.)."51 Appropriately, H. G. Mitchell sums up Zechariah's promise, "Yahweh shall then be worshipped by all men, and that under the one name, Yahweh, revealed to the Chosen People."52

In conclusion, given the very limited number of examples elsewhere in the biblical corpus where closer examination, the contention that $\$$ should be thus understood in Malachi 2:15

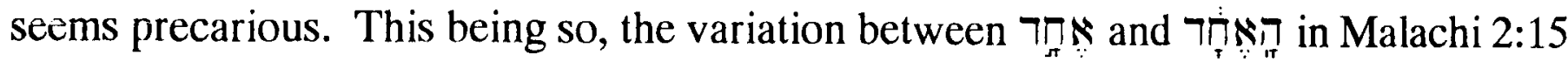
remains unexplained.

We conclude that though the attempt to explain Malachi 2:15 in the light of Genesis is attractive, ultimately this view which takes "one" in vs. $15 \mathrm{a} \alpha$ as a reference to God the Creator is fraught with difficulty.

\subsection{Views which consider $7 \underline{\$}$ to be employed in a pronominal sense (i.e.,} רח is taken to mean "not one," "no one," or "nobody") with

\section{understood as the subject of its clause}

Currently, perhaps the most popular interpretation of Malachi 2:15 among scholars is that

49 In support of this interpretation of Job 31:15, cf., e.g., J. H. Kroeze, Het Boek Job (1961) 356f. J. E. Hartley excludes this interpretation of the MT on the basis of the qāmes in $\square$ ח imply an article (The Book of Job, 414, n. 3). Cf., however, GKC §102f. and Lambdin §29d.

50 On this allusion to Deuteronomy 6:4, cf. S. Dean McBride Jr., "The Yoke of the Kingdom" (1973) 278, n. 10, and R. L. Smith, Micah-Malachi (1984) 289.

51 Cf., e.g., W. Rudolph, Haggai, Sacharja 1-8, Sacharja 9-14, Maleachi (1976) 230, 232, and 236. In further support, cf. the similar promise that "his name will be great" in Psalm 76:2 [ET 1]. Cf. also such passages as Proverbs 18:10 and Isaiah 12:4.

52 H. G. Mitchell, J. M. P. Smith, J. A. Bewer, A Critical and Exegetical Commentary on Haggai, Zechariah, Malachi and Jonah (1912) 347. Cr. also J. G. Baldwin, Haggai, Zechariah, Malachi, 203f. 
mean "not one," "no one," or "nobody."53 So, for example, S. Schreiner renders Malachi 2:15, "Und niemand tut (so etwas), sofern er einen Rest von Verstand besitzt; denn was sucht derjenige (der so etwas tut): Kinder! Doch bewahrt (euch) euren Verstand, und die Frau seiner Jugend behandele niemand treulos."54

In support of this approach, it is often noted that $\boldsymbol{k} ל+\underset{7}{ } \boldsymbol{s}$ elsewhere bears a similar pronominal meaning in a number of passages, including Exodus 8:27 [ET 31], 9:6; נולאיאח עִ עָָׁה to be a declarative clause (K. Budde is a notable exception), nevertheless, there are considerable differences over the precise interpretation of the text, particularly of $15 \mathrm{a} \gamma$, and the possible need for textual emendation (although it is a notable strength of this view that a number of scholars support the unemended MT in 15a: for example, A. B. Ehrlich, P. M. Schumpp, S. Schreiner, A. Tosato, C. Locher, P. A. Verhoef, and B. Glazier-McDonald).

\subsubsection{Objections to views which consider pronominal sense (i.e., לאיצות is taken to mean "not one," "no one," or "nobody")}

While one may wonder about the justification for Schreiner's parenthetical addition, "so etwas," found nowhere in the text, and doubt Schreiner's interpretation of רֶּ "Verstand," unsupported by BDB, KB, or THAT, the most serious difficulty with Schreiner's understanding of vs. 15 has to do with the resulting logic of vss. 14-16, as Schreiner construes these verses. As noted by W. Rudolph, it would be very strange for Malachi to insist that divorce is perfidy in $14 \mathrm{~b}, 15 \mathrm{~b}$, and $16 \mathrm{~b}$ and that it is a moral and religious offence of such gravity that it causes Yahweh to reject Israel's sacrifices, while in vs. $15 \mathrm{a}$ it is suddenly branded as mere stupidity! 55

In addition to these and other difficulties with the various particular views of scholars following the present approach, there are a number of more fundamental objections which have been raised against this approach which considers employed in a pronominal sense:

53 The present view is held by the following scholars among others: B. Duhm (Die zwölf Propheten in den Versmassen der Urschrift übersetzt [1910]), A. B. Ehrlich (Randglossen zur hebräischen Bibel (V [1912] 360), A. von Bulmerincq ("Die Mischehen im B. Maleachi" [1926] and Der Prophet Maleachi, II [1932] 290ff.), F. Horst (Nahum bis Maleachi [1964] 268), I. G. Matthews ("Haggai (Malachi" [1935] 23f.), K. Elliger (Das Buch der zwölfkleinen Propheten II [1950] 189), D. R. Jones (Haggai, Zechariah, Malachi [1962]), A. Tosato ("Il ripudio: delitto e pena [Mal 2,10-16]" [1978] 552), S. Schreiner ("Mischehen Ehebruch - Ehescheidung. Betrachtungen zu Mal 2 10-16" [1979] 217), P. M. Schumpp (Das Buch der zwölf Propheten [1950] 393), P. A. Verhoef (Maleachi [1972] and The Books of Haggai and Malachi [1987]), and B. Glazier-McDonald (Malachi: The Divine Messenger [1987]).

54 "Mischehen - Ehebruch - Ehescheidung. Betrachtungen zu Mal 2 10-16" (1979) 217: “And no one does (any such thing), so long as he has an ounce of intelligence/understanding; for what does such a one seek (who does any such thing): Children! So guard (for yourselves) your intelligence/understanding, and let no one treat the wife of his youth faithlessly."

55 "Zu Malachi 2:10-16" (1981) 85-90. 
1) Various scholars have noted the inherent difficulty which this view seems to

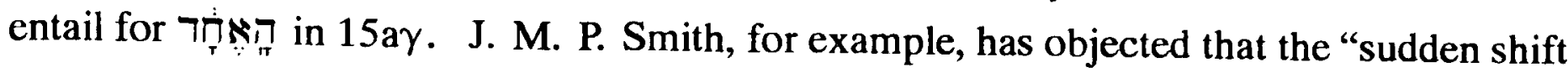
of stand-point in the word 'one' is most remarkable and unnatural."56 Putting this same objection somewhat differently, Van der Woude simply asserts, "it is unlikely that the author of the verse could refer to 'no one' by 'that one' (hä'ehād)."57

2) J. Packard, among others, has noted that the present view assumes an ellipsis of the direct object of דָז

3) Packard further objects to the present view noting that an interrogative sense appears to be indicated for $15 \mathrm{a} a$ both by the position of clause, and by the explicit question introduced by the first clause by 7$) .59$

4) Finally, Packard and others note that the pronominal rendering "no one" for

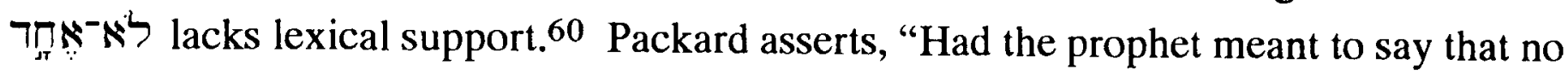
one ever did so, he would have used אין, as as Gen. xxix. 11, or simply Packard is cited approvingly by W. C. Kaiser Jr., it appears that this assertion somewhat oversimplifies the evidence. ${ }^{61}$ While it is true that the Old Testament does commonly use איץ to mean "no one," this is by no means its exclusive practice, ${ }^{62}$ and, in fact, אין are nowhere employed with a perfect, as would be required in the present

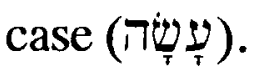

Nevertheless, the essence of Packard's objection stands. The vast majority of times when an Old Testament author intends to say "no one ... [some verb in the perfect]" this is accomplished by employing לא ל + לאיא + a perfect (as in Genesis 41:44), or more simply + a perfect (as in Genesis 41:21), or even ל ל + a third person plural perfect (as in Genesis

56 Op. cit., 55.

57 Op. cit., 69. Cf. J. Packard, who notes that the presence of an article on the second "one," החוזר, favours a reference back to the first "one," א א ("The Book of Malachi" [1876] 17).

K. Budde appears to have appreciated this difficulty when he suggested that the MT הָָ represents a corruption from an original $\mathrm{N}$. Indeed, had Malachi intended what the present interpretation alleges, one might have expected the text to have read $\mathrm{N}$. However, this emendation is purely conjectural, lacking any versional support.

58 J. Packard, "The Book of Malachi" (1876) 17. Similarly, J. M. P. Smith objects to the RVmargin, "And not one hath done so who had a residue of the spirit...," because "so" is missing from the MT (op. cit., 54).

59 Cf. also J. Owen's comment: "The position of the words shows that it is a question, for there is no interrogative particle. So it is in our language, 'Has he not made one?' And that it is a question, is evident from what follows, 'and why one?"' (John Owen, translator, in John Calvin, Zechariah and Malachi, 555, n. 1). J. M. P. Smith notes, "it is in an unusual position for the subject of a verbal sentence, unless it is intended to be emphatic; and it is just as abnormal a position for the object" (op. cit., 59). This argument favouring an interrogative sense for $15 \mathrm{a} a$ will be developed more fully at the end of the present chapter.

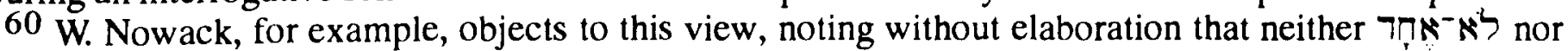
กำ bear the alleged meanings (op. cit., 420).

61 W. C. Kaiser Jr., Malachi (1984) 72.

62 The NIV Old Testament, for example, offers the rendering "no one" 293 times, two of which occur in the Aramaic portion of Daniel. Of the Hebrew occurrences, nearly one half of them, that is, 139 out of

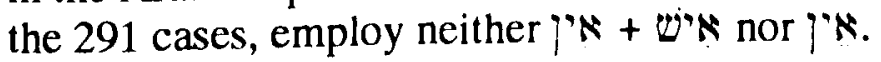


26:22 and 35:5). On the other hand, against the present view no example of offers clear support for the pronominal rendering posited for Malachi 2:15. Although in its various forms occurs some six hundred and ninety-nine times in the Old Testament, ${ }^{63}$

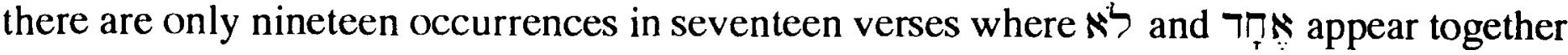
within the same clause, ${ }^{64}$ and of these, there are only three verses where the precise phrase לא אֶחר is attested: the Kethib of Psalm 139:16, Job 14:4, and Malachi 2:15.65

Considering first the sixteen occurrences where לא and occur together, but not

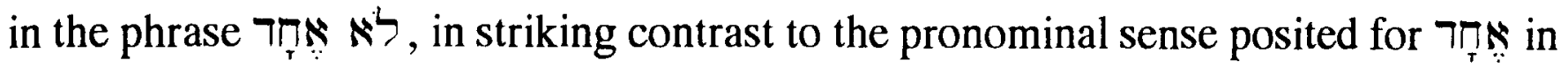
Malachi 2:15, in none of these cases does Instead, in each case the numerical sense of

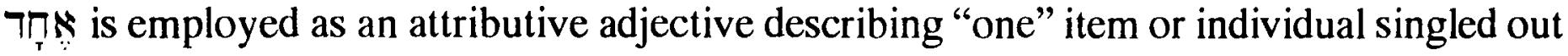
from, or contrasted with, a larger number mentioned in the context (i.e., Numbers 11:19, 35:30, Deuteronomy 19:15, Joshua 17:17, 23:14 [bis], and 1 Kings 8:56). In eight other examples, singled out from, or contrasted with, a larger number mentioned in the context (i.e., Exodus 8:27 [ET 31]; 10:19) and is often accompanied by either מִ , hence "one out of" (i.e., Exodus 9:6, Numbers 16:15 [bis], 2 Samuel 13:30, and Psalm 106:11) or $\exists$ (i.e., 2 Samuel 17:12).

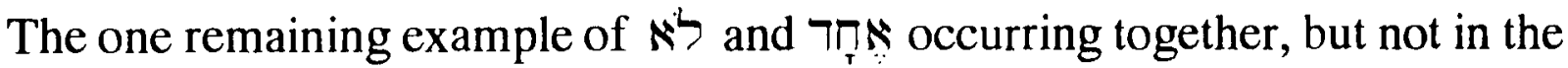

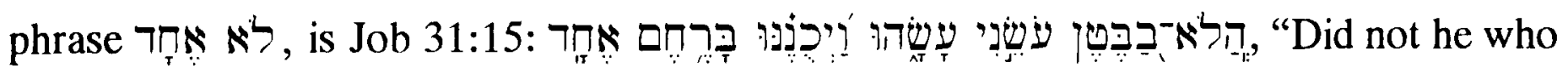
made me in the womb make him? And did not one fashion us in the womb?" (RSV). However, there are two difficulties about this example which require special comment. First, on almost any interpretation, it is necessary to assume that לא ל has been elided in the second clause. Second, as we noted earlier ( $\$ 5.2 .1$ above), it is uncertain whether $7 \prod_{n} \aleph$ should be understood as a reference to God, "And did not one [or, the same God] fashion us in the womb?" or whether $7 \prod_{n} \aleph$ should be understood as an attributive adjective modifying ?ח, that is, "And did he not fashion us in one [or, the same] womb?" Although this later interpretation of Job 31:15 may be preferable, ${ }^{66}$ on either interpretation רח appears to have been chosen in order to emphasize the fact that Job and his slave had one rather than two distinct origins.

Turning, finally, to the two examples (apart from Malachi 2:15) where the precise

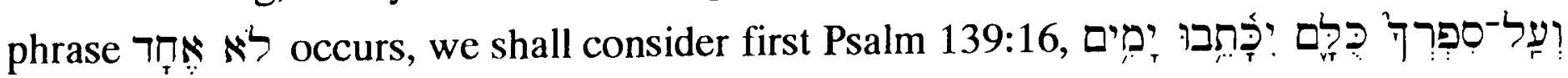
"All the days ordained for me were written in your book when as

63 So Even-Shoshan, s.v.

64 I.e., Exodus 8:27; 9:6; 10:19; Numbers 11:19; 16:15; 35:30; Deuteronomy 19:15; Joshua 17:17; 23:14; 2 Samuel 13:30; 17:12; 1 Kings 8:56; Malachi 2:15; Psalms 106:11; 139:16 (Kethib); Job 14:4; and $31: 15$.

65 אח 65 is equally rare, occurring only in Psalm 14:3, its parallel, Psalm 53:4 (ET 53:3), and Daniel 10:21.

66 Cf. J. H. Kroeze, Het Boek Job (1961) 346f. 
yet there was not one of them." Unfortunately, the case of Psalm 139:16 is difficult, requiring the resolution of several lexical and text-critical uncertainties, not the least of which is the need to decide whether to follow the Qere reading of לו לא in place of thus eliminating this example altogether. If one accepts the Kethib, however, once again employed as a cardinal and not an indefinite pronoun, with its numerical sense emphasized both by contrast to "all of them [the days]," mentioned earlier in the verse, and by the

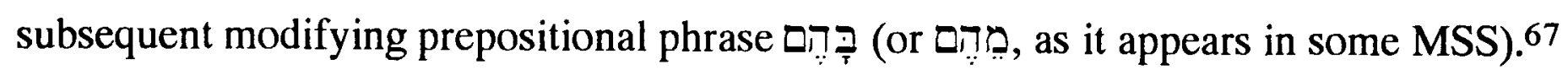

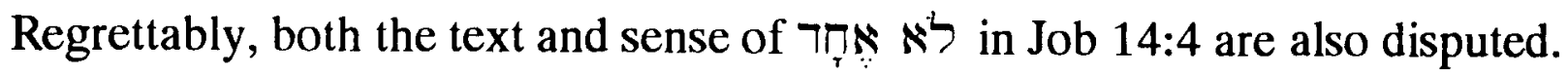
Having asked the question, "Who can bring what is pure out from the impure," the answer

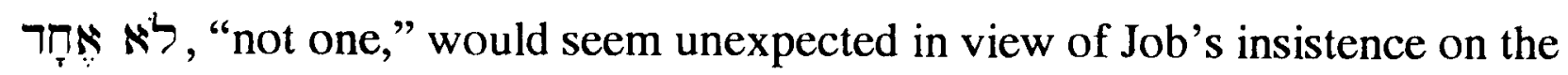
omnipotence of God. As a result, a number of scholars have suggested following the sense of the Vulgate (which offers, nonne tu qui solus est ["is it not you alone?"]) and the Targum (which adds, "except God") and emend the MT, for example, repointing לא לא "ל, "the Mighty One."68 F. I. Andersen, who notes that Hebrew normally expresses the idea "not one" by employing the negative existential predicator $\rceil \aleph$, offers the alternative suggestion that perhaps On this approach Job 14:4 would then, presumably, be interpreted with the Vulgate as an unmarked rhetorical interrogative: "Is it not 'The One'?" Whatever the proper solution might be to Job 14:4, M. H. Pope has argued that from a metrical point of view the MT לא אֶָר appears to be "entirely too short."70

Thus, with so many uncertainties surrounding Job $14: 4$, it would appear unwise to allow this single example to overturn the impression gained from the widely established

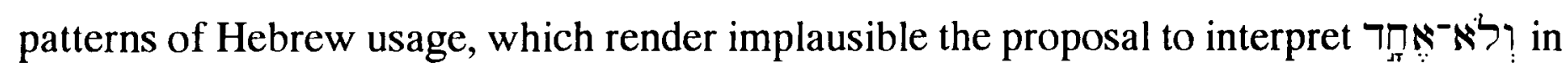
Malachi 2:15 in a pronominal sense.

\subsection{Views which, following the LXX, emend 7 , to}

J. Ziegler offers the following restored text for the LXX in Malachi 2:15: kai oủk

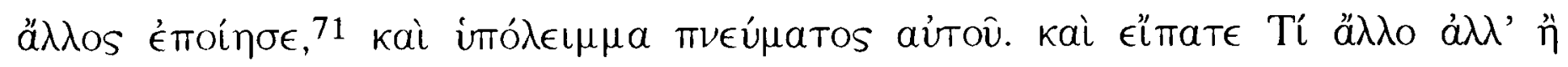

67 A. A. Anderson, Psalms, II, 910, considers the MT of 139:16b (לא אחר כרכתם) to be "obscure," as does L. C. Allen, Psalms 101-150, 252, n. 16d., and M. Dahood, Psalms III, 295 (who attempts to resolve this "baffling" phrase by repointing אח as a Niphal).

In support of the MT we may note that we have already considered a number of examples where modified by a prepositional phrase introduced by $¥$ or (i.e., Exodus 9:6; Numbers 16:15 [bis]; Joshua 23:14 [bis]; 2 Samuel 13:30; 17:12; 1 Kings 8:56; and Psalm 106:11).

68 Cf. M. Dahood, Psalms I, 46, 144; idem, Psalms II, 212-213; and idem, "Hebrew-Ugaritic Lexicography IV (1966) 408. Cf. RSP III, I, 118f, h; A. C. M. Blommerde, Northwest Semitic Grammar and Job (1969) 118; L. Sabottka, Zephanja (1972) 17f.; F. I. Andersen, Job (1976) 171; and E. B. Smick, "Job" (1988) 926.

$69 \mathrm{Job}, 171$.

$70 \mathrm{Job}(1973) 106 \mathrm{f}$.

71 A. Ralphs' edition of the LXX offers é $\operatorname{l}$ roí $\eta \sigma \in v$. 


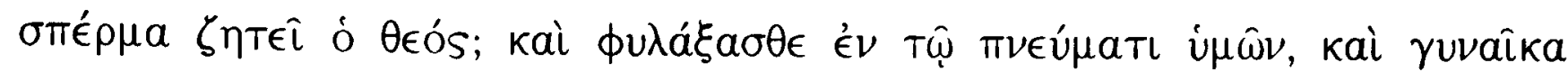

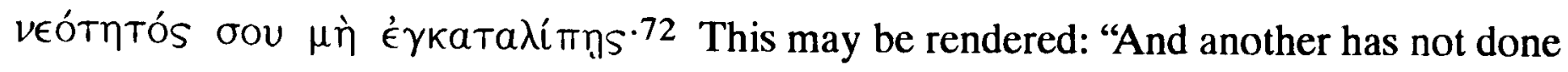
[so], and [there was] a remnant of his spirit. But you say, "What else does God seek but a seed?' But guard your spirit, and do not forsake the wife of your youth."73

Commenting on the LXX of Malachi 2:15, J. Packard once wrote, "The Septuagint translator seems to have given his understanding a holiday, and made his pen supply its place."74 The harshness of Packard's criticism, however, may have been due in large part to the inferior text of the LXX to which he and most older commentators had access. This emphasizes the first need which much be addressed with respect to the LXX, namely, the need to establish the text of the LXX itself. Once this is done, we shall then consider the value of the LXX as a witness to a Hebrew Vorlage, which may have differed from the MT and by which the MT might need to be corrected.

1) With respect to the text of the LXX in 15aa, while Ziegler's conjectured original

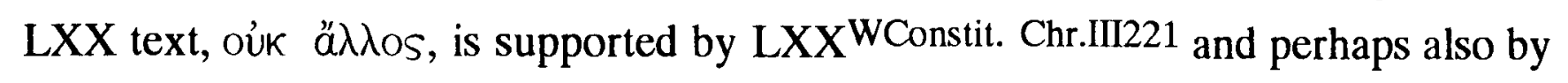

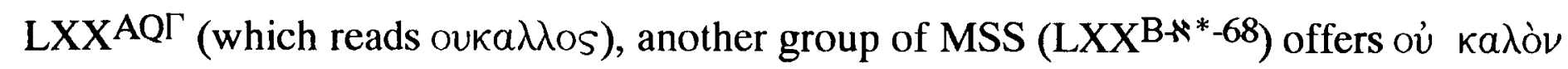
É $\pi \circ i \eta \sigma \epsilon(v)$; (“did he not do a good thing?"), which is the reading reproduced in most of the older printed editions of the LXX and presumably was the reading to which Packard was referring. Besides this alternative reading, it should be noted that $\mathrm{LXX}^{\aleph 2.86}$ reads kaì ou

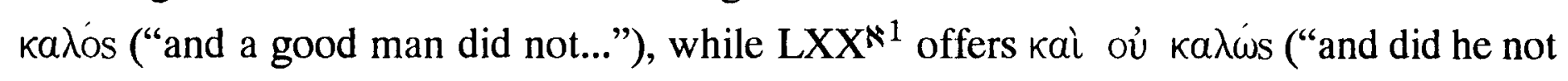
do well?"). ${ }^{75}$ As J. M. P. Smith, A. von Bulmerincq, and others have argued, these alternative readings almost certainly represent inner-Greek corruptions. The proper word division is most probably ouk $a \lambda \lambda \mathrm{OS}$ or, less likely, ouk $a \lambda \lambda \mathrm{o \nu .}{ }^{76}$ This fact can be further established by the evidence of the daughter versions, which, except for the Slavic, uniformly support the proposed division. ${ }^{77}$ The patristic evidence likewise supports this division. 78

2) The restored LXX differs from the MT in four respects. First, the reading of kai

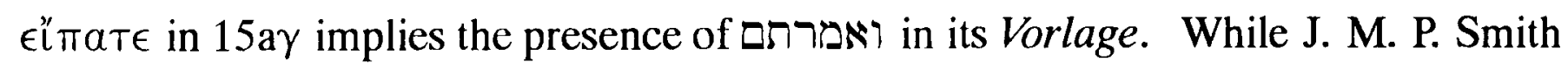

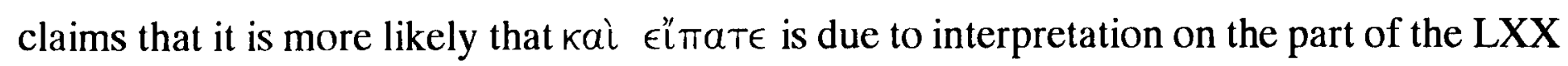
translator, rather than to a Vorlage which differed from the MT, it now appears that the inclusion of may be supported by 4QXIIa, based on considerations of line length. ${ }^{79}$

72 J. Ziegler, Duodecim prophetae (1984).

73 I.e., "And nobody else has done [so]...."

74 "The Book of Malachi" (1876) 16.

75 Cf. J. M. P. Smith, "A Note on Malachi 2:15a," 205.

76 Cf. J. M. P. Smith, "A Note on Malachi 2:15a," 205; J. M. P. Smith, Malachi, 59; and A. von Bulmerineq, Der Prophet Maleachi, II, 295.

77 Cf. A. von Bulmerincq, who offers the various readings of the Arabic, Syro-hexapla, Ethiopic, Old Latin (fragmenta Sangallensia), Armenian, and Coptic (Bohairic) versions (op. cit.).

${ }_{78} \mathrm{~A}$. von Bulmerincq mentions Theodor and Theodoret, both of whom read oùk ä $\lambda \lambda$ os, while LXXV

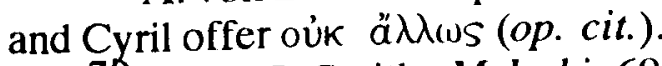

79 J. M. P. Smith, Malachi, 60. See also $\$ 5.8 .1 .3$ below. 


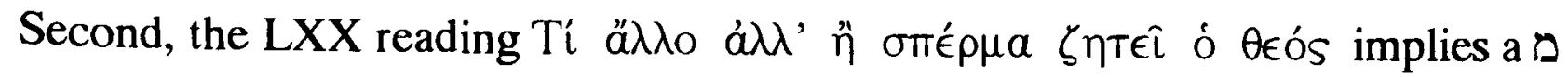

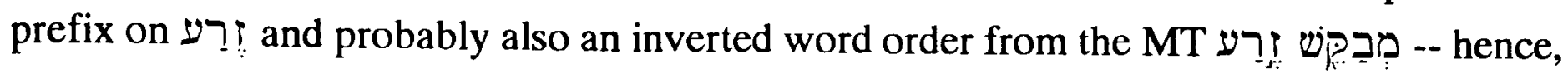

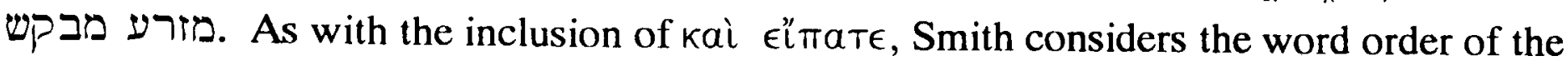
LXX to be due to interpretation and concludes, "the sense secured is not sufficiently strong to carry these textual changes." Unfortunately, the text of $4 \mathrm{QXII}{ }^{\mathrm{a}}$ is not preserved in $15 \mathrm{a}$, and so, apart from the indirect evidence of line length mentioned above, it neither confirms nor challenges the reading of the LXX. As is suggested by ;Smith's claim that the LXX is "interpretative," the sense of the LXX is not so radically different from the MT (apart from the introductory, "but you say") as to be demonstrably inappropriate in the context.

Nevertheless, it is only on the assumption of the priority of the MT that one can best account for all the versional evidence in $15 \mathrm{a} \gamma$. In further support of the superiority of the MT, as we have noted in another context the phrase זٕרע אל sems particularly apt in

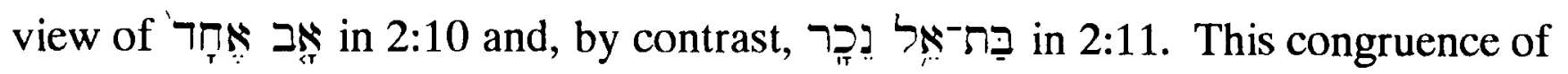
imagery seems unlikely to be merely coincidental and, hence, supports the MT (and Peshitta, Targum, and Vulgate) over against the LXX.

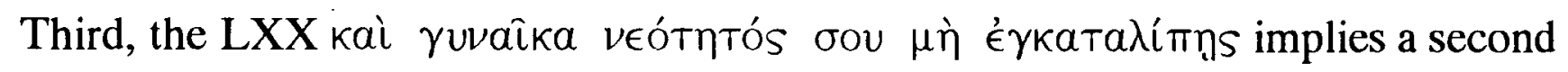
masculine singular form תבגד in place of the third masculine singular jussive resolving an awkward shift in personal reference in the MT of $15 \mathrm{~b} \beta$. Although this emendation is favoured by J. Wellhausen and A. van Hoonacker, among other scholars, and has the support of the Targum and Vulgate, it appears preferable to maintain the MT as the lectio difficilior. Not only does Hebrew tolerate such shifts in personal reference, making this emendation unnecessary, but also by maintaining the MT a more adequate account can be given for the alternative reading of the Peshitta, which resolves the same conflict in a different manner, namely by reading a third masculine singular suffix, נעוריו 80 Without implying a different Vorlage, it should be mentioned that the LXX

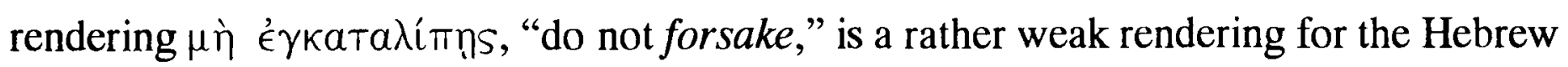
אל-יבגּר

Finally, perhaps the most significant discrepancy between the LXX and the MT involves the rendering a ${ }^{\prime} \lambda$ os $_{\text {in }} 15 \mathrm{aa}$, suggesting that the Vorlage of the LXX had Similarly, the LXX offers ố $\lambda$ o for the that its Vorlage read אח. While A. von Bulmerincq follows O. Isopescul in assuming that אחר is merely a graphic variant for the more original easily argue that the MT אח is a graphic variant for an original

80 In defence of such shifts of personal reference, cf. A. S. van der Woude, who cites C. F. Keil, P. A. Verhoef, and S. Schreiner in support of maintaining the MT in Malachi 2:15b while noting the similar difficulty in Isaiah 1:29 and Psalm 49:20 ("Malachi's Struggle for a Pure Community," 70, n. 30).

81 Cf. W. E. Barnes, Malachi with Notes and Introduction, ad loc.

82 A. von Bulmerincq, op. cit., 40f. Cf. also P. A. Verhoef, who considers the LXX reading, "and nobody else," to be an example of "Fehlerkonsequenz, because one error leads to a following one" (The Books of Haggai and Malachi, 276). 


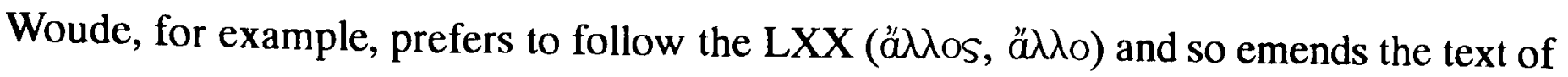
the MT to Jew," a meaning that he claims is widely attested in later Hebrew.83 Thus Van der Woude renders the verse: "A foreigner does not do this, as long as he has a remnant of spirit. What is such a foreigner? One who wants godly children! Then take heed to your spirit and let no one be unfaithful to the wife of your youth." 84

One may question, however, the likelihood that a passage which is so inimical to mixed marriage and idolatry would turn around and appeal to those very idolatrous foreigners as examples of proper behaviour to rebuke apostate Israelites. Furthermore, Van

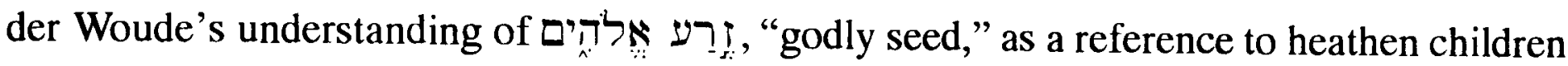
who are faithful to the idols of their forebears seems contrived, and his definition of referring to "foreigner" or "non-Jew" is unconvincing. While Van der Woude appeals to Jastrow for support that this usage is "widely attested in later Hebrew," this does not suffice because Jastrow makes explicit that this usage refers only to plural forms of

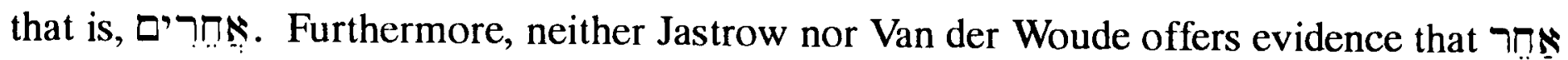
in any of its forms can bear this meaning in isolation. That is, while Gentiles in a particular context, as it does in the two examples cited by Jastrow, it does not mean "Gentiles." 85 In other words, the practice of later Hebrew does not appear to differ from that of Biblical Hebrew, which Van der Woude fails to mention, where forms of

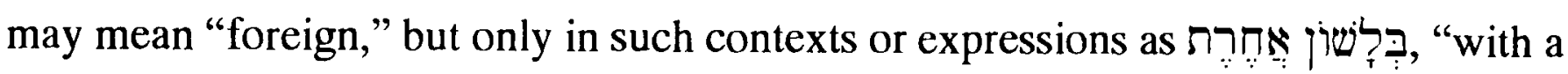
another/foreign language" (Isaiah 28:11), לעיטם אַחר], "to a another/foreign people" (Deuteronomy 28:32),

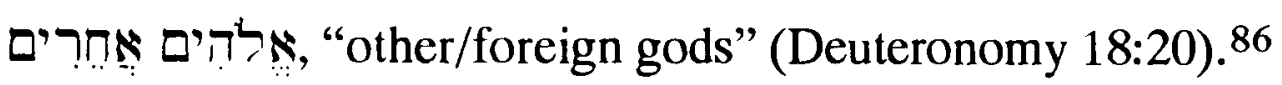

83 A. S. van der Woude, "Malachi's Struggle for a Pure Community," 69f. In support of this statement Van der Woude cites Jastrow, I, 41. Cf. also A. S. van der Woude, Haggai, Maleachi (1982) 116, 121-123.

84 So A. S. van der Woude, "Malachi's Struggle for a Pure Community," 70. In Haggai, Maleachi, 116, Van der Woude understands רִ רomewhat differently, rendering this term "bezinning" ["sense"]: "Een vreemde doet zo niet, zolang hij een rest van bezinning heeft. Hoe is die vreemde? Iemand die streeft naar een godsfamilie! Bewaart dus uw bezinning! Handel niet ontrouw jegens de vrouw van uw jeugd!"

85 The two examples cited by Jastrow for this usage demonstrate the inapplicability of this evidence for Malachi 2:15. The first example is $b$. San. 52b, "Our Rabbis taught: And the man that committeth adultery with another man's wife, even he that committeth adultery with his neighbour's wife, the adulterer and the adulteress shall surely be put to death.... 'with his neighbour's wife' excludes the wife of others [פרט לאשת אחרים]." Although this last expression is rendered by Jastrow as "the wife of a non-Israelite," this rendering is unnecessarily interpretative and fails to reflect the plural form of אחרים. To be sure the context makes clear that the reference of presumably, Gentiles, but the traditional more literal rendering, "excludes the wife of others," appears to be entirely adequate.

Jastrow's second example, b. B. Mes. 111b, is similar: "Thou shall not oppress an hired servant that is poor and needy, whether he be of thy brethren' - this excludes others [פרט לאחרים]...." While the context makes clear that "others" refers to persons who are not "thy brethren," hence Gentiles, once again this example fails to support the claim that אחרים means "Gentiles" apart from such a context. Cf. J. Neusner, for example, who retains the more literal rendering of "אר in such contexts as "others" (The Talmud of Babylonia, An American Translation. Volume XXID: Tractate Bava Mesia Chapters 7-10 [1990] 167).

86 אלדים אחרים אחר "appears sixty-three times. Cf. S. Erlandsson, TDOT, I, 201-203. 


\subsubsection{Objections to views which emend}

We now turn to a more general consideration of the value of the LXX in 2:15. As noted earlier, it is important to realize that the implied Vorlage of the LXX in 15a does not merely involve the choice of reading אחר in place of the MT אחר, but also in 15ay it appears that it would require a prefix on זִ זרע and possibly also an inverted word from the

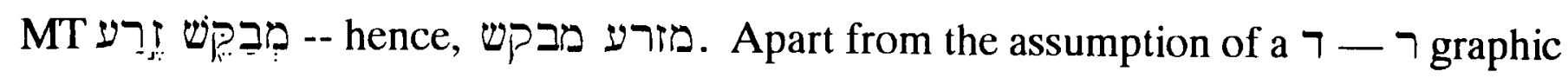
variant to explain the LXX מבז, the remaining discrepancies between the MT and the LXX are not easily explained in terms of the normal mechanisms of textual corruption and appear to be the result of interpretation on the part of the translators of the LXX (much as we observed in 2:16). Finally, as it stands, the LXX appears particularly implausible since Malachi does not answer the objection of his opponents: "But you say, "What else does God seek but a seed?"' In other words, Malachi's opponents are permitted to raise a

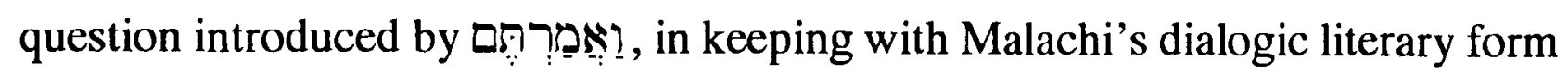
elsewhere, but it is one which Malachi proceeds to ignore. Nowhere else does Malachi permit his opponents to have the last word in this manner. ${ }^{87}$

\subsection{Views which, following the Peshitta, read of in place of consequently either delete $7 \Pi \$$ or construe it as an attributive adjective}

The Peshitta of Malachi 2:15 reads as follows:

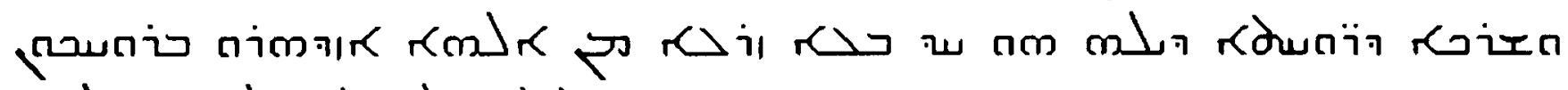

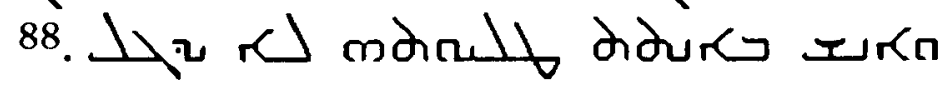

Acknowledging the unusual obscurity of the Peshitta in Malachi 2:15a, L. KruseBlinkenberg offers the following very qualified rendering: "Why is (?, was?) there not a [i.e., one] man?; and the rest of his spirits; this (?) one sought seed from God."89 Although Kruse-Blinkenberg does not discuss $15 \mathrm{~b}$, for the sake of completeness we may add: "Therefore guard your spirit and let a man not act falsely against the wife of his youth."

87 Cf. also $\$ 5.8 .1 .3$. below.

88 The text here conforms to The Old Testament in Syriac According to the Peshitta Version, prepared by the Peshitta Institute, Leiden; Part III, fasc. 4 (Leiden: E. J. Brill, 1980). Cf. also L. KruseBlinkenberg, "The Pesitta [sic] of the Book of Malachi" (1966) 102, 108.

To aid comparison, we may transcribe the Estrangela script into Aramaic square script as follows:

89 Op. cit., 102. 
With this rendering in mind, it may help to list the possible divergences of the Peshitta from the MT:

1) Kruse-Blinkenberg plausibly suggests translating meaning which is as well attested for this compound term in Syriac as is the case for its Hebrew cognate למה דמה Vorlage.

2) As noted by a number of scholars, the Peshitta's reading of ححi at the end of

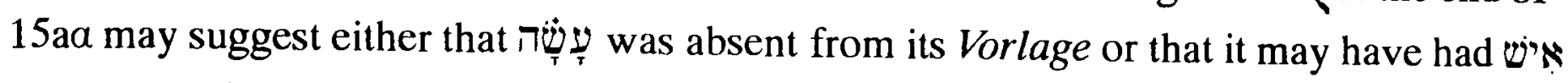

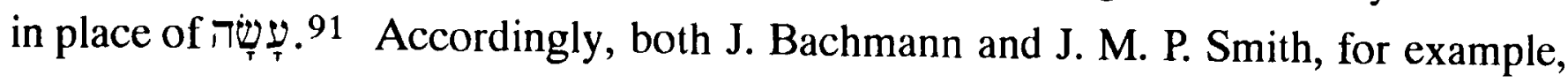
appeal to the Peshitta for their proposed restoration of $\boldsymbol{N}$ in place of the MT 92

3) While the Peshitta's rendering

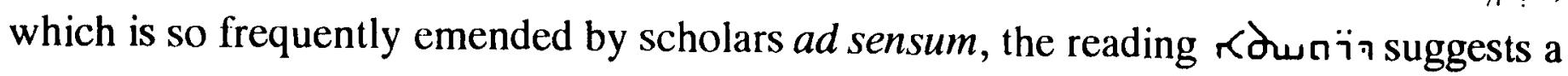
plural form "spirits" in contrast to the singular form of the MT, זiר

4) It is apparent that the presumed Vorlage of the Peshitta lacked both the conjunction and the interrogative pronoun is in $15 \mathrm{a}$. This evidence is used by J. M. P. Smith, for example, to emend the MT on the assumption that מָה was intruded into the text from a marginal gloss deriving from "some puzzled reader."93

5) Finally, the Peshitta moralל has frequently been adduced to support the

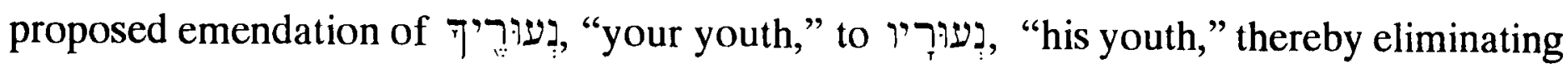
the abrupt shift in personal reference in $15 \mathrm{~b} \beta$.

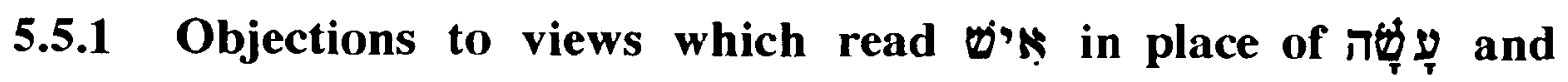 consequently either delete}

Although L. Kruse-Blinkenberg considers the text of the Peshitta in 2:15 to be "almost as obscure as MT," his tortured rendering may give a misimpression of even less agreement with the MT than actually exists: "Why is (?, was?) there not a [i.e., one] man?;

90 Cf. C. Brockelmann, Lexicon Syriacum (1928) 372, s.v. خطا.

91 Cf. J. M. P. Smith, who favours this emendation for the MT (Malachi, ad loc.). A. von Bulmerincq considers that it read $\boldsymbol{E}$, a reading which may also find support in the Targum (Der Prophet Maleachi, II, 295).

92 J. Bachmann, Alttestamentliche Untersuchungen (1894) 35. Bachmann also reads שִ שמפר. in place of

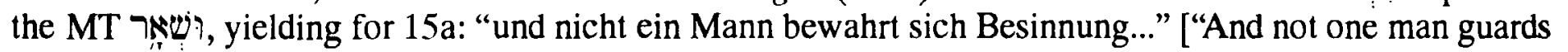
consciousness"]. Cf. also J. M. P. Smith, "A Note on Malachi 2:15a" (1912) 206, and idem, A Critical and Exegetical Commentary on the book of Malachi (1912) 59f.

93 Malachi, 59.

Thus accepting the view of the Peshitta that

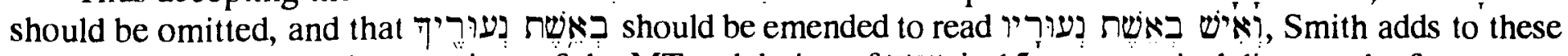
the following additional corrections of the MT: a deletion of 1 in 15 a as a vertical dittography from

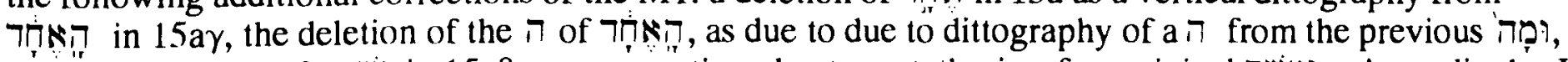
and the correction of רשיש in in $15 \mathrm{a} \beta$ as a corruption, due to metathesis, of an original Accordingly, J. M. P. Smith restores the text as:

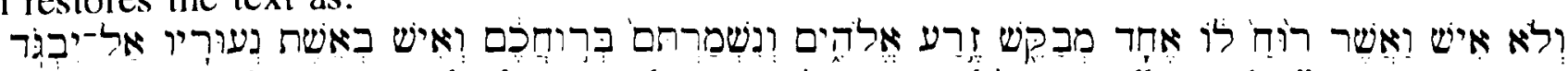
Smith renders this, "there is not one who has moral sense, viz. one seeking a godly seed...." 
and the rest of his spirits; this (?) one sought seed from God."94 In the following comments we shall attempt to support the following alternative rendering: "Was there not one man? [or "Was not one man made?"] and the rest of the spirits are his. This one was seeking seed from God. Therefore guard your spirit and let a man not act falsely against the wife of his youth."

1) Although Kruse-Blinkenberg plausibly suggests rendering given the absence of a corresponding term such as למה in the MT (or in any of the other versions), offering this rendering as a first choice unnecessarily introduces an apparent discrepancy between the Peshitta and the MT.95 Alternatively, we may identify simply as the common interrogative particle in Syriac, for which compare, for example, the primary definition of $\circlearrowleft$ offered by R. Payne Smith. ${ }^{96}$ Thus understood, represent merely an interpretative rendering of the MT (since the MT of 15a is capable of an interrogative interpretation as it stands), or it may support the commonly proposed

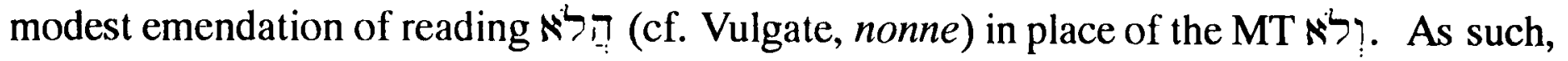
we prefer Kruse-Blinkenberg's alternative rendering, "Was there not one man?"97

2) As noted by a number of scholars, the Peshitta's reading of حרi in $15 \mathrm{a}$ may suggest either that its Vorlage omitted

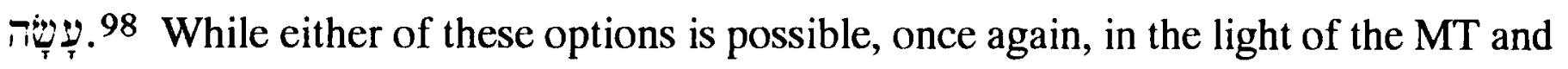
other versions, each of these options appears to introduce unnecessarily an apparent discrepancy between the Peshitta and the MT. In support of the MT, it is equally possible that the Peshitta ححن is merely interpretative, making more explicit what is intended by the

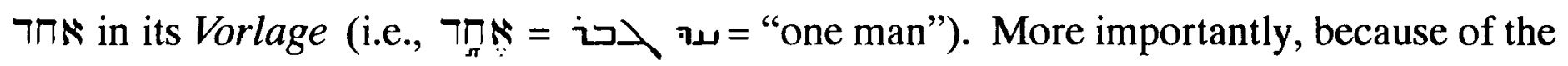
semantic range of $\mathrm{r}(\mathrm{nm}$, which is defined by $\mathrm{R}$. P. Smith as including "to be made," as well as "to be," this term may have been chosen to render an original עשה in its Vorlage, hence supporting the MT. 99 For this reason we propose to render vs. 15aa of the Peshitta: "Was not one man made?" Supporting this understanding of rnm, G. M. Lamsa translates the Peshitta of our verse, "Did not he make them one? And the rest of the spirits

94 Op. cit., 102.

95 In support of the rendering "why," cf. C. Brockelmann, Lexicon Syriacum (1828) 372, s.v. حما.

96 Cf. R. Payne Smith, A Compendius Syriac Dictionary (1903) 242f., s.v. \لا.

Cf. also T. Nöldeke, Compendius Syriac Grammar (1904) \$373 for a discussion of 15$\rangle$, as an interrogative particle, appearing both with (usually, though not always, for indirect interrogatives) as well as without the prefixed,.

97 Cf. also J. M. P. Smith, who translates: "was there not one man?... one sought seed from God" (Malachi, 59f.).

98 Cf. J. M. P. Smith, who favours this emendation for the MT (Malachi, ad loc.). A. von Bulmerincq considers that it read $\boldsymbol{W}$, a reading which may also find support in the Targum (Der Prophet Maleachi, II, 295).

99 Cf. R. Payne Smith, A Compendius Syriac Dictionary, 101, s.v. Joo.

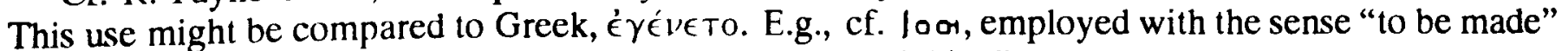

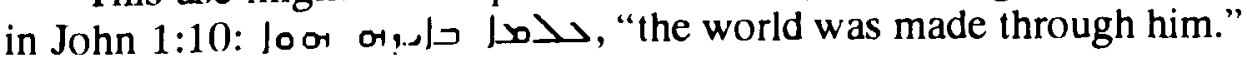


are his also. And therefore a man seeks one offspring from God. Therefore take heed to your spirit, and let none deal treacherously against the wife of his youth."100

3) As noted above, the reading रдun i suggests a plural form "spirits" in contrast to the singular form of the MT זịn. Since the singular of the MT, however, is supported by the LXX and Vulgate and clearly represents a lectio difficilior, it seems plausible that the plural form of the Peshitta arose under the influence of שִ שִ "a remnant of."101

4) It appears that the Vorlage of the Peshitta omitted both the interrogative and the preceding conjunction ומָ in in $15 \mathrm{a} \gamma .102$ It is difficult to be sure whether $\pi \mathrm{m}$, which occurs at the point where the interrogative would have been expected, is an attempt to render some term which was present in its Vorlage, or whether it merely stresses the definiteness of הָאָ

5) Finally, while it would appear that the Peshitta moral$\succ$ supports the proposed

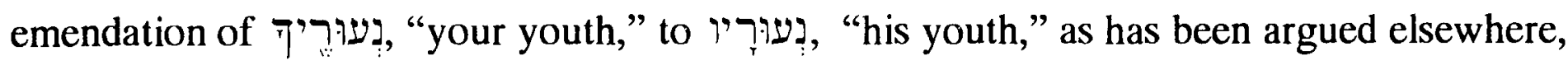
it seems preferable to maintain the MT as the lectio difficilior. Not only is this suggested by alternative reading of the LXX, Vulgate, and Targum (which resolves the same conflict differently, namely by reading a second person masculine singular form תבגד in place of

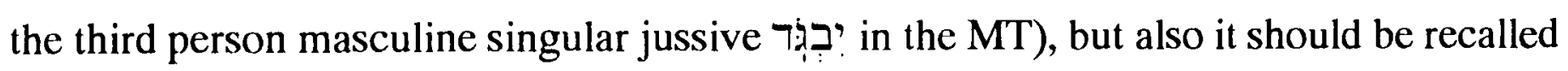
that seemingly abrupt shifts in personal reference are well attested elsewhere in the Old Testament.

Although the Peshitta may not be quite so obscure as Kruse-Blinkenberg supposes, we may appropriately conclude with his summary of the evidence of the Peshitta for Malachi 2:15a: "The most important thing in this connection is to state that $\mathrm{P}$ [the Peshitta], too, does not seem to understand MT; the text according to $\mathrm{P}$ does not seem to be due to a 'better' MT than the present."104

\subsection{Views which consider 7 to refer to the unity of God's covenant people; as such, $7 \Pi$ is the direct object of assumed subject}

Having weighed and rejected those views which understand of its clause, including those which consider $\prod_{\pi}$ to be a corruption of we

100 G. M. Lamsa, The Holy Bible from Ancient Eastern Manuscripts (1933).

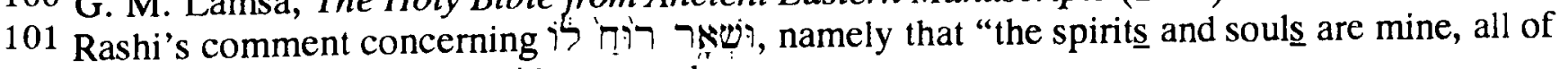
them came from the first man," provides an analogy.

102 Alternatively, perhaps it is possible that the Peshitta interpreted מָ as a relative pronoun, "who" (which it can be at times, as can $\mathrm{N}^{\mathrm{J}}$ ), rather than the interrogative, and so rendered it $\mathrm{n} \mathrm{m}$, which can also be used in this manner (though Payne indicates that when so used it is prefixed with ?). If so, then only the conjunction is unattested.

103 Cf. T. Nöldeke, op. cit., $\$ 70$.

104 Op. cit., 102. 
now turn to examine those views which take $\prod_{\pi} \wedge$ to be the object of its clause. As will be noted, most commentators find here an allusion to covenant or creation traditions enshrined in the Pentateuch, but disagree about the point of the allusion.

T. V. Moore renders Malachi 2:15: "And did he not make (us) one? And the remainder of the Spirit was with him. And wherefore (did he thus isolate us as) one (people? Because he was thus) seeking a seed of God. Take heed then to your spirits, and do not act treacherously to the wife of your youth."105 Moore follows P. Fairbairn in noting that Malachi appears to have laid a foundation for vs. 15 in vs. 10, where he emphasized the oneness of the Jewish people as the offspring of "One Father" and "One God."106 According to Moore, it is this oneness as the people of God that was necessarily violated when Malachi's contemporaries divorced their Jewish wives and subsequently entered into mixed marriages with idolaters. 107 Suitably, Moore considers vs. 15 to begin with a reminder of that threatened oneness. To clarify Malachi's logic in 2:15, Moore offers the following paraphrase:

"Did not God make us one? Did he not separate us from other nations into an isolated unity? Yet this was not done because the blessing was too narrow to be spread over other nations, or because infinite fulness was exhausted; for the residue of the Spirit was with him. There remained an inexhaustible fulness of spiritual blessing that might have been given to other nations. Why then did he choose but one? It was that he might make a seed of God, a nation which he should train to be the repository of his covenant and the stock of his Messiah, a people in which the true doctrine of the unity of God should be cherished amid surrounding polytheism and idolatry, until the fulness of time should come. Now to introduce this very polytheism and idolatry into the chosen people, and to reject the wives who were protected by the covenant, was to break up this oneness, and do that which if persisted in would amalgamate the Jewish people with the other nations of the earth."108

Fairbairn's and Moore's argument appears cogent that while divine attribute in vs. 10 , since the "oneness" of God demands a corresponding unity among his people in that verse, this may permit $\prod_{\pi}$ to be used with reference to his people in vs. 15 . Nevertheless, against this view the crucial direct object "us" is elided in vs. 15aa and cannot easily be discovered from the context, which is predominantly constructed in the second person (with occasional third person references). In fact, the closest reference for a first person plural pronoun occurs back in vs. 10. Furthermore, unlike vs. 10 ("Why then are we faithless [בגד] to one another?"), the concluding exhortation in vs. 15 does not

105 T. V. Moore, A Commentary on Haggai and Malachi (1856) 135.

T. V. Moore's view has been quoted and followed by others, including M. Dods and A. R. Fausset (M. Dods, The Post-Exilian Prophets [1881] 144f.; A. R. Fausset, "Malachi" [1887] 738).

106 Cf. P. Fairbairn, The Christian Treasury (1847) 187.

107 Op. cit., 137.

108 Ibid. 
prohibit faithlessness against fellow-Israelites, as the present view would lead us to expect, but faithless treatment [בגר] against the wife of one's youth.

\subsection{Views which consider 7 to refer to Adam or to Eve (but not to}

\section{Genesis 2:24) with "Yahweh" to be the assumed subject of}

Although it is common to lump together interpreters who find in Malachi 2:15a any kind of allusion to Genesis 1 or 2 , in fact there are important differences between those who understand אח Adam or of Eve, or of mankind in general, conceived in terms of Genesis 1:27) and those who understand primordial marriage (Genesis 2:24). We shall consider the first group of scholars in the present section and then take up the second group in the section which follows.

Perhaps the most substantial defence of the present approach is that offered by W.

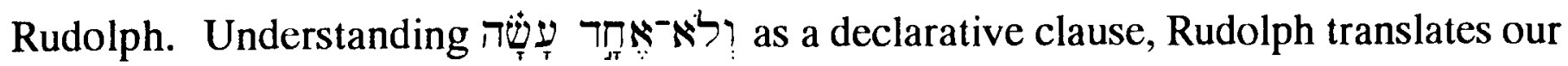
verse: "Er hat ja nicht ein Einzelwesen erschaffen, sondern <Fleisch (aus seinem Fleisch) zur Ergänzung> für es; und was sollte der Eine erstreben? Samen <nach dem Willen> Gottes! So hütet euch, wenn euch euer Leben lieb ist, und niemand handle treulos an der Frau <seiner> Jugend."109 At another point, Rudolph rewords his rendering, "Nicht einen Einzigen (allein), d. h., Adam, hat er geschaffen...."110

Certainly a major strength of Rudolph's view is the degree of inner coherence and consistency of reference which is achieved. For example, Rudolph notes that vs. 15 offers the expected explanation for Malachi's remarkable characterization of a wife as

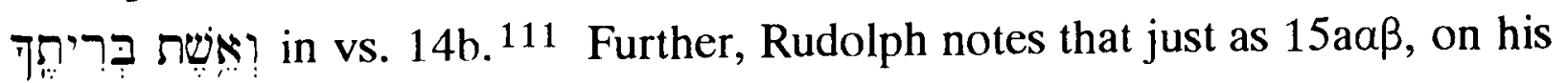
interpretation, reflects Genesis 2:23 (the mentioned "flesh" recalls the mode of Eve's creation to complete Adam), so also 15 a $\gamma$ reflects Genesis 2:24. Similarly, according to Rudolph, Adam's existence as "one flesh," for which reason he is called "the One" in $15 \mathrm{a}$, prepares for and logically relates to his desire for children, the topic to which the text consequently turns. ${ }^{112}$

109 W. Rudolph, Haggai, Sacharja 1-8, Sacharja 9-14, Maleachi (1976) 268: "He has not created a single person [Einzelwesen], but $<$ flesh (out of his flesh) as a supplement $>$ for it; and what does the One (i.e., Adam as 'one flesh') seek? A seed <according to the will of $>$ God. So watch yourselves, if your lives are dear to you, and let no one act faithlessly toward the wife of <his $>$ youth."

Cf. also, W. Rudolph, "Zu Mal. 210-16" (1981) 85-90.

Similar is R. Vuilleumier in S. Amsler, A. Lacocque, and R. Vuilleumier, Aggée, Zacharie, Malachie (1981).

110 Maleachi ,270: "Not a single individual (alone), i.e., Adam, did he create."

111 Cf. "Zu Mal 2 10-16," 86.

112 A. Tosato notes that Rudolph differs from the more common view (as represented in present day translations of $2: 15$ ), by understanding וּשיש,, "flesh," as referring not to that of the first Adam's flesh, but that with which God formed Eve (“Il ripudio: delitto e pena [Mal 2,10-16]," 549). 
Finally, Rudolph's interpretation of deemed a welcome contribution on a phrase which frequently has been neglected by scholars, whose attention has been understandably absorbed by the more blatant difficulties posed by $2: 15 \mathrm{a}$ and 16a. Rudolph understands the $\Xi$ in

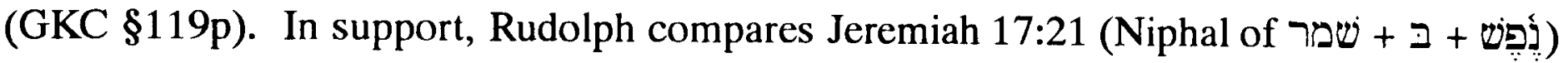
contrasting this to the use of $ל$ in Deuteronomy 4:15 and Joshua 23:11 (Niphal of שמר

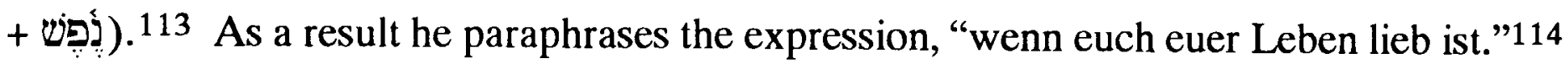
Given that Jeremiah 17:21 offers the only other example in Biblical Hebrew of the use of the Niphal of שמר followed by $\supseteq$ (besides Malachi 2:15,16) any conclusion about the precise force of $\exists$ in Malachi 2:15f. must necessarily remain tentative. ${ }^{115}$ Nevertheless, Rudolph's interpretation reflects the consensus of modern commentators with respect to Jeremiah 17:21, and the application to Malachi 2:15f. appears plausible. 116

Nevertheless, Rudolph's overall interpretation is seriously diminished by the extensive number of conjectural and other emendations which it presupposes. Although Rudolph indicates these by the use of angle brackets, it will help for us to list them

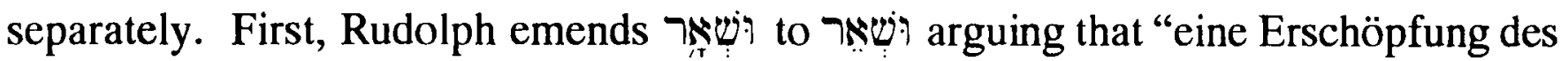
Gottesgeistes is für das AT ein unmöglicher Gedanke."117 Second, Rudolph repoints గִּ רִ to $\Pi \underline{\eta}$, a term which means "space, interval," but in the present context is to be understood as a "complement" -- recalling Eve's creation as a suitable companion for Adam (Genesis $2: 18,20,23) .118$ Third, Rudolph suggests that perhaps מִשֶׁאר should be restored to clarify an intended reference of the text to Genesis 2:23. Rudolph explains that this term

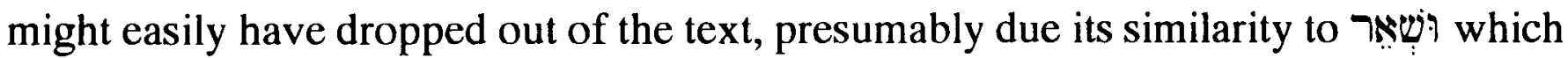
immediately precedes it. Fourth, and more tentatively, Rudolph suggests inserting after

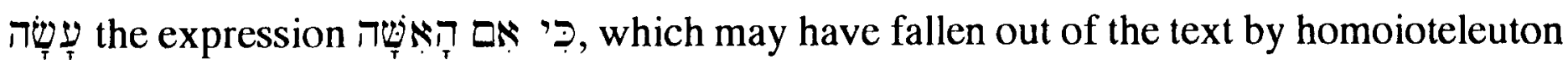
(before the addition of the Masoretic diacritical marks which distinguish $\boldsymbol{E}$ and $ש$ ). Once again, the effect of this emendation would be to render more explicit a reference to Genesis 2. If this suggestion is accepted, the text would then read, "Nicht einen Einzelnen hat er geschaffen, sondern auch die Frau aus seinem Fleisch als Ergänzung für ihn"119 and would

113 E. Sellin and D. Deden, though lacking the detail of Rudolph's treatment, also point to Jeremiah 17:21 in their discussions of Malachi 2:15ba.

114 "If your lives are dear to you."

115 Similarly, Deuteronomy 4:15 and Joshua 23:11 offer the only examples of the use of กำ.

116 E.g., J. Bright renders, “as you value your lives" (Jeremiah [1965] 117). J. A. Thompson cites and agrees with the opinion of Bright (The Book of Jeremiah [1980] 428). W. L. Holladay offers "for the sake of your lives" (Jeremiah 1 [1986] 508). W. McKane renders, "you are putting your lives in danger" (A Critical and Exegetical Commentary on Jeremiah, vol. 1 [1986]).

117 Ibid.: "a depletion of the Spirit of God is an impossible concept for the OT."

In "Zu Mal 210-16," 86, Rudolph may leave the misleading impression that the word iשאר is employed in Genesis 2:23.

118 Rudolph's term is “Erweiterung," i.e., "expansion” (Haggai, Sacharja 1-8, Sacharja 9-14, Maleachi, 270).

119 "He did not create an isolated being but the woman also out of his flesh as a supplement for him." 


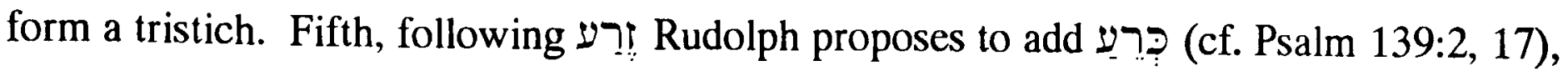
which he assumes fell out of the text by homoioteleuton. The resulting expression consequently affirms that Adam's desire for progeny was "nach dem Willen (Gottes)."

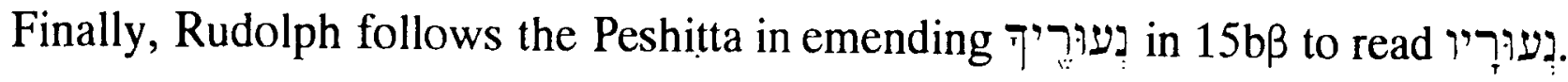

Leaving aside the individual merits of each of these proposals, here we merely observe that the cumulative effect of so many emendations is to leave the result in doubt -particularly when there is so little concern to support these from the versional evidence. ${ }^{120}$ Not surprisingly, C. van der Woude, P. A. Verhoef, A. Tosato, and C. Locher have all rejected Rudolph's approach, explicitly mentioning his numerous conjectural emendations as a major objection. 121

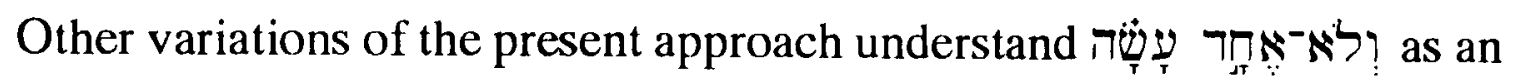
interrogative clause. For example, according to H. Cowles, and perhaps the AV, , חח may be taken as a reference to Eve. ${ }^{122}$ The $\mathrm{AV}$ renders the verse: "And did not he make one? Yet had he the residue of the spirit. And wherefore one? That he might seek a godly seed. Therefore take heed to your spirit, and let none deal treacherously against the wife of his youth." Cowles notes that although God "had the residue of the creative Spirit, and might easily have made for Adam another wife, or even a score of wives, if he had thought it best," he restricted Adam to one wife because he sought a godly seed. ${ }^{123}$ In other words, אח is intended to underscore God's determination to provide Adam with one wife.

If it had been Malachi's intention, however, to refer to God's determination to create but one wife for Adam, we should have expected not the masculine form $15 \mathrm{a} a$ and $15 \mathrm{a}$, but the feminine form ${ }^{124}$ Furthermore, even appears too elliptical. Had Malachi intended to express what Cowles supposes, it seems likely that he

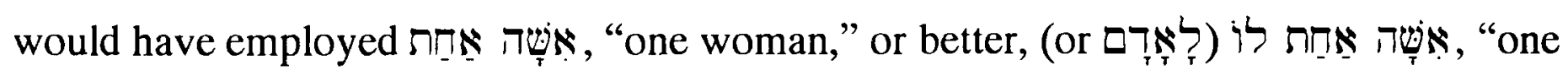
woman for him (or, for the man)," not simply

Alternatively, if mentioned in Genesis 1:27 (as apparently is intended by the NAB), then in spite of E. B. Pusey's claim that "they both together are called one man [Gen. 1:27]" אָָ is not actually employed in Genesis 1:27.125 Furthermore, as noted by A. von Bulmerincq,

120 Rudolph largely dismisses the versions as presupposing MT: "Auch die Versionen brauchen nicht einzeln aufgezählt zu werden, da sie deutlich nur 2 [ [= MT] voraussetzen" (Haggai, Sacharja 1-8, Sacharja 914, Maleachi, 270).

121 A. S. van der Woude, "Malachi's Struggle for a Pure Community," 69; P. A. Verhoef, The Books of Haggai and Malachi, 277, n. 34; A. Tosato, "Il ripudio: delitto e pena [Mal 2,10-16]" 549f.; C. Locher, "Altes und Neues zu Maleachi 2,10-16," 255.

122 The Minor Prophets (1867) 392.

123 Cf. also M. Dods, The Post-Exilian Prophets (1881) 144.

124 As noted by GKC $\$ 97$ a, chiastic concord of cardinals in Hebrew (where masculine forms are used to modify feminine nouns, etc.) involves only the numbers three through ten.

125 E. B. Pusey, The Minor Prophets, vol. 2 (1883) 483. 
expression for Adam inclusive of Eve is entirely without analogy anywhere in the Hebrew Bible. ${ }^{126}$

\subsection{Views which consider 7 \$ to offer an allusion to the "one flesh" marital unity of Adam and Eve in Genesis 2:24. On this approach $7 \pi \%$ is the direct object of $\pi$}

All those who follow this eighth and final approach consider Yahweh to be the

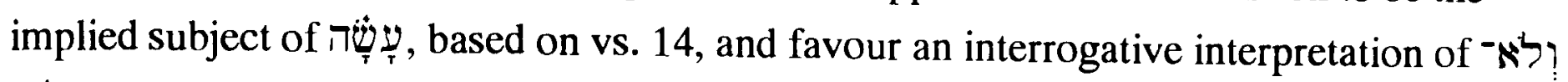

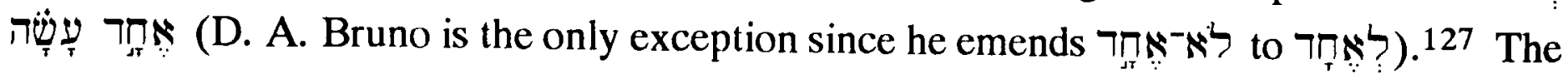
major textual issue for this approach is the decision whether to maintain the MT of "and a remnant of," or to accept A. van Hoonacker's proposal to revocalize the MT to read

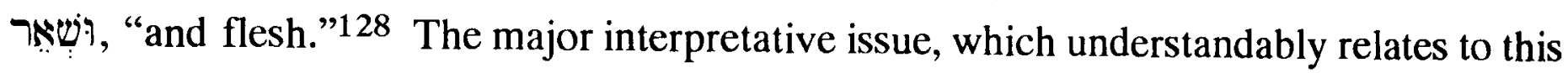

For a discussion of this common understanding of $7 \Pi \rightarrow$, cf. A. Tosato, "Il ripudio: delitto e pena (Mal 2,10-16)," 549.

126 Der Prophet Maleachi, II, 294. 233.

127 D. A. Bruno, Das Buch der Zwölf. Eine rhythmische und textkritische Untersuchung (1957) 181,

128 A. van Hoonacker renders Malachi 2:15, “Ne 'les' a-t-il point faits pour n'être qu'un seul [être ], qui a sa chair [et] sa vie? Et cet [être ] unique à quoi tend-il? A une postérité pour Dieu! Ayez donc soin de votre vie, - et ne 'sois' point perfide envers l'épouse de ta jeunesse" ["Did he not make 'them' to be a single [being], which has its flesh [and] its life? And what does this unique [being] seek? A posterity for God! Therefore take care of your life, - and 'do not be' faithless to the wife of your youth"] (Les douze petits prophètes [1908] 726, 728).

Those scholars who hold a similar view to Van Hoonacker include D. Deden (De Kleine Profeten [1953] 393), T. Chary (Aggée - Zacharie - Malachie [1969] 258, 260); NAB; JB; and perhaps J. G. Baldwin (Haggai, Zechariah, Malachi [1972] 240f.) and the NIV.

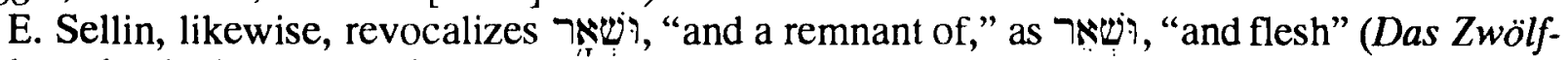
prophetenbuch übersetzt und erklärt [1922] 550ff.). But Sellin, in addition to several other proposed

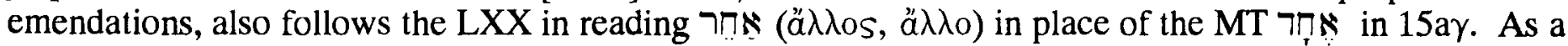
result, Sellin renders Malachi 2:15, "Hat er nicht zu Einem gemacht $/<$ Fleisch> und Leben $<$ dir $>$ ? $/<$ Aber ihr sprecht: Was anderes $>/<$ Als $>$ Nachkommenschaft verlangt Gott? / Doch hütet euch für euer Leben!/ Und gegen das Weib <eurer> Jugend <seid> nicht treulos!" [Did he not make into one, flesh and life for you (sing.)? But you (pl.) say: What does God require other than progeny? Indeed, take heed for your (pl.) life! And do not be faithless against the wife of your (pl.) youth!"] Later, Sellin offers more paraphrastically, "Hat er (nämlich Jahwe vlg. 14a) nicht zu Einem Fleisch und Leben dir (nämlich dem in v. 14 Angeredeten mit seinem Weibe) gemacht?"

Offering similar views to that of Sellin are W. Nowack, Die kleinen Propheten übersezt und reklärt (3 Aufl. 1922) 420f.; J. E. McFadyen, "Malachi” (1929) 835; A. Deissler, Zwölf Propheten, Die Neue Echter Bibel, 4 (Stuttgart: Echter, 1981 -- cf. also Deissler in A. Deissler and M. Delcor, Les petits prophètes, II, Michée-Mal, 1964); and A. Renker Die Tora bei Maleachi. Ein Beitrag zur Bedeutungsgeschichte von tôra im Alten Testament (1979) 73.

Among those scholars who support the present approach while maintaining the MT of רit are Rashi (as against the implication of E. Cashdan, "Malachi," 347), John Calvin (Zechariah and Malachi (554), J. Drusius (Commentarius in prophetas minores [1627]), L. Cappellus (Commentarii et notae criticae in Vetus Testamentum [1689]), J. Tarnovius (In prophetas minores commentarius [1688]), J. Coccejus (Commentarius in prophetas duodecim minores (Opera III [1689] 387-699), E. Pococke ("A Commentary on the prophecy of Malachi" [1740] -- all according to A. von Bulmerincq [Der Prophet Maleachi, II, 291]), T. Scott (The Holy Bible with Explanatory Notes, Practical Observations, and Copious Marginal References [1788-1792]), W. Newcome (Minor Prophets [1836]), E. Henderson (The Book of the Twelve Minor Prophets [1858]), J. C. K. von Hofmann (Der Schriftbeweis 2 [1857-60] 399f. -- so according to A. 
textual decision, concerns whether or not to understand the clause concessive sense: "though he [i.e., Yahweh] had a remnant (or abundance) of the spirit [with which God might have made more than one wife for Adam, had he so desired]." This concessive interpretation is held to imply that Malachi intended to oppose polygyny by an appeal to the primordial monogamous marriage of Adam and Eve. Rather than supposing that Malachi 2:15 opposes polygyny, however, it seems more probable from the context that Malachi appeals to the "one flesh" unity of the paradigmatic marriage of Adam and Eve in order to oppose divorce. Accordingly, we suggest rendering Malachi 2:15 as follows: "Did He not make [you/them] one, with a remnant of the spirit belonging to it? And what was the One seeking? A godly seed! Therefore watch out for your lives and do not act faithlessly against the wife of your youth."

In particular, $7 \prod_{\pi} N$ is to be understood as an allusion to the "one flesh" character of the primeval marriage described in Genesis 2:24. Nevertheless, while and alludes to that text, Malachi's rhetorical question has as its immediate referent the contemporary marriage described in the preceding verse, Malachi 2:14. Just as God had made Adam and Eve to be "one" in their marriage, the husband and wife of Malachi's day must also recognize that God made them to be "one."

To better appreciate this dual referencing, it may help to note that Malachi employs a similar kind of melding of a paradigmatic historical event with a contemporaneous application in vs. 10. In that verse Malachi asks, "Have we not all one father? Did not one God create us?" Yet, as argued in a previous chapter, this fatherhood of God, this creative work primarily alludes to the redemptive events surrounding Sinai which, in terms of the biblical representation, formed the nation of Israel nearly a millennium before Malachi's own day. While those redemptive events involved Israelites who lived centuries earlier

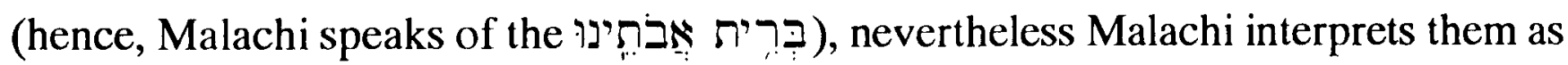
applying equally to his own contemporaries (hence, "Have we not all one father? Did not one God create $u s$ ?”).

von Bulmerincq, Der Prophet Maleachi, II, 291, 8), J. Packard ("The Book of Malachi" [1876] 16), E. B. Pusey (The Minor Prophets, vol. 2 [1883]), T. T. Perowne, Malachi (1890), W. H. Lowe ("Malachi" [no date]), C. L. Feinberg (The Major Messages of the Minor Prophets [1951] 115), H. Frey (Das Buch der Kirche in der Weltwende. Die kleinen nachexilichen Propheten [1957] 157-160), T. J. Delaughter (Malachi, Messenger of Divine Love [1976] 101), P. H. Kelley (Layman's Bible Book Commentary, Micah, Nahum, Habakkuk, Zephaniah, Haggai, Zechariah, Malachi [1984]), W. C. Kaiser Jr. (Malachi [1984] 71f.), and R. L. Smith (Micah-Malachi [1984] 319), as well as the RV, ASV, and the RSVmargin.

Kaiser's view is typical of many of these scholars who maintain the MT. He translates, "Did not he [God] make them one? - even though he had the residue of the spirit [i.e., 'enough creative power in reserve'] [presumably to 'supply many partners']. So why only one [partner]? Because he was seeking godly offspring" (Malachi [1984] 139).

"The thought would then run like this: Why did God make Adam and Eve only one flesh, when he might have given Adam many wives, for God certainly had more than enough of the Spirit, or his creative power, in reserve to furnish many partners? However, our God was seeking a godly offspring, and such plurality would not have been conducive to this result" (op. cit., 71f.). 


\subsubsection{Special features of the present view}

Before attempting to answer the various objections which have been raised against this view, it will help to consider in some detail five major features which distinguish this present view from those which share its basic perspective, namely that understood as an allusion to the "one flesh" character of the primeval marriage described in Genesis 2:24.

\subsubsection{The antecedent of in the expression not Yahweh}

As already mentioned, many interpreters who share the present approach consider

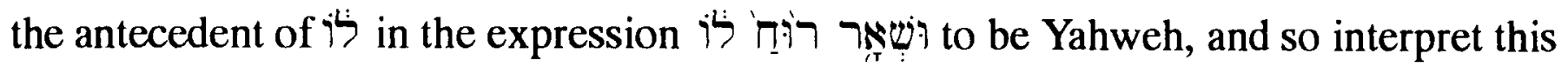
difficult clause as polemic against polygyny. Allegedly, Malachi is recalling how God had plenty of spirit left after creating Eve; so the divine choice not to create more than a single wife for Adam implies a repudiation of polygyny. ${ }^{129}$

This interpretation fails on at least three different grounds. First, such an

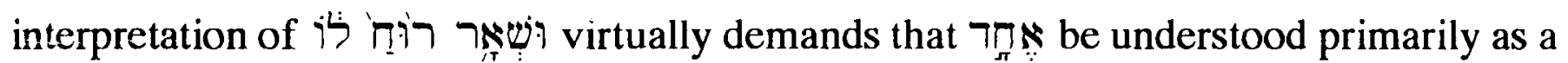
reference to Eve, not to marriage: "Did he not make just one [wife for Adam], even though he had a remnant of the Spirit?" Yet, as already argued, such an interpretation would expect the feminine form strange that there would have been any need in the post-exilic context for Malachi to insist that Yahweh's creative potential, that is, his గịา, was not exhausted after the creation of the first two souls. Surely, not even the most ardent polygynist would have thought otherwise. Finally, a repudiation of polygyny in vs. 15 would appear unexpected in its context. Nowhere else in 2:10-16 is polygyny mentioned, nor is there any allusion to this as a problem elsewhere in the post-exilic biblical corpus. ${ }^{130}$ Moreover, at least according to some interpreters, Malachi's condemnation of exogamous marriage in 2:10-12 and of divorce in 2:13-16, if anything, presupposes monogamy among Malachi's contemporaries. In other words, if polygyny had been a common practice, seemingly there would have been little reason for a man who wished to marry a pagan woman to divorce "the [Jewish] wife of his youth." Alternatively, even apart from this possible connection between divorce and exogamous marriage, there is a clear linkage between vss. 14, 15, and 16 (with the latter

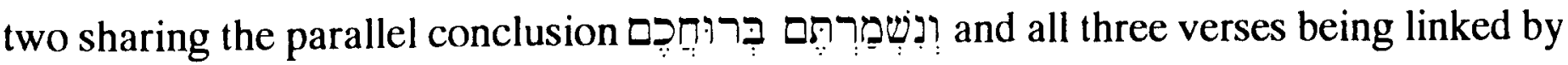
the term בגר), and in vs. 16 the practice condemned is explicitly identified as divorce, not polygyny.

129 Cf., e.g., P. A. Verhoef, The Books of Haggai and Malachi.

$130 \mathrm{Cf}$. the discussion of polygyny in $\$ 4.6$ above. 
1) Although the discussion of the proposed emendation normally focuses on the

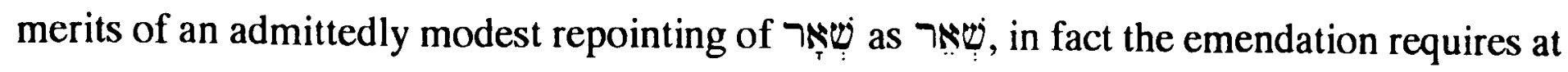
least one, and very often two, additional changes in the text: First, the introduction of the

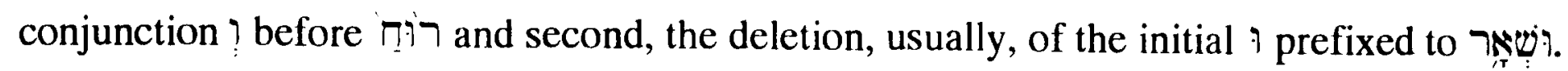
These changes are not trivial and require a more adequate defence according to the canons of textual criticism.

2) As A. Tosato has noted, the MT vocalization for רזּר, "remainder," is uniformly

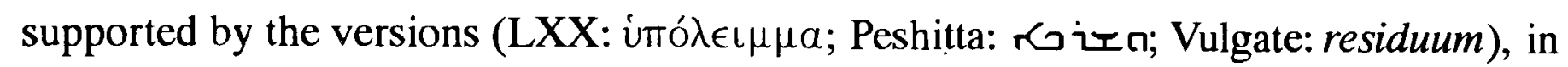
spite of the marked divergence from the MT of those same versions elsewhere in vs. 15.

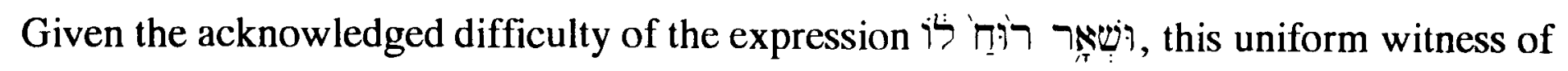
the versions is remarkable and would be hard to explain on any other basis than the assumption of the originality of the MT.

3) Related to the comment just made, even apart from the supportive witness of the versions, it is hard to imagine how a supposed original text which was understood as

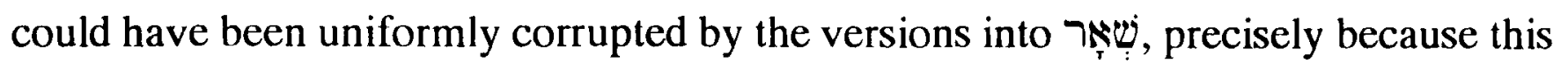
resulting reading is so difficult (principle of lectio difficilior). ${ }^{134}$

4) Further, as noted by A. Tosato, there is at least a slight grammatical confirmation

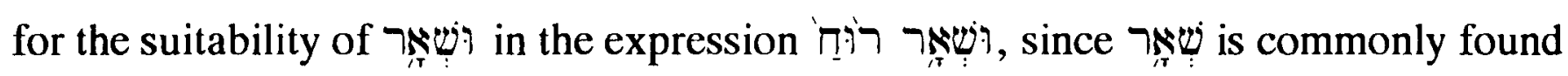
elsewhere in the Old Testament in the construct state, just as it appears in the present verse. 135

5) Finally, the claim of J. M. P. Smith and others, namely that "remnant of the spirit" lacks analogy elsewhere in the Old Testament is true only for the usual view, which holds that ל has Yahweh for its referent. ${ }^{136}$ As mentioned earlier, however, our interpretation holds that the antecedent of

With A. von Bulmerincq and others, 끅, both in $15 \mathrm{a} \beta$ and in $15 \mathrm{ba}$, is to be understood as in Psalm 104:29f.; Job 32:8; Daniel 5:12; and 6:4, namely as a reference to the spirit of God which resides in man. If spirit, then a possible analogy for our text may be found in Numbers 11:25, where the Lord

134 As such, L. Kruse-Blinkenberg argues that it is impossible to reconstruct or improve the MT in $2: 15$ by the help of LXX, Peshitta, or Targum (op. cit., 113).

135 E.g., Isaiah 10:19, 20;11:11, 16;28:5; Nehemiah 11:20; 1 Chronicles 11:8; and 2 Chronicles 24:14, according to Tosato, "Il ripudio: delitto e pena (Mal 2,10-16)," 551, n. 15.

Tosato adds to this the observation that there is a certain linguistic congruence between $7 \prod_{T} \boldsymbol{N}^{-}$and שאר as is apparent from a number of examples including, e.g., Exodus 8:27; 10:19;14:28. This observation, however, lacks conviction because in the cases cited 7 ש not as a (G-stem) noun.

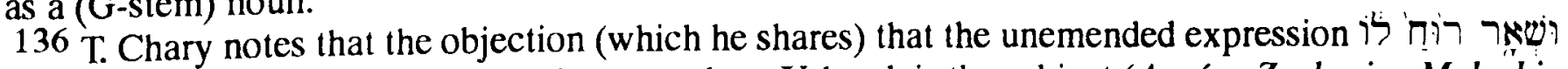
makes no sense applies particularly to the case where Yahweh is the subject (Aggée-Zacharie - Malachie [1969] 261). 
By contrast, the present view follows the suggestion of H. Frey and others and

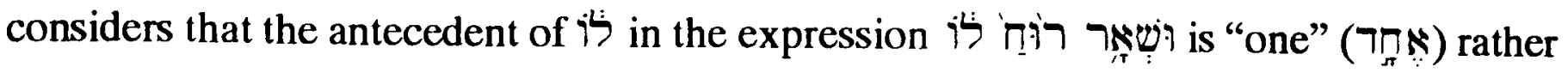
than Yahweh: "with a remnant of the spirit belonging to it?" Admittedly, this interpretation has its own difficulties -- although it may be salutary to recognize that the expression is problematic on every interpretation thus far considered. While other texts may support the notion that an individual may possess the spirit, nowhere else does the Bible suggest that a married couple as such might similarly possess the spirit. Nevertheless, there are a number of texts which teach that the community of Israel corporately possesses the spirit who is present as a witness to the covenant. ${ }^{131}$

\subsubsection{In spite of its admitted difficulty, the MT לִּר should be maintained}

As noted earlier, the proposal first made by A. van Hoonacker to emend ad sensum

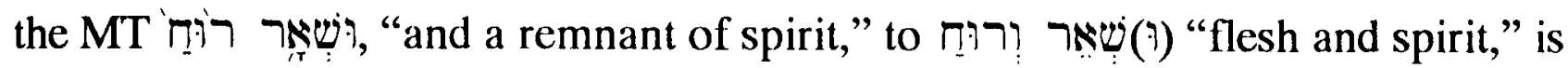

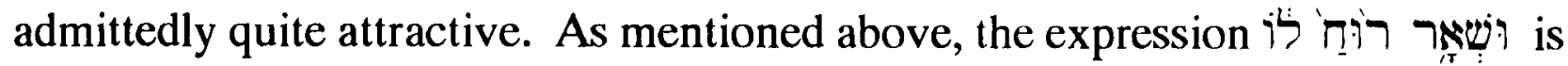
problematic on virtually any view of 2:15. J. M. P. Smith, for example, has noted, " "remnant of the Spirit' is scarcely a Hebrew point of view, and it lacks all analogy."132 Acknowledging this difficulty, Smith's observation has often been thought to favour an

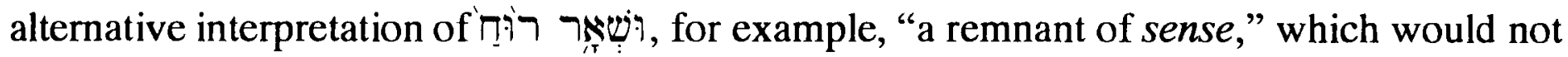
favour the present approach to vs. $15 \mathrm{a} .{ }^{133}$ While this interpretation may be suggestive of various modern idioms, such as "an ounce of sense," it finds little lexical support in the ancient texts. Moreover, it appears to be opposed by the use of חרוּ in vs. $15 \mathrm{~b}$, since

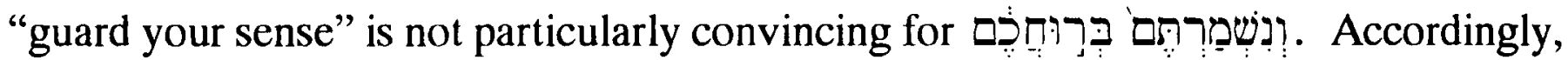

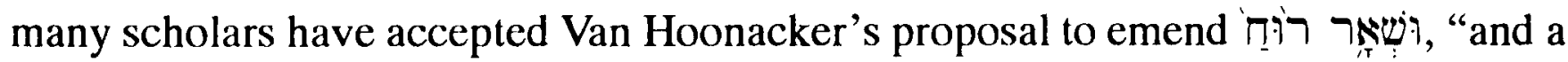
remnant of spirit," to to (1), "flesh and spirit." The sense resulting from this emendation comports with the present interpretative approach to 2:15 as it makes more explicit the assumed allusion to Genesis 2:24 -- the emended text recalls how God "made

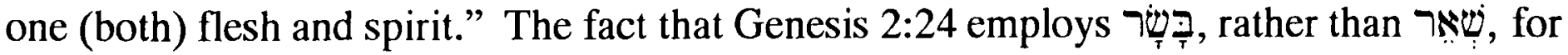
"flesh" need not detract from this view since these two terms function elsewhere as close synonyms.

While recognizing the plausibility of Van Hoonacker's proposal, nevertheless, our

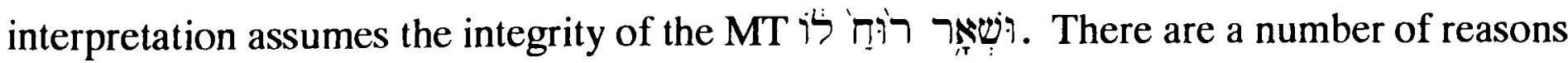
for this choice.

131 E.g., cf. Haggai 2:5 and the interpretation of this verse offered in M. G. Kline, The Structure of Biblical Authority (1972) 201f. Cf. also, M. M. Kline, "The Holy Spirit as Covenant Witness" (1972) passim.

132 Malachi, 54.

133 Cf., e.g., P. A. Verhoef, The Books of Haggai and Malachi, 276. 
"took some of the spirit that was upon him [i.e., Moses] and put it upon the seventy elders."137

Nevertheless, since the presence of the spirit which comes from God and a creature's life are coterminous (cf. Psalm 104:29f.138), ח̣: ר may be at one and the same

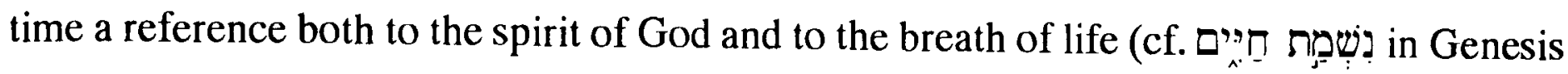
$2: 7) .{ }^{139}$ If רוּ is understood as a reference to one's life breath, the present clause may find an analogous text in Daniel 10:17, where the Niphal of שאר is used to describe the near depletion of one's life-breath (צְשָָָׁה): "How can my lord's servant talk with my lord? For

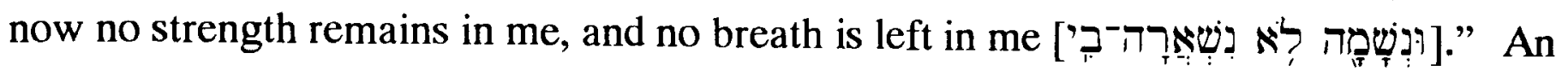
advantage of this interpretation is noted by Tosato, namely that it maintains the same sense for $\Pi 17$ in the present expression as it bears later in vs. $15 \mathrm{~b}$ and in $16 \mathrm{c} .{ }^{140}$ Tosato notes that the warning to guard one's life-spirit in those two later passages corroborates his interpretation here of an implied threat of being completely deprived of 끄.

Finally, in support of the present interpretation of $2: 15 \mathrm{a} \beta, \mathrm{H}$. Frey makes the interesting proposal that Malachi, having already drawn attention to creation and the marriage of Adam and Eve, now obliquely alludes to Genesis 6 as well, where God determined that his holy life-giving spirit would not continue to strive with mankind (Genesis 6:3) as a result of the marital infractions described in that context. So here, men

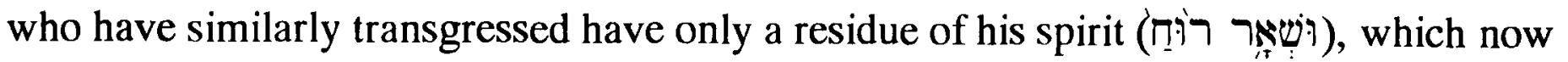

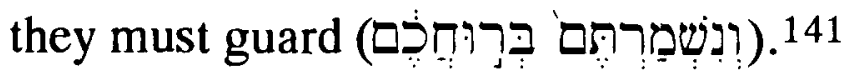

\subsubsection{The MT of 15ar should be maintained in spite of the evidence of the LXX and $4 Q X I I^{a}$}

While recognizing the general quality of the text of the MT in Malachi, nevertheless, with E. Sellin, A. Deissler, and others, the evidence of the LXX kai $\epsilon l \pi a t \epsilon$ cannot easily be disregarded as an expansion. ${ }^{142}$ It is true that most scholars who support the restoration

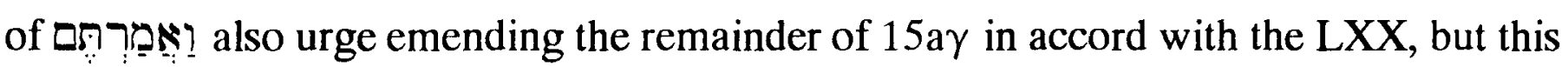

137 This parallel is acknowledged by P. A. Verhoef, The Books of Haggai and Malachi, 276.

138 RSV: "When thou hidest thy face, they are dismayed; when thou takest away their breath [0חּ๊] ], they die and return to their dust. When thou sendest forth thy Spirit [न! renewest the face of the ground."

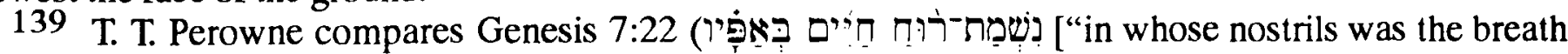
of the spirit of life"]) (Malachi [1890] 27).

140 A. Tosato cites D. Lys, "Rûach" (1962) 336, as presenting evidence that this corresponds to the prevalent sense which 71 ר bears in all the post-exilic texts where it is found ("Il ripudio: delitto e pena [Mal 2,10-16]," 551, n. 16)

${ }_{141} \mathrm{H}$. Frey, Das Buch der Kirche in der Weltwende, 160.

142 It is true that the unemended MT in 15 ar is not particularly difficult and, as such, may not seem to demand the presence of consistency of a text-critical methodology which resorts to the versions only when the MT is considered difficult or corrupt. Cf., e.g., R. W. Klein's warning, "A common mistake in Old Testament textual studies is to resort to LXX only when the MT, for one reason or another, seems difficult or corrupt" (Textual Criticism of the Old Testament From the Septuagint to Qumran [1974] 62). 
more radical emendation of the MT is unnecessary, and, as we have argued above, the reading of the LXX is not convincing. ${ }^{143}$ Furthermore, as noted by R. Fuller, while the text of Malachi 2:15 in 4QXIIa is off the leather, considerations of line length favour the assumption that this verse was slightly longer in 4QXII ${ }^{\mathrm{a}}$ than it is in the MT, and hence support the inference that it included 144

The following observations, however, weigh against the originality of וְִּ in in $15 \mathrm{a} \gamma$. First, the presence of the initial i on

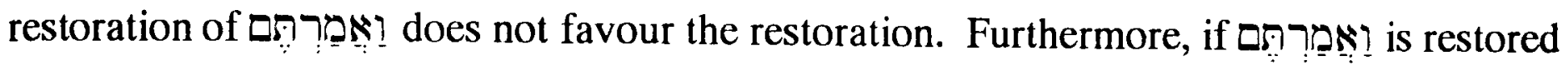
in $15 a \gamma$, the question, "And what does He desire," is no longer a rhetorical question on Malachi's lips, but a question which Malachi anticipates from his audience (or one which they actually articulated). Unlike every other example of $2: 14,17 ; 3: 7,8,13)$, however, there is nothing about the context of this question which would allow one to understand how it would ever have arisen in the mind of Malachi's audience. In every other case, Malachi makes an assertion to which his audience directly objects using synonyms, if not identical vocabulary. Here there is nothing of the kind; the supposed direct discourse does not appear even to be an objection. Finally, it should be noted that elsewhere the LXX, and presumably its Vorlage, frequently expands texts by the interpretative insertion of some form of $\lambda \epsilon \gamma \in \hat{\imath} \nu$ / $\epsilon \hat{\imath} \pi \epsilon \hat{\imath} \nu$ / $\epsilon \rho \epsilon \hat{\imath} \nu$ to introduce what was believed to be direct discourse. Compare, for example, Genesis 31:32 [LXX'A, 44 [LXXA], 46; Numbers 9:2; Joshua 22:34; 1 Samuel 1:20; etc. While it is significant that 4QXII ${ }^{a}$ probably read in $15 \mathrm{a} \gamma$ and hence supports the LXX at this point, the textual quality of this witness should not be exaggerated. R. Fuller observes that 4QXII holds a middle position between the MT and the LXX in Malachi. Specifically, 4QXIIa agrees with the LXX against the MT seven times (four of these being inferior readings to the MT); it agrees with the MT against the LXX four times (one of which appears to be an inferior reading); and once it offers a unique reading, which may be superior to both LXX and MT. ${ }^{145}$

In any case, on the present interpretation of Malachi 2:15, the presence or absence

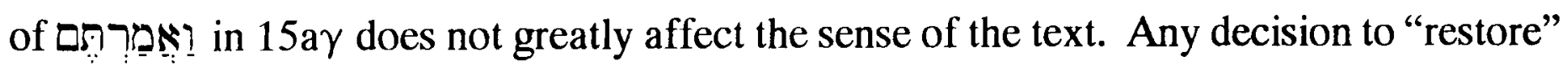

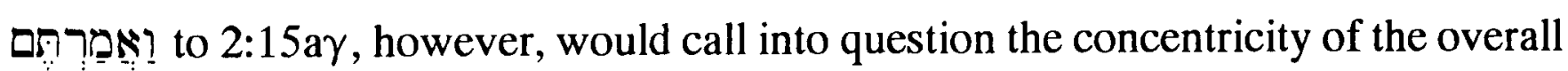
literary structure of Malachi as discussed in Chapter 1 and is, therefore, to be resisted in the absence of more compelling evidence.

143 For scholars who emend the remainder of $15 \mathrm{ar}$ in accord with the LXX, cf. E. Sellin, W. Nowack3rd edition, A. Deissler, A. Renker, and R. Fuller (in "Does Yahweh Hate Divorce? Malachi 2:16 and the Text of Malachi at Qumran").

144 R. Fuller, "Does Yahweh Hate Divorce? Malachi 2:16 and the Text of Malachi at Qumran." Cf. also R. Fuller's forthcoming article on Malachi 2:10-16 in JBL and edition of 4QXII ${ }^{\mathrm{a}}$ in the DJD series. 145 "Does Yahweh Hate Divorce? Malachi 2:16 and the Text of Malachi at Qumran." 


\subsubsection{4 חצ alludes to Genesis 2:24 while}

Unlike most interpretations, the present view considers it likely that in Malachi 2:15 do not share an identical reference. Even if this conviction were proved false, however, once again our conclusions concerning the overall interpretation of Malachi 2:15 would not be greatly affected.

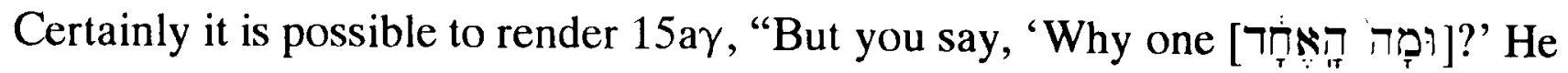

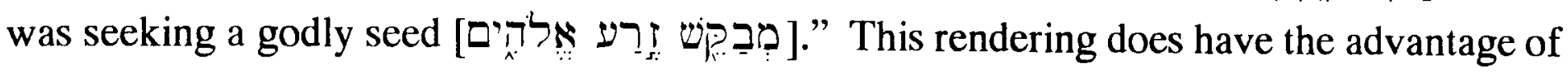
allowing which weigh against this alternative. First, while an unaccompanied ڤָ may on occasion mean "why," this is hardly its most common sense as it is found in only seventeen or so of its five hundred and fifty-four occurences in the OT. ${ }^{146}$ It may also be significant that in none of these examples does מָה bear the meaning "why" in a verbless clause, such as would be required in $15 \mathrm{a} \gamma$. Second, the rendering "why one?" appears to ignore without justification the article on pronominal subject with a participle, such as is posited by the rendering: "he was seeking a godly seed."147 The one other example in Malachi, namely 2:9, differs significantly from

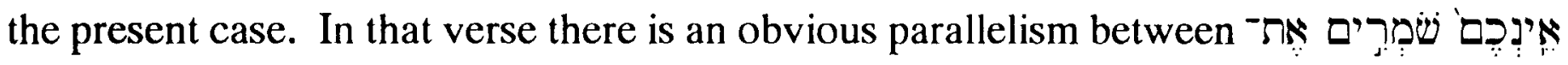

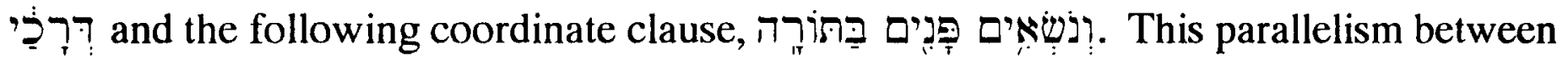
two coordinate participial clauses makes the elided subject for the second participle readily apparent. But it is precisely this sort of parallelism that is lacking in Malachi 2:15.

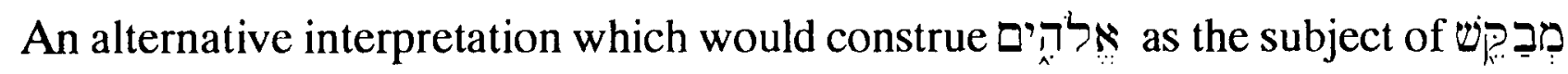
(cf. the LXX) requires an unusual word order for the clause (participle-object-subject) and appears to be excluded by the resulting sense: "And why one? Because God was seeking a seed!"148 Since the Bible recognizes how progeny can result equally from exogamous, adulterous, as well as other illicit unions, there is no obvious logical relation between God's desire for mankind to reproduce and the question posed concerning this marital "oneness."149 Further, even if some connection were posited, this line of discussion

146 Cf. Even-Shoshan. BDB, s.v., 553, offer the following examples of with the meaning "why": Exodus 14:15; 17:2; 2 Kings 6:33; 7:3; Psalm 42:6; Job 15:12; and Song 8:4. While KB, s.v., offer a number of additional examples, all of these actually read מָה and, in any case, may not require the rendering "why": Genesis 3:13; 12:18; 26:10; Judges 18:24; 1 Kings 21:5; and 2 Kings 1:5.

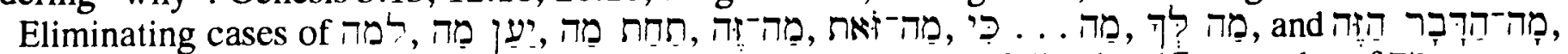
none of which could support a rendering "why" in Malachi 2:15, the following 17 examples of (excluding Malachi 2:15) are rendered "why" in either the NIV or RSV: Exodus 14:15; 17:2; ; Joshua 7:25; 2 Kings 6:33; 7:3; Jeremiah 2:36; 30:15; 49:4; Psalms 42:6; 42:12; 43:5; $52: 3$ [ET 52:1]; Job 7:21; 15:12; Song 7:1 [ET 6:13]; Ecclesiastes 7:10; and Lamentations 3:39.

147 It is acknowledged that the decision to separate the subject of מבקי, has the support of the Masoretic cantillation marks (as indicated by the zāqēp q'tonnāh).

148 F. I. Andersen notes that there are only five examples (out of 355) in the Pentateuch where a participial predicate introduces an independent verbless clause (The Hebrew Verbless Clause in the Pentateuch, 48).

149 E.g., cf. Lot and his daughters in Genesis 19, Esau and his Canaanite wives in Genesis 36, or David and Bathsheba in 2 Samuel 11. 
would be at best tangential to Malachi's concern to oppose divorce and exogamous marriage (indeed, it could be argued that this interpretation of the clause would actually justify the divorce of an infertile wife).

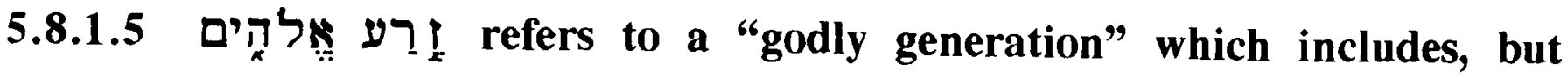 need not be confined to, literal children in their minority}

It is granted that from the biblical perspective all children are viewed as having come from God (cf. Psalm 127:3). ז

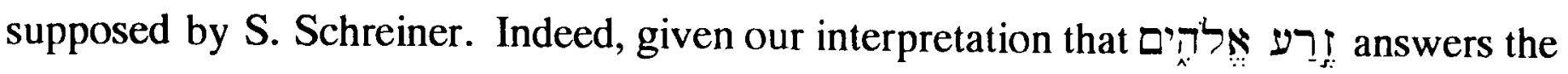
question "What was the One [i.e., Yahweh] seeking?" it is doubtful that Malachi intends the construct to express merely the origin of this seed, that is, "seed from God."151 Rather, in the context of Malachi 2:10-16, "seed of God [יצרע אליהים]" seems to reflect the imagery

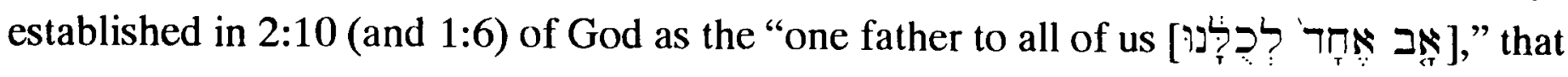
is, to his people in virtue of his redemptive acts and covenant, and seems to offer an

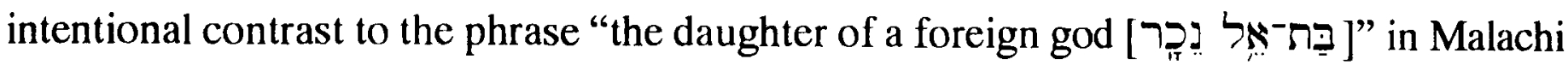
$2: 11.152$

Since God's paternity in 2:10 is not restricted to youngsters and "the daughter of a foreign god" is similarly not confined to girls in their minority, this context has been used by J. Ridderbos to suggest that זٕרע אליה is intended as a reference to Israel herself, rather than the actual dependent children of some human couple. This interpretation may find further support in Ezra 9:2, where [י] [ ["holy race"] appears to refer to Israel as

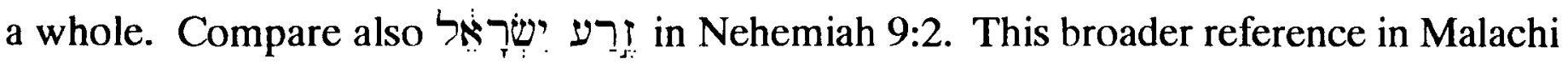
2:15 appears plausible, but it would seem unwarranted to exclude a reference to literal children as well, particularly in the light of the parallel concern in Ezra and Nehemiah regarding the spiritual disqualification and erosion of faith and Hebrew culture in the literal children born to mixed marriages (cf. Ezra 10:3, 44; and Nehemiah 13:24f.), as well as the threat to faith entailed in the sin of the giving and taking of literal daughters in mixed marriage (Ezra 9:2, 12; and Nehemiah 13:25ff.). ${ }^{153}$

Combining these perspectives, H. Frey notes that "the One" who is the Father of Israel desires not merely indiscriminate procreation, but the proliferation of covenant

150 As noted by J. Wellhausen, Die kleinen Propheten (1898) 240.

151 Cf. S. Schreiner, "Mischehen-Ehebruch-Ehescheidung," 217, n. 71.

$152 \mathrm{Ibid}$. Cf. also P. A. Verhoef, The Books of Haggai and Malachi, 265.

153 If it is objected that Ezra and Nehemiah are concerned primarily with mixed marriage and not divorce (as in Malachi 2:15), it should not be supposed that divorce would have been any less perilous to the goal of securing a "godly seed" since Ezra and Nehemiah offer supportive evidence that children went with their divorced mothers and as such were disinherited and spiritually disqualified from involvement in the Israelite cultus (cf. Ezra 10:3, 44). Cf. the similar fate of Ishmael in the expulsion of Hagar. Cf. also Isaiah 50:1, Jeremiah 3:14, and Hosea 1:2; 2:4. 
children -- seed born not just of the will of man but of God (cf. 1 John 5:1, 4; John 3:3ff.). In other words, the seed mentioned in $2: 15$ a $\gamma$ should be understood as having the same kind of dual interdependent paternity as does Israel in Malachi 2:10: "Have we not all one father ... why then are we faithless to one another, profaning the covenant of our fathers?"

Given the allusion to Genesis 2:24 in Malachi 2:15a (and allusions elsewhere in Malachi to the Genesis narrative -- cf. Malachi 1:2), significant support for the present understanding of זٕרע אליה appears to be offered by the ensuing parallel and sustained concern within Genesis with the bifurcation between the "seed" of the woman and the "seed" of the serpent beginning with Genesis 3:15.154

Finally, it is possible that Malachi returns to this concern with godly children in the closing promise concerning the ministry of Elijah, who will "turn the hearts of the fathers to their children and the hearts of children to their fathers" (Malachi 3:24 [ET 4:6]). Once again it appears that there is an intentional twofold reference in this promise. On the one hand, and most simply, the "fathers" and "children" are to be understood as literal members of the same families. In this respect Malachi's promise finds support not only in the biblical picture of family discord as an evidence of divine curse (cf. Micah 6:6), but also in ancient Near Eastern eschatology, which similarly promises a period of restored social harmony. ${ }^{155}$ On the other hand, it appears likely that a more spiritual (or covenantal) family is also in view in 3:24 [ET 4:6], based on the references to Israel's forebears described as "fathers" elsewhere in Malachi: Levi (Malachi 3:3), Jacob (Malachi 3:6), and the Exodus generation (Malachi 2:10), etc.; with the "children" representing the present, much later generation of Israel. This possibility finds further support in the immediate context, in 3:22 [ET 4:4], where family solidarity is presupposed between post-exilic Israel and the exodus generation, as "all Israel," including Malachi's contemporaries, was obligated by the covenant at Horeb. On this interpretation, when the "hearts of the children are turned to their fathers" Israel will recapture the faith and loyalty of Levi, etc. ${ }^{156}$

154 Already in Genesis 4 and 5, there is a sharp differentiation between the Cainites and the Sethites, with only the latter sharing a family likeness to God: God "made him [Adam] in the likeness of God" (Genesis 5:1), and subsequently Adam "became the father of a son [Seth] in his own likeness, after his image" (Genesis 5:3), etc., down to Noah, who "found favour in the eyes of the Lord." (Genesis 6:8).

Later, in a manner which paralleles the experience of Malachi's contemporaries, Abraham moved from Ur of the Chaldeans to come to live in the occupied land of promise, where Sarah gave birth to a son, Isaac, the godly child of the promise (cf. Genesis 21:12). But this was only after the birth of Ishmael, the fruit of merely human plans and a mixed marriage which threatened the marriage of Abraham with Sarah, the wife of his youth. (Cf. H. Frey, Das Buch der Kirche in der Weltwende, 160.) To safeguard the covenant line, later Abraham's servant is prohibited from procuring a wife for Isaac from among the Canaanites and is commanded, rather, to find a wife from among Abraham's own relatives (Genesis 24:3f.). Still later while Esau weds some local Hittite women, Rebekah pleads with Isaac to instruct Jacob to find a wife from among their kinsmen and so to beget children who would be heirs of the Abrahamic blessing in Genesis (cf. Genesis 27:46ff.).

155 Cf. P. A. Verhoef, The Books of Haggai and Malachi, 342, citing A. Jeremias, The Old Testament in the Light of the Ancient East (1911) 2:312.

156 This more spiritual reference may also be favoured by Malachi 1:6, where Malachi takes it for granted that sons generally honour their fathers (an assumption which Micah, for example, might not have found so gratuitous). 
Alternatively, since Abraham, Levi, etc., have long since died, the promise that "he will turn the hearts of the fathers to their children" would then have to be understood figuratively, perhaps in a manner which would resemble Isaiah 63:16. 157

\subsubsection{Objections raised, and answered, to the present approach which considers and Eve in Genesis 2:24}

Having considered certain distinctive features of the interpretation of Malachi 2:15 which is favoured here, we now need to examine a variety of objections which have been raised against the present approach.

\subsubsection{The problem of conjectural textual emendations}

A. Tosato and A. S. van der Woude, among others, have objected that interpretations of Malachi 2:15 which consider $\prod_{\pi} \aleph$ to allude to the "one flesh" marital unity of Adam and Eve, frequently require a number of purely conjectural textual emendations in the latter part of vs. $15 \mathrm{a} .{ }^{158}$ Obviously, an uncertain theory is not rendered more convincing by the accumulation of additional uncertainties. The present view, however, neither requires nor favours any emendation of the MT.159

We have already discussed our reasons for rejecting the common proposal to emend

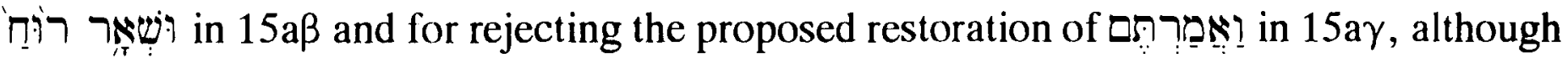
this latter emendation would not greatly affect the sense of the text. We also noted that

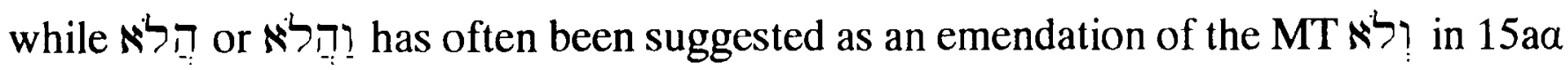
(based on Targum Jonathan, the Peshitta, and the Vulgate) this emendation too is unnecessary. ${ }^{160}$ Finally, two proposals have been advanced to temper or eliminate the odd shifts of personal reference in the MT of $15 \mathrm{~b}$ (from second masculine plural, to second

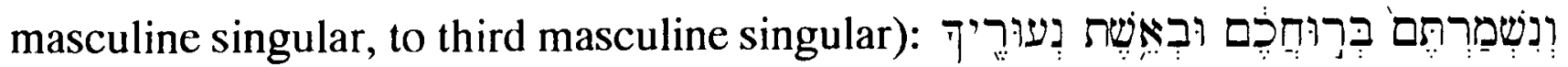

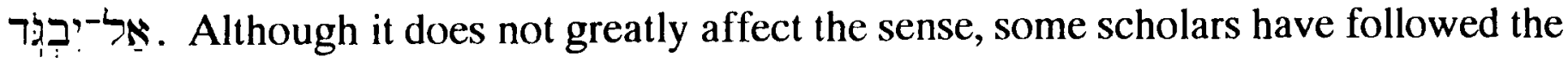

157 Cf. P. A. Verhoef, The Books of Haggai and Malachi, 342.

158 Cf. A. Tosato, "Il ripudio: delitto e pena (Mal 2,10-16)," 548-553, and A. S. van der Woude, "Malachi's Struggle for a Pure Community," 69.

159 It is entirely possible with A. Tosato that the confusion of the ancient versions concerning 2:15 may be less the result of variations in their Vorlagen or misunderstandings of the meaning of the text than studied attempts to avoid that meaning ("Il ripudio: delitto e pena [Mal 2,10-16]," 553).

160 See our more detailed discussion of unmarked rhetorical interrogatives below.

Favouring הל הל are, among others, J. Wellhausen, Die kleinen Propheten (1898); H. Oort, Textus Hebraici Emendationes (1900); W. Nowack, Die kleinen Propheten (1903); A. van Hoonacker, Les douze petits prophètes (1908); and O. Isopescul, Der Prophet Malachias (1908), according to J. M. P. Smith, Malachi, 59. So also E. Sellin, Das Zwölfprophetenbuch (1922); F. Nötscher, Zwölfprophetenbuch (1957); D. Deden, De kleine profeten (1953); and A. Deissler in A. Deissler and M. Delcor, Les petits prophètes, II, Michée-Mal (1964), according to A. S. van der Woude, "Malachi's Struggle for a Pure Community," 69.

Favouring וְהל is H. Graetz, Emendatioines in plerosque Sacrae Scrupturae V. T. libros ex relicto defuncti auctoris manuscripto (1892-94) II, 26 -- as cited by A. von Bulmerincq, Der Prophet Maleachi, II, 294. 


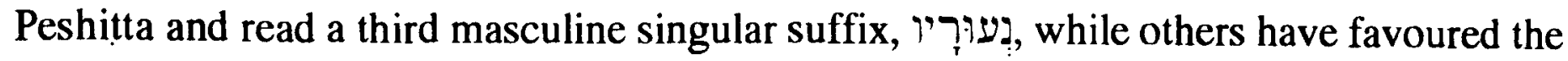
approach of the LXX, Targum Jonathan, Vulgate, and a few MSS of the MT by reading a second masculine singular form, in place of the third masculine singular jussive verb, 161

Neither of these proposals is required. It is widely recognized (cf., e.g., E. W. Bullinger, Figures of Speech, 524f.; GKC \$144p) that to a much greater degree than English, Hebrew tolerates heterosis (= change) of person and number. As such, the Hebrew Bible includes numerous examples of exactly the kind of mixing of personal reference as is found in our text. Not all of these examples can be dismissed as the result of textual corruption, and some of them may even reflect an intentional stylistic choice. ${ }^{162}$ Moreover, in the light of the contradictory versional evidence for Malachi 2:15b, emendation to remove the heterosis of person in the MT appears to be misguided. This is so because it is only on the assumption of the originality of the MT, which has both second and third person references in tension, that a reasonable account can be given for the simpler uniform third person reference of the Peshitta as well as the simpler uniform second person reference of the LXX, Targum Jonathan, and Vulgate. In other words, the MT should be maintained on the principle of lectio difficilior.

\subsubsection{The problem of the supposed need for an interrogative in $15 \mathbf{a a}$}

It has often been argued that had it been Malachi's intention to express a rhetorical interrogative in 15aa, as those following the present approach are required to hold (D. A. Bruno being the only exception), Malachi would have done so by utilizing an interrogative $\pi$ as he does in vs. 10. This is not to deny the possibility that at times Hebrew may omit the interrogative $\pi$ in rhetorical questions. But, as argued by A. Tosato, citing Joüon $\$ 161 \mathrm{a}$ in support, the cases where Hebrew omits the interrogative $\mathrm{B}$ significantly differ from the present instance. ${ }^{163}$ Opposing those who would emend וְל וְלא Wellhausen, et al.) or ובה (H. Graetz) to bring vs. 15 into conformity with Malachi's practice in vs. 10, A. von Bulmerincq notes that the corrected LXX opposes an

161 נִעוּר is favoured by J. M. P. Smith, as well as Hugo Grotius (Annotata ad Vetus Testamentum, 1644), W. Nowack, K. Marti, B. Duhm, and perhaps O. Isopescul, according to Smith.

On the other hand, תבכגר is favoured by J. Wellhausen, H. Oort, W. Nowack, S. R. Driver, C. von Orelli, E. Sievers, and A. van Hoonacker.

162 So S. Schreiner, op. cit., 213, who appeals to E. König, Stilistik, Rhetorik, Poetik (1900) $238 \mathrm{ff}$. Cf. also J. Sperber, "Der Personenwechsel" (1918/19) 23-33. Cf. further the discussion of this same point in C. Locher, "Altes und Neues zu Maleachi 2,10-16", 256, and A. S. van der Woude, "Malachi's Struggle for a Pure Community," 70, n. 30. Cf. also M. Fishbane, who discusses shifts of personal reference in Deuteronomy 1-6, denying that they have any implication for the isolation of variant sources in that context (Biblical Interpretation in Ancient Israel [1985] 321f.).

163 Op. cit., 550. 
interrogative sense for $15 \mathrm{a} a$ and so supports the MT in opposition to the suggestion to emend. 164

In response to these arguments against an interrogative interpretation for this verse, we may note that Malachi 1:8 appears to offer two more examples within Malachi of the use of an unmarked rhetorical interrogative. In any case, the appeal to vs. 10 proves only that Malachi was capable of using the interrogative $\mathrm{n}$ to express a rhetorical question; it does not prove that Malachi was incapable of expressing a rhetorical question without the use of an interrogative $ה$.

It is commonly recognized that in Hebrew a clause may be interrogative without being explicitly marked by an interrogative pronoun, an interrogative adverb, or the interrogative $1.165 \mathrm{GKC}$, for example, notes that "frequently the natural emphasis upon the words is of itself sufficient to indicate an interrogative."166 In particular, GKC notes the relative frequency of cases where the unmarked interrogative clause is introduced with 7 (e.g., cf. Jonah 4:11, among numerous other examples) or לוl) (cf. Exodus 8:22 [ET 26]; 2 Kings 5:26; and Lamentations 3:38). 167 Although it is not mentioned by GKC in this connection, inverted word order has also been identified as a common indicator of the kind of "emphasis" which GKC considered to be a frequent characteristic of unmarked interrogative clauses. 168 As such, inverted word order is mentioned by P. Joüon and R.

164 A. von Bulmerincq, Der Prophet Maleachi, II, 294f. So also, H. Graetz, Emendatioines in plerosque Sacrae Scrupturae V. T. libros ex relicto defuncti auctoris manuscripto (1892-94) II, 26, as cited by von Bulmerincq.

165 In addition to citing GKC \$150a in support, A. von Bulmerincq mentions H. Ewald, Ausführliches Lehrbuch der hebräischen Sprache des alten Bundes (1870) \$324a; E. König, Historisch-comparative Syntax der hebräischen Sprache (1897) §353c; and C. Brockelmann, Grundriss der vergleichenden Grammatik der semitischen Sprachen (1908-1913) II §113a (op. cit., 295).

Cf., e.g. the comments on 15 aa offered by L. Reinke, G. H. A. von Ewald, C. von Orelli3rd edition, de Moor, E. Sellin, and W. Nowack ${ }^{3 \text { rd }}$ edition, each of whom maintains an interrogative sense for the unemended MT ולאיאו?

$166 \mathrm{GKC} \$ 150 \mathrm{a}$. The still definitive study of this phenomenon is that of H. G. Mitchell, "The Omission of the Interrogative Particle," in Old Testament and Semitic Studies in memory of William Rainey Harper, I (Chicago, 1908) 115-129.

Mitchell, op. cit., p. 117, objects to GKC's characterization of unmarked interrogatives as occurring "frequently" given that he is able to discover only 27 clear examples of this phenomenon within the Old Testament (e.g., Genesis 3:1; 18:12; Judges 11:9; 1 Samuel 21:16/15; 22:7, 15; 2 Samuel 16:17; 19:23/22; 1 Kings 1:24; $21: 7$; Isaiah 14:10; Hosea 10:9; Habakkuk 2:19; Zechariah 8:6; Proverbs 22:29; 26:12; 29:20; Job 2:9, 10;11:3; 14:3; 37:18; 38:18; 40:30 [ET 41:6]; Song of Songs 3:3; and Lamentations $3: 36,38$ ), with a remaining 12 cases which he considered to be likely the result of textual corruption (e.g., Genesis 27:24; I Samuel 16:4; 30:8; 2 Samuel 18:29; 2 Kings 5:26; 9:19; Ezekiel 11:3, 13; 17:9; Proverbs 5:16; 30:24; and Job 40:25 [ET 41:1]).

167 For a further discussion of the interrogative/affirmative use of לא, cf. G. R. Driver, "'I was [am] no prophet, neither was [am] I a prophet's son.' (RV)" (1955-56) 91-92.

168 Though cf. GKC $\$ 141 \mathrm{n}$ where inversion of word order is observed in interrogative verbless clauses. However, the example which GKC cites, namely 1 Samuel 16:4, is problematic both because it may be textually corrupt and also because, at least according to the analysis of F. I. Andersen, its word order (P-S) may be construed as entirely normal for such a clause where $\mathrm{P}$ is indefinite (The Hebrew Verbless Clause in the Pentateuch [1970] 106).

While recognizing the remaining uncertainties regarding word order in Biblical Hebrew, for our present purpose we accept as valid the main conclusions of F. I. Andersen concerning the typical core sequence of P-S in independent verbless clauses of classification (i.e., clauses where $P$ is indefinite), of S-P in clauses of identification (i.e., clauses where $P$ is definite), of S-P in a circumstantial clause of classification, and of $S$ - 
Meyer, among others, as a prominent, though not invariable, feature of otherwise unmarked interrogative clauses. ${ }^{169}$ As we noted earlier, Tosato's citation of Joüon \$161a against an interrogative interpretation of 2:15a a is misleading because Tosato fails to give adequate attention to Joüon's insight concerning inverted word order. Specifically, we may note that of the thirty-two examples of unmarked interrogative clauses cited by GKC, a list which is by no means exhaustive, ${ }^{170}$ inverted word order occurs in twenty-two cases: Genesis 18:12; Exodus 33:14;171 Judges 11:23; 14:16; 1 Samuel 11:12;172 20:9; 22:7; 2 Samuel 11:11; 15:20; 1 Kings 1:24;173 2 Kings 5:26;174 Job 2:10;175 10:9; Isaiah 37:11; 44:19b; Jeremiah 25:29; 45:5; 49:12; Lamentations 3:38; Ezekiel 20:31; Zechariah 8:6; and Jonah 4:11. Concerning the remaining ten examples cited in GKC \$150a where word order is not inverted, five of these appear to be in need of textual emendation (i.e., Genesis 27:24;176 Exodus 8:22 [ET 26];177 1 Samuel 16:4;178 2 Samuel 18:29;179 Proverbs

$P$ in participial clauses. In so doing, we do not necessarily accept each of Andersen's explanations of the exceptions to these sequences, and, particularly, we do not need to accept his exclusion of "emphasis" as an appropriate, even if subjective, explanatory category (cf.op. cit., 18, 24). Cf. also Williams, Syntax $\S \S 577-582$.

Andersen's aversion to the notion of "emphasis" has been been challenged both by J. Hoftijzer, "The Nominal Clause Reconsidered" (1973) 475 (whose analysis stresses the notion of "contrastiveness") and especially by T. Muraoka, Emphatic Words and Structures in Biblical Hebrew (1985) 1-46, at p. 6.

With respect to the word order of verbal clauses, we accept the consensus summary offered by Williams, Syntax \$\$571-576, and T. Muraoka, Emphatic Words and Structures in Biblical Hebrew, 28-46, both of whom begin by acknowledging verb-subject(-object-prepositional phrase/adverb) as the normal sequence of independent verbal clauses. To be noted also is the often overlooked, but helpful distinction between conjunctive and disjunctive verbal clauses (not just circumstantial clauses, as in Muraoka) which is offered in Lambdin $\$ \S 133,197$.

169 Joüon §161a, 495 and R. Meyer, Hebräische Grammatik, III (1972) §111, 1.

170 Cf., e.g., H. G. Mitchell, "The Omission of the Interrogative Particle," 117, and C. L. Meyers and E. M. Meyers, Haggai, Zechariah 1-8, 417. 118.

171 Alternatively, this may be a declarative clause, as in the NIV. Cf. also H. G. Mitchell, op. cit.,

172 Unless the MT should be emended with the LXX to include a negative: "Who was it who said, 'Saul shall not reign over us!'?" (so also H. P. Smith, op. cit., 81; H. G. Mitchell, op. cit., 118; P. K. McCarter, ad loc.; contra S. R. Driver, op. cit., ad loc. and R. W. Klein, op. cit., 103).

173 It will be noted below with Mitchell that questions which are expressed by an unmarked interrogative clause are invariably rhetorical. 1 Kings 1:24 may not seem to require this conclusion, since it is possible that Nathan wished to appear uncertain of the answer to his question. However, since to presuppose David's complicity with Adonijah's revolt would be accuse David of disobedience, it appears more likely that Nathan asked his question in a rhetorical fashion.

$174 \mathrm{H}$. G. Mitchell considers the MT to be corrupt, but this appears unnecessary ("The Omission of the Interrogative Particle," 115f.). Cf., e.g., M. Cogan and H. Tadmor in support of the MT (II Kings [1988] 66). Alternatively, with G. H. Jones, this may be a declarative clause (1 and 2 Kings, II, 420).

175 Frequently rendered, "shall we accept good... and not evil?," but with É. Dhorme, perhaps better is a conditional rendering: "if we accept good, shall we not accept evil?" (Job, 20).

176 Correct with the Samaritan Pentateuch to include the interrogative $\mathrm{n}$.

177 Delete וl with LXX, Syriac, and Vulgate, resulting in a declarative clause: "they will stone us!"

178 The elliptical inquiry here concerning one's well-being may be idiomatic, cf. 2 Samuel 18:29, or the text may need to be emended to include an interrogative $\rightarrow$ following the LXX and Sebir -- so Mitchell, op. cit., K. McCarter, 1 Samuel, 274, and R. Klein, I Samuel, 157.

179 The elliptical inquiry here concerning one's well-being may be idiomatic, cf. 1 Samuel 16:4, or the text may need to be emended to include an interrogative $\mathrm{n}$, as in 18:32, with some MSS, Sebir, Targum [codex Reuchlinianus], Vulgate -- so Mitchell, op. cit., BHS, contra S. R. Driver, op. cit. 
$5: 16^{180}$ ), and three appear more likely to be declarative clauses (i.e., 2 Samuel $16: 17 ; 181$ Isaiah 28:28;182 and Hosea 4:16183). This leaves only two examples (1 Samuel 24:20 [ET 19]; ${ }^{184} 25: 11$ ), both of which happen to be apodoses and one of which gains its interrogative sense from an initial explicit interrogative pronoun (1 Samuel 25:10f. ${ }^{185}$ ).

We may summarize the data to this point by saying that where the text of the MT is sound and an interrogative sense is clear, the word order of unmarked interrogative verbal clauses is frequently inverted (having other core elements fronted before the verb). ${ }^{186}$ We may also note that in every case there is a passionate rhetorical character to the unmarked interrogative with the expected answer never in doubt. ${ }^{187}$ As such, the evidence clearly supports H. G. Mitchell's contention that the purposeful omission of the interrogative lends to the clause an element of incredulity, sarcasm, or irony. ${ }^{188}$ While it is possible to

180 The text may need to be emended with $\operatorname{LXXB} * *^{*}-68$ which prefix $\mu \eta$ implying, perhaps, an initial 犯. Cf. $B H S$.

181 Most interpreters understand Absalom's first question to Hushai as rhetorical and sarcastic, "Is this your loyalty to your friend?!" Cf., e.g., P. K. McCarter Jr., 2 Samuel, ad. loc.; H. W. Hertzberg, op. cit., ad loc.; and J. P. Fokkelman, Narrative Art and Poetry in the Books of Samuel, Vol. 1: King David (II Sarn. 9-120 \& I Kings 1-2) (1981) 207.

However, it is not at all obvious why Absalom would have been so sarcastic on this occasion. What could Absalom hope to gain by offending Hushai if he had, in fact, transferred his loyalty as was the case, presumably, with many of Absalom's supporters (cf., e.g. Ahithophel). On the other hand, it would not be at all unexpected for Absalom to doubt and wish to test Hushai's supposed transfer in loyalty. For this reason it seems preferable to understand this clause in a declarative sense, expressing an accusation: "This is [only] an act of loyalty to your friend! Why did you not go with your friend?" Absalom suspected that Hushai had remained behind in order to serve David in some way, and now he demanded to know what he was up to, what he hoped to accomplish by not accompanying David.

182 This may be a declarative clause, so NIV, O. Kaiser (Isaiah 13-39 [1974] 258), H. Wildberger (Jesaja. 3. Teilband: Jesaja 28-39 [1982] 1083f.), J. N. Oswalt (The Book of Isaiah: Chapters 1-39, 523), and J. D. W. Watts (Isaiah 1-33, 374).

183 It seems preferable to take this as a declarative clause based on the usual precative function of the introductory עת ע. Cf. F. I. Andersen and D. N. Freedman, Hosea (1980) 334, 377.

184 "And if a man finds his enemy will he send him on his way in peace?" Rather than intending a rhetorical appeal to common sense, it is perhaps possible that Saul was quoting a proverbial expression which summarizes the legal requirement to love one's enemies,(cf., e.g., Exodus 23:4) on the ground of which David's obedience would merit God's blessing -- "And if a man finds his enemy, he should send him on his way in peace."

185 "Who is David... that I should take my bread...."

186 By "core elements" is meant either a subject or an object, not simply a conjunction, negative particle, or adverb, all of which commonly precede verbs in verbal clauses.

187 Omitting only the textually dubious Genesis $27: 24$.

In cases where there might have been some doubt as to the appropriate answer, such as 2 Samuel 11:11 where David puzzles over Uriah's unwillingness to go home, considerable effort is expended to introduce the unmarked interrogative so that no doubt could remain concerning its answer. Uriah rehearses for David how the ark and Israel's army are all in tents -- recalling in an ironic manner David's own sentiment in 2 Samuel 7:2. Obviously, under such a circumstance it would be unthinkable for him to return home. Cf. also Judges 11:23; 14:16, Isaiah 37:11, and Jonah 4:11.

A possible exception to this observation may be offered by the special case of inquiries concerning another's well-being which were asked, presumably, without knowledge of the answer (i.e., 1 Samuel 16:4 and 2 Samuel 18:29). However both of these examples involve some textual uncertainty. If the MT is to be maintained, it is conceivable that manners dictated the appearance of the presumption of well-being for the inquirer ("He is well, isn't he?").

188 Op. cit., 209. 
explain the inverted word order of Malachi 2:15 differently, it appears plausible that it is best explained as an indicator of an otherwise unmarked interrogative. 189

A further argument which at times has been mentioned as favouring an interrogative interpretation of $15 \mathrm{a} a$ is the possible co-ordination of $15 \mathrm{a} a$ with $15 \mathrm{a} \gamma$, which is explicitly interrogative. In any case, this conclusion in favour of an interrogative sense in $2: 15 \mathrm{a} a$ appears also to enjoy the support of the major versions. In particular, the reading of

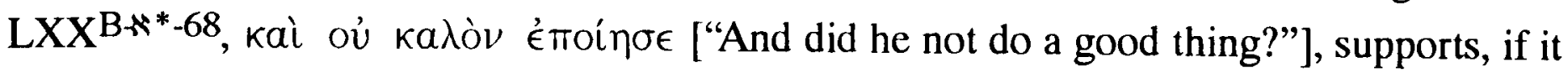
does not require, an interrogative interpretation of Malachi 2:15aa. ${ }^{190}$ Less clearly interrogative, but still likely, is the reading of LXX WConstit. Chr.II221 (and $\mathrm{AQ \Gamma ),} \mathrm{\kappa ai} \mathrm{oúk}$

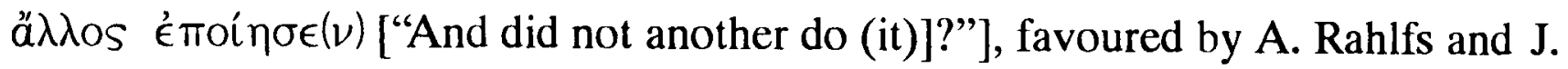
Ziegler. ${ }^{191}$ While there may remain some uncertainty regarding the LXX, unambiguous corroborative support for an interrogative interpretation of $15 \mathrm{a} a$ is found in the the Peshitta (ד) (הלא), Targum , and Vulgate (nonne).

\subsubsection{The problem of the use of ברז in vs. 10 to refer to God's creative act which appears to oppose the use of עִ עִ in vs. 15 as a reference to creation}

Contrary to the present view which interprets עָ 2: 2:15 as a reference to creation,

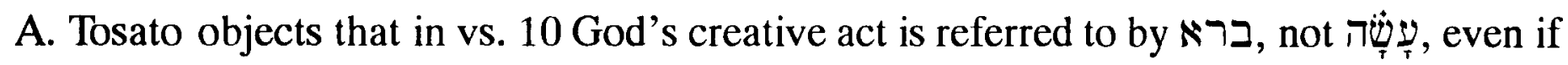
vs. 10 probably refers to the creation of Israel as the people of God, rather than to the original creation of Genesis 1-2. Against Tosato, however, the use of ברז in vs. 10 does

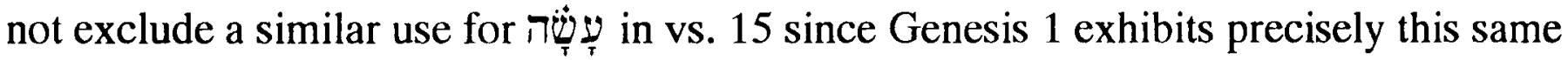
diversity of usage and, in particular, uses עִ עָטָּה for the creation of man in 1:26. 192 Compare also Genesis 2:4, where both עשה appear. Furthermore, while Tosato draws attention to Malachi's use of עָ עָ שָׁה elsewhere with reference to the misconduct of his compatriots (i.e., $2: 11,12,13$ ), this need not control our interpretation of 2:15.193 It is

189 This conclusion obtains whether one interprets $7 \Pi$ s as a negated subject or negated direct object fronted before the finite verb. If the former is the case, Malachi 2:15 finds a precise parallel in 2 Kings 5:26; if the later, a precise parallel exists in 1 Samuel 20:9.

Referring to the fronting of $7 \prod_{\Perp}$ in $15 \mathrm{aa}$, J. M. P. Smith remarks, "It is an unusual position for the subject of a verbal sentence, unless it is intended to be emphatic; and it is just as abnormal a position for the object" (Malachi, 59).

190 So, e.g., both E. Sellin (Das Zwölfprophetenbuch [1922] 553) and W. Nowack (Die kleinen Propheten, 420) cite the LXX as supporting their conjecture that one should read הלא in place of the MT אל.

A. von Bulmerincq, who defends oúk $\ddot{a} \lambda \lambda \mathrm{os} / \nu$ as the proper word division of the LXX, asserts that the LXX supports a declarative sense in vs. 15a (Der Prophet Maleachi, II, 294f.).

191 A. Rahlfs, Septuaginta (1935) and Septuaginta. Vetus Testamentum Graecum Auctoritate Academiae Scientiarum Gottingensis editum, J. Ziegler, ed. (1984).

In support of recognizing ou at the head of its clause as a marker of a rhetorical question expecting an affirmative answer, cf. Blass and Debruner $\$ \$ 427,433,440$, and $\mathrm{R}$. W. Funk, $A$ Beginning-Intermediate Grammar of Hellenistic Greek (1973) \$617.7.

192 Cf. also W. Rudolph, "Zu Mal 210-16," 90, esp. note 12.

193 Cf. also 3:19 [ET 4:1]. 
hardly to be expected that Malachi would have used such a common verb as עָ עָָׁ in some univocal sense (cf. 3:17 and 3:21 [ET 4:3], where Malachi employs עָָָָָ to describe Yahweh's eschatological redemptive intervention!). ${ }^{194}$

\subsubsection{The problem with Yahweh as the assumed antecedent of}

A. von Bulmerincq has objected to the present view that it appears forced because it requires "Yahweh" to be the implied subject of עָ עָ in vs. 15aa, but the closest explicit reference to "Yahweh" is found in vs. 14a, seemingly too distant to allow it to be the required antecedent. 195 Against this objection, however, T. Chary has observed that although the explicit mention of "Yahweh" does occur at some remove from 15aa, he can still be the subject of $15 \mathrm{a} a$ because, in fact, he dominates the logic of the entire preceding verse. 196

\subsubsection{The problem with a lack of parsimony in requiring דָָ to bear a different reference}

A final argument against the present view, which understands bear a different reference, is that such an interpretation lacks parsimony. We have already considered, however, numerous arguments which appear to demand the conclusion that, in

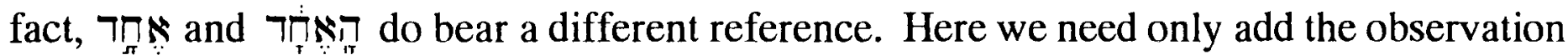
that the dual referencing of 2 in $2: 15$ appears to find adequate preparation in the logic of Malachi 2:10. As R. L. Smith has noted, the whole burden of 2:10 is to impress upon Malachi's hearers that because Yahweh is "one" so should they be "one."197 It is possible that by analogy with 2:10 Malachi implies in 2:15 that the One God who made Adam and Eve likewise made them to be "one" and hence, on penalty of their lives (2:15ba, cf. Genesis 2:23), requires that they should act as "one" (cf. Genesis 1:27 and 2:24).

\subsubsection{Further support for an allusion to Genesis 2:24 in Malachi 2:15}

Without reviewing all our previous conclusions, it may be noted here that the present view, which finds in 2:15 an allusion to Genesis 2:24, enjoys the indirect support which comes from the prior exclusion of every other view. In addition to this "negative" evidence and in addition to what has already been observed regarding the language of

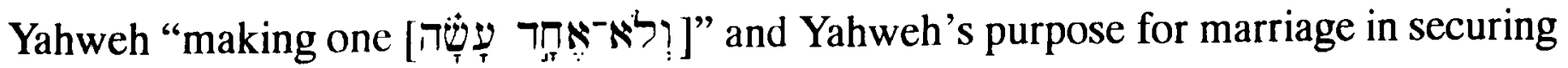

194 On the present view, of course, עִשָׁi in Malachi 2:15 refers not to creation in general, but to the special creative activity of God (related in Ǵnesis 2:18-24) by which he made Adam and Eve to become one flesh in Genesis 2:24.

195 A. von Bulmerincq, Der Prophet Maleachi, II, 294.

196 Aggée - Zacharie - Malachie, 261.

197 Micah-Malachi, 321. 
נירע אליה:, there are five further arguments in support of an allusion to Genesis 2:24 in Malachi 2:15.

First, the context of Malachi 2:15 prepares the reader in several ways for an allusion to Genesis 2:24 within this verse. In terms of the wider context of Malachi, an allusion to Genesis 2 in Malachi 2:15 can come as no surprise in a book which is so conscious of its subservience to the law of Moses (cf. Malachi 3:22 [ET 4:4]) and so fraught with allusions to Pentateuchal texts, especially Genesis. 198

Second, focusing more narrowly on Malachi 2:10-16, it has been observed that Malachi 2:10 in particular prepares for an allusion to Genesis by its use of the imagery of creation, although this allusion is indirect since the creation immediately in view is not the primeval creation, but a recreation in the formation of Israel (also accomplished by way of a judicial separation of the waters and subsequent habitation of a paradise land, etc.).

Third, as W. C. Kaiser Jr. has noted, already in Malachi 2:14 there appears to be a conceptual framework for marriage which parallels Genesis 2 , if it is not directly indebted to it, in its radical view of the position of the wife. ${ }^{199}$ In Genesis not only is the wife called "a helper, suitable for him," but also the highest natural loyalty owed by a man to his parents is now to be superseded by an even higher loyalty to his wife -- as a husband, he "leaves his father and mother and cleaves [a term employed elsewhere in covenantal contexts] to his wife." Consequently, Kaiser writes, "Perhaps there is an echo of the "one

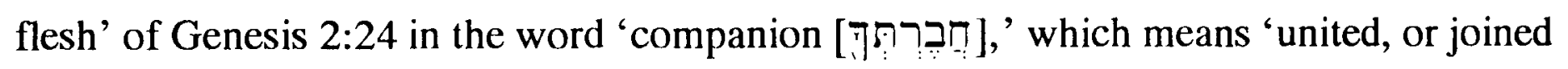
together." Similarly, although S. Schreiner does not accept the present interpretation of 2:15a, he recognizes a possible allusion to Genesis 2:23f. in the wider context of Malachi 2:15, citing Tobit 8:6ff. in support. 200

Fourth, perhaps the most striking point of similarity between Genesis 2 and Malachi 2 is the fact that the primary obligation of marriage as stressed in both of these texts is not that of the wife toward her husband, as might be expected from their ancient contexts, but that of the husband toward his wife. We will leave to the end of this chapter a closer examination of Adam's obligation to nurture and to love his wife. This obligation is already implied in the mode of Eve's creation, but it is explicit in Adam's recognition of Eve as "bone of my bones and flesh of my flesh," as well as in the narrator's conclusion in Genesis 2:24. In a similar manner, throughout Malachi 2:14-16 the prophet repeatedly stresses the fidelity which is required, not of the wife, but of the husband, whose disloyalty against his wife constitutes a threat against his own life. Apart from Genesis 2 (and much

$198 \mathrm{Cf}$. a discussion of our discussion in $\$ 1.1$ and $\$ 1.2$ above.

199 Malachi, 70

200 "Mischehen-Ehebruch-Ehescheidung," 226.

According to Schreiner, this possibility was also favoured by J. Saurin, Kurtzer Entwurff der Christlichen Theologie und Sitten-Lehre (= abregé de theologie et morale chretienne, dt.) (1723) 473. 
later texts, such as Ephesians 5:21-33, which are dependent on it), such a perspective is almost unparalleled.

Finally, in the past scholars have been understandably impatient with interpreters who read a fully developed New Testament theology back into associated Old Testament texts. In recent years, however, there has been a fresh appreciation for the Jewish background of the teachings of Jesus of Nazareth and his radical dependence on the Old Testament in keeping with his own disavowal of originality (Matthew 5:17-20). ${ }^{201}$ Having established the likelihood of the present interpretation of Malachi 2:15, whereby Malachi grounds his prohibition of divorce in the conjugal unity effected by God in marriage, as taught in its institution in Genesis 2, many scholars (such as A. van Hoonacker, E. Sellin, and H. Frey) appropriately cite Matthew 19:4-9 as evidence that Jesus was dependent on Malachi 2:15 for his view or, at least, that he understood the implication of Genesis 2:24 in a manner which parallels and corroborates the present interpretation of Malachi 2:15. It is a remarkable fact that the Adam and Eve narrative similarly influenced the understanding of marriage in at least two works dating from the 2nd century B.C., Tobit 8:5-6 and Sirach 25:24-26, besides several well-known New Testament texts in addition to Matthew 19:4-9 (// Mark 10:6-9), namely, Ephesians 5:21-33; 1 Corinthians 6:16; 11:8, 9; and 1 Timothy $2: 13.202$

\subsubsection{Concluding remarks on the view that "one flesh" marital unity of Adam and Eve in Genesis 2:24}

We began this chapter by reviewing seven alternative interpretative approaches to Malachi 2:15, which take $7 \prod_{\pi} \aleph$ in $15 \mathrm{a} a$ as the subject of its clause $(\$ 5.1-\S 5.5)$ or else emend $\prod_{\pi} \aleph$ with the LXX or Peshitta (\$5.6- \$5.7). While the evidence adduced for these approaches was deemed unconvincing, many of them share the conviction that Malachi is alluding to Genesis, mainly based on the recognition of a number of verbal and conceptual links between 2:10 and 2:15; this we believe is a correct insight. ${ }^{203}$

In the present section (\$5.8) we have been examining the view that $\prod_{\pi} \aleph$ is, in fact, the direct object of ע்ָָׁ This recognition brings with it two further implications, namely

201 Cf., e.g., C. H. Dodd, According to the Scriptures: The Substructure of New Testament Theology (1952); R. T. France, Jesus and the Old Testament (1971); and D. A. Carson and H. G. M. Williamson, eds., It is Written: Scripture Citing Scripture (1988). Cf. also J. H. Charlesworth, Jesus Within Judaism. New Light from Exciting Archaeological Discoveries (1988).

202 P. W. Skehan and A. A. Di Lella render Sirach 25:24-26, "In a woman was sin's beginning: on her account we all die. Allow water no outlet, and be not indulgent to an erring wife; If she walks not by your side, cut her away from your flesh with a bill of divorce" (The Wisdom of Ben Sira, [1987] 343f., cf. also 348f.). 2:15.

Cf. N. Lohfink and J. Bergman, "דָ̣ 'echādh," TDOT, I, 198, who cite Sirach 25:24-26 and Malachi

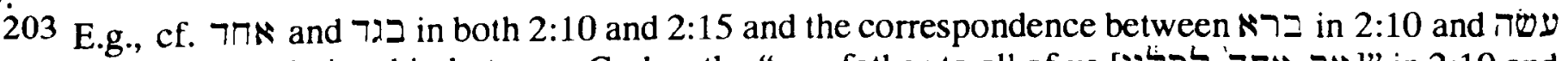

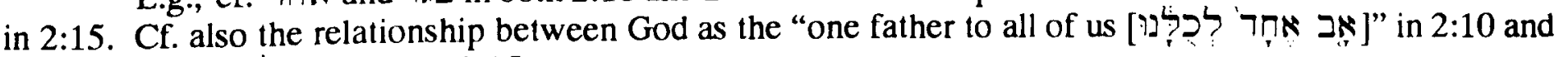

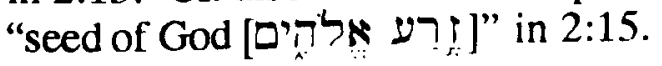




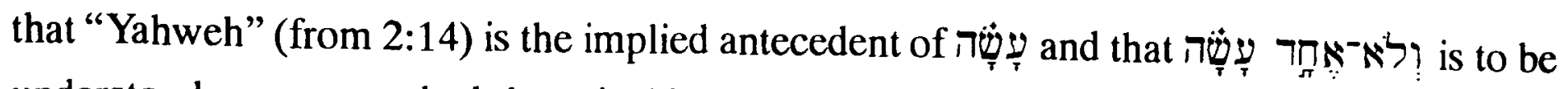
understood as an unmarked rhetorical interrogative. Accordingly, we suggest rendering Malachi 2:15: "Did He not make [you/them] one, with a remnant of the spirit belonging to it? And what was the One seeking? A godly seed! Therefore watch out for your lives and do not act faithlessly against the wife of your youth."

In support, it was noted that the present view requires no emendation of the MT. Furthermore, it was argued that an unmarked rhetorical interrogative in $15 \mathrm{a} a$ is paralleled elsewhere in Malachi (1:8) and is favoured by the inverted word order of its clause ( $\$ 5.8 .2 .2$ above), by the co-ordination of $15 \mathrm{a} a$ with $15 \mathrm{a} \gamma$, which is explicitly interrogative, and by the versional evidence for $15 \mathrm{a} a\left(\mathrm{LXX}^{\mathrm{B}}{ }^{* *}-68\right.$, Peshitta, Targum, Vulgate, and probably LXXWConstit. Chr.III221 (and $\mathrm{AQ} \Gamma$ )).

A particular advantage of the present view, as noted by A. van Hoonacker, E. Sellin and others, which also helps to confirm it, begins with the recognition that the warnings in $15 \mathrm{~b}$ and $16 \mathrm{~b}$ carry the radical implication that for an unfaithful spouse, divorce is an offence against one's own life. In other words, concern for one's life and fidelity to one's legitimate spouse are considered virtually synonymous (cf. Ephesians 5:28). It follows that in 15a Malachi must have intended to articulate a principle which would establish this equivalence. As elucidated by the present approach, Malachi does this very thing. The principle which is articulated is the profound communion of life which God effects between a man and a woman within marriage, as established in Genesis 2:24: "Did He not make [you/them] one...?" Thus interpreted, as noted above, there is a remarkable similarity between the logic of Malachi 2:15 and the teaching of Jesus in Matthew 19:5ff.

We conclude the present section noting that from Malachi's own perspective his view of marriage was not unprecedented, but was consciously derived from, or at least supported by, the paradigmatic marriage of Adam and Eve (Genesis 2:24) -- a fact which is entirely at home in a book so fraught with allusions to Pentateuchal texts.

\subsection{The likelihood that Malachi justified or, perhaps, even derived his view of marriage as a covenant (2:14) from Genesis 2-3}

In this concluding section we shall consider the evidence of Genesis 2 more directly, not so much to determine the grammatico-historical "correctness" of Malachi's implied exegesis, but merely to determine if the character of Adam and Eve's marriage would have lent itself to being identified as a בִּרִ by Malachi (2:14). ${ }^{204}$

204 In support, cf. G. J. Wenham, Genesis 1-15 (1987) 71; and V. P. Hamilton, The Book of Genesis, Chapters 1-17(1990) 181, both of whom identify Adam's marriage to Eve as covenantal. 


\subsubsection{Adam and Eve as a paradigm for marriage}

Obvious to any reader of Genesis 2-3 is the fact that the account of Adam and Eve is characterized by a luxuriance of meaning and intention. One need not exclude any of the various aetiological concerns which have been posited for the narrative (particularly the need to explain the origin and character of the human race), or any literary concerns (such as to provide an introduction to Genesis, or to the entire J document, etc.), however, in order to recognise the prominence, at least in the canonical form of the text, of a didactic concern to provide in the account of Adam and Eve a normative paradigm for marriage. ${ }^{205}$

205 Besides the need to explain the origin and character of the human race, various other aetiological purposes have been suggested for Genesis 2-3 including the following: the need to explain the lack of ribs about the abdomen; the presence of the navel; embarrassed consciousness of sexuality in 3:7; the use of clothes in 3:7,21; the origin of (or perhaps new postlapsarian significance for) the leglessness of snakes in 3:14; woman's fear of snakes (3:15); pain in childbearing (3:16); futility of labour (3:17ff.); the existence of death (3:19); man's need to till the ground to gain a living and why he is buried in the ground when he dies (based on a pun between Humbert, "Études sur le récit du Paradis et de la chute dans la Genèse," 57f., as cited by J. A. Bailey, "Initiation and the Primal Woman in Gilgamesh and Genesis 2-3," 142; N. Lohfink, "Gen 2-3 as "historical etiology';" G. von Rad, Genesis, ad loc.; J. Rogerson, The Supernatural in the Old Testament, 27; M. Oduyoye, The Sons of the Gods and the Daughters of Men; C. Westermann, Genesis 1-11, ad loc.

Recent Old Testament scholarship has heen increasingly alert to the literary function of the Adam and Eve narrative within the framework of Genesis in particular, but also within the larger literary work of the Pentateuch. For example, A. J. Hauser has explored the literary parallels between Genesis 2-3 and the story of Cain and Abel in Genesis 4 ("Linguistic and Thematic Links between Genesis 4:1-16 and Genesis 2-3" [1980]).

Likewise, I. M. Kikawada stresses ways in which the Adam and Eve narrative anticipates and prepares for the account of the deluge, which in turn offers a kind of judicial decreation followed by a redemptive recreation ("Literary Convention of the Primaeval History" [1975]). Cf. also the similar observations in D. J. A. Clines, "The Theology of the Flood Narrative" (1972-73); and idem, The Theme of the Pentateuch (1978) 73ff.; M. G. Kline, Kingdom Prologue (1981-85); I. M. Kikawada and A. Quinn, Before Abraham Was. The Unity of Genesis 1-11 (1985); and W. A. Gage, The Gospel of Genesis. Studies in Protology and Eschatology (1984). The possible identification of the mysterious of Genesis 2:6 as a "flood," fructifying in the case of Eden, but nevertheless a major water source in view of the mentioned four rivers in Genesis 2:10ff., may provide further support (D. Kidner, "Genesis 2:5,6: wet or dry?").

Similarly D. J. A. Clines emphasizes the parallels between Adam and Abraham (The Theme of the Pentateuch [1978]; cf. also W. Berg, "Der Sündenfall Abrahams und Saras nach Gen 16,1-6" [1982]). On the other hand, B. T. Dahlberg notes how Genesis 2-3, and the Primeval History more generally is paralleled by the Joseph Narrative (Genesis 37-50), thereby forming an inclusio for the book ("On recognizing the unity of Genesis;" cf. also D. J. A. Clines, The Theme of the Pentateuch, 84-85).

Looking beyond Genesis, I. M. Kikawada and A. Quinn demonstrate how the Primeval History offers a close literary parallel to Exodus 1-2 (Before Abraham Was). They also briefly suggest a much broader comparison of the whole of Exodus with Creation by identifying Genesis as a "foretelling of the Exodus," much as Deuteronomy offers a "retelling."

Further afield, and for this reason less secure, is a purpose first articulated by W. Brueggemann, who argues for an intentional extended parallel between Adam and Eve, on the one hand, and David and Bathsheba on the other ("David and His Theologian" [1968]). As summarized by G. W. Coats, Genesis 2:4-3:24 "derives from circles (wisdom?) who stand over against the king to admonish, instruct, and correct him, or finally to impeach him.... At earlier stages, the tradition may have served as a critical judgment on the power of the king. It reflects the efforts to limit and thus to instruct the king in his administration of state affairs. It calls on mythological tradition which, by annual repetition in the ritual of the royal cult, secured the stability of the king's world" (Genesis with an Introduction to Narrative Literature [1983] 39, 59f.). Cf. the similar views of W. M. Clark, "The Flood and the Structure of the Pre-patriarchal History" (1971); J. W. Rosenberg, "The Garden Story Forward and Backward: The Non-Narrative Dimension of Gen. 2-3" (1981) 1-27; and idem, King and Kin: Political Allegory in the Hebrew Bible (1986); J. M. Kennedy, "Peasants in Revolt: Political Allegory in Genesis 2-3" (1990) 3-14. Against this approach, however, cf. D. J. A. Clines, The Theme of the Pentateuch, 73f.; and W. Richter, "Urgeschichte und Hoftheologie." 
Admittedly, certain strands of critical scholarship have tended to obscure this purpose by minimizing the function of Genesis 2:24, the locus classicus of marriage: "Therefore a man leaves his father and his mother and cleaves to his wife, and they become

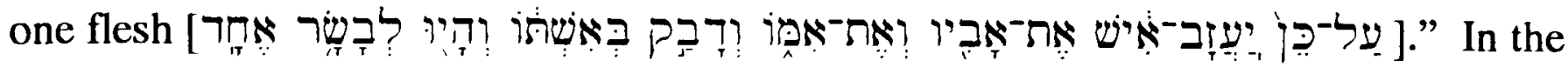
existing text this verse unquestionably offers a climactic summary for the whole of Genesis 2:18-24.206 But in place of this canonically explicit purpose, scholars at times have preferred to highlight other purposes within the text, some of which would be evident only in hypothesized pre-canonical sources.

So, for example, C. Westermann asserts that Genesis 2:24 is a later addition to the text which bears an aetiological motif to explain "the basic drive of the sexes to each other" (citing von Rad) but that this purpose is extraneous to that of the larger narrative unit, which is concerned with the "creation of the humankind which reaches its goal in the complementary society of man and woman."207 Thus viewing 2:24 as secondary, not surprisingly Westermann explicitly rejects the claim of von Rad (with which we would agree) that "in this statement [2:24] the entire narrative so far arrives at the primary purpose toward which it was oriented from the beginning." 208 Consistent with this devaluation of 2:24, Westermann also strenuously rejects the claim of F. Delitzsch, A. Dillmann, and olhers that "the narrative is the foundation of monogamy" since "it is not concerned with the foundation of any sort of institution, but with primeval event."209

It appears that Westermann may have allowed his form/source critical presuppositions to obscure a vital and even determinative purpose within the present narrative -- a purpose which would not have been missed in Malachi's day by those who read the text with pre-critical eyes. For such readers, the explicit introductory "therefore

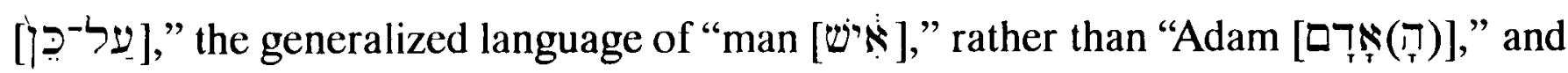
especially the mention of leaving one's father and mother, a qualification which could not have applied literally to Adam, all make plain the narrator's intention: this summary is to be interpreted as a general norm substantiated by the preceding narrative. As G. W. Coats concludes, Genesis 2:24 is the aetiological goal of the entire narrative unit (Genesis 2:1825). 210

206 Vs. 25 then functions as a transitional verse, connected to 3:1ff. perhaps by the verbal linkage of a

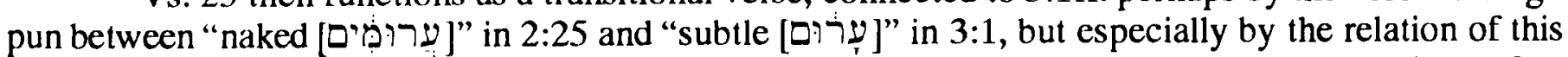
verse to the mentioned shame and remedy for their nakedness in 3:7ff. Qualifying the recognition of a deliberate pun, in a language like Hebrew with only twenty five consonantal phonemes (if one accepts the view of J. Blau, On Polyphony in Biblical Hebrew, regarding bivalent $\Pi, \mathcal{\nu}$, and $ש$ ) and largely triconsonantal roots, one should not be surprised by frequent assonance, which may be merely accidental.

207 Genesis 1-11, 232f. The only proof offered by Westermann for his assessment of 2:24 is the criterion of excisability: "It is clear then that v. 24 is but an addition to the narrative which is complete without it, ending with v. 23."

208 lbid., 233. G. von Rad, Genesis, 84. Later, however, C. Westermann somewhat inconsistently states that "the narrative $2: 4 \mathrm{~b}-8,18-24$ is brought to a conclusion in v. 24" (op. cit., 234).

209 Genesis 1-11,232. Of course Delitzsch and Dillmann were "misled" in their assessment by the fact that 2:24 clearly does, in fact, have the institution of marriage in view.

210 Genesis with an Introduction to Narrative Literature, 53. 
There are yet other indications that the Adam and Eve narrative was intended, at least in part, to offer a normative paradigm for marriage, as Malachi appears to have understood the text. For example, supportive of this conclusion is the generic naming in

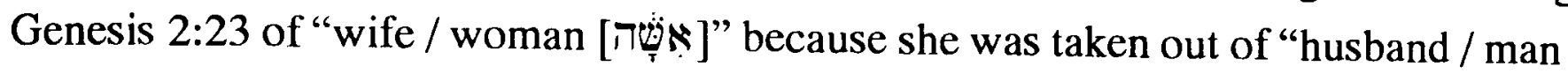

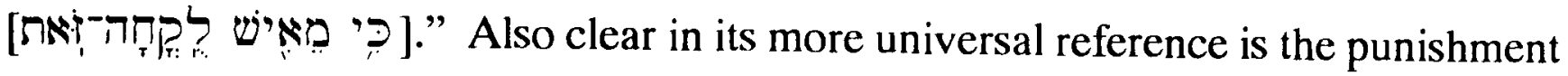
articulated in Genesis 3:14-19 and especially vs. 16. As noted by N. M. Sarna, the curse of multiplied pain in childbirth in $3: 16$, as also the curse in $3: 15$, presupposes the blessing and universal mandate of Genesis 1:28: "And God blessed them, and God said to them, 'Be fruitful and multiply, and fill the earth and subdue it; and have dominion over the fish of the sea and over the birds of the air and over every living thing that moves upon the earth.""211 Just as this blessing was not restricted to, or exhausted by, the original pair (cf. Genesis 9:1), the correlative curse appears similarly to go beyond Adam and Eve to encompass every one of their descendants in its baleful grip. 212

Finally, in view of the literary parallels between Genesis $1-11$ and various ancient Near Eastern creation accounts and other myths (e.g., the Sumerian King List, the Sumerian Flood Story or its reconstructed form as the Eridu Genesis, the Memphis creation documents, the Atra-hasīs Epic, Enūma Eliš, the Gilgameš Epic, the Adapa Myth, etc.), the inclusion of an intentionally paradigmatic marriage in Genesis 2-3 should not be surprising. ${ }^{213}$ In fact, such an account may even serve to foster the pervasive anti-pagan

211 Genesis (1989) 27.

212 This universal reference is apparent even though 2 f.s. and 3 m.s. forms occur throughout in the Hebrew text. Apart from such an extended application, the seemingly intentional parallelism of a universal scope in the other two cursings (of the serpent in 3:14-15 and of the ground/Adam in 3:17-19) would inexplicably break down in this middle member (3:16). For this reason there is virtual unanimity among exegetes that such a wider application is intended, whether or not one accepts the Augustinian theory of "original sin." Cf. S. E. Porter, "The Pauline Concept of Original Sin, in Light of Rabbinic Background" (1990) 3-30.

213 The secondary literature on these myths and their comparison with Genesis is vast. Cf., e.g., T. Jacobsen, The Sumerian King List (1939); A. Heidel, The Gilgamesh Epic and Old Testament Parallels, 2nd ed. (1949); idem, The Babylonian Genesis. The Story of Creation, 2nd ed. (1951); W. G. Lambert, "A New Look at the Babylonian Background of Genesis" (1965); A. R. Millard, "A New Babylonian 'Genesis' Story" (1967); W. G. Lambert and A. R. Millard, Atra-hasis: The Babylonian Story of the Flood with the Sumerian Flood Story by Miguel Civil (1969); W. M. Clark, "The Flood and the Structure of the PrePatriarchal History" (1971); I. M. Kikawada, "Literary Convention of the Primaeval History" (1975); T. Frymer-Kensky, "The Atrahasis Epic and its Significance for our Understanding of Genesis 1-9" (1977); W. H. Shea, "Adam in Ancient Mesopotamian Traditions" (1977); T. Jacobsen, "The Eridu Genesis" (1981); N. E. Andreasen, "Adam and Adapa: Two Anthropological Characters" (1981); W. H. Shea, "A Comparison of Narrative Elements in Ancient Mesopotamian Creation-Flood Stories with Genesis 1-9" (1984); J. D. Bing, "Adapa and Immortality" (1984); I. M. Kikawada and A. Quinn, Before Abraham Was. The Unity of Genesis 1-11 (1985); G. Wenham, Genesis 1-15 (1987) xxxvii-xlii, xlvii-1, 52f.; W. G. Lambert, "Old Testament Mythology in its Ancient Near Eastern Context" (1988); and J. H. Walton, Ancient Israelite Literature in its Cultural Context (1989) 19-47.

This is not to say, of course, that scholars have established any direct awareness of, say, Enūma Elis on the part of the biblical author. Indeed, such is very unlikely to have been the case. The point is rather that many of the religious concepts instanced in the various pagan creation myths appear to have had wide currency in the ancient Near East. It is these concepts which Genesis appears to be refuting using, appropriately, a genre which finds a close parallel in Enüma Eliš, and especially the Eridu Genesis and the Atra-hasis Epic, and hence constitutes a genre where precisely such questions may have been expected by the ancient reader to be addressed. 
polemical intent underlying the biblical account, as detected by many scholars. 214 While many specific facets of this polemic have been identified, none is more foundational than the implied repudiation in Genesis of the polytheism and related theomachy, the begetting of subordinate deities, etc., of its ancient Near Eastern antecedents. 215

Germane to our thesis and of special interest in a number of recent studies is the extent to which the ancient Near Eastern myths may explicitly address the relation between the sexes. This theme in the myths may suggest an additional corresponding polemical interest within Genesis. H. Ringgren notes how Enkidu in the Gilgamer epic "attains civilization through sexual intercourse with a temple prostitute... [who] then addresses him, 'You are wise, you have become like a god."'216 A degree of similarity between this tale and the Genesis narrative has often been noted. ${ }^{217}$ Based on that similarity, Ringgren suggests "it might be possible to find in the Israelite narrative a tacit polemic against the role of women in the Canaanite fertility cult." In his more extensive study of these same parallels, J. A. Bailey concludes:

"the Gilgames parallel is of significance not because it indicates the path which $\mathrm{J}$ followed, but rather the path which he knew but from which he departed. Within the context of Mesopotamian fertility religion it is understandable that sexual experience would be considered the means of initiation into civilization. But in the context of the religion of Israel, which does not see fertility as the ground of all being human and divine, there was not place for such an initiation. $\mathrm{J}$ therefore altered the tradition he knew at this point." 218

S. F. Bigger offers further support for this perspective with the observation that the ancient Near Eastern myths typically feature divine prototypes for marriage. ${ }^{219}$ It is widely supposed that these prototypes may have been acted out in the cultus in terms of sacred prostitution or a representative divine marriage of the king. ${ }^{220}$ In the Sumerian mythology

214 Cf., e.g., A. Heidel, The Gilgamesh Epic and Old Testament Parallels, 225f.; idem, The Babylonian Genesis, 89-96, 120-126; A. Phillips, Lower than the Angels, 24; and I. M. Kikawada and A. Quinn, Before Abraham Was, 51, 57.

215 Cf. A. Heidel, The Babylonian Genesis, 96-114. Genesis also distances itself from the mythical by its quasi-precise location of Eden near the Tigris and Euphrates rivers, its insistence that Adam and Eve are the progenitors of the entire human race, etc. These features demand that the biblical creation and subsequent history be understood as real events at the head of the continuum of real time and space. Cf., e.g., W. Brueggemann, Genesis, 96f., 102-115; and H. Blocher, In The Beginning, 154-170.

216 Israelite Religion, 111. n. 24.

217 Cf., e.g., E. A. Speiser, Genesis, 26f., and S. G. F. Brandon, Creation Legends of the Ancient Near East, 131f., both cited by Ringgren.

218 "Initiation and the Primal Woman in Gilgamesh and Genesis 2-3," 147.

219 "Hebrew Marriage and Family in the Old Testament Period," xviiff.

This is not to claim that there are no parallels for a concern with the human institution of marriage. The Atra-hasis Epic, I, lns. 255ff., records the creation of an original seven human couples, and considers the topic of human marriage in In. 301. The first of these observations qualifies the claim of J. A. Bailey that Genesis 2 provides the only account of the creation of a woman to be found in all the extant ancient Near Eastern literature ("Initiation," p. 143).

220 In support of these suggestions concerning the cultus and royal marriages, Bigger cites $\mathrm{S}$. $\mathrm{H}$. Hooke, ed., Myth and Ritual (1935); idem, Myth, Ritual and Kingship (1958); E. D. James, Myths and Rites in the Ancient Near East (1958); and P. Grelot, Man and Wife in Scripture, 22f.

Bigger may be on less secure ground, however, as he proceeds to affirm the commonly repeated notion that the purpose of such cultic re-enactments was to secure "fertility to families, flocks and fields." Cf. the 
he points especially to the two divine couples, Inanna and Dumuzi and Enki and Ninhursaga. In the Babylonian mythology Ishtar and her numerous divine marriages (affairs?) are mentioned; at Ugarit El and his consort Atrt, as well as other wives, and the marriage between $N k l$ and $Y r h$ are offered as important examples. 221 When Bigger turns to Israel's "mythology," he notes by contrast: "Yahweh had no consort, so the Old Testament presents no divine prototype for marriage....222 However, a human prototype for marriage was postulated. Marriage was instituted, according to Hebrew mythology, with the first couple, Adam and Eve...."223

For all these reasons, then, and especially because of Genesis 2:24, it appears that Malachi, as well as certain other intertestamental and New Testament authors, was justified in his understanding of the Adam and Eve narrative as providing a normative paradigm for marriage. 224

\subsubsection{The paradigmatic marriage of Adam and Eve as a "covenant [כָּרִרית"}

If Genesis 2-3 was correctly perceived by Malachi as a normative account of Hebrew marriage, does it support his description of marriage as a "covenant [כּרְר? [? could be established that Genesis 2-3 views marriage as covenantal, we shall have refuted A. Isaksson's claim that Malachi's views, if taken as a reference to literal marriage, were an unprecedented novelty. 225

Admittedly, the precise term בִּרִ is not employed in Genesis 2-3. By itself, however, this observation does not prohibit the recognition of Adam and Eve's marriage as

recent cautions of W. G. Lambert about "the modern term 'fertility', beloved of historians of religion but not so easily found in the ancient texts" ("Trees, snakes and gods in ancient Syria and Anatolia," 436).

221 A. van Selms appears to share Bigger's understanding of these divine marriages as prototypical of human marriage or at any rate as so highly reflective of human marriage, that one may freely draw upon the epic texts for a study of the dynamics of purely human marriage at Ugarit (Marriage and Family Life in Ugaritic Literature, 10-12.)

222 Later Bigger offers two modest qualifications of this statement. First, he notes the common prophetic image of Yahweh's marriage to his people (op. cit., xix-xx), and second, he accepts the interpretation of Genesis 6:1-4 which understands this text as the residue of an earlier myth of divine-human marriages (ibid., $\mathbf{x x}$ ).

The assumed lack of a consort for Yahweh has been challenged recently on archaeological grounds. Cf., e.g., W. G. Dever, "Asherah, Consort of Yahweh? New Evidence from Kuntillet 'Ajrud" (1984) 21-37. But the observation is hardly debatable for the Genesis text. In any case, against Dever's interpretation of the "Ajrud inscriptions which refer to "Yahweh and his Asherah," cf., e.g., J. A. Emerton, who objects that Hebrew does not affix pronominal suffixes to proper nouns as Dever supposes ("New Light on Israelite Religion: the Implications of the Inscriptions from Kuntillet 'Ajrud," 3-9, 14-15). Cf. also J. H. Tigay, "Israelite Religion: The Onomastic and Epigraphic Evidence" (1987) 157-194, esp. 173f.

223 Ibid., xviii-xx.

224 For allusions to Adam and Eve's marriage in Job 18:12 (uncertain); Tobit 8:5-6; Sirach 25:24-26; Matthew 19:4-9; Ephesians 5:21-33; etc. Cf. G. P. Hugenberger, "Women in Church Office: Hermeneutics or Exegesis? (A Survey of Approaches to 1 Timothy 2:8-15)," JETS (forthcoming), and especially P. Grelot, "The Institution of Marriage: Its Evolution in the Old Testament" (1970) 39-50.

225 Marriage and Ministry in the New Temple (1965) 34. 
a covenant since Malachi appears to have been unencumbered by what modern linguists term the "word-thing fallacy."226 For example, Malachi recognizes another otherwise unrecorded "covenant [ברּרִית], namely one with Levi in Malachi 2:4, 5, and 8. This covenant seemingly refers to the special privileges accorded the Levites as a reward for their self-ordaining zeal in executing their idolatrous brethren in Exodus 32:26-29 (cf.

Deuteronomy 33:8-11). The later recognition of such a covenant may have been inferred

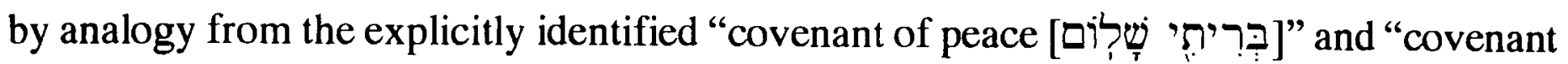

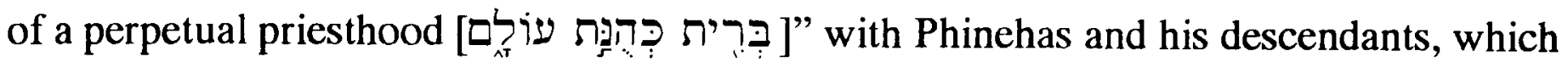
was grounded in a similar act of zeal recorded in Numbers 25:11-13 (cf. also Jeremiah 33:20-21).

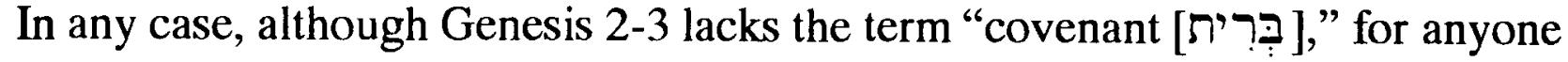
with Malachi's penchant for covenant concepts, there is sufficient evidence in Genesis 2-3 to suggest the appropriateness of this designation for the relationship between Adam and Eve. ${ }^{227}$ Without anticipating the results of the next chapter, where we shall attempt to establish the definition of בִּרִ identify David's relationship with Jonathan as a בִּרִ

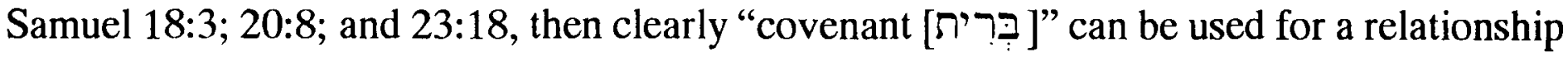
between private individuals and is not restricted to "divine-human" relationships, on the one hand, or international "treaty" relationships, on the other. More particularly, although the "covenant" commitment cannot be reduced to "love," since Jonathan's love for David preceded their covenant and, in fact, provided its explicit motive (1 Samuel 18:1, 3), nevertheless it is remarkable that Jonathan fulfils his covenant obligation to David by showing David greater loyalty than he shows to his own father (1 Samuel 19:2ff.; 20:9, 13, 30). ${ }^{228}$ In an analogous manner, Genesis 2:24 summarizes the husband's obligation to his

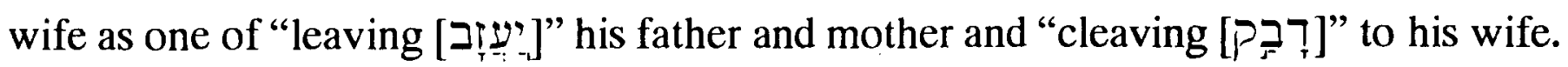

\subsubsection{1 "Therefore a man shall leave his father and his mother and cleave to his wife..." (Genesis $2: 24 a)$}

The precise implication of this command in Genesis 2:24 has been much contested among biblical scholars. Beginning with W. R. Smith, a number of scholars have argued

226 A scholarly consensus appears to have emerged that warns against the frequent error of denying the presence of a כרית merely because of the absence of the term. Cf., e.g., W. Eichrodt, Theology of the Old Testament, I (1961) 17f.; G. von Rad, Old Testament Theology, I (1962) 133; J. Barr, "Some Semantic Notes on the Covenant" (1977); P. J. Naylor, "The Language of Covenant" (1980); and P. Kalluveettil, Declaration and Covenant (1982) 3; 91, n. 356.

227 On the importance and sophistication of covenant concepts in Malachi, cf. J. G. Baldwin, Haggai, Zechariah, Malachi (1972) 216; P. J. Naylor, "The Language of Covenant" (1980) 422; L. C. H. Fourie, "Die betekenis van die verbond as sleutel vir Maleagi" (1982), as cited with approval by P. A. Verhoef, Malachi, 180, n. 2; S. L. McKenzie and H. N. Wallace, "Covenant Themes in Malachi" (1983); and R. L. Smith, "The Shape of Theology in the Book of Malachi" (1987) 24.

$228 \mathrm{Cf}$. the classic study of W. L. Moran, "The Ancient Near Eastern Background of the Love of God in Deuteronomy" (1963). 
that Genesis 2:24 reflects a hypothesized primitive matriarchy. ${ }^{229}$ While this view can offer a plausible parallelism between "leaving" and "cleaving," in that the authority of the wife over her husband may be considered to replace the former authority of a man's parents, in fact most of those who hold this view do not consider the implied matriarchy to operate in this fashion. As R. de Vaux notes, such a thorough-going matriarchy is rare within "primitive" societies and, in any case, is contradicted by the quite emphatic patriarchal order upheld elsewhere in Genesis and stated explicitly in Genesis 3:16.230 The kind of matriarchy most commonly defended is not one where the wife exercises authority over her husband, but a more limited type where a child is considered to belong to the mother's family and social group (i.e., matrilineal descent). This theory, however, is unconvincing in the few biblical examples it offers as proof, for which reason it has been largely discredited among recent scholars; in any case, it fails to support the proposed exegesis for Genesis 2:24.231

Alternatively, C. H. Gordon, among others, has argued that Genesis 2:24 is a "survival" from a primitive form of marriage termed an erébu marriage. ${ }^{232}$ It is argued that in this kind of marriage the husband enters his father-in-law's house in effect to be adopted as the son of the father-in-law in the absence of any true sons. However, the evidence frequently cited for the existence of this hypothesized form of marriage appears doubtful. 233 Nevertheless, even if some examples of an erēbu type of marriage remain

229 W. R. Smith, Kinship and Marriage in Early Arabia, 2nd ed. (1903) 82-87; J. Morgenstern, "Beena Marriage (Matriarchat) in Ancient Israel and its Historical Implications" (1929); and idem, "Additional Notes on Beena Marriage (Matriarchat) in Ancient Israel" (1931).

230 Ancient Israel, Social Institutions, 19.

The discussion of an original Semitic matriarchy often has been flawed by a tendency to apply conclusions drawn from modern "primitive" societies to the far less accessible ancient societies which were frequently anything but primitive.

Some scholars prefer to assign Genesis 2:24 and 3:16 to different recensions (so H. Gressmann and Van Doorninck, according to J. Skinner, Genesis, 70). Even so, since Genesis 2:24 is "an editorial comment," one would expect on the critical methodology that it would represent one of the latest elements in our text and hence come from a time in Israelite history when such a marital arrangement would be least imaginable.

231 For a more fundamental critique of the assumption of an original matriarchy, cf. Th. C. Vriezen, Onderzoek naar de paradijsvoorstelling bij de oude semietische volken (1937) 170f.; D. R. Mace, Hebrew Marriage (1953) 35-43, 76-94; and R. de Vaux, Ancient Israel, Social Institutions, $19 \mathrm{f}$.

Against matrilineal descent, cf. R. W. Wilson, "Sociology of the Old Testament" (1985) 970-971. For a recent attempt to rehabilitate the notion of an early "non-patriarchal" social system in ancient Israel, including matrilineal descent, cf. S. J. Teubal, Sarah the Priestess (1984). Teubal, however, does not discuss Genesis 2:24.

232 C. H. Gordon, "Erēbu Marriage" (1981) 159. Previous advocates of the view that an erébu marriage was a recognized marriage form in the ancient Near East, rather than an exceptional condition arising out of individual circumstances, include $\mathrm{H}$. Gunkel (according to J. Skinner, Genesis, 70); $\mathrm{M}$. Burrows ("The Complaint of Laban's Daughters" [1937] 259-276); C. H. Gordon ("The Story of Jacob and Laban in the Light of the Nuzi Tablets" [1937] 25-27); and E. Neufeld (Ancient Hebrew Marriage Laws [1944] 56-67).

233 Erebu is the Akkadian word "to enter" and is utilized to describe this hypothesized form of marriage based on its appearance MAL A $\$ 27$, where it is found in the $1 / 3$ ("frequentive") stem: "If a woman is living in her father's house (and) her husband has been frequently entering [êtanarrab], any marriage-gift [nudunnã, perhaps better rendered, "widow's settlement"], which her husband gave her, he may take back as his own, (but) he may not touch what belongs to her father's house." It is possible, however, that the husband in MAL A $\$ 27$ is authorized to take back the nudunnü because his father-in-law has thwarted the 
after closer scrutiny, one is far from establishing the kind of widespread practice as would seem to be required for this interpretation of Genesis 2:24.

Moreover, it is not at all clear that "leave" ought to be understood in such a literalistic manner, as if this term could refer only to a change in domicile (although, cf. Ruth 2:11). ${ }^{234}$ Rather, it is far more likely that the terms "leave" and "cleave" are intended to define each other. Since it is unlikely that the author of Genesis 2:24 intended to require a literal or physical "cleaving" or "fastening" to one's wife, it is doubtful that in this context a literal "leaving" of one's parents was intended. As C. Westermann notes wryly, the text says "leaves his parents," not his "parents' house"!235

Accordingly, the language of "leave" and "cleave" appears intended to stress the necessity of a radical change, not of domicile, but of one's pre-eminent loyalty -- a husband is to transfer to his wife the primary familial loyalty which he once owed to his parents. ${ }^{236}$ For a modern generation of readers who at times may be all too willing to "forsake father and mother," we can hardly appreciate enough the impact such a stipulation would have had in its ancient societal context. 237

consummation of the marriage in an irregular manner by refusing permission for his daughter to leave home (the husband's intent is made clear by his repeated "entering"). On such a view, the existing marriage is an "inchoate" marriage, not an erēbu marriage as often supposed.

Alleged examples of erēbu marriage in the Bible include Jacob, Moses, and Samson. However, since Jacob and Moses were both fugitives when they entered marriage and later relocate their domicile outside the home of their in-laws, their value as evidence for this theory is greatly diminished. Had Jacob's marriage been of the erébu type, T. L. Thompson argues that he should not have paid a marriage present consisting of his labour, the equivalent of a terhatu (The Historicity of the Patriarchal Narratives, 279f.). Least convincing is the case of Samson since his Timnahite father-in-law was emphatically unaware of the erēbu theory and, as a result, interpreted Samson's leaving as a repudiation of the marriage!

For a detailed refutation of the example of Jacob, and challenge to the alleged parallel between Jacob's marriages and the Nuzi marriage contract Gadd 51, which is frequently cited in support of erëbu marriage, cf. J. Van Seters, “Jacob's Marriages and Ancient Near East Customs: a re-examination” (1969) 377-95; T. L. Thompson, The Historicity of the Patriarchal Narratives (1974) 269-280; M. J. Selman, "Published and Unpublished Fifteenth Century B.C. Cuneiform Documents and Their Bearing on the Patriarchal Narratives of the OT" (1975) 29, 251-259; and J. Van Seters, Abraham in History and Tradition (1975) 72-82.

Against the theory of erébu marriage cf. also G. R. Driver and J. C. Miles, The Assyrian Laws, 134ff.; and S. F. Bigger, "Hebrew Marriage and Family in the Old Testament Period" (1974) 163-174.

$234 \mathrm{Cf}$. also the reading of Targum Onkelos for Genesis 2:24, “Therefore a man leaves the sleepingabode [בית משכבי] of his father and mother." It is likely that this interpretative reading arose to avoid the impression that Genesis 2:24 might require a man to leave his parents' house, rather than just their bedroom, since in Talmudic times it was customary for the new bride to come to live in her father-in-law's house. Cf. M. Aberbach and B. Grossfeld, Targum Onkelos to Genesis (1982) 33.

235 Op. cit., 233.

236 A psychological reference, such as is suggested by M. M. Bravmann, seems unlikely (“Concerning the Phrase "and shall cleave to his wife"" [1972]; idem, "The Original Meaning of "A Man Leaves His Father and Mother' (Gen 2.24)" [1975]; and idem, Studies in Semitic Philology [1977] 593-95). Bravmann considers that the text reflects the typical case where a husband experiences an easier emotional detachment from his family than does a wife. Against this, cf. V. P. Hamilton, Genesis 1-17, $180 \mathrm{f}$.

237 Cf. W. Neuer, Man and Woman in Christian Perspective, 68. For a discussion of the loyalty normally due one's parents, see A. Mawhinney, "God as Father: Two Popular Theories Reconsidered" (1988) 181-189. Cf. also P. A. H. De Boer, Fatherhood and Motherhood in Israelite and Judean Piety (1974), and K. van der Toorn, Sin and Sanction in Israel and Mesopotamia (1985) 13-15. 
In support, it may be noted that "leave [עיזָר]" is often used elsewhere in a figurative manner, offering many examples where it expresses the relinquishment of one's commitment to another (cf., e.g., Genesis 24:27; Deuteronomy 28:20; 29:25 [MT:24]; $31: 8,16,17$; Joshua 1:5; etc.). In particular, "leave [ [עָזָ] ]" is frequently used in covenant contexts, as when Israel is warned not to forsake [עז] the covenant (Deuteronomy 29:24 [ET 25]) or is condemned for forsaking [ע] Yahweh and so breaking the covenant (Deuteronomy 31:16), while the promise is affirmed that Yahweh will not forsake [עזב]

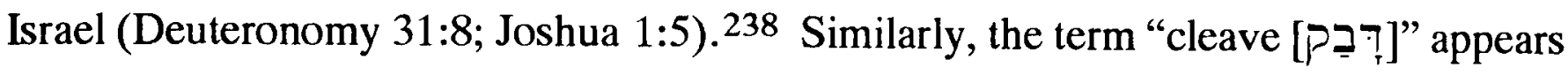
elsewhere with a figurative reference and offers a number of examples where it refers to the assumption of an ardent covenant loyalty. ${ }^{239}$ These covenantal associations seem especially clear in such passages as Deuteronomy 4:4; 10:20; 11:22; 13:5 [ET 4]; 30:20;

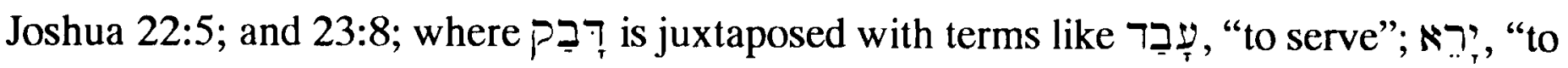

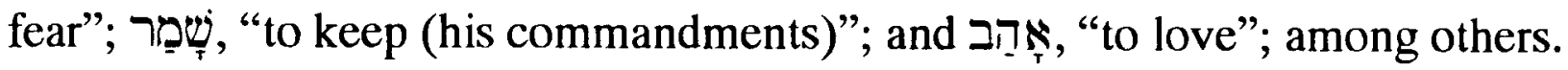

\subsubsection{2 "... and they will become one flesh" (Genesis 2:24b)}

Another key feature of Genesis 2:24 which may also be suggestive of the presence

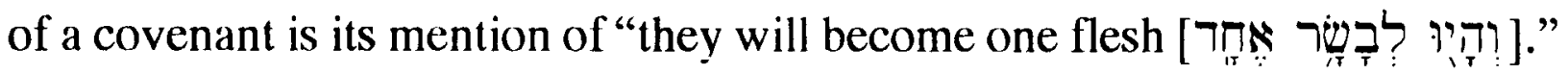
Understandably, this enigmatic clause has occasioned a great deal of scholarly discussion.

The view of Rashi, repeated by G. von Rad and others, that we have here an allusion to offspring, seems least likely. ${ }^{240}$ This is so not only because on this view the expression seems to equate parents with their own children ("they will become..."), but also because it requires a sense for

A second view which is perhaps possible, but on closer examination unlikely, is that of J. Skinner and others, who equate "become one flesh" with sexual union. ${ }^{241}$ This

238 V. P. Hamilton notes that "the verb forsake frequently describes Israel's rejection of her covenant relationship with Yahweh (Jer. $1: 16 ; 2: 13,17,19 ; 5: 7 ; 16: 11 ; 17: 13 ; 19: 4 ; 22: 9$; many other examples from the OT could be cited)" (Genesis 1-17, 181).

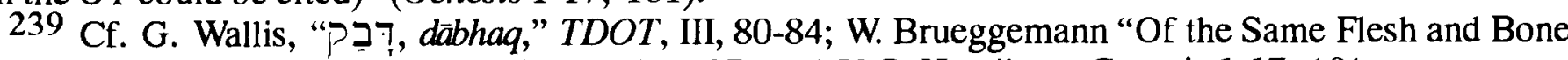
(Gn 2,23a)," 540; U. Cassuto, Genesis, Part I, 137; and V. P. Hamilton, Genesis 1-17, 181.

Others have taken "cleave" to refer to sexual union. So, apparently, D. Kidner, who writes "Note the order: 'leaving' before 'cleaving'; marriage, nothing less before intercourse" (Genesis, 66. n. 1). Such a sexual sense for "cleave" fails to offer the expected parallelism with "leave" and, in any case, is elsewhere unattested (1 Kings 11:2 is doubtful). Against this, cf. also G. Wallis, "P

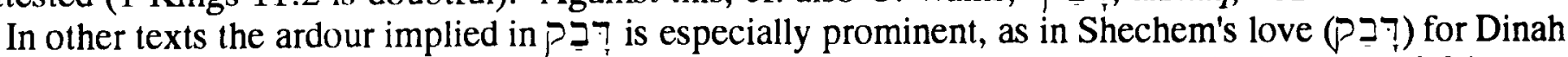
in Genesis 34:3. But the concept of loyalty seems almost always to be stressed, as in Proverbs 18:24 where again $P$ T offers a synonym for love (N) in its parallel member, or Ruth 1:14.

240 For Rashi's views, cf. A. M. Silbermann and M. Rosenbaum, Chumash with Targum Onkelos, Haphtaroth and Rashi's Commentary: Bereshith (1934) 12. Cf. also O. Procksch, Die Genesis, ad loc. (so, according to W. H. Gispen, Genesis vertaald en verklaard, 131), and G. von Rad, Genesis, 85.

Although J. Skinner considers that the interpretative addition of משניהם in the Samaritan Pentateuch suggests that it may have understood the text in this manner (the full Samaritan text reads והיה משניהם לבשר אחד), it seems forced in the present context, and may require an assumption of the death of the parents which is nowhere suggested in the text (Genesis, 70). Cf. also H. W. Wolff against this view (Anthropology of the Old Testament, 93).

241 J. Skinner, Genesis (1930) 70, and N. M. Sarna, Genesis (1989) 23. 
interpretation rests mainly on an inference from the chronological sequence of what might be expected to follow "leaving" and "cleaving" and also on contextual clues which suggest a reference to sexual intimacy. It is self-evident that the sexual associations of "flesh

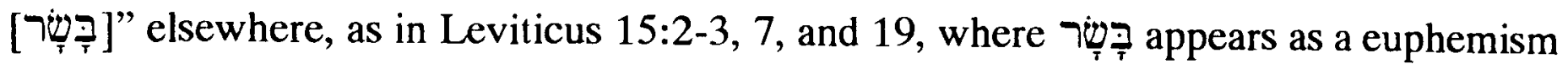
for male and female genitals, cannot be applied to the present case. 242

Certainly we are prepared for an interpretation of 2:24 which stresses a physical union of man and woman because of their derivation from a very literal "one flesh" in the preceding verses. 243 What appears decisive for this interpretation, however, is the implication of sexual intimacy in the immediately following verse, Genesis $2: 25$, where we read "and the man and his wife were both naked, and were not ashamed." 244

Nevertheless, had it been the author's intention to refer merely to the act of sexual union, it is unclear why he employed such an unusual expression as "become one flesh,"

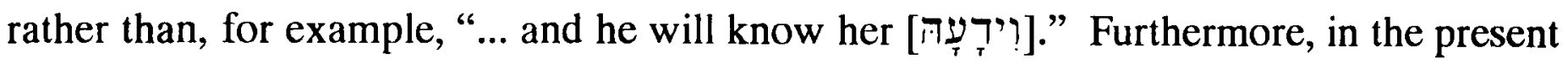

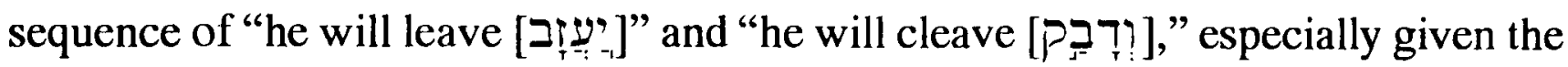
semantic implication of "cleaving" as expressive of on-going adherence and loyalty rather than a punctiliar act, one expects the third member of the sequence likewise to refer to an enduring state, rather than a single act of intercourse, or even series of such acts. In other words, it is doubtful that the reader is to imagine that following the consummation of the marriage in sexual union or following each particular successive act of intercourse, the couple reverts to their former state of being two separate fleshes!

Moreover, this objection and its underlying assumption find support in each of the several ancient texts which allude to this passage. The advice in Sirach 25:26 with respect to a wayward wife is to "cut her off from your flesh with a bill of divorce." The implication here is that being one flesh expresses the on-going state of matrimony, while separation from the one flesh reality constitutes divorce (not merely a period of sexual abstinence). Similarly, 1 Corinthians 6:16 makes emphatic that becoming "one flesh" is a result of sexual union, rather than to be equated with it: "Do you not know that he who joins himself to a prostitute becomes one body with her? For, as it is written, 'The two shall become one flesh." 'The same implication of an enduring state obtains in Matthew 19:5, 6: "“For this reason a man shall leave his father and mother and be joined to his wife, and the two shall become one flesh'? So they are no longer two but one flesh. What therefore God has joined together, let not man put asunder."245

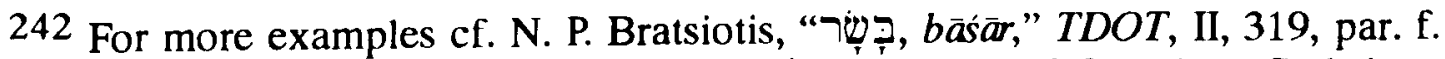

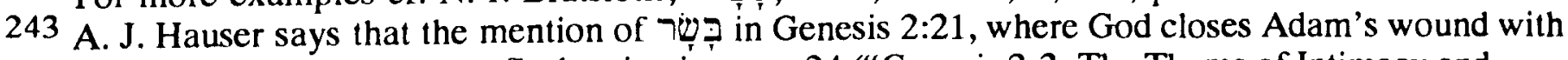
flesh, prepares the reader for the one flesh union in verse 24 ("Genesis 2-3: The Theme of Intimacy and Alienation" [1982] 23). Cf. also G. von Rad, Genesis, 85.

244 G. von Rad, op. cit., 85. C. Westermann acknowledges verse 25 as "a bridge" between what precedes and what follows; however, he agrees with $\mathrm{H}$. Gunkel, rather than G. von Rad, in stressing the latter rather than the former (Genesis 1-11,234).

245 Cf. Mark 10:6-9. 
Possibly the most common view of what it means to "become one flesh" considers the expression to refer not to sexual union itself, but to the bondedness which results from and is expressed by sexual union. 246 As H. W. Wolff writes, "It means the physical union of man and woman, whose utter solidarity is expressed in this way."247 Appealing to the context of 2:24, as well as to the support of Sirach 25, 1 Corinthians 6, etc., considered above, M. Gilbert concludes that the "one flesh" reality is not simply carnal union, but a bond which is founded on a love commitment which exceeds even filiation. ${ }^{248}$ Such an interpretation enjoys the strengths of the previous view (in its attempt to relate physical intimacy) while avoiding some of its difficulties (by referring to a resultant state, rather than to a punctiliar act). Nevertheless, the view lacks lexical support for its interpretation of 249

Perhaps more attractive is a melding of this view (that "become one flesh" refers to the bondedness which results from and is expressed by sexual union) with the suggestion that becoming "one flesh" refers to the establishment of a new family unit -- or, to put it in different terms, the "bondedness" expressed by bondedness. 250 A special benefit of this interpretation is the manner in which it achieves a balance in Genesis 2:24 between the parents, that is, the family which is "left," and the result of "cleaving" to one's wife, namely the establishment of a new family: "they become one [or "the same"] flesh."

The principal support for this view, however, is the use of 37:27; Leviticus 18:6; 25:49; 2 Samuel 5:1; and Isaiah 58:7, where the term refers to the members of one's family (or kin). ${ }^{251}$ While the case of Leviticus 25:49 is indecisive, in the five other texts it seems plausible that the designation of another person as one's "flesh" not

246 Cf. especially M. Gilbert, “'Une seule chair' (Gn 2,24)” (1978) 66-89. Cf. also J. de Fraine, Genesis uit de grondtekst vertaald en uitgelegd (1963) 52; A. van Selms, Genesis deel I, 4e druk (1984)

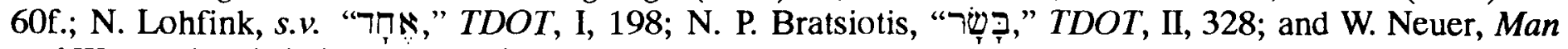
and Woman in Christian Perspective, 63.

Others express a similar view, considering "they shall become one flesh" to be expressive of a profound emotional, if not also spiritual union, but without indicating any possible relation between this union and the sexual act. Cf., e.g., S. R. Driver, The Book of Genesis with Introduction and Notes 3rd. ed. (1904) 43. W. H. Gispen argues against the similar view of H. Junker, who considers "they shall become one flesh" to be merely a poetic way of saying "two people have become one heart and soul," noting that this approach fails to do justice to the context (Genesis vertaald en verklaard, 131).

247 Anthropology of the Old Testament, 93.

248 “'Une seule chair' (Gn 2,24)."

249 While acknowledging that "becoming one flesh" in part refers to the physical side of marriage, B. Vawter cites Psalm 84:3 to demonstrate that "flesh" can also refer to one's "very being itself, his identity, his heart and soul" (On Genesis, 75f.). While the principle of pars pro toto is unobjectionable, Vawter's conclusion that "becoming one flesh" means, accordingly, "a union of persons who together make up a new person" is unconvincing, if not unimaginable.

$250 \mathrm{~J}$. Skinner considers this a possible view, though prefers a reference to the "connubium" (Genesis, 70). U. Cassuto also appears to favour this view, though he offers no argumentation (Genesis, Part One, 137). However, cf. especially G. J. Wenham, "The Restoration of Marriage Reconsidered" (1979) 36-40; idem, Leviticus (1979) 253-61; A. F. L. Beeston, "One Flesh" (1986) 115-117; and G. J. Wenham, Genesis 1-15 (1987) 71.

251 For kinship terminology utilizing בָָּּר, cf. S. Rattray, “Marriage Rules, Kinship Terms and Family Structure in the Bible" (1987) 537-544. 
only identifies him as a member of one's family, but also brings with this an implication of requisite caring and loyalty. This is transparently so in the case of Genesis 29:14; 37:27; and 2 Samuel 5:1, to which we shall return later. Likewise, in Leviticus 18:6 the wording of the general prohibition against sexual relations with "any of the flesh of his flesh [כָל

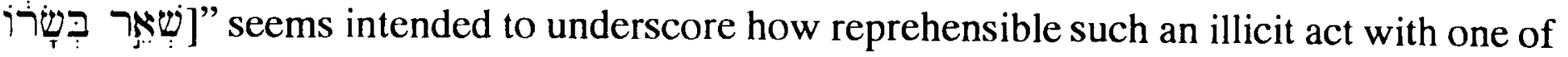
these individuals would be, an emphasis which is continued throughout the incest prohibitions in vss. 6-17 with their analogous appended motive clauses: "because she is your nakedness!" etc. ${ }^{252}$ This emotive connotation is perhaps even clearer in Isaiah 58:7: "Is it not to share your bread with the hungry, and bring the homeless poor into your house; when you see the naked, to cover him, and not to hide yourself from your own flesh

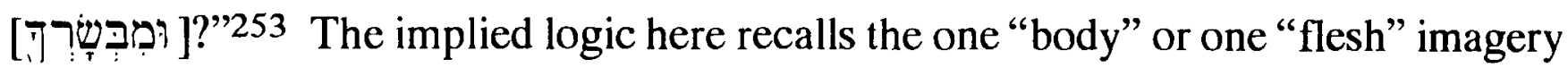
employed by Paul in 1 Corinthians 12 and Ephesians 4, with respect to the love obligation of Christians toward their fellow believers, and in Ephesians 5, with respect to marriage.

In summary, it appears likely that "they become one flesh" refers to the familial bondedness of marriage which finds its quintessential expression in sexual union. Given the widely recognized purpose of covenant to create unity and, especially, given the tendency to employ familial terminology to articulate that unity (covenant partners are fiequently designated "father" and "son," or "brothers"), the implication of "they become one flesh," as understood above, entirely comports with the assumption that Adam and Eve's marriage may have been viewed as a covenant. 254

\subsubsection{The Bundesformel: "This at last is bone of my bones and flesh of my flesh..." (Genesis 2:23)}

While some features of Genesis 2-3 suggest the possibility that the marriage of Adam and Eve may have been viewed as a "covenant [בְּרִ [? $]$ " and other features may be illuminated by such an interpretative assumption (e.g., Adam's naming of Eve), the relational formula in Genesis 2:23 virtually requires this conclusion. ${ }^{255}$

252 Cf. G. J. Wenham, Leviticus, $254 \mathrm{f}$.

$253 \mathrm{Cf}$. also Nehemiah 5:5.

254 Cf., e.g., P. Kalluveettil who summarizes, "Covenant is relational, in one way or other it creates unity, community" (Declaration and Covenant, 51 -- cf. also pp. 51-57; 102f.). Similarly, D. J. McCarthy concludes that the basic idea of a covenant was "a union based on an oath" (Treaty and Covenant [1963] 96). At another point he notes that covenant was "the means the ancient world took to extend relationships beyond the natural unity by blood" (ibid., 175).

For the use of the terms "father" and "son" and "brothers" to refer to covenant partners, cf., e.g., P. Kalluveettil, op. cit., 98-101, and passim.

255 It seems likely that Adam's naming of Eve bears some relation to God's own naming of his creation (cf. Genesis $1: 5,8,10 ; 5: 2$ ) as well as Adam's previous naming of the animals (Genesis 2:19). One possible background for such naming activity may be discerned in the example of kings elsewhere in the biblical record, and the ancient Near East, who name animals and plants, perhaps as an expression of their royal dominion, but especially to exhibit their great wisdom and discriminating judgment (cf., e.g., 1 Kings 4:33).

How such parallels should be applied to the case of the naming of Eve is less clear. Cf., e.g., $\mathrm{O}$. Eissfeldt, "Renaming in the Old Testament," 69-79; P. Trible, God and the Rhetoric of Sexuality, $133 \mathrm{f} . ;$ G. 
It is commonplace in recent discussion to consider Genesis 2:23 as Adam's "jubilant welcome" of Eve. ${ }^{256}$ The particular context and phraseology chosen for Adam's declaration, however, appear to carry a further important implication. There is an unmistakeable formulaic quality about the expression, "this ... is bone of my bones and flesh of my flesh," which finds remarkably close parallels in Genesis 29:14; 2 Samuel 5:1; 19:13f. [ET 12f.]; and 1 Chronicles 11:1 (cf. also Judges 9:2).

While we shall leave to the next chapters a closer examination of these texts and their implication for Genesis 2:24, here we may briefly anticipate some of our conclusions. First of all, each of these texts employs "the relationship formula" to affirm familial propinquity, thereby suggesting that Adam's intention goes beyond the mere acknowledgement of Eve's origin (including any "jubilant welcome” or descriptive praise) to an acknowledgement of Eve as a family member, that is, as his wife.

Second, as argued by W. Brueggemann and others, in several of these examples it is clear that the "relationship formula" is not merely an assertion of an existing blood tie, "but is rather a covenant oath which affirms and establishes a pattern of solidarity."257 This appears to be the case, for example, when Israel gathered at Hebron to make David their king declaring, "Behold, we are your bone and flesh" (2 Samuel 5:1) -- compare 2

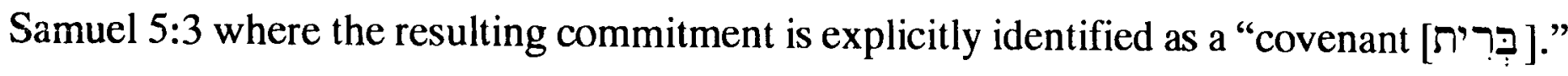
In other words, under certain circumstances, which we shall seek to identify in Chapter 7, "the relationship formula" may constitute a solemn "Declaration Formula," which will be seen to be functionally indistinguishable from a covenant-ratifying oath. 258

F. Hawthorne, "Name"; P. Kalluveettil, op. cit., 76; and D. J. A. Clines, What Does Eve Do to Help? (1990) 38f.

However, if this naming activity is understood in terms of covenant concepts, there is an especially intriguing parallel for consideration. As pointed out by $\mathrm{H}$. Blocher, ancient suzerains often (re)named their covenant partners when entering into a covenant, as when Nebuchadnezzar renamed Eliakim as Jehoiakim (2 Kings 23:34) and Mattaniah became Zedekiah (2 Kings 24:17), etc. (In The Beginning, 91). It would be easy to multiply examples (cf., e.g., Daniel 1:7). This practice may provide a more adequate interpretation for God's practice of naming his creation than simply the expression of his wisdom (for the idea of a covenant with creation, cf., e.g., Genesis 9:16), and for renaming his human vassals, such as when Abram became Abraham, or Jacob became Israel, than the frequent claim to find here an evidence of conversion.

In terms of this background, Adam names Eve "woman" or better, "wife [ה they enter into a covenant (of marriage), as indicated by the Bundesformel, "This is bone of my bones...." Adam's renaming of his wife as "Eve" in Genesis 3:20, coincides with the renewal of their marriage following its acute breakdown in the alienation expressed in Genesis 3:7, 12.

256 So J. G. Herder as quoted by C. Westermann, Genesis 1-11, 231. Similarly, cf. J. A. Bailey, "Initiation and the Primal Woman in Gilgamesh and Genesis 2-3," 142f.; A. J. Hauser, "Genesis 2-3: The Theme of Intimacy and Alienation," 24; and W. Neuer, Man and Woman in Christian Perspective, 67.

257 W. Brueggemann, "Of The Same Flesh and Bone," $535 \mathrm{ff}$.

Although it goes beyond the scope of the present study, the text implies reciprocal obligations for both Adam and Eve based on the mode of Eve's creation from the rib of Adam (not just obligations on the part of Adam, as stressed by earlier commentators such as Calvin). For a fuller discussion, cf. G. P. Hugenberger, "Rib" (1988) 183-185.

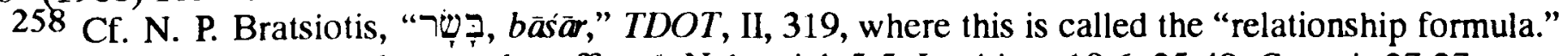
The following partial examples are also offered: Nehemiah 5:5; Leviticus 18:6; 25:49; Genesis 37:27. 
In favour of this interpretation of the "relationship formula" in Genesis 2:23, Adam does not address his "jubilant welcome" to Eve ("you are now bone of my bones..."), as one would have expected for a mere welcome, but to God as witness ("this is now bone of

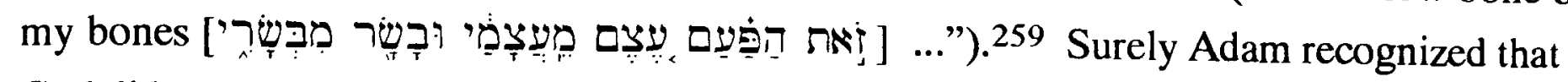
God did not need to be informed concerning Eve's origins. Rather, these words appear to have been intended as a solemn affirmation of his marital commitment, an elliptical way of saying something like, "I hereby invite you, God, to hold me accountable to treat this woman as part of my own body." As will be demonstrated in the next chapter, the concise statement in 2:23 is entirely in keeping with the elliptical character of ancient oath formulae.

\section{$\underline{5.10 \quad \text { Summary }}$}

We began this chapter by noting what is perhaps A. Isaksson's most fundamental

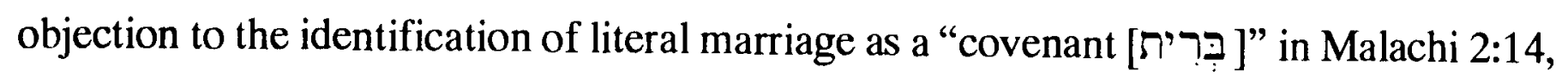
namely, the claim that such a view would be unprecedented and anachronistic in the postexilic period. While we shall defer to Chapter 8 the evidence of other biblical texts which view marriage as a covenant (or presuppose such a view), it has been our concern in the present chapter to argue that from Malachi's own perspective his view of marriage was not unprecedented, but was consciously derived from, or at least supported by, the paradigmatic marriage of Adam and Eve (Genesis 2:24), to which he makes allusion in Malachi 2:15.

After rejecting seven alternative interpretative approaches, we determined that Malachi 2:15 is best rendered, "Did He not make [you/them] one [ח the spirit belonging to it? And what was the One seeking? A godly seed! Therefore watch out for your lives and do not act faithlessly against the wife of your youth."

Although we stressed the grammatical and textual support for this interpretation, which has the advantage of requiring no emendation of the MT, it was noted that a further important confirmation for this view comes from the concluding admonition in $2: 15 \mathrm{~b}$ (cf. also 2:16b). This warning carries the radical implication that for an unfaithful spouse divorce is an offence against one's own life. Only when 2:15a is rendered as suggested above ("Did He not make [you/them] one...?") is this equivalence between concern for one's life and fidelity to one's spouse explained; it is the result of the profound communion of life which God effects between a man and his wife as established in Genesis 2:24. In a book so replete with allusions to Pentateuchal texts, the present allusion to the "one flesh"

259 Cf. Malachi 2:14. Cf. also in support, W. Reiser, "Die Verwandtschaftsformel in Gen. 2,23" (1960) 1-4.

It does not detract from the present view that the relationship formula is pronounced by Adam, rather than Eve. P. Kalluveettil notes that the superior party typically utters the Bundesformel (op. cit., 213).

For an alternative explanation for the use of the third person in Genesis 2:23, viewing this as an evidence of "descriptive praise," cf. C. Westermann, Genesis 1-11, 231. Westermann, however, does not consider this interpretation to exclude the recognition of 2:23 as a relationship formula. 
marital unity of Adam and Eve in Genesis 2:24 is hardly out of place -- particularly given the preparation for this allusion in the imagery of creation in Malachi 2:10 and given the widely recognized verbal and conceptual links which exist between 2:10 and 2:15. Further confirming Malachi's indebtedness to Genesis 2:23f. is the remarkable stress throughout Malachi 2:14-16 on the primacy of a husband's obligation of fidelity toward his wife, a viewpoint which is almost unparalleled apart from these two texts. 260

In other words, as throughout his work, the prophet's argument in Malachi 2:10-16 proceeds by way of reminder and appeal to the ancient standards and to common convictions (cf. Malachi 3:22 [ET 4:4]), rather than by way of innovatory insights. Indeed, Malachi's condemnation of his contemporaries would have lost all its force if the underlying understanding of marriage as a covenant could not command their assent or could not be substantiated from the received texts -- particularly since he tosses off the

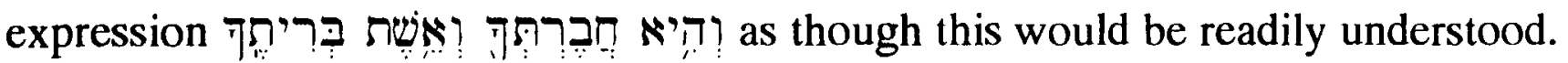

We concluded the chapter by arguing that the character of Adam and Eve's marriage

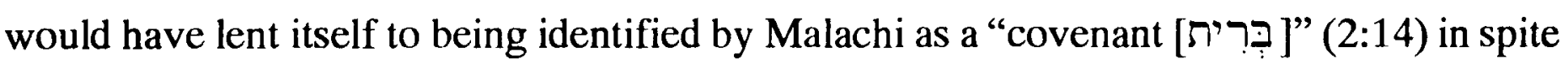
of the absence of this term in Genesis 2-3. This identification is suggested by the original purpose of marriage, which parallels that of covenant, namely, to create a unity between unrelated persons. It is further suggested by the vocabulary and content of the husband's

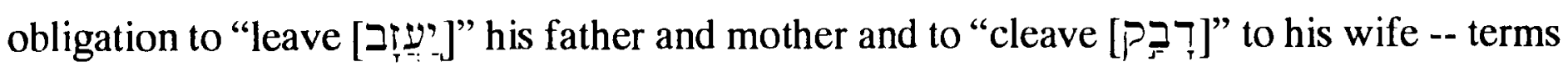
frequently associated with covenant contexts. Especially clear, however, is Adam's use of the relationship formula, "This at last is bone of my bones and flesh of my flesh" (Genesis 2:23). This expression finds a close parallel in texts such as 2 Samuel 5:1 and 1 Chronicles $11: 1$, where it is employed as a covenant-ratifying declaration formula.

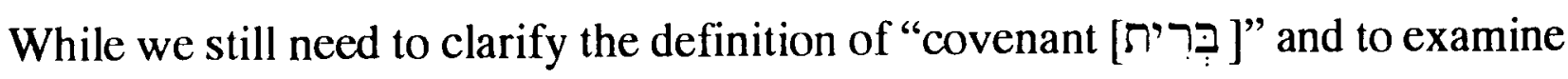
more carefully the nature of covenant-ratifying oaths (including declaration formulae), to which we shall turn our attention in the following chapter, we may conclude provisionally that Malachi appears to have been justified in grounding his view of marriage as a "covenant" in the paradigmatic marriage of Adam and Eve.

$260 \mathrm{Cf}$. $\$ 5.8 .3$ for a survey of arguments in support of an allusion to Genesis 2 in Malachi 2:15. 


\section{Outline of Chapter 6: "Covenant" and "Oath" Defined}

6.1 The definition of בִּר

6.1.1 A field-oriented approach......................................... 188

6.1.2 A concept-oriented approach to the distinct senses of בִּר?

6.1.3 Four diagnostic sentences to help test the first sense posited for בִּרִ 196

6.1.3.1 "He made a covenant, but it was with another person."......... 196

6.1.3.2 "He made a covenant, but it was with a non-relative.".......... 199

6.1.3.3 "He made a covenant, but it was one with obligations." .......200

6.1.3.4 "He made a covenant, but it was one with an oath."............202

6.2 Toward a solution regarding the apparent lack of an oath in marriage...............205

6.2.1 The lack of any explicit reference to an oath within marriage in the ancient Near Eastern law collections or extant marriage contracts is not unexpected ............................................... 205

6.2.2 Oaths may often be accompanied by, or even consist of, symbolic acts ("oath-signs").

6.2.3 Oaths and oath-signs may invoke the deity to witness an attendant declaration or promise without employing an explicit selfmalediction. At times they may only implicitly invoke the deity by a solemn declaration or depiction of a commitment being undertaken......215

6.2.3.1 Not all rites connected with covenant making are oath-signs ... 216

6.2.3.2 However, some rites, in spite of their opacity to modern readers, may prove to be self-maledictory oath-signs after all ... 217

6.2.3.3 Other covenant-making rites may be oath-signs, but they need not be overtly self-maledictory........................ 218

6.2.3.3.1 Verbal oaths are frequently not explicitly self-maledictory

6.2.3.3.2 An uplifted hand, though not overtly selfmaledictory, may function as an oath-sign since it expresses an appeal to the deity to act as a witness.

6.2.3.3.3 Eating together, at times, may function as an oath-sign by solemnly depicting the covenant commitment (and, possibly, also its sanction) 
6.2.3.3.4 The giving of a hand may function as an oath-sign by solemnly depicting the covenant commitment ................................... 229

6.2.3.3.5 Other examples of symbolic acts which may function as oath-signs by solemnly depicting the covenant commitment .............231

6.3 Summary. 


\section{Chapter 6: "Covenant [ברית]" and "Oath" Defined}

Having established that Malachi and Genesis 2-3 probably regard marriage as a covenant, we need to address a fundamental objection to this view raised by J. Milgrom and M. Greenberg. It is claimed that a ratifying oath is indispensable for the existence of a בִּרִית 1 Lacking evidence for any such oath in marriage, Milgrom and Greenberg have questioned the identification of marriage in the Old Testament as a בִּר 2 To deal with this objection, we must look at what constitutes a covenant in the Old Testament, as well as elsewhere in the ancient Near East, to determine whether marriage fits this understanding of covenant. Accordingly, the present chapter endeavours first to establish the definition of בִּרִ בִית In particular, we shall examine the claim that a ratifying oath is indispensable for a in its normal sense. Leaving aside the question of whether such an oath exists in marriage, we will then consider the appropriateness of the use of the term in to marriage. In the second half of the chapter it will be suggested that the search for the requisite covenant-ratifying oath in marriage has been hampered by two factors: first, by the tendency to expect evidence in the wrong place, and second, by the tendency to reduce "oath" to verbal self-malediction. By contrast, it will be demonstrated that biblical oaths in general and, hence, covenant-ratifying oaths in particular, may be gestural or enacted ( = "oath-signs") and that they need not always be overtly self-maledictory. It will be left for the following chapter to apply these arguments to the search for the requisite covenantratifying oath or oath-sign for marriage in the Old Testament.

\subsection{The definition of}

\subsubsection{A field-oriented approach}

In the Introduction we observed that in the past too often the recognition of marriage as a "covenant [בְּרִ ] ברית]" in the Old Testament proceeded from the now-discredited notion

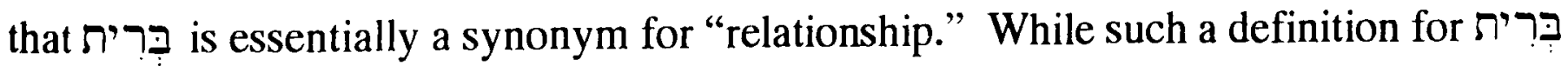
appropriately stresses a prominent aspect of covenants and appears to reflect the wide range of application for this term in biblical texts, its inadequacy is apparent in a text such as

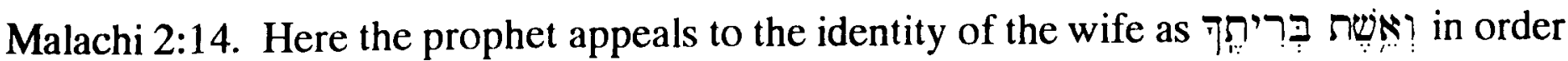

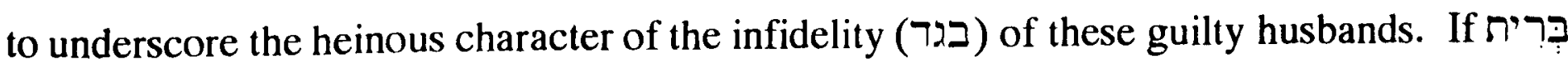

1 Cf., e.g., M. Weinfeld, "תיר בִ berîth," TDOT, II, 256.

2 J. Milgrom, Cult and Conscience (1976) 134, and M. Greenberg, Ezekiel 1-20 (1983) 278. 
conveyed nothing more than "relationship," Malachi's comment would seem strangely vacuous and add little to what is already more forcefully implied in the designation T... ת תֵֶ, "your wife."

Generalizing the evidence of this single example, typically among its 283 occurrences in 263 verses there is some sense of obligation attending the presence of a

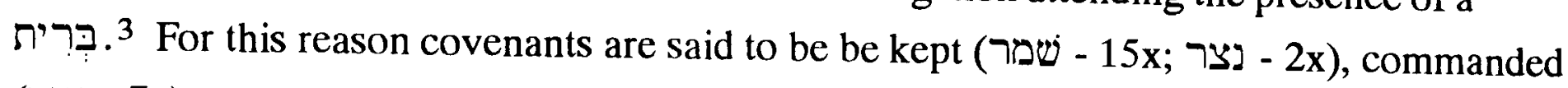

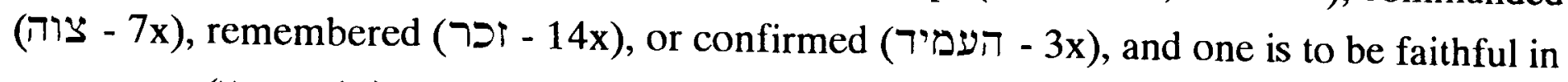

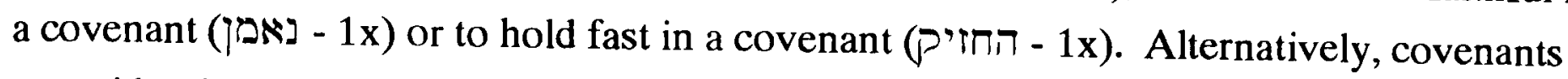

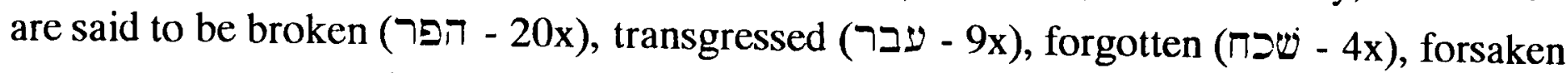

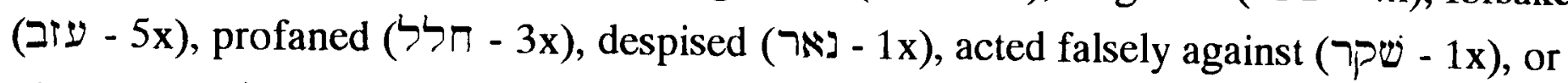
violated (שחת - 1x).4

Also problematic for an interpretation of בִּרִ "relationship" are a number of examples, such as Ezra 10:3; 2 Kings 11:4; 2 Chronicles 23:1; and Jeremiah 34:8-10, where a בְרִ does not appear to effect a relationship at all, but merely secures a stipulated course of action. In other texts, far from creating a relationship de novo, the making of a covenant seems to presuppose an existing relationship, to which explicit appeal is made during the negotiations to make the covenant. This appears to be the case, for example, in the covenant between Abraham and Abimelech in Genesis 21:22ff. 5

For reasons such as these, E. Kutsch has argued that בִּרִ never establishes a relationship. ${ }^{6}$ Instead, virtually everywhere it consists of an obligation, whether this is self-imposed, as in a promise or the undertaking of an obligation, or imposed on another, as in an imposed law. ${ }^{7}$

While many texts support this emphasis on the obligations implied in covenants, Kutsch appears to have gone too far in denying that בִּרִ ever creates a relationship. J.

${ }^{3}$ Statistics are from Even-Shoshan, s.v. E. Kutsch offers 287, presumably including in that count the textually uncertain Ezekiel 20:37 ("תִּרִ berit Verpflichtung," THAT, I, 341).

For a careful examination of all extra-biblical examples of $b r(y) t$, having the meaning "agreement, compact, or covenant," cf. K. A. Kitchen, "Egypt, Ugarit, Qatna and Covenant" (1979) 453-464.

${ }^{4}$ For a more exhaustive treatment of these and other syntagms of בדיר, cf. P. J. Naylor, "The Language of Covenant. A Structural Analysis of the Semantic Field of כרית in Biblical Hebrew, with Particular Reference to the Book of Genesis" (1980).

5 D. J. McCarthy summarizes the pattern of some 13 older accounts of "secular" covenant making within the Bible: Genesis 21:22-34 ( $\mathrm{J}$ and E); 26:23-33; Genesis 31:25-32:5 (at least 2 narratives); Joshua 9:1-10:1; 1 Samuel 11:1-3; 18:1-4 + 20:5-8; 20:11-17 + 23:16-18; 2 Samuel 3:17-21 + 5:1-3; 3:12-21; 1 Kings 15:19; 20:31-34; 2 Kings 11 (= 2 Chronicles 23) (Treaty and Covenant [1981] 19f.). McCarthy concludes, "the negotiations ... begin regularly with an affirmation that a real though general relationship already exists between the parties." Cf. also op. cit., 297.

6 E. Kutsch, Verheissung und Gesetz (1973), and idem, "Gesetz und Gnade. Probleme des alttestamentlichen Bundesbegriff" (1967) 18-35. Cf. also L. Perlitt, Bundestheologie im Alten Testament (1969), and E. W. Nicholson, God and His People. Covenant and Theology in the Old Testament (1986).

7 For self-imposed examples, cf., e.g., Genesis 14:13; Exodus 23:32; 34:12, 15; Deuteronomy 7:2; Judges 2:2; 2 Samuel 5:3; 1 Kings 15:19; Isaiah 33:8; Jeremiah 34:10; Malachi 2:14; Obadiah 7; Psalm 55:21; Job 31:1; 40:29; 1 Chronicles 11:3; and 2 Chronicles 16:3. For examples where a on another, cf., e.g., Joshua 24:25; 2 Chronicles 23:1, 3; Jeremiah 34:8; Ezekiel 17:13-16:18; and Job 5:23. Covenants with mutually assumed obligations appear in 1 Kings 15:19; Amos 1:9; Psalm 83:6; and 2 Chronicles 16:33. 
Barr has argued against Kutsch's conclusions noting the logical dependence of Kutsch's view on the very uncertain etymology which he proposes -- deriving בִּרִ from the rare and uncertain root ברה II, supposed to mean, "to look for, to choose" (related to the Akkadian barûm, "to look"), and hence, "determining" and, finally, "obligation [Verpflichtung]." Barr further suggests that in spite of Kutsch's appropriate concern with the context in each of the appearances of בִּר confuse the words spoken when a בִּרִ is made and the effects which are promised or

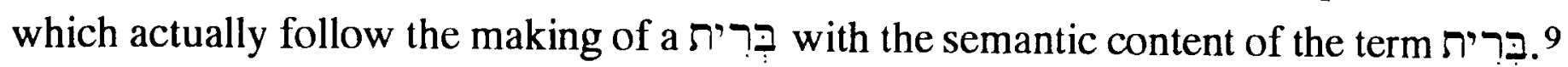
Finally, Barr wonders if Kutsch may have been unduly influenced by a theological agenda since "the whole discussion seems dominated by a strong sense of the opposition between grace and law, promise and law, which makes the reader uncomfortable."10

As noted in the Introduction, any attempt to reduce the numerous occurrences of ת to some univocal sense, basic meaning, or original meaning, whether one chooses

8 E. Kutsch, "Sehen und Bestimmen. Die Etymologie von ברית" (1970) 165-178; idem, Verheissung und Gesetz (1973). Kutsch proposes the following etymological development for ברית II ברה : ברית: sehen ersehen - auswählen - bestimmen - Bestimmung - Verpflichtung (Verheissung und Gesetz, 39).

Cf. also J. Barr, "Some Semantic Notes on the Covenant" (1977) 24, 25 and 36. Barr notes that as a matter of procedure Kutsch is careful not to begin with this etymological argument: "But logically his proposal depends rather more on etymology than this would suggest. The total effect of his reasoning depends very considerably on the proposal...." Later Barr observes that an analogy which is offered by Kutsch in support, based on the older English term "beholden" (which appears to suggest a development from "to see" to "to be obligated") is inapplicable. This is so since "beholden," in the sense of "to be obligated," comes from a term meaning "to hold, retain," and not from "to behold" in the sense of "to see," as Kutsch supposes.

Not surprisingly, Kutsch's proposal has found little support. Cf. M. L. Newman, "review of Verheissung und Gesetz" (1975); M. Weinfeld, "תִ "כִ berith," TDOT, II, 255. However, it should be acknowledged that neither have any of the other proposed etymologies for בִרית received notable support. Perhaps most widely favoured is the proposal of E. Meyer, followed by L. Köhler and others, who consider that בנרית I derived from the root which means "to eat," alluding to the meal which frequently accompanies the covenant-making ceremony (E. Meyer, Die Israeliten und ihre Nachbarstämme [1906]; L. Köhler, "Problems in the Study of the Language of the Old Testament" [1956] 3-24).

Others, however, prefer relating בִּרִ בִ to the Akkadian term birtu / biritu meaning "a fetter" (so M.

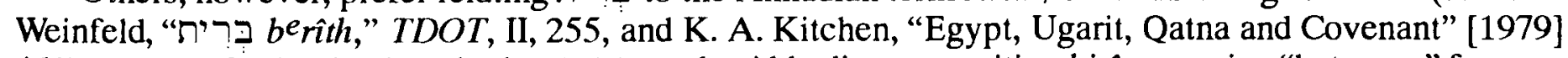
461 ), or to go further back and relate רִּר to the Akkadian preposition birît, meaning "between," from which birtu possibly derives (so, O. Loretz, "Berît - Band, Bund" [1966] 239-41; M. Noth, "Old Testament Covenant Making in the Light of a Text from Mari" [1967] 108-117).

A more recent suggestion is that of E. B. Smick, who relates

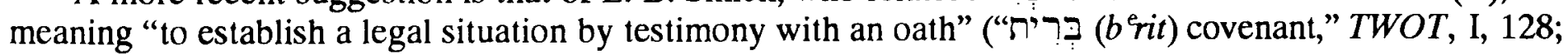
cf. $C A D, \mathrm{~B}, 125 \mathrm{ff}$.).

9 J. Barr, "Some Semantic Notes on the Covenant" (1977) 37.

10 lbid., 37. Barr's reservations about Kutsch have been cited with approval by D. J. McCarthy, Treaty and Covenant [1981]16, n. 26. McCarthy likewise suggests that "there is more than merely scientific interest at work [behind the concern to demonstrate that בִּ בִיח means Verpflichtung, 'obligation']. There are theological positions, probably subconscious but still very real, in the background. There is the fear of seeming to tie God to a contract and creating a quid pro quo pharisaism..." (op. cit., 17).

For a further critical discussion of Kutsch's views, cf. M. Weinfeld, "B'rit - Covenant vs. Obligation" (1975) 120-128, esp. 124f.; D. J. McCarthy's substantial review article of L. Perlitt, Bundestheologie im Alten Testament, entitled, " $b$ 'rit in Old Testament History and Theology" (1972) 110-121; and P. J. Naylor, "The Language of Covenant," 34ff., 42. Cf. also M. J. Buss, "Review: L. Perlitt, Bundestheologie im Alten Testament (WMANT 36)" (1971). 
"relationship," "obligation," "oath," or "solemn promise," is unwarranted.11 Although a predisposition against this sort of reductionism or oversystemization is now a common feature of modern linguistics, this point has been made with particular force by P. J. Naylor with reference to the study of בִּר 12

Naylor's primarily concern is to develop a "field-oriented" approach to the various senses of בְּרִ Naylor offers a salutary reminder that one must, at least in principle, be prepared to identify any possible features of linguistic differentiation for sִּרִ such as diachrony, dialect, idiolect, style, and other incidental features, rather than lumping every occurrence together indifferently as R. B. Girdlestone, P. Buis, and other scholars appear to have done. ${ }^{13}$ If this differentiation is recognized, it turns out that stylistic variation (whether occurs in a narrative, legal, prophetic, or poetic context) is by far the most dominant.

\subsubsection{A concept-oriented approach to the distinct senses of}

While Naylor's "field-oriented" approach is to be appreciated, it does not exclude a more "concept-oriented" approach to the various senses of בִִּ רִ use in the present study. ${ }^{14}$ In terms of this alternative approach to lexical semantics, we may delineate the following senses of בִּרִ

1) The predominant sense of בִּרִ in Bרִית Biblical Hebrew is an elected, as opposed to natural, relationship of obligation established under divine sanction. ${ }^{15}$ It is this sense in particular which we intend by the English term "covenant." 16

11 Appropriately, $B D B$ suggests something of richness of this term by offering the following translational equivalents: "pact," "compact," "covenant," "treaty," "alliance," "league," "constitution," "ordinance," "agreement," and "pledge."

12 P. J. Naylor, "The Language of Covenant" (1980).

Cf. also D. J. McCarthy, Old Testament Covenant (1972) 4, and P Kalluveettil, Declaration and Covenant (1982) $15 \mathrm{f}$.

13 Cf. P. J. Naylor, op. cit., 70-72.

$14 \mathrm{Cf}$. P. Cotterell and M. Turner for a discussion of the distinction between "field-oriented" and "concept-oriented" approaches to lexical semantics (Linguistics and Biblical Interpretation [1989] 145-181).

15 Cf. M. G. Kline, who defines בְּרִ relationship or follow a stipulated course of action. In general, then a covenant may be defined as a relationship under sanctions" (By Oath Consigned, 16). The definition offered by G. E. Mendenhall is similar: "A solemn promise made binding by an oath, which may be either a verbal formula or a symbolic oath" ("Covenant," 714). Cf. W. Dyrness, Themes in Old Testament Theology (1979) 113. Cf. also M. L. Newman, who defines covenant as a "formal relationship of obligation between two parties, normally resulting from some prior common experience and sealed by a solemn oath or cultic rite" ("Review of Verheissung und Gesetz" [1975] 120).

16 Although this translational choice is rather arbitrary, it reflects a common convention established by the translational practice of the AV (which so renders 260 times). As a translation, "covenant" has been faulted because of the many inappropriate senses which attach to this term in contemporary English (e.g., a mutual agreement, especially regarding the use of land; a financial or church membership pledge; etc.). However, as J. Barr observes, the objections raised by, e.g., E. Kutsch against the traditional German rendering, "Bund," (since ברית does not mean "alliance" or "agreement,") do not apply to the English term "covenant" ("Some Semantic Notes on the Covenant," 36). In any case, the utility of "covenant" as a translation choice can be defended based on the fact that for most English speakers this term is largely an "empty word," deriving any meaning it may have from biblical usage (J. Barr, op. cit., 36). 
In the biblical corpus not only does occur most frequently with this sense, it does so most often while referring to covenants between Yahweh and his people, as in Exodus 19:5, etc. (appearing in what Naylor terms the 3rd dimension of its semantic field, after the first two dimensions of literal and figurative uses). ברּר also bears this sense while referring to secular relationships, as in Genesis 14:13, 1 Samuel 18:3, etc. (Naylor's 1st dimension). An important special case of this usage occurs when the relationship in question is of an international political nature. In such a case a more specific English rendering for בִּרִ would be "treaty" (e.g., cf. 1 Samuel 11:1 and 1 Kings 5:26 [ET 12]).

As is well-known, a great deal of scholarly attention has been devoted to the apparent analogy between the ancient Near Eastern treaty texts and various portions of the Bible which refer to a covenant between Yahweh and Israel since this comparison was first suggested, apparently independently, by D. J. Wiseman, E. Bickerman, G. E. Mendenhall, and K. Baltzer. ${ }^{17}$ Without entering further into this vast area of scholarly discussion, it is sufficient to emphasize here that not all covenants are treaties, and thus it should not be expected that wherever a covenant is mentioned it will necessarily exhibit any or all of the features of some single "covenant form" derived from a detailed comparison of international treaty texts. ${ }^{18}$ In particular, it is the concern of the present thesis to argue that a number of Oid Testament texts, and Malachi in particular, conceive of marriage as a בִּרִ -- not as a "treaty" and thus not necessarily in a manner which exhibits each of the well-rehearsed features of ancient Near Eastern treaty relationships, but, nevertheless, in the presently understood sense of its hypernym, "covenant." 19

Since this first sense of shall consider it in fuller detail after briefly surveying, for the sake of completeness, the remaining attested senses of 20

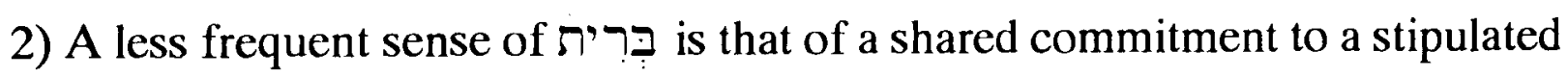
course of action, established under divine sanction. A frequent and useful English rendering for בִּרִ when it bears this sense is "pact." Understood in this manner, a "pact"

17 D. J. Wiseman, in a paper read to the Society of Old Testament Studies in January 1948, according to M. G. Kline, The Structure of Biblical Authority, 114, n. 2; E. Bickerman, "Couper une alliance" (195051), according to E. W. Nicholson, God and His People (1986) 57; G. E. Mendenhall, "Law and Covenant in Israel and the Ancient Near East" (1954); and K. Baltzer, Das Bundesformular (1960). These scholars based their work on V. Korosec's foundational study of the structure of the Hittite treaties, Hethitische Staatsverträge: Ein Beitrag zur ihrer juristischen Wertung (1931).

18 Cf. D. J. McCarthy, Old Testament Covenant, 4.

19 The texts which are most explicit in their identification of marriage as a כִּרִ are Malachi 2:14; Proverbs 2:17; and Ezekiel 16:8.

As noted by D. L Magnetti, there is a considerable conceptual and terminological overlap between the ancient Near Eastern treaties and the ancient Near Eastern interpersonal covenants "The Oath in the Old Testament in the Light of Related Terms and in the Legal and Covenantal Context of the Ancient Near East" [1969] 94).

20 We may note a number of examples where ברית is used with the present sense, but in a figurative manner. The fact that these examples are confined to poetic and highly rhetorical contexts, and the fact that one of the covenant partners is typically an impersonal entity, but personified for the purpose of the figure, confirms their recognition as figurative uses. Cf., e.g., Isaiah 28:15, 18. 
differs from a "covenant" primarily in the more limited nature of the commitment undertaken. An example of בְּר with this sense is found in Ezra 10:3: "Therefore let us make a covenant with our God to put away all these wives and their children, according to the counsel of my lord and of those who tremble at the commandment of our God; and let it be done according to the law."21

3) Occasionally מִּרִ bears the sense of the documentary witness (book/tables) of the covenant. This sense appears to be related by encapsulation to either of the common

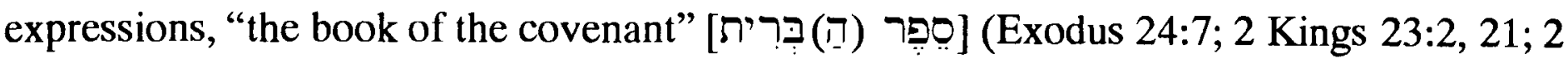

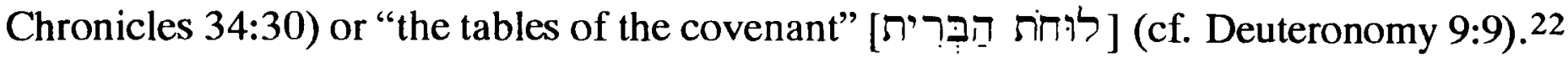

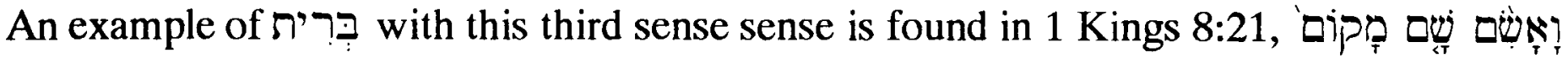
["And there I have provided a place for the ark, in which is the covenant of the LORD..."]. ${ }^{23}$ Clearly the ark did not contain the covenant relationship itself, but merely the documentary witness to the covenant. ${ }^{24}$ Based on this example, it is plausible that the forty-two biblical occurrences of the expression ["ark of the covenant"], including its various congeners, should all be considered as further examples of בִּרִ bearing this third sense.

4) A further case of encapsulation may be noted in examples where בִּרִ bears the

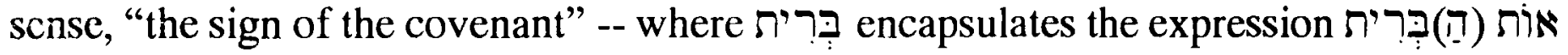
(Genesis 9:12, 13, 17; 17:11). An example of this sense is offered in Genesis 17:13. Already in vs. 11 circumcision is explicitly identified as "a sign of the covenant." But in

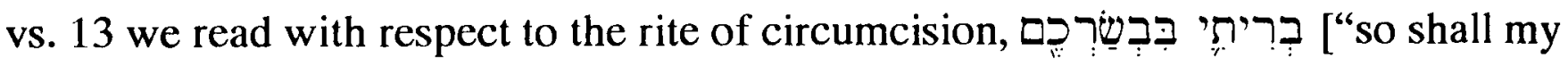
covenant be in your flesh"]. In this clause בִּרִ do does not refer to covenant relationship itself, but to the sign of the covenant. 25

5) While in the first two senses considered above בִּר ית refers to the covenant or pact as a whole, by synecdoche בִּרִ may at times signify a specific obligation undertaken within the covenant. An example of this sense may be found in Leviticus 24:8 [ִרְרית עif : "Every sabbath day Aaron shall set it in order before the LORD continually on behalf of the people of Israel as a covenant [stipulation] forever." Compare the parallel

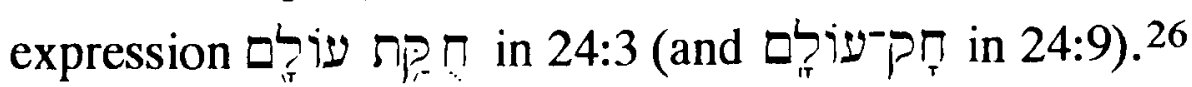

21 It is not always possible to be certain which of the first two senses of ברִ Isaiah 33:8; Hosea 10:4). The following instances appear to be fairly clear examples of בִ כִ כearing its second sense: Ezra 10:3; 2 Kings 11:4 and its parallel in 2 Chronicles 23:1 (Jehoiada the priest and the captains of Judah); Jeremiah 34:8, 10, 15, 18 (bis) (Zedekiah with people in Jerusalem); and Psalm 83:6 [ET 5] (the enemies covenant against Lord and Israel).

22 "Encapsulation" is a term coined and defined by J. Lyons as the "lexicalization of ... [a] syntagmatic modifying component” (Semantics, I, 262). Cf. also P. J. Naylor, op. cit., 93.

$23 \mathrm{Cf}$. also the parallel in 2 Chronicles 6:11.

24 Apart from the expression ארוֹן ב-רית, "Ark of the Covenant," the only other clear example is 2 Chronicles 6:11, the parallel text to 1 Kings 8:21.

25 Cf. also, possibly, Leviticus 24:8.

26 Cf. also, possibly, Exodus 31:16. 
6) There are also a couple of idiomatic expressions involving Tִּרִ to be noted. The first of these is the characteristic, though not exclusive, expression for making (remaking) a

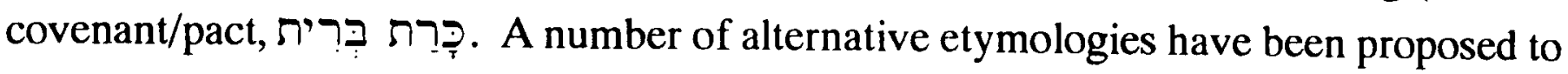
account for this remarkable expression. 27 However, with G. E. Mendenhall, "it seems most likely that the original meaning was lost in antiquity before the time of Moses, and had simply become a technical term [for making/remaking a covenant]."28

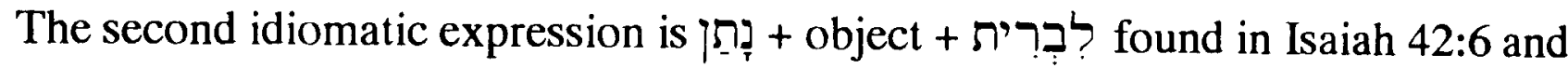

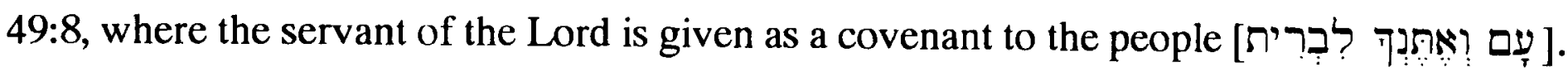
Based on the remarkable semantic proximity of ברית מל אלה, P. J. Naylor argues that פתן לברית should be understood as a case of an emphatic metonymy, precisely as is the case with the parallel syntagm נתן לאלה in Numbers 5:21, Jeremiah 29:18,42:18, and 44:12. 29 Accordingly, as the cursed woman in Numbers 5:21 was an embodiment of that curse, so the servant of Yahweh in Isaiah, "constitutes the embodiment, and personal existentialisation, of all that the covenant entailed." 30

It will be helpful to return now to a more detailed discussion of the first and primary sense of בִּרִּר , namely that of "an elected, as opposed to natural, relationship of obligation esiablished under divine sanction."

A chief difficulty which vexes any discussion of the term בִּרִ semantic range of בִּרִ semantic field. ${ }^{31}$ This fact alone renders implausible, for example, the overly precise analysis of A. Jepsen who argues that בִּר a always refers to the constitutive act which produces a relationship, rather than to the relationship itself. ${ }^{32}$ Certainly some texts employ to refer to the constitutive act (e.g., Exodus 24:8). Other texts, however, seem equally clear in their reference to the relationship more generally. For example, the

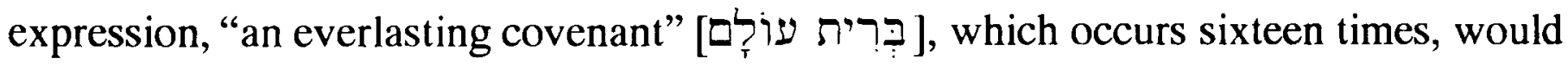
seem rather odd if only the constitutive act were in view. ${ }^{33}$

27 Cf., e.g., M. G. Kline, By Oath Consigned (1968) 42, n. 8; D. L. Magnetti, "The Oath in the Old

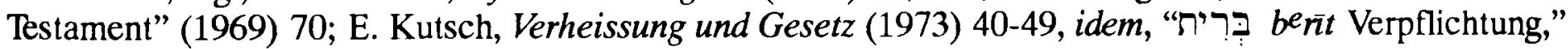
THAT, I (1984) 339-352; M. Weinfeld, "ברית berith," TDOT, II (1977) 253-279; D. J. McCarthy, Treaty and Covenant (1981) 16ff., 92f.; K. A. Kitchen, "Egypt, Ugarit, Qatna and Covenant" (1979) 460f.; and P Kalluveettil, Declaration and Covenant (1982) 92f., n. 25.

28 G. E. Mendenhall, "Covenant," 716.

29 Op. cit., 380-395.

30 lbid., 394.

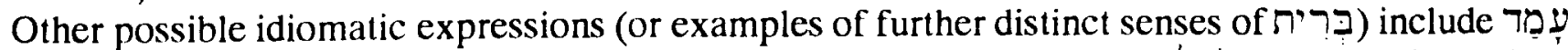
בכּבְברית, found in 2 Kings 23:2: "all the people joined in the covenant," and 1 Kings 20:34, "I will let you go on these terms."

31 Cf. J. Barr, "Some Semantic Notes on the Covenant" (1977) 31-33, and M. Weinfeld, "בְרית berith," TDOT, II, 256-262.

32 A. Jepsen, "Berith. Ein Beitrag zur Theologie der Exilszeit" (1961) 161-179.

33 Genesis 9:16; 17:7, 13, 19; Exodus 31:16; Leviticus 24:8; 2 Samuel 23:5; Isaiah 24:5; 55:3; 61:8; Jeremiah 32:40; 50:5; Ezekiel 16:60; 37:26; Psalm 105:10; and 1 Chronicles 16:17. By contrast, no text

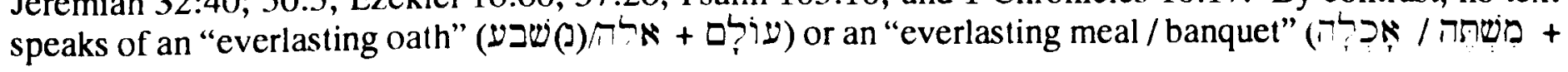


A second problem that needs to be discussed is the apparent complexity of the definition which has been offered: "an elected, as opposed to natural, relationship of obligation established under divine sanction" -- especially if it is to be argued, as it will be, that this definition is operative for בּרִ in Malachi 2:14.

Reflecting a fundamental assumption of modern linguistics, J. Barr has warned biblical scholars against what he has termed "illegitimate totality transfer." This error is committed when "the 'meaning' of a word (understood as the total series of relations in which it is used in the literature) is read into a particular case as its sense and implication there."34 Stating this principle more positively, E. A. Nida urges that "the correct meaning of any term is that which contributes least to the total context." 35

While this principle offers an important corrective against certain interpretative excesses in the past, it appears to overstate the case and has recently been criticized and replaced by a more nuanced approach offered by $\mathrm{A}$. Wierzbicka and $\mathrm{P}$. Cotterell and $\mathrm{M}$. Turner. 36 Offering the English word "bicycle" as an example, Cotterell and Turner note that any English speaker would recognize as semantically anomalous the sentence: "It's a bicycle, but you steer it with handlebars." This is so because the possession of handlebars is properly part of the sense or lexical concept of the term "bicycle," even if handlebars are not normally a contextually focused element for "bicycle." 37 Not only is the sense or lexical concept of a term frequently more detailed than might first be imagined, but, as Cotterell and Turner observe, the context of a term often further enriches its meaning (its "discourse concept") so that the resulting sense goes considerably beyond "that which contributes least to the total context." 38

In the case of Malachi 2:14, from the context of the whole book it is clear that Malachi employs בִּרית and its related terms with a degree of sophistication (cf. P. J. Naylor who concludes his dissertation with an extended abstract from Malachi, noting its "abundant evidence of language oriented to covenant"39). Even apart from a consideration

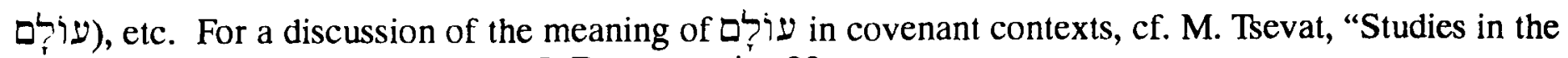
Book of Samuel," 75-77. Cf. also J. Barr, op. cit., 33.

Other attributes of ברית may also favour a reference to the relationship itself rather than to its

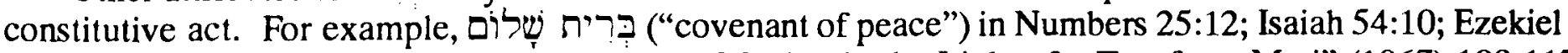
34:25. Cf. M. Noth, "Old Testament Covenant Making in the Light of a Text from Mari” (1967) 108-117.

Finally, although Daniel 9:27 teems with interpretative difficulties, the fact that it can be said of the

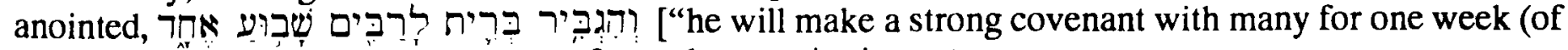

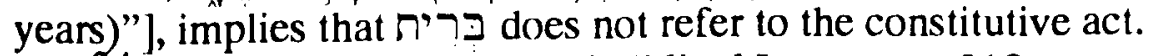

$34 \mathrm{~J}$. Barr, The Semantics of Biblical Language, 218.

35 E. A. Nida, "The Implications of Contemporary Linguistics for Biblical Scholarship" (1972) 86. Cf. also A. C. Thiselton, "Semantics and New Testament Interpretation" (1977) 84.

36 A. Wierzbicka, Lexicography and Conceptual Analysis (1985); P. Cotterell and M. Turner, Linguistics and Biblical Interpretation, 122-123.

37 Op. cit., 148f. Cotterell and Turner draw this example from Wierzbicka's work.

38 Ibid., 152.

39 Op. cit., $422 \mathrm{f}$. 
of that relatively sophisticated use of terminology, however, we have already noted the inadequacy of any attempt to reduce ברִּר in in Malachi 2:14 merely to "relationship."

\subsubsection{Four diagnostic sentences to help test the first sense posited for בְּרִ}

It remains for us to attempt to justify each of the elements in our definition of the first sense of בִּרִ would be desirable to construct a series of diagnostic sentences and discover which, if any, of these appear anomalous to a native speaker of Biblical Hebrew. While we shall begin each section of our discussion with a proposed diagnostic question, obviously, in the absence of native speakers and with the limited body of evidence at our disposal, our conclusions will necessarily be far more tentative.

\subsubsection{1 "He made a covenant, but it was with another person."}

While cannot be reduced to "relationship," nevertheless supporting the centrality of relationship in the vast majority of biblical examples is the observation that virtually everywhere בִּרִ exists. ${ }^{40}$ In particular, the majority of references in the Old Testament to covenants where God is one of the partners: e.g., the covenant between Yahweh and Noah (Genesis 6:18, 9:9-17); Yahweh and Abraham (Genesis 15:8-18, 17:1-4; etc.); Yahweh and Abraham, together with his descendants (Genesis 17:7, etc.); Yahweh and Isaac (Genesis 17:21, etc.); Yahweh and the Patriarchs (Exodus 6:4); Yahweh and Israel (Exodus 19:5; etc.); Yahweh and Phinehas (Numbers 25:12f.); Yahweh and David (2 Chronicles 7:18, etc.); Yahweh and Levi (Malachi 2:4ff.); Yahweh and the eschatological Israel (Jeremiah 31:31; Isaiah 42:6; 49:6-8; 55:3; etc.); and so on.

Besides these theological covenants, there are numerous examples of secular covenants, that is, covenants between persons other than God, although God remains their guarantor. Apart from possible examples involving marriage, the biblical text mentions covenants which exist between individuals (Genesis 21:22f.; 26:23ff.; 31:44ff.; 47:29; 1 Samuel 18:3; 20:8; 22:8; 23:18; 2 Samuel 3:12f.; 1 Kings 2:42-46; etc.); between leaders, often acting as representatives of their peoples (Genesis 14:13; 1 Kings 5:26 [ET 12]; 15:19; 20:34; perhaps 2 Samuel 3:13, 21, etc.); between people groups (Joshua 9:6, 11, 15f.); between leaders and their subjects (2 Samuel 5:3 = 1 Chronicles 11:3; 2 Kings 11:17 $=2$ Chronicles 23:16, 3; cf. Hosea 6:7-11a; 10:3-4); between an individual and the

40 Among those scholars who reject "relationship" [Verhältnis] as central to תבִ are E. Kutsch (Verheissung und Gesetz) and, following Kutsch, L. Perlitt (Bundestheologie im Alten Testament), and E. W. Nicholson (God and His People). Cf. also M. J. Buss, op. cit., and D. J. McCarthy, "berît in Old Testament History and Theology" (1972). 
representatives of a people (Joshua 2); and between a priest and military leaders ( 2 Kings 11:4 = 2 Chronicles 23:1).

In only a few cases do we read about covenants involving impersonal entities, such as a covenant between men and animals (Job 5:23; 40:28 [ET 41:4]; and perhaps Hosea 2:20 [ET 18], where Yahweh is mediator); between a man and the stones of the field (Job 5:23); between Israel's apostate leaders and death (Isaiah 28:15-18); between Job and his eyes (Job 31:1); and between Yahweh and day and night (Jeremiah 33:20, 25). These examples, however, all appear in poetic contexts, often involving hyperbole, personification, or other rhetorical features which suggest that בִּרִ is being employed only in a figurative manner. ${ }^{41}$ It is notable that even in these cases there are no examples of a which involves only a single party. In this respect a בִּרִ differs markedly from, for example, a vow (e.g., cf. the Nazirite vow in Numbers 6:2ff.). ${ }^{42}$

Supportive, also, of the centrality of relationship in covenant is the frequency with which familial or social relationships appear to provide a model for the obligations of a covenant and, consequently, for the terminology by which reference is made to the partners of a covenant. For example, scholars have noted that "brother" [Nָ ] may be employed as a designation of a partner in a covenant. This is clearly the case in certain extra-biblical texts. ${ }^{43}$ It may also be the case in Judges 9:3; 1 Kings 9:13; 20:32; 2 Samuel 1:26; and, perhaps, Numbers 20:14.44 Possibly the clearest example is the expression in בּרִ Amos 1:9 used of the treaty between Tyre and Israel. 45 Similarly, the terms for "father" and "son" appear in extra-biblical texts as designations of covenant partners; within biblical texts this may be the case in 1 Samuel 25:8; 2 Samuel 7:14; 2 Kings 16:7; Isaiah 63:16 (bis); 64:7 [ET 8]; Jeremiah 31:9; Psalm 2:7; 89:27f. [ET 26f.]; and 116:16. 46

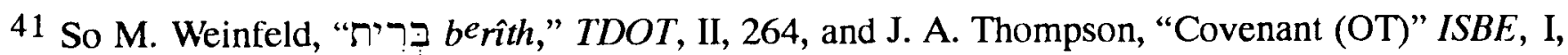
791, who lists these (and, curiously, Zechariah 11:10) as "metaphorical covenants."

42 Apart from the Nazirite vow, most vows also differ from covenants in being conditional (cf., e.g., Genesis 28:20; 1 Samuel 1:11). On the other hand, vows, like covenants, include an oath and hence involve God as a witness or guarantor.

D. L. Magnetti defines a "vow" [נדר] as "a solemn promise made to God to do or to perform a certain act in the context of the cult" (op. cit., 199).

43 D. J. McCarthy, Treaty and Covenant (1981) 106ff. Cf. P Kalluveettil, Declaration and Covenant, 99-101.

44 So P. Kalluveettil, op. cit., Chapter 6, “The Formula 'Brother'," 198-210.

One needs to be careful not to fall into "pan-covenantalism," however, since "brother" may often be merely a polite designation, or, even, a term of endearment. In this respect one may compare examples where a wife is called "sister." Apart from the problematic case of the Patriarchal narratives (Genesis 12:13, 19; $21: 2 \mathrm{ff} . ; 26: 7 \mathrm{ff}$.), each of the remaining examples occurs in a highly poetic context, and none appear to have any necessary covenantal implication (i.e., Proverbs 7:4; Song 4:9f., 12; 5:1f.).

45 Cf. J. F. Priest, "The Covenant of Brothers" (1965) 400-406, and F. C. Fensham, “The Treaty between the Israelites and Tyrians" (1969) 80.

46 For a discussion of "father" and "son" terminology in extra-biblical texts, cf. P. Kalluveettil, op. cit., 98f.; 129f. For the biblical use of these terms with reference to covenant partners, cf. F. C. Fensham, "Father and Son Terminology for Treaty and Covenant" (1971); D. J. McCarthy, "Notes on the Love of God in Dt. and the Father-Son Relationship between Yahweh and Israel" (1965) 144-147; J. W. McKay, "Man's Love for God and the Father/Teacher - Son/Pupil Relationship" (1972) 426-435; and M. Weinfeld, "Covenant, Davidic" (1976) 190f. Cf. also the developed father-son analogy in Hosea 11. 
Further, of special interest to the present study, the husband-wife analogy, although unattested outside the Bible, is used extensively to depict the deity's relationship to Israel in Hosea, Isaiah, Jeremiah, and Ezekiel and is perhaps already implied in the language of

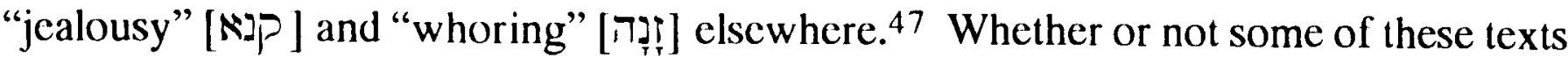
demand an interpretation of marriage as a covenant, as will be argued later, they certainly support an emphasis on the relational aspect of בִּר (perhaps including even an emotional component). ${ }^{48}$

Turning to the social sphere, the terms "lord" and "servant" are well attested as designations of covenant partners in extra-biblical covenants. ${ }^{49}$ Within the Bible there are numerous plausible examples of "lord" and "servant" used in this manner both of theological and secular covenants. For example, compare Genesis 50:18; Joshua 9:8; 1 Samuel 25:8; 27:12; 2 Kings 10:5-6; 16:7; 24:1; and Psalm 116:16. 50 Further, the language of "friend" [אהָב] ] texts of covenant partners and possibly within the Bible. ${ }^{51}$ Compare, for example, אהבר used of Hiram's relationship to David in 1 Kings 5:15 [ET 5:1]; or the use of אדהב in 1 Samuel 18:1, 3; compare also the uses of חבר in Malachi 2:14; Psalm 94:20; Daniel 11:6, 23; 2 Chronicles 20:35, 27; and Hosea 4:17.

Related to these familial and social models for covenant is the primary covenantal obligation of "love" [אהב] (cf. Deuteronomy 6:5; 7:8, 13; 23:6 [ET 5]; 30:6, 15, 16, 20),

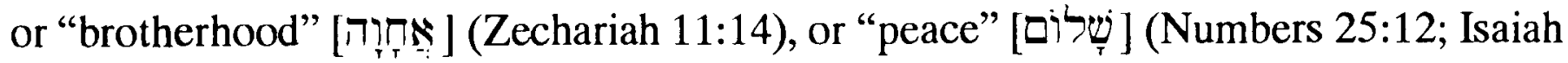
54:10; Ezekiel 34:25; 37:26), etc. ${ }^{2}$ Recognizing this, P. Kalluveettil writes, "even these texts where 'obligation' outshines other aspects of covenant, do not deny the idea of relation, from which obligation originates."53 Putting this somewhat speculatively, Kalluveettil states, "For Semitic peoples, obligation, for instance, was not an isolated concept."54

Summarizing these observations, D. J. McCarthy writes: "Covenant is not contract, as we have had occasion to repeat more than once. It is personal union pledged by symbol

47 Cf., e.g., Hosea 1, 3; Isaiah 43, 49, 51, 62, 63; Jeremiah 2, 3, 30; Ezekiel 16, and 23.

For the absence of this analogy in extra-biblical texts, cf. M. Weinfeld, Deuteronomy and the Deuteronomic School, 81f., n. 6. However, qualifying Weinfeld's claim, cf. \$7.1.1.5 below.

48 So M. Weinfeld, Deuteronomy, 81f., n. 6 and idem, "ברית berîth," TDOT, II, 278. Cf. G. Wallis, " אהבר, 'ähabh," TDOT, I, $113 \mathrm{f}$.

49 Cf. D. J. McCarthy, Treaty and Covenant (1981) 79, n. 80, and P. Kalluveettil, op. cit., 93-99.

50 For Joshua 9:8, cf. F. C. Fensham, "The Treaty Between Israel and the Gibeonites" (1964) 96-100.

51 Cf., e.g., W. L. Moran, "The Ancient Near Eastern Background of Love of God in Deuteronomy" (1963); F. C. Fensham, "The Treaty between the Israelites and Tyrians" (1969) 71-87; P. Kalluveettil, op. cit., 51-53, 99f., 101-102; and E. W. Nicholson, God and His People (1986) 61f.

52 Cf. W. L. Moran, op. cit.; D. J. McCarthy, Treaty and Covenant (1981) 160f., n. 6; P. J. Naylor, op. cit., 27; and P. Kalluveettil, op. cit., 84.

This "love" should not be reduced to mere loyalty, as if it were entirely dispassionate -- cf. Jeremiah 2:2 and M. Weinfeld, Deuteronomy and the Deuteronomic School, 81f.

Cf. also D. J. Wiseman, "Is it Peace? - Covenant and Diplomacy" (1982) 311-326.

53 Op. cit., 91, n. 354.

54 Ibid., 18, n. 9. 
and/or oath. The relationship comes first." 55 Similarly, P. Kalluveettil asserts, "Covenant is relational, in one way or other it creates unity, community." 56 At another point he states: "The idea, 'I am yours, you are mine' underlies every covenant declaration. This implies a quasi-familial bond which makes sons and brothers. The act of accepting the other as one's own reflects the basic idea of covenant: an attempt to extend the bond of blood beyond the kinship sphere, or, in other words, to make partner one's own flesh and blood. The study of the DF [declaration formulae] has shown that covenant is relational." 57

In terms of this relational aspect of covenant and the primacy of the obligation of love, it should hardly be surprising if a text such as Malachi 2:14 did, in fact, identify

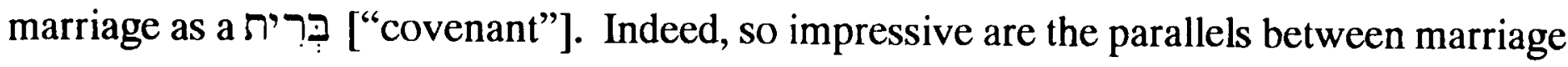
and other kinds of covenant within the Old Testament, some scholars have argued that marriage, along with adoption, provide the underlying model and subsequently formulae for the theological covenants of the Old Testament. 58 Alternatively, if this conclusion is not accepted, J. Ziegler's view seems plausible, that the covenant between Yahweh and Israel suggested the marriage metaphor of the prophets precisely because marriage was also understood as a covenant. 59

\subsubsection{2 "He made a covenant, but it was with a non-relative."}

Supportive of the emphasis in our definition on an elected as opposed to natural relationship, D. J. McCarthy remarks that covenants were "the means the ancient world

55 D. J. McCarthy, Treaty and Covenant (1981) 297. At another point McCarthy writes, "rites and cultic acts are what bring the covenant relationship into being. They are 'sacrifices of union' (šlämîm) which establish a certain community between God and Israel. The treaties aim at the same effect designated by the cognate term, 'peaceful union,' (šalîmu) but the means is not rite but the agreement based on a pledge which they represent" (ibid., 295).

56 Ibid., 51. Cf. also Kalluveettil's comment on p. 91: "Secular covenant actually means, 'relation and obligation, commitment and action'; one cannot separate the idea of relationship from it."

57 Ibid., 212. Cf. also McCarthy's summary, "there is no doubt that covenants, even treaties, were thought of as establishing a kind of quasi-familial unity" (Old Testament Covenant, 33).

Cf. M. L. Newman, who writes with respect to E. Kutsch's one-sided emphasis on obligation in covenant, "Although obligation is invariably one element in the meaning of $b^{e}$ rit, it does not exhaust that meaning. Relationship is also an essential feature. Berit always involves two parties and a specific relation between them" ("Review of Verheissung und Gesetz," 120).

58 R. Smend and N. Lohfink, among others, have argued that marriage and adoption were the ultimate models for covenant and hence the "Bundesformel," the declaration "I will be your God and you will be my people," may itself derive from the legal formulae for marriage and adoption. Cf. R. Smend, Die Bundesformel (1963); Die Mitte des Alten Testaments (1970) 49-54; and N. Lohfink, “Dt 26,17-19 und die Bundesformel" (1969) 517-53.

Cf. also M. Weinfeld, who asserts that the "Bundesformel" is "a legal formula taken from the sphere of marriage, as attested in various legal documents from the ancient Near East (cf. Hos. 2:4 [2])" ("כרי "כ $b^{e}$ rith," TDOT, II, 278). Less convinced is P. Kalluveettil, op. cit., 213.

L. Perlitt has argued against the assumed covenant setting for the "Bundesformel" (Bundestheologie im Alten Testament [1969] 105-115). His objections, however, appear to have been adequately refuted by D. J. McCarthy, Treaty and Covenant (1981) 182-185.

59 J. Ziegler, "Die Liebe Gottes bei den Propheten" (1930) 73-77. Cf. also T. C. Vriezen, An Outline of Old Testament Theology (1958) 146, and M. H. Woudstra, “The Everlasting Covenant in Ezekiel 16:5963" (1971) 25. 
took to extend relationships beyond the natural unity by blood."60 The same point was made a generation earlier by W. R. Smith, who noted, "a covenant means an artificial brotherhood."61

Appropriately iִּרִ is nowhere employed of naturally occurring relationships and the ordinary obligations which attend them, such as those which exist between parents and a child or between blood brothers (cf. Genesis 4:9). On the other hand, stressing their special and volitional character (even if volitional only on the part the suzerain), covenants are frequently said to be cut, or (re)made (ערת) - שקים) -

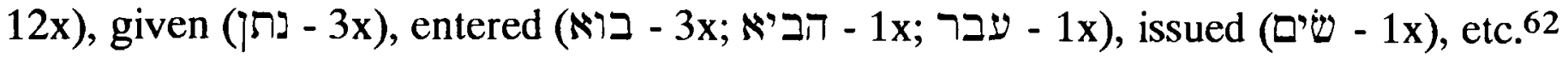

In terms of this aspect of the character of covenants, marriage in general, and the marriage of Adam and Eve in particular, appears to be eminently qualified as a plausible example of a בִּרִ extends family relationships so that incest with an affine is no less heinous than incest with a consanguine. ${ }^{63}$ Additionally, Genesis 2:24 describes the obligation of a husband toward his wife precisely in terms of a familial loyalty which is comparable to that owed to one's parents: "Therefore a man leaves his father and his mother and cleaves to his wife, and they become one flesh."

\subsubsection{3 "He made a covenant, but it was one with obligations."}

E. Kutsch has defended the centrality of "obligation" in covenant, although, as previously noted, Kutsch appears to have gone too far in insisting that בִּרִ should always be rendered "Verpflichtung" ("duty" or "command"). ${ }^{64}$ In a more balanced presentation of the evidence, M. Weinfeld begins with the notion of "obligation," citing certain passages wherein a covenant is "commanded" (Psalm 111:9 and Judges 2:20), while noting that in other passages the terms "covenant" and "commandment" function synonymously (e.g. Deuteronomy 4:13; 33:9; Isaiah 24:5; Psalm 50:16; and 103:18). ${ }^{65}$

60 Treaty and Covenant, 1st ed. (1963) 175. This section was eliminated from the second edition. But its essential point is reiterated and nowhere disavowed. Cf., e.g., idem, Treaty and Covenant, 2nd ed. (1981) 295.

Cf. also McCarthy's assertion elsewhere, "there is no doubt that covenants, even treaties, were thought of as establishing a kind of quasi-familial unity" (Old Testament Covenant [1972] 33).

61 W. R. Smith, Lectures on the Religion of the Semites (1927) 318.

62 These statistics derive from P. J. Naylor, op. cit.

What is intended by "an elected as opposed to natural relationship of obligation," could also be expressed as a "formal [italics added] relationship of obligation," as does M. L. Newman, "Review of Verheissung und Gesetz" (1975) 120.

63 Cf. G. J. Wenham, "The Restoration of Marriage Reconsidered," 36-40.

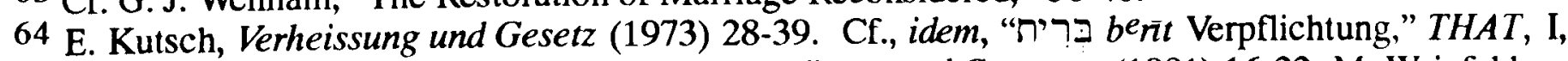
339-352. For a critique of Kutsch, cf. D. J. McCarthy, Treaty and Covenant (1981) 16-22; M. Weinfeld, "B rît - Covenant vs. Obligation" (1975) 120-128; and M. L. Newman, "review of Verheissung und Gesetz" (1975) 117-120.

65 M. Weinfeld, “פרית $b^{e}$ rith," TDOT, II, 255. 
Not surprisingly, there seems to be a scholarly consensus that "covenant" entails obligation. ${ }^{66}$ There has been, however, debate over the issue of whether the obligations of a covenant are necessarily mutual, particularly in connection with certain covenants between Yahweh and his people, or whether covenants of promise (where Yahweh is considered to assume all necessary obligations) may be distinguished rather sharply from law covenants (where the obligations are more clearly mutual). ${ }^{67}$ Favouring the assumption that there is invariably a degree of mutual obligation, D. McCarthy states that "all covenants ... have their conditions," and he goes on to observe that these conditions or obligations may often be merely assumed as matters of cultural convention. 68

Whether McCarthy's analysis is correct or not, in terms of this aspect of (mutual) obligation marriage is very plausibly identified as a בִּרִ marriage of Adam and Eve, we noted in the previous chapter the obligations (without any denigration) of a wife toward her husband. In part, as we have argued elsewhere, these obligations are already implied in the mode of Eve's creation, having been made from the

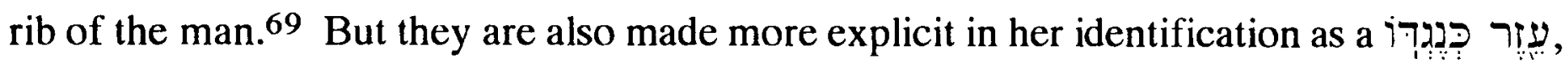
"a helper corresponding to him." A similar implication may be detected in Malachi 2:14 in

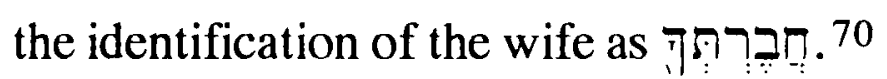

What is especially striking, as was noted in the previous chapter, is the fact that the primary obligation of marriage as stressed in both Genesis 2 and in Malachi 2 is not that of the wife toward her husband, as might be expected from its ancient context, but that of the husband toward his wife. An obligation of nurture and love on Adam's part is already implied in the mode of Eve's creation as well as in Adam's recognition of Eve as "bone of my bones and flesh of my flesh." Removing any doubt concerning this pre-eminent obligation, however, the narrator concludes in Genesis 2:24 that a man should "leave his father and his mother" and "cleave to his wife, and they will become one flesh." The greatest and most enduring natural love and loyalty which a man once owed to his parents

\footnotetext{
66 For a discussion of the metonymic synonyms for covenant based on the stipulations of the covenant, cf. P. Kalluveettil, op. cit., $30 \mathrm{ff}$.

67 What we are terming a "covenant of promise" is called by G. E. Mendenhall a "patron" covenant ("Covenant," 717). Mendenhall uses the term "promissory covenant" to describe the kind of covenant found in Ezra 10:3 where no new relationship is established, but where the covenant serves to guarantee a stipulated course of action.

68 Old Testament Covenant, 3. In support of the "inseparability of covenant and commandment," D. J. McCarthy cites E. Gerstenberger, Wesen und Herkunft des Apodiktischen Rechts, 145-6 (Old Testament Covenant, 3, n. 4). M. G. Kline similarly favours the mutuality of obligations in a covenant (The Structure of Biblical Authority, 125f., 145f.).

69 Cf. G. P. Hugenberger, "Rib," ISBERevised, 4 (1988) 183-185.

70 On the covenantal associations of חב, cf. P. Kalluveettil, op. cit., 51-53.

P. Kalluveettil notes that while the stipulations of a covenant are generally indicated, at times these may be left unspecified, apart from the general obligation of behaviour befitting friends (as appears to have been the case in the Abimelech-Abraham pact) (op. cit., 91). Kalluveettil cites approvingly the comment of W. R. Smith, Religion of the Semites, 315f:: "Primarily the covenant is not a special engagement to this or that particular effect, but a bond of troth and life-fellowship to all the effects for which kinsmen are permanently bound together."
} 
is now to be superseded by an even greater love and loyalty to his wife. Similarly, in Malachi 2:14-16 the prophet stresses the fidelity which is required, not of the wife, but of the husband. Indeed, in both vss. 15 and 16 Malachi makes it clear that a man threatens his own life if he is guilty of disloyalty against the wife of his youth.

\subsubsection{4 "He made a covenant, but it was one with an oath."}

While one need not accept N. Lohfink's definition of בִּרִ as ath," the relative indispensability of an oath for ratifying a covenant commands a widespread scholarly consensus. ${ }^{71}$ Accordingly, G. M. Tucker states: "the covenant formula was based on the oath pattern and the contract was not."72 M. Weinfeld concludes in a similar manner: "berith as a commitment has to be confirmed by an oath...: Gen. 21:22ff.; 26:26ff.; Dt. 29:9ff. (10ff.); Josh. 9:15-20; 2 K. 11:4; Ezk. 16:8; 17:13ff.... The oath gives the obligation its binding validity...."73

Offering compelling support for this conclusion, P. J. Naylor has established the remarkable semantic proximity of אל with functional commutativity, and, especially, syntagmatic intersection. ${ }^{74}$ Reflecting this

71 N. Lohfink, Die Landverheissung als Eid (1967) 101-13. For a brief critique of Lohfink, cf. D. J. McCarthy, who, nevertheless, acknowledges that both originally and still in "many" Old Testament texts חיר may mean "oath" (Treaty and Covenant [1981] 22).

Conversely, it is interesting that although the Akkadian phrase riksu [/ rikiltu ] u māmîtu ("bond and oath") is the standard expression for "treaty," the term mōmîtu, "oath," by itself can refer to a treaty by metonymy.

72 "Covenant Forms and Contract Forms," 500. If oaths were optional in the contract form, as Tucker argues, this should not be understood to imply that they are infrequently attested. Indeed, as D. L. Magnetti argues, it seems that "the swearing of an oath was part of the normal procedure" for contracts in Egypt, Mesopotamia, and Syria-Palestine (op. cit., 47, cf. also pp. 49, 65-85).

73 M. Weinfeld, "תר כִ $b^{e}$ rîth," TDOT, II, 256.

Likewise, D. J. McCarthy concludes that the basic idea of a treaty is "a union based on an oath" (Treaty and Covenant [1981] 141). Cf. the similar insistence on oaths as an indispensable feature of covenants in G. E. Mendenhall, "Covenant" (1962) 716; H. C. Brichto, The Problem of 'Curse' in the Hebrew Bible (1963) 70; G. M. Tucker, "Covenant Forms and Contract Forms" (1965) 488-490; D. L. Magnetti, "The Oath in the Old Testament" (1969) 72-4, 113, 123 and passim; K. A. Kitchen, The Bible in Its World (1977) 80f.; J. Barr, "Some Semantic Notes on the Covenant" (1977) 23-38, esp. p. 32.; J. Scharbert, “דָ 'âläh," TDOT, I (1978) 264; and E. W. Nicholson, God and His People (1986) 103.

74 Cf. P. J. Naylor, op. cit., 380-395.

In support of the semantic proximity of אלר with ברית in terms of collocation: אלה appears with ברית in Hosea 10:4; in an hendiadys in Deuteronomy 29:11,13; in synonymous parallelism in Ezekiel $16: 59 ; 17: 16,18,19$; and in functional parallelism in Genesis $26: 28$.

Idiomatic overlap is apparent in the hendiadys mentioned above that is comparable to the Akkadian phrase riksu u mōmîtu. Of interest also is a Phoenician incantation text involving a covenant granted by the god Ashur, along with other deities, to the people (Z. Zevit, "A Phoenician Inscription and Biblical

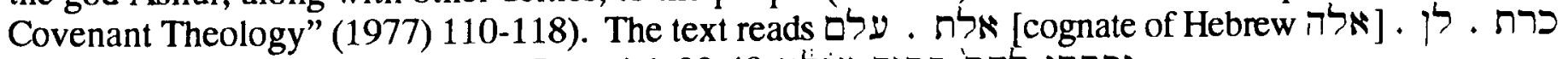

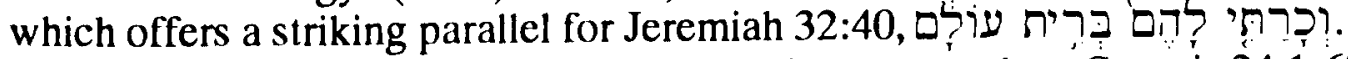

Functional commutativity is illustrated in a text such as Genesis $24: 1-67$. Here it appears that and שבועה may be used interchangeably (cf. vss. 3, 9, and 37 with vss. 8 and 41). Elsewhere it is apparent

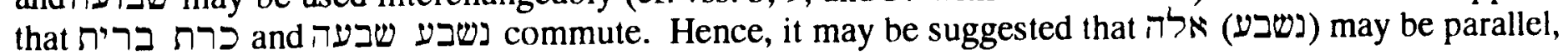
though not necessarily interchangeable, with כרת ברת ברית.

Finally, the following are shared syntagms, demonstrating syntagmatic intersection:

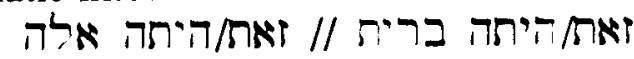

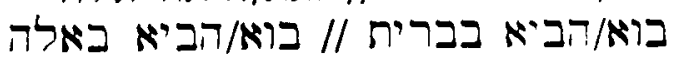

נשבע כריח // נשבע אלה בואות נית 


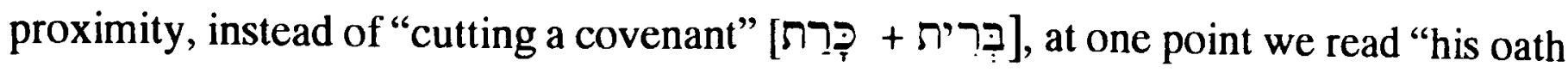

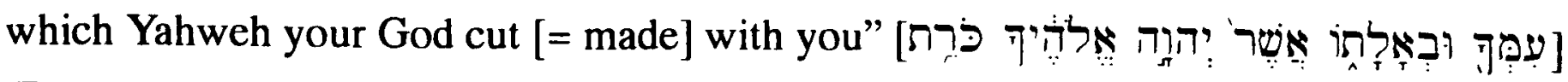
(Deuteronomy 29:11 [ET 12]). Alternatively, just as one can swear an oath, several texts

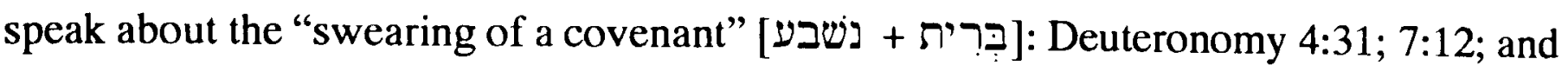
8:18. Similarly, rather than entering a covenant, a couple of passages speak of entering (בא / עבר) an oath: Deuteronomy 29:11 [ET 12] and Nehemiah 10:30 [ET 29]. Finally,

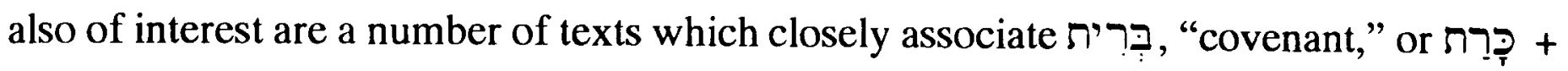

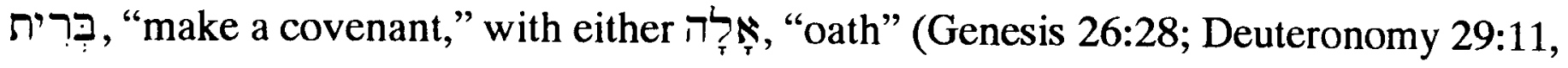
13, 20 [ET 12, 14, 21], Ezekiel 16:59f.; 17:13, 16, 18, 19; Hosea 10:4; Nehemiah 10:31 [ET 30]), or with שִׁבוְָּה, "oath" (Deuteronomy 7:8f.; Jeremiah 11:3-5; Psalm 105:9; Nehemiah 10:30; 2 Chronicles 15:12-15), or with נשבע, "swear," (Genesis 21:31-32; 26:28-31; and 31:44 compared with 31:53; Deuteronomy 7:8f.; 31:20; Joshua 9:15f.; Judges 2:1; and 1 Samuel 20:8 compared with 20:17; 2 Kings 11:4; Isaiah 54:9f.; Jeremiah 11:3-5; Ezekiel 16:8; Psalm 89:4 [ET 3]; 132:11f.; Ezra 10:3-5; and 2 Chronicles 15:1215).

Having established four essential ingredients in the Old Testament understanding of בִּרִ obligations and 4) is established through an oath, the first three of which are clearly present in marriage, we must now examine if there is evidence for this fourth element of a ratifying oath in marriage. From the evidence considered above, it appears that such a ratifying oath may well be the sine qua non of covenant precisely because it invokes the deity to act against any subsequent breach of the covenant. If this is so, the lack of an oath in marriage, as J. Milgrom has argued, indeed would appear to prohibit marriage from being considered a בִּרִ בית . Milgrom observes, "though countless marriage contracts and laws from [the] ancient Near East are known, not a single one to my knowledge stipulates an oath."75

Milgrom proceeds to counter specific arguments which might imply that an oath did accompany marriage whether elsewhere in the ancient Near East or in Israel. He argues, perhaps not altogether convincingly, that the fact that the cuneiform laws so frequently allow an injured husband to mitigate or waive the death penalty against an adulterer, implies that adultery did not entail the breach of an oath. ${ }^{76}$ He notes that the oath mentioned in

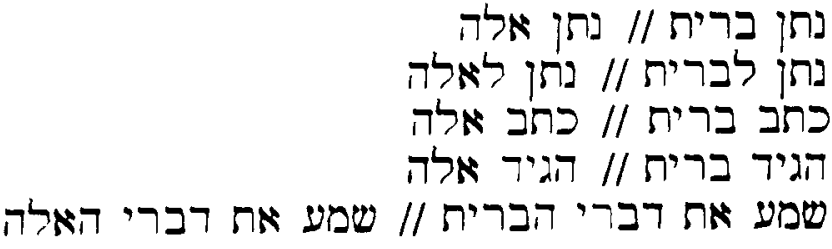

75 Cult and Conscience (1976) 134.

76 Ibid., 134, where he cites CH §129; MAL A \$\$14-16; and HL \$\$192f. 
Genesis 31:50ff. has to do with prohibiting future marriages to Jacob, not with the contraction of his already existing marriages to Rachel and Leah. ${ }^{77}$ Referring to Ezekiel 16:8, Milgrom observes that the oath "is taken by God whereas it should have been expected of the bride, Israel, for it is the bride, not the husband, who is subject to the laws of adultery." Milgrom adds that there is a similar anomaly with respect to the charge of infidelity in Malachi 2:14.

Milgrom goes on to counter the assumption of an oath connected with marriage as a means of accounting for the remarkable use of the term in Numbers 5:11ff. He notes that this term is used precisely of an oath violation in Numbers 5:6-8 and is everywhere else used exclusively of sins against God. Nevertheless, Milgrom considers that its usage in Numbers 5:11ff. is best understood as a "literary metaphor."

Finally, the actual reason for his digression into the subject of marriage as a covenant, Milgrom denies that the penalty prescribed for the violation of a betrothed slavegirl in Leviticus 19:20-22, namely an supposition that adultery violates an individual oath made at the time of her betrothal (after all, the paramour is punished although he had not taken an oath!). ${ }^{78}$ Rather, according to Milgrom, the the Decalogue and hence violates Israel's collective oath of commitment to Yahweh by which they bound themselves to the Sinaitic covenant. ${ }^{79}$

We need now to consider the possibility that there may yet be an "oath" associated with marriage, both a verbal oath and, more importantly, an "oath-sign," which has generally been overlooked hitherto.

77 While Milgrom discusses this example at some length, with the implication that it is erroneously used to buttress the theory of covenantal marriage, he does not cite any scholar who has made the mistake he alleges. Concern about prohibiting other marriages is a common feature of ancient Near Eastern marriage contracts (e.g. from Nuzi).

78 According to J. Milgrom, the God when committed under mitigating circumstances (Cult and Conscience [1976] 133). These crimes divide between "sancta trespass" (the subject of Chapter 2) and "oath violation" (the subject of Chapter 3).

$79 \mathrm{lbid}$., 135f. We may add here that Milgrom qualifies his own objections by acknowledging that "the betrothal/marriage rite might be conceived as a covenant if there were a mutual exchange of verba solemnia even though an oath formula was not used" (ibid., 135, n. 487). Milgrom goes on to cite some evidence for the likelihood of such a verbal exchange, including Hosea 2:4 [ET: 2]. On the crucial oath-like function of such solemn declarations, see our discussion below in $\$ 6.2 .3 .3 .1$. 


\subsubsection{The lack of any explicit reference to an oath within marriage in the ancient Near Eastern law collections or extant marriage contracts is not unexpected}

Although Milgrom observes that none of the extant marriage contracts or laws from the ancient Near East stipulates an oath for marriage, three considerations may help to put this objection into perspective. ${ }^{80}$

1) First of all, it should be recalled that ancient Near Eastern law in general, just as biblical law in particular, is predominantly concerned with the unusual and difficult, not with what could be assumed. ${ }^{81}$ For example, limiting our attention to sexual issues within the Old Testament legislation, there are a number of surprising gaps which have often been observed, such as the lack of an explicit prohibition against father-daughter incest, the rape of a married woman, self-induced abortion, or lesbianism. ${ }^{82}$ In terms of positive stipulations, it has often been noted that there is a surprising lack of an explicit requirement

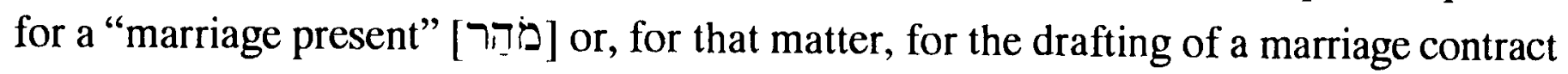

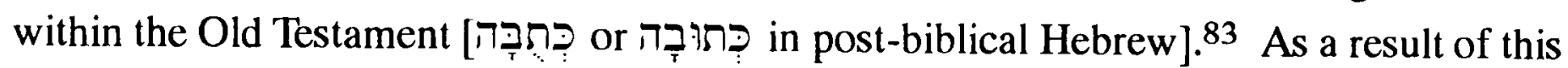

80 Op. cit., 134.

81 On the problematic nature of the so-called "law codes," their incompleteness, and emphasis on exceptional cases, their purpose, etc., cf., e.g., G. E. Mendenhall, "Ancient Oriental and Biblical Law" (1954) 26-46; J. J. Finkelstein, "Ammisaduqa's Edict and the Babylonian Law Codes" (1961) 103-104; D. J. Wiseman, "The Laws of Hammurabi Again" (1962) 161-72; S. Greengus, "Law in the OT," IDBSup. (1976) 533; R. Westbrook, "Biblical and Cuneiform Law Codes" (1985) 247-264; and M. Fishbane, Biblical Interpretation in Ancient Israel (1985) 91-97. In fact, according to Fishbane, the frequent lacunae and ambiguities in biblical law impelled subsequent inner and extrabiblical interpretation, apart from which the law would have been inoperative.

82 Contrast CH §154; HL §195; and MAL A §53. Of course, a prohibition against father-daughter incest, for example, might be inferred from Leviticus 18:6,10,17, or Genesis 19:30ff. Similarly, it is possible that a prohibition against the rape of a married woman could be inferred from the more difficult case of the rape of a betrothed woman in Deuteronomy 22:25-27. Also cf. the anti-rape theme of Judges 5 treated by M. Z. Levin, "A Protest Against Rape in the Story of Deborah" (in Hebrew) [reviewed in OTA 4:1 (1981) \#142]. For a discussion of the legal status of abortion on the basis of Exodus 21:22-25, cf., e.g., B. S. Jackson, "The Problem of Ex. xxi 22-25 (Ius Talionis)" (1973) 273-304; S. E. Loewenstamm, "Exodus xxi 22-25" (1977) 352-60; M. G. Kline, "Lex Talionis and the Human Fetus" (1977) 193-201; R. Westbrook, "Lex talionis and Exodus 21:22-25" (1986) 52-69; and M. Fishbane, op. cit., 92-94.

83 Exodus 22:16 and Deuteronomy 22:29 treat exceptional cases of the "marriage present" [פרוֹ].

Marriage contracts are attested for Jews in the post-exilic period. For the earliest such evidence, cf. the

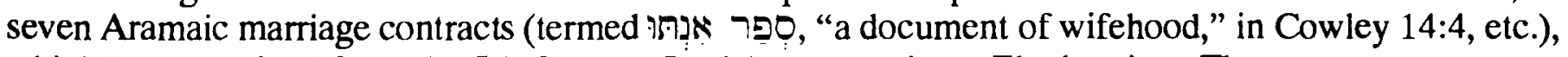
which have survived from the 5th Century Jewish community at Elephantine. The seven contracts may be found in Cowley, Kraeling, and, recently re-edited, in Porten-Yardeni. Cf. also the fragmentary betrothal contract, Cowley 48. For the use of contracts among Jews in the second century B.C., cf. Tobit 7:13,14.

For the later practice of the early second century A.D. Jews, cf. three fragmentary Aramaic Jewish marriage contracts, two of which were published in $D J D$, II, as no. 20 (pp. 109ff.) and no. 21 on (pp. 114ff.). For the third, cf. DJD, II, 253, n. 5. In addition two further Jewish marriage contracts written in Greek were found at Murabba'at and published in DJD, no. 115 on $243 \mathrm{ff}$. and no. 116 on $254 \mathrm{ff}$. Cf. M. A. Friedman, Jewish Marriage in Palestine: A Cairo Geniza Study (1980-81) I, 7-9.

For Talmudic practice, cf. $b$. Qidd. $2 \mathrm{~b}$. For the much later Gaonic period (10th and 11 th centuries A.D.), cf. M. A. Friedman, Jewish Marriage in Palestine. A Cairo Geniza Study (1980-81).

It is less clear whether the Jews utilized marriage contracts in the pre-exilic period. In favour of this assumption, cf. R. de Vaux, Ancient Israel, I, 33. More cautious is R. Yaron, Introduction to the Law of the Aramaic Papyri, 49; and idem, "Aramaic Marriage Contracts from Elephantine," 36f. 
well-documented tendency toward lacunae, both in biblical law and in ancient Near Eastern law in general, it should not be surprising that an oath connected with marriage is nowhere stipulated even if such an oath were customary or mandatory.

2) In spite of the widespread scholarly recognition of the indispensability of an oath, whether verbal or symbolic, as the requisite means for ratifying covenants, K. A. Kitchen has noted that in the fifty-seven extant extra-biblical treaty documents a ratifying oath is only rarely stipulated. ${ }^{84}$ G. Mendenhall makes a similar observation: "The oath itself is lacking in both the Israelite and the Hittite covenants, though there is no doubt that this was the formality which made the covenant valid." 85 One evidence in support of this assumption of a ratifying oath in biblical covenants is seen in later texts which frequently refer to such an oath, even though it was unrecorded in the original instance.86 Hence, by analogy with the practice of the treaty documents, it appears unwarranted to assume from the lack of a similar stipulation in marriage documents that a ratifying oath was necessarily lacking in actual practice. ${ }^{87}$

\section{3) Contrary to Milgrom's assertion that none of the extant marriage contracts} stipulates an oath, in point of fact, a considerable number of marriage contracts include an

84 K. A. Kitchen, The Bible in Its World (1977) 79-85, esp., 80f.; idem, "Law, Treaty, Covenant and Deuteronomy" (1988). So also D. J. McCarthy, Treaty and Covenant (1981) 182, and J. H. Walton, Ancient Israelite Literature in its Cultural Context (1989) 95.

Kitchen's summary of the evidence contradicts E. Gerstenberger, who mistakenly equates the common documentary curse, "If anyone changes the words of this tablet...," with the ratifying oath, or treaty curse ("Covenant and Commandment" [1965] 38-51). Cf. F. B. Knutson, "Literary Genres in PRU IV," RSP, II, $157 f$.

85 G. E. Mendenhall, “Covenant” in $I D B, \mathrm{I}, 720$. Cf. also D. L. Magnetti, op. cit., $72 \mathrm{ff}$.

Analogous to the situation with covenants and their assumed attending verbal oaths or oath-signs, $\mathbf{M}$. Malul has noted that the ancient Near Eastern law compendia in general, "except for one or two cases in MAL, do not make reference to symbolic acts...," although there can be little doubt that a rich variety of symbolic acts were customary and even mandatory (Studies in Mesopotamian Legal Symbolism, 12f.). Cf. also M. Malul, op. cit., 449-452.

$86 \mathrm{Cf}$, e.g., the reference to Yahweh's oath to David to establish his throne in 2 Samuel 3:9, nowhere suggested in the earlier narrative. Cf. similar examples in Isaiah 54:9, which mentions Yahweh's oath not to allow another deluge after Noah, and Ezekiel 16:8 and 20:5-6, which mention Yahweh's otherwise unrecorded oath with respect to the Mosaic covenant. Finally, although Genesis 22:16 does record an explicit oath taken by Yahweh to bless Abraham and his progeny, it nowhere mentions Yahweh's intention to give Israel the promised land (as in Genesis 15:18-20 and 17:8). Nevertheless, in more than forty Old Testament texts, reference is made to an oath of Yahweh guaranteeing possession of the promised land (e.g., cf. Genesis 24:7; 26:3; Exodus 32:11-13; Deuteronomy 8:18; Judges 2:1; Jeremiah 11:3-5; and 2

Chronicles 15:15). Cf. also D. L. Magnetti, who discusses these texts and notes that while it is unusual, an oath sworn by the sovereign is attested in extra-biblical treaties (op. cit., 113ff., 70f., 125, cf. $A T$ nos. 3 and 456).

87 While this argument assumes some similarity between the treaties as international covenants and marriage as an interpersonal covenant (cf., e.g., D. L. Magnetti, op. cit., 94), it does not presuppose a particularly close analogy between treaty documents and the betrothal/marriage documents. As will be stressed below, the marriage documents, in fact, are not closely related to the treaties since they are typically contract documents (following a contract form and primarily concerned to list human witnesses, though at times they may include curses, etc.) and not covenant documents (which have an altogether distinct form which includes the mention or assumption of a divine witness). 
oath. For instance, eight out of the forty-five neo- and late-Babylonian marriage contracts assembled by $M$. T. Roth invoke a curse against anyone who would violate the terms of the agreement (Nos. 2, 5, 8, 14, 18, 19, 26, and 30). ${ }^{88}$ In one case (No. 6), and possibly a second (No. 16), the contract specifies a mutual oath by which both bride and groom are bound to the terms of the contract.

Roth offers the following translation for No. 6:

(1-4) Nabû-ah-iddin, son of Aplā, spoke to Dalīli-ešsu, son of Arba'ilā, as follows: (4-6): "Please give me fBanât-Esagil, your daughter, the lass. Let her be my wife."

(7-9) Dā̄li-ešsu consented to his (proposal), and gave fBanât-Esagil, his daughter, the lass, to him in marriage.

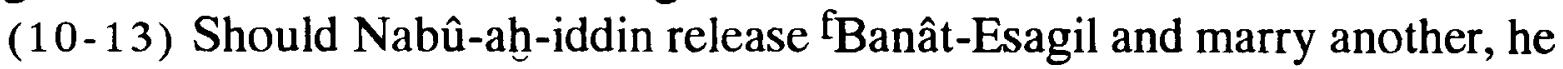
will give her six minas of silver and she may go where she wishes.

(14-16) Should fBanât-Esagil < be found > with another man, she will die by the iron dagger.

(17-19) They swore ${ }^{89}$ by Nabû and Marduk their gods, and by Nebuchadnezzar, the king, their lord, not to contravene (this agreement).

(20) At the sealing of this document (21-27) before: Šulā, son of Samašiddin, descendant of Rab-bāni; Šamaš-mukīn-apli, son of Nūrea, descendant of Zērija; Marduk-nādin-ahi, son of Zababa-iddin, descendant of Rab-bāni; Mār-

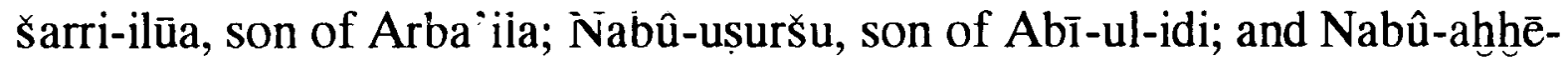
iddin the scribe, son of Šlâ, descendant of Egibi.

$(28-29)$ Opis, month II, day 13, year 41, of Nebuchadnezzar, king of Babylon.

While the discovery of the oath in lines 17-19 might seem attractive for the present thesis, on closer examination it appears unlikely that this oath effected the marriage (covenant) itself. If it had, one would expect it to have been mentioned immediately after the "historical" sketch of the marriage in lines 1-9, rather than following the stipulations of lines 10-16. Located where it is, it seems more likely that this oath is to be viewed solely in terms of the precise stipulations of this contract. That is, the couple agreed in advance to the sanctions to be applied in the event that Nabû-ah-iddin were to choose a second wife, or that $\mathrm{f}$ Banât-Esagil were to commit adultery (and be caught in flagrante delicto); and for

88 M. T. Roth, Babylonian Marriage Agreements: 7th - 3rd Centuries B.C. (1989), 19.

Cf. also the MB Hana marriage document, discussed by A. Skaist, wherein the couple "swore an oath by the god and the king before Pagirum" ("Studies in Ancient Mesopotamian Family Law Pertaining to Marriage and Divorce," 89-93), and a 17th century B.C. marriage contract from Sippar discussed by J. Klíma, wherein the bride (a priestess) and groom "both swore in the names of God Shamash, God Marduk and the town of Sippar" ("Marriage and Family in Ancient Mesopotamia" [1966] 100).

$89 i z-k u-r u$, is a V/ 1 Preterite, expressive of simple past action. As such, this text does not stipulate an oath for marriage, but merely records as a matter of fact that the couple (the antecedent is clearly Nabû-ah-

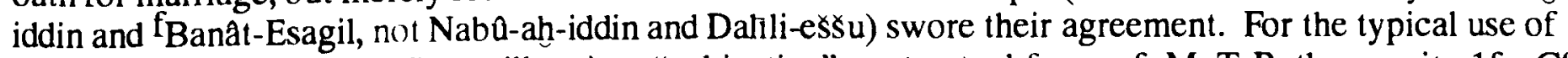
historical narrative in the first millennium "subjective" contractual form, cf. M. T. Roth, op. cit., 1f. Cf. also T. Pinches, "Babylonian Contract-Tablets with Historical References" (1890). 
reasons that elude us, they decided to make this a matter of a contract sealed in the presence of witnesses and further confirmed by means of a mutual oath. 90

Further supporting this interpretation, a comparison with the remaining marriage agreements suggests that this oath is the functional equivalent of the curses mentioned in the eight other contracts indicated above; those curse are similarly placed after the stipulations and immediately before the list of human witnesses. Although there is significant variety in detail, the curse in No. 5 is typical (lines 26-29): "May Marduk and Zarpānītu decree the destruction of whoever contravenes this matter, and may Nabû, the scribe of Esagila, cut short his long days. May Nebuchadnezzar, king of Babylon, decree his destruction." What makes this functional equivalence of mutual oath and curse significant is the observation that in marriage agreement No. 8, at least, there is a third party, in addition to the husband and wife, who is bound by the curse. This is so because No. 8 is a betrothal agreement. In this case the mother of the bride has promised her daughter in marriage (lines 1-5). However, the marriage has not yet been consummated and a later stipulation in the contract (lines 8-11) anticipates the possibility that the mother may yet renege on her promise: "Should fQudāšu [the mother of the bride] not give fImmertu [her daughter] (in marriage) to Nabû-balāssu-iqbi [the groom], fQudāšu will pay five minas of silver from her own dowry to Nabû-balāssu-iqbi." Since fQudāsu is a party to this agreement and has an obligation which is included within its stipulations, presumably she, along with the bride and groom, are together the objects of the curse (lines 20-24): "May Marduk and Zarpānītu decree the destruction of whoever contravenes this matter; may Nabû, the scribe of Esagil, cut short his long days; may Nergal, the almighty, the overpowering among the gods, not save his life from plague and massacre." Being bound by this curse, alternatively the mother could have been made the subject of a mutual oath, at least in principle. But clearly, such an oath bears little resemblance to the kind of exclusive oath between a husband and wife which ought to be expected of marriage if, indeed, it was a covenant.

Considering the presence of oaths and curses in contracts which already have human guarantors, D. L. Magnetti notes that while "contracts were made in a sphere in which men could take care of the situation... the fact remains that evidence indicates that oaths were sworn as part of contract procedure in at least some ancient Near Eastern civilizations. Perhaps this was due to influence by the procedure in the law court [where oaths of clearance or oaths for witnesses were required at times] or to a desire for the additional sanction of the supernatural."91

On the other hand, contrary to Milgrom's expectation, it is unlikely that any betrothal or marriage contract would necessarily stipulate a marriage-ratifying oath precisely

90 I.e., this marriage agreement indicates that the couple were oath bound to the terms of the marriage contract, but not that they were, necessarily, oath bound to the marriage itself. Cf. also M. T. Roth, "“She will die by the iron dagger': Adultery and Neo-Babylonian Marriage" (1988) 186-206.

91 D. L. Magnetti, op. cit., 49f. 
because of the special commercial and ancillary focus of these contracts. With respect to the extant marriage contracts, Milgrom himself notes, "it seems that in Babylonian betrothal / marriage, contracts were not even written, except when additional stipulations had to be made."92 What Milgrom correctly acknowledges for Babylonian betrothal and marriage contracts, based on the landmark studies of S. Greengus, has since been confirmed by R. Westbrook and others and has also been convincingly demonstrated for Late Babylonian and Neo-Babylonian marriage contracts as well as the Jewish Aramaic marriage contracts from Elephantine. ${ }^{93}$ In other words, documentary attestation for marriages appears to have

92 J. Milgrom, op. cit.., 134, n. 484.

Supplementing what was said in the previous note with respect to Jewish marriage contracts, it may help to enumerate here, at least in an approximate manner, the quantity and provenance of the extant nonJewish marriage contracts: 107f.)

- a number of Sumerian marriage contracts (cf. A. Falkenstein, Neusumerische Gerichtsurkunden, I,

- 4 from the Old Assyrian period (so J. M. Breneman, Nuzi Marriage Tablets, 13; cf. ANET, 543; A. Skaist, Studies in Ancient Mesopotamian Family Law, 70-84)

- the Middle Babylonian Hana text (A. T. Clay, Babylonian Records in the Library of J. Pierpont Morgan, Part IV (1923) 4, no. 52, 50-52; cf. also A. J. Skaist, op. cit., 89-93, and M. Malul, op. cit., 130f.)

- 1 Middle Assyrian text (A. Skaist, op. cit., 85-89)

- Approximately 29 tablets from the Old Dabylonian period (so J. M. Breneman, op. cit., 13; A. Skaist, op. cit., 43-68; cf., e.g., G. R. Driver and J. C. Miles, The Babylonian Laws, I, 253-9; S. Greengus, "The Old Babylonian Marriage Contract"; R. Harris, "The Case of Three Babylonian Marriage Contracts" [1974] 363-365; and especially R. Westbrook, Old Babylonian Marriage Law, I [1982] 60-325. Of the large number of private legal documents related to marriage which Westbrook presents, he considers only 19 to be straightforward marriage contracts [op. cit., II, 109])

- Over 100 tablets relating to marriage from Nuzi, many of which appear to be marriage contracts (cf. J.

M. Breneman, Nuzi Marriage Tablets [1971]; A. Skaist, op. cit., 93-107)

- some marriage tablets from Kultepe (so J. M. Breneman, op. cit.)

- some marriage tablets from Ashur (so J. M. Breneman, op. cit.)

- 4 from Alalah (cf. D. J. Wiseman, The Alalakh Tablets, texts 91-94, 54ff. Cf. also I. Mendelsohn, "Marriage in Alalakh," 352f., A. Skaist, op. cit., 108-115, and the translation and discussion of $A T 92$ in M. Malul, op. cit., 111f.)

- 9 (a couple of which are fragmentary) Neo-Assyrian marriage documents (V. A. Jakobson, "Studies in Neo-Assyrian Law" [1974] 115-121; and J. N. Postgate, Fifty Neo-Assyrian Legal Documents [1976] 101107)

- 45 Neo- and Late Babylonian marriage contracts (M. T. Roth, Babylonian Marriage Agreements: 7th 3rd Centuries B.C. [1989])

- a number of marriage contracts from Egypt (cf. J. J. Rabinowitz, "Marriage Contracts in Ancient Egypt in the Light of Jewish Sources" [1953]; E. Lüddeckens, Ägyptische Eheverträge [1960]; P. W. Pestman, Marriage and Matrimonial Property in Ancient Egypt [1961]).

93 S. Greengus, "Old Babylonian Marriage Ceremonies and Rites" (1966) 55-72; idem, "The Old Babylonian Marriage Contract" (1969) 505-532; R. Westbrook, op. cit., II, 52ff.; J. J. Finkelstein, "Cutting the sissiktu in Divorce Proceedings," 236; and M. Malul, op. cit. p. 160; H. J. Hendriks, Juridical Aspects, 20 (noting the surprising absence of any mention of a marriage contract in MAL A $\$ 41$ ), 51 ; M. T. Roth, Babylonian Marriage Agreements: 7th - 3rd Centuries B.C. (1989) 24-28; and B. Porten, Archives from Elephantine (1968) 208.

The Mesopotamian legal tradition reflected in the LE $\$ \$ 27-28$ and $\mathrm{CH} \S 128$, which stipulates the use of a marriage contract (riksatu) is not unambiguous in its implication. An earlier view considered it possible that marriages in general did not require a riksatu, but that apart from this written document a woman who lived with a man would not be accorded the legal status of aššatu (so G. R. Driver and J. C. Miles, The Babylonian Laws, I, 245-249, and H. J. Hendriks, Juridical Aspects of the Marriage Metaphor in Hosea and Jeremiah, 20). Cf. also CH §\$150, 151, 165; MAL A §§34, 36; and NBL $\$ 8$.

S. Greengus, however, argues that while riksātu meant a "written contract" in Neo-Babylonian times, in the Old Babylonian period it meant a "contract" whether or not this was written ("The Old Babylonian Marriage Contract"). In part, Greengus bases his interpretation of riksätu on the root rakāsum, meaning "to 
been largely concerned to specify extraordinary requirements, not to belabour what was typical and could be assumed. Hence, the lack of an explicit stipulation of a ratifying oath in marriage need occasion no surprise. Agreeably, P. Kalluveettil writes, "since the main concern of marriage contracts were economic, the marriage ratifying rites as such were not described in them."94

It seems, therefore, that the stipulation of an oath within extant betrothal and marriage contracts should not generally be expected precisely because these were contracts; they were documents intended to attest to various ancillary agreements related to marriage (often between the husband and his father-in-law, though other arrangements are not uncommon), but they were not intended to attest to the marriage covenant itself. Indeed, not infrequently, as in the arrangement between Laban and Jacob in Genesis 31, these documents were not drafted until long after the marriage was contracted. ${ }^{95}$ As forcibly argued by $\mathrm{R}$. Westbrook in his recent study of Old Babylonian marriage law, "marriage is a

bind" or "to tie." There appears to be nothing in the terms riksätu or rakāsum which indicates a written document. On the contrary, when, for example, $\mathrm{CH}$ intends to prescribe a written document, "it does so unambiguously and employs for unmistakable clarity terms like tuppum, kanikum, and kunukkum" (op. cit., 507).

Greengus explains that cases where a marriage contract was committed to writing invariably reflect a special need to address certain abnormal family circumstances. He concludes, "In our judgment, therefore, the primary purpose of the so-called marriage documents was not to record marriage, but to record important transactions which could affect the status and rights of husbands or wives" (op. cit., 512). Supporting such a conclusion for $\mathrm{OB}$ as well as later practice are the significant number of contracts which indicate the presence of children (requiring the clarification of property rights in the event of the dissolution of the marriage). In support of Greengus' view, cf., e.g., B. Porten, op. cit., 208, and P. W. Pestman, op. cit., 28-30.

R. Yaron, however, has some reservations regarding Greengus's view (The Laws of Eshnunna [1988] 200-205). Unfortunately, the Nuzi marriage tablets, studied in detail by J. M. Breneman, neither support nor refute the claim made by Greengus concerning riksatu (Nuzi Marriage Tablets, 257-261). They do suggest, however, that at times marriage contracts may have been intended merely to provide legal protection for the wife and not to address any unusual family circumstance or property concern.

M. T. Roth, however, concludes that it is unlikely that a written agreement always accompanied marriage in the Neo-Babylonian period (Babylonian Marriage Agreements, 26). As an impressive example she offers the case of the 6th-5th century family of Itti-Marduk-balatu concerning whom "hundreds of documents pertaining to the family's economic and legal activities have survived, including documents revealing the dowry transfers of nine women (five daughters who married out, four brides who married into the family) over three generations." In spite of this impressive documentation, no marriage contracts have survived from this family, almost certainly because none were written.

94 P. Kalluveettil, op. cit., 110. In general, Kalluveettil's conclusion seems well founded (and especially convincing in the case of Elephantine -- cf. B. Porten, Archives from Elephantine, 208). "Main concern," however, should not be misunderstood as "only concern." For example, there are a number of Nuzi marriage tablets which say nothing about inheritance or personal property (i.e., texts $1,3,9,11,12$, 14,15 , as well as all the slave marriage texts, 16-22), and some texts are silent about the bride-price as well (i.e., texts 14 and 21). As a consequence, J. M. Breneman concludes that at times marriage tablets may have been drafted merely for the legal protection of the wife (op. cit., 258-260).

Similarly, M. T. Roth emphasizes economics as the most frequent consideration in the Neo- and Late Babylonian marriage contracts, but also acknowledges that the purpose, or purposes, behind many other texts is entirely elusive (Babylonian Marriage Agreements, 28). One evidence of this ancillary focus in the marriage contracts is the fact that only a tiny fraction of the extant marriage contracts, namely ten, all from the Neo-Babylonian period, consider the subject of adultery. Cf. M. T. Roth, "'She will die by the iron dagger': Adultery and Neo-Babylonian Marriage" (1988) 186, n. 1.

95 Cf., e.g., P. W. Pestman, op. cit., 28. 
legal status and must be distinguished from the marriage contract which is incidental thereto."96

In terms of G. M. Tucker's analysis of covenant forms and contract forms, the marriage documents are characterized by features which are typical of contracts rather than covenants. 97 That is, they usually include a date, the names of the parties, a description of the transaction and its conditions, and conclude with the names of human witnesses. It is this last feature particularly which demonstrates that the principal guarantors of these agreements were the courts and community, rather than God or the gods. 98 Hence, these arrangements represent private legal and commercial agreements, that is, contracts, rather than covenants (which, ratified by oath, do not require witnesses or the apparatus of the court to enforce).

This acknowledgement that the extant marriage documents are contracts does not affect the hypothesis that marriage itself may be a covenant. Tucker recognizes other examples of a similar mixture of contract and covenant, for instance, the commercial arrangement between Solomon and Hiram in 1 Kings 5:15ff. [ET 5:1ff.] (called a בִּרִ in the text, but undoubtedly included aspects of conveyance as well). ${ }^{99}$

96 R. Westbrook, "Old Babylonian Marriage Law," I, ii. Westbrook considers this observation to be the central thesis of his study. Cf., especially, R. Westbrook, op. cit., II, 149-157.

This understanding contrasts radically with the view of I. Mendelsohn, for example, who defines marriage in the ancient Near East as "a civil affair based on a written contract" ("On Marriage in Alalakh," 351). Other scholars similarly confuse the covenant of marriage with the marriage contract. Cf., e.g., R. de Vaux, Ancient Israel, Vol. 1, Social Institutions (1961) 33; A. Isaksson, op. cit., 31; and R. S. Westcott, "The Concept of berit with Regard to Marriage in the Old Testament" (1985) 43.

97 G. M. Tucker, "Covenant Forms and Contract Forms" (1965) 487-503; cf. J. B. Torrance, “Covenant or Contract?" (1970) 51-76.

Evidence for the contract form within the Old Testament can be detected in Jeremiah 32:10-12 (Jeremiah's purchase of a field at Anathoth); Genesis 23:9-18 (Abraham's purchase of the field of Ephron); Ruth 4:9-11; and 2 Samuel 24:18-25 (= 1 Chronicles 21:18-27). Cf. discussion of these texts in G. M. Tucker, op. cit., 499-500.

98 Tucker appears to have overstated the evidence slightly in that some contracts do, in fact, include oaths. Cf. the discussion above on pp. $207 \mathrm{ff}$. Cf. also M. T. Roth, op. cit., 19; and D. L. Magnetti, op. cit., 49 f.

99 Cf. G. M. Tucker, op. cit., 502 and F. C. Fensham, "The Treaty between Solomon and Hiram and the Alalakh Tablets" (1960) 59-60.

In a similar fashion, $\mathrm{R}$. Westbrook sharply distinguishes marriage as a status, analogous to adoption, from the betrothal and/or marriage contracts which at times attended it (op. cit., II, 56f., 149-152).

D. J. McCarthy suggests that Nehemiah 8-10 offers a further remarkable example of the people entering into a written contract to observe the already obligatory covenant law of Yahweh -- a contract which stresses, notably, their economic obligations ("berît in Old Testament History and Theology," 119). Though בדרית is not used of this arrangement (cf. Nehemiah 10:1 [ET 9:38]), cf. Ezra 10:3, where a similar commitment is termed a כרית. Cf. F. B. Knutson, who argues against Baltzer that neither Nehemiah nor Ezra depict a covenant renewal ("Literary Genres in PRU IV," $R S P$, II, 177-180). Rather, in Nehemiah "we have not a covenant, but a promise, a pledge, to keep the covenant already in effect." On the other hand, in Ezra we have a covenant intended for a special purpose, namely, the putting away of foreign wives. 


\subsubsection{Oaths may often be accompanied by, or even consist of, symbolic acts ("oath-signs")}

In attempting to discern the presence or absence of an oath in marriage, it is vital to be clear about what exactly constitutes an oath. ${ }^{100}$ We understand by "oath," any solemn declaration or enactment which invokes the deity to act against the one who would be false to an attendant commitment or affirmation. ${ }^{101}$

Although oaths are referred to in a wide variety of ways in the Old Testament, שִשבוּעָה swearing and the content of what is sworn as distinct senses). ${ }^{102}$ The fact that (originally, meaning “curse," cf. Genesis 24:41; Deuteronomy 29:19 [ET 20]; 30:7; Isaiah 24:6; Jeremiah 23:10; Psalm 10:7; 59:13) is used in this manner serves to emphasize the

$100 \mathrm{M}$. Malul has lamented the fact that prior to his own work, no comprehensive study had been made of the complex subject of the legal symbolism of Mesopotamia (op. cit., v). Because a similar deficiency exists with respect to biblical practice, with a few notable exceptions such as P. Kalluveettil, Declaration and Covenant, the reader's indulgence is asked as we build on these works and undertake a methodical consideration of the specialized topic of biblical oath-signs (cf. M. Malul, op. cit., 36).

101 Although this definition covers the great majority of cases and, in particular, all examples involving covenant making, to take full account of the evidence it is necessary to acknowledge that some less solemn oaths could be sworn by the life of another individual, generally the king (what Fensham terms "profane" as opposed to "sacred" oaths; cf. Genesis 42:15f.; 1 Samuel 17:55; 2 Samuel 11:11), with the implication that it is the king or other individual, rather than God (or in addition to God, as in 1 Samuel $20: 3 ; 25: 26 ; 2$ Kings $2: 2,4,6 ; 4: 30 ; 15: 21$ ), who is invoked to examine and act against any perjury. For ancient Near Eastern parallels to oath-taking by the life of the overlord, cf. the examples cited by $P$.

Kalluveettil, op. cit., 87, n. 329 (although note that some biblical oaths are sworn by the life of an equal, as in 2 Kings $2: 2,4,6$ ).

For a more adequate treatment of oaths, see the full-scale study of D. L. Magnetti, "The Oath in the Old Testament in the Light of Related Terms and in the Legal and Covenantal Context of the Ancient Near East" (1969). Cf. also S. H. Blank, "The Curse, Blasphemy, the Spell, and the Oath" (1950-51) 73-95; H. C. Brichto, The Problem of "Curse" in the Hebrew Bible (1963); A. D. Crown, "Aposiopesis in the Old Testament and the Hebrew Conditional Oath" (1963-64) 96-111; F. C. Fensham, "The Treaty Between Israel and the Gibeonites" (1964) 96-100; F. C. Fensham, "Oath," ISBE Revised, III (1986) 572-574; M. Greenberg, "The Hebrew Oath Particle, hay / hê" (1957) 34-39; F. Horst, "Der Eid im AT" (1957) 366-384;

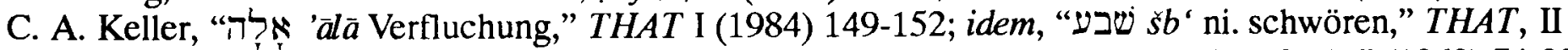
(1984) 855-863; M. G. Kline, By Oath Consigned (1968); M. R. Lehmann, "Biblical Oaths" (1969) 74-92; J. Pedersen, Der Eid bei den Semiten (1914); M. H. Pope, "Oaths," IBD, III, 575-577; J. M. Price, "The Oath in Court Procedure in Early Babylonia and the Old Testament" (1929) 22-29; H. Ringgren, "חיז, chāyäh," TDOT, IV, 339-340; J. Scharbert, “'Fluchen' und 'Segnen' im Alten Testament" (1958) 1-26; idem, "אל 'alah," TDOT, I, 261-266; M. Tsevat, "Neo-Assyrian and Neo-Babylonian Vassal Oaths and the Prophet Ezekicl" (1959) 199-204; M. Weinfeld, "The Loyalty Oath in the Ancient Near East" (1976) 379414; H. C. White, "The Divine Oath in Genesis" (1973) 165-179; and J. A. Wilson, "The Oath in Ancient Egypt" (1948) 129-156.

102 For example, apart from explicit references employing the verb שבעי oaths may be referred to by the mention of an accompanying rite (such as the dividing of animals in Jeremiah 34:18ff.), an accompanying gesture (such as the raising of the hand in Exodus 6:8), or by the

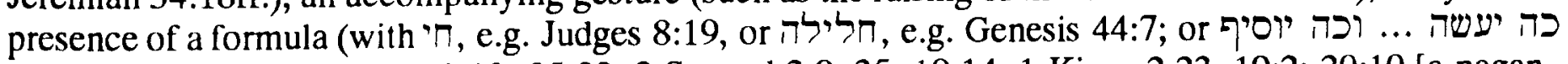
i.e., 1 Samuel 3:17; 14:44; 20:13; 25:22; 2 Samuel 3:9, 35; 19:14; 1 Kings 2:23; 19:2; $20: 10$ [a pagan oath]; 2 Kings 6:31; Ruth 1:17), or by the use of certain grammatical constructions involving אa, particularly if stated before God, cf. Psalm 137:5f.; 7:4ff.; Job 31:5ff.; etc.), or by the content of the oath itself spoken before God (e.g., cf. Exodus 24:3; 2 Samuel 5:1). Cf. D. L. Magnetti, who employs such criteria to discover 127 oaths employed in non-legal and non-covenantal contexts within the Old Testament (op. cit., 147-193). 
hypothetical self-curse which underlies biblical oaths -- that is, if the oath should be broken, a curse will come into effect. 103

As implied in our definition, one important misunderstanding to be avoided is the tendency to equate oaths exclusively with verbal acts. Rather, as elsewhere in the ancient Near East, oaths in the Old Testament are not infrequently symbolic rather than verbal, or, at least, not merely verbal. In particular, such symbolic oaths, or "oath-signs" as they have been termed, were frequently employed in the ratification of covenants. ${ }^{104}$ So, for example, G. E. Mendenhall defines a covenant as "a solemn promise made binding by an oath, which may be either a verbal formula or a symbolic action."105

As an especially vivid illustration of the use of such an oath rite, M. G. Kline cites the eighth-century treaty of Ashurnirari V and Mati'ilu, the King of Arpad. ${ }^{106}$ According to the treaty a ram was to be removed from its herd, and "If Mati'ilu [sins] against the treaty sworn by the gods, just as this ram is broug[ht here] from his herd and to his herd will not return [and stand] at its head, so may Mati'ilu with his sons, [his nobles,] the people of his land [be brought] far from his land and to his land not return [to stand] at the head of his land." 107 Not content with this malediction of exile, the treaty goes on to specify that the ram was to be decapitated: "This head is not the head of a ram; it is the head of Mati' ilu, the head of his sons, his nobles, the people of his land. If those named [sin] against this treaty, as the head of this ram is c[ut off,] his leg put in his mouth [...] so may the head of those named be cut off." Finally, the shoulder of the ram is torn off, and once again the treaty threatens that the shoulder of Mati'ilu, and his sons, etc., would similarly be torn out if Mati'ilu sins against the treaty.

In view of this, and many other similar examples, it is possible, with D. J. McCarthy and others, that the prominence of such cutting oath-signs in the ratification ceremony for covenants gave rise to the widespread terminology of "cutting" a covenant as well as "cutting" a curse (Deuteronomy 29:13 [ET 14]), etc., attested in Hebrew, Aramaic, and Phoenician texts, and the cuneiform texts from Qatna. ${ }^{108}$ This example from the treaty

103 Cf. 1 Kings 8:31; Ezekiel 16:59; 17:16, 18f.; Zechariah 5:3; Job 31:30; Proverbs 29:24; 2 Chronicles 6:22.

As D. L. Magnetti notes, "every oath contains at least an implicit self-curse" (op. cit., 40). J. Scharbert similarly notes, "In translating the different forms [of ${ }_{\text {in }}$ ], one should always begin with the

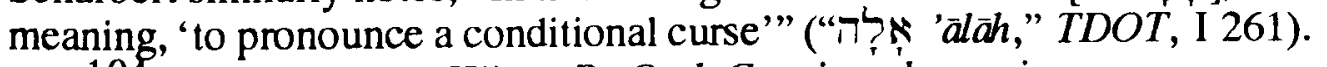

104 E.g., cf. M. G. Kline, By Oath Consigned, passim.

105 G. E. Mendenhall, "Covenant" in IDB, I, 714-23, at p. 714.

106 M. G. Kline, op. cit., 41.

107 This translation, followed by Kline, is that offered by D. J. McCarthy, Treaty and Covenant, 1st edition (1963) 195. For a more recent translation, cf. S. Parpola and K. Watanabe, eds., Neo-Assyrian Treaties and Loyalty Oaths (1988) 8ff.

108 D. J. McCarthy, Treaty and Covenant, 2nd ed. (1981) 91ff.; idem, Old Testament Covenant, 42. Cf. also W. F. Albright, "The Hebrew Expression for 'Making a Covenant' in Pre-Israelite Documents" (1951), 21-22; D. R. Hillers, Treaty-Curses and the Old Testament Prophets (1964) 20, n. 27; M. G. Kline, By Oath Consigned (1968) 42; and K. A. Kitchen, "Egypt, Ugarit, Qatna and Covenant" (1979) 453-464. 
of Ashurnirari V and Mati'ilu is especially instructive in that it offers a clear instance of a self-maledictory oath-sign which does not involve cutting, namely the separation of the ram from its herd.

The Old Testament, likewise, provides numerous examples of both cutting and noncutting rites employed in connection with the swearing of oaths and, more particularly, in the ratification of covenants. However, unlike the case of the treaty of Ashurnirari $V$ and Mati'ilu, the Bible is not always so helpful in making explicit the precise symbolism of many of these acts. For this reason, there is often room for doubt whether any individual covenant rite, for example, the animal cutting ceremony recorded in Genesis 15 , is necessarily intended to depict such an oath. 109

In any case, circumcision appears to be one obvious example of an Old Testament cutting rite which was intended as a covenant-ratifying oath-sign. 110 As noted by M. G. Kline, the explicit curse mentioned in Genesis 17:14, that one who breaks God's covenant of circumcision would be "cut off" (כרת) from among his people, suggests that it was this dreadful curse which was intended to be dramatized in the cutting rite of circumcision. ${ }^{111}$ Offering further corroboration for identifying circumcision as an oath-sign, Kline points out that the manner in which Genesis 17 identifies the covenant with circumcision (vss. 9, 10, 13) exactly parallels the identification of a covenant with its oath elsewhere in the Old Testament as well as in the extra-biblical treaties.

The Akkadian expression hãram qatālum berît $X u Y$, "to kill an ass," which was idiomatic at Mari for covenant making, offers additional conceptual support for the prominence of a ratificatory oath-sign in covenant making. Cf. D. J. McCarthy, Treaty and Covenant (1981) 91.

$109 \mathrm{Cf}$. Jeremiah 34:18ff. In support of this widely held interpretation, cf., e.g., M. G. Kline, $B y$ Oath Consigned, 16f., 42; E. Kutsch, "§ר krt," THAT, I, 857-860; E. Speiser, Genesis, 112; E. B. Smick, "כָּר (kärat)," TWOT, I, 456-457; and L. Perlitt, Bundestheologie im Alten Testament (1969) (who uses a comparison between Genesis 15:18ff. and Jeremiah 34, as well as an 8th century treaty between Ashurnirari V and Mati'ilu, the King of Arpad, as evidence for a late dating for Genesis 15:18ff. -- cf. the counter-argument by D. J. McCarthy, "berît in Old Testament History and Theology," 115). Cf. also J. Ha, Genesis 15: A Theological Compendium of Pentateuchal History (1989).

In further support, cf. Genesis 24:7, where Abraham himself refers to an otherwise unrecorded oath on Yahweh's part, unless he intended a reference to the rite in Genesis 15.

However, G. F. Hasel ("The Meaning of the Animal Rite in Genesis 15" [1981] 61-78) and G. J. Wenham ("The Symbolism of the Animal Rite in Genesis 15: A Response to G. F. Hasel, JSOT 19 (1981) 61-78" [1982] 134-137; idem, Genesis 1-15 [1987] 332-333), among others, reject a comparison with Jeremiah 34 and $A N E S T P, 532$. While these scholars also reject an identification of the theophanic procession between divided animals as a hypothetical self-malediction, this conclusion may not be necessary. Cf., e.g., D. J. McCarthy, who rejects the traditional comparison of Genesis 15 with Jeremiah 34 , but nevertheless accepts an interpretation of Genesis 15 as a self-maledictory rite (Old Testament Covenant [1972] 60f.). Cf. also D. J. McCarthy, Treaty and Covenant (1981) 91-96, 255, and idem, "berît in Old Testament History and Theology" (1985) 110-121, at $115 \mathrm{f}$.

110 For a fuller treatment of circumcision, cf. M. G. Kline, By Oath Consigned, 39-49; 86-89. Cf. also E. Isaac, "Circumcision as Covenant Rite" (1964) 444-456. For an alternative interpretation, cf. W. H. Propp, "The Origins of Infant Circumcision in Israel" (1987) 355-370.

111 M. G. Kline, op. cit., 43: "In the cutting off of the foreskin the judgment of excision from the covenant relationship was symbolized." Noting that circumcision was performed on the organ of generation, Kline later supplements this interpretation of its symbolism stating, "we may now add that the specific malediction expressed by the symbolic action of circumcising the foreskin was the cutting off of the vassal's descendants so as to leave him without heir or name in the kingdom" (op. cit., 87). 
This is not to say that the symbolism of circumcision is exhausted in its selfmaledictory aspect. On the contrary, Kline argues that since the oath symbolized by circumcision was an oath of allegiance, circumcision incorporates simultaneously a more positive symbolism, namely, that of "consecration."112 This is the meaning of circumcision, for example, which is reflected in Jeremiah's call to repentance: "Circumcise yourselves to the Lord, remove the foreskin of your hearts" (Jeremiah 4:4a). ${ }^{113}$

\subsubsection{Oaths and oath-signs may invoke the deity to witness an attendant declaration or promise without employing an explicit self-malediction. At times they may only implicitly invoke the deity by a solemn declaration or depiction of a commitment being undertaken}

The obscurity and variety of the various gestures and acts attested in the Old Testament in connection with oaths or covenant making, including the lifting of the hand, placing hands under another's thigh, the exchange of gifts, the exchange of clothes, shaking hands, eating common meals, the use of salt, oil, etc., has led D. J. McCarthy and others to suggest that at times the ratification of a covenant was accomplished by a rite rather than by an oath. ${ }^{114}$ In this manner, for example, McCarthy attempts to distinguish the covenant ratification in Exodus 24, accomplished by the rites of a common meal, the

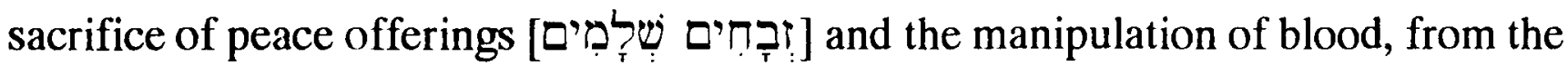
ratifying practice of oath swearing attested in the suzerainty treaties. ${ }^{115}$

Similarly, P. Kalluveettil has argued at length that while "covenant generally implies oath," 116 and that "the oath is the most important factor" 117 for covenant making, it is also the case that "a covenant can be ratified by pledged word or by rites," 118 which, in many cases, may not have an oath function. ${ }^{119}$ Kalluveettil is especially interested in demonstrating that a "Declaration Formula" such as the solemn assertion of Israel to David at Hebron that "we are your bone and flesh," by itself can effect a covenant between parties and notes in support that 2 Samuel 5:1-3 (= 1 Chronicles 11:1-3) offers no mention of an accompanying oath. ${ }^{120}$ Hence, on McCarthy's and Kalluveettil's view, an oath may not

112 Ibid., $43 \mathrm{ff}$.

113 Cf. also the figurative use of ערל in Leviticus 19:23-25. Cf. also the use of "circumcision / uncircumcision" as descriptive of one's heart in Leviticus 26:41; Deuteronomy 10:16; 30:6; and Jeremiah 6:10; 9:24, 25 [ET 25, 26].

114 So D. J. McCarthy, Treaty and Covenant (1981) 254ff.; 294, n. 39; idem, "Three Covenants in Genesis," 179-89; idem, Old Testament Covenant, 41; and E. W. Nicholson, God and His People, 69, 171.

115 Treaty and Covenant (1981) 256.

116 P. Kalluveettil, op. cit., 5.

117 lbid., 91.

118 lbid., 9.

119 lbid., 9 , n. 14 and p. 15.

120 Ibid., 13. Kalluveettil also cites 1 Kings 20:31-34 as a second possible example. 
always be the sine qua non constitutive element of covenant. On the contrary, other acts may well serve to ratify a covenant. 121

\subsubsection{Not all rites connected with covenant making are oath-signs}

It must be acknowledged that not all rites connected with oath taking or covenant making are necessarily intended as oath-signs. For example, the placing of one's hand

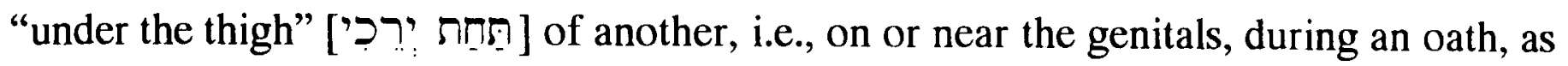
recorded in Genesis 24:2, 9 and 47:29, may well be intended as an act of acknowledgement on the part of the subordinate concerning his continuing obligation of fidelity to the progeny of his superior, whose genitals are being touched. ${ }^{122}$

Likewise, the erection of stones in Genesis 31:45ff., Joshua 24:26f., and Isaiah 19:19-20 appears to be intended not as some kind of symbolized oath, but as a recognition of these as a figurative enduring witness to the covenant-making procedure. ${ }^{123}$ Of course, neither of these examples supports Kalluveettil's thesis since elsewhere in the context of each there is the explicit mention of an accompanying oath.

Similarly, in covenant contexts the exchange of gifts and, less commonly, the giving of clothes, at times may be intended merely to foster amity. ${ }^{124}$ However, depending upon the context, these same acts may carry various further legal implications, perhaps the most prominent of which is to serve as a legal witness to the existence of a covenant. 125 However, in spite of the frequent association between gift giving and covenant, there is no

121 Ibid., 9, 20. P. Kalluveettil distinguishes certain rites connected with covenant making from the ratifying oath by their differing purposes (op. cit., 10). Discussing the E account of the AbimelechAbraham covenant in Genesis $21: 22-24 ; 27: 31$ ), Kalluveettil writes, "Although the swearing makes berît binding and gives it a sacred and inviolable character, it does not directly constitute the covenant relationship, i.e., union. The other covenant ceremony, that of accepting sheep and oxen, does that function, the gift is directed at forming the fellowship between Abraham and Abimelech."

However, while a conceptual distinction between making a בִּרִ binding and constituting a covenant relationship is perhaps useful in the modern analysis of covenant-making narratives, it is not so easy to derive this distinction from the texts themselves.

122 Cf. Z. W. Falk, "Gestures Expressing Affirmation" (1959) 269; M. Malul, "More on pahad yișhäq (Genesis xxiv 42,53) and the oath by the thigh" (1985) 192-200; and idem, "Touching the Sexual Organs as an Oath Ceremony in an Akkadian Letter" (1987) 491-2.

Other interpretations of this gesture are possible. Cf., e.g., E. A. Speiser, "I Know Not the Day of My Death' [Gen 27:2]" (1955) 252-256; idem, Genesis, 178; M. H. Pope, “Oaths" (1962) 576; T. C. Vriezen, "Eid" Biblische-historisches Handwörterbuch, I (1962) 374-76; D. L. Magnetti, op. cit., 209; O Böcher, "Der Judeneid" (1970) 671-681; R. D. Freedman, "'Put Your Hand Under My Thigh' - The Patriarchal Oath" (1976) 3-4; and D. G. Burke, "Gesture," ISBE Revised, II (1986) 451f.

123 Cf. Deuteronomy 27:2ff. Cf. also Exodus 24:4; Joshua 4:20f.; 24:26f.; 1 Kings 18:31; Isaiah 19:19f.

124 Such a purpose is unsurprising based on non-covenantal contexts. Cf., e.g., Proverbs 19:6.

125 Cf., e.g., E. Neufeld, Ancient Hebrew Marriage Laws, 115-117; D. G. Burke, "Gift," ISBE Revised, II, 465-467; and G. A. Anderson, Sacrifices and Offerings in Ancient Israel (1987) 57-75 (for a discussion of Ehud's gift of tribute to Eglon in Judges 3). 
compelling evidence, contrary to $\mathrm{P}$. Kalluveettil, that gift giving or the exchange of clothes ever effected a covenant in the absence of an oath. 126

For example, modern scholars generally disassociate the covenant-ratifying oath mentioned in Genesis 21:23, 31b from the gift of the seven ewe lambs in 21:27-31a. However, regardless of how one resolves the difficult source-critical issues posed by Genesis 21, nowhere does the text suggest that "the gift served to establish the covenant relationship," even apart from an oath, as suggested by Kalluveettil. ${ }^{127}$ Instead, Abraham

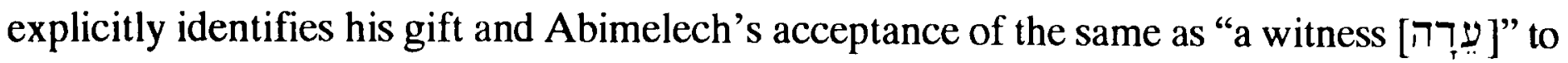
Abraham's contested ownership of the well at Beersheba. ${ }^{128}$

Similarly, Kalluveettil's attempt to identify Jonathan's act of clothing David in 1 Samuel 18 as a symbol of "the gift of himself" which effected a covenant, seems less likely than the widely held interpretation that the gift of these particular clothes (e.g., the מִעִיל, cf. 1 Samuel 24:5 [ET 4]) represented a willing abdication to David of Jonathan's rights as crown prince. 129 At least this appears to have been Saul's view of the substance of this covenant (cf. 1 Samuel 20:30ff.; 22:8). Accordingly, the purpose of such a gift would be, once again, not to effect the covenant, but rather to constitute a public and enduring evidence, a "witness" to Jonathan's commitment. In the nature of the case, for such an abdication to be effective it was necessary for David to be in possession of the kind of tangible evidence which would have been offered by the possession of these clothes and weapons. 130

\subsubsection{However, some rites, in spite of their opacity to modern readers, may prove to be self-maledictory oath-signs after all}

With respect to covenant-making narratives which fail to mention a ratifying oath or oath-sign, in most cases it is doubtful whether one may exclude the possibility that the

126 P. Kalluveettil, op. cit., 10-12, 29. P. Kalluveettil cites J. Pedersen (Der Eid, 25, 49, 52; idem, Israel, 1-2, 296ff.) for evidence that "gift created relationship and effected covenant among the ancient Semites and Hebrews" (op. cit., 10, n. 16.).

127 Op. cit., 10.

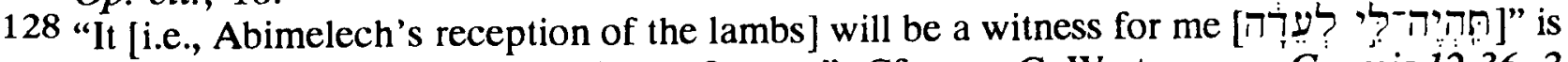
preferable to the RSV, “you will be a witness for me." Cf., e.g., C. Westermann, Genesis 12-36, 349.

129 This royal outfitting appears to have been ironically prefigured in Saul's clothing of David in 1 Samuel 17:38f.

Cf. J. Morgenstern, "David and Jonathan" (1959) 322; T. N. D. Mettinger, King and Messiah (1976) 39; D. K. Jobling, The Sense of Biblical Narrative (1978) 12; P. K. McCarter Jr., I Samuel, 305; R. W. Klein, 1 Samuel (1983) 182; and R. P. Gordon, I \& 2 Samuel (1986) 159. Cf. also the use of royal garments in $R S$ 17.159:22-31 -- cf. F. B. Knutson, “Political and Foreign Affairs," RSP, II, 120-122.

130 Other texts likewise suggest an association between the donning of clothes and the acquisition of throne rights (or inheritance rights) or, alternatively, between the removal of clothes and the loss of throne rights (or inheritance rights). Cf. RSP, II, 122-215, where 1 Kings 11:30-31; Genesis 37 (the special garment of Joseph); Isaiah 22:21; Numbers 20:24-28; and 1 Kings 19:19-21 are discussed. Cf. also the fuller discussion below and in Chapter 7 on the use of garments. Cf. also M. Malul, who discusses cuneiform texts which require the removal/leaving of one's garment as an expression of disinherison (Studies in Mesopotamian Legal Symbolism, 93ff.). 
covenants in question were ratified by other unrecorded acts (oaths or oath-signs), or that the rites which are mentioned may, after all, be better understood as oath-signs in spite of their opacity to the modern reader. ${ }^{131}$ As two examples of this latter option, one may consider the frequently overlooked, but possible self-maledictory symbolism of salt (as in Numbers 18:19, Leviticus 2:13, and 2 Chronicles 13:5) and of oil (as in Hosea 12:2 [ET $12: 1])$ when these appear in covenant contexts. ${ }^{132}$

\subsubsection{Other covenant-making rites may be oath-signs, but they need not be overtly self-maledictory}

Perhaps the most telling objection, however, against McCarthy's and Kalluveettil's understanding of oaths is their implied assumption that oaths and oath-signs must be overtly self-maledictory. ${ }^{133}$ To be sure, oaths are at times explicitly self-maledictory, and, as we have seen, oath-signs likewise frequently share this same characteristic. ${ }^{134}$ But not all do so.

131 P. Kalluveettil seems to overlook the option that there may have been a ratifying oath or oath-sign which the narrator did not bother to record, frequently preferring to build his case on negative evidence. For example, at times Kalluveettil attaches special significance to the observation that an oath does not happen to be mentioned in a particular account. Cf., e.g., "the fact that oath does not appear in $2 \mathrm{Kg} \mathrm{10,15f.} \mathrm{and}$ Lam 5,6 deserves special attention" (op. cit., 26). Cf. also p. 91, n. 357. At other points, Kalluveettil's observation that a particular covenant lacks a ratifying oath applies only to one source-critical strand of the account. E.g., P. Kalluveettil notes that according to the $\mathrm{J}$ account, there was no oath in the AbimelechAbraham covenant, although an oath is mentioned three times over in verses frequently assigned to $\mathrm{E}$, i.e., Genesis 21:23, 24, 31 (op. cit., 10). Cf. ibid., 29.

E. Gerstenberger appears to have a similar objection in mind when he suggest that McCarthy fails to take into consideration that in the Old Testament we do not have "drafts of treaties, but, at best, narratives and sermons about covenants... [McCarthy's] distinction of 'ritual' and 'verbal' treaty form (162f., 176) may be a direct result from this oversight" ("Review of Treaty and Covenant" [1964] 199).

132 In support of the possible self-maledictory symbolism of salt, cf. F. C. Fensham, "Salt as curse in the Old Testament and the Ancient Near East" (1962) 48-50, and D. J. McCarthy, Old Testament Covenant, 42. Cf. also J. F. Ross, "Salt," IDB, IV, 167; P. J. Naylor, op. cit., 200; and D. Stuart, Old Testament Exegesis (1984) 63f., who also cites H. C. Trumbull, The Covenant of Salt (1899).

For alternative views of the symbolism of salt, cf. P. J. Budd, Numbers, 206, G. J. Wenham, Numbers, 144; M. Malul, op. cit., 378; and especially, J. E. Latham, The Religious Symbolism of Salt (1982).

In support of the self-maledictory symbolism of oil, cf. D. J. McCarthy, "Hosea XII 2: Covenant by Oil" (1964) 215-21; K. Deller, "šmn bll (Hosea 12, 2). Additional Evidence" (1965) 349-52; K. R.

Veenhof, review of E. Kutsch, Salbung als Rechtsakt im Alten Testament und im alten Orient (1966) 30813; D. J. McCarthy, Old Testament Covenant, 41f., n. 2; idem, Treaty and Covenant (1981) 119, n. 46; P. Kalluveettil, op. cit., 14, n. 34; and D. Stuart, Hosea - Jonah (1987) 189f. Cf. also lines 622ff. of the Vassal-Treaty of Esarhaddon with Ramataya in ANET, 540 and Psalm 109:18.

An alternative view (perhaps involving an altogether different use of oil) is posited by M. Malul, op. cit., $161,176$.

133 This assumption may have been influenced by the use of (literally, "curse") for "oath." As J. Scharbert notes, "In translating the different forms [of w w w , one should always begin with the meaning, "to pronounce a conditional curse"” "“דָ 'äläh," TDOT, I, 261).

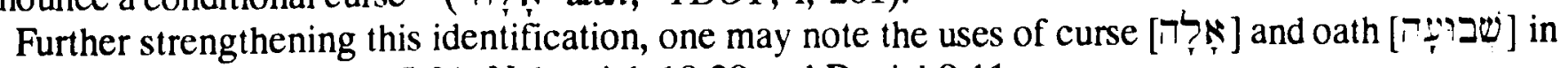
close proximity in Numbers 5:21; Nehemiah 10:29 and Daniel 9:11.

134 The full unexpurgated oath with an elaboration of curses is found in Numbers 5:19-28; Psalm 7:45; 137:5-6; Job 31:5, 7-8; 31:9-10; 31:16-17, 19-22. Cf. Deuteronomy 21:1-9. 


\subsection{Verbal oaths are frequently not explicitly self-maledictory}

Considering first the case of verbal oaths, many such oaths include only a highly abbreviated or incomplete self-malediction. For example, in 2 Samuel 3:35 David explicitly invokes God in a statement which is identified in the text as an oath, but the precise selfmalediction is left stereotypically undefined: "but David swore saying, 'God do so to me

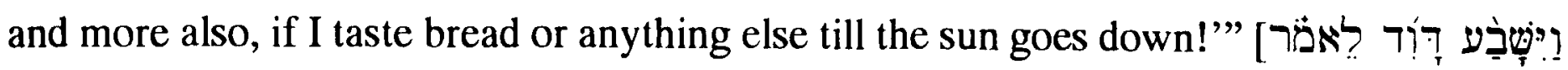

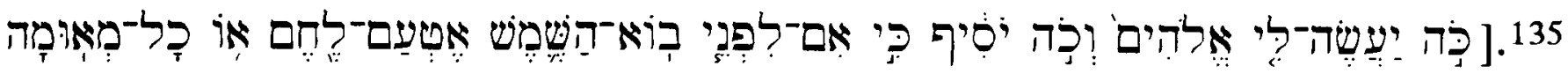

Alternatively, oaths frequently consist merely of a protasis, with the apodosis (the assumed details of the self-malediction) left unmentioned. Compare, for example, 1 Kings

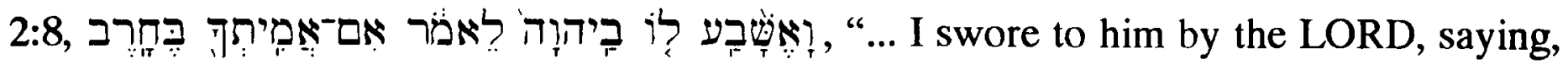
'If I put you to death with the sword...!'" Presumably the ellipsis was meant to imply something like, "then may I also be put to death" or "may I be cursed."136 To avoid the awkwardness of an incomplete sentence in English, typically such a formation is rendered as a negative oath, as in the RSV: "I swore ..., 'I will not put you to death with the sword!" But such renderings should not be allowed to obscure the underlying implied self-malediction or, as a consequence, the implied invocation of the deity to act against the one who would be false to his commitment or affirmation. ${ }^{137}$

Other oaths merely acknowledge God as a witness to the statement or promise of the swearer. Although these examples may not include even an abbreviated selfmalediction, the acknowledgement of God as witness brings with it the clear implication that God will take action against any perjury or infidelity. This is the case, for example, in Genesis 31:50: "If you ill-treat my daughters, or if you take wives besides my daughters, although no man is with us, remember, God is witness between you and me

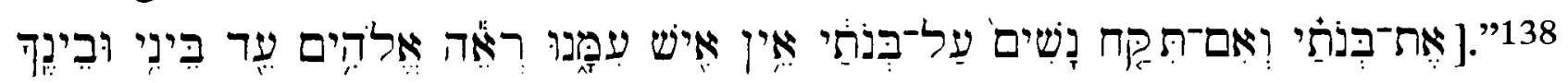

Similarly, a very common oath formula entails the invocation of God merely by a solemn confession of the deity's existence: "as the Lord/God lives [... ' $\pi$ ]," but again this carries the implication that the deity will now hold the swearer responsible for what he states or promises. 139

135 For further examples, cf. 1 Samuel 3:17; 14:44; 20:13; 25:22 (cf. S. R. Driver, op. cit., 199 for proposed emendation); 2 Samuel 3:9, 35; 19:14; 1 Kings 2:23; 2 Kings 6:31; Ruth 1:17; and Jeremiah 42:5. Compare 1 Kings 19:2 and 20:10, where the same formula, in the plural, is used by Jezebel and Benhadad with reference to their pagan deities: "So may the gods do to me, and more also..." Cf. D. L. Magnetti, op. cit., 200f., and G. M. Tucker, op. cit., 491.

136 Cf. M. R. Lehmann, "Biblical Oaths," 88.

137 Note that just as an incomplete conditional introduced with 0 results in a negative oath, one introduced by saying, 'If the land ... shall not be an inheritance for you..,", becomes, "Surely the land ... shall be an

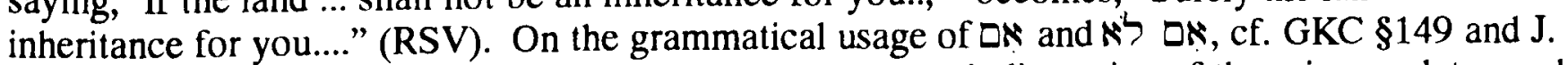

Pedersen, Eid, 117f. Cf. M. R. Lehmann for a more thorough discussion of these incomplete conditionals, not all of which are introduced with 0 ("Biblical Oaths," 86-92).

138 Cf. Judges 11:10; 1 Samuel 12:5; 20:12; Jeremiah 42:5; Micah 1:2; Malachi 2:14, and 3:5. Cf. also Genesis 31:53.

139 Cf., e.g., G. M. Tucker, "Covenant Forms and Contract Forms," 491. 
Finally, still other oaths consist merely of the solemn declaration of one's commitment, with God's presence either assumed from the context or invoked only by implication. These verba solemnia, or "declaration formulae," as they are termed by Kalluveettil, are not solemn merely because they are made with deliberation. Rather, they are solemn because they are uttered before the deity. ${ }^{140}$ Accordingly, a number of texts underscore the importance of words when uttered in God's presence: Judges 11:11, “... and Jephthah spoke all his words before the LORD at Mizpah."141 Compare also 1 Kings 8:31f.; 2 Chronicles 6:22f.; Jeremiah 34:15; and Hosea 4:15.142 Of course, the point of this stress in the biblical record on how particular oaths were made in various sanctuaries is just a reflection of the more pervasive concern to have God be a witness to one's oath. ${ }^{143}$

For example, as we have noted in the previous chapter, the third person reference in Genesis 2:23, with God's presence affirmed in the immediate context, implies that Adam was addressing his affirmation not to Eve, nor, presumably, to himself, but to God as witness when he said, "This at last is bone of my bones and flesh of my flesh... [תז]

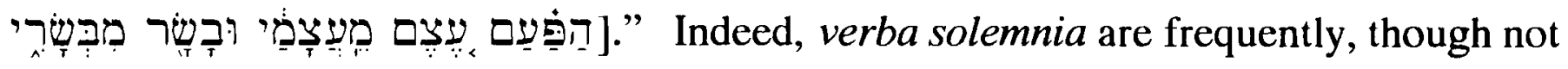
exclusively, couched in the third person, as in Genesis 2:23, with the apparent implication that they are being stated before God as witness. ${ }^{144}$ Compare also the affirmation of the men of Shechem concerning Abimelech, "he is our brother" (Judges 9:3). ${ }^{145}$

The emphasis suggested here on the implicit curse in all oaths contrasts with the conclusions of $\mathbf{M}$. R. Lehmann regarding oaths employing the ${ }^{\prime}$ formula ("Biblical Oaths" [1969] 74-92). However, Lehmann's hypothesis of an original blessing-oath signalled by $\pi$, of which Deuteronomy 32:40 is the lone surviving example, appears unconvincing.

In support of the interpretation of the $ח$-oath formula as a solemn acknowledgement of the existence of the guarantor of an oath, cf. F. C. Fensham, "Oath," ISBE Revised, III, 573; H.-J. Kraus, "Der lebendige Gott" (1967) 169-200; and H. Ringgren, "חָ chäyäh," TDOT, IV, 339-340. Cf. also D. L. Magnetti, op. cit., 202ff. After discussing this oath form in detail, Magnetti cites approvingly the interpretation of Moshe Segal, "Yahweh is a witness who lives forever" (op. cit., 215, n. 38).

Cf. also M. Greenberg, “The Hebrew Oath Particle, hay / hêe" (1957) 34-39.

140 By contrast, P. Kalluveettil distinguishes rather sharply the purpose of the declaration formulae [DF] from that of oaths (op. cit., 212). According to Kalluveettil, "The DF contained in a nutshell all the duties and privileges of an ally.... The oral declarations of relationship is not a substitute for oath. Both of them are important covenant elements, but destined to fulfil different functions. Oath has stipulations as its object, one swears to the observance of the covenant terms.... The DF is concerned with the covenant union; it serves to affirm and effect the relationship."

This distinction, however, may be more a product of modern scholarship than ancient reality since, as Kalluveettil acknowledges, often the declaration formulae constitute the content of the oath (op. cit., 212, $\mathrm{n}$. 9; cf. also 93f.).

141 Cf. R. G. Boling, Judges, 199, and P. Kalluveettil, op. cit., 33f.

142 The sanctuaries at Gilgal and Beth-aven were places where oaths were administered -- cf. M. H. Pope, "Oaths," 576.

143 The emphasis on God as a divine witness to oaths and covenants is manifest in Genesis 31:50; Joshua 24:22, 27; 1 Samuel 12:5; 20:23 [if MT עִ ער ] ער ] Je to bemiah 42:5; Genesis 31:49 (where God is to watch); and Genesis 31:53 (where God is to judge). Cf. 1 Samuel 20:42 and Judges 11:10. Cf. also Ezekiel 17 where God determines to punish Zedekiah for breaking "my covenant" and "despising" "my oath," although in fact it was a covenant imposed by the Babylonian overlord on Zedekiah,

144 In the case of Genesis $2: 23$, the absence of any human witnesses to these verba solemnia, such as the elders of the city, other family members, etc., helps to clarify God's role as witness. 
Alternatively, an example of verba solemnia couched in the second person is offered in 2 Samuel 5:2f., where the context makes plain their function as part of a covenantal commitment made "before the LORD": "Then all the tribes of Israel came to David at Hebron, and said, 'Behold, we are your bone and flesh....' So all the elders of Israel came to the king at Hebron; and King David made a covenant with them at Hebron before the LORD, and they anointed David king over Israel."

D. J. McCarthy and P. Kalluveettil both agree that solemn declarations are "solemn" precisely in that they implicitly invoke the deity. And both scholars go to considerable lengths to stress how "oath-like" are certain examples of such verba solemnia. For example, McCarthy concedes with respect to his interpretation of Exodus 24:3 ("All the words which the LORD has spoken we will do") that any such "public commitment to follow Yahweh who has just presented Himself in all his power is the equivalent of an oath [italics added]."146 Similarly, Kalluveettil writes with respect to Israel's affirmation in Exodus 19:8 ["All that the LORD has spoken we will do"]: "From this pledging of the people to obedience (it amounts almost to the oath of a vassal treaty [italics added]) results the lord-servant relationship among the parties, and this fellowship paved the way for the proclamation of covenant laws and for the formal realization of pact as described in ch. 24."147 In the same manner, Kalluveettil comments with respect to the people's acclamation of Saul in 1 Samuel 10:24 ["Long live the king!"], made in the presence of the prophet Samuel and immediately after the Lord had revealed his choice of Saul: "they bind themselves to him [i.e., Saul]; the act amounted to an oath [italics added]."148

In terms of ancient Near Eastern parallels, cf. the use of the third person in the formulae, "this is our king" (cf. P. Kalluveettil, op. cit., 94, n. 5; p. 107); "he is the king" (op. cit., 107); "this is my brother" (op. cit., 105); and, especially, "she is my wife" [ašsiti ̌̌̃t ] in MAL A §41 (also cf. op. cit., 111).

Note that in a NB letter, $A B L 280$, r. 3, Belibni reports to king Ashurbanipal how the leaders of two cities surrendered to Mushezi-Marduk: "They took the oath of loyalty to Mushezib-Marduk declaring: we are vassals of the king of Assyria" (P. Kalluveettil, op. cit., 93). This is a clear example of a declaration formula, identified as the content of their oath (even though it lacks any self-malediction).

For second person formulae, cf. Genesis 29:14; 2 Samuel 5:2f.; and "our life is yours" (P. Kalluveettil, op. cit. 87).

145 Cf. P. Kalluveettil, op. cit., 209ff. Cf. also 1 Kings 20:32.

146 D. J. McCarthy, Treaty and Covenant (1981) 253. So also D. L. Magnetti, op. cit., 128. While McCarthy makes this concession, his analysis of the Sinai covenant as a ritual covenant, rather than a verbal covenant in the tradition of the ancient Near Eastern treaties, requires him to reassert a fundamental difference between what is "the equivalent of an oath" and what is actually an oath. "The ritual is a familial thing and not the terrorizing acted out oaths of some treaty rituals" (op. cit., 276). This difference, however, is not altogether convincing in the face of McCarthy's acknowledgment that the oath-bound treaties similarly effected a familial union between the covenant partners. Cf. the similar point made by $\mathbf{M}$. G. Kline, The Structure of Biblical Authority, 2nd ed., 116.

147 P. Kalluveettil, op. cit., 157.

148 P. Kalluveettil, op. cit., 61. Though the text does not identify this as a covenant, Kalluveettil is convinced that the reality was there.

Cf. also Kalluveettil's earlier discusion where he calls Laban's words in the E version of his covenant with Jacob (Genesis 31:45, 49, 50, 53b, 54) "analogous to an oath formula, vv. 49 and 50b" (op. cit., 11). 
If solemn declarations result in sanction-sealed commitments to which God is witness, then there appears to be little justification for McCarthy's and Kalluveettil's reluctance to identify them as "oaths," rather than "the equivalent of an oath," etc. To refuse to recognize such verba solemnia as oaths merely because they are not explicitly self-maledictory is to introduce a distinction where there is no difference.

\subsection{An uplifted hand, though not overtly self-maledictory, may function as an oath-sign since it expresses an appeal to the deity to act as a witness}

What is true of solemn declarations appears to be equally true of solemn enactments, i.e., oath-signs. While, as we have seen, some oath-signs consist of a Drohritus, that is, an acted-out conditional curse, not all oath-signs are so explicitly selfmaledictory. For example, perhaps the most common symbolic action in connection with

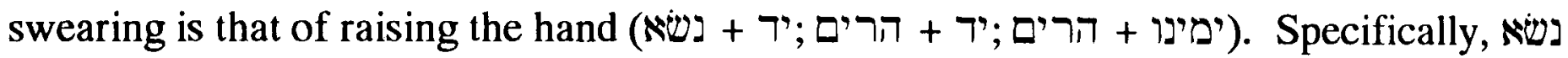
+7 , when used of oaths, refers exclusively to oaths taken by God: Exodus 6:8; Numbers 14:30; Deuteronomy 32:40; Ezekiel 20:5 (bis), 6, 15, 23, 28, 42; 36:7; 44:12; 47:14; יד + הרים 106:26. On the other hand, the related expression 9:15; and Psalm appears as an oath-accompanying gesture on the part of Abraham in Genesis 14:22, while the expression שמאלו + ימינו + הרים appears as a gesture of swearing on the part of an angel in Daniel 12:7.149

Although there appears to be little doubt that the upraised hand is intended as a symbol of swearing in the texts which have been mentioned, it appears that, as with many symbolic acts, the same gesture may bear a different significance when found in a different context (cf., e.g., Exodus 17:11). Furthermore, it is possible that the same gesture assumed different meanings over time or that it had become so stereotypically associated with oaths that its precise meaning was lost sight of. ${ }^{150}$ Nevertheless, without excluding other possibilities, it seems most probable that in oath contexts the upraised hand represents an appeal to the deity to act as a witness against any perjury or infidelity. ${ }^{151}$

Supporting this interpretation, it may be noted that in certain non-oath contexts, the raising of the hand(s) also seems to symbolize an appeal to the deity, functioning as a

149 The writer is unaware of any explanation for the interesting distribution of these three closely related idioms. Cf. also Isaiah 62:8.

For a more detailed discussion of the various expressions for upraised hands and their Akkadian equivalents, cf. M. I. Gruber, Aspects of Nonverbal Communication in the Ancient East (1980) 22-89.

$150 \mathrm{M}$. Malul warns about a further possibility with respect to Mesopotamian legal symbolic acts: what may seem like a performable gesture is in fact merely a graphic figure of speech, much like the English expression “to pull one's leg" (op. cit., 19, 23-27).

In the present case this appears to be excluded by the use of varied phraseology (an important indicator according to Malul, op. cit., 25) and especially by the abundant iconographic evidence of actual performance to be adduced below. Naturally, when applied to the deity, it appears that this gesture is being attributed as a vivid anthropomorphism.

151 So, e.g., S. R. Driver, Deuteronomy, 379, and J. A. Thompson, Deuteronomy, 303. 
gesture of supplication (e.g., cf. נשים + נשא in Psalm 28:2; 134:2 and Habakkuk 3:10; + כך in Psalm 63:5 [ET 4]; 119:48; and Lamentations 2:19; and יד + הרים in Exodus $17: 11) .152$

If this is the proper interpretation of "raising the hand," then this gesture is only implicitly self-maledictory and, as such, appears to be a symbolic equivalent of the widelyattested oath formula, "as the Lord lives."153

Certain other oath-signs, similarly, do not appear to be overtly or exclusively selfmaledictory. In contrast to "raising the hand," which represents a direct appeal to the deity to act as witness, these oath-signs function by offering a solemn depiction of the covenant commitment being undertaken and thereby only implicitly invoke God as witness. As such, these oath-signs function in a manner which is comparable to the verba solemnia discussed earlier. We shall focus on two examples of this kind of oath-sign, namely eating together and shaking hands, not only because of their intrinsic importance, but also because of manifest similarities which exist between these well-recognized oath-signs and the oathsign to be posited for marriage in the next chapter, namely sexual union. In proceeding to discuss these two examples, however, it is again necessary to keep in mind that the symbolism involved in these acts need not be univocal (as was seen above in the case of circumcision) and that their function may change according to context; the same act may not be an oath-sign when it appears in a different setting.

\subsection{Eating together, at times, may function as an oath-sign by solemnly depicting the covenant commitment (and, possibly, also its sanction)}

One need not agree with scholars like E. Meyer and L. Köhler, who suppose that the idea of "covenant" originally derived from the practice of a shared meal (reflected in an assumed etymology of ברה from בִּר I, "to eat"), to be impressed with the frequency that such meals are associated with covenant ratification within the Old Testament and elsewhere in the ancient Near East. ${ }^{154}$

152 It is possible that this gesture of supplication in turn derived from the use of raising hands as a hailing or greeting gesture. Cf. the use of נש +7 in Isaiah 49:22. Cf. also Keel \#414 and Keel's discussion on p. 311.

153 Alternatively, even if the oath-sign of the upraised hand symbolizes an incomplete self-malediction (cf. the frequent use of upraised hands in non-oath contexts as a sign of surrender as in Keel \#15, 25, 39, 40,63 , etc.), implying the hypothetical surrender of oneself to the deity to do with the swearer as he pleases if there is any perjury or infidelity, nevertheless, it does not constitute a Drohritus.

154 Cf., e.g., Genesis 26:30; 31:46-54; Joshua 9:14; Exodus 18:12; Psalm 23:5; 41:10 [ET 9]; 69:23 [22]; 1 Kings 1:9, 25; 1 Chronicles 12:39f.; 29:22; and 2 Chronicles 18:2. For extra-biblical examples, cf., e.g, J. A. Knudtzon, et al., Die El-Amarna-Tafeln (1915) \# 162, 22f., and D. J. McCarthy, Treaty and Covenant (1981) 254, n. 19.

Cf. also E. Meyer, Die Israeliten und ihre Nachbarstämme (1906) 558, n. 1, and L. Köhler, "Problems in the study of the Language of the Old Testament" (1956) 4-7. 


\section{Given certain widely acknowledged cultural attitudes regarding shared meals}

evident throughout the Old Testament, such an association with covenants seems entirely appropriate. This is not to suggest that every instance of a common meal within the Old Testament is fraught with significance. It is to suggest that even in seemingly incidental references to a shared meal, often there are important cultural presuppositions of expected behaviour and attitudes associated with such meals to which the reader should be alert. 155

1) For example, just as fasting can be expressive of grief, feasting together in a common meal is frequently expressive of well-being and rejoicing. ${ }^{156}$ Given how frequently covenants were intended to end a period of alienation, hostility, need or deprivation, or to introduce a period of peace and prosperity, it is not surprising to find plausible examples of this celebratory use of common meals in covenant-making or renewing contexts, where the meals in question do not function as oath-signs. See, for example, 1 Kings 3:15.157 See also Deuteronomy 12:7; 14:26; 27:7; and perhaps, 1 Chronicles 29:22, all of which stress how Israel was to eat together before the Lord rejoicing. ${ }^{158}$

2) A second widely-attested cultural assumption concerning shared meals was the expectation that mutual amity and loyalty would attend and be secured by the sharing of a meal. Accordingly, common meals at times functioned analogously to the giving of a gift, as discussed above. 159

155 Cf. P. Farb, Consuming Passions: The Anthropology of Eating (1980), cited approvingly by M. Malul (op. cit., 377f.) in support of the general importance of shared meals throughout history as a means of securing comity.

Focusing on biblical and ancient Near Eastern practice, cf., e.g., W. T. McCree, "The Covenant Meal in the Old Testament" (1926) 120-128; J. F. Ross, "Meal," IDB, 3, 315-318; D. J. McCarthy, Treaty and Covenant (1981) 254, n. 19; P. Kalluveettil, op. cit., 11, 12f., 118; and M. Malul, op. cit., 176, 346, 353, 356, 376-378.

156 Thus the biblical record mentions common meals which were held to celebrate, inter alia, a birthday (Genesis 40:20), the day when a child is weaned (Genesis 21:8), the conclusion of sheep shearing (1 Samuel 25:4-13; 2 Samuel 13:23f.), the conclusion of the grape harvest (Judges 9:27), the conclusion of a temple building project ( 2 Chronicles $7: 8 ; 30: 23$ ), and, with special significance for the present thesis, the conclusion of marriage negotiations (Genesis 24:33, 54) and a wedding (Genesis 29:22; Judges 14:10). Cf. also Genesis 31:27f. For Jewish practice beyond the Old Testament, cf. Tobit 8:19f.; 10:7ff.; 2 Esdras 9:47; Matthew 22:2; John 2; and m. Seb. 7:4.

Related to this sense of conviviality and gratitude for one's well-being, a number of texts imply an expectation that such festive meals would be shared often with neighbours and persons who were less fortunate. Cf., e.g., Exodus 12:4; Deuteronomy 12:12, 18; 1 Samuel 30:24; 2 Kings 7:9; Esther 1:3, 5, 9; and Job 31:16f.

157 Cf. S. J. DeVries, I Kings (1985) 53. The fact that this feast was not one which was shared between the covenanting parties (the covenant was between Yahweh and Solomon, not Solomon and his servants) makes clear that this feast functioned in a celebratory manner, rather than as an oath-sign.

158 Cf. also Isaiah 55:2f.

Alternatively, the meal in 1 Chronicles 29:22 may be part of a covenant-ratifying ceremony presided over by David, designed to establish Solomon as king.

$159 \mathrm{Cf}$., for example, the protest of the Judahites against the men of Israel, "Because the king is near of kin to us. Why then are you angry over this matter? Have we eaten at all at the king's expense? Or has he given us any gift?" (2 Samuel 19:42) 
This expectation of amity appears to be presupposed in the prophetic image for the last days when, "The wolf and the lamb shall feed together..." (Isaiah 65:25). 160 For this reason also, not only is the lack of love at shared banquets seen to be a contradiction (cf. Proverbs 15:17), but any subsequent acts of disloyalty are judged particularly reprehensible when they are committed by those who have eaten together (without any necessary implication that the common meal had effected a covenant). Compare, for example, Psalm 41:10 [ET 9], "Even my bosom friend in whom I trusted, who ate of my bread, has lifted his heel against me." Related to this expectation concerning common meals, the invitation to join in a common meal was an expression of good will and favour. Compare, for example, Ruth 2:14.161 Correspondingly, the willingness to avail oneself of the hospitality of another implies a willingness for amity, while the refusal to share another's food implies condemnation, alienation or hostility. Compare, for example, 1 Samuel 20:5; 1 Kings 13:8; and Psalm 141:4.

With such associations, it is not surprising that examples abound of the use of common meals in the context of covenant, perhaps often intended merely as an expression of the family-like amity (since it is families who typically eat together) which is secured or formalized in covenant. ${ }^{162}$ Compare, for example, Genesis 26:30. In cases, however, where it is stated or implied that a common meal was eaten in the presence of the Lord, the reader has warrant to suppose that the meal may have functioned as a covenant-ratifying oath-sign. In such a case the solemn depiction of friendship and mutual loyalty would function analogously to the verba solemnia considered earlier. ${ }^{163}$ The possibility that some covenants were sworn by a common meal seems to be required by the comparative ancient Near Eastern evidence such as the mention of the oath "by the laden table and by drinking

160 Cf. Isaiah 11:7. Cf. also Psalm 23:5. While the traditional view that Psalm 23:5 alludes to food on a common table (perhaps from a sacrifice, in view of the implied temple setting in vs. 6) remains probable, it is possible that one should read this text in the light of $A N E P$, \#608 (= Keel \# 122, 96, cf. discussion on 95f.), which appears also to have a temple setting. If so, there were covenant documents on the table rather than food.

161 Perhaps similar in its romantic associations is the mention of how Tamar prepared and then fed Amnon "heart-shaped cakes" [לבכבר?] 2 Samuel 13:6, 8, 10.

The obligation to extend hospitality to strangers may be compared here, although some texts make clear that in such contexts it was not always necessary to eat together. Cf. Genesis 18:5, 8 (where the men ate while Abraham stood by) and Judges 13:15ff. (this is an important text since by substituting a burnt offering in this theophanic context, it implies an equivalence between burnt offerings shared with God and common meals shared with mortals). Cf. also Genesis 19:3; 43:32; Judges 19:4, 8, 19, 21.

For examples where the king shows his munificence and personal favour by invitations to share in a common meal, cf. 2 Samuel 9:7-13; 19:28, 43 [ET 42]; 1 Kings 2:7; 18:19; and Esther 5:12. Cf. also Judges $1: 7$ and 2 Kings 25:27-30.

162 This point is made by D. J. McCarthy (Treaty and Covenant [1981] 253ff., 266, 276) and P. Kalluveettil (op. cit., 11: “Indeed they become kinsmen, since only kinsmen eat together”), inter alios.

163 In some contexts, particularly where sacrifices (i.e., burnt offerings -- cf. Judges 13:15ff. which, by substituting a burnt offering in this theophanic context, implies an equivalence between burnt offerings shared with God and common meals shared with mortals) are included with their symbolism of the deity figuratively sharing in the table fellowship, such meals express simultaneously a renewed commitment to the deity. Cf. also S. R. Driver, Genesis, 289. 
from the cup" in lines 154-156 of the Vassal-Treaty of Esarhaddon with Ramataya. ${ }^{164}$ A plausible example of a common meal employed as a covenant-ratifying oath-sign appears in Genesis 31:46 (where the common meal is consumed in the presence of the heap, and perhaps also the pillar if it is not a secondary expansion, which function as symbols of the deity) and perhaps also Genesis 31:54. ${ }^{165}$ An interesting special case of the use of a common meal as a possible covenant-making oath-sign is found in examples where such a meal serves in the recognition of a new king. Compare, for example, e.g., 1 Kings 1:9, 25,$41 ; 4: 20 ; 1$ Chronicles $12: 39 f$; $29: 22 ; 2$ Chronicles $18: 2$; and especially 2 Samuel 3:1221.166 Finally, mention should be made of two important, though controversial, examples of common meals functioning as oath-signs: Exodus 18:12 and Joshua 9:14.167 The efficacy of the Gibeonite covenant in Joshua 9, in spite of the Gibeonite's deception, finds an intriguing nineteenth-century parallel, cited by D. J. McCarthy: "Doughty frequently snatched bread and salt in the tent of an Arab whom he feared. Even such a forced eating with the other was enough to assure protection, in effect, a covenant."168

3) There is a third possible symbolism for common meals within the Old Testament, namely, that of a self-maledictory rite. In particular, the hypothetical implication of such a meal consumed in the presence of the deity might be to invite the deity to act as a witness against any perjury or infidelity by abandoning the offender to a similar fate as that experienced by the devoured animals. ${ }^{169}$ Putting it this way makes clear that, as opposed

164 Cf. ANET, 536, as noted by M. G. Kline, The Structure of Biblical Authority, 2nd ed., 117, n. 8. Cf. also D. J. Wiseman, The Vassal Treaties of Esarhaddon (1958) 84; S. Parpola and K. Watanabe, op. cit., 35; and R. Borger, "Zu den Asarhaddon Verträgen aus Nimrud" (1961) 173-196.

For another example, cf. J. A. Knudtzon, et al., Die El-Amarna-Tafeln (1915) \# 162, $22 \mathrm{f}$.

165 On the complex source-critical issues raised by Genesis 31:43-54, cf., e.g., D. J. McCarthy, "Three Covenants in Genesis" (1964) 179-189; and, offering a different analysis, C. Westermann, Genesis $12-36,490,498 \mathrm{ff}$.

It appears that the heap (and perhaps the pillar) was intended as a symbol of the deity, who is identified

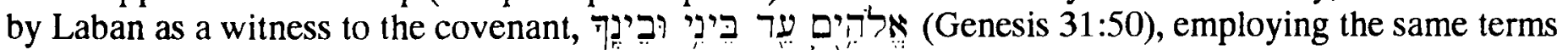

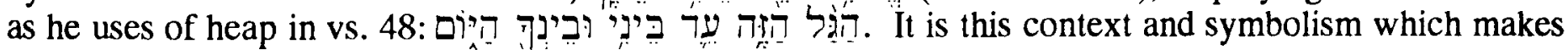
particularly significant the fact that "they ate there by the heap" (Genesis 31:46). The arrangement of pillar and heap, if original to the text, may recall an earlier dual representation of the deity in the "smoking fire pot and a flaming torch" in Genesis 15 and may have been intended to replicate the twofold pillar of God's presence in oath posture (Exodus 13:21, etc.; cf. 1 Kings 7:21). Cf. M. M. Kline, "The Holy Spirit as Covenant Witness" (1972).

166 Cf. P. Kalluveettil, op. cit., 12f., who also cites D. J. McCarthy, "Brît and Covenant in the Deuteronomistic History," 80f.; W. T. McCree, "The Covenant Meal in the Old Testament," $126 \mathrm{f}$; A. Malamat, "Organs of Statecraft in the Israelite Monarchy," BAR III, 164f.; and T. C. Vriezen, "The Exegesis of Exodus 24:9-11," 112 (op. cit., 13, n. 26). R. Smend, however, denies a covenant implication for this meal ("Essen und Trinken - ein Stück Weltlichkeit des AT," 456).

167 For Exodus 18:12, cf. A. Cody, "Jethro Accepts a Covenant with the Israelites" (1968) 153-166. For Joshua 9:14, cf. F. C. Fensham, "The Treaty Between Israel and the Gibeonites" (1964) 96-100; J. M. Grintz, "The Treaty of Joshua with the Gibeonites" (1966) 113-126; D. J. McCarthy, Old Testament Covenant, 43; and P. Kalluveettil, op. cit., $116 \mathrm{f}$.

168 D. J. McCarthy, Treaty and Covenant (1981) 254, n. 19, referring to events recorded in C. M. Doughty, Travels in Arabia Deserta (1888).

169 In terms of modern sensibilities, by which we prefer to dissociate the slaughter of animals from our subsequent dining by the services of a butcher, any such symbolism may appear far-fetched. In 
to the previously considered symbolism, this proposed meaning is not concerned with the communal nature of such meals, i.e., that they would be eaten together. Rather, any selfmaledictory symbolism applies only to the antecedent death of animals in preparation for the meal and perhaps also to the physical act of consumption, whether of food or drink. ${ }^{170}$

Reflecting this difference in the symbolism, it should be possible, at least in principle, for the same occasion of eating and drinking to function as an oath-sign by offering both a positive symbol of the covenant commitment and, simultaneously, a negative symbol of the covenant sanction. For this kind of symbolic multivalence, one may recall the example of circumcision considered earlier, with both its self-maledictory symbolism and its more positive consecratory symbolism, neither of which excludes the other. ${ }^{171}$

Supporting the possibility of this proposed maledictory symbolism for shared meals, numerous texts within the Old Testament and elsewhere in the ancient Near East depict God's judgment precisely in terms of the imagery of having one's flesh devoured or one's blood drunk, etc. ${ }^{172}$ Compare, for example, Ezekiel 39:17-20; Jeremiah 12:9; 19:7; and 34:20.173 More explicit support that these stereotypical curses may have been enacted in a self-maledictory rite may be found in the proliferation of curses which conclude the Vassal-Treaty of Esarhaddon with Ramataya:

"Just as (these) yearlings and spring lambs, male and female, are cut open and their entrails are rolled around their feet, so may the entrails of your sons and daughters be rolled around your feet.... Just as [this?] bread and wine enter the

antiquity, however, the connection between slaughter / sacrifice and eating was patently closer and in covenant-making contexts, as we have seen, frequently explicit. Cf. W. W. Hallo, "The Origins of the Sacrificial Cult: New Evidence from Mesopotamia and Israel" (1987) 3-13.

170 Some scholars would prefer to stress how the sacrificial blood is a symbol of life rather than threat of death. Cf. D. J. McCarthy, op. cit., 294f. It is not clear that these alternatives are mutually exclusive.

171 Perhaps affording a still closer parallel, one might consider the New Testament Eucharist, referred to by Pliny the Younger in his letter to Trajan: " [Christians] come together to bind themselves by an oath." Paul's threat that whoever eats and drinks unworthily will "eat and drink judgment upon himself" (1 Corinthians 11:27ff.) supports a self-maledictory symbolism underlying the Lord's Supper (our infidelity deserves the same dreadful curse which overtook Christ whose death is symbolized in the elements). At the same time, Paul affirms a more positive symbolism entailed in the communal nature of this meal: "Because there is one bread, we who are many are one body, for we all partake of the one bread" (1 Corinthians 10:17). In the following verse Paul invites a similar comparison between the symbolism of the Lord's Supper and Old Testament sacrifices as is being presently suggested: "Consider the people of Israel; are not those who eat the sacrifices partners in the altar?" (1 Corinthians 10:18)

Cf., e.g., G. E. Mendenhall, who relates the cup of the New Covenant to OT concepts of oath and curse ("Covenant," 722). Cf. also C. F. D. Moule, "The Judgment Theme in the Sacraments," 464-481; A. R. Millard, "Covenant and Communion in First Corinthians," 242-248; and M. G. Kline, By Oath Consigned, 80f. For a similar approach to Passover, cf. K. van der Toorn, "Ordeal Procedures in the Psalms and the Passover Meal" (1988) 427-445.

$172 \mathrm{Cf}$. The Vassal Treaty of Esarhaddon with Ramataya, $A N E T, 538$, lines $425 \mathrm{ff}$., where the curse is that Ninurta would "give your flesh to eagles and vultures to feed upon," and lines 440ff. where Adad is asked to bring such famine that you would eat your own children, and, rather than grinding barley, they would "grind your bones" and the bones of "your sons and daughters."

173 Cf. also Numbers 26:10; cf. Deuteronomy 11:6; Psalm 69:15; Isaiah 5:14; 9:12; 34:6-7; Jeremiah 46:10, 20-21; 50:6f.; Ezekiel 34:28; Daniel 7:5; and Amos 3:12. 
intestines, so may they (the gods) let this oath enter your intestines and the intestines of your sons and daughters.... Just as [this?] honey is sweet, so may the blood of your women, your sons and daughters taste sweet in your mouths.... Just as (this) gall is bitter, so may you, your women, your sons and daughters be bitter to each other." 174

Within the Old Testament, the jealousy-ordeal in Numbers 5:11-31 (however one interprets the outcome for the woman) and the "anti-communion service" in Jeremiah 25:15 offer clear examples of explicit self-maledictory eating or drinking. ${ }^{175}$ Alternatively, perhaps the most controversial example of a plausible instance of a covenant-ratifying meal is that found in Exodus 24:11, "And he did not lay his hand on the chief men of the people of Israel; they beheld God, and ate and drank." M. G. Kline summarizes the ancient Near Eastern comparative evidence for eating and drinking as a self-maledictory oath-sign and asserts, "Israel's eating and drinking in the persons of her representatives on the mount of God (Exod. 24:11) was a recognized symbolic method by which people swore treaties."176 Other scholars, however, are less certain.

For example, D. J. McCarthy's central thesis in Treaty and Covenant is his claim that the Sinai pericope (Exodus 19-24), whether in whole or in any of its parts, does not exhibit the treaty pattern known from ancient Near Eastern parallels. According to McCarthy, the Sinai pericope in its original form lacks curses, oath taking, and an historical prologue, all expected from the treaty tradition. As a consequence in Exodus 19-24 we find a "ritual" as opposed to "verbal" covenant, which builds on Yahweh's theophany which is terrible enough (without historical appeals or sanctions) to arouse obedience to the divine will. According to McCarthy, then, in terms of that theophany the purpose of the covenantratifying meal in Exodus 24 was not an oath-pledge of obedience on the part of the people (as would be expected from the treaty pattern), but a gesture of comity to reassure a terrified people of the benevolence of the deity and to symbolize their acceptance into the family of God. Likewise, the sacrifices of communion effect a union between God and people. The blood sprinkled on the altar and people expresses the reality that Yahweh and his people share the same blood and are members of one family. ${ }^{177}$

174 ANET, 539f., lines 551ff.

175 Cf. M. Fishbane, "Accusations of Adultery, A Study of Law and Scribal Practice in Numbers 5:11-31" (1974) 24-45; H. C. Brichto, "The Case of the Sota and a Reconsideration of Biblical 'Law'" (1975) 55-70; G. J. Wenham, Numbers (1981) 79-85; P. J. Budd, Numbers (1984) 60-67; and T. FrymerKensky, "The Strange Case of the Suspected Sotah (Numbers v 11-31)" (1984) 11-26.

Cf. also Isaiah 51:17, 22; Zechariah 12:2; and Habakkuk 2:15.

176 M. G. Kline, op. cit., 116 .

177 Alternatively, noting that "eating and drinking in the presence of God cannot be understood as ipso facto the making of a covenant with God," E. Nicholson has urged that the meal in Exodus 24:11 need not be covenant making in any sense (God and His People, 126). Cf. also ibid, 121-133; 164-178.

Nicholson prefers to view this meal as an expression of their enjoyment of life, or the simple fact that they continued to live after their visio dei. In support of this interpretation of "eat and drink," Nicholson cites 1 Kings 4:20, Jeremiah 22:15, and Ecclesiastes 5:16. However, unlike the case of Exodus 24, none of these texts imply that the eating and drinking in question was of a shared meal nor that the meal was consumed in the presence of God. Furthermore, Nicholson's claim that Exodus 24:11 offers an instance of 
Without attempting to resolve the problematic source analysis of Exodus 24 or to address the related controversy regarding the history of the covenant concept in Israel's religion, we may note that in the present form of the text, the common meal in vs. 11 appears to presuppose the earlier sacrifices of vs. 5. Further, the text is explicit that this meal was eaten by Israel's representatives (Moses, Aaron, and the elders of Israel) in the presence of their God. As has been widely recognized, the confluence of these details closely parallels the common meal before God in Exodus 18:12 and, as such, may support their coherence in the present context. ${ }^{178}$ Following Israel's solemn affirmation "all that the Lord has spoken we will do, and we will be obedient," it appears likely that the meal in Exodus 24:11 served in the ratification of Yahweh's covenant with Israel. Whether it is preferable to view the underlying symbolism of this oath-sign exclusively in terms of its positive depiction of communion between Israel and Yahweh, as does D. J. McCarthy, or whether there may not also be a self-maledictory aspect for this meal and its antecedent sacrifices is less clear. 179

\subsection{The giving of a hand may function as an oath-sign by solemnly depicting the covenant commitment}

The gesture of giving one's hand in a handshake, נתן +7 , appears with possible covenant-making implication in 2 Kings 10:15; Jeremiah 50:15; Ezekiel 17:18;

Lamentations 5:6; Ezra 10:19; 1 Chronicles 29:24; and 2 Chronicles 30:8. ${ }^{180}$ In addition, it is possible that Psalm 144:8, 11, "whose right hand [ימינם'] is a right hand [ין ] falsehood," alludes not to the oath gesture of an upraised hand, as is often assumed, but to

parallelismus membrorum, where "they saw God" is balanced with "they ate and drank," is unconvincing (ibid., 131).

178 Further support may be offered by the frequent association elsewhere of a common meal shared in a covenant-making context accompanied by antecedent sacrifices (e.g., cf. Genesis 31:54 where the parties tarry on the mountain in a manner which resembles Exodus $24 ; 1$ Kings 1:9, 25; 1 Chronicles 29:22; 2 Chronicles 18:2).

179 D. J. McCarthy, Treaty and Covenant (1981) 294, n. 34. Alternatively, cf., e.g., M. G. Kline, By Oath Consigned, 18; idem, Treaty of the Great King, $15 \mathrm{f}$.

It is possible that McCarthy's analysis of Exodus 24 was influenced by the view of earlier scholars who hypothesized an evolution from covenant ratification through symbolic ritual, supposed to be a characteristic feature of second millennium treaties, to ratification by verbal oaths, supposed to be a characteristic feature of first millennium treaties (cf. I. J. Gelb, "Review of D. J. Wiseman, The VassalTreaties of Esarhaddon," 161-162; M. Weinfeld, "Deuteronomy -- The Present State of Inquiry," 225, n. 34). This supposed evolution has been rejected by more recent scholars. Cf., e.g., D. L. Magnetti, who argues that oath and ritual are, in fact, integrally connected in the earlier treaties, while rituals, even if less elaborate ones, continue to accompany oaths in the later treaties (op. cit., 106, n. 59).

180 In support of the covenant-making associations of this gesture in these texts, cf., e.g, J. W. Wevers, Ezekiel (1969) 106; D. Hillers, Lamentations (1972) 98; J. M. Myers, 2 Chronicles (1979) 175 (who cites in support, R. Kraetzchmar, Die Bundesvorstellung im Alten Testament, 47, and J. Wellhausen, Reste aräbischen Heidentums, 186); F. C. Fensham, The Books of Ezra and Nehemiah (1982) 143; R. L. Braun,,I Chronicles (1986) 285; and M. Cogan and H. Tadmor, II Kings (1988) 115. 
the gesture of "giving the right hand," that is, "shaking hands."181 Finally, there are a number of references to handshakes in extra-biblical texts and in ancient Near Eastern iconography which support the biblical evidence for the use of this gesture as a pact or covenant-making rite. 182

Perhaps the clearest biblical text, in its association between the gesture of giving the hand and covenant making, is Ezekiel 17:18: "Because he despised the oath and broke the

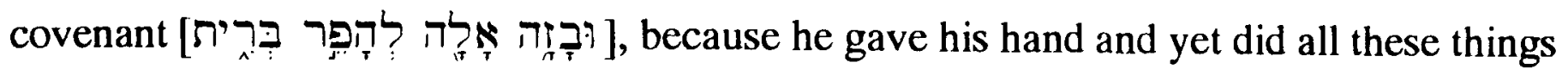

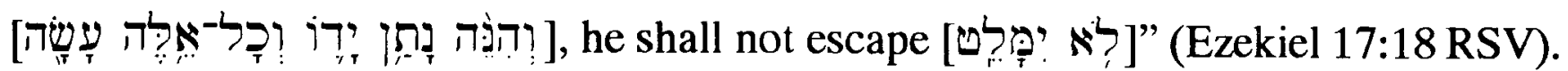

Kalluveettil writes with respect to this example, "There are two covenant-making acts in Ez 17,11-21: an oath (v. 13 wayyābe '’ 'ôtô be'älâ) sworn in the name of God (2 Chr 36,13) and the rite of nātan yād (v. 18) which was not merely a gesture of assent to the covenant terms, but a sign which effected the covenant relationship." 183 Kalluveettil offers the plausible suggestion that "the hand stands for the person"; as such, giving one's hand to another symbolizes the giving of oneself. 184

However, as mentioned earlier, Kalluveettil wishes to distinguish between rites or actions which "effect" or "constitute the covenant relationship, i.e., union" and any oath which merely makes the covenant binding and "gives it a sacred and inviolable character."185 As elsewhere, however, in the present case this distinction is not entirely convincing. This is so because there is no suggestion in vs. 18 that Yahweh considers the commitment symbolized in the offer of Zedekiah's hand to Nebuchadnezzar to be any less

181 So Keel, p. 96. The ancient Near Eastern iconographic evidence supports the assumption here that it was the right hand which was used for shaking hands (cf., e.g., Keel \#123, 96.).

Some scholars suggest that the gesture of "giving a hand" is the same as "striking hands" (עפים + כע ח $/ \varnothing / 7 ?)$, particularly as found in Proverbs $6: 1 ; 11: 15 ; 17: 18 ; 22: 26$; and Job 17:3. This is the view, for example, of Keel, p. 96, and C. H. Toy, Proverbs, 120. Against this, however, cf. Psalm 47:2 [ET 1] and Nahum 3:19, which suggest that "striking hands" consisted in clapping one's own hands (less probably in slapping the other person's hands), but not in a handshake [ = כפים + בכה, cf., e.g., 2 Kings 11:12].

182 The Akkadian expressions leqũm + qātâtim ("take hands"), nasāhum + qūāâtim ("remove hands"), and șabātum + qūtatim ("seize hands") all have to do with the assumption or repeal of suretyship and do not appear to be related to the handshake being considered here (cf. M. Malul, op. cit., 219-231).

On the other hand, the less well attested nadanu + qätu ("give the hand"), discussed by Kalluveettil, does appear to describe a similar gesture, possibly with similar significance, as its Hebrew cognate, פתן (op. cit., 21f.).

Kalluveettil also mentions a related Egyptian idiom, which appears in the Instruction of the Pharaoh Amenem-Het, "It was the eater of my food that made insurrection, I gave to him my two hands (rai'.n.i' n.f 'wy.i') and he produced terror" (op. cit., 22, n. 25). Kalluveettil suggests that the giving of hands "seems to be used here metonymically for the covenant-making itself." Cf. F. L. Griffith, "The Millingen Papyrus" (1896) 35-51. Cf. also Keel \#123, 96.

183 P. Kalluveettil, op. cit., 14.

$184 \mathrm{lbid} ., 21$, based on the gesture of "striking the hand," as in Proverbs 6:1; 11:15; 17:18; Job 17:3 (cf. Proverbs 22:26).

M. Malul prefers to interpret the hand as emblematic of a person's power (op. cit., 221, 225, and passim). This interpretation is reasonable in the contexts of concern to Malul, for example in the expression ana qâăäti $(m)$ nadánu $(m)$, "to give into the hands" (op. cit., 220). But in other contexts the hand appears to represent the person as a whole on the principle of pars pro toto. For example, compare the symbolism of washing one's hands to represent the cleansing of the whole person in Leviticus 5:11 and Job 9:30 (cf. 2 Samuel 22:21; Deuteronomy 21:6-7; Psalm 73:13).

185 Ibid., 10, with reference to the Abimelech - Abraham covenant. 
inviolable than the oath which Zedekiah despised. Indeed, contrary to Kalluveettil, vs. 18 seems to imply that the oath which Zedekiah had despised, resulting in the breach of the covenant, was one and the same as the gesture of giving his hand!

This interpretation becomes even more plausible if the protasis of vs. 18 begins with וְִ̣, as would be more typical in Biblical Hebrew and as it does in vs. 10, rather than

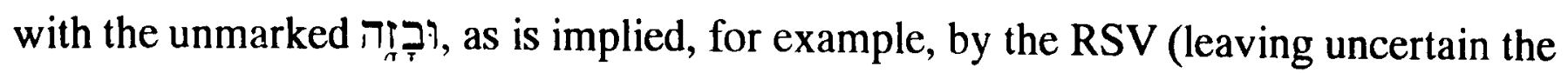

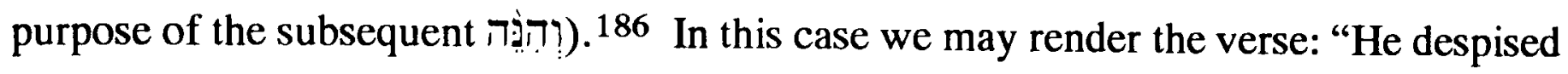
the oath by breaking the covenant [cf. the identical expression in 16:59]. If he gave his hand and (yet) did all these things, he shall not escape."187 The inexorable judgment which will overtake Zedekiah will come precisely because he "gave his hand," a gesture for which Yahweh intends to act as guarantor, and yet in violation of this he sought an alliance with Egypt. ${ }^{188}$ Given this context, not surprisingly M. Greenberg identifies the giving of the hand as "a gesture of promise and compact."189

\subsection{Other examples of symbolic acts which may function as oath-signs by solemnly depicting the covenant commitment}

There are a number of other symbolic acts, less frequently attested in the Old Testament, which may function as oath-signs by their solemn depiction of the covenant commitment. Included among these are the water libation mentioned in 1 Samuel 7:6 (cf.

186 Cf. D. J. McCarthy, "The Uses of $w$ ehinnēh in Biblical Hebrew," 336f.

187 This seems preferable to the rendering of M. Greenberg, who takes the ו? clause as concessive and parenthetical (Ezekiel 1-20,308). Greenberg translates: "He flouted the curse-oath to violate the covenant - although he gave his hand to it yet he did all these things! - he shall not escape!"

${ }^{188}$ Further confirmation for this suggestion may be offered if vs. 18 is read in the light of the literary structure of its context. As analyzed by M. Greenberg, Ezekiel 17 reveals a chiastic structure, A-B-B'-A', with each end member consisting of an extended allegory (Ezekiel 1-20, 317-324). The first allegory (vss. 1-10) begins describing an eagle who lops off the top of a cedar and later plants it. But the planting turns to another great eagle who transplants it. In this figure Ezekiel considers the activities of Nebuchadnezzar and Pharaoh Psammetichus II, the two eagles, with respect to Nebuchadnezzar's rebellious vassal, Zedekiah. The closing allegory (22-24) opens similarly, but rather than speaking of an eagle (representing a merely human agent), it speaks directly of Yahweh who personally lops off the top of the cedar and later himself plants and cultivates it. In this manner the prophet represents the promised restoration of his people. The change in focus from human agents to Yahweh evident in the allegories is likewise reflected in the two central interpretative sections. While the first B section (vss. 11-18) considers the role of Nebuchadnezzar and Psammetichus II, the second B section (vss. 9-21) attributes the impending judgment of Judah exclusively to Yahweh.

In terms of this structure, coming at the end of its section, vs. 18 summarizes Zedekiah's crime (12-15) and threatened punishment (16-17), repeating key terms which appear in the rhetorical question of vs. 15 and its answer in vs. 16:

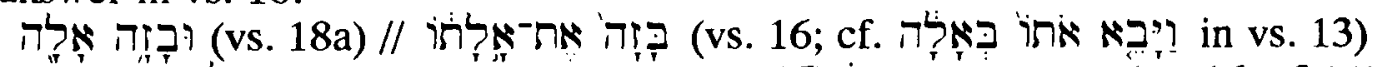

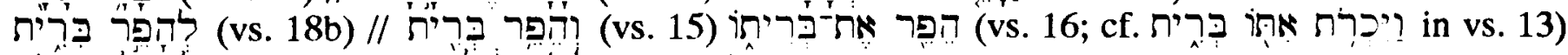

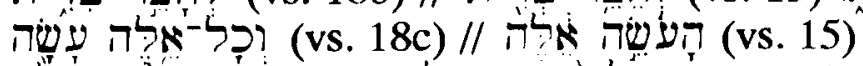

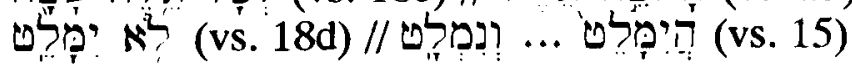

As a summary verse, so closely related to what precedes (particularly vss. 15-16), one should expect to find an appropriate antecedent for the gesture of "giving his hand" mentioned in vs. 18b which makes Zedekiah's perfidy so reprehensible and his judgment consequently inescapable. On the present interpretation that gesture was understood as the oath(-sign) by which Zedekiah became Nebuchadnezzar's vassal.

189 Ezekiel 1-20, 315. 
Isaiah 30:1 and also 2 Samuel 14:14 and Lamentations 2:19), 190 and especially the act of "taking hold of [the hem of] a garment," as in Zechariah 8:23.191 This latter gesture, and its converse of "letting go of the hem of a garment," or "cutting [the hem of] a garment," are well-attested in cuneiform sources. While not limited to covenant contexts, both these gestures appear with transparent significance in one of the stipulations of the treaty between Abba-AN of Yamkhad and Yarimlin of Alalakh: "If he lets go of the hem of Abba-AN's robe and takes hold of another king's robe, he [shall forfe]it his cities and territories."192 Such a covenantal implication in Zechariah 8:23 would comport with the more explicit perspective of Zechariah 2:15 [ET 11], "And many nations shall join themselves to the

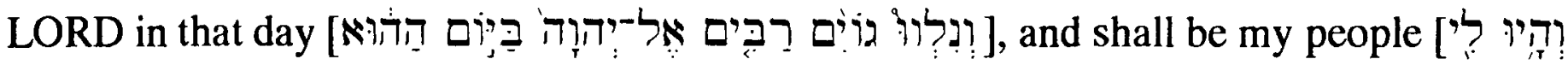
[ל : Samuel's garment in 1 Samuel 15:27. The unintended implication of this gesture seems to be that Saul had now expressed and sealed his rebellion against Samuel, and consequently against Yahweh whom Samuel represented. As Yarimlin of Alalakh would forfeit his kingdom as a vassal monarch should he "let go of the hem of Abba-AN's robe," so now Saul would forfeit his right to rule as Yahweh's vassal over the kingdom of Israel. ${ }^{194}$

\subsection{Summary}

We began this chapter by acknowledging a fundamental objection raised by $\mathrm{J}$. Milgrom and M. Greenberg against the identification of literal marriage as a "covenant

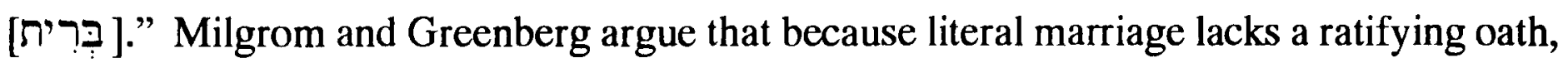
which is considered to be indispensable for any בְּרִ "covenant [דּרִּר] ]." Having argued in previous chapters, especially Chapter 2, that Malachi

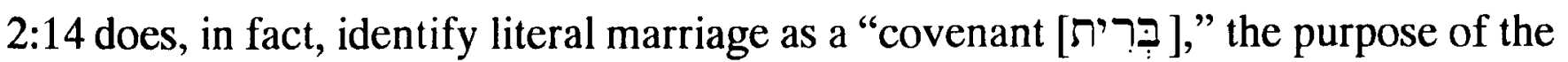
present chapter has been to respond to this important objection of Milgrom and Greenberg first by establishing the definition of the term בִּר indispensability of a ratifying oath, and then by examining more carefully the characteristics of covenant-ratifying oaths.

190 Cf. P. Kalluveettil, op. cit., 28.

191 Cf. R. A. Brauner, “'To Grasp the Hem' and 1 Samuel 15:27” (1974) 35-38; E. L. Greenstein, “'To grasp the Hem' in Ugaritic Literature" (1982) 217-218; H. Tadmor, "Treaty and Oath in the Ancient Near East: An Historian's Approach” (1982) 134; and M. Malul, Studies in Mesopotamian Legal Symbolism (1988) 422-431.

192 As translated in D. J. McCarthy, Treaty and Covenant (1981) 307.

193 For the theme of the eschatological ingrafting of the nations, cf., inter alia, Isaiah 66 and Psalm 87. For its partial realization in the post-exilic period, cf. Esther 8:17; and 9:27.

P. Kalluveettil adds as further support the observation that Abimelech likewise was motivated to conclude his covenant with Abraham and Isaac because of his conviction that "God/Yahweh is with you" (Genesis $21: 22 ; 26: 28$ ). Cf. also Joshua 2:9-11; 9:9-11.

$194 \mathrm{Cf}$. also 1 Samuel 24:5, 6, 12 [ET 4, 5, 11]. 
From our lexical study it was determined that the predominant sense of Biblical Hebrew is that of "an elected, as opposed to natural, relationship of obligation established under divine sanction." With the help of four "diagnostic" sentences it was argued that there are four essential ingredients in the Old Testament understanding of בִּרִ namely, 1) a relationship 2) with a non-relative 3) which involves obligations and 4) is established through an oath. Since the first three of these ingredients were seen to be clearly present in marriage, Milgrom and Greenberg have correctly focused scholarly attention on the fourth element.

Unfortunately, however, the attempt to determine if marriage possesses a ratifying oath has been hindered by two problems. First, there has been a tendency to seek evidence where it is unlikely to be found, as in the marriage contracts, which address various economic and other matters ancillary to the marriage itself and so should not be confused with the marriage covenant. 195 Second, there has been a tendency to reduce "oath" to verbal self-malediction. In response to this second, more serious defect, we have argued that an "oath" can be any solemn declaration or enactment (an "oath-sign") which invokes the deity to act against the one who would be false to an attendant commitment or affirmation. In particular, it was noted that oaths are often not self-maledictory and may consist simply of a solemn positive declaration (i.e., verba solemnia) or a solemn depiction of the commitment being undertaken (i.e., oath-signs such as sharing in a meal or the giving of a hand). 196

Having thus established the indispensability of a ratifying oath for בִּרִ in its normal sense, in agreement with Milgrom and Greenberg, and having elucidated the character of such oaths as often positive in their solemn articulation or depiction of the covenant commitment, in the following chapter we shall complete our answer to Milgrom's and Greenberg's objection as we attempt to discover if such an oath and/or oath-sign was employed in the case of biblical marriage.

195 Cf. $\$ 6.2 .1$ above.

196 Particular attention was given to these last two oath-signs, not only because of their intrinsic importance as examples of positively oriented oath-signs, but also because of manifest similarities which exist between these well-recognized oath-signs and the oath-sign to be posited for marriage in the next chapter. 


\section{Outline of Chapter 7: \\ Verba Solemnia and Sexual Union: The requisite covenant- ratifying oath and oath-sign for marriage}

7.1 Evidence for the use of a verbal oath (verba solemnia) in marriage................. 234

7.1.1 Ancient Near Eastern parallels ........................................ 234

7.1.1.1 An Old Babylonian legal document from Ishchali..............235

7.1.1.2 Old Babylonian literary texts.............................. 236

7.1.1.3 Declaration formulae in marriage may be inferred from the widely attested use of corresponding divorce formulae..........237

7.1.1.4 Middle Assyrian verba solemnia ............................ 240

7.1.1.5 Old Babylonian magical texts................................. 241

7.1.2 Extrabiblical evidence for the use of verba solemnia among Israelites and Jews......................................................... 243

7.1.2.1 Elephantine............................................... 243

7.1.2.2 Five second century A.D. marriage documents from Wadi Murabba'at ................................................ 246

7.1.2.3 Talmudic evidence ..................................... 247

7.1 .3 Biblical texts.................................................. 248

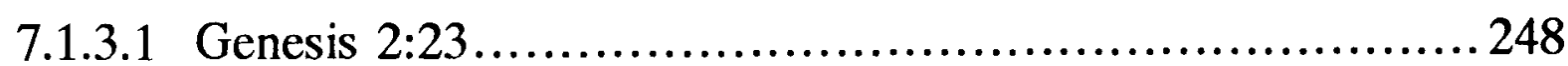

7.1.3.2 Hosea $2: 4[$ ET 2] .................................... 248

7.1.3.3 Hosea 2:17-19 [ET 15-17] ............................. 251

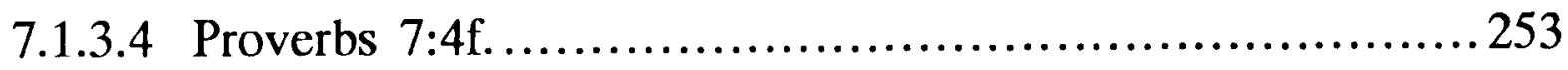

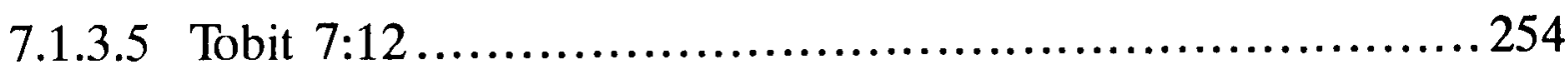

7.1.4 Further biblical texts, or expressions, which may allude to the marriage formula.............................................. 255

7.1 .5 Conclusions ..................................................... 256

7.2 Evidence suggesting that sexual union may be the requisite covenant-ratifying

(and renewing) oath-sign for marriage................................. 257

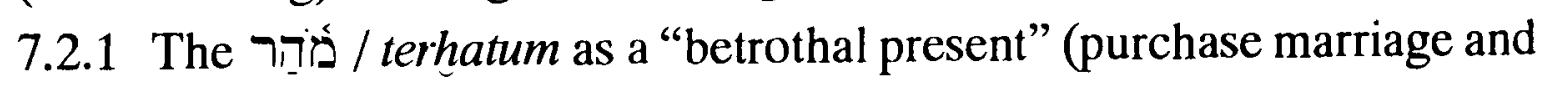

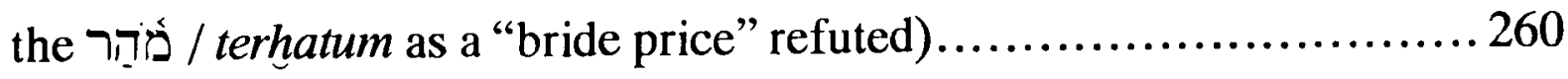

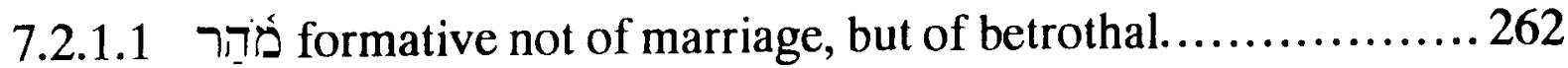

7.2 .2 Sexual Union.................................................... 264

7.2.2.1 Ancient Near Eastern evidence for the role of sexual union in the consummation of marriage 
7.2.2.2 Biblical evidence for the formation of marriage by sexual union .................................................... 265

7.2.2.2.1 Deuteronomy $21: 10-14 \ldots \ldots \ldots \ldots \ldots \ldots . . \ldots 265$

7.2.2.2.2 Deuteronomy $25: 5 \ldots \ldots \ldots \ldots \ldots \ldots \ldots . . . . . . .266$

7.2.2.2.3 Genesis 38:8, 18.......................266

7.2.2.2.4 Genesis 29:21-28.......................... 267

7.2.2.2.5 The legal implications of "premarital" sex ..... 267

Exodus $22: 15,16$ [ET 16, 17] ...............268

Deuteronomy $22: 28,29 . \ldots \ldots \ldots \ldots \ldots \ldots \ldots . . . . .271$

Genesis 34 and 2 Samuel 13:16 ...............276

7.2.2.3 The obligatory nature of sexual union for the consummation of marriage ............................................ 277

7.2.2.4 Instances of synecdoche by which the consummation of marriage is effectively identified with sexual union ..............2279

7.2.2.5 E. Neufeld's view of "בִיָָה Marriage" rejected................ 280

7.2.2.6 Consequences of the inherently private nature of sexual union 281

7.2.3 Sexual union meets the conditions expected of an oath-sign and, as such, resembles other covenant-ratifying oath-signs 281

7.2.4 The covenantal implication of referring to sexual union with the verb ע

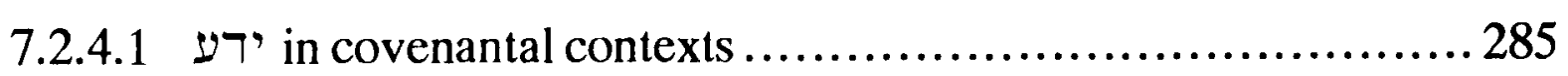

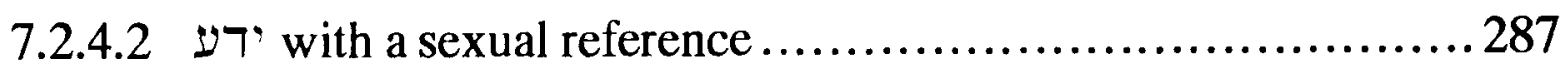

7.2.4.3 The principal biblical texts which support an identification of sexual union as a covenant-ratifying oath sign............... 289

7.2.4.3.1 Hosea 2:22 [ET 20] ...................... 289

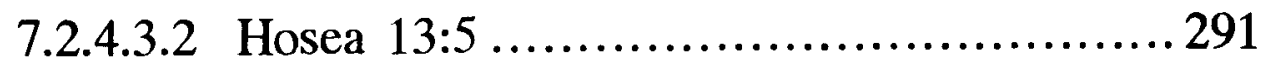

7.2.4.3.3 Hosea $5: 3-4 \ldots \ldots \ldots \ldots \ldots \ldots \ldots \ldots . . . . . . . .292$

7.2.4.3.4 Jeremiah $31: 34 \ldots \ldots \ldots \ldots \ldots \ldots \ldots \ldots \ldots . \ldots . \ldots . \ldots . \ldots 29$

7.3 Conclusions 293 


\section{Chapter 7: \\ Verba Solemnia and Sexual Union: The requisite covenant- ratifying oath and oath-sign for marriage}

In the previous chapter it was argued that for marriage to constitute a בִִִּ in in its normal sense it must be accompanied by a ratifying oath and/or oath-sign. In the course of investigating the precise characteristics of such oaths and oath-signs, it was noted that while some are explicitly self-maledictory (though the self-malediction is frequently truncated), many others are only implicitly so in that they function by invoking the deity merely by a solemn declaration or depiction of the commitment being undertaken.

The present chapter will seek first to demonstrate that during the Old Testament period verba solemnia were typically employed as the requisite covenant-ratifying oath for marriage. Second, evidence will be offered that sexual union likewise functioned as a mandatory covenant-ratifying oath-sign for marriage. It will be recalled how ancient covenants were frequently ratified by an accumulation of oath(s) and oath-sign(s). In the present case, because of the necessarily private, though no less binding, nature of sexual union as an oath-sign, the complementary verba solemnia were especially appropriate as they offer essential public evidence of the solemnization of a marriage.

\subsection{Evidence for the use of a verbal oath (verba solemnia) in marriage}

Given that no Old Testament text expressly stipulates the use of declaration formulae in marriage, it is, of course, impossible to be certain that any such formulae accompanied or were expected to accompany Israelite marriages. Nevertheless, there are a number of arguments which in their cumulative weight render it highly probable that verba solemnia were in fact normally employed in Israelite marriage. We shall consider each of these arguments in turn, beginning with the extra-biblical comparative evidence first from ancient Near Eastern texts preceding or contemporary with the Old Testament and then from Jewish texts later than the Old Testament. Finally, we shall consider evidence within the Old Testament itself.

\subsubsection{Ancient Near Eastern parallels}

Although the cuneiform legal corpora of the Old Babylonian period nowhere stipulate the use of verba solemnia for marriage in the OB period, nevertheless in his classic essay, "The Old Babylonian Marriage Contract," S. Greengus argued that verba solemnia 
were so employed. ${ }^{1}$ Greengus based his argument mainly on the following: 1) a document recording a litigation, 2) scattered references in various $O B$ literary sources, 3) the implication of the better attested corresponding divorce formulae, 4) evidence from later periods (especially MAL A $\$ 41$ ), and finally 5) an OB magical text. ${ }^{2}$ Given the wide scholarly acceptance of Greengus' view on this matter, it would be enough merely to cite his classic defence were it not for the fact that recently it has received a detailed critique by R. Westbrook in his comprehensive study of Old Babylonian marriage law. ${ }^{3}$ As a result, it is necessary to reevaluate Greengus' evidence in the light of Westbrook's criticisms.

\subsubsection{An Old Babylonian legal document from Ishchali}

One OB legal document from Ishchali includes the positive formula, "You are my husband [muti atta]."4 However, with Greengus, it is clear that this text does not record the actual verba solemnia of a marriage. This is the case because the text refers to the results of a litigation which stipulated the dissolution of a marriage, or perhaps an engagement, between Abu-tabum and Sin-nada, that is, a kallutum-relationship (so Westbrook). The result of the court's decision is that a fine is imposed on Sin-nada (which was paid to the father, or perhaps owner, of Abu-tabum) and "the hem of Sin-nada is cut [si-si-iq-tipdEN.ZU-na-da ba-at-qá-at]." 5 Further, it is stipulated that Abu-tabum cannot "raise claims against Sin-nada in respect to her being a wife. Sin-nada shall not say to Abutabum, 'you are my husband [muti atta]"” (Ins. 19-24).

If "you are my husband" were understood as referring to the verba solemnia of marriage, this text would prevent Sin-nada from marrying Abu-tabum against his will and in spite of the dissolution of their previous relationship. ${ }^{6}$ Any such concern seems

1 S. Greengus, "The Old Babylonian Marriage Contract" (1969) 514ff.

For earlier scholars holding a similar view, cf., inter alios, G. R. Driver and J. C. Miles, The Babylonian Laws, I (1952) 402, n. 2; and A. J. Skaist, "Studies in Ancient Mesopotamian Family Law Pertaining to Marriage and Divorce" (1963) 124.

2 For convenience, these evidences are listed here in an order which differs slightly from that found in Greengus. To these Mesopotamian examples could be added further evidence from Egypt. In Egyptian marriage contracts there is ample documentation for the use of the following marriage declaration formulae (Eheschliessungsklausel): “The woman has said to the man: 'You have made me your wife.' The man has said to the woman, 'I have made you my wife."' Cf. P. W. Pestman, Marriage and Matrimonial Property in Ancient Egypt (1961) diagram A par. 12-15; diagram B par 11-12.

3 R. Westbrook, "Old Babylonian Marriage Law" (1982) 120-125.

4 S. Greengus, Old Babylonian Tablets from Ishchali and Vicinity (1979) 25. S. Greengus refers to this text as A 7757 prior to its publication ("The Old Babylonian Marriage Contract," 517, n. 57).

Cf. the more recent edition of this text in R. Westbrook, "Old Babylonian Marriage Law," I, 193-195, with relevant discussion in $\mathrm{II}, 121 \mathrm{f}$.

5 Or "the hem of Sin-nada has been cut." For such a rendering of the I/1 Stative batqat, cf. J Huehnergard, An Introduction to Old Babylonian Akkadian, \$18.2.

For a recent study of this well-attested symbolic act employed in Old Babylonian and Nuzi documents to effect a divorce, cf. M. Malul, Studies in Mesopotamian Legal Symbolism, 197-208. Cf. also the discussion of other examples of this action used outside the context of divorce in ibid., 153-159, 196-198. Cf. also S. Greengus, "The Old Babylonian Marriage Contract," 515, n. 44.

6 So R. Westbrook, "Old Babylonian Marriage Law," II, $121 \mathrm{f}$. 
doubtful. Accordingly, the prohibited declaration, "you are my husband," must be understood as some kind of formal legal claim on the part of the woman that her marriage (or perhaps her inchoate marriage) still exists. Nevertheless, Greengus suggests that the wife's prohibited words "could be patterned after the marriage formulas: lū mutī attā or attā lū mutima."7

R. Westbrook objects to Greengus' suggestion, noting that the present formula bears an "entirely different" function from that required for the verba solemnia of marriage, and therefore denies any necessary resemblance between this declaration and that which is posited for marriage. 8 In response to Westbrook, however, perhaps an "entirely [italics added] different" function overstates the case. The primary legal function of the posited verba solemnia is, to be sure, the formation of a marriage. Nevertheless, a declaration such as "you are my husband," which formally asserts the existence of a relationship, is not so far from the solemn acknowledgement of a relationship, that is, a "Bundesformel," which carries with it implications of consent and commitment. With Westbrook, however, it appears likely that the hypothesized formulae, $l \bar{u}$ muti attā or attā lù mutīma, "surely you are my husband,"9 fail to take sufficient account of the differing contexts of these legal declarations. If, however, the posited reflex for the wife's formal claim, "you are my husband," is the husband's prior verba solemnia, "I am your husband ${ }^{10}$ [lü anāku mutka]," then Westbrook's objection is answered.

\subsubsection{Old Babylonian literary texts}

Other texts cited by Greengus for the OB period include a few lines of the Assyrian version of the Gilgameš Epic, where Ištar proposes to Gilgameš, "Come Gilgameš, be thou my (var. an) espouser (var. groom); give me thy charms for a gift; be thou my husband, I will be thy wife," (vi 7-9) and a similar text in the myth of Nergal and Ereshkigal, where the queen of the underworld proposes to Nergal, "You be my husband, I will be thy wife.... Be thou master, I will be mistress" (EA 375, lns. 82-85). ${ }^{11}$ As R. Westbrook notes, however, since each of these texts records a proposal for marriage, rather than discourse from the marriage itself, their value as evidence for the posited verba solemnia of marriage is greatly diminished. 12

7 “The Old Babylonian Marriage Contract," 517, n. 57.

8 “Old Babylonian Marriage Law," II, 181, n. 8.

9 Or "may you be my husband."

10 Or "may I be your husband." In this case, greater semantic congruence is to be preferred over the greater lexical similarity afforded by Greengus' proposal.

11 "The Old Babylonian Marriage Contract," 516f. (cf. especially n. 55 and n. 56 for additional examples).

12 “Old Babylonian Marriage Law," II, 122. 


\subsubsection{Declaration formulae in marriage may be inferred from the widely attested use of corresponding divorce formulae}

A further evidence in favour of the assumption of the use of verba solemnia in the formation of marriage, noted by S. Greengus, is the well-attested counterpart verba solemnia of divorce or the disavowal of marriage: "you are not my wife"13 and "you are not my husband,"14 attested in the OB period; and "she / fPN is not my wife,"15 "he is not my husband,"16 and "I will not be your wife,"17 attested for later periods. If such solemn declarations were required to dissolve marriage, it seems a reasonable inference that corresponding positive statements may have been used for the formation of marriage.

This inference of a close reciprocal relationship between formulae for marriage and divorce is further strengthened by the analogous counterpart formulae for adoption, or the legitimating of children, and the repudiation of the adoptive relationship, or disinherison. As in the case of marriage, the positive formulae are poorly attested, though still probable. ${ }^{18}$ Compare, for example, the declaration formula, "my children [mârü'a]!," mentioned in $\mathrm{CH} \$ \$ 170-171$, by which a man legitimates his natural children born by a slave. The corresponding repudiation formulae, however, appear frequently. ${ }^{19}$ Compare,

13 Cf. ana ittišu A §6, "If a husband says to his wife, 'You are not my wife’ [ul aššati atta], he shall pay 1/2 mina of silver by weight" (G. R. Driver and J. C. Miles, The Babylonian Laws, II, $310 \mathrm{f}$.).

As just one example, cf. the use of this formula in the OB marriage document $C T$ 48:50, "You are not my wife [ul aššati atti]." For other examples, cf., e.g., M. Schorr, Urkunden des Altbabylonischen Zivilund Prozessrechts (1913) p. 7, no. 2, and passim; A. T. Clay, Babylonian Records in the Library of J. Pierpont Morgan, Part IV (1923) 50-52, text 52; R. Harris, "The Case of Three Babylonian Marriage Contracts" (1974) 363-365; and R. Westbrook, "Old Babylonian Marriage Law," II, 192f. For Sumerian parallels, cf. A. Poebel, Babylonian Legal and Business Documents (1909) 35-38.

14 Cf. ana ittǐ̌ A \$5, "If a wife has hated her husband says, 'You are not my husband' [ul muti atta], they shall throw her into the river" (G. R. Driver and J. C. Miles, The Babylonian Laws, II, 310f.). For example, cf. the use of this formula in the OB marriage document $C T 48: 50$, "You are not my husband [ul mutī attā]." For other examples, cf. the sources cited in the previous note.

15 Cf. document No. 5 in M. T. Roth, Babylonian Marriage Agreements 7th-3rd Centuries B.C., 4447 , discussed below. Roth considers the use the third person divorce formula, "W is not my wife," to be "the most obvious difference between the OB formulation and that found in No. 5" (op. cit., 13).

Similarly, Kraeling 7 (= Porten-Yardeni, B3.8) lines 21-22, "Tomorrow or (the) next day, should Ananiah stand up in an assembly and say: 'I hated my wife Jehoishma; she shall not be my wife [א תהוה חל, ל, '..."

16 Cf. also S. Greengus, "A Textbook case of Adultery in Ancient Mesopotamia” (1969-70) 40ff.; and idem, "The Old Babylonian Marriage Contract" (1969) 516ff. Cf. the MB marriage contract from Hana in A. T. Clay, Babylonian Records in the Library of J. Pierpont Morgan, Part IV (1923) 4, no. 52, 50-52; and a MA marriage document, TIM IV, 45.

17 Kraeling 7 (= Porten-Yardeni, B3.8) lines 24-25, "And if Jehoishm[a] hate [sic] her husband Ananiah and say to him: "I hated you; I will not be your wife [לא אהוה לך אנתח]' ...."

18 Cf. also Psalm 2:7, a text which is generally thought to include verba solemnia for adoption: "I will tell of the decree of the LORD: He said to me, "You are my son, today I have begotten you." Cf. also the corresponding acknowledgement by David in Psalm 89:27, "You are my Father."

Cf. H. -J. Boecker, "Anmerkungen zur Adoption im AT" (1974) 86-89; S. M. Paul, “Adoption Formulae" (1978) 31-36; idem, "Adoption Formulae: A Study of Cuneiform and Biblical Legal Clauses" (1979-1980) 173-85; H. J. Hendriks, "Juridical Aspects of the Marriage Metaphor in Hosea and Jeremiah," 61; and M. Malul, "Adoption of Foundlings in the Bible and Mesopotamian Documents" (1990) 99, $111 \mathrm{f}$.

Rejecting this interpretation is H. Donner, “Adoption oder Legitimation?" (1969) 87-119. Against Donner, however, cf. H. J. Hendriks, op. cit., 61f.

19 Cf. the many examples cited by Greengus, "The Old Babylonian Marriage Contract," 518, n. 60. 
for example, "you are not my father [ul abi atta]" and "you are not my mother [ul ummi atti]," found in $\mathrm{CH} \$ 192.20$ Compare also the declaration, "you are not my son [ul mâri atta]," mentioned in tablets of adoption cited by G. R. Driver and J. C. Miles. ${ }^{21}$ Compare further the disinherison formulae used with natural children: "you are not our son" and "[PN] is not my son." 22

Finally, it should be noted that the relative rarity of positive verba solemnia, whether for marriage or for adoption, by contrast to their negative counterparts, is only to be expected considering the nature of the extant sources. In the case of marriage, for example, the majority of marriage documents were drafted upon completion of the marriage and often, as noted in the previous chapter, even after the birth of children. As such, their interest is typically with economic and other issues ancillary to the marriage itself. As a result, they reveal little about any words, verba solemnia or otherwise, or any other ceremony, for that matter, which may have been formative of the marriage itself, though some such words or rite, or both, are likely to have existed.

In the same manner, the silence of the legal corpora concerning the hypothesized verba solemnia for marriage is quite expected. As also argued in the previous chapter, the legal corpora are typically concerned with the exceptional and the difficult, such as issues surrounding adultery, desertion, the dissolution of marriage, or inheritance under special circumstances, etc., not with what was normal or could be assumed, such as would be the case with verba solemnia, if these were employed in the manner argued by Greengus.

Although R. Westbrook argues for a profound similarity between marriage and adoption, nevertheless he questions whether Greengus' critical example of the positive use of verba solemnia recorded in $\mathrm{CH} \S \S 170-171$ is applicable beyond the very limited circumstances envisaged in this law. ${ }^{23}$ If Westbrook is correct that verba solemnia may not

$20 \mathrm{Cf}$. also ana ittǐ̌ A $\S 1$, which appears to refer to a natural son, "If a son says to his father, 'You are not my father,' [ul abi atta] he may/will shave him, he may/will put a slave-mark on him [and] sell him" (G. R. Driver and J. C. Miles, The Babylonian Laws, II, 308f.). Cf. also ana ittisu A $\$ 2$ and SL $\$ 4$ (in $A N E T, 526$ ).

$A R N$ 36, ln. 3 and $B E 6 / 159$ offer important evidence that these examples of verba solemnia were actually recited in a public (court-room) setting. Cf. S. Greengus, op. cit., 518.

21 The Babylonian Laws, I, 402f.

Cf. ana ittišu A §3, which appears to refer to a natural son, "If a father says to his son, 'You are not my son,' [ul mâri atta], he forfeits house and wall" (G. R. Driver and J. C. Miles, The Babylonian Laws, II, 308f.). Cf. also, ana ittisu A §4, “If a mother says to her son, 'You are not my son,' she forfeits house and furniture" (G. R. Driver and J. C. Miles, The Babylonian Laws, II, 310f.).

Cf. also SL \$\$5-6, which has the father and mother saying, "You are not our son" (ANET, 526).

22 Cf. $B E 6 / 2$, p. 31, text 57; and HSS 19, 27, discussed by M. Malul, Studies in Mesopotamian Legal Symbolism, 85. Underscoring the possible primacy of symbolic actions over declaration formulae, the document goes on to specify that "from [this] day I have broken his clod [...PN] is no more my s[on!]" Cf. also ibid., 88.

23 R. Westbrook, “Old Babylonian Marriage Law," II, 123f.

In the "Abstract" for his dissertation, R. Westbrook writes, "The central thesis of the dissertation is that marriage is a legal status and must be distinguished from the marriage contract which is incidental thereto. Marriage should therefore be compared to other forms of status such as adoption rather than to forms of contract" ("Old Babylonian Marriage Law"). Cf. also op. cit., II, 56f., 149-152. 
have been employed in adoption more generally, then the assumed reciprocal relationship between "my children!" and the repudiation formulae, "you are not my son," etc., evaporates. Westbrook agrees that $\mathrm{CH} \$ \$ 170-171$ demonstrates that verba solemnia could be constitutive of a legal relationship in OB law and, therefore, that it is possible that they were so employed in the formation of marriage as well. Nevertheless, Westbrook insists that a stricter analogy with $\mathrm{CH} \S \$ 170-171$ at most allows the inference that verba solemnia may have been so employed only in the case of the elevation to the legal status of "wife" of a woman who was already de facto wife, i.e. a concubine. 24

In response to Westbrook, however, it is doubtful whether the use of the verba solemnia, "my children," found in $\mathrm{CH} \S \S 170-171$, was as restricted as he suggests. Indeed, if these verba solemnia were not more generally employed to effect adoptions elsewhere, one would be left to wonder about their origin within this law. Why use verba solemnia at all, rather than some other rite invented solely for the purpose? Without the assumption of the more normal usage, would contemporaries have understood a father's intention under these particular circumstances?

It should be recalled that the purpose of $\mathrm{CH} \$ \$ 170-171$ is not to introduce a novel procedure for legitimation, but merely to establish the rights of inheritance by the lcgitimated sons born to a concubine (or to deny the same if the natural sons by the concubine were not so legitimated). Further, as noted by M. David and G. R. Driver and J. C. Miles, this more general use of verba solemnia appears to be implied by a legal text in which a mother surrenders her son for adoption saying, "Take the lad away; surely (he is) thy son [tabli șuhāram lâ mâruki]."25

Finally, M. T. Roth discusses a very impressive example of the reciprocal relationship between the verba solemnia of marriage and divorce, which is found in a NeoBabylonian marriage document (No. 5). ${ }^{26}$ In Ins. 9-10 the positive declaration is made: "fBazītu is the wife of Qul-dibbīja-ile'i-Nusku [fba-zi-tum al-ti I qul-dib-bi-ia-DA-dNusku

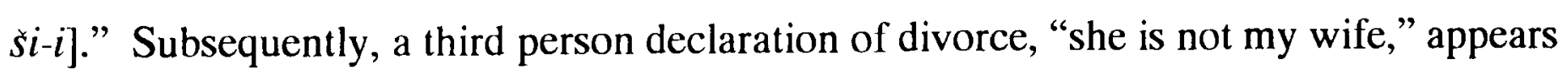
in Ins. 12-16: "Should Qul-dibbīja-ile'i-Nusku declare: ' ${ }^{\mathrm{fBaz}} \mathrm{t}$ tu is not a wife [fba-zi-tum ul $a \breve{s}$-ša-tum ši-i],' Sîn-ahhēe-iddin will give to fBazītu six minas of silver as her divorce settlement, and send her back to her (father's) house." Roth observes, "The renunciation of marriage in No. $5[W u l$ ašsatu š̂l $]$ is a direct negation of the statement made earlier in the

24 Of course, this is precisely the case envisaged in MAL A $\$ 41$.

25 M. Schorr, Urkunden des altbabylonischen Zivil- und Prozessrechts Vorderasiatische Bibliothek, 5 , 78:10-11. Similar is VAT 8946:6-7, " $\mathrm{PN}_{1}$ is her father and $\mathrm{PN}_{2}$ is his daughter." Cf. P. Kalluveettil, op. cit., 109.

Accordingly, M. David has argued in favour of the assumption of the use of verba solemnia for adoption under normal circumstances (Die Adoption im altbabylonischen Recht [1927] 79-81). Cf. G. R. Driver and J. C. Miles, Babylonian Laws, I, 401f.

26 Babylonian Marriage Agreements 7th-3rd Centuries B.C., 13, 44-47. 
document in connection with the formation of the marriage: Walti $H s \hat{\imath}, \mathrm{W}$ is the wife of H.'"27

\subsubsection{Middle Assyrian verba solemnia}

Certainly the clearest evidence for the mandatory use of marriage-forming verba solemnia in Mesopotamia is found in MAL A $\$ 41$. This law concerns itself with a man who has a captive wife, an esirtu. ${ }^{28}$ If such a man wishes to confer on his esirtu the higher status of a "wife" [aššat a'ili] or "veiled wife" [aššatu pașșuntu], thereby conferring full rights of inheritance to any children of their union, he must "assemble five or six of his neighbours and he shall veil her [cf. MAL A §40] in their presence and say, 'she is my wife.' Then she will be his wife" [hamšat šeššat tappā'ēšu ušeššab ana pânīšnu upașșanši ma aššiti š̃t iqabbi aššassu š̃t $].{ }^{29}$ The specification of witnesses helps underscore the solemn and binding character of this pronouncement.

According to Greengus, similar formulae are attested in a number of NeoBabylonian sources as well. ${ }^{30}$ For example, Greengus cites Strassmaier Liverpool 8:6, "may she be my wife [lu-ú aš-ša-ti ši-i]]" and VS 6 6:3f., "may she be my wife [lu-ú DAM$a s ̌ i-i]$." The apparent one-sidedness of these declaration formulae may be merely conventional. S. Greengus notes, for example, the remarkable mutuality exhibited in TIM IV 45:1-9:31

PN ū fPN ina migratî̌sunu mutūtu $\bar{u}$ aššutūta idbubū PN mussa ū fPN aššassu ina eqli ù libbi ā[lim] palāha ahu a[ha] ippušu

"PN and fPN of their own accord agreed to marriage; PN is her husband; fPN is his wife. They shall show respect to one another at home and abroad."

R. Westbrook, however, argues that the formation of marriage by verba solemnia attested in MAL A $\$ 41$ cannot be extended beyond the vary narrow circumstance envisaged in this law, namely the elevation to the status of "wife" of an esirtu who is already de facto wife. ${ }^{32}$ Westbrook argues that since the woman in question was already living in her husband's house, neither in domum deductio nor copula carnalis could serve the desired

27 Ibid., 13.

28 Although "concubine" is commonly offered for esirtu $(C A D, \mathrm{E}, 336)$, because of the inappropriate connotations of the English term "concubine," perhaps the rendering "slave-wife" or "captive-wife" would be more felicitous.

29 Cf. G. R. Driver and J. C. Miles, The Assyrian Laws, 186-189.

P. Kalluveettil notes that in most cases the superior party utters the "Bundesformel" (op. cit., 213). It is possible, however, that the androcentricity of this law is exceptional or merely conventional and that in actual practice brides also pronounced corresponding verba solemnia. After noting the declaration formula of the bride Ereskigal in $E A$ 357:84f., "Be thou master, I will be mistress," S. Greengus concludes, "We see therefore that the patriarchal character of Babylonian family structure, even with possible legal subordination of its women, need not preclude brides from participating in the formation of the marriage contract via recitation of verba solemnia" ("The Old Babylonian Marriage Contract," 521).

30 "The Old Babylonian Marriage Contract," 516, n. 48.

31 Op. cit., 521, n. 75 . The normalization is from Greengus.

32 Old Babylonian Marriage Law, II, 125. 
purpose of granting her the full legal status of "wife." Accordingly, "the pronouncement of verba solemnia before witnesses would certainly be among the most appropriate modes." 33 Rejecting in this manner a broader application for MAL A $\$ 41, \mathrm{R}$. Westbrook summarizes his critique: “Accordingly, while we must reject for lack of evidence Greengus' theory of verba solemnia for the formation of marriage in general, it seems to us an acceptable hypothesis in the very narrow case of the subsequent marriage of one's own concubine."34

Just as in the case of the use of verba solemnia in adoption, however, it appears doubtful that MAL A $\$ 41$ intends to introduce an entirely novel mode for the formation of marriage. On the contrary, the fact that this law specifies the procedure for elevating an esirtu-wife, rather than for taking a wife under more normal circumstances, in many respects only increases its value as evidence for the general use of the declaration formula, "she is my wife" [ašsiti š̃ $t$. Had the law treated marriage under entirely unremarkable circumstances, the stipulation of a declaration formula would raise the question of whether it may represent a (perhaps unsuccessful) legal innovation. ${ }^{35}$

\subsubsection{Old Babylonian magical texts}

Of the OB texts the first and clearest example cited by S. Greengus is "the etlu tablet," a much discussed bilingual magical text, originally published by T. G. Pinches, but re-edited more recently by S. Lackenbacher. ${ }^{36}$ In this text betrothal is used as a metaphor for demon possession, which metaphor is well-attested elsewhere. ${ }^{37}$ In the course of the "marriage" the following apparent verba solemnia are spoken by the demon to the young man [the $e t l u$ ], who assumes the role of bride-victim: ${ }^{38}$

11. dumu-nun-na gá-e-me-en ba-ni-in-du 11 // ma-ri ru-bi-e a-na-ku iq-bi-iš

12. guškin kù-babbar úr-zu ba-ni-in-si // KÙ.BABBAR GUSKKIN su-un-ka ú-ma-lu

13. dam-mu hé-me-en // at-ta ${ }^{39}$ lu-ú aš-ša-tú

33 Based on an analogy drawn from $\mathrm{CH} \$ 170$, Westbrook is prepared to allow the provision of MAL A $\$ 41$ to apply to the OB period.

34 Old Babylonian Marriage Law, II, 125.

35 As we discussed in $§ 5.2 .1$ above, cuneiform law is predominantly concerned with the unusual and difficult, not with what could be assumed.

The special circumstances of this law may help to account for the absence of any specification of a marriage contract (cf. MAL A $\$ \$ 34,36$ ) or marriage present, etc.

36 T. G. Pinches, "Notes" (1892-93); S. Lackenbacher, "Note sur l'ardat-lili" (1971) 124ff.

For the history of interpretation of this text, cf. S. Greengus, "The Old Babylonian Marriage Contract," 516, n. 53. For a more recent discussion, cf. M. Malul, Studies in Mesopotamian Legal Symbolism, 127, $171 \mathrm{f} ., 173$, n. 55 and $182 \mathrm{ff}$.

37 Cf. CAD H, s.v. hâru. Cf. also S. Greengus, "The Old Babylonian Marriage Contract," 516.

38 Lackenbacher $(R A-65,126)$ Text No. 1, col II, Ins. 11-15.

$39 \mathrm{~S}$. Greengus is troubled by the unexpected masculine atta in place of feminine atta and, similarly, the masculine - $k a$ in place of the expected feminine - $k i$ ("The Old Babylonian Marriage Contract," 516, $\mathrm{n}$. 51). He suggests this may reflect Aramaic influence where the final vowels of some forms became indistinguishable. Cf. $G A G, \S 13$ b-c.

However, this difficulty disappears if, with M. Malul, the etlu is the victim who is espoused by the unnamed demon (op. cit., 171f., n. 49). This interpretation seems preferable to Lackenbacher's view that the etlu has been transformed into a demon on an analogy with the ardat lili described in text no. 2 (the ardat 
14. gá-e dam-zu hé-a // ana-ku lu-ú mu-ut-ka

15. mu-un-na-ab-bé // iq-bi-ši

"'I am of princely descent' he said to her; 'thy lap I will fill with silver and gold; you be my (!) wife, I will be thy husband' - he said to her."40

Supporting the interpretation of this text, the reverse of the etlu tablet, col. I, Ins. 1ff., refers to a ritual for delivering the etlu from his demonic possession and so curing him of a demonically induced illness. The text prescribes a symbolic "marriage" between a piglet and a sickness-figurine in which the god Šamaš acts as witness. ${ }^{41}$ Deliverance from the demon is accomplished, apparently, by tricking the demon to leave its victim in order to marry the figurine instead. Although verba solemnia are not explicitly mentioned in this second marriage, their presence may be inferred from the intended parallel between this "marriage" and the earlier one, a parallel which is reinforced by the shared mention of the well-attested marriage rite of tying a purse of gold and silver into the hem of the bride. 42 The fact that the god Samaš acts as witness to this procedure, and hence, to its accompanying solemn declarations, supports the interpretation of the recitation of such words as verba solemnia.

A second bilingual magical text, the ardat lili tablet, unavailable to Greengus, appears to offer a close parallel to the etlu tablet, including the mention of the indicated verba solemnia. As reconstructed by Lackenbacher, the text of rev. col. II, Ins 1-6 reads:
1. [
2. [
// lu-u mu-ut-ka a]na-ku
3. 1
// lu-u áššsatu a]t-ta-mi
4. 1
// an-nu-ú? q]í?-bi-šu
5. 1 $/ / x x(x)$ KÙ.B]ABBAR ù GUŚKIN
6. [
// i-na qa-]an-ni-ša
// ir-t]a-kas

"I [be your husband, be y] ou [(my) wife, these are] his [wo]rds(?), ... [si]lver and gold [he t]ied [in] her [h]em."43

lilî tablet). This is so especially since, as Malul notes, the reverse of the etlu tablet, col. II, Ins 18-20, refers to the etlu as the one to be cured and delivered.

40 As rendered by S. Greengus, "The Old Babylonian Marriage Contract," 516. M. Malul prefers, "I am filling" for the II/1 durative, ú-ma-lu (op. cit., 183).

41 Cf. W. G. Kunstmann, Die babylonische Gebetsbeschwörung, Leipziger semitische Studien NF 2, 106 , n. 9 , as cited by M. Malul, op. cit., 173, n. 55 .

42 For this practice, cf. M. Malul, op. cit., 171f.; 173, n. 55; $183 \mathrm{ff}$.

43 Text no. 2 in S. Lackenbacher, "Note sur l'ardat-lith," 138 (cf. 142f., n. 20). Cf. M. Malul, op. cit., 183 , and 184, n. 98 . 
In his critique of Greengus, Westbrook unaccountably overlooks these magical texts which comprise perhaps the most compelling evidence in support of Greengus' theory for the use of verba solemnia in the OB period. ${ }^{44}$

\subsubsection{Extrabiblical evidence for the use of verba solemnia among Israelites and Jews}

\subsubsection{Elephantine ${ }^{45}$}

The marriage formula, "she is my wife and I am her husband from this day and forever[הי אנתתי ואנה בעלה מן יומא זנה ער עלם]," appears with virtually the same wording in four marriage documents from Elephantine: Cowley 15:4;46 Kraeling 2:3f.;47 $7: 4,48$ and 14:3f. ${ }^{49}$ As noted by R. Yaron, nothing similar occurs in Egyptian marriage contracts, an observation which increases the value of this evidence as indicative of an indigenous Hebrew practice. ${ }^{50}$ In each case this formula appears at the conclusion of a brief introductory narrative in which the husband reviews, in a stereotypical manner, how he secured consent for the marriage from his wife's guardian (father, mother, brother, or master), the other party in the marriage contract with the husband. For example, Cowley 15:1-4 reads: "On the 26th [of] 'I'ishri ... Eshor ... said to Mah[seiah ...]..., 'I [c]ame to your house (and asked you) to give me your daughter Mipta(h)iah for wifehood. She is my wife and I am her husband from this day and forever." 51

With respect to the double form of the marriage formula, R. Yaron considers that "she is my wife" is the principal affirmation. ${ }^{52}$ This is so because, according to Yaron, the

44 The etlu tablet was also the key example used by G. R. Driver and J. C. Miles, before Greengus, for their argument in favour of the supposition of verba solemnia in marriage (Babylonian Laws, I, 402).

It should be noted with $\mathrm{M}$. David and others that the magical nature of this text in no way diminishes its value as evidence for the normal marriage rite. Indeed, it is precisely in such an unusual context that one is prepared to find a more complete account of the normal marital practice, including details which would be abbreviated or omitted in other less remarkable texts because they were so widely assumed. Cf. M. David, Die Adoption im altbabylonischen Recht (1927) 80, n. 46. Cf. also S. Greengus, op. cit., 516, n. 53, and M. Malul, op. cit., 127, 171f., 173, n. 55 and $182 \mathrm{ff}$.

45 Cf. B. Porten, Archives from Elephantine (1968) 206, esp. n. 23; J. A. Fitzmyer, "A Re-Study of an Elephantine Aramaic Marriage Contract (AP 15)" (1971) 137-68; M. J. Geller, "The Elephantine Papyri and Hosea 2, 3: Evidence for the form of the Early Jewish Divorce Writ" (1977) 139-148; and, for further bibliography, Porten-Yardeni, 30, 60, 82, 132.

46 = היא אשרתי ואני בעלה מן היום הזה וער עולם ....

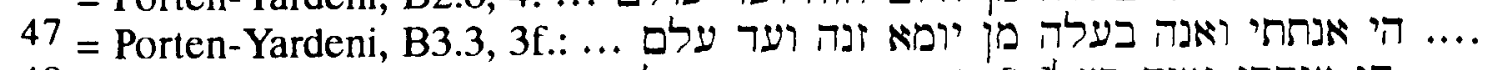

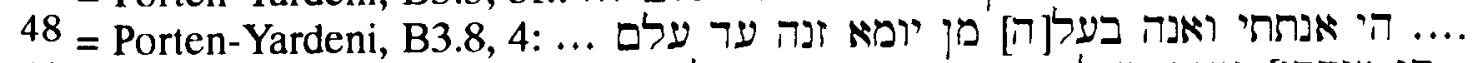

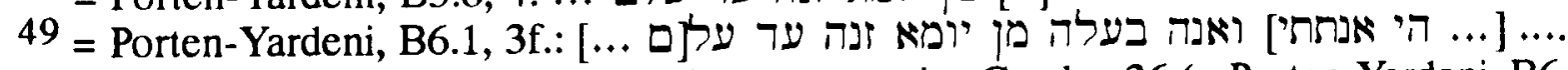

Fragments from three more marriage documents exist, Cowley 36 (= Porten-Yardeni, B6.2), Cowley 46 (= Porten-Yardeni, B6.3) and Cowley 18 (= Porten-Yardeni, B6.4), but they do not include the introductory section in which the marriage formula would be expected.

50 “Aramaic Marriage Contracts from Elephantine," 30.

This is not to imply, however, that Egyptian marriage contracts were altogether lacking in a documentary formula for marriage. E. M. Yamauchi observes that Egyptian contracts typically began with the phrase, "I have made you my wife" ("Cultural Aspects of Marriage in the Ancient World," 245).

51 = Porten-Yardeni, B2.6:1-4. As indicated by the use of ellipses, the translation is abbreviated here for greater clarity.

52 Introduction to the Law of the Aramaic Papyri, 47. 
documents mainly stress wifehood. Compare, for example, "I [c]ame to your house (and asked you) to give me your daughter Mipta(h)iah for wifehood";53 "I hated my wife Jehoishma; she shall not be my wife";54 "I hated you; I will not be your wife."55 Yaron acknowledges that the addition " and I am her husband" does indicate an element of mutuality, but exactly what legal consequences are attached to it is doubtful."56 Here, however, it may be that Yaron is being overly cautious. The contracts elsewhere do not hesitate to threaten the husband with penalties or to impose on him various restrictions, for example, the prohibition against acknowledging any other wife or heir or the prohibition against removing property from a wife, each with specified penalties for its contravention. 57

Furthermore, although the contracting parties in each of these documents are the husband and his wife's guardian, rather than the husband and his wife, there are so many indications of mutuality, there is little reason to doubt that similar "legal consequences" as attached to "she is my wife" did, in fact, attach to "I am her husband." It is notable, for example, that the contracts stipulate a similar right for both husband and wife to inherit the estate of a spouse who dies without issue. Even more striking, the contracts recognize the wife as enjoying a right to initiate divorce similar to that of her husband -- and both face considerable financial penalties if they exercise this "right" unjustifiably or merely because of "hatred." 58

53 Cowley 15:3 (= Porten-Yardeni, B2.6:3).

54 Kraeling 7:21f. (= Porten-Yardeni, B3.8:21f.).

A present tense "hate" for the stative perfect may be preferable here, and elsewhere, to the past tense "hated" offered by Porten and Yardeni. Alternatively, these may be instances of the present perfect usage for certain first person perfect verbs in Aramaic documents (= "I hereby hate"), as also in Biblical Hebrew and other Semitic languages, discussed by Y. Muffs, Studies in the Aramaic Legal Documents from Elephantine, 2nd ed. (1973) 32, n. 2. Cf. also M. A. Friedman, "The Minimum Mohar Payment as Reflected in the Geniza Documents: Marriage Gift or Endowment Pledge?" (1976) 42, n. 56.

55 Kraeling 7:25 (= Porten-Yardeni, B3.8:25).

56 Op. cit., 47.

57 Cf., c.g., Cowley 15:32ff. (= Porten-Yardeni, B2.6:32ff.) and Cowley 15:35f. (= Porten-Yardeni, B2.6:35f.).

58 Cf. \$3.4.2.2, where it was argued with R. Westbrook, against R. Yaron, that while witred," is often associated with divorce it is not to be equated with it. Rather, this term implies an unjustified divorce, that is, a divorce based merely on aversion. Cf. also M. A. Friedman, Jewish Marriage in Palestine, I, 314f., n. 10.

$\mathrm{R}$. Yaron considers that the recognition of a wife's capacity to initiate divorce is in contrast to the entire practice of the ancient East, as well as Talmudic law, and must, therefore, derive from Egyptian influence (Introduction to the Law of the Aramaic Papyri, 53).

However, favouring Semitic rather than Egyptian influence for the right of the wife to initiate divorce, cf. A. J. Skaist, "Studies in Ancient Mesopotamian Family Law Pertaining to Marriage and Divorce," 154160, and E. Lipinski, "The Wife's Right to Divorce in the light of an Ancient Near Eastern Tradition" (1981) 22f. Cf. also R. Westbrook, “Old Babylonian Marriage Law," II, 223-238, who rejects Driver and Miles' view that the wife had no right at all to initiate divorce in OB law, as well as the earlier view of $A$. van Praag, that the wife's rights were nearly identical to that of her husband. Cf. further I. Mendelsohn, "On Marriage in Alalakh" (1959) 352-353.

Note that Mur 20 (DJD II, 109ff.) recognizes the wife's right to divorce in the 2 nd century A. D., a view that was continued in the Palestinian tradition of Judaism represented in the Cairo Geniza. Cf. M. A. Friedman, Jewish Marriage in Palestine, I, 312-346. Based on this evidence, B. Porten considers it 
Furthermore, two contracts, Kraeling 7 and Cowley 18, by using much the same language, prohibit both the wife and husband from palingamy. 59 See, for example, Kraeling 7:33f., 36f.: "But Jeho[ishma] does not have the right [to] acquire another husband be[sides] Anani. And if she do thus, it is hatred; they shall do to her [the law of ha]tred;"60 "Moreover, [Ananiah shall] n[ot be able to] take anoth[er] woman [besides Jehoishma] for himself for wifehood. If he do [thus, it is hatred. H]e [shall do] to her [the la]w of [ha]tred."61 Although the precise interpretation of this prohibition has been disputed (whether it prohibits palingamy or, less likely, polygamy or adultery), a degree of mutuality appears self-evident and is supported by the heretofore undetected parallel literary structure of the protective clauses (lines $21 \mathrm{~b}-40 \mathrm{a}$ ) as a whole. 62

Offering a refinement of the traditional interpretation of the marriage formula at Elephantine, M. A. Friedman argues that "she is my wife and I am her husband from this day and forever" is perhaps better identified as a documentary formula, rather than as exact

hazardous to assume that women did not have the right to divorce in the Old Testament (Archives from Elephantine [1968] 261f.).

59 Kraeling 7 = Porten-Yardeni, B3.8; Cowley 18 = Porten-Yardeni, B6.4. Because the beginning of Cowley 18 is missing, only the prohibition against the husband taking another wife happens to be preserved.

60 Kraeling 7:33f. (= Porten-Yardeni, B3.8:33f.). This rendering, taken from Porten-Yardeni, 82, is somewhat lacking in the felicity of its English (e.g., "do," rather than "does"; "thus" rather than "so"; "the law of hatred" rather than "according to "the law of hatred"),

61 Kraeling 7:36f. (= Porten-Yardeni, B3.8:36f.).

Alternatively, as appears from Porten-Yardeni, Fold-out No. 19, ln 37b may be restored as

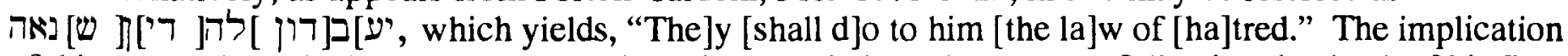
of this restored text is that such a husband, having married another woman following the death of his first wife who died without issue, must relinquish the wealth of his first wife, presumably to be returned to her family (a consequence which resembles the case where he divorces her merely on the ground of aversion).

62 Favouring a reference to palingamy is E. Volterra, Iura 6 (1955) 359, according to B. Porten, Archives From Elephantine, 224. For an alternative view, cf. R. Yaron, Introduction to the Law of the Aramaic Papyri, 60f., 73f.; idem, "Aramaic Marriage Contracts from Elephantine," 24ff.

Confirming a reference to palingamy, or at least some mutually prohibited act, is the linguistic parallelism and balanced literary structure of the protective clauses as a whole:

A. Divorce by husband who declares his hatred for his wife, and the consequence thereof (she receives back her dowry and is free to go where she pleases) -- lns. 21b-24a

$\mathrm{A}^{\prime}$. Divorce by wife who declares her hatred for her husband, and the consequence thereof (she forfeits her dowry and returns to her father's house) -- Ins. 24b-28a.

B. Predecease of husband without issue, wife inherits everything; penalty for anyone who attempts to thwart this provision

Prohibition against the wife acquiring another husband and the consequence of any contravention thereof -- $\operatorname{lns}$. $28 \mathrm{~b}-34 \mathrm{a}$

B'. Predecease of wife without issue, husband inherits everything;

Prohibition against the husband taking another wife and the consequence of any contravention thereof -- Ins. 34b-37a.

C. Prohibition against the husband not doing to his wife "the law of one or two" [= conjugal rights?] and the consequence of any contravention thereof -- Ins. 37b-39a.

$\mathrm{C}$. Prohibition against the wife not doing to her husband "the law of one or two" and the consequence of any contravention thereof -- $\operatorname{lns} 39 \mathrm{~b}-40 \mathrm{a}$. 
reproduction of the verba solemnia of marriage. ${ }^{63}$ In introducing this distinction, Friedman is concerned to argue that the original oral formulae would have been mutual, perhaps with the husband declaring, "you are my wife," and the wife responding, "you are my husband." In any case, Friedman insists that the verba solemnia were accurately summarized in the documentary formula. ${ }^{64}$

\subsubsection{Five second century A.D. marriage documents from Wadi Murabba'at}

Among the important discoveries found at the Wadi Murabba'at were five fragmentary Jewish marriage contracts written during the early second century A.D. prior to the Bar Kokhba revolt. Three of these are written in Aramaic (Mur 20, 21, Babata's marriage contract); the remaining two are in Greek (Mur 115, 116). ${ }^{65}$

Mur 20 is dated by its editors about 117 A.D. ${ }^{66}$ As with the other marriage contracts from Murabba'at (as far as can been determined from their poor state of preservation) Mur 20 appears to exhibit the following established pattern: 1) date, 2) contracting parties, 3 ) report of the marriage formula and any general promises, 4) record of financial matters, 5) protective clauses for the wife and children in the case of death or divorce, and 6) concluding list of witnesses. Specifically, Mur 20, lns. 1-3, read: “[On] the seventh of Adar, in year e[leven of ..., the son] of Manasseh from the sons of Eliashib $\left[\ldots\right.$, , that you $^{67}$ shall become mine in wifehood according to the law of $\mathrm{M}$ [oses],

63 "Israel's Response in Hosea 2:17b: 'You are my Husband"" (1980) 203. For the traditional view that the marriage formula do reproduce the verba solemnia of marriage, cf. B. Porten, Archives from Elephantine, 206.

64 To Friedman's arguments we may add the observation that similar documentary formulae are attested elsewhere among the marriage documents which have survived from the ancient Near East. Cf., e.g., "Kikkinu is her husband; Bitti-Dagan is his wife" (lns. 4f. of the MB marriage document from Hana in A. T. Clay, Babylonian Records in the Library of J. Pierpont Morgan, Part IV, text 52, 50-52).

The mutual negative verba solemnia of divorce which immediately follow this documentary formula, "thou art not my wife" (ln. 8), and "thou art not my husband" (ln. 13), support the suggestion that the documentary formula may reflect the earlier unrecorded mutual marriage verba solemnia, "you are my wife" and "you are my husband."

65 P. Benoit, J. T. Milik and R. de Vaux, Les Grottes de Murabba'at, DJD II (1961) 109ff., 114ff., 243ff., 254ff. Cf. also the reprint of these texts in E. Koffmahn, Die Doppelurkunden aus der Wüste Juda (1968) $114 \mathrm{ff}$.

The full text of "Babata's marriage contract" is, apparently, still unpublished. However, it is mentioned in Mur, p. 253, n. 5, and portions have been published by Y. Yadin, "Expedition D - The Cave of the Letters" (1962) 244-245.

66 Confusingly, Mur 20 has been variously referred to as the "Bar Menasheh marriage deed" as well as the "Kephar Bebhayu marriage deed." Cf. S. A. Birnbaum, "The Kephar Bebhayu Marriage Deed" (1958) 12-18; idem, The Bar Menasheh Marriage Deed (1962) 7; and S. Greengus, “Old Babylonian Marriage Contract," 522, n. 83.

67 In support of an interpretation of Marriage in Palestine, I, 158, n. 31. 


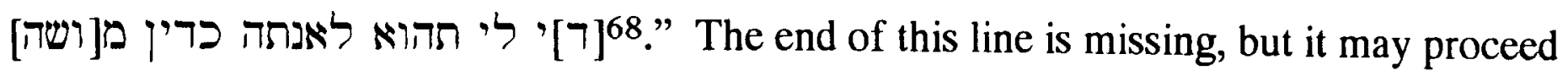
to detail various promises from the groom to care for his wife from this day "and forever, [1]" לעלם [the start of line 5), such as are found in the later Geniza marriage contracts.

The marriage formulae attested in Mur 21 and Babata's marriage contract are similar, though the texts are fragmentary. Unfortunately, due to its poor state of preservation Mur 116 lacks the marriage formula. On the other hand, Mur 115, dated 124 A.D., offers a significant variation in the wording of its marriage formula in line 4: "the

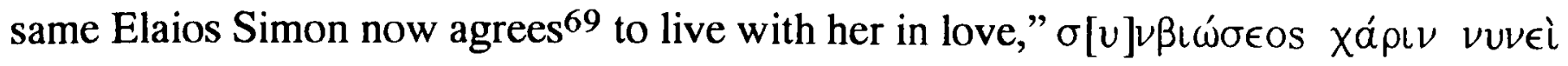

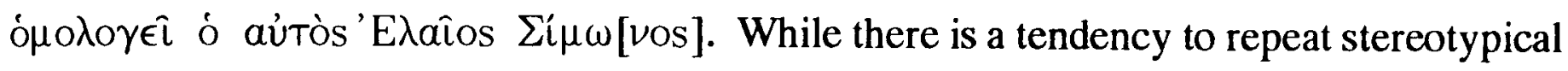
formulae in the extant Jewish marriage documents, especially those from the later quite rigid Gaonic Babylonian tradition, the evidence of Mur 115 provides a salutary reminder that creative variation was permitted among Jews operating within other traditions. ${ }^{70}$

\subsubsection{Talmudic evidence}

No complete formulary of the marriage contract $\left(k^{e} t u b b \hat{a}\right)$ is preserved in the Talmud. Almost all extant marriage contracts and references in the Tannaitic literature, however, support the following proposal for the groom: "Be to me a wife according to the law of Moses and Israel [הואי לי לאנתו כדת משה וישראל]."71

Of special interest is an marriage contract from AlexandriaAlexandrian marriage document which was studied by Hillel (about 30 B.C.) and is cited in the Tosefta and both Talmuds. ${ }^{72}$ This $k^{e} t u b b a \hat{~ e x h i b i t s ~ a ~ f o r m ~ w h i c h ~ i s ~ s i m i l a r ~ t o ~ t h a t ~ o f ~ t h e ~ c o n t r a c t s ~ f r o m ~}$ Murabba'at and the Palestinian-type contracts from the Cairo Geniza (10th and 11th century A.D.). ${ }^{73}$ The marriage formula is "When you enter my house/the wedding chamber, you will be mine in wifehood [לכשתיכנסי לביתי / לחופה תהוין לי לאנתו]."

From the evidence thus far considered it appears that verba solemnia were a regular feature in the contraction of marriage throughout the ancient Near East and into post-biblical times. This fact predisposes us to find allusions to marital verba solemnia in the Old Testament. We turn now to an examination of the relevant biblical texts.

68 J. T. Milik proposes ' $[$ [ת] for the start of line 3, which he understands as the (intensive) second person feminine singular pronoun. M. A. Friedman has challenged this, arguing that the expected second person form would be אנ, as in no. 21, line 12 (Jewish Marriage in Palestine, I, 158). As a result he proposes to restore the relative ' [\urcorner$]$. 75).

69 Though uncertain, S. Bigger's rendering "swears" for ó $0 \lambda \circ \gamma \in \hat{\imath}$ is an intriguing possibility (op. cit.,

70 L. M. Epstein fails to take adequate account of this potential for variation, both here and in the 66 Palestinian-style marriage contracts found among the Cairo Geniza (The Jewish Marriage Contract [1927] 57). On the latter, cf. M. A. Friedman, Jewish Marriage in Palestine, 2 vols. (1980)

71 Cf. L. M. Epstein, The Jewish Marriage Contract (1927) 57, and M. A. Friedman, Jewish Marriage in Palestine, I, 147.

72 Cf. t. Ketub. 4:9; y. Ketub. 4:8, 29a; y. Yebam. 15:3, 14d; and b. B. Mes. 104a.

73 Cf. M. A. Friedman, op. cit., I, 156-8. 


\subsubsection{Biblical texts}

\subsubsection{Genesis 2:23}

Already in \$5.9.2.3 above we observed that the paradigmatic marriage of Adam and Eve was accompanied by verba solemnia, spoken by Adam before God: "This at last is bone of my bones and flesh of my flesh; she shall be called Woman, because she was taken out of Man." As we argued, the fact that the "bone of my bones" formula is well-attested elsewhere within the Old Testament helps to identify these words as covenant-forming verba solemnia, rather than merely an ejaculatory comment of delight. This formula, with variations, is found in Genesis 29:14; Judges 9:2-3; 2 Samuel 5:2 (and the parallel in 1 Chronicles 11:1); and 2 Samuel 19:13f. [ET 12f.]. Although in each case some notion of kinship is in view, the formula produces an effect well beyond the bare recognition of a familial relationship to include a commitment of loyalty and an appeal for reciprocal allegiance (i.e., as expected for verba solemnia, it effects a covenant commitment). ${ }^{74}$ As suggested already by D. Daube some years ago, in the ancient world the solemn acknowledgement of a relationship was frequently the very means of creating it. ${ }^{75}$ These parallels as well as Adam's words spoiken in the presence of the deity in Genesis 2:23 appear to offer unmistakable examples.

\subsubsection{Hosea 2:4 [ET 2]}

Given the use of similar formulae for divorce, or the disavowal of marriage, elsewhere in the ancient Near East (i.e., "you are not my wife," "you are not my husband," "she is not my wife," "he is not my husband," "I will not be your wife"), the expression,

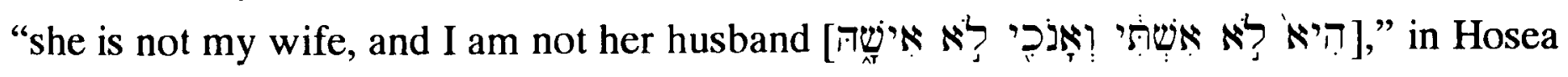
2:4 [ET 2] has long been recognized as a possible example of such verba solemnia. ${ }^{76}$ Even

74 On this formula, cf. W. Reiser, "Der Verwandschaftformel in Gen 2,23" (1960), and W. Brueggemann, "Of the Same Flesh and Bone (Gen 2,23a)" (1970). Cf. also D. Daube and R. Yaron, "Jacob's Reception by Laban" (1956); F. I. Andersen, "Israelite Kinship Terminology and Social Structure" (1969); R. G. Boling, Judges (1975) 171; and P. Kalluveettil, op. cit., $209 \mathrm{f}$.

75 D. Daube, Studies in Biblical Law (1947) $7 \mathrm{f}$.

76 Cf., e.g., C. H. Gordon, "Hosea 2:4-5 in the Light of New Semitic Inscriptions" (1936); R. Yaron, "On Divorce in Old Testament Times" (1957), idem, "Aramaic Marriage Contracts from Elephantine" (1958) 30-31; R. de Vaux, Ancient Israel, I (1961) 35; S. Greengus, "Old Babylonian Marriage Contract" (1966) 522, n. 82; U. Cassuto, "Second Chapter of the Book of Hosea" (1973) 120-122; H. W. Wolff, Hasea (1974) 33f.; and M. Fishbane, "Accusations of Adultery. A Study of Law and Scribal Practice in Numbers 5,11-31" (1974) 40.

M. A. Friedman suggests that Hosea actually introduced two modifications to the original formula (“Israel's Response in Hosea 2:17b: 'You are my Husband"' [1980] 199). First, Friedman considers it likely that the original formula was expressed in the second person, "You are not my wife, and I am not your husband." Though possible, this suggestion may not be required since third person disavowal formulae (presumably stated before witnesses) are attested elsewhere. Cf., e.g., M. T. Roth, op. cit., No. 5, 13. 
before modern scholarship this same formula, for example, was used by the Karaites during the Middle Ages, presumably in dependence on this biblical text. ${ }^{77}$ Since the Elephantine marriage documents attest to the corresponding marriage formula "she is my

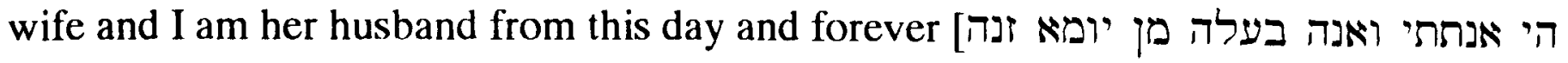
[ עד עלם ," whether this is to be understood as the marriage-forming verba solemnia or, with Friedman, as their reflex in a documentary formula, it seems likely, with S. Greengus, that Hosea's words were "apparently modelled upon a marriage formula similar to the one used in the papyri."78 If so, Hosea's words offer indirect testimony to the use of the positive verba solemnia in eighth-century B.C. Israelite practice.

This recognition of Hosea 2:4a [ET 2a] as containing a formula for divorce or the disavowal of marriage, however, raises questions for the precise function of such a formula within the larger context of Hosea 2:4-25 [ET 2-23]. It goes beyond the limits of the present study to attempt to resolve this larger interpretative question. Nevertheless, it is apparent from the larger context that the expression, "she is not my wife, and I am not her husband," in Hosea 2:4 does not immediately effect a divorce or dissolution of the relationship between Yahweh and Israel. On the contrary, as noted by F. I. Andersen and D. N. Freedman, among others, the verses which follow, at least to vs. 15 [ET 13], presuppose the continuance of the marriage between Yahweh and his people, for which reason Israel continues to be accused of "adultery," not just "promiscuity."79

As a consequence, it is possible, with Andersen and Freedman, that Hosea 2:4a [ET 2a] should be viewed as Yahweh's private acknowledgment that his wife's adultery and desertion has rendered his marriage as dissolved de facto, but since these words have no legal effect (because of their nonjuridical/informal setting and purpose), the marriage remains in force de jure. 80 This interpretation does not require, however, Andersen and Freedman's denial that Hosea 2:4a [ET 2a] includes the divorce formula. ${ }^{81}$ It merely

Second, Friedman supposes that the original formula employed the expression בעל for "husband," as attested in the Elephantine papyri, for example, a term which Hosea eschewed for its association with the Baal cult. Cf. Hosea 2:18f. [ET 16f.].

M. J. Geller has offered an alternative explanation for Hosea 2:18f. [ET 16f.], suggesting that in this text בעל bears the meaning "lover," as he supposes it does in Kraeling 7:33 (= Porten-Yardeni, B3.8:33) ("The Elephantine Papyri and Hosea 2,3: Evidence for the form of the Early Jewish Divorce Writ," 146, n. 21). Against this view, cf. M. A. Friedman, “Israel's Response in Hosea 2:17b,” 201, n. 9.

77 Cf. M. A. Friedman, “Israel's Response in Hosea 2:17b,” 198, n. 1.

78 S. Greengus, "Old Babylonian Marriage Contract," 522, n. 82

Cf. Cowley 15:4 (= Porten-Yardeni, B2.6); Kraeling 2:3f. (= Porten-Yardeni, B3.3); 7:4 (= PortenYardeni, B3.8); and 14:3f. (= Porten-Yardeni, B6.1).

79 F. I. Andersen and D. N. Freedman, Hosea, 219-224.

80 Against this view, J. L. Mays posits a juridical setting for Hosea 2, but rejects 2:4a [ET 2a] as a divorce formula (Hosea, 35ff.). Alternatively, A. Phillips recognizes 2:4a [ET 2a] as a divorce formula, but insists that as a matter of family law, neither a juridical setting, nor even necessarily a public setting, was required for divorce ("Some Aspects of Family Law in Pre-Exilic Israel," 352).

81 F. I. Andersen and D. N. Freedman explicitly reject the proposed identification of Hosea 2:4a [ET $2 \mathrm{a}$ as a divorce formula (Hosea, 200f.). This conclusion is demanded only if it is assumed that the divorce formula necessarily terminates a marriage then and there. 
recognizes the possible effect of context on an expression which elsewhere constitutes performative discourse.

Alternatively, it may be preferable to understand Hosea 2:4a [ET 2a] as entailing an imminent and well-deserved threat of divorce by its invocation of the divorce formula -- a threat which is realized by the end of vs. 15 [ET 13]. ${ }^{82}$ In this manner, the interpretation of Hosea 2:4a [ET 2a] better parallels that of Hosea 1:9, which similarly threatens the imminent dissolution of Yahweh's covenant with Israel by its use of the parallel covenant dissolution formula "for you are not my people and I am not your God" (appearing in the context of the oracular names of Hosea's children). 83 Although positing a complex redactional history for Hosea, G. A. Yee considers that the author of Hosea 2:4 avoids using the customary divorce formula precisely to highlight this reversal of the covenant reflected in Hosea 1:9.84

Accordingly, just as the threatened covenant dissolution in Hosea 1 is followed by an unexpected promise of covenant renewal in Hosea 2:1-3 [ET 1:10-2:1], so also the threatened divorce in Hosea 2:4ff. [ET 2ff.] is followed by an unexpected promise of a new marriage in Hosea 2:16ff. [ET 14ff.]. Moreover, in each case the promised restoration is expressed in terms of the use of positive declaration formulae which correspond to and rcverse the preceding negative dissolution formulae. 85 This structural parallelism is clearly intentional since Hosea identifies the effects of the restored marriage at the end of chapter 2 with the effects of the earlier promised restored covenant:

Other scholars have disputed the identification of a divorce formula in Hosea 2:4a [ET 2a], including $\mathbf{R}$. Gordis, "Hosea's Marriage and Message: A New Approach" (1954) 9-35, esp. 20f.; H. H. Rowley, “The Marriage of Hosea" (1963) 92; W. Rudolph, Hosea (1966) 65; J. A. Fitzmyer, "A Re-Study of an Elephantine Marriage Contract (AP 15)," 150; and J. L. Mays, Hasea (1969) 37f.

Cf., however, H. J. Hendriks' response to Gordis ("Juridical Aspects of the Marriage Metaphor in Hosea and Jeremiah," $57 \mathrm{ff}$.).

82 In support of Hosea 2:4a [ET 2a] as a threat of divorce based on its nonjuridical setting and the conditional threat of vs. 3, cf. H. McKeating, Amos, Hosea, Micah, 83.

83 F. I. Andersen and D. N. Freedman are inconsistent in their interpretation of these parallel verses (Hosea, 197f., 223f.). As mentioned, they consider Hosea 2:4a [ET 2a] to be a private complaint or perhaps even an affirmation if $ל$ is asseverative, but on either view Yahweh has no intention to dissolve the marriage. By contrast, noting the positive covenant-making formulae in Leviticus $26: 12$ and 2 Samuel $7: 14$, they consider that with the corresponding negative formulae in Hosea 1:9, "All this is now undone; a relationship hundreds of years old has been dissolved [italics added]."

Cf. also Exodus 6:5-7; Jeremiah 7:21-23; 11:4; Ezekiel 11:20; 14:11; 37:26-27, for other examples of the corresponding positive covenant formula.

84 G. A. Yee, Composition and Tradition in the Book of Hosea: A Redaction Critical Investigation (1987) 105-108.

Yee posits a four-stage redactional history for Hosea, yielding some interpretative novelties, such as his view that the original adulterous mother of chapter 2 is Rachel, the favourite wife of Jacob, not Gomer, and that her children are the northern tribes, the House of Israel (op. cit., 305).

85 Cf. "Children of the Living God" [בכני אל 2:1 [1:10], perhaps by contrast to "I am not Ehyeh

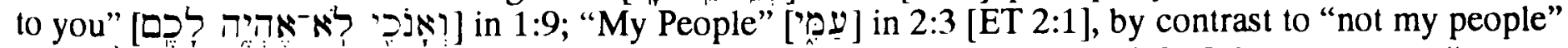

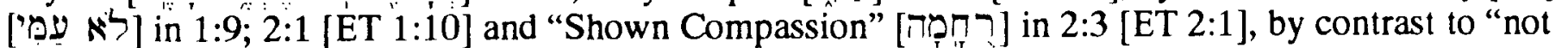
pitied" [לא רָחמָה] in $1: 6,8$. Cf. the use of "my children" as the formula for legitimation in $\mathrm{CH} \$ \$ 170$ 171 , discussed earlier.

For Hosea 2:16-25 [ET 14-23], cf. the discussion below. 
And in that day, says the LORD, I will answer the heavens and they shall answer the earth; and the earth shall answer the grain, the wine, and the oil, and they shall answer Jezreel [cf. 1:4f., 11]; and I will sow him for myself in the land. And I will have pity on Not pitied [cf. 1:6f.; 2:3 [ET 2:1]], and I will say to Not my people [cf. 1:9f.; 2:3 [ET 2:1]], "You are my people"; and he shall say "Thou art my God." (Hosea 2:23-25 [ET 21-23])

In addition to these structural considerations which highlight the parallel between Hosea 2:4 [ET 2:2] and Hosea 1:9 and to the ancient Near Eastern parallels to Hosea 2:4 [ET 2:2] already mentioned, H. J. Hendriks offers a number of arguments in support of interpreting Hosea 2:4a [ET 2a] as a divorce formula which threatens the dissolution of Yahweh's "marriage" with Israel.86 Only three will be briefly repeated here. First, the remarriage promised in Hosea 2:16-25 [ET 14-23] appears to presuppose the prior dissolution of a previous marriage in 2:4-2:15 [ET 2:2-13]. ${ }^{87}$ Second, the threat of stripping in vs. 5 [ET 3] is a well-attested symbolic action for dissolving relationships and, specifically, effecting divorce; it is thus congruent with the initial threat of divorce posited for 2:4 [ET 2:2].88 Finally, Jeremiah, a book which is widely recognized as having been influenced by Hosea's message and his use of the marriage metaphor in particular, in 3:8 interprets Israel's broken relationship with Yahweh as a divorce. 89

\subsubsection{Hosea 2:17-19 [ET 15-17]}

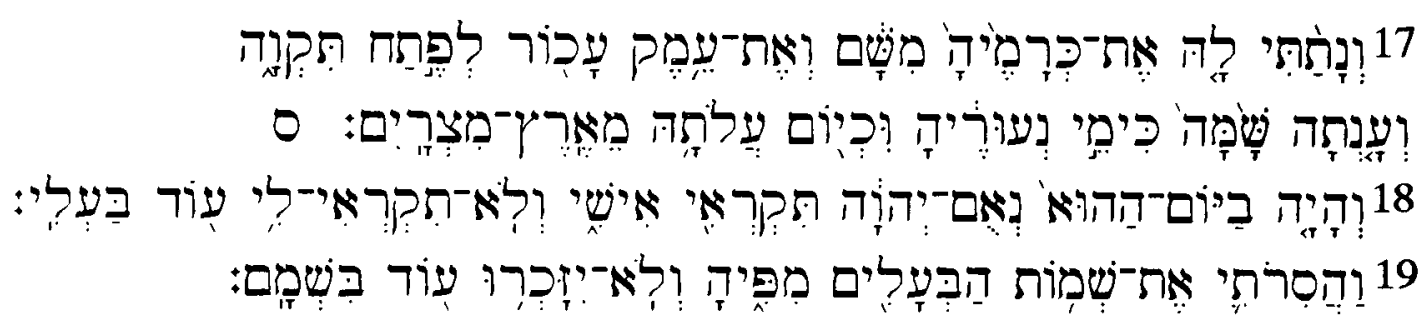

${ }^{15}$ And there I will give her her vineyards, and make the Valley of Achor a door of hope. And there she shall answer as in the days of her youth, as at the time when she came out of the land of Egypt. ${ }^{16}$ And in that day, says the

86 Cf., e.g., H. J. Hendriks, op. cit., 58.

87 In support, Hendriks appeals to his overall treatment of Hosea 2-3, which cannot be reproduced here.

88 Ibid., $47 \mathrm{f}$.

89 It is possible that the reference to Yahweh as "my first husband" in Hosea 2:9 [ET 2:7] implies the prior dissolution of the marriage. If it is objected that the promised renewed marriage between Yahweh and Israel would then contravene the express prohibition of Deuteronomy 24:1ff., it may be responded that Jeremiah 3:1 raises the very same objection -- perhaps as a threat to stress Israel's irreparable ruin if she continues in her religious harlotry, or, if intending to depict her state as already irremissible, then posing an insuperable legal obstacle which, in the end, only the relentless love of God can overcome. P. Grelot observes with respect to Yahweh's promised remarriage of his bride, "according to the law and customs of those days no husband would have acted like this" ("The Institution of Marriage: Its Evolution in the Old Testament," 46)

On the relationship between Hosea and Jeremiah, cf., e.g., J. Skinner, Prophecy and Religion. Studies in the Life of Jeremiah (1922) 21; H. J. Hendriks, op. cit., 182-186; and J. A. Thompson, The Book of Jeremiah (1980) 81-87. Thompson cites the full-scale study of this subject provided by K. Goss, "Die literarische Verwandschaft Jeremias mit Hosea" (1930), and idem, "Hoseas Einfluss auf Jeremias Anschauungen" (1931). 
LORD, you will call me, 'My husband,' and no longer will you call me, 'My Baal.' ${ }^{17}$ For I will remove the names of the Baals from her mouth, and they shall be mentioned by name no more.

As noted in the preceding discussion, Hosea 2:17-19 [ET 15-17] appears within an oracle (Hosea 2:16-25 [ET 14-23]), which promises a new marriage between Yahweh and his people "in that day." 90 It has already been mentioned that the parallel promise of covenant renewal in Hosea 2:1-3 [ET 1:10-2:1] employs positive declaration formulae which correspond to and reverse the preceding negative dissolution formulae. It appears that, in the very same manner, Hosea 2:17-19 [ET 15-17] uses "My husband ["איש:" as an example of the wife's verba solemnia, establishing this new marriage and so reversing the

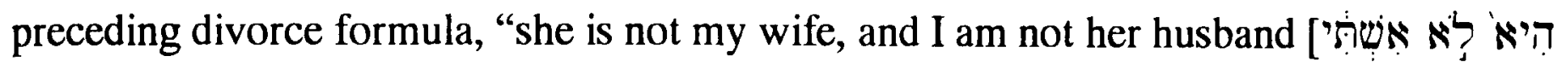

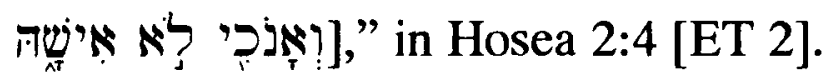

In a careful study of this text, M. A. Friedman concludes that 2:18 [ET 16] alludes

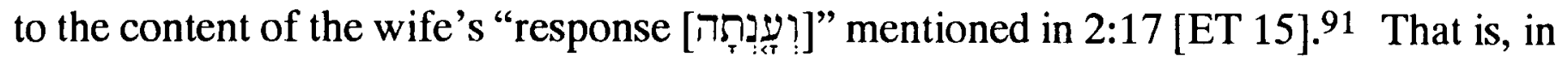
2:16 [ET 14] Hosea alludes to God's proposal of (re)marriage, which is made explicit in Hosea 2:21f. [ET 19f.]. ${ }^{92}$ Naturally, Hosea assumes his audience knows what must have been the customary marriage formula of the time, perhaps one in which the husband

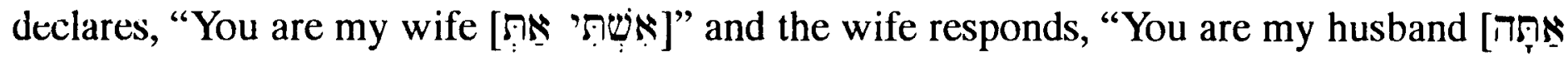

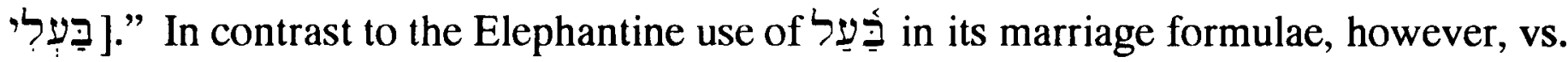
18 [ET 16] instructs the bride that her response can no longer be "my Baal (= husband)

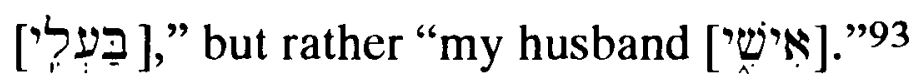

Most commentators consider that this change in vocabulary signals a total repudiation of Baal worship (cf. 2:19 [ET 18]). It may also be the case, with C. V. Camp and others, that the wife's response of implies a heightened character of intimacy in this renewed marriage. ${ }^{94}$ As Camp tentatively suggests, "'In that day' this relationship will

90 Unfortunately, there is some dispute about the precise beginning of the oracle of restoration. E.g., J. L. Mays, H. W. Wolff, and D. K. Stuart favour starting with the eschatological "In that day" [הידיר 'ביוֹם־ה 2:18 [ET 2:16], while J. Lindblom (Prophecy in Ancient Israel [1962] 243); H. J. Hendriks,

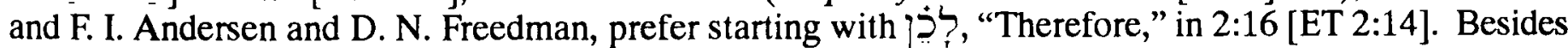
allowing the preceding section to end with the structural indicator, the principal advantages of this second approach is that it better reflects the change in tone from judgment to promise which occurs at 2:16 [ET 2:14], and, further, it preserves the coherence between 2:17 [ET 2:15] and 2:18 [ET 2:16]. On this last point, cf. M. A. Friedman, "Israel's Response in Hosea 2:17b." Accordingly, the entire oracle is the unexpected (because of its positive tone) third member in a series of 2:11 [ET 9]) which follow Yahweh's complaint against his adulterous wife in 2:4-7 [ET 2-5]. Cf. also H. J. Hendriks, op. cit., 157-160.

91 M. A. Friedman, "Israel's Response in Hosea 2:17b: 'You are my Husband"” (1980).

92 Friedman cites Judges 19:3, especially, as well as 2 Samuel 19:8; Isaiah 40:2; 2 Chronicles 30:22;

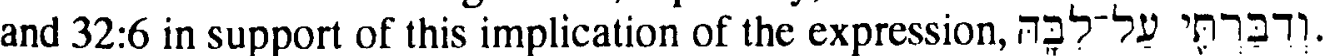

93 M. A. Friedman, op. cit., 200. Friedman rejects M. J. Geller's proposal that lover," in favour of the traditional view that Hosea's opposition to the term כִ כעל stems from a repudiation of Baal worship (op. cit., 21, n. 8).

94 C. V. Camp, Wisdom and the Feminine in the Book of Proverbs (1985) 106f. However, elsewhere Camp acknowledges that in Proverbs $31: 11,23$, and 28 (op. cit., 91f.). Cf. also L. M. Muntingh, "Married Life in Israel according 
be transformed. No longer will Israel call the deity 'my ba'al,' my master, but rather 'my 'î̌, my husband, my man." In support, she cites studies by W. Brueggemann and P. Trible which argue for an implied mutuality in the terms

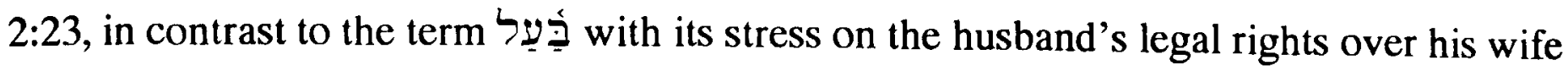
as her "lord" or "possessor." 95

In any case, the marriage-forming declaration, "my husband ["we, " and its assumed counterpart declaration, "you are my wife [אשתי את]," prepare for and clearly parallel the later declaration formulae in vs. 25 [ET 23]. In that verse Yahweh declares of

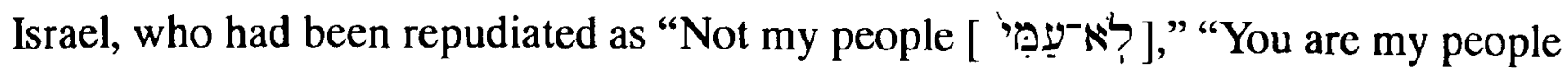

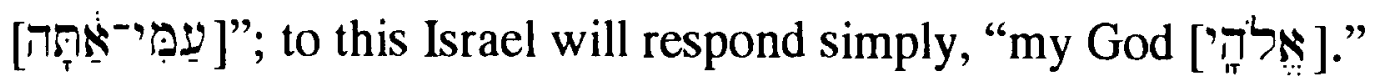

\subsubsection{Proverbs 7:4f.}

Although its use is metaphoric, Z. W. Falk has suggested that there is a plausible allusion to a marriage-forming verba solemnia in Proverbs 7:4f.: "Say to wisdom, 'You are

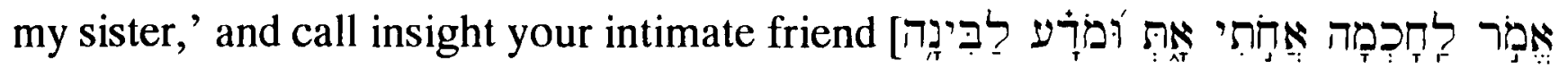
Iקת:; to preserve you from the loose woman, from the adventuress with her smooth words."96

With respect to the wording of the posited verba solemnia, it appears that "You are

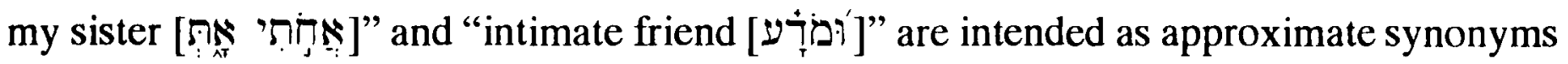
because of the chiastic arrangement of 7:4f. Unfortunately, however, there is considerable

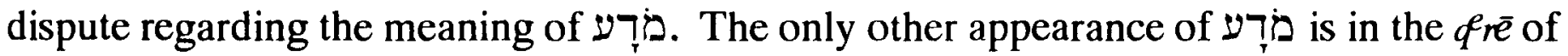

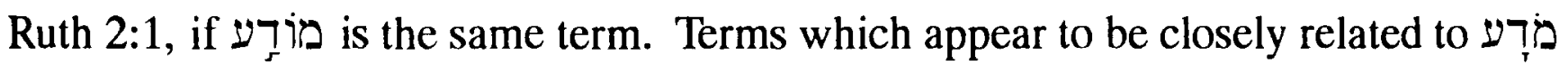

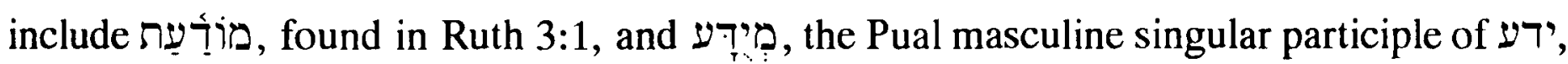
found in the $k^{e} t \hat{i} b$ of Ruth $2: 1$ and also in 2 Kings 10:11; Psalm 31:12 [ET 11]; 55:14 [ET 13]; 88:9, 19 [ET 8, 18]; and Job 19:14.

While "acquaintance," "friend," or "relative" have been suggested for each of these מ-noun formations from ידע, none of these is without difficulty. Alternatively, E. F. Campbell has argued that these terms may include the same covenantal associations as does the verb analyzed in the studies of H. B. Huffmon and S. Parker. ${ }^{97}$ Accordingly,

to the Book of Hosea" (1964-65) 80; C. van Leeuwen, Hosea (1968) 72; J. L. Mays, Hosea, 48; and H. J. Hendriks, op. cit., 145.

95 W. Brueggemann, "Of the Same Flesh and Bone (Gn 2,23a)," 538f.; and P. Trible, God and the Rhetoric of Sexuality (1978) 100-102.

96 Z. W. Falk, Hebrew Law in Biblical Times. An Introduction (1964) 134f. So also M. A. Friedman, op. cit., 203, n. 18.

97 Cf. E. F. Campbell Jr., Ruth (1975) 88-90, 117; H. B. Huffmon, “The Treaty Background of Hebrew $y \bar{a} d d^{\prime}$ " (1966) 31-37; and H. B. Huffmon and S. B. Parker, "A Further Note on the Treaty Background of Hebrew yōda" (1966) 36-38.

Against Campbell cf., e.g., J. M. Sasson, Ruth (1979) 39. However, Sasson's inconsistent rendering of מִיריע in Ruth 2:1 as "acquaintance" (doubtful in view of the subsequent identification of Boaz as "of the 


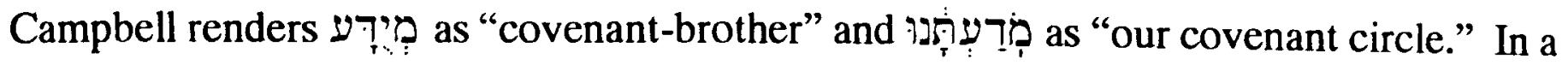
similar manner, J. Gray explains the sense of מירע in Ruth 2:1: "The term means one known to another, probably with the more pregnant sense of mutual acknowledgement of social obligations as between kinsmen, as indicated in 2:20..."98

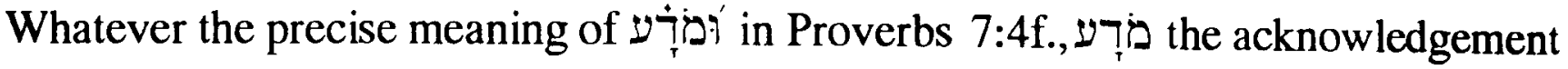

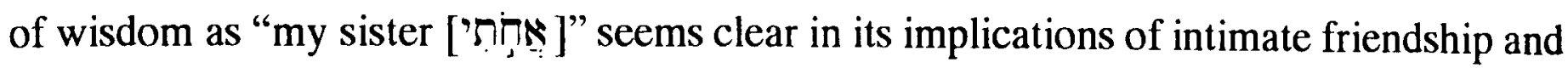
commitment. It is helpful to recognize not only that "sister" and "brother" are favourite epithets for lovers, for example in Egyptian love poetry, but also that the term "sister" is

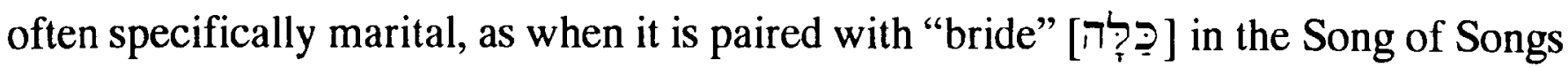
(e.g. 4:9, 10, 12; 5:1).99 Perhaps, also, the use of "brother" as an established term for the recognition of covenant partners should be compared here. 100 In any case, if one's bride is wisdom, the greater implications of mutuality implicit in the term "sister" seem eminently appropriate. 101

\subsubsection{Tobit 7:12}

The seventh and eighth chapters of the book of Tobit, thought to have been composed in Hebrew or Aramaic during the second century B.C., offer the modern scholar one of the most detailed narratives regarding the contraction of a marriage available from the ancient world. 102 In the course of the narrative, Raguel gives his daughter Sarah to be married to Tobias and says, "Here she is; take her according to the law of Moses."103 Just prior to doing so, Raguel addresses Tobias, "From henceforth you are her brother, and she

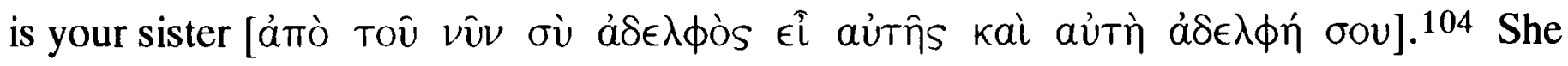
has been given to you from today and forever."

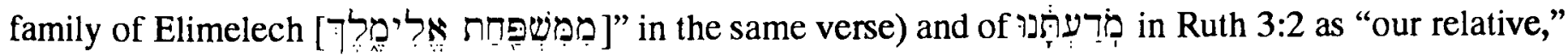
are unconvincing.

98 Joshua, Judges, Ruth (1986) 390.

99 On the use of "sister" in Egyptian marriage contracts from the sixth century B.C., cf. E. Lüddeckens, Ägyptische Eheverträge (1960) nos. 3, 4, 13-15. Cf. also J. B. White, $A$ Study of the Language of Love in the Song of Songs and Ancient Egyptian Poetry (1978) 95.

${ }_{100}$ Cf. J. Priest, "The Covenant of Brothers" (1965) 400-406; D. J. McCarthy, Treaty and Covenant (1981) 98, 104, 106; P. Kalluveettil, op. cit., 99-101; and H. Tadmor, "Treaty and Oath in the Ancient Near East: An Historian's Approach" (1982) 131.

$101 \mathrm{Cf}$. also the words of "Anat to Aqht, trying to win his confidence, "You are my brother and I am [your sister], at ah wan [ahtk]" (III Aqht rev. 24 = Aqht B i 24 in ANET, 152). Although the following lines are too fragmentary to secure the interpretation of this line, A van Selms compares the formulae used in adoption and marriage in Mesopotamia and Israel (Marriage and Family Life in Ugaritic Literature [1954] 120).

102 On marriage in Tobit, cf. P. Grelot, "The Institution of Marriage: Its Evolution in the Old Testament" (1970) 39-50.

103 The reference to the "law of Moses" may be compared to the same formula attested in the Mur 20 and the Babata marriage contract from Muraba'at, marriage contracts from the Cairo Geniza, and the "traditional" Jewish marriage contract. Cf. M. A. Friedman, Jewish Marriage in Palestine, I, 163.

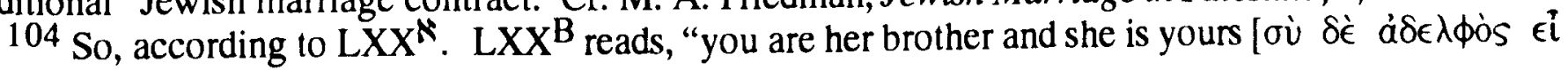

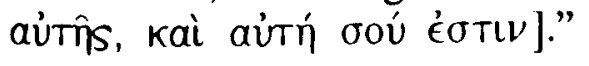


While it is the case that "brother" and "sister" are used within Tobit of mother $(5: 20)$, relatives $(3: 14 ; 5: 13)$, and liberally of fellow Jews $(1: 3,10,16 ; 2: 2 ; 4: 12,13 ; 5: 6$, 11; etc.), they are also used of husbands and wives (cf. Tobit 7:16; 8:4, 7), as in the case of Proverbs 7:4 and the Song of Songs. Accordingly, M. A. Friedman has plausibly identified this declaration in 7:12 as the verba solemnia of the marriage. ${ }^{105}$

Although it is surprising, based on the examples thus far considered, for the fatherin-law to pronounce the verba solemnia, nevertheless, it is clear that these words do, in fact, effect the requisite change in the status of Tobias and Sarah. ${ }^{106}$ Furthermore, they

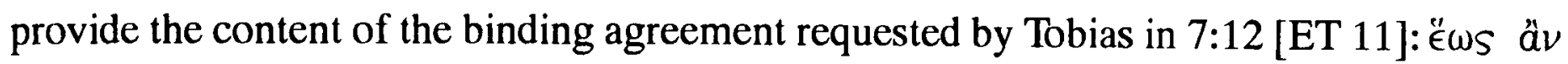

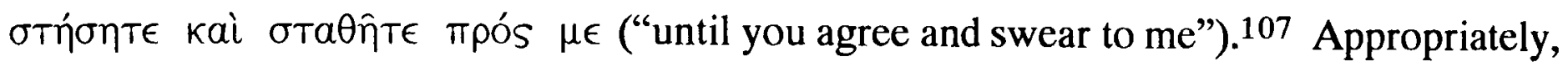
after Raguel's declaration and following the writing out of a marriage contract and a meal (7:14), the couple sleep together, and Tobias addresses Sarah, his wife, as "sister" $(8: 4,7)$.

\subsubsection{Further biblical texts, or expressions, which may allude to the marriage formula}

Although a number of scholars have suggested that the idiomatic expressions היה + אשיה + איל, which refer to marriage, may derive from marriage formulae, the evidence for this hypothesis is not compelling. ${ }^{108}$

More likely is a possible allusion to the marriage verba solemnia in an expression, repeated with variations, found in Song of Songs: "My beloved is mine and I am his [רוֹרי

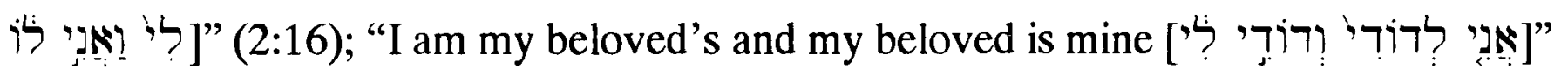

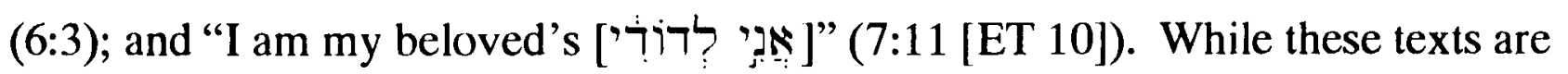
comparable to other examples of relationship formulae, none of them occurs within the context of marriage formation. ${ }^{109}$ Accordingly, their evidence for the use of verba solemnia in marriage is, at best, indirect. Nevertheless, these texts may help to underscore the mutual belonging of (marital?) love and, as such, may support the assumption of reciprocal marriage formulae during the biblical period.

105 M. A. Friedman, "Israel's Response in Hosea 2:17b: 'You are My Husband," 203.

$106 \mathrm{Z}$. W. Falk explains this as due to the fact that Sarah was a potential heiress, requiring marriage to a relative, and the related fact that there had been no marriage present (Introduction to Jewish Law of the Second Commonwealth, vol. 2 [1978] 281).

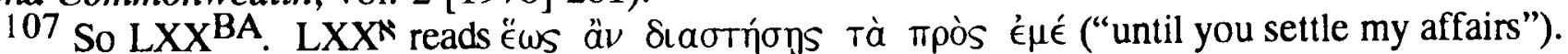

108 L. M. Epstein, The Jewish Marriage Contract (1927) 1-52, esp. 55; Z. W. Falk, Hebrew Law in Biblical Times (1964) 142; H. L. Ginsberg, "Studies in Hosea 1-3," 53; and H. J. Hendriks, op. cit., 60.

109 Cf., e.g., Deuteronomy 26:17f.; 29:12 [ET 13]; Hosea 2:24; Jeremiah 7:23; 11:4; 24:7; 31:33; Ezekiel 34:30f.; 36:28; 37:23; and perhaps Psalm 95:7; 100:3 -- all as cited by M. H. Pope, Song of Songs, 405. 


\subsubsection{Conclusions}

In his rejection of the identification of marriage as a covenant, J. Milgrom concedes that "The betrothal/marriage rite might be conceived as a covenant if there were a mutual exchange of verba solemnia even though an oath formula was not used."110 While not every example considered above proved equally convincing, from a broad range of biblical and extrabiblical evidence there can be little doubt that marriage in biblical times was, in fact, typically formed with the use of verba solemnia.

Furthermore, from the many different examples considered, it is apparent that a wide variety of formulae were permissible; hence a case such as Genesis 2:23 cannot be rejected merely because it fails to reproduce the standard formula of the much later (Gaonic) Babylonian $k^{e} t u b b a \hat{~}$. In addition, while verba solemnia were nearly always declared by the groom (Tobit 7:12 is the only exception), it is notable that at times a reciprocal formula was pronounced by the bride as well. ${ }^{111}$

Finally, in many cases the verba solemnia may have been articulated before human witnesses, as often they were repeated in documentary form (i.e., in the marriage contracts) before human witnesses. If so, presumably this served the practical purpose of providing necessary public evidence for the new marital status of the individuals involved. ${ }^{112}$ Most examples, however, leave unmentioned the presence of human witnesses, ${ }^{113}$ perhaps allowing the implication that the primary witness was the deity. ${ }^{114}$ In any case, a few examples, in particular "the etlu tablet," perhaps Tobit 7-8, and especially Genesis 2:23, are explicit in their recognition that the deity was witness to the marriage-forming verba solemnia. ${ }^{115}$ Furthermore, the marriage analogy in Hosea 1-2, which utilizes the verba solemnia of marriage to represent divine covenant-forming verba solemnia (2:17-19 [ET 15-17]), tends to a similar conclusion. In Chapter 8 supportive evidence will be sought for this implication, namely that in the minds of at least some Old Testament authors, the deity was understood to have been a witness to the marital verba solemnia (and/or oath-sign)

110 Cult and Conscience, 135 , n. 487.

111 The clearest evidence for mutual formulae is from the $O B$ legal document from Ishchali and from Hosea 2:17-19 [ET 15-17]. However, mutual formulae may also be implied by the corresponding mutual formulae for the disavowal of marriage or divorce, which are attested for most periods. Finally, it is possible that the mutual character of documentary formulae such as "she is my wife and I am her husband," attested at Elephantine, for example, may imply that the corresponding original oral formulae were pronounced by both husband and wife (although the similar oral formula known from the OB etlu tablet and the ardat lili tablet demonstrate that this is not a necessary conclusion).

112 Cf. MAL A \$41. Cf. also R. Westbrook, “Old Babylonian Marriage Law,” II, 125.

$113 \mathrm{Cf}$. the analogous situation of the legitimating formula in $\mathrm{CH} \$ \$ 170-171$.

$114 \mathrm{Cf}$. the treatment of oath-like character of verba solemnia in the previous chapter.

115 The context of the verba solemnia in Tobit is thoroughly religious, with Raguel pronouncing a blessing on the couple immediately following his pronouncement. Cf. also Raguel's command to Tobias, to "take her [Sarah] according to the law of Moses" in Tobit 7:12, with its apparent implication that his marital responsibilities were defined in the Scripture, which, if so, would imply their sanctioning by the deity. Cf. the similar mention of "the law of Moses" in the verba solemnia attested in the Babata marriage contract, marriage contracts from the Cairo Geniza, and the "traditional" Jewish marriage contract. 
and, accordingly, would judge marital offences even in cases which might not be humanly judiciable. Compare Malachi 2:14 and perhaps Genesis 31:50.

\subsection{Evidence suggesting that sexual union may be the requisite covenant- ratifying (and renewing) oath-sign for marriage}

Having established that verba solemnia were customary for marriage in the Old Testament, we shall now investigate the significance of gifts and especially sexual union in the contraction of marriage. In general, verba solemnia do not take the place of symbolic acts in effecting changes in legal status, contracts, or covenants, but rather typically supplement them. ${ }^{116}$ In fact, as opposed to our modern prejudice in favour of consensual contract with its almost exclusive emphasis on the written word, or at least the spoken word, it appears that the ancients often considered symbolic acts to be the constitutive instrument for effecting a desired legal outcome. 117 As a consequence, there is a prima facie likelihood that, if marriage was a covenant, there may have been a covenant-ratifying oath-sign or even a variety of such oath-signs associated with the formation of marriage.

A considerable number of ceremonies and symbolic rites are known to have been associated with the formation of marriage elsewhere in the ancient Near East (e.g., cf. a prenuptial bath, perhaps for both bride and groom; pouring oil on the bride's head; clothing of the bride [or perhaps tying clothes together between bride and groom]; sewing the dowry into the bride's garment; and a processional celebration for the removal of the bride from her father's home to that of her husband). ${ }^{118}$ Some of these rites were even mandatory (e.g., cf. the need to settle a marriage contract [riksātu] in LE §§27-28 and $\mathrm{CH} \S 128$; the required kirrum in LE $\$ \S 27-28$, generally understood as some kind of formality involving beer; or the veiling of the bride in MAL A \$\$40-41). Nevertheless, the biblical evidence for these or any other wedding ceremonies is regrettably scant. ${ }^{119}$ Some texts are so terse the

116 So M. Malul, op. cit., 2-3, 51, 85, and passim.

117 Cf. M. Malul, op. cit., 2ff., 88, and passim.

118 Cf. MAL A §\$42-43. Cf. also S. Greengus, "Old Babylonian Marriage Ceremonies and Rites" (1966) 55-72; R. Yaron, The Laws of Eshnunna, 2nd. ed. (1988) 59, 200-205; R. Westbrook, "Old Babylonian Marriage Law," I, 52; II, 155; and M. Malul, op. cit., 152, 161-197; 345.

M. Malul, for example, notes how the groom's and bride's garments could be tied together to symbolize marriage (op. cit., $200 \mathrm{n} .197,345$ ). By contrast, there is some evidence that when a couple divorced their clothes would again be tied together, only this time it would be in order to immediately cut them apart (op. cit., 206f.).

119 Cf., e.g., O. J. Baab, "Marriage" IDB 3 (1962); S. B. Parker, "The Marriage Blessing in Israelite and Ugaritic Literature" (1976); E. M. Yamauchi, "Cultural Aspects of Marriage in the Ancient World" (1978) 241-252; P. A. Kruger, "The Hem of the Garment in Marriage" (1984); and M. Malul, op. cit., 196, n. $125 ; 336 f$.

Prior to the formation of marriage, one may consider circumcision (Genesis 34:22ff.; Exodus 4:24-26 is doubtful); a gift of clothes or covering of the bride (Ezekiel 16:10-12, and perhaps, Ruth 3:9); and anointing the bride (Ezekiel 16:9, though it is more likely that this anointing, and washing and clothing, are merely illustrative of Yahweh's exemplary care, by contrast to Ezekiel 16:4-5).

Actions which are expressive of the joy of a wedding include music, songs and group celebrations which need not imply any particular formalities (Psalm 78:63; Jeremiah 7:34; 16:9; $25: 10$; cf. also Isaiah 
impression is left that marriage, at least at times, could have been contracted almost entirely without ceremony. Compare, for example, Genesis 24:67, "Then Isaac brought her into the tent, and took Rebekah, and she became his wife; and he loved her."120 Even where ceremonies are mentioned, or alluded to, it would seem unwarranted to assume that any given rite was necessarily universally practiced. Furthermore, because of the limitations of our evidence, the symbolism and legal consequences, if any, of any individual ceremony are often very much in doubt.

In any case, besides the verba solemnia discussed earlier, two actions especially have dominated scholarly discussion of the formation of marriage and are thought to be indispensable for its validity. These are the payment of a betrothal present (terhatum / (פ) $)^{121}$, and sexual intercourse (the copula carnalis).

62:4-5), as well as the donning of special wedding attire (Isaiah 61:10; perhaps Song of Songs 3:11; Psalm 45:13-14; Jeremiah 2:32; a veil is mentioned in Genesis 24:65 and may be implied in implied in Genesis 29:23, 25 -- cf. MAL A \$\$40-41), though not royal attire (cf. M. Pope, Song of Songs, 141-144); a procession of bride and groom (1 Maccabees 9:37-39); and a common meal (Genesis 24:54 and Genesis 29:22).

While Genesis 24:54 indicates that the common meal lasted only a single evening (though the family may have wished for ten days, cf. Genesis 20:55), from Genesis 29:27 it appears that the wedding feast and celebration were intended to last an entire week. Judges 14:12, likewise, mentions a week long marriage feast, but from the context it is clear that this practice was either confined to Philistia, or at least it was no longer being observed in Israel in the period of the author/editor of the text: "And his father went down to the woman, and Samson made a feast there; for so the young men used to do" (Judges 14:10). On the other hand, by the time of Tobit $8: 19 ; 10: 7$, the wedding banquet lasted two weeks (preceded by a meal between the father-in-law and groom in 7:14 and 8:1). Cf. also Judges 19:4-9.

Other briefly mentioned ceremonies and rites include the giving of a dowry [שלוּחים] to the bride from her family (1 Kings 9:16; Micah 1:14; Tobit 8:21; and perhaps 1 Samuel 25:42), bridal gifts given by the husband to his bride at the time of the wedding (termed כִ כִ "blessing," in Joshua 15:19 and Judges 1:15; but appearing without the term in Hosea 2:17), and a possible allusion to the kirrum ceremony in Genesis 49:6 (as pointed out to the writer by G. J. Wenham; cf. D. W. Young, "A Ghost Word in the Testament of Jacob [Gen 49:5]?" [1981] 335-342).

Other actions may be intended primarily as expressions of the consent of the bride's family. These include the presentation of the bride to the groom by her father (Tobit 7:13; cf. also Genesis 2:22 and Genesis 29:23); the writing of a marriage contract, or a contract for cohabitation (if with $S$. Zeitlin,

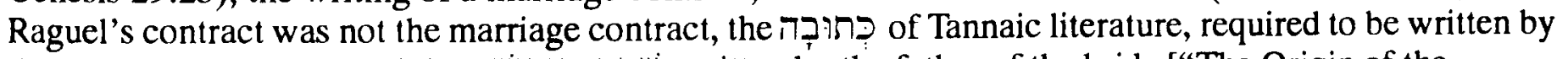

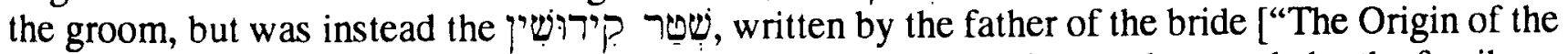
Kethubah: A Study in the Institution of Marriage"]); and a blessing on the couple by the family and other guests (Genesis 24:60; Ruth 4:11; and Tobit 10:12).

120 Though even this text mentions Rebekah's self-veiling in vs. 66, perhaps reflective of the ancient Near Eastern practice cited above. In any case, naturally this marriage takes place under exceptional circumstances, since most of the attested celebrations appear to have taken place at the wife's home, while Rebekah's marriage takes place hundreds of miles from her father's house. Cf. also Genesis 38:2.

121 The terminology and significance of marriage prestations in cuneiform law and practice is complex, and, at many points, very uncertain. For a recent discussion of this topic, cf. G. Cardascia, Les lois assyriens (1969); R. Westbrook, “Old Babylonian Marriage Law," II, passim; M. T. Roth, "Marriage and Matrimonial Prestations in First Millennium B.C. Babylonia" (1989) 245-255; and R. Westbrook, et al., "Responses to Prof. Roth's Paper" (1989) 256-260.

The following chart, may be useful for the present discussion.

Label $=$ Definition

OB laws
OB demts
MAL NB

Dowry = property provided by the

bride's family (a daughter's share of her 
father's estate). The meaning of sirku, appearing only in MAL A $\S 9$, is uncertain according to $\mathrm{G}$. Cardascia and R. Borger, Babylonisch-Assyrische Lesestücke, II, 275. Dowry is termed mulügu in Amarna and Nuzi texts.

siriktum nudunnũm sirku(?) nudunnũ nudunnũ

Alternative term for dowry, when restricted to slaves

Alternative term for dowry, when restricted to cash -- perhaps more accessible to the wife, with the husband's access correspondingly more limited.

Bridewealth or marriage present $=$ property given by the husband, or his family, to the bride's family (this use of biblu $(m)$ is mentioned only in $\mathrm{CH}$ $\S \S 159-161$, MAL A $\$ 30$, and M. T. Roth, Babylonian Marriage Agreements, Nos. 34, 35).

biblum biblu biblu

Alternative term for Bridewealth or marriage present

Alternative term for Bridewealth or marriage present

$\begin{array}{lccc}\text { terhatum } & \text { terhatum } & \text { terhutu } & \\ \text { zubullũm } & & & \\ & & & \\ \text { nudunullũ } & \\ & \text { siriktum } & \text { nudunnũ } & \text { širiktu } \\ & & & \\ & & \text { nungurtu }\end{array}$

Widow's settlement $=$ property given by the husband to the wife in anticipation of her maintenance needs as a widow.

"Dower" or the nungurtu-settlement = property given by the father of the groom to the groom.

quppu

mulūgu

terhutu

R. Westbrook differs from M. T. Roth's view regarding the nudunnũm / širiktum, "widow's settlement" ("Responses to Prof. Roth's Paper" [1989] 256f.). Westbrook considers this term in the OB period (and $\mathrm{CH}$ ) to describe the totality of the property of the wife, or what is assigned to the wife, including the dowry as well as any further special gifts to the bride from the groom. Confusingly, these special gifts may also be called nudunnüm, and hence, the nudunnüm in its broad sense would include the nudunnüm in the narrow sense. In other words, while nudunnüm elsewhere includes the siriktum, in $\mathrm{CH}$ $\$ \$ 171-172$ these terms are used contrastively because in this case nudunnum refers merely to the special gifts from the husband (for which reason these laws are careful to qualify the term with "which her husband gave to her [ša mussa iddinǚsim]," or "her husband did not give to her [mussa ... la iddinüsim]").

Unfortunately, there are no examples in either $\mathrm{CH}$ or in MAL where nudunnũ $(m)$ bears the comprehensive meaning posited by Westbrook. Besides $\mathrm{CH} \S \$ 171-172$, the term appears also in MAL A \$27. According to the restored text of G. R. Driver and J. C. Miles, nudunnũ also appears in MAL A §32. But this is almost certainly wrong since nudunnũ is not feminine, as would be required by the following tadnat (a third person, feminine singular $\mathrm{I} / 1$ Stative of of tadānu).

According to W. Lambert (oral communication) the biblu(m) mentioned in $\mathrm{CH} \S \S 159-161$ as well as MAL A $\$ 30$ may have been a douceur. The key to this interpretation is the recognition that there are two engagements in MAL A $\$ 30$, with the initial one (where sinniltu is used) not having progressed as far as the second one (where ašsatu is used). The biblu(m) only expresses interest in a marriage, it is not a "bride price" or "marriage present." Lambert suspects this was a gift given to the future father-in-law when the man initiates his own marriage, rather than having his parents arrange it. The biblu(m) would offer tangible proof that the young man was at one point quite eager for the marriage. For other evidence for this older 


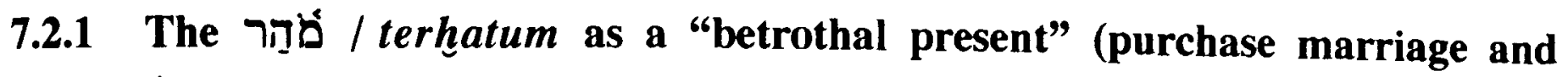 the מִָרָ / terhatum as a "bride price" refuted)}

According to the majority view of an earlier generation of scholars, especially following P. Koschaker and E. Neufeld (who applied Koschaker's theory to Israelite practice), marriage throughout the ancient Near East (or at least in OB, Nuzian, and MA practice) conforms to the pattern of "marriage by purchase." 122 In other words, it was argued that the husband legally purchased his bride from her guardian, usually her father, by paying a "bride price," the terhatum / מִ. 123 As in all sales transactions, the sale would be completed not by the use of the object purchased (in the case of marriage, this would be the copula carnalis), but merely by its transfer, the traditio (which in the case of marriage would imply a consummation of the marriage by the in domum deductio). ${ }^{124}$

Having been repeatedly criticized from its inception, especially by G. R. Driver and J. C. Miles, Koschaker's theory of "marriage by purchase" and his corresponding identification of the terhatum / פָרָר a a "bride price" has been all but abandoned among recent Assyriologists. ${ }^{125}$ In addition to a number of studies which have challenged its applicability to Hittite, Egyptian, Nuzian, and Israelite practice, most recently the theory has

view, that the biblu(m) was an engagement gift, by contrast to the terhatum, the bridal gift, cf. P.

Koschaker, Rechtsvergleichende Studien zur Gesetzgebung Hammurabis, 133f.; F. Mezger, "Promised but not engaged," 28-31; and G. R. Driver and J. C. Miles, The Babylonian Laws, 249-265.

Against this view, cf. J. Renger, "Who are all those People?" (1973) 259-273, 267-72; R. Westbrook, "Old Babylonian Marriage Law," II, 303-306. Westbrook concludes that the biblu(m) "is a gift of various items other than money made on the occasion of 'marriage' celebrations by members of the groom's family to members of the bride's family" (op. cit., 305).

122 P. Koschaker expressed his views regarding OB purchase marriage in "Zum Eherecht," Chapter 2 in his Rechtsvergleichende Studien zur Gesetzgebung Hammurapis (1917) 111-235, and idem, "Eheschliessung und Kauf nach altem Recht, mit besonderer Berücksichtigung der älteren Keilschriftrechte" (1950) 210-296. Koschaker's views for MA practice are expressed in his "Quellenkritische Untersuchungen zu den altassyrischen Gesetzen" (1921), and his views regarding Nuzi practice are in "Neue keilschriftliche Rechtsurkunden aus der El-Amarna Zeit" (1928).

Koschaker later argued that all marriages in which a terhatum is mentioned are purchase-marriages ("Fratriarchat, Hausgemeinschaft und Mutterrecht in Keilschriftrechten" [1933] 24).

Cf. also E. Neufeld, Ancient Hebrew Marriage Laws (1944) 94-117.

123 P. Koschaker, Rechtsvergleichende Studien zur Gesetzgebung Hammurapis, 130, 137, 197; and idem, "Eheschliessung und Kauf nach altem Recht, mit besonderer Berücksichtigung der älteren Keilschriftrechte," 212.

124 P. Koschaker, Rechtsvergleichende Studien zur Gesetzgebung Hammurapis, 115, 141 (where Koschaker denies that Babylonian law ever regards copula carnalis as decisive); idem, "Eheschliessung und Kauf nach altem Recht, mit besonderer Berücksichtigung der älteren Keilschriftrechte," 287.

The in domum deductio may not be strictly necessary for there to be the requisite removal of the bride from the physical control of the her parents. Cf. R. Westbrook, "Old Babylonian Marriage Law," II, 126.

125 G. R. Driver and J. C. Miles, The Assyrian Laws (1935) 142-173; and idem, The Babylonian Laws, I, 259-265. Cf. also M. Burrows, The Basis of Israelite Marriage (1938) passim; A. van Praag, Droit matrimonial assyro-babylonien (1945) 139-143; A. J. Skaist, "Studies in Ancient Mesopotamian Family Law Pertaining to Marriage and Divorce" (1963); and R. Yaron, The Laws of Eshnunna (1988) 174179. 
been rejected decisively by $R$. Westbrook for the OB period, the very period for which the evidence had been thought to be the strongest. 126

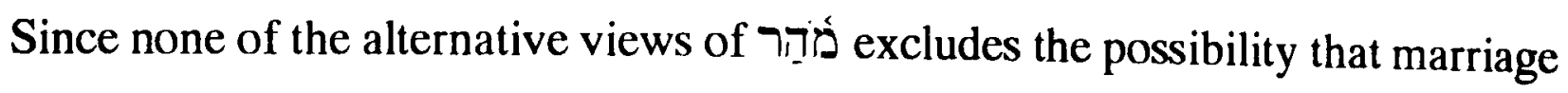
may have been consummated in sexual union, as does Koschaker's view, or that the marriage itself may have been a covenant between a husband and wife, we do not need to consider these views any further in the present context. Here we merely record our agreement with the main substance of M. Burrows' view regarding the מִהּר more precision by $\mathrm{R}$. Westbrook with respect to the terhatum.

In contrast to Koschaker's attempt to compare the law of marriage to that of sale, and hence to identify the terhatum as the price, Westbrook argues persuasively that the comparison ought rather to be between marriage and adoption and that this analogy was one which was recognized by ancient jurisprudence. 127 Like adoption, marriage is a status with rules peculiar to itself. ${ }^{128}$ Just as there are two modes of adoption, there are also two

126 R. Westbrook, “Old Babylonian Marriage Law,” II, 137-149.

Against the identification of Hittite kušata $(\mathrm{HL} \$ \S 29-30,34)$ as a "bride price" and the applicability of the theory of marriage by purchase to Hittite practice, cf. F. Mezger, "Promised but not engaged" (1944) 2831.

Against the application of the theory of purchase marriage to Egyptian practice (or the identification of the $̌ p$ as a "bride price"), cf. E. Lüddeckens, Ägyptische Eheverträge, I (1960) 3; P. W. Pestman, Marriage and Matrimonial Property in Ancient Egypt (1961) 49f., 182-184; and H. J. Hendricks, op. cit., 27-28.

With respect to Nuzi practice, cf., e.g., K. Grosz, "Some Aspects of the Position of Women in Nuzi" (1989) 171.

Naturally, if the theory of marriage by purchase is untenable for cuneiform practice, this removes a principal argument for its application in Israel. Nevertheless, for arguments against this theory based on the biblical evidence, cf., inter alios, M. Burrows, The Basis of Israelite Marriage, passim; H. Weiss, "The Use of QNH in Connection with Marriage" (1964) 246; and W. Plautz, "Die Form der Eheschliessung im Alten Testament" (1964) 298-318.

Ironically, Genesis 31:14-16, a text which frequently is cited in support of the theory of purchase marriage in the Old Testament (cf., e.g., E. Neufeld, Ancient Hebrew Marriage Laws, 98, n. 2), proves on closer examination to offer significant evidence against this view. Had Rachel and Leah held that marriage consisted of a woman being sold to her husband, they could have raised no complaint at what Laban had done. On the contrary, however, the very force of their complaint stems from the irregularity of Laban's demeaning treatment of them -- "Are we not regarded by him as foreigners?" they ask, the implication being that one might sell a foreigner, but surely never a daughter! As a result, they insist that Laban had defrauded them of what was rightfully theirs, namely "the money given for us." Whatever רָ' had accrued from Jacob's years of labour, Laban was using up when it should have been returned in their dowry, or inheritance, as was customary throughout the ancient Near East. Rightfully, it belonged to them. In other words, Leah and Rachel themselves reject Laban's apparent view of marriage by purchase! Cf., e.g., C. Westermann, Genesis 12-36, 492.

For the practice of returning the terhatum / מִ with the dowry, a practices which undermines the theory of marriage by purchase, cf., e.g., $\mathrm{CH} \$ \S 163 \mathrm{f}$. Cf. also A. van Praag, Droit matrimonial assyrobabylonien (1945) 152ff.; M. Burrows, op. cit., 44; G. R. Driver and J. C. Miles, The Babylonian Laws, I, 253ff.; I. Mendelsohn, "On Marriage in Alalakh" (1959) 352ff.; R. de Vaux, Ancient Israel, I, 26-29; R. Yaron, Introduction to the Law of the Aramaic Papyri (1961) 47ff.; S. Dalley, "Old Babylonian Dowries" (1980) 53-74, at 57f.; K. Grosz, "Dowry and Brideprice in Nuzi" (1981) 161-182, esp. 170; R. Westbrook, "Old Babylonian Marriage Law," II, 300-303; and M. T. Roth, Babylonian Marriage Agreements 7th - 3rd Centuries B.C., $11 \mathrm{f}$.

127 “Old Babylonian Marriage Law," II, 150.

128 Westbrook defines a "status," distinguishing it from "contract," as a "set of rights and obligations between persons the extent and character of which is determined by the general rules of law.... But it is its own rules, not the agreement of the parties, which give the status its substance" ("Old Babylonian Marriage Law," I, 151f.). Cf. also the distinction between status and contract discussed by M. T. Roth, "She will die by the iron dagger': Adultery and Neo-Babylonian Marriage," 187, 189, 190. 
modes of marriage. In the primary mode, where no third party is involved, a man adopts a foundling, an orphaned baby he finds in the market place. ${ }^{129}$ Under such a circumstance, by the unilateral act of adoption without any contract the law simply accords the relationship the status of "sonship" [mârütum].

The second mode of adoption differs from the first by the fact that the adoptee has natural parents. In this case, before the adoptive relationship can be created, the legal relationship of the adoptee to his natural parents must first be extinguished. This dual transaction in which the natural parents first relinquish their rights of control over the child to allow the adoptive parent to perform his act of adoption is typically recorded in an adoption document (the form and content of which is remarkably parallel to that of the marriage documents $\left.{ }^{130}\right)$. The contract, however, is ancillary to the adoption itself.

While the adoption documents offer no direct analogy for the terhatum, Westbrook argues that the terhatum was the price paid, not for ownership of the bride, as Koschaker had argued, or even for the right of cohabitation, since persons other than the groom at times paid the terhatum, but for the right to exercise control over the bride for a specified purpose. ${ }^{131}$ "In the marriage documents the marriage formula expresses the transfer of control over the bride from her parents to the groom for the purpose of marriage; in the kallutuin documents the formula expresses transfer of control from parents to parents-inlaw for the purpose of daughter-in-lawship."132 In each case the parents are not ceding all of their rights as parents, but only this one aspect which is necessary for the parents-in-law to perform their duty or for the groom to perform the act of marriage.

\subsubsection{1 מִֹ formative not of marriage, but of betrothal}

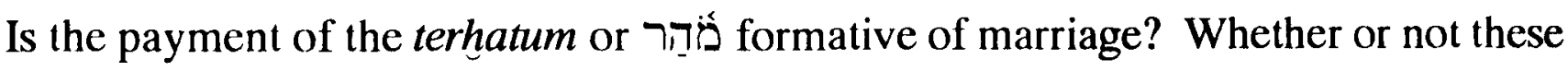
payments were obligatory to gain the required consent of in-laws, there is no evidence that

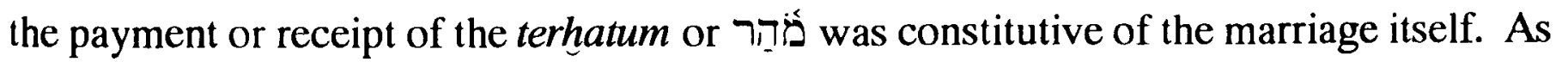
summarized by M. Burrows, "what mohar effected was not marriage but betrothal."133 Compare, for example, 2 Samuel 3:14, in which David is quite explicit about the legal import of the מָּה as effecting his betrothal [ארש]: "Give me my wife Michal, whom I betrothed at the price of a hundred foreskins of the Philistines

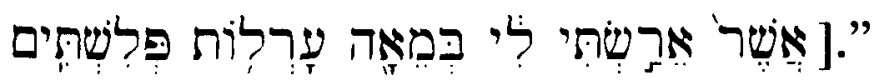

129 Westbrook notes that this is the situation, for example, recorded in UET 5260 ("Old Babylonian Marriage Law," II, 186, n. 74).

130 Westbrook considers this parallelism of form and content between the marriage contracts and adoption contracts to be supportive of the analogy between marriage and adoption (op. cit., II, 150f.).

131 Ibid., II, 155.

132 bid., II, 156. In both cases ahāaum expresses the transfer of control.

133 The Basis of Israelite Marriage, 20. 
Certainly, when the terhatum is paid a woman gains the title of "wife" [aššatum, according to $\mathrm{CH} \$ 161$ ]; 134 but, with Westbrook, it appears that this does not imply the full legal status of wife. This intermediate status, termed "inchoate marriage" by Driver and Miles, has implications only for third persons. ${ }^{135}$ In Westbrook's words, the terhatum "is effective to change betrothal into inchoate marriage, with a sharp rise in the protection of the groom's interest and drastic consequences upon the conduct of third parties [LE §26]."136 With respect to the couple themselves, however, it is still legally possible to prevent the marriage from taking place; hence the terhatum did not itself effect a marriage. 137

As A. Skaist observes more generally, one must be careful to distinguish two distinct relationships which were involved in the formation of marriage in ancient Near Eastern practice. ${ }^{138}$ The first is attested in the documents (i.e., the riksātum) and consists of a contract between a husband (or his guardian) and his father-in-law (or other guardian of the bride). ${ }^{139}$ In terms of this relationship in which the terhatum plays a vital role, the wife appears as an object with the husband invariably marrying the wife, acquiring her from her father or other guardian (he "takes" her, she is "given" to him, etc.). The second relationship is the marriage proper, a relationship which exists between a husband and his wife.

If one considers only the first of these aspects of marriage, for example, if one supposes that the husband and the father-in-law create the marriage, it should be expected that only the husband and the father-in-law would have the authority to dissolve the marriage. Conversely, just as a piece of land cannot alter an agreement between a buyer and a seller, so it might be supposed that the wife would have no right to dissolve the marriage. In reality, however, there is no evidence that the bride's father can dissolve a marriage once it is formed; in fact, there is no evidence that he plays any continuing role in

134 Cf. V. Korosec, "Ehe," in $R L A$, II, 282.

H. J. Hendriks cites $\mathrm{CH} \S 160$ as evidence that "a marriage is legally effected" with the bringing and acceptance of a terhatum (op. cit., 19). CH $\$ 160$ does not, however, support this view. It proves only that acceptance of the terhatum (and/or biblum) obligates a father-in-law to give his daughter in marriage and that, should he fail to do so, he will will incur a financial penalty.

135 Cf. R. Westbrook, op. cit., 50. Cf. LE §26. Cf. also Deuteronomy 20:7; 22:23-29; Exodus 22:16-17; 1 Samuel 18:25; and 2 Samuel 3:13.

Following common practice, the present study employs the terms "betrothal" and "inchoate marriage" interchangeably to refer to the married status of couples prior to their cohabitation. R. Westbrook, however, prefers to distinguish these terms and employs "betrothal" to refer only to the preliminary stage in the marriage negotiations preceding the giving of the terhatum (op. cit. 51).

136 lbid., II, 153.

137 Ibid., II, 50.

138 A. J. Skaist, "Studies in Ancient Mesopotamian Family Law Pertaining to Marriage and Divorce" (1963) $7 \mathrm{f}$.

139 This understanding of the riksātum is preferable to that of S. Greengus who assumes that the contract mentioned in LE $\S \S 27-28$ and $\mathrm{CH} \S 128$ is a contract between the bride and groom. Against S. Greengus on this point, cf. R. Westbrook, “Old Babylonian Marriage Law,” II, 56-58. 
the marriage. Furthermore, contrary to expectation, for most of the ancient Near East there is substantial evidence that the wife did have a legal right to dissolve the marriage. 140

Accordingly, it is the conclusion of the present study that the terhatum / פִ was not a "bride price," but was instead a "betrothal present," that is, a gift or payment which effected not marriage but betrothal, as noted already by M. Burrows. 141 Furthermore, although a number of other ceremonies may have accompanied a wedding, no rite other than copula carnalis may be deemed constitutive of the marriage itself in a manner such as would permit it to be identified as an oath-sign.

\subsubsection{Sexual Union}

It is the burden of the present section to attempt to demonstrate that sexual union (copula carnalis), when engaged in with consent (i.e., both parental, in the case of dependent daughters, and mutual consent between the parties), was understood as a marriage-constituting act and, correspondingly, was considered a requisite covenantratifying (and renewing) oath-sign for marriage, at least in the view of certain biblical authors.

Before turning to this posited covenant-ratifying implication, however, we must first consider the evidence that sexual union did, in fact, consummate marriage (contrary to the implication of the theory of purchase-marriage).

\subsubsection{Ancient Near Eastern evidence for the role of sexual union in the consummation of marriage}

G. R. Driver and J. C. Miles argue that in both OB and MA practice "inchoate marriage" was effected by the giving and receiving of the terhatu $(m)$, while marriage itself was completed by sexual union, for which the riksu offered confirmatory evidence. ${ }^{142}$

$140 \mathrm{Cf}$. CH $\$ 142$. For examples among OB marriage documents, cf. A. Poebel, Babylonian legal and business documents from the time of the 1. Dynasty of Babylon, vol. 6:2 (1906) nos. 40, 59. Cf. also A. J. Skaist, op. cit., 154-160; E. Lipiński, "The Wife's Right to Divorce in the light of an Ancient Near Eastern Tradition" (1981) 22f.; and Y. Zakovitch, "The Woman's Rights in the Biblical Law of Divorce" (1981) 28-46. Cf. also R. Westbrook, op. cit., II, 223-238. See also footnote 58 above.

141 Op. cit., 20.

142 The Assyrian Laws, 172. Cf. also M. Burrows, op. cit., 19.

Similarly, A. van Praag argues that copula carnalis consummates marriage, while the terhatu(m) was originally intended to provide evidence for the legitimacy of the marriage, that it was not merely "concubinage" (Droit matrimonial assyro-babylonien [1945] 87f.). According to Van Praag, although the terhatu $(m)$ continued to be paid in later periods, its evidentiary value was rendered redundant with the advent of written marriage contracts.

R. Westbrook criticizes Van Praag, however, for identifying alläzum in CH $\$ \S 128,142,159-61$, etc. as a reference to sexual relations (Old Babylonian Marriage Law, II, 182, n. 22). Westbrook argues that in legal contexts related to marriage ahāaum is not euphemistic for sexual intercourse, but is used to express "the acquisition of control over a woman by a man, sometimes expressly by way of transfer from her parent 
This understanding of sexual union as consummating marriage is perhaps most evident in $\mathrm{CH} \$ \S 155 \mathrm{f}$. If a man is caught having relations with a daughter-in-law whom he chose for his son [ana mârǐsu kallatam ihîrma] after his son has "known her [ilmassi]," this is considered a capital offence. If, however, his son has "not yet known her [la ilmassima]," a financial penalty is imposed on the father-in-law, and the girl is permitted to leave and be married by another man. Other laws demonstrate that betrothal already confers on a woman the protective status of "wife [aššatum]" with respect to outside parties, rendering any extramarital sexual intercourse to be treated as adultery. ${ }^{143} \mathrm{It}$ is readily apparent, however, from a comparison of the present two cases that when a woman is betrothed or promised, sexual union with her promised husband decisively changes her status with respect to this man and any other persons having control over her (e.g., her father-in-law).

\subsubsection{Biblical evidence for the formation of marriage by sexual union}

\subsection{Deuteronomy 21:10-14}

R. Westbrook's analogy between marriage and the two modes of adoption is helpful for understanding the mode of marriage in Deuteronomy 21:10-14, which is analogous to the primary mode of adoption, that is, cases in which a third party (the adoptee's natural parent) is not involved:

When you go forth to war against your enemies... and see among the captives a beautiful woman, and you have desire for her and would take her for yourself as wife, then you shall bring her home to your house, and she shall shave her head and pare her nails. And she shall put off her captive's garb, and shall remain in your house and bewail her father and her mother a full month; ${ }^{144}$ after that you may go in to her, and be her husband, and she shall be your wife

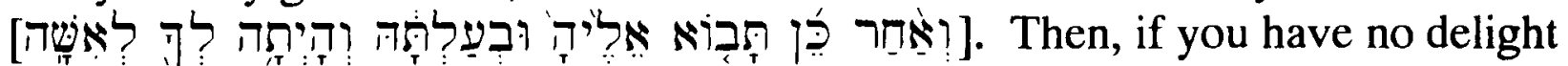
in her, you shall let her go where she will; but you shall not sell her for money, you shall not treat her as a slave, ${ }^{145}$ since you have had your way with her.

or guardian, and specifically for the purpose of placing both in the status of marriage" (op. cit., 4; cf. also pp. 1-19).

While this understanding of ahăzum is convincing for expressions like ana ašsūtim ahōaum, "to take for wifeship," which find a counterpart in the parents' promise ana ašsutim nadanum, "to give for wifeship," it is not so clear in other contexts, such as $C H \$ 142$ or $C T 837 \mathrm{~d}$. Westbrook's otherwise careful treatment appears to assume a false disjunction: either ahōaum in marital-legal contexts must always refers to sexual union (which he demonstrates is certainly not the case), or it may never do so (here his treatment is less convincing). In fact, it appears that $\mathrm{OB}$ ahāzum may, at times, have a sexual reference, as it does in MB -a usage conceded by Westbrook (op. cit., 19). Cf. the fuller discussion of ahäzum below.

Accepting $\operatorname{ch} \bar{a} z u(m)$ as a reference to intercourse in the relevant texts, M. Burrows argues that sexual union regularly consummates marriage in Mesopotamian practice (op. cit., 19, n. 13).

143 So G. R. Driver and J. C. Miles, The Babylonian Laws, I, 318f. Cf. also idem, The Assyrian Iaws, 162-164.

144 It may have been of more than incidental benefit that the month of mourning would also serve to assure the captor of his paternity of any children born to the union.

145 Or "merchandise." Cf., e.g., P. C. Craigie, Deuteronomy, 282. 
Because this woman was taken captive, there is no need to secure her parents' consent or to transfer control over the bride from them to the groom, and, accordingly, there is no mention of any marriage negotiations, marriage present, etc. Instead, in vs. 13

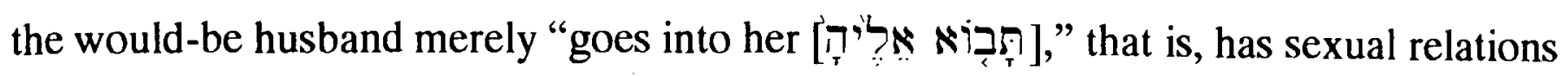
with her, and the result of this single act is that he becomes her husband, and she becomes his wife. In other words, vs. 13 does not describe three separate actions in temporal

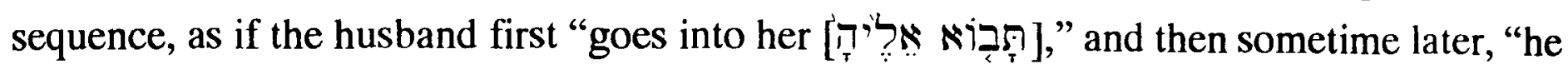

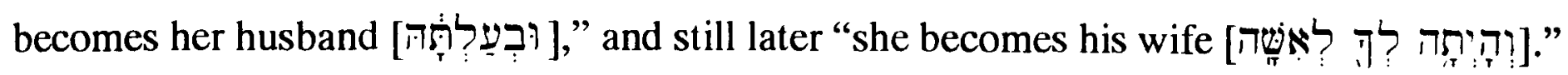
Rather, the last two clauses are epexegetical and, as such, are simultaneous reciprocal consequences of the first clause. ${ }^{146}$

\subsection{Deuteronomy 25:5}

A second example of Westbrook's "primary mode of marriage" is found in Deuteronomy 25:5, the case of levirate marriage, where, because of her widowed status, a bride can once again enter marriage without a transfer of control from her father (or other guardian): "If brothers dwell together, and one of them dies and has no son, the wife of the dead shall not be married outside the family to a stranger

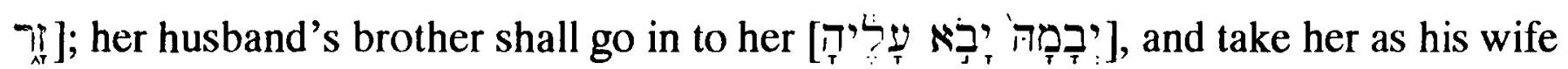

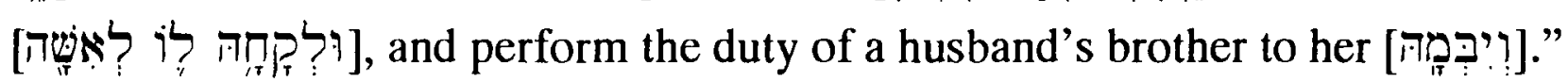

Without attempting to resolve here the many complexities of the institution of the levirate, this text identifies the brother's act of sexual union with marriage. The clause, "her husband's brother shall go in to her," is explained in the two subsequent clauses, each of which is introduced by a converted perfect: "he shall take her [החק "il] as his wife" and "he will perform the duty of a husband's brother to her [ה:?]?]." This sequence is hardly chronological, since the normal idiom would be first to "take" a wife and then to "go in to her."147

\subsection{Genesis 38:8, 18}

An illustration of Deuteronomy 25:5 is offered in Genesis 38:8: “Then Judah said to Onan, 'Go in to your brother's wife, and perform the duty of a brother-in-law to her, and raise up offspring for your brother." In this situation of widowhood, where marriage negotiations, etc., are neither present nor expected, the whole duty and formation of a levirate marriage is identified with sexual union. Accordingly, Judah's own unwitting sexual intercourse in vs. 18 appears to have sufficed to form a legal marriage from which 39.2.4.

146 For the converted perfect used to express epexegesis, cf. Waltke and O'Connor $\$ \$ 32.1 \mathrm{e}, 32.2 .3 \mathrm{e}$,

$147 \mathrm{Cf}$. the previous note. As is also the case with Deuteronomy $21: 10-14$, this abbreviated account does not exclude the possibility that there may have been various unrecorded ceremonies or rites which attended the marriage. It merely implies that these were without the decisive legal import which is accorded to sexual intercourse. 
issued Perez and Zerah as legitimate offspring and to have constituted a fulfilment of Judah's shirked obligation for levirate marriage (for which reason Judah rescinds his condemnation of Tamar for her supposed adultery). ${ }^{148}$ Whatever the precise explanation for Genesis 38:26, “... And he did not lie with her again,” this statement appears to presuppose the existence of a marriage between Judah and Tamar in which such relations would have been expected. 149

\subsection{Genesis 29:21-28}

Perhaps the clearest example of sexual union consummating a marriage is provided by Genesis 29:21-28. After having met his contractual obligation to work for Laban for seven years in exchange for Rachel, "Then Jacob said to Laban, 'Give me my wife that I may go in to her, for my time is completed"" (Genesis 29:21). ${ }^{150}$ From this verse it is apparent that copula carnalis is not only a characteristic feature of marriage, it is the decisive expression of the end of mere betrothal and, as such, consummates the marriage.

From the modern point of view where contracts are routinely nullified for an error in essentialibus, the following verses, Genesis 29:23-28, offer a surprising example of the irrevocable consequences of sexual union following the appropriate preliminaries of betrothal (payment of the marriage present, here in the form of seven years' labour, as well as the expressed desire for consummation on the part of the groom, and the consent of the guardian of the bride). On Jacob's wedding night Laban tricked Jacob into having sexual intercourse with Leah, rather than Rachel (perhaps helped by an unmentioned customary use of veiling ${ }^{151}$ ). In the morning Jacob discovers his error and complains bitterly about Laban's deceit. ${ }^{152}$ At no point, however, is any question raised about the validity of the marriage which was thus formed by sexual union. The legal consequences of this action for the creation of a valid marriage appear to have been deemed irreversible. ${ }^{153}$

\subsection{The legal implications of "premarital" sex}

Consistent with a predisposition to view sexual union as a marriage-forming act, Exodus 22:15, 16 [ET 16, 17]; Deuteronomy 22:28f.; as well as the examples of the

148 Cf. Ruth 4:12.

$149 \mathrm{C}$. Westermann, for example, suggests that apart from the initial sexual union intended to father a child for the deceased husband, any subsequent relations may have been deemed incestuous (Genesis 37-50, 55). However, given the acceptance elsewhere in Genesis of endogamous marriage (cf., e.g., Abraham and his half-sister, Sarah; etc.), this suggestion appears unconvincing.

${ }^{150}$ Ezekiel 16:32 differs in that its subject is a woman rather than a man, but also because it refers to adulterous unions as well as the rejected marital sexual union: "Adulterous wife, who takes strangers instead of her husband!"

151 So, e.g., D. Daube, Studies in Biblical Law, 191f.

152 Cf. Z. Jagendorf, “'In the morning, behold, it was Leah': Genesis and the Reversal of Sexual Knowledge" (1984) 187-192.

153 Another text which is less clear in the implication it attaches to sexual union is Deuteronomy 22:13-21. This is so because the husband's act may be mentioned not for its legal consequence, but for its practical consequence in accounting for the ensuing pregnancy. 
seduction of Dinah in Genesis 34 and that of Tamar in 2 Samuel 13, all encourage or insist on the formalizing of marriage following an act of "premarital" sex. This formalization consists simply of paying the marriage present, which, if accepted, constitutes an ex post facto approval of the union by the girl's parents and extinction of their parental authority over the bride.

\section{Exodus 22:15, 16 [ET 16, 17]}

Exodus 22:15, 16 [ET 16,17] stipulates, "If a man seduces a virgin/girl of marriageable age who is not betrothed, and lies with her, he shall give the marriage present for her, making her his wife. If her father utterly refuses to give her to him, he shall pay money equivalent to the marriage present for virgins/girls of marriageable age."

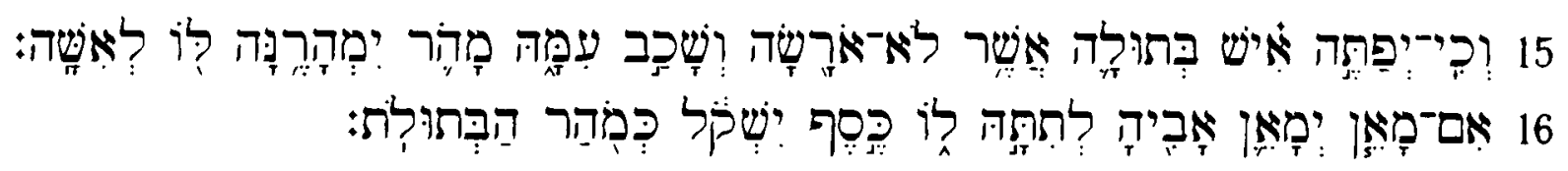

As recognized by most interpreters, the present law considers the case of the seduction of an unbetrothed nubile woman. The first condition, namely that the man seduces [פתה] the girl, is important not only because it emphasizes the man's primary responsibility for this illicit act -- he seduces her, not the reverse (cf., e.g. MAL A $\$ 56$ or SL $\$ 8^{154}$ ) -- but especially because it distinguishes the present case from that of rape, which is not explicitly considered in the Covenant Code. ${ }^{155}$ Such a concern with the presumption of consent, or lack thereof, on the part of a woman is recognized as of critical importance in determining culpability in cases of extramarital sex (i.e., whether such acts are to be prosecuted as adultery or rape) ${ }^{156}$ and would be a necessary consequence of the

154 MAL A §56: "If the virgin has given herself to the seignior, the seignior shall (so) swear and they shall not touch his wife; the seducer shall give the (extra) third in silver as the value of a virgin (and) the father shall treat his daughter as he wishes" $(A N E T, 185)$

SL §8: "If (a man) deflowered the daughter of a free citizen in the street, her father and her mother having known (that she was in the street) but the man who deflowered her denied that he knew (her to be of the free-citizen class), and, standing at the temple gate, swore an oath (to this effect, he shall be freed)" (ANET, 526).

With respect to the woman in SL $\S 8$, J. J. Finkelstein notes that her presence "in the street" implies loitering in a manner that causes the man to mistake her for a prostitute, to which misimpression he swears ("Sex Offences in Sumerian Laws" [1966] 357ff.).

Cf. further the legal recognition of the possibility of a (married) woman seducing a man in LU $\$ 4$, "If a wife of a man, by resort to her charms, enticed a(nother) man, so that he slept with her, he! (i.e., the husband) shall slay that woman, but that man shall be set free."

155 Cf. U. Cassuto, Exodus, 288. The failure of the Covenant Code to consider the case of rape is typical of its incompleteness (as is also the case with all ancient law collections). Cf., e.g., N. M. Sarna, Exploring Exodus, 168-171.

156 Cf. Deuteronomy 22:22-27.

This interest with the presumption of consent, or lack thereof, is abundantly paralleled in cuneiform law. The following are deemed cases of rape (where only the rapist is liable to a death penalty) based on the woman's lack of consent inferred from circumstantial evidence: LE §26; CH §155; MAL A §\$12, 23b; and HL \$197a. The following are deemed cases of adultery (where the woman and, usually, the man are both criminally liable) based on the woman's consent inferred from circumstantial evidence: LU \$4; LE \$28; CH $\S \S 129,133 \mathrm{~b}$; MAL A $\$ 13,14,15,16,23 \mathrm{a}, 23 \mathrm{c}$; and HL $\$ 197 \mathrm{~b}$. 
recognized need for volition in the contraction of covenants and the resulting nullity of covenants made under duress. ${ }^{157}$

The further qualification that the woman in question is "not betrothed" serves to distinguish the present case from that of adultery (cf. Deuteronomy 22:23-29). ${ }^{158}$ It is not

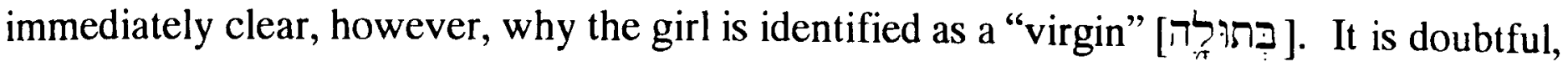
for example, that the text intends to stress her lack of previous sexual experience, since such a background would appear to be immaterial in the present case. In any case, as argued by G. J. Wenham, the term בִּתוּ לָדה refers to a girl of marriageable age, not necessarily a virgo intacta. ${ }^{159}$ Such a qualification in the present context may be intended to stress the woman's capacity to give consent or, perhaps, to differentiate this case from one of paedophilia (although biblical law gives little indication of how such a case might be viewed). Alternatively, and perhaps preferably, the identification of this woman as a may be intended merely to distinguish this case from one involving a divorcée

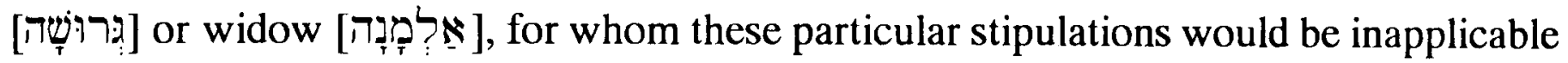

157 Cf. D. Daube, “Covenanting under Duress” (1967) 352-59.

M. Malul stresses the importance of intention as a basic characteristic of symbolic actions having dispositive force (op. cit., 27). There can be no intention if there is coercion.

Alternatively, cf. the stress on volition, particularly as expressed in the extant marriage contracts. Cf., e.g., Y. Muffs, Studies in the Aramaic Legal Documents from Elephantine (1973); idem, "Joy and Love as Metaphorical Expressions of Willingness and Spontaneity in Cuneiform, Ancient Hebrew, and Related Literatures" (1975) 1-36; idem, "Love and Joy as Metaphors of Volition in Hebrew and Related Literatures" (1979) 91-111; and M. T. Roth, Babylonian Marriage Agreements: 7th - 3rd Centuries B.C. (1989) 1.

158 So also U. Cassuto, Exodus, 288. The alternative view of D. H. Weiss seems less likely ("A

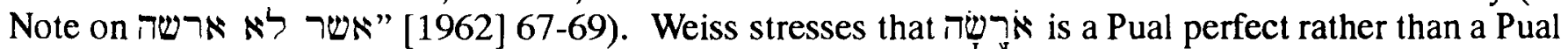
participle, hence, "who had (never) been betrothed." According to Weiss the rationale for such a condition is that if the girl had ever been betrothed, even if the betrothal was later dissolved, the father would already have received a marriage present and so would incur no financial loss from this seduction.

However, the perfect of statives and quasi-fientive verbs, such as ארש אר, is normally best rendered as a present tense, especially in the case of passives. So Waltke and O'Connor §30.5.3. Furthermore, as Weiss acknowledges, the LXX, Vulgate, and Targumim all agree with a present tense rendering for Exodus 22:15 [ET 16] and Deuteronomy 22:28, perhaps because of their appreciation of the complementarity between this law in Deuteronomy 22:28f. and those which precede it (where the girl is betrothed).

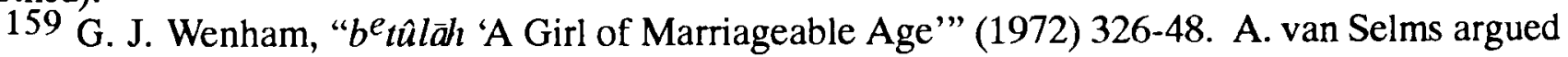
similarly for the cognate Ugaritic term, glmt, noting, for example, the case of one lesser god, gpn wugr, who is called a son of (the divine) glmt (Marriage and Family Life in Ugaritic Literature [1954] 38f.). Cf. also B. Landsberger, "Jungfräulichkeit: Ein Beitrag zum Thema 'Beilager und Eheschliessung"” (1968) 41105 , who stresses the evidence of the cognate Akkadian term batultu for a reference to age and not virginity as such, and M. Tsevat, TDOT, II, s.v. "בּתוּל 342f. Cf. further J. J. Finkelstein, "Sex Offences in Sumerian Laws" 356f. and CAD B, s.v., batulu, which favour "nubile," "marriageable," etc., rather than "virgin" as renderings of batulu.

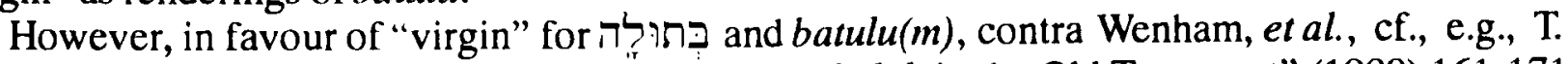
Wadsworth, "Is There a Hebrew Word for Virgin? Bethulah in the Old Testament" (1980) 161-171, and especially C. Locher, Die Ehre einer Frau in Israel (1986). Likewise, M. T. Roth favours a reference to virginity among the range of meanings of batulu in the NB period ("Age at Marriage and the Household: A Study of Neo-Babylonian and Neo-Assyrian Household Forms" [1987] 742ff.). It is possible that the conflicting impression of these scholars may be the result of a confusion of reference with meaning -- since in the ancient Near East a "marriageable" young woman would almost always be a virgin.

Alternatively, J. M. Sasson suggests that בִּתוּ means "virgin" in the sense that the womb of such a girl had been opened neither by birth nor by miscarriage (Ruth, 133). 
inapplicable (i.e., in their case a marriage would not require a father's consent and the amount of the expected marriage present, if any would even be required, would differ). ${ }^{160}$

The normal situation anticipated by this law is that any such act of "premarital" sex will be resolved by the man paying the marriage present [פהר], which, if accepted, formalizes the relationship in marriage. ${ }^{161}$ For our present purposes what is crucial to note

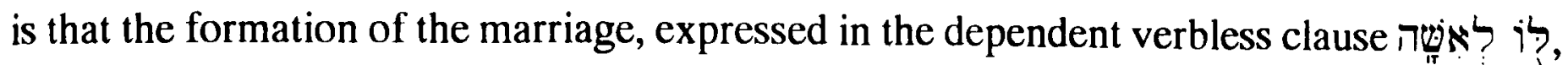
is not a third item in a list, contrary to a possible implication of the rendering of the RSV: “... lies with her, he shall give the marriage present for her, and make her his wife." Instead, the girl is constituted a wife by meeting two, and only two, indispensable requirements, namely sexual union and securing the formal consent of the bride's parents expressed in the payment and receipt of the marriage present: "... and lies with her, he shall

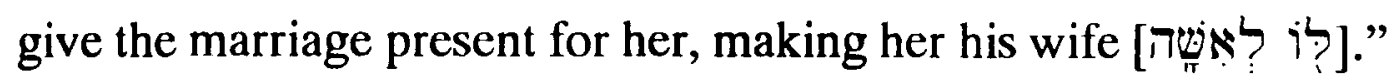

The subsidiary case in Exodus 22:16 [ET 17] considers the situation where the father of the girl refuses to give his daughter in marriage to the offending man. In such a case, the man must still pay "money equivalent to the marriage present for virgins." It seems plausible that the requirement for a marriage present in the main case (with its implied negotiations and receipt by the father) makes clear the consent of the girl's father and the subsequent legitimacy of the marriage, as well as providing indirectly for the financial well-being of the bride (as the מהר was customarily returned to brides in the dowry ${ }^{162}$ ). Whatever the precise justification for the payment in the subsidiary case (not identified as a marriage present [מהר], because in this case there would be no marriage), it is clearly viewed as a penalty against the man for his sexual misconduct. ${ }^{163}$

Furthermore, if the qualifying phrase, "the marriage present for virgins," applies to the main case as well, in view of Shechem's desperate willingness to pay any price for Dinah and the readiness of Dinah's brothers to take advantage of his willingness, the intention of this text may have been to protect such a committed suitor from extortion. ${ }^{164}$

$160 \mathrm{M}$. Burrows, for example, notes that a terhatum was not normally required for marriage to a widow (The Basis of Israelite Marriage, 30). Cf. MAL A \$34. Cf. the treatment of this law in V. Korosec, "Die Ususehe nach assyrischem Recht" (1937) 1-12.

161 The primary case may assume that the man in question is unmarried (cf. MAL $\mathrm{A} \$ 55$ ). For the more general case, cf. LE $\$ \$ 26-27$ and MAL A $\$ \$ 55-56$.

$162 \mathrm{Cf}$. footnote 126 above.

$163 \mathrm{E}$. Neufeld argues that the fine in the subsidiary case was intended as compensation for the father's financial loss (op. cit., 101, 103). So also M. Weinfeld, Deuteronomy and the Deuteronomic School, $284 \mathrm{f}$. But this explanation makes two assumptions which need justification. First, it assumes that such a daughter would now be unmarriageable. But cf. the readiness of David, for example, to marry the widowed Abigail, etc. Cf. also the apparent marriageability of the nonvirginal Ruth, Rahab, Bathsheba, etc. Second, Neufeld appears to assume that the father incurred a loss because, had his daughter married, he would have been enriched by her husband's מהר. As mentioned earlier, however, in actual practice the מהר was not kept by the father, but was normally returned in the dowry.

164 Given that such matters normally are made public only in the event of a pregnancy, one wonders if this factor may also have contributed to Shechem's fervency. Genesis 34:26 makes clear that Dinah was already living with Shechem. 
The law stipulates that the מָּ will be no more (and no less) than the customary amount for a virgin.

Finally, the ability of the father to disallow the marriage in the subsidiary case (an ability presupposed also in the account of Shechem and Dinah in Genesis 34165) does not contradict the possibility that sexual union in certain contexts may have been viewed (at least by some biblical authors) as a covenant-forming oath-sign. This is the case since this provision may be viewed merely as a corollary of a father's more general right to disallow any vow made by a dependant daughter (Numbers 30:3-5). ${ }^{166}$ On the other hand, the major case, where the seducer marries the girl, may be compared to the normal requirement in Leviticus 5:1-4 to keep even a rash oath (cf. Numbers 30:2). ${ }^{167}$

\section{Deuteronomy 22:28, 29}

Deuteronomy 22:28, 29 reads:

"If a man meets a virgin/a woman of marriageable age who is not betrothed, and seizes her and lies with her, and they are found, then the man who lay with her shall give to the father of the young woman fifty shekels of silver, and she shall be his wife, because he has violated her; he may not put her away all his days."

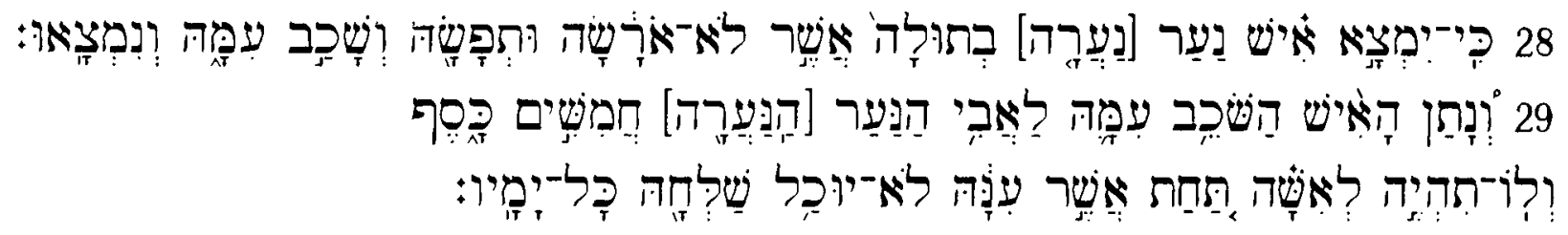

Representative of a number of scholars, P. C. Craigie considers this law under the rubric: "The rape of a single woman." 168 The NIV shares a similar understanding, which it reinforces by the parallel construction of its translation of vss. 25 and 28 , both using the verbs "meet" and "rapes":

Deuteronomy 22:25 [NIV]: "But if out in the country a man happens to meet

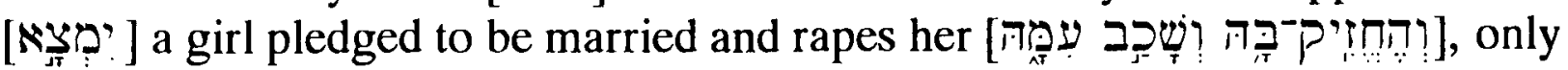
the man who has done this shall die."

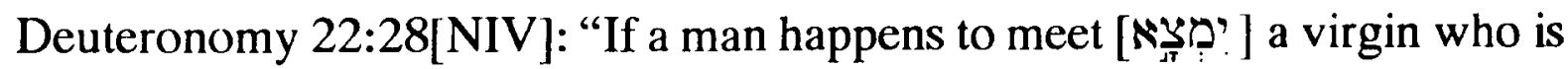

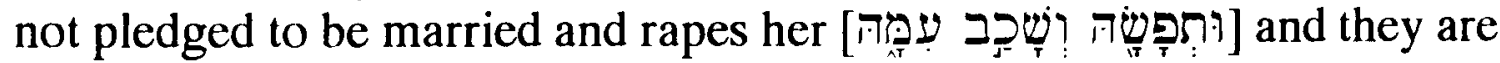
discovered...."

165 Cf. F. C. Fensham, "Genesis 34 and Mari" (1975) 87-90.

$166 \mathrm{R}$. Yaron similarly appeals to Numbers 30 to explain why a lapse in the marital status of a woman following desertion, divorce or widowhood, does not re-establish the father's authority (The Laws of Eshnunna [1988] 220, n. 174). Hence she is free to contract her own second marriage (cf. LE $\$ \$ 29,30,59$, $\mathrm{CH} \S \S 137,156,172$; and MAL A $\S 36,45)$. For the similar Talmudic practice under such circumstances, cf. $m$. Ketub. $4: 2$.

167 Cf. also Psalm 15:4; Jeremiah 7:9; Psalm 24:4; and Ecclesiastes 5:4ff.

168 Deuteronomy, 295. So also J. Morgenstern, "The Book of the Covenant, Part 2" (1930) 118ff.; G. von Rad, Deuteronomy (1966) 143; J. Ridderbos, Deuteronomy (1984) 227. M. Weinfeld observes that this is the typical view of rabbinic exegetes as well (Deuteronomy and the Deuteronomic School, 287, n. 2). 
From the context, there is no question but that Deuteronomy 22:25 deals with an act of rape, and all interpreters understand it as such. Accordingly, an idiomatic rendering of

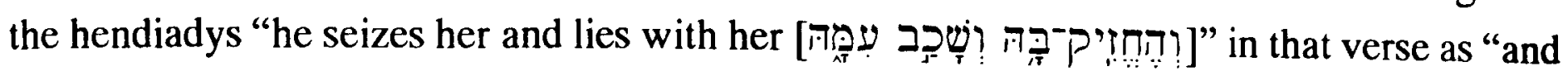
rapes her" is perhaps justified. 169

Contrary to Craigie and the NIV, however, it is not at all clear that Deuteronomy 22:28-29 treats a case of rape rather than seduction or even premarital sex with mutual consent, as in the parallel case of Exodus 22:15, 16 [ET 16, 17]. The fact that this law employs vocabulary in vs. 28 different from that used in vs. 25 (החזיק rather than does not favour the assumption that the context of rape in vss. 25-27 necessarily carries over to 28-29. Furthermore, while it is true that the verb תפש, "to lay hold of," "to seize," can be used with reference to the detainment of persons (as in Deuteronomy 21:19, or even

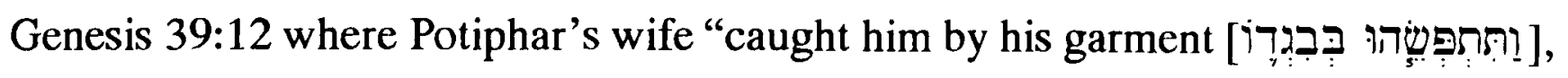
saying, 'Lie with me"') or acts of violence (as perhaps in Psalm 71:11), it can also be used in a quite general manner, as in Deuteronomy 9:17, "So I took hold of the two tables...," or Ezekiel 14:5, "that I may lay hold of the hearts of the house of Israel...."170

An extrabiblical parallel may support the possibility that the mention of "seizing" can be intended only to indicate the man's initiative, but that it need not preclude the woman's consent. In HL $\$ 197$ a a man "seizes a woman in the mountains, it is the man's crime and he will be killed." The apparent implication of the mountainous setting is that the screams for help of this woman could not be heard, and hence the case is one of rape. HL $\$ 197 b$, however, states, "But if he seizes her in (her) house, it is the woman's crime and the woman shall be killed." In this setting, with her apparent failure to cry for help, the law presumes that she gave her consent in spite of the use of the term "seize."171

Although a term for "seize" does not happen to be employed in MAL A §23b,c, a similar situation is envisaged in which a woman did not intend to engage in extramarital relations and appears to have done so only under duress (although there is some uncertainty about the meaning of $k \hat{\imath}$ pige in line $30^{172}$ ). The facts of the case are sufficient to presume coercion in MAL A $\$ 23 \mathrm{~b}$ if the woman immediately declares upon leaving the house that

169 The Hiphil of 7 typically means "seize," "take hold of," "overpower," etc., and is used elsewhere in quite general ways (e.g., cf. Psalm 35:2, "Take hold of shield and buckler," or Proverbs 4:13, "Keep hold of instruction"), as well as in connection with various acts of physical violence, including sexual violence (i.e., Judges 19:25 and 2 Samuel 13:11). It is important to note, however, that in these last two examples, pir refers only to the seizure of the female victim, not to the sexual act itself. Judges 19:25 makes this especially clear since the man who "seized" the Levite's concubine was not among those who sexually abused her.

170 Cf. also Amos 2:15 and Jeremiah 2:8.

M. Weinfeld concludes, "The word ותפשה means 'held' and not necessarily 'attacked"” (op. cit., 286); G. J. Wenham suggests "grab (impetuously)" (in a private communication).

171 This presumption of consent is confirmed by the mention of "finding them" in the subsidiary case which immediately follows, "If the husband finds them, he may kill them, there shall be no punishment for him."

172 It is unclear whether kî pîge in line 30 should be rendered "under threats," (cf. G. R. Driver and J. C. Miles, The Assyrian Laws, 467) or "under a pretext" (cf. R. Borger, et al., Rechtsbücher [1982] 84). 
"she had been forced to have illicit relations [nîkutūni]." In MAL A §23c the woman neglects to make this critical declaration. Since this is the only difference from the earlier situation, which was deemed to be a case of rape, it must have been assumed that the man finally gained her consent (for which reason she did not later complain), and so the case is treated as one of adultery rather than rape.

Decisive evidence that Deuteronomy 22:28-29 concerns a case of consenting premarital sex rather than rape, however, appears in the expression, "and they are found

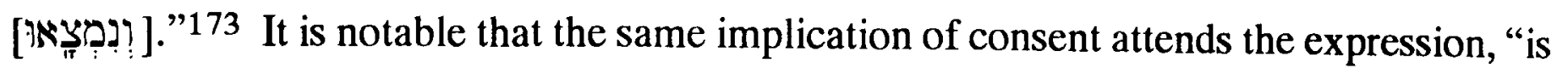

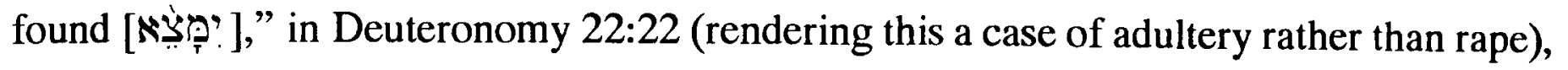
and a similar implication attends the Akkadian equivalent of this expression (the IV/1 perfect of sabātum) in cuneiform law. ${ }^{174}$

Furthermore, as noted by A. D. H. Mayes, the verb "violate" [ענה] found in vs. 29

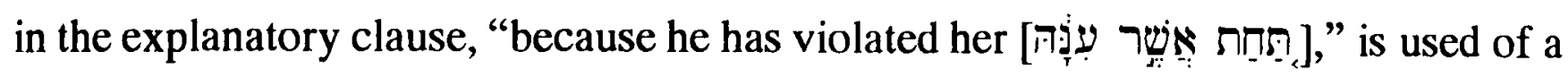
consenting woman earlier in the same chapter in vs. 24 and so does not require the assumption of rape, as often supposed. ${ }^{175}$ Mayes suggests rendering the expression: "because he had his way with her."176

Finally, given the likely concern for the well-being of the woman reflected in the denial of the guilty husband's right to divorce in vs. 29 , the remedy of an enforced marriage to a rapist whom she may have bitterly hated appears contradictory and quite inexplicable. 177 The clearest indication elsewhere regarding the biblical attitude toward the rape of an unbetrothed woman, namely 2 Samuel 13, suggests that marriage was possible if the couple were willing; otherwise, the implication of Tamar's scream in vs. 19 (cf.

Deuteronomy 22:24, 27; cf. also MAL A \$23b and HL \$197a) and the subsequent narrative

\footnotetext{
173 So also M. Weinfeld, op. cit., 286; and A. D. H. Mayes, Deuteronomy, 312.

$174 \mathrm{Cf}$., e.g. "if the wife of a man is found [ittaşbat] lying with another man..." in $\mathrm{CH} \$ 129$. Cf. also LE $\$ 28$ and MAL A $\$ 15$.

Cf. also M. T. Roth, “She will die by the iron dagger': Adultery and Neo-Babylonian Marriage” (1988) 192-7, for a discussion of the stipulation in certain Neo-Babylonian marriage documents, "Should fPN be found with another man...." Roth considers that this expression implies the woman's consent and also the fact that the aduiterers are caught in flagrante delicto (much as in $\mathrm{CH} \S \S 129,131,132$; LE $\S 28$; and MAL A $\$ 15$.

Confirming the assumption of the woman's consent in 22:28f. and the relevance of the repetition of the

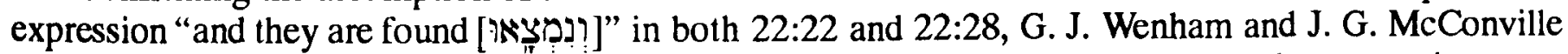
argue for an extensive intentional parallelism between the first three and the second three cases in Deuteronomy 22:13-29, such that the law of adultery in 22:22 corresponds to the present law in 22:28f. ("Drafting Techniques in Some Deuteronomic Laws" [1980] 248-252).

175 Deuteronomy, 313. So also M. Weinfeld, op. cit., 286.

$176 \mathrm{Op}$. cit., 304. Note the similar sequence of verbs in Genesis 34:2, "and when Shechem the son of

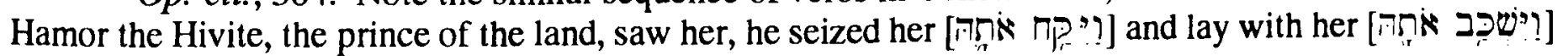

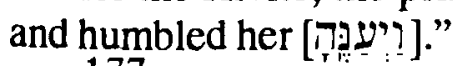

177 Cf. M. Weinfeld, op. cit., $286 \mathrm{f}$.

Although biblical practice, as elsewhere in the ancient Near East, can hardly be said to stress the role of love as a motivation for marriage, or even the consent of the bride, there are a number of texts which reveal that such concerns may not have been totally disregarded. Cf., e.g., Genesis 24:5, 57ff.; 29:18; Exodus $2: 21$; Judges 14:3, 7; 1 Samuel 18:20; 2 Samuel 13:13; Proverbs 18:22; and Tobit 6:17. Cf. also $M$. Burrows, op. cit., 24f.; T. L. Thompson, The Historicity of the Patriarchal Narratives, 251f.; and T. Jacobsen, The Harps That Once... Sumerian Poetry in Translation (1987) 10-15.
} 
indicate that such a rape merited the death penalty. ${ }^{178}$ In any case, although the rather severe MAL A $\$ 55$ may permit marriage in the case of a rape, nowhere among cuneiform examples is marriage a required remedy for rape, as would be implied in Deuteronomy $22: 28 f$. on the view that this text concerns rape. 179

Having argued that Deuteronomy 22:28f. treats a case of premarital sex, rather than rape, there are a number of points of contrast to be observed between this law and the similar case in Exodus 22:15, 16 [ET 16, 17].

One obvious difference is the precise specification of the amount of the מָּר namely "fifty shekels of silver." Based on Exodus 22:15, 16 [ET 16, 17], W. H. Gispen, for example, assumes that this amount represented the normal possible, but not certain. As argued earlier, this figure may be exceptionally high in order to penalize the offender. At the same time, there may also be a secondary concern to compensate the parents who are deprived, to some extent, of their customary right of refusal in contrast to the case in Exodus 22. In support of understanding the fifty shekel payment primarily as a penalty, G. J. Wenham and J. G. McConville note a chiastic literary structure in Deuteronomy 22:13-29, whereby this fifty shekels paid to the girl's father and the prohibition of divorce find corresponding stipulations in the first case treated in vs. 19 , where they are clearly intended as penalties. ${ }^{181}$

The apparent denial of the parents' right of refusal constitutes a second striking difference between the present law and that found in Exodus 22. A. D. H. Mayes suggests

178 The justice of Absalom's execution of Amnon is nowhere questioned, and appears as an indictment against David's perversion of justice (advertised by Absalom in 2 Samuel 15:3f.) for having failed to deal with Amnon.

179 The ensuing requirement in MAL A $\$ 55$ that the wife of the rapist was now to be sexually abused (as a rigid, if not impractical, application of the lex talionis) has been called by J. J. Finkelstein, "a piece of typically Assyrian moralistic "calculated frightfulness"” ("Sex Offences in Sumerian Laws," 357).

The apparently mandatory marriage to a rapist in $\mathrm{SL} \$ 7$ is a result of a mistranslation (ANET, 525f.). As appears from Finkelstein's transliteration of the text, the content of the girl's statement, if it was the girl's and not the offending man's, is not found in the text. Consequently, it is possible that the offending man or the girl merely reported to her parents what happened, and the text ought to be translated: "If (a man) deflowered the daughter of a free citizen in the street, and her father and her mother (did not know it), and she/he (then) tells her father and her mother, her father and her mother may give her to him as a wife."

On the other hand, in cases of cohabitation, where there is obvious consent on the part of the girl, but not as yet from her parents, cuneiform law requires this defect to be remedied by negotiating a marriage contract with her parents to formalize their consent. Apart from this remedy, no amount of time can regularize the marriage. Cf. LE $\$ \S 27,28$, and $\mathrm{CH} \$ 128$. Cf. R. Westbrook, "Old Babylonian Marriage Law," II, 57f.

Cf. MAL A $\$ 56$ and SL $\$ 8$ for cases of solicitation (not merely consent) on the part of an unbetrothed girl.

Accordingly, K. van der Toorn argues that in Sumerian and Babylonian law a man had to marry a virgin, if he seduced her, but only if the latter agreed (Sin and Sanction in Israel and Mesopotamia [1985] 161, n. 75). Cf. also B. Landsberger, "Jungfräulichkeit: Ein Beitrag zum Thema 'Beilager und Eheschliessung'," 50-52, cited by Van der Toorn.

180 Exodus, 221. J. P. Hyatt, however, considers it more likely that it was not so high in the earlier period represented by the Covenant Code (Exodus, 241).

181 "Drafting Techniques in Some Deuteronomic Laws" (1980) 250. 
two possible explanations. First, it is thought that the Deuteronomic insistence on marriage may represent an innovation intended to protect the girl by ensuring that she would not be left unmarried. While possible, this insinuates that the girl needs protection from her own father's poor judgment, since Exodus 22 already insists on a marriage apart from his refusal. Second, Mayes suggests that the required marriage may be intended to prevent the girl's father from receiving a second marriage present. 182 It is unclear, however, why this would be deemed a problem given the examples cited elsewhere of widows and divorcees who commanded a second marriage present. ${ }^{183}$

C. M. Carmichael offers an alternative explanation for the denial of the parents' right of refusal in this law. ${ }^{184}$ Given the concern expressed in Deuteronomy 22:13-21 about marriage to a nonvirginal (or perhaps pregnant) bride, Deuteronomy 22:28-29 may be intended to prevent this possibility by its insistence on marriage without exception.

A final possibility is that the explanation for the differing remedies in these laws is to be found in the degree of the girl's consent and (perhaps even on-going) abetment

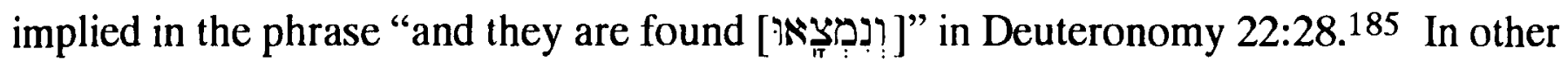
words, while Exodus 22 considers the case of the seduction of an unbetrothed nubile girl (a one-time occurrence perhaps requiring some assessment by her father of the degree of her reluctant consent), Deuteronomy considers the special case where there is unmistakable circumstantial evidence for consenting premarital sex..$^{186}$

The last significant difference between Exodus 22:15, 16 [ET 16, 17] and Deuteronomy 22:28, 29 concerns the revocation of the husband's right of divorce in the latter text (as also in Deuteronomy 22:19b). The inequality of this punishment, for example, by contrast to Deuteronomy 22:22 where the girl is also punished, and the remarkable protection it affords to the wife suggest that this law "recognizes that an injury has been inflicted on the girl. This is entirely in accord with Deuteronomy's humanitarian

182 Similarly, C. M. Carmichael suggests that under the influence of Genesis 34, Deuteronomy 22 is intended to close a loophole left by the provision in Exodus 22 (Law and Narrative in the Bible [1985] 218220). A father eager for financial gain, is limited by Exodus 22 from jacking up the "bride price" beyond what was normal for virgins. Accordingly, he decides to collect the fine and double his gain by arranging another marriage. Deuteronomy 22 prevents this scenario by fixing the "bride price" and insisting on marriage.

183 For example, R. Westbrook cites a case where a terhatum was paid for a nonvirgin bride (“Old Babylonian Marriage Law," II, 155).

184 Op. cit., 220.

185 Cf. M. Weinfeld, op. cit., 286.

C. M. Carmichael, on the other hand, argues that the purpose of the qualifier, "and they are found" is merely to establish their guilt (op. cit., 220): "Without it, a woman in collusion with her father could exploit a man, especially under the existing law in Exod 22:16, 17)." It may be doubted, however, that in biblical times there would have been many girls or fathers who would have considered the potential damage to the daughter's reputation to be worth this potential financial gain. The case of Potiphar's wife, cited by Carmichael, significantly differs. The claim to have rebuffed the sexual advances of a youthful and handsome Joseph could only enhance her reputation and appearance of rectitude.

186 With this evidence of the girl's complicity, there would be little point in a father so disregarding his daughter's implied wishes by forbidding a marriage. Cf. 1 Samuel 18:20 and 2 Samuel 13:13. Cf. also footnote 175 above. 
ideals, particularly towards those who had no means of protecting themselves through the courts (Deut. 10:18, 24:17-22)."187 This recognition of an injury to the girl need not contradict the earlier claim for her consent. Vs. 28a makes plain the man's initiative and so greater responsibility for what transpires: He "meets a virgin... seizes her and lies with her."188

Furthermore, if it is the case that in Exodus 22 the couple voluntarily reveal what has transpired, while in Deuteronomy "they are found," this difference may suggest a further explanation for the forfeiture of the husband's right of divorce in Deuteronomy 22. It may be that this law considers this man's marital intentions to be questionable, as in Deuteronomy 22:19 where a husband who was looking for a way out his marriage (but wanted to keep the marital property?) similarly forfeits his right of divorce. ${ }^{189}$ In Exodus 22 , on the other hand, no such provision is necessary because it appears that this groom is quite ready to rectify his situation (much as was the case with Shechem). Not only are his honourable intentions suggested by the implication of their self-revelation, but also the only impediment anticipated is that the bride's father might "utterly refuse" his request. As will be recalled, the stipulated customary "marriage present for virgins" may offer further testimony to the repentant groom's willingness, in that it may have been intended to protect him from extortion (cf. Genesis 34:11, 12).

\section{Genesis 34 and 2 Samuel 13:16}

The narrative of Shechem's premarital sexual intercourse with Dinah in Genesis 34 and that of Amnon with Tamar in 2 Samuel 13 are both abundantly clear in their moral censure for these acts (cf. Genesis 34:5, 7, 31; and 2 Samuel 13:12f.). Both texts appear to exonerate the woman in question by stressing the forcible nature of the seduction ("he seized her [ח Genesis 34:2; and "he took hold of her... he would not listen to her; and being stronger

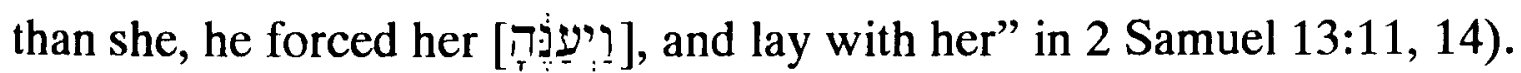

While both wrongs are finally redressed by the execution of the lover by the victim's brother, made possible by a deception, it is remarkable that the narrator leaves little doubt that the preferred remedy would have been the urgent regularizing of these

187 A. Phillips, "Another Look at Adultery" (1981) 9f., cf. also p. 12. Phillips accepts D. H. Weiss's proposal discussed above ("A Note on אשר לא ארשה" [1962] 67-69).

188 As argued by J. J. Finkelstein, unmarried women (normally girls) in the ancient Near East almost never sought out sexual experiences on their own initiative ("Sex Offenses in Sumerian Laws," 368ff.). As a result, the law collections normally assume an element of coercion or persuasion on the part of the man in such cases (MAL A $\$ 56$ and SL $\$ 8$ are exceptions).

189 In support of a parallel between the third and sixth cases presented in Deuteronomy 22:13-29, cf. again the structural analysis of G. J. Wenham and J. G. McConville, op. cit.

190 Given the lack of any certain examples of שכ being used transitively (2 Samuel 13:14 and Ezekiel 23:8 are both doubtful), perhaps și should be repointed with $B H S$, following the LXX (and Syriac, Targum Pseudo-Jonathan, and Vulgate): $\mu \in T^{\prime}$ aủiñs. 
relationships in marriage. ${ }^{191}$ Compare Genesis 34:4, 8, 11f.; 49:5-7; and especially Tamar's words to Amnon in 2 Samuel 13:16: "No, my brother, for this wrong in sending me away is greater than the other which you did to me." In other words, both texts imply that in the case of premarital sex the in domum deductio was expected to coincide with copula carnalis. Genesis 34:17, 26 makes explicit the fact that after intercourse Dinah remained in Shechem's home, even while negotiations were under way for the marriage. ${ }^{192}$ On the other hand, Amnon's eviction of Tamar from his home was immediately understood as a decisive repudiation of any marital intention -- in effect, redefining their act of intercourse as rape (in 2 Samuel 13:19 Tamar leaves expressing her grief and "crying aloud

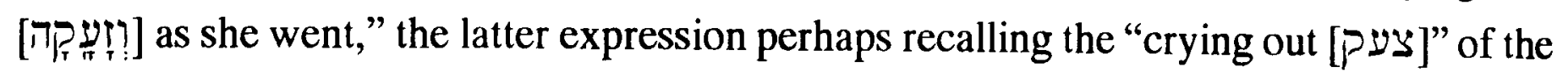
rape victim in Deuteronomy 22:24, 27 and the "calling [N]" of Genesis 39:14f., 18). ${ }^{193}$

\subsubsection{The obligatory nature of sexual union for the consummation of marriage}

Cuneiform law makes plain a legal obligation on the part of the groom to consummate marriage once there has been inchoate marriage. Compare, for example, $\mathrm{CH}$ $\$ 159$, where a groom has paid the biblum and terhatum, but later has his eyes on another woman. 194 He announces to his father-in-law, "I will not take your daughter [mâratka ul ăhhaz]," and, accordingly, forfeits the biblum and terhatum as a penalty.

One legal document from Sippar demonstrates this obligation in actual practice. $C T$ 45,86 is a court procedure having to do with a groom who refuses to consummate his marriage. 195 In the presence of witnesses, Aham-nirshi is questioned, "'Is this lady your

191 Because of the inversion of love into hate in 2 Samuel 13:15 (perhaps a result of transferred guilt), it is perhaps too easy to dismiss the earlier mention of Amnon's "love" for Tamar in 13:1 as a euphemism for lust. In any case, the text implies that Tamar cared for Amnon, not only because of her ministration to him in his "sickness," as well as her willingness to feed him from her own hand the suggestive "heart-

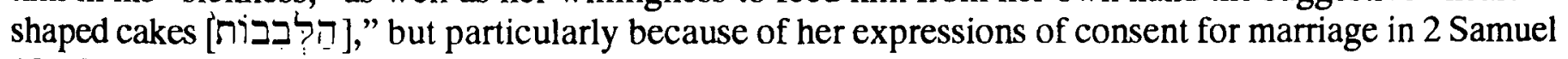
13:13 and 13:16.

While Genesis 34 offers nowhere explicitly mentions Dinah's love or consent, this consent may be inferred from the extraordinary emphasis in the narrative on Shechem's love and willingness to pay any price for her hand in marriage (cf. Genesis $34: 3,4,8,11,12$ ).

It is doubtful whether there would be the same expectation for the urgent regularizing of sexual relationships in marriage apart from such a context of consent and even love.

192 Alternatively, M. Sternberg sees Dinah's detention as an offence, offering proof that her brothers were negotiating under duress and were justified to resort to "guile and violence" (The Poetics of Biblical Narrative [1985] 456ff., as pointed out to the writer by G. J. Wenham). However, as conceded by Sternberg, the text is not so clear in its moral assessment of the brothers' stratagem. In any case, at no point does the text state or imply that Dinah's residency in Shechem's home was either against her will or that it supported the brothers' charge that their sister was being treated like a harlot (whether by Judah, as Sternberg suggests, or by Shechem). Harlots were paid for their services, not domiciled. Furthermore, the contrast between Genesis 34:17,26, and 2 Samuel 13:16, as well as the emphasis in Genesis 34 on Shechem's love for Dinah, does not favour Sternberg's view on this point.

193 Cf. also S. Rattray, "Marriage Rules, Kinship Terms and Family Structure in the Bible" (1987) 537-544, and P. Trible, Texts of Terror, 37-63.

194 This may be mentioned in order to stress the groom's culpability, rather than to suggest any defect in the girl which would warrant this change in plans.

195 For a new edition of this text, cf. R. Westbrook, “Old Babylonian Marriage Law," I, 145-147. 
wife?' He said, 'Hang me on a peg and dismember me! I will not do the taking [ul ăhhaz]"" (Ins. 18b-22). Accordingly, Aham-nirshi proceeds to bind up his bride's hem and cut it off in a recognized legal gesture for effecting a divorce, providing evidence that a formal divorce was required for dissolving even an inchoate marriage. 196

The precise reference of the verb ahōzum, "to take," is ambiguous in both of these examples. This verb may refer to the consummation of a marriage in general terms (perhaps referring to the acquisition of responsibility for and control over the bride), but it may also refer more particularly to sexual intercourse, as it appears to in $\mathrm{CH} \S 142.197$

The Old Testament nowhere makes explicit the legal obligation, assuming such exists, of the groom to consummate a marriage in sexual union following betrothal. The celebrated case of Onan in Genesis 38:9 involves not a refusal to consummate a marriage in sexual intercourse, but a stratagem for avoiding impregnation. Genesis 38 does seem to imply an obligation on the part of Shua or Judah to consummate a marriage with the widowed Tamar, but it is arguable that this evidence would be applicable only to cases of levirate betrothal, not betrothal more generally.

Nevertheless, Deuteronomy 20:7 does indicate the high social priority which was placed on the consummation of marriage following betrothal. 198 After the conquest (during which all Israel was to fight), if Israel finds herself confronted by an enemy, the officers of the people were to exempt several categories of recruits, including men whose marriages were unconsummated: “... what man is there that has betrothed a wife and has not taken her? Let him go back to his house, lest he die in the battle and another man take her."199

Alternatively, Deuteronomy 28:30 lists among the curses for covenant breaking, "You shall betroth a wife, and another man shall lie ${ }^{200}$ with her; you shall build a house, and you shall not dwell in it; you shall plant a vineyard, and you shall not use the fruit of it" -- each threat reversing one of the three exemptions listed in Deuteronomy 20:5-7.201

196 Cf. J. J. Finkelstein, “Cutting the sissiktu in Divorce Proceedings" (1975-76) 236-240, at 240; and M. Malul, op. cit., 203f. Cf. also Matthew 1:19.

197 "If a woman hated her husband and [šumma sinništum mussa izêrma] she has declared, "you may not take me [ul tãhhazanni iqtabi]', ...." The context and subsequent investigation of the wife makes plain that this was a full-fledged marriage, and so "take" can not refer to the groom's acquisition of responsibility for and control over the bride from his father-in-law -- this was already the case. Accordingly, most interpreters take tãhhazanni as a reference to the refusal of conjugal rights.

So also $C A D$ A $/ 1$, s.v. ahāzu, 1(b), and G. R. Driver and J. C. Miles, The Babylonian Laws, I, 299301; II, 57, 223. Further possible examples of dhozum with a sexual reference are $C T 837 \mathrm{~d}, \ln .3$ and especially YOS 851 , In. 7 (both of which are available in R. Westbrook, op. cit., I, 137-138, 309-311). A contrary view is expressed by R. Westbrook, op. cit., II, 16-18.

198 Cf. also Deuteronomy 24:5.

199 J. A. Thompson notes how this law expresses the humanitarian concern typical of Deuteronomy elsewhere (Deuteronomy, 221).

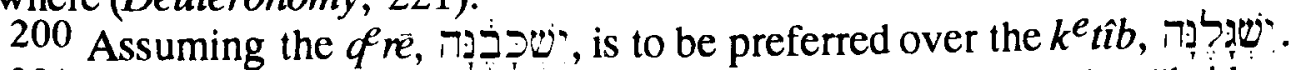

201 It is unlikely that Joel $1: 8$ refers to a girl's mourning for her "bridegroom" (i.e., a betrothal situation). Cf. G. J. Wenham, "betüläh 'A Girl of Marriageable Age”" (1972) 345. 


\subsubsection{Instances of synecdoche by which the consummation of marriage is effectively identified with sexual union}

The evidence thus far considered for the manner in which sexual union consummates marriage is further supported by a number of examples of synecdoche of both the whole (expressions for marriage used to refer to sexual union in particular) and of the part (expressions for sexual union used to refer to marriage).

Specifically, it may be noted that while (צ) ("come to") in its sexual usage is not restricted to marital unions, in at least one case, in Joshua 23:12, ("come to") appears to refer to the contraction of marriage as a whole by synecdoche: "For if you turn back, and join the remnant of these nations left here among you, and make marriages with them, so that you marry their women and they yours

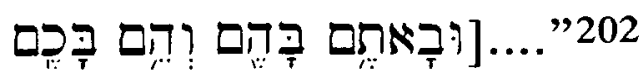

A similar extension of meaning from sexual union to the marriage it consummates may be observed with ידע in at least six texts where the expression ידע ל + ידע appears with reference to unmarried women. Although these examples merit more detailed consideration, it is enough to suggest here that the expressions, "who have not known a man," "whom no man had known," etc., may have less to do with a claim for technical virginity than with the more public and observable fact that such a woman had not yet experienced the consummation of a marriage. For example, Numbers 31:17 records how the Israelite soldiers were to kill "every woman who has known a man." How were the Israelite soldiers to check for the requisite virginity? By impromptu medical examinations? By interviews? Would these women tell the truth about such a private matter, especially

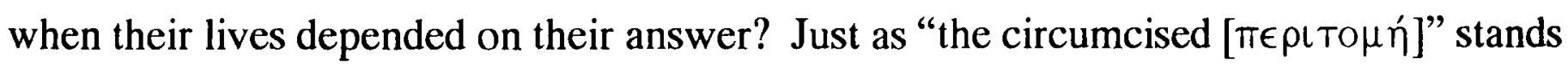
by synecdoche for "the Jews" in New Testament Greek (with no need for medical examinations), it seems likely that the concern in Numbers 31:17 is with marital status, referred to in terms of this expression for sexual intercourse, not technical virginity. Marital status, that is, whether a woman was currently married, a widow, or a divorcee, would be a matter of public record (perhaps evidenced in an item of dress such as a veil) and so would be readily ascertainable by the soldiers. Compare also Genesis 19:8, 24:16; Numbers 31:35; Judges 11:39; and Judges 21:12.

Finally, Genesis 24:67 offers a possible example of synecdoche of the whole for the part involving the term לקח: "Then Isaac brought her into the tent of his mother Sarah

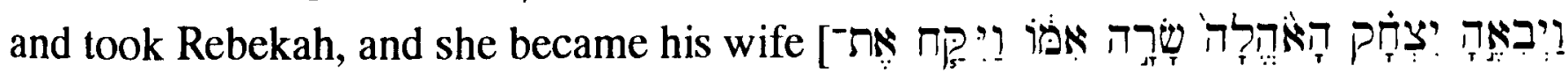

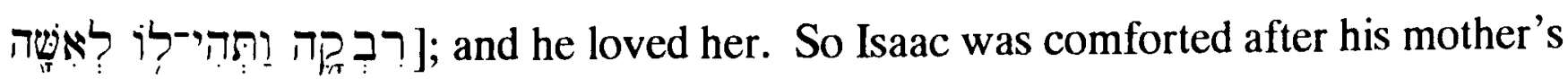
death." Although context of this passage, especially following the mention of Rebekah's entrance into the

202 As rendered by the RSV.

203 Cf., e.g., Genesis 28:6; Judges 14:3; etc. Even-Shoshan lists 52 examples. 
family tent, it appears likely that "taking" Rebekah specifically refers to the act of sexual

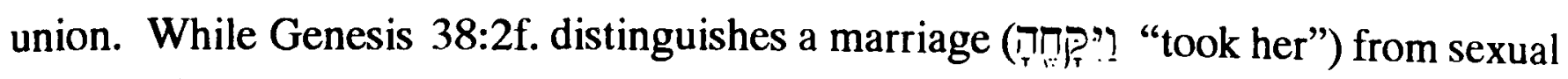

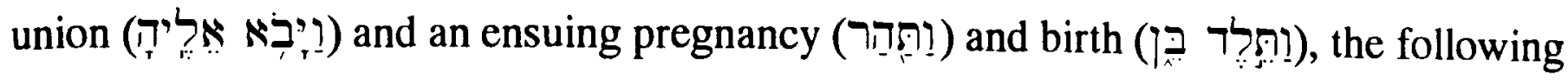
three texts are of interest because they appear to employ marriage and sexual union (or to sexual union by synecdoche): Exodus 2:1f. ("and he took [to wife] a daughter of Levi and the woman conceived and bore a son."); Hosea 1:3 ("he took [to wife] Gomer the daughter of Diblaim and she conceived and bore him a son."); and possibly 1 Chronicles 4:17f. ("Bithiah, the daughter of Pharaoh, whom Mered took [to wife], and she conceived and bore Miriam...").204

\subsubsection{E. Neufeld's view of "בִִּ Marriage" rejected}

From the evidence thus far considered, it is apparent that sexual union not only constitutes an important communicative gesture, but it also serves a legal dispositive purpose, namely the consummation of marriage. 205 Recognition of this fact is not to imply

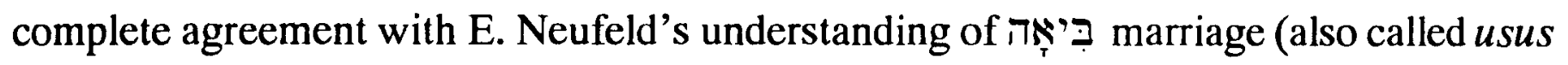
marriage from the analogous Roman practice). Neufeld supposes that בִּ marriage, that is, marriage formed simply by cohabitation, was one of the earliest forms of marriage, of which traces remain in the Bible: Genesis 38:2; Deuteronomy 22:13; and 2 Samuel 12:24. As further support, Neufeld notes that the Talmud offers its reluctant recognition of the validity of such a marriage. 206 The Talmudic evidence, however, may merely reflect the influence of later Roman practice, while none of the biblical examples is particularly convincing as evidence for the development posited by Neufeld. ${ }^{207}$ Accordingly, S. F. Bigger concludes: “Neufeld's Biāh formula was not an early marriage form, but, when used in connection with terms expressing marriage, it was the normal expression for the consummation [of marriage], and only in the case of the captive wife [and, we may add, perhaps also widows] was this sufficient without any negotiations or preliminaries."208 Putting this conclusion in different terms, there is little evidence for any period that a man could marry a bride simply by cohabitation, if the bride in question was a dependent and the

204 The RSV transposes "took [to wife]" from the end of vs. 18. Whether or not the MT is emended to support this transposition, the sense demands that the expression "take to wife" be considered as referring to an event prior to the conception and birth.

205 Cf. M. Malul, op. cit., 22f., and M. I. Gruber, Nonverbal Communication, passim.

206 The legality of a בִּיאה marriage is recognized in $b$. Qidd. 1a, but discouraged as immoral in $b$. Qidd. $12 \mathrm{~b}$ and $b$. Yebam. 52a. Cf. also b. Ketub. 46a.

207 Cf. P. E. Corbett, The Roman Law of Marriage (1930).

208 Op. cit., 84.

Cf. LU $\S 8$, which considers the case of a widow who has cohabited with a man without a marriage contract. The law does not call into question the validity of such a marriage, as it would, presumably, if the woman had been a dependent in her father's house and the marriage had lacked her parents' consent (as in LE $\$ \$ 27-28 ; \mathrm{CH} \$ 128$ ). It merely demonstrates that in the absence of such a contract, a widow may be divorced without any compensation. Cf. also MAL A \$34, where cohabitation of two years is required for a widow without a contract to assume the full rights of a wife with respect to divorce protection. 
husband had failed to gain the prior consent of her guardian. ${ }^{209}$ This requirement for parental (or guardian) consent is explicit in a text such as Exodus 22:15-16 [ET 16-17] and is clear in Mesopotamian practice. Compare, for example, LE §§26, 27, and 28.210

\subsubsection{Consequences of the inherently private nature of sexual union}

Although sexual union was the means by which marriage was consummated in the Old Testament, as well as elsewhere in the ancient Near East, the inherently private nature of this act renders it unsuitable for some legal purposes. $\mathrm{CH} \$ \$ 151-152$, for example, considers the case of liability for prenuptial debts. Obviously a creditor cannot be privy to the precise moment of the copula carnalis, and so for pragmatic reasons the point at which the couple becomes liable for each other's debts starts when the woman "entered into the house of the man."211

As a result, there is a need for a degree of semiotic redundancy in the formation of marriage in order to give public evidence of the consummation of marriage. As in the modern world where couples may exchange rings, light a common candle, etc., giving public expression to the bond which will be privately expressed in sexual union, so also in the ancient world festivities, processions, pouring oil on the bride's head, symbolic acts involving clothes, the change of domicile, etc., served to give notice of the (impending) consummation of marriage. Nevertheless, it is clear that these additional ceremonies do not have the constitutive effect possessed by copula carnalis. For example, it would not be expected that if a wife were to remain in the domicile of her father, this would prohibit a valid marriage, as would be the case if she were to refuse copula carnalis. ${ }^{212}$

\subsubsection{Sexual union meets the conditions expected of an oath-sign and, as such, resembles other covenant-ratifying oath-signs}

Since sexual intercourse is the indispensable means for the consummation of marriage in the Old Testament, as elsewhere in the ancient Near East, can it also be viewed as an oath-sign for the ratification of the covenant of marriage? In that no text offers a theoretical discussion of sexual union in terms of covenant concepts, our discussion must necessarily proceed by way of probability and the accumulation of a weight of evidence.

209 The case of Judges 21 is extraordinary and complicated by the issue of kidnapping. Even here, however, parental consent was extracted ex post facto.

210 Cf. also S. Greengus, "The Old Babylonian Marriage Contract," 521.

211 Accordingly, this law has been cited as the clearest evidence for in domum deductio, as argued by P. Koschaker. Cf. R. Westbrook, op. cit., II, 125-131.

The drafting of this law is less than felicitous given the discrepancy between $\mathrm{CH} \S \$ 151-152, \ln .37$, which describes the transition point for liability for the husband's debts as when he "took that woman [sinništam su'äti îhlazu]," while Ins. 44-45, and especially Ins. 54-55, use the woman's entrance into the house of the man as the transition point: "If the debt is incurred by them after that woman entered into the house of the man [šumma ištu sinništum sĩ ana bît awìlim îrubu]...."

212 Cf. also R. Westbrook, op. cit., 131. 
Before examining those texts which offer the most direct evidence for identifying sexual union as a covenant-ratifying oath-sign, we shall first consider several important characteristics of sexual union which support this identification.

In the treaty between Muršiliš II of Hatti and Talmi-Šarruma of Aleppo, Muršilis II enjoins his vassal, "May all of us together and our house be one [gab-bi-ni ù bitt-ni lu-úu ištên]. For this thing may the gods of the Hatti land and the gods of the Aleppo land be witness." 213 A similar commitment to being "one" is articulated in a number of other treaties and implied in a great many alternative formulae such as references to being "father" and "son," "brothers," "friends," etc. 214

Corresponding to this characteristic stress on unity, a number of the oath-signs discussed in Chapter 6 function merely by offering a solemn depiction of the covenant commitment to unity being undertaken. For example, it was argued that such was the case with the gesture of eating together and with giving one's hand in a handshake. With respect to the possible identification of sexual union as a similar oath-sign, it is self-evident that this act is ideally suited to depict the "one flesh" reality which is definitional of marriage in Genesis 2:24. In fact, this depiction is so clear that some scholars have identified the two becoming "one flesh" as a reference to the sexual act itself.215 Furthermore, as in the case of giving one's hand in a hand shake, it is notable how many oath-signs involve physical contact or the use of the parts of the body to represent one's whole person on the principle of pars pro toto. 216 More particularly, at least two oath gestures involve the organs of generation. This is the case with both circumcision and the oath-accompanying gesture of placing one's hands under another's "thigh" (Genesis 24:2, 9 and 47:29). ${ }^{217} \mathrm{At}$

213 E. F. Weidner, Politische Documente, 86f., r. 9-10, as cited by P. Kalluveettil, Declaration and Covenant, 102 (text \#15).

214 Other examples of "becoming one" mentioned in the treaties are found in the treaty between Muwatallis and Sunassurah of Lizzuwatna, Ins. 35-36, and in A. K. Grayson, Assyrian Royal Inscriptions, II, \$459. Cf. further P. Kalluveettil, op. cit., 93-106.

215 E.g., cf. J. Skinner, Genesis (1930) 70; and H. Gunkel, according to C. Westermann, Genesis 1$11,233$.

Against limiting the reference of "one flesh" in Genesis 2:24 to the sexual act, cf. M. Gilbert, “'Une seule chair' (Gn 2,24)" (1978) 66-89.

216 The giving of the hand represents the person, according to P. Kalluveettil, op. cit., 21. M. Malul discusses how gestures involving the forehead and the head as a whole are similarly used to represent the person (op. cit., 74, 176, 249ff.). Likewise, hair, fingernails, saliva, etc., in various gestures and ceremonies are identified by P. Koschaker as emblems of the person (so Malul, op. cit., 115, n. 100).

Cf. also the claim of W. G. E. Watson that in Isaiah 28:15 the parties metaphorically conclude a covenant with death by ceremonially facing each other and touching each other's chests (Classical Hebrew Poetry, 57). Related to this, according to Watson, is the manner in which covenants could be broken by fondling another's breasts as in Isaiah 28:3dc. Cf. CAD $S, 165 \mathrm{f}$.

If Koschaker is correct that garments (undergarments), because of their proximity to the intimate parts of one's body, were a symbol of personality and could represent the owner, then it is all the more likely that those intimate parts themselves were symbolic of the person as a whole. In support of this understanding of garments, cf. also M. Malul, op. cit. 114f., 152.

217 Cf. R. D. Freedman, "Put Your Hand Under My Thigh" (1976) 3ff.; M. Malul, "More on pahod yishäq (Genesis xxiv 42,53) and the oath by the thigh" (1985) 192-200; and idem, "Touching the Sexual Organs as an Oath Ceremony in an Akkadian Letter" (1987) 491-2. 
the very least, these examples provide an associative context between the genitalia and oath taking.

Finally, recalling D. J. McCarthy's explanation for how a shared meal effects a covenant bond because only kinsmen eat together, a similar logic may well apply to sexual union. 218 Since sexual intercourse is characteristic of marriage and, further, since licit sexual acts take place only between husbands and wives, for a couple to willingly engage in sexual intercourse may, at the same time, imply the recognition of each other as husband and wife.

As an adjunct to McCarthy's explanation, it is possible that the covenant-forming effect of touching, or of eating together, may not be entirely arbitrary. ${ }^{219}$ In any case, although it raises questions which exceed the scope of this present study, it is possible that the posited union effected by sexual intercourse reflects and is reinforced by a deeper sociobiological reality of sexual imprinting and pair-bonding. 220

\subsubsection{The covenantal implication of referring to sexual union with the verb ידע}

Not only does the symbolism of intercourse suggest that it may have functioned as a covenant-ratifying oath-sign, but also one of the prominent terms used to refer to intercourse, the term דעי ("know"), may also point in the same direction. Whatever the precise historical explanation for the use of ירע' ("know") with reference to sexual

218 Treaty and Covenant, 253ff., 266, 276. Cf. also P. Kalluveettil, op. cit., 11.

219 In support of the importance of shared meals throughout history as a means of securing comity, cf. P. Farb, Consuming Passions. The Anthropology of Eating (1980).

220 Cf. D. Morris, The Naked Ape (1967); idem, Intimate Behavior (1971).

For more technical studies in defence of the theory of (normally monogamous) pair-bonding in homo sapiens, cf. I. Eibl-Eibesfeldt, Ethnology: The Biology of Behavior (1975) 502; D. P. Barash, Sociobiology and Behavior (1977) 297, 360; L. A. Fairbanks, "Animal and human behavior: guidelines for generalization across species" (1977) 87-110; B. A. Hamburg, "The biosocial basis of sex differences" (1978) 155-213; and S. B. Hrdy, The Woman That Never Evolved (1981).

D. Morris, I. Eibl-Eibesfeldt, and S. B. Hrdy speculate that the extreme demands of rearing human children, due especially to their slow maturation by comparison to other primates, necessitated the permanent association of the parents (required to allow a more significant paternal investment in the offspring), which fostered the evolution of the "pair-bond." The similarity of human pair-bonding to that found in about 8,000 bird species, a few members of the dog family (coyotes, bat-eared foxes), and some other primates (the gibbons, or lesser apes, siamang, and marmoset) appears to be the result of convergence toward a similar solution to a similar problem, namely the special challenge of rearing offspring (cf. L. A. Fairbanks, op. cit., 100). In each of these recognized pair-bonding species, the father contributes substantially to the care of the young.

Against the assumption of human adult male-female pair-bonding, based particularly on the sexual dimorphism of humans (a feature normally associated with non pair-bonding species), cf. E. O. Wilson, Sociobiology: The New Synthesis (1975); idem, On Human Nature (1978); and D. Symons, The Evolution of Human Sexuality (1979) 96-141.

M. Konner argues for an intermediate position: humans are pair-bonding, but imperfectly so (The Tangled Wing: Biological ('onstraints on the Human Spirit [1982] 261-290). 
union, ${ }^{221}$ an association between the distinctive "covenantal" use of this term and its sexual use (apparent, for example, in cases of double entendre) may have fostered an ancient identification of sexual union as a means of covenant recognition. Before presenting the evidence for this association, it is necessary to review briefly the evidence for the aforementioned "covenantal" usage.

As argued by H. B. Huffmon and S. B. Parker, and since supported by other scholars, there are a number of examples in the Old Testament where 7 ' is used with personal objects in a non-cognitive and non-experiential manner (apart from references to sexual union). ${ }^{222}$ Huffmon explains these relational uses as instances of a technical usage of "know" drawn from treaty practice, in which the suzerain and vassal "recognize" each other as covenant partners. ${ }^{223}$ Huffmon offers as evidence of this background a similar use of the Hittite verb šek-/ sak-, meaning “(legally) recognize.” For example, in the treaty between Suppiluliumas and Huqqanas, the suzerain Suppiluliumas tells his vassal, "And you, Huqqanas, know only the Sun [a designation for the Hittite king] regarding lordship.... Moreover, another lord ... do not ... know!"224

221 In spite of numerous attempts, the relevant facts for recovering the origin of the sexual sense of "know" lie irrecoverably buried in hoary antiquity. Cf., e.g., G. J. Botterweck, "ערע, yāda', TDOT, V, 448-481.

While it is possible that the range of usage for Hebrew ירע (paralleled by Ugaritic yd) represents an independent development, it seems more likely that this remarkable range reflects an early semantic borrowing, probably from Akkadian (where both idüm and lamādum, "to know," may be used in both a cognitive sense as well as a sexual one). However, it is not clear whether the Akkadian usage of idüm and lamōdum itself may reflect a still earlier semantic borrowing from Sumerian $z u$, which also means "to know" and can bear a sexual sense, or whether the borrowing went the other way (as is now recognized to have often been the case). It is also of interest that the Egyptian term th can bear a sexual sense.

222 H. B. Huffmon, "The Theaty Background of Hebrew yāda" (1966) 31-37; H. B. Huffmon and S. B. Parker, "A Further Note on the Treaty Background of Hebrew yāda"" (1966) 36-38. In support, cf., e.g., F. M. Cross, Canaanite Myth and Hebrew Epic (1973) 269, 273; and A. D. H. Mayes, Deuteronomy, 202. Cf. also F. C. Fensham, "Covenant, Alliance" (1980).

As an example of a simple "cognitive" use of the Qal of to be acquainted with" cf., e.g., Genesis 29:5, "Do you know Laban the son of Nahor?" Cf. also Deuteronomy 9:2; 22:2; 2 Samuel 22:44; Psalm 18:44 [ET 43]; Ezekiel 28:19.

Related to this cognitive use is what might be termed an "analytic" use of "דר'. Here the knower is cognizant of the character of the individual, and hence 5 ' could be rendered, "to know what an individual is like," "to understand." Cf., e.g., Exodus 32:22, "And Aaron said, 'Let not the anger of my lord burn hot; you know the people, that they are set on evil.'” Cf. also 2 Samuel 3:25; 17:8; 2 Kings 9:11; Job 11:11; Psalm 139:1, 14; Jeremiah 9:23 [ET 24];12:3

The "experiential" use of the Qal of דירע' with a personal object refers to cases where $ע$ ' is used to indicate that the knower personally knows the other individual, hence, "to know personally." Cf., e.g., 1 Samuel 3:7, "Now Samuel did not yet know the LORD, and the word of the LORD had not yet been revealed to him." Cf. also Exodus 33:13; Deuteronomy 11:28; 13:3 [ET 2], 7 [ET 6], 14 [ET 13]; 28:33; 29:25 [ET 26]; 32:17; Judges 2:10; Ruth 2:11; 1 Samuel 2:12; 10:11; Job 19:13; 42:11; Isaiah 1:3; 29:15; 45:20; 55:5 (bis); Jeremiah 7:9f.; 19:4; 44:3; and Daniel 11:38.

223 H. B. Huffmon, "The Treaty Background of Hebrew yada'," 31.

224 Huffmon suggests that the use of $y \bar{a} d a$ " as "(legally) recognize" and a similar use of $i d \tilde{u}$ in the Amarna tablets, not found in Akkadian more generally, may represent a calque from Hittite sek- / sak-, which normally means "know," but in the treaty texts can mean "legally recognize."

A. Goetze has challenged the assumption of direct borrowing from Hittite based on the fact that when sek- / sak-means "legally recognize," it is accompanied by the reflexive particle -za, usually attached to the first word in the sentence, while when it means "know," the particle -za is lacking ("Hittite sek- / sak'(Legally) Recognize' in the Treaties" [1968-69] 7f.). While G. J. Botterweck concludes that this leaves Huffmon and Parker's analysis of 2 , "without foundation," this is far from the case (s. v. L'? in TDOT, 
Since Huffmon's studies, under the strictures of modern lexical semantics, Biblical scholars have become considerably more sceptical about any claims for a technical usage. 225 Without insisting on Huffmon's posited restriction to formal covenantal contexts, a result of his assumption of a "technical" use, nevertheless, many of the noncognitive, non-experiential examples of דרע ' discussed by Huffmon and others do appear to support his interpretation of these as meaning "to acknowledge (the authority of, the claims of, etc.)," "to recognize (legally, covenantally)," that is, "to recognize (or even to establish another as a covenant partner)."226

\subsubsection{1 ירע in covenantal contexts}

There are several examples of $7 \boldsymbol{Y}$, where both the subject and the object are human, which appear to support the substance of Huffmon's understanding. Deuteronomy 33:9 reads: "[Levi] who said of his father and mother, 'I regard them not'; he disowned his

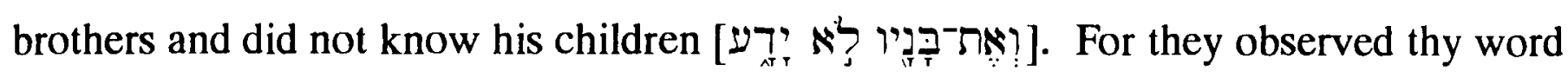
and kept thy covenant."227 This example is instructive in that it both supports and improves Huffmon's thesis. It is supportive in that Levi is blessed for his readiness to refuse to be bound by natural loyalties to his own children, that is, his refusal to "acknowledge" his own children, permitting him the requisite zeal to judge Israel for her idolatry in the incident of the golden calf. ${ }^{228}$ As noted by D. Daube, the language here is formal and intended to express the legal severance of family relationships. ${ }^{229}$ On the other hand, improving Huffmon's thesis by extending his conclusions beyond a restriction to treaty contexts, the "acknowledgment" here is one not of treaty partners, but of family members. Similar in its import and vocabulary is Isaiah 63:16: "For thou art our Father,

$\mathrm{V}$, 478). Goetze's argument concerns only the posited origin for this particular usage of Amarna Akkadian idü and Hebrew 2 '? '. Goetze nowhere challenges and, in fact, appears to accept Huffmon's analysis of the usage itself in Hebrew, Akkadian, and Hittite. And even with respect to the origin of this usage, Goetze acknowledges that the Hebrew usage might still derive from Hittite, but merely insists that if it does, the borrowing is more complicated than at first thought. In support of Huffmon and Parker, however, since Hebrew and Akkadian both lack anything comparable to the separable particle $-z a$, it is possible that a calque would depend simply on context to discriminate these usages.

225 Cf., e.g., D. A. Carson, Exegetical Fallacies (1984) 45-48.

226 E. W. Nicholson rejects Huffmon's proposal without citation (God and His People [1986] 80). Nicholson prefers the definition offered by Baumann, "know someone for one's own," or "choose and make someone one's own" (cf. E. Baumann, "Yäda' und seine Derivate. Ein sprachlich-exegetische Studie," 39). It is not clear, however, what Baumann means by "know someone for one's own" or "choose and make someone one's own" or that he intends anything different from Huffmon's definition (expressed, to be sure, without the tabooed adverb "covenantal").

S. E. Loewenstamm agrees that, apart from Huffmon's one-sided emphasis on the "mutual recognition of the partners to a treaty," his understanding of the "covenantal" usage of 2 " is comparable to that of Baumann's (“A Didactic Ugaritic Drinkers' Burlesque” [1980] 374-375).

227 This verse involves a minor $k^{e} t i \hat{b}-q^{q} \overline{r e}_{\bar{e}}$ problem with

228 Cf. A. D. H. Mayes, Deuteronomy, 403.

229 D. Daube, Studies in Biblical Law, 1947, 7f., and idem, "Rechtsgedanken in den Erzählungen des Pentateuchs" (1961) 34. 
though Abraham does not know us and Israel does not acknowledge us

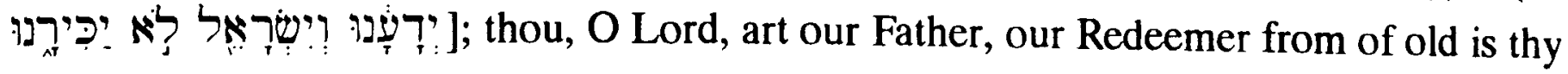
name." Compare also Exodus 1:8.230

Turning to examples which support Huffmon and where God is the subject of רעי', Amos 3:2 offers what is perhaps the parade example of the posited covenantal usage of

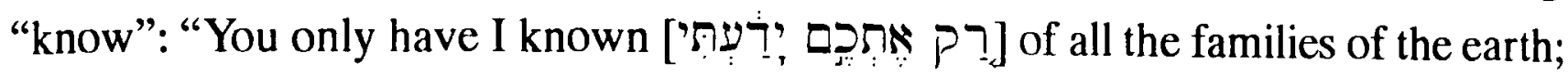
therefore I will punish you for all your iniquities." Not only would the assumed attributes of Yahweh, such as omniscience, appear to exclude any of the normal cognitive or experiential uses of 'דע' as unlikely for Amos 3:2, but also even apart from such assumptions these meanings appear inappropriate in the present context. Accordingly, W. H. Wolff translates the verb "selected."231 Similarly, D. Stuart offers "chosen" or "am I specially related to." 232

While "select" or "choose" is a common rendering for this verse, one should not miss the fact that the "election" () of Israel in the Old Testament conception appears to be inextricably bound up with covenant recognition. ${ }^{233}$ In contrast to בחר, for example, which can mean "to choose" even when used with impersonal objects (cf., e.g., Genesis 13:11), ידע is never so used. Likewise, although בחר with a personal object can mean to "choose" or "select" for some task (cf., e.g, Exodus 17:9), רע' seems to require that the choosing result in a more enduring relationship. ${ }^{234}$ Accordingly, although Huffmon does not exclude the rendering of "choose," he observes that " election' is subsidiary to the covenant" and so some variation of "recognize (by covenant)" may be more adequate for ער' in those verses where the idea of election is in view. 235

230 This verse could hardly refer to the new Pharaoh's lack of personal acquaintance with Joseph -such would be obvious and require no special comment since Joseph had long since died. The ensuing report of persecution shows that loyalty is what is at issue.

231 W. H. Wolff, Amos, 174, $176 \mathrm{f}$.

232 Hosea - Jonah, 321f. J. Lindblom offers "care for," "be interest in, concerned in" (Prophecy in Ancient Israel [1962] 326). S. R. Driver offers "took notice of, deemed worthy of His self-revealing friendship and regard," as also in Genesis 18:19 and Deuteronomy 34:10 (Joel and Amos [1915] and idem, Deuteronomy [1902] 425).

233 Cf., e.g., G. E. Mendenhall, "Election," IDB, II, 79f. Those scholars who reject any preDeuteronomic reference to Yahweh's covenant with Israel (see footnote 59 in \$8.2.2 below), explain Amos 3:2 as a reference to "election theology" (of J), rather than "covenant theology." Accepting a covenantal allusion in Amos 3:2, however, are H. L. Mays, Amos (1969) 56f., H. McKeating, The Books of Amos, Hosea and Micah (1971) 26f.; D. Stuart, Hosea - Jonah (1987) 321f.; G. V. Smith, Amos. A Commentary (1989) 105; and F. I. Andersen and D. N. Freedman, Amos (1989) 381f.; among others.

234 This is not to deny that בחר at times may also be used in this manner. Cf., e.g., Deuteronomy 7:6; and Psalm 78:70.

235 H. B. Huffmon, op. cit., 35.

Cf. also G. V. Smith, op. cit., 105, and F. I. Andersen and D. N. Freedman, op. cit., 381f. Andersen and Freedman argue for a covenantal implication for "know" in Amos 3:2, comparing Exodus 33:12, etc., as well as appealing to notions of intimacy (see M. Dahood on Psalm 1:6) and the use of "know" in marital contexts.

K. Cramer suggests that Amos 3:2 may presuppose the marriage metaphor. Accordingly, he renders the verse, "With you alone is my marriage bond" (Amos [1930] 32, 57, 60, as noted in TDNT, I, 698). It appears, however, that Cramer may have confused a particular usage of 
Other possible examples where God is the subject of "covenantal" knowing include the following: Genesis 18:19; Exodus 33:12, 17; Deuteronomy 9:24; 34:10; 2 Samuel 7:20; 1 Chronicles 17:18; Psalm 144:3; Hosea 5:3; 13:5; Nahum 1:7; and especially Jeremiah

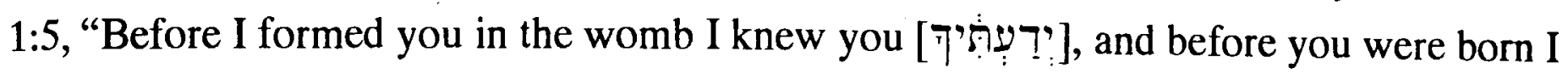

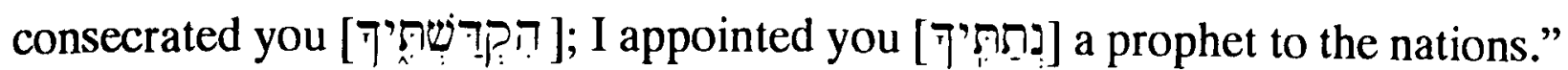

There are a number of examples where God is the object of this kind of knowing which may be helpful to note. 236 Jeremiah $22: 16$, for example, says of the righteous king, "He judged the cause of the poor and needy; then it was well. Is not this to know me

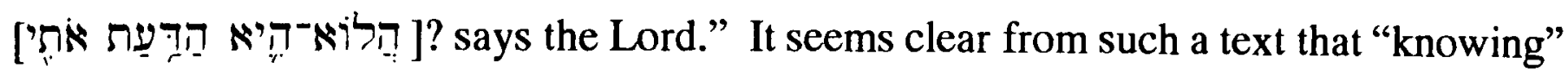
God is more than a matter of mere cognition! Similarly stressing the commitment of service implied in "knowing" God, David enjoins his son Solomon, "And you, Solomon my son,

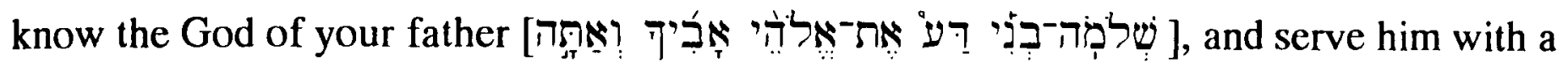
whole heart and with a willing mind; for the Lord searches all hearts, and understands every plan and thought" (1 Chronicles 28:9). Of note also is Hosea 6:6, which sets "the knowledge of God" in synonymous parallelism with "steadfast loyalty [סחֶ]": "For I

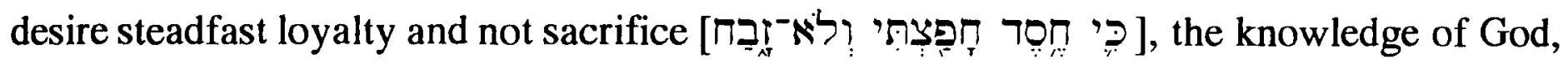

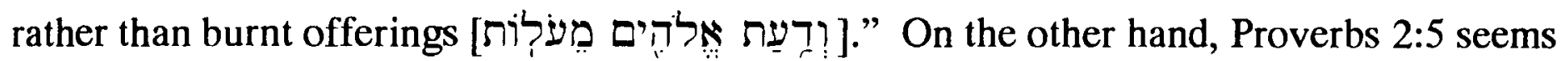
to equate the "fear of the Lord" with "knowing" God: "Then you will understand the fear of

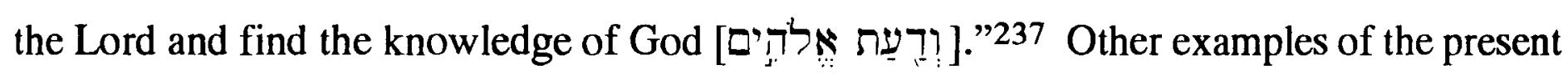
use of דע', where God is the object, include the following: Exodus 5:2; Job 18:21;24:1; Psalm 36:11 [ET 10]; 79:6; 87:4; Proverbs 3:6; 9:10; Isaiah 19:21; 43:10; 45:4; 5; 53:11;238 Jeremiah 2:8; 4:22; 9:2 [ET 3]; 9:5 [ET 6]; 10:25; 24:7; 31:34 (2x); Ezekiel 38:16; Daniel 11:32; Hosea 2:22 [ET 20]; 4:1; 5:4; 6:3 (bis); 8:2; and 13:4.

\subsubsection{2 ירע with a sexual reference}

Apart from the above-mentioned "covenantal" use of cognitive and non-experiential examples of 7 ' used with personal objects are fourteen texts where ידע' refers to sexual union. In other words, the only relational uses of 'דע 'דעי are either "covenantal" or "sexual."

236 Cf. also, "They shall not hurt or destroy in all my holy mountain; for the earth shall be full of the knowledge of the Lord [דָ

237 In this poetic verse, the "knowledge of God" is set in synonymous parallelism with the "fear of the Lord." The popular misimpression of this latter expression, as if it meant "cowering dread," fails to take account of such remarkable passages as Exodus 20:20 (where Israel is told explicitly not to "fear" God in the sense of dread but to "fear" him only in the sense of the reverent undivided attention which promotes obedience) or even more strikingly, Psalm 130:4 [NIV], "But with you there is forgiveness, therefore you are feared."

$238 \mathrm{D}$. W. Thomas has suggested that the verb in question here is not derived from the common meaning "to know" but from a homonym meaning "to be humiliated." So also R. N. Whybray, Isaiah 40 66, 180f. Against Thomas, cf. W. Johnstone, “yd' II, 'be humbled, humiliated”?" (1991). Cf. also J. Barr, Comparative Philology, 20. 
In eight of these examples the man is the subject and the woman the object of

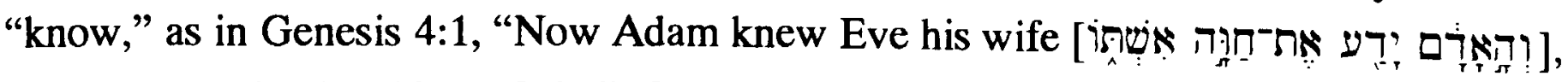
and she conceived and bore Cain." Compare also Genesis 4:17, 25; 24:16; 38:26; Judges 19:25; 1 Samuel 1:19; and 1 Kings 1:4. Four examples have the woman as the subject and the man as the object of the "knowing": Genesis 19:8, "Behold, I have two daughters who

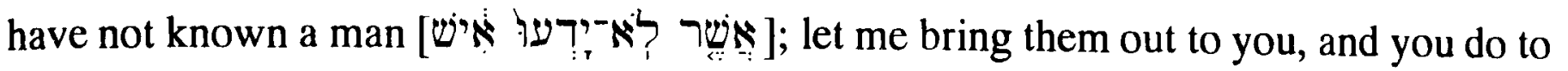
them as you please"; Numbers 31:17; Judges 11:39; and 21:12. Compare also the related Numbers 31:35 and Judges 21:11, which likewise describe unmarried enemy women who

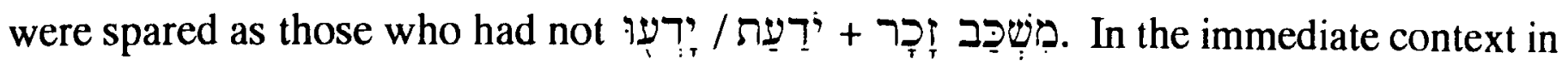
both passages (i.e., Numbers 31:17 and Judges 21:12) the parallel expressions

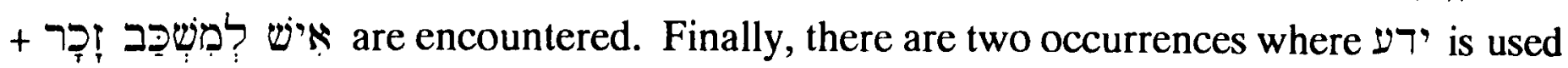
of homosexual intercourse: Genesis 19:5, "Bring them out to us, that we may know them

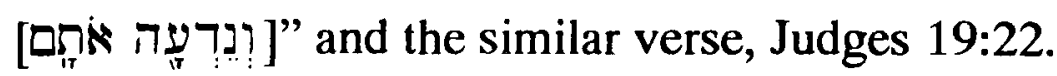

In eleven out of the fourteen cases discussed, it is likely that the sexual acts referred to by 'דע' are, in fact, marital unions. This is so, even for quite general expressions such as

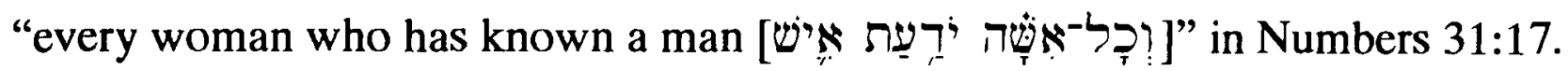

Without a great deal of effort, it is possible to explain the three remaining nonmarital cases as instances of irony or double entendre, where ירע was chosen for its covenantal associations. For example, in Genesis 19:5 when the Sodomites demand that Lot bring out

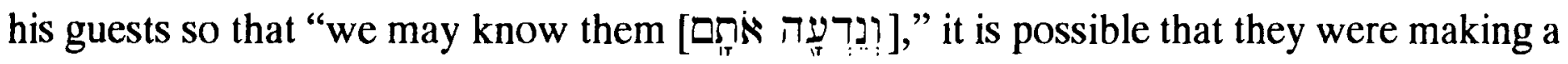
mocking effort to obscure their perverted intention with words which could be understood in a quite different sense. Indeed, the Sodomites should have "known" these guests, in the sense of "recognizing" them (covenantally) and so establishing them as covenant partners!239 The same explanation would account for the Gibeahite mob's request in Judges 19:22, "Bring out the man who came into your house, that we may know him

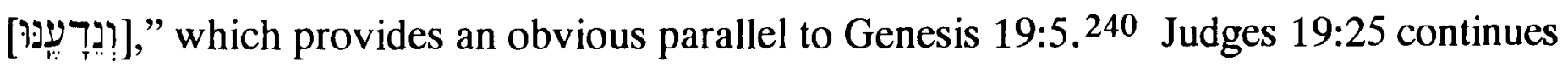
the narrative, "So the man seized his [i.e., the other man's ${ }^{241}$ ] concubine, and put her out

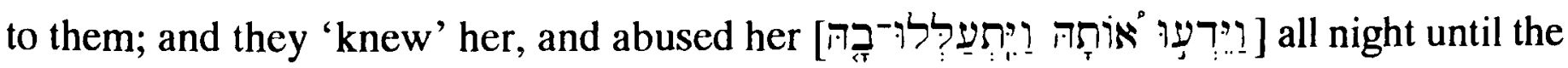
morning." It is possible that when the narrator reports how the Gibeahites "knew" the concubine, he picks up this term from its earlier use by the Gibeahite mob, as if to underscore in bitter irony the heinousness of this atrocity. ${ }^{242}$ Their brutal act was the antithesis of the kind of covenantal "knowing" which should have taken place. To avoid

239 Cf. R. Boling (Judges, 276) and P. Trible (Texts of Terror, 73), both of whom note the ambiguity of the identical clause in Judges 19:22.

240 Cf. S. Niditch, "The 'Sodomite' Theme in Judges 19-20: Family, Community, and Social Disintegration" (1982) 365-378; R. Alter, Putting Together Biblical Narrative (1988); and H.-W. Jüngling, Richter 19 -. Ein Plädoyer für das Königtum (1981).

241 This interpretation is supported by the extensive parallels between Genesis 19 and Judges 19, implying that it was the host, not the Levite, who negotiated with the Gibeahite mob. For additional arguments cf. D. K. Stuart, Old Testament Exegesis (1984) 59f.

242 So, e.g., P. Trible, Texts of Terror, 76. 
any misunderstanding, however, the narrator makes explicit that the Gibeahites' "knowing" consisted rather in "abusing her all night until the morning."

As a modern parallel to this ironic use of "know," one might imagine a gang of hoodlums demanding to "have a little fun" with some guest (an example of an ironic use of a normally inoffensive phrase). Later, a newspaper account reports that the gang "had their fun" and adds in order to clarify the bitter sarcasm, that "they abused her all night...." Our translation of Judges 19:25 reflects this interpretation by its use of quotation marks around "knew." Naturally, because of the laconic nature of these texts, any such interpretation of Genesis 19 or Judges 19 can be no more than a suggestion. Nevertheless, if correct, it provides an interesting example of the possible interplay between the "covenantal" and sexual senses of 2 'י

\subsubsection{The principal biblical texts which support an identification of sexual union as a covenant-ratifying oath sign}

Apart from the possible ironic examples in Genesis 19 and Judges 19,243 there are several key texts which clearly associate the two relational senses of 7 ', that is, the covenantal and the sexual senses, by means of double entendre. Of these texts, Hosea 2:22 [ET 20] and possibly Hosea 13:5 are crucial in that they consider Yahweh's covenantal relationship with Israel in terms of the metaphor of marriage and, in this context, appear to equate sexual union in the metaphor (referred to by ידע') with the ratifying oath of the covenant. Such a use, if demonstrated, offers significant evidence for the posited identification of sexual union in literal marriage as a covenant-ratifying oath-sign.

\subsection{Hosea 2:22 [ET 20]}

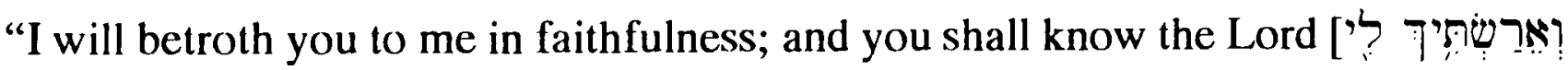

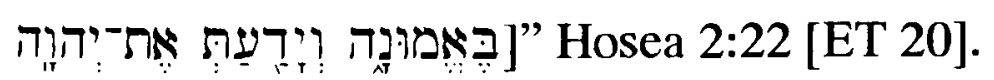

This passage provides critical evidence in that it uses "know" in an explicitly covenantal context (Hosea 2:20 [ET 18]) which alternatively describes Israel's promised restored relationship with God in terms of a marriage metaphor. According to most scholars, the variant reading found in a number of MSS, פִי אִני יהוה, is to be rejected as a tendentious alteration of the text. ${ }^{244}$ The presence of such a reading, however, offers its own eloquent testimony to the unmistakable sexual allusion contained in the MT.

243 E. F. Campbell Jr. suggests that Ruth 3:3, “do not let yourself be known," may offer yet another example of sexual double entendre -- although in this case, the primary sense of covenantal (Ruth, 131f.).

Cf. also the earlier discussion of Amos 3:2, according to the interpretations of K. Cramer, Amos (1930), and F. I. Andersen and D. N. Freedman, Amos (1989) 381f.

244 H. W. Wolff, "Erkenntnis Gottes im AT" (1955) 428ff. So also F. I. Andersen and D. N. Freedman, Hosea, 283, and G. A. Yee, Composition and Tradition in the Book of Hosea (1987) 88. 
J. L. Mays notes that "the language of the sentence of consummation lends itself to a construction in terms of the marriage metaphor; 'to know' is one of the biblical terms for the sexual act."245 Nevertheless, Mays appropriately doubts that Hosea would be promising here a literal eschatological hieros gamos between Yahweh and Israel. Indeed, if anything, it is arguable that the imagery behind Hosea 2:22 [ET 20] is intended as a polemic against the fertility cultus. 246 To defend his conviction Mays appears to impose on the reader a false dilemma: Does the rejection of a literal eschatological hieros gamos exclude the sexual meaning for 'רע ? It does so only if it is forgotten that Hosea is speaking metaphorically. Certainly the promise of 2:22a [ET 20a], "I will betroth you to me in faithfulness," ought not be pressed as if Israel were "really" going to marry Yahweh -though one need not deny that in terms of the metaphor still literally means "betroth." Similarly, allowing "know" in 2:22 [ET 20] to include a marital-sexual allusion need not imply any literal eschatological sexual relation between Yahweh and Israel precisely because in the present context "know" is being used metaphorically. ${ }^{247}$ Similarly, Mays' observation that Hosea elsewhere customarily uses "know" in a covenantal/theological sense, rather than in a sexual sense, carries little weight if the reader is prepared to allow a quite deliberate association of these senses in the present text by means of the marriage metaphor.

F. I. Andersen and D. N. Freedman assert that 'דע cannot have a sexual connotation in Hosea 2:22 [ET 20] since here it is used of the bride Israel "knowing" Yahweh but elsewhere in the Bible it is so used only with a male as the subject. ${ }^{248}$ Here, however, Andersen and Freedman are merely repeating a frequently expressed misconception. One obvious counter-example inter alia is Judges 11:39, where we read of Jephthah's daughter, who bewailed her virginity for two months upon the mountains: "she had never known a man."249

To insist with Mays and others that Hosea suddenly departs in vs. 22b [ET 20b] from the extended marital imagery which controls most, if not all, of 2:4-22a [ET 2-20a] is unpersuasive. ${ }^{250}$ This is especially so since in their view Hosea accomplishes this imagined abrupt change in imagery by utilizing the second person feminine singular of ידע', a term which is emphatically at home within a marital context and entirely to be expected following the promised betrothal "in faithfulness," in contrast to Israel's previous adultery.

Finally, as already suggested, to allow "know" in the present verse to include a sexual allusion does not imply that Hosea is necessarily abandoning his customary

245 J. L. Mays, Hosea, 52.

246 O. J. Baab, “Marriage," IBD 3 (1962) 286.

247 Cf. H. McKeating, Amos, Hosea, Micah, 88.

248 Hosea, 284.

249 Cf. also Genesis 19:8; Numbers 31:17, 35; and Judges 21:12.

250 Cf., e.g., H. W. Wolff, Hosea, 53. 
covenantal understanding of this verb. ${ }^{251}$ Indeed, embedded as it is in the present marital imagery, the use of "know" within this verse offers an impressive confirmation of our hypothesis that as the marriage covenant-ratifying (and renewing) act, sexual union is the means by which an individual "acknowledges" his or her spouse as covenant partner.

\subsection{Hosea 13:5}

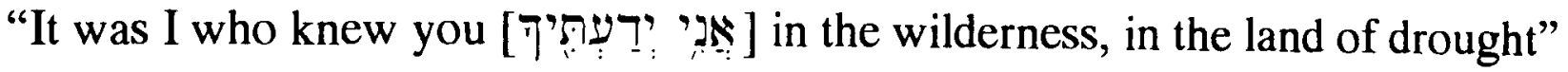
(Hosea 13:5). This verse offers an intriguing example of the usage under question. Unfortunately, however, the text of the MT is not beyond dispute. H. W. Wolff and J. L.

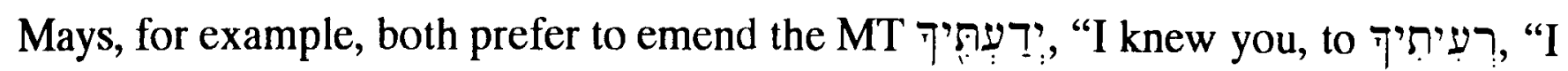
pastured you," following the LXX, Targum, Syriac, and Vulgate. 252 Accordingly, the MT may be explained in terms of a $า-\urcorner$ graphic confusion and dittography of the final yôd of the preceding reverse errors, and the MT supported as a lectio difficilior. ${ }^{253}$ The use of the emphatic pronoun may suggest a contrastive reference to the knowing mentioned previously in vs. 4, "I am the Lord your God from the land of Egypt; you were to know no God but me

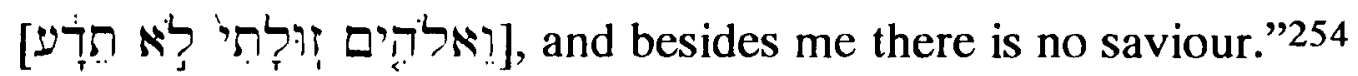

H. B. Huffmon has advanced an important argument in support of the MT which had been previously overlooked.255 Huffmon notes that 2 in this context offers a specific allusion to the covenant at Sinai, which is referred to as the place where God "knew" Israel in Deuteronomy 9:24, "You have been rebellious against the LORD from the

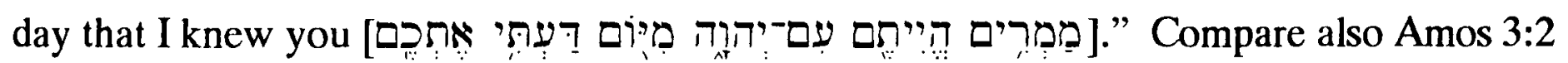
and Deuteronomy 2:7.

As noted by F. I. Andersen and D. N. Freedman, Hosea 13:4-6 briefly alludes to the marriage metaphor developed in chapter 2, as it recalls the redemption from Egypt and subsequent wilderness wanderings under the figure of a trysting place. ${ }^{256}$ Although the imagery is not blatant and lacks feminine gender references, the connections with Hosea 2 in vocabulary and subject matter are clear enough to recognize the allusion. In addition to the mention of "Egypt" and "wilderness" in Hosea 13:4f. (cf. 2:16f. [ET 14f.]), the repetition of the theme of the provisioning of Israel in 13:6 (cf. 2:7, 10, 11 [ET 5, 8, 9])

251 Cf. also D. K. Stuart, Hosea - Jonah, 60, and G. A. Yee, Composition and Tradition in the Book of Hosea, 88, although Yee considers $22 \mathrm{~b}$ [ET 20b] to be an insertion by the final redactor.

252 H. W. Wolff, Hosea, 220; and J. L. Mays, Hosea, 5. Cf. also W. R. Harper, Amos and Hosea, 397; and D. K. Stuart, Hosea - Jonah, 200, n. 5a; 203.

253 In support of the MT, cf. C. van Leeuwen, Hosea, 258f., and F. I. Andersen and D. N. Freedman, Hosea, 634. W. Nowack, Die kleinen Propheten (1897 2nd ed.; 1903 3rd. ed.), retains the MT and then adds to the beginning of v. 6: "I shepherded you" (based on the LXX).

254 On this rendering of the Imperfect

255 "The Treaty Background of Hebrew ידע" (1966) 31-7.

256 Hosea, 634. 
and the subsequent indictment that in their satiety Israel "forgot me" (cf. 2:15 [ET 13]), all offer points of contact.

In 2:16-17 [ET 14-15], Hosea identifies the period of the Exodus and wilderness wanderings as the point when Yahweh contracted his "marriage" with Israel. As Hosea 2:21f. [ET 19f.] promises a day when Yahweh's marriage will be renewed, when he will betroth Israel to himself forever, and when "you will know Yahweh" (employing the metaphor of the sexual consummation of the marriage covenant), so Hosea 13:5 recalls that

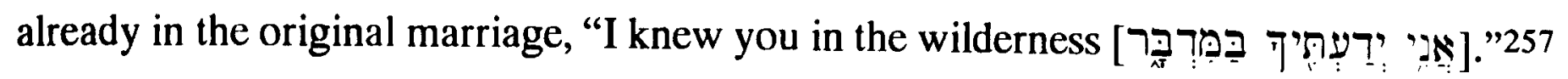
In keeping with the same imagery, when Hosea 13:4 rehearses the central stipulation of the Sinaitic covenant, it does so in a manner which comports perfectly with the marital imagery. 258 As a wife owes her husband exclusive sexual fidelity, so "you [Israel] were to

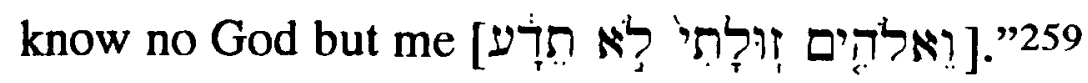

\subsection{Hosea 5:3-4}

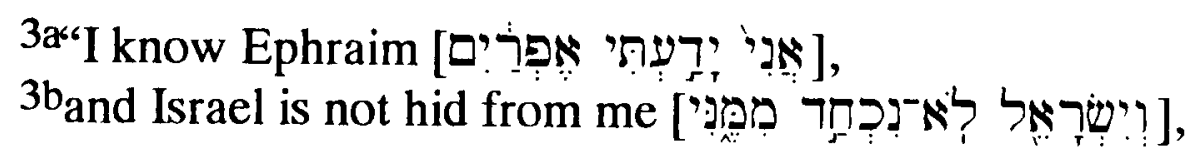

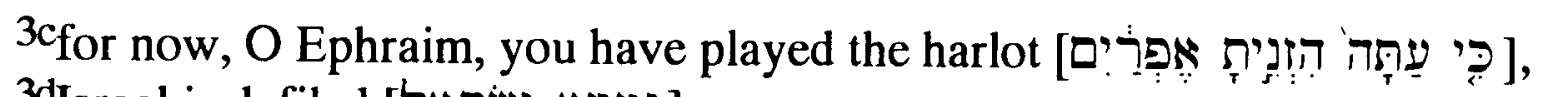

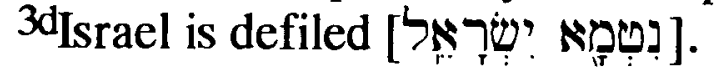

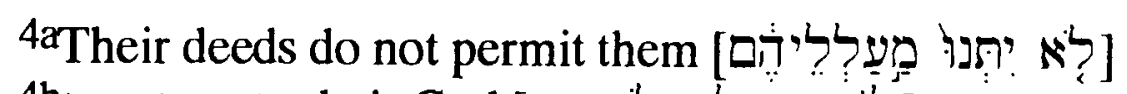

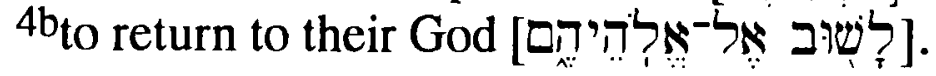

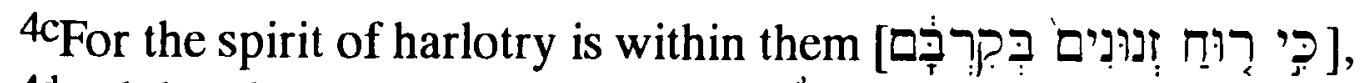

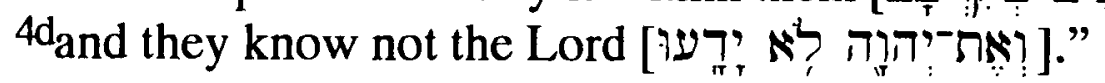

From the synonymous parallelism between $3 \mathrm{a}$ and $3 \mathrm{~b}$, it is apparent that "know

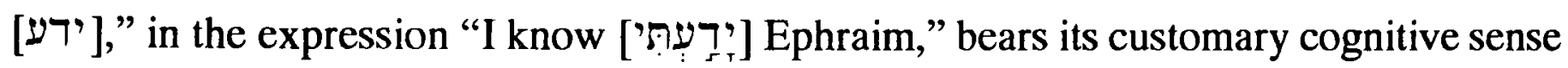
(where Yahweh "understands" or "knows the character" of an individual, as in Psalm 139:1). As F. I. Andersen and D. N. Freedman point out, however, a closer analysis of these verses suggests that there may be an intentional inclusio between this first mention of "know" in 3a and that in 4d, with the result: "I know Ephraim ... but they don't know

257 Could the fructifying effect of that "knowing" in the subsequent verses continue the implicit sexual allusion?

258 D. K. Stuart observes, "In effect the Sinai covenant's preamble (identification of Yahweh as the sovereign), prologue (recitation of his benevolence toward his people), and central stipulation (the first commandment) are all restated in this verse" (Hosea - Jonah, 203)

259 This identification of the formation of Yahweh's covenant with Israel at Sinai as a marriage, first made by Hosea, was greatly elaborated in later Jewish speculation. The result of this speculation not only profoundly influenced the understanding of Yahweh's covenant, but it also had a reciprocal effect on the traditional Jewish marriage ceremony (turning it in certain respects into an enacted parable of Sinai). Cf. T. Gaster, Customs and Folkways of Jewish Life (1955) 109-110; 126-128; and M. R. Wilson, "Marriage and Sinai: Two Covenants Compared," in Our Father Abraham. Jewish Roots of the Christian Faith (1989) 203-208. 
me."260 Moreover, given the fact that this inclusio frames repeated references to Israel's idolatry expressed in terms of the metaphor of sexual infidelity (most obvious in "you have played the harlot" and "the spirit of harlotry is within them," but probably also intended by "Israel is defiled,"261 and allowed by "their deeds"262), it appears likely that the second reference to "know," and probably also the first, offer an allusion to the sexual sense of "know" by double entendre.

\subsection{Jeremiah 31:34}

In addition to the Hoseanic texts just considered, there is one final text, Jeremiah $31: 34$, which is less clear in its implication, but may provide further evidence for an association between "know" as a reference to sexual union and its covenantal use. Jeremiah 31:34 reads: "And no longer shall each man teach his neighbour and each his

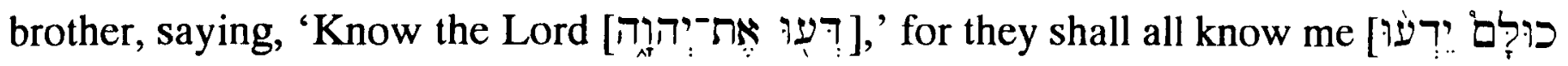
'și ], from the least of them to the greatest, says the Lord; for I will forgive their iniquity, and I will remember their sin no more." In the context, especially in view of the preceding verse ("But this is the covenant which I will make with the house of Israel after those days, says the Lord: I will put my law within them, and I will write it upon their hearts; and I will be their God, and they shall be my people."), a covenantal nuance to "know" seems plausible. ${ }^{263}$ This passage is of special interest, however, in that Jeremiah 31:32 (if we are

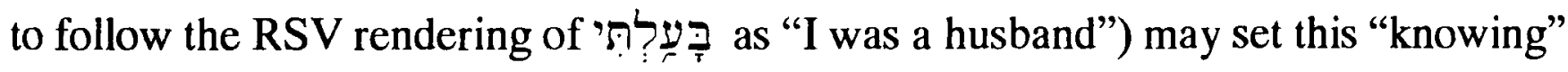
within the context of the marriage metaphor for the relationship between God and Israel. Jeremiah uses this metaphor elsewhere (Jeremiah 3), which may be assumed to have derived from Hosea. While it must remain uncertain, it is possible that he briefly alludes to the marriage metaphor again in the present context. If so, a reference to "knowing" in the context of the marriage metaphor suggests a similar covenant-forming or renewing function for sexual union as for this recognition of Yahweh.

\subsection{Conclusions}

Chapters 6 and 7 have been concerned to answer the objection of J. Milgrom and M. Greenberg, who deny that literal marriage is a covenant based on the fact that a ratifying oath is indispensable for the existence of a "covenant [ lack any such oath. To prepare for a more adequate examination of the evidence in the

260 Hosea, 391.

261 Cf. Leviticus 18:20; Numbers 5:14, 29; Ezekiel 18:6, 11, 15; 33:26; etc., as examples elsewhere of $N$ D applied to adultery.

262 מעל is a sufficiently general term that it may refer to acts of sexual immorality, as it does in Psalm 106:39.

263 Cf. J. A. Thompson, Jeremiah, 581. 
present chapter, in Chapter 6 it was argued that covenant-ratifying oaths do not need to be self-maledictory, but that they often consist of verba solemnia, that is, a solemn declaration of the commitment being undertaken -- solemn, because the deity was implicitly invoked as a witness. Moreover, it was also noted that in the Old Testament, as well as elsewhere in the ancient Near East, oaths were frequently symbolic, that is, they consisted of "oathsigns," rather than being exclusively verbal.

In this chapter we began by considering a broad range of extrabiblical evidence (especially MAL A $\$ 41$, the etlu tablet, the ardat lili tablet, the marriage formulae from Elephantine and Murabba'at, and the implication of the corresponding divorce formulae), as well as biblical evidence (namely Genesis 2:23; Hosea 2:4, 17-19 [ET 2:2, 15-17]; Proverbs 7:4f.; and Tobit 7:12), which demonstrates that throughout this period marriage was, in fact, typically formed with the use of verba solemnia.

Furthermore, since verbal oaths, such as verba solemnia, do not preclude the use of oath-signs, but instead typically supplement them, we examined the evidence for identifying sexual union as the expected covenant-ratifying oath-sign for marriage. To support this identification it was first necessary to exclude the once popular theory of "marriage by purchase," according to which the terhatum / פַ is held to be a "brideprice." The theory of "marriage by purchase" is antithetical to the view of marriage as a covenant not only because of its stress on the primacy of the relationship between a man and his father-in-law, rather than between a man and his wife, but also because of its expectation that the marriage-sale should be consummated not by the use of the object purchased (i.e., sexual union), but merely by its transfer (i.e., the in domum deductio), as in all sales transactions.

Accepting the present scholarly consensus which has rejected the theory of "marriage by purchase," we argued that payment and receipt of the terhatum / מָרֵ is formative not of marriage, but merely of betrothal (also called "inchoate marriage"). Furthermore, we examined the evidence that copula carnalis does, in fact, consummate marriage (denied by the theory of "marriage by purchase"). In particular, supporting an analogy, suggested by R. Westbrook, between the two modes of adoption (i.e., adoption of foundlings vs. adoption of children who have natural parents) and the two corresponding modes of marriage, it was noted that in cases such as the marriage of a captive woman (Deuteronomy 21:10-14), where there is no need to secure the parents' consent, the act of sexual union by itself is constitutive of marriage. A similar perspective of sexual union as constitutive of marriage is suggested by instances of synecdoche, by which sexual union is used to refer to marriage and vice versa.

Likewise, consistent with this predisposition to view sexual union as a marriageforming act, Exodus 22:15, 16 [ET 16, 17]; Deuteronomy 22:28f.; Genesis 34; and 2 Samuel 13 all encourage or insist on the formalizing of marriage following an act of 
"premarital" sex. This formalization consists simply of paying the marriage present, which, if accepted, constitutes an ex post facto approval of the union by the girl's parents and extinction of their parental authority.

Clearly, sexual union is the indispensable means for the consummation of marriage both in the Old Testament and elsewhere in the ancient Near East. While it is less certain, it seems probable that sexual union functioned in this manner precisely because it was viewed as an oath-sign. For example, Israel's covenant with Gibeon in Joshua 9 was considered irrevocable once Israel ratified it by the oath-sign of a shared meal, even though Gibeon secured this covenant through a blatant deception. 264 In an analogous manner, as was noted in our discussion of Genesis 29, Jacob's marriage with Leah appears to have been deemed valid and irrevocable, in spite of the underlying deception, once Jacob consummated the marriage through sexual union with Leah.

In any case, in support of this identification of sexual union it was recalled how oath-signs, such as eating together or giving one's hand in a hand shake, often function merely by offering a solemn depiction of the covenant commitment to unity being undertaken. With respect to sexual union, it is clear that this act is ideally suited to depict the "one flesh" reality which is definitional of marriage in Genesis 2:24. Furthermore, it is notable that a number of oath-signs involve physical contact or the use of the parts of the body to represent one's whole person on the principle of pars pro toto, and two oath gestures involve the organs of generation (i.e., circumcision and placing one's hands under another's "thigh"). At the very least, such examples provide an associative context between the genitalia and oath taking.

264 Cf. 2 Samuel 21 for the enduring consequences of this commitment which Saul attempted to revoke. Nevertheless, Joshua 9:14 makes plain that this meal was the decisive point of Israel's failure to consult the Lord, "So the men partook of their provisions, and did not ask direction from the LORD." Cf. R. G. Boling and G. E. Wright, Joshua, 265. 
8.3 The problem of adultery and the claimed indifference of the Old Testament to a man's sexual fidelity ................................................... 328

8.3.1 Conventional androcentricity of legal discourse ....................... 332

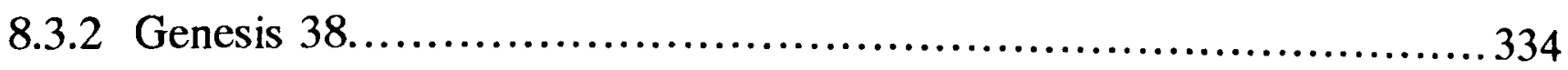

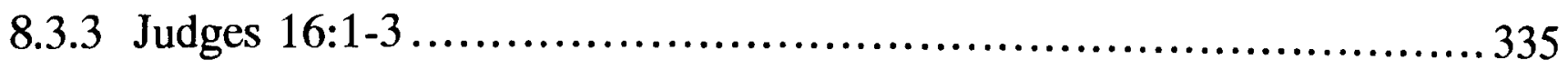

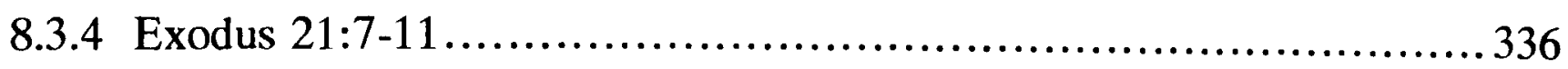

8.3.5 Exodus 22:15-16 [ET 16-17] (and Deuteronomy 22:13-21) ............. 338

8.3.6 There are no texts which demonstrate that the extramarital sexual activity of men or the sexual activity of unmarried women was a matter of moral indifference ......................................... 338

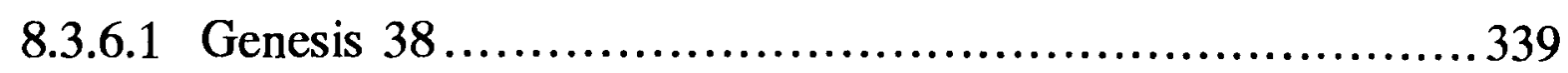

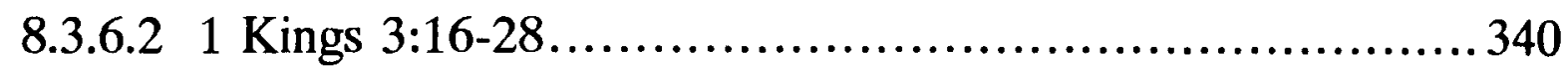

8.3.6.3 There are no texts which demonstrate that the non-cultic, non-commercial sexual activity of unmarried women was a matter of moral indifference

8.3.7 Texts which encourage a husband's sexual fidelity regardless of the married state of the mistress.......................................... 343

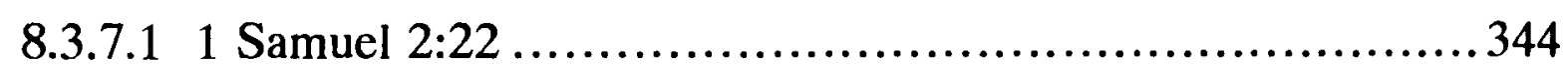

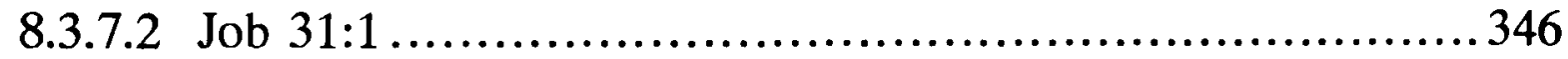

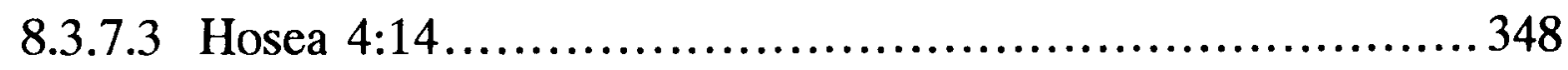

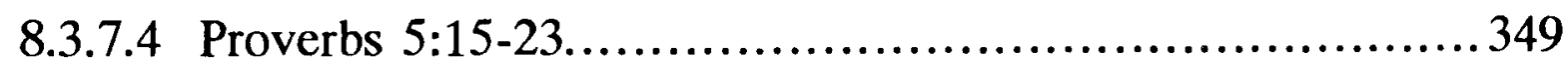

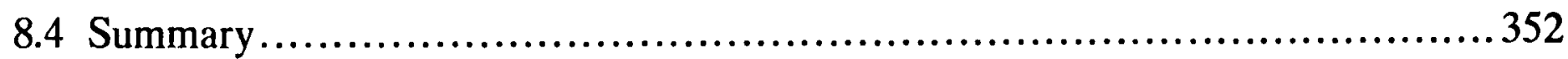




\section{Outline of Chapter 8: \\ Marriage as a "Covenant [בר I] "Elsewhere Within the Old Testament}

8.1 Confirmatory (indirect) evidence for the existence of an oath, or oath-sign, in marriage.

8.1.1 Marital offences may be identified as sin (פשע, פטא, etc.), perfidy

(בעל), or infidelity (בגד) against one's spouse.

8.1.1.1 The significance of the use of מעל for marital offences........298

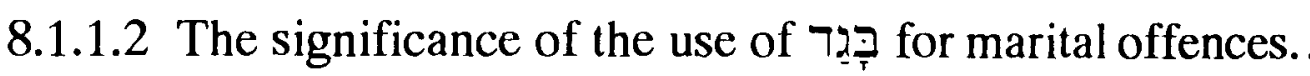
304

8.1.2 Second, if God was invoked in any ratifying oath to act as guarantor of the marriage covenant, offences against the marriage on the part of either the husband or the wife may be identified as a $\sin (N)$ ח, פשי, etc.), etc., against God.

8.1.3 Because God is necessarily invoked to act as guarantor in any ratifying oath, should there be marital infidelity, this ought to prompt God's judgment against the offending party 308

8.1.4 Because the deity is necessarily invoked in any ratifying oath, intermarriage with pagans should be prohibited because of the idolatry that would necessarily ensue when a ratifying oath is sworn.....309

8.2 Texts (other than Malachi 2:14) which explicitly, or implicitly, identify

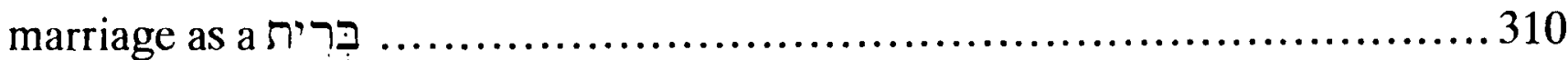

8.2.1 The marriage analogy and especially Hosea 2:18-22 [ET: 16-20] ......... 311

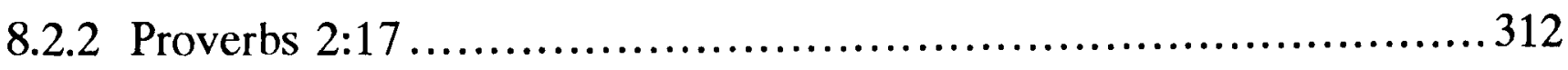

8.2.2.1 G. Boström's view that "the covenant of her god [ִרְית

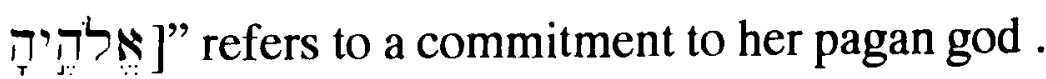

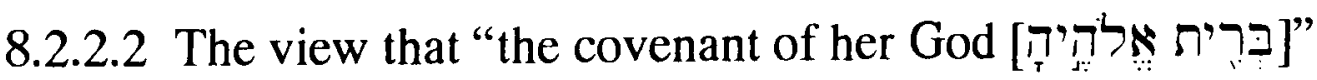
refers to the Sinaitic covenant

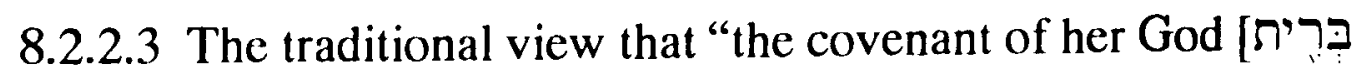

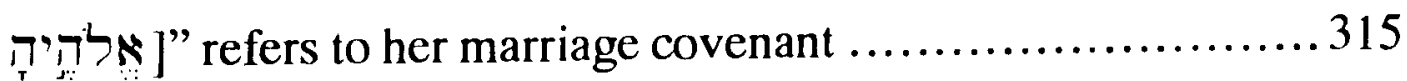

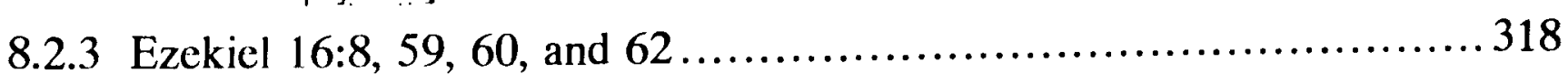

8.2.4 Two doubtful examples.......................................... 325

8.2.4.1 Genesis 31:50 ....................................... 325

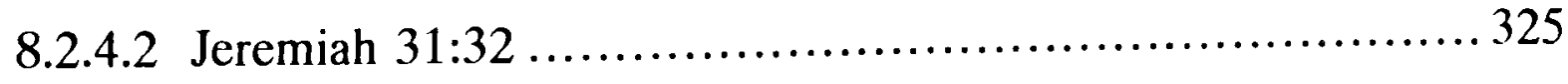

8.2.5 1 Samuel 18-20 -- a narrative analogy between David's covenant with

Jonathan and David's (marriage) covenant with Michal ................ 326 


\section{Chapter 8: \\ Marriage as a "Covenant [ברית]" Elsewhere Within the Old Testament}

In the preceding chapters we have established that Malachi identifies marriage as a covenant, grounded in his interpretation of the Adam and Eve narrative. We have also demonstrated that, in keeping with its identity as a covenant, marriage appears to have been ratified by verba solemnia, as well as by the oath-sign of sexual union. We turn now to consider further corroborating evidence for an identification of marriage as a covenant elsewhere within the Old Testament.

Specifically, first we shall look at various indirect evidences that marriage was viewed as a sanction-sealed commitment between a husband and his wife. Second, we shall examine the other texts within the Old Testament which explicitly or implicitly identify marriage as a בִּרִ י Finally, we shall consider the claimed indifference of the Old Testament to the husband's sexual fidelity, an indifference which has been thought to contradict the identification of marriage as a covenant.

With a view to this last objection, it will be of special interest throughout this chapter to determine, wherever possible, what was the precise nature of the sanction-sealed commitment undertaken by the husband and wife respectively. For example, if there were no other oath than the rather imprecise verba solemnia, "She is my wife and I am her husband from this day and forever," 1 presumably the content of this commitment would be largely dependent on inherited cultural norms. ${ }^{2}$ It is possible, for instance, that a husband in such an oath-bound marriage might be under no culturally defined obligation to be sexually faithful to his wife, while this might be the wife's principal obligation toward her husband. As an analogy, one might compare the disparity of obligations typical of suzerainty treaties, in which the vassal would be oath-bound to an exclusive loyalty to his suzerain without any hint that the suzerain should reciprocate by refraining from acquiring additional vassals. ${ }^{3}$

Alternatively, if a marriage was ratified by the more demanding declaration formula of Genesis 2:23, as interpreted by Genesis 2:24 (or if the defining cultural norms for "I am her husband" included such texts as Genesis 2, Job 31, Proverbs 5, Malachi 2, etc.), and if

\footnotetext{
1 So Cowley 15 , line 4 .

2 So, M. T. Roth, with respect to the declaration formula, "She will be my 'wife' [lu ašša si]," found in NB marriage documents ("'She will die by the iron dagger': Adultery and Neo-Babylonian Marriage," 190).

${ }^{3}$ Cf., e.g., Esarhaddon's Succession Treaty, In. 129: you shall not "sw[ear an oa]th to any other king or any other lord" (S. Parpola and K. Watanabe, Neo-Assyrian Treaties and Loyalty Oaths [1988] 34).
} 
sexual union was recognized as its inherently mutual oath-sign, then it may be expected that in such a marriage there would be a moral, though not necessarily legal, obligation of exclusive sexual fidelity on the part of the husband, no less than the wife. However, such an obligation is regularly denied by scholars, mainly because of the failure to differentiate legality from ethical approval (a problem which was seen similarly to vex the scholarly discussion of polygyny in $\$ 4.6$ above). This assumption will be scrutinized here.

\subsection{Confirmatory (indirect) evidence for the existence of an oath, or oath- sign. in marriage}

Having posited the use of verba solemnia as a ratifying oath in marriage and having identified sexual union as a complementary ratifying oath-sign, we shall argue that marriage was not only a status regulated by custom (ethics) and family law, but also, at least in the minds of some biblical authors, a sanction-sealed commitment to which the deity was witness.

As has been discussed, the most direct evidence for this perspective is found in Malachi 2:14: "You ask, 'Why does he not?' Because the LORD was witness between you

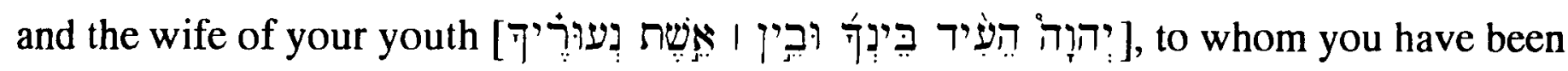

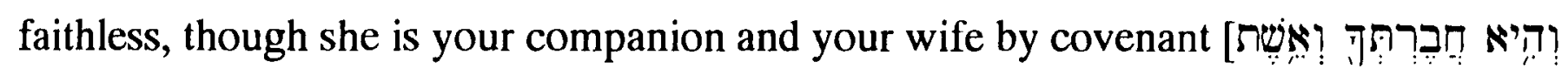

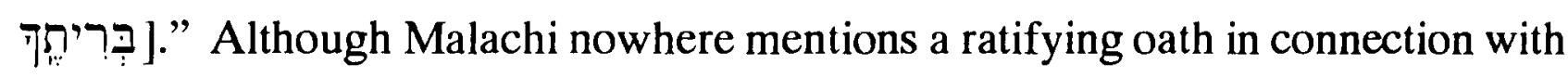
marriage, the presence of such an oath, which would invoke the deity to act as a witness, is implied in his explicit identification of Yahweh as a "witness" between the husband and his wife. $^{4}$

However, if marriage was understood more widely as a sanction-sealed commitment between husband and wife to which the deity was witness, even if other texts may be less explicit than Malachi, a number of implications follow for which we may seek evidence:

1) First of all, if a covenant existed between a husband and his wife, any offence against the marriage on the part of either the husband or the wife may be identified as an act of sin (פטשע, פטע, etc.), perfidy (מעל), or infidelity (בגד) against the other.

${ }^{4}$ There are only two other Old Testament texts where God is acknowledged as a "witness between

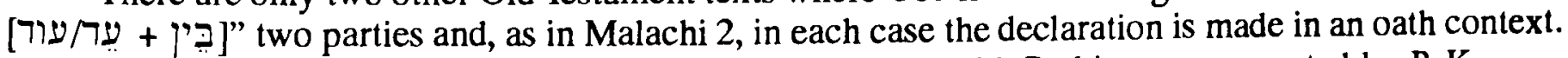
Cf. Genesis 31:50 and 1 Samuel 20:12, if the MT is emended with Peshitta, as suggested by P. K. McCarter Jr., 1 Samuel, 336. Cf. also Genesis 31:48, where in a covenant-ratifying oath context, the "heap," perhaps acting as a representation of the deity, is acknowledged as "a witness between you and me." Cf. further Genesis 31:44, and Joshua 22:27.

Finally, cf. Judges 11:10, which employs different vocabulary: "And the elders of Gilead said to

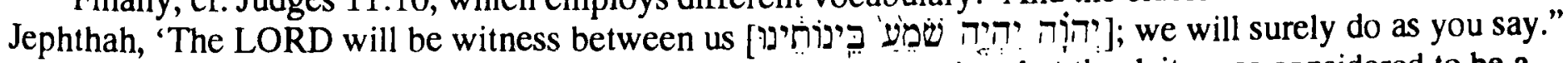

Cf. our discussion in $\$ 7.1 .5$ above in support of the assumption that the deity was considered to be a witness to marriage. 
2) Second, because God is invoked in any ratifying oath to act as guarantor of the covenant, any offence against the marriage on the part of either the husband or the wife may be identified as a sin (פשע, פט, etc.) etc., against God.

3) Third, because God is invoked to act as guarantor of the covenant in any ratifying oath, any marital infidelity ought to prompt God's judgment against the offending party.

4) Finally, because the deity is necessarily invoked in any ratifying oath, intermarriage with pagans should be prohibited because of the idolatry that would necessarily ensue when a ratifying oath is sworn.

While these indirect evidences are not individually or even collectively sufficient to demonstrate the present thesis (since they readily admit alternative explanations), nevertheless, they are necessary conditions if marriage was considered an oath-ratified covenant. Moreover, if they are found to be the case, they would provide significant confirmatory support.

\subsubsection{Marital offences may be identified as sin ( (בעל) against one's spouse}

As mentioned, if a covenant existed between a husband and his wife, then any offence against the marriage on the part of either the husband or the wife may be identified as an act of $\sin ($ פשעע, פטא, etc.), perfidy (מעל), or infidelity (בגר) against the other, as these terms are so employed elsewhere in analogous cases of covenant violation (e.g., 2 Kings $1: 1 ; 18: 14$; etc.).

Given the relatively few specific examples of adultery mentioned in the Old Testament, it is perhaps unsurprising that no biblical text identifies adultery, or any other marital offence, specifically as a sin (פטשע) against one's spouse. ${ }^{5}$ Nevertheless, some texts do describe adultery as "perfidy [מעל]" or "infidelity [בגר]" against one's spouse.

\subsubsection{The significance of the use of מעל for marital offences}

Numbers 5:12, 27 describe a wife's adultery as an example of מעל מעל against her husband. Stressing the significance of these examples, J. Milgrom notes that these two verses represent the only occasion where מעל is used outside the sacral sphere of sancta

${ }^{5}$ Some texts are ambiguous in that they pertain to the marriage analogy of Israel's relationship to Yahweh, describing the Israel's spiritual "adultery" as פשע. Cf. Isaiah 50:1 and 57:4. Cf. also Jeremiah 3:13. Alternatively Jeremiah 2:22 declares to adulterous Israel: the ineradicable "stain of your guilt

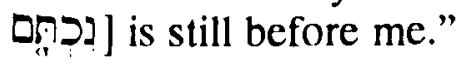


and oath violations. ${ }^{6}$ This observation makes very appealing the hypothesis that the reason מעל is applied to adultery is the fact that it refers to a violation of the oath by which the marriage covenant was ratified. Further supporting the hypothesis of such an oath is the

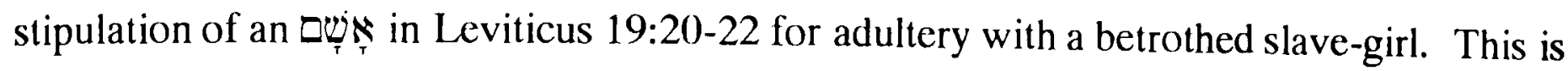
so because, as Milgrom notes, the offering intended to redress sancta trespass or oath violations. ${ }^{7}$

But having drawn attention to these points, which naturally suggest that a covenantratifying oath was involved in marriage, Milgrom considers, but rejects this inference for the following four reasons:

1) The lack of an explicit stipulation of an oath in any of the law codes or extant marriage contracts which have survived from the ancient Near East.

This objection has already been answered in $\$ 6.2 .1$.

2) What explicit evidence there is in the Bible of an oath in marriage, namely Ezekiel $16: 8$, refers to an oath taken by Yahweh, the husband in this metaphor. However, according to Milgrom, "it should have been expected of the bride, Israel, for it is the bride, not the husband, who is subject to the laws of adultery." 8

In large measure this objection has already been answered in Chapter 7, where we considered the evidence for an oath or oath-sign on the part of both the husband and the wife. However, even apart from that evidence, the fact that one chapter in Ezekiel mentions an oath on the part of the husband hardly requires the conclusion that there could have been no corresponding oath on the part of the wife.

At the end of the present chapter we shall cxamine in more detail the widely-held assumption, shared by Milgrom, that the Old Testament obligates only wives and not husbands to sexual fidelity. Nevertheless, this has no bearing on the interpretation of Numbers 5 or its implication that adultery may represent an oath-violation, i.e. מעל, since the adultery in view in this chapter is on the part of the wife.

3) In Numbers 5:11ff. מעל is used to refer to a wife's suspected adultery against her husband (vss. 12, 27). However, everywhere else in the Old Testament מעל מע ised of

${ }^{6}$ Cult and Conscience, 133f. For examples of מעל with sancta violation, cf. Joshua 7:1; 2 Chronicles 26:16, 18. For use with oath violation, cf. Numbers 5:6-8, Leviticus 26:40, and Ezekiel 17:18-20. For מעל applied to adultery, cf. Numbers 5:12, 27.

Cf. also Numbers 31:16, where מעל is used for the Baal of Peor incident; Ezekiel 20:27, where it is used of idolatry; and Ezra 10:2, 10, which so describes interfaith marriage.

Milgrom argues that these two categories of מעל, sancta trespass and oath violation, are essentially similar and were so considered throughout the ancient Near East (op. cit., 21f.).

7 Milgrom notes that is found only with

8 Ibid., 134. 
sancta or oath-violations committed against God. Hence Milgrom argues that מעל in this passage is "a literary metaphor and has no legal value." 9

Milgrom's assertion appears unconvincing. There is nothing in these texts to suggest the presence of "a literary metaphor" or an allusion to the prophetic marriage analogy. Given the limited corpus from which to reconstruct ancient Israel's jurisprudence, it is precarious to eliminate any data from consideration ex hypothesi. Rather, it seems likely that Milgrom has unnecessarily restricted the usage of מעל and that, based on the evidence of Numbers 5:12,27, מעל can be used of oath violations against persons other than God. See Numbers 5:6f., which is instructive in its awareness of such compound guilt and its significant conjoining of מעל מאם and "Speak to the Israelites: When a man or

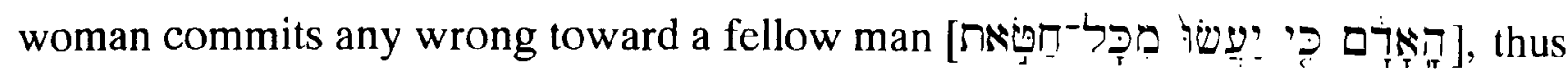

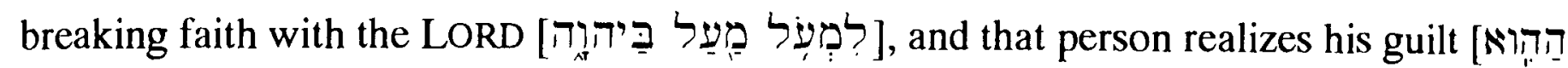

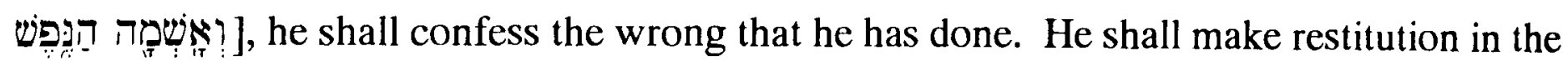

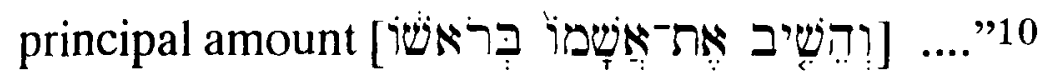

Although מעל is relatively well-attested outside of Numbers 5:12, 27, in that the verb appears 35 times and the noun 29 times, one should not exaggerate the frequency of occurrence by failing to note that in 18 cases the verb מעל is employed with its cognate accusative (as in Numbers 5:12,27). Furthermore, it is notable that in most of its occurrences, including Numbers 5:6, both the verb and the noun are accompanied by 13 13 באלהי ... 12 בי / 11ביהוה the Lord God. While this complementary prepositional phrase may be redundant, perhaps for emphasis, it is also possible that the phrase is required because מעל can be committed against persons or entities other than God. This last option seems to be confirmed by Joshua 7:1 where מערם + ב + מעל is found. Here ב marks an impersonal object, "the ban,"

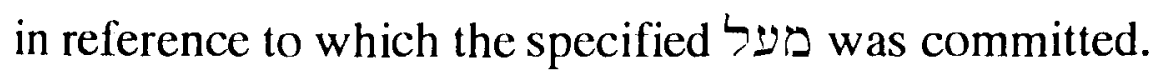

Lastly, a couple of examples of מעעל do not easily conform to the very restricted usage posited by Milgrom: Proverbs 16:10 and Job 21:34.14

4) Finally, Milgrom argues with respect to Leviticus 19:20-22, "If the violation of the alleged betrothal oath is responsible for the penalty, why is the paramour liable at all -

${ }^{9} \mathrm{Ibid}$. Cf. especially note 486, where Milgrom suggests that the use of מעל מעל in Numbers 5 probably derives from the analogy of Israel as an unfaithful wife whose מעל against Yahweh was literal. "Since maal denotes straying after other gods, it can also describe straying after other men."

10 As rendered by the NJPS. In support, cf. J. Milgrom, op. cit., 17, 105, n. 388.

11 Leviticus 5:21 [ET 6:2]; Numbers 5:6; Joshua 22:31; 1 Chronicles 10:13; 2 Chronicles 12:2; $26: 16 ; 28: 19,22$; and $30: 7$.

12 Deuteronomy 32:51; Leviticus 26:40; Ezekiel 14:13; 20:27; and 39:23, 26.

13 Joshua 22:16; Ezra 10:2; Nehemiah 13:27; and 1 Chronicles 5:25.

14 Milgrom considers these both to refer to oath violation: "the king who commits maal with 'his mouth' by deviating from God's justice and the self-assumed authority of Job's friends to speak for God's theodicy" (op. cit., 20, n. 64). 
he did not take the oath!"15 Rather than allowing Leviticus 19:20-22 to overturn his view

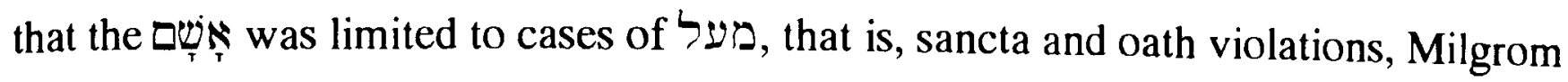
argues that adultery entails an oath violation after all -- not the violation of a betrothal vow, since the paramour was no party to this, but the violation of the Sinaitic oath by which all Israelites were obligated to adhere to the seventh commandment against adultery.

There are four main difficulties with Milgrom's explanation of Leviticus 19:20-22, however.

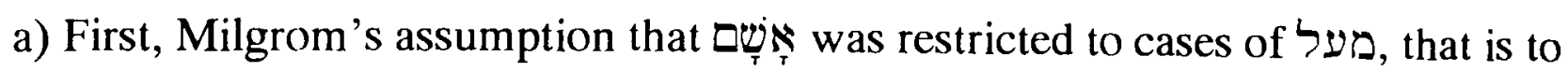
sancta and oath violations, is not so clear. Milgrom's view on this matter finds its strongest support in Leviticus 5:14-24 [ET 6:5], the one text which addresses the purpose of the in a general manner. However, the limited evidence available by which to test this interpretation forbids certainty. ${ }^{16}$ While the term Old Testament bearing the meaning "reparation offering,"17 eleven of these are grouped within Leviticus 5-7. Of the remaining twenty-three examples, the only instances which offer support for Milgrom's view are four verses in 1 Samuel 6, where the Philistines

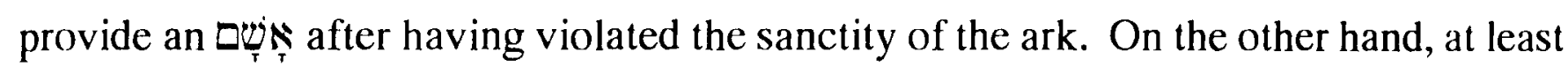
thirteen examples occurring in four separate contexts call for explanation from Milgrom, as they are not obviously related to oath or sancta violation. ${ }^{18}$

b) On Milgrom's view, any violation of any one of the commandments of the Decalogue ought to require an מעז an oath violation (of the Sinaitic oath). One looks in vain, however, for examples of applied to desecration of the Sabbath, dishonour to parents, murder, theft, covetousness,

15 Ibid., $134 \mathrm{f}$.

16 Perhaps the most decisive issue in establishing the meaning of the Milgrom that "reparation offering." Cf. J. Milgrom, op. cit., \$2, 3-7. For alternative explanations, however, cf., e.g., D. Kellermann, "שָא 'äshän," TDOT, I, 431-434. Cf. also B. A. Levine, In the Presence of the Lord (1974) 91-101 [reviewed by J. Milgrom, op. cit., Appendix D, 142f.].

17 Leviticus $5: 15,16,18,19,25 ; 6: 10$ [ET 17]; 7:1, 2, 5, 7, 37; 14:12, 13, 14, 17, 21, 24, 25 (2x), 28; 19:21, 22; Numbers 6:12; 18:9; 1 Samuel 6:3, 4, 8, 17; Ezra 10:19; Isaiah 53:10; Ezekiel 40:39; 42:13; 44:29; and 46:20. For Isaiah 53:10, cf. T. H. Gaster, "Sacrifices and Offerings, OT," IDB, IV, 152.

Some scholars would add six additional occurrences of "guilt offering," to this list: Leviticus 5:6, 7, 15, 24 [ET 6:5], 25 [ET 6:6] and 19:21.

If Leviticus 5:6 and 7 are added, they would imply an essential identity between the offerings. The first occurrence of

Alternatively, with J. Milgrom (op. cit., \$2, 3-7), B. A. Levine (Leviticus, 28, 30), and G. J. Wenham (Leviticus, 104-112), "reparation."

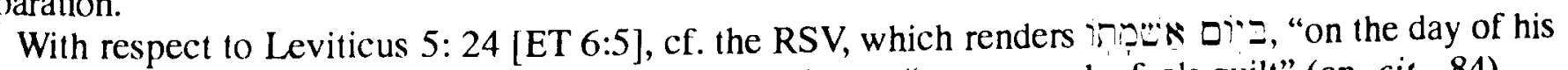
guilt offering." Alternatively, J. Milgrom renders the phrase, "as soon as he feels guilt" (op. cit., 84).

18 These are: nine examples found in Leviticus 14 , as a required offering for persons who have been cleansed of a serious skin disease (ibid., \$45, 80-82); two (or three) examples in Leviticus 19, the text regarding sex with a promised female slave (ibid., 129-137); one example in Numbers 6, the required offering for the Nazirite for his or her premature desanctification (ibid., \$39,66-70); and one example in Ezra 10, where this offering is made after intermarriage with pagans (ibid., $\$ 41,71-73$ ). 
etc., or similarly, cases where an $\underset{i}{\sin }$ is required for desecration of the Sabbath, dishonour to parents, murder, adultery, covetousness, etc. ${ }^{19}$

c) Furthermore, it is not clear that Leviticus 19:20-22, in fact, depicts a case of adultery and, hence, concerns a violation of the seventh commandment. The operative term נאר is conspicuously absent, ${ }^{20}$ and it is possible that this absence reflects the fact that the concern of this law is with a borderline case, one which superficially resembles adultery (hence the stipulation in vs. 20 that they not be put to death), but which entails an important difference with the result that adultery in fact has not been committed, and so the usual sanction for adultery is inapplicable. ${ }^{21}$ Perhaps that difference resides in the diminished capacity of a female slave to resist the sexual advances of the lover, 22 or perhaps it inheres in the fact that this woman was not yet betrothed (i.e., inchoately married), but only pledged (see below for a defence of this interpretation). ${ }^{23}$

d) Finally, it should be noted that text critical problems, and especially the presence of several hapax legomena, render the details of Leviticus 19:20-22 uncertain. ${ }^{24}$ For example, it is unclear whether the hapax legomenon $37 \underset{7}{7}$ refers to some additional

19 Achan's theft in Joshua 7:1 is better explained as a case of sancta trespass. For Leviticus 19:20-22, often considered as a case of adultery, cf. the discussion below.

20 Cf. Exodus 20:14 and Deuteronomy 5:18. Cf. also Leviticus 20:10.

The absence of $7 \mathrm{~N}$ may not be decisive, however, since the term is similarly absent from

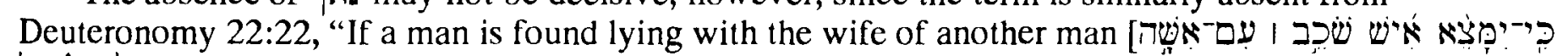

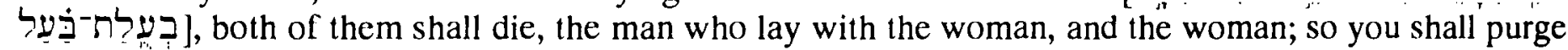
the evil from Israel." Nevertheless, the more general language of Deuteronomy 22:22 [ט have been dictated by the desire to establish more clearly the legal parallel which exists between adultery with a married woman, $7 \mathrm{~N}$, and the case of extramarital relations with a betrothed woman, which, contrary to $\mathrm{KB}$, and $T W O T$, s.v., is nowhere described as נאר, and may not be within the linguistic usage of (cf. Deuteronomy 22:23-24).

21 Cf. Deuteronomy 22:23f.

22 On Milgrom's view this difference resides in the remaining slave-status of the woman, which denies her the legal status of a person (op. cit., 130, n. 463). It seems reasonable that the present law takes into account the diminished capacity of a slave to resist the sexual advances of a man (perhaps a member of her owner's household?), however, it is less clear why this law does not simply apply the death penalty to the offending man for having raped a betrothed woman who may be presumed to have been an unwilling victim (cf. Deuteronomy 22:25-27). While it can be no more than a suggestion, it is possible that on this interpretation this law would not exclude such a penalty, assuming that it could be established that a rape took place. However, it may be that the controlling purpose of this law was simply to exclude the joint death penalty which was normally required where there was circumstantial evidence for the woman's consent, precisely because of a female slave's diminished capacity to withhold consent.

23 As will be argued below, the fact that this woman was pledged, but not betrothed, is indicated both by the lack of her redemption or manumission, as well as by the use of the hapax legomenon 197 , as opposed to the customary expression for betrothal, $\boldsymbol{W}$, as in Deuteronomy 22.

24 The Samaritan Pentateuch adds $l w$, "to him" or "regarding him," after and reads a singular, yielding: bqrt thy $h$ lw l'ywmt. The singular reading, "he will not die," may imply a resemblance of this case to rape, as in Deuteronomy 22:25-27 (cf. LE \$26; CH \$130; HL \$197), rather than to adultery, as in Deuteronomy 22:23-24. In support of the singular reading of the Samaritan Pentateuch, a resemblance to rape may better account for the subsequent stress on the man's guilt and the lack of any punishment stipulated for the woman. On the other hand, it is not obvious why the man should not be put to death "because she was not free."

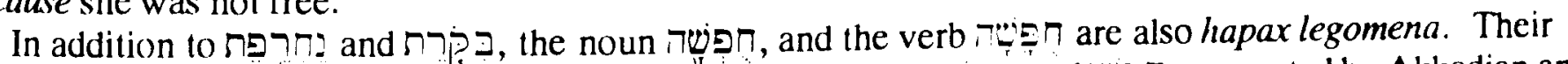
meaning is not in dispute, however, based on the related forms Ugaritic cognates. 
penalty, perhaps a reprimand or more likely financial compensation, or whether it refers to an inquiry. 25

More importantly, the key term נִחרִפִ in vs. 20 occurs nowhere else in Biblical Hebrew. Based on a cognate term חרופה found in Talmudic Hebrew, Milgrom has argued for the meaning "betrothed." 26 This may also be favoured by the expected liability to the death penalty mentioned in vs. 20 , implying at least a de facto resemblance to betrothal on the basis of Deuteronomy 22:23f.27 The fact that חרף is used in Leviticus 19, however, in preference to the customary term in, "betrothed" (cf. Deuteronomy 22:15 [ET 16], 23, 25,27 , and 28), suggests the possibility of a distinction in terms and does not favour Milgrom's interpretation. Based on the Akkadian harāpu, "to be early, arrive early," E. A. Speiser and others have argued for "assigned in advance," that is, a pledge toward betrothal and marriage in advance of redemption or manumission. ${ }^{28}$

Besides the term חרך, three further considerations support this understanding of the slave's marital status as being less than betrothal: First, the text places considerable stress on the fact that the female slave was not yet redeemed or manumitted (vs. 20) -- a point that could already be inferred from her designation as a שפבְזה Although Milgrom adduces some ancient Near Eastern parallels for the betrothal and even marriage of an unmanumitted female slave to a man other than her owner, this situation must have been unusual in Israel or the text would not have needed to make this specification with such clarity. ${ }^{29}$ Second, if betrothal normally affords a woman the same legal protection and responsibility in terms of rape and adultery as does marriage (cf. Deuteronomy 22:23-27), then, as interpreted by Milgrom, Leviticus 19:20-22 would suggest a similar clemency toward rape and adultery with a married slave. However, there is no evidence to support such a view. On the contrary, the brutal rape of the Levite's concubine in Judges 19, for example, is viewed with the utmost gravity, demanding a judicial response on the part of all Israel. ${ }^{30}$ Third, a

25 Cf., e.g., K. Elliger, Leviticus (1966) ad loc.; Holladay, s.v.; KB, s.v.; E. A. Speiser, "Leviticus and the Critics," 33ff.; and J. Milgrom, op. cit., 129, n. 460.

26 So J. Milgrom, op. cit., 129, n. 459. Cf. Jastrow, s.v.

27 Cf. ibid, 130, and G. J. Wenham, Leviticus, 271.

28 E. A. Speiser, "Leviticus and the Critics," 34f. Cf. CAD, s.v. harāpu, A. So also B. Maarsingh, Leviticus (1980) 169, and B. A. Levine, Leviticus (1989) 130.

S. M. Paul wonders if חרך may be related to the huruppatu tokens of engagement in MAL A $\$ 42: 17$ and \$43:20 (Studies in the Book of the Covenant in the Iight of Cuneiform and Biblical Law [1970] 54, $\mathrm{n}$. 3).

29 J. Milgrom, op. cit., 131, n. 467.

Such a situation would seem inherently contradictory with the girl caught between a conflict of loyalties to her owner and to her husband, both designated as her ذِ. Moreover, if the woman was not yet engaged, that is, if the betrothal gift (brideprice) had not yet been fully paid, this fact would explain why she had not yet been "ransomed" (Leviticus 19:20) -- the requisite money had not yet been paid.

$30 \mathrm{Cf}$. also Genesis 49:4 and 2 Samuel 16:21ff.

F. Hauck supposes that the law of adultery was simply more lenient when applied to slaves (Leviticus 19:20ff.), while it was more severe when applied to a priest's daughter (requiring burning, according to

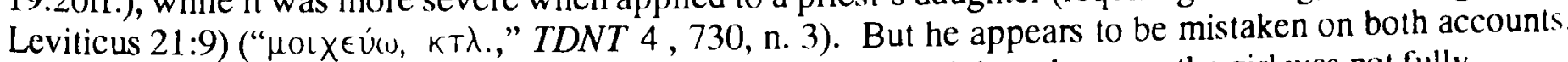
As argued here, Leviticus 19:20ff. does not consider a case of adultery because the girl was not fully betrothed, and Leviticus $21: 9$ is explicit that it pertains not to adultery ( $(\mathrm{F})$, but to prostitution ( 7 i) -.. 
similar pre-betrothal status appears to be presupposed in cuneiform law. ${ }^{31}$ In $\mathrm{CH} \$ 156$, for example, a man "chooses a bride [kallatam ihîma]" for his son, but before their marriage is consummated, the father lies with her himself. In such a case the father is required to pay a stiff fine and to return any dowry to the girl; she is then allowed to be married by the husband of her choice. However, given that $\mathrm{CH} \$ 130$ stipulates a death penalty for a man who has sex with a betrothed girl, that is, an ašsat awilum, "the wife of a man" who has not yet known a man, it must be that the expression "choosing a bride [kallatam ihirma]" in CH $\$ 156$ reflects an earlier stage in the process of marriage negotiation, at which point the bride-to-be is not yet accorded the legal status of an aššat awilum.

To sum up, Leviticus 19:20-22 should not be regarded as a case of intercourse with a betrothed slave-girl, but with a pledged pre-betrothal slave-girl. This is why the offence attracts a lesser penalty and requires atonement with an that marriage included an oath, the presence of which is indicated by the use of מעל with reference to its breach in Numbers 5:12, 27. This view finds further support in the use of בגד with respect to marital offences, since בגד is an approximate synonym of מעד.

\subsubsection{The significance of the use of}

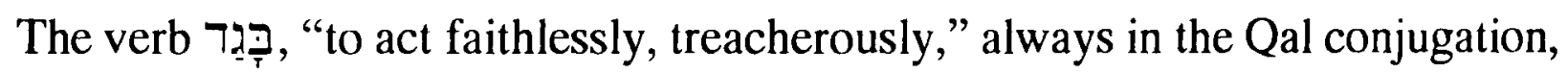
appears forty-nine times in thirty-nine verses in the Old Testament. In addition, there are five, or possibly six, occurrences of the cognate noun בֶּ, "faithlessness"; the abstract

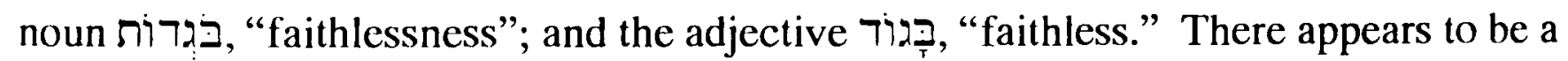
scholarly consensus that these various forms of בגר בדגר refer not to improbity in general, but specifically to perfidy against some culturally expected or oath-imposed obligation. BDB, for example, suggests that the basic meaning of the root is "act or deal treacherously." 32

Reflecting this more general meaning, it is not surprising to find used to refer to infidelity against a covenant partner. ${ }^{33}$ An example of this usage, involving the violation of a secular covenant, is found in Judges 9:23: "And God sent an evil spirit between Abimelech and the men of Shechem; and the men of Shechem dealt treacherously

perhaps especially heinous in the case of priestly daughters because of the resemblance to cultic prostitution. Cf. also the penalty of burning in Genesis 38:24 and Leviticus 20:14.

31 Cf. also HL \$\$28-29. Cf. F. Mezger, "Promised but not engaged” (1944) 28-31.

32 Cf. also KB, s.v. ("treulos handeln," "treulos verlassen"); S. Erlandsson, "גִִּ 470-73 ("to act faithlessly [treacherously])"; and M. A. Klopfenstein, "בגר bgd treulos handeln," THAT, I, 261-4.

${ }^{33}$ Cf. S. Erlandsson, op. cit., 471-2. 


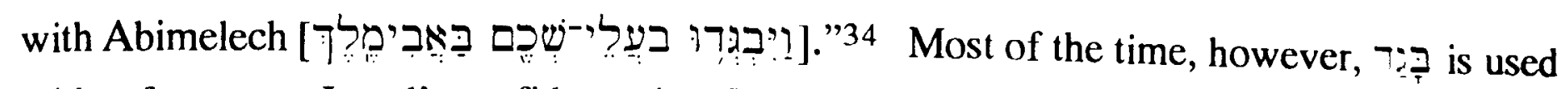
with reference to Israel's perfidy against Yahweh's covenant. ${ }^{35}$ See, for example, Hosea 6:7: "But at [or, like?] Adam they transgressed the covenant; there they dealt faithlessly

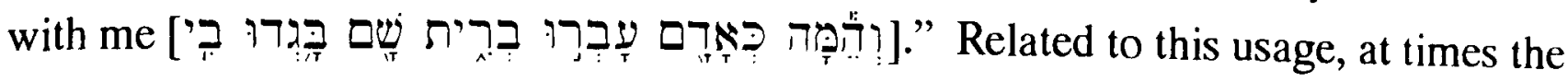
infidelity is more particularly directed against one's fellow Israelite, as in Malachi 2:10: "Have we not all one father? Has not one God created us? Why then are we faithless to

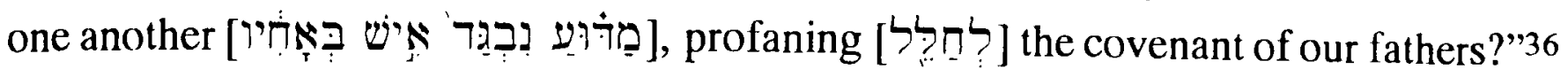

Consistent with this usage of בגד בגד as a description of perfidy against one's covenant partner, בגד is frequently applied to marital offences, often in passages where the marriage analogy is employed for Israel's covenantal infidelity against Yahweh. ${ }^{37}$ What is especially noteworthy is the fact that בגד is utilized not only to describe an unfaithful wife, whose infidelity typically consists of adultery or harlotry, but also to describe an unfaithful husband, whose infidelity also proves to be sexual, though at times may include other offences as well. For example, a wife's infidelity is termed בגד in Jeremiah 3:20: "Surely,

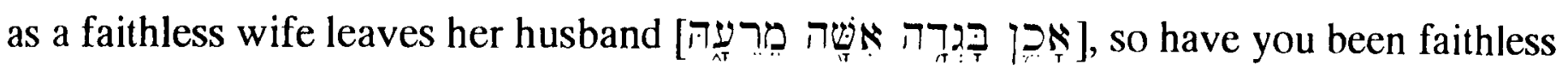

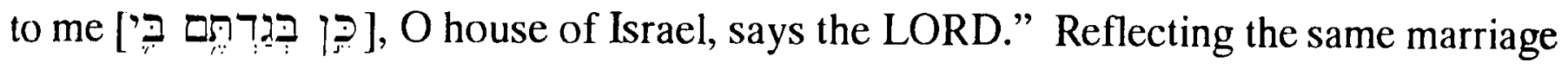
analogy, Jeremiah 3:8 identifies a wife's adultery and harlotry as בגד: "She saw that for all

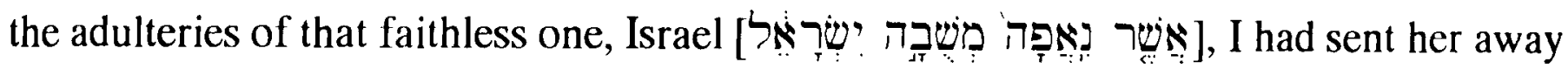

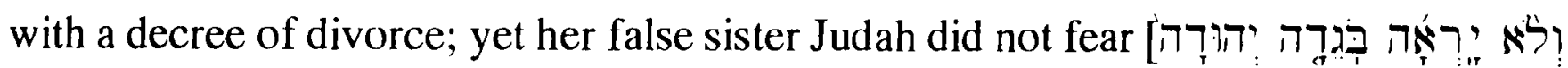

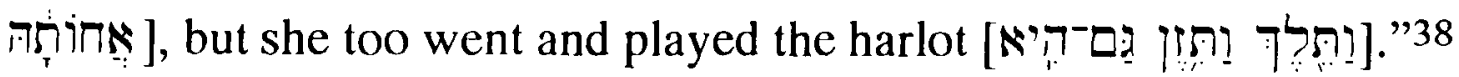

However, in other verses it is the husband who is guilty of committing בגר. What is particularly interesting is that several of these examples make explicit that the בגר in view is committed against $[+\beth$ ] one's wife and not merely against one's father-in-law, as some might suppose by extrapolating from the example of Laban's covenant with Jacob in Genesis 31:44 or from the evidence of many of the ancient Near Eastern marriage בגד

${ }^{34}$ For evidence that there was a covenant between Abimelech and the men of Shechem, cf. Judges 9:3, 6 and the discussion of these texts in R. G. Boling, Judges, 171, and P. Kalluveettil, op. cit., 62f.; 209f.

35 Cf., e.g., 1 Samuel 14:33; Psalm 25:3; 73:15; 78:57; 119:158; Isaiah 24:16; 48:8; Jeremiah 3:7, $8,10,11,20 ; 5: 11 ; 12: 1 ;$ Hosea 5:7; and Malachi 2:11.

36 J. M. P. Smith observes that, "A covenant was regularly confirmed by an oath and thus given religious sanction; hence its violation is properly characterised as profanation; cf. Ps. $55^{21} 8932.34$ " (Malachi, 48).

37 Cf. S. Erlandsson, op. cit., 470.

As mentioned earlier, the obligations which are transgressed when there is "perfidy [ 72 ]" may be merely culturally expected rather than specifically oath-imposed, or covenantal. Cf., e.g., Lamentations 1:2. However, the fact that these terms are so often used of violations of a covenant makes their appearance with marriage unsurprising on the view that marriage is a covenant.

38 Cf. also Jeremiah 3:11 and Hosea 5:7.

${ }^{39} \mathrm{~K}$. van der Toorn notes that Akkadian texts tend "to picture adultery as a breach of the good faith reigning among men" (Sin and Sanction in Israel and Mesopotamia, 17)

However, cf. the discussion of marriage contracts in the previous chapter and R. Westbrook's summary: "marriage is a legal status and must be distinguished from the marriage contract which is incidental thereto" (op. cit., I, ii). 
against his wife because of his act of capricious divorce: "You ask, 'Why does he not?' Because the LORD was witness to the covenant between you and the wife of your youth, to

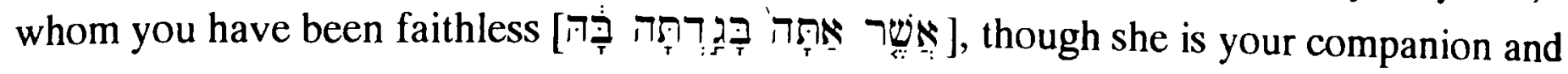
your wife by covenant." Compare also Exodus 21:8 and Malachi 2:16.40

As we have already noted in Chapter 5 , by its allusion to the creation account Malachi 2:15 reflects a yet more encompassing obligation of fidelity on the part of the husband to be "one" with his wife: "Did He not make [you/them] one, with a remnant of the spirit belonging to it? But you say, 'And what was the One seeking?' A godly seed! Therefore watch out for your lives and do not act faithlessly against the wife of your youth

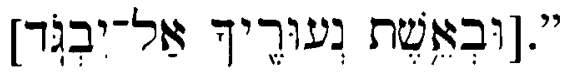

Consistent with this usage, Jeremiah 9:1 [ET 2] similarly condemns adultery on the part of a husband as בגד, although it does not make explicit the object of the infidelity, whether it is the offended wife, the cuckolded husband, society at large, or God. Jeremiah 9:1 [ET 2] reads: "O that I had in the desert a wayfarers' lodging place, that I might leave

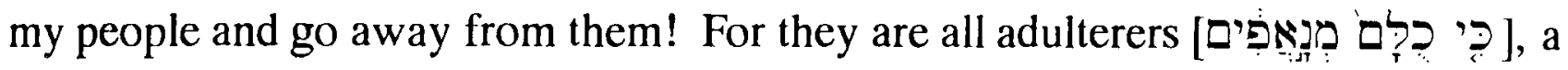

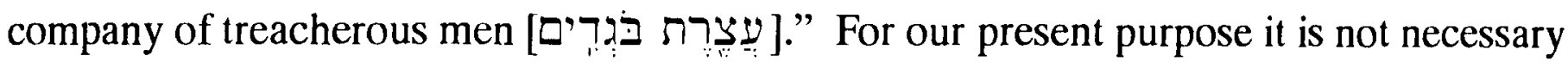
to decide if the "adultery" referred to in Jeremiah 9:1 [ET 2] is literal or metaphoric since on either view the prophet equates adultery [מנאר] with infidelity [בגד] through semantic parallelism, which is characteristic of the entire lament. ${ }^{41}$

One final example of interest is Proverbs 23:27, 28: "For a harlot is a deep pit

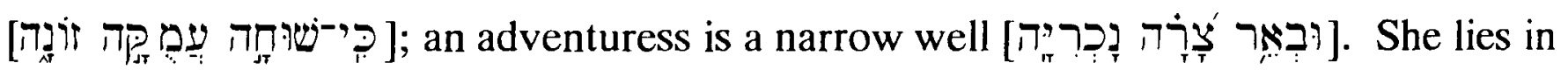

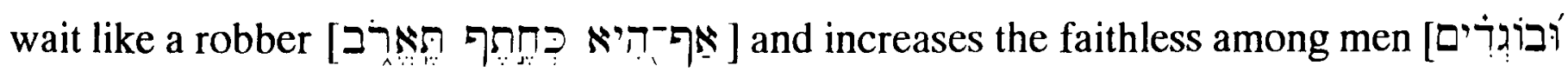

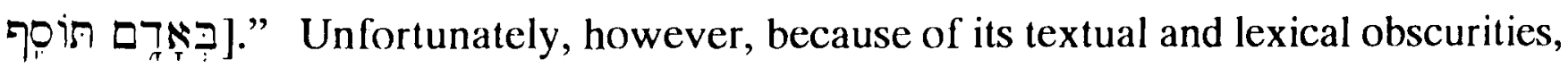
Proverbs 23:27f. cannot help advance the present discussion. The precise implication of

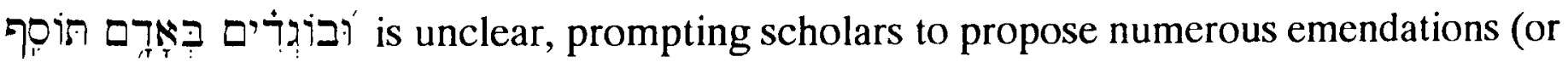

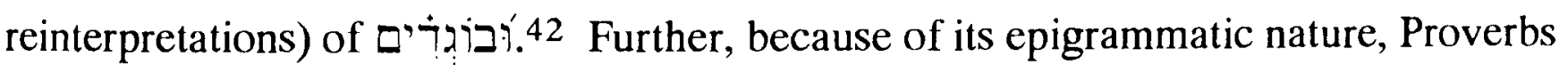
23:27, 28 leaves unspecified the marital status of either the man or the woman (although the "harlot [זוֹנה]]" may typically have been unmarried, there are numerous exceptions). So, while it is possible that Proverbs 23:27f. condemns extramarital sex with an unmarried woman as בגר, this is far from certain.

${ }^{40} \mathrm{Cf}$. the fuller discussion of Exodus 21:8 in $§ 8.3 .4$ below. Cf. Chapter 3 for a defence of our rendering of Malachi 2:16.

$41 \mathrm{~W}$. McKane, among others, favours a figurative reference here and in Hosea 7:4, which is thought to be parallel (Jeremiah, I, 199). However, J. L. Mays and others note that Hosea usually uses "adultery," in contrast to "harlotry," for literal sexual unfaithfulness (Hosea, 105). Moreover, contrary to McKane, Jeremiah 2:20ff. and 3:1-5 differ significantly from Jeremiah 9:1 [ET 2] because, in keeping with the marriage metaphor elsewhere, their references to adultery are consistently in the feminine gender, not masculine plural as here. Cf. also Ezekiel 16 and 23. Furthermore, the mention of adultery in Jeremiah 9:1 [ET 2] constitutes the first in a (perhaps rhetorical or stereotypical) sequence of offences including falsehood, evil, untrustworthiness, slander, deception, oppression, etc. Since each of these successive offences appear to bear its literal sense, there is little reason to suppose otherwise for "adulterers."

42 For a sampling of alternatives, cf. C. H. Toy, Proverbs, 437f., and W. McKane, Proverbs, 391. 


\subsubsection{Second, if God was invoked in any ratifying oath to act as guarantor of the marriage covenant, offences against the marriage on the part of either the husband or the wife may be identified as a sin (פשט, (פט, etc.), etc., against God}

A number of biblical texts identify adultery as iniquitous, a sin against God. etc., which, correspondingly, brings shame and renders both of the participants unclean and guilty. If the converse of this were true, that is, if the Old Testament made clear that marital oflences were not considered as sins against God, etc., such a perspective would contradict the view that marriage was a sanction-sealed covenant. Naturally, it is unnecessary to suppose that each particular condemnation was a conscious reflection of a covenantal view of marriage or even a reflection of the explicit prohibitions against adultery set forth in the Decalogue or elsewhere.

Rather, the Old Testament appears to presuppose a general moral consciousness in man, shared even by pagans, which acknowledges adultery as a heinous wrong committed not only against the injured husband, but also against God. Hence, Genesis 20:6 records God's words to the pagan king Abimelech: "Then God said to him in the dream, 'Yes, I know that you have done this in the integrity of your heart, and it was I who kept you from

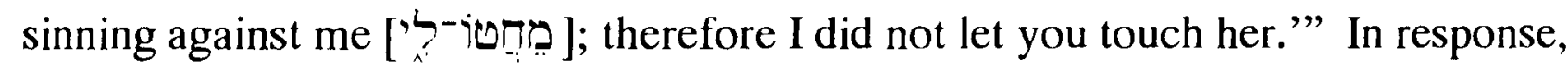
Abimelech asked Abraham, "What have you done to us? And how have I sinned against

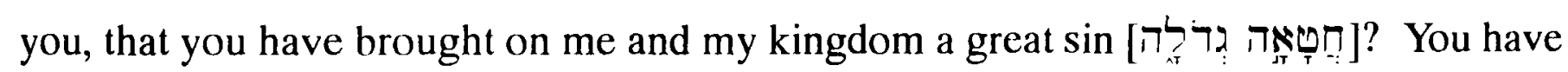
done to me things that ought not to be done" (Genesis 20:9). Similarly, Abimelech addresses Isaac: "What is this you have done to us? One of the people might easily have

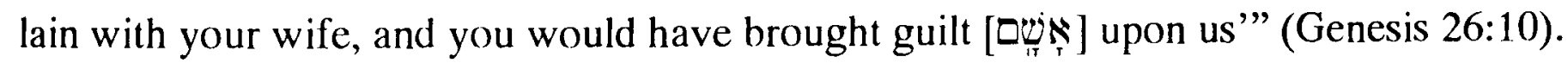

Supportive of these acknowledgments of adultery as a "great sin" on the lips of non-Israelites, an Akkadian text from Ugarit similarly condemns the adultery of Ammištamru's wife, the queen of Ugarit, saying she "sinned a great sin [hi-it-tá ra-ba-a tiih-te-tị]" against her husband. ${ }^{43}$ While this particular text stresses adultery as an offence against the cuckolded husband, S. E. Loewenstamm has assembled a number of cuneiform religious texts which characterize adultery as a sin against the gods, deserving their punishment. ${ }^{44}$ For example, a bilingual Sumero-Akkadian hymn to Ninurta lists adultery as one of many sins against Ninurta, saying: "He who has intercourse with (another) man's

43 PRU IV, 139. Cf. also W. L. Moran, "The Scandal of the 'Great Sin' at Ugarit" (1959) 28()I. J. J. Rabinowitz, notes that the same expression is attested in four Egyptian marriage contracts from about the ninth century B.C. ("The 'Great Sin' in Ancient Egyptian Marriage Contracts" [1959] 73).

Note, however, that the Akkadian expression "a great $\sin$ " also occurs in PRU III, 96, where it refers to forging royal tablets. Hence, the phrase must simply refer to a serious offence, of which adultery wasi only an example. Cf. F. B. Knutson, "Literary Phrases and Formulae," RSP, II, 409-411.

44 "The Laws of Adultery and Murder in Biblical and Mesopotamian Law," 146-53. 
wife, his guilt is grievous [a-ran-ř kab-[tum-ma]]."45 Interestingly, one text echoes the tenth commandment, "A man who covets his neighbour's wife [sáa-na al-ti tap-pi-sú iš-su-

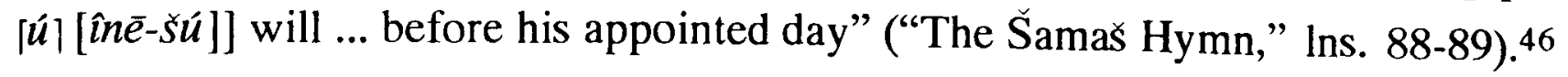
Compare also Joseph's words in Genesis 39:9: "How then could I do such a wicked thing

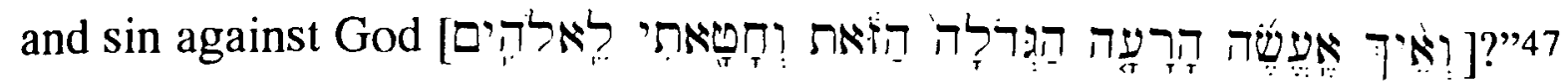

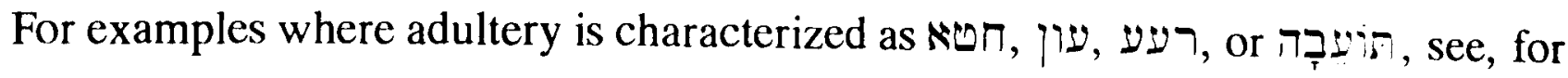
example, Leviticus 18:29; Numbers 5:15, 31; Deuteronomy 22:22, 24; 2 Samuel 12:9, 13; Jeremiah 7:9f., 23:10; and Ezekiel 22:11. ${ }^{48}$ Similarly reflecting this moral assessment of adultery as an offence against God, the Old Testament considers that adultery defiles [0] both the man and the woman (and their land), whether or not they are caught. See, for example, Leviticus 18:20, 25, 27; Numbers 5:13f., 19f., 28f.; Ezekiel 18:6, 11, 15; and $33: 26$.

\subsubsection{Because God is necessarily invoked to act as guarantor in any ratifying oath, should there be marital infidelity, this ought to prompt God's judgment against the offending party}

A number of biblical texts indicate that marital infidelity and particularly adultery provoke God's direct judgment against the offenders, whether or not the adultery in question would have been justiciable within Israel's courts. ${ }^{49}$ While this fact is consistent with the present view that marriage was a sanction-sealed covenant, once again, it is unlikely that these texts represent a conscious reflection of this fact. This is the case because, as in Mesopotamian practice, God is generally depicted as judging the guilty lover who was not a party to the marriage vow. 50 So, for example, God closed the wombs of Abimelech's wife and his female slaves as a deterrent against committing adultery with Sarah. He further warned Abimelech in a dream that if Abimelech should go ahead and commit adultery with Sarah, God would kill Abimelech and his family (Genesis 20:7, 18).

45 W. G. Lambert, Babylonian Wisdom Literature (1960) 119, ln. 4.

46 Ibid., 130f. The broken text is thought to predict a premature death for the one who lusts.

47 The citation of ancient Near Eastern parallels is not intended to imply necessarily an identity of outlook or jurisprudence with biblical practice. In the present case, for example, it appears that Joseph does share the outlook of LU $\$ 4$, Ins. 222-231, which considers it a mitigating circumstance if the woman entices the man into adultery. In such a case she is to be executed, while the man is allowed to go free. Of course, it is possible that while free of any criminal sanction, such a man might still be considered to be guilty before the gods.

Cf. also J. J. Finkelstein, who discusses the Mesopotamian predisposition to impute the burden of guilt for adultery to the married woman ("Sex Offences in Sumerian Laws," 366ff.). Cf. MAL A \$\$14, 16, and 22. Cf. also K. van der Toorn, op. cit., $17 \mathrm{f}$.

48 If Numbers 5:6 may also be applied to the adulteress in Numbers 5:11-31, then her offence may be

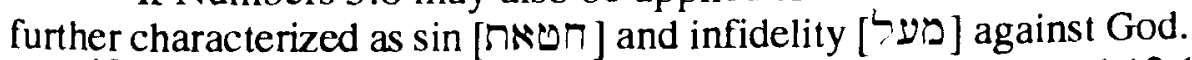

49 Cf. Genesis $12: 10-13: 1 ; 20: 1-8 ; 26: 10 ; 39: 9 ; 2$ Samuel 12:13; and Wisdom of Solomon 3:16-19 (cf. $4: 6)$.

50 Cf., e.g., K. van der Toorn, op. cit., 17, 161, n. 80.

Similarly, S. E. Loewenstamm notes several cuneiform texts which assume that the offended gods will kill an adulterer ("The Laws of Adultery and Murder in Biblical and Mesopotamian Law," 146-5.3). 
Although the book of Job rejects the simplistic views of suffering put forth by Job's "comforters," nevertheless in his oath of clearance in 31:9-12, Job himself acknowledges that the sin of adultery would rightfully incur both human and divine retribution.

Other texts warn Israel that since adultery was one of the chief sins which prompted Yahweh's wrath against the Canaanites and for which Yahweh cast them out, Israel will incur a like judgment for her practice of adultery (Leviticus 18:24; Jeremiah 5:7-9; 7:9-15; 23:10; 29:23; and Ezekiel 33:26). 51

\subsubsection{Because the deity is necessarily invoked in any ratifying oath, intermarriage with pagans should be prohibited because of the idolatry that would necessarily ensue when a ratifying oath is sworn}

D. L. Magnetti has argued that international parity treaties were prohibited for Israel because of the idolatry that would be a necessary consequence of swearing ratificatory oaths (Exodus 23:32; Deuteronomy 7:2; and Judges 2:2). ${ }^{52}$ Although suzerains did not generally impose the worship of their gods on their unwilling vassals, the gods of both parties were invoked in parity treaties, and such an invocation carries an implicit acknowledgement of the reality of those gods and their ability to punish any would-be covenant breaker. 53

If this is so, it would seem likely that the same concern would require an analogous prohibition of intermarriage with pagans if, as is being argued, marriage required the mutual swearing of ratifying oaths. As expected, there are several Old Testament prohibitions against intermarriage with pagans: Exodus 34:12-16; Deuteronomy 7:2-4; Judges 3:6; 1 Kings 11:2; Ezra 9:12; Nehemiah 10:31 [ET 30]; and 13:25. 54 Of these, the most remarkable is found in Ezra 10:2,10, where this offence is condemned as מעל, a term often used of oath violation. 55 As argued in an earlier chapter, these prohibitions are concerned only to prohibit interfaith marriage, not exogamous marriage as such.

Moreover, the prohibitions assume that when a marriage is concluded with a pagan wife, idolatry will be an inevitable result. For example, Exodus 34:16 asserts that "their

51 Nathan's consolation to David after his repentance in 2 Samuel 12:13 implies that David's wrong was similarly deserving of a divinely-imposed death penalty: "The Lord also has put away your sin; you shall not die." However, because of the compound nature of David's offence (he was guilty of both adultery and murder), the text does not contribute unambiguously to the present argument.

52 "The Oath in the Old Testament in the Light of Related Terms and in the Legal and Covenantal Context of the Ancient Near East" (1969) 85f.

On the importance of swearing one's oaths in the name of Yahweh, cf. Deuteronomy 6:13; 10:20; Isaiah 48:1; and Jeremiah 12:16.

53 Cf. Genesis 31:53.

Cf. also G. E. Mendenhall, "Puppy and Lettuce in Northwest Semitic Covenant Making" (1954) 39; R. Frankena, "The Vassal Treaties of Esarhaddon and the Dating of Deuteronomy" (1965) 130; D. J.

McCarthy, Treaty and Covenant (1981) 120; and P. Kalluveettil, op. cit., 81, n. 301.

$54 \mathrm{Cf}$. also Numbers 25.

55 However, an oath, such as is recorded in Nehemiah 13:25, may provide a sufficient explanation for terming this offence מעל. 
daughters will play the harlot after their gods and make your sons play the harlot after their gods." This confidence is puzzling if it assumes that Yahwistic husbands or wives will succumb in every case to a more resolute faith of their pagan spouses. On the other hand, it is entirely comprehensible if the mentioned idolatry is a necessary consequence of the very act of solemnizing such a marriage by means of bilateral oaths.

This brief review of the terminology associated with marriage breaking (i.e., אטח, בגד, מעל ,פשע, etc.) shows that the Old Testament regarded marriage as a mutual commitment probably sanction-sealed by an oath. This makes it likely that marriage was seen as a covenant, though this conclusion is not inevitable. We now turn to texts outside Malachi which render this conclusion certain by their explicit, or implicit, identification of marriage as a covenant.

\subsection{Texts (other than Malachi 2:14) which explicitly, or implicitly, identify marriage as a}

We have already established a general conceptual and terminological compatibility between marriage and "covenant [תרְּר] (\$6.1.3 above), placing particular stress on the evidence for a covenant-ratifying oath in marriage in the form of verba solemnia and for sexual union as a complementary oath-sign (Chapter 7). Seeking to confirm the presence of such an oath, we began this chapter by considering various forms of indirect evidence that marriage was viewed as a sanction-sealed commitment to which the deity was witness, in particular noting the terminology of marital infidelity which is associated elsewhere with

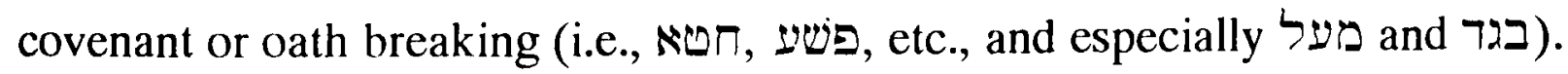

Further evidence of this general conceptual and terminological compatibility between marriage and covenant, which serves to confirm the identification of marriage as a בִּרִ may be found in those texts which express Yahweh's relation to Israel in terms of the marriage analogy. Certainly other factors may also have played a significant role in this development, including a polemical interest against the fertility cults, but it is likely that the recognition of marriage as a covenant may have been of special importance in fostering this development. ${ }^{56}$

56 O. J. Baab, for example, suggests that the marriage metaphor may have been a reflex of Israel's polemic against the fertility cults ("Marriage," 286).

Alternatively, W. Zimmerli considers that the marriage analogy may have been suggested by the popular Old Testament figure of speech by which Zion, Egypt, Babylon, etc. were described as young women (Ezekiel 1, 335). Cf., e.g., Amos 5:2 where Israel is called "virgin Israel" (cf. also Jeremiah 4:31; 46:11, 24; and 50:42).

It is possible that the attribute of Yahweh as a "jealous God [N] other texts, may also have contributed to this development, given the characteristic use of "jealousy" in marital contexts (cf., e.g., Numbers 5:14; etc.). This is so, especially, since a text such as Exodus 34:1416 appeals to Yahweh's character as a jealous God ("whose name is Jealous") as the basis for prohibiting "a 


\subsubsection{The marriage analogy and especially Hosea 2:18-22 [ET 16-20]}

Hosea appears to have been the first to describe Israel's infidelity as “adultery [§]. " and to develop the marriage analogy so fully (cf., e.g., Hosea 2:4-25 [ET 2-23]). As a result of chronological priority, it is generally assumed that Hosea's use of the marriage analogy is the source of its reappearance in Isaiah (cf. Isaiah 1:21; 54:5-8; 57:310; 61:10-11; 62:4-5); Jeremiah (cf. Jeremiah 2:2, 20; 3:1-5; 3:6-25; 13:27; 23:10; 31:32); Ezekiel (Ezekiel 16, 23); and perhaps also Proverbs (Proverbs 8). ${ }^{57}$ However, dependence on Hosea is not certain, and it is possible that some of these examples may represent an independent development. 58

In the previous chapter (\$7.1.3) we examined Hosea 2:18-22 [ET 16-20] in an attempt to provide evidence for the use of marriage-forming verba solemnia in the biblical period. In that discussion evidence was offered for an extensive parallelism between Yahweh's relationship with Israel (identified as a בִּרִ in Hosea 8:1 and perhaps also 6:7) and the marital relationship between Hosea and Gomer, which is generally considered to have been the immediate impetus for Hosea's development of the marriage analogy. 59 Compare, for example, the manner in which Hosea 2:4 [ET 2] sets the formula for divorce

covenant with the inhabitants of the land" and, consequently intermarriage with these pagans, because "they play the harlot after their gods" and they will "make your sons play the harlot after their gods." Cf. M. Greenberg for a discussion of harlotry (not specifically a marital offence), as descriptive of Israel's forbidden alliances with foreign powers (Ezekiel 1-20,282f.). Cf. also examples where the harlotry refers instead to Israel's apostasy after other gods, as in Numbers 25:1 and Judges 2:17.

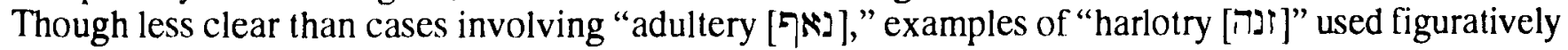
may also have been suggestive of the marriage metaphor, if they do not presuppose it. Cf., e.g., Deuteronomy 31:16.

57 Cf. M. DeRoche, “Jeremiah 2:2-3 and Israel's Love for God during the Wilderness Wandering" (1983) 364-76; and C. V. Camp Wisdom and the Feminine in the Book of Proverbs, 106-109 and especially 269-271.

58 Although Malachi nowhere employs the marriage analogy itself (where Yahweh's covenant relationship to Israel is compared to a marriage), from this literary parallelism, it is apparent that Malachi acknowledged a profound similarity between Israel's covenant with Yahweh and the marriage covenant. However, it is doubtful that Malachi has "literalized" the earlier metaphor, against C. V. Camp, if this is intended to imply that the identification of marriage as a covenant was first suggested by the marriage analogy (op. cit., 323, n. 8). To be sure, Malachi appears to offer the first of many "reverse applications" of the marriage analogy. In other words, while the marriage analogy was originally intended to elucidate Yahweh's relationship to Israel, it is now being reapplied to serve as a paradigm for marriage itself. Cf., e.g., Ephesians 5:21-33, and, especially the later rabbinic view of the marriage ceremony as a replica of the formation of God's covenant with Israel at Mt. Sinai. Cf. L. Ginzberg, The Legends of the Jews (1928) 6, 36, n. 200; T. H. Gaster, Customs and Folkways of Jewish Life (1955) 109f., 126-28; and M. R. Wilson, "Marriage and Sinai: Two Covenants Compared," in Our Father Abraham (1989) 203-208.

59 Some scholars deny the relevance of Hosea 6:7, claiming that it refers to a political treaty rather than to Yahweh's covenant with Israel, and the authenticity of the reference to the covenant in Hosea 8:1. deeming it to be a later Deuteronomic addition. So, e.g., L Perlitt, Bundestheologie im Alten Tistament (1969) $141-144,146-149$. If this is so, then the marriage analogy as such offers no particular support for the identification of marriage as a covenant. However, against the tendency to eliminate all preDeuteronomic references to covenant, cf. J. Day, "Pre-Deuteronomic Allusions to the Covenant in Hosea and Psalm LXXVIII" (1986) 1-12, and E. W. Nicholson, God and His People (1986) 179-188. 
in parallel with the formula for the dissolution of the covenant in Hosea 1:9, inviting an identification of a corresponding parallel between marriage and covenant.

While Hosea intercalates the promise of a new covenant [כּרִ 2:20] [ET 18] between his two promises of an eschatological marriage to Yahweh (in vs. 18 [ET 16] and vs. 21f. [ET 19f.]), he does not explicitly identify the coming marriage as a covenant. Nevertheless, that identification seems probable given how Hosea parallels the marriageforming verba solemnia in vs. 18 [ET 16], "My husband," with the theological covenantmaking verba solemnia in vs. 25 [ET 23], "You are my people" and "Thou art my God."

What is implied in the marriage analogy is made explicit elsewhere. In addition to Malachi 2:14, there are five other texts which traditionally have been understood to identify marriage as a בִר ית: Proverbs 2:17; Ezekiel 16:8, 59, 60, and 62. Two other texts, Genesis $31: 50$ and Jeremiah 31:32, are also sometimes advanced as further examples of an identification of marriage as a בִרִ ית , but these prove to be inadequate on closer examination. Finally, we shall add a new text, 1 Samuel 18-20, as corroborative evidence for the identification of marriage as a -- - a בִרִ - an implication of the carefully drawn analogy between David's marriage to Michal and his relationship to Jonathan (which is repeatedly termed a בִּרִ (דיר). To these examples we now turn.

\subsubsection{Proverbs 2:17}

Proverbs 2:16f. promises the young man that if he attains wisdom:

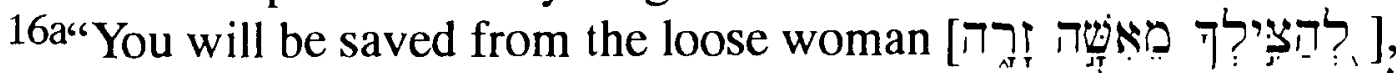

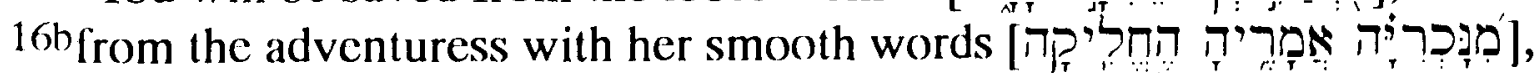

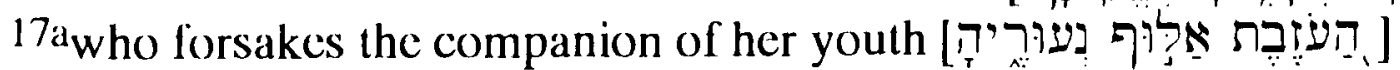

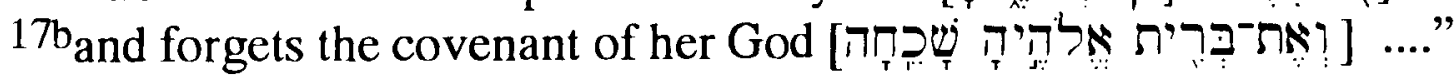

Relying mainly on the context and the awareness of other biblical texts which identify marriage as a covenant, earlier commentators have generally identified "the

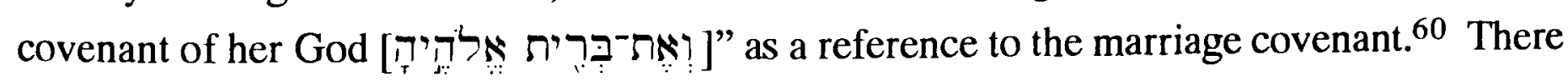
are two main alternative interpretations to this traditional view.

60 Cf., e.g., J. Calvin, The Twelve Minor Prophets, Vol. V, Zechariah and Malachi, 553; F. Delitzsch, Proverbs, 82; and C. H. Toy, Proverbs (1899) 47.

Modern commentators who consider the covenant to be that of marriage include B. Gemser, "The Instructions of Onchsheshonqy and Biblical Wisdom Literature" (1960) 102-128; and R. B. Y. Scott, Proverbs (1965) 43. 


\subsubsection{G. Boström's view that "the covenant of her god [ְִִִּית

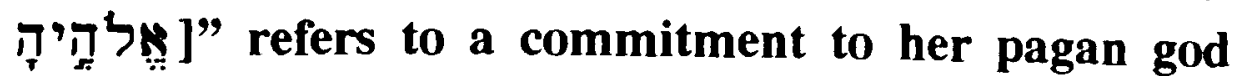

Defending the widely held view that זָזָרִיזיה woman's non-Israelite status, G. Boström argues that "her god [אלה ניהיק] is most naturally interpreted as a reference to this foreign woman's pagan deity (cf., e.g., 2 Kings 19:37; 2 Chronicles 32:21; Isaiah 37:38; Daniel 1:2; and Jonah 1:5). ${ }^{61}$ Boström supports his interpretation by the observation that "Yahweh [יהוה]" is used consistently throughout Proverbs 1-9 (where it appears nineteen times) and so a reference to אלהים is likely to be to a pagan deity.

However, Boström's interpretation fails for five reasons: First, אלהים appears also in Proverbs 2:5 (where it is in synonymous parallelism to יהוה) and 3:4 (where it also offers an unmistakable reference to the true God), so that its appearance in 2:17 as a reference to Israel's God is not without parallel within the corpus of Proverbs 1-9. Although אלהים appears only twice more in Proverbs 10-30, namely 25:2 and 30:9, in both cases the reference is, once again, to the true God. Second, since יהוה nowhere appears with a pronominal suffix, there is no lexical choice available for the precise

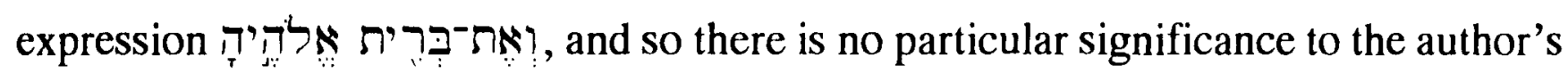
choice of אלהים instead of יהוה in such an expression. Third, it is unlikely that the orthodox author of Proverbs would condemn this woman for any offence against her pagan deity or that he would bother to brand her sexual immorality as such an offence, rather than emphasizing the wrong committed against the true God, or more likely, the principles of wisdom. Fourth, while there is some evidence for the concept of a covenant between pagan deities and their followers, it is far too slight to make its appearance probable in the

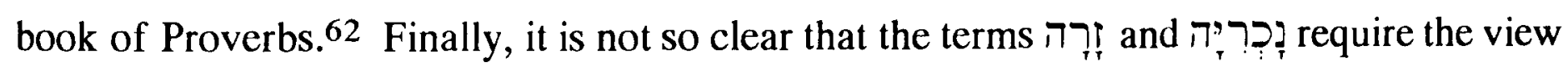
that this woman is a non-Israelite, as Boström and others suppose. ${ }^{63}$ For example, it may be that this woman is termed a "strange" woman in order to stress the fact that she is not the man's own legitimate wife. ${ }^{64}$ Alternatively, L. A. Snijders has argued that these terms may

61 Proverbiastudien: die Weisheit und das fremde Weib in Sprüche 1-9 (1935) 103ff. In support of i? and ינכריה as references to this woman's non-Israelite status, cf., e.g., J. G. Williams, Women Recounted. Narrative Thinking and the God of Israel (1982) 107-109.

62 Cf., e.g., D. L. Magnetti, The Oath in the Old Testament (1969) 138; Z. Zevit, "A Phoenician Inscription and Biblical Covenant Theology" (1977) 110-118; K. A. Kitchen "Egypt, Ugarit, Qatna, and Covenant" (1979) 462, 453; and D. J. McCarthy, Treaty and Covenant (1981) 31, n. 6.

K. van der Toorn summarizes the evidence, "Compared with the Mesopotamian documents, the Old Testament displays a striking preference for the covenantal concept to define the relation between God and his creatures" (Sin and Sanction, 49).

63 Against Boström's view that personified Wisdom in Proverbs 1-9 is pitted against the "strange woman" who is literally a foreigner and devotee of Ishtar (or Canaanite Astarte), cf. R. N. Whybray, Wisdom in Proverbs (1965) 89-92; W. McKane, Proverbs (1970) 286, 312, 328-331; and C. V. Camp, Wisdom and the Feminine in the Book of Proverbs (1985) 25-28.

64 So also P. Humbert, who argues that the author is mainly concerned to offer a polemic against adultery ("La femme étrangère du Livre des Proverbes" [1937] 40-64; and idem, "Les adjectifs 'Zâr' et 'Nokri' et la femme étrangère" [1939] 259-66). 
stress the fact that this woman is a "social outsider," an Israelite woman who has become an outcast because of her behaviour. ${ }^{65}$ Consequently, Snijders suggests rendering them as "loose," "unrestrained," or "unchaste," much as does the RSV.

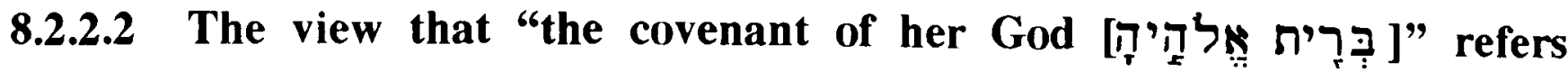 to the Sinaitic covenant}

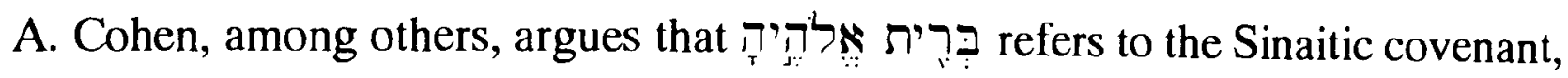
noting that "the prohibition of adultery formed part of God's covenant with Israel (Exod. xx. 13)."66 Although the seventh commandment is framed in conventionally androcentric

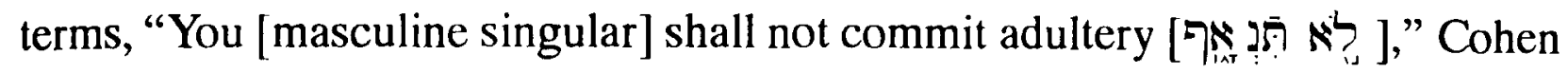
presupposes, reasonably enough, that this commandment applied no less to women.

D. Kidner's interpretation is similar, but he adds the observation that had the text intended to refer to the marriage covenant, the wording would have been closer to that found in Malachi 2:14.67 In other words, Kidner considers that the text should have read

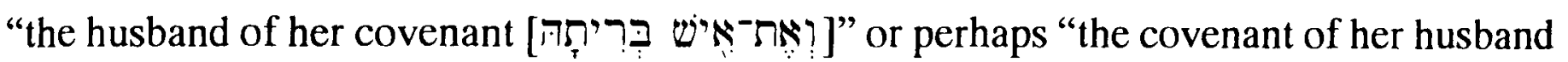

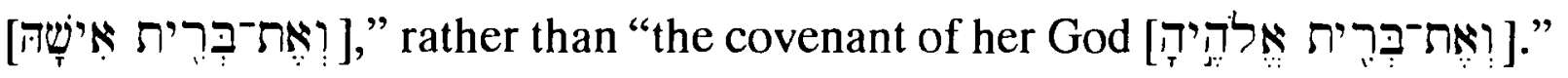

W. McKane and others carry this interpretation further, arguing that there is no reference at all to marriage in Proverbs 2:17 because 7 in vs.17a does not refer to the woman's husband. ${ }^{68}$ McKane renders the verse "who forsakes the teacher of her youth,

Likewise, J. Huehnergard discusses a case of a will (Text 2) specifying that if the deceased's wife should later "go after a strange man [amilli zayyāri], let her put her clothes on a stool, and go where she will" ("Five Tablets From the Vicinity of Emar" [1983] 19, 30). Comparing Deuteronomy 25:5, Huehnergard argues that "strange" means a man of another family. Cf. also K. van der Toorn, "Female Prostitution in Payment of Vows in Ancient Israel" (1989) 199.

Alternatively, F. Hauck and S. Schulz reject the identification of זָז as merely the wife of another, or a foreigner, much less an allegorical reference to the alien secular wisdom of Greece ("móp $\nu \eta \kappa \tau \lambda$.," in TDNT VI, 586). Rather, citing Egyptian Wisdom literature which "warns against wandering women from other places [Böhlig]," they suggest a reference to native Israelite women who are strangers to a particular locality and, as such, constitute a dangerous temptation to the local male population. Cf. "The Instruction of Ani," in ANET, 420.

Finally, G. A. Yee leaves undecided the precise identity of the זָז that, analogous to lady Wisdom, a composite portrait of a single immoral woman stands behind the various

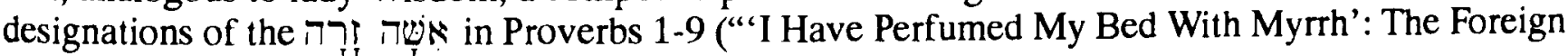
Woman ('išsâa zârâa) in Proverbs 1-9," 54).

65 Cf. L. A. Snijders, "The Meaning of $z \bar{a} r$ in the Old Testamenl" (1954) 1-154; and idem, "רור, $z a r / z \bar{a}, "$ TDOT, IV, 56.

66 A. Cohen, Proverbs (1946) 11f. So also H. W. Wolff, Anthropology of the Old Testament (1974) 168, citing E. Kutsch, Verheissung und Gesetz (1973) 134ff. Wolff nevertheless accepts the evidence of Malachi 2:14 and Ezekiel 16:8, understanding these texts as references to the covenant of marriage.

67 Proverbs (1964) 62.

68 Proverbs, 286. The rendering of the KJV is similar: "Which forsaketh the guide of her youth." Cf. also B. Gemser, "The Instructions of Onchsheshonqy and Biblical Wisdom Literature" (1960) 102-128.

C. H. Toy mentions that some commentators suggest that "the companion of her youth [? ? ריר:" in Proverbs 2:17 refers to God (Proverbs, 46). The similar expression in Jeremiah 3:4 does appear to refer to God. But there it occurs within a metaphor of marriage. At the level of the metaphor itself, with most commentators, the reference is to her husband. Specific arguments in favour of this view are presented below. 
and has forgotten the covenant of her God."69 McKane supports his understanding of צ' as "teacher" based on Jeremiah 3:4 (suggesting that her "teacher" may have been her father) and 13:21.

\subsubsection{The traditional view that "the covenant of her God

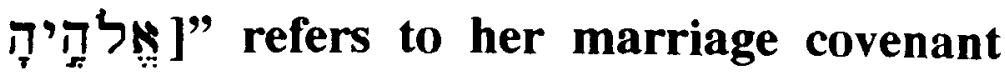

The following arguments may be advanced in support of the traditional interpretation of Proverbs 2:17:

1) Although the verb אלף I (appearing only in Job 15:5; 33:33; 35:11; and Proverbs 22:25) is recognized as meaning "to learn" or "to teach," McKane's proposal to render the noun a ateacher" is unconvincing. ${ }^{70}$ While McKane appeals to Jeremiah 3:4 as an example of אל מלוּ bearing this meaning, the context does not appear to favour the proposal. Appearing in the midst of an extended marriage metaphor, it would be most unexpected for Israel, the harlot bride, to describe Yahweh as her teacher! Rather, "My father" and "the friend of my youth" appear to be intended as endearing appellations for a husband from a wife who remains brazenly unrepentant. ${ }^{71}$ Accordingly, W. L. Holladay, for example, supports the traditional rendering of as asomeone trusted, confidant" for this text. McKane also appeals to Jeremiah 13:21 in support of his proposal, but against McKane both the text and the sense of this verse are uncertain. ${ }^{73}$ Apart from these two examples, no other occurrence of requires or supports McKane's suggested meaning (see Micah 7:5; Psalm 55:14 [ET 13]; 144:14; Proverbs 16:28; 17:9; and Sirach 38:25). ${ }^{74}$

2) Three considerations favour understanding "the companion of her youth [N

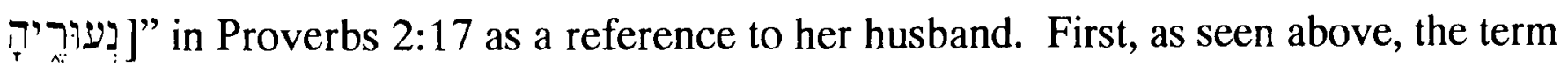
אליוּ is nowhere else used as an appellation for the deity. Although sefer to

69 W. McKane, Proverbs, 213.

${ }^{70} \mathrm{~KB}, 57$, adds Job 32:13, if the text is emended.

71 Though unexampled elsewhere in the Old Testament, for the use of "father" as an affectionate epithet for a husband, cf. L. M. Muntingh, "Amorite Married and Family Life according to the Mari Texts" (1974) 58-60, and J. B. White, $A$ Study of the Language of Love in the Song of Songs and Ancient Egyptian Poetry (1978) 95.

72 Jeremiah 1, 115. Further supporting this marital interpretation of seremiah 3:4 is the similarity of its formation to that found in Joel 1:8; Malachi 2:15; and Proverbs 2:17. Cf. also Hosea 2:9, 17 [ET 7, 15]; and Ezekiel 16:43.

73 J. Bright, for example, despairs of offering any translation (Jeremiah, 93, 95). Alternatively, W. Rudolph (Jeremia), A. Weiser (Das Buch Jeremia), and R. P. Carroll (Jeremiah) maintain the traditional rendering of אל איפים איפים should be understood as bearing its first sense of "tamed," which KB recognizes for Jeremiah 11:19. Cf. W. L. Holladay, Jeremiah 1, 411, 414.

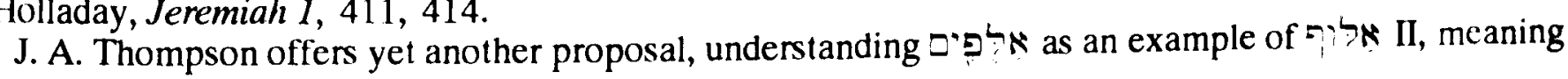
"tribal leader" (Jeremiah, 371).

74 Though noting Gemser's proposal, KB offers zutraulich, Vertrauter, and Rind, for (I). The remaining forty-two occurrences of אלי (II) bear the meaning "tribal chief." C. H. Toy says simply of , אלוף, "the sense guide, instructor, is not found in the OT" (Proverbs, 46). 
God in Jeremiah 3:4, this is so only because of the presence of the marriage metaphor in

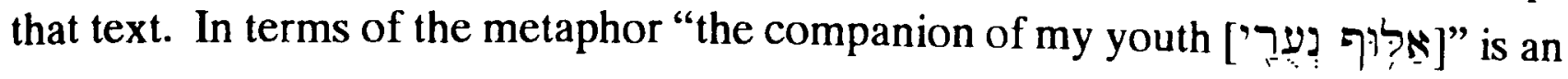
endearing epithet used by a harlot (Israel) to refer to her husband (Yahweh). Second, the

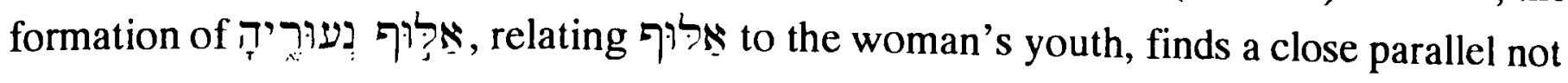

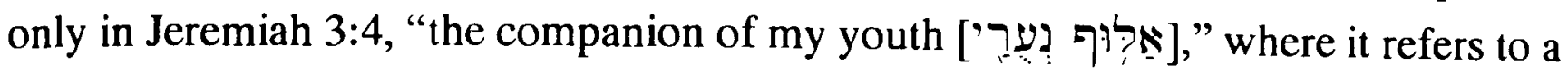
husband (in the metaphor), but also in Proverbs 5:18, "the wife of your youth [ [

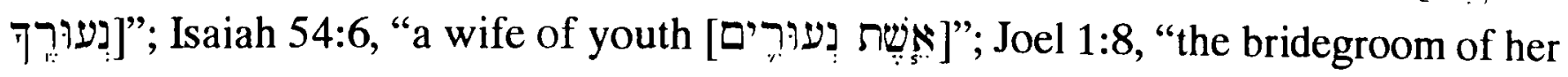

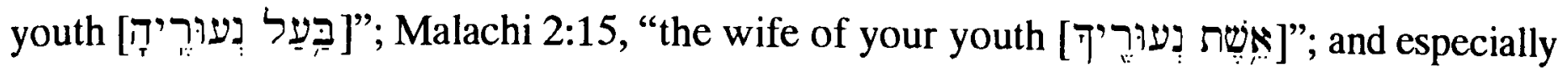
Malachi 2:14: "Because the LORD was witness to the covenant between you and the wife

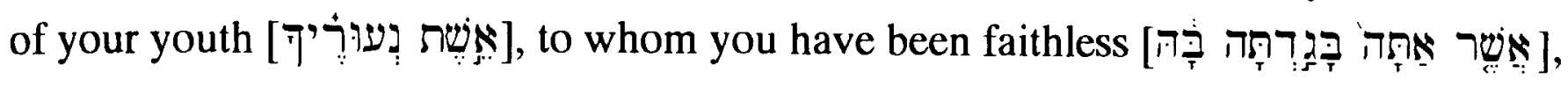

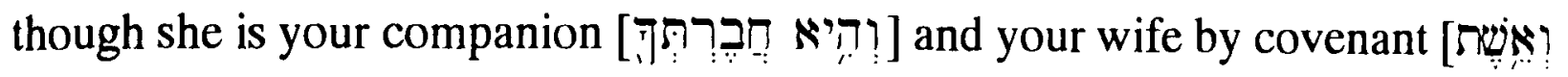

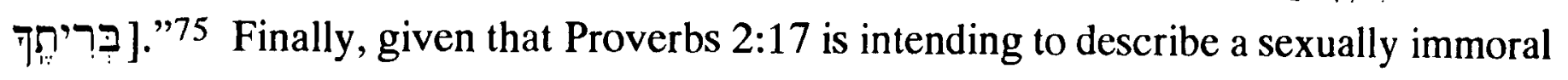
woman, it is not at all unexpected that such a woman would be described as one who "forsakes [ע]" her husband. By contrast, compare Proverbs 4:6, where the young man is enjoined not to "forsake [בע]" wisdom, which is personified as a bride. 76 Compare also Deuteronomy 31:16 and Hosea 4:10, where, perhaps in terms of the marriage metaphor, Israel is accused of committing "prostitution [IנI]" by which she has "forsaken [IIV]" the Lord.

3) Kidner's argument that Proverbs 2:17 should have read "the husband of her

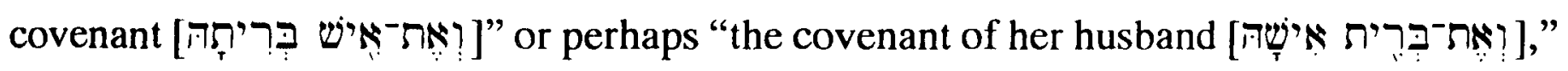

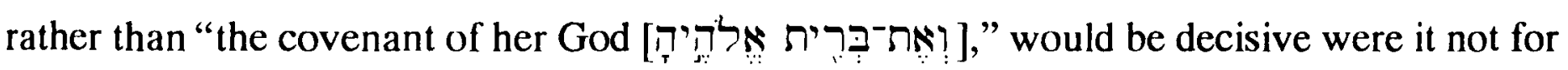
the fact that there are several examples of inter-human covenants being identified simultaneously as covenants of God. Ezekiel 17:16-20, for example, condemns Zedekiah for breaking his covenant with Nebuchadnezzar, assuring him of Yahweh's impending judgment because of Zedekiah's perfidy and rebellious league with Pharaoh Psammetichus II. Although vss. 16 and 18 state that the covenant and oath were with Nebuchadnezzar, vs. 19 concludes, “Therefore thus says the Lord GOD: As I live, surely my oath which he

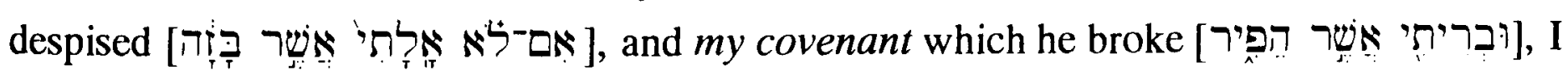
will requite upon his head." Ezekiel considers this inter-human covenant (vassal-treaty) as sacrosanct, in spite of its extorted ratificatory oath (Ezekiel 17:13), presumably because Yahweh's name was invoked (so 2 Chronicles 36:13). Accordingly, Yahweh identifies the covenant and oath as his own and characterizes their breach as "treason against me

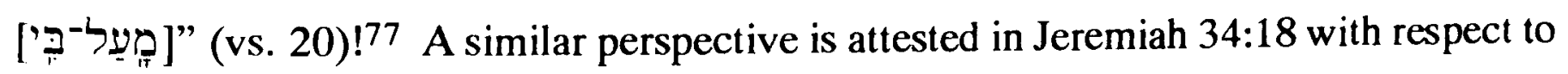

75 Cf. also Hosea 2:9, 17 [ET 7, 15]; and Ezekiel 16:43.

76 For this personification, cf. C. V. Camp, op. cit., passim.

For other examples of "forsake" used in marital contexts, cf. Isaiah 54:6; 62:4.

77 Cf. M. Tsevat, "The Neo-Assyrian and Neo-Babylonian Vassal Oaths and the Prophet Ezekiel" (1959) 199-204. So also C. T. Begg, "Berit in Ezekiel," 77, 79. More recent evidence of the imposition on vassals of an oath of allegiance by their own deity is provided by R. Frankena, "The Vassal Treaties of 


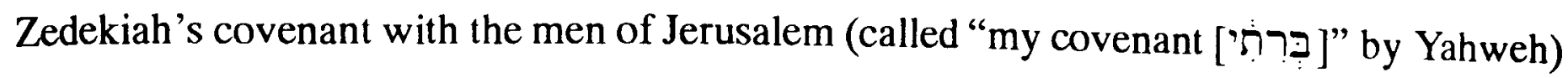
and in 1 Samuel 20:8, where David refers to his covenant with Jonathan as "a covenant of

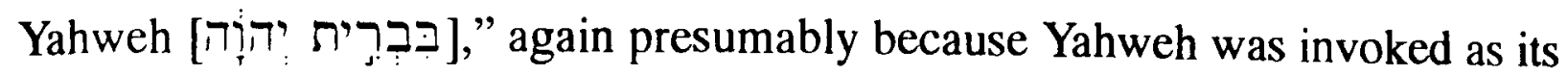
guarantor. ${ }^{78}$

4) Against the view that וּקת refers to the Sinaitic covenant is the

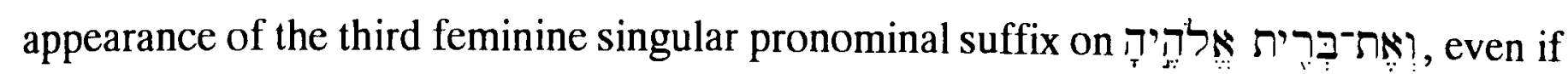
such a usage may not be impossible. ${ }^{79}$ If the suffix applies to אלהים, "she has forgotten the covenant with her God," the reference to "her God" seems unnecessarily restrictive as a reference to the God of the Sinaitic covenant. 80 The God of Sinai was Israel's God, the God of "our fathers," or "your God."81 Alternatively, if the suffix applies to בִּרִ "she has forgotten her covenant with God," the reference to "her covenant" fails to take adequate account of the corporate identity of Israel as Yahweh's covenant partner at Sinai, applying an individualistic interpretation to that event which requires support.

5) To these arguments it may be added that in view of the general concerns of Proverbs as wisdom literature finding any reference to the Sinaitic covenant should be deemed unexpected. In general, Proverbs is not particularly alert to historical or biblicaltheological matters. For example, nowhere is there any mention of the patriarchs, Moses, the Exodus, Sinai / Horeb, David (apart from the ascription in 1:1), Zion / Jerusalem, the temple, etc. Furthermore, it is surely significant that 2:17 is the only text in Proverbs even to mention a בִִִּ use of ברּר , that is, as a reference to marriage, which is entirely appropriate in the context of $2: 17$, rather than to a theological construct (i.e., this woman's relation to the Sinaitic covenant).

Esarhaddon and the Dating of the Deuteronomy" (1965) 131, and M. Cogan, Imperialism and Religion: Assyria, Judah and Israel in the Eighth and Seventh Centuries B.C.E. (1974) $46 f$.

Against this view is M. Greenberg, who argues that vss. 19-21 are concerned not with the vassal treaty of Zedekiah to Nebuchadnezzar, but Yahweh's covenant with Israel, which Zedekiah was obligated to uphold and to which there is reference also in Ezekiel 16:59 ("Ezekiel 17: A Holistic Interpretation," 152f. and idem, Ezekiel, 1-20,317-324). But to maintain his view, Greenberg is forced to dismiss the evidence of 2 Chronicles 36:13 as a reflex of the Chronicler's misunderstanding of Ezekiel 17.

78 Cf., e.g., R. P. Gordon, 1 \& 2 Samuel, 166.

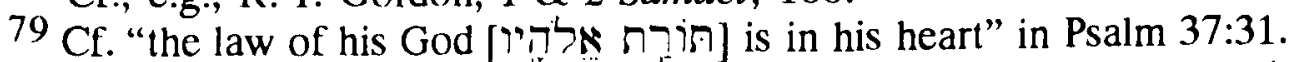

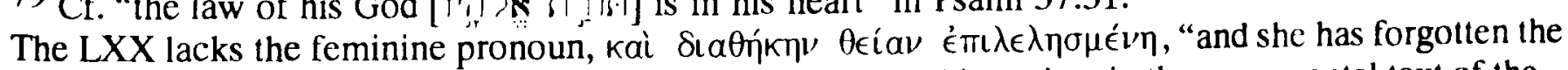
covenant of God." Presumably this reading is the result of a graphic variant in the consonantal text of the Vorlage of the LXX which read אלהיה אלדים. Wather than most commentators, the MT אידיה is to preferred as a lectio difficilior.

80 By contrast, cf. Psalm 78:10 and 2 Chronicles 34:32.

$81 \mathrm{Cf}$. the collective second person pronominal reference in Leviticus $2: 13$, referring to any Israclitc who brings an offering, "You shall season all your cereal offerings with salt; you shall not let the salt of the covenant with your God [מלבח ברית אלדית] be lacking from your cereal offering; with all your offerings you shall offer salt." 
6) Finally, building on the study of A. Robert, C. V. Camp notes the concentration of similar concerns and vocabulary between Proverbs 2:16f. and Malachi 2:10-16 -although the perspective in Malachi is more radical than that in Proverbs in that it is the husband who is faithless, rather than the wife. ${ }^{82}$ Furthermore, there appears to have been a transformation from the "strange woman" in Proverbs, assuming she is thus designated because she is an adulteress, not because she is a non-Israelite, to the literal foreign woman in Malachi 2:11.83

Nevertheless, in terms of this resemblance, "forsakes the companion of her youth

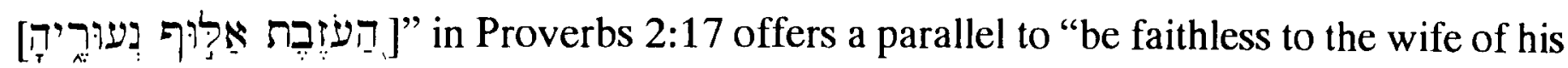

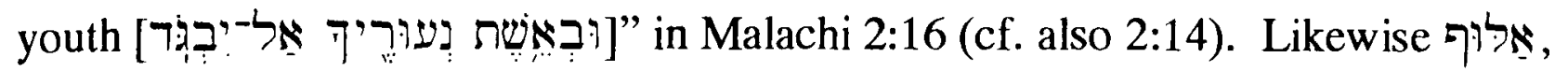

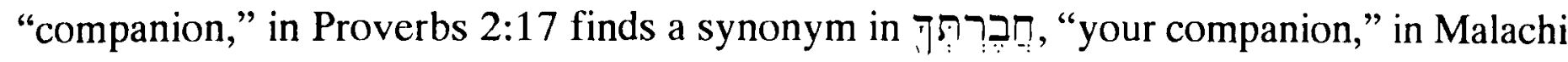

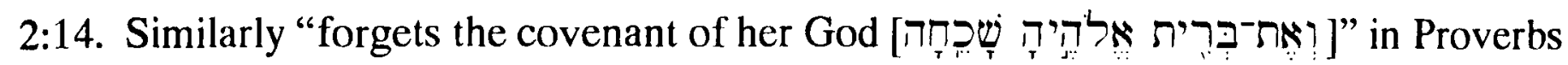
2:17 corresponds to "against whom you have been faithless, though she is ... your wife by

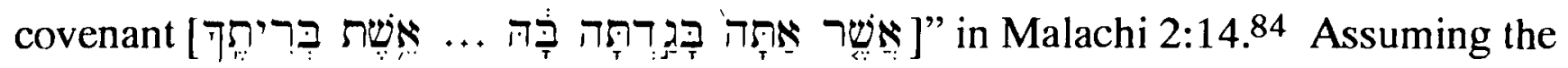
correctness of our previous exegesis of Malachi 2:14, where it was argued that the "covenant" in that text refers to the marriage relationship, this last correspondence confirms the identification of the בִּר in Proverbs 2:17 as a reference to marriage as well.

\subsubsection{Ezekiel 16:8, 59, 60, and 62}

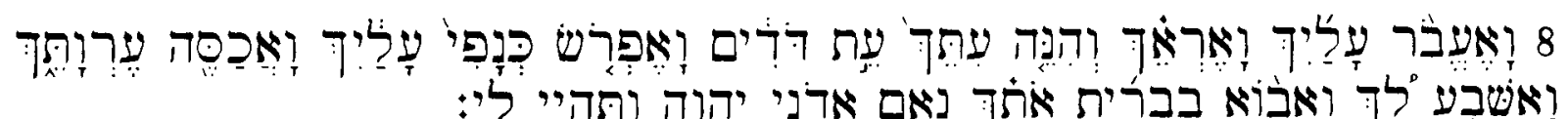

"When I passed by you again and looked upon you, behold, you were at the age for love; and I spread my skirt over you, and covered your nakedness: yea, I plighted my troth to you and entered into a covenant with you, says the Lord GOD, and you became mine."

In the context of an arraignment against Jerusalem for her wanton infidelity (so vs. 2), Ezekiel 16 offers an extended metaphor of Yahweh's relationship with Jerusalem. ${ }^{85}$ The text begins with an historical review of Yahweh's benefactions toward Jerusalem

82 C. V. Camp op. cit., 235-237, 269-271; and A. Robert, "Les attaches litteraires bibliques de Prov. I-IX," 505-25.

83 This transformation need not have been particularly radical since it is likely that some allusion to foreign women, perhaps through double entendre, may underlie the immoral woman's twofold designation

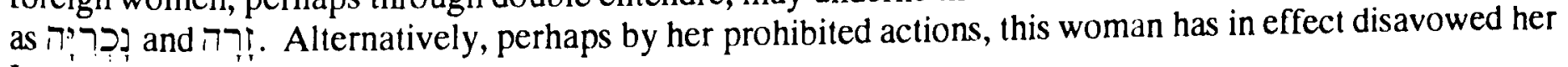
Israelite heritage.

84 Cf. C. V. Camp op. cit., 319, n. 5.

85 This context of an arraignment is made explicit in the Targum of vs. 2, "Arraign ... and declare

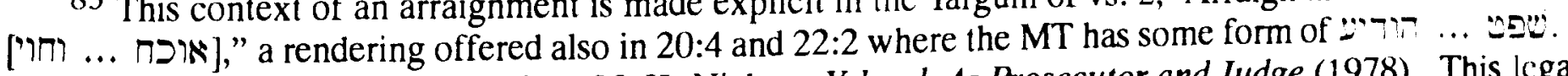
Cf. M. Greenberg, Ezekiel 1-20, 273. Cf. K. Nielsen, Yahweh As Prosecutor and Judge (1978). This lcgal setting is also discussed by W. Zimmerli, Ezekiel I (1979) 333ff.; and H. F. Fuhs, Ezechiel 1-24 (1984) $80 \mathrm{ff}$. 
described first in terms of his rescue (and adoption ${ }^{86}$ ) of her as a foundling (vss. 3-7). This theme of benefaction continues in the second section, vss. 8-14, which describes Yahweh's marriage to Israel and his early lavish provisions for his wife-people. In the third section, vss. 15-43, the theme of undeserved benefaction from Yahweh changes to an indictment of the nymphomaniacal adultery of the wife-Jerusalem. In vss. 44-58, this indictment is continued in terms of an invidious comparison between the wife-Jerusalem and her sisters Sodom and Samaria. The closing verses of the chapter, vss. 59-63, assure Jerusalem of judgment (vs. 59), but they also promise a new and eternal covenant with Jerusalem, which will be met on her part with remorse over her past ways.

Attempting to correlate this sequence of the rescue (adoption) of a foundling Jerusalem, Yahweh's marriage to her, and her subsequent infidelity to historical reality, there are two main interpretative approaches. The first approach, represented by $\mathrm{M}$. Greenberg among others, follows the Targum and considers that Jerusalem is a figure for the people of God as a whole. ${ }^{87}$ Israel's birthplace was in Canaan, where Yahweh revealed himself to Abraham and entered into covenant with him (Genesis 15). Israel's period of abandonment in Egypt, when she was "like an infant abandoned in the field, whose navel-cord was not cut," followed. Later God had mercy on her, delivering Israel out of Egypt and marrying her at Sinai, where he "entered into a covenant with you" (Ezekiel 16:8). ${ }^{88}$

The alternative approach considers "Jerusalem" to represent the city by that name (i.e., its inhabitants) and, associated with it, the Davidic dynasty. On this view, the "rescue" corresponds to David's conquest of Jebus; the marriage corresponds to Yahweh's covenant with David (2 Samuel 7), which established the Davidic dynasty and Yahweh's choice of Jerusalem as the place where he would cause his name to dwell (where the temple was to be built). ${ }^{89}$ This latter approach recognizes that the history of Jerusalem epitomizes the history of Israel; as such, to some degree the history of the Davidic covenant reflects or recapitulates the history of the Sinaitic covenant. Such a view is represented by W. H. Brownlee, among others, and may do greater justice to the focus of the text on Jerusalem. ${ }^{90}$

Focusing our attention on Ezekiel 16:8, there is considerable uncertainty about the precise symbolism intended by the expression, "I spread my skirt over you, and covered

$86 \mathrm{Cf}$. CH $\$ 185$. Cf. the detailed support offered by M. Malul, "Adoption of Foundlings in the Bible and Mesopotamian Documents. A Study of Some Legal Metaphors in Ezekiel 16:1-7" (1990) 97-126.

87 Ezekiel 1-20, 273-306. Cf. also, e.g., C. F. Keil, Ezekiel, 195; A. B. Davidson and A. W. Streane, The Book of the Prophet Ezekiel (1916); and J. B. Taylor, Ezekiel (1969) 132ff.

${ }^{88} \mathrm{Kimchi}$, for example, relates Ezekiel 16:8a, where Yahweh notices Jerusalem for a second time, to the vision of the burning bush when Yahweh announced his intention to deliver Israel (so according to $\mathrm{S}$. Fisch, Ezekiel [1950] 86).

89 Cf. also Psalm 132:13-17, cited by R. H. Alexander, "Ezekiel," 812.

90 W. H. Brownlee, Ezekiel 1-19, 219-221, 226ff. and passim. So also Cf. H. -J. Kraus, Worship in Israel (1965) 179; J. W. Wevers, Ezekiel (1969) 94ff.; W. Eichrodt, Ezekiel (1970) 201ff.; W. Zimmerli, Ezekiel 1, 333-353; and R. H. Alexander, "Ezekiel" (1986) 810ff. 
your nakedness." W. H. Brownlee, for example, doubts that a literal action was ever performed, even apart from the present metaphoric use, and suggests instead that the expression probably refers to sexual intercourse. ${ }^{91}$ Accordingly he suggests the translation, "I opened my robe to you...."92

While recognizing the notorious difficulty in distinguishing between symbolic actions and merely performable figures of speech (like "pulling one's leg" in English), it seems likely that the mentioned covering was, in fact, typically performed, contrary to Brownlee's assumption. There are three arguments in favour of this view. First, literal garments are known to have been used in various symbolic actions connected with marriage and divorce elsewhere in the ancient Near East, making reasonable the assumption of their use in Israelite marriage. ${ }^{93}$ Moreover, there is an especially close parallel to the present text in early Arabic practice, where a widow could be acquired by a relative without the payment of a marriage present (mahr) merely by throwing his garment over her. It is likely, but not certain, that this action was also used more generally in the contraction of marriage. ${ }^{94}$ Second, the fact that the common expression "to uncover the nakedness of [גלה ערות]" someone refers to (illicit) sexual intimacy makes it doubtful that the opposite expression "to cover the nakedness [כסה ערות]" would also refer to sexual intimacy.95 Finally, if the "covering" mentioned in Ezekiel 16:8 refers to sexual union, the resulting order of sexual union preceding betrothal would be anomalous and, as such, would be unexpected as a description of divine activity. ${ }^{96}$

It seems more likely, then, that Ezekiel refers to a literal act of covering which was typically performed in the contraction of marriage, although, of course, not in the present case because of the allegorical context. It has been suggested that this action may have symbolized a claim of ownership, ${ }^{97}$ or perhaps it constituted a pledge from the groom for the on-going provision of his bride with the necessities of life. ${ }^{98}$ Alternatively, it has been suggested that the act of covering implies that the woman was now to be "covered" from all other men. ${ }^{99}$ Alternatively, since the covering was accomplished with the use of one's

91 Ezekiel 1-19, 225.

92 Cf. also C. M. Carmichael, “Treading' in the Book of Ruth" (1980) $258 \mathrm{f}$.

93 M. Malul, Studies in Mesopotamian Legal Symbolism, 179-208.

94 Cf. W. R. Smith, who discusses the statement which refers to this practice in Tabari's commentary on the Qur'ān 4,19 (Kinship and Marriage in Early Arabia, 104f.). Cf. also D. Mace, Hebrew Marriage, 181-182; E. Neufeld, Ancient Hebrew Marriage Laws, 31f.; and M. Greenberg, Ezekiel 1-20, 277.

95 Cf. W. Zimmerli, Ezekiel 1, 340. Cf. also Deuteronomy 23:1 [ET 22:30]; 27:20.

96 Brownlee's attempt to answer this objection by comparing David's capture of Jerusalem to a man passionately seizing a woman who acquiesces after a brief struggle is unconvincing (Ezekiel 1-19, 225).

${ }^{97} \mathrm{M}$. Greenberg compares $m$. Pe' $a$ 4:3, "If a poor man threw himself upon [the crop] and spread his cloak over it [in order to claim it], he is removed therefrom" (Ezekiel 1-20, 277).

98 Traditionally the necessities were "food, oil, and clothing." Such a reference may find support in the subsequent mention of clothing in vss. 10-12, and perhaps also the use of nakedness in divorce -- leaving the house with nothing. Cf. also the ironic reversal of symbolism in Isaiah 4:1.

${ }_{99}$ Hence, illicit sexual relations can be described as "uncovering the edge of the father's garment," as in Deuteronomy 23:1. 
own hem, it may have symbolized how the man and the woman would now be considered as one -- being covered by the same clothes. ${ }^{100}$ Finally, it is possible that the covering conveyed a promise of protection, especially in the light of Ruth 2:12.101 In spite of this uncertainty about the precise symbolism, however, there appears little doubt that the gesture of covering in Ezekiel 16:8 was intended as a marriage-forming act, especially given the support of Ruth 3:9.102

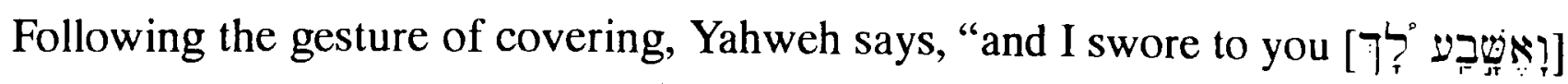

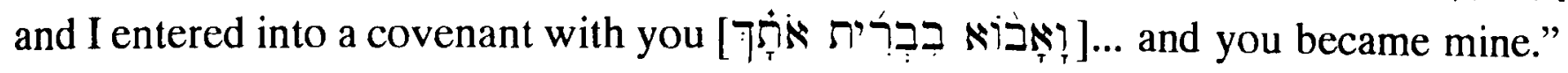
While Malachi 2:14 implies the presence of an oath in marriage with its reference to Yahweh as "witness" to the covenant, and while Proverbs 2:17 similarly implies a ratificatory oath which invoked the deity since it identifies the marriage covenant as a "covenant of God," no other biblical text is so explicit in identifying the presence of an oath in marriage as is Ezekiel 16:8 (and vs. 59). ${ }^{103}$

However, M. Greenberg, among others, rejects an identification of the covenant and oath mentioned in vs. 8 (as also in vss. 59, 60, and 62) with marriage.104 Although Greenberg accepts the likelihood of the use of verba solemnia in marriage (citing the

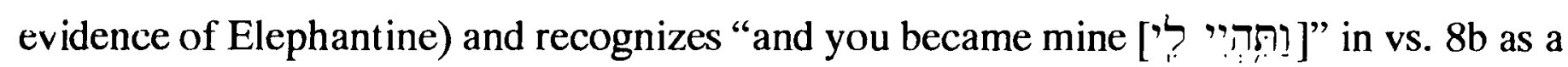
declaration formula, Greenberg objects, "Nowhere but in Ezekiel is this [marriage] declaration called an oath." 105 Furthermore, Greenberg cites J. Milgrom (Cult and Conscience, pp. 133f.) for an alternative interpretation of Malachi 2:14 and Proverbs 2:17, the two other key texts which traditionally have been thought to offer the clearest evidence for an identification of marriage as a covenant. Accordingly, Greenberg believes that the oath and covenant mentioned in vs. 8 are instances where the metaphor has given way to the underlying reality -- they refer only to the Sinaitic covenant and not to marriage.

100 This symbolism of unity may be favoured by the symbolic joining of clothes in marriage and in certain divorce rites, where the clothes are suddenly severed. For examples, cf. M. Malul, Studies in Mesopotamian Legal Symbolism, 152; 200, n. 197; 206f.; 345.

101 Cf. B. Green, "A Study of Field and Seed Symbolism in the Biblical Story of Ruth" (1980) 142, as cited by R. H. Hubbard Jr., Ruth, 212. Hubbard notes that the gesture may have simultaneously expressed both a promise of protection as well as a man's readiness for sexual consummation.

So also J. W. Wevers, Ezekiel, 96. J. Gray compares the custom of a kinsman putting part of his garment over a widow, citing J. Lewy, "Les textes paléo-assyriens et l'Ancien Testament" (1934) $31 \mathrm{ff}$. (Joshua, Judges, Ruth, 392).

102 Cf., e.g, A. Phillips, "Uncovering the Father's Skirt" (1980) 39; E. W. Davies, "Inheritance Rights and the Hebrew Levirate Marriage, Part 1" (1981) 143f.; and R. L. Hubbard Jr., Ruth, 212. Hubbard also mentions Deuteronomy 23:1 [ET 22:30]; 27:20; and Malachi 2:16, in support.

103 C. T. Begg considers that Ezekiel's use of the marriage covenant as a figure for Yahweh's historic covenant with Israel (or David?) is yet another unique contribution of the prophet (" $B^{e}$ rit in Ezekiel," 79f.).

104 M. Greenberg, Ezekiel 1-20, 278. Cf. also, e.g., J. Herrmann, Ezechiel (1924) ad loc.; B. M. Vellas, Israelite Marriage, 24; M. Malul, "Adoption of Foundlings in the Bible and Mesopotamian Documents. A Study of Some Legal Metaphors in Ezekiel 16:1-7," 126, n. 112; and P. Kalluveettil, Declaration and Covenant, 79.

105 Ezekiel 1-20, 278. 
The following considerations may be advanced against Greenberg's interpretation.

1) It has already been argued that the proposed alternative interpretations for Malachi 2:14 and Proverbs 2:17 are not convincing. Hence marriage is identified elsewhere as a בִרִית; ; accordingly, there can be no presumptive objection to its similar identification in the present text.

2) Further, it has been demonstrated that verba solemnia do have an oath-like function, as is apparent in examples such as Genesis 2:23 and Exodus 24:3.106 In fact, by failing to identify the oath function of verba solemnia, Greenberg is forced to suppose that the author of Ezekiel 16:8 has (con)fused the record of Yahweh's oath to the patriarchs to grant the land of Canaan to their descendants (Genesis 26:3; Deuteronomy 1:8, etc.) with the supposedly non-oath verba solemnia of mutual obligation connected with the Exodus and Sinaitic covenant (according to $\mathrm{P}$ and to Deuteronomy). 107 Greenberg also cites Ezekiel 20:6 in support of his assumption of a fusion of the patriarchal and Exodus traditions. But any intentional allusion to the patriarchal period would be out of place in Ezekiel 20:6, which is so explicit about its chronological setting: "On the day when I chose Israel, I swore to the seed of the house of Jacob, making myself known to them in the land of Egypt, I swore to them, saying, I am the LORD your God. On that day I swore to them that I would bring them out of the land of Egypt into a land that I had searched out for them, a land flowing with milk and honey, the most glorious of all lands" (Ezekiel 20:5-6). Moreover, even an unintended confusion of patriarchal and exodus traditions seems unnecessary, if Ezekiel understood, contrary to Greenberg, that Yahweh's sworn promise to give the land was renewed by its solemn oath-like reiteration in Exodus 6:2ff., for example. ${ }^{108}$ In any case, it does not commend an interpretative theory to require confusion on the part of the ancient source in order to sustain it.

3) Greenberg's view that the marriage metaphor has suddenly given way to the underlying covenant reality in Ezekiel 16:8 is unconvincing given the fact that the author so carefully maintains the metaphor throughout the whole of Ezekiel 16. At only three other points does Greenberg even suggest the possibility that the referent has similarly intruded into the metaphor, namely vss. 24 (cf. also 25, 31, 39), 41 and 59ff. And on closer examination, each of these three possibilities proves doubtful.

106 "Moses came and told the people all the words of the LORD and all the ordinances; and all the people answered with one voice, and said, 'All the words which the LORD has spoken we will do." As D. J. McCarthy, concedes concerning this text, any such "public commitment to follow Yahweh who has just presented Himself in all his power is the equivalent of an oath [italics mine]" (Treaty and Covenant [1981] 253). So also D. L. Magnetti, op. cit., 128.

107 Op. cit., 278.

108 Exodus 6:6 was also understood by the Rabbis to imply an oath. Cf. R. Tanhuma, Wayera, 2 (Midrashic commentary on the Pentateuch dating from the fourth century A.D.), as cited by S. Fisch, Ezekiel, 86. 
a) Vss. 24f. reads: "you built yourself a vaulted chamber [בגב

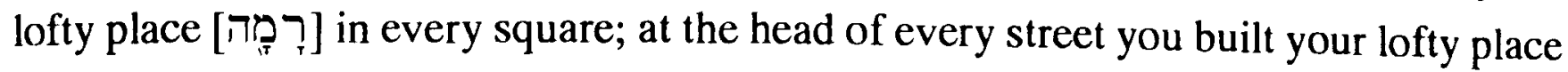
[רָּרָך]

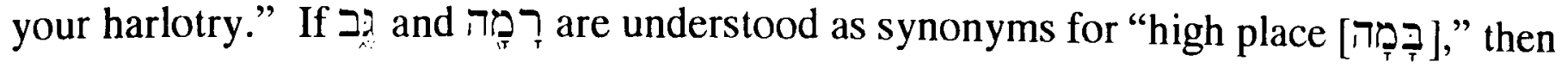
the referent intrudes into the metaphor in vs. 24 , as also in vss. $25,31,39$, where these terms reappear. The posited identification for these difficult, perhaps quite general architectural terms, however, is far from certain. ${ }^{109}$ For example, the LXX renders

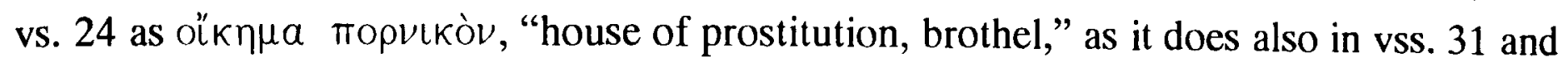

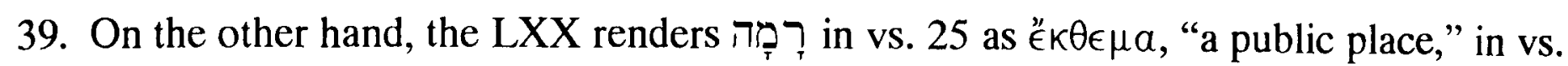

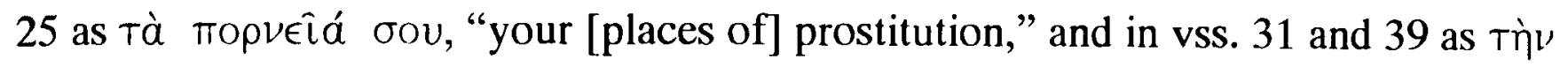

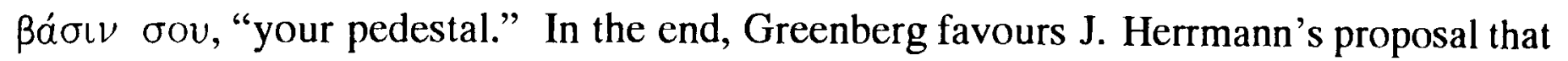
רָרָה means a "[harlot's] stand or booth."110 It is likely that some such meaning is required, and, if so, contrary to Greenberg's initial suggestion, the metaphor is maintained in these verse after all.

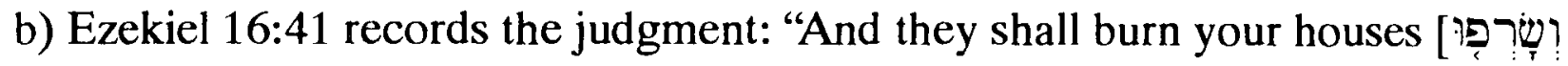

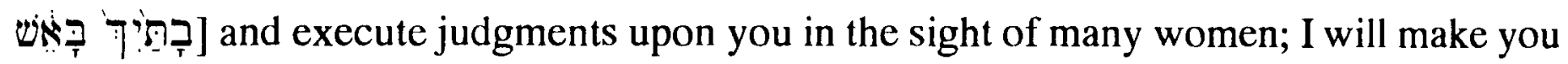
stop playing the harlot, and you shall also give hire no more." Greenberg suggests that here, once again, the referent may have intruded into the metaphor since the houses of Jerusalem were in fact burned by Nebuchadnezzar's invading army, as 2 Kings 25:9 reports.

W. Zimmerli prefers to emend the MT with certain MSS, and the Syriac, to read "they will burn you with fire [ושרפוך בתוך האש]."111 If this proposal were accepted, the metaphor would be maintained. However, Greenberg convincingly rejects this proposal, noting that the emendation yields unidiomatic Hebrew (elsewhere burning "with fire" is

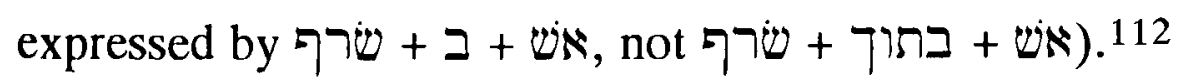

Nevertheless, the metaphor may not have been forgotten even in the unemended text of Ezekiel 16:41. After all, the verse is explicit that this burning is to take place "in the sight of many women." It is doubtful that the metaphor should have spoken of the burning of the harlot, rather than of her houses, in spite of the evidence of Genesis 38:24 and Leviticus 21:9. This is so because Ezekiel 16:40 has already specified that the harlot Jerusalem is to be executed by stoning; this mode of execution finds support in other texts, for example Deuteronomy 22:21 and, perhaps, 22:24.

If this harlot has filled the city with her brothels, as mentioned in vss. $24,25,31$,

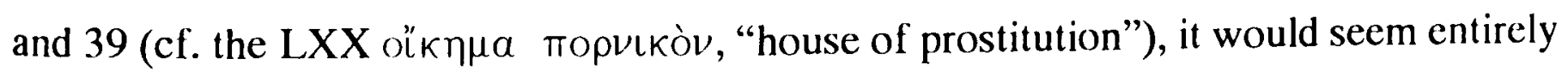

109 Cf., e.g., the use of ג in Ezekiel 43:13 with a proper altar for Yahweh.

110 J. Herrmann, Ezechiel (1924) ad loc. Cf. also B. Lang, Wisdom and the Book of Proverbs. 99f. Lang cites the Akkadian term ram, "to settle down," and Ugaritic $\mathrm{rmm}$ "to erect a building," as possible cognates for רמר (op. cit., 168, n. 17).

111 Ezekiel 1, 330f.

112 M. Greenberg, Ezekiel 1-20, 288. 
appropriate that such polluting structures would be burned following her execution. 113 Although no legal text specifies this requirement regarding the burning of brothels (Deuteronomy 13:17 [ET 16] may provide an analogy, as perhaps also Judges 14:15), Ezekiel 23:47 appears to offer a precise parallel: "And the host shall stone them [the harlots Oholah and Oholibah] and dispatch them with their swords; they shall slay their sons and their daughters, and burn up their houses."114

c) The only remaining example where Greenberg suggests that Ezekiel may have forgotten his metaphor is Ezekiel 16:59ff. Here Yahweh condemns Jerusalem who "despised the oath in breaking the covenant, yet I will remember my covenant with you in the days of your youth, and I will establish with you an everlasting covenant." If "covenant" and "oath" in these verses, which parallel vs. 8, are not allowed to apply to marriage but are deemed intrusions of the referent, then these are the only clear cases of such intrusions in sixty-one verses (vss. 3-63). In the immediate context the marriage metaphor is vividly maintained throughout vss. 59-63. This is apparent in the mention of Jerusalem's anticipated shame over her past misdeeds (vss. 61 and 63), the days of Jerusalem's youth, her sisters, etc., as well as in the consistent use of feminine singular gender references throughout. Accordingly, W. H. Brownlee, for example, does not hesitate to identify the recalled "covenant with you in the days of your youth" as a marriage covenant. ${ }^{115}$ Indeed, if vs. 8 is interpreted in a straightforward manner as identifying marriage as a covenant which included a ratificatory oath, then vss. $59 \mathrm{ff}$. pose little problem in their similar reference to that original marriage covenant and its subsequently violated oath, as well as in their gracious promise of a future marriage covenant.

4) Finally, it has often been noted that Ezekiel's references to clus cluster in Ezekiel 16 (6x) and 17:11-21 (6x), with only six other occurrences elsewhere (Ezekiel $20: 37 ; 30: 5 ; 34: 25 ; 37: 26$ [bis]; 44:7). Whether or not Ezekiel lacks a "well-defined covenant theology,"116 it appears likely that the concentration of the use of this term in these two texts is due precisely to the influence of its "secular" uses -- in Ezekiel 16, because of the reference to marriage; in Ezekiel 17, because of the reference to an international treaty. ${ }^{117}$

$113 \mathrm{Cf}$. Jeremiah 5:7 for the use of בית in reference to these "houses of prostitution." Cf. also, perhaps, Joshua 6:22.

114 It is easier to suppose that the burning of the harlot's house or brothel may have been a standard penalty than to suppose that Ezekiel has committed the very same lapse in this text as he is supposed to have in Ezekiel 16.

115 Ezekiel 1-19, 251. The mention of "the days of your youth" favours this. Cf. the earlier discussion of references to youth in marital contexts.

116 So, e.g., W. Zimmerli, Ezekiel I, 46, and C. T. Begg, "Berit in Ezekiel," 81.

117 It should be noted that elsewhere, Ezekiel finds little difficulty in reviewing Israel's history without explicit reference to any $:$ בִר , as in chapter 23 , or its future hope, as in 11:14-21; 36:1-38.

W. Eichrodt holds a view of Ezekiel 16 opposite to that being proposed here (Ezekiel, 206). On his view Ezekiel's understanding of Yahweh's divine covenant exercised a perceptible influence upon the narrative which resulted in the depiction of a marriage which imposed a stronger tie upon the husband. 


\subsubsection{Two doubtful examples}

\subsubsection{Genesis 31:50}

Although Genesis 31:50 is often adduced as evidence of the covenantal nature of marriage, $\mathbf{J}$. Milgrom is correct in rejecting this claim. ${ }^{118}$ While the text is explicit about the presence of a בִרִית (so 31:44) ratified with bilateral oaths, the covenant in question (apparently a combination of a marriage contract and a mutual non-aggression pact ${ }^{119}$ ) exists between Laban and Jacob, not between Jacob and his wives, as would be required for the covenant of marriage. Furthermore, as with many of the extrabiblical marriage contracts (contracts, as will be recalled, which are ancillary to the marriage itself), the text leaves no doubt that this arrangement was concluded long after the formation of the marriage. 120

\subsubsection{Jeremiah $31: 32$}

Jeremiah 31:31f. reads: "Behold, the days are coming, says the LORD, when I will make a new covenant with the house of Israel and the house of Judah, not like the covenant which I made with their fathers when I took them by the hand to bring them out of the land

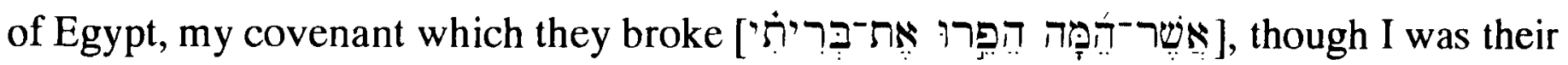

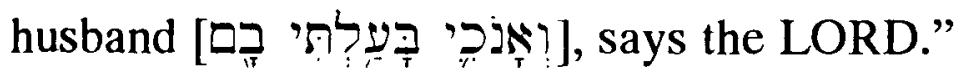

While the verb בָּ עִ בער can mean "to be a master," the RSV has chosen to render the term with its alternative well-attested meaning "to be a husband": "though I was their husband." This interpretation has also been favoured by R. P. Carroll, among others. ${ }^{121}$ If this rendering is accepted, this text would suggest that Jeremiah also viewed marriage as a covenant. The choice between these alternative renderings of Jeremiah 3 demonstrates the fact that the prophet was familiar with the marriage analogy (in

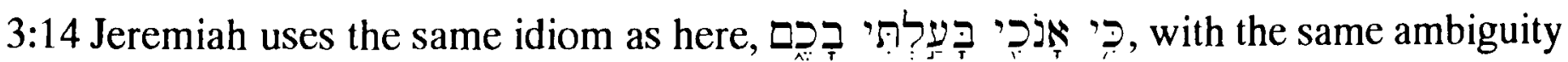
of whether he intends "for I am your master [RSV]" or "for I am your husband [AV]"), and

One final argument against interpreting Ezekiel 16:8 as identifying literal marriage as a covenant is advanced by J. Milgrom, op. cit., 134. According to Milgrom, the mentioned oath "should have been expected of the bride, Israel, for it is the bride, not the husband, who is subject to the laws of adultery." This objection will be considered in more detail below in $\$ 8.3$.

$118 \mathrm{~J}$. Milgrom, op. cit., 134.

119 Cf., e.g., M. G. Kline, "Genesis," $104 \mathrm{f}$.

120 It may be noted that the protective clause prohibiting Jacob from taking additional wives (given that his wives have already borne children) and the use of oaths are both features which also find ample parallels in the extrabiblical marriage contracts.

121 Jeremiah, 610. So also J. Coppens, “La nouvelle alliance en Jér 31.31-4," 14-15, as cited with approval by D. J. McCarthy, Old Testament Covenant, 33. Cf. also G. R. Dunstan, "The Marriage Covenant," 246, and S.-T. Sohn, "The Divine Election of Israel," $45 f$. 
the use of this analogy in Hosea 2 to describe both the old covenant and a promised new covenant make quite attractive the rendering of "husband" in the present text. 122

However, several considerations appear to favour the rendering "lord." First, if Jeremiah had meant to utilize the marriage analogy, it might be expected that he would have employed a feminine singular reference for Israel, at least within the immediate context, "though I was her husband," rather than the masculine plural, "though I was their husband

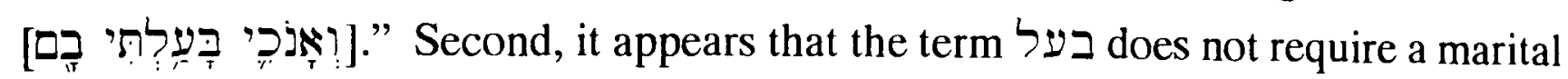
reference to be at home within a covenant context. Compare, for example, the reference in Genesis 14:13 to Mamre the Amorite, brother of Eshcol and of Aner, as "'lords' of the

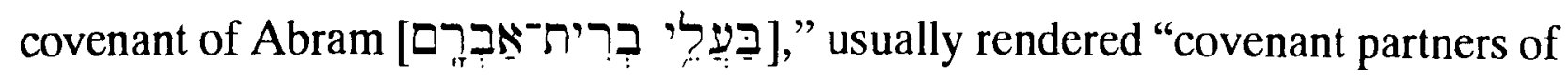
Abram."123 Finally, the rendering "though I was their lord" may seem tautological in view of the earlier assertions that Yahweh had made a covenant with his people and delivered them out of Egypt. However, the grammar of Jeremiah 31:32, with ș ș to interpreted either as an intensive pronoun or a nominative absolute, stresses not the predicate, as in "though I was their husband," but the subject, "though I myself was their lord [or possibly "covenant partner"?]." In other words, it should not be expected that Jeremiah was introducing some new quality in Yahweh, namely his husband-like love, to highlight Israel's sin, but merely contrasting Israel's perfidy with the reminder that their covenant partner was no less than Yahweh, the very same one who had made the covenant in the first place and had redeemed his people.

\subsubsection{Samuel 18-20 -- a narrative analogy between David's covenant with Jonathan and David's (marriage) covenant with Michal}

To the classic examples for the identification of marriage as a covenant considered above, we now add one further important line of evidence drawn from the narrative analogy between David's covenant with Jonathan and David's marriage with Michal in 1 Samuel 18-20. As was the case in the covenant between Zedekiah and Nebuchadnezzar in Ezekiel 17 and between Zedekiah and the people of Jerusalem in Jeremiah 34, the private covenant between David and Jonathan is similarly identified as Yahweh's own covenant in 1 Samuel ב" ברברית[ 20:8 ("for you have brought your servant into a covenant of Yahweh with you

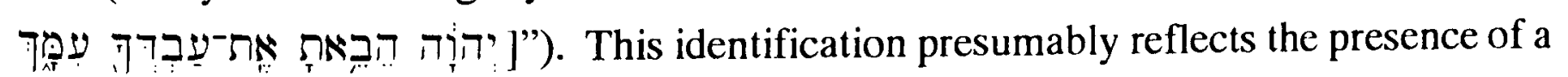
ratifying oath taken in the name of Yahweh (cf. 1 Samuel 20:23; 23:18). ${ }^{124}$

122 In support of this appeal to Hosea 2, it is notable that the idea of a new covenant for the end time is found only in Jeremiah 31:31-34, Hosea 2:20 [ET 18], and Ezekiel 36:24-32. As may be the case in Jeremiah 31 , the promised new covenant is expressed in Hosea 2 in terms of the marriage metaphor. $\mathrm{Cf}$. $\mathrm{H}$. W. Wolff, Hosea, 51.

123 Cf. C. Westermann, Genesis 12-36, 200. Cf. also "For many in Judah were bound by oath to him

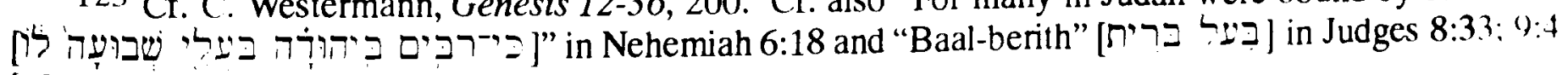
[cf. 9:46].

124 Cf. P. Kalluveettil, op. cit., 12. 
It has often been observed that the author of the "History of David's Rise" (approximately, 1 Samuel 15- 2 Samuel $8^{125}$ ) deliberately parallels and contrasts David's relationship to Jonathan with his relationship to Michal. ${ }^{126}$ Jonathan and Michal were both children of Saul, and David's relationship with both helped to legitimise his claim to the throne. ${ }^{127}$ Likewise, both of them appear to have initiated their relationship with David, with the text stressing to a remarkable degree their "love" for David. ${ }^{28}$ Indeed, David enters into his covenant with Jonathan in 1 Samuel 18:1ff. precisely at the point where the reader expects David to marry a child of Saul, based on the promise of 1 Samuel 17:25 for the champion who would defeat Goliath. Just as this first act of valour appears to have gained Jonathan's affection, a second act of valour would gain the hand of Michal in 1 Samuel 18:25ff.

The vivid contrast between Jonathan and Michal, however, comes into focus in the artistic juxtaposition of their respective attempts to defend David against the murderous intentions of their father Saul in 1 Samuel 19-20. To be noted is the envelope structure of the narrative, also called "an incremental repetition," providing an A-B-A pattern, where the A sections help to interpret the $B$ section, but also where the second A section offers a significant development or resolution over the first A section. ${ }^{129}$ In the first A section, 1 Samuel 19:1-7, Jonathan successfully defends David before his father, who was intent on murdering David. In the B section, 1 Samuel 19:8-17, Michal aides David's escape from her father, but in the end protects herself from Saul's wrath by accusing David of having threatened uxoricide.

While one may be tempted to sympathize with Michal, her false testimony appears to have provided Saul with the requisite circumstantial evidence that David had repudiated his marriage, allowing her to be given to another man. ${ }^{130}$ In addition, her deception appears to have confirmed her father in his estimate of David and further incited him against David -- perhaps accounting for Jonathan's failure to assuage Saul in 1 Samuel 20, in

125 With H. M. Wolf, "The Apology of Hattusilis Compared with Other Political Self-Justifications of the Ancient Near East" (1967).

126 A. Berlin writes, "This comparison cries out to be made" ("Characterization in Biblical Narrative: David's Wives" [1982] 70).

127 See $\$ 6.2 .3 .1$ above, especially footnote 129 .

1 Samuel 18:26 suggests David's own awareness of the potential political implications of his marriage to Michal. His desire to have Michal returned at the point of his accession to the throne at Hebron in 2 Samuel 3:13f. may, in part, have been similarly motivated. Cf. 1 Samuel 18:22f. Cf. J. D. Levenson and B. Halpern, "The Political Import of David's Marriage" (1980) 507-518, and A. Berlin, "Characterization in Biblical Narrative: David's Wives" (1982) 69-85.

128 In the case of Jonathan, cf. 1 Samuel 18:1, 3; 20:17; 2 Samuel 1:26. In the case of Michal, cf. 1 Samuel 18:20, 28 (the Bible almost never mentions the girl's love as a motivation for marriage, but it may do so here in order to highlight this comparison with Jonathan).

129 Cf. the discussion of the A-B-A pattern in 1 Samuel 24-26 offered by R. P. Gordon, "David's Rise and Saul's Demise: Narrative Analogy in 1 Sam. 24-26" (1980) 37-64. The same structure appears in 1 Samuel 13-15.

130 1 Samuel 25:44. Cf. Judges 15:2. 
contrast to his previous success in 1 Samuel 19:1-7. In any case, in 1 Samuel 26:19 David condemns exactly this sort of lie which had fed Saul's implacable enmity. ${ }^{131}$

In the second A section, 1 Samuel 20, Jonathan, in contrast to Michal, risks his life to defend David before his outraged father, but to no avail.

Accordingly, in the end David laments Jonathan in 2 Samuel 1:26: "I am distressed for you, my brother Jonathan; very pleasant have you been to me; your love for me was

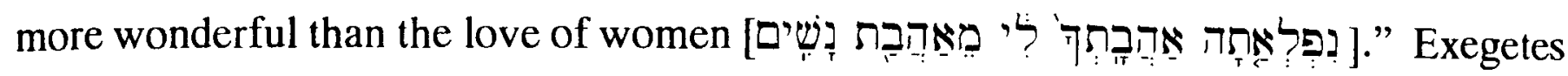
who would find in this eulogy a veiled allusion to homosexuality have missed the point of 1 Samuel 18-20 and the covenant love and loyalty of Jonathan, which did, in fact, surpass that of Michal. 132

In terms of our present purpose, however, it is enough to notice that a text which is so deliberate in drawing such extensive parallels between David's relationship with Jonathan and his marriage to Michal does so precisely by emphasizing that David was in a covenant [ביברית ] with Jonathan (1 Samuel 18:3; 20:8; and 23:18). Indeed, the use of the exchange of clothing in the formation of Jonathan's covenant with David (1 Samuel 18:4) recalls the similar use of clothing in the formation of marriage in Ruth 3:9 and Ezekiel 16:8.

In conclusion, there are texts scattered throughout the Old Testament which like Malachi identify marriage as a covenant, e.g., Hosea 2:18-22 [ET 16-20]; Proverbs 2:17; Ezekiel 16:8, 59, 60, and 62; and 1 Samuel 18-20. This supports our contention that in the Old Testament era marriage was seen as covenantal.

\subsection{The problem of adultery and the claimed indifference of the Old Testament to a man's sexual fidelity}

We now address one final problem with viewing marriage as a covenant, namely the alleged existence of a double standard in Israel whereby a wife had to be exclusively loyal to her husband, while a husband was allowed to indulge in extramarital sex with unattached women without censure. This view has wide scholarly currency.

Ezekiel 16:8 refers to an oath taken by Yahweh, the husband in the marriage metaphor: "When I passed by you again and looked upon you, behold, you were at the age for love; and I spread my skirt over you, and covered your nakedness: yea, I plighted my

131 This justified, but unwitting curse of Michal recalls Saul's earlier unjustified and unwitting curse of Jonathan in 1 Samuel 14:24. 2 Samuel 6:20-23 appears to suggest that Michal's offence at David's dancing before the ark was motivated by her preference for her father to her husband. In vs. 23 , it is significant that she is identified as "Michal, the daughter of Saul," rather than "Michal, the wife of David."

132 Cf. also J. A. Thompson, "The Significance of the Verb Love in the David-Jonathan Narratives in I Samuel" (1974) 334-38; and P. R. Ackroyd, "The Verb Love -- 'âhēb in the David-Jonathan Narritives; A Footnote" (1975) 213-214.

R. P. Gordon suggests that "brother" may also refer to the covenant relationship (cf. 1 Kings 9:13 and Amos 1:9) ( 1 \& 2 Samuel, 212). 


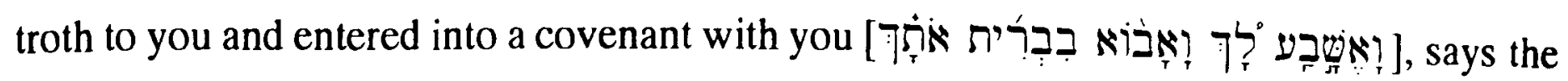
Lord GOD, and you became mine." However, according to J. Milgrom, "it should have been expected of the bride, Israel, for it is the bride, not the husband, who is subject to the laws of adultery."133

It has already been argued that there can be no fundamental objection to a husband binding himself in oath to his wife. Even if one accepts that there is a disparity of status and obligation in marriage which places the wife in an inferior position, the frequently attested analogy of ancient suzerains binding themselves by oath to their weaker partners would appear to offer sufficient support for the arrangement implied in Ezekiel 16:8. 134 Furthermore, when one turns to the more direct evidence of oath taking within the covenant of marriage, such as Genesis 2:23 and the verba solemnia from the Elephantine marriage documents, the evidence is clearest precisely for a verbal oath on the part of the husband and less clear, though still likely, for an oath on the part of the wife.

Milgrom's objection, however, reflects the nearly unanimous view of scholars that within the Old Testament, as well as elsewhere in the ancient Near East, adultery [ [אר] was restricted exclusively to an offence committed against a married man. ${ }^{135}$ To express this in other terms, it would not be "adultery" if a married man had extramarital sex with an unmarried woman. This traditional view, which contrasts radically with modern usage, finds its most explicit support from the two texts which prohibit adultery with a "neighbour's wife," namely Leviticus 20:10 and Jeremiah 29:23. While this may appear to be a rather narrow base on which to construct the prevailing view, at least a dozen other texts reinforce the same point by condemning those who would "covet [חמר]," "lie carnally

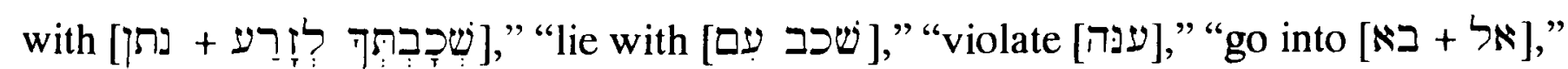

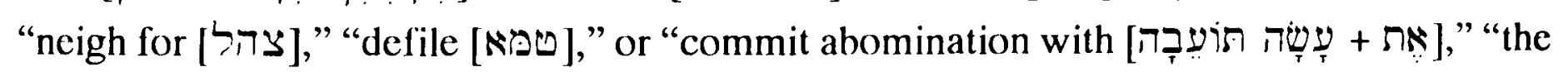
wife of one's neighbour."136 Furthermore, in spite of the presence of seventeen examples where a woman is said to commit adultery [נאר], there is not one indisputable example where the woman involved was clearly unmarried. ${ }^{137}$

In addition to these lexical arguments, B. Stade and others have argued that sexual intercourse by a married man with an unmarried and unbetrothed woman was considered

133 Op. cit., 134.

134 Cf. the example of Abba-AN of Yamkhad and Yarimlim of Alalah discussed in §6.2.3.3.5. For additional examples, cf. P. Kalluveettil, op. cit., 87f., n. 329.

135 Cf., e.g., J. J. Finkelstein, "Sex Offences in Sumerian Laws" (1966) 366, n. 34, and M. T. Roth, “'She will die by the iron dagger': Adultery and Neo-Babylonian Marriage" (1988) 186, n. 1.

T. S. Frymer-Kensky, however, argues that LU $\$ 11$ refers to a case of an accusation of "adultery" against a man ("The Judicial Ordeal in the Ancient Near East" [1977] 145ff.). But other scholars have challenged this interpretation. Cf., e.g., M. T. Roth, “'She will die by the iron dagger': Adultery and NeoBabylonian Marriage" (1988) 194, n. 20.

136 Cf. Exodus 20:17; Leviticus 18:20; Deuteronomy 5:21; 22:22, 24; Job 31:9; Proverbs 6:29; Jeremiah 5:8; Ezekiel 18:6, 11, 15; 22:11; and 33:26.

137 Leviticus 20:10 (1x); Proverbs 30:20; Isaiah 57:3; Jeremiah 3:8, 9; 13:27; Ezekiel 16:32. 38; 23:37 (2x), 43 (? cf. NIV), 45 (2x); Hosea 2:4 [ET 2]; 3:1; 4:13; and 4:14. 
morally inoffensive in the Old Testament, based on Genesis 38 and Judges 16, although it did entail a property violation according to Exodus 22:15f. [ET 16f.]. ${ }^{138}$ Similarly, E. Neufeld writes:

"Hebrew law imposes no restraints on the husband in the sphere of extramarital intercourse, which was not regarded as adulterous. A man cannot sin against his own wife, as his wife has no proprietary rights as against him which he can infringe. Accordingly the adulterous conduct of a Hebrew man must refer exclusively to the case of a man having intercourse with another man's wife or betrothed, the offence being thus interference with that man's property. The husband was under no obligation whatsoever to his wife to refrain from extramarital intercourse, nor had the wife any ground for complaint, at all events as long as he did not deprive her of her necessary maintenance and her right to marital intercourse. This seems to be an implication of Ex. 21,10."139

Drawing out the implication of this understanding of adultery for an interpretation of marriage as a covenant, P. F. Palmer states, "In a society where ... adultery [was considered] a violation of the rights of the Hebrew male,... it would be unreal to speak of Jewish marriage as a covenant either of love or of fidelity."140

In response to this concluding objection to the identification of marriage in the Old Testament as a "covenant," it may be granted that in terms of its linguistic usage (Qal or Piel), the specific term meaning "to commit adultery," and its cognate nominal forms

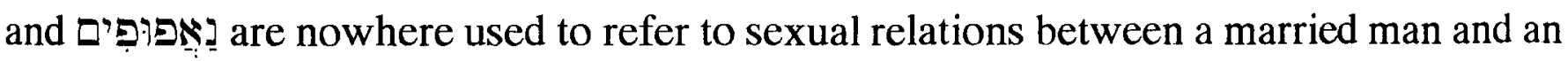
unmarried woman. Likewise, the dozen or so other texts mentioned above, which prohibit extramarital sexual relations without employing נאף, invariably have in mind infidelity involving a married woman.

However, it is also the case that there are no indisputable examples of "adultery [7N:]" being committed by an unmarried man. ${ }^{141}$ As a pragmatic matter, the fact is that is doubtful that there would have been very many persons in the ancient world who would

138 B. Stade, Biblische Theologie des Alten Testaments, I, (1905) 199. Cf. also G. R. Driver and J. C. Miles, The Assyrian Laws (1935) 37ff.; M. Burrows, The Basis of Israelite Marriage (1938) 27; W.

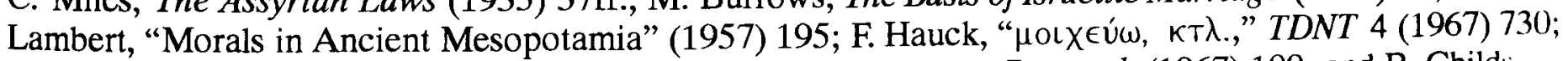
J. J. Stamm and M. E. Andrew, The Ten Commandments in Recent Research (1967) 100; and B. Childs, Exodus, 422.

139 Ancient Hebrew Marriage Laws (1944) 163.

140 P. F. Palmer, "Christian Marriage: Contract or Covenant?" (1972) 621.

The view that a wife was considered the husband's property, and the related theory of marriage by purchase (especially as articulated by P. Koschaker) can no longer be maintained. Cf. \$7.2.1 above.

Emphasizing the mandatory death penalty for adultery in Israelite law when the offenders are caught in flagrante delicto, A. Phillips argues that the concern of the law of adultery was not with protecting a husband's property, because "a wife's position is not to be confused with that of a daughter. By her marriage the wife became an "extension' of the husband himself (Gen. 2:24)..." ("Another Look at Adultery" [1981] 7, citing his earlier work, Ancient Israel's Criminal Law, 117ff.).

141 The hypothetical adultery which was sought by Potiphar's wife with the apparently unmarried Joseph in Genesis 39, does not happen to be termed $7 *:$ and, in any case, was refused by Joseph. 
have been sexually mature and yet unmarried. ${ }^{142}$ Although the Old Testament nowhere explicitly states the typical ages for marriage, the mention of the "age for (sexual) love" in Ezekiel 16:8 may suggest that women generally married soon after puberty. In support of such an assumption, E. M. Yamauchi observes that in Egypt girls were married between the ages of twelve and fourteen, while boys were married between fourteen and twenty. ${ }^{143}$ Likewise, MAL A $\$ 43$ states that a boy had to be ten years of age before he could marry. ${ }^{144}$ Consistent with this picture of an early age for marriage, the Talmud recommends that girls marry at puberty, that is, at twelve or twelve and a half ( $b$. Yebam. $62 \mathrm{~b}$ ), while boys were recommended to marry between fourteen and eighteen. ${ }^{145}$

In addition to this assumption in favour of early marriage in Israel, it appears that sexually nubile but as yet unbetrothed women would have been rendered virtually inaccessible not only by parental or sibling protection, but also by a combination of legal, religious, and cultural sanctions; fear of pregnancy, humiliation, and ostracism for any bastard offspring; etc. ${ }^{146}$ Compare, for example, Amnon's complaint about Tamar in 2 Samuel 13:2-4 and the relatively demanding stratagem that was required even for a halfbrother to be alone with her. Likewise, Tamar's emphatic disinterest in non-marital sexual intimacy, in spite of her apparent affection for Amnon, offers eloquent testimony to the deterring impact of those cultural and religions sanctions on at least one unmarried Israelite woman. If Tamar's views were at all representative, it should not be surprising that there are so few, if any, examples of "adultery" involving an unbetrothed woman.

142 As a result, for example, it is often observed in connection with Jeremiah $16: 2$ that the Old Testament does not even have a word for "bachelor."

143 "Cultural Aspects of Marriage in the Ancient World" (1978) 241-243.

Yamauchi reports that while Greek girls were married as early as twelve, it was more common for them to be between fourteen and twenty, while the boys normally married after their military service, that is, after twenty, and often closer to thirty. On the other hand, in Rome the legal age for marriage for girls was set at twelve at the time of Augustus, and for boys, at fourteen. Cf. also M. K. Hopkins, "The Age of Roman Girls at Marriage" (1964-5) 309-27, and J. L. Blevins, "The Age of Marriage in First-Century Palestine" (1980) 65-7.

144 M. T. Roth suggests that in Neo-Babylonian times girls may have married at about 14 to 20 years of age, while the boys were typically about 26 to 32 ("Age at Marriage and the Household: A Study of NeoBabylonian and Neo-Assyrian Forms" [1987] 715-47).

This pattern of postponed marriage for the men, if it was so, appears to have been due mainly to economic factors, in that most men did not marry until after their fathers' deaths in order to realize their inheritance. Cf. also M. T. Roth, Babylonian Marriage Agreements 7th - 3rd Centuries B.C., 9.

However, Roth's conclusions concerning matrimonial age depend primarily on the indirect evidence of age as reflected in whether or not living parents are mentioned for the bride and for the groom in the extant marriage documents and assumed figures for longevity in ancient Mesopotamia.

145 While the consent of older girls was required, if a girl was under twelve and a half she could not refuse a marriage arranged by her father (b. Qidd. 2b).

From the discussion above, it appears that the modern reader must guard against reading back into the biblical text his cultural assumptions of a large population of "available" sexually active unmarried women. The fact that many of those accused of prostitution in the Old Testament were actually married, tells against such a presupposition.

$146 \mathrm{Cf}$. Genesis 34 and Absalom's concern to avenge the seduction/rape of Tamar.

Widows, who in other respects were perhaps the most legally "empowered" women in the ancient Near East in that they could marry without permission, have acquired wealth, etc., were likewise expected to be sexually chaste. Cf. Judith 8:2-8 and 16:25. Cf. also R. Harris, "Independent Women in Ancient Mesopotamia?" (1989) 147. 


\subsubsection{Conventional androcentricity of legal discourse}

Finally, the fact that a number of biblical texts expressly prohibit or condemn adultery with another man's wife does not necessarily imply that extramarital sex with another woman's husband would have been condoned. Given the conventional androcentricity of all ancient legal discourse, it is often difficult to decide whether the ancients would have construed any particular law as necessarily inapplicable to women (assuming that the appropriate gender changes are made). For example, although the Decalogue is consistently androcentric in its perspective (e.g., Exodus 20:17, "You shall not covet your neighbour's house; you shall not covet your neighbour's wife, etc."; note

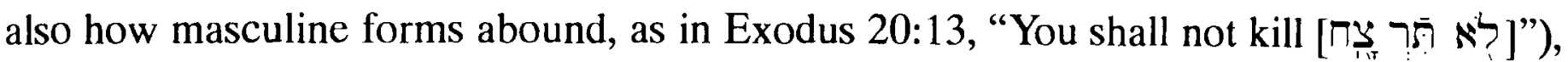
other biblical texts do not hesitate to apply these standards to women. See, for example, Deuteronomy 13:7-10 [ET 6-9] (re. idolatry); Ezekiel 16:38 and 23:44 (re. murder). ${ }^{147}$

It is possible, with A. Phillips, that the Deuteronomic law deliberately extended to women a number of provisions which were previously restricted to men (cf., e.g., Deuteronomy $5: 21 ; 7: 3 ; 13: 6-9 ; 15: 12-17 ; 17: 2-5$; and 22:22). ${ }^{148}$ For example, according to Phillips, the original prohibition against adultery did not include women at all; as a result, originally only the lover was to be put to death (citing Hosea 2:4 [ET 2] and Jeremiah 3:8 in support). ${ }^{149}$ Whether or not Phillips' viewpoint is to be accepted, it appears that the author(s) of the Deuteronomic law and later editors of the Pentateuch did not consider it inconsistent to reinterpret earlier androcentric laws in this manner. One may compare also the example of certain laws, such as Numbers 5:6 and 6:2, which begin "when either a man or a woman...," but proceed to consider only the case involving the man. Seemingly, the

$147 \mathrm{Cf}$. also $\mathrm{CH} \$ 153$ as an example of the criminal liability of a woman for the murder of her husband. Cf. further $\mathrm{CH} \$ 151$, where women are liable for their premarital debts (implying a degree of financial activity for women).

In spite of the fact that women do not enjoy a particularly high status in MA culture (cf. C. Saporetti, The Status of Women in the Middle Assyrian Period [1979]), it is instructive to note that women are liable to the laws against adultery (MAL A $\$ \$ 1,2,7,8,14,15,22,23,24$ ), as well as lesser acts of sexual misconduct (MAL A \$9). Furthermore, they are explicitly prohibited from blasphemy (MAL A $\$ 2$ ), theft of temple property (MAL A $\$ 1$ ), theft of a husband's property (MAL A $\$ \S 3,4$ ), theft of private property (MAL A §5), assault (MAL A \$\$7, 8), murder (MAL A \$10), and magic (MAL A \$47).

On the other hand women can own property, as a widow, and the remarried widow can even acquire her husband's property if he enters her house (MAL A §35)!

Even MAL A \$59, which limits the injuries a husband may inflict on his wife, presupposes there are limits. This law may be compared to MAL A $\$ 44$, which limits the power of a creditor over the person of the debtor. Of interest also is MAL A $\$ 39$, which protects women from cruelty if they are in the hands of their creditors.

Cf. G. R. Driver and J. C. Miles, The Assyrian Laws, 291. Protect the life of a wife with capital punishment in MAL A \$50.

148 Ancient Israel's Criminal Law (1970) 15f., 110f. Cf. also idem, "Some Aspects of Family Law in Pre-Exilic Israel" (1973) 353; idem, "The Decalogue - Ancient Israel's Criminal Law" (1983) 6; and idem,

"The Laws of Slavery: Exodus 21:2-11" (1984) 56.

149 "Some Aspects of Family Law in Pre-Exilic Israel," 353. 
legislator intends the subsequent androcentric case law to apply, with suitable gender modification, to a woman as well.

Cuneiform parallels may help caution against an overly facile assumption that an androcentric law would never be applied to women in actual practice. For example, one will from the vicinity of Emar reads, "I have established my daughter Unara as female and male," and proceeds to grant Unara the right to invoke her father's gods (and perhaps deceased ancestors), apparently involving "a kind of symbolic title to family property." 150 It should be noted that, in contrast to the situation with the daughters of Zelophehad in Numbers 27, Unara is granted this privilege in spite of the fact that the will mentions her three brothers. Another will says, "Now then, my wife Hebate is father and mother of my estate. Now then, I have established my daughter Al-hātĩ as female and male."151 This second will also grants Al-hătī the right to call on her father's gods (and deceased ancestors?) and then proceeds to designate Al-hāti as the heir of her father's entire estate. While household authority and guardianship are normally restricted to fathers and inheritance rights are normally limited to sons, the legal fiction by which a wife is designated a "father" or a daughter is designated a "male" obviously allows these traditional norms to be applied across the gender boundary. 152

In view of these and other similar examples of ancient Near Eastern circumvention of androcentric norms, one cannot assume without further proof that it was a legal innovation for the Jews at Elephantine to permit their women to initiate divorce, in spite of the androcentric wording of Deuteronomy 24:1ff., or for Jesus of Nazareth to speak of men committing adultery against their wives, in spite of the androcentric wording of Leviticus 20:10, etc. ${ }^{153}$

150 J. Huehnergard, "Five Tablets From the Vicinity of Emar" (1983) Text 1, lns. 6-7. Huehnergard suggests a comparison with Rachel's expropriation of the household gods in Genesis 31:34ff. and employs the above quotation from A. E. Draffkorn, "Ilāni/Elohim" (1957) 219 (op. cit., 28).

151 J. Huehnergard, op. cit., Text 2, lns. 5-10.

152 Even if the written law seems relatively indifferent to the concerns of women, it is doubtful that those entrusted with dispensing justice were supposed to be. As noted by W. Lambert, in Mesopotamia justice was designed to aid most those who were without rights ("Morals," 192). Cf., e.g., LU lines 161168, and J. J. Finkelstein, "Laws of Ur-Nammu," 68. estate."

Cf. also J. Huehnergard, op. cit, Text 3, Ins 3-5, where a wife is designated "father and mother of my

Huehnergard also notes the Nuzi custom of adopting a woman so that she could acquire or inherit real estate (op. cit, 27, n. 23). Cf. also Z. Ben-Barak, "Inheritance by Daughters in the Ancient Near East" (1980) 22-33; and K. Grosz, "Daughters Adopted as Sons at Nuzi and Emar" (1987) 81-86.

The main conclusion to be drawn from these examples is that when the need or desire arose, women could, at least on certain occasions, assume the culturally expected roles of men.

$153 \mathrm{Cf}$. Mark 10:11 land parallels in Luke 16:18 and Matthew 19:9], where Jesus asserts that adultery

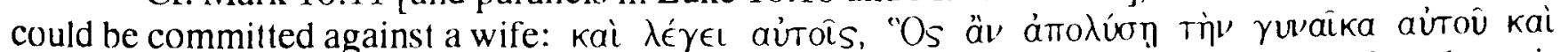

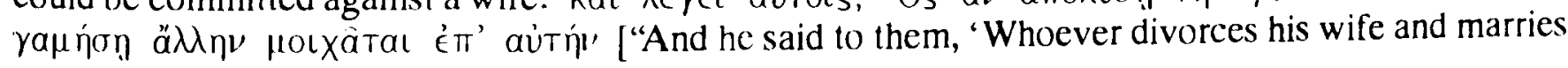
another, commits adultery against her."”]

Admittedly, it is possible to translate ét" aúríl as "with her," i.e., with the second wife, rather than "against her," i.e., against the first wife. However, even on this view, the adultery exists only because it is committed against the first wife. C.,. e.g., C. S. Mann, Mark (1986) 392. 
Of course, the view of B. Stade, E. Neufeld, et al., regarding a husband's extramarital sex would be established if evidence could be found that the Old Testament does in fact approve, or at least disregard, instances of sex between a married man and an unmarried woman. However, on closer inspection the texts cited by Stade and Neufeld prove to be unconvincing.

\subsubsection{Genesis 38}

For example, although Genesis 38 relates Judah's liaison with the disguised Tamar without moral censure -- its interests lay elsewhere -- it hardly endorses prostitution since Judah himself demanded Tamar's execution for her presumed guilt (so Genesis 38:24). E. J. Fisher thinks that "Tamar's penalty must be for adultery, not simple prostitution, since this alone carried the death penalty (Ezk 16:37-40)."154 This is not so clear, however, because according to Deuteronomy 22:22 adultery only carries a death penalty if the couple are caught in flagrante delicto; in addition, it is required that both the guilty parties be executed (cf. also Leviticus 20:10). Neither of these conditions is met in the case in Genesis 38.

Although it is possible that Judah was operating on legal principles other than those articulated within Deuteronomic or Priestly law, Tamar's situation appears to be remarkably consistent with Leviticus 21:9 and especially Deuteronomy 22:13-21.155 Tamar was

Z. W. Falk notes that the Talmud recognizes the principle of the applicability of androcentric laws to women, with appropriate gender changes, even if it is inconsistent in its application (Introduction to Jewish Law of the Second Commonwealth II [1978] 261-263). Accordingly, b. B. Qam. 15a states, "Scripture made women equal to men in regard to every law in the Torah" (cf. also Sipre Numbers 2 and Deuteronomy 190). Hence "women were never forced to sue through a guardian or representative" acc. to Falk. On the other hand, women were prohibited both from bearing witness and from judging ( $m$. Nid. VI 4) and were not liable in tort (m. B. Qam. VIII 4).

On the other hand, certain other texts may seem to be androcentric and perhaps even supportive of a double standard in Old Testament sexual ethics, but on closer examination may prove not to be so. For example, the case of the Śtă in Numbers 5:11-31 may seem to place a higher premium on a wife's sexual fidelity than that of her husband -- after all, where in the Old Testament is there a special ordeal to determine the sexual fidelity of a husband for the sake of his jealous wife? However, such a question almost certainly misunderstands the intention of Numbers 5:11-31. Based on the apparent effect of the ordeal, causing a miscarriage and infertility (cf. 5:22, 27f., though other suggestions include thrombophlebitis, false pregnancy, or dropsy -- cf. G. J. Wenham, Numbers, 84), it seems likely that it was an unexpected pregnancy which prompted the husband's jealousy. If so, what is at issue is not marital harmony so much as paternity. In support of viewing Numbers 5:11ff. as a "paternity rite," cf. A. Phillips, "Another Look at Adultery," 7f. A similar concern for the paternity of an unexpected pregnancy (occurring immediately after marriage) seems to be behind Deuteronomy 22:13-21, a text which has often been misunderstood as

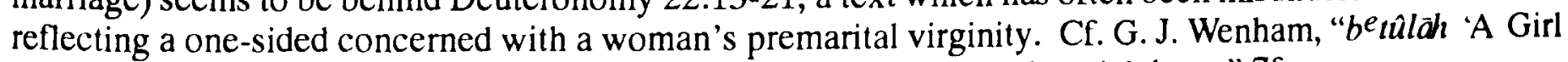
of Marriageable Age"" (1972) 326-48; and A. Phillips, "Another Look at Adultery," 7f.

154 "Cultic Prostitution in the Ancient Near East? A Reassessment" (1976) 232, n. 30.

155 For the recognition that Tamar was being charged not with adultery, but with prostitution / fornication, cf. B. S. Jackson, "Reflections on Biblical Criminal Law," 60, and A. Phillips, "Another Look at Adultery," 24, n. 57. 
dwelling "in her father's house" (Genesis 38:11) at the time of her presumed act of prostitution. Furthermore, she is discovered by her pregnancy. Finally, Judah's right to press for her execution may stem from the fact that Tamar was not only Judah's daughterin-law, she was also promised to Shelah (cf. Genesis 38:11).

In any case, Genesis 38 does not support the notion that a man's philandering was considered morally inoffensive to his wife, or that the only concern was with the aggrieved rights of the cuckolded husband. This is so because the text explicitly states that Judah's wife had died (so Genesis 38:12), presumably in order to stress Judah's personal eligibility and hence $\sin$ in failing to fulfil the obligation of levirate marriage toward his twicewidowed daughter-in-law. ${ }^{156}$ Given that Judah acknowledges in Genesis 38:26 that his own guilt was greater than Tamar's, stressing his fault in driving Tamar to her stratagem, it may be pedantic to insist that the text further condemn Judah specifically for consorting with Tamar, particularly since the "prostitution" in question proved imaginary.

\subsubsection{Judges 16:1-3}

Similarly, the example of Samson's involvement with the prostitute at Gaza, recorded in Judges 16:1-3, fails to sunport the view of B. Stade, E. Neufeld, et al. As in the case of Judah, Judges 15:6 makes clear that Samson was now a widower and so was incapable of committing adultery against his own wife. Furthermore, while it is true that the text reports Samson's relationship with the prostitute of Gaza without moral censure, this negative evidence is at best ambiguous. On a conventional reading, moral censure is implied throughout the Samson narrative. 157 Alternatively, it is possible to interpret Judges 16:1-3 in the light of the often overlooked, but no less impressive literary and thematic parallels which exist between this text and Joshua 2, where the Israelite spies visit Rahab the harlot. ${ }^{158}$ If, as is generally supposed, there was no sexual misconduct on the part of the spies in the latter text, in spite of its titillating language $\left(N_{\tau}+\underset{\tau}{\tau}\right)$, it is possible that the same assumption should obtain for Samson at Gaza.

156 Cf. Deuteronomy 25:5-10 and Ruth 4:1-12. Cf. also MAL A $\$ 30,31,33$ and HL $\S 193$, which agree that the father-in-law is next in line after any brothers to assume the obligation of the levirate.

157 Cf., e.g., L. R. Klein, The Triumph of Irony in the Book of Judges (1987).

158 These parallels within the Deuteronomic History are rooted in the deeper analogy between Joshua, as the successor to Moses, and each of the subsequent judges of Israel, as well as in the on-going task under the judges to complete the conquest of Canaan which had been begun under Joshua. Judges 1:18, when emended with the LXX, asserts that Judah failed to take Gaza, demonstrating the later need for Samson to dispossess these Canaanites/Philistines.

In both texts, Israelites visit an enemy city where, in the nature of the case, the hostile Israelites cannot easily avail themselves of the hospitality of the city elders. This is the case not simply because of their desire to maintain secrecy. It is so because to benefit from the hospitality of the elders, eating together with them, etc., would result in a commitment of friendship that would prohibit their intended imminent attack. $\mathrm{Cf}$. the discussion of the import of shared meals in $\$ 6.2 .3 .3 .3$. Instead, they find a prostitute [ 7 ] with whom they choose to spend part of the night. 


\subsubsection{Exodus 21:7-11}

The appeal to Exodus 21:7-11 as evidence that a husband was under no obligation to refrain from extramarital intercourse, as long as he did not deprive his wife of her necessary maintenance and intercourse, is likewise highly problematic. Even if it supposed, with E. Neufeld, that the third case (21:10-11) requires a wife to accede to her husband's polygyny, so long as he does not "deprive the first one of her food, clothing and marital rights," it is not at all obvious that this stipulation would apply beyond the irregular circumstance envisioned by this law, namely a case where the wife in question was at the same time a slave. Furthermore, the acknowledgment of polygynous marriage under such a special circumstance is hardly to be equated with indifference toward extramarital intercourse.

On the other hand, an alternative interpretation of Exodus 21:7-11 is equally possible, and perhaps preferable. On this view, the text nowhere states or implies that the master had sexual relations with his אָָז. Supported by the careful literary analysis of Exodus 21:2-11 offered by Y. Zakovitch, ${ }^{159}$ this approach considers the antecedent of

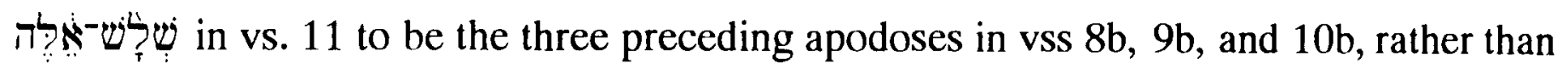
"her food, clothing and marital rights [שְאר

159 Y. Zakovitch, op. cit., as discussed with approval by G. C. Chirichigno, "Debt Slavery in the Ancient Near East and Israel: An Examination of the Biblical Manumission Laws in Exod 21:2-6, 7-11; Deut 15:12-18; Lev. 25:39-54" (1989) 174-175. Cf. also B. S. Jackson, "Some Literary Features of the Mishpatim" (1987) 235-242, as cited by Chirichigno.

Chirichigno summarizes Zakovitch's view (op. cit., 175): "In each law the fourth sub-section ... [here called the "Exception Case"] deals with an exceptional occurrence which does not fit in with the general principle - viz., the male slave chooses to remain with his master rather than going free in the seventh year, and the female slave goes out without payment when her lord does not fulfil his contractual obligations to her (i.e., Exod 21:8-10). Moreover, the fourth section ... of each law forms a chiastic structure with the two general principles in v. $2,7 \ldots$ the male slave goes out free without payment in v. 2 as does the female slave in ... [vs. 11]; the female slave does not go out free in v. 7 as does the male slave who chooses to stay with his master in ... [vss. 5, 6]."

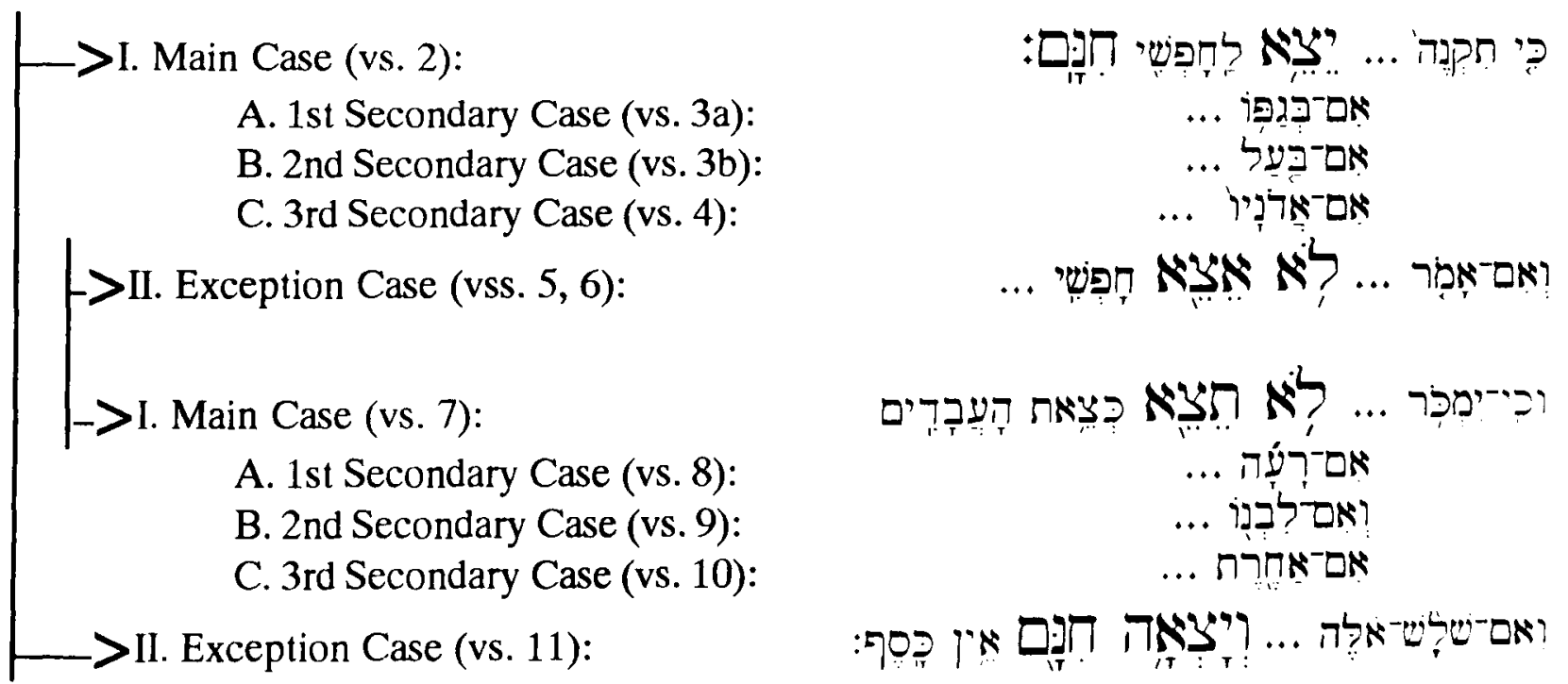

160 So, e.g., Rashi, Ibn Ezra, and Rashbam, with whom A. Cohen agrees (A. Cohen, The Soncino Chumash [1947] 473); I. Mcndelsohn, "Slavery in the OT," IIDB IV, 384, and Y. Zakovitch, 'Ior 17ree ... and for Four': The Pattern for the Numerical Sequence Three - Four in the Bible (Hebrew) (1979), as discussed by G. C. Chirichigno, op. cit., 226. 
considers the rendering "conjugal rights" for alternative suggestions (including "oil" or "shelter") which have been advanced for this hapax legomenon. 161

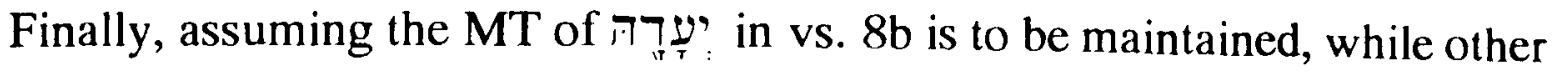
interpretations remain possible, it seems likely that this unusual expression was intended to refer either to betrothal (so the LXX and Vulgate) or to a pre-betrothal arrangement, i.e., a "promise" or "designation" (so Targum Onkelos and Pseudo-Jonathan). ${ }^{162}$ As appears from the second subsidiary case in vs. 9 , in contrast to the Nuzi practice of adoptio in matrimonium, in biblical law, according to S. Paul, "the girl is no longer considered a type of property that can be passed on from one husband to the next."163 As the text makes clear, such a slave was to be treated by the master "according to the rights of daughters

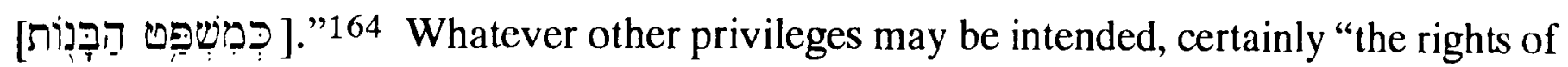
daughters" would prohibit promiscuous relations with the girl on the part of her owner. ${ }^{165}$ As summarized by D. Patrick: "If the man purchases the woman for marriage with his son (vs. 9), he must treat her as a daughter within the household until she is married.

Presumably this means that he is not to have sexual intercourse with her or treat her in a demeaning way."166

Accordingly, if any intended marriage with the female slave in Exodus 21:7-11 had not yet been consummated, as is being suggested here, then contrary to Neufeld, et al., Exodus 21:7-11 can hardly be adduced as evidence that a husband was under no obligation to refrain from extramarital relations. ${ }^{167}$

161 The view that וענתמה is to be rendered "her marital rights" supposes, in general, that this term is

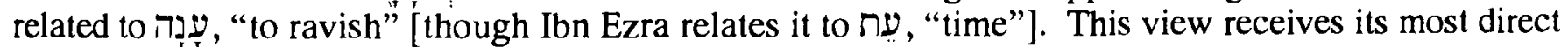

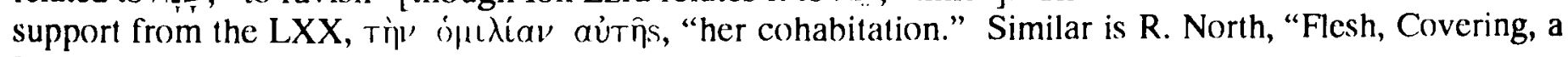
Response, Ex. xxi 10" (1955) 204-6,

A second interpretation of רוֹ has been proposed by S. M. Paul, "Exod. 21:10: a Threefold Maintenance Clause" (1969) 48-53, and idem, Studies in the Book of the Covenant in the Light of

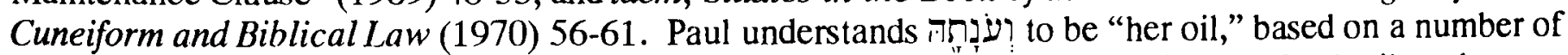
Akkadian (and Sumerian) texts which stereotypically list ipru, piššatu, and lubuštu, "food, oil, and clothing," as the main necessities of life. Although these parallels are attractive, the lists are highly variable (cf., e.g., MAL A. $\$ 36$, Ins. 86-88; Ecclesiastes 9:7-9; etc.), the meaning "oil" is otherwise

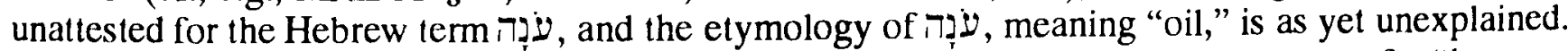

Yet a third alternative, perhaps to be preferred, is offered by U. Cassuto, who argues for "her quarters" or "the conditions of her abode," based on Rashbam's suggested derivation from pמע "refuge, home" (Exodus, 268). See now W. von Soden, "Zum hebräischen Wörterbuch" (1981) $159 \mathrm{f}$.

162 So S. Paul, op. cit., 54, n. 1.

For an analogous distinction in Hittite law between a girl who is "promised," taranza, and one who is "engaged" or "bound," hamenkanza, cf. F. Mezger, "Promised but not engaged" (1944) 28-31.

163 S. Paul, op. cit., 53

$164 \mathrm{~S}$. Paul, op. cit., 5., renders this phrase "as is the practice with free maidens"

165 Cf. Leviticus 18:8, 15 and 20:11,12; Deuteronomy 27:20; Amos 2:7, and Deuteronomy 22:30.

Although the Old Testament does not happen to prohibit in an explicit manner father-daughter incest, such a prohibition was no doubt assumed and is attested in cuneiform law (cf. $\$ 6.2 .1$ above and $\mathrm{CH} \$ \$ 154-156)$.

166 D. Patrick, Old Testament Law, 71.

167 Note that the use of

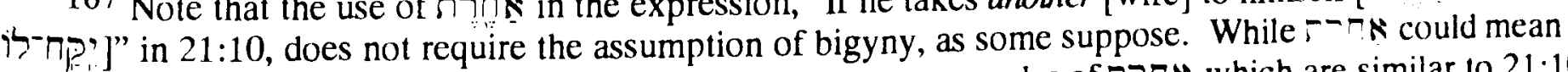
"another," in the sense of an "additional" wife, there are many examples of $N$ which are similar to 21:10 which suggest that it may mean "another" wife in the sense of a "different" wife -- that is, another wife 


\subsubsection{Exodus 22:15-16 [ET 16-17] (and Deuteronomy 22:13-21)}

Likewise, the appeal to Exodus 22:15-16 [ET 16-17] hardly warrants the conclusion that sexual intercourse with an unbetrothed virgin constitutes a mere property violation. To be sure the text requires the payment of a "marriage present [פָהר],, which is

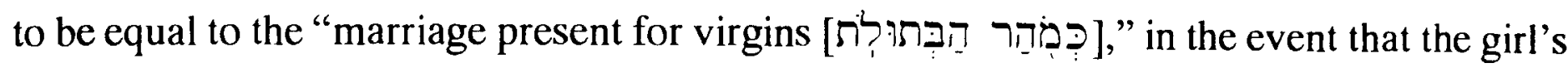
father refuses his permission for the expected marriage. But what should not be overlooked is the more fundamental and normal requirement: "and [he shall] make her his wife."168

Moreover, however one is to interpret Deuteronomy 22:13-21, whether the underlying concern is with a wife's premarital virginity in general, ${ }^{169}$ or whether the concern is more particularly with a honeymoon pregnancy which prompted a question of paternity, ${ }^{170}$ the conclusion leaves little doubt that sexual promiscuity for an unbetrothed woman was no less morally reprehensible than for a married woman: "because she has

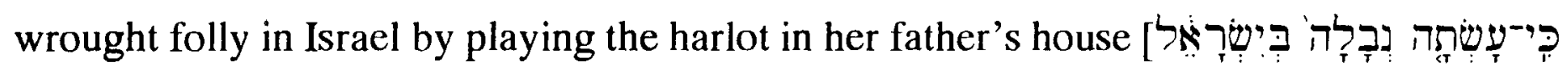

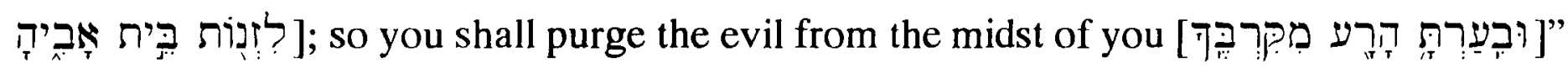
(Deuteronomy 22:21). ${ }^{171}$

\subsubsection{There are no texts which demonstrate that the extramarital sexual activity of men or the sexual activity of unmarried women was a matter of moral indifference}

D. Patrick writes:

"In the realm of extramarital sex, the double standard [where "a woman owed sexual fidelity to one man, but her husband did not owe her the same"] permitted a married man to have sexual intercourse with unattached women. Although prostitution ... was condemned in ancient Israel, it seems to have been tolerated [italics added] .... However, extramarital sexual relations generally, though they were permitted [italics added], were morally condemned."172

instead of the female slave. Cf., e.g., Genesis 29:19; Deuteronomy 24:2; Judges 11:2; Jeremiah 3:1; etc. Cf. also W. C. Kaiser Jr., Old Testament Ethics, $184 \mathrm{f}$.

$168 \mathrm{Cf}$. also the discussion of this text in $\$ 7.2 .2 .2 .5$ above.

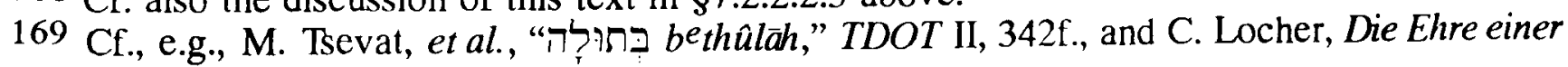
Frau in Israel (1986).

170 Cf. G. J. Wenham, “betûläh 'A Girl of Marriageable Age”" (1972) 326-48.

171 H. G. Reventlow argues that the seduction of an unbetrothed woman was considered "shameful," and hence morally objectionable (Gebot und Predigt im Dekalog, 78f.). Cf. also B. Childs, Exodus, 422.

This text contradicts the assertion of B. Malina regarding the attitudes of both the Old Testament and the New Testament: "in no case is pre-betrothal, non-commercial, non-cultic heterosexual intercourse (what is commonly called ‘fornication' today) prohibited!" ("Does Porneia Mean Fornication?," 15). For a detailed refutation of Malina, cf. J. Jensen, "Does Porneia Mean Fornication? A Critique of Bruce Malina," (1978) $161-84$.

172 Old Testament Law, 55. 
Similarly, P. Bird states that the harlot "was in every period a figure of disrepute and shame (Gen 34.31; Judg 11.1; 1 Kings 22.38; Isa 1.21; Jer 3.3; Ezek 16.30), at best merely ostracized, at worst (in circumstances involving infidelity and defilement) subjected to punishment of death (Gen 38.24; see also Lev 21.9). But the harlot was also tolerated [italics added] in every period by men who incurred no legal penalties - or even censure for the enjoyment of her services (Gen 38.15ff.)."173 S. Niditch and C. V. Camp make similar observations, especially with respect to Judah's treatment of Tamar in Genesis 38 . Rightly objecting to the double standard inherent in Judah's treatment of his supposed harlot daughter-in-law, Camp notes that harlots were "marginally acceptable [italics added]" in Israel, particularly by those desiring their services, but only as long as they were no man's virgin daughter or wife!174

But is it really the case that extramarital relations or prostitution were "tolerated," "permitted," or "acceptable" in Israel? And in what sense are these terms intended when they are qualified by the mention of social and moral condemnation? ${ }^{175}$ Any examination of the evidence is complicated by at least two factors: First, it is necessary to distinguish actual practice and attitudes held by the various members of a society from the views and ideals of its moralists (i.e., in the present case the biblical authors). ${ }^{176}$ Second, there is the further need to distinguish criminal sanction from moral censure and to guard against the modern tendency to assume that the lack of criminal sanction necessarily indicates greater moral tolerance, if not approbation.

\subsubsection{Genesis 38}

In Genesis 38, for example, the "double standard," to which P. Bird, S. Niditch, C. V. Camp, and others object, pertains to what may be inferred of Judah's personal value system. It is doubtful, however, that the narrator shares Judah's viewpoint in this matter;

173 P. Bird, "Images of Women in the Old Testament" (1974) 66f.

174 C. V. Camp, Wisdom and the Feminine in the Book of Proverbs (1985) 112-114, and S. Niditch, "The Wronged Woman Righted: An Analysis of Gen 38" (1979) 147.

175 For an indication of the contempt in which harlots were held, cf., e.g, 1 Kings 22:38; Amos 7:17; and especially the extended harlot metaphor for folly in Proverbs 1-7.

It is notable that even in Mesopotamia, where cult prostitutes and common harlots (ex officio devotees of Ishtar) abounded, it appears that, at least among some thinkers, this practice was not entirely

"acceptable." In the Babylonian Counsels of Wisdom, for example, a man is advised against marrying such a woman: "Do not marry a prostitute, whose husbands are legion, a temple harlot who is dedicated to a god, a courtesan whose favours are many...." W. G. Lambert briefly discusses this text, summarizing, "Here no distinction is made between different species of the kind, but all alike are condemned as unfit for marriage" ("Morals in Ancient Mesopotamia," 195).

176 Cf. the OB document $R A$ 69, 120ff. No. 8 (M. Anbar, "Textes de l'époque babylonienne ancienne" [1975] 109-136). Although Anbar considered the text to concern a husband and wife who agree not to refrain from sexual relations, $R$. Westbrook has argued that the text actually prohibits (by mutual oaths) a married man from engaging in sexual relations with a particular harlot ("The Enforcement of Morals in Mesopotamia" [1984] 753-756)! n. 14. 
the narrative is so thoroughly disapproving of Judah and correspondingly sympathetic toward Tamar.

In addition to Judah's own explicit confession of Tamar's superior righteousness (Genesis 38:26), the narrative offers its own eloquent, if less direct, judgment against Judah through the device of narrative analogy. Twice before her encounter with Judah, Tamar is depicted as a tragic victim of the wickedness of Judah's sons: "But Er, Judah's first-born, was wicked in the sight of the Lord; and the Lord slew him" (Genesis 38:7); "And what he [Onan] did was displeasing in the sight of the Lord, and he slew him also" (Genesis 38:10). The reader cannot fail to see a pattern developing, since Judah himself recognizes it: "Then Judah said to Tamar his daughter-in-law, 'Remain a widow in your father's house, till Shelah my son grows up' -- for he feared that he would die, like his brothers. So Tamar went and dwelt in her father's house" (Genesis 38:11). The irony is, however, that while Judah sought to protect his family from incurring Yahweh's righteous judgment yet once more, his self-serving deception recalls that of his son Onan and establishes Judah himself as the third member in the pattern. Although the reader is prepared for the refrain, "And what Judah did was displeasing in the sight of the Lord, and he slew him also," Tamar, in effect, saves Judah from the full extremity of the wrong he was intending by her deception, itself an ironic reversal and fitting retribution for Judah's earlier deception of Tamar. 177

Finally, reinforcing the implicit moral indictment against Judah, in Genesis 38:2023 Judah secures the help of his friend Hirah to pay his debt to the anonymous harlot (Tamar in disguise), perhaps out of a self-condemning shame. ${ }^{178}$ This sense of shame is made explicit when Hirah returns, having failed his mission, and is instructed by Judah to give up further search and allow the disguised Tamar to keep the valuable pledge left by

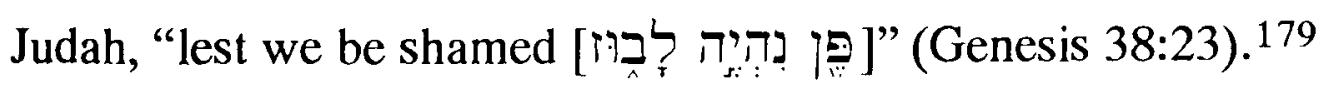

\subsubsection{1 Kings $3: 16-28$}

Another text which is sometimes cited as demonstrating the toleration of prostitution in Israel is 1 Kings 3:16-28. Here it is mentioned in a matter-of-fact manner that it was two

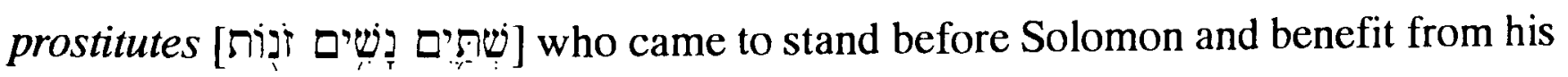
divinely inspired sagacity, as he determined the rightful mother of their surviving baby.

177 "Poetic justice" or ironic reversals of this sort, are a standard narrative device for intimating divine judgment within the Old Testament. Cf., e.g., G. J. Wenham, Numbers, 84.

B. Lang says "Tamar, in the book of Genesis, was able to play the harlot without losing face" (Wisdom and the Book of Proverbs [1986] 98). Such a statement fails to take account of Tamar's extraordinary circumstance as one who had been wronged by Judah's refusal to provide his son Shelah as a husband or personally to assume the responsibility of the levirate.

178 Cf. A. Brenner, The Israelite Woman (1985) 82.

179 So the AV. The RSV "be laughed at" should not be misconstrued as if it merely implied the fear of a mild social embarrassment. Elsewhere $n \geq$ (cf. its probable by-form, 7 ) connotes notions of shame, disgrace, disdain, and contempt. Cf., e.g, M. Görg, "ה בָ 
Perhaps to the reader's surprise, nowhere does Solomon even question their livelihood, much less demand the exaction of any criminal penalty for their prostitution.

Such negative evidence, however, must be treated with particular caution in a text like this since it is clear that the interest of the narrator is almost exclusively directed toward the goal of exalting Solomon. For example, it has been noted that the two prostitutes are so insignificant as persons that "their names are not important enough to be preserved, stated, or invented."180 Perhaps more to the point, it is possible that their occupation as harlots is mentioned precisely in order to stress not their guilt, but the gracious condescension of this "wise king [who] would act on behalf of the very lowest of his subjects."181 Furthermore, the absence in the text of any criminal sanction or, especially, any moral censure against prostitution may be no more significant than the corresponding absence of any such sanction or censure against kidnapping, deceit, or perjury, all of which are committed in the same episode. Yet no scholar has suggested that kidnapping or perjury was "tolerated" in Israel.

Nevertheless, it is possible that the fact that these two prostitutes lived alone (stressed in 1 Kings 3:17f.), rather than in their father's house (cf. Genesis 38:11, 24; Leviticus 21:9 and Deuteronomy 22:21), or under a husband's authority (in which case their harlotry would constitute adultery as well -- cf. Ezekiel 16), may have been an extenuating circumstance which allowed their prostitution to be free from criminal sanction. In the ancient world the lack of such a male patron or protector was likely to render a woman especially vulnerable to the sexual advances of unprincipled men and, at the same time, place her in considerable financial hardship. ${ }^{182}$ It is possible that the criminal law and probable that moral law (or at least, public opinion) took into account such mitigating factors. 183

\subsubsection{There are no texts which demonstrate that the non-cultic, non- commercial sexual activity of unmarried women was a matter of moral indifference}

B. Malina asserts that, apart from ritualistic sexual acts and prostitution, the willing sexual acts of an unmarried woman were viewed with moral indifference in the Old

180 A. Brenner, op. cit., 81.

181 S. J. DeVries, 1 Kings, 61. With similar import, cf. the characterization of Jesus as a "friend of ... 'sinners"” (Matthew 11:19).

182 A similar awareness of the vulnerability of women when alone (in the open country, rather than in the city where cries for help could be heard), radically affects the law of adultery with betrothed women in Deuteronomy 22:23-27.

183 Proverbs 6:30 may support supposition that public opinion, if not moral norms, can take such factors into account: "Men do not despise a thief if he stole to satisfy his soul when he is hungry...."

Proverbs 7:14, 20 may provide more direct confirmation that financial destitution could be a mitigating factor in judging prostitution, if the interpretation of $\mathrm{K}$. van der Toorn is accepted ("Female Prostitution in Payment of Vows in Ancient Israel," 199). Cf. also b. Ketub. 44b which suggests that the penalty prescribed in Deuteronomy 22:21 could be waived in the case of an orphan. 
Testament. ${ }^{184}$ However, as we have observed, the evidence simply does not support such a claim. In actuality, the fact that only three Old Testament examples exist for consideration (i.e., Genesis 34, Genesis 38, and 2 Samuel 13) may reflect the rarity of such acts in the ancient world. We have already considered each of these texts above (cf. \$7.2.2.2 and §8.3.2); none of them appears to support Malina's contention. Specifically, it should be noted that both Shechem's relationship with Dinah in Genesis 34 and Amnon's forcible seduction of Tamar in 2 Samuel 13 are condemned in the strongest possible manner by the term נִבְרָ, a term which significantly reappears in Deuteronomy 22:21, a text which is also concerned with a woman's premarital sexual activity. 185 Dinah's brothers make clear their negative view of "premarital sex," even though Shechem loved Dinah (Genesis 34:3) and sought to remedy his offence with an earnest appeal for marriage. After killing Hamor, Shechem, and the men of Shechem because of Shechem's act, they justified their brutality

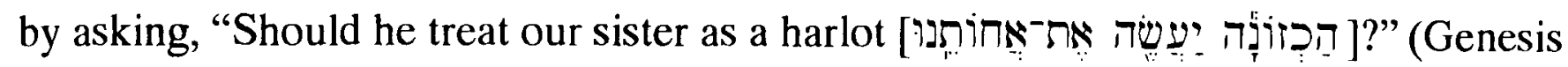
$34: 31) .{ }^{186}$

The key legal texts (e.g., Exodus 21:7-11; 22:15-16 [ET 16-17]; Leviticus 19:2022 ; Deuteronomy $21: 10-14 ; 22: 13-21 ; 22: 28-29$ ) have been discussed previously and, similarly, were found nowhere to suggest an indifference to the sexual acts of unmarried women. Far from any such indifference, Exodus 22:15-16 [ET 16-17] and Deuteronomy 22:28-29 require a marriage proposal to follow any act of "premarital sex." Failing this marital remedy, it is notable that Deuteronomy 22:21 recalls the objection of Dinah's brothers in Genesis 34:31 by describing what may have been a single act of noncommercial sex with an unmarried girl as "prostitution" [זנה ], as well as "grievous folly"

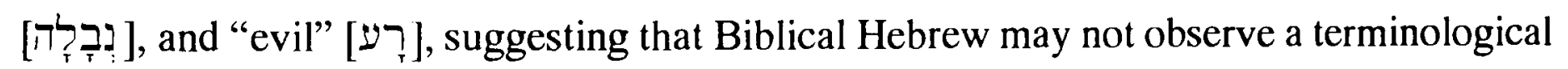
distinction between prostitution and fornication. 187

\subsubsection{Texts which encourage a husband's sexual fidelity regardless of the married state of the mistress}

The modern categorical distinction between "illegal" and "immoral" does not apply so easily to biblical practice, where criminal and moral norms were so thoroughly and deliberately intertwined. For example, A. Phillips notes that within the Covenant Code criminal and civil norms "which carry specific penalties to be enforced by the courts" (Exodus 21:12-22:19 [ET 20]) are juxtaposed with "humanitarian and cultic injunctions

184 "Does Porneia Mean Fornication?," 11, n. 2 and p. 15.

185 The traditional English rendering of נִבר as as "folly" cannot adequately convey the horror evoked by words or actions which are so termed in Hebrew and which are so regularly met with a death penalty (whether threatened or exacted by the wrath of God, or by human courts). Cf. A. Phillips, "Nebalah - a term for serious disorderly and unruly conduct" (1975) 237-42.

186 Notable is the fact that the brothers do not objecl to Shechem because he was an uncircumcised outsider. Cf. J. Jensen, "Does Porneia Mean Fornication? A Critique of Bruce Malina," 168.

187 Cf. J. Jensen, op. cit., 166. 
which envisage no legal action for their breach and specify no penalties" (22:20 [ET 21]23:19). ${ }^{188}$ Although this second category of "law" depends on religious sanctions and moral suasion, rather than the threat of criminal sanction for its observance, it is no less obligatory and no less crucial for the proper functioning of the community of Israel.

The Decalogue itself offers a similar example of apodictic law which, at least in its present form, includes unenforceable injunctions alongside criminal norms. Even in the case of a particular criminal law, such as the prohibition of adultery, the fact that adultery is punishable with death only when the couple is caught in flagrante delicto cannot be construed as implying that under other circumstances adultery would be "approved" or even "tolerated."189

\section{Whatever legal apparatus there may have been to enforce a husband's sexual} fidelity, it is clear that a moral obligation of sexual fidelity applied to the husband no less than to the wife -- even where the extramarital relations would be with an unmarried woman. ${ }^{190}$ This is the case even in Mesopotamian practice. ${ }^{191} \mathrm{~K}$. van der Toorn, for

188 “The Law of Slavery," 52.

189 Given the limitations of the present study, it not possible to consider in more detail the problematic evidence concerning the penal sanctions which attach to adultery (cf., e.g., Proverbs 6:34f.) and their possible historical development or to enter into the larger debate concerning the claim that Old Testament law (at least, at some stage) was characterized by radically different principles from those presupposed in ancient Near Eastern law elsewhere. Specifically, it is claimed that while ancient Near Eastern law considered adultery to be an offence against the husband, who was consequently authorized to determine the punishment of his wife (with the law requiring equal treatment for the lover), biblical law considered adultery as a sin against God and in every case where the couple was caught in flagrante delicto demanded the exaction of the death penalty, denying to the husband any prerogative to commute the execution. This claim does not deny that other ancient Near Eastern societies likewise considered adultery as a sin against the deity. It merely asserts that this moral conviction did not inform their legal practice with the same consistency as is attested in the Bible.

Those who reject the radical distinctiveness of Old Testament law, especially regarding adultery, include S. E. Loewenstamm, "The Laws of Adultery and Murder in Biblical and Mesopotamian Law" (1980 [originally published in Hebrew in 1962]) 146-53; idem, "The Laws of Adultery and Murder in the Bible. A reply to M. Weinfeld" (1980) 171-172; B. S. Jackson, “Reflections on Biblical Criminal Law" (1973) 8-38; H. McKeating, "Sanctions against Adultery in Ancient Israelite Society, with Some Reflections on Methodology in the Study of Old Testament Ethics" (1979) 57-72; idem, "A Response to Dr Phillips" (1981) 25-26; and J. W. Welch, "Reflections on Postulates: Power and Ancient Laws - A Response to Moshe Greenberg" (1990) 113-119.

Those who support a radical distinctiveness for Old Testament law, particularly regarding adultery, include M. Greenberg, "Some Postulates of Biblical Criminal Law" (1960) 5-28; idem, "Crimes and Punishments" in IDB, I, 737b; idem, "More Reflections on Biblical Criminal Law" (1986); idem, "Reply to the Comments of John Welch" (1990) 120-125; S. M. Paul, Studies in the Book of the Covenant in the Light of Cuneiform and Biblical Law (1970); A. Phillips, Ancient Israel's Criminal Law: A New Approach to the Decalogue (1970); idem, "Another Look at Adultery" (1981) 3-25; idem, "A Response to Dr. McKeating (JSOT 20 [1981] 25-26)" (1981) 142-143; idem, "The Decalogue - Ancient Israel's Criminal Law" (1983) 1-20; and H. J. Boecker, Law and the Administration of Justice in the Old Testament and Ancient East (1980) 113.

Cf. also M. T. Roth, “' She will die by the iron dagger': Adultery and Neo-Babylonian Marriage" (1988) 186-206. Cf. further LU \$4; LE §28; CH §129; MAL A \$13, 14, 15, 16, 23; and HL \$\$197, 198.

190 With respect to the claim that "sexual relations between a man and an unmarried woman are taken up only in the case of rape or seduction of a virgin, where it is a civil, not moral crime," J. Jensen writes, "Such views are frequently expressed, but they do not appear to rest on a full consideration of the Old Testament cvidence. Somc of Israel's laws can lead to a different conclusion; and there are further indications in the historical and wisdom traditions" (op. cit., 165).

$191 \mathrm{Cf}$. footnote 176 above. 
example, mentions the Myth of the Guilty Slave Girl, where "The goddess Inanna accuses the girl Amanamtagga, 'The-guilty-one', of having learned coitus and kissing from Dumuzi, her husband." Although the text nowhere hints of a legal charge against her husband of adultery with this single girl, nevertheless, "the act is referred to as an ikkibu (ÈM.GIG), a 'taboo'."192 Other texts likewise stress the taboo violation or defilement which comes from sexual promiscuity. To these examples, Van der Toorn adds a reference to Babylonian behavioural omens which stress the detrimental effects of illicit sexual intercourse. Compare, for example, "If he is a fornicator (na' 'ik): what he owns will decrease, he will become poor."193

Turning to the biblical data, perhaps the clearest examples of texts which appear to discourage sexual promiscuity on the part of husbands, even when it is committed with unmarried lovers, are: 1 Samuel 2:22 (the least clear example); Job 31:1; Hosea 4:14; and especially, Proverbs 5.194

\subsubsection{1 Samuel 2:22}

1 Samuel 2:22 records how Eli heard that his (married) sons “... lay with the

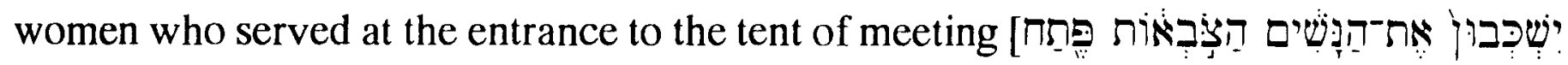

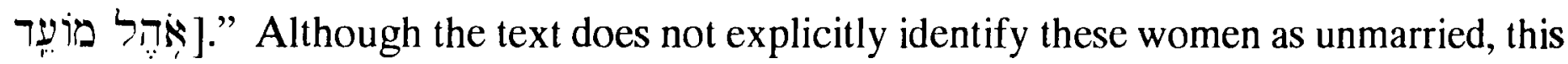
inference seems likely. First of all, husbands are nowhere mentioned or alluded to in the context. This omission would be particularly surprising, if the women had been married, given the sexual nature of the offence. Second, the term "adultery" [ נא ] nowhere appears. Third, when Eli reproves his sons, he says, "If a man sins against a man, God"195 will mediate for him; but if a man sins against the LORD, who can intercede for him?" (1 Samuel 2:25). This statement may imply that Hophni and Phinehas had sinned only against God, not man, and so it may be surmised there were no offended husbands. ${ }^{196}$ Finally, if the ministry of these women was modelled on that of Miriam, assuming Miriam was unmarried, as appears to have been the case, this status may have been required of all such women. ${ }^{197}$

192 Op. cit., $17 \mathrm{f}$.

193 CT 51, 147, Rev. 21, as cited by K. van der Toorn, op. cit., 161, n. 80.

194 Since harlots were so frequently married, texts which condemn their use are less clear since they may merely reflect a condemnation of adultery. Cf., e.g., Jeremiah 5:7 and Ezekiel 24:44, if emended with the LXX.

195 "God" is understood by J. G. Baldwin as a possible reference to the "judges" (cf. Exodus 21:6; 22:8-9) ( 1 and 2 Samuel, 61).

1962 Samuel 12:13 and Psalm 51:5 [ET 4] could be considered counter examples for this inference.

$197 \mathrm{Cr}$. Exodus 38:8 and the possibly relevant evidence of the concept of unmarried women being "married" to the deity attested elsewhere in the ancient Near East as well as in the New Testament (Luke 2:36; 1 Timothy 5:11). As R. Harris points out, when a nadt tum entered a cloister, it was considered analogous to marriage ("The Naditu Woman" ([1964] 105-135). For this reason a biblum was given. Cf. also R. Westbrook, “Old Babylonian Marriage Law,” II, 304. 
While Israel's complaint and the threatened divine judgment against Hophni and Phinehas for their promiscuity may offer an example of a text which disapproves sexual promiscuity with unmarried women, there are a number of difficulties with this text which diminish its utility.

First, whatever the precise character of Hophni and Phinehas's offence, the exclusive interest of the text seems to be in condemning this wrong as an abuse of their priestly office, not as an offence against their marriages.

Second, the clause, "and how they lay with the women who served at the entrance to the tent of meeting," is missing from two key witnesses, $4 \mathrm{QSam}^{\mathrm{a}}$ and $\mathrm{LXX}^{\mathrm{B}}$. Accordingly, P. K. McCarter Jr. and R. W. Klein, for example, argue that it should be excised as a gloss from Exodus 38:8, inspired by a perceived link between the present situation and the Baal of Peor incident in Numbers 25:6-15.198 In support of the MT, however, the postulated connection with Numbers 25:6-15 is not so strong as alleged. Further, it is notable that the MT is supported by $\mathrm{LXX}^{\mathrm{L}}$ and Josephus, Antiquities 5.339; accordingly, it is possible that the omission in $4 \mathrm{QSam}^{\mathrm{a}}$ and $\mathrm{LXX}^{\mathrm{B}}$ was merely the result of homoioarchton. 199

Finally, although it seems likely that these women are the same as those mentioned in Exodus 38:8 where צבא also appears, there has been no scholarly consensus regarding the precise identity or function of these women. H. W. Hertzberg, for example, suggests that they "have the task of keeping the entrance clean; this was particularly important for what took place in the sanctuary."200 J. P. Hyatt makes a similar suggestion, adding the possibility that they also repaired the tabernacle. ${ }^{201}$ Alternatively, Hyatt and others have wondered if they may have ministered by dancing and singing (perhaps following Miriam's example in Exodus 15:20), or if they may have functioned as prostitutes (which, perhaps, would account for their wealth). ${ }^{202}$

The suggestion of cultic prostitution in either Exodus 38:8 or 1 Samuel 2:22, however, seems unlikely. This is especially the case in Exodus 38:8, which explains that Bezalel made the copper laver and its pedestal "from the mirrors of the ministering women who ministered at the door of the tent of meeting." As J. I. Durham notes, "it is not likely that a reference associating the Laver with anything so antithetical to the P concept of cultic acceptability as cultic prostitution would have been included without some such explanation

198 P. K. McCarter Jr., 1 Samuel (1980) 81, and R. W. Klein, 1 Samuel (1983) 22.

Taking the opposite view, J. P. Hyatt argues that Exodus 38:8 is a gloss deriving from 1 Samuel 2:22 (Exodus [1971] 330).

F. M. Cross Jr. compares the mention of "male cult prostitutes" in "houses" which "were in the house of the LORD, where the women wove hangings for the Asherah" in 2 Kings 23:7 (Canaanite Myth and Hebrew Epic [1973] 201-203).

199 Cf. also R. P Gordon, 1 \& 2 Samuel, 83.

200 I and II Samuel (1964) 36.

201 Exodus (1971) 330.

202 Cf. G. H. Davies, Exodus (1967) 251, and R. A. Cole, Exodus (1973) 236. Cf. also Judges $11: 34 ; 21: 21$; and 1 Samuel 18:6. 
as that given in Num 17:1-5 [16:36-40], regarding the use upon the altar of the copper of the censers of Korah's company of rebels."203 In any case, since צבא is also employed to describe the service of the Levites (Numbers $4: 23 ; 8: 24$ ), there is no need to assume a different sort of ministry for these women in either Exodus 38:8 or 1 Samuel 2:22. 204 Moreover, the mention in 1 Samuel 2:22 of the service of the women "at the entrance of the tent of meeting" seems calculated to render Hophni and Phinehas all the more culpable for their offence, in a manner which was analogous to the priest's abuse of the offerings of the worshippers in vss. 13-17.205 Further, the ability and willingness of Hophni and Phinehas to resort to force to commit their offence against the offerings mentioned in 1 Samuel 2:16 allow the possibility that they may have used similar force to have their way with these women. If so, this was not cultic prostitution for which the women would have to have willingly offered themselves.

\subsubsection{Job 31:1}

Job 31:1 reads, "I have made a covenant with my eyes; how then could I look upon

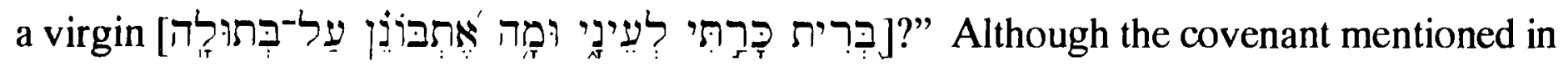
this verse is clearly figurative and does not refer to the marriage covenant itself, the verse is revealing for the manner in which it extends the ethic of the tenth commandment (cf. Proverbs 6:25). Whereas Exodus 20:17 and Deuteronomy 5:21 prohibit coveting "your

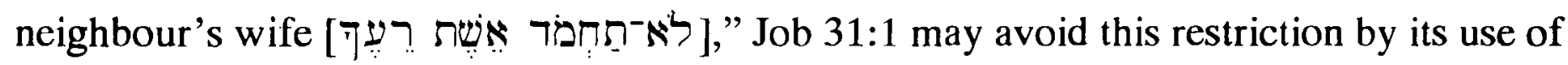
בְּתוּלָה term which refers mainly, though perhaps not exclusively, to unmarried women.206

Some scholars, however, have suggested that בְּתוּל or "the Queen of Heaven." 207 On this view Job 31:1 constitutes a disavowal of idolatry, a

203 Exodus, 488.

204 Cf. J. G. Baldwin, 1 and 2 Samuel (1988) 60.

R. P. Gordon identifies these women as "female ancillary staff who performed menial duties in the premonarchical sanctuaries" ( $1 \& 2$ Samuel, 83$)$. Though Gordon is cautious to avoid a more precise job צבא elsewhere.

205 So, e.g., H. W. Hertzberg, 1 \& 2 Samuel, 36, and R. A. Cole, Exodus, 236.

206 Cf. G. J. Wenham, "betaläh 'A Girl of Marriageable Age"” (1972) 326-48. Wenham, however, suggests that in the case of Job 31:1 the reference of בּתחוּלָה is to betrothed or married women exclusively (op. cit., 345f.).

Apart from the uncertain case of Job 31:1, it is remarkable that among its fifty biblical occurrences the ברתוּלדה is employed in order to refer to a woman whose marriage was not yet consummated. Cf., e.g., H.W. Wolff, Joel and Amos, 29-31, and D. Stuart, Hosea - Jonah, 243. Cf. also Deuteronomy 20:7.

207 Cf., e.g, M. H. Pope, Job (1973) 228; A. R. Ceresko, Job 29-31 in the Light of Northwest

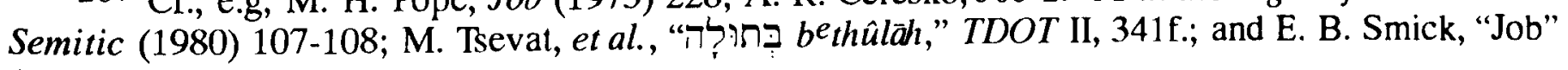
(1988) $992 f$.

Against this interpretation, cf. M. H. Pope, Job, 228f. (Pope, however, prefers Peake's unwarranted

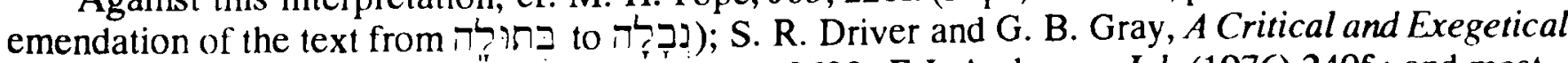
Commentary on the Book of Job (2nd ed., 1950) 262f.; F. I. Andersen, Job (1976) 240f.; and most recently, N. C. Habel, The Book of Job (1985) $431 \mathrm{f}$. 
theme which is resumed in Job 31:26f. The main advantage of this view is the conviction that only idolatry would be of sufficient gravity to account for why this offence was chosen to head the list of the disavowed sins which comprise chapter 31.208

However, the more obvious reference to sexual purity may not be so out of place in Job 31:1.209 For example, there a possible inclusio between Job's eyes in vs. 1 and God's all-seeing vision in vs. 4 . Furthermore, from the wider context it is apparent that Job recognizes that God's righteous judgment takes into account not merely overt acts, such as adultery, but also the thoughts and intentions of the heart, such as the posited lust in vs. 1 . Compare, for example, Job's disavowal that he has rejoiced at his wealth (vs. 25) or gloated at the ruin of his enemies (vs. 29 -- cf. Proverbs 24:17). Indeed, as R. Gordis has argued, the stress throughout Job 31 is on the fact that Job has adhered to a standard of piety that goes well beyond such palpable crimes as murder, theft, etc. ${ }^{210}$ Here are almost exclusively clandestine sins of the spirit representing a level of piety consistent with the earlier reference in Job 1:5, where Job offered burnt offerings for his sons in case they had "cursed God in their hearts."211

M. Tsevat argues against the traditional reference to lust in vs. 1, claiming that this interpretation renders vss. 9-12 superfluous. ${ }^{212}$ However, the precise sin disavowed in vss. 9-12 involves overt adultery with a neighbour's wife, not merely lust for a normally unmarried בְִּתוּ 213

On the other hand, problematic for the proposed reference to idolatry in vs. 1 is the fact that while "Virgin "Anath" [btlt ' $n t]$ is a well-known epithet from the Ugaritic texts, nowhere is "Anath referred to simply as the "virgin" [btlt = בְּתוּל ב? ], as is required for Job 31:1. Furthermore, as N. C. Habel notes, "in the pre-Israelite world of the patriarchal heroes where the poet has located Job, a direct allusion to 'Anath as the rival of Yahweh would be anachronistic."214

Though not interacting with this suggestion, in support of the traditional interpretation, cf. further E. Dhorme, A Commentary on the Book of Job (1984) 450; R. Gordis, The Book of Job (1978) 344f. and 542f.; and J. E. Hartley, The Book of Job (1988) 409.

208 Cf. E. B. Smick, op. cit., 992.

209 Cf., e.g., the $N A B$, which rearranges Job 31, placing vs. 1 with vs. 9 . In defence of this rearrangement of the text, cf. P. W. Skehan, Studies in Israelite Poetry and Wisdom (1971) 116-120. However, as noted by M. H. Pope, this proposal founders on the self-evident need for an introduction to vss. 2-4 (Job, 228). Moreover, as argued by E. B. Smick, the present arrangement offers a semantic inclusio by which Job's eyes in vs. 1 find a parallel in the mention of God's vision in vs. 4 (op. cit., 992). Finally, as noted by R. Gordis, the proposed rearrangement destroys the present double heptad structure of fourteen possible offences (The Book of Job, 345).

210 The Book of Job, 344f. and 542f. Only adultery appears as an exception, but it is included because it too, in general, is carried on secretively. Cf. also J. E. Hartley, The Book of Job, 407.

211 So noted by N. C. Habel, The Book of Job, 431.

212 M. Tsevat, et al., "הלְ̦

213 Similarly, R. Gordis observes, "the sharp distinction in Semitic and biblical law between the status of a virgin and that of a married woman rules out the combining of these two themes on substantive grounds as well" (The Book of Job, 345).

214 N. Habel, The Book of Job, $431 \mathrm{f}$. 
Finally, Sirach 9:5 offers a supportive parallel for the traditional interpretation of Job 31:1, from which it may well derive: "At a virgin do not look [בבתולה אל תתבונן], lest you be trapped into sin with her."215 M. Tsevat is unimpressed with this comparison, arguing that "it may be foolish to look upon an (unmarried) maiden (this is the meaning of the quotation of this passage in Sir. 9:5, an item in a catalogue of women), but it is not sinful (Job 31:3)."216 However, Tsevat's objection fails to be persuasive because it assumes precisely what it needs to prove.

\subsubsection{Hosea $4: 14$}

Although D. Patrick considers that a "double standard" obtains elsewhere in the Old Testament, where a husband was under no obligation to sexual fidelity, he notes that "the prophet Hosea goes so far as to remove the double standard in an ironic twist: 'I will not

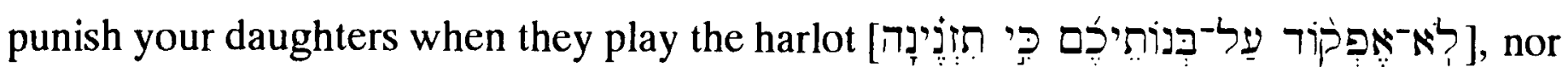
your brides when they commit adultery; for the men themselves go aside with harlots, and sacrifice with cult prostitutes, and a people without understanding shall come to ruin' (4:14). ${ }^{217}$ The fathers and husbands would like God to punish their wayward women, but God will not because it is they who corrupt them." In a similar manner, D. Kidner contrasts Judah's hypocritical readiness to execute Tamar with Hosea 4:14 and states of the Hosea text that it "is in fact a landmark in moral history by its refusal to treat a man's sexual sins more leniently than a woman's."218

A number of scholars, however, have questioned this interpretation of Hosea 4:14.219 F. I. Andersen and D. N. Freedman, for example, consider it "inconceivable that the women could be exculpated, even if the men were primarily responsible." 220 As a result, they propose interpreting 14 a either as a rhetorical question, "shall I not punish...?" (restoring an initial interrogative $\mathrm{T}$, lost by haplography), or as a positive assertion (with the $\boldsymbol{k}$ probably to be understood as an asseverative particle or perhaps to be corrected to

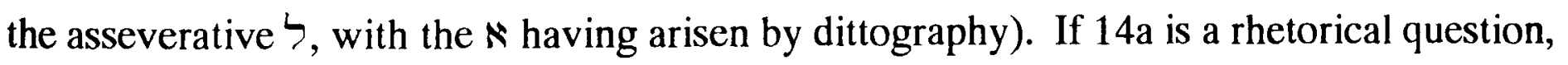
Hosea 4:14 still opposes a double standard by insisting on the punishment of the guilty men (14b) as well as the guilty women (14a). ${ }^{221}$ On the asseverative view of Andersen and

215 As rendered by M. Pope from the Hebrew text of the Cairo Genizah (Job, 228).

On Sirach's dependency on Job 31:1, cf. R. Gordis, The Book of Job, 344; and P. W. Skehan and A. A. Di Lella, The Wisdom of Ben Sira (1987) 219.

216 M. Tsevat, et al., "דּ כִ bethûlăh," TDOT II, 341.

217 Old Testament Law, 55, quoting from the RSV.

218 Love to the Loveless. The Message of Hosea (1981) 53.

219 In support of the traditional rendering, cf., e.g., W. R. Harper, $A$ Critical and Exegetical Commentary on Amos and Hosea (1905) 261; J. L. Mays, Hosea (1969) 75f.; and H. W. Wolff, Hasea (1974) 87-89.

220 F. I. Andersen and D. N. Freedman, Hosea, 369. D. Stuart similarly wonders, "How would God punish 'land' and 'people' yet exempt the women?" (Hosea -Jonah, 83).

221 Cf. D. Stuart, Hasea - Jonah, 71, 83f. On Stuart's view, most of the occurrences of הנ in Hosea are metaphoric, particularly when referring to Gomer. Against this cf., e.g., I. H. Eybers, who objects that 
Freedman, however, vss. 13a-14a form a parenthesis, with vs. $14 \mathrm{~b}$ resuming the discourse about the priests which ended in vs. $12 \mathrm{~b}$. With vss. 13a-14a thus isolated, it is no longer so clear that the punishment of the guilty male priests in vs. $14 \mathrm{~b}$ corresponds to the punishment threatened against the harlotrous women.

However, Andersen and Freedman's proposal is problematic: It obliterates the frequently observed parallelism between vss. 13 and $14 .{ }^{222}$ Furthermore, there is little evidence for the posited parenthetical character of vss. 13a-14a, and the proposal to emend

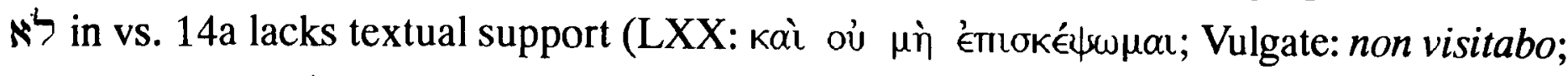

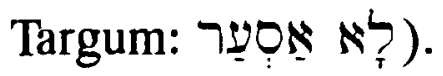

Finally, it should be noted that an allusion in vs. 14 to the disputed practice of ius primae noctis is possible, but unnecessary. ${ }^{223}$ It is perhaps more likely that the prophet is condemning a widespread and quite general state of sexual immorality, fostered, to be sure,

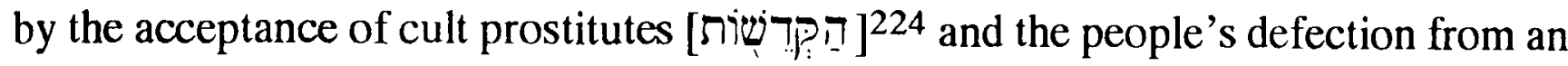
orthodox faith in Yahweh.

\subsubsection{Proverbs 5:15-23}

Although a text such as Proverbs 6:24-35 "admonishes the married man not to have intercourse with a harlot," 225 since the harlot is depicted as married, it is possible, though perhaps doubtful, that this text is concerned merely to prohibit adultery against her cuckolded husband or to warn about the dire consequences of being caught.

Proverbs 5:15-23, on the other hand, is indisputably concerned to promote a husband's fidelity to his own wife, regardless of the married state of any potential lovers. ${ }^{226}$ In a manner which resembles the awareness of God's omniscience in Job 31, Proverbs 5:21 warns, "For a man's ways are before the eyes of the LORD, and he watches all his paths." As a consequence, although a man's misdeeds may be beyond the pale of criminal sanction, "The iniquities of the wicked ensnare him, and he is caught in the toils of his sin. He dies for lack of discipline, and because of his great folly he is lost" (Proverbs

had Gomer been guilty only of idolatry, it is doubtful that the people, who were enmeshed in the same idolatry, would have noticed or comprehended this "prophetic sign" ("The Matrimonial Life of Hosea," 1134, esp. 15). Stuart, however, acknowledges that in the present verse 3 ds is clearly literal.

222 Cf. W. R. Harper, Amos and Hosea, 261.

$223 \mathrm{H}$. W. Wolff strongly favours such a reference (Hosea, 9f., 14 ["The Sex Cult"], 15f. and 86f.). J. L. Mays, however, is undecided (Hasea, 74f.).

Cf. also W. G. Lambert, "Morals in Ancient Mesopotamia" (1957-8) 195f.

224 Perhaps of the sort envisioned by K. van der Toorn, "Female Prostitution in Payment of Vows in Ancient Israel," though cf. D. Stuart, Hosea - Jonah, 83f.

225 So F. Hauck and S. Schulz, in "тó $\rho \nu \eta \kappa \tau \lambda$.," TDNT, VI, 586.

226 The attempt to transpose this text into an allegory for wisdom, etc., evident already in the Targum which identifies the wife as the law in vs. 19, appears doubtful. So, e.g., C. H. Toy, Proverbs, 111. Even if such an allegory is intended, however, the implications for literal marriage must still hold true or the force of the allegory would be lost. 
5:22f.). In view of such a warning, the preceding verses require what criminal law cannot, namely an exclusive and absorbing love and fidelity from a husband for his wife.

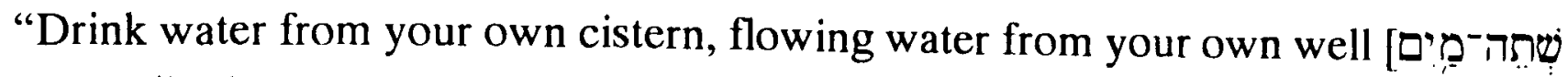

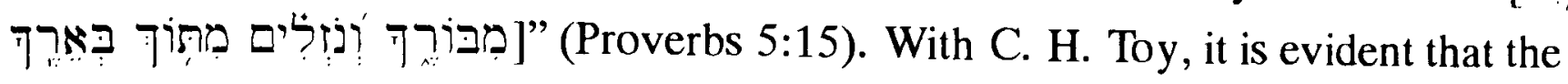
imagery of drinking from a cistern or well is intended to convey the ideas of sensual enjoyment, contentment, and satisfaction (cf. Isaiah 36:16), without any necessary allusion to procreation. 227 The text "introduces the wife not as child-bearer, but as source of pleasure." 228 As noted by R. B. Y. Scott, the fact that cisterns and wells were typically privately owned gives point to this metaphor for confining the satisfaction of sexual desire to one's own wife. ${ }^{229}$ So that the lesson is not missed, W. McKane rather prosaically summarizes the verse, "Have sexual intercourse only with your wife."230

Assuming the presence of an unmarked interrogative in vs. 16, it appears that Proverbs 5:16f. offers a figure for sexual infidelity. ${ }^{231}$ The main interpretative question is whether the infidelity in view is that of the husband or the wife: "Should your springs be

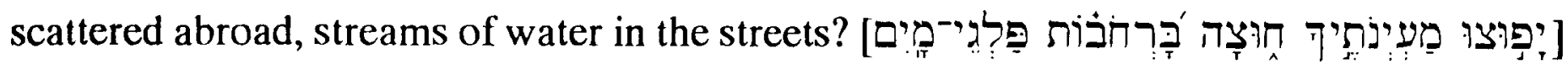

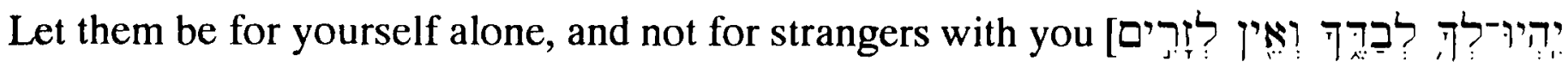
7. abroad" refers to a wife's promiscuity which may be a response to her husband's infidelity. An advantage of this view is the manner in which it allows for a consistency of water

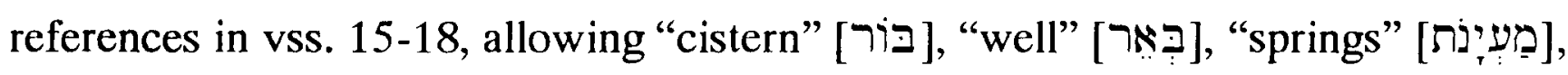

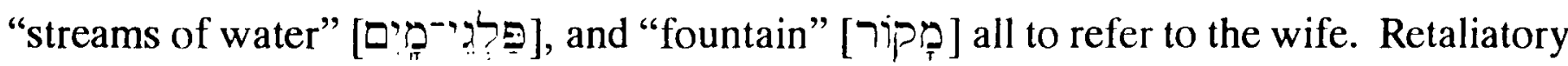
promiscuity, however, seems too modern a notion for such an ancient text.

Alternatively, it is possible that vss. 16f. refer to the husband's infidelity, whether "springs" and "streams of water" are intended as references to illicit sources of enjoyment (harlots and adulteresses -- since they are "scattered abroad" or "in the streets") 232 or, as

227 C. H. Toy, Proverbs, $112 \mathrm{f}$.

Obviously, Proverbs 5 does not stand alone in the Old Testament in its affirmation of erotic pleasure within marriage. Cf., e.g., Deuteronomy 24:5; Song of Songs 4:1-16, and passim; and Ecclesiastes 9:9. Cf. W. C. Kaiser Jr., Toward Old Testament Ethics, 192-195, and W. Neuer, Man and Woman in Christian Perspective (1990) 81-83. Naturally, the awareness of this aspect of marriage need not denigrate other less sensual aspects. Cf., e.g., Genesis 2:18, 24; Proverbs 31:10-31; and Sirach 26:1-14; 36:23 [28].

228 C. H. Toy, Proverbs, 113.

229 R. B. Y. Scott, Proverbs; Ecclesiastes, 58.

Cf. Song of Songs $4: 12,15$, for the underlying image of a fountain or well representing a woman. C. V. Camp argues that Proverbs 5:15 alludes to Song of Songs 4:15 as a way to explain the incongruous

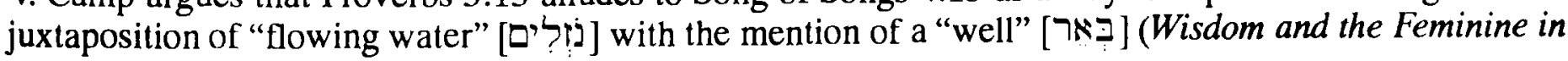
the Book of Proverbs, 205f.).

230 Proverbs, 318.

231 An alternative interpretation of the MT is offered by the AV (and Vulgate) which takes vs. 16 as jussive: "Let thy fountains...," perhaps implying "from such a marriage, blessing streams out in the persons and influences of a true family" (so D. Kidner, Proverbs, 70).

Alternatively, as noted by W. McKane, if $\mu$ ì is read with the $\mathrm{LXX}$, vs. 16 may be rendered either "lest [פ] your springs be dispersed outside..." (with B. Gemser, Sprüche Salomos [1963]) or "Let not [N] your springs be dispersed outside..." (op. cit., 318). Cf. BHS.

232 So C. H. Toy, Proverbs, 113. 
seems more likely based on vs. 17 , to semen. ${ }^{233}$ Favouring this line of interpretation, it is

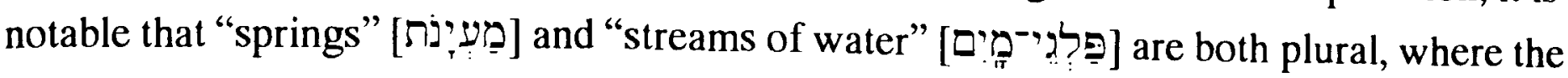

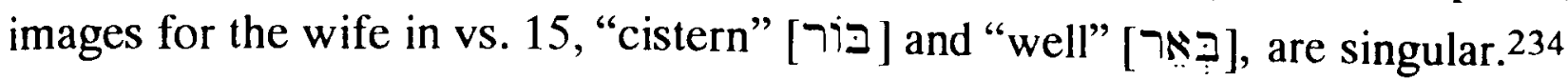

Accordingly, vs. 20 offers the literal meaning of vss. 16f., just as vss. 18f. give the literal meaning of vs. 15.235 Compare also Sirach 26:19-21.

Turning to vs. 18 , the reference of "your fountain" [מקוֹרך]"

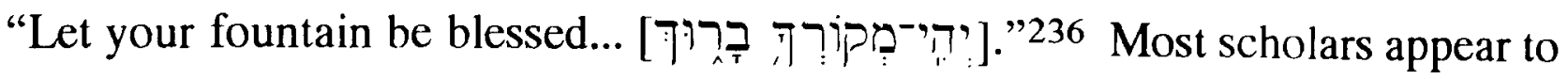
understand it as a reference to the wife, comparable to the other water sources in vs. 15 ,

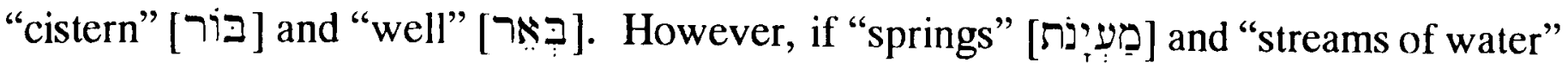

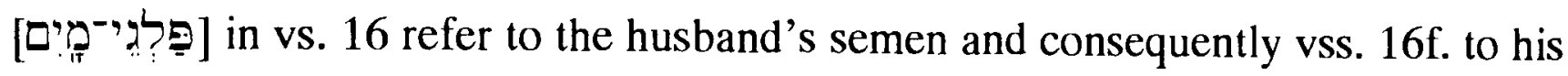
infidelity, then it is possible that "your fountain" continues this male imagery with a reference to the husband's own generative powers as the source of semen. ${ }^{237}$

Regardless of how vs. $18 \mathrm{a}$ is to be interpreted, vss. $18 \mathrm{~b}$ and 19 are clear enough:

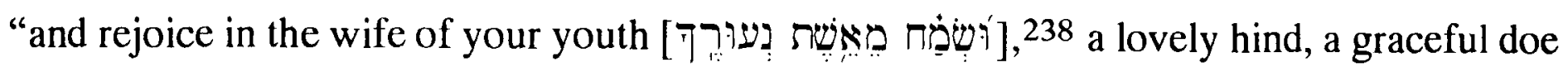

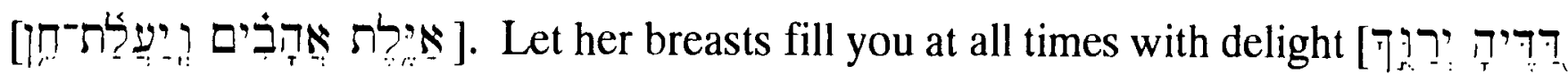

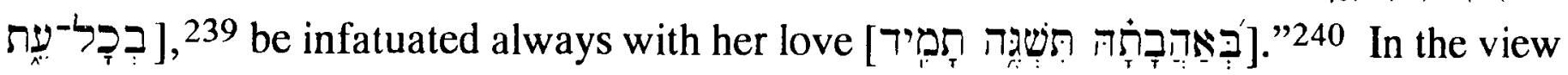

233 Cf. G. Boström, Proverbiastudien: die Weisheit und das fremde Weib in Sprüche 1-9 (1935), and W. McKane, Proverbs, 319.

The older view of Aquila, Saadia, and Ibn Ezra, which finds a reference in vss. 16f. to descendants, has been defended more recently by A. Cohen (Proverbs [1946] 28), L. A. Snijders ("The Meaning of zar in the Old Testament: an exegetical study" [1954] 93), and H. Ringgren (Sprüche/Prediger [1962]). On this approach vs. 16 may be either interrogative, "Should your springs be dispersed outside?," or declarative: "(and so) your springs will be dispersed outside." Although the latter approach (Snijders and Ringgren) has the advantage that it does not require an unmarked interrogative, W. McKane considers it unlikely, noting that water from a cistern, running to waste in the streets, is normally to be avoided -- a thought which is clearly inapplicable to descendants (Proverbs, 318).

234 This is also the case with "fountain" [רוק ] in vs. 18, although it is uncertain whether this refers to the wife or to the husband. Cf. below.

235 Cf. C. H. Toy, Proverbs, 113.

236 R. B. Y. Scott offers "be grateful for" as a paraphrase for "let it be blessed (by you)" (Proverbs, 58). This suggestion is rejected by C. V. Camp, Wisdom and the Feminine in the Book of Proverbs, 204 and 317, n. 15.

237 Yet a third option has been suggested by C. V. Camp, that "your fountain" refers to "the relationship of the two [i.e., the man and the woman] (op. cit., 203f.) This certainly includes an allusion to their sexual pleasure (so Gemser and Toy) and may also imply offspring (McKane), but not necessarily.

238 For "the wife of your youth," cf. Proverbs 2:17, Isaiah 54:6, and especially Malachi 2:14f. Cf. W. H. Wolff, Joel and Amos, 30.

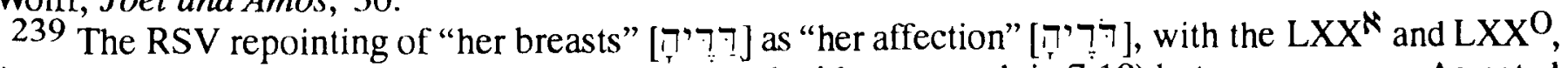
$\dot{\eta} \delta \dot{\epsilon} \phi \iota \lambda \dot{a}$, is possible (as it parallels "love" and used with same verb in 7:18) but unnecessary. As noted by D. Kidner, "the traditional rendering 'breasts' makes a rather more telling contrast with vs. 20 [which mentions the "bosom" of the adventuress], and should probably be retained" (Proverbs, 71). Cf. also C. H. Toy, Proverbs, 115. G. A. Yee notes a chiasm in vss. 19 and 20, with the A members having "her breasts"

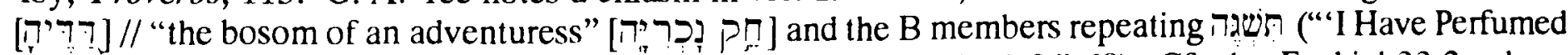
My Bed With Myrrh': The Foreign Woman ('iššâa zârâ) in Proverbs 1-9," 60). Cf. also Ezekiel 23:3, where the fondling of breasts is used in a description of harlotry: "there their breasts [שריהן] were pressed and their

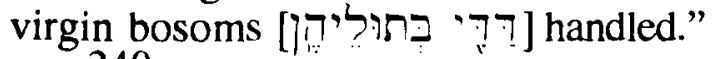

240 A number of scholars propose to relocate Proverbs 6:22 after 5:19. In support, cf. P. W. Skehan, Studies in Israelite Poetry and Wisdom, 1-8; R. B. Y. Scott, Proverbs, 58; and R. E. Murphy, Wisdom Literature: Job, Proverbs, Ruth, Canticles, Ecclesiastes, Esther, 59. 
the author, such intoxicating ${ }^{241}$ love for one's wife renders senseless any extramarital relations: "Why should you be infatuated, my son, with a loose woman and embrace the

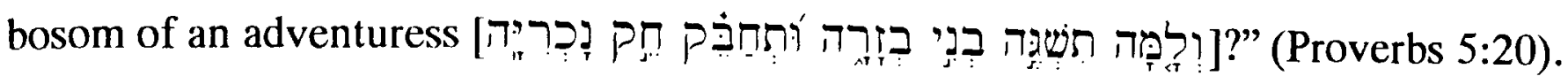
Although it is an allegorical text, perhaps one may compare Proverbs 4:5b-9 for its implication of a husband's devotion to his wife. "Get wisdom; get insight. Do not forsake her, and she will keep you; love her, and she will guard you.... Prize her highly, and she will exalt you; she will honour you if you embrace her. She will place on your head a fair garland; she will bestow on you a beautiful crown." 242

Whatever other conclusions may be warranted from this remarkable paean to marital love, it is clear that the demand for a husband's sexual fidelity was certainly not too romantic an ideal for the ancient world to entertain.

\subsection{Summary}

In this concluding chapter we began by considering various indirect evidences which would be not only consistent with, but also necessary for, a view of marriage as a sanction-sealed commitment between a husband and his wife. In particular, it was noted that Yahweh is identified as a "witness between" husbands and wives and that marital offences are, in fact, identified as perfidy (מעל), a term frequently used of oath violation, and infidelity (בגד) against one's spouse.

Second, we examined the other texts within the Old Testament which, in addition to Malachi 2:14, explicitly or implicitly identify marriage as a כִּר marriage metaphor, especially as articulated in Hosea 2:1-22 [ET 16-20], as well as the explicit evidence of Proverbs 2:17, Ezekiel 16:8, 59, 60, 62, and 1 Samuel 18-20 all proved to be convincing in their identification of marriage as a

Finally, we considered the claimed indifference of the Old Testament to a husband's sexual fidelity, an indifference which has been thought to contradict the identification of marriage as a covenant, particularly if this covenant was ratified by the kind of declaration formula found in Genesis 2:23 (cf. also 2:24) and if sexual union was recognized as its inherently mutual oath-sign. After surveying the alleged examples of this indifference, it

241 שגה, which normally means "to stagger, go astray, to be lost," as in vs. 23, can at times be used of the effects of intoxication (as in 20:1 and Isaiah 28:7). On this view the verb may be rendered "be intoxicated" or "swoon" in vss. 19 and 20. Cf. A. Cohen, Proverbs, 29; R. B. Y. Scott, Proverbs, 55, and D. Kidner, Proverbs, 71.

Alternatively, with W. McKane, שגד may have the meaning "wrapped in" (Proverbs, 313, 319).

$242 \mathrm{~W}$. McKane argues that the scene is not of marriage but of a wealthy patroness embracing her

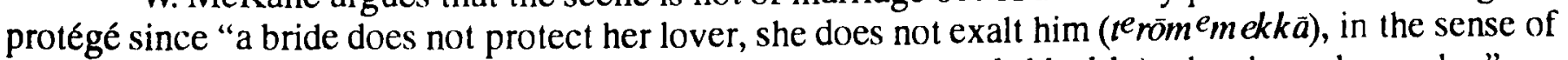
securing his preferment, nor does she get honour for her lover $(t e k a b b \bar{e} t k k \bar{a})$ when he embraces her" (Proverbs, 305f.). Cf. C. V. Camp, who rejects McKane's suggestion and defends the traditional view (op. cit., 93-95). Cf. H. Ringgren, who suggests that vs. 9 includes a reference to wedding customs (Word and Wisdom [1947] 106). Cf. also G. Boström, Proverbiastudien, 162. 
was determined that there are, in fact, no texts which condone a husband's sexual infidelity. On the contrary, it was demonstrated that a number of texts, including Job 31:1; Hosea 4:14; and particularly Proverbs 5:15-23, make clear that, whether or not there was any legal obligation, there definitely was a moral obligation for exclusive sexual fidelity on the part of husbands. ${ }^{243}$ This is consonant with the supposition that the Old Testament viewed marriage as a divinely protected covenant between husband and wife.

243 Cf. also Genesis 2:24. 


\section{Summary and Conclusions}

The purpose of the present study has been to explore Malachi's teaching concerning marriage as a בִרִ in Malachi 2:10-16, especially in the light of a growing number, if not the majority, of recent interpretations which deny this identification. Although other scholars have continued to support the traditional interpretation of marriage as a "covenant [ברִיח]," in general this conclusion has been upheld without sufficient attention to these recent challenges and, as noted in the Introduction, has yielded confusing and often contradictory results. Benefited by a vast scholarly literature devoted to the exploration of covenant concepts over the past half-century and further helped by a number of important recent studies on marriage elsewhere in the ancient Near East, this thesis has come to a variety of conclusions about the application of covenant concepts to marriage in the Old Testament. Only the most important of these will be summarized here.

We began our study by examining the historical and canonical context of Malachi and its literary structure in order to establish a proper interpretative framework within which to understand Malachi 2:10-16 (Chapter 1). After enumerating five principal arguments (\$2.1) in support of the traditional interpretation of Malachi 2:14, where Malachi identifies marriage as a "covenant [ברּרִ ]," we attempted to answer the two main objections to this view arising from considerations internal to the book of Malachi:

1) Against those who argue that Malachi's reference to marriage is figurative, based especially on the sustained interests in cultic and priestly matters throughout the rest of his book (e.g., C. C. Torrey, I. G. Matthews, F. F. Hvidberg, A. Isaksson, J. Milgrom, G. $\mathrm{S}$. Ogden, and others), it was argued that there is no reason to deem inappropriate a concern with literal marital offences in Malachi 2:10-16 in the light of the example of Ezra, and to a lesser degree of Nehemiah, where these same concerns coexist. Moreover, consistent with his emphasis elsewhere, Malachi stresses the detrimental effects of these offences on the cult (they profane the sanctuary of Yahweh [2:11], they provoke Yahweh's rejection of their offerings [2:13], etc.). In doing so, he employs vocabulary and concepts similar to that found in Nehemiah's declamation regarding interfaith marriage (cf., e.g., Nehemiah 13:29). A previously undetected concentric literary structure for the book of Malachi also appears to favour a reference to literal marital offences in the 3 rd disputation (2:10-16), since this section is balanced by the 4 th disputation $(2: 17-3: 5$ [or $3: 6])$, which offers a corroborating parallel in its treatment of literal marital and other ethical offences (Chapter 2). 
2) A number of arguments were advanced against those ss rs (K. Marti, W. Nowack, E. Sellin, C. Locher, A. S. van der Woude, and others) who accept a reference to literal marriage in Malachi 2, but who hold that the covenant mentioned in 2:14, "your wife

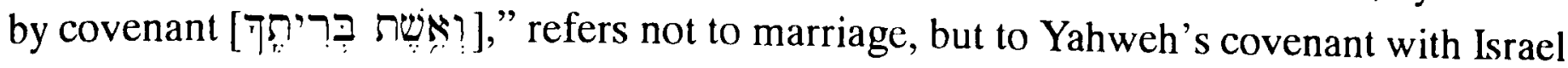
as in Malachi 2:10 (thereby identifying the wife as a fellow-Jew). Perhaps the most significant of these was the observation that this interpretation overlooks the opposing evidence of the four nominal syntagms of בִּרִ attested in Biblical Hebrew which parallel

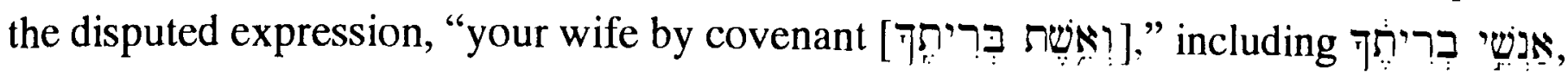

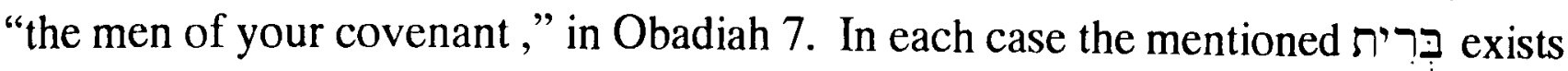
between the person(s) indicated by the nomen regens and the person referred to by the pronominal suffix or additional construct, exactly as is being argued for Malachi 2:14 (Chapter 2).

Having established the plausibility that Malachi 2:14 identifies literal marriage as a

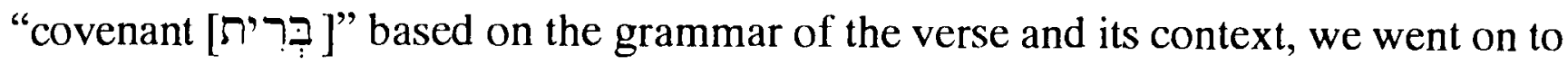
consider in Chapters 3 and 4 two further difficulties for this view which arise from the wider context of this verse.

1) A reference to literal marriage in Malachi 2 has been challenged based on the contradiction between the unqualified condemnation of divorce in Malachi 2:16, as this verse is often interpreted, and its apparent toleration in Deuteronomy 24 (A. Isaksson and A. S. van der Woude). A closer examination of these texts, however, suggests that the perspectives of Malachi and Deuteronomy may not be so incompatible. Taking the initial clause as an unmarked conditional (favoured by its fronted position and the versional

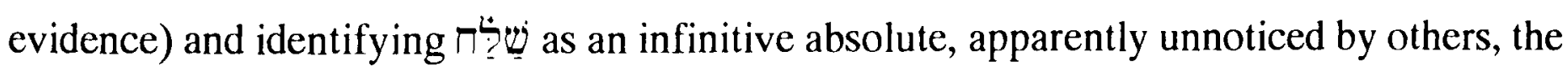
MT of Malachi 2:16 can be maintained as the lectio difficilior and rendered: "If one hates and divorces, says Yahweh, God of Israel, he covers his garment with violence, says Yahweh of hosts...."

Accordingly, while Malachi nowhere implies that such divorces were illegal, he does condemn divorce based on aversion [שנט] as ethically reprehensible and as anstance of infidelity [בגר], or covenant breaking (cf. 2:14), susceptible to divine judgment:

"Therefore, take heed to yourselves!" Such a perspective offers significant support for the identification of literal marriage as a covenant in 2:14. Moreover, this moral assessment of divorce based on aversion is not in conflict with Deuteronomy 24:1-4 since, with $\mathrm{R}$.

Westbrook, it appears likely that Deuteronomy presupposes a similar negative appraisal of divorce when based on aversion (i.e., the pairing in vs. 3 of the second case of divorce. which was motivated by hatred [שנא], with the case of the death of the husband may imply a favourable financial settlement for the offended wife) (Chapter 3 ). 
2) A second objection to a reference to literal marriage in Malachi 2:14 arising from the wider context of this verse has been raised by $\mathrm{C}$. C. Torrey and A. Isaksson. These scholars argue that a reference to literal marriage in Malachi 2:10-16 is contradicted by the assumption that polygyny would have been freely tolerated by Malachi and his contemporaries. In response, it was argued that the traditional interpretation of Malachi 2:10-16, which assumes a causal relationship between the offences of mixed marriage and divorce (Jewish men had divorced their Jewish wives in order to marry Gentile women), is unnecessary. The text nowhere explicitly relates these two offences in a causal manner, and it may be preferable to explain their juxtaposition by another means. Specifically, it was suggested that Malachi intended the chiastic parallelism between 2:10-12 and 2:13-16 to underscore the similarity of the infidelity [בגד] against "the covenant of our fathers," which results from the sin of mixed marriage, to the infidelity [בגד] against a marriage covenant, which results from divorce based on mere aversion. In any case, it was argued that although polygyny was never illegal, monogamy is seen as the marital ideal in a number of texts (e.g., Genesis 4:19ff., Leviticus 18:18, and Deuteronomy 17:17) and that actual marital practice would have been monogamous with few, if any, exceptions, especially in the post-exilic period (Chapter 4).

After thus defending the coherence of Malachi's theory of marriage and his identification of marriage as a "covenant [בְּרִ [? 2:14 in terms of both its immediate and its wider context, we attempted to answer three more fundamental objections to this interpretation: 1) Malachi's identification of marriage as a covenant would be unprecedented and anachronistic in the post-exilic period (A. Isaksson and others); 2) marriage cannot be a covenant because it lacks a ratifying oath (J. Milgrom and M. Greenberg); and 3) marriage cannot be a covenant because of the double standard of the Old Testament which demands only a wife's exclusive sexual loyalty (A. Isaksson, J. Milgrom, and P. F. Palmer).

1) We sought to answer in two ways the claim that the identification of literal marriage as a "covenant [בְּרִ $]$ ]" in Malachi 2:14 would be unprecedented and anachronistic in the post-exilic period. First, we argued that from Malachi's own perspective his view of marriage was not unprecedented, but was consciously derived from, or at least supported by, the paradigmatic marriage of Adam and Eve (Genesis 2:24), to which he makes allusion in Malachi 2:15. While acknowledging the problematic character of this verse, it was argued that the MT is best maintained and rendered, "Did He not make [you/them] one [ $\rceil_{\pi}$ ], with a remnant of the spirit belonging to it? And what was the One seeking? A godly seed! Therefore watch out for your lives and do not act faithlessly against the wife of your youth."

We stressed the grammatical and textual advantages of this interpretation (with its assumption of an unmarked rhetorical interrogative) and noted that an important 
confirmation for this rendering comes from the concluding admonition in 2:15b (cf. also 2:16b). Malachi warns any would-be unfaithful spouse that divorce constitutes an offence against one's own life. Only when 2:15a is rendered as suggested above ("Did He not make [you/them] one...?") is this equivalence between concern for one's life and fidelity to one's spouse explained; it is the result of the profound communion of life which God effects between a man and his wife as established in Genesis 2:24. Helping to confirm Malachi's indebtedness to Genesis 2:23f. is the fact that Genesis 2 invites an identification of the marriage of Adam and Eve as a covenant, especially based on the verba solemnia appearing in 2:23 (cf. also $\$ 5.8 .3$ and $\$ 5.9 .2 .3$ ). Notable also is the remarkable emphasis throughout Malachi 2:14-16 on the primacy of a husband's obligation of fidelity toward his wife, a viewpoint which is almost unparalleled apart from these two texts (Chapter 5).

We deferred to the last chapter a more encompassing answer to the objection that Malachi's view of marriage, if taken literally, would be unprecedented. There we argued

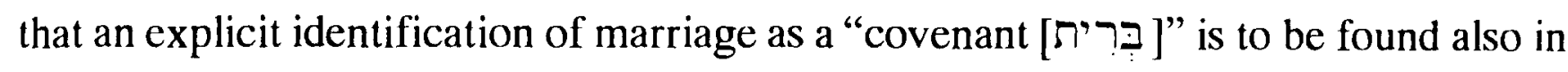
Proverbs 2:17 and Ezekiel 16. Furthermore, the same identification of marriage as a "covenant [ברּר [בר ]" appears to be implied in the marriage metaphor in Hosea 2:18-22 [ET: 16-20] as well as in 1 Samuel 18-20 (Chapter 8).

2) The second fundamental objection to the identification of marriage as a "covenant [בְּרִית]" in the Old Testament is based on the assumption that a ratifying oath is indispensable for the existence of a בִּרית. According to J. Milgrom and M. Greenberg marriage lacks such an oath and hence cannot be identified as a בִִּּרִ

To respond to this objection it was necessary first to clarify the Old Testament view

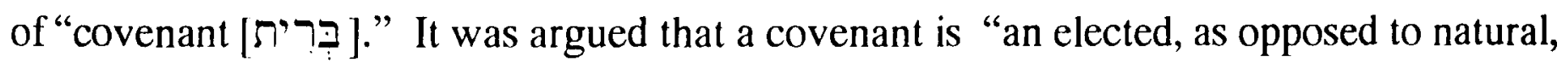
relationship of obligation established under divine sanction." In terms of this understanding, it was agreed with Milgrom and Greenberg that a ratifying oath is the sine qua non of covenant because it invokes the deity to act against any subsequent breach of the covenant. Against Milgrom and Greenberg, however, it was emphasized that such oaths are not all overtly self-maledictory, nor are they exclusively verbal. In particular, many oaths function by a solemn positive declaration (i.e., verba solemnia) or symbolic depiction of the commitment being undertaken (such as the "oath-signs" of a shared meal or handshake) (Chapter 6).

In the case of marriage, it was demonstrated that verba solemnia did, in fact, function as the customary covenant-ratifying oath based on a broad range of extrabiblical evidence (e.g., MAL A $\$ 41$, the etlu tablet, the ardat lili tablet, the documentary marriage formulae from Elephantine and Murabba'at, and the implication of the corresponding divorce formulae), as well as biblical evidence (i.e., Genesis 2:23; Hosea 2:4, 17-19 [ET 2:2,15-17]; Proverbs 7:4f.; and Tobit 7:12). In the course of this search for an oath in the formation of marriage, it was necessary to oppose the tendency to confuse marriage as a 
"status," similar to adoption (pointed out by R. Westbrook), with the marriage contract, whether oral or written, which was concerned with a variety of economic and other matters ancillary to the marriage itself (so also A. Skaist -- see $\$ 6.2 .1$ and \$7.2.1.1). With this distinction in mind, it appears that any rejection of the covenantal nature of marriage in the Old Testament (e.g., A. Isaksson), no less than any defence or elucidation of that covenantal nature (e.g., B. Glazier-McDonald) which proceeds by way of a study of the extant marriage documents is methodologically flawed.

Furthermore, it was deemed likely that sexual union was understood as a complementary covenant-ratifying oath-sign, at least by some biblical authors. In support of this identification of the significance of sexual union, it was argued (contradicting the theory of "marriage by purchase") that sexual union is the indispensable means for the consummation of marriage both in the Old Testament and elsewhere in the ancient Near East. Further, it was recalled how oath-signs, such as a shared meal or handshake, often function by offering a solemn depiction of the covenant commitment to unity. With respect to sexual union, it is clear that this act is ideally suited to depict the "one flesh" reality which is definitional of marriage in Genesis 2:24 and may also be supported by the use of the genitalia in other instances of oath taking (i.e., circumcision and placing one's hands under another's "thigh"). Finally, we examined a number of texts, especially Hosea 2:22 [ET 20] and 13:5, which associate the two relational senses of 'דע' ("know"), that is, its covenantal and sexual sense, by means of double entendre. The fact that Hosea 2:22 [ET 20] can use 'ד ' "know") in an extended marriage metaphor to describe the point at which Israel will "acknowledge" Yahweh as her covenant partner appears to confirm our hypothesis that sexual union, as a marriage covenant-ratifying act, is the decisive means by which an individual "acknowledges" his or her spouse as covenant partner (Chapter 7).

3) Finally, we considered a third fundamental objection, namely, that marriage cannot be a covenant because of the double standard of the Old Testament, which demands a wife's exclusive sexual loyalty while appearing to be indifferent to a husband's extramarital sexual behaviour (A. Isaksson, J. Milgrom, and P. F. Palmer). After examining the alleged examples of this indifference, it was determined that there are, in fact, no texts which condone a husband's sexual infidelity. On the contrary, a number of texts, including Job 31:1; Hosea 4:14; and especially Proverbs 5:15-23, make clear that whether or not there was any legal obligation, there definitely was a moral obligation for exclusive sexual fidelity on the part of a husband. This comports with the view of this thesis that the Old Testament considered marriage as a divinely protected covenant between husband and wife. 


\section{Bibliography of Cited Works}

The Holy Bible. The Revised Version (Oxford and London: Oxford University; and New York: Thomas Y. Crowell, 1885)

Cuneiform Texts from Babylonian Tablets, etc., in the British Museum (London: British Museum, Department of Egyptian and Assyrian Antiquities, 1896-)

The Holy Bible containing the Old and New Testaments. Newly Edited by the American Revision Committee, A.D. 1901, Standard Edition (New York: Thomas Nelson \& Sons, 1901)

The Holy Scriptures according to the Masoretic Text (Philadelphia, PA: The Jewish

Publication Society of America, 1917)

The New American Standard Bible (LaHabra, CA: The Lockman Foundation, 1960)

The New American Bible (Nashville, Camden, and New York: Thomas Nelson, 1970)

The Holy Bible. An American Translation (New Haven, Missouri: Leader, 1976)

The Holy Bible. New International Version (Grand Rapids, MI: Zondervan, 1978;

London, Sydney, Auckland, Toronto: Hodder and Stoughton, 1979)

The Old Testament in Syriac According to the Peshitta Version, Prepared by the Peshitta Institute, Leiden, Part 3, fasc. 4 (Leiden: E. J. Brill, 1980)

מקראות גדולות (Jerusalem: J. Weinfeld \& Co., n.d.)

Aalders, G. Ch., Obadja en Jona, COT (Kampen: J. H. Kok, 1958)

Aberbach, M. and B. Grossfeld, Targum Onkelos to Genesis: A Critical Analysis together with an English Translation of the Text (New York: KTAV; University of Denver:

Center for Judaic Studies, 1982)

Achtemeier, Elizabeth, Nahum-Malachi, Interpretation. A Bible Commentary for Teaching and Preaching, James L. Mays, Patrick D. Miller, and Paul J. Achtemeier, eds.

(Atlanta, GA: John Knox, 1986)

Ackroyd, Peter R., "The Verb Love -- 'āhēb in the David-Jonathan Narratives; A Footnote," VT 25 (1975) 213-214

,"The History of Israel in the Exilic and Post-Exilic Periods," in Tradition and Interpretation. Essays by Members of the Society for Old Testament Study, G. W. Anderson, ed. (Oxford: Clarendon, 1979) 320-350

Aejmelaeus, Anneli, “Function and Interpretation of 2 in Biblical Hebrew," JBL 105 (1986) 193-209

Ahlström, Gösta Werner, Aspects of Syncretism in Israelite Religion, Eric J. Sharpe, trans. (Lund: C. W. K. Gleerup, 1963).

, Joel and the Temple Cult of Jerusalem, SVT 21 (Leiden: E. J. Brill, 1971)

Albertz, M., and Claus Westermann, "ח̣in rûah Geist," in THAT 2 (München: Chr. Kaiser Verlag and Zürich: Theologischer Verlag, 1984) 726-52

Albright, William F., "The Hebrew Expression for 'Making a Covenant' in Pre-Israelite Documents," BASOR 121 (1951) 21-22

Inc., 1968)

, Yahweh and the Gods of Canaan (Garden City, NY: Doubleday \& Co., 
Alden, Robert L., "Malachi," in The Expositor's Bible Commentary, 7, Frank E. Gaebelein, ed. (Grand Rapids, MI: Zondervan, 1985) 701-725

Alexander, T. Desmond, David W. Baker, and Bruce K. Waltke, Obadiah, Jonah, Micah. An Introduction and Commentary, TOTC (Leicester, England and Downers Grove, IL: Inter-Varsity Press, 1988)

Alexander, Ralph H., "Ezekiel," in The Expositor's Bible Commentary, 6, Frank E. Gaebelein, ed. (Grand Rapids, MI: Zondervan, 1986) 737-996

Allam, Schafik, "Ehe," Lexicon der Ägyptologie, Band 1, Wolfgang Helck and Eberhard Otto, eds. (Wiesbaden: Otto Harrassowitz, 1975) 1162-81

, Some Pages from Everyday Life in Ancient Egypt, Prism Archaeological

Series, 1 (Guizeh, Egypt: Prism [Foreign Cultural Information Dept.], 1985)

Allen, Leslie C., The Books of Joel, Obadiah, Jonah and Micah, NICOT (Grand Rapids, MI: Eerdmans, 1976)

Allen, Leslie C., Psalms 101-150, WBC 21 (Waco, TX: Word Books, 1983)

Alt, A., "Ein phönikisches Staatswesen des frühen Altertums," Forschungen und Fortschritte 13 (1942) 207-209

Alter, Robert, Putting Together Biblical Narrative, The Albert T. Bilgray Lecture, University of Arizona (Tucson, Arizona: The Bilgray Lectureship of Temple EmanuEl, 1988)

Altschul, David, see "מצראות גדולות included in

Althann, Robert, "Malachy 2,13-14 and UT 125,12-13," Biblica 58 (1977) 418-21

Al-Zeebari, Akram, Texts in the Iraq Museum.Old Babylonian Letters, Part 1 [ = TIM 1] (Baghdad, 1964)

Amram, David Werner, The Jewish Law of Divorce According to Bible and Talmud with some reference to its development in Post-Talmudic Times (Philadelphia, PA: E. Stern \& Co., 1896 [reprint New York: Hermon Press 1968]).

Amsler, Samuel, André Lacocque and René Vuillcumicr, Aggée, Zacharie, Malachie, Commentaire de l'Ancien Testament, XIc (Neuchatel and Paris: Delachaux \& Niestlé Éditeurs, 1981)

Anbar, M., “Textes de l'époque babylonienne ancienne,” $R A 69$ (1975) 109-136

Andersen, Francis I., "Israelite Kinship Terminology and Social Structure," The Bible Translator 20 (1969) 29-39

, The Hebrew Verbless Clause in the Pentateuch, JBL Monograph Series, 14, Robert A. Kraft ed. (Nashville and New York: Abingdon, 1970)

, The Sentence in Biblical Hebrew, Janua linguarum, Series practica 231 (The Hague: Mouton Publishers, 1974)

1976)

, Job, An Introduction and Commentary, TOTC (London: Inter-Varsity,

Andersen, Francis I. and David N. Freedman, Hosea. A New Translation with Introduction and Commentary, AB 24 (Garden City, NY: Doubleday \& Company, 1980)

Andersen, Francis I., and David Noel Freedman, Amos. A New Translation with Introduction and Commentary, AB 24A (New York, London, Toronto, Sydney, Auckland: Doubleday, 1989)

Anderson, Arnold Albert, The Book of Psalms, 2 vols., NCB (London: Oliphants and Greenwood, SC: Attic, 1972) 
, "The Marriage of Ruth,” JSS 23 (1978) 171-183

, 2 Samuel, WBC 11 (Dallas, TX: Word Books, 1989)

Anderson, Gary, Sacrifices and Offerings in Ancient Israel. Studies in Their Social and Political Importance, HSS 41 (Atlanta, Georgia: Scholars, 1987)

Andreasen, Niels-Erik, "Adam and Adapa: Two Anthropological Characters," AUSS 19 (1981) 179-194

anonymous, "Art. IV - The General Assembly of 1842," The Biblical Repertory and Princeton Review 14:3 (1842) 472-523, at 518-520

anonymous, "Baboon Bonding," Discover 11 (April, 1990) 20

Armerding, Carl E., "Obadiah," in The Expositor's Bible Commentary, 7, Frank E.

Gaebelein, ed. (Grand Rapids, MI: Zondervan, 1985) 335-357

Atkinson, David John, To Have and to Hold: The Marriage Covenant and the Discipline of

Divorce (Grand Rapids, MI: Eerdmans, 1979)

Baab, Otto Justice, “Marriage," in IDB 3 (Nashville and New York: Abingdon, 1962) 278287

Bachmann, Paul Johannes, Alttestamentliche Untersuchungen (Berlin: S. Calvary \& Co., 1894).

Bailey, John A., "Initiation and the Primal Woman in Gilgamesh and Genesis 2-3," JBL 89 (1970) 137-150

Baker, David W. see A. T. Desmond. D. W. Baker, and B. K. Waltke, Obadiah, Jonah, Micah

Baldwin, Joyce G., Haggai, Zechariah, Malachi: An Introduction and Commentary, TOTC (Downers Grove, IL: Inter-Varsity, 1972)

117-24 , "Malachi 1:11 and the Worship of the Nations in the OT," TB 23 (1972)

, 1 and 2 Samuel. An Introduction and Commentary, TOTC (Leicester, England and Downers Grove, IL: Inter-Varsity, 1988)

Baltzer, Klaus, The Covenant Formulary in Old Testament, Jewish, and Early Christian Writings, David E. Green, trans. (Philadelphia, PA: Fortress, 1971 [from Das

Bundesformular, WMANT 4, 2e. Aufl., Neukirchen-Vluyn 1964; 1e Aufl. 1960])

Barash, D. P., Sociobiology and Behavior (New York: Elsevier North-Holland, 1977)

Barnes, William Emery, Malachi with Notes and Introduction, Cambridge Bible for

Schools and Colleges, A. F. Kirkpatrick, ed. (Cambridge: University, 1917 [2nd ed. 1934, F. S. Marsh, ed.])

Barr, James, The Semantics of Biblical Language (Oxford: Oxford University, 1961)

, "Some Semantic Notes on the Covenant," in Beiträge zur

alttestamentlischen Theologie. Fs für Walther Zimmerli zum 70. Geburtstag, Herbert

Donner, Robert Hanhart, and Rudolf Smend, eds. (Göttingen: Vandenhoeck \&

Ruprecht, 1977) 23-38

, "Semitic Philology and the Interpretation of the Old Testament," in Tradition and Interpretation. Essays by Members of the Society for Old Testament Study, G. W. Anderson, ed. (Oxford: Clarendon, 1979) 31-64

, Comparative Philology and the Text of the Old Testament, expanded edition (Winona Lake, IN: Eisenbrauns, 1987 [1st ed., Oxford: Oxford University Press, 1968]) 
Barth, Markus, Ephesians. A New Translation with Introduction and Commentary, 2 vols., AB 34, 34A (Garden City, NY: Doubleday \& Company, 1974)

Barthélemy, Dominique, A. R. Hulst, Norbert Lohfink, W. D. McHardy, H. P. Rüger, and James A. Sanders, Preliminary and Interim Report on the Hebrew Old Testament Text Project (New York: United Bible Societies, 1979-80)

Barton, John, Reading the Old Testament. Method in Biblical Study (London: Darton, Longman \& Todd, 1984)

Bauer, Hans, and Pontus Leander, Historische Grammatik der hebräischen Sprache des Alten Testamentes (Halle: Niemeyer, 1922 [reprinted 1965 by Georg Olms, Hildesheim])

Baumann, E., "Yāda' und seine Derivate. Ein sprachlich-exegetische Studie," $Z A W 28$ (1908) 22-41 and 110-143

Beckwith, Roger 'T., “The Unity and Diversity of God's Covenants," TB 38 (1987) 93118

Beeston, A. F. L., "One Flesh," VT 36 (1986) 115-117

Begg, Christopher T., "Berit in Ezekiel," in Proceedings of the Ninth World Congress of Jewish Studies, Jerusalem, August 4-12, 1985. Division A: The Period of the Bible (Jerusalem: World Union of Jewish Studies, 1986) 77-84

Begrich, J., "Berit. Ein Beitrag zur Erfassung einer alttestamentlichen Denkform," $Z A W 60$ (1944) 1-11

Ben-Barak, Zafrira, "The legal background to the restoration of Michal to David," Studies in Historical Books of the Old Testament, VTSup 30, J. A. Emerton, ed. (Leiden: E. J. Brill, 1979) 15-29 , "Inheritance by Daughters in the Ancient Near East," JSS 25 (1980) 22-33

Benoit, Pierre, J. T. Milik and Roland de Vaux, Les Grottes de Murabba'at, DJD 2 (Oxford: Clarendon, 1961)

Benton Jr., W. Wilson, "Federal Theology: Review for Revision," in Through Christ's Word. A Fs for Dr. Philip E. Hughes, W. Robert Godfrey and Jesse L. Boyd III, eds. (Phillipsburg, NJ: Presbyterian and Reformed, 1985) 180-204

Berg, Werner, "Der Sündenfall Abrahams und Saras nach Gen 16,1-6," Biblische Notizen 19 (1982) 7-14

Berlin, Adele, "Characterization in Biblical Narrative: David's Wives," JSOT 23 (1982) 6985

Bewer, Julius A., see J. M. P. Smith, W. H. Ward, and J. A. Bewer, A Critical and Exegetical Commentary on Micah, Zephaniah, Nahum, Habakkuk, Obadiah, and Joel

Biale, Rachel, Women and Jewish Law. An Exploration of Women's Issues in Halakhic Sources (New York: Schocken Books, 1984)

Bickerman, E., "Couper une alliance," Archives d'Histoire du Droit Oriental 5 (1950-51) 133-56

Bigger, Stephen Frank, "Hebrew Marriage and Family in the Old Testament Period. A Perspective from the Standpoint of Social History and Social Anthropology," Ph.D. diss. (University of Manchester, 1974)

Bing, J. D., "Adapa and Immortality," Ugarit-Forschungen 16 (1984) 53-56

Bird, Phyllis, "Images of Women in the Old Testament," in Religion and Sexism, Rosemary Radford Ruether, ed. (New York City: Simon \& Schuster, 1974) 41-88 
Birnbaum, Solomon A., "The Kephar Bebhayu Marriage Deed," JAOS 78 (1958) 12-18 , "The Bar Menasheh Marriage Deed," Uitgaven van het Nederlands Historisch-Archaelogisch Instituut te Istanbul 13 (1962) 1-26

Blank, Sheldon H., "The Curse, Blasphemy, the Spell, and the Oath," HUCA 23 (195051) 73-95

Blass, F., and A. Debrunner, A Greek Grammar of the New Testament and Other Early Christian Literature, trans. and revised by Robert W. Funk (Chicago and London: University of Chicago, 1961)

Blau, Joshua, On Polyphony in Biblical Hebrew, Proceedings of the Israel Academy of Sciences and Humanities, VI/2 (Jerusalem: Ahva, Ltd., 1982)

Blenkinsopp, Joseph, Ezra - Nehemiah, A Commentary, OTL (Philadelphia:

Westminster, 1988)

Blevins, James L., "The Age of Marriage in First-Century Palestine," Biblical Illustrator 7 (1980) 65-7

Blocher, Henri, In the Beginning. The opening chapters of Genesis, David G. Preston, trans. (Leicester, England and Downers Grove, IL: Inter-Varsity, 1984)

Blommerde, Anton C. M., Northwest Semitic Grammar and Job, BibOr 22 (Rome:

Pontifical Biblical Institute, 1969)

Böcher, O., “Der Judeneid,” EvT 30 (1970) 671-681

Boecker, Hans Jochen, "Bemerkungen zur formgeschichtlichen Terminologie des Buches Maleachi," $Z A W 78$ (1966) 78-80

, "Anmerkungen zur Adoption im AT," $Z A W 86$ (1974) 86-89

, Law and the Administration of Justice in the Old Testament and Ancient

East, Jeremy Moiser, trans. (Minneapolis, MN: Augsburg; London: SPCK, 1980)

Boling, Robert G., Judges: A New Translation with Introduction and Commentary, AB 6A (Garden City, NY: Doubleday \& Company, 1975)

Boling, Robert G., and G. Ernest Wright, Joshua. A New Translation with Notes and Commentary, AB 6 (Garden City, NY: Doubleday \& Company, 1982)

Borger, Rykle, "Zu den Asarhaddon Verträgen aus Nimrud," Zeitschrift für Assyriologie 54 (1961) 173-196

, Babylonisch-Assyrische Lesestücke, 2 Bde, 2e Aufl., AnOr 54 (Rome:

Pontifical Biblical Institute, 1979)

Borger, Rykle, Heiner Lutzmann, Willem H. Ph. Römer, and Einar von Schüler,

Rechtsbücher, Texte aus der Umwelt des Alten Testaments, I/1, Rykle Borger,

Wilhelmus C. Delsman, Manfried Dietrich, Ursula Kaplony-Heckel, Hans Martin

Kümmel, Oswald Loretz, Walter W. Müller, Willem H. Ph. Römer, and Otto Kaiser

(Gütersloh: Gerd Mohn, 1982)

Bossman O. F. M., David, "Ezra's Marriage Reform: Israel Redefined," Biblical Theology Bulletin 9 (1979) 32-38

Boström, Gustav, Proverbiastudien: die Weisheit und das fremde Weib in Sprüche 1-9, Lunds Universitets Årsskrift, N.F., Avd. I, Bd. 30, Nr. 3 (Lund: Gleerup, 1935)

Böttcher, Friedrich, Neue exegetisch-kritische Aehrenlese zum Alten Testamente (Leipzig: J. A. Barth, 1863-65)

Botterweck, G. Johannes, "Schelt- und Mahnrede gegen Mischehe und Ehescheidung. Auslegung von Malachias 2, 10-16," Bibel und Leben 1 (1960) 179-185 
, "עיר, yāda'," in TDOT 5 (Grand Rapids, MI: Eerdmans, 1986) 448-481

Botterweck, G. Johannes, and Helmer Ringgren, eds., Theological Dictionary of the Old Testament (Grand Rapids, MI: Eerdmans, 1977-)

Brandon, S. G. F., Creation Legends of the Ancient Near East (London: Hodder and Stoughton, 1963)

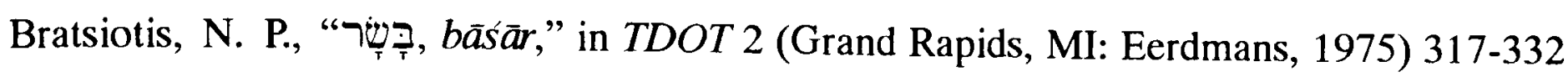

Braun, Roddy L., 1 Chronicles, WBC 14 (Waco, TX: Word Books, 1986)

Brauner, Ronald A., “'To Grasp the Hem' and 1 Samuel 15:27," JANESCU 6 (1974) 3538

Bravmann, M. M., "Concerning the Phrase 'and shall cleave to his wife'," Le Muséon Louvain 85 (1972) 269-74

,"The Original Meaning of 'A Man Leaves His Father and Mother' (Gen 2.24)," Le Muséon Louvain 88 (1975) 449-553

, Studies in Semitic Philology (Leiden: E. J. Brill, 1977)

Brekelmans, C. H. W., "Exodus XVIII and the Origins of Yahwism in Israel," OTS 10 (1954) 215-224

Brenenan, J. Mervin, "Nuzi Marriage Tablets," Ph.D. diss. (Brandeis University, Waltham, MA, 1971)

Brenner, Athalya, The Israelite Woman: Social Role and Literary Type in Biblical Narrative, The Biblical Seminar (Sheffield, England: JSOT Press, 1985)

Brichto, Herbert Chanan, The Problem of 'Curse' in the Hebrew Bible, JBL Monograph Series, 13 (Philadelphia: Society of Biblical Literature, 1963 [reprinted 1968]). (1975) $55-70$

"The Case of the Sottā and a Reconsideration of Biblical 'Law'," HUCA 46

Briggs, Charles Augustus, and Emilie Grace Briggs, $A$ Critical and Exegetical Commentary on the Book of Psalms, 2 vols., ICC (Edinburgh: T. \& T. Clark, 1906)

Bright, John, Jeremiah. A New Translation with Introduction and Commentary, AB 21 (Garden City, NY: Doubleday \& Co., 1965)

, A History of Israel, 3rd ed. (Philadelphia: Westminster, 1981 [1st ed. 1959;

2nd ed. 1972])

Brinkman, John A., Miguel Civil, Ignace J. Gelb, A. Leo Oppenheim, and Erica Reiner, eds., The Assyrian Dictionary of the Oriental Institute of the University of Chicago (Chicago, IL: The Oriental Institute; and Glückstadt, Germany: J. J. Augustin Verlagsbuchhandlung, 1956-)

Brockelmann, Carl, Grundriss der vergleichenden Grammatik der semitischen Sprachen, 2 Bde. (Berlin: Reuter und Reichard, 1908-1913 [reprinted 1961 Hildesheim: Olms]) , Lexicon syriacum, 2nd ed. (Halle: Max Niemeyer, 1928 [reprinted 1965, Hildesheim: Olms])

, Hebräische Syntax (Neukirchen-Vluyn: Neukirchener Verlag, 1956)

Brockington, Leonard Herbert, "Malachi," in Peake's Commentary on the Bible, Matthew Black and H. H. Rowley, eds. (London: Nelson, 1962) 656-658

, The Hebrew Text of the Old Testament, The readings adopted by the translators of the new English Bible (Oxford, Cambridge, London: Oxford University Press, 1973) 
Brown, Francis, Samuel Rolles Driver, and Charles A. Briggs, A Hebrew and English

Lexicon of the Old Testament (Oxford: Clarendon, 1907 [repr. 1962, 1966])

Brownlee, William H., Ezekiel 1-19, WBC 28 (Waco, TX: Word Books, 1986)

Brueggemann, Walter, "David and His Theologian," CBQ 30 (1968) 156-81

, "Of the Same Flesh and Bone (Gn 2,23a)," CBQ 32 (1970) 532-42

, Genesis. Interpretation, A Bible Commentary for Teaching and Preaching

(Atlanta, GA: John Knox, 1982)

Bruno, D. Arvid, Das Buch der Zwölf. Eine rhythmische und textkritische Untersuchung

(Stockholm: Almqvist \& Wiksell, 1957)

Budd, Philip J., Numbers, WBC 5 (Waco, TX: Word Books, 1984)

Budde, K., "Zum Text der drei letzten kleinen Propheten," $Z A W 26$ (1906) 1-28

Bullinger, E. W., Figures of Speech Used in the Bible: Explained and Illustrated (London:

Messrs. Eyre and Spottiswoode, 1898 [reprinted 1968 Grand Rapids, MI: Baker])

Bulmerincq, Alexander von, Der Prophet Maleachi, Band 1: Einleitung in das Buch des

Propheten Maleachi (Dorpat: Acta et Commentationes, Univ. Dorpat, 1926)

, "Die Mischehen im B. Maleachi," in Oriental Studies published in

commemoration of the fortieth anniversary (1883-1923) of Paul Haupt as Director of

the Oriental Seminary of the Johns Hopkins University, Baltimore, MD, Cyrus Adler and Aaron Ember, eds. (Baltimore, MD: The Johns Hopkins Press, 1926) 31-42

, Der Prophet Maleachi, Band 2: Kommentar zum Buche des Propheten

Maleachi (Tartu: Kommissionsverlag von J. G. Krüger, 1932)

Burke, David G., "Gesture," in ISBE 2 (Grand Rapids, MI: Eerdmans, 1986) 449-457

Burney, C. F., The Book of Judges With Introduction and Notes and Notes on the Hebrew Text of the Books of Kings with an Introduction and Appendix, Prolegomenon by

William F. Albright; 2nd ed., The Library of Biblical Studies (New York: Ktav, 1970 [first published 1903 and 1919])

Burrows, Millar, “The Complaint of Laban's Daughters," JAOS 57 (1937) 259-276

, The Basis of Israelite Marriage, American Oriental Series 15 (New Haven,

CN: American Oriental Society, 1938)

Bush, George, Notes, Critical and Practical, on the Book of Leviticus (New York:

Newman and Ivison, 1842)

Buss, Martin J., "Review: L. Perlitt, Bundestheologie im Alten Testament (WMANT 36)," JBL 90 (1971) 210-212

Callison, Walter L., "Divorce, the Law, and Jesus," Your Church (May, 1986) 18-23

Calmet, Augustin, Les douze petits prophètes, Commentaire littéral sur tous les livres de l'ancien et du nouveau Testament, Bd. XVI (Paris: P. Emery, 1715)

Calovius, Abraham, "Annotata ad Malachiam," in Biblia Testamenti Veteris illustrata, 4 Bde. fol., Part 2 (Francofurti a. M., 1672-1676) 1041-1076

Calvin, John, The Twelve Minor Prophets, Vol. V, Zechariah and Malachi, John Owen, trans. (Edinburgh: T. \& T. Clark, 1849)

, Commentaries on the First Book of Moses called Genesis, Vol. 1, John King, trans. and ed. (Grand Rapids, MI: Baker, 1979 reprint [first published in Latin, 1554]) 
, Commentaries on the Four Last Books of Moses Arranged in the Form of a Harmony, vol. 3, Charles W. Bingham, trans. (Grand Rapids, MI: Baker, reprint 1979)

Camp, Claudia V., Wisdom and the Feminine in the Book of Proverbs, Bible and Literature Series, 11 (Sheffield: Almond, 1985)

Campbell Jr., Edward F., Ruth. A New Translation with Introduction, Notes and Commentary, AB 7 (Garden City, NY: Doubleday \& Company, 1975)

Campbell, Robert C., "Teachings of the Old Testament concerning Divorce," Foundations $6(1963) 174-178$

Cappellus, Ludovicus, Commentarii et notae criticae in Vetus Testamentum (Amstelodami, 1689)

Cardascia, Guillaume, Les lois assyriens. Introduction, traduction, commentaire, Litt. Anc. du Proche-Orient, 2 (Paris: Editions du Cerf, 1969)

Carmichael, Calum M., The Laws of Deuteronomy (Ithaca, NY: Cornell University, 1974) , Women, Law, and the Genesis Traditions (Edinburgh: Edinburgh University, 1979) , "Treading' in the Book of Ruth," $Z A W 92$ (1980) 248-66 , Law and Narrative in the Bible. The Evidence of the Deuteronomic Laws and the Decalogue (Ithaca and London: Cornell University, 1985)

Carmignac, J., "Précisions apportées au vocabulaire de l'hébreu biblique par la Guerre des fils de lumière contre les fils de ténèbres," VT 5 (1955) 345-365

Carroll, Robert P., Jeremiah. A Commentary, OTL 8 (London: SCM Ltd., 1986)

Carson, D. A., Exegetical Fallacies (Grand Rapids, MI: Baker, 1984)

Carson, D. A. and H. G. M. Williamson, eds., It is Written: Scripture Citing Scripture. Essays in Honour of Barnabas Lindars (Cambridge: University Press, 1988)

Cashdan, Eli, "Malachi," in The Twelve Prophets, Soncino Books of the Bible, Abraham Cohen, ed. (London, Jerusalem, N: w York: Soncino, 1948) 335-356

Cassuto, Umberto, A Commentary on the Book of Genesis. Part I: From Adam to Noah, Genesis I-VI 8, Israel Abrahams, trans. (Jerusalem: Magnes, The Hebrew University, 1961)

, A Commentary on the Book of Exodus, Israel Abrahams, trans. (Jerusalem: Magnes, The Hebrew University, 1967) , "Second Chapter of the Book of Hosea," in U. Cassuto, Biblical and Oriental Studies, I: Bible (Jerusalem: Magnes, 1973) 101-140

Cathcart, Kevin J., and Robert P. Gordon, The Targum of the Minor Prophets: Translated, with a Critical Introduction, Apparatus, and Notes, The Aramaic Bible, 14 (Wilmington, DE: Michael Glazier, 1989)

Cazelles, Henri, "חָָרָ, chābhar," in TDOT 4 (Grand Rapids, MI: Eerdmans, 1980) 193 197

Ceresko, Anthony R., Job 29-31 in the Light of Northwest Semitic. A Translation and Philological Commentary, BibOr 36 (Rome: Biblical Institute, 1980)

Charles, R. H., ed., The Apocrypha and Pseudepigrapha of the Old Testament in English (Oxford: Clarendon, 1913) 
Charlesworth, James H., Jesus Within Judaism. New Light from Exciting Archaeological Discoveries, The Anchor Bible Reference Library (New York, London, Toronto, Sydney, Auckland: Doubleday \& Company, Inc., 1988)

Chary O.F.M., Théophane, Aggée - Zacharie - Malachie, Sources Bibliques (Paris: J. Gabalda et Cie, 1969)

Childs, Brevard S., The Book of Exodus: A Critical, Theological Commentary, OTL (Philadelphia, PA: Westminster, 1974) 1979) , Introduction to the Old Testament as Scripture (Philadelphia, PA: Fortress,

Chirichigno, Gregory Conrad, "Debt Slavery in the Ancient Near East and Israel: An Examination of the Biblical Manumission Laws in Exod 21:2-6, 7-11; Deut 15:12-18; Lev. 25:39-54," Ph.D. diss. (Council for National Academic Awards, 1989)

Çiğ, M., H. Kizilyay, F. R. Kraus, Altbabylonische Rechtsurkunden aus Nippur (Istanbul, 1952)

Clark, W. Malcolm, "The Flood and the Structure of the Pre-Patriarchal History," $Z A W 83$ (1971) 204-10

Clay, Albert Tobias, Babylonian Records in the Library of J. Pierpont Morgan, Part 4 (New Haven: Yale University, 1923)

Clements, Ronald E., Abraham and David. Genesis 15 and its Meaning for Israelite Tradition, SBT II/5 (Geneva, AL: Allenson-Breckinridge and London: SCM, 1967)

Clines, David J. A., “The Theology of the Flood Narrative," Faith and Thought 100 (19723) $128-42$

, The Theme of the Pentateuch, JSOTSup 10, D. J. A. Clines, P. R. Davies, and D. M. Gunn, eds. (Sheffield, England: University of Sheffield, 1978)

, Ezra, Nehemiah, Esther, NCB (Grand Rapids, MI: Eerdmans; and London: Marshall, Morgan \& Scott Publishing, Ltd., 1984)

, What Does Eve Do to Help? and Other Readerly Questions to the Old Testament, JSOTSup 94 (Sheffield: Sheffield Academic, 1990)

Coats, George W., Genesis with an Introduction to Narrative Literature, The Forms of Old Testament Literature, 1, Rolf Knierim and Gene M. Tucker, eds. (Grand Rapids, MI: Eerdmans, 1983)

Coccejus, Johannes, Commentarius in prophetas duodecim minores, Opera III (Fracofurti a. M., 1689)

Cody O.S.B., Aelred, "Jethro Accepts a Covenant with the Israelites," Biblica 49 (1968) 153-166

Cogan, Morton, Imperialism and Religion: Assyria, Judah and Israel in the Eighth and Seventh Centuries B.C.E., SBLMS 19 (Missoula, Montana: Scholars, 1974)

Cogan, Mordechai, and Hayim Tadmor, II Kings. A New Translation with Introduction and Commentary, AB 11 (Garden City, NY: Doubleday \& Company, 1988)

Coggins, R. J., Haggai, Zechariah, Malachi, Old Testament Guides (Sheffield: JSOT Press, 1987)

Cohen, Abraham, Proverbs. Hebrew Text and English Translation with an Introduction and Commentary, Soncino Books of the Bible, Abraham Cohen, ed. (London: Soncino, 1946) 
, The Soncino Chumash. The Five Books of Moses with Haphtaroth. Hebrew text and English translation with an exposition based on the classical Jewish commentaries, Soncino Books of the Bible, Abraham Cohen, ed. (London: Soncino, 1947)

, "Zephaniah,” in The Twelve Prophets. Hebrew Text \& English Translation with Introductions and Commentary, Soncino Books of the Bible, Abraham Cohen, ed. (London: Soncino, 1948)

Cohen, Boaz, Jewish and Roman Law. A Comparative Study, 2 vols. (New York: Jewish Theological Seminary of America, 1966)

Cohen, Shaye J. D., "Conversion to Judaism in Historical Perspective: From Biblical Israel to Post-Biblical Judaism," Conservative Judaism 36 (1983) 31-45

, "From the Bible to the Talmud: The Prohibition of Intermarriage," Hebrew Annual Review, Vol. 7. Biblical and Other Studies in Honor of Robert Gordis, Columbus: Department of Judaic and Near Eastern Languages and Literatures, The Ohio State University, Reuben Ahroni, ed. (1984) 23-39 (1985) 5-13

,"The Origins of the Matrilineal Principle in Rabbinic Law," Judaism 34

Cole, R. Alan, Exodus. An Introduction and Commentary, TOTC (London and Downers Grove, IL: Inter-Varsity, 1973)

Collins, John J., "The Message of Malachi," The Bible Today 22 (1984) 209-15

Cooke, G. A., A Critical and Exegetical Commentary on the Book of Ezekiel, ICC (Edinburgh: T. \& T. Clark, 1936)

Coppens, J., "La nouvelle alliance en Jér 31.31-4," CBQ 25 (1963) 14-15

Corbett, P. E., The Roman Law of Marriage (Oxford: Clarendon, 1930)

Cotterell, Peter, and Max Turner, Linguistics and Biblical Interpretation (Downers Grove, IL: InterVarsity, 1989)

Cowles, Henry, The Minor Prophets; with Notes, Critical, Explanatory, and Practical, designed for both pastors and people (New York: D. Appleton and Company, 1867)

Cowlcy, A. E., Aramaic Papyri of the Fifth Century B.C. Edited with Translation and Notes (Oxford: Clarendon, 1923 [reprinted 1967])

Craigie, Peter C., The Book of Deuteronomy, NICOT (Grand Rapids, MI: Eerdmans, 1976)

, Psalms 1-50, WBC 19 (Waco, TX: Word Books, 1983)

, Twelve Prophets. Vol. 2, The Daily Study Bible Series, John C. L.

Gibson, ed. (Philadelphia, PA: Westminster, 1985)

Cramer, Karl, Amos, BWANT, 51 (Stuttgart: W. Kohlhammer, 1930)

Cresson, Bruce C., "The Condemnation of Edom," in The Use of the Old Testament in the New. W. F. Stinespring Fs, J. M. Efird, ed. (Durham, NC: Duke University, 1972) $125-48$

Cross Jr., Frank Moore, Canaanite Myth and Hebrew Epic. Essays in the History of the Religion of Israel (Cambridge, MA: Harvard University, 1973) , "אל, 'él," in TDOT 1 (Grand Rapids, MI: Eerdmans, 1977) 242-261

Cross Jr., Frank Moore, and Richard J. Saley, "Phoenician Incantations on a Plaque of the Seventh Century B.C. from Arslan Tash in Upper Syria," BASOR 197 (1970) $42-49$ 
Crown, A. D., "Aposiopesis in the Old Testament and the Hebrew Conditional Oath," $A b r$ Nahrain 4 (1963-64) 96-111

Cuq, E., Études sur le droit babylonien, les lois assyriennes et les lois hittites (Paris: Geuthner, 1929)

Curtis, Edward Lewis, and Albert Alonzo Madsen, A Critical and Exegetical Commentary on the Books of Chronicles, ICC (Edinburgh: T. \& T. Clark and New York: Charles Scribner's Sons, 1910)

Dahlberg, Bruce T., "On recognizing the unity of Genesis," Theology Digest 24 (1976) 360-67

Dahood, Mitchell, Psalms I: 1-50, Introduction, Translation, and Notes, AB 16 (Garden City, NY: Doubleday \& Company, 1965)

, "Hebrew-Ugaritic Lexicography IV," Biblica 47 (1966) 403-419

"The Phoenician Contribution to Biblical Wisdom Literature," in The Role

of the Phoenicians in the Interaction of Mediterranean Civilizations. Papers presented to the Archaeological Symposium at the American University of Beyrouth, March,

1967, William A. Ward, ed. (Beirut: The American University of Beirut, 1968) 12353

, Psalms II: 51-100, Introduction, Translation, and Notes, AB 17 (Garden

City, NY: Doubleday \& Company, 1968)

, Psalms III: 101-150, Introduction, Translation, and Notes, with an Appendix, The Grammar of the Psalter, AB 17A (Garden City, NY: Doubleday \& Company, 1970)

Dahood, Mitchell, and Tadeusz Penar, "Ugaritic-Hebrew Parallel Pairs," in RSP 1 (Rome: Pontifical Biblical Institute, 1972) 71-382

Dalley, Stephanie, “Old Babylonian Dowries," Iraq 42 (1980) 53-74

Daube, David, Studies in Biblical Law (Cambridge: University, 1947)

, "Terms for Divorce," in The New Testament and Rabbinic Judaism, David

Daube, ed. (London: Athlone, 1956 [reprint by Arno, New York, 1973]) 366

, "Rechtsgedanken in den Erzählungen des Pentateuchs," in Von Ugarit nach Qumran. Beiträge zur alttestamentlichen und altorientalischen Forschung Otto

Eissfeldt zum 1. September 1957 dargebracht von Freunden und Schülern, W. F.

Albright, W. Baumgartner, J. Lindblom, J. Pedersen, and H. H. Rowley, eds.,

BZAW, 77 (Berlin: W. de Gruyter, 1961) 32-41

, "Covenanting under Duress," The Irish Jurist 2 (1967) 352-59

Daube, David, and Reuven Yaron, “Jacob's Reception by Laban,” JSS 1 (1956) 60-62

David, Martin, Die Adoption im altbabylonischen Recht, Leipziger rechtswissenschaftliche Studien 23 (Leipzig: Th. Weicher, 1927)

, Vorm en wezen van de huwelijkssluiting naar de oud-oostersche rechtsopvatting; openbare les gehouden bij den aanvang van zijn lessen als privaatdocent in de oostersche rechtsgeschiedenis en de grieksch-egyptische papyrologie aan de Rijks-Universiteit te Leiden op Woensdag 31 Januari 1934 (Leiden: E. J. Brill, 1934)

Davidson, A. B., and A. W. Streane, The Book of the Prophet Ezekiel, Cambridge Bible for Schools and Colleges (Cambridge: Cambridge University, 1916)

Davies, Eryl W., "Inheritance Rights and the Hebrew Levirate Marriage, Part 1," VT 31 (1981) 138-144 

(1981) $257-268$

"Inheritance Rights and the Hebrew Levirate Marriage, Part 2," VT 31

Davies, G. H., Exodus, Torch Bible Commentary (London: SCM, 1967)

Day, John, "Pre-Deuteronomic Allusions to the Covenant in Hosea and Psalm LXXVIII," VT 36 (1986) 1-12

De Boer, P. A. H., Fatherhood and Motherhood in Israelite and Judean Piety (Leiden: E. J. Brill, 1974)

Deane, W. J., "Exposition of Malachi," in The Pulpit Commentary, H. D. M. Spence and Joseph S. Exell, eds. (New York: Funk \& Wagnalls, Co., n.d.)

Deden, D., De kleine profeten, BOT (Roermond-Maaseik: Romen \& Zonen, 1953)

Deissler, Alfons, Zwölf Propheten, Die Neue Echter Bibel, 4 (Stuttgart: Echter, 1981)

Deissler, Alfons, and M. Delcor, Les petits prophètes, II, Michée-Malachi, La Sainte Bible, Pirot-Clamer 8 (Paris: Letouzey \& Ané, 1964)

Delaughter, Thomas J., Malachi: Messenger of Divine Love (New Orleans: Insight, 1976)

Delitzsch, Franz, Proverbs, Ecclesiastes, Song of Solomon, James Martin, trans., in Carl Friedrich Keil and F. Delitzsch, Commentary on the Old Testament (Edinburgh: T. \& T. Clark, 1875 [reprinted 1982 by Eerdmans, Grand Rapids, MI])

Deller, K., “šmn bll (Hosea 12,2). Additional Evidence," Biblica 46 (1965) 349-52

Dentan, Robert C., and Willard L. Sperry, "The Book of Malachi," in The Interpreter's Bible, 6, George Arthur Buttrick, ed, (New York and Nashville: Abingdon; London: Nelson, 1956) 1115-1144

DeRoche, Michael, "Jeremiah 2:2-3 and Israel's Love for God during the Wilderness Wandering," CBQ 45 (1983) 364-76

Dever, William G., "Asherah, Consort of Yahweh? New Evidence from Kuntillet 'Ajrûd," BASOR 255 (1984) 21-37

DeVries, Simon J., 1 Kings, WBC 12 (Waco, TX: Waco Books, 1985)

Dhorme, Édouard, $A$ Commentary on the Book of Job, with a Prefatory Note by H. H. Rowley; with a Preface by Francis I. Andersen, Harold Knight, trans. (Nashville, Camden, New York: Thomas Nelson, 1984)

Dieu, Ludovicus de, Critica sacra (Amstelodami, 1693)

Dijk, H. J. van, Ezekiel's Prophecy on Tyre, BibOr 20 (Rome: Pontifical Biblical Institute, 1968)

Dodd, C. H., According to the Scriptures. The Substructure of New Testament Theology (Digswell Place, Welwyn, Herts: James Nisbet and Co., Ltd., 1952)

Dods, Marcus, The Post-Exilian Prophets. Haggai, Zechariah, Malachi; with Introductions and Notes in Handbooks for Bible Classes (Edinburgh: T. \& T. Clark, 1881)

Dommershausen, Werner, "חלל chälal II," in TDOT 4 (Grand Rapids, MI: Eerdmans, 1980) $417-421$

Donner, Herbert, “Adoption oder Legitimation?” Oriens Antiquus 8 (1969) 87-119

Doughty, Charles Montagu, Travels in Arabia Deserta, 2 vols. (Cambridge: Cambridge University Press, 1888)

Draffkorn, Anne E., "Ilāni/Elohim,” JBL 76 (1957) 216-224

Drake, W., "Malachi," in The Holy Bible according to the Authorized Version (A.D. 1611), with an Explanatory and Critical Commentary and a Revision of the 
Translation by Bishops and Other Clergy of the Anglican Church, VI, F. C. Cook, ed. (New York: Charles Scribner's Sons, 1897)

Driver, Godfrey Rolles, “'I was [am] no prophet, neither was [am] I a prophet's son.' (RV)," ExpTim 67 (1955-56) 91-92

Driver, Godfrey Rolles, and John C. Miles, The Assyrian Laws. Edited with translation and commentary (Oxford: Clarendon, 1935)

Driver, Godfrey Rolles, and John C. Miles, The Babylonian Laws, 2 vols., (Oxford: Clarendon, vol. 1, 1952, vol. 2, 1955)

Driver, Samuel Rolles, A Treatise on the Use of Tenses in Hebrew and Some Other Syntactical Questions, 3rd ed. (Oxford: Clarendon, 1892 [1st ed. 1874])

, A Critical and Exegetical Commentary on Deuteronomy, 3rd ed., ICC (Edinburgh: T. \& T. Clark, 1902)

The Book of Genesis with Introduction and Notes, 3rd ed. (London:

Methuen \& Co., 1904)

, The Minor Prophets: Nahum, Habakkuk, Zephaniah, Haggai, Zechariah, Malachi. Introductions, Revised Version with Notes, Index, and Map The Century Bible, Walter F. Adeney, ed. (Edinburgh and London: T. C. and E. J. Jack; New York: Oxford, 1906)

Driver, Samuel Rolles, and George Buchanan Gray, A Critical and Exegetical Commentary on the Book of Job Together with a New Translation, 2 vols., ICC (Edinburgh: T. \& T. Clark, 1921 [2nd ed., 1950])

Driver, Samuel Rolles, and H. C. O. Lanchester, The Books of Joel and Amos, The Cambridge Bible for Schools and Colleges, Alexander Francis Kirkpatrick, ed. (Cambridge: The University Press, 1915 [1st ed. 1897])

Drusius, Joh., Commentarius in prophetas minores XII, ed. Sixtinus Amama (Amstelredami, 1627)

Duhm, Bernhard, Die zwölf Propheten in den Versmassen der Urschrift übersetzt (Tübingen: J. C. B. Mohr [P. Siebeck], 1910)

, Anmerkungen zu den zwölf Propheten Sonderabdruck aus der ZAW 31: 143; 81-1 10; 161-204 (Giessen: Rickeische, 1911)

Dumbrell, William J., "Malachi and the Ezra-Nehemiah Reforms," The Reformed Theological Review 35 (1976) 42-52

Dunstan, Gordon R., "The Marriage Covenant," Theology 78 (1975) 244-52

Dupont-Sommer, A., The Essene Writings From Qumran, G. Vermes, trans. (Oxford:

Basil Blackwell, 1961 [reprinted 1973 by Peter Smith, Gloucester, MA])

Durham, John I., Exodus, WBC 3 (Waco, TX: Word Books, 1987)

Dwight, Sereno Edwards, The Hebrew Wife (New York: Leavitt, 1836)

Dyrness, William, Themes in Old Testament Theology (Downers Grove, IL: InterVarsity, 1979)

Ebcling, Erich, Die akkadische Gebetsserie "Handerhebung" von neuem gesammelt und herausgegeben (Berlin: Akademie Verlag, 1953)

, ed., Keilschrifttexte aus Assur juristischen Inhalts, Wissenschaftliche Veröffentlichungen der Deutschen Orient-Gesellschaft 50 (Leipzig: J. C.

Hinrichs, 1927) 
Ehrlich, Arnold Bogumil, Randglossen zur hebräischen Bibel. Textkritisches, Sprachliches und Sachliches, 7 Bde (Leipzig: Hinrichs, 1908-1914 [reprint Hildesheim 1968])

Eibl-Eibesfeldt, I., Ethnology: The Biology of Behavior (New York: Holt, Rinehart and Winston, 1975)

Eichrodt, Walther, Theology of the Old Testament, 2 vols., P. R. Ackroyd, trans. (London: SCM, 1961)

Ezekiel. A Commentary, Cosslett Quin, trans., OTL (Philadelphia:

Westminster, 1970)

, "Prophet and Covenant," in Proclamation and Presence. Old Testament essays in honour of G. Henton Davies, John I. Durham and J. R. Porter, eds. (London and Richmond: John Knox Press, 1970) 167-188

Eissfeldt, Otto, The Old Testament: An Introduction, P. R. Ackroyd, trans. (New York: Harper \& Row, 1965)

, "Renaming in the Old Testament," in Words and Meanings. Essays presented to David Winton Thomas on his retirement from the Regius Professorship of Hebrew in the University of Cambridge, 1968, Peter R. Ackroyd and Barnabas Lindars, eds. (Cambridge: University Press, 1968) 69-79

Elliger, Karl, Das Buch der zwölf kleinen Propheten. II. Die Propheten Nahum, Habakuk, Zephanja, Haggai, Zacharja, Maleachi, ATD 25/2 (Göttingen: Vandenhoeck \& Ruprecht, 1950 [8 Aufl. 1981]) , Leviticus, HAT (Tühingen: J. C. B. Mohr [Paul Siebeck], 1966)

, Deuterojesaja. 1. Teilband: Jesaja 40,1-45,7, BKAT XI/1 (NeukirchenVluyn: Neukirchener Verlag, 1978)

Elliger, Karl, and W. Rudolph, eds., Biblia Hebraica Stuttgartensia (Stuttgart: Deutsche Bibelgesellschaft, 1983)

Epstein, Louis M., The Jewish Marriage Contract. A Study in the Status of the Woman in Jewish Law (New York: Jewish Theological Seminary of America, 1927)

, Marriage Laws in Bible and Talmud, HSS 12 (Cambridge, MA: Harvard University [reprinted 1968], 1942)

Erlandsson, Seth, "אָר 'acherr," in TDOT 1 (Grand Rapids, MI: Eerdmans, 1977) 201203

, “דָָּּר, bāghadh," in TDOT 1 (Grand Rapids, MI: Eerdmans, 1977) 470-473 , "זָזָ, zānāh," in TDOT 4 (Grand Rapids, MI: Eerdmans, 1980) 99-104

Even-Shoshan, Abraham, ed., A New Concordance of the Old Testament Using the Hebrew and Aramaic Text, Intro. by John H. Sailhamer (Grand Rapids, MI: Baker and Ridgefield, 1984 [Jerusalem: Kiryat Sepher, 1983])

Ewald, Georg Heinrich August von, Commentary on the Prophets of the Old Testament, 5: Commentary on the Books of Haggái, Zakharya, Mal'aki, Yona, Barûkh, Daniel, with Translation, J. Frederick Smith, trans. (Edinburgh and London: Williams and Norgate, 1881)

, Ausführliches Lehrbuch der hebräischen Sprache des alten Bundes, 8 ed. (Leipzig: Hinrichs, 1870)

Eybers, I. H., "The Matrimonial Life of Hosea," Die Ou-Testamentiese Werkgemeenskap in Suid-Afrika 7 (1964-65) 11-34 
Faber, Johann Melchior, "Abweichungen der alten Uebersetzer des Propheten Malachias," Repertorium für Biblische und Morgenländische Litteratur (Leipzig) 6 (1780) 104124

Fairbairn, Patrick, The Christian Treasury (Edinburgh: Johnson, Hunter \& Co., 1847)

Fairbanks, L. A., "Animal and human behavior: guidelines for generalization across species," in Ethnological Psychiatry: Psychopathology in the Context of Evolution Biology, M. T. McGuire and L. A. Fairbanks, eds. (New York: Grune \& Stratton, 1977) $87-110$

Falk, Ze'ev W., "Gestures Expressing Affirmation,” JSS 4 (1959) 268-269 Books, 1964)

, Hebrew Law in Biblical Times. An Introduction (Jerusalem: Wahrmann

, Introduction to Jewish Law of the Second Commonwealth, Arbeiten zur Geschichte des antiken Judentums und des Urchristentums, 11 (Leiden: E. J. Brill, vol. 1, 1972; vol. 2, 1978)

Falkenstein, Adam, Die neusumerischen Gerichtsurkunden, 1 Teil, Bayerische Akademie der Wissenschaften, Philosophisch-historische Klasse, Abhandlungen - Neue Folge Heft 39 (München: Beck, 1956)

Farb, Peter, Consuming Passions: The Anthropology of Eating (New York: Washington Square, 1980)

Fausset, A. R., "Malachi," in A Commentary, Critical and Explanatory on the Old and New Testaments, vol. 1, Robert Iamieson, A. R. Fausset, and David Brown, eds. (Hartford: S. S. Scranton \& Co., 1887)

Feigin, Samuel I., "The Captives in Cuneiform Inscription," AJSL 50 (1934) 217-245

Feinberg, Charles Lee, The Major Messages of the Minor Prophets. Habakkuk: Problems of Faith; Zephaniah: The Day of the Lord; Haggai: Rebuilding the Temple; Malachi:

Formal Worship (New York: American Board of Missions to the Jews, 1951)

Feldman, David M., Marital Relations, Birth Control, and Abortion in Jewish Law (New York: Schocken Books, 1974)

Fensham, Frank Charles, "The Treaty between Solomon and Hiram and the Alalakh Tablets," JBL 79 (1960) 59-60

,"Salt as curse in the Old Testament and the Ancient Near East," BA 25 (1962) $48-50$

,"The Treaty Between Israel and the Gibeonites," BA 27 (1964 |reprinted in The Biblical Archaeologist Reader 3, Edward F. Campbell Jr. and David Noel Freedman, eds., Garden City, NY: Doubleday \& Company, 1970, 121-126]) 96-100

,"The Covenant-Idea in the Book of Hosea," Die Ou-Testamentiese Werkgemeenskap in Suid-Afrika 7 (1964-65) 35-49

, "The Treaty between the Israelites and Tyrians," in International Organization for the study of the Old Testament, Congress Volume, Rome, VTSup 17 (Leiden: E. J. Brill, 1969) 71-87

,"The Covenant as Giving Expression to the Relationship between Old Testament and New Testament," TB 22 (1971) 82-94

, "Father and Son as Terminology for Treaty and Covenant," in Near Eastern Studies in Honor of William Foxwell Albright, Hans Goedicke, ed. (Baltimore: The Johns Hopkins University Press, 1971) 121-135

, “Genesis 34 and Mari," JNSL 4 (1975) 87-90 
, "Covenant, Alliance," in The Illustrated Bible Dictionary, rev. ed., 1, J. D.

Douglas, et al., eds. (Wheaton, IL: Tyndale House Publishers, 1980) 326-331

1982)

, The Books of Ezra and Nehemiah, NICOT (Grand Rapids, MI: Eerdmans,

, Exodus, 3de druk, POT (Nijkerk: G. F. Callenbach, 1984)

, "Oath," in ISBE 3 (Grand Rapids, MI: Eerdmans, 1986) 572-574

Finkelstein, Jacob Joel, "Ammisaduqa's Edict and the Babylonian Law Codes," JCS 15 (1961) 103-104

, "Sex Offences in Sumerian Laws," JAOS 86 (1966) 355-72

, "Cutting the sissiktu in Divorce Proceedings," Die Welt des Orients 8

(1975-76) 236-40

Fisch, Solomon, Ezekiel. Hebrew Text \& English Translation with an Introduction and Commentary, Soncino Books of the Bible, Abraham Cohen, ed. (London: Soncino, 1950)

Fischer, James A., "Notes on the Literary Form and Message of Malachi," $C B Q 34$ (1972) $315-20$

Fishbane, Michael, "Accusations of Adultery: A Study of Law and Scribal Practice in Numbers 5:11-31," HUCA 45 (1974) 24-45

, Biblical Interpretation in Ancient Israel (Oxford: Clarendon, 1985)

Fisher, Eugene J., "Cultic Prostitution in the Ancient Near East? A Reassessment," Biblical Theology Bulletin 6 (1976) 225-236

Fisher, Loren R., F. Brent Knutson, and Donn F. Morgan, eds., Ras Shamra Parallels: Texts From Ugarit and the Hebrew Bible, 1, AnOr 49 (Rome: Pontifical Biblical Institute, 1972)

Fisher, Loren R., Duane E. Smith, and Stan Rummel, eds., Ras Shamra Parallels: Texts From Ugarit and the Hebrew Bible, 2, AnOr 50 (Rome: Pontifical Biblical Institute, 1975)

Fitzmyer S. J., Joseph A., "A Re-Study of an Elephantine Aramaic Marriage Contract (AP 15)," in Near Eastern Studies in Honor of William F. Albright, Hans Goedicke, ed. (Baltimore and London: The Johns Hopkins University Press, 1971 [=A Wandering Aramaean. Collected Aramaic Essays, Missoula, Montana, 1979, 243-71]) 137-68

Fohrer, Georg, “Altes Testament - 'Amphiktyonie' und 'Bund'?” TLZ 91 (1966 [= G. Fohrer, Studien zur alttestamentlichen Theologie und Geschichte, 84-119]) 801-16, 893-904 1968)

, Introduction to the Old Testament, David Green, trans. (London: S.P.C.K.,

Fokkelman, Jan P., Narrative Art and Poetry in the Book of Samuel. Vol. 1: King David (2 Sam. 9-20 and 1 Kings 1-2) (Assen, The Netherlands: Van Gorcum, 1981)

Fourie, L. C. H., "Die betekenis van die verbond as sleutel vir Maleagi," M.Th. diss. (University of Stellenbosch, 1982)

Fraine S.J., J. de, Genesis uit de grondtekst vertaald en uitgelegd, BOT Deel 1 / Boek 1 (Roermond and Maaseik: J. J. Romen \& Zonen Uitgevers, 1963)

France, Richard Thomas, Jesus and the Old Testament (Downers Grove, IL: InterVarsity Press, 1971) 
Frankena, Rintje, "The Vassal Treaties of Esarhaddon and the Dating of Deuteronomy," OTS 14 (1965) 122-154

Freedman, R. David, “'Put Your Hand Under My Thigh' - The Patriarchal Oath,” BAR 2:2(1976) 3-4

Frei, Hans W., The Eclipse of Biblical Narrative. A Study in Eighteenth and Nineteenth Century Hermeneutics Yale University, 1974)

Frey, Hellmuth, Das Buch der Kirche in der Weltwende: Die kleinen nachexilischen Propheten, Die Botschaft des Alten Testaments 24, 5e Aufl. (Stuttgart: Calwer, 1963)

Friedman, M. A., "The Minimum Mohar Payment as Reflected in the Geniza Documents: Marriage Gift or Endowment Pledge?" Proceedings of the American Academy for Jewish Research 43 (1976) 15-48

(1980) 199-204

"Israel's Response in Hosea 2:17b: 'You Are My Husband'," JBL 99

, Jewish Marriage in Palestine. A Cairo Geniza Study, 2 vols. (Tel-Aviv: Tel Aviv University, The Chaim Rosenberg School of Jewish Studies and 'Moreshet' Project for the Study of Eastern Jewry; and New York: The Jewish Theological Seminary of America, 1980-81)

Frymer-Kensky, Tikva S., "The Atrahasis Epic and its Significance for our Understanding of Genesis 1-9," BA 40 (1977) 147-155 (1984) 11-26

"The Strange Case of the Suspected Sotah (Numbers v 11-31)," VT 34 , "The Judicial Ordeal in the Ancient Near East," Ph.D. diss. (Yale, 1977)

Fuhs, H. F., Ezechiel 1-24, Die Neue Echter Bibel (Würzburg: Echter, 1984)

Fuller, Daniel P., Gospel and Law: Contrast or Continuum? (Grand Rapids, MI:

Eerdmans, 1980)

Fuller, Russell, "Does Yahweh Hate Divorce? Malachi 2:16 and Text of Malachi at Qumran," a paper read at the Annual Meeting of the New England Section of the Society of Biblical Literature, Cambridge, MA, March 25, 1988 (1988)

, "untitled paper on Malachi 2:10-16," (c/o Wellesley College, Wellesley, MA 02181, n.d.) 1-12. See Fuller's forthcoming treatment of 4QXIIa in JBL and DJD.

Funk, Robert W., A Beginning-Intermediate Grammar of Hellenistic Greek, Sources for Biblical Study, 2 (Missoula, Montana: Scholars, 1973)

Gadd, Cyril John, “Tablets from Kirkuk," $R A 23$ (1926) 49-161

, "The Harran Inscriptions of Nabonidus," Anatolian Studies 8 (1958) 35-92

Gage, Warren Austin, The Gospel of Genesis. Studies in Protology and Eschatology, Foreword by Bruce K. Waltke (Winona Lake, IN: Carpenter Books, 1984)

Gaster, Theodor H., Customs and Folkways of Jewish Life (New York: William Sloane Associates Publishers, 1955)

, "Sacrifices and Offerings, OT," in IDB 4 (Nashville and New York: Abingdon, 1962) 147-159

, The Dead Sea Scriptures in English Translation with Introduction and Notes, 3rd ed. (Garden City, NY: Anchor / Doubleday, 1976)

Gelb, Ignace Jay, “Review of D. J. Wiseman, The Vassal-Treaties of Esarhaddon,” BibOr 19 (1962) $161-162$ 
Gelin, Albert, Aggée, Zacharie, Malachie, Bible de Jerusalem (Paris: Éditions du Cerf, 1973)

Geller, Markham J., "The Elephantine Papyri and Hosea 2,3: Evidence for the form of the Early Jewish Divorce Writ," JSJ 8 (1977) 139-148

Gemser, Berend, "The Importance of the Motive Clause in Old Testament Law," in International Organization for the Study of the Old Testament, Congress Volume, Copenhagen, 1953, VTSup 1 (Leiden: E. J. Brill, 1953) 50-66

,"The rîb- or Controversy-Pattern in Hebrew Mentality," in Wisdom in Israel and the Ancient Near East. Presented to Harold Henry Rowley by the Editorial Board of Vetus Testamentum in celebration of his 65th birthday, 24 March 1955, M. Noth and D. Winton Thomas, eds., VTSup 3 (Leiden: E. J. Brill, 1955) 120-137

,"The Instructions of Onchsheshonqy and Biblical Wisdom Literature," International Organization for the Study of the Old Testament, Congress Volume, Oxford, 1959, VTSup 7 (Leiden: E. J. Brill, 1960) 102-128

, Sprüche Salomos, 2e Aufl., HAT 16 (Tübingen: J. C. B. Mohr, 1963)

Gerstenberger, Erhard, "review of Treaty and Covenant, by Dennis J. McCarthy, S.J., Rome: Pontifical Biblical Institute, 1963 (AnBib, Vol. 21)," JBL 83 (1964) 198-99

, "Covenant and Commandment," JBL 84 (1965) 38-51

, Wesen und Herkunft des Apodiktischen Rechts, WMANT 20 (NeukirchenVluyn: Neukirchener Verlag, 1965)

, "בעת t'b pi. verabscheuen," in THAT 2 (München: Chr. Kaiser Verlag; Zürich: Theologischer Verlag, 1984) 1051-1055

Gesenius, Wilhelm, Hebrew Grammar, rev. by E. Kautzsch, 2nd English ed., A. E. Cowley, ed. and tr. (Oxford: Clarendon, 1910)

, Gesenius' Hebrew and Chaldee Lexicon, Samuel P. Tregelles, trans.

(Grand Rapids, MI: Eerdmans, 1949 [German orig., 1835])

Gibson, John C. L., Textbook of Syrian Semitic Inscriptions. Vol II: Aramaic Inscriptions including inscriptions in the dialect of Zenjirli (Oxford: Clarendon, 1975)

Gilbert S. J., Maurice, “'Une seule chair’ (Gn 2,24),” Nouvelle Revue Théologique 100 (1978) 66-89

Ginsberg, H. Louis, "Studies in Hosea 1-3," in Yehezkel Kaufmann Jubilee Volume, M. Haran, ed. (Jerusalem: Magnes, 1960)

Ginzberg, L., The Legends of the Jews (Philadelphia: Jewish Publication Society, 1928)

Gispen, W. H., Genesis vertaald en verklaard, COT (Kampen: J. H. Kok, 1974)

, Exodus, Ed van der Maas, trans., Bible Student's Commentary (Grand

Rapids, MI: Zondervan and St. Catharines, Ont.: Paideia, 1982)

Glazier-McDonald, Beth, "Malachi 2:12: ‘ēr we‘ōneh - Another Look," JBL 105 (1986) 295-298

, "Intermarriage, Divorce, and the bat 'èl nēkār: Insights into Mal 2:10-16," $J B L 106$ (1987) 603-611

, Malachi: The Divine Messenger, SBLDS, 98, J. J. M. Roberts and Charles Talbert, eds. (Atlanta, GA: Scholars, 1987)

Goetze, Albrecht, “Hittite ふ̌ek- / šak- '(Legally) Recognize' in the Treaties,” JCS 22 (196869) $7-8$ 
Goldman, Solomon, "Obadiah," in The Twelve Prophets, Soncino Books of the Bible, Abraham Cohen, ed. (London, Jerusalem, New York: Soncino, 1948) 127-135

Gordis, Robert, "Hosea's Marriage and Message: A New Approach," HUCA 25 (1954) 9. 35

, The Book of Job. Commentary, New Translation and Special Studies (New York City: The Jewish Theological Seminary of America, 1978)

Gordon, Cyrus H., "Nuzi Tablets Relating to Women," in Miscellanea Orientalia dedicata Antonio Deimel annos LXX complenti, AnOr 12 (Rome: Pontifical Biblical Institute, 1935) 163-84 (1936) $277-280$

"Hosea 2:4-5 in the Light of New Semitic Inscriptions," $Z A W 54$ [N.F. 13] 66 (1937) 25-27

[Supplement, 1967])

Ugaritic Textbook, AnOr 38 (Rome: Pontifical Biblical Institute, 1965

, "His Name is 'One'," JNES 29 (1970) 198-199

, "Erēbu Marriage," in Studies on the Civilization and Culture of Nuzi and the Hurrians in Honor of Ernest R. Lacheman, Martha A. Morrison and David I. Owen, eds. (Winona Lake, IN: Eisenbrauns, 1981) 155-160

Gordon, Robert Patterson, "David's Rise and Saul's Demise: Narrative Analogy in 1 Samuel 24-26 (Tyndale OT Lecture 1979)," TB 31 (1980) 37-64

, 1 and 2 Samuel, Old Testament Guides, R. N. Whybray, ed. (Sheffield:

JSOT Press, 1984)

, $1 \& 2$ Samuel. A Commentary (Exeter: Paternoster, 1986)

Görg, M., "굮 bāzāh," in TDOT 1 (Grand Rapids, MI: Eerdmans, 1977) 60-65

Goslinga, C. J., Het Tweede Boek Samuël, COT (Kampen: J. H. Kok, 1962)

Goss, Karl, "Die literarische Verwandschaft Jeremias mit Hosea," Ph.D. diss. (Berlin, 1930)

42 (1931) 241-265; 327-343 "

Gottwald, Norman K., The Hebrew Bible: A Socio-Literary Introduction (Philadelphia, PA: Fortress, 1985)

Gowan, Donald E., "Prophets, Deuteronomy and Syncretistic Cult in Israel," in Essays in Divinity VI: Transitions in Biblical Scholarship, J. Coert Rylaarsdam, ed. (Chicago, IL: The University of Chicago, 1968) 93-112

Graetz, H., Emendationes in plerosque Sacrae Scripturae V. T. libros ex relicto defuncti auctoris manuscripto, 3 Lieff., Guil. Bacher, ed. (Vratislaviae, 1892-94)

Granqvist, Hilma, Marriage Conditions in a Palestinian Village I-II. Societas Scientarum Fennica, Commentationes Humanarum Litterarum, III,8, and VI,8 (Helsingfors: Centraltryckeriet, 1931,1935)

Gray, George Buchanan. Isaiah I-XXVII, 4th ed., ICC (Edinburgh: T. \& T. Clark, 1956 [1st ed., 1912])

Gray, John, Joshua, Judges, and Ruth, NCB (Grand Rapids, MI: Eerdmans, and Basingstoke: Marshall Morgan \& Scott Publishing Ltd., 1986) 
Grayson, Albert Kirk, Assyrian Royal Inscriptions, 2 vols., Records of the Ancient Near East, Hans Goedicke, ed. (Wiesbaden: Otto Harrassowitz, vol. 1 1972, vol. 2 1976)

Green, B., "A Study of Field and Seed Symbolism in the Biblical Story of Ruth," Ph.D. diss. (Graduate Theological Union, 1980)

Greenberg, Moshe, "The Hebrew Oath Particle, hay / hêe," JBL 76 (1957) 34-39

, "Some Postulates of Biblical Criminal Law," in Yehezkel Kaufmann Jubilee Volume, M. Haran, ed. (Jerusalem: Magnes, 1960) 5-28

1962) 733-744

"Crimes and Punishments," in IDB 1 (Nashville and New York: Abingdon,

, Ezekiel 1-20. A New Translation with Introduction and Commentary, AB

22 (Garden City, NY: Doubleday \& Company, 1983)

, "Ezekiel 17: A Holistic Interpretation," JAOS 103 (1983) 149-154

, "More Reflections on Biblical Criminal Law," in Studies in Bible 1986:

Scripta Hierosolymitana: Publications of the Hebrew University Jerusalem 31, S.

Japhet, ed. (Jerusalem: Magnes, 1986)

, "Reply to the Comments of John Welch," in Religion and Law. Biblical-

Judaic and Islamic Perspectives, Edwin B. Firmage, Bernard G. Weiss, and John W. Welch, eds. (Winona Lake, IN: Eisenbrauns, 1990) 120-125

Greengus, Samuel, "The Aramaic Marriage Contracts in the Light of the Ancient Near East and the Later Jewish Materials," M.A. diss. (University of Chicago, 1959)

, "Old Babylonian Marriage Ceremonies and Rites," JCS 20 (1966) 55-72

, "The Old Babylonian Marriage Contract," JAOS 89 (1969) 505-32

, "A Textbook Case of Adultery in Ancient Mesopotamia," HUCA 40-41

(1969-70) 33-44

, "Law in the OT," in IDBSup (Nashville, TN: Abingdon, 1976) 532-537

Old Babylonian Tablets from Ishchali and Vicinity, Nederlands Historisch-

Archaelogisch Institut te Instanbul (Leiden: Nederlands Instituut voor het Nabije

Oosten, 1979)

Greenstein, E. L., “'To grasp the Hem' in Ugaritic Literature,” VT 32 (1982) 217-218

Greidanus, Sidney, Sola Scriptura. Problems and Principles in Preaching Historical Texts

(Toronto: Wedge Publishing Foundation, 1970)

Grelot, Pierre, Man and Wife in Scripture (New York: Herder and Herder, 1964)

, "The Institution of Marriage: Its Evolution in the Old Testament," Concilium $55(1970) 39-50$

Griffith, F. L., "The Millingen Papyrus," Zeitschrift für ägyptische Sprache und Altertumskunde 34 (1896) 35-51

Grintz, Jehoshua M., "The Treaty of Joshua with the Gibeonites," JAOS 86 (1966) 113 126

Grosz, Katarzyna, "Daughters Adopted as Sons at Nuzi and Emar," in La Femme dans le proche-orient antique, Compte Rendu de la XXXIVeme Rencontre Assyriologique Internationale (Paris, 7-10 Juillet 1986), Jean-Maric Durand, ed. (Paris: Editions Recherche sur les Civilisations, 1987) 81-86

, "Some Aspects of the Position of Women in Nuzi," in Women's Earliest Records From Ancient Egypt and Western Asia. Proceedings of the Conference on Women in the Ancient Near East, Brown University, Providence Rhode Island, 
November 5-7, 1987, Barbara S. Lesko, ed., Brown Judaic Studies 166 (Atlanta, Georgia: Scholars, 1989) 167-180 (responses on pp. 181-189)

Grotius, Hugo, Opera omnia theologica, I, Annotationes ad Vetus Testamentum (Basileae, 1732)

Gruber, Mayer I., Aspects of Nonverbal Communication In the Ancient Near East, 2 vols., Studia Pohl 12/1 and 12/2 (Rome: Biblical Institute, 1980)

Gunkel, Hermann, Genesis übersetzt und erklärt, 9e Aufl., HKAT I/1, W. Nowack, ed. (Göttingen: Vandenhoeck und Ruprecht [1st ed.: 1902], 1977 [= 3e Aufl., 1910])

Ha, John, Genesis 15: A Theological Compendium of Pentateuchal History (Berlin: Walter de Gruyter, 1989)

Haase, Richard, Einführung in das Studium Keilschriftlicher Rechtsquellen (Wiesbaden: O. Harrassowitz, 1965)

Habel, Norman C., The Book of Job. A Commentary, OTL (Philadelphia: Westminster and London: SCM Ltd., 1985)

Halbe, J., Das Privilegrecht Jahwes. Ex. 34, 10-26: Gestalt und Wesen, Herkunft und Wirken in vordeuteronomischer Zeit, FRLANT, 114 (Göttingen: Vandenhoeck \& Ruprecht, 1975)

Haller, Max, Das Judentum. Geschichtsschreibung, Prophetie und Gesetzgebung nach dem Exil, 2e Aufl., Die Schriften des Alten Testaments [SAT] in Auswahl übersetzt und erklärt von Hermann Gunkel u. a., II/3 (Göttingen: Vandenhoeck \& Ruprecht, 1925 [1e Aufl. 1914])

Hallo, William W., "The Origins of the Sacrificial Cult: New Evidence from Mesopotamia and Israel," in Ancient Israelite Religion. Essays in Honor of Frank Moore Cross, Patrick D. Miller Jr., Paul D. Hanson, and S. Dean McBride, eds. (Philadelphia: Fortress, 1987) 3-13

Hamburg, B. A., "The biosocial basis of sex differences," in Human Evolution: Biosocial Perspectives, S. L. Washburn and E. R. McCown, eds. (Menlow Park, CA: Benjamin/Cummings, 1978) 155-213

Hamilton, Victor P., The Book of Genesis, Chapters 1-17, NICOT (Grand Rapids, MI: Eerdmans, 1990)

Hammond, Philip C., The Nabataeans - Their History, Culture and Archaeology, Studies in Mediterranean Archaeology 27 (Gothenburg, Sweden: Paul Astroms, 1973)

Harper, Robert Francis, Assyrian and Babylonian Letters, 14 vols. (Chicago: University Press, 1892-1914)

Harper, William Rainey, A Critical and Exegetical Commentary on Amos and Hosea, ICC (Edinburgh: T. \& T. Clark, 1905)

Harris, R. Laird, Gleason L. Archer Jr., and Bruce K. Waltke, eds., Theological Wordbook of the Old Testament (Chicago: Moody Press, 1980)

Harris, Rivkah, "The Naditu Woman," in Studies presented to A. Leo Oppenheim, June 7, 1964, R. D. Biggs and J. A. Brinkman, eds. (Chicago: Oriental Institute, University of Chicago Press, 1964) 105-35

365

"The Case of Three Babylonian Marriage Contracts," JNES 33 (1974) 363-

, "Independent Women in Ancient Mesopotamia?" in Women's Earliest Records From Ancient Egypt and Western Asia. Proceedings of the Conference on Women in the Ancient Near East, Brown University, Providence Rhode Island 
November 5-7, 1987, Barbara S. Lesko, ed., Brown Judaic Studies 166 (Atlanta, Georgia: Scholars, 1989) 145-156

Harrison, Roland Kenneth, Introduction to the Old Testament (Grand Rapids, MI:
Eerdmans, 1969)

Inter-Varsity, 1980)

Hartley, John E., The Book of Job, NICOT (Grand Rapids, MI: Eerdmans, 1988)

Hartman C.SS.R., Louis F., and Alexander A. Di Lella O.F.M., The Book of Daniel, AB 23 (Garden City, NY: Doubleday and Company, 1978)

Hartmann, B., "Es gibt keinen Gott ausser Jahwe. Zur generellen Verneinung im Hebräischen," ZDMG 110 (1960) 229-235

Hasel, Gerhard F., Old Testament Theology: Basic Issues in the Current Debate, 2nd ed.

(Grand Rapids, MI: Eerdmans, 1975)

"Linguistic Considerations Regarding the Translation of Isaiah's Shear-

Jashub : A Reassessment," AUSS 9 (1971) 36-46

$152-69$

"Semantic Values of Derivatives of the Hebrew root s'r," AUSS 11 (1973)

, "Remnant," in IDBSup (Nashville, TN: Abingdon, 1976) 736-38

The Remnant. The History and Theology of the Remnant Idea from Genesis

to Isaiah, 3rd. ed., Andrews University Monographs, 5 (Berrien Springs: Andrews

University, 1980)

, "The Meaning of the Animal Rite in Genesis 15," JSOT 19 (1981) 61-78

Hauck, Friedrich, " $\mu \mathrm{O} \chi \chi \in \dot{U} \omega, \kappa T \lambda .$, " in TDNT 4 (Grand Rapids, MI: Eerdmans, 1967) 729-735

Hauck, Friedrich, and Siegfried Schulz, "то́ $\nu \nu \eta, к T \lambda ., "$ in TDNT 6 (Grand Rapids, MI: Eerdmans, 1968) 579-595

Hauser, Alan Jon, "Linguistic and Thematic Links between Genesis 4:1-16 and Genesis 23," JETS 23 (1980) 297-305

" "Genesis 2-3: The Theme of Intimacy and Alienation," in Art and Meaning: Rhetoric in Biblical Literature, JSOTSup 19, D. J. A. Clines, D. M. Gunn, and A. J. Hauser, eds. (Sheffield: JSOT Press, 1982) 20-36

Hawthorne, G. F., "Name," in ISBE 3 (Grand Rapids, MI: Eerdmans, 1986) 480-483

Heaton, Eric William, “The Root $s$ ' $r$ and the Doctrine of the Remnant," JTS NS 3 (1952) 27-39

Heidel, Alexander, The Gilgamesh Epic and Old Testament Parallels, 2nd ed. (Chicago: The University of Chicago, 1949)

The Babylonian Genesis. The Story of Creation, 2nd ed. (Chicago: The University of Chicago, 1951)

Held, Moshe, "Philological Notes on the Mari Covenant Rituals," BASOR 200 (1970) 32 40

Henderson, Ebenezer, The Twelve Minor Prophets. Translated from the original Hebrew with a critical and exegetical commentary, 2nd ed. (Hamilton, Adams and Co.. 1858 [reprinted by Baker, 1980])

Hendricks, Hans Jurgens, "Juridical Aspects of the Marriage Metaphor in Hosea and Jeremiah,” D.Lit. diss. (University of Stellenbosch, South Africa, n.d. [1974?]) 
Hengstenberg, Ernst Wilhelm, Christology of the Old Testament, 2 vols. (McLean, VA: MacDonald [reprint, n.d.], 1854)

Herrmann, Johannes, Ezechiel, KAT XI (Leipzig and Erlangen: A. Deichert, 1924)

Hertz, J. H., "Foreword," in The Babylonian Talmud. Seder Nashim, 4 vols., Isidore Epstein, ed. 1 (London: Soncino, 1936) xiii-xxvi

Hertzberg, Hans Wilhem, I and II Samuel. A Commentary, J. S. Bowden, trans., OTL (Philadelphia: Westminster, 1964)

Heth, William A., and Gordon J. Wenham, Jesus and Divorce. Towards an Evangelical Understanding of New Testament Teaching (London, Sydney, Auckland, Toronto: Hodder and Stoughton, 1984)

Hieronymus (Jerome), "Commentariorum in Malachiam Prophetam," in S. Hieronymi Presbyteria Opera, Pars I, Opera Exegetica 6 in the Corpus Christianorum series (Turnholti: Typographi Brepols Editores Pontificii, 1970)

Hillers, Delbert Roy, Treaty-Curses and the Old Testament Prophets, BibOr 16 (Rome:

Pontifical Biblical Institute, 1964)

, Covenant: The History of a Biblical Idea, Seminars in the History of Ideas

(Baltimore, MD: The Johns Hopkins University Press, 1969)

, Lamentations. Introduction, Translation and Notes, AB 7A (Garden City,

New York: Doubleday \& Company, 1972)

Hitzig, Ferdinand, and Heinrich Steiner, Die zwölf kleinen Propheten, 4e Aufl.,

Kurzgefasstes exegetisches, HAT [KEH] (Leipzig: S. Hirzel, 1881)

Hoehner, Harold W., "A Response to Divorce and Remarriage [a paper read by William A. Heth]," in Applying the Scriptures. Papers from ICBI Summit III, Kenneth S.

Kantzer, ed. (Grand Rapids, MI: Academie Books, Zondervan, 1987) 240-246

Hofmann, Johann Christian Konrad von, Der Schriftbeweis, 2 Hälften in 3 Bden, 2. Aufl. (Nördlingen: C. H. Beck, 1857-60)

Hoftijzer, J., "Review: the Nominal Clause Reconsidered," VT 23 (1973) 446-510

Holladay, William L., A Concise Hebrew and Aramaic Lexicon of the Old Testament.

Based upon the lexical work of Ludwig Koehler and Walter Baumgartner (Grand Rapids, MI: Eerdmans; and Leiden: E. J. Brill, 1971)

, Jeremiah 1. A Commentary on the Book of the Prophet Jeremiah, Chapters

$1-25$, Hermeneia (Philadelphia: Fortress, 1986)

Holst, Robert, "Polygamy and the Bible," International Review of Missions (London Edinburgh Geneva) 56 (1967) 205-213

Holtzmann, Oskar, "Der Prophet Maleachi und der Ursprung des Pharisäerbundes," Archiv für Religionswissenschaft 29 (1931) 1-21

Hooke, Samuel Henry, ed., Myth and Ritual. Essays on the myth and ritual of the Hebrews in relation to the culture pattern of the ancient East (London: Oxford University Press, 1933)

, Myth, Ritual and Kingship. Essays on the Theory and Practice of Kingship in the Ancient Near East and in Israel (Oxford: Clarendon Press, 1958)

Hoonacker, A. van, Les douze petits prophètes, traduits et commentés, Études Bibliques (Paris: Librairie Victor Lecoffre, J. Gabalda et Cie, 1908)

Hopkins, M. K., “The Age of Roman Girls at Marriage,” Population Studies 18 (1964-5) 309-27 
Horst, Friedrich, "Nahum bis Maleachi," in Die zwölf kleinen Propheten, Theodore H. Robinson and Friedrich Horst, ed., HAT, 3e Aufl. (Tübingen: J. C. B. Mohr [Paul Siebeck], 1964 [1e Aufl. 1938])

House, Paul R., The Unity of the Twelve, Bible and Literature Series, 27, JSOTSup 97 (Sheffield: Almond [Sheffield Academic], 1990)

Hrdy, S. B., The Woman That Never Evolved (Boston: Harvard University, 1981)

Hubbard Jr., Robert L., The Book of Ruth, NICOT (Grand Rapids, MI: Eerdmans, 1988)

Huehnergard, John, An Introduction to Old Babylonian Akkadian (New York: Columbia University, 1982) , "Five Tablets From the Vicinity of Emar," RA 77 (1983) 11-43

Huey Jr., F. B., "An Exposition of Malachi," Southwestern Journal of Theology 30 (1987) $12-21$

Huffmon, Herbert B., "The Covenant Lawsuit in the Prophets," JBL 78 (1959) 285-95 , "The Exodus, Sinai and the Credo," $C B Q 27$ (1965) 101-113 , "The Treaty Background of Hebrew yāda", BASOR 181 (1966) 31-37

Huffmon, Herbert B., and S. B. Parker, "A Further Note on the Treaty Background of Hebrew yäda'," BASOR 184 (1966) 36-38

Hugenberger, Gordon P., "Michal," in ISBE 3 (Grand Rapids, MI: Eerdmans, 1986) 348 , "Rib," in ISBE 4 (Grand Rapids, MI: Eerdmans, 1988) 183-185 , "Women in Church Office: Hermeneutics or Exegesis? (A Survey of Approaches to 1 Timothy 2:8-15),"JETS (forthcoming)

Hughes, John H., and Frederick Prussner, Old Testament Theology, its History and Development (Atlanta, GA: John Knox, 1985)

Humbert, Paul, "Mythe de création et mythe paradisiaque dans le second chapitre de la Genèse," Revue d'histoire et de philosophie religieuses 16 (1936) 445-461

, "La femme étrangère du Livre des Proverbes," Revue des Études Sémitique $6(1937) 40-64$

"Les adjectifs 'Zâr' et 'Nokri' et la femme étrangère," in Mélanges Syriens offerts à M. René Dussaud I, Bibliothèque Archéologique et Historique, tome 30 (Paris: Librairie Orientalisk Paul Geuthner, 1939 [= Opuscles d'un hébraïsant. Mémoires de l'Université de Neuchâtel, 26, 1958, 111-118]) 259-66

, "Études sur le récit du paradis et de la chute dans la Genèse," Mémoires de l'Univ. de Neuchâtel 14 (1940) 1-193

, "Etendre la main," VT 12 (1962) 383-395

Hurvitz, Avi, "The Evidence of Language in Dating the Priestly Code; A Linguistic Study in Technical Idioms and Terminology," $R B 81$ (1974) 24-56

, A Linguistic Study of the Relationship between the Priestly Source and the Book of Ezekiel: A New Approach to an Old Problem, Cahiers de la Revue Biblique, 20 (Paris: J. Gabalda et Cie, 1982)

,"The Language of the Priestly Source and its Historical Setting - the Case for an Early Date," Proceedings of the Eighth World Congress of Jewish Studies, Jerusalem, August 16-21, 1981. Panel Sessions: Bible Studies and Hebrew Language (Jerusalem: World Union of Jewish Studies and The Perry Foundation for Biblical Research, 1983) 83-94 

Hvidberg, Flemming Friis, "The Canaanitic Background of Gen I-III," VT 10 (1960) 285 -
94

Weeping and Laughter in the Old Testament. A Study of Canaanite-Israelite Religion, N. Haislund, trans. (Leiden: E. J. Brill; and København: Nyt Nordisk Forlag, Arnold Busck, 1962)

Hyatt, J. Philip, Exodus, NCB (Grand Rapids, MI: Eerdmans; and London: Marshall, Morgan \& Scott Publishing Ltd., 1971)

Isaac, Erich, "Circumcision as Covenant Rite," Anthropos 59 (1964) 444-456

Isaksson, Abel, Marriage and Ministry in the New Temple: A Study With Special

Reference to Mt. 19:1 - 12 and 1 Cor. 11:3-16, Neil Tomkinson with the assistance

of Jean Gray, trans., Acta Seminarii Neotestamentici Upsaliensis 24 (Lund: Gleerup /

Copenhagen: Munsgaard, 1965)

Isopescul, Octavian, Der Prophet Malachias. Einleitung, Übersetzung und Auslegung

(Czernowitz: K. K. Hof und Staatsdruckerei in Wien, 1908)

Jackson, Bernard S., “The Problem of Exodus XXI 22-25 (Ius Talionis)," VT 23 (1973)

271-304

, "Reflections on Biblical Criminal Law," JJS 24 (1973) 8-38

, "Some Literary Features of the Mishpatim," in Wünschet Jerusalem

Frieden. Collected Communications to the XIIth Congress of the International

Organization for the Study of the Old Testament, Jerusalem 1986 (Frankfurt am

Main, Bern, New York, Paris: Verlag Peter Lang, 1987) 235-242

Jacobsen, Thorkild, The Sumerian King List (Chicago: University of Chicago, 1939)

, "The Eridu Genesis," JBL 100 (1981) 513-529

, The Harps That Once... Sumerian Poetry in Translation (New Haven and

London: Yale University Press, 1987)

Jagendorf, Zvi, “'In the morning, behold, it was Leah': Genesis and the Reversal of Sexual

Knowledge," Prooftexts: A Journal of Jewish Literary History 4 (1984) 187-192

Jakobson, Vladimir A., "Studies in Neo-Assyrian Law (I. Matrimonial Law; 2. Legal

Practice)," Altorientalische Forschungen 1 (1974) 115-121

James, Edwin Oliver, Myths and Rites in the Ancient Near East. An Archaeological and Documentary Study (London: Thames and Hudson, 1958)

Japhet, Sara, "Law and 'the Law' in Ezra-Nehemiah," in Proceedings of the Ninth World Congress of Jewish Studies, 1985 Panel Sessions: Bible Studies and Ancient Near East, Moshe Goshen-Gottstein, ed. (Jerusalem: World Union of Jewish Studies, 1988) 66-98

Jastrow, Marcus, A Dictionary of the Targumim, the Talmud Babli and Yerushalmi, and the Midrashic Literature (New York: Traditional Inc., 1903)

Jenni, Ernst, and Claus Westermann, eds., Theologisches Handwörterbuch zum Alten Testament, 2 Bde (München: Chr. Kaiser Verlag und Zürich: Theologischer Verlag, 1971, 1984)

Jensen, Joseph, "Does Porneia Mean Fornication? A Critique of Bruce Malina," NovT 20 (1978) 161-84

Jepsen, Alfred, “Ama ${ }^{h}$ und Schiphchah," VT 8 (1958) 293-97

, "Berith. Ein Beitrag zur Theologie der Exilszeit," in Verbannung und Heimkehr. Beiträge zur Geschichte und Theologie Israels im 6. und 5. Jahrhundert v: 
Chr. Fs für Wilhelm Rudolph, Arnulf Kuschke, ed. (Tübingen: J. C. B. Mohr [Paul Siebeck], 1961) 161-179

Jeremias, Alfred, The Old Testament in the Light of the Ancient East, 2 vols., C. H. W. Johns, ed., C. L. Beaumont, trans. (New York: Putnam's Sons, 1911)

Job, John B., The Covenant of Marriage, The eighth annual lecture sponsored by the association of Conservative Evangelicals in Methodism. Presented at Wroxham Road Methodist Church, Norwich, 1 July, 1981 (n.p., 1981)

Jobling, David K., The Sense of Biblical Narrative: Three Structural Analyses in the Old Testament (1 Samuel 13-31; Numbers 11-12; 1 Kings 17-18), JSOTSup 7 (Sheffield, England: JSOT Press, 1978)

Johnstone, William, “ $y d$ ‘ II, 'be humbled, humiliated'?” VT 41 (1991) 49-62

Jones, Alexander, ed., The Jerusalem Bible (Garden City, NY: Doubleday and Company; London: Darton, Longman \& Todd, Ltd., 1966)

Jones, Douglas Rawlinson, Haggai, Zechariah, Malachi. Introduction and Commentary, Torch Bible Commentaries, John Marsh and Alan Richardson, eds. (London: SCM Ltd., 1962)

Jones, Gwilym H., 1 and 2 Kings, 2 vols., NCB (Grand Rapids, MI: Eerdmans and London: Marshall, Morgan \& Scott Publishing Ltd., 1984)

Joüon, Paul, Grammaire de l'hébreu biblique, 2nd ed. (Rome: Pontifical Biblical Institute, 1923)

Jüngling, Hans-Winfried, Richter 19 -- Ein Plädoyer für das Königtum. Stilistische Analyse der Tendenzerzählung Ri 19, 1-30a; 21,25, AnBib 84 (Rome: Biblical Institute, 1981)

Junker, Hubert, Das Buch Deuteronomium übersetzt und erklärt, Die Heilige Schrift des Alten Testamentes II/2 (Bonn: Peter Hanstein, 1933)

Die zwölf kleinen Propheten. II Häfte: Nahum, Habakuk, Sophonias, Aggäus, Zacharias, Malachias, Die Heilige Schrift des Alten Testamentes VIII/3/II (Bonn: Peter Hanstein, 1938)

Kaiser Jr., Walter C., Toward an Old Testament Theology (Grand Rapids, MI: Zondervan, 1978)

, Toward Old Testament Ethics (Grand Rapids, MI: Academie Books, Zondervan, 1983)

, Malachi. God's Unchanging Love (Grand Rapids, MI: Baker, 1984)

Kaiser, Otto, Isaiah 13-39, A Commentary, R. A. Wilson, trans., OTL (Philadelphia: Westminster, 1974)

Kalluveettil C.M.I., Paul, Declaration and Covenant. A Comprehensive Review of Covenant Formulae from the Old Testament and the Ancient Near East, AnBib 88 (Rome: Biblical Institute, 1982)

Kaufman, Stephen A., "The Structure of the Deuteronomic Law," Maarav 1/2 (1978-79) 105-158

Kedar, Benjamin, "The Latin Translations," in Mikra. Text, Translation, Reading and Interpretation of the Hebrew Bible in Ancient Judaism and Early Christianity, Martin Jan Mulder, ed., Compendia Rerum Iudaicarum ad Novum Testamentum II/1 (Assen/Maastricht: Van Gorcum, and Philadelphia: Fortress, 1988) 299-338

Keel, Othmar, The Symbolism of the Biblical World. Ancient Near Eastern Iconography and the Book of Psalms, Timothy J. Hallett, trans. (New York: Seabury, 1978) 
Keil, Carl Friedrich, Biblical Commentary on the Prophecies of Ezekiel, 3 vols. in 1, James Martin, trans., in Carl Friedrich Keil and F. Delitzsch, Commentary on the Old Testament (Edinburgh: T. \& T. Clark, 1876 [Reprinted Grand Rapids MI: Eerdmans, 1982])

Keil, Carl Friedrich, and Franz Delitzsch, The Pentateuch, 3 vols. James Martin, trans., in Carl Friedrich Keil and F. Delitzsch, Commentary on the Old Testament (Edinburgh: T. \& T. Clark, 1878 [Reprinted Grand Rapids MI: Eerdmans, 1981])

Keil, Carl Friedrich, and Franz Delitzsch, The Twelve Minor Prophets, 2 vols., James Martin, trans., in Carl Friedrich Keil and F. Delitzsch, Commentary on the Old Testament (Edinburgh: T. \& T. Clark, 1868 [reprinted Grand Rapids, MI: Eerdmans, 1954])

Keller, C. A., "“ָָ 'ālā Verfluchung," THAT 1 (München: Chr. Kaiser Verlag, Zürich: Theologischer Verlag, 1984) 149-152

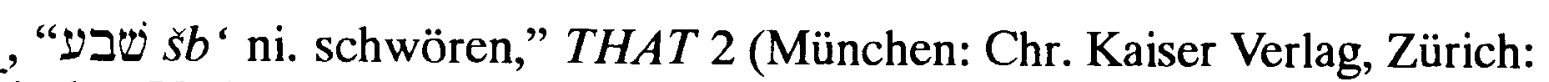
Theologischer Verlag, 1984) 855-863

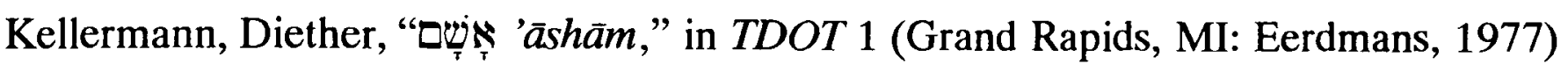
429-437

Kellermann, Ulrich, "Erwägungen zum Esragesetz," $Z A W 80$ (1968) 373-85

Kelley, Page H., Layman's Bible Book Commentary, Micah, Nahum, Habakkuk, Zephaniah, Haggai, Zechariah, Malachi (Nashville, TN: Broadman, 1984)

Kennedy, James M., "Peasants in Revolt: Political Allegory in Genesis 2-3," JSOT 47 (1990) 3-14

Khanjian, John, "Wisdom," in RSP 2 (Rome: Pontifical Biblical Institute, 1975) 371-400

Kidner, Derek, Proverbs. An Introduction and Commentary, TOTC (Downers Grove, IL: InterVarsity, 1964)

, “Genesis 2:5,6: wet or dry?" TB 17 (1966) 109-114

, Genesis. An Introduction and Commentary, TOTC (Downers Grove, IL:

Inter-Varsity, 1967)

, Ezra and Nehemiah. An Introduction and Commentary, TOTC (Leicester,

England: InterVarsity, 1979)

Love to the Loveless. The Message of Hosea, The Bible Speaks Today,

John R. W. Stott and J. A. Motyer, eds. (Downers Grove, IL: InterVarsity, 1981)

Kikawada, Isaac M., "Literary Convention of the Primaeval History," Annual of Japanese Biblical Institute 1 (1975) 3-21

Kikawada, Isaac M., and Arthur Quinn, Before Abraham Was. The Unity of Genesis 1-11 (Nashville: Abingdon, 1985)

King, Leonard William, Babylonian Magic and Sorcery, being "The Prayers of the Lifting of the Hand" (London: Luzac and Co., 1896)

Kirkpatrick, Alexander Francis, The Doctrine of the Prophets. The Warburtonian Lectures for 1886-1890, 3rd ed. (London: MacMillan and Co., Ltd., 1907 [1st ed. 1892])

Kitchen, Kenneth A., Ancient Orient and Old Testament (Downers Grove, IL and Leicester: InterVarsity, 1966)

, The Bible in Its World. The Bible and Archaeology Today (Exeter:

Paternoster; and Downers Grove, IL: InterVarsity, 1977) 
, "Egypt, Ugarit, Qatna and Covenant," in Ugarit-Forschungen.

Internationales Jahrbuch für die Altertumskunde Syrien-Palästinas 11, K. Bergerhof, M. Dietrich, and O. Loretz, eds. (Kevelaer: Verlag Butzon \& Bercker; and Neukirchen-Vluyn: Neukirchener Verlag, 1979) 453-464

, "Law, Treaty, Covenant and Deuteronomy," a paper read on 13 July 1988, Old Testament Study Group of Tyndale Fellowship Cambridge, England (1988)

Klein, Ralph W., Textual Criticism of the Old Testament From the Septuagint to Qumran,

Old Testament Guides to Biblical Scholarship, Gene M. Tucker, ed. (Philadelphia:

Fortress, 1974)

, 1 Samuel, WBC 10 (Waco, TX: Word Books, 1983)

Klíma, Josef, "Marriage and Family in Ancient Mesopotamia," New Orient (Prague) 5 (1966) 99-103

Kline, Meredith G., "The Two Tables of the Covenant," WTJ 22 (1959/60) 133-146

, “Divine Kingship and Genesis 6:1-4,” WTJ 24 (1961/1962) 187-204

, Treaty of the Great King. The Covenant Structure of Deuteronomy: Studies and Commentary (Grand Rapids, MI: Eerdmans, 1963)

, “Abram's Amen," WTJ 31 (1968) 1-11

, By Oath Consigned. A Reinterpretation of the Covenant Signs of

Circumcision and Baptism (Grand Rapids, MI: Eerdmans, 1968)

, "Genesis," in The New Bible Commentary, 3rd rev. ed., D. Guthrie, ed.

(Downers Grove, IL: Inter-Varsity, 1970) 79-114

1975)

, The Structure of Biblical Authority, 2nd ed. (Grand Rapids, MI: Eerdmans,

, “Lex Talionis and the Human Fetus," JETS 20 (1977) 193-201

, Images of the Spirit, Baker Biblical Monograph (Grand Rapids, MI: Baker,

1980)

, Kingdom Prologue (South Hamilton, MA: M. G. Kline, 1981-85)

Kline, Meredith M., "The Holy Spirit as Covenant Witness," Th.M. diss. (Westminster

Theological Seminary, 1972)

Klopfenstein, M. A., Die Lüge nach dem AT (Zürich: Gotthelf Verlag, 1964)

" " bgd treulos handeln," THAT 1 (München: Chr. Kaiser, Zürich:

Theologischer Verlag, 1984) 261-264

Knight, G. A. F., “The Lord is One," ExpTim 79 (1967/68) 8-10

Knudtzon, Jörgen Alexander, Otto Weber, and Erich Ebeling, Die El-Amarna-Tafeln, 2

Bde, Vorderasiatische Bibliothek, 2 (Leipzig: Hinrichs, 1915)

Knutson, F. Brent, "Literary Genres in PRU IV," in RSP 2 (Rome: Pontifical Biblical

Institute, 1975) 153-214

, "Literary Phrases and Formulae," in RSP 2 (Rome: Pontifical Biblical

Institute, 1975) 401-422

, "Political and Foreign Affairs," in RSP 2 (Rome: Pontifical Biblical

Institute, 1975) 109-129

Koch, Robert, "Spirit," in Sacramentum Verbi. An Encyclopedia of Biblical Theology, 3, Johannes B. Bauer, ed. (New York: Herder and Herder, 1970) 869-889 
Kodell O. S. B., Jerome, Lamentations, Haggai, Zechariah, Malachi, Obadiah, Joel, Second Zechariah, Baruch, Old Testament Message, A Biblical-Theological Commentary, 14, Carroll Stuhlmueller C.P. and Martin McNamara M.S.C., eds. (Wilmington, DE: Michael Glazier, 1982)

Koehler, Ludwig, and Walter Baumgartner, Supplementum ad Lexicon in Veteris Testamenti Libros (Leiden: E. J. Brill, 1958)

Koehler, Ludwig, and Walter Baumgartner, Hebräisches und aramäisches Lexicon zum Alten Testament, 3e Aufl. (Leiden: E. J. Brill, 1967, 1974, 1983, 1990)

Koffmahn, E., Die Doppelurkunden aus der Wüste Juda (Leiden: E. J. Brill, 1968)

Köhler, August, Die Weissagungen Maleachis, Die nachexilischen Propheten (Erlangen: Deichert, 1865)

Köhler, Ludwig, "Problems in the Study of the Language of the Old Testament," JSS 1 (1956) 3-24

König, Eduard, Historisch-comparative Syntax der hebräischen Sprache, Schlussteil des historisch-kritischen Lehrgebäudes des Hebräischen (Leipzig: Hinrichs, 1897) , Stilistik, Rhetorik, Poetik in Bezug auf die biblische Litteratur (Leipzig: T. Weicher, 1900).

Konner, Melvin, The Tangled Wing: Biological Constraints on the Human Spirit (New York: Holt, Rinehart and Winston, 1982)

Korošec, Viktor, Hethitische Staatsverträge: Ein Beitrag zur ihrer juristischen Wertung, Leipziger rechtswissenschafilicite Studien, Heft 60 (Leipzig: T. Weicher, 1931)

, "Die Ususehe nach assyrischem Recht," Orientalia NS 6 (1937) 1-12

"Ehe," in Reallexikon der Assyriologie und Vorderasiatischen Archäologie,

Band II: Ber-Ezur und Nachträge, Erich Ebeling and Bruno Meisser, eds. (Berlin and Leipzig: Walter de Gruyter, 1938) 281-299

Korpel, Marjo C. A., “The Poetic Structure of the Priestly Blessing,” JSOT 45 (1989) 3-13

Koschaker, P., Rechtsvergleichende Studien zur Gesetzgebung Hammurapis, Königs von Babylon (Leipzig: Veit, 1917)

,"Quellenkritische Untersuchungen zu den altassyrischen Gesetzen,"

Mitteilungen der Vorderasiatischen Gesellschaft 26 (1921) 1-84

, Neue keilschriftliche Rechtsurkunden aus der El-Amarna Zeit (Leipzig:

Hirzel, 1928 [= Abhandlungen der Sächsischen Akademie der Wissenschaften, PhiloHist. Klasse 39/5, 1929])

,"Fratriarchat, Hausgemeinschaft und Mutterrecht in Keilschriftrechten,"

Zeitschrift für Assyriologie 41 (1933) 1-89

, "Eheschliessung und Kauf nach altem Recht, mit besonderer

Berücksichtigung der älteren Keilschriftrechte," Archiv Orientálni 18 (1950) 210-296

, “Zur Interpretation der Art. 59 des Codex Bilalama,” JCS 5 (1951) 104-122

Kraeling, E., The Brooklyn Museum Aramaic Papyri. New Documents of the Fifth

Century B.C. from the Jewish Colony of Elephantine (New Haven, CN: Yale, 1953

[reprinted New York, 1969])

Kraetzschmar, Richard, Die Bundesvorstellung im Alten Testament in ihrer geschichtlichen Entwicklung, untersucht und dargestellt (Marburg: N. G. Elwert, 1896)

Kraus, Hans-Joachim, Worship in Israel (Richmond: John Knox, 1965) 
, "Der lebendige Gott," EvT 27 (1967 [reprinted in his Biblisch-theologische Aufsätze, 1972, 1-36]) 169-200

Kroeze, J. H., Het Boek Job, COT (Kampen: J. H. Kok, 1961)

Kruger, Paul A., "The Hem of the Garment in Marriage. The Meaning of the Symbolic Gesture in Ruth 3:9 and Ezekiel 16:8,"JNSL 12 (1984) 79-86

Kruse-Blinkenberg, L., "The Pesitta [sic] of the Book of Malachi," Studia Theologica 20 (1966) 95-119

,"The Book of Malachi according to Codex Syro-Hexaplaris Ambrosianus," Studia Theologica 21 (1967) 62-82

Kuhl, Curt, "Neue Dokumente zum Verständnis von Hosea 2, 4-15," ZAW 52 (1934) 102109

,The Prophets of Israel, 2nd ed. (Edinburgh: Oliver \& Boyd, 1963)

Külling, S. R., Zur Datierung der “Genesis-P-Stücke," namentlich des Kapitels Genesis 17 (Kampen: J. H. Kok, 1964)

Kunstmann, Walter G., Die babylonische Gebetsbeschwörung, Leipziger semitische Studien NF 2, Benno Landsberger and H. H. Schaeder, eds. (Leipzig: J. C. Hinrichs, 1932)

Kutsch, Ernst, "Gesetz und Gnade. Probleme des alttestamentlichen Bundesbegriff," $Z A W$ 79 (1967) 18-35

,"Sehen und Bestimmen. Die Etymologie von ברית," in Archäologie und Altes Testament. Festschrift für Kurt Galling, z. 8 Jan. 1970, Arnulf Kuschke and Ernst Kutsch, eds. (Tübingen: J. C. B. Mohr [Paul Siebeck], 1970) 165-178

, Verheissung und Gesetz. Untersuchungen zum sogennanten 'Bund' im Alten Testament, BZAW 131 (Berlin: Walter de Gruyter, 1973)

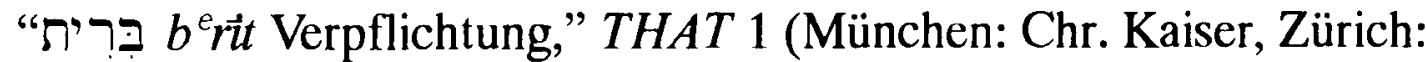

Theologischer Verlag, 1984) 339-352

Lackenbacher, S., "Note sur l'ardat-lilî," $R A 65$ (1971) 119-154

Laetsch, Theodore, Bible Commentary. The Minor Prophets (St. Louis, MO: Concordia, 1956)

Lamarche, Paul, Zacharie IX-XIV, Structure Littéraire et Messianisme (Paris: J. Gabalda et Cie, 1961)

Lambdin, Thomas O., Introduction to Biblical Hebrew (New York: Charles Scribner's Sons and London: Darton, Longman and Todd, 1971)

Lambert, W. G., Babylonian Wisdom Literature (Oxford: Clarendon, 1960) $287-300$

, "A New Look at the Babylonian Background of Genesis," JTS 16 (1965)

, "Trees, snakes and gods in ancient Syria and Anatolia," Bulletin of the School of Oriental and African Studies, University of London 48 (1985) 435-451

, "Old Testament Mythology in its Ancient Near Eastern Context," in International Organization for the study of the Old Testament, Congress Volume Jerusalem 1986, VTSup 40, J. A. Emerton, ed. (Leiden: E. J. Brill, 1988)

Lambert, W. G., and A. R. Millard, Atra-hasis: The Babylonian Story of the Flood with the Sumerian Flood Story by Miguel Civil (Oxford: Oxford University, 1969) 
Lambert, W. G., and Simon B. Parker, Enuma Elis. The Babylonian Epic of Creation. The Cuneiform Text (Birmingham, England: W. G. Lambert, on sale by Blackwell's, Oxford, 1966)

Lamsa, George M., The Holy Bible From the Ancient Eastern Text (Philadelphia, PA: A. J. Holman Co., 1933)

Landsberger, Benno, Die Serie ana ittišu, MSL, 1 (Roma: Pontifical Biblical Institute, 1937)

, "Jungfräulichkeit: Ein Beitrag zum Thema 'Beilager und Eheschliessung' (mit einem Anhang: Neue Lesungen und Deutungen im Gesetzbuch von Eshnunna)," in Symbolae Iuridicae et Historicae Martino David dedicatae, vol. 2, J. A. Ankum, R. Feenstra, and W. F. Leemans, eds., Iura Orientis Antiqui (Leiden: E. J. Brill, 1968) 41-105

Lang, Bernhard, Wisdom and the Book of Proverbs: an Israelite Goddess redefined (New York: Pilgrim, 1986)

Lapide [van den Steen], Cornelius à, Commentaria in duodecim prophetas minores, 2 Bde. (Antwerp [Antverpiae], 1625)

LaSor, William Sanford, Handbook of Biblical Hebrew: An inductive approach based on the Hebrew text of Esther, 3 vols. (Grand Rapids, MI: Eerdmans, 1979)

LaSor, William S., D. A. Hubbard, and F. W. Bush, Old Testament Survey. The Message, Form, and Background of the Old Testament (Grand Rapids, MI: Eerdmans, 1982)

Latham, James E., The Religious Symbolism of Salt, Théologie Historique 64 (Paris: Éditions Beauchesne, 1982)

Lawlor, J. I., The Nabataeans in Historical Perspective (Grand Rapids, MI: Baker, 1974) Leeuwen, C. van, Hosea, 3e druk, POT (Nijkerk: G. F. Callenbach, 1984 [1 druk, 1978])

Leggett, Donald A., The Levirate and Goel Institutions in the Old Testament with Special Attention to the Book of Ruth (Cherry Hill, New Jersey: Mack, 1974)

Lehmann, Manfred R., "Biblical Oaths," $Z A W 81$ (1969) 74-92

Lemche, Niels Peter, "The 'Hebrew Slave.' Comments on the Slave Law Ex. xxi 2-11," VT 25 (1975) 129-144

Levenson, Jon D. and Baruch Halpern, “The Political Import of David's Marriage," JBL 99 (1980) 507-518

Levin, M. Z., "A Protest Against Rape in the Story of Deborah," Beth Mikra [Hebrew] 25 (1979) 83-84

Levine, Baruch A., In the Presence of the Lord (Leiden: E. J. Brill, 1974)

, Leviticus. The Traditional Hebrew Text with the New JPS Translation, The JPS Torah Commentary, Nahum M. Sarna and Chaim Potok eds. (Philadelphia, New York, Jerusalem: The Jewish Publication Society, 1989)

Levine, Etan, “On Intra-familial Institutions of the Bible," Biblica 57 (1976) 554-559

Levy, Jacob, Neuhebräisches und chaldäisches Wörterbuch über die Talmudim und Midraschim, 2 Bde. (Leipzig: Brockhaus, 1878)

Lewy, Julius, "Les textes paléo-assyriens et l'Ancien Testament," Revue de l'histoire des religions 110 (1934) 29ff.

,"On some institutions of the Old Assyrian Empire," HUCA 27 (1956) 1-79 
Lillback, P. A., "Covenant," in New Dictionary of Theology, Sinclair B. Ferguson, David F. Wright, and J. I. Packer, eds. (Downers Grove, IL and Leicester, England: InterVarsity, 1988) 173-176

Limburg, James, "The Root $r y b$ and the Prophetic Lawsuit Speeches," JBL 88 (1969) $291 \mathrm{ff}$

Lindblom, Johannes, Prophecy in Ancient Israel (Philadelphia, PA: Fortress, 1962)

Lipiński, E., "Malachi, Book of," in Encyclopaedia Judaica 11 (Jerusalem, Israel: Keter; and NY: The Macmillan Company, 1971) 812-816

,"The Wife's Right to Divorce in the light of an Ancient Near Eastern

Tradition," Jewish Law Annual, 4, B. S. Jackson, ed. (Leiden: E.J. Brill, 1981) 927

Locher, Clemens, "Altes und Neues zu Maleachi 2,10-16," in Mélanges Dominique Barthélemy; études bibliques offertes à l'occasion de son 60e anniversaire, Pierre Casetti, et al., eds., Orbis biblicus et orientalis 38 (Freiburg Schweiz:

Universitätsverlag; and Göttingen: Vandenhoeck \& Ruprecht, 1981) 241-271

, Die Ehre einer Frau in Israel. Exegetische und rechtsvergleichende Studien zu Deuteronomium 22,13-21, Orbis biblicus et orientalis 70 (Freiburg Schweiz: Universitätsverlag; and Göttingen: Vandenhoeck \& Ruprecht, 1986)

Loewenstamm, Samuel E., "Exodus XXI 22-25," VT 27 (1977) 352-60

, "A Didactic Ugaritic Drinkers' Burlesque," in Comparative Studies in Biblical and Ancient Oriental Literatures, AOAT 204 (Kevelaer: Verlag Butzon \& Bercker; and Neukirchen-Vluyn: Neukirchener Verlag, 1980)

,"The Laws of Adultery and Murder in Biblical and Mesopotamian Law," in Comparative Studies in Biblical and Ancient Oriental Literatures, AOAT 204 (Kevelaer: Verlag Butzon \& Bercker; and Neukirchen-Vluyn: Neukirchener Verlag, 1980) $146-53$

,"The Laws of Adultery and Murder in the Bible. A reply to M. Weinfeld," in Comparative Studies in Biblical and Ancient Oriental Literatures, AOAT 204 (Kevelaer: Verlag Butzon \& Bercker; and Neukirchen-Vluyn: Neukirchener Verlag, 1980) $171-172$

Lohfink S.J., Norbert, “Gen 2-3 as 'historical etiology'," Theology Digest 13 (1965) 11 17

, Die Landverheissung als Eid: Eine Studie zu Gn. 15, Stuttgarter Bibel-

Studien 28 (Stuttgart: Verlag Katholisches Bibelwerk, 1967)

, "Dt 26,17-19 und die Bundesformel," Zeitschrift für katholische Theologie $91(1969) 517-53$

Lohfink S.J., Norbert, and Jan Bergman, “אָ 'echādh,” in TDOT 1 (Grand Rapids, MI: Eerdmans, 1977) 193-201

Loretz, O., "Berît — Band, Bund," VT 16 (1966) 239-41

Lowe, W. H., "Malachi," in A Bible Commentary for English Readers by Various Authors, 5, Jeremiah to Malachi, Charles John Ellicott, ed. (London, Paris, New York and Melbourne: Cassell and Company, Ltd., n.d.) 597-609

Luck, William F., Divorce and Remarriage. Recovering the Biblical View (San Francisco, CA: Harper \& Row, 1987)

Lüddeckens, E., Ägyptische Eheverträge, Ägyptologische Abhandlungen 1 (Wiesbaden: O. Harrassowitz, 1960) 
Luther, Martin, Die Bibel nach der deutschen Übersetzung d. Martin Luthers (Berlin:

Evangelisch Haupt-Bibelgesellschaft, 1962)

, Luther's Works, vol. 18: Lectures on the Minor Prophets I: Hosea, Joel, Amos, Obadiah, Micah, Nahum, Zephaniah, Haggai, Malachi, Hilton C. Oswald, ed. (the Wittenberg Text), Richard J. Dinda, trans. (St. Louis, MO: Concordia, 1975)

Lyons, John, Semantics, 2 vol. (Cambridge: Cambridge University, 1977)

Lys, Daniel, "Rûach," in his, Le Souffle dans l'Ancien Testament. Enquête

anthropologique à travers l'histoire théologique d'Israël (Paris: Presses Universitaires de France, 1962) 19ff.

Maarsingh, B., Het Huwelijk in Het Oude Testament (Baarn: Bosch \& Keuning, 1963) , Leviticus, 2de druk, POT (Nijkerk: G. F. Callenbach, 1980)

Mace, David R., Hebrew Marriage: A Sociological Study (London: Epworth, 1953)

Magnetti S.J., Donald Louis, "The Oath in the Old Testament in the Light of Related Terms and in the Legal and Covenantal Context of the Ancient Near East," Ph.D. diss. (The Johns Hopkins University, 1969)

Malamat, Abraham, "Organs of Statecraft in the Israelite Monarchy," BA 28 (1965 [= The Biblical Archaeologist Reader 3, Edward F. Campbell Jr. and David Noel Freedman, eds., Garden City, NY: Doubleday \& Company, 1970, pp. 163-198]) 34-65

, "The Twilight of Judah in the Egyptian-Babylonian Maelstrom," in International Organization for the study of the Old Testament, Congress Volume, Edinburgh, VTSup 28 (Leiden: E. J. Brill, 1975) 123-45

Malina, Bruce, "Does Porneia Mean Fornication?” NovT 14 (1972) 10-17

Malul, Meir, "More on pahad yișhāq (Genesis xxiv 42,53) and the oath by the thigh," VT 35 (1985) 192-200

, "sissiktu and sikku -- Their Meaning and Function," BO 43 (1986) 20-36

,"Touching the Sexual Organs as an Oath Ceremony in an Akkadian Letter," VT 37 (1987) 491-2

, Studies in Mesopotamian Legal Symbolism, AOAT 221 (Kevelaer: Verlag Butzon \& Bercker; and Neukirchen-Vluyn: Neukirchener Verlag, 1988)

, "Adoption of Foundlings in the Bible and Mesopotamian Documents. A Study of Some Legal Metaphors in Ezekiel 16:1-7," JSOT 46 (1990) 97-126

Mann, C. S., Mark. A New Translation with Introduction and Commentary, AB 27 (Garden City, NY: Doubleday and Company, 1986)

Margolis, Max Leopold, "תורה נביאים וכחובים עם (The Twelve Prophets],” in פירוש מרעי [Perush Maddai], Abraham Kahana, ed. (Zhitomir: n. p., 1903-1930)

Marks, Herbert, "The Twelve Prophets," in The Literary Guide to the Bible, Robert Alter and Frank Kermode, eds. (Cambridge, MA: Harvard University and Glasgow: William Collins Sons \& Co., Ltd., 1987) 207-233

Marshall, I. Howard, "Some Observations on the Covenant in the New Testament," in Jesus, the Saviour. Studies in New Testament Theology, I. Howard Marshall, ed. (Downers Grove, IL: InterVarsity, 1990) 275-289

Marshall, J. T., "The Theology of Malachi," ExpTim 7 (1896) 16-19, 73-75, 125-127

Marti, Karl, Das Dodekapropheton, Kurzer Hand-Commentar zum Alten Testament, XIII, I. Benzinger, et al., eds. (Tübingen: J. C. B. Mohr [Paul Siebeck], 1904)

Martin, James D., “The Forensic Background to Jeremiah III 1," VT 19 (1969) 82-92 
Marvin R. Wilson, Our Father Abraham. Jewish Roots of the Christian Faith (Grand Rapids, MI: Eerdmans and Dayton, OH: Center for Judaic-Christian Studies, 1989)

Mason, Rex A., The Books of Haggai, Zechariah, and Malachi, CBC (Cambridge: University, 1977)

Matthews, I. G., "Tammuz Worship in the Book of Malachi," Journal of the Palestine Oriental Society (1931) 42-50

, "Haggai, Malachi," in An American Commentary on the Old Testament, The Minor Prophets, 2 (Philadelphia: The American Baptist Publication Society (The Judson), 1935)

Maurer, Franz Joseph Valentin Dominik, "Malachias," in Commentarius grammaticus criticus in Vetus Testamentum, 3 Bde., 2 (Lipsiae: Volckmar, 1835-38) 717-36

Mawhinney, Allen, “God as Father: Two Popular Theories Reconsidered," JETS 31:2 (1988) 181-189

Mayes, A. D. H., Deuteronomy, NCB (Greenwood, S.C.: The Attic Press, 1979)

Mays, James Luther, Hosea, A Commentary, OTL (London: SCM Ltd and Philadelphia: Westminster, 1969)

, Amos, A Commentary, OTL (London: SCM Press Ltd and Philadelphia:

Westminster, 1969)

McBride Jr., S. Dean, “The Yoke of the Kingdom,” Interpretation 27 (1973) 272-306

McCarter Jr., P. Kyle, “The Apology of David,” JBL 99 (1980) 489-504

, I Samuel. A New Translation with Introduction, Notes and Commentary, AB 8 (Garden City, NY: Doubleday \& Company, 1980)

, II Samuel. A New Translation with Introduction, Notes and Commentary, AB 9 (Garden City, NY: Doubleday \& Company, 1984)

McCarthy S.J., Dennis J., Old Testament Covenant: A Survey of Current Opinions (Oxford: Basil Blackwell, 1972)

,"Hosea XII 2: Covenant by Oil," VT 14 (1964 [= "Hosea XII 2: Covenant by Oil," Institution and Narrative: Collected Essays, AnBib 108, Rome: Biblical Institute, 1985, 14-20]) 215-221

, "Three Covenants in Genesis," CBQ 26 (1964 [= Institution and Narrative: Collected Essays, 1985, 3-13]) 179-89

"Notes on the Love of God in Deuteronomy and the Father-Son

Relationship Between Yahweh and Israel," CBQ 27 (1965) 144-147

, "berit in Old Testament History and Theology," Biblica 53 (1972) 110-121

, "Berit and Covenant in the Deuteronomistic History," in Studies in the

Religion of Ancient Israel, VTSup 23, P. A. H. de Boer, ed. (Leiden: E. J. Brill, 1972 [reprinted in Institution and Narrative: Collected Essays, AnBib 108, Rome: Biblical Institute, 1985, 21-41]) 65-85

"The Uses of wehinnēh in Biblical Hebrew," Biblica 61 (1980 |reprinted in Institution and Narrative: Collected Essays, AnBib 108, Rome: Biblical Institute, 1985, 237-49]) 330-342

, Treaty and Covenant: A Study in Form in the Ancient Oriental Documents and in the Old Testament, AnBib 21a (Rome: Pontifical Biblical Institute, 1981 [1st ed, 1963]) 
, Institution and Narrative: Collected Essays, AnBib 108 (Rome: Biblical Institute, 1985)

McComiskey, Thomas Edward, "The Status of the Secondary Wife: Its Development in Ancient Near Eastern Law. A Study and Comprehensive Index," Ph.D. diss. (Brandeis University, 1965)

, The Covenants of Promise. A Theology of the Old Testament Covenants (Grand Rapids, MI: Baker, 1985)

McConville, J. Gordon, "Priests and Levites in Ezekiel. A Crux in the Interpretation of Israel's History," TB 34 (1983) 3-31 JSOT Press, 1984)

McCree, W. T., "The Covenant Meal in the Old Testament," JBL 45 (1926) 120-128

McEvenue, Sean E., The Narrative Style of the Priestly Writer (Rome: Pontifical Biblical Institute, 1971)

McFadyen, John Edgar, "Malachi," in The Abingdon Bible Commentary, Frederick Carl Eiselen, Edwin Lewis, and David G. Downey, eds. (New York: Abingdon, 1929)

McKane, William, Proverbs. A New Approach, OTL (London: SCM Ltd., 1970)

, A Critical and Exegetical Commentary on Jeremiah Vol. 1, Introduction and Commentary on Jeremiah I-XXV, ICC (Edinburgh: T. \& T. Clark, 1985)

McKay, J. W., "Man's Love for God and the Father/Teacher - Son/Pupil Relationship," VT 22 (1972) 426-435

McKeating, Henry, The Books of Amos, Hosea and Micah, CBC (Cambridge: Cambridge University Press, 1971)

, "Sanctions against Adultery in Ancient Israelite Society, with Some

Reflections on Methodology in the Study of Old Testament Ethics," JSOT 11 (1979) $57-72$

, “A Response to Dr Phillips,” JSOT 20 (1981) 25-26

McKenzie, Steven L., and Howard N. Wallace, "Covenant Themes in Malachi," CBQ 45 (1983) 549-563

Mendelsohn, Isaac, "The Conditional Sale into Slavery of Free-born Daughters in Nuzi and the Law of Ex. 21:7-11," JAOS 55 (1935) 190-95

, Slavery in the Ancient Near East (Oxford: Oxford University, 1949)

, "Samuel's Denunciation of Kingship in the Light of the Akkadian

Documents from Ugarit," BASOR 143 (1956) 17-22

, "On Marriage in Alalakh," in Essays on Jewish Life and Thought presented in honor of Salo Wittmayer Baron, J. L. Blau, A. Hertzberg, Ph. Friedman, and I. Mendelsohn, eds. (New York: Columbia University, 1959) 351-57

$383-391$

, "Slavery in the OT," in IDB 4 (Nashville and New York: Abingdon, 1962)

Mendenhall, George E., "Puppy and Lettuce in Northwest-Semitic Covenant Making," BASOR 133 (1954) 26-30

, "Ancient Oriental and Biblical Law," BA 17 (1954 [reprinted in The Biblical Archaeology Reader; 3, Edward F. Campbell Jr. and David Noel Freedman, eds, Garden City, NY: Doubleday \& Company, 1970, 3-24]) 26-46 
, "Covenant Forms in Israelite Tradition," BA 17 (1954 [reprinted in The Biblical Archaeology Reader, 3, Edward F. Campbell Jr. and David Noel Freedman, eds, Garden City, NY: Doubleday \& Company, 1970, 25-53]) 50-76

, Law and Covenant in Israel and the Ancient Near East (Pittsburgh, PA: The Biblical Colloquium [reprinted from The Biblical Archaeologist 17, 1954, 26-46, 49 76], 1955)

, "Covenant," in IDB 1 (Nashville and New York: Abingdon, 1962) 714-723 , "Election," in IDB 2 (Nashville and New York: Abingdon, 1962) 76-82

, The Tenth Generation: The Origins of the Biblical Tradition (Baltimore, MD: The Johns Hopkins University Press, 1973)

Merton, Robert K., "The Fallacy of the Latest Word: The Case of 'Pietism and Science'," American Journal of Sociology 89 (1984) 1091-1121

Mettinger, Tryggve N. D., King and Messiah: The Civil and Sacral Legitimation of the Israelite Kings, Coniectanea biblica, Old Testament Series 8 (Lund: C. W. K. Gleerup, 1976)

Meyer, Ed., Die Israeliten und ihre Nachbarstämme (Halle: Max Niemeyer, 1906)

Meyer, Rudolph, Hebräische Grammatik, 3 Aufl., Sammlung Göschen Band 5765 (Berlin: Walter de Gruyter, 1966-72)

Meyers, Carol L., and Eric M. Meyers, Haggai, Zechariah 1-8. A New Translation with Introduction and Commentary, AB 25B (Garden City, NY: Doubleday \& Co., 1987)

Meyers, Eric M., "Priestly language in the book of Malachi," Hebrew Annual Review, Reuben Ahroni, ed., Biblical and Other Studies. Tenth Anniversary Volume (The Ohio State University, Department of Judaic and Near Eastern Languages and Literatures, 1986) 10 (1986) 225-237

Mezger, Fritz, "Promised but not engaged," JAOS 64 (1944) 28-31

Michaelis, Johann David, Deutsche Übersetzung des A. T. mit Anmerkungen für Ungelehrte, 13 Teile; Teil XI: Die zwölf Kleinen Propheten (Göttingen and Gotha, 1782)

Milgrom, Jacob, Cult and Conscience: The Asham and the Priestly Doctrine of Repentance, Studies in Judaism in Late Antiquity 18, Jacob Neusner, ed. (Leiden: E. J. Brill, 1976)

Millard, Alan R., “A New Babylonian 'Genesis' Story,” TB 18 (1967) 3-18

, "Covenant and Communion in First Corinthians," in Apostolic History and the Gospel. Biblical and Historical Essays Presented to F. F. Bruce on his 60th Birthday, W. Ward Gasque and Ralph P. Martin, eds. (Grand Rapids: William B. Eerdmans, 1970) 242-248

Mitchell, Hinckley G., "The Omission of the Interrogative Particle," in Old Testament and Semitic Studies in memory of William Rainey Harper, vol. 1, Robert Francis Harper, Francis Brown, and George Foot Moore, eds. (Chicago: University of Chicago, 1908) 115-129

Mitchell, Hinckley G., John Merlin Powis Smith, and Julius A. Bewer, A Critical and Exegetical Commentary on Haggai, Zechariah, Malachi and Jonah, ICC (Edinburgh:

T. \& T. Clark, 1912)

Montgomery, James A., and Henry Snyder Gehman, $A$ Critical and Exegetical Commentary on the Book of Kings, ICC (Edinburgh: T. \& T. Clark, 1951)

Moor, Johannes Cornelis de, De Profeet Maleachi (Amsterdam: Kirberger \& Kesper, 1903) 
Moore, Carey A., Esther. Introduction, Translation, and Notes, AB 7B (Garden City, NY: Doubleday \& Company, 1971)

Moore, George Foot, $A$ Critical and Exegetical Commentary on Judges, ICC (Edinburgh:

T. \& T. Clark, 1895)

, Judaism in the First Centuries of the Christian Era (Cambridge, MA:

Harvard University, 1927)

Moore, Thomas V., A Commentary on Haggai and Malachi: A New Translation with Notes (New York: Robert Carter \& Bros., 1856 [reprinted 1960 in The Geneva Series Commentary by Banner of Truth Trust, London])

Moran, William L., "The Use of the Canaanite Infinitive Absolute as a Finite Verb in the Amarna Letters from Byblos," JCS 4 (1950) 169-172 , "The Scandal of the 'Great Sin' at Ugarit," JNES 18 (1959) 280-1

, "The Ancient Near Eastern Background of the Love of God in Deuteronomy," $C B Q 25$ (1963) 77-87

Morgenstern, Julian, "Beena Marriage (Matriarchat) in Ancient Israel and its Historical Implications," $Z A W 47$ (1929) 91-110

, "The Book of the Covenant, Part 2," HUCA 7 (1930) 19-258

, "Additional Notes on Beena Marriage (Matriarchat) in Ancient Israel," $Z A W$ 49 (1931) 46-58

, "Jerusalem - 485 B.C.," HUCA 28 (1957) 15-47

, "David and Jonathan," JBL 78 (1959) 322-325

Morris, Desmond, The Naked Ape (New York: McGraw-Hill, 1967)

, Intimate Behavior (New York: Random House, 1971)

Moule, C. F. D., "The Judgment Theme in the Sacraments," in The Background of the New Testament and Its Eschatology (Festschrift for Charles Harold Dodd), W. D. Davies and D. Daube, eds. (Cambridge: University Press, 1956) 464-481

Mowinckel, Sigmund Olaf Plytt, The Psalms in Israel's Worship, 2 vols., D. R. ApThomas, trans. (New York and Nashville: Abingdon and Oxford: B. Blackwell, 1962)

Muffs, Yohanan, "Studies in Biblical Law, IV: The Antiquity of P," Lectures at the Jewish Theological Seminary of America New York (New York: mimeographed by the Jewish Theological Seminary of America, 1965)

, Studies in the Aramaic Legal Documents from Elephantine, 2nd. ed., Studia et Documenta ad Iura Orientalis Antiqui Pertinentia 8 (Leiden: E. J. Brill, and New York: Ktav, 1973 [1st ed. 1969])

, "Joy and Love as Metaphorical Expressions of Willingness and Spontaneity in Cuneiform, Ancient Hebrew, and Related Literatures," in Christianity, Judaism and Other Greco-Roman Cults, Studies for Morton Sinith at Sixty, Part 3: Judaism Before 70, Jacob Neusner, ed., Studies in Judaism in Late Antiquity 12 (Leiden: E. J. Brill, 1975) 1-36

, "Love and Joy as Metaphors of Volition in Hebrew and Related Literatures, Part II: The Joy of Giving," JANESCU 11 (1979) 91-111

Munn-Rankin, J. M., "Diplomacy in Western Asia in the Early Second Millennium B.C.," Iraq 18 (1956) 68-110 
Muntingh, L. M., "Married Life in Israel according to the Book of Hosea," Die Ou-

Testamentiese Werkgemeenskap in Suid-Afrika 7-8 (1964-65) 77-84 (1974) $50-70$ "Amorite Married and Family Life according to the Mari Texts," JNSL 3

Muraoka, Takamitsu, Emphatic Words and Structures in Biblical Hebrew (Jerusalem: Magnes and Leiden: E. J. Brill, 1985)

Murdock, George Peter, Social Structure (London and New York: Macmillan Co., 1949)

Murphy, Roland E., Wisdom Literature: Job, Proverbs, Ruth, Canticles, Ecclesiastes, Esther, The Forms of The Old Testament Literature, 13, Rolf Knierim and Gene M. Tucker, eds. (Grand Rapids, MI: Eerdmans, 1981)

Murray, John, The Covenant of Grace. A Biblico-Theological Study (London: Tyndale, 1954 [reprinted 1988 by Presbyterian and Reformed, Phillipsburg, NJ])

, Principles of Conduct. Aspects of Biblical Ethics (Grand Rapids, MI:

Eerdmans; and London: Tyndale, 1957)

, Divorce (Phillipsburg, NJ: Presbyterian and Reformed, 1961)

Myers, Jacob M., Ezra, Nehemiah, AB 14 (Garden City, NY: Doubleday \& Company, 1965)

, II Chronicles. Introduction, Translation, and Notes, AB 13 (Garden City, NY: Doubleday \& Company, 1965 [2nd ed. 1979])

, The World of the Restoration, Backgrounds to the Bible Series, Bruce

Vawter ed. (Englewood Cliffs, NJ: Prentice-Hall, 1968)

Naylor, Peter John, "The Language of Covenant. A Structural Analysis of the Semantic

Field of ברית in Biblical Hebrew, with Particular Reference to the Book of Genesis,"

D.Phil. diss. (Oxford University, 1980)

Neil, W., "Malachi," in IDB 3 (Nashville and New York: Abingdon, 1962) 228-232

Neuer, Werner, Man and Woman in Christian Perspective, Gordon J. Wenham, trans.

(London, Sydney, Aukland, Toronto: Hodder \& Stoughton, 1990)

Neufeld, E., Ancient Hebrew Marriage Laws -- With special references to General Semitic

Laws and Customs (London, New York, Toronto: Longmans, Green \& Co., 1944)

Neusner, Jacob, translator, The Talmud of Babylonia, An American Translation. Volume

XXID: Tractate Bava Mesia Chapters 7-10, Brown Judaic Studies 216 (Atlanta, GA:

Scholars Press, 1990)

Newcome, William, An Attempt towards a metrical arrangement, and an explanation of the

Twelve Minor Prophets (London: J. J. Johnson, C. G. J. and J. Robinson, 1785)

Newman, Murray L., "Review of E. Kutsch, Verheissung und Gesetz," JBL 94 (1975)

$117-120$

Nicholson, Ernest W., God and His People. Covenant and Theology in the Old Testament (Oxford: Clarendon, 1986)

Nida, Eugene A., "The Implications of Contemporary Linguistics for Biblical

Scholarship," JBL 91 (1972) 73-89

Niditch, Susan, "The Wronged Woman Righted: An Analysis of Genesis 38," HTR 72 (1979) 143-49

, "The 'Sodomite' Theme in Judges 19-20: Family, Community, and Social

Disintegration," $C B Q 44$ (1982) 365-378 
Nielsen, Eduard, Shechem: A Traditio-Historical Investigation, 2nd ed. (Copenhagen: G.

E. C. Gad, 1959 [1st ed., 1955])

Nielsen, Kirsten, Yahweh As Prosecutor and Judge. An Investigation of the Prophetic Lawsuit (Rîb-pattern), Frederick Cryer, trans., JSOTS 9 (Sheffield, England: JSOT Press, 1978)

Nöldeke, Theodor, Compendius Syriac Grammar, J. A. Crichton, trans. (London: Williams \& Norgate, 1904)

North, Robert, "Flesh, Covering, a Response, Ex. xxi 10," VT 5 (1955) 204-6

Noth, Martin, Das System der zwölf Stämme Israels, BWANT IV:1 (Stuttgart, Berlin: Kohlhammer, 1930)

, The History of Israel, 2nd ed., P. R. Ackroyd, trans. (New York and London: Harper \& Row, 1960 [1st ed. 1958])

, "Old Testament Covenant Making in the Light of a Text from Mari," in his

The Laws in the Pentateuch and Other Studies, D. R. Ap-Thomas, trans. (Edinburgh and London: Oliver \& Boyd, 1966) 108-117

Nötscher, F., Zwölfprophetenbuch, Echter Bibel, 2e Aufl. (Würzburg: Echter, 1957)

Nowack, Wilhelm, Die kleinen Propheten, Göttinger HKAT III/4, 3e Aufl. (Göttingen:

Vandenhoeck \& Ruprecht, 1922 [1e Aufl., 1897; 2e Aufl., 1903])

Nyberg, H., Studien zum Hoseabuch (Uppsala: Lundequistska, 1935)

O'Brien, Julia M., "Torah and Prophets: Malachi and the Date of the Priestly Code," a paper read at the Annual Meeting of the Society of Biblical Literature in Chicago November 20, 1988 (1988)

Priest and Levite in Malachi, SBLDS 121, David L. Petersen and Pheme Perkins, eds. (Atlanta, GA: Scholars, 1990)

O'Connor, M., "Northwest Semitic Designations for Elective Social Affinities," The JANESCU 18 (1986) 67-80

Oates, David, "The Excavations of Nimrud (Kalhu)," Iraq 25 (1962) 6-37

Oduyoye, Modupe, The Sons of the Gods and the Daughters of Men: An Afro-Asiatic Interpretation of Genesis 1-11 (Maryknoll, NY: Orbis, 1984)

Ogden, Graham S., "The Use of Figurative Language in Malachi 2:10-16," Bible Translator 39 (1988) 223-230

Ogden, Graham S., and Richard R. Deutsch, A Promise of Hope - A Call to Obedience. $A$ Commentary on the Books of Joel and Malachi, International Theological Commentary, George A. F. Knight and Frederick Carlson Holmgren, eds. (Grand Rapids, MI: Eerdmans; and Edinburgh: The Handsel Press Ltd., 1987)

Oort, H., Textus Hebraici Emendationes 1900)

Orelli, Conrad von, The Twelve Minor Prophets, J. S. Banks, trans. (Edinburgh: T. \& T. Clark, 1893 [reprinted 1977 by Klock \& Klock, Minneapolis, MN])

, Die zwölf kleinen Propheten, 3e Aufl., kurzgefaßter Kommentar zu den heiligen Schriften Alten und Neuen Testamentes zowie zu den Apokryphen [SZKK], A. Altes Testament, 5. Abteilung, 2 Hälfte, Hermann Strack and Otto Zöckler, eds. (München: C. H. Beck, 1908 [1e Aufl., 1888])

Oswalt, John N., The Book of Isaiah: Chapters 1-39, NICOT (Grand Rapids, MI: Eerdmans, 1986) 
Packard, Joseph, "The Book of Malachi," in Commentary on the Holy Scriptures, Critical, Doctrinal and Homiletical: Minor Prophets, John Peter Lange, ed. (New York: Scribner, Armstrong \& Co., 1876 [reprinted Grand Rapids, MI: Zondervan, n.d.])

Palmer S. J., Paul F., “Christian Marriage: Contract or Covenant?” Theological Studies 33 (1972) 617-665

Parker, B., "The Numrud Tablets, 1952 - Business Documents," Iraq 16 (1954) 29-58

Parker, Simon B., "The Marriage Blessing in Israelite and Ugaritic Literature," JBL 95 (1976) 23-30

Parpola, Simo, and Kazuko Watanabe, eds., Neo-Assyrian Treaties and Loyalty Oaths, Robert M. Whiting, Karlheinz Deller, Frederick Mario Fales, Simo Parpola, and Nicholas Postgate, eds.; State Archives of Assyria. Published by The Neo-Assyrian Text Corpus Project of the Academy of Finland in cooperation with Deutsche OrientGesellschaft 2 (Helsinki: Helsinki University, 1988)

Parrot, André, "Gestes de la prière dans le monde mesopotamien," in Maqqēl shâqédh: La Branche d'Amandier: Hommage à Wilhelm Vischer (Montpellier: Causse, Graille, Castelnau, 1960) 177-180

Patai, Raphael, Sex and Family in the Bible and in the Middle East (Garden City, NY: Doubleday, 1959) , The Hebrew Goddess (New York: Ktav, 1967)

Patterson, Richard D., "Old Babylonian Parataxis as Exhibited in the Royal Letters of the Middle Old Babylonian Period and in the Code of Hammurapi," Ph.D. diss.

(University of California, Los Angeles, 1970)

Paul, Shalom M., “Exod. 21:10: a Threefold Maintenance Clause,” JNES 28 (1969) 48-53 , Studies in the Book of the Covenant in the Light of Cuneiform and Biblical Law, VTSup 18 (Leiden: E. J. Brill, 1970)

, "Adoption Formulae: A Study of Cuneiform and Biblical Legal Clauses,"

Maarav 2:2 (1979-1980 [revision of an earlier Hebrew article by the same name published in H. L. Ginsberg Volume, Eretz-Israel, 14, Jerusalem: Israel Exploration Society and The Jewish Theological Seminary of America, 1978, 31-36]) 173-85

Payne, John Barton, The Theology of the Older Testament (Grand Rapids: Zondervan, 1962)

Payne, J. Barton, “rûah," in TWOT 2 (Chicago: Moody, 1980) $386 \mathrm{f}$

Pedersen, Johannes, Der Eid bei den Semiten in seinem Verhältnis zu verwandten Erscheinungen, sowie die Stellung des Eides im Islam, Studien zur Geschichte und Kultur des islamischen Orients, 3 (Zwanglose Beihefte zu der Zeitschrift "Der Islam") (Strassburg: Trubner, 1914)

, Israel, Its Life and Culture, I-II, rev. ed. (London: Oxford University Press, 1959 [1st ed., Copenhagen: S. L. Møller, 1946-1947])

Perlitt, Lothar, Bundestheologie im Alten Testament, WMANT 36 (Neukirchen-Vluyn: Neukirchener Verlag, 1969)

Perowne, T. T., Malachi, with Notes and Introduction, The Cambridge Bible for Schools and Colleges, J. J. S. Perowne, ed. (Cambridge: University, 1890)

Pestman, P. W., Marriage and Matrimonial Property in Ancient Egypt, Papyrologica Lugduno-Batava 9 (Leiden: E. J. Brill, 1961)

Pfeiffer, E., “Die Disputationsworte im Buche Maleachi," EvT 19 (1959) 546-68 
Pfeiffer, Robert H., Introduction to the Old Testament (New York: Harper \& Bros., 1948)

Pfeiffer, Robert H., and E. A. Speiser, 100 New Selected Nuzi Texts, transliterated by Robert H. Pfeiffer, with translations and commentary by E. A. Speiser, AASOR 16 (New Haven: Yale University, 1935-36)

Phillips, Anthony, Ancient Israel's Criminal Law: A New Approach to the Decalogue (Oxford: Clarendon and New York: Schocken, 1970)

, Deuteronomy, CBC (Cambridge: Cambridge University, 1973)

(1973) 237-242

"Nebalah - a term for serious disorderly and unruly conduct," VT 25

, "Some Aspects of Family Law in Pre-Exilic Israel," VT 23 (1973) 349-361

, "Uncovering the Father's Skirt," VT 30 (1980) 38-43

, “Another Example of Family Law," VT 30 (1980) 240-245.

, “Another Look at Adultery," JSOT 20 (1981) 3-25

$142-143$

“A Response to Dr. McKeating (JSOT 20 [1981] 25-26)," JSOT 22 (1981)

, "The Decalogue - Ancient Israel's Criminal Law," JJS 34 (1983) 1-20

, Lower than the Angels. Questions raised by Genesis 1-11. Foreword by

Stuart Blanch (London: The Bible Reading Fellowship, 1983)

, “The Laws of Slavery: Exodus 21:2-11," JSOT 30 (1984) 51-66

,"The Book of Ruth - Deception and Shame," JJS 37 (1986) 1-17

Pierce, Ronald W., "Literary Connectors and a Haggai / Zechariah / Malachi Corpus," JETS 27 (1984) 277-89

,"A Thematic Development of the Haggai / Zechariah / Malachi Corpus," JETS 27 (1984) 401-411

Pinches, T. G., "Babylonian Contract-Tablets with Historical References," Records of the Past NS 4 (1890)

21-23

, "Notes," Journal of the Transactions of the Victoria Institute 26 (1892-93)

Plautz, Werner, "Die Frau in Familie und Ehe. Ein Beitrag zum Problem ihrer Stellung im Alten Testament," Ph.D. diss. (Kiel, 1959)

, "Monogamie und Polygynie im Alten Testament," $Z A W 75$ (1963) 3-27

"Die Form der Eheschliessung im Alten Testament," $Z A W 76$ (1964) 298-

318

Pococke, Edward, "A Commentary on the Prophecy of Malachi," in Theological Works, vol. 1, Leonard Twells, ed. (London, 1740) 105-206

Poebel, Arno, Babylonian Legal and Business Documents from the time of the first dynasty of Babylon chiefly from Nippur, The Babylonian Expedition of the University of Pennsylvania, Series A, vol. 6, part 2, H. V. Hilprecht, ed. (Philadelphia:

Department of Archaeology, University of Pennsylvania, 1909)

Poole, Matthew, Annotations upon the Holy Bible, 1 (Glasgow: John Kirk and Robert Williamson, 1803)

Pope, Marvin H., "Oaths," in IDB 3 (Nashville and New York: Abingdon, 1962) 575-577 , Job. A New Translation with Introduction and Commentary, 3rd ed., AB 15 (Garden City, NY: Doubleday \& Company, 1973) 
, Song of Songs. A New Translation with Introduction and Commentary, AB 7C (Garden City, NY: Doubleday \& Company, 1977)

Porten, Bezalel, Archives from Elephantine (Berkeley and Los Angeles: University of California, 1968)

Porten, Bezalel, and Ada Yardeni, Textbook of Aramaic Documents From Ancient Egypt, Volume 2: Contracts, The Hebrew University Department of the History of the Jewish People. Texts and Studies for Students (Jerusalem: Hebrew University, 1989)

Porter, Stanley E., "The Pauline Concept of Original Sin, in the Light of Rabbinic Background," TB 41 (1990) 3-30

Postgate, J. N., Fifty Neo-Assyrian Legal Documents (Warminster, England: Aris \& Phillips, Ltd., 1976)

Praag, A. van, Droit matrimonial assyro-babylonien, Allard Pierson Stichting, Archaeologische-Historische Bijdragen, XII (Amsterdam: Noord-Hollandsche, 1945)

Pressel, Wilhelm, Commentar zu den Schriften der Propheten Haggai, Sacharja, und Maleachi (Gotha: Schloessmann, 1870)

Price, J. M., "The Oath in Court Procedure in Early Babylonia and the Old Testament," JAOS 49 (1929) 22-29

Priest, John F., “The Covenant of Brothers," JBL 84 (1965) 400-406

Pritchard, James B., ed., Ancient Near Eastern Pictures (Princeton, NJ: Princeton University, 1969)

, ed., Ancient Near Eastern Texts Relating to the Old Testament (Princeton,

NJ: Princeton University, 1969)

Procksch, Otto, Die Genesis übersetzt und erklärt, 2-3 Aufl., KAT (Leipzig: A.

Diechertsche Verlagsbuchhandlung; and Erlangen: Dr. Werner Scholl, 1924)

, Die kleinen prophetischen Schriften nach dem Exil, Erläuterungen zum

Alten Testament, 2e Aufl., Teil VI (Stuttgart: Calwer, 1929 [1e Aufl., 1916])

Propp, William H., "The Origins of Infant Circumcision in Israel," Hebrew Annual Review 11 (1987) 355-370

Puscy, Edward Bouveric, The Minor Prophets with a Commentary. Explanatory and Practical and Introductions to the Several Books, Vol 2: Micah, Nahum, Habakkuk, Zephaniah, Haggai, Zechariah and Malachi (New York: Funk \& Wagnalls; and London: Walter Smith, 1885 [1st ed. published in London: Parker, Deighton, Bell \& Co., 1860])

Qimron, Elisha, The Hebrew of the Dead Sea Scrolls, HSS 29 (Atlanta, Georgia: Scholars, 1986)

Rabinowitz, Jacob J., "Marriage Contracts in Ancient Egypt in the Light of Jewish Sources," HTR 46 (1953) 91-7

, Jewish Law. Its Influence on the Development of Legal Institutions (New York: Bloch, 1956)

73

, "The 'Great Sin' in Ancient Egyptian Marriage Contracts," JNES 18 (1959)

Rad, Gerhard von, Old Testament Theology, D. M. G. Stalker, trans. (New York: Harper \& Row, 1962-65 [Theologie des Alten Testaments, 1957, 1960])

, Deuteronomy. A Commentary, Dorothea Barton, trans., OTL (Philadelphia:

The Westminster Press, 1966) 
, Genesis. A Commentary, revised ed., John H. Marks, trans., OTL

(Philadelphia: The Westminster Press, 1972)

Radday, Yehuda T., and Moshe A. Pollatschek, "Vocabulary Richness in Post-Exilic Prophetic Books," ZAW 92 (1980) 333-46

Radday, Yehuda T., and Dieter Wickmann, "The Unity of Zechariah Examined in the light of Statistical Linguistics," ZAW 87 (1975) 30-55

Rahlfs, Alfred, ed., Septuaginta id est Vetus Testamentum graece iuxta LXX interpretes (Stuttgart: Württembergische Bibelanstalt, 1935)

Rattray, Susan, "Marriage Rules, Kinship Terms and Family Structure in the Bible," in Society of Biblical Literature 1987 Seminar Papers, Kent Harold Richards, ed. (Atlanta, GA: Scholars, 1987) 537-544

Rawlinson, George, Ezra and Nehemiah: Their Lives and Times (New York: Randolf, 1890)

Reckendorf, H., Arabische Syntax (Heidelberg: Winter, 1921 [reprinted 1973 by A. P. A., Amsterdam])

Reinke, Laur., Der Prophet Maleachi (Giessen: Ferber'sche Universitätsbuchhandlung, 1856)

Reiser, Werner, "Die Verwandtschaftsformel in Gen. 2,23," Theologische Zeitschrift 16 (1960) 1-4

Rendsburg, Gary A., "Late Biblical Hebrew and the Date of P," JANESCU 12 (1980) 6580 , "A New Look at the Pentateuchal HW '," Biblica 63 (1982) 351-369

, The Redaction of Genesis (Winona Lake, IN: Eisenbrauns, 1986)

Rendtorff, Rolf, "Maleachibuch," in $R G G^{3}$ IV, K. Galling, ed. (Tübingen: J. C. B. Mohr [Paul Siebeck], 1957-65) 628f

Ltd., 1985)

The Old Testament. An Introduction, J. Bowden, trans. (London: SCM

Renger, J., "Who are all those People?" Orientalia 42 (1973) 259-273, 267-72

Renker, Alwin, Die Tora bei Maleachi: Ein Beitrag zur Bedeutungsgeschichte von tôrā im Alten Testament, Freiburger Theologische Studien 112, Remigius Bäumer, Alfons Deissler, and Helmut Riedlinger, eds. (Freiburg, Basel, Wien: Herder, 1979)

Reuss, Eduard, "Die Propheten," in Das Alte Testament übersetz, eingeleitet und erläutert, aus dem Nachlass des Verfassers, Bd. 2, Lic. Erichson and Prf. Dr. Horst, eds. (Braunschweig: C. A. Schwetschke \& Sohn, 1892)

Reventlow, Henning Graf, Gebot und Predigt im Dekalog (Gütersloh: Gerd Mohn, 1962)

, Problems of Old Testament Theology in the Twentieth Century

(Philadelphia, PA: Fortress, 1985)

Richter, W., "Urgeschichte und Hoftheologie," Biblische Zeitschrift 10 (1966) 96-105

Ridderbos, Jan, Het Godswoord der Profeten, Vol. IV: Van Ezechiel tot Maleachi (Kampen: J. H. Kok, 1941)

, Deuteronomy, Ed M. van der Maas, trans., Bible Student's Commentary (Grand Rapids, MI: Zondervan and St. Catharines, Ont.: Paideia, 1984)

De kleine profeten. Opnieuw uit den grondtekst vertaald en verklaard; IIIde Deel: Haggai, Zacharia, Maleachi, Korte Verklaring der Heilige Schrift met nieuwe Vertaling, 3de druk (Kampen: J. H. Kok, N. V., 1968) 
Riemann, P. A., “Covenant, Mosaic," in IDBSup (Nashville, TN: Abingdon, 1976) 192197

Riessler, Paul, Die kleinen Propheten oder das Zwölfprophetenbuch nach dem Urtext übersetzt und erklärt (Rottenburg a. N.: Badaer, 1911)

Ringgren, Helmer, Word and Wisdom: Studies in the Hypostatization of Divine Qualities and Functions in the Ancient Near East (Lund: Hakan Ohlssons Boktryckeri, 1947) , Sprüche/Prediger, ATD 16/1 (Göttingen: Vandenhoeck \& Ruprecht, 1962) , Israelite Religion, David Green, trans. (London: S.P.C.K. and Philadelphia, PA: Fortress, 1966)

, "דָז chāyāh," in TDOT 4 (Grand Rapids, MI: Eerdmans, 1980) 324-344

Rivkin, Ellis, "Aaron, Aaronides," in IDBSup (Nashville, TN: Abingdon, 1976) 1-3

Robert, A., "Les attaches littéraires bibliques de Prov. I-IX," $R B \quad 43$ (1934) 42-68, 172 204, 374-84

$505-25$

"Les attaches littéraires bibliques de Prov. I-IX," RB 44 (1935) 344-65;

Robertson, O. Palmer, The Christ of the Covenants (Grand Rapids, MI: Baker, 1980)

Robinson, G. L., The Twelve Minor Prophets (Grand Rapids, MI: Baker, 1952)

Robinson, Theodore H., and Friedrich Horst, Die zwölf kleinen Propheten, Bd 2, 3e

Aufl., HAT 1/14 (Tübingen: J. C. B. Mohr [Paul Siebeck], 1964 [1 Aufl., 1938])

Rogers, Virgil M., “The Use of ד־ in an Oath,” JBL 74 (1955) 272-73

Rogerson, John, The Supernatural in the Old Testament (Guildford and London:

Lutterworth, 1976)

Rooy, Herculaas Frederik van, "Conditional Sentences in Biblical Hebrew," in

Proceedings of the Ninth World Congress of Jewish Studies, Jerusalem, August 412, 1985 Division D, Vol. 1: Hebrew and Jewish Languages (Jerusalem: Magnes, 1986)

Rosenberg, Joel W., "The Garden Story Forward and Backward: The Non-Narrative

Dimension of Gen. 2-3," Prooftexts: A Journal of Jewish Literary History 1 (1981) $1-27$

King and Kin. Political Allegory in the Hebrew Bible (Bloomington and Indianapolis: Indiana University, 1986)

Rosenmüller, Ernst Friedrich Karl, Scholia in Vetus Testamentum. Partis Septimae,

Prophetas Minores Continentis, Volumen Quartum: Zephania, Haggai, Zacharias,

Maleachi (Lipsiae: Sumtibus Joh. Ambros. Barthii, 1828)

Rosenthal, Franz, "יום טוב", HUCA 18 (1944) 157-176

Ross, James F., "Meal," in IDB 3 (Nashville and New York: Abingdon, 1962) 315

"Salt," in IDB 4 (Nashville and New York: Abingdon, 1962) 167

Roth, Martha T., "Age at Marriage and the Household: A Study of Neo-Babylonian and

Neo-Assyrian Forms," Comparative Studies in Society and History (Cambridge

University) 29 (1987) 715-47

"She will die by the iron dagger': Adultery and Neo-Babylonian Marriage,"

Journal of the Economic and Social History of the Orient 31 (1988) 186-206 
, Babylonian Marriage Agreements: 7th - 3rd Centuries B.C., AOAT 222 (Kevelaer: Verlag Butzon \& Bercker; and Neukirchen-Vluyn: Neukirchener Verlag, 1989)

,"Marriage and Matrimonial Prestations in First Millennium B.C. Babylonia," in Women's Earliest Records From Ancient Egypt and Western Asia. Proceedings of the Conference on Women in the Ancient Near East, Brown University, Providence Rhode Island, November 5-7, 1987, Barbara S. Lesko, ed., Brown Judaic Studies 166 (Atlanta, Georgia: Scholars, 1989) 245-255 (responses on pp. 256-260)

Rowley, Harold Henry, "The Chronological Order of Ezra and Nehemiah," in Ignace Goldziher Memorial Volume, S. Löwinger and J. Somogyi, eds. (Budapest, 1948 [reprinted in The Servant of the Lord and Other Essays on the Old Testament, 2nd. ed., Oxford: Blackwell; and Naperville, IL: Allenson, 1965, 135-168]) 117-149 , "The Marriage of Hosea," Bulletin of the John Rylands Library 39 (1956-7 [reprinted in Men of God: Studies in Old Testament History and Prophecy, London: Nelson, 1963, 66-97]) 200-233

Rudolph, Wilhelm, Chronikbücher, HAT (Tübingen: Mohr, 1955) , Hosea, KAT 13/1 (Gütersloh: Gerd Mohn, 1966) 1968) , Jeremia, 3e Aufl., HAT 12 (Tübingen: J. C. B. Mohr [Paul Siebeck], , Haggai, Sacharja 1-8, Sacharja 9-14, Maleachi, mit einer Zeittafel von Alfred Jepsen, KAT XIII/4 (Gütersloh: Gerd Mohn and Neukirchen: Neukirchener Verlag, 1976)

, “Zu Malachi 2:10-16,” ZAW 93 (1981) 85-90

Rummel, Stan, ed., Ras Shamra Parallels: The Texts From Ugarit and the Hebrew Bible, vol. 3, AnOr 51 (Rome: Biblical Institute, 1981)

Sabottka, Liudger, Zephanja: Versuch einer Neü̈bersetzung mit philogischem Kommentar, BibOr 25 (Rome: Pontifical Biblical Institute, 1972)

Sanders, Henry A., and Carl Schmidt, The Minor Prophets in the Freer Collection and The Berlin Fragment of Genesis (New York and London: Macmillan, 1927)

Sänger, Max, Maleachi: Eine exegetische Studie über die Eigenthümlichkeiten seiner Redeweise (Jena: Diss. Jena, 1867)

Saporetti, Claudio, The Status of Women in the Middle Assyrian Period, Monographs on the Ancient Near East, vol. 2, fasc. 1 (Malibu, CA: Undena Publications, 1979)

Sarna, Nahum M., Exploring Exodus. The Heritage of Biblical Israel (New York: Schocken Books, 1986)

Genesis. The Traditional Hebrew Text with the New JPS Translation, The JPS Torah Commentary, Nahum M. Sarna and Chaim Potok, eds. (Philadelphia, New York, Jerusalem: The Jewish Publication Society, 1989)

Sasson, Jack M., Ruth: A New Translation with a Philological Commentary and a Formalist-Folklorist Interpretation, Johns Hopkins Near Eastern Studies (Baltimore, MD: The Johns Hopkins University Press, 1979)

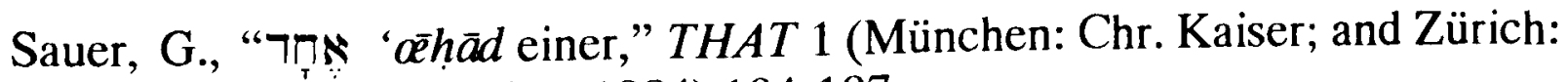
Theologischer Verlag, 1984) 104-107

Saurin, Jacques, Kurtzer Entwurff [sic] der Christlichen Theologie und Sitten-Lehre I= abregé de theologie et morale chretienne, dt.] (1723) 
Scharbert, Josef, “'Fluchen' und 'Segnen' im Alten Testament,” Biblica 39 (1958) 1-26

, "Ehe und Eheschliessung in der Rechtssprache des Pentateuchs und beim Chronisten," in Studien zum Pentateuch (Fs. Walter Kornfeld), Georg Braulik, ed. (Wien, Freiburg, Basel: Herder, 1977) 213-25 , ברך, brk," in TDOT 1 (Grand Rapids, MI: Eerdmans, 1977) 279-308 , "דָָ

Schillebeeckx, E., Marriage: Human Reality and Saving Mystery, N. D. Smith, trans. (New York: Sheed and Ward, 1965)

Schmidt, Werner H., Introduction to the Old Testament, Matthew J. O'Connell, trans. (London: SCM, 1984)

Schoors, A., "The Particle 'כִ, Remembering All the Way, OTS, 21 (A. S. van der Woude, ed., Leiden: E. J. Brill, 1981) 240-276

Schorr, Moses, Urkunden des altbabylonischen Zivil- und Prozessrechts, Vorderasiatische Bibliothek 5 (Leipzig: J. C. Hinrichs, 1913)

Schreiner, Stefan, "Mischehen-Ehebruch-Ehescheidung. Betrachtungen zu Mal 2,10-16," $Z A W 91$ (1979) 207-28

Schumpp, P. Meinrad, Das Buch der zwölf Propheten, Herders Bibelkommentar X/2 (Die Heilige Schrift für das Leben erklärt) Edmund Kalt, ed. (Freiburg: Herder, 1950)

Scott, R. B. Y., Proverbs. Ecclesiastes. Introduction, Translation, and Notes, 2nd. ed., AB 18 (New York, London, Toronto, Sydney, Auckland: Doubleday, 1965)

Scott, Thomas, The Holy Bible containing the Old and New Testaments, according to the Authorized Version; with Explanatory Notes, Practical Observations, and Copious Marginal References, Vol. 4 (Boston: Samuel T. Armstrong, and Crocker and Brewster, 1832 [reprint of the 1st ed., 1788-1792])

Sellin, Ernst, Das Zwölfprophetenbuch. Zweite Hälfte: Nahum-Maleachi, KAT XII (Leipzig: A. Diechertsche Verlagsbuchhandlung; Erlangen: Dr. Werner Scholl, 1922 [2e and 3e Aufl., 1930])

Selman, Martin J., "Published and Unpublished Fifteenth Century B.C. Cuneiform Documents and Their Bearing on the Patriarchal Narratives of the Old Testament," Ph.D. diss. (University of Wales, 1975)

Selms, Adriaan van, Marriage and Family Life in Ugaritic Literature (London: Luzac and Co., Ltd., 1954)

, "The Inner Cohesion of the Book of Malachi," in Studies in Old Testament Prophecy, W. C. van Wyk, ed., OTWSA (Potchefstroom: Pro Rege, 1975) 27-40

, Genesis deel I, 4e druk, POT (Nijkerk: G. F. Callenbach, 1984 [1 druk, 1967])

Shea, William H., “Adam in Ancient Mesopotamian Traditions," AUSS 15 (1977) 27-41

"A Comparison of Narrative Elements in Ancient Mesopotamian CreationFlood Stories with Genesis 1-9," Origins 11 (1984) 9-29

Sievers, Eduard, Metrische Studien, I, Studie zur hebräischen Metrik, Abhandlungen der philologisch-historischen Classe der königlich Sächsischen Gesellschaft der Wissenschaften, 21 (Leipzig: B. G. Teubner, 1901)

Alttestamentliche Miscellen, 4, Zu Maleachi, Abhandlungen der philologisch-historischen Classe der königlich Sächsischen Gesellschaft der Wissenschaften, 57 (Leipzig: B. G. Teubner, 1905) 
Silbermann, A. M., and M. Rosenbaum, Chumash with Targum Onkelos, Haphtaroth and Rashi's Commentary: Bereshith, translated into English and Annotated (Jerusalem: The Silbermann Family, 1934)

Silva, Moisés, Biblical Words and Their Meaning: An Introduction to Lexical Semantics (Grand Rapids, MI: Zondervan, 1983)

Skaist, Aaron J., "Studies in Ancient Mesopotamian Family Law Pertaining to Marriage and Divorce," Ph.D. diss. (University of Pennsylvania, 1963)

Skehan, Patrick W., Studies in Israelite Poetry and Wisdom, Catholic Biblical Quarterly Monograph Series, 1 (Washington, D.C.: Catholic Biblical Association, 1971)

Skehan, Patrick W., and Alexander A. Di Lella, The Wisdom of Ben Sira. A New Translation with Notes by Patrick W. Skehan. Introduction and Commentary by Alexander A. DiLella, AB 39 (New York: Doubleday \& Company, 1987)

Skinner, John, Prophecy and Religion. Studies in the Life of Jeremiah, 2nd ed. (Cambridge: Cambridge University, 1922)

, A Critical and Exegetical Commentary on Genesis, 2nd. ed., ICC

(Edinburgh: T. \& T. Clark Ltd., 1930 [1st ed. 1910])

Smend, Rudolf, Die Bundesformel, Theologische Studien 68 (Zürich: EVZ-Verlag, 1963) Verlag, 1970) Die Mitte des Alten Testaments, Theologische Studien 101 (Zürich: EVZ-

, "Essen und Trinken - ein Stück Weltlichkeit des AT," in Beiträge zur alttestamentlischen Theologie. Fs für Walther Zimmerli zum 70. Geburtstag, Herbert Donner, Robert Hanhart, and Rudolf Smend, eds. (Göttingen: Vandenhoeck \& Ruprecht, 1977) 446-459

Smick, Elmer B., "כר Moody, 1980) 456-457

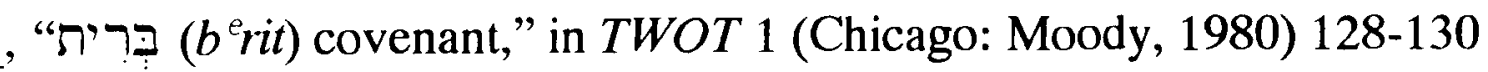
, “Job," in The Expositor's Bible Commentary, 4, Frank E. Gaebelein, ed. (Grand Rapids, MI: Zondervan, 1988) 843-1060

Smit, G., De kleine profeten, III: Habakuk, Haggai, Zacharia, Maleachi, Texte und Untersuchungen (Den Haag: Wolters, 1934)

Smith, George Adam, The Book of the Twelve Prophets Commonly Called the Minor in Two Volumes -- Volume 2: Zephaniah, Nahum, Habakkuk, Obadiah, Haggai, Zechariah, Malachi, Joel, Jonah, 2nd ed. (New York and London: Harper \& Brothers, 1929 [1st ed. 1899])

Smith, Gary V., "Malachi," in ISBE 3 (Grand Rapids, MI: Eerdmans, 1986) 226-28 , Amos. A Commentary, The Library of Biblical Interpretation (Grand Rapids, MI: Zondervan, 1989)

Smith, John Merlin Powis: see H. G. Mitchell, J. M. Powis Smith, and J. A. Bewer, A Critical and Exegetical Commentary on Haggai, Zechariah, Malachi and Jonah

Smith, John Merlin Powis, "A Note on Malachi 2:15a," AJSL 28 (1911/12) 204-206 , "The Syntax and Meaning of Genesis 1:1-3," AJSL 44 (1928) 108-115 , "The Use of Divine Names as Superlatives," AJSL 45 (1929) 212-213

Smith, John Merlin Powis, William Hayes Ward, and Julius A. Bewer, A Critical and Exegetical Commentary on Micah, Zephaniah, Nahum, Habakkuk, Obadiah and Joel, ICC (Edinburgh: T. \& T. Clark, 1911 [reprinted 1974]) 
Smith, Morton, "Jewish religious life in the Persian period," in The Cambridge History of Judaism. Vol 1: Introduction; The Persian Period, W. D. Davies and Louis Finkelstein, eds. (Cambridge, London, and New York: Cambridge University, 1984)
219-278

Smith, Ralph L., Micah-Malachi, WBC 32 (Waco, TX: Word Books, 1984)

,"The Shape of Theology in the Book of Malachi," Southwestern Journal of Theology 30 (1987) 22-27

Smith, R. Payne, A Compendious Syriac Dictionary, J. Payne Smith, ed. (Oxford: Clarendon, 1903)

Smith, Sidney, "The Age of Ashurbanipal," in Cambridge Ancient History, III: The Assyrian Empire, J. B. Bury, S. A. Cook, and F. E. Adcock, eds. (Cambridge, London, New York, and Melbourne: Cambridge University Press, 1929 [1st edition 1925]) 89-112 (“Assyrian Law” on pp. 104-108)

Smith, William Robertson, Kinship and Marriage in Early Arabia, 2nd ed. (Cambridge and London: Cambridge University, 1903 [reprinted 1963 by Beacon, Boston]) , Lectures on the Religion of the Semites: The Fundamental Institutions, 3rd ed. (London and New York: Macmillan, 1927)

Snijders, Lambertus A., "The Meaning of zār in the Old Testament," OTS 10 (1954) 1-154 , "רiז/, zûrr/zãr," in TDOT 4 (Grand Rapids, MI: Eerdmans, 1980) 52-58

Snyman, S. D., "Antiteses in die boek Maleagi," Ph.D. diss. (University of Pretoria, South Africa, 1985)

, "Antitheses in Malachi 1,2-5," $Z A W 98$ (1986 [previously published as "Chiasmes in Mal. 1:2-5," Skrif en Kerk, 1984, 17-22]) 436-38

Soden, Wolfram von, "Die Unterweltsvision eines assyrischen Kronprinzen," Zeitschrift für Assyriologie und verwandte Gebiete 43 (1936) 1-31

, Akkadisches Handwörterbuch, 2e Aufl., 3 Bde (Wiesbaden: Otto Harrassowitz, 1959-1985)

, Grundriss der Akkadischen Grammatik, samt Ergänzungsheft zum Grundriss der Akkadischen Grammatik, AnOr 33 and 47 (Rome: Pontifical Biblical Institute, 1969)

, "Zum hebräischen Wörterbuch," in Ugarit-Forschungen. Internationales

Jahrbuch für die Altertumskunde Syrien-Palästinas 13, Kurt Bergerhof, Manfried Dietrich, and Oswald Loretz, eds. (Kevelaer: Verlag Butzon \& Bercker; and Neukirchen-Vluyn: Neukirchener Verlag, 1981) 157-164

Soggin, J. Alberto, "Akkadisch TAR berîti und hebräisch krt bryt," VT 18 (1968) 210-215

, Introduction to the Old Testament From Its Origins to the Closing of the Alexandrian Canon, 3rd ed., John Bowden, trans., OTL (Philadelphia: Westminster, 1989)

Sohn, Seock-Tae, “The Divine Election of Israel," Ph.D. diss. (New York University, 1986)

Sonsino, R., "Characteristics of Biblical Law," Judaism 33 (1984) 202-209

Speiser, Ephraim Avigdor, New Kirkuk Documents Relating to Family Laws, AASOR 10 (New Haven: Yale University, 1930)

,"Ethnic Movements in the Near East in the Second Millennium," AASOR

13 (New Haven: Yale University, 1933) 13-54 
, 100 New Selected Nuzi Texts, see Robert H. Pfeiffer and E. A. Speiser ,"I Know Not the Day of My Death' [Gen 27:2]," JBL 74 (1955) 252-256 "Leviticus and the Critics," in Yehezkel Kaufmann Jubilee Volume, M. Haran, ed. (Jerusalem: Magnes, 1960) 29-45

, Genesis. Introduction, Translation, and Notes, AB 1 (Garden City, NY: Doubleday \& Company, 1964 [3rd ed. 1979])

Sperber, Alexander, The Bible in Aramaic, III: The Latter Prophets according to Targum Jonathan, The Bible in Aramaic (Leiden: E. J. Brill, 1962)

Sperber, J., "Der Personenwechsel," Zeitschrift für Assyriologie und verwandte Gebiete $32(1918 / 19) 23-33$

Spoer, Hans H., "Some New Considerations towards the Dating of the Book of Malachi," Jewish Quarterly Review 20 (1908) 167-86

Stade, Bernhard, Lehrbuch der hebräischen Grammatik (Leipzig: Vogel, 1879) 1905) , Biblische Theologie des Alten Testaments 1 (Tübingen: J. C. B. Mohr,

Stamm, Johann Jakob, and Maurice Edward Andrew, The Ten Commandments in Recent Research, Studies in Biblical Theology, 2nd. series, 2, C. F. D. Moule, James Barr, Peter Ackroyd, Floyd V. Filson, and G. Ernest Wright, eds. (London: SCM Ltd.; and Nashville, TN: Alec R. Allenson, 1967)

Sternberg, Meir, The Poetics of Biblical Narrative: Ideological Literature and the Drama of Reading, Indiana Literary Biblical Series, Robert M. Polzin, ed. (Bloomington, IN: Indiana University Press, 1985)

Stock, Richard and Samuel Torshell, A Commentary upon the Prophecy of Malachi, Nichol's Series of Commentaries (Edinburgh: James Nichol, 1865)

Strack, H. L., and P. Billerbeck, Kommentar zum Neuen Testament aus Talmud und Midrasch, 6 Bde (München: Beck, 1923-1961)

Strassmaier, Johann Nepomucen, Die babylonischen Inschriften im Museum zu Liverpool, nebst anderen aus der Zeit von Nebukadnezzar bis Darius, Actes du sixième congrès international des Orientalistes tenu en 1883 à Leide, II, Section Sémitique (1) (Leipzig, J. C. Hinrichs, 1885)

Streck, Maximilian, Assurbanipal und die letzten assyrischen Könige bis zum Untergang Niniveh's, Vorderasiatische Bibliothek 7 (Leipzig, J. C. Hinrichs, 1916)

Stuart, Douglas K., Hosea - Jonah, WBC 31 (Waco, TX: Word Books, 1987) , Old Testament Exegesis: A Primer for Students and Pastors, 2nd ed. (Philadelphia, PA: Westminster, 1984)

Stuhlmueller, Carroll, "Malachi," in The Jerome Biblical Commentary, Raymond E. Brown, Joseph A. Fitzmyer, and Roland E. Murphy, eds. (London: Geoffrey Chapman, 1970) 398-401

, "Sacrifice among the Nations," The Bible Today 22 (1984) 223-25

Swetnam S. J., James, "Malachi 1,11: An Interpretation," CBQ 31 (1969) 200-209

Symons, Donald, The Evolution of Human Sexuality (New York and Oxford: Oxford University, 1979)

Tadmor, Hayim, "Treaty and Oath in the Ancient Near East: An Historian's Approach," in Humanizing America's Iconic Book: Society of Biblical Literature Centennial Addresses 1980, SBL Centennial Publications, Scholars Press, Gene M. Tucker and 
Douglas A. Knight, eds., Society of Biblical Literature Biblical Scholarship in North America, 6 (Chico, CA: Scholars Press, 1982) 127-152

Tarnovius [Johannes Tarnow], Johannes, In prophetas minores commentarius cum praefatione Joh. Bened. Carpzovii (Fracofurti et Lipsiae, 1688)

Taylor, John B., Ezekiel. An Introduction and Commentary, TOTC (Downers Grove, IL: Inter-Varsity, 1969)

Teubal, Savina J., Sarah the Priestess. The First Matriarch of Genesis (Athens, Ohio; Chicago; London: Swallow, 1984)

Thiselton, Anthony C., "Semantics and New Testament Interpretation," in New Testament Interpretation, I. Howard Marshall, ed. (Exeter: Paternoster; and Grand Rapids, MI: Eerdmans, 1977) 75-104

Thompson, John Arthur, Deuteronomy. An Introduction and Commentary, TOTC (Downers Grove, IL: InterVarsity, 1974)

Samuel," VT 24 (1974) 334-38

, "Covenant (OT)," in ISBE 1 (Grand Rapids, MI: Eerdmans, 1979) 790-793

, The Book of Jeremiah, NICOT (Grand Rapids, MI: Eerdmans, 1980)

Thompson, Thomas L., The Historicity of the Patriarchal Narratives. The Quest for the Historical Abraham, BZAW 133, Georg Fohrer, ed. (Berlin and New York: Walter de Gruyter, 1974)

Tigay, Jeffrey H., "Israelite Religion: The Onomastic and Epigraphic Evidence," in Ancient Israelite Religion. Essays in Honor of Frank Moore Cross, Patrick D. Miller Jr., Paul D. Hanson, and S. Dean McBride, eds. (Philadelphia: Fortress, 1987) 157-194

Toorn, Karel van der, Sin and Sanction in Israel and Mesopotamia: a comparative study, Studia Semitica Neerlandica, 22 (Assen: Van Gorcum, 1985)

$427-445$

"Ordeal Procedures in the Psalms and the Passover Meal," VT 38 (1988)

, "Female Prostitution in Payment of Vows in Ancient Israel," JBL 108

(1989) 193-205

Torczyner, Harry, Lachish I. The Lachish Letters (Oxford and London: Oxford University, 1938)

Torrance, James B., "Covenant or Contract? A Study of the Theological Background of Worship in Seventeeth-Century Scotland," Scottish Journal of Theology 23 (1970) 51-76

Torrey, Charles Cutler, “The Edomites in Southern Judah,” JBL 17 (1898) 16-20 , “The Prophecy of 'Malachi'," JBL 17 (1898) 1-15

Tosato, Angelo, Il matrimonio nel Giudaismo antico e nel Nuovo Testamento (Rome: Pontifical Institute, 1976) , "Il ripudio: delitto e pena (Mal 2,10-16)," Biblica 59 (1978) 548-553

, Il matrimonio israelitico. Una theoria generale, AnBib 100 (Rome: Biblical Institute, 1982)

,"The Law of Leviticus 18:18: A Reexamination," CBQ 46 (1984) 199-214

Toy, Crawford H., A Critical and Exegetical Commentary on the Book of Proverbs, ICC (Edinburgh: T. \& T. Clark, 1899) 

Trible, Phyllis, God and the Rhetoric of Sexuality, Overtures to Biblical Theology
(Philadelphia, PA: Fortress, 1978)

, Texts of Terror: Literary-Feminist Readings of Biblical Narratives,

Overtures to Biblical Theology, Walter Brueggemann, ed. (Philadelphia: Fortress, 1984)

Trumbull, H. C., The Covenant of Salt, as Based on the significance and Symbolism of Salt in Primitive Thought (New York: Scribner, 1899)

Tsevat, Matitiahu, "Marriage and Monarchical Legitimacy in Ugarit and in Israel," JSS 3 (1958) 237-243

"The Neo-Assyrian and Neo-Babylonian Vassal Oaths and the Prophet

Ezekiel," JBL 78 (1959) 199-204

, "Studies in the Book of Samuel," HUCA 34 (1963) 71-82

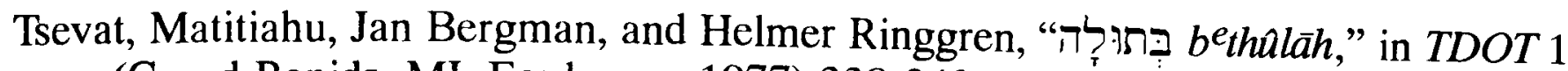

(Grand Rapids, MI: Eerdmans, 1977) 338-343

Tuck, R., "Homilies by Various Authors on Malachi," in The Pulpit Commentary, H. D.

M. Spence and Joseph S. Exell, eds. (New York: Funk \& Wagnalls, Co., n.d.)

Tucker, Gene M., "Covenant Forms and Contract Forms," VT 15 (1965) 487-503

"Prophetic Superscriptions and the Growth of a Canon," in Canon and

Authority. Essays in Old Testament Religion and Theology, George W. Coats and

Burke O. Long, eds. (Philadelphia: Fortress, 1977) 56-70

Tur-Sinai [Torczyner], N. H., The Book of Job, rev. ed. (Jerusalem: Kiryat-Sefer, 1967)

Ulrich Jr., Eugene Charles, The Qumran Text of Samuel and Josephus (Missoula, MT:

Scholars, 1978)

Van Seters, John, "The Problem of Childlessness in Near Eastern Law and the Patriarchs of Israel," JBL 87 (1968) 401-8

HTR 62 (1969) 377-95

, Abraham in History and Tradition (New Haven: Yale University, 1975)

Vannoy, J. Robert, Covenant Renewal at Gilgal. A Study of 1 Samuel 11:14-12:25

(Cherry Hill, NJ: Mack, 1978)

Vaux O.P., Roland de, Ancient Israel, Vol. 1, Social Institutions (New York: McGraw-

Hill, 1961 [orig. published as Les Institutions de L'Acien Testament, 1, Paris: Les

Éditions du Cerf, 1958])

Vawter, Bruce, "The Biblical Theology of Divorce," Proceedings of the Catholic

Theological Society of America 22 (1967) 223-43

1977)

, On Genesis: A New Reading (Garden City, NY: Doubleday \& Company,

Veenhof, K. R., "review of E. Kutsch, Salbung als Rechtsakt im Alten Testament und im alten Orient," BO 23 (1966) 308-13

Vellas, Basil M., Israelite Marriage, John S. Koulouras, trans. (Athens: n.p., 1956)

Venema, Hermannus, Commentarius ad librum elenctico-propheticum Malachiae (Leovardiae, 1763)

Verhoef, Pieter Adriaan, "Some Notes on Malachi 1:11," in Biblical Essays, Proceedings of the Ninth Meeting of Die Ou-Testamentiese Werkgemeenskap in Suid-Afrika, held 
at the University of Stellenbosch, July 1966 (Potchefstroom: Pro Rege, 1967 [reprint in Nederduits Gereformeerde Teologiese Tydskrif, 21, 1980, 21-30]) 163-72 , Maleachi, COT 19 (Kampen: J. H. Kok, 1972)

1987) The Books of Haggai and Malachi, NICOT (Grand Rapids, MI: Eerdmans,

Viganò, Lorenzo, Nomi e titoli di YHWH alla luce del semitico del Nord-ovest, BibOr 31

(Rome: Pontifical Biblical Institute, 1976)

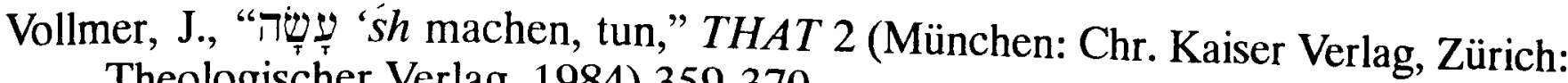
Theologischer Verlag, 1984) 359-370

Volterra, E., Iura 6 (1955) 340-360

Vriezen, Theodorus Christaan, Onderzoek naar de paradijsvoorstelling bij de oude semietische volken. Diss. Utrecht (Wageningen: H. Veenman, 1937) Co., 1958)

An Outline of Old Testament Theology (Newton, MA: Charles T. Brantford "Eid," in Biblische-historisches Handwörterbuch, Bd. 1, B. Reicke and L. Rost, eds. (Göttingen: Vanderhoeck \& Ruprecht, 1962-66) 374-76 , "The Exegesis of Exodus 24:9-11," OTS 17 (1972) 100-133 , "How to Understand Malachi 1:11," in Grace upon Grace: Essays in Honor of Lester J. Kuyper, James I. Cook, ed. (Grand Rapids, MI: Eerdmans, 1975) 12836

Vuilleumier, René, see Samuel Amsler, André Lacocque and René Vuilleumier, Aggée, Zacharie, Malachie

Wadsworth, T., "Is There a Hebrew Word for Virgin? Bethulah in the Old Testament," Restoration Quarterly 23 (1980) 161-171

Walker, Larry Lee, “Zephaniah,” in The Expositor's Bible Commentary, 7, Frank E. Gaebelein, ed. (Grand Rapids, MI: Zondervan, 1985)

Wallis, Gerhard, "Wesen und Struktur der Botschaft Maleachis," in Das ferne und nahe Wort: Fs Leonard Rost, Fritz Maass, ed., BZAW 105 (Berlin: A. Töpelmann, 1967) 229-237

, “אָאָ, 'āhabh,” in TDOT 1 (Grand Rapids, MI: Eerdmans, 1978) 99-118 , "7ָּבק, dābhaq," in TDOT 3 (Grand Rapids, MI: Eerdmans, 1978) 79-84

Walls, A. F., "Proverbs," in The New Bible Commentary Revised, D. Guthrie, J. A. Motyer, A. M. Stibbs, and D. J. Wiseman, eds. (Leicester, England: Inter-Varsity, 1970) $548-569$

Waltke, Bruce K., and M. O'Connor, An Introduction to Biblical Hebrew Syntax (Winona Lake, IN: Eisenbrauns, 1990)

Walton, John H., Ancient Israelite Literature in its Cultural Context. A Survey of Parallels Between Biblical and Ancient Near Eastern Literature (Grand Rapids, MI: Zondervan, 1989)

Ward, William A., "Reflections on some Egyptian terms presumed to mean 'harem, haremwoman, concubine'," Berytus 31 (1983) 67-74

Watson, Wilfred G. E., Classical Hebrew Poetry. A Guide to Its Techniques, JSOTSup 26 (Sheffield, England: JSOT Press, 1984, 1986)

Watt, W. Montgomery, Muhammad, Prophet and Statesman (London: Oxford University, 1964) 
Watts, John D. W., Obadiah. A Critical Exegetical Commentary (Grand Rapids, MI:

Eerdmans, 1969 [reprinted 1981 by Winona Lake, IN: Alpha Publications]) , Isaiah 1-33, WBC 24 (Waco, TX: Word Books, 1985) , Isaiah 34-66, WBC 25 (Waco, TX: Word Books, 1987)

Weber, Max, Ancient Judaism, Hans H. Gerth, trans. and ed. (Glencoe, IL: Free Press, 1952)

Weber, Robertus, et al., eds., Biblia Sacra Iuxta Vulgatam Versionem (Stuttgart: Deutsche Bibelgesellschaft, 1983)

Weinfeld, Moshe, "Deuteronomy -- The Present State of Inquiry," JBL 86 (1967) 249-262 ,"The Covenant of Grant in the Old Testament and in the Ancient Near East," JAOS 90 (1970) 184-203

, Deuteronomy and the Deuteronomic School (Oxford: Clarendon, 1972) , "Berît - Covenant vs. Obligation," Biblica 56 (1975) 120-128 , "Covenant, Davidic," in IDBSup (Nashville, TN: Abingdon, 1976) 188-

192

,"The Loyalty Oath in the Ancient Near East," in Ugarit-Forschungen, 8 (1976) 379-414

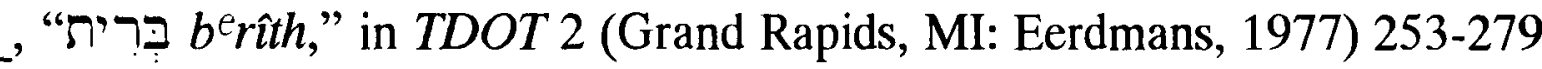

, "Social and Cultic Institutions in the Priestly Source against their Ancient

Near Eastern Background," in Proceedings of the Eighth World Congress of Jewish Studies, Jerusalem, August 16-21, 1981. Panel Sessions: Bible Studies and Hebrew Language (Jerusalem: World Union of Jewish Studies and The Perry Foundation for Biblical Research, 1983) 95-129

Weiser, Artur, Das Buch Jeremia, ATD 20/21 (Göttingen: Vandenhoeck \& Ruprecht, 1969)

Weiss, David Halivni, “A Note on אשר לא ארשה," JBL 81 (1962-69 , "The Use of qnh in Connection with Marriage," HTR 57 (1964) 244-248

Welch, Adam Cleghorn, Post-Exilic Judaism, The Baird Lecture for 1934 (Edinburgh: Blackwood, 1935)

Welch, John W., "Reflections on Postulates: Power and Ancient Laws - A Response to Moshe Greenberg," in Religion and Law. Biblical-Judaic and Islamic Perspectives, Edwin B. Firmage, Bernard G. Weiss, and John W. Welch, eds. (Winona Lake, IN: Eisenbrauns, 1990) 113-119

Wellhausen, Julius, Skizzen und Vorarbeiten. Die kleinen Propheten übersetzt, mit Noten, 5e Aufl. (Berlin: Georg Reimer, 1892 [4e Aufl. reprinted by W. De Gruyter, Berlin, 1963])

Wendland, Ernst, "Linear and Concentric Patterns in Malachi," The Bible Translator 36 (1985) 108-121

Wenham, Gordon J., "Legal Forms in the Book of the Covenant," TB 22 (1971) 95-102 , "betûlāh 'A Girl of Marriageable Age'," VT 22 (1972) 326-48 , The Book of Leviticus, NICOT (Grand Rapids, MI: Eerdmans, 1979) " "The Restoration of Marriage Reconsidered," JJS 30 (1979) 36-40 , Numbers. An Introduction and Commentary, TOTC (Leicester, England and Downers Grove, IL: Inter-Varsity, 1981) 
"The Symbolism of the Animal Rite in Genesis 15: A Response to G. F. Hasel, JSOT 19 (1981) 61-78," JSOT 22 (1982) 134-137

, "Sanctuary Symbolism in the Garden of Eden," in Proceedings of the Ninth World Congress of Jewish Studies, Jerusalem, August 4-12, 1985. Division A: The Period of the Bible (Jerusalem: World Union of Jewish Studies, 1986) 19-25 , Genesis 1-15, WBC 1 (Waco, TX: Word Books, 1987)

Wenham, Gordon J., and J. G. McConville, "Drafting Techniques in Some Deuteronomic Laws," VT 30 (1980) 248-252

Westbrook, Raymond, “Old Babylonian Marriage Law,” Ph.D. diss. (Yale University, 1982)

, "The Enforcement of Morals in Mesopotamia," JAOS 104 (1984) 753-756

, "Biblical and Cuneiform Law Codes," RB 92 (1985) 247-264

, "Lex talionis and Exodus 21:22-25," RB 93 (1986) 52-69

,"The Prohibition on Restoration of Marriage in Deuteronomy 24:1-4," in

Studies in Bible 1986: Scripta Hierosolymitana: Publications of the Hebrew

University Jerusalem, 31, S. Japhet, ed. (Jerusalem: Magnes, 1986) 387-405

Westbrook, Raymond, et al., "Responses to Prof. Roth's Paper," in Women's Earliest

Records From Ancient Egypt and Western Asia. Proceedings of the Conference on Women in the Ancient Near East, Brown University, Providence Rhode Island,

November 5-7, 1987, Barbara S. Lesko, ed., Brown Judaic Studies 166 (Atlanta, Georgia: Scholars, 1989) 256-26́0

Westcott, Richard S., "The Concept of $b^{e}$ rît with Regard to Marriage in the Old

Testament," Th.M. diss. (Dallas Theological Seminary, 1985)

Westermann, Claus, Genesis 1-11: A Commentary, John J. Scullion S.J., trans. (London: SPCK and Minneapolis: Augsburg, 1984)

, Genesis 12-36: A Commentary, John J. Scullion S.J., trans. (Minneapolis:

Augsburg, 1985)

, Genesis 37-50: A Commentary, John J. Scullion S.J., trans. (Minneapolis:

Augsburg, 1986)

Westermann, Claus, and R. Albertz, "חַּר רü rah Geist," THAT 2 (München: Chr. Kaiser Verlag, Zürich: Theologischer Verlag, 1984) 726-753

Wette, Wilhelm Martin Leberecht de, A Critical and Historical Introduction to the Canonical Scriptures of the Old Testament, 2 vols., Theodore Parker trans. (Boston, MA: Little \& Brown, 1843 [1 Aufl. 1817; 7 Aufl. 1852])

Wevers, John William, Ezekiel, NCB (London: Thomas Nelson and Sons Ltd., 1969)

Whitaker, Richard E., ed., The Eerdmans Analytical Concordance to the Revised Standard Version of The Bible (Grand Rapids, MI: Eerdmans, 1988)

White, Hugh C., "The Divine Oath in Genesis," JBL 92 (1973) 165-179

White, John Bradley, A Study of the Language of Love in the Song of Songs and Ancient Egyptian Poetry, SBLDS 38 (Missoula, MT: Scholars, 1978)

Whybray, R. N., Wisdom in Proverbs, Studies in Biblical Theology 45 (London: SCM, 1965)

Widengren, Geo., "The Persian Period," in Israelite and Judean History, John H. Hayes and J. Maxwell Miller, eds. (Philadelphia: Westminster, 1977) 489-538

Wierzbicka, Anna, Lexicography and Conceptual Analysis (Ann Arbor: Karoma, 1985) 
Wifall Jr., Walter R., "Bone of my Bones and Flesh of my Flesh - The Politics of the Yahwist," Currents in Theology and Missions 10 (1983) 176-183

Wildberger, Hans, Jesaja. I. Teilband: Jesaja 1-12, BKAT X/1 (Neukirchen-Vluyn: Neukirchener Verlag, 1972)

, Jesaja. 2. Teilband: Jesaja 13-27, BKAT X/2 (Neukirchen-Vluyn:

Neukirchener Verlag, 1978)

, Jesaja. 3. Teilband: Jesaja 28-39; Das Buch, der Prophet und seine

Botschaft, BKAT X/3 (Neukirchen-Vluyn: Neukirchener Verlag, 1982)

, “ שמאר šr'rübrig sein,” THAT 2 (München: Chr. Kaiser, Zürich:

Theologischer Verlag, 1984) 844-55

Willesen, F., "Die Eselsöhne von Sichem als Bundesgenossen," VT 14 (1964) 216-217

Williams, James G., Women Recounted: Narrative Thinking and the God of Israel, Bible and Literature Series, 6 (Sheffield: Almond, 1982)

Williams, Ronald J., Hebrew Syntax: An Outline, 2nd ed. (Toronto and Buffalo: University of Toronto, 1976)

Williamson, H. G. M., Ezra, Nehemiah, WBC 16 (Waco, TX: Word Books, 1985)

Wilson, Edward O., Sociobiology: The New Synthesis (Cambridge, MA: The Belknap of Harvard University, 1975)

, On Human Nature (Cambridge, MA: Harvard University, 1978)

Wilson, John A., “The Oath in Ancient Egypt," JNES 7 (1948) 129-156

Wilson, Marvin R., Our Father Abraham. Jewish Roots of the Christian Faith (Grand

Rapids, MI: Eerdmans; and Dayton, OH: Center for Judaic-Christian Studies, 1989)

Wilson, Robert W., "Sociology of the Old Testament," in Harper's Bible Dictionary, Paul

J. Achtemeier, et al., eds. (San Francisco: Harper and Row, 1985) 968-973

Winckler, Hugo, "Maleachi," in Altorientalische Forschungen, II Reihe, Band III (Leipzig: Eduard E. Pfeiffer, 1899) 531-539

Winter, Jakob, and Aug. Wünsche, Die Jüdische Litterature seit Abschluss des Kanons, 3 Bd. (Trier: S. Mayer, 1894-96)

Wiseman, Donald J., The Alalakh Tablets, Occasional Publications of the British Institute of Archaeology at Ankara, No. 2 (London: The British Institute of Archaeology at Ankara, 1953)

, "Supplementary Copies of Alalakh Tablets," JCS 8 (1954) 1-30

, "Abban and Alalah," JCS 12 (1958) 124-129

, The Vassal-Treaties of Esarhaddon, Iraq, 20, Part 1 (London: British

School of Archaeology in Iraq, 1958)

,"The Laws of Hammurabi Again," JSS 8 (1962) 161-72

“'Is it Peace?' - Covenant and Diplomacy," VT 32 (1982) 311-326

Wolf, Herbert, Haggai and Malachi: Rededication and Renewal, Everyman's Bible

Commentary (Chicago: Moody, 1976)

"The Apology of Hattušilis Compared with Other Political Self-

Justifications of the Ancient Near East," Ph.D. diss. (Brandeis University, 1967)

Wolff, Hans Walter, "Erkenntnis Gottes im AT," EvT 15 (1955) 426-431

,"The Kerygma of the Yahwist," Interpretation 20 (1966) 131-58 [orig.

published in $E v T 24,1964,73-97]$ 
, Anthropology of the Old Testament, Margaret Kohl, trans. (Philadelphia, PA: Fortress and London: SCM Ltd., 1974)

, Hosea. A Commentary on the Book of the Prophet Hosea, Hermeneia

(Philadelphia: Fortress, 1974)

, Joel, Amos. A Commentary on the Books of the Prophets Joel and Amos,

Hermeneia, W. Janzen, S. D. McBride Jr., and C. D. Muenchow, trans.

(Philadelphia: Fortress, 1977)

, Obadiah and Jonah. A Commentary, Margaret Kohl, trans. (London:

SPCK; and Minneapolis: Augsburg, 1986)

Wordsworth, Christopher, The Holy Bible in the Authorized Version, with Notes and

Introductions. Commentary on the Old Testament, Vol 6, Daniel and the Minor

Prophets (London: Rivingtons, 1872)

Woude, Adam Simon van der, “1 Reg. $20_{34}$," $Z A W 76$ (1964) 188-190

, Haggai, Maleachi, POT (Nijkerk: G. F. Callenbach, 1982)

, "Malachi's Struggle for a Pure Community. Reflections on Malachi 2:10-

16 ," in Tradition and Re-interpretation in Jewish and Early Christian Literature.

Essays in Honour of Jürgen C. H. Lebram, J. W. van Henten, H. J. de Jonge, P. T. van Rooden, and J. W. Wesselius, eds., Studia Post-Biblica 36 (Leiden: E. J. Brill, 1986) 65-71

Woudstra, Marten H., "The Everlasting Covenant in Ezekiel 16:59-63," Calvin Theological Journal 6 (1971) 22-48

Wright, Christopher J. H., An Eye for An Eye (Downers Grove, IL: InterVarsity, 1983)

Wright, G. E., "The Lawsuit of God. A Form-Critical Study of Deuteronomy 32," in Israel's Prophetic Heritage, B. W. Anderson and W. Harelson, eds. (New York and London: Harper, 1962) 26-67

Würthwein, Ernst, The Text of the Old Testament, Erroll F. Rhodes, trans. (Grand Rapids, MI: Eerdmans, 1979)

Yadin, Yigael, "Expedition D - The Cave of the Letters," IEJ 12 (1962) 244-245

Yamauchi, Edwin M., "Ezra, Nehemiah," in The Expositor's Bible Commentary, 4, Frank E. Gaebelein, ed. (Grand Rapids, MI: Zondervan, 1988) 565-771

(1978) 241-252

"Cultural Aspects of Marriage in the Ancient World," Bibliotheca Sacra 135

, “The reverse order of Ezra/Nehemiah reconsidered," Themelios 5 (1980) 7-

13

Yaron, Reuven, "On Divorce in Old Testament Times," Revue Internationale des Droits de l'Antiquité, 3rd series 4 (1957) 117-128

, “Aramaic Marriage Contracts from Elephantine," JSS 3 (1958) 1-39

, “Aramaic Marriage Contracts: Corrigenda and Addenda,"JSS 5 (1960) 66-

70

, Introduction to the Law of the Aramaic Papyri (Oxford: Clarendon, 1961)

, "Matrimonial Mishaps at Eshnunna," JSS 8 (1963) 1-16

, "The Restoration of Marriage," JJS 17 (1966) 1-11

, The Laws of Eshnunna, 2nd ed. (Leiden: E. J. Brill; and Jerusalem:

Magnes, The Hebrew University, 1988) 
Yee, Gale A., Composition and Tradition in the Book of Hosea: A Redaction Critical Investigation, SBLDS 102 (Atlanta, GA: Scholars, 1987)

, 'I Have Perfumed My Bed With Myrrh': The Foreign Woman ('ił̌ša zārâ) in Proverbs 1-9," JSOT 43 (1989) 53-68

Young, Dwight Wayne, "A Ghost Word in the Testament of Jacob (Gen 49:5)?" JBL 100 (1981) 335-342

Young, Edward J., An Introduction to the Old Testament, rev. ed. (Grand Rapids, MI: Eerdmans, 1964)

,The Book of Isaiah, Vol. 1, Chapters 1-18, 2nd ed., NICOT (Grand Rapids, MI: Eerdmans, 1972)

Young, Edward J., and Joyce G. Baldwin, "Malachi," in The Illustrated Bible Dictionary, rev. ed., 2, J. D. Douglas and N. Hillyer, eds. (Leicester, England: Intervarsity; and Wheaton, IL: Tyndale House, 1980) 937f

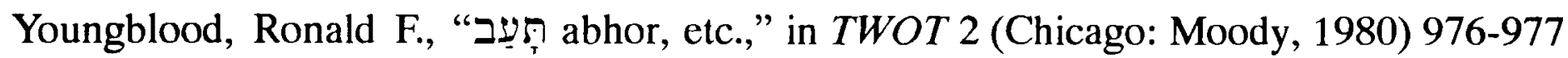

Zakovitch, Yair, 'For Three ... and for Four': The Pattern for the Numerical Sequence Three - Four in the Bible [Hebrew] (Jerusalem: Makor Publishing Ltd., 1979) ,"The Woman's Rights in the Biblical Law of Divorce," The Jewish Law Annual, 4, B. S. Jackson, ed. (Leiden: E. J. Brill, 1981) 28-46

Zeitlin, Solomon, "The Origin of the Kethubah: A Study in the Institution of Marriage," Jewish Quarterly Review N.S. 24 (1933-34) 1-7

Zevit, Ziony, "A Phoenician Inscription and Biblical Covenant Theology," IEJ 27 (1977) 110-118 $481-511$

, "Converging Lines of Evidence Bearing on the Date of $\mathrm{P}, " Z A W(1982)$

Ziegler, Joseph, "Die Liebe Gottes bei den Propheten," Alttestamentliche Abhandlungen 11 (1930) 73-77

ed., Duodecim Prophetae. Septuaginta, Vetus Testamentum Graecum, Auctoritate Academiae Scientiarum Gottingensis editum, 13 (Göttingen: Vandenhoeck \& Ruprecht, 1984)

Zimmerli, Walther, Ezekiel I. A Commentary on the Book of the Prophet Ezekiel, Chapters 1-24, Hermeneia, R. E. Clements, trans. (Philadelphia: Fortress, 1979) , Ezekiel 2. A Commentary on the Book of the Prophet Ezekiel Chapters 2548, J. D. Martin, trans., Hermeneia (Philadelphia: Fortress, 1983) 


\section{Index of Biblical Citations}

N.B.: This index is complete only for the main body of the dissertation and includes only occasional references to certain more important citations found within the footnotes.

\section{Genesis}

$1-261,65$

$1: 26168$

$1: 27124,150,152,169$

$222,118,120,296,357$

Genesis 2-3, possible aetiological purposes for note \#205 173

$2: 7158$

$2: 18,20,23151$

2:18-22 124

Genesis 2:23 [\$7.1.3.1] 248

Genesis 2:23, the

Bundesformel: "This at last is bone of my bones and flesh of my flesh..." [\$5.9.2.3] 184-186

$2: 23150,169,175,187,220$, $253,256,294,296,322$, $329,352,357$

2:23f. 170,357

Genesis $2: 24$, “... and they will become one flesh" [\$5.9.2.2] 181-184

Genesis 2:24, "Therefore a man shall leave his father and his mother and cleave to his wife..." [\$5.9.2.1] 178-181

$2: 24124,126,127,150,154$, $155,169,171,174,186-$ 187, 200, 201, 282, 295, $296,352,356,357,358$

\section{2:25 182}

3:14-19 175

3:15 162

3:16 179

4:1 288

4:9 200

$4: 17,25288$

4:19ff. $118,120,356$

$4: 20) 226$

$6: 3158$

$6: 18196$

9:1 175

9:9-17 196

$9: 12,13,17193$

$12: 321$

13:11286

$14: 1329,192,196,326$

$14: 22222$

15214,319
$15: 8-18196$

17:1-4 196

17:7 196

$17: 9,10,13214$

17:11 193

17:13 193

$17: 14214$

17:21 196

18:12 166

$18: 19287$

19:5 288

19:8 279, 288

20:6 307

20:7, 18308

20:9 307

$21: 1471$

21:22f. 196

21:22ff. 189, 202

$21: 23,31 \mathrm{~b} 217$

21:27-31a 217

21:31-32 203

$24: 2,9216,282$

24:2-488

$24: 788$

$24: 16279,288$

$24: 27181$

24:41 212

$24: 67258,279$

$26: 3322$

26:10 307

26:22 139

26:23ff. 196

26:26ff. 202

26:28 203

26:28-31 203

26:30 225

26:34-35 89

27:24 166

$27: 4689$

29:14 183, 185, 248

Genesis 29:21-28 [\$7.2.2.2.4] Exodus

\begin{tabular}{|c|c|}
\hline & \\
\hline $\begin{array}{c}267 \\
29: 3170\end{array}$ & $1: 8286$ \\
\hline $31: 32,44,46159$ & 2:1f. 280 \\
\hline $31: 4428,203,305,325$ & $\begin{array}{l}4: 24-263 \\
5 \cdot 2287\end{array}$ \\
\hline 31:44ff. 196 & $\begin{array}{l}3: 2<81 \\
6: 2 \mathrm{ff} .322\end{array}$ \\
\hline $31: 45$ ff. 216 & $6: 4196$ \\
\hline $31: 46226$ & $6: 8222$ \\
\hline $31: 48$ f. 28 & $7: 360$ \\
\hline Genesis $31: 50[\$ 8.2 .4 .1] 325$ & $8: 22$ [ET 26] $165-166$ \\
\hline $31: 5028,56,89,219,257$ & $8: 27$ [ET 31$] 138,140$ \\
\hline 312 & $9: 6138,140$ \\
\hline $31: 50$ ff. 4,203 & $10: 19140$ \\
\hline
\end{tabular}

\author{
$31: 53203$ \\ $31: 54226$ \\ 34 268, 271, 276-277, 294, \\ 342 \\ $34: 2276$ \\ $34: 3342$ \\ $34: 4,8,11$ f. 277 \\ $34: 5,7,31276$ \\ $34: 11,12276$ \\ $34: 17,26277$ \\ $34: 31339,342$ \\ $35: 5140$ \\ $37: 27183$ \\ Genesis 38 [\$8.3.2] 334-335 \\ Genesis 38 [\$8.3.6.1] 339-340 \\ $38114,278,330,342$ \\ $38: 2280$ \\ 38:2f. 280 \\ $38: 7340$ \\ Genesis 38:8, 18 [\$7.2.2.2.3] \\ $266-267$ \\ $38: 9278$ \\ $38: 10340$ \\ $38: 11$ 335, 340, 341 \\ $38: 12335$ \\ 38:15ff. 339 \\ 38:20-23 340 \\ $38: 23340$ \\ $38: 24323,334,339,341$ \\ $38: 26267,288,335,340$ \\ 39:9 308 \\ 39:11 139 \\ 39:12 272 \\ 39:14f., 18277 \\ $41: 21139$ \\ 41:44139 \\ $47: 29196,216,282$ \\ 49:5-7 277 \\ 50:18 198
}




\section{$15: 20345$}

17:9 286

$17: 11222,223$

18:12 226, 229

19-24 228

19:5 50, 192, 196

19:8 221

20:13 332

$20: 1460$

$20: 17332,346$

21:2-11 336

Exodus 21:7-11 [ $\$ 8.3 .4]$ 336337

$21: 7-11342$

$21: 8306$

$21: 8 b 336,337$

21:8f. 113

21:9b 336

21:10 330

Exodus 21:10-11 and

Deuteronomy 21:15-17 [\$4.6.2.1.3] 112-113

21:10-11 111, 120, 336

21:10b 336

21:12-22:19 [ET 20] 342

22 274, 276

Exodus 22:15-16 [ET 16-17] (and Deuteronomy 22:13 21) $[\S 8.3 .5] 338$

22:15, 16 [ET 16, 17] 267, 268-271, 272, 274, 275, $281,294,342$

22:15f. [ET 16f.] 330

22:20 [ET 21] -23:19 343

23:5 69

23:26 118

23:32 309

24215

24:3 221, 322

$24: 7193$

24:8 194

24:11 228, 229

28:27f. 53

32:26-29 178

$33: 12287$

33:14 166

$34: 12-1689,309$

$34: 1698,309$

$38: 8345,346$

\section{Leviticus}

2:13 218

5-7 301

5:1-4 271

5:14-24 [ET 6:5] 301

$13: 1669$

15:2-3, 7, and 19182

Leviticus 18 , the literary structure of 116

18200

18:6 183
Leviticus 18:17, 18

[\$4.6.2.1.5] 114-117

$18: 17,18111$

$18: 18112,118,120,356$

$18: 20,25,27308$

18:22-30 46

$18: 24309$

$18: 29308$

1921,303

$19: 17,18117$

19:20 60, 303

19:20-22 204, 299, 300, 302, $303,304,342$

19:29 115

20200

$20: 1060,329,333,334$

$20: 1346$

$21: 771$

$21: 9323,334,339,341$

22:13 71

$24: 3193$

$24: 8193$

$24: 9193$

$25: 2569$

25:49 183

27:30f. 19

\section{Numbers}

4:23 346

$5: 6300,332$

5:6-8 204

5:6f. 300

5:11-31 228

5:11ff. 204, 299

5:12, 27 298, 299, 300, 304

5:13f., 19f., 28f. 308

$5: 15,31308$

5:21 194

$6: 2332$

6:2ff. 197

6:23-27 19, 21

8:24346

9:2 159

11:19 140

$11: 25157$

14:30 222

$16: 15140$

$17: 1-5$ [16:36-40] 346

18:19 218

18:21-31 19

18:26f. 19

20:14 197

$21: 2935$

2589

25:1ff. 89

25:6-15 345

25:11-13 178

25:12 198

25:12f. 19, 196

27333

$27: 869$

30:2 271

30:3-5 271
30:10 71

$31: 17279,288$

$31: 35279,288$

35:30140

\section{Deuteronomy}

Deuteronomy 10

$1: 8322$

2:7 291

4:4 181

4:10ff. 49

4:13 200

4:15 151

4:31 88, 203

4:37 49

$5: 1860$

$5: 21332,346$

6:4 133, 136

6:5 198

7:2 309

7:2-4 309

$7: 360,332$

7:3f. 89,98

$7: 650$

7:6ff. 49

$7: 8,13198$

7:8f. 203

$7: 12203$

7:12-14 88

7:14 118

8:549

$8: 1888,203$

9:9 193

9:17 272

9:24 287, 291

10:18 276

10:20181

11:22 181

12:7 224

13:5 [ET 4] 181

13:7-10 [ET 6-9] 332

13:17 [ET 16] 324

$14: 149$

$14: 1-250$

14:26 224

15:12-17 332

$17: 2-5332$

17:16 119

17:17 119-120, 356

18:1ff. 49

18:20 144

19:15 140

20:5-7 278

$20: 7278$

20:14 107

21:10-14 107, 294, 342

Deuteronomy 21:10-14 [\$7.2.2.2.1] 265-266

21:14 71

Deuteronomy 21:15-17 and Exodus 21:10-11

[\$4.6.2.1.3] 112-11.3 


\begin{tabular}{|c|c|c|}
\hline $21: 15-1770,111,120$ & $29: 19$ [ET 20] 212 & $21: 12279,288$ \\
\hline $21: 19272$ & $29: 24$ [ET 25] 181 & \\
\hline $22: 13280$ & $30: 6,15,16,20198$ & $\underline{\text { Ruth }}$ \\
\hline $22: 13,1670$ & $30: 7212$ & Ruth 65 \\
\hline Deuteronomy $22: 13-21$ and & $30: 20181$ & $\begin{array}{l}\text { Ruth } 65 \\
2: 1253\end{array}$ \\
\hline Exodus 22:15-16 [ET 16- & $31: 8181$ & $\begin{array}{l}2: 1253 \\
2.11180\end{array}$ \\
\hline 17] $[\S 8.3 .5] 338$ & $31: 8,16,17181$ & $2: 11180$ \\
\hline $22: 13-21275,334,342$ & $31: 16181,316$ & $2: 12321$ \\
\hline $22: 13-29274$ & $31: 20203$ & $2: 14225$ \\
\hline $22: 153$ & $32: 640,49,131$ & $2: 20254$ \\
\hline $22: 15$ [ET 16], 23, 25, 27, and & $32: 1935$ & $3: 1253$ \\
\hline 28303 & $32: 40222$ & $3: 974,321,328$ \\
\hline $22: 19276$ & $33: 8-1149,178$ & $4: 6114$ \\
\hline $22: 19,2971$ & $33: 9200,285$ & \\
\hline $22: 19 b 275$ & $33: 1019$ & 1 Samuel \\
\hline $22: 21323,338,341$, note & $34: 10287$ & 1108 \\
\hline \#183 341, 342 & & $1: 6117$ \\
\hline $22: 22273,275,332,334$ & hua & $1: 19288$ \\
\hline $22: 22,24308$ & & $1: 20159$ \\
\hline $22: 22-2960$ & $\begin{array}{l}1: 5181 \\
2107335\end{array}$ & $2: 13-17346$ \\
\hline $22: 23-27114,303$ & $\begin{array}{l}2197,335 \\
7 \cdot 1300\end{array}$ & $2: 16346$ \\
\hline $22: 23-29269$ & $\begin{array}{ll}1: 1300 \\
0226\end{array}$ & $2: 22344,345,346$ \\
\hline $22: 23 f .303$ & $\begin{array}{l}9226 \\
0.6 \quad 11 \quad 15 f \quad 106\end{array}$ & 1 Samuel 2:22 [\$8.3.7.1] 344- \\
\hline $22: 24323$ & $9: 6,11,15 f .196$ & 346 \\
\hline $22: 24,27273,277$ & $\begin{array}{l}9: 8198 \\
9 \cdot 14226\end{array}$ & $2: 25344$ \\
\hline $22: 25271,272$ & & 6301 \\
\hline $22: 28,29271-276$ & $\begin{array}{l}9: 15-20202 \\
9: 15 f .203\end{array}$ & $7: 6231$ \\
\hline $22: 28-29342$ & $\begin{array}{l}9: 151.203 \\
17: 17140\end{array}$ & $10: 24221$ \\
\hline 22:28f. 267,294 & $\begin{array}{l}17: 1 / 140 \\
22: 5181\end{array}$ & 11:1 192 \\
\hline $22: 30[$ ET 23:1] 74 & $\begin{array}{l}22: 5181 \\
22: 34159\end{array}$ & $11: 12166$ \\
\hline $23: 4$ [ET 3] 60 & $\begin{array}{l}22.34159 \\
2310\end{array}$ & $11: 14-12: 2510$ \\
\hline 23:6 [ET 5] 198 & $\begin{array}{l}2310 \\
23: 8181\end{array}$ & $14: 3329$ \\
\hline $23: 19$ [ET 18] 46, 113 & $\begin{array}{l}23: 8 \quad 181 \\
23: 11 \quad 151\end{array}$ & 15- 2 Samuel 8327 \\
\hline 2448,355 & $23: 12279$ & $15: 27232$ \\
\hline Deuteronomy $24: 1-4[\S 3.5] 75-$ & $\begin{array}{l}23: 12 \text { 2/9 } \\
23: 14140\end{array}$ & $16: 4166$ \\
\hline 81 & $\begin{array}{l}25.14140 \\
2410\end{array}$ & $17: 25327$ \\
\hline $24: 1-458$ & $24: 26 f .216$ & 18217 \\
\hline $24: 1,371$ & & $18-20312,352,357$ \\
\hline $24: 1,3,471$ & & 1 Samuel $18-20$-- a narrative \\
\hline $24: 1-47,22,50,65,82,94$ & ges & analogy between David's \\
\hline $\begin{array}{c}355 \\
34 \cdot 1 \mathrm{ff} \quad 60 \quad 333\end{array}$ & $2: 1203$ & covenant with Jonathan \\
\hline 24:1ff. 60,333 & $2: 2309$ & and David's (marriage) \\
\hline $24: 360,70,80,81$ & $2: 20200$ & covenant with Michal \\
\hline $24: 446$ & $3: 6309$ & {$[\S 8.2 .5] 326-328$} \\
\hline $24: 17-22276$ & $9: 2185$ & $18: 1,3178,198$ \\
\hline Deuteronomy $25: 5$ [\$7.2.2.2.2] & $9: 2-3248$ & $18: 1 \mathrm{ff} .327$ \\
\hline 266 & $9: 3197,220$ & $18: 3178,192,196,328$ \\
\hline Deuteronomy $25: 5-10$ & $9: 23304$ & $18: 4328$ \\
\hline$[\$ 4.6 .2 .1 .4] 113-114$ & $11: 1339$ & 18:25ff. 327 \\
\hline $25: 5-10111$ & $11: 2144$ & $19: 1-7327,328$ \\
\hline $26: 12$ ff. 49 & $11: 11220$ & $19: 2 \mathrm{ff} .178$ \\
\hline $26: 1850$ & $11: 23166$ & $19: 8-17327$ \\
\hline $26: 1949$ & $11: 39279,288,290$ & 20328 \\
\hline $27: 7224$ & $14: 15324$ & $20: 5225$ \\
\hline $28: 4118$ & $14: 16166$ & $20: 8178,196,203,317,326$ \\
\hline $28: 20181$ & $15: 270$ & 328 \\
\hline $28: 30278$ & $15: 6335$ & $20: 9166$ \\
\hline 28:32 144 & 16330 & $20: 9,13,30178$ \\
\hline 29:9ff. [ET 10ff.] 202 & Judges $16: 1-3[\$ 8.3 .3] 335$ & $20: 17203$ \\
\hline 29:11 [ET 12] 203 & 19303 & $20: 23326$ \\
\hline $29: 11,13,20[$ ET 12, 14, 21] & $19: 22288$ & $20: 30 f f .217$ \\
\hline 203 & $19: 25288$ & 22:7 166 \\
\hline $29: 13$ [ET 14] 213 & $21: 11288$ & $22: 8196,217$ \\
\hline
\end{tabular}


$23: 18178,196,326,328$

24:20 [ET 19] 167

24:5 [ET 4] 217

24:7 [ET 6] 55

25:8 197, 198

25:10f. 167

25:11 167

26:19 328

27:12 198

\section{Samuel}

1:26 197, 328

3:12-21 226

3:12f. 196

$3: 13,21196$

3:14 262

3:15 97

3:35 219

$5: 1183,185,187$

5:1-3 (= 1 Chron. 11:1-3) 215

$5: 2248$

5:2f. 221

$5: 3185,196$

$6: 654,55$

76,319

7:14 197

7:20 287

11:11 166

12:7-8 111

2 Samuel 12:7-8 [\$4.6.2.1.2] 112

$12: 9,13308$

12:11 112

12:24 280

$13268,273,294,342$

13:2-4 331

$13: 11,14276$

13:12f. 276

13:16 276, 277

13:19 277

$13: 30140$

14:14 232

15:20166

16:17 167

16:22 112

17:12 140

18:29 166

19:13f. [ET 12f.] 185, 248

$23: 56$

\section{Kings}

$1: 4288$

$1: 9,25,41226$

1:24 166

$2: 8219$

2:42-46 196

3:15 224

1 Kings 3:16-28 [\$8.3.6.2] 340-341

3:17f. 341

5:15 [ET 5:1] 198

5:15ff. [ET 5:1ff.] 211
5:26 [ET 12] 192, 196

$8: 21193$

8:31f. 220

8:56 140

9:13 197

11:1-10 119

11:1ff. 119

11:2 309

13:8 225

15:19 196

16:31-33 119

18:1 21

18:20 21

18:21 21

20:32 197

20:34 196

$22: 38339$

\section{Kings}

1:1 298

$5: 26165,166$

10:5-6 198

10:11 253

10:15 229

11:4 189, 197, 202, 203

11:17 196

$16: 7197,198$

17:15 88

18:14 298

19:37 313

23:2, 21193

24:1 198

\section{Chronicles}

4:17f. 280

$11: 1185,187,248$

11:3 196

12:39f. 226

17:18 287

28:9 287

$29: 22224,226$

29:24 229

\section{Chronicles}

6:22f. 220

7:18 196

13:5 218

15:12-15 203

18:2 226

20:35, 27198

20:35ff. 28

23:1 189, 197

23:16, 3196

30:8 229

$32: 21313$

34:30193

$36: 13230,316$

\section{Ezra}

Ezra 88, 91, 354

5:1 14
6:14 14

$7: 12,25-2618$

$9-1015,65,95,102,104$

$9: 1,11$, and 1446

9:2 161

$9: 2,489$

$9: 2,11,1498$

9:3-15 88

9:10f., 1489

$9: 12161,309$

$9: 1446$

$107,59,97,104$

$10: 2,10309$

$10: 3189,193$

$10: 3,44101,102,161$

$10: 3-5203$

$10: 1088$

$10: 19229$

10:44 71

\section{Nehemiah}

Nehemiah 88, 91, 354

5:1-5 15

$5: 14,15,1815$

6:17-19 104

8:13-18 18

$9: 2161$

9:15 222

10:30 [ET 29] 203

10:31 [ET 30] 15, 203, 309

10:33-40 [ET 32-39] 15, 18

$12: 2615$

$13: 1-3,23-2715$

$13: 1$ ff. 60,89

13:4, 28104

$13: 4-9,3015$

13:10-13 15

13:23-29 94

13:23ff. 101, 102

$13: 2415,94$

13:24f. 161

13:25 309

$13: 25,2916,94$

13:25ff. 161

13:26ff. 89

$13: 2816,94$

$13: 2915,16,88,89,94,354$

Job

1:5347

1:21 137

2:10 166

5:23 197

9-12347

10:9 166

$14: 4138,140,141$

$15: 5315$

18:21 287

19:14 253

$21: 34300$

24:1 287

$31296,347,34()$ 
Job $31: 1$ [\$8.3.7.2] 346-348

$31: 1$ 197, 344, 353, 358

$31: 3348$

$31: 4347$

31:9-12 309

$31: 15133,136,140$

$31: 25347$

$31: 26 f .347$

$31: 29347$

$32: 8157$

$33: 33315$

$35: 11315$

40:28 [ET 41:4] 197

\section{Psalm}

2:7 197

10:7 212

25:10 29

28:2 223

31:12 [ET 11] 253

36:11 [ET 10] 287

41:10 [ET 9] 225

50:16 200

55:14 [ET 13] 253, 315

59:13 212

63:5 [ET 4] 223

$71: 11272$

$73: 674$

$74: 2033$

$78: 5729$

$79: 6287$

$87: 4287$

$88: 9,19$ [ET 8, 18] 253

896

89:4 [ET 3] 203

89:27f. [ET 26f.] 197

94:20 198

103:18 29, 200

104:29f. 157,158

105:9 203

106:11 140

106:26 222

109:18 74

111:9 200

116:16 197, 198

119:48 223

$127: 3161$

132:11f. 203

$134: 2223$

$135: 449$

139:1 292

$139: 2,17152$

139:16 140)

141:4 225

$144: 3287$

$144: 8,11229$

$144: 14315$

\section{Proverbs}

Proverbs 120

1-9 313

$1: 1317$
$2: 5287,313$

2:16f. 22, 318, 312

Proverbs 2:17 [\$8.2.2] 312318

Proverbs 2:17, G. Boström's view that "the covenant of her god [כרית אלהיזיה]" refers to a commitment to her pagan god [\$8.2.2.1] 313-314

Proverbs $2: 17$, the traditional view that "the covenant of

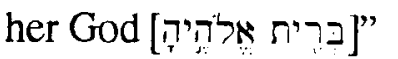
refers to her marriage covenant [\$8.2.2.3] 315318

Proverbs 2:17, the view that "the covenant of her God [כרית אלדיה:" refers to the Sinaitic covenant [\$8.2.2.2] 314-315

$2: 176,103,321,328,352$, 357

3:4 313

3:6 287

4:5b-9 352

4:6 316

5296,344

$5: 15350,351$

5:15-18 350

Proverbs 5:15-23 [\$8.3.7.4] 349-352

5:15-23 353, 358

$5: 16166,350$

5:16f. 350,351

$5: 17351$

$5: 18104,316,351$

5:18f. 351

5:19 351

$5: 20351,352$

$5: 21349$

5:22f. 349

6:24-35 349

$6: 25346$

$7: 4255$

Proverbs 7:4f. [\$7.1.3.4] 253254

7:4f. 294, 357

8311

9:10 287

10-30 313

$15: 17225$

$16: 10300$

$16: 28315$

$17: 9315$

$22: 25315$

$23: 27,28306$

$24: 17347$

$25: 2313$

$30: 9313$

$30: 2370$

\section{Song of Songs}

Song of Songs 255

2:16 255

$4: 9,10,12254$

$5: 1254$

6:3 255

7:11 [ET 10] 255

Isaiah

1:21 311, 339

2:7-9 119

7119

19:18-25 38

19:19-20 216

19:21 287

24:5 200

24:6 212

28:11 144

28:15-18 197

28:28 167

30:1 231

30:1-7 119

30:1f. 119

31:1 119

31:1-3 119

$36: 16350$

$37: 11166$

37:38 313

42:6 194, 196

43:10 287

44:19b 166

$45: 4 ; 5287$

$45: 638$

49:6-8 196

49:8 194

50:1 71

$51: 2128,130$

$53: 11287$

54:5-8311

54:6 104, 316

54:9f. 203

54:10 198

$55: 3196$

56:1-896

57:3-10 311

$58: 7183$

$59: 1938$

60:15 70

61:10-11311

62:4-5 311

$63: 1640,131,163,197,285$

64:7 [ET 8] 40, 131, 197

$65: 25225$

$66: 20-138$

\section{Jeremiah}

Jeremiah 251

$1: 5287$

$2: 2,20311$

$2: 8287$

$2: 3474$ 
3293

$3: 1,871$

3:1-5 311

3:1-10 note \#156 81

Jeremiah 3:1-13, parallels to Malachi 2:14-16 note \#82 63

$3: 14325$

3:20 305

$3: 2129$

3:3 339

$3: 4315,316$

Jeremiah 3:6-13 and Ezekiel 23 [\$4.6.2.1.1] 111-112

3:6-25 311

$3: 871,251,305,332$

$4: 4 \mathrm{a} 215$

$4: 1388$

$4: 22287$

5:7-9 309

7:9-15 309

7:9f. 308

9:1 [ET 2] 306

9:2 [ET 3] 287

9:5 [ET 6] 287

10:25 287

11:3-5 203

11:3ff. 93

$12: 9227$

$13: 21315$

$13: 27311$

17:5-21 93

$17: 21151$

19:7 227

$22: 16287$

$23: 10212,308,309,311$

24:7 287

$25: 15228$

25:29 166

29:18 194

29:23 309, 329

31:9 197

$31: 31196$

31:31f. 325

Jeremiah $31: 32$ [\$8.2.4.2] 325326

31:32 293, 311, 312

Jeremiah 31:34 [\$7.2.4.3.4] 293

$31: 34287$

$33: 2019$

$33: 20,25197$

$33: 20-21178$

34326

34:8-10 189

$34: 15220$

$34: 18316$

$34: 20227$

42:18 194

$44: 12194$

$45: 5166$

$49: 12166$

$50: 15229$

\section{Lamentations}

$2: 19223,232$

$3: 38165,166$

5:6 229

\section{Ezekiel}

$8: 1443$

$14: 5272$

$16311,318,324,341,357$

16:3-7319

16:3-63 324

$16: 85,6,74,202,203,204$, $299,328,329,331$

Ezekiel 16:8, 59, 60, and 62 [\$8.2.3] 318-324

$16: 8,59,60$, and 62312,328 , 352

16:8-14 319

$16: 15-43319$

$16: 2246$

$16: 24322$

$16: 24,25,31$, and 39323

16:24f. 323

$16: 25322$

$16: 30339$

16:31 322

$16: 37-40334$

$16: 38332$

$16: 39322$

$16: 41322,323$

$16: 44-58319$

16:53-63 111

$16: 59231$

$16: 59-63319,324$

16:59f. 203

$16: 59$ ff. 322,324

17324,326

17:11-21 230, 324

$17: 13316$

$17: 13,16,18,19203$

17:13ff. 202

17:16-20 316

$17: 18229,230$

$17: 20316$

$18: 6,11,15308$

$20: 5,6,15,23,28,42222$

20:6 322

$20: 31166$

$20: 37324$

22:11 308

Ezekiel 23 and Jeremiah 3:6-13 [\$4.6.2.1.1] 111-112

23311

23:44 332

23:47 324

30:5 324

$33: 24127,128,130$

$33: 26308,309$

$34: 25198,324$

$36: 7222$

$37: 26198,324$
$38: 16287$

39:17-20 227

$44: 7324$

$44: 12222$

$44: 2271$

$47: 14222$

Daniel

$1: 2313$

5:12 157

$6: 4157$

$10: 17158$

$11: 28,30,3233$

$11: 32287$

$11: 6,2328,198$

$12: 7222$

\section{Hosea}

1250

1-2 256

$1: 3280$

$1: 4 \mathrm{f} ., 11251$

$1: 6 f .251$

$1: 9250,251,312$

$1: 9 \mathrm{f} .251$

2:1-22 [ET 16-20] 352

2:1-3 [ET 1:10-2:1] 250, 252

2:3 [ET 2:1] 251

Hosea 2:4 [ET 2] [\$7.1.3.2] 248-251

2:4 [ET 2] 311, 332, 357

2:4, 17-19 [ET 2:2, 15-17] 294

2:4-22a [ET 2-20a] 290

2:4-25 [ET 2-23] 311

2:4-2:15 [ET 2:2-13] 251

2:4ff. [ET 2ff.] 250

2:5 [ET 3] 251

$2: 7,10,11$ [ET 5, 8, 9] 291

2:15 [ET 13] 250, 292

2:16 [ET 14] 252

2:16-17 [ET 14-15] 292

2:16-25 [ET 14-23] 251, 252

2:16f. [ET 14f.] 291

2:16ff. [ET 14ff.] 250

Hosea 2:17-19 [ET 15-17]

[\$7.1.3.3] 251-253

2:17-19 [ET 15-17] 256, 357

2:18-22 [ET 16-20] 311-312, 328,357

2:20 [ET 18] 197, 289

2:21f. [ET 19f.] 252, 292

2:22 [ET 20] 287, 289, 291, 358

2:23-25 [ET 21-23] 251

2:25 [ET 23] 253

$4: 1287$

4:10 316

$4: 12$ b 349

4:13 349

4:13a-14a 349

Hosea 4:14 [\$8.3.7.3] 348-349

$4: 14344,353,358$ 


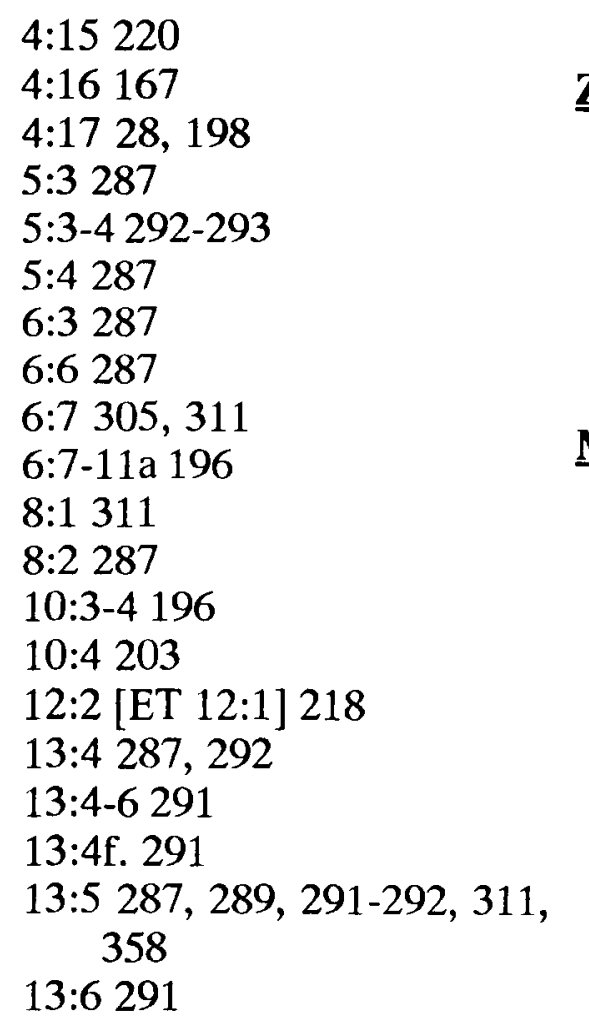

\section{Joel}

1:8 104, 316

\section{Amos}

1:9 197

3:2 286, 291

\section{Obadian}

$729,33,46,355$

1354

$13 \mathrm{~b} 55$

\section{Lonah}

1:5313

4:11 165, 166

\section{Micah}

5:10ff. 119

6:6 162

$6: 773$

$7: 5315$

\section{Nahum}

$1: 7287$

\section{Habakkuk}

3:10 223

\section{Zephaniah}

$2: 1138$

3:6 44

\section{Haggai}

$1: 1,1415$

$2: 2,21 \quad 15$

\section{Zechariah}

2:15 [ET 11] 232

8:6 166

$8: 23232$

11:14 198

$14: 9136$

\section{Malachi}

$1: 123,25$, note \#4 48

$1: 223$

$1: 2,6,7128$

$1: 2,6,13159$

1:2-3 21

$1: 2-523,25,37,90$

$1: 2 \mathrm{f} .21$

$1: 537$

$1: 5,11,1436,40$

$1: 618,41,161$

$1: 6-1415,40$

$1: 6-2: 915,19,21,23,25,90$

$1: 6 f .23$

$1: 6$ ff. 49

$1: 7,992$

$1: 815,165$

$1: 1015$

$1: 1136-39,86,93$

$1: 1288$

$1: 13103$

$1: 1418,103$

1:14ff. 93

2296

$2: 118$

2:1-9 15, 41

$2: 3,10,1592$

$2: 4,531$

$2: 4,5,8,10,1421,50$

$2: 4,5$, and 827,178

$2: 4,816,18$

2:4ff. 196

$2: 718$

2:9160

$2: 1016,22,23,27,29,35$, $36,39,40,46,56,86$, $90,101,128,130,135$, $136,143,149,161,162$, $164,168,169,187,305$, 355

2:10f. 15,30

2:10-12 17, 356

Malachi 2:10-16 and the Toleration of Polygyny Elsewhere in the Old Testament [Chapter 4] 84122

Malachi 2:10-16, the literary structure of 26,99

$2: 10-167,13,22,23,25,26$, $41,48,84,111-122,318$, 354,356

$2: 10 ; 3: 133$
Malachi 2:11, 12 as a later interpolation 36

$2: 118,34,42,43,143,161$, 318,354

$2: 11,12,13168$

2:11f. 26, 47, 85-94

$2: 1216,17,42,43$, note $\# 43$ 93,94

Malachi 2:13, alleged ritual weeping here favours the interpretation of $2: 11$ and $2: 14$ as referring to idolatry rather than to literal marriage [\$2.2.5] 43-46

$2: 138,32,47,73,354$

2:13-16 17, 95, 356

2:13a note \#2790

2:13f. 43

Malachi 2:14 -- "Covenant [ברית]" in Malachi 2:14: Does it refer to marriage? [Chapter 2] 27-47

$2: 145,6,13,22,23,81,82$, $124,186,188,198,232$, $257,297,305,312,314$, $316,318,321,352,354$, 355,356

$2: 14,1530$

$2: 14,17128,159$

2:14f. 17

2:14-16 202, 357

2:14b 150

$2: 158,15,22,60,94,120$, 316,356

Malachi 2:15a: Malachi's appeal to Adam and Eve for his understanding of marriage as a "covenant [ברית]" [Chapter 5] 123187

2:15a 357

2:15b 67, 68, 357

Malachi 2:16 -- Malachi 2:16 and Divorce [Chapter 3] 48-83

$2: 167,17,22,145,306,318$, 355

2:16b 186, 357

$2: 1723,103,124$

2:17-3:5 41, 90

2:17-3:5 [or 3:6] 23, 25, 41, 354

3:1 note \#11 15, 21, 27, 50

$3: 1,5,18$, and 23 [ET 4:5] 92

$3: 1,815$

3:1ff. 39

$3: 318,22,162$

$3: 3,1922$

$3: 515,21,41,103,124$

3:6 162

3:6 [or 3:7]-12 23, 25

$3: 6-12 \quad 15,90$ 
3:6-18 41

3:6f. 23

3:7 89

$3: 7,8,13159$

$3: 7,8,13$ ff. 128

$3: 7,14,18,22$ [ET 4:4] 41

3:7f. 23

3:8 15

$3: 1221,39$

3:13 23

3:13-21 [ET 4:3] 23, 25, 90

3:14f. 103

$3: 15,18124$

$3: 1749,169$

3:18 22

3:18-21 60

3:21 [ET 4:3] 169

3:22 [ET 4:4] 20, 21, 38, note \#4 48, 49, 124, 162, 187 3:22-24 [ET: 4:4-6] 23, 25 3:23f. [ET 4:5f.] 21

3:24 [ET 4:6] 15, 21, 41, 103, 162

\section{Esdras}

2 Esdras note \#5 14

\section{Tobit}

Tobit 254

$1: 3,10,16255$

2:2 255

3:14 255

4:12, 13255

$5: 6,11255$

$5: 13255$

$5: 20255$

76

7-8 256

Tobit 7:12 [\$7.1.3.5] 254-255

$7: 12$ 256, 294, 357

$7: 16255$

$8: 4,7255$

8:5-6 171

$8: 6$ ff. 170

\section{Sirach}

9:5348

25183

25:24-26 171

25:26 182

26:19-21351

$38: 25315$

48:10 15

49:10 15

\section{Matthew}

5:17-20 171

19:4-9 171

$19: 5,6182$

19:5ff. 172

\section{Mark}

10:6-9 171

John

3:3ff. 162

1 Corinthians

6183

6:16 171, 182

$11: 8,9171$

12184

Galatians

4112

Ephesians

4184

5184

5:21-33 171

5:28 172

1 Timothy

2:13 171

3:2, 12 note $\# 140121$

5:9 netc \#140 121

\section{Titus}

1:6 note \#140 121

1 John

5:1, 4162 


\section{$\underline{\text { Index of Other Ancient Sources }}$}

N.B.: This index is complete only for the main body of the dissertation and includes only occasional references to certain more important citations found within the footnotes.

\section{Cuneiform legal corpora}

\section{ana ittisu A}

$\S 1$ note \#20 238

$\$ 2$ note \#20 238

$\$ 3$ note \#21 238

$\$ 4$ note \#21 238

$\$ 5$ note \#122 71, note \#14 237

$\$ 6$ note \#13 237

\section{CH}

\$6-7 note \#150 79

$\$ 128$ note \#93 209, 257, note \#139 263, note \#142 264, note \#179 274, note \#208 280

$\$ 129$ note \#29 4, note \#151 79 , note \#75 203, note \#156 268, note \#174 273, note \#189 343

$\$ 130$ note \#24 302, 304

$\$ 133$ b note \#156 268

$\$ 13671$, note \#153 80

$\$ 137$ note \#150 79, note \#96 107 , note \#166 271

$\$ 138$ note \#150 79

$\$ 138-140$ note \#150 79

$\$ 141$ note \#100 108

$\$ 141-14280$

$\$ 141-143$ note \#151 79

$\$ 142$ note \#123 71, note \#153 80 , note \#140 264, note \#142 264, 278

$\$ 144$ note \#96 107

\$144-147 note \#100 108

\$144-148 note \#103 110

$\$ 145$ note \#44 57, note \#96

107,108 , note \#100 108

$\$ 146$ note \#44 57, note \#100 108

$\$ 147$ note \#150 79, note \#100 LE 108

$\$ 148108$, note \#100 108

$\$ 150,151$ note \#93 209

$\$ 151$ note \#147 332

$\$ 151-152$ 281, note \#211 281

$\$ 153$ note \#150 79, note \#147 332

$\$ 154$ note \#82 205

\$154-156 note \#165 337

$\$ 155$ note \#156 268
$\S 155-156265$

$\$ 156$ note \#166 271, 304

$\$ 159277$

$\$ 159-161$ note \#121 258, note \#142 264

$\$ 160$ note \#134 263

$\$ 161263$

$\S 163 f$. note \#126 261

$\$ 165$ note \#93 209

$\$ 170$ note \#100 108, note \#33 241

$\$ 170-171237,238-239$, note \#85 250, note \#113 256

$\$ 171$ note \#100 108

$\$ 171-72$ note \#121 258

$\$ 171$ b-172 note \#150 79

$\$ 172$ note \#166 271

$\$ 183$ note \#96 107

$\$ 184$ note \#96 107

$\$ 185$ note \#86 319

$\$ 192238$

$\$ 193$ note \#123 71, note \#153 80

$\underline{\mathrm{HL}}$

\$28-29 note \#31 304

\$29-30 note \#126 261

$\$ 34$ note \#126 261

\$192f. note \#29 4, note \#75 203

$\$ 193$ note \#116 114, note \#156335

$\$ 195$ note \#151 79, note \#82 205

$\$ 197272,273$, note \#24 302, note \#189 343

\$197-198 note \#15179

\$197a note \#156 268

\$197b note \#156 268

$\$ 198$ note \#189343

$\$ 26263$, \#135 263, note \#156 268 , note \#24 302

\$26-27 note \#161 270

§26-28 281

$\$ 27-28$ note \#93 209, 257, note \#139 263, note \#179 274, note \#208 280

$\$ 28$ note \#151 79, note \#156 268 , note \#174 273, note \#189343
\$29-30 note \#166 271

$\$ 30$ note \#123 71, note \#153 80

$\$ 59$ note \#150 79, 108, note \#100 108, note \#166 271

$\underline{\text { LI }}$

$\$ 24$ note $\# 100108$

$\$ 25$ note \#100 108

$\$ 28$ note \#44 57, note \#100 108

$\underline{\mathbf{L U}}$

LU lines 161-168 note \#152 333

$\$ 4$ note \#154 268, note \#156 268 , note \#47 308, note \#189343

\$6-7 note \#150 79

$\$ 8$ note \#208 280

$\$ 11$ note \#135 329

\section{MAL A}

$\$ 1$ note \#147 332

$\$ 2$ note \#147332

\$3 note \#147 332

$\$ 4$ note \#147 332

$\$ 7$ note \#147 332

$\$ 8$ note \#147332

$\$ 9$ note \#121 258 , note \#147 332

$\$ 10$ note \#147 332

$\$ 12$ note \#156 268

$\$ 13$ note \#189 343

\$13-16 note \#151 79, note \#156 268

$\$ 14$ note \#47 308, note \#147 332 , note \#189 343

\$14-16 note \#29 4, note \#75 203

$\$ 15$ note \#174 273, note \#147 332 , note \#189343

$\$ 16$ note \#47 308, note \#189 343

$\$ 20$ note \#150 79

$\$ 22$ note \#47 308, note \#1.47 332

$\$ 23$ note \#151 79, 272, note \#147 3.32, note \#1893.43

\$23b note \#156268

$\$ 23 \mathrm{c}$ note \#156 268 
$\$ 24$ note \#147332

$\$ 27$ note \#233 179, note \#121 258

$\$ 29$ note \#151 79

$\$ 30$ note \#121 258,note \#156 335

$\$ 31$ note \#156 335

$\$ 32$ note \#121 258

$\$ 33$ note \#156 335

$\$ 34$ note \#93 209, note \#35 241 , note \#160 270, note \#208 280

$\$ 35$ note \#147 332

$\$ 36$ note \#110 112, note \#93 209, note \#35 241, note \#166 271, note \#161 337

$\$ 37$ f. note \#150 79

$\$ 39$ note \#147 332

$\$ 4024()$

$\$ 40-41257$, note \#119 257

$\$ 41$ note \#93 209, note \#144 22(), 23.5, notc \#24 239, 240-241, note \#33 241, note \#112 256, 294, 357

$\$ 42$ note \#28 303

$\$ 42-43$ note \#118 257

$\$ 43$ note \#115 114 , note \#28 303,331

$\$ 44$ note \#147 332

$\$ 45$ note \#166 271

$\$ 47$ note \#147 332

$\$ 50$ note \#147 332

$\$ 53$ note \#82 205

$\$ 55$ note \#101 110, 114, 274, note \#179 274

\$55-56 note \#161 270

$\$ 56268$, note \#154 268, note \#156 268, note \#179 274, note \#188 276

$\$ 59$ note \#147 332

\section{NBL}

\$8 note \#93 209

$\$ 12$ note \#150 79

\section{$\underline{\text { SL }}$}

$\$ 4$ note \#20 238

§5-6 note \#21 238

$\$ 7$ note \#179 274

$\$ 8268$, note \#154 268, note $\# 179274$, note \#188 276

$\$ 12,13,14$ note \#100) 108

\section{Other cuneiform texts}

ABL 280 note \#144220

Alalah Texts 91-94 note \#92 209

Alalah Text 91:24-31 note \#100 108

Alalah Text 92 note \#100 108 ardat lilî tablet 242-243, 294, 357

ARN 36 note \#20 238

$B E$ 6/1 59 note \#20 238

$B E$ 6/2 note \#22 238

CT 8 37d note \#142 264, note $\# 197278$

CT 45, 86277

CT 48,50 note \#13 237, note $\# 14237$

CT 51, 147 note \#193 344

EA 357:84f. note \#29 240

EA 375, Ins. 82-85 236

etlu tablet 241-242, 256, 294, 357

Hana text note $\# 88$ 207, note \#92 209, note \#16 237

HSS 5, 67108

HSS 19, 27238

Huehnergard 1 note \#150333

Huehnergard 2 note \#1.51333

Huchncrgard 2 nole \#64 313

Huehnergard 3 note \#152333

Hymn to Ninurta 307

Myth of the Guilty Slave Girl 344

Neo-Assyrian marriage document, Iraq 26, No. ND 230771

Nuzi marriage contract 1 note \#100 108

Nuzi marriage contract 2 note \#100 108

Nuzi marriage contract 4 note \#100 108

Nuzi marriage contract 5 note \#100 108

Nuzi marriage contract 6 note \#100 108

Nuzi marriage contract 8 note \#100 108

Nuzi marriage contract 101 note \#100 108

Nuzi marriage contract 104 note \#100 108

$R A 69,120$ ff. No. 8 note \#176 339

Roth 1 note \#100 108

Roth 2 note \#100 108, 207

Roth 4 note \#100 108

Roth 5 note \#100 108, 207 , 208, note \#15 237, 239, note \#76 248

Roth 6 note \#100 108, 207

Roth 8 note \#100 108, 207 , 208

Roth 14207

Roth 15 note \#100 108

Roth 16 note \#10() 108, 207

Roth 17 note \#100 108

Roth 18207

Roth 19 note \#100 108, 207

Roth 20 note \#100 108
Roth 25 note \#100 108

Roth 26 note \#100 108, 207

Roth 30 note \#100 108, 207

Roth 34 note \#100 108, note \#121 258

Roth 35 note \#121 258

Samas Hymn 308

Strassmaier, Liverpool 8:6 240

TIM IV 45:1-9 note \#16 237 , 240

UET 5260 note \#129262

$V A T$ 8946:6-7 note \#25 239

VS 6 6:3f. 240

YOS 851 note \#197 278

\section{Ugaritic texts}

PRU III, 96 note \#43 307

PRU IV, 139307

UT 119 note \#95 106

UT 1077 note \#95 106

UT 1080 note \#95 106

UT 1142 note \#95 106

UT 2044 note \#95 106

UT 2068 note \#95 106

\section{Qumran texts}

11QTemple 57 note \#120 115, 120

CD 4 note \#120 115

\section{Elephantine}

Cowley 14:4 note \#83 205

Cowley 1570

Cowley 15:1-4 243

Cowley 15:3 244

Cowley 15:4 243, note \#78 249

Cowley 15:32ff. note \#57 244

Cowley 15:35ff. note \#57 244

Cowley 18 note \#49 243, 245, note \#59 245

Cowley 36 note \#49 243

Cowley 46 note \#49 243

Cowley 48 note \#83 205

Kraeling 270

Kraeling 2:3f. 243, note \#78 249

Kraeling 7 70, 245, note \#59 245

Kraeling 7:4 243, notc \#78 249

Kraeling 7:21f. note \#15237. note \#54 244

Kraeling 7:24-25 note \#17237

Kraeling 7:25 note \#55 244

Kraeling 7:33 note \#76 248

Kraeling 7:33f. 36f. 245, note \#60 245

Kracling 7:36f. note \#61 245

Kraeling 14:3f. 24.3 


\section{Murabba'at}

Babata's marriage contract 246 , note \#65 246, 247, note \#103 254, note \#115 256 Mur 20 21, note \#58 244, 246, note \#66 246, note \#103254

Mur 21247

Mur 115, 116 246, 247

Mur 116247

\section{Rabbinic texts}

b. B. Mes. 104 a note \#72 247

b. B. Mes. 111 b note \#85 144

b. B. Qam. 15a note \#153 333

b. B. Qam. 82 b note \#150 79

b. Git. 90 b note \#50 57, 62, note \#74 62

b. Ketub. 44b note \#183 341

b. Ketub. 46 a note \#206 280

b. Qidd. 1 a note \#206 280

b. Qidd. 2 b note \#83 205, note \#145 331

b. Qidd. 12 b note \#206 280

b. San. 52b note \#85 144

b. Sota 24a note \#103 110

b. Yebam. 44a note \#103 110, note \#113 113

b. Yebam. 52a note \#206 280

b. Yebam. 61b note \#103110

b. Yebam. 62b 331

b. Yebam. 64b note \#99 108

b. Yebam. 65a note \#103110

m. B. Qam. 8:4 note \#153 333

m. Ber. 8:4 note \#103 110

m. Git. 2:7; 3:1 note \#103 110

m. Ketub. 1:2 note \#15079

m. Ketub. 4:2 note \#166 271

m. Ketub. 7:1 note \#150 79

m. Ketub. 7:6 note \#150 79, note \#151 79, 80

m. Ketub. 10:1-2 note \#150 79

m. Ketub. 10:1-6 note \#103 110

m. Nid. 6:4 note \#153 333

m. Pe'a 4:3 note \#92 320

m. Qidd. 2:6-7 note \#103 110

m. Sota 6:2 note \#103 110

m. Seb. 7:4 note \#156224

m. Yebam. 4:11 note \#103 110,113

t. Ketub. 4:9 note \#72 247

y. Ketub. 4:8, 29a note \#72 247

y. Qidd. I 58c, 16 66, note \#93 66

y. Yebam. $15: 3,14 \mathrm{~d}$ note $\# 72$ 247

\section{Other Rabbinic texts}

Gen. Rab. 18, 12c 66, note \#9366
Sipre Numbers 2 note \#153 333

Sipre Deuteronomy 190 note \#153 333

\section{Josephus}

Antiquities 5.339345

Antiquities $11.302-312$ note \#86 104

Antiquities 11, iv, i-v, 8 note \#5 14

\section{Qur'ān}

2:187 74

4:3 note \#103 110

4:19 note \#94 320 


\section{Index of Words}

N.B.: This index is complete only for the main body of the dissertation and includes only occasional references to certain more important citations found within the footnotes.

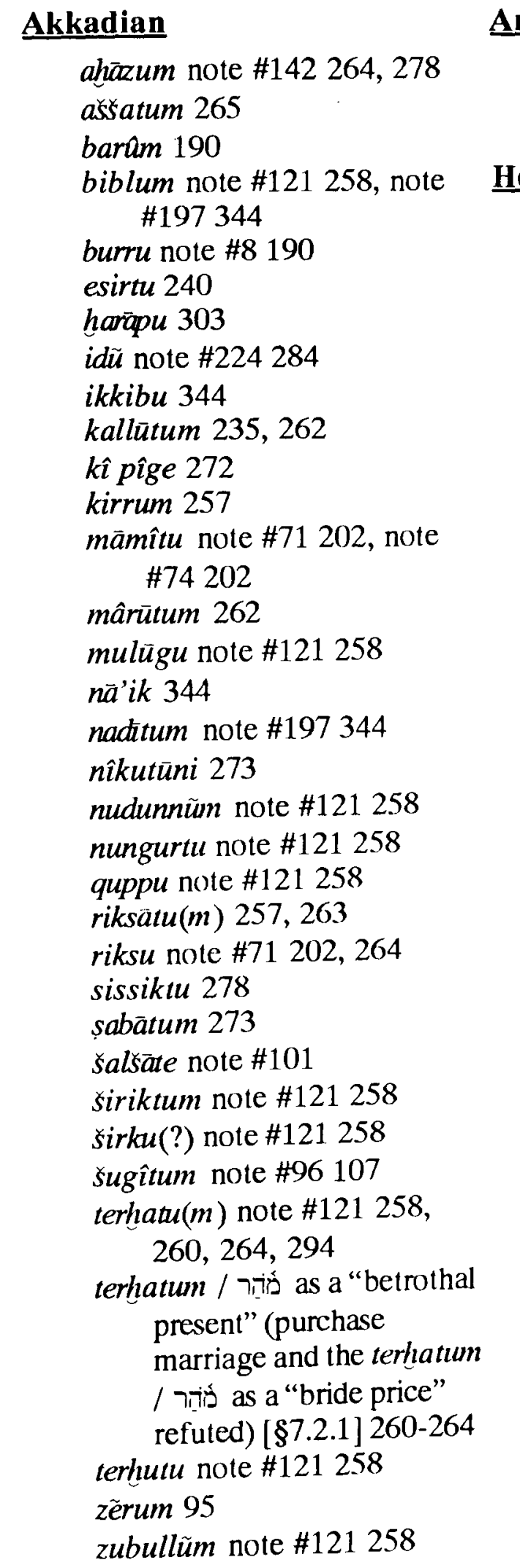

\section{$\underline{\text { Arabic }}$}

lb's 74

\section{Aramaic}

פote \#28 53

70, 95

\section{Hebrew}

198, 328, note \#132 328

198

197

100, 133, 356

137,140

198

144

44 מאין 444

252-253

23, 24, 90

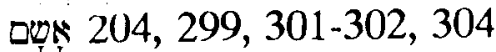

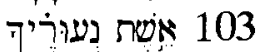

212 אָּרָה

a note \#137 219

107

202 אלה 189

189 נאמן 202

262, 303 ארט

115

$\beth$ pretii 151

28, 29, 88, 297, 298, $304,306,310,352,355$, 356

כִּר used for marital offences [\$8.1.1.1] 304

200

279 אל + בווא

200 הביא

286 בחר 200

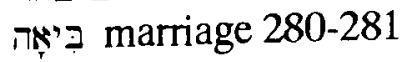

323 כָכָָה ביאה

325-326 בָּעַל בָּר

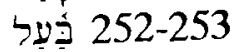

302

168

223

[Chapter 6] 188-233, defined 233, 357

בִרית defined [\$6.1] 188-204

,בּר בִית , nominal syntagms of parallel to 29- 29 30

ברית, secular use of 317,324

313-314, 315, 318

34-36, 43, 101, 131

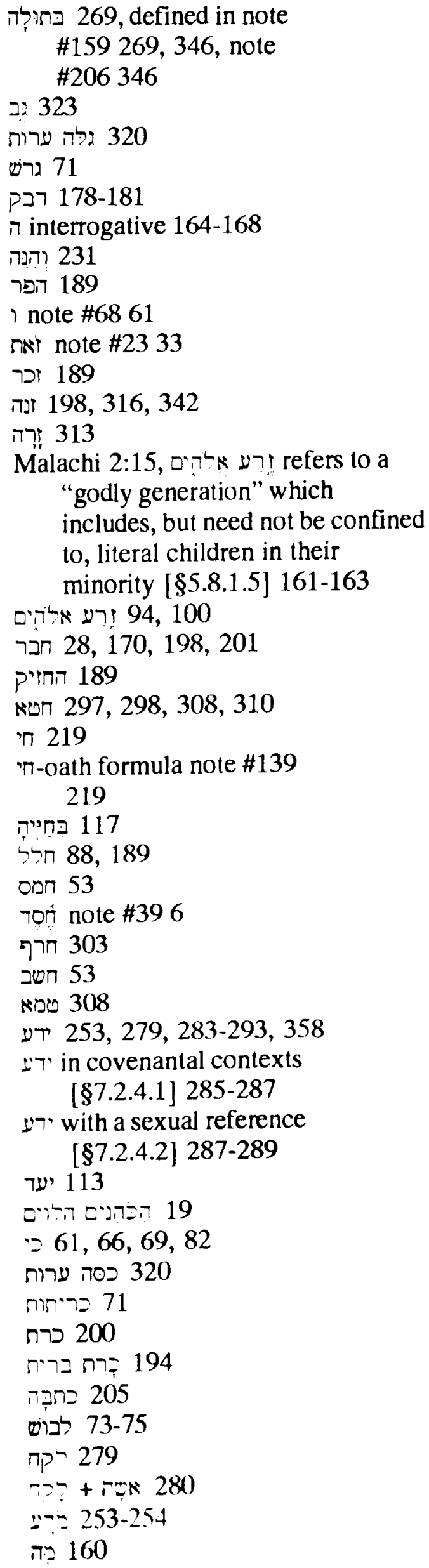


מדרי 178-181, 189

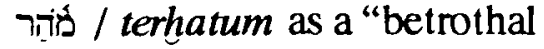
present" (purchase marriage and the / terhatum as a "bride price" refuted) [\$7.2.1] $260-264$

formative not of marriage, but of betrothal [\$7.2.1.1] 262-264

253, 254

253, 254

37 מעל מעל ל, 353

89, 204, 297, 298, 304, 309, 310,352

מעל used for marital offences [\$8.1.1.1] 298-304

18

302, 311, 329-330, 344

189

342

303 ניחרפטת 313

313 נְכרִיריה

189

ניד 222

223

223 כף + נים + נמשא

200

229

49

189, 200
201

note \#4 297

308

28

189 העמיד 337

337

42 עִר וענפה

168

107

297, 298, 310

345, 346 צבא

189

117

42

200

198

138, 157

151

222, 223

222

222 שמאלו + ימינו + הרים

323

308

200

שנש note \#34 54,63,70, 82, 95,355

שטר $127,131,134,156-158$

ש $156-158$

203

203, 212
189 ש 189

กวए 189

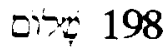

53, 54, 55, 71-72, 82, 355

טשר 151,189

שיר note \#23 33, 44

107, 303

189

תוֹ תוֹבָה n156 45-46, 81, 308

תפט 272

18, 19

\section{Hittite}

hamenkanza note \#162 337

kušata note \#126 261

sek- / sak- 284 , note \#224 284

taranza note \#162 337

-za note \#224 284

\section{Syriac}

14, 146, 147

\section{Ugaritic}

belt 347

btlt ' $n t 347$ 


\section{Index of Authors (medieval to modern)}

N.B.: This index is complete only for the main body of the dissertation and includes only occasional references to certain more important citations found within the footnotes.

Aejmelaeus note \#95 67

Ahlström 45

Allam 110

Al-Qumisi 62

Althann 89, note \#23 33

Andersen 141, 249, 290, 291, 292, 348, 349

Atkinson 2, 3

Baab 2

Bailey 176

Baldwin 40, 59, 99

Baltzer 10, 192

Barr 189, 195

Bickerman 192

Bigger 1, 176, 280

Bird 339

Boström 313-314

Brockington 133

Brownlee 319, 320, 324

Brueggemann 185, 253

Bruno 153, 164

Budde 138

Buis 191

Bullinger 164

Bulmerincq 59, 82, 142, 143, $152,157,164,169$

Burrows 3, 261, 262, 264

Callison notc \#12471

Calvin 128, 132

Camp note \#47 38, 99, 252 , 318, 339,

Campbell 253

Carmichael 275

Carroll 325

Cashdan 127

Chary 99, 136, 169

Childs 21

Coats 174

Coggins 21

Cohen 314

Collins 85, 95-98

Cotterell 195

Cowles 104-105, 121, 152

Craigie 271, 272

Dahood 136

Daube 248, 285

David 239

Deissler 158

Delitzsch 174

Dhorme 136

Dillmann 174

Doughty 226

Drake 128
Driver, G. R. 238, 239, 260, 263,264

Dumbrell 49, 65

Dunstan 3

Durham 345

Ehrlich 138

Eissfeldt 87, 93, 101

Epstein 1

Erlandsson 29

Ewald 85, 95

Fairbairn 149

Falk 1, 253

Feigin note \#96 107

Fishbane 19

Fisher 334

Freedman 249, 290, 291, 292, 348,349

Frey $156,158,161,171$

Friedman 245, 249, 252, 255

Fuller note \#46 57, note \#43 $93,58,159$

Gilbert 183

Girdlestone 191

Gispen 274

Glazier-McDonald 19, 46, 138, 358

Gordon 136, 179

Gractz 164

Gray 254

Greenberg 5, 6, 188, 231, 232, 233, 293, 319, 321, 322, $323,324,356,357$

Greengus 209, 234, 235, 236, $237,238,240,241,242$, 243,249

Grelot 65

Habel 347

Halévy 129

Hendriks 251

Hermann 323

Hertzberg 345

Heth 6, 97

Hillel 247

Hitzig 129

Holst 111

Hoonacker 143, 153, 156, 171, 172

Huffmon 253, 284, 285, 286, 291

Hvidberg 13, 43, 52, 81, 354

Hyatt 345

Ibn Ezra 62, 129

Isaksson $13,35,41,45,48$, $52,81,84,108,121,123$,
$177,186,354,355,356$, 358

Isopescul 143

Jastrow 144

Jephet Ben Eli 62

Jerome 101, 133

Job 3

Joüon 165

Kaiser 134, 139, 170

Kalluveettil 28, 198, 199, 210, $215,217,220,221,222$, 230

Keil 64, 129

Kidner 314, 348

Kimchi, D. 57, 127, 128, 129

Kimchi, J. 130

Kitchen 206

Klein 345

Kline 213, 214, 215, 228

Koschaker 260, 261

Köhler 223

Kruse-Blinkenberg 58, 85, 95, 97, 145-148

Kutsch 189, 200

Lackenbacher 241, 242

Laetsch 63

Lamsa 147

Locher 138, 152, 355

Loewenstamm 307

Lohfink 11, 202

Luck 121

Luther 128, 129

Maarsingh 1

Mace 1

Magnetti 208, 309

Maimonides 57

Malina 341

Marks 21

Marti 135, 355

Mason 52, 91

Matthews 13, 52-54, 73, 81, 354

Mayes 119, 274

Mays 290, 291

McCarter 345

McCarthy 11, 198, 199, 201. $213,215,221,222,226$, $228,229,283$

McConville note \#10 49, 274

McKane 314, 315, 350

McKenzie 2, 50

Mendenhall 6, 10, 192, 194 . 213

Meyer 165,223 
Miles 238, 239, 260, 263, 264

Milgrom 4, 5, 7, 18, 188, 203, 204, 205, 206, 208, $232,233,293,298,299$, $300,301,303,321,325$, $329,354,356,357,358$

Mitchell 137, 167

Moor 129, 130

Moore 69, 73, 131, 132, 149

Muraoka note \#95 67

Murdock note \#128 117

Murray 65

Myers 104

Naylor 29, 191, 192, 194, 195,202

Neufeld 1, 108, 260, 280, 330, $334,335,336,337$

Nida 195

Niditch 339

Nowack 355

O'Brien 20

Ogden 13, note \#19 87, 354

Orelli 98, 129

Packard 139, 142

Palmer 3, 4, 330, 356, 358

Parker 253, 284

Patai 1

Patrick 337, 338, 348

Paul 337

Phillips 332, 342

Pinches 241

Plautz 1, 118

Pococke 74

Pope 141

Pusey 152

$\operatorname{Rad} 174,181$

Rahlfs 168

Rashi 57, note \#90 104, note \#17 127, 181

Ridderbos 161

Riessler 129, 130

Ringgren 176

Robert 318

Rosenmüller 129, 130

Roth 207, 239

Rudolph 61, 62, 63, 138, 150

Sabottka 134

Sarna 175

Sänger 130

Schreiner 60, 62, 82, 138, 161,170

Schumpp 1.38

Scott 350

Sellin 59, 158, 171, 172, 355

Shammai 113

Sievers 135, 136

Skaist 263, 358

Skinner 181

Smith, G. A. 37, 86, 87, 90, 91,105

Smith, J. M. P. 19, 35, 53, $59,67,70,72,125,139$, $142,143,156,157$
Smith, M. 85

Smith, R. L. 21, 35, 169

Smith, R. P. 147

Smith, W. R. 178, 200

Snijders 313, 314

Speiser 303

Spoer 85,95

Stade 329, 334, 335

Strassmaier 240

Stuart 286

Toorn 343

Torrey 7, 13, 32, 33, 35, 52, $81,84,99,101,108,121$, 354,356

Tosato 1,21 , note \#82 63, $116-117,138,152,157$, $158,163,164,166,168$

Toy 350

Trible 253

Tsevat 348

Tucker 11, 202, 211

Turner 195

Vaux 1, 118, 179

Vawter 7, 13, 32, 33, 111, 118

Verhoef 35, 36, 37, 39, 62, $64,73,138,152$

Wallace 2, 50

Weinfeld 11, 200, 202

Weicil 91

Wellhausen 18,19 , note \#10 $49,85,99,122,135,143$, 164

Wendland 24, 26

Wenham 6, 97, 274

Westbrook 59, 67-68, 70, 95, $209,210,235,236,238$, $239,240,241,243,261$, $263,265,266,294,355$, 358

Westermann 174, 180

Wierzbicka 195

Williamson 65, 102, 104

Winckler 15,73

Wiseman 192

Wolff 183, 286, 291

Woude $33,48,54,57,64,75$, $81,84,87,91,92,93$, $94,121,125,139,143$, $144,152,163,355$

Yamauchi 331

Yaron 243

Yec 250

Zakovitch 336

Ziegler 58, 141, 142, 168, 199

Zimmerli 323 


\section{$\underline{\text { Index of Topics }}$}

N.B.: This index is complete only for the main body of the dissertation and includes only occasional references to certain more important citations found within the footnotes.

4QXII 58,159

Abraham 126, 127, 130-132

Adam 126

Adam and Eve as a paradigm for marriage [\$5.9.1] 173-177

Adam and Eve, the paradigmatic marriage of as a "covenant [פרית] [5.9.1] 177-186

Adapa Myth 175

adoptio in matrimonium 337

adoption 199, 239, 261, 265, 294, 319, 358

adoption formulae 237

adultery $203,245,265,268,269,298,299$, $302,307,333$

adultery and the claimed indifference of the Old Testament to a man's sexual fidelity [\$8.3] 328-352

adultery and the condition of being caught in flagrante delicto note \#15179

adultery as a cause for the dispossession of Canaan 309

adultery, the penal sanctions for and their possible historical development note \#189 343

age for marriage 331

Alalakh marriage document, JCS 8, No. 9470

'Anath 347

androcentric language in Israelite law 314

androcentricity conventional in legal discourse [§8.3.1] 332-334

apodictic law 343

apodosis marked by a ? + perfect 69

asyndeton 83

Atra-hasis Epic 175

betrothal 262, 294, 303

betrothal defined note \#135263

betrothal of a female slave to a man other than her owner 303

betrothal present $260-264$

blood 228

bone of my bones formula 248

bride-price 294

brother 197, 254, 255

captive wife 240,280

captive-wife 107

ceremonies associated with marriage 257

ceremonies associated with marriage note \#119 257

circumcision $214,227,282,358$

clothes, the gift of as expressive of the acquisition of inheritance rights note \#130 217

clothing of the bride 257 companion 198

concubine 107 , note $\# 96107,239$, note $\# 28$

240,303

consensual contract 257

consent 268

consent of bride for marriage note \#175273

consummate marriage, obligation to 277,278

consummation of marriage $264,280-281$

contract 358

contract form 211

contract vs. covenant 210

copula carnalis $260,267,277,281$

"Covenant [ברית]" and "Oath" Defined [Chapter 6] 188-233

covenant [כִרית] defined 11

covenant as the "centre" of Old Testament theology 9

covenant between God and Israel 9

Covenant Code 268, 342

covenant concepts, the importance of in Malachi note \#227 178

“covenant" (English term] defined 191

covenant, controversies surrounding the study of [\$0.3.1] 8-10

covenant "lawsuit" 10

covenant, pre-deuteronomic references to note \#59311

covenantal nature of marriage in the Old Testament, desirability at the present time for a study of the [\$0.2] 2-8

covenantal nature of marriage in the Old Testament, the importance of the topic [\$0.2.1] 2

covering with garments 320,321

covet 308

cultic prostitution 345,349

cutting (i.e., making) a covenant 213

cutting the hem (sissiktu) to express divorce 278

David's relationship with Jonathan as a 178

Decalogue 10, 301, 332, 343

Declaration Formula 215

demon possession 241

Deuteronomic perspective of Malachi $48-50$

Deuteronomy's humanitarian ideals 275

diplomatic alliances 118

disinherison formulae 2.37

divorce 355

divorce for inchoate marriage 278

divorce formulae $237-240,311,357$

divorce, husband's right to initiate forfeited 276 divorce, the wife's right to initiate 244 , note $\$ .58$ 244,264 , note $\# 140264,333$

documentary formula 245 
double standard $328,348,356$

dowry sewed into the bride's garment 257

Drohritus 222

eating together 282,295

eating together as an oath-sign [\$6.2.3.3.3] 223229

Egyptian marriage contracts 243

El and Atrt 177

election 286

Elephantine 209, 294, 333, 357

Elephantine, view of polygyny at 121

Elijah 162

ellipsis in oath formulae 219

ellipsis of pronominal subjects with participles in Hebrew 63

emphasis 165

emphatic state in Syriac 148

encapsulation 70, 193, note \#22 193

Enki and Ninhursaga 177

Enūma Elis 175

erébu marriage 179-180

Eridu Genesis 175

eschatological marriage to Yahweh 312

estoppel 80

evangelistic calling of Israel and the Abrahamic covenant note \#50 39

Eve 126,152

exchange of clothes 216

excisability 89

exogamy 131

extramarital sexual activity of men or the sexual activity of unmarried women nowhere a matter of moral indifference [ $\$ 8.3 .6] 338$ 342

family-like relationship in covenant [ $\$ 6.1 .3 .2]$ 199-200

fasting 224

father 197

feasting 224

federal theology 9

fertility cultus 290

foreign alliances, prohibited to Israel 118

friend 198

Gaonic Babylonian tradition 247

genitals employed in oaths 216

Gibeonite covenant 226

gift-giving 216, 224

Gilgames Epic 175, 236

giving of a hand (handshake) as an oath-sign [\$6.2.3.3.4] 229-231

God's judgment against marital infidelity necessitated because the deity is invoked as guarantor in any ratifying oath $[\$ 8.1 .3] 308$ 309

great $\sin 307$

Hagar 127

hands placed under another's "thigh" 282

handshake 229, 282

hatred 244

heap and pillar in Genesis 31 as symbols of the witnessing deity 226 hem of a garment, taking hold of or letting go 232

hem of the bride, rite of tying money into 242

heterosis of person and number $62,92,164$

hieros gamos 290

History of David's Rise 327

Holiness Code 117

homosexuality 328

idolatry 309

illegitimate totality transfer 195

in domum deductio 240, 260, 277, 294

in flagrante delicto 207, 334, 343, note \#189 343

Inanna and Dumuzi 177

incest 200, note \#165337

inchoate marriage 263, 264, 294

infertility 118

infertility, as a motive for polygyny 108

infidelity 297, 298

infinitive absolute 72

inheritance 240

inheritance rights extended to daughters 333

interfaith marriage 88-89, 96

intermarriage $36,298,354$

intermarriage with and the inclusion of converted Gentiles in Israel note \#5797

intermarriage with pagans prohibited because of the idolatry that would necessarily ensue when a ratifying oath is sworn $[\$ 8.1 .4] 309$. 310

Ishchali 235

ius primae noctis 349

jealousy 198

jealousy-ordeal 228

Jeremiah, influenced by Hosea 251

kallūtum documents 262

kallūtum-relationship 235

Karaites 115, 249

ketubbâ 247

kudurru stones 10

law, incompleteness of ancient Near Eastern 205

law, the characteristic mixing of criminal and ethical norms in biblical 342

law, the distinctiveness of Old Testament note \#189 343

levirate 113-114, 266, 335

lex imperfecta 117

lex talionis note \#179 274

lexical choice 313

lexical semantics 285

liability for prenuptial debts 281

lord 198

love as a motive for marriage note \#175 273

Malachi in relation to Dtr and especially $P$ [\$1.1.2] 18-20

Malachi in relation to Ezra and Nehemiah [\$1.1.1] 16-17

Malachi, canonical context of $[\$ 1.2] 20-22$

Malachi, poetry or prose? 93

Malachi, the date of $[\$ 1.1] 14-20$

Malachi, the literary structure of $[\$ 1.3] 22-26$

Malachi, the literary structure of 25,90 
marital offences identified as sin (פטע, פט , etc.) against God [\$8.1.2] 307-308

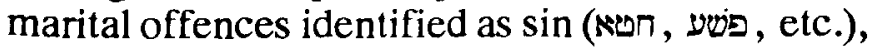
perfidy (מעל), or infidelity (בגד) against one's spouse [\$8.1.1] 298-306

marriage analogy and especially Hosea $2: 18-22$ [ET: 16-20] [\$8.2.1] 311-312

marriage analogy (or metaphor) 199, 241, note \#56 310, 352

Marriage as a "Covenant [ברית]" Elsewhere Within the Old Testament [Chapter 8] 296 353

marriage as a "covenant," arguments against identifying [\$0.2.3] 3-8

marriage as a "covenant," the contradictory results of those who support the identification of [\$0.2.2] 2-3

marriage as a covenant, problems with the present study [\$0.3] 8-12

marriage as a legal status 210,358

marriage as a model for the theological covenants 199

marriage by purchase $260,294,358$

marriage ceremony (the traditional Jewish) as a replica of the Sinaitic covenant note \#259 292, note \#58 311

marriage contract (or document) 205, 209-211, 358

marriage contract and oath 203

marriage contract from Alexandria 247

marriage contract vs. the marriage proper 263

marriage contracts extant from the ANE note \#92 209

marriage contracts from the Cairo Geniza 247

marriage contracts which include an oath 206-211

marriage contracts, Jewish use of note \#83 205

marriage contracts, not always written note $\# 93$ 209

marriage identified as a בִר outside Malachi 2:14 [\$8.2] 310-328

marriage in the OT, survey of recent scholarship [\$0.1] 1

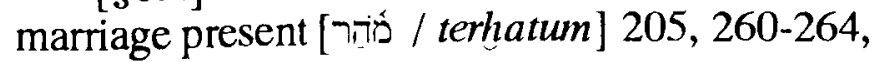
270

marriage present [ מֵنה / terhatum] generally returned with dowry note \#126261

marriage prestations note \#121258

matriarchy 179

McCarthy's Treaty and Covenant 228

Memphis creation documents 175

method of approach for the present study [\$0.3.2] 11-12

mitigating factors in criminal liability 341

mixed marriage and idolatry note \#3 123

modes of marriage 261

monogamy 152,356

monogamy, texts which presuppose or may encourage as the ideal form of marriage [\$4.6.2.2] 118

Murabba'at 294

mutuality 244

Name Theology 49 naming, the significance of note \#255 184

narrative analogy 340

Neo-Babylonian marriage document No. 5239

Neo-Babylonian marriage document No. 6207

Neufeld's view of "בִּזָה Marriage" rejected

[\$7.2.2.5] 280-281

Nkl and Yrh 177

oath 11,321

oath "by the laden table and by drinking from the cup" 225

"oath" defined [Chapter 6] 188-233

oath defined 212, 233

oath in marriage, toward a solution regarding the apparent lack of [\$6.2] 205-232

oath indispensible for a covenant [\$6.1.3.4] 202 204

oath of clearance 208,309

oath or oath-sign in marriage, indirect evidence for [\$8.1] 297-310

oath, the lack of any explicit reference to within marriage in the ancient Near Eastern law collections or extant marriage contracts is not unexpected [\$6.2.1] 205-211

oath-sign 188, 213, 231-232, 294, 357

oath-signs: oaths may often be accompanied by, or even consist of, symbolic acts [\$6.2.2] 212-215

oaths and oath-signs may invoke the deity without employing an explicit selfmalediction [\$6.2.3] 215-232

obligation prominent in covenant $[\$ 6.1 .3 .3] 200$ 202

oil 218

oil poured on the bride's head 257

Old Testament and New Testament, their interrelation 9

one, commitment to be 282

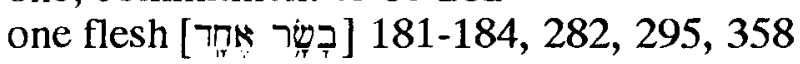

pair-bonding 283, note \#220 283

palingamy 245

parental (or guardian) consent 281,294

pars pro toto 282,295

paternity, dual 162

perfidy 297,298

placing of one's hand "under the thigh" 216,358

pledged or designated, a pre-betrothal status 302 , 303, 304, 337

polygyny (or polygamy) 61, 110, 155, 245, 336, 356

Polygyny, an excursus on the practice of in ancient Israel [\$4.6] 106-121

polygyny, its prevelance in the ancient Near East note \#95 106

polygyny, restraints on the practice elsewhere in the ancient Near East note \#100 108

polygyny, texts which are alleged to approve 111-117

Polygyny, the ethical stance of the Old

Testament concerning [\$4.6.2] 110-120

polyphony in Biblical Hebrew note \#206 174

polytheism 176

premarital sex 295, 341-342 
premarital sex, its legal implications [\$7.2.2.2.5] 267-277

prenuptial bath 257

priesthood, Wellhausen's reconstruction of the history of note \#10 49

primary mode of marriage 265,266

procession of the bride from her father's home 257

prostitution 334-341, 342

prototypical marriage 176

Qumran 115, 119

rape $268,271,273,274$

rape of a concubine 303

rebellion 298

relationship formula 185

relationship prominent in covenant [\$6.1.3.1] 196-199

relationship prominent in covenant 188

renunciation of marriage 239

rib 201

rite, rather than oath, supposed to ratify covenant 215

rites connected with covenant making [\$6.2.3.1] 216-217

ritual covenant 228

romance 104

royal polygyny 119

sacrifices of communion 228

salt 218

self-maledictory oath-signs connected with covenant making [\$6.2.3.2] 217-218

semiotic redundancy 281

servant 198

sexual activity of unmarried women was not a matter of moral indifference [\$8.3.6.3] 341342

sexual fidelity on the part of the husband encouraged $[\$ 8.3 .6] 342-352$

sexual imprinting 283

sexual union 358

sexual union as the covenant-ratifying (and renewing) oath-sign for marriage, the evidence [\$7.2] 257-293

sexual union as an oath-sign 295

sexual union compared to other covenantratifying oath-signs [\$7.2.3] 281-283

sexual union, the covenantal implication of the use of $y$, to refer to [\$7.2.4] 283-293

sexual union, the means by which marriage was consummated [ $\$ 7.2 .2] 264-281$

$\sin 297,298$

Sinai pericope 228

Sippar 277

sister 254, 255

slave-girl, status if betrothed 299

slave-wife 107

sociobiology note \#220 283

son 197

spirit of God, as witness to the covenant 156

status 261, note \#128 261, 297

Sumerian Flood Story 175

Sumerian King List 175 suzerainty treaty 296

symbolic multivalence 227

taboo 344

Talmud 110

Tammuz 52

traditio 260

treaty between Mursiliš II and Talmi-Sarruma 282

treaty documents 206

treaty form 10

treaty of Ashurnirari V and Mati'ilu 213

treaty texts 192

universalism 91

universalism in Malachi 36-40

unmarked interrogative 164-168

uplifted hand as an oath-sign $[\$ 6.2 .3 .3 .2] 222$ 223

usus marriage 280

Vassal-Treaty of Esarhaddon 226

verba solemnia 220-222, 233, 294, 312, 357

Verba Solemnia and Sexual Union: The requisite covenant-ratifying oath and oath-sign for marriage [Chapter 7] 234-295

verba solemnia in marriage, ancient Near Eastern evidence for the use of [\$7.1.1] 234-243

verba solemnia in marriage, biblical evidence for the use of [\$7.1.3] 248-255

verba solemnia in marriage, conclusions concerning the use of $[\$ 7.1 .5] 256-257$

verba solemnia in marriage, extrabiblical evidence for the use of among Israelites and Jews [\$7.1.2] 243-247

verba solemnia in marriage, indirect biblical evidence for the use of [\$7.1.4] 255

verba solemnia in marriage, the evidence [\$7.1] 234-257

verbal oaths are frequently not explicitly selfmaledictory [\$6.2.3.3.1] 219-222

virgin 269

Wadi Murabba'at 246

water libation 231

whoring 198

witness 297

witness to marriage, the deity as $242,256,294$

witnesses (symbolic and real) to covenant 216217

word order in Biblical Hebrew note \#168 165 word-thing fallacy 178

Zadokites 115, 119 